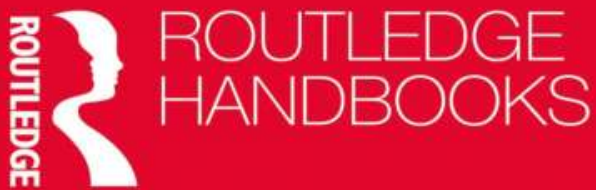
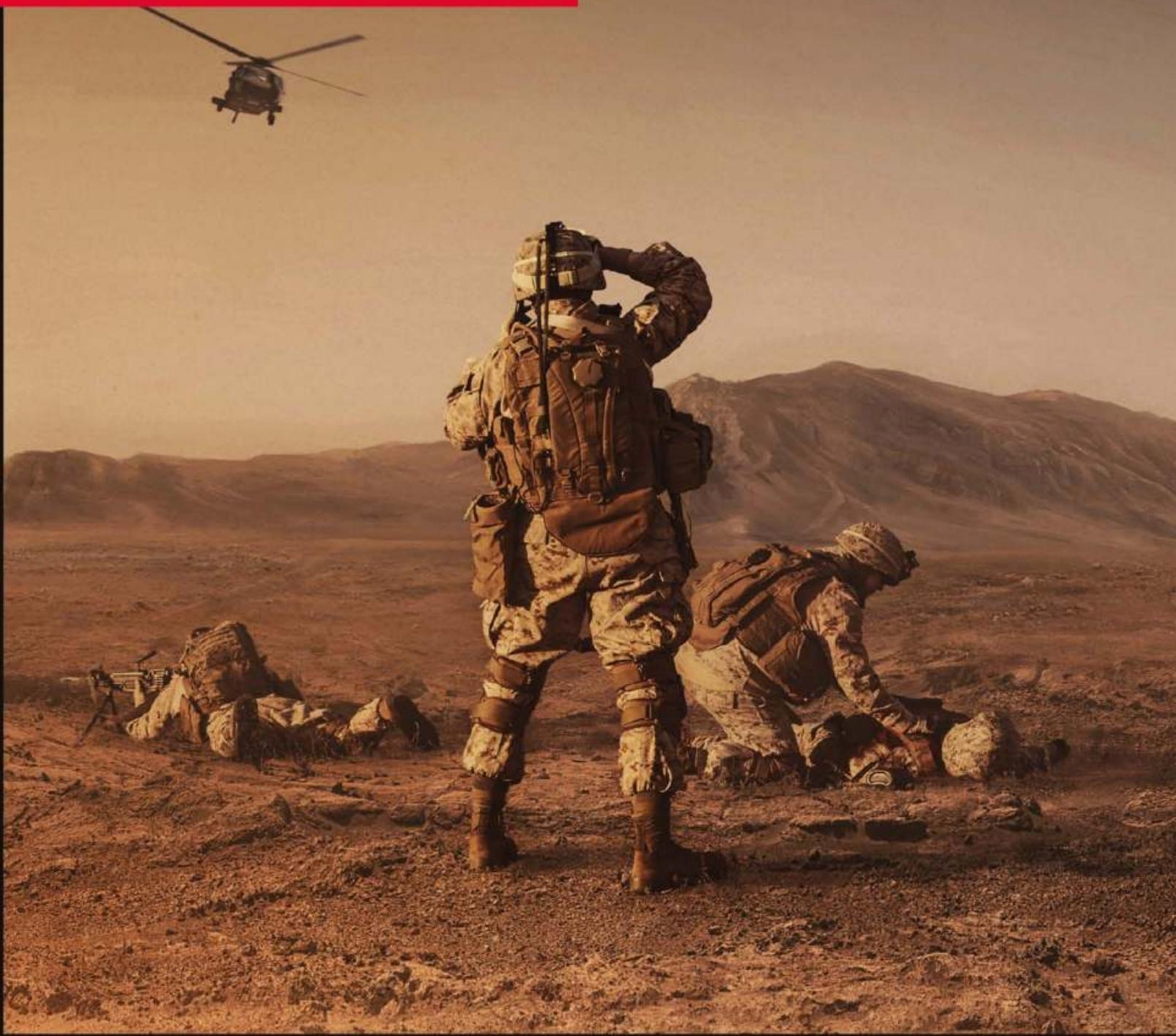

Routledge Handbook of

U.S. Counterterrorism and Irregular Warfare Operations

Edited by Michael A. Sheehan,

Erich Marquardt, and Liam Collins 
'A unique, exceptional volume of compelling, thoughtful, and informative essays on the subjects of irregular warfare, counter-insurgency, and counter-terrorism - endeavors that will, unfortunately, continue to be unavoidable and necessary, even as the U.S. and our allies and partners shift our focus to Asia and the Pacific in an era of renewed great power rivalries. The co-editors - the late Michael Sheehan, a brilliant comrade in uniform and beyond, Liam Collins, one of America's most talented and accomplished special operators and scholars on these subjects, and Erich Marquardt, the founding editor of the CTC Sentinel-have done a masterful job of assembling the works of the best and brightest on these subjects - subjects that will continue to demand our attention, resources, and commitment.'

General (ret.) David Petraeus, former Commander of the Surge in Afghanistan, U.S. Central Command, and Coalition Forces in Afghanistan and former Director of the CIA

'Terrorism will continue to be a featured security challenge for the foreseeable future. We need to be careful about losing the intellectual and practical expertise hard-won over the last twenty years. This handbook, the brainchild of my late friend and longtime counter-terrorism expert Michael Sheehan, is an extraordinary resource for future policymakers and CT practitioners who will grapple with the evolving terrorism threat.'

General (ret.) Joseph Votel, former commander of US Special Operations Command and US Central Command

'This volume will be essential reading for a new generation of practitioners and scholars. Providing vibrant first-hand accounts from experts in counterterrorism and irregular warfare, from 9/11 until the present, this book presents a blueprint of recent efforts and impending challenges. Terrorism is a perpetual threat, one that never goes away, but requires expertise and attention to compress its scale and scope. These essays provide the way forward.

Nancy Collins, author of Grey Wars and senior fellow of the Modern War Institute, West Point

'The post-9/11 literature on counterterrorism has been dominated by academics and policy practitioners. The Routledge Handbook of U.S. Counterterrorism and Irregular Warfare Operations widens the existing scope of scholarship on terrorism and counterterrorism by adding a critically important operational perspective to the discussion. Conceived by the legendary Ambassador Michael Sheehan, the handbook assembles a stellar cast of contributors in a unique volume that will enlighten and inspire all those who take part and interest in the ongoing effort to stem one of the most pressing security challenges of our time - from scholars to decisionmakers, and from policy practitioners to military operators.'

Assaf Moghadam, Interdisciplinary Center Herzliya, Israel, author of Nexus of Global Jihad: Understanding Cooperation among Terrorist Actors

'The Routledge Handbook of US Counterterrorism and Irregular Warfare Operations consolidates and advances our understanding of the American experience at war since the mass murder attacks of September 11, 2001. It is a book that should be read and discussed beyond the military, as the contributors' findings are consistent with Sir Michael Howard's observation that, in war, the causes of victory or defeat are often found far from the battlefield.'

Lt.-General (ret.) H.R. McMaster, former US National Security Advisor and author of Dereliction of Duty and Battlegrounds: The Fight to Defend the Free World 
- Taylor \& Francis

Taylor \& Francis Group

http://taylorandfrancis.com 


\section{ROUTLEDGE HANDBOOK OF U.S. COUNTERTERRORISM AND IRREGULAR WARFARE OPERATIONS}

This handbook comprises essays by leading scholars and practitioners on the topic of U.S. counterterrorism and irregular warfare campaigns and operations around the globe.

Terrorist groups have evolved substantially since 9/11, with the Islamic State often described as a pseudostate, a terrorist group, and insurgency all at the same time. While researchers', analysts', and policymakers' understanding of terrorism has grown immensely over the past two decades, similar advancements in the understanding of counterterrorism lag. As such, this handbook explains why it is necessary to take a broader view of counterterrorism, which can, and often does, include irregular warfare.

The volume is divided into three thematic sections:

- Part I examines modern terrorism in the Islamic world and gives an overview of the major terrorist groups from the past three decades;

- Part II provides a wide variety of case studies of counterterrorism and irregular warfare operations, spanning from the 1980s to the irregular warfare campaign against the Islamic State in northern Syria in 2018;

- Part III examines the government instruments used to combat terrorism and wage irregular warfare, such as drones, Theater Special Operations Commands, and Theater Commands.

The handbook fills a gap in the traditional counterterrorism literature by its inclusion of irregular warfare and by providing analyses from academic experts as well as practitioners. It will be of much interest to students of counterterrorism, counterinsurgency, U.S. national security, military affairs, and international relations.

The late Michael A. Sheehan previously served as the U.S. Department of State's coordinator for counterterrorism, the New York City Police Department's deputy commissioner for counterterrorism, and the assistant secretary of defense for special operations and low intensity conflict.

Erich Marquardt founded the U.S. military's premier open-source counterterrorism journal, the CTC Sentinel, and served as editor-in-chief for seven years.

Liam Collins is a fellow at New America, former director of the Combating Terrorism Center at West Point, and founding director of the Modern War Institute at West Point. He co-authored Letters from Abbottabad: Bin Ladin Sidelined?, the first report to analyze the documents captured from Bin Ladin's compound during the Abbottabad raid. 
- Taylor \& Francis

Taylor \& Francis Group

http://taylorandfrancis.com 


\section{ROUTLEDGE HANDBOOK OF U.S. COUNTERTERRORISM AND IRREGULAR WARFARE OPERATIONS}

Edited by Michael A. Sheehan, Erich Marquardt, and Liam Collins 


\author{
First published 2022 \\ by Routledge \\ 2 Park Square, Milton Park, Abingdon, Oxon OX14 4RN \\ and by Routledge \\ 605 Third Avenue, New York, NY 10158
}

Routledge is an imprint of the Taylor \& Francis Group, an informa business

(C) 2022 selection and editorial matter, Michael A. Sheehan, Erich Marquardt, and Liam

Collins; individual chapters, the contributors

The right of Michael A. Sheehan, Erich Marquardt, and Liam Collins to be identified as the authors of the editorial material, and of the authors for their individual chapters, has been asserted in accordance with sections 77 and 78 of the Copyright, Designs and Patents Act 1988.

The Open Access version of this book, available at www.taylorfrancis.com, has been made available under a Creative Commons Attribution-Non Commercial-No Derivatives 4.0 license.

Trademark notice: Product or corporate names may be trademarks or registered trademarks, and are used only for identification and explanation without intent to infringe.

British Library Cataloguing-in-Publication Data

A catalogue record for this book is available from the British Library

Library of Congress Cataloging-in-Publication Data

Names: Sheehan, Michael A., editor. | Marquardt, Erich, 1980- editor. | Collins, Liam, 1970- editor.

Title: Routledge handbook of U.S. counterterrorism and irregular warfare operations / edited by Michael A. Sheehan, Erich Marquardt, and Liam Collins. Description: Abingdon, Oxon ; New York, NY : Routledge, 2022. | Includes bibliographical references and index.

Identifiers: LCCN 2021006929 (print) | LCCN 2021006930 (ebook) | ISBN 9780367758363 (hardback) | ISBN 9780367759032 (paperback) | ISBN 9781003164500 (ebook)

Subjects: LCSH: Terrorism-United States-Prevention. | Terrorism-Prevention. |

Irregular warfare-United States. | Military policy-United States.

Classification: LCC HV6432 .R68 2022 (print) | LCC HV6432 (ebook) | DDC 363.325/170973 - dc23

LC record available at https://lccn.loc.gov/2021006929

LC ebook record available at https://1ccn.loc.gov/2021006930

ISBN: 978-0-367-75836-3 (hbk)

ISBN: 978-0-367-75903-2 (pbk)

ISBN: 978-1-003-16450-0 (ebk)

DOI: $10.4324 / 9781003164500$

Typeset in Bembo

by Apex CoVantage, LLC 
This handbook is dedicated to Ambassador Michael A. Sheehan, a devoted public servant who provided a lifetime of service to our nation before ultimately succumbing to cancer in July of 2018.

Mike was a West Point classmate, a close personal friend and advisor, and "uncle" to my sons. He was a warrior and scholar who served his country as a jungle fighter, a diplomat, and a public servant of the highest order. With his passing in 2018, our nation lost an irreplaceable member of its praetorian caste.

Mike always described terrorism as a symptom of modern governments' inability to provide for the broader society. Motivated by extreme and reactive interpretations of religious ideologies and political philosophies, the adoption of seemingly random violence as a means to a political result had to be countered and combated directly. He took it personally when an innocent life was lost to terrorism.

This compendium is shaped by his lifelong study and experience from his efforts to defeat terrorism at all levels. Mike assembled an unparalleled roster of experts in terrorism, counterterrorism, and irregular warfare to produce this book. He sought to contribute to the discourse by developing a book that examined counterterrorism and irregular warfare from the operational perspective, so that future warfighters-our West Point cadets-as well as current warfighters, scholars, and policymakers, could learn from the experiences of veterans and practitioners involved in conflicts from El Salvador to the Philippines to Afghanistan.

Mike's lifelong commitment to countering terrorism and irregular warfare was shaped by his days as a Special Forces advisor in El Salvador and continued until his untimely passing. As the nation's first ambassador-at-large for counterterrorism in the late 1990s, Mike realized that there was a general lack of understanding of terrorism and the threat it posed. This shaped Part I of this volume, which discusses the threat and regional security issues. Part II of the volume, which includes a number of case studies of U.S. irregular warfare campaigns, was shaped by his experience as the assistant secretary of defense for special operations and low-intensity conflict at the Pentagon.

As the ambassador-at-large for counterterrorism in the late 1990s and as the New York City Police Department's first deputy commissioner for counterterrorism in the early 2000s, Mike understood that combating terrorism requires a whole-of-government approach. As such, Part III of the handbook expands beyond the primarily military case studies to discuss other aspects of countering terrorism.

The completion of this book provided Mike strength, energy, and purpose to fight and hold against a treacherous disease longer than many may have. The book is now complete; Mike is at rest.

"Be thou at peace, classmate, friend, warrior, and scholar." 
- Taylor \& Francis

Taylor \& Francis Group

http://taylorandfrancis.com 


\section{CONTENTS}

Acknowledgment

xiii

Preface

xiv

List of figures

$x v i$

List of abbreviations

xvii

List of contributors

Introduction

Liam Collins

\section{PART I}

The threat and regional security issues

1 The evolution of Islamist terrorism in the 20th century James J.F. Forest

2 The ideology behind al-Qaida and the Islamic State

Daniel Rudder and Christopher Heffelfinger

3 The evolution of al-Qaida: 1988 to present day

Seth G. Jones

4 The history of the Islamic State: from Abu Musab al-Zarqawi to Abu Bakr al-Baghdadi

Brian Fishman

5 Contemporary conflict and political violence in the Levant Benedetta Berti 
6 Jihadi militancy and Houthi insurgency in Yemen Elisabeth Kendall

7 The roots of terrorism in North and West Africa: AQIM and Boko Haram Alice Hunt Friend

8 Al-Shabaab and the Horn of Africa

Ken Menkhaus

9 The history of terrorism in Southeast Asia

Peter Chalk

10 The Taliban and the modern history of Afghanistan Rob Johnson

11 The modern history of Iran and the birth of the Shia proxy model Alex Vatanka

12 Terrorism, insurgency, and criminal insurgency in Latin America Román D. Ortiz

\section{PART II}

\section{Operational case studies}

13 El Salvador: Operations and Planning Assistance Training Teams and a minimalist approach to counterinsurgency

Cecil E. Bailey

14 Plan Colombia and the U.S. Army's 7th Special Forces Group Kevin M. Higgins

15 The story of the U.S. role in the killing of Pablo Escobar Mark Bowden

16 The Iran-Contra Affair and the Afghan Task Force: lessons in covert action Jack Devine and Amanda Mattingly

17 The horse soldiers: lessons from expeditionary unconventional warfare Mark E. Mitchell

18 Special Operations Forces and Afghan Local Police programs 
19 U.S. civilian architecture for stabilization and counterinsurgency in Northern Afghanistan (2012-2013)

Keith Mines

20 Dismantling al-Qaida in Iraq

Liam Collins

21 Operation Enduring Freedom-Philippines: lessons in special warfare

David S. Maxwell

22 Operation Serval: a swift intervention with a small footprint in Mali

Michael A. Sheehan and Pascale C. Siegel

23 U.S. counterterrorism policy in Yemen from 2010-2020

Luke Hartig

24 Defeating the Islamic State: Special Operations Forces in Syria

Anthony Messenger, Nick Lewis-Walls, Mike Parker, Bert Pedrigi, and David P. Kearns

\section{PART III}

Government instruments in countering terrorism and waging irregular warfare

25 The Joint Terrorism Task Force: investigating to disrupt and prosecute terrorists Ali Soufan

26 Creating the NYPD Counterterrorism Bureau

Michael A. Sheehan

27 The inside story of how the NYPD's Intelligence Division adapted in the wake of $9 / 11$

David Cohen

28 Lessons learned from four high-casualty terrorist attacks in the

United States since 9/11

Paul Cruickshank

29 Social media recruitment of Americans: a case study from the Islamic State Alexander Meleagrou-Hitchens and Seamus Hughes

30 Countering extremist organizations in the information domain

Joseph Mroszczyk and Max Abrahms 
31 Theater Special Operations Command: the operational employment of U.S. Special Operations Forces

Charles T. Cleveland and Liam Collins

32 Theater command in Afghanistan: taking charge of "The Other War" in 2003-2005

David W. Barno

33 America's drone wars outside of conventional war zones

Peter Bergen and A.G. Sims

34 The United Kingdom's approach to counterterrorism

Robin Simcox and Hannah Stuart

Conclusion

492

Hy Rothstein

Index 


\section{ACKNOWLEDGMENT}

The editors would like to thank Mr. Vincent Viola, Michael A. Sheehan's West Point classmate and friend. This handbook would not have been possible without his support. 


\section{PREFACE}

The Routledge Handbook of U.S. Counterterrorism and Irregular Warfare Operations is a volume of chapters intended to provide audiences with a comprehensive background of Islamist terrorist groups and the regions where they operate, an in-depth review of key American and other nations' counterterrorism efforts across the globe, and an examination of government instruments used to combat terrorism and wage irregular warfare. This handbook is unique because it fills the gap in the traditional counterterrorism literature by offering chapters written from the perspective of counterterrorism and irregular warfare practitioners.

The handbook is the brainchild of the late Michael A. Sheehan, the former distinguished chair of the Combating Terrorism Center at the U.S. Military Academy at West Point. Sheehan had a storied career as a U.S. Army Special Forces officer in Latin America, the State Department's coordinator for counterterrorism, the New York City Police Department's deputy commissioner for counterterrorism, and the assistant secretary of defense for special operations and low-intensity conflict at the Pentagon.

He recognized that students at the United States service academies-as well as graduate-level diplomacy, military, intelligence, and security professionals - could be better served by having access to course readings that told the counterterrorism story from an operational, rather than policy, perspective. From the academies, to the war colleges, to graduate programs, the first-hand accounts of this handbook's seasoned authors will benefit members of the armed forces, intelligence community, foreign service, and other security professionals.

Sheehan-with the support of Erich Marquardt, who for seven years served as the editor-in-chief of the U.S. military's premier open source counterterrorism journal, the CTC Sentinel-recruited some of the world's foremost experts on terrorism and irregular warfare to provide the handbook's operational vignettes and other first-hand accounts of the challenges the various authors faced in their missions. Buttressing these accounts are detailed histories of some of the world's most dangerous terrorist groups, as well as contextual knowledge of the regions where they operate, authored by some of the world's leading experts.

Sheehan, who fought multiple myeloma for years, devoted his energy and resources to this handbook up until his untimely passing in 2018. He remained committed to ensuring that this handbook would inform a new generation of students, scholars, and soldiers. He found great energy coordinating with the handbook's various authors and outlining his vision behind the volume.

Although I had discussed the project in its infancy with Sheehan, I did not join the project until later. Having served as the director of the Combating Terrorism Center, the director of the Defense and Strategic Studies Program, the founding director of the Modern War Institute, and the director of the 
Department of Military Instruction at West Point, I could immediately see the need for the handbook and would have used it when I was teaching undergraduate courses at the United States Military Academy and graduate courses at Princeton University.

Although not part of a formal series, this is the fourth terrorism-related volume produced by the staff or former staff of West Point's Combating Terrorism Center. Russell Howard and Reid Sawyer edited the first, Terrorism and Counterterrorism: Understanding the New Security Environment: Readings and Interpretations, which became a textbook "best seller." Howard and Sawyer partnered again to edit Defeating Terrorism: Shaping the New Security Environment. Howard partnered with James J.F. Forest and Joanne Moore to produce Homeland Security and Terrorism: Readings and Interpretations.

This most recent volume continues in the vein of its predecessors: aiming to fill a gap in the counterterrorism and irregular warfare landscape. I hope that readers of this handbook will appreciate the vibrancy of the first-hand accounts and the practitioner perspective that the volume conveys.

Liam Collins 


\section{FIGURES}

3.1 Al-Qaida waves of activity measured by fatalities, 2000-2017. 42

3.2 Al-Qaida's envisioned caliphate. 44

5.1 Countries constituting the Levant. $\quad 72$

8.1 Map of the Horn of Africa. 106

9.1 Map of Southeast Asia. 118

17.1 Major U.S. Special Forces operations in Afghanistan, 2001-2002. 230

19.1 Map of PRTs in northern Afghanistan, 2012. 256

21.1 Map of the Philippines. $\quad 282$

22.1 Phases of French operations in Mali, 2013. 298

24.1 Initial disposition of forces in Syria, March 2018. 324

24.2 ODA 5133 containing the Islamic State in the Hajin Pocket, March 2018.

24.3 Green Village and the desert axis, April/May 2018. 334

24.4 CAT 613 area of operations, April-October 2018. 342

32.1 Five Pillar framework. $\quad 451$

32.2 The Three Wars of Afghanistan. 453

33.1 U.S. air and drone strikes in Pakistan, 2004-2020. 464

33.2 U.S. strikes in Yemen by type of strike, 2002-2020. 466

33.3 U.S. strikes in Somalia by type of strike, 2003-2020. 467

33.4 Deaths from drone strikes in Pakistan, Yemen, Somalia, and Libya, 2004-2020. 469 


\section{ABBREVIATIONS}

ALP

Afghan Local Police

AMAL

Lebanese Resistance Regiments

AMISOM

African Union Mission in Somalia

AOB

advanced operations base

AQAP

AQI

al-Qaida in the Arabian Peninsula

AQIM

al-Qaida in Iraq

AQIS

al-Qaida in the Islamic Maghreb

ASG

al-Qaida in the Indian Subcontinent

CAT

Abu Sayyaf Group

CENTCOM

civil affairs team

CFC-A

U.S. Central Command

CFSOCC-A

Combined Forces Command-Afghanistan

CJSOTF-A

Combined Forces Special Operations Component Command-Afghanistan

CJTF

CIA

CTB

CTD

DEA

EIJ

EOD

ESAF

Combined Joint Special Operations Task Force-Afghanistan

Combined Joint Task Force

Central Intelligence Agency

[New York City Police Department] Counterterrorism Bureau

[New York City Police Department] Counterterrorism Division

Drug Enforcement Administration

Egyptian Islamic Jihad

explosive ordnance disposal

ETSS

El Salvadoran Armed Forces

Europol

Extended Training Services Support

EXEVAL

European Union Agency for Law Enforcement Cooperation

external evaluation

F3EA

find, fix, finish, exploit, and analyze

FARC

Revolutionary Armed Forces of Colombia

FATA

Federally Administered Tribal Areas

FBI

Federal Bureau of Investigation

FGS

Federal Government of Somalia

FMLN

Farabundo Martí National Liberation Front 


\begin{tabular}{|c|c|}
\hline FSB & Federal Security Service \\
\hline GCC & geographic combatant command \\
\hline GDP & gross domestic product \\
\hline GIA & Armed Islamic Group \\
\hline GSPC & Salafist Group for Preaching and Combat \\
\hline ICU & Islamic Courts Union \\
\hline IDF & Israel Defense Forces \\
\hline IRA & Irish Republican Army \\
\hline IRGC & Islamic Revolutionary Guards Corps \\
\hline ISAF & International Security Assistance Force \\
\hline ISI & Islamic State of Iraq \\
\hline ISIS & Islamic State in Iraq and al-Sham \\
\hline ISR & intelligence, surveillance, and reconnaissance \\
\hline JAT & Jamaah Ansharut Tauhid \\
\hline JI & Jemaah Islamiyya \\
\hline JIATF & Joint Interagency Task Force \\
\hline JPAT & Joint Planning and Assistance Team \\
\hline JSOTF-N & Joint Special Operations Task Force-North \\
\hline JSOTF-P & Joint Special Operations Task Force-Philippines \\
\hline JTTF & Joint Terrorism Task Force \\
\hline $\mathrm{K} 2$ & Karshi Khanabad airbase \\
\hline MILF & Moro Islamic Liberation Front \\
\hline MILGP & Military Group \\
\hline MIT & Mujahidin Indonesia Timor \\
\hline MNLA & National Movement for the Liberation of Azawad \\
\hline MNLF & Moro National Liberation Front \\
\hline MSS & mission support site \\
\hline MTT & mobile training team \\
\hline MUJAO & Movement for Oneness and Jihad in West Africa \\
\hline NATO & North Atlantic Treaty Organization \\
\hline NSC & National Security Council \\
\hline NYPD & New York City Police Department \\
\hline ODA & Operational Detachment Alpha \\
\hline ODC & Operational Detachment Charlie \\
\hline OPATT & Operations and Planning Assistance Training Team \\
\hline PFLP & Popular Front for the Liberation of Palestine \\
\hline PACOM & U.S. Army Pacific Command \\
\hline PIJ & Palestinian Islamic Jihad \\
\hline PLO & Palestine Liberation Organization \\
\hline PRF & pro-regime forces \\
\hline PRT & Provincial Reconstruction Team \\
\hline SDF & Syrian Democratic Forces \\
\hline SEAL & Sea, Air, and Land Forces \\
\hline SOCCENT & U.S. Special Operations Command Central \\
\hline SOCPAC & U.S. Special Operations Command Pacific \\
\hline SOCOM & U.S. Special Operations Command \\
\hline SOCSOUTH & U.S. Special Operations Command South \\
\hline SOF & Special Operations Forces \\
\hline
\end{tabular}




\section{Abbreviations}

$\begin{array}{ll}\text { SOUTHCOM } & \text { U.S. Southern Command } \\ \text { TAT } & \text { Tactical Analysis Team } \\ \text { TF } & \text { task force } \\ \text { TSOC } & \text { Theater Special Operations Command } \\ \text { UK } & \text { United Kingdom } \\ \text { UNAMA } & \text { United Nations Mission in Afghanistan } \\ \text { USAID } & \text { U.S. Agency for International Development } \\ \text { USSR } & \text { Union of Soviet Socialist Republics } \\ \text { VEO } & \text { violent extremist organization } \\ \text { VSO } & \text { Village Stability Operations } \\ \text { VTC } & \text { video teleconference } \\ \text { WMD } & \text { weapons of mass destruction }\end{array}$




\section{CONTRIBUTORS}

Max Abrahms is a professor of political science and public policy at Northeastern University. He has published extensively on terrorism, with articles in International Organization, International Security, International Studies Quarterly, Security Studies, Comparative Political Studies, Harvard Business Review, Foreign Affairs, Foreign Policy, and the New York Times. He has had affiliations with the Center for International Security and Cooperation at Stanford University, the Dickey Center at Dartmouth College, the Council on Foreign Relations, and the Belfer Center.

Cecil E. Bailey is a retired U.S. Army Special Forces officer with two tours in El Salvador, the second as the Military Group operations officer. He also served as Army attaché to Honduras during the Central American Peace Plan; Army Staff Directorate Strategy, Plans and Policy during Desert Storm; and Crisis Management Team, Office of the Secretary of Defense, during the Haitian and Cuban migrant crises. He received a master's degree from Georgetown University.

David W. Barno is a retired U.S. Army lieutenant general and a visiting professor of strategic studies and a senior fellow at the Merrill Center at Johns Hopkins School of Advanced International Studies. He is also a contributing editor at War on the Rocks. Barno served as the overall U.S. and coalition commander in Afghanistan from 2003 to 2005. After leaving active duty, he served as the director of the Near East South Asia Center for Strategic Studies at the National Defense University and later as a senior advisor and senior fellow at the Center for a New American Security.

Peter Bergen is vice president for global studies and fellows at New America, CNN national security analyst, professor of practice at Arizona State University, and the author or editor of nine books, three of which were New York Times bestsellers and four of which were named among the best non-fiction books of the year by the Washington Post. The books have been translated into 21 languages. Together with Daniel Rothenberg, he edited Drone Wars: Transforming Conflict, Law, and Policy.

Benedetta Berti is associate researcher at the Institute for European Studies at Vrije Universiteit Brussels, visiting professor at the College of Europe, and a senior fellow at the Foreign Policy Research Institute. Her researchfocusing on armed groups, internal wars, and protection of civilians - has appeared in multiple publications, and she has authored four books, including Armed Political Organizations: From Conflict to Integration. 
Donald C. Bolduc is a U.S. Army Special Forces officer who retired as a brigadier general after 33 years of service. He conducted 10 deployments to Afghanistan, including assignments as a commander of Combined Forces Special Operations Component Command-Afghanistan; Combined Joint Special Operation Task Force-Afghanistan; and Task Force-31 while serving as the battalion commander for 1st Battalion, 3rd Special Forces Group. He also served as the commander of Special Operations Command Africa. He is an associate professor at New England College.

Mark Bowden is the author of 13 books, including the \#1 New York Times bestseller Black Hawk Down. He reported at the Philadelphia Inquirer for 20 years and now writes for The Atlantic. His most recent book is a collection of stories entitled The Case of the Vanishing Blonde.

Peter Chalk is a subject matter expert with Valens Global and the Institute for Security Governance, an adjunct senior political scientist with RAND, and associate editor of Studies in Conflict and Terrorism. Chalk has regularly testified before the U.S. Senate on issues pertaining to national and international terrorism and is the author of numerous books and publications on low-intensity conflict in the contemporary world.

Charles T. Cleveland is a 1978 West Point graduate who retired as a lieutenant general in 2015, his last tour as commanding general, U.S. Army Special Operations Command. He has the distinction of commanding two separate Theater Special Operations Commands for six consecutive years, 2005-2011. As 10th Special Forces Group (Airborne) commander during the 2003 invasion of Iraq, he commanded Task Force Viking, which included over 5,000 Special Operations Forces and 65,000 Kurdish peshmerga. He serves as an Army War College senior mentor and adjunct at RAND. Cleveland and Mary Ann, his wife of 42 years, have three adult children.

David Cohen has had a nearly five-decade career in intelligence, including 35 years with the Central Intelligence Agency and 12 years as NYPD deputy commissioner for intelligence. During his CIA career, Cohen served as deputy director of operations overseeing the CIA's clandestine collection, covert action, and counterintelligence activities and its global network of personnel, as well as its relationships with foreign government security and intelligence services. Previously, he was the CIA's associate deputy director of intelligence and oversaw all CIA economic, political, and military analysis and reporting provided to the president and national security leadership.

Liam Collins is a retired U.S. Army Special Forces colonel who conducted operational deployments to Afghanistan, Iraq, South America, the Horn of Africa, and Bosnia. He was the founding director of the Modern War Institute at West Point, the director of the Combating Terrorism Center at West Point, a fellow at New America, and a permanent member with the Council on Foreign Relations. Collins' work has been cited by the assistant to the president for homeland security and counterterrorism, the White House press secretary, the New York Times, the Associated Press, CNN, ABC News, Fox News, NPR, the Wall Street Journal, and USA Today. He holds a PhD from Princeton University.

Paul Cruickshank is the editor-in-chief of the CTC Sentinel, the flagship publication of the Combating Terrorism Center at West Point. As CNN's terrorism analyst between 2010 and 2021, he contributed to the network's coverage for more than a decade. He is the co-author of Nine Lives: My Time as MI6's Top Spy Inside al Qaeda and Agent Storm: My Life Inside al Qaeda and the CIA.

Jack Devine is a 32-year veteran of the Central Intelligence Agency, who served as acting director and associate director of the CIA's operations outside the United States from 1993-1995. Previously, Devine 
headed the CIA's Afghan Task Force, headed the CIA's Counternarcotics Center, served as chief of the Latin American Division, and was the principal manager of the CIA's sensitive projects in Latin America. $\mathrm{He}$ is the president of The Arkin Group and author of Good Hunting: An American Spymaster's Story and Spymaster's Prism: The Fight Against Russian Aggression.

Brian Fishman previously served as the director of research at the Combating Terrorism Center at West Point and maintains affiliations with the Combating Terrorism Center, New America, Stanford University's Center for International Security and Cooperation, and the University of California, Berkeley. He currently serves as a policy director at Facebook responsible for countering dangerous organizations. Fishman authored The Master Plan: ISIS, al-Qaeda, and the Jihadi Strategy for Final Victory and co-authored Al-Qa'ida's Foreign Fighters in Iraq: A First Look at the Sinjar Records.

James J.F. Forest is a professor at the University of Massachusetts Lowell and a visiting professor at the Fletcher School of Law and Diplomacy, Tufts University. He has published 20 books and dozens of research articles and is co-editor of the peer-reviewed journal Perspectives on Terrorism. Forest previously served as director of terrorism studies at the Combating Terrorism Center at West Point.

Alice Hunt Friend was the principal director for African affairs in the Office of the Under Secretary of Defense for Policy from 2012 to 2014. She has also worked at the Center for Strategic and International Studies and as an adjunct lecturer at American University in Washington, DC. She holds a doctorate and master's degree in international relations from American University and a bachelor's degree in government from Smith College.

Luke Hartig is a fellow in New America's International Security Program and a senior vice president at National Journal. Previously, Hartig served as senior director for counterterrorism at the National Security Council and deputy director for counterterrorism operations in the Office of the Secretary of Defense.

Christopher Heffelfinger is the author of Radical Islam in America: Salafism's Journey from Arabia to the West. He previously served as a fellow at the Combating Terrorism Center at West Point and the Global Terrorism Research Centre at Monash University, Australia. He has also worked for the Federal Bureau of Investigation in various teaching, analytical, and investigative capacities.

Chris Hensley is a retired U.S. Army Special Forces officer. He conducted six deployments to Afghanistan and one each to Kuwait, Jordan, and Kazakhstan. Hensley is currently a strategic planner for Booz Allen Hamilton in the U.S. Special Operations Command Central.

Kevin M. Higgins is a retired U.S. Army Special Forces colonel and former U.S. State Department personal service contractor. He was the Military Group commander, U.S. Embassy Bogota, and helped design and execute Plan Colombia (1999-2001) and the State Department's Airmobile Operations advisor to the Colombian Antinarcotics Police (2001-2011). Higgins has conducted missions in 22 countries and has worked overseas for 34 years, primarily in Latin America.

Seamus Hughes is the deputy director of the Program on Extremism at George Washington University. He has authored numerous reports, including "ISIS in America: From Retweets to Raqqa" and "The Threat to the United States from the Islamic State's Virtual Entrepreneurs." He previously worked at the U.S. National Counterterrorism Center, serving as a lead staffer on government efforts to implement a national Countering Violent Extremist strategy. Hughes also served as the senior counterterrorism advisor for the U.S. Senate Homeland Security and Governmental Affairs Committee. 
Rob Johnson is the director of the Changing Character of War Center at the University of Oxford. He has assisted U.S. forces in Afghanistan on campaign design, the Afghan National Army's leadership development, and the Afghan local forces initiatives and advised NATO, the U.S. Army, and America's partners on strategic analysis, operations, and information warfare. Johnson authored The Afghan Way of War and has published extensively on insurgency, counterinsurgency, and conflicts in the region.

Seth G. Jones is the senior vice president, Harold Brown Chair, and the director of the International Security Program at the Center for Strategic and International Studies, as well as a lecturer at Johns Hopkins University's School for Advanced International Studies. Jones served in several civilian positions in U.S. Special Operations Command, including Afghanistan. He authored Three Dangerous Men, A Covert Action, Waging Insurgent Warfare, Hunting in the Shadows: The Pursuit of al Qa'ida after 9/11, and In the Graveyard of Empires: America's War in Afghanistan.

David P. Kearns served as an engineer and Special Operations Civil Affairs officer in the U.S. Army for 10 years. During this time, he supported operations across Europe and the Middle East, including deployments to Syria, Afghanistan, and Lebanon. He currently works as a civilian instructor at the U.S. Army Special Operations Captains Career Course while continuing uniformed service in the U.S. Army Reserves.

Elisabeth Kendall is senior research fellow in Arabic and Islamic Studies at Pembroke College, University of Oxford. She spends significant time in the field, particularly in Yemen, examining how militant jihadi movements win local audiences. Kendall is the author or editor of several books, including Reclaiming Islamic Tradition (with Ahmad Khan); Twenty-First Century Jihad (with Ewan Stein); Literature, Journalism and the Avant-Garde; Diplomacy Arabic; and Media Arabic. She has presented her research at various academic, intelligence, and military establishments and parliaments and government ministries around the world and is a regular contributor to the international media.

Nick Lewis-Walls is a U.S. Army Special Forces officer who has deployed to Syria and Afghanistan. He holds a master's degree in Global Affairs from Yale University's Jackson Institute and was a U.S. Army General Wayne A. Downing Scholar.

Erich Marquardt has a long-standing editing, research, and writing career. His reports for the Jamestown Foundation were widely disseminated among scholars and practitioners alike. In addition, he founded the U.S. military's premier open-source counterterrorism journal, the CTC Sentinel, and served as editor-inchief for seven years. His oversight of the CTC Sentinel made it an essential publication for experts, academics, and the general public on counterterrorism issues. He has a Master of Arts in security studies from University of Massachusetts-Lowell.

Amanda Mattingly is a managing director at The Arkin Group. Previously, she worked in the Bureau of Western Hemisphere Affairs at the U.S. State Department and the Inter-American Affairs Office at the National Security Council.

David S. Maxwell is a senior fellow at the Foundation for Defense of Democracies. A retired U.S. Army Special Forces colonel, he commanded 1st Battalion, 1st Special Forces Group in Okinawa, including the first deployment to Mindanao for Operation Enduring Freedom-Philippines in 2001-2002. He later commanded the Joint Special Operations Task Force-Philippines in 2006-2007. He is on the board of directors for the Committee for Human Rights in North Korea, the Small Wars Journal, and the OSS Society. He earned a master's degree in National Security from National Defense University. 
Alexander Meleagrou-Hitchens is the research director of the Program on Extremism at George Washington University and lecturer in Terrorism and Radicalisation at King's College London. He is the author of Incitement: Anwar al-Awlaki's Western Jihad and Homegrown: ISIS in America.

Ken Menkhaus is C. Louise Nelson professor of political science at Davidson College. He specializes on the Horn of Africa, focusing primarily on conflict analysis, peacebuilding, humanitarian response, and political Islam. He has published more than 50 articles and chapters on Somalia and the Horn of Africa, including the monograph Somalia: State Collapse and the Threat of Terrorism, "Governance without Government in Somalia" in International Security, and "Terrorism, Security, and the State" in the Routledge Handbook of African Politics. He has been an adjunct instructor for the Combating Terrorism Center's practitioner education program since 2007.

Anthony Messenger is an active duty U.S. Army Special Forces officer. He has deployed to Syria, Iraq, the United Arab Emirates, Jordan, and Qatar. He holds a master's degree in international relations from the University of Kansas.

Keith Mines is director for Latin America at the U.S. Institute of Peace. A former senior Foreign Service Officer and Special Forces officer, Mines has worked on counterinsurgency in Central America; peace efforts in Israel and the West Bank; post-conflict stabilization and political consolidation in Haiti, Iraq, and Afghanistan; NATO expansion in Hungary; counternarcotics in Mexico; and famine relief in Somalia and Darfur. His book, Why Nation Building Matters: Political Consolidation, Building Security Forces, and Economic Development in Failed and Fragile States, recounts many of these experiences.

Mark E. Mitchell is a highly decorated Special Forces combat veteran with extensive experience in the Middle East and South Asia. He was awarded the Distinguished Service Cross for his actions in the November 2001 Battle of Qala-i-Jangi in Mazar-i-Sharif. He commanded the 5th Special Forces Group and served as a director for counterterrorism on the National Security Council. Mitchell also served as a senior fellow at the Combating Terrorism Center at West Point and as the principal deputy and acting assistant secretary of defense for special operations and low-intensity conflict.

Joseph Mroszczyk is a defense contractor working as a war gaming specialist in support of the U.S. Naval War College. He has previously worked at the Department of Homeland Security, with the Human Terrain System program in Iraq, and in various private sector intelligence-related roles. He also serves as an officer in the U.S. Navy Reserve and has deployed to East Africa.

Román D. Ortiz is the vice president of Cordillera Applications Group and the adjunct professor with the William J. Perry Center for Hemispheric Defense Studies at National Defense University. Previously, he worked as a consultant to the U.S. Agency for International Development and CNA Corporation, for which he developed projects on Latin American security and defense affairs. Between 2010 and 2014, he was advisor to the Colombian minister of defense on counterinsurgency, counterterrorism, and counternarcotics. During this period, he advised the planning and execution of the "Sword of Honor" campaign that played a critical role in the reduction of the guerrilla threat in Colombia.

Mike Parker is an active duty U.S. Army Special Forces officer. He has deployed to Syria, Iraq, Afghanistan, Jordan, and Turkey. He holds a Master of Business Administration from North Carolina State University. 
Bert Pedrigi is an active duty U.S. Army Special Forces officer. He has deployed to Syria, the United Arab Emirates, and Afghanistan.

Hy Rothstein is a retired U.S. Army Special Forces colonel who recently retired from the faculty at the Naval Postgraduate School in Monterey, CA. He spent considerable time in Afghanistan, Iraq, and the Philippines, observing the conduct of those wars. He has written and edited books about Afghanistan and Iraq and a comprehensive volume on military deception, as well as a short anthology that explores the similarities between insurgency and gang violence. He earned his $\mathrm{PhD}$ in international relations from the Fletcher School at Tufts University.

Daniel Rudder served as a member of the New York City Police Department's Counterterrorism Bureau. His work focused on monitoring international terrorist threats and providing actionable analyses to NYPD and Joint Terrorism Task Force officials. Rudder has spent two decades gathering and analyzing intelligence in support of national security, foreign policy, and investment objectives, most recently as a partner at Control Risks, the global intelligence, security, and political risk consulting firm.

Michael A. Sheehan retired after a 20-year career as a Special Forces officer in the U.S. Army before a storied career as the U.S. Department of State's coordinator for counterterrorism, the New York City Police Department's deputy commissioner for counterterrorism, the assistant secretary of defense for special operations and low intensity conflict at the Pentagon, and distinguished chair for the Combating Terrorism Center at West Point. He authored Crush the Cell: How to Defeat Terrorism Without Terrorizing Ourselves. He passed away in 2018 after a long battle with cancer.

Pascale C. Siegel is the managing director in the geopolitical intelligence division at Ankura Consulting Group. She is an international affairs expert specializing in sociopolitical analysis, strategic influence, and cross-cultural communications issues. She has participated in multinational strategic simulations and war games on current complex problems such as violent extremism, the future of international organizations, and regional developments in Western Africa or Europe.

Robin Simcox is the director of the Counter Extremism Group. Previously, Simcox was the Margaret Thatcher Fellow at the Heritage Foundation, where he oversaw counterterrorism policy. He has testified before the U.S. Congress on issues related to global terrorism; his analysis is widely published in newspapers, magazines, and journals; and he provides comment for media outlets around the world.

A.G. Sims is a writer and editor and was previously a policy analyst for the International Security Program at New America, where she researched and wrote about the U.S. drone program and other counterterrorism topics.

Ali Soufan is the chief executive officer of The Soufan Group and a member of the U.S. Homeland Security Advisory Council. As a former supervisory special agent with the Federal Bureau of Investigation, he investigated and supervised international terrorism cases, including the East Africa U.S. Embassy bombings, the USS Cole attack, and 9/11. Soufan authored Anatomy of Terror: From the Death of bin Laden to the Rise of the Islamic State and the New York Times bestseller The Black Banners: The Inside Story of 9/11 and the War Against al Qaeda, winner of the 2012 Ridenhour Book Prize.

Hannah Stuart is director of research at the Counter Extremism Group. She specializes in extremism and has written reports on radicalization, terrorism, and jihadi ideology, as well as civility and religion in 
public life. Stuart was previously head of research at the UK government's independent Commission for Countering Extremism, where she led the Commission's report to the home secretary on extremism in England and Wales.

Alex Vatanka is a senior fellow at the Middle East Institute, a senior fellow in Middle East Studies at the U.S. Air Force Special Operations School at Hurlburt Field, and adjunct professor at DISAS at WrightPatterson Air Force Base. He authored The Battle of the Ayatollahs in Iran: The United States, Foreign Policy and Political Rivalry Since 1979 and Iran and Pakistan: Security, Diplomacy, and American Influence. 


\title{
INTRODUCTION
}

\author{
Liam Collins
}

Al-Qaida's 9/11 attacks were a seminal event in modern history and fundamentally changed the way in which the world viewed terrorism and shaped various counterterrorism responses. Within 24 hours, NATO invoked Article 5 for the first time in its history. One week later, the United States Congress passed the Authorization for Use of Military Force, the equivalent of a declaration of war in the modern era, against "those nations, organizations, or persons [the president] determines planned, authorized, committed or aided the terrorist attacks . . or harbored such organizations or persons."

Within a few short weeks, an international team-spearheaded by the Central Intelligence Agency and Special Operations Forces and supported by U.S. airpower-conducted an unconventional warfare campaign that toppled the Taliban regime. ${ }^{2}$ Yet two decades later, the United States still has troops in Afghanistan, and the threat from Islamist terrorist groups has expanded and contracted in various countries throughout the region and the world: al-Qaida in Iraq, the Islamic State throughout the region, al-Qaida in the Islamic Maghreb, Boko Haram in Nigeria, al-Qaida in the Arabian Peninsula, al-Shabaab in the Horn of Africa, Jemaah Islamiyya in Indonesia, and the Abu Sayyaf Group in the Republic of the Philippines, among others. It is estimated that the United States alone has spent trillions of dollars on counterterrorism efforts, yet the threat landscape is arguably worse now than it was on $9 / 11 .^{3}$

While researchers', analysts', and policymakers' understanding of terrorism-such as the various groups' motivations and capabilities - has grown immensely over the past two decades, similar advancements in the understanding of counterterrorism lag. Thus, this handbook seeks to expand this knowledge, with a special focus on operational-level case studies.

Another distinguishing characteristic of this handbook is its expansion from a narrow focus on counterterrorism to a broader examination that includes irregular warfare. For context, however, it is important to define and discuss both terms. The U.S. Department of Defense defines counterterrorism as "activities and operations taken to neutralize terrorists and their organizations and networks in order to render them incapable of using violence to instill fear and coerce governments or societies to achieve their goals." ${ }^{4}$ Irregular warfare is "a violent struggle among state and non-state actors for legitimacy and influence over the relevant population(s)." 5

According to U.S. military doctrine, counterterrorism is an irregular warfare activity. Other irregular warfare activities include foreign internal defense, security force assistance, counterinsurgency, stability operations, strategic communications, psychological operations, information operations, civil-military operations, intelligence and counterintelligence, and law enforcement. ${ }^{6}$ Over time, the scope of counterterrorism has broadened from "narrowly defined 'offensive operations' typically conducted by [Special 
Operations Forces] to one that incorporates . . . a wide range of actions through 'direct and indirect approaches' in unified action against violent extremism." ${ }^{7}$

Counterterrorism operations are often conducted in support of other irregular warfare operations, or these same operations may be conducted in support of counterterrorism operations. ${ }^{8}$ Thus, when studying counterterrorism, it is necessary to take a broader examination where counterterrorism may be the lead strategy or a supporting operation as part of a larger strategy.

A second reason this expansion is necessary is that the counterterrorism responses by the United States and many other nations in the immediate aftermath of $9 / 11$ and in the successive decades were shaped by their pre-9/11 counterterrorism and irregular warfare experiences. Nations relied on existing meansorganizations, procedures, policy, culture, and experience-to combat this "new" threat while building novel capabilities, organizations, and authorities. As such, it is important to understand how organizational entropy impacted post-9/11 operations and strategy; for example, how U.S. Special Operations Forces employment in the 1990s shaped their employment in the 2000s.

A third reason a broader view of counterterrorism is necessary is the fact that many of today's terrorist groups do not fit neatly into the single category of "terrorist group." As Fishman notes in his chapter on the Islamic State, "Even as the Islamic State built a military and administrative capability for its new caliphate, the group prepared terrorist attacks around the globe and used insurgent tactics to counter an ever-growing list of enemies." He continues,

The group did not fit neatly into traditional analytical categories: it was a pseudo-state, a terrorist group, and an insurgency simultaneously. This complexity both complicated analysis of the organization's rise and challenged traditional metrics for determining progress and victory in the war against them. ${ }^{9}$

Thus, if a group is a pseudo-state, a terrorist group, and insurgency at the same time, then counterterrorism operations are only one part of the solution.

Therefore, counterterrorism efforts against the Islamic State and other terrorist groups require a much broader approach that includes irregular warfare in which counterterrorism may play a supporting rather than a leading role. Back in 2009, when the Obama administration sought to determine its strategy for Afghanistan, the debate often came down to whether it should adopt a counterinsurgency strategy or a counterterrorism strategy. ${ }^{10}$ It was never really a binary choice but a debate as to whether to adopt a primarily counterinsurgency strategy with counterterrorism operations in support or to adopt a primarily counterterrorism strategy with counterinsurgency operations in support.

Another unique aspect of this handbook is its focus on operational cases and the government instruments used to combat terrorism and wage irregular warfare. Few terrorism handbooks examine counterterrorism cases, and the few that do often focus on the strategic or policy levels. This handbook focuses on the operational or campaign level, which is not to be confused with the tactical level, which includes battles, engagements, and small-unit and crew actions. ${ }^{11}$

Of course, expanding the handbook to include an examination of irregular warfare and operational case studies comes with trade-offs. As indicated by the handbook's title, it is not aimed to be an all-inclusive guide to terrorism. As such, it will not address every terrorist group; it focuses primarily on Islamist, and especially Sunni, extremist groups because they have commanded most of the West's attention over the past two decades in its "long war." Likewise, it does not seek to explain the individual pathways to violent extremism, nor does it analyze in depth why groups choose to adopt terrorism to achieve their goals. While that work is extremely important, it is simply not possible to include in this handbook without eliminating the important operational case studies that make this handbook unique.

This handbook is divided into three parts. The first examines terrorist groups, including al-Qaida and its various affiliates; the Islamic State; and other groups in the Middle East, Southeast Asia, and Latin 
America. The second part includes operational case studies, including examinations of pre-9/11 operations in Latin America, to post-9/11 operations in Afghanistan, Iraq, the Philippines, Mali, Yemen, and Syria. The final section examines a number of government instruments or constructs used to combat terrorism and wage irregular warfare. It examines the counterterrorism efforts of the New York City Police Department after 9/11, command constructs used to wage counterterrorism and irregular warfare campaigns, drone warfare, and the role of social media as a terrorist and counterterrorist tool.

\section{Part I: the threat and regional security issues}

Part I provides a review of modern terrorism in the Islamic world and an overview of the major terrorist groups from the past three decades. In addition to providing a history of al-Qaida, it examines the Islamic State, Hezbollah, Hamas, al-Qaida in the Arabian Peninsula, al-Qaida in the Islamic Maghreb, Boko Haram, al-Shabaab, Jemaah Islamiyya, the Abu Sayyaf Group, the Taliban, and terrorism in Latin America. It examines these groups from a regional and a broader political violence perspective, with chapters authored by renowned terrorism experts.

James J.F. Forest, in "The evolution of Islamist terrorism in the 20th century," discusses terrorism in the Islamic world over the past half-century, accounting for the rise and sometimes fall of several prominent terrorist groups, and explains how this historical evolution impacts the understanding of the Islamist terrorist threat today. He provides a review of the Muslim Brotherhood, a movement that served as the primary contributor to the evolution of Islamist terrorism, and a brief history of terrorism in the Palestinian Territories, the Levant, North Africa, and Asia.

In their chapter "The ideology behind al-Qaida and the Islamic State," Daniel Rudder and Christopher Heffelfinger review the evolution of Islamism, beginning with an examination of Ibn Taymiyya's historical role in shaping militant interpretations of Islam. It then takes up the reformers and activists of the 19th and 20th centuries who revived Ibn Taymiyya's ideas to effect change in their societies and connects these earlier foundational movements to modern, militant jihadi groups like al-Qaida that found rationales within them to carry out terrorist attacks.

No volume would be complete without a discussion on al-Qaida. As such, Seth G. Jones conducts a detailed examination of the group in his chapter, “The evolution of al-Qaida: 1988 to present day." Jones finds that despite some key successes along the way, al-Qaida is no closer to achieving its ambitious goal of a pan-Islamic caliphate than it was 30 years ago and has been unable to successfully perpetrate a major terrorist attack in the United States since 9/11.

In "The history of the Islamic State: from Abu Musab al-Zarqawi to Abu Bakr al-Baghdadi," Brian Fishman describes the evolution of the Islamic State, a group that, by 2014, had eclipsed al-Qaida in both reach and reputation. Fishman recounts the group's rise to power, culminating with its control of large swaths of territory in Syria and Iraq. Yet the group's unwillingness to build sustainable alliances hardened its enemies and contributed to a slow crippling resource drain that has furthered its decline. While the group lost most of its territory, it remains capable of disrupting societies in the Middle East and projecting terrorism globally.

In "Contemporary conflict and political violence in the Levant," Benedetta Berti examines how the unresolved "Palestine question" and the Arab-Israeli conflict have contributed to the development of terrorist groups in the Levant. In accounting for the conflict dynamics in the region, Berti examines the role played by non-state armed groups, focusing on the Palestine Liberation Organization, Hezbollah, and Hamas.

By 2012, U.S. intelligence officials considered al-Qaida in the Arabian Peninsula al-Qaida's "most dangerous affiliate." ${ }^{2}$ While the group's power has waned, Yemen, and the threat of Islamist militancy emanating from its borders, must be understood. As such, Elisabeth Kendall addresses this threat in "Jihadi militancy and Houthi insurgency in Yemen." She provides an overview of Yemen's modern history, which 
is necessary to understand the origins of today's conflicts. Kendall also examines the emergence and development of al-Qaida in the Arabian Peninsula and the Islamic State in Yemen, assessing the goals, strategies, and successes of each. Finally, she describes how the Houthi insurgency managed to take over the government and overrun much of the country in 2014.

In "The roots of terrorism in North and West Africa: AQIM and Boko Haram," Alice Hunt Friend reviews the region's two most prominent terrorist groups. Friend examines their roots; the political conditions that motivated their historical and contemporary manifestations; and how the regional governments, in particular Algeria and Nigeria, have acted to combat them.

Ken Menkhaus discusses the most significant terrorist group on the eastern side of the African continent in his chapter, "Al-Shabaab and the Horn of Africa." Al-Shabaab emerged in 2006 as a cadre of hard-core Islamist fighters within Somalia's Islamic Courts Union; by 2012, al-Shabaab became an official al-Qaida affiliate. The group remains the most dangerous terrorist group operating in the Horn today. Menkhaus examines the evolution and growth of al-Shabaab and factors that have allowed it to remain resilient in the face of persistent U.S. and international opposition.

In "The history of terrorism in Southeast Asia," Peter Chalk examines terrorism in Indonesia, the Philippines, and Thailand. While these countries have a long history with terrorism and sub-state political violence dating to the struggle of ethno-nationalism and religious groups fighting for minority selfdetermination during the Cold War, the challenge posed by militant extremism has risen in recent decades. Beyond addressing the region's most significant groups of the past two decades - the Philippines' Abu Sayyaf Group and Indonesia's Jemaah Islamiyya - he also discusses the Moro National Liberation Front, the Moro Islamic Liberation Front, the Bangsamoro Islamic Freedom Fighters, the New People's Army, and southern Thailand's "Old" and "New Guard" of Islamist militants.

In 1978, communists seized Kabul, setting in motion a string of events that ultimately led to the rise of the Taliban and al-Qaida. In "The Taliban and the modern history of Afghanistan," Rob Johnson describes how Afghanistan's civil war and the anti-Soviet insurgency led to the rise of the Taliban and how that group took power in Kabul in 1996. Johnson also examines the key themes of the post-9/11 conflict in the state: insurgency, terrorism, narcotics, governance, and military assistance. While the Taliban's power has surged since being ousted in 2001, the Taliban has yet to dislodge U.S. forces or dispose the Afghan government.

In 1979, the Supreme Leader Ayatollah Ruhollah Khomeini overthrew the Shah, signaling the modern world's first theocracy. It also signaled the end of close economic, military, and strategic ties that the United States had enjoyed with Iran since 1941. In "The modern history of Iran and the birth of the Shia proxy model," Alex Vatanka provides a short history of contemporary Iran before outlining the challenges that the Iranian Islamist regime poses from an American perspective. He describes how military conflicts-where Iran has been a direct participant or an influential actor-have influenced the evolution of Iranian foreign policy and what it signals for Tehran's future priorities on the regional and international stages.

In "Terrorism, insurgency, and criminal insurgency in Latin America," Román D. Ortiz examines the evolution of the region's terrorist threats over the past 40 years with a focus on El Salvador's Farabundo Marti Liberation Front, Peru's Shining Path, the Revolutionary Armed Forces of Colombia, the United Self-Defense Groups of Colombia, and Mexico's Los Zetas. Ortiz also reviews the activities of Islamist terrorist groups in the region, specifically Hezbollah and the Islamic State.

\section{Part II: operational case studies}

Part II explores a wide variety of counterterrorism and irregular warfare operations, spanning from the 1980s to the irregular warfare campaign against the Islamic State in northern Syria in 2018. It examines American irregular warfare operations in El Salvador, Colombia, Nicaragua, and Afghanistan in the 1980s, as well as operations in Afghanistan, Iraq, The Philippines, Mali, Yemen, and Syria after 9/11. The irregular warfare campaigns of the 1980s and 1990s shaped the counterterrorism operations in the post-9/11 era. 
Most of the chapters are authored by accomplished practitioners who were deeply involved in the operations in which they describe, while others are told by subject matter experts.

Cecil E. Bailey, a retired Special Forces officer with two tours in El Salvador, authors "El Salvador: Operations and Planning Assistance Training Teams and a minimalist approach to counterinsurgency." The role of the United States in helping end El Salvador's long counterinsurgency is understudied despite being considered a relative success. In contrast to the American experiences in Vietnam and Iraq, the United States followed a "minimalist" approach with its military support. Bailey recounts the history of the small, Special Forces Operations and Planning Assistance Training Teams and offers lessons for security assistance in counterinsurgency campaigns.

In "Plan Colombia and the U.S. Army's 7th Special Forces Group," retired Special Forces officer Kevin M. Higgins recounts the history of U.S. support to Colombia, starting with its assistance to Andean Ridge police units in 1987. Higgins spent a good portion of his military career in the region, including 1999-2001, when he served as the Military Group commander at the U.S. Embassy in Bogota, where he helped design and execute Plan Colombia.

Renowned author Mark Bowden recounts the killing of Colombian drug kingpin Pablo Escobar. In "The story of the U.S. role in the killing of Pablo Escobar," Bowden details U.S. support to the Colombian government efforts to target Escobar and other Colombian drug lords. The covert support-consisting largely, but not exclusively, of intelligence support - ultimately contributed to the killing of Escobar. Yet the support raised a number of legal and ethical challenges that Bowden addresses in the chapter.

Jack Devine, a 32-year Central Intelligence Agency veteran, and Amanda Mattingly, a former National Security Council staffer and foreign service officer, explore two of the most consequential proxy wars of the Cold War in "The Iran-Contra Affair and the Afghan Task Force: lessons in covert action." When President Reagan came to office in 1981, he brought a national security team focused on defeating the Soviet Union and winning the Cold War. For Reagan and his team, this meant taking the fight to the Soviets, their surrogates, and the nations they threatened. The authors examine key lessons learned in why covert action largely failed in Nicaragua but succeeded in Afghanistan.

The first post-9/11 case study begins with the primary account of Mark E. Mitchell in "The horse soldiers: lessons from expeditionary unconventional warfare." Mitchell, a highly decorated Special Forces combat veteran, was one of the first "horse soldiers" to deploy to Afghanistan and later served as the acting assistant secretary of defense for special operations and low-intensity conflict at the Pentagon. Mitchell recounts his experiences and the challenges he encountered working with Northern Alliance forces and reveals how the Northern Alliance-supported by the Central Intelligence Agency, Special Operations Forces, and airpower- toppled the Taliban regime in a few short weeks.

Donald C. Bolduc and Chris Hensley, two Special Forces officers and veterans of multiple combat tours in Afghanistan, team up to author "Special Operations Forces and Afghan Local Police programs." They recount the development and application of Village Stability Operations and Afghan Local Police programs in Afghanistan from 2009-2013. This unique approach integrated security, development, and governance through a balanced, mutually supportive method that addressed many of the underlying sources of instability in rural Afghanistan. While not a panacea for all security and stability issues, the authors provide lessons that may prove valuable when considering the employment of irregular forces in similar environments.

Although a former Special Forces officer, Keith Mines pens his chapter, "U.S. civilian architecture for stabilization and counterinsurgency in Northern Afghanistan (2012-2013)," based on his experience as a foreign service officer in Mazar-i-Sharif. He describes the challenging operating environment that Afghanistan faced and the three "lines of effort"-economy, security and the rule of law, and governance- that he attempted to advance. After his year in Afghanistan, he noted that progress had been made, but the gains were far from irreversible without continued U.S. and international commitment.

In "Dismantling al-Qaida in Iraq," I detail how the operators and intelligence professionals under General Stanley McChrystal transformed his task force into a highly efficient and effective network, taking 
thousands of terrorists off the battlefield and greatly reducing the number of suicide attacks in the country. It also includes a vignette that describes how the task force located and ultimately killed Abu Musab alZarqawi, the leader of al-Qaida in Iraq.

Retired Special Forces Colonel David S. Maxwell provides lessons in training and advising a partner force in his chapter, "Operation Enduring Freedom-Philippines: lessons in special warfare." The chapter is based on Maxwell's experience in 2001-2002 as a Special Forces battalion commander who commanded the first deployment to Mindanao in support of Operation Enduring Freedom-Philippines and in 2006-2007 as the commander of the Joint Special Operations Task Force-Philippines. He examines U.S. strategy and operations through the lens of special warfare, a special operations activity based on persistent engagement to achieve long-term effects.

The late Ambassador Michael A. Sheehan joined with Pascale C. Siegel to pen "Operation Serval: a swift intervention with a small footprint in Mali." They describe how a group of Tuareg separatists from the National Movement for the Liberation of Azawad, backed by al-Qaida in the Islamic Maghreb, attacked government outposts in northern Mali and launched a separatist insurgency in January 2012. By April, the rebels had captured the major population centers in northern Mali and imposed a harsh form of Sharia (Islamic law). With little action from the international community, the rebels gained strength and sent a column of fighters toward the capital less than a year later. The authors describe how a swift, measured, and efficient French-led response-with critical U.S. support—saved the capital from collapse and quelled the jihadi-backed uprising. It provides a model of allied and multilateral cooperation.

In "U.S. counterterrorism policy in Yemen from 2010-2020," Luke Hartig, former senior director for counterterrorism at the National Security Council, outlines U.S. counterterrorism policy in Yemen from 2010-2020, with a particular focus on the Obama administration's efforts to counter al-Qaida in the Arabian Peninsula and respond to a Houthi power grab in Sanaa. He provides context about how al-Qaida maintains ties to local tribal groups in Yemen and operates in ungoverned spaces, which has allowed the group to persist as a terrorist threat to the United States. American efforts in Yemen have largely failed, and Hartig provides an explanation of what went wrong.

In "Defeating the Islamic State: Special Operations Forces in Syria," five Special Forces and Civil Affairs officers collaborate to describe their experience working with the Syrian Democratic Forces to defeat the Islamic State in northern Syria in 2018. They demonstrate the challenge of working with a partner force in the midst of a civil war in which Russian-supported regime forces routinely attacked, and the Turkish military routinely bombed, the U.S. partner force. The tenuous coalition ultimately succeeded in dislodging the Islamic State, and the authors offer a number of lessons they learned from their experience.

\section{Part III: government instruments in combating terrorism and waging irregular warfare}

The handbook's final section includes chapters that examine the government instruments used to combat terrorism and wage irregular warfare. It includes chapters examining domestic responses in New York City, which remains a top terrorist target; lessons that can be learned from high-casualty attacks; the role of social media as a terrorist recruitment tool and efforts to counter violent extremist organizations in the information domain; some of the military constructs used to wage counterterrorism and irregular warfare campaigns; the employment of drones outside of combat zones; and the United Kingdom's approach to counterterrorism. The chapters are authored by renowned experts and accomplished practitioners who had a significant role in the organizations in which they discuss.

Former Federal Bureau of Investigation (FBI) Agent Ali Soufan authors "The Joint Terrorism Task Force: investigating to disrupt and prosecute terrorists." Established in 1980 as the nation's first, the New York Joint Terrorism Task Force has investigated and disrupted some of the most significant terrorist plots 
in the past 30 years. As a result, the activities of the Joint Terrorism Task Force represent a fascinating lens through which to view the United States' ongoing war against terrorism.

"Creating the NYPD Counterterrorism Bureau" is the first of two chapters that describe how New York City built its counterterrorism capability following the devastating 9/11 attacks. This first-hand account is authored by the late Michael A. Sheehan, who served as the New York City Police Department's (NYPD) deputy commissioner for counterterrorism from 2003-2006. He describes the creation of the NYPD's Counterterrorism Bureau and its two principal components: the Counterterrorism Division and the NYPD contribution to the FBI's Joint Terrorism Task Force.

In "The inside story of how the NYPD's Intelligence Division adapted in the wake of 9/11," David Cohen focuses on how the NYPD reengineered its intelligence structure, operations, and culture to address the post-9/11 threat to New York City. While the NYPD's response included a broad array of counterterrorism programs, Cohen's chapter focuses on the evolution of its intelligence activities. Cohen spent 35 years with the Central Intelligence Agency, culminating as deputy director of operations, and then another 12 years as the NYPD deputy commissioner for intelligence, a position established in the wake of the $9 / 11$ attacks.

In "Lessons learned from four high-casualty terrorist attacks in the United States since 9/11," Paul Cruickshank analyzes the Fort Hood shooting of 2009, the Boston Marathon bombings of 2013, the San Bernardino attack of 2015, and the Orlando nightclub attack of 2016. Collectively, the attacks killed nearly 80 people and wounded hundreds more. Cruickshank provides a number of lessons that can be learned from the attacks.

Alexander Meleagrou-Hitchens and Seamus Hughes collaborate to write "Social media recruitment of Americans: a case study from the Islamic State." Together, they examine the impact of what they call "virtual entrepreneurs" on the United States. They find that the Islamic State has used social media to reach out to and correspond with radicalized Westerners. In some cases, virtual entrepreneurs have helped plot and direct attacks by so-called "lone wolves," but, more often, the virtual plotters act in more of an auxiliary capacity.

The frontlines in the fight against violent extremist organizations have not only spanned the globe, but the conflict has raged in the information domain. Violent extremist organizations have harnessed 21stcentury media capabilities to disseminate their propaganda messaging to coerce enemies, recruit operatives, instill fear, and generate support. Images, videos, and other propaganda materials can reach a worldwide audience in seconds. In their chapter, "Countering extremist organizations in the information domain," Joseph Mroszczyk and Max Abrahms assess violent extremist organizations operations in the information domain and evaluate the evolution of the measures used to counter their influence.

I partner with Charlie T. Cleveland, a retired three-star general and Special Forces officer, to author "Theater Special Operations Command: the operational employment of U.S. Special Operations Forces." Together, we describe the Special Operations Forces headquarters that are responsible for planning and executing special operations missions around the world. Cleveland leverages his experience as the theater special operations commander of U.S. Southern Command from 2005-2008 and U.S. Central Command from 2008-2011 to provide an understanding of how special operations are conducted across the globe.

In "Theater command in Afghanistan: taking charge of the 'Other War' in 2003-2005," retired threestar general David W. Barno recounts his experiences as the theater commander in Afghanistan. With the U.S. invasion of Iraq in March 2003, Afghanistan became a secondary effort - or a "supporting effort," to use military terminology-for the United States. Barno describes the counterinsurgency strategy he designed and implemented and the challenges he faced.

Peter Bergen and A.G. Sims team to write "America's drone wars outside of conventional war zones." Since 9/11, the United States has conducted hundreds of drone strikes against suspected terrorists outside of traditional warzones. Bergen and Sims explain how these attacks change the character of warfare while at 
the same time raising questions about the legality of the strikes. They examine how three different American presidents have relied on armed drones to strike at hard-to-reach targets.

In "The United Kingdom's approach to counterterrorism," Robin Simcox and Hannah Stuart examine the evolution of the United Kingdom's response to terrorism over the past two decades. Following the 9/11 attacks, the United Kingdom's counterterrorism efforts focused on fighting terrorism abroad to prevent attacks on British soil. After the 2005 London bombings, however, the United Kingdom altered its approach to focus on homegrown terrorism. The authors also assess the Islamic State and how it impacted counterterrorism efforts before a brief examination of other European nations' counterterrorism responses.

Finally, Hy Rothstein provides the volume's conclusion. The former Special Forces officer and Naval Postgraduate School professor provides some of the findings that result from this volume. Rothstein describes how the character of terrorism has changed, while the nature has remained the same. In summarizing counterterrorism and irregular warfare responses, he provides insight into which responses can be most effective at achieving the desired political outcome and leader traits unique to leading irregular warfare and counterterrorism campaigns.

\section{Notes}

1 Authorization for Use of Military Force, Pub. L. No. 107-40 \& 1, 115 Stat. 225 (2001), www.congress.gov/107/ plaws/publ40/PLAW-107publ40.pdf.

2 See Mark E. Mitchell, “The horse soldiers: lessons from expeditionary unconventional warfare," in this handbook.

3 Stimson Center, Counterterrorism Spending: Protecting America While Promoting Efficiencies and Accountability (Washington, DC: Stimson Center, 2018), 5.

4 Joint Chiefs of Staff, Counterterrorism, JP 3-26 (Washington, DC: Joint Chiefs of Staff, 2009), I-2.

5 Joint Chiefs of Staff, Doctrine for the Armed Forces of the United States, JP 1 (Washington, DC: Joint Chiefs of Staff, 2017), I-6.

6 Joint Chiefs of Staff, Counterterrorism, I-11.

7 Ibid., I-12.

8 Ibid., I-12-13.

9 See Brian Fishman, "A history of the Islamic State: from Abu Musab al-Zarqawi to Abu Bakr al-Baghdadi," in this handbook.

10 See, for example, Fred Kaplan, "CT or COIN? Obama Must Choose Between Two Radically Different Afghan Policies," Slate, March 24, 2009, https://slate.com/news-and-politics/2009/03/obama-must-choose-this-weekbetween-two-radically-different-afghanistan-policies.html.

11 Joint Chiefs of Staff, Doctrine for the Armed Forces of the United States, I-7.

12 Jane Onyanga-Omara, "Al-Qaeda Second-in-Command Killed in U.S. Airstrike," USA Today, June 16, 2015, www.usatoday.com/story/news/world/2015/06/16/al-qaeda-says-leader-killed/28796037/. 


\section{PART I}

The threat and regional security issues 
- Taylor \& Francis

Taylor \& Francis Group

http://taylorandfrancis.com 


\title{
1 \\ THE EVOLUTION OF ISLAMIST TERRORISM IN THE 20TH CENTURY
}

\author{
James J.F. Forest
}

On November 13, 2015, terrorists from the Islamic State launched a multipronged assault in Paris and the surrounding area, killing 130 people in the deadliest attack on France since World War II. There have been dozens of Islamist terrorist attacks in recent years, and the Islamic State continues to plot and conduct attacks in the West and the Middle East. Yet before the advent of the Islamic State, key events in the 20th century set the foundation for today's terrorism threat from al-Qaida, the Islamic State, and their many affiliates. A half century ago, terrorism was not as brutally lethal or indiscriminate as it is today. From an ideological and strategic perspective, several streams have emerged over time and flowed in a similar direction, leading to what is now a global sea of groups and individuals who are committed to carrying out brutal terrorist attacks on behalf of violent Islamist ideologies.

This chapter describes various forms of terrorism in the Islamic world through nearly half a century, accounts for the rise and sometimes decline of several prominent terrorist groups during this period, and explains how this historical evolution impacts the understanding of the Islamist terrorist threat today. The chapter begins with a review of a movement that served as the primary contributor to the evolution of Islamist terrorism: the Muslim Brotherhood. It then describes the historical prominence of Palestinian terrorist groups, including the Palestine Liberation Organization, Palestinian Islamic Jihad, and Hamas. Next, it describes the evolution of Hezbollah and the contribution it made in popularizing suicide bombings as a terrorist tactic.

The chapter then provides a brief history of terrorism in Algeria and Egypt, with a focus on the Armed Islamic Group and Egyptian Islamic Jihad, and describes how some terrorist groups transitioned their targeting from the "near enemy" (local governments) to the "far enemy" (the West). Finally, the chapter describes the critical role that Afghanistan played in Islamist terrorism.

\section{The ideology of violence: the Muslim Brotherhood}

The Muslim Brotherhood was founded in 1928 by Hassan al-Banna, a schoolteacher and imam, primarily as a response to what he viewed as threats from both outside and within the Muslim world—not least of which was the British military presence in Egypt at the time. ${ }^{1}$ Al-Banna argued that Muslims around the world should engage in jihad against infidel rulers in Muslim lands. He said that the greater jihad was not the internal spiritual struggle in which most Muslims believed, but rather it was the armed physical struggle against injustice and disbelief, as well as a God-ordained defensive requirement for all Muslims. 
Throughout the 1930s and 1940s, the Muslim Brotherhood gathered a large following, including some senior members of the Egyptian government. When the fighting of World War II reached Egyptian soil, members of the Brotherhood protested the presence of alcohol, drugs, and prostitution that accompanied the Westerners. In 1946, Egyptian Prime Minister Ismail Sidqi facilitated the distribution of funds, books, and supplies to the Brotherhood's schools. ${ }^{2}$

In 1948, Brotherhood members volunteered to fight in the war over Palestine. When the secularminded Egyptian Prime Minister Mahmud Fahmi al-Nuqrashi was assassinated in 1948 shortly after outlawing the Muslim Brotherhood, Egyptian authorities killed al-Banna and several of his associates, sparking a brief Islamist armed uprising that was brutally suppressed.

Yet the Muslim Brotherhood continued to grow into a powerful political force. One of its most influential figures during the 1950s and 1960s was Sayyid Qutb. Qutb not only spent a large portion of his life in prison (where he wrote his popular book Milestones, ${ }^{3}$ also known as Signposts), but he would become a martyr to Arab and Muslim revivalists after his execution by Egyptian authorities. ${ }^{4}$ Milestones is reportedly one of the most widely read books in the Muslim world besides the Quran and has become the ideological cornerstone of many Islamist reform movements. In his book, Qutb criticized not only Western society but also all Muslim societies where he described a loss of direction because the people were willfully ignorant of true Islam. He urged that Islamic societies be judged by how closely they adhere to Sharia (Islamic law) and that governments which are branded takfir, or apostate, must be forcefully replaced.

Qutb proposed a multi-stage process for reviving true Islam. First, a true Muslim movement is formed, whose vanguard sounds the call to the community to return to sovereignty only under God and Sharia. Second, this movement's message is ignored by the jahiliyya (age of ignorance) society and the government. Third, the movement then removes itself either spiritually or physically (or both) from the ignorant society to purify itself and to build up its strength. The final stage is the movement's jihad bil saif (armed and violent struggle) to overthrow the existing unbelieving regime and restore justice and the practice of true Islam. God as man's legitimate ruler, according to Qutb, makes this victory possible. Qutb embraced a secular and nationalistic conception of jihad and its role in establishing a "truly" Islamic government, and he also incorporated a 13th-century notion of jihad that includes the overthrow of regimes that fail to enforce Sharia.

In 1952, a group within the Egyptian Army led a revolution and established a new government, with Gamal Abd al-Nasser as its president. Al-Nasser promoted ideals of pan-Arabism and African unity and proceeded to suppress religious movements like the Muslim Brotherhood. Following an assassination attempt against al-Nasser in 1956, the government responded with lengthy prison sentences for many Muslim Brotherhood members. Since Qutb advocated the use of violence to achieve political and societal change, he was incarcerated from 1955 to 1964 and then executed in 1966 by al-Nasser's government. ${ }^{6}$ He remains one of the most enduring ideological inspirations for most Sunni Islamist extremist groups worldwide.

The Muslim Brotherhood also helped establish and nurture a variety of groups throughout the region, from Morocco to the Palestinian Territories (including Hamas and Palestinian Islamic Jihad) to Syria. In many cases, these groups originally built up popular support through educational programs, social services, and political activism. The Muslim Brotherhood in Egypt renounced violence in the 1970s, but that had the effect of causing more radical members to spin off and create their own groups.

In sum, the rise of the Muslim Brotherhood and its affiliated groups throughout the Middle East can be seen as an evolutionary cornerstone of Islamist terrorism. The core ideology of violence originating from this movement influences a broad spectrum of today's terrorist groups and informs our understanding of what those groups hope to achieve through the use of violence.

\section{The historical prominence of Palestinian terrorist groups}

In the Palestinian Territories, the most prominent terrorist factions today are Islamist groups. Yet the early history of terrorism in the Palestinian Territories was mainly secular. In fact, leaders of Islamist groups 
across the globe have drawn inspirational and operational lessons from the nationalist groups of the 1960s and 1970s like the Popular Front for the Liberation of Palestine (PFLP), the Popular Front for the Liberation of Palestine-General Command, and the Democratic Front for the Liberation of Palestine. These and other groups have at one time or another been factions of the umbrella Palestine Liberation Organization (PLO) that was established in 1964 as an attempt to form a government in exile that would represent the interests of the Palestinian people. ${ }^{7}$

Following the 1947 resolution by the United Nations to partition Palestine into Jewish and Arab states, the Israeli military forced many Palestinian families to flee their homes, while other Palestinians fled on their own accord. Refugee camps in Jordan, Lebanon, and Egypt swelled to hundreds of thousands, becoming fertile grounds for recruiting angry young men seeking vengeance. Meanwhile, the surrounding Arab countries rejected Israel's May 14, 1948, declaration of independence and attacked the new state on several occasions. Israel was victorious each time, giving little hope to Palestinians that they would someday be able to return to their homes.

By the late 1960s, they turned toward militant groups like the PLO. Originally, the al-Fatah faction led by Yasser Arafat came to dominate the PLO, but when the PFLP joined in 1968, it became the second largest faction. These and other PLO factions launched a campaign of terrorist attacks, including kidnappings, shootings, bombings, and hijackings.

Palestinian militants viewed terrorism as a means to achieve the following key objectives: boost recruitment and moral support among Palestinian refugees; attract financial support from nation-states, such as the Soviet Union; and draw international attention to the Palestinian cause. Arafat and other leaders of this era frequently described terrorism as a necessary means to liberate Palestinians by making life unbearable for Israelis. For decades, Palestinians living in refugee camps or under Israeli military control felt powerless to bring about change - and the quest for power is central to the strategy behind terrorism.

According to terrorism expert Bruce Hoffman, terrorism is designed "to create power where there is none or to consolidate power where there is very little." perceived credibility and legitimacy of a government, impair its ability to carry out routine operations, demoralize its leaders, and erode trust in its ability to provide security for its citizens. This form of political violence can intimidate others and coerce their behavior in ways a terrorist group desires and sometimes provoke a heavy-handed response to the attacks that will eventually turn citizens against a government they view as overly repressive. ${ }^{9}$

During this period, the Palestinians used terrorism to draw attention to their cause. A common tactic was to hijack a commercial airliner. One of the most prominent incidents occurred in July 1968, when five members of the PFLP hijacked an El Al flight from Rome to Tel Aviv and forced the plane to divert to Algeria. Upon landing, five Israeli passengers and seven crew members were taken as hostages for the next month and used as a negotiating tool for the release of Palestinians held in Israeli prisons. ${ }^{10}$ This was also the year that Palestinian nationalist Sirhan Sirhan shot U.S. presidential candidate Robert F. Kennedy in Los Angeles on June 5, 1968. Kennedy died the next day from his wounds. Prosecutors argued that Sirhan was angered by Kennedy's support for Israel during the previous year's Six-Day War, and during the investigation, a notebook found by Sirhan's bedside contained the phrase "Kennedy must be sacrificed for the cause of the poor exploited people." 11

During the following year, PFLP members hijacked a flight from Los Angeles to Tel Aviv and forced it to land in Syria, where members of the PFLP moved passengers to an undisclosed location and then blew up the cockpit. In February 1970, members of the PFLP attacked passengers in a bus at the Munich Airport with guns and grenades. In September of that year, the PFLP hijacked three planes en route to New York from different European countries. Two of the planes landed at an abandoned British airport in Jordan and, with several media camera crews watching, the hijackers removed the passengers and blew up both aircraft.

The most notable event to attract international attention to the Palestinian cause was the 1972 Munich Olympics attack by PLO faction Black September. On September 5, a group of nine Palestinians stormed 
the Olympic athletes' compound and took 11 members of the Israeli team hostage. After nearly 24 hours of failed negotiations (during which time the group demanded the release of incarcerated Palestinians and other terrorists), the German government provided helicopter transport for the terrorists and hostages to an airport, where they would ostensibly board a flight to an undisclosed Arab country. At the airport, the police tried a rescue attempt that failed, resulting in the deaths of all the Israeli hostages and most of the Palestinian terrorists.

Throughout the day's events, hundreds of media services from around the world-in Munich to cover the Olympics - provided a global audience to the unfolding drama. The Palestinians finally had the international attention they craved. Although Black September continued to conduct terrorist attacks, PLO leader Yasser Arafat pursued new political strategies, publicly called for violence to end, and was invited to speak at the United Nations General Assembly, where the PLO was granted special observer status. By the end of the 1970s, the PLO had formal diplomatic relations with more countries than the state of Israel. ${ }^{12}$ In the eyes of the Palestinians and nationalist movements worldwide, they had demonstrated that terrorism could be effective in achieving some political objectives.

Other groups rejected the PLO's attempts at politics. Most notably, Sabri al-Banna left the PLO in 1974 following a dispute over establishing diplomatic ties with Israel and founded the Abu Nidal Organization. Over the next two decades, the Abu Nidal Organization mounted terrorist operations in 20 countries, killing about 300 people. ${ }^{13}$ The group's overall goals were to undermine diplomatic relations between the PLO and the West, as well as the destruction of Israel—goals which attracted significant support from Syria, Libya, and Iraq.

Meanwhile, rogue factions of the PLO carried out attacks that were sometimes disavowed by the PLO leadership. For example, in October 1985, four members of the Palestinian Liberation Front hijacked the Italian cruise ship Achille Lauro during a tour of the eastern Mediterranean Sea and took more than 700 hostages. One passenger — a U.S. citizen—was murdered before the Egyptian government facilitated safe passage for the terrorists to escape. ${ }^{14}$

\section{The rise of the Islamist factions: Palestinian Islamic Jihad and Hamas}

Deteriorating unity among secular Palestinian nationalist groups, combined with a growing dissatisfaction at the lack of resolution to the conflict with Israel and corruption within the PLO, created an enabling environment for the rise of Palestinian Islamist terrorist groups beginning in the late 1970s. Palestinian Islamic Jihad (PIJ) was originally established in neighboring Egypt. ${ }^{15}$ The PIJ's original leaders, Fathi Shaqaqi and Abd al-Aziz Awda, called for the destruction of Israel and the establishment of a sovereign Palestinian state. Although they attracted only a small following, these Islamist extremists argued that God would help faithful, devout Palestinians defeat Israel.

In 1981, following the assassination of Egyptian President Anwar Sadat, Egypt expelled the PIJ to Gaza. Members of the PIJ have been responsible for many attacks in Gaza and Tel Aviv, and they threatened to attack the U.S. Embassy if it is relocated to Jerusalem from Tel Aviv. ${ }^{16}$ In 1987, the PIJ was exiled from Gaza to Lebanon, where it cultivated a relationship with Hezbollah and received training from Iran's Islamic Revolutionary Guards Corps.

On July 6, 1989, PIJ became the first Palestinian group to take responsibility for a suicide terrorist attack. A PIJ member named Abd al-Hadi Ghanim seized the steering wheel of a crowded commuter bus and forced it over a steep cliff into a ravine, killing 16 passengers. Several years later, the group took responsibility for a series of suicide bombings, but PIJ was soon eclipsed by a different Islamist group that rose to prominence during this period: Hamas.

While the PIJ began in Egypt, moved to Gaza for six years, and then was exiled to Lebanon, Hamas founder Sheikh Ahmed Yassin had been preaching and performing charitable work in the West Bank and Gaza Strip since the 1960s as a local branch of the Muslim Brotherhood. As a result, he and his close 
followers had developed deep roots and significant credibility among the Palestinian communities when they announced the establishment of Hamas, an acronym for Harakat al-Muqawama al-Islamiyya (Islamic Resistance Movement), in December 1987. ${ }^{17}$

This announcement took place during what became known as the first intifada, a five-year uprising that began as a grassroots protest for the rights of Palestinians and escalated into full-blown riots with rock throwing and Molotov cocktails. Hamas joined the fray, encouraging Muslim clerics to call upon all Palestinians to defend their holy sites and coordinating demonstrations, boycotts, and other political protest activities. ${ }^{18}$ Yassin and other leaders of Hamas sought to take advantage of the intifada to supplant the secular Palestinian groups whom they felt had grown corrupted by power and money. ${ }^{19}$ Its charter, published a year later, called for the destruction of Israel and the establishment of an Islamic society in historic Palestine. ${ }^{20}$

By early 1990, Hamas had become the main Palestinian opposition to the PLO, competing against the nationalist militant groups for recruits and financial support. When Arafat indicated support for Saddam Hussein's invasion of Kuwait, Yassin took a much different, more critical stance and benefited from doing so as many Gulf States diverted aid funds from the PLO. Local support for Hamas grew considerably after they conducted their first terrorist attack against Israel—stabbing three Israelis to death on December 14, 1990, ostensibly as revenge for the killings of 17 Palestinians at Haram al-Sharif in Jerusalem by Israeli soldiers. ${ }^{21}$ They established a militant wing-the Izz al-Din al-Qassam Brigades, led by Sheikh Salah Shehade - and carried out a variety of attacks. Israeli Prime Minister Yitzhak Rabin arrested 415 Hamas members and deported them to southern Lebanon in December 1992.22

The first suicide bombing by Hamas occurred in $1994 .{ }^{23}$ The group subsequently launched a campaign of suicide bombings to maintain pressure on the Israeli government and populace, a campaign Hamas claimed was in retaliation for the actions of Israeli security forces. ${ }^{24}$ Compared to the PIJ or other groups in the Palestinian Territories, the increasing use of suicide bombings by Hamas during the early 1990s also gained it significantly more "street credibility" among sympathizers in the Palestinian community.

Shortly after Hamas's first suicide attack, PLO leader Arafat and Israeli Prime Minister Rabin signed a peace agreement that became known as the Oslo Accords, which Hamas condemned. ${ }^{25}$ In this agreement, the PLO formally recognized Israel, and in return, Israel allowed for limited self-government for parts of the West Bank and Gaza under the Palestinian Authority. The PIJ also condemned the Oslo peace process and the PLO's abandonment of the strategy of the complete liberation of Palestine, arguing that no one had the right to "barter any of this land away." ${ }^{26}$ Several terrorist attacks by both Hamas and PIJ were claimed as retribution for this agreement, including bus bombings in Jerusalem in August 1995 and February 1996 and three simultaneous suicide bombings in September 1997 at the Ben Yehuda shopping mall in Jerusalem.

By the end of the 1990s, Hamas was by far the largest and most active terrorist group in the region, bringing a distinctly Islamist flavor to the longstanding conflict between Israel and the Palestinians. While a majority of terrorist actors during the 1960s and 1970s were Palestinian secular nationalists, they created an environment that enabled the rise of more extreme Islamist groups such as Hamas and the PIJ. The failure to resolve the Israeli-Palestinian conflict also suggests the ideological narrative of these Islamist terror groups will continue to resonate among certain populations throughout the region. Collectively, Palestinian terrorist groups of all ideological orientations provided examples that would be followed by Islamist terrorist groups in other parts of the world.

\section{Hezbollah: kidnappings and truck bombs}

In neighboring Lebanon, a civil war that began in 1975 and lasted until 1990 was largely influenced by longstanding sectarian strife between Maronite Christians, Shia Muslims, Sunni Muslims, Druze, and other ethno-religious groups—each of which had developed their own armed militias. 
Among these groups, the Shia were considered the most oppressed minority group - the result of power sharing agreements established during the 1940s between Sunnis and Christians, through which Lebanese national leaders were chosen through a confessional system of government in which power was allocated based upon the size of each religious confession or sect, as determined by the results of a 1932 national census. To this day, the deeply fragmented social and political structure-which has not been altered despite massive demographic changes, including significant increases in the proportion of Shia Muslims — continues to undermine healthy democratic progress in the country.

To complicate matters, the PLO's relocation with other Palestinian terrorist groups to southern Lebanon in 1970, combined with significant growth in the size of the refugee population, contributed to the country's political instability. By 1974, the situation prompted a prominent Shia cleric, Musa al-Sadr, to launch a new militant group called the Lebanese Resistance Regiments (better known by the acronym AMAL), which was meant to defend the interests of Shia communities. Within this context, violent extremism among the Shia became virtually inevitable.

It was the 1979 Islamic Revolution in Iran, however, that had the greatest impact on the Shia communities in both Lebanon and Syria. ${ }^{27}$ The successful overthrow of the pro-Western leader Mohammad Reza Shah Pahlavi and the introduction of an Islamic regime provided ideological inspiration-and, in some cases, direct financial and material support-for Shia militia groups in those countries. Sharia was instituted by Iran's new clerical leader, Ayatollah Ruhollah Khomeini, who also deployed members of the Islamic Revolutionary Guards Corps to Lebanon to aid the Shia militias in training and planning for operations against the other sectarian groups and, shortly after, Israeli adversaries.

In addition to military training and hardware, Iran also devoted significant financial resources to the Lebanese Shia. ${ }^{28}$ The country's leaders have consistently promoted a hard-line, hostile attitude toward the United States, and beginning in 1979, they allowed Shia Islamist radicals to hold hostage 52 Americans at the U.S. Embassy in Tehran for 444 days, an incident known as the Iran Hostage Crisis. Iran also sponsored the local terrorist groups al-Dawa and the Committee for Safeguarding the Islamic Revolution. ${ }^{29}$

Compared to other militia groups in Lebanon and the Palestinian Territories, Hezbollah ("Party of God") distinguished itself during the 1980s by adopting a particularly lethal and effective tactic: suicide bombings. As noted earlier in this chapter, a secular political agenda drove a majority of the Palestinian groups, and they sought regional and global attention for their cause. None of the secular groups, however, had used suicide terrorist attacks. These tactics did not become a feature of the Israeli-Palestinian struggle until the PIJ and Hamas adopted the practice in the early 1990s. They were inspired to do so by Hezbollah's decision, nearly a decade earlier, to embrace suicide terrorism.

The founders of Hezbollah believed that the use of this tactic was necessary to confront militarily superior forces they felt were unjustly occupying Lebanon. Their primary goal was to inflict enough damage on these forces to make it politically untenable for them to remain in the country. The strategic advantages of suicide bombings quickly became self-evident. To begin with, traditional concepts of security are based on deterring terrorist attacks, and these approaches to deterrence typically assume that the terrorist fears death or capture. Suicide attacks, however, depend on the death of the terrorist.

In other words, the suicide bomber does not care about his or her death, imprisonment, or torture at the time of the attack. They have no need for an escape plan, which is traditionally the most difficult part of a terrorist operation. Both the terrorist group and the suicide bomber have a strong desire for the mission to succeed. Groups can also benefit from public perception (although it can also have an adverse impact) when using a suicide bomber because employing this tactic demonstrates the commitment of the group and of those whom they recruit. ${ }^{30}$

Another important aspect of a group's decision to adopt suicide terrorism is based on whether this tactic is viewed as effective. According to a study by Robert Pape, terrorists achieved some political gains in over half of the major suicide terrorism campaigns between 1980 and 2003. In these instances, some of the 
states involved in the attacks either fully or partially withdrew from territory they were occupying, began negotiations with the terrorist group, or released a terrorist leader. ${ }^{31}$

Al-Dawa — a Shia Islamist militia group based in Iraq during the 1980s-is credited with the first modern suicide car bomb attack, which destroyed the Iraqi Embassy in Beirut on December 15, 1981, killing 16 people. Lebanese Shia militants who were forming what eventually became Hezbollah were inspired to embrace this tactic, using a combination of cars, trucks, grenades, and explosive belts in mass casualty attacks. One of its most prominent attacks involved a suicide car bombing against the U.S. Embassy in Beirut on April 18, 1983, which killed 63 people-including 17 Americans, one of whom was Central Intelligence Agency (CIA) Near East Director Robert Ames. ${ }^{32}$

Then, on October 23, 1983, a young Lebanese man from a Shia family rammed an explosives-laden truck through the guard post at the entrance to the U.S. Marine battalion headquarters building in Beirut. Composed of at least 18,000 pounds of explosives - the equivalent of six tons of dynamite-the bomb demolished the four-story building on the edge of Beirut Airport. ${ }^{33}$ Seconds later, a nearly identical attack targeted the French Multinational Force building less than four miles away. The bomb destroyed the eightstory building where the paratroopers were staying. These attacks killed 241 Americans and 58 French nationals. ${ }^{34}$

In early 1984, AMAL leader Nabih Berri encouraged the United States and France to leave Lebanon. ${ }^{35}$ On February 7, President Ronald Reagan, likely influenced by public sentiment during his re-election year, ordered all U.S. forces to begin withdrawing from Lebanon, which was completed in July $1984 .{ }^{36}$ In his memoirs, President Reagan reflected that, "We couldn't stay there and run the risk of another suicide attack on the Marines" ${ }^{37}$ - in essence, a public confirmation that suicide attacks were effective in forcing concessions from a powerful government. Following the U.S. lead, the rest of the multinational forces (British, French, and Italian) also withdrew, demonstrating to militia groups throughout the Middle East and elsewhere that terrorism could be effective in achieving strategic objectives.

Hezbollah also gained tremendous support and respect among Palestinians and Lebanese. During the previous two decades, the military forces of the Arab nations had been defeated several times by the Israelis, and Israeli forces had stormed into southern Lebanon relatively unopposed in 1982. Yet Hezbollah's terrorist attacks showed that it could compel a superpower and its allies to withdraw from the region. As a result, positive public perceptions about Hezbollah in parts of the region facilitated the group's sustained growth in recruitment, finances, and political power ever since.

Unfortunately, the withdrawal of U.S. forces did not curb the attacks or bloodshed in Lebanon. In March 1984, Shia militants kidnapped CIA Beirut Station Chief William Buckley and killed him after 15 months in captivity. Less than a year later, Shia militants bombed the U.S. Embassy annex, killing 24 people. ${ }^{38}$

Hezbollah had not yet formally announced itself as an organization when all these incidents occurredinstead, a group calling itself "the Islamic Jihad Organization" took responsibility for the attacks. Subsequent research confirmed that the attacks were organized and carried out by Shia militia members who formed a core element of what became Hezbollah. They had been trained by Iran, with whom they shared a fierce animosity towards the United States. ${ }^{39}$

While Iran has denied any involvement in these attacks, the government erected a monument in Tehran in 2004 to commemorate the 1983 bombings and its "martyrs." ${ }^{40}$ The Islamic Revolutionary Guards Corps were also instrumental in establishing several training camps in the Bekaa Valley of Lebanon, aiding Hezbollah and other terrorist groups with material support, guerrilla warfare training, and strategic guidance. ${ }^{41}$ Furthermore, some experts have estimated that Hezbollah receives more than $\$ 100$ million per year from Iran..$^{42}$

Despite the withdrawal of peacekeeping forces from Lebanon in 1984, Islamist terrorist attacks by Hezbollah against Western targets continued. One of the more prominent examples was the June 1985 hijacking of TWA Flight 847 from Athens to Rome-carrying 145 passengers and eight crew members—which 
involved members of both AMAL and Hezbollah. After diverting the plane to Beirut International Airport, the hijackers shot U.S. Navy Petty Officer Robert Stethem and dumped his body onto the tarmac. Several other passengers were removed from the plane and held in various locations throughout the city.

The plane then flew to Algiers, where a majority of passengers were released following negotiations with the Algerian government and the International Red Cross. After 16 days, and significant global media attention, all remaining hostages were exchanged for the release of several hundred Lebanese Shia prisoners in Israel.

In February 1988, members of Hezbollah kidnapped and later murdered U.S. Marine Corps Lieutenant Colonel William Higgins, who at the time was serving with the United Nations Truce Supervision Organization in southern Lebanon. In March 1992, members of Hezbollah carried out a suicide bombing against the Israeli Embassy in Buenos Aires, Argentina, killing 29 people and injuring 242. In July 1994, another terrorist attack destroyed a Jewish community center in Buenos Aires, killing 85 people and injuring hundreds more. Hezbollah is also thought to be responsible for the June 25, 1996, attack against the Khobar Towers near Dhahran, Saudi Arabia, which killed 19 U.S. airmen. ${ }^{43}$

These and other attacks generated sympathy and support for Hezbollah throughout the Shia communities in the region. Just like Hamas in the Palestinian Territories, Hezbollah also gained significant local support by providing social services to Shia communities in southern Lebanon. This local support proved vital when Hezbollah participated in the 1992 Lebanese parliamentary elections; the group won in a landslide where it fielded candidates, and eight members were elected to parliament. ${ }^{44}$ While the combination of state sponsorship and local support has led to a great deal of political power for Hezbollah, it also brings constraints related to political and economic realities. They have a vested interest in maintaining collaborative relationships with their state sponsors Iran and Syria, as well as with their local constituents.

As a result, Hezbollah can be seen as a uniquely self-constrained terrorist group, one that today rarely conducts operations outside Lebanon, Syria, and Israel. Its use of kidnappings, bombings, and other tactics of terrorism are largely meant to influence the Lebanese political context and Israel. Like Hamas, Hezbollah has never attacked the U.S. homeland and has rarely attacked European targets. Their deliberately "limited" use of terrorism is meant to achieve strategic goals while also allowing them to function as a political party within Lebanon. Hezbollah pushes the boundaries but cautiously seeks to avoid generating a backlash from countries in Europe, a region the group uses as a staging ground for operations to be carried out elsewhere, as a logistics hub, and where they raise funds through a variety of criminal enterprises. ${ }^{45}$

Finally, by focusing mainly on fighting the Israel Defense Forces, Hezbollah consolidated its power over southern Lebanon, eventually compelling Israeli forces in 2000 to withdraw from the region that they had occupied since 1982. Furthermore, during the summer of 2006, the group fought a four-week war with Israel that ended in a United Nations-negotiated cease-fire (considered a victory by many in Lebanon).

Most recently, Hezbollah joined the Syrian civil war, fighting on behalf of Syrian leader Bashar al-Assad against Sunni militant groups. The group's decision to engage in Syria was driven by its commitment to defending Shia communities throughout the region as well as its state sponsors, Iran and Syria. ${ }^{46}$ Overall, because of their perceived strength and success over the past four decades, Hezbollah has built a constituency that guarantees the group's longevity and importance for the foreseeable future. ${ }^{47}$

\section{The bloody Algerian revolution}

In Algeria, the history of Islamist terrorism took an altogether different turn. An Islamic political movement that began in the late 1970s led to the growth of the Islamic Salvation Front, a political party that attracted significant support from the population. In 1992, Algeria's military government canceled an election in which it appeared the Islamic Salvation Front would emerge victorious. The ruling government annulled the election results, sparking a bloody civil war. Many Islamists who had been trained in armed 
conflicts elsewhere in the world, such as in Afghanistan, formed the Islamic Salvation Army, a militant group linked to the Islamic Salvation Front.

Soon, a separate group of Islamists also developed and quickly gained a reputation for employing terrorist attacks nearly indiscriminately. Calling themselves the Armed Islamic Group (GIA), they targeted not only members of the military and government but also foreigners and innocent civilians. ${ }^{48}$ Through a campaign of kidnappings and assassinations, members of the GIA and other Islamist groups sought to undermine the perceived legitimacy of the Algerian government by fostering a climate of widespread public insecurity and provoking the regime to increase its repression of the various Islamist organizations who formed the main political opposition parties. For its part, the government responded to the threat through draconian measures-executing Islamists, imposing curfews, censoring news, outlawing and dissolving the Islamic Salvation Front, and restricting political protests.

The Islamists also sought to make the situation intolerable for foreigners living in Algeria, believing that a massive flight of foreign capital would eventually lead to the collapse of economic stability, further eroding the Algerian government's ability to function. For decades, millions of European expatriates had enjoyed a relatively comfortable lifestyle in the former French colony. Yet now Algerian forces roamed Algeria's largest cities using armored personnel carriers, helicopters, and all-terrain vehicles. ${ }^{49}$ The GIA kidnapped prominent foreigners, generating publicity that the GIA then used to warn the broader community of foreigners that they should leave the country. Seemingly random, indiscriminate bombings in public places - particularly at establishments popular among foreigners - increased the sense of insecurity and encouraged more repression from the government.

By the mid-1990s, the GIA had also begun to conduct terrorist attacks in France (its former colonial power), provoking the government in Paris to react by conducting massive police sweeps and arrests throughout the country. This reflected another GIA goal: exacerbating tensions between the French government and the millions of Muslim immigrants from North Africa living in France. ${ }^{50}$ In turn, the GIA believed this would eventually lead the French government to withdraw its support for the Algerian regime as well as encouraging at least some of the hundreds of thousands of Algerian immigrants in France to return home to join the fight.

In 1994, the GIA hijacked an Air France jet in Algiers and flew the plane to Marseilles, France. Although French authorities resolved the incident by storming the plane, the hijackers' goal was to crash the jet into the Eiffel Tower in Paris. ${ }^{51}$ The following year, a series of bombings in the Paris metro and other public places killed eight and wounded dozens more. ${ }^{52}$

Overall, the GIA killed thousands of Algerian and French civilians in these terrorist attacks. The strategic gains were limited at best: the Islamists did not gain any political power or concessions from the Algerian government. By comparison, the use of terrorism by Islamist militants in the Palestinian Territories generated regional sympathy and international attention, while terrorist attacks by Hezbollah led to the withdrawal of U.S. forces from Lebanon.

In Algeria, on the other hand, the Islamists' indiscriminate brutality eventually eroded their own potential for support. In fact, the GIA's popularity was in such steep decline by 1998 that a number of members left to form a new group, the Salafist Group for Preaching and Combat. A government amnesty program in 1999 led many fighters to turn in their weapons, further diminishing the ranks of the Islamist insurgency. Less than a decade later, the remaining members of the group changed their name to al-Qaida in the Islamic Maghreb, a terrorist group and official al-Qaida affiliate that remains active in North Africa today.

\section{The Muslim Brotherhood moderates and Egyptian Islamic Jihad splinters}

Several Islamist groups emerged in Egypt during the 1960s and 1970s, including Egyptian Islamic Jihad (EIJ), Takfir wal-Hijra (Flight and Repentance), and the Egyptian Islamic Group (Gamaat al-Islamiyya). 
These groups attracted more extreme members from the Muslim Brotherhood, which was seen as increasingly oriented toward political compromise.

In 1971, in the context of the Cold War, Egyptian President Anwar Sadat released Muslim Brotherhood members from prison and encouraged Islamist student organizations throughout the 1970s to counteract leftist organizations. The EIJ grew to have the largest membership of the emerging Islamist groups, with a clear leadership structure and goals that resonated particularly among students in Cairo. Its leader, Muhammad Abd al-Salam Faraj, authored The Neglected Duty, a pamphlet that built on Qutb's ideas and argued that Muslim rulers who were un-Islamic must be overthrown. Their ideological goals clearly demanded regime change in Egypt.

On October 6, 1981, the EIJ's assassination of President Anwar Sadat brought the group global recognition but also a swift and brutal response from the security forces. Faraj and many others in the EIJ were arrested and tortured by the government - including a young Egyptian doctor named Ayman al-Zawahiri, who had been active in Islamic extremist groups since he was 15 years old and who many years later would become the head of al-Qaida after Usama bin Ladin's death in 2011. ${ }^{53}$

Like the EIJ, the Egyptian Islamic Group also sought the overthrow of the Egyptian government, and the group is responsible for a number of attacks on tourists in Egypt. In November 1997, Islamic Group gunmen opened fire on tourists near Luxor, killing 58 foreign nationals. The terrorists also used knives to butcher bodies. The brutality of the attack caused a backlash against the group in Egypt.

The spiritual inspiration for both of these terrorist groups was a cleric named Omar Abdel Rahman, also known as "the blind sheikh." Abdel Rahman had trained in theology at Cairo University and al-Azhar University and by the 1980s had earned a large following for his outspoken preaching in favor of Islamic governance.

The Egyptian government arrested Abdel Rahman for alleged involvement in Sadat's assassination, but he was later released. He left the country shortly thereafter, traveling to Pakistan and Sudan where he gave sermons that praised and encouraged jihad. He eventually moved to New Jersey in the early 1990s, where he gathered a small following who were receptive to his preaching.

On February 26, 1993, a truck bomb exploded in the parking garage of the World Trade Center in New York City, killing six and injuring more than 1,000 people. ${ }^{54}$ The leader of the cell responsible for this attack was Ramzi Yousef, a Pakistani who grew up in Kuwait and England and was a follower of Abdel Rahman. According to court testimony years later, the plan for the 1993 attack was to cripple the support beams of the corner of the North Tower so it would topple over and knock the South Tower down at the same time. ${ }^{55}$ Although Yousef fled the United States after the attack, investigators discovered information that led to Abdel Rahman's conviction for conspiracy to blow up buildings, bridges, and tunnels in New York. Abdel Rahman died in a U.S. prison in February 2017.

Yousef traveled to Pakistan, Thailand, and the Philippines, meeting up with various other terroristsincluding his uncle, Khalid Sheikh Mohammed, who was the architect of the 9/11 attacks in the United States. In fact, a year earlier, Mohammed had wired $\$ 600$ to Yousef to help with the 1993 World Trade Center bombing in New York. ${ }^{56}$

Beginning in mid-1994, the two of them developed what became known as "Oplan Bojinka," an ambitious plan to simultaneously detonate explosives on 12 mostly U.S.-bound airplanes while in flight over the Pacific Ocean. ${ }^{57}$ On December 12, 1994, Yousef conducted a test to see if their improvised explosive devices could make it through airport security and detonate. He boarded a Philippines Airlines flight from Manila to Narita, Tokyo (via Cebu, Philippines), placed the device under his seat, and deplaned in Cebu. Although the explosion made a hole in the fuselage, killing a Japanese passenger and injuring several others, the plane did not explode..$^{58}$

Yousef subsequently worked on refining the explosives but also discussed with his colleagues an idea about hijacking planes and using them in suicide attacks against key targets, like the CIA headquarters in Langley, Virginia, ${ }^{59}$ an idea that was operationalized by his uncle, Khalid Sheikh Mohammed, years later. 
He was eventually arrested in Pakistan and extradited to the United States, where he was tried and convicted of the 1993 World Trade Center attack, and he is currently incarcerated in the supermax prison in Colorado.

Ayman al-Zawahiri also left Egypt when he was released from prison in 1985 and traveled to Saudi Arabia, Sudan, and eventually Pakistan, where he worked as a doctor treating fighters wounded in the conflict against Soviet forces occupying Afghanistan. ${ }^{60}$ During his travels, al-Zawahiri authored several articles and books in which he lamented the fall of the Ottoman Empire, arguing that the Ottomans had successfully defended the Muslim world for five centuries before the British-led Arab revolt against the sultan after World War I.

He also argued that the West was pursuing an agenda of intentionally marginalizing and weakening the Muslim world. In his book Knights Under the Prophet's Banner, al-Zawahiri wrote about the founding and development of a transnational Islamic extremist movement. ${ }^{61}$ He suggested that the worldwide jihad should focus on small teams conducting suicide operations, and that a fundamentalist "base of operations" must be established in the Middle East to support and coordinate this campaign. Al-Zawahiri agreed with the views of other Islamist thinkers that corrupt, apostate regimes in the Arab world had to be overthrown, focusing the bulk of his terrorist efforts on overthrowing the Egyptian government. ${ }^{62}$

In time, however, al-Zawahiri came to agree with Bin Ladin's argument that the "far enemy" (the West) must be hit first because the great oppressive powers would not allow the mujahidin (Islamic fighters) to achieve power in their own societies. ${ }^{63}$ In 1998, al-Zawahiri was one of several senior Islamists who signed the so-called "Declaration of the World Islamic Front for Jihad against the Jews and the Crusaders," which called on Muslims to kill Americans. ${ }^{64}$

Meanwhile, Egypt's neighbor Libya struggled with its own Islamist movements during this era, most notably the Libyan Islamic Fighting Group, which was founded in 1990. Members of the group were accused of attempting to kill the country's dictator Muammar Gaddafi at least three times over the course of seven years, but the group had been effectively suppressed by 1998. Libya, however, also played a different and more prominent role in the history of terrorism, one centered largely around its support for nationalist groups.

During the 1970s and 1980s, Gaddafi provided safe haven and even military instruction to members of the PFLP and other Palestinian terrorist groups. ${ }^{65} \mathrm{He}$ viewed his country's destiny as a revolutionary catalyst that should sponsor these kinds of groups (particularly those faithful to Islam) as well as groups opposed to imperialism. ${ }^{66}$

Furthermore, the employment of different terrorist groups by the Libyan government was an intrinsic feature of its foreign policy for a number of years. ${ }^{67}$ In December 1985, simultaneous terrorist attacks at the Rome and Vienna airports killed four Americans, an operation later linked to the Libyan government. In April 1986, Libyan agents were tied to the bombing of a Berlin disco, an attack that killed two American soldiers. President Ronald Reagan responded with airstrikes against several military targets in Tripoli and Benghazi, as well as against Gaddafi's headquarters.

Then, in December 1988, in one of the worst aviation terrorist attacks on record, a bomb destroyed Pan American Airlines Flight 103 as it flew over Lockerbie, Scotland, killing all 259 passengers and crew, plus 11 people on the ground at the crash site. In November 1991, following an extensive investigation, the United States and Scotland simultaneously indicted a pair of Libyan intelligence operatives, whom they accused of planting the bomb aboard the flight before it left the airport in Frankfurt, West Germany.

Despite his state sponsorship of terrorism, however, Gaddafi was noticeably worried about Islamist extremists, whom he felt were becoming a threat to all the secular regimes in the region. Perhaps witnessing the struggles of government leaders in neighboring Egypt and Algeria influenced his views. It is noteworthy that in the mid-1990s, Libya was one of the first countries to file an arrest warrant with Interpol to try and capture one particularly well-known Islamist terrorist: Usama bin Ladin. 
In summary, Islamist terrorist groups in each of these North African countries ultimately failed to achieve their political objectives, but their operational and tactical successes provided inspiration to fellow jihadi groups in other parts of the world. No country provided more inspiration and operational training than Afghanistan.

\section{The critical contributions of Afghanistan to Islamist terrorism}

In 1979, the Soviet Union invaded Afghanistan, and Islamist extremists from the Middle East, North Africa, and Southeast Asia raised a call for jihad to expel an "infidel invader" from a Muslim country. Thousands responded. ${ }^{68}$ The governments in Egypt, Jordan, Saudi Arabia, Libya, and other countries were willing to see these radicals go abroad instead of causing trouble at home. Some governments even funded their trips, probably expecting that most of them would not return. The fact that these Islamists would be fighting the Soviet Union also served their national interests, particularly regarding relations with the United States. The CIA and Pakistan's Inter-Services Intelligence encouraged, armed, and trained some of these foreign jihadis, as well as the Afghan mujahidin fighters who were already fighting the Soviets in Afghanistan.

A young, wealthy Saudi named Usama bin Ladin was among those who traveled to Afghanistan in pursuit of jihad. He met a charismatic Palestinian cleric named Abdullah Azzam, who had recently established a training and support network in Pakistan for foreign fighters, called the Afghan Services Bureau (Maktab al-Khidamat), and also helped to organize the Afghan resistance effort by coalescing various armed militia leaders to discuss strategy and doctrine. Azzam traveled widely to promote foreign Muslim participation in the Afghan jihad. Like Muslim Brotherhood founder Hassan al-Banna, he insisted that after devoting oneself to Islam, the second greatest obligation for Muslims was jihad by force in defense of the global umma (Islamic community).

Azzam was also influenced by al-Banna's notion of jihad as required for all Muslims and preached about an anti-Islam campaign allegedly conducted by the Soviet Union, Israel, and the West. His books, Defense of Muslim Lands (1979) and Join the Caravan (1987), urged Muslims to come to Afghanistan and fight. He justified the jihad by claiming that all Muslim land that fell under infidel control had to be reclaimed. Notably, his books were publicly endorsed by Saudi Arabia's leading cleric, Sheikh Abdul Aziz bin Baz. For his part, Bin Ladin used his connections and personal wealth to help raise funds for the jihad and support Azzam's work.

In 1989, the Soviets withdrew from Afghanistan, and shortly afterward, the Soviet Union broke apart. The mujahidin declared victory, and the Arab foreign fighters took far more credit than they deserved for the Soviet defeat. Azzam, Bin Ladin, and their associates became convinced of the superiority of Islamist guerrilla fighters against a superpower, and this conviction led them to establish al-Qaida (Arabic for "the base") to serve as a central hub of support for launching a jihad against apostate regimes and other perceived enemies of the Muslim world (and, eventually, their Western supporters like the United States). Azzam's long-term personal goal was to assemble a global Muslim resistance movement to free Palestine from Israel, although Bin Ladin and his Egyptian associate Ayman al-Zawahiri had much loftier objectives of launching a global jihad.

Azzam was assassinated in a mysterious car bomb in Pakistan in 1989, and Bin Ladin assumed full control over al-Qaida. A year later, Iraqi dictator Saddam Hussein invaded Kuwait and seized the country's oil fields, leading to concern in neighboring Saudi Arabia. Bin Ladin approached the Saudi ruling family with an offer to bring his "army" of jihadi militants to protect the kingdom against the Iraqi army. The Saudis rejected his offer, preferring instead to allow U.S. troops to establish bases in Saudi Arabia from which they would lead an international coalition of forces to defeat Saddam Hussein and restore Kuwaiti sovereignty. Within weeks, the hundreds of thousands of Western soldiers-including women-along with foreign 
journalists led to a sense of embarrassment and humiliation for some Saudi citizens (including Bin Ladin) that "crusaders" were needed to protect Islam's holiest land. ${ }^{69}$

In 1992, Bin Ladin returned briefly to Afghanistan and Pakistan, but when the Afghan civil war began that year, he moved to Sudan, established a collection of training camps and legitimate businesses, and provided some financial support to key Sudanese leaders in return for safe haven. Later that year, al-Qaida operatives were caught at an airport in Aden, Yemen, preparing to launch rockets at U.S. military planes. This is the first known attempt by al-Qaida operatives to attack U.S. targets. ${ }^{70}$

Throughout the 1980s and the 1990s, Afghanistan served as a hub of training for aspiring young jihadis. In many cases, former security forces personnel from Egypt, Algeria, Syria, Pakistan, and the Soviet Union served as instructors in these training camps. ${ }^{71}$ They produced extensive training manuals, like the Encyclopedia of Afghan Jihad - 7,000 pages of information on the tactics of terrorism and guerrilla warfare, with lessons in security and intelligence, topography, using and maintaining weapons, first aid, explosives, and more. $^{72}$

Some researchers have estimated that nearly 10,000 men trained in these camps, while other estimates are much higher; Saudi intelligence services, for example, have suggested that between 15,000 and 25,000 Saudi youths trained in Afghanistan. ${ }^{73}$ While the persistent violence in Afghanistan offered many opportunities to gain battlefield experience, many of these jihadis graduated to fight in Kashmir, Kosovo, Uzbekistan, Bangladesh, the Philippines, Algeria, Bosnia, and other conflict zones. Bin Ladin viewed this network of mostly battle-hardened jihadi veterans as a potential stockpile of human resources that could support the objectives of global jihad wherever they may be needed.

\section{Conclusion}

The evolution of Islamist terrorism during the 1960s through the 1990s involved dozens of countries and hundreds of thousands of fighters, leaders, clerics, and ideological entrepreneurs. Several Islamist thinkers played key roles in the evolution of the ideology used to justify this violence, from Hassan al-Banna and Sayyid Qutb in Egypt to the Palestinian cleric Abdullah Azzam. Many terrorist groups established during this period are still active today. They generally adhere to the same collection of Islamist ideological tenets promoted by other groups that were established during this period but faded or were destroyed, such as Palestinian Islamic Jihad, the Armed Islamic Group in Algeria, and the Egyptian Islamic Group.

The reasons these groups embraced terrorism vary, but in most cases their violent attacks were meant to draw international attention to their cause, attract financial support, weaken the perceived credibility and legitimacy of a government, force policy concessions, and coerce behavior through intimidation and fear. The strategies and tactics of terrorism have been embraced by an increasing number of groups, operating in an expanding swath of countries from North Africa to Central and Southeast Asia. When reviewing this historical evolution of Islamist terrorism, a clear pattern emerges: successful outcomes attributed to terrorism are rare.

In Egypt, the Muslim Brotherhood failed to achieve its objectives and eventually cut a deal with a government that Islamists throughout the region considered corrupt and illegitimate. Their rejection of violence led to major rifts within the broader Islamist movement, helping to spark other, more violent Islamist groups such as the EIJ, who viewed the Brotherhood's moderate change as soft and weak. Perhaps it is unsurprising that in later years, few Islamist groups have chosen a similar path of moderation.

In the Palestinian Territories, nationalist groups originally used kidnappings and hijackings as a means to gain international publicity, but over time, their movement evolved to include suicide bombings by Islamist groups like PIJ and Hamas. Despite the escalation of tactics and bloodshed, Palestinians today are no closer to achieving statehood than they were four decades ago. 
In Algeria, various Islamist groups failed to undermine the Algerian government despite two decades of terrorist attacks. Furthermore, through their indiscriminate, bloody violence during the 1990s, they managed to turn the population against them and in doing so weakened the prospects of Islamist groups in the future gaining acceptance or political support.

In Lebanon, Hezbollah has probably achieved the most success through adopting terrorism. Its use of brutal terrorist tactics, including suicide car bombings, as well as traditional insurgent tactics, forced the United States and other multinational forces to withdraw from Lebanon in 1984, compelled Israel to end its occupation of southern Lebanon in 2000, and brought Israeli forces to a standstill when they invaded southern Lebanon in 2006.

In sum, the major Islamist terrorist groups of the last half of the 20th century largely failed to achieve most of their declared goals; however, Islamist terrorist groups are active in each of these countries today, indicating a troubling resilience associated with this kind of religiously motivated violence. Indeed, after several decades of rising Islamist terrorism within each of these countries, a development even more ominous and transnational emerged by the late 1990s.

The harbinger of a new era of terrorism occurred on August 7, 1998, when terrorists drove two trucks laden with explosives into the U.S. Embassies in Nairobi, Kenya, and Dar es Salaam, Tanzania. Just six months earlier, Ayman al-Zawahiri had formally merged the remaining members of the EIJ into what was formally called The World Islamic Front for Jihad against the Jews and Crusaders. Today, everyone refers to them as al-Qaida. ${ }^{74}$

As described elsewhere in this handbook, al-Qaida launched a new era of Islamist terrorism. The core principles of the Muslim Brotherhood-using violence to achieve an Islamist political agenda—remain at the center of al-Qaida's motivating ideology, but Islamist terrorism today transcends the local or national aspirations of these earlier groups in Egypt, the Palestinian Territories, Lebanon, and Algeria. Al-Qaida, its progeny the Islamic State, and their various affiliate groups have regional and even global ambitions, beginning with the re-establishment of a transnational caliphate and eventually altering the global system of political and economic relations in ways that give primacy to more extreme, Salafi interpretations of Islam. This impacts the radicalization, targeting and tactics, and lethality of today's Islamist terrorist groups and will in turn shape the future of terrorism.

\section{Notes}

1 Sherifa Zuhur, "State Power and the Progress of Militant and Moderate Islamism in Egypt," in Countering Terrorism and Insurgency in the 21st Century, ed. James J.F. Forest, volume 3 (Westport, CT: Praeger, 2007), 444.

2 Ibid., 445.

3 Sayyid Qutb, Milestones [English translation] (New Delhi: Islamic Book Service, 2001).

4 For more on Sayyid Qutb, see Emmanuel Sivan, Radical Islam: Medieval Theology and Modern Politics (New Haven: Yale University Press, 1985); Gilles Kepel, Muslim Extremism in Egypt: The Prophet and the Pharaoh, trans. Jon Rothschild (Berkeley: University of California Press, 1993), 26-43; Yvonne Haddad, "Sayyid Qutb: Ideologue of Islamic Revival," in Voices of Resurgent Islam, ed. John Esposito (New York: Oxford University Press, 1983), 67-98.

5 Jahiliyya describes the age of ignorance in which Arabs were supposed to have lived before the revelation of Islam to the Prophet Muhammad at the beginning of the 7th century.

6 Zuhur, "State Power," 445.

7 Yezid Sayigh, Armed Struggle and the Search for State: The Palestinian National Movement, 1949-1993 (New York: Oxford University Press, 1997).

8 Bruce Hoffman, Inside Terrorism (New York: Columbia University Press, 2006), 40-41.

9 Andrew H. Kydd and Barbra F. Walter, "The Strategies of Terrorism," International Security 31, no. 1 (2006): 49-80; Martha Crenshaw, "The Logic of Terrorism: Terrorist Behavior as a Product of Strategic Choice," in Origins of Terrorism: Psychologies, Ideologies, Theories, States of Mind, ed. Walter Reich (Washington, DC: Woodrow Wilson Center Press, 1998); Hoffman, Inside Terrorism; Max Abrahms, "What Terrorists Really Want," International Security 32, no. 4 (2008): 78-105. 
10 Yoram Schweitzer, "Innovation in Terrorist Organizations: The Case of PFLP and Its Offshoots," in Terrorist Innovations in Weapons of Mass Effect: Preconditions, Causes and Predictive Behaviors, ed. Maria J. Rasmussen and Mohammed M. Hafez (Washington, DC: Defense Threat Reduction Agency, 2010).

11 Robert F. Kennedy Assassination," Federal Bureau of Investigation, May 4, 1977, https://vault.fbi.gov/Robert\%20 F\%20Kennedy\%20 \%28Assassination\%29\%20.

12 Hoffman, Inside Terrorism, 70.

13 "Abu Nidal Organization," Council on Foreign Relations, May 27, 2009, www.cfr.org/israel/abu-nidal-organizationano-aka-fatah-revolutionary-council-arab-revolutionary-brigades-revolutionary-organization-socialist-muslims/ p9153.

14 Sean Anderson and Peter Spagnolo, "The Achille Lauro Hijacking," in Countering Terrorism and Insurgency in the 21st Century, ed. James J.F. Forest, volume 3 (Westport, CT: Praeger, 2007), 52-69.

15 This description of the PIJ is adapted from Holly Fletcher, "Palestinian Islamic Jihad," Council on Foreign Relations, April 10, 2008, www.cfr.org/israel/palestinian-islamic-jihad/p15984.

16 Ibid.

17 Kim R. Cragin, “Learning to Survive: The Case of the Islamic Resistance Movement (Hamas)," in Teaching Terror: Strategic and Tactical Learning in the Terrorist World, ed. James J.F. Forest (Lanham, MD: Rowman \& Littlefield, 2006), 191-192.

18 Ibid., 194.

19 “The First Intifada," Al Jazeera, December 9, 2003, www.aljazeera.com/archive/2003/12/2008410151246804713. html.

20 Shaul Mishal and Avraham Sela, eds., “The Charter of the Islamic Resistance Movement (Hamas)," in The Palestinian Hamas: Vision, Violence and Coexistence (New York: Columbia University Press, 2000), 175-199.

21 Cragin, "Learning to Survive," 194.

22 Ibid., 195.

23 Nasra Hassan, "An Arsenal of Believers," New Yorker, November 19, 2001, www.newyorker.com/magazine/ 2001/11/19/an-arsenal-of-believers.

24 Cragin, "Learning to Survive," 196.

25 Zachary Laub, "Hamas," Council on Foreign Relations, August 1, 2014, www.cfr.org/israel/hamas/p8968.

26 Meir Hatina, Islam and Salvation in Palestine: The Islamic Jihad Movement (Tel Aviv: Moshe Dayan Center for Middle Eastern and African Studies, 2001), 85-106.

27 Richard M. Wrona, Jr., "Lebanon, Hizbollah, and the Patrons of Terrorism," in Countering Terrorism and Insurgency in the 21st Century, ed. James J.F. Forest, volume 3 (Westport, CT: Praeger, 2007), 366-367.

28 Ibid., 370.

29 Hoffman, Inside Terrorism, 85.

30 For more analysis on this topic, see James J.F. Forest, The Terrorism Lectures (Los Angeles: Nortia Press, 2015), 303-318.

31 Robert Pape, “The Strategic Logic of Suicide Terrorism," American Political Science Review 97, no. 3 (2003): 344.

32 Matthew Levitt, "The Origins of Hezbollah," The Atlantic, October 23, 2013.

33 Ibid.

34 Ibid.

35 Robin Wright, Sacred Rage (New York: Simon and Schuster, 2001), 72.

36 Timothy J. Geraghty, Peacekeepers at War: Beirut 1983-The Marine Commander Tells His Story (Washington, DC: Potomac Books, 2009).

37 Ronald Reagan, An American Life (New York: Simon and Schuster, 1990), 456.

38 Ibid.

39 The relationship between Hezbollah's leadership and Iran's clergy and security institutions is detailed extensively in Magnus Ranstorp, Hizb' Allah in Lebanon: The Politics of the Western Hostage Crisis (New York: St. Martin's Press, 1997).

40 Geraghty, Peacekeepers at War, 185.

41 Magnus Ranstorp, “The Hizbollah Training Camps of Lebanon," in The Making of a Terrorist, ed. James J.F. Forest (Westport, CT: Praeger, 2005).

42 Matthew Levitt, Hezbollah Finances: Funding the Party of God (Washington, DC: The Washington Institute, 2005).

43 Christopher Gross, "20 Years Later: Remembering the Attack on Khobar Towers," Air Force News Service, June 24, 2016, www.af.mil/News/Article-Display/Article/811370/20-years-later-remembering-the-attack-onkhobar-towers/\%201/.

44 Hala Jaber, Hezbollah: Born with a Vengeance (New York: Columbia University Press, 1997). 
45 Matthew Levitt, "Hezbollah's Organized Criminal Enterprises in Europe," Perspectives on Terrorism 7, no. 4 (2013): 27-40.

46 Graeme Wood, The Way of the Strangers (New York: Random House, 2016), 10.

47 Wrona, "Lebanon, Hizbollah, and the Patrons of Terrorism," 371-373.

48 Laren Vriens, "Armed Islamic Group," Council on Foreign Relations, May 27, 2009, www.cfr.org/backgrounder/ armed-islamic-group-algeria-islamists.

49 Martha Crenshaw, "Crisis in Algeria," in Mediterranean Politics, ed. Richard Gillespie (London: Pinter Publishers, 1994), 204.

50 Ibid., 205.

51 Lorenzo Vidino, Al-Qaeda in Europe: The New Battleground for International Jihad (Amherst: Prometheus Books, 2006).

52 Walter Laqueur, The New Terrorism: Fanaticism and the Arms of Mass Destruction (London: Oxford University Press, 1999), 130-133.

53 Jayshree Bajoria and Lee Hudson Teslik, "Profile: Ayman al-Zawahiri,” Council on Foreign Relations, July 14, 2011, www.cfr.org/backgrounder/profile-ayman-al-zawahiri.

54 Daniel Baracskay, "The February 1993 Attack on the World Trade Center," in Countering Terrorism and Insurgency in the 21st Century, ed. James J.F. Forest, volume 3 (Westport, CT: Praeger, 2007), 70-87.

55 Gary A. Ackerman and Sundara Vadlamudi, "The Case of Ramzi Youssef," in Countering Terrorism and Insurgency in the 21st Century, ed. James J.F. Forest, volume 3 (Westport, CT: Praeger, 2007), 128-144.

56 Robert Wesley, "Capturing Khalid Sheikh Mohammad," in Countering Terrorism and Insurgency in the 21st Century, ed. James J.F. Forest, volume 3 (Westport, CT: Praeger, 2007), 164.

57 Ackerman and Vadlamudi, "The Case of Ramzi Youssef," 131-132.

58 Rohan Gunaratna, “Al Qaeda's Lose and Learn Doctrine: The Trajectory from Oplan Bojinka to 9/11," in Teaching Terrorism: Strategic and Tactical Learning in the Terrorist World, ed. James J.F. Forest (Boulder: Rowman \& Littlefield, 2005), 171-188.

59 Ibid., $174-175$.

60 For more detail on Ayman al-Zawahiri, see Montasser al-Zayyat, The Road to Al Qaeda: The Story of Bin Laden's Right Hand Man (London: Pluto Press, 2004).

61 Ayman al-Zawahiri, Knights Under the Prophet's Banner (London: Al-Sharq al-Awsat, 2011).

62 Fawaz A. Gerges, The Far Enemy: Why Jihad Went Global (New York: Cambridge University Press, 2005), 11.

63 Ibid., 13.

64 Usama bin Ladin et al., "Jihad Against Jews and Crusaders," February 23, 1998, www.fas.org/irp/world/para/ docs/980223-fatwa.htm.

65 Boaz Ganor, "Libya and Terrorism," Survey of Arab Affairs—A Periodic Supplement to Jerusalem Letter/Viewpoints 28 (1992).

66 J. Bowyer Bell, The IRA, 1968-2000: Analysis of a Secret Army (London: Frank Cass, 2000), 184.

67 Christopher Boucek, "Libyan State-Sponsored Terrorism: An Historical Perspective," Terrorism Monitor 3, no. 6 (2005).

68 Many of the sources for this historical summary are a matter of public record, but also see Lawrence Wright, The Looming Tower: Al Qaeda and the Road to 9/11 (New York: Alfred A. Knopf, 2006); National Commission on Terrorist Attacks, The 9/11 Commission Report: Final Report of the National Commission On Terrorist Attacks Upon the United States (New York: W.W. Norton, 2004), 47-70; Bruce Reidel, The Search for Al Qaeda (Washington, DC: Brookings, 2008).

69 Wright, The Looming Tower, 155-160.

70 National Commission on Terrorist Attacks, The 9/11 Commission Report, 47-70.

71 Rohan Gunaratna and Arabinda Acharya, "The Terrorist Training Camps of al Qaeda," in The Making of a Terrorist, ed. James J.F. Forest, volume 2 (Westport, CT: Praeger, 2007), 177.

72 Ibid., 178.

73 Wright, The Looming Tower, 163.

74 Bin Ladin et al., "Jihad Against Jews and Crusaders." 


\section{2 \\ THE IDEOLOGY BEHIND AL-QAIDA AND THE ISLAMIC STATE}

\section{Daniel Rudder and Christopher Heffelfinger}

Islamist militancy is often equated solely with the term jihad, and while that concept is critical to the movement, Islamist militancy is a set of values, tenets, and ideas set forth - and often argued over-by numerous scholars and reformers. To understand Islamist militancy, it is crucial from the outset to establish the distinction between Islam and Islamism. As opposed to the religion of Islam, Islamism is the organized effort to advocate for Sharia (Islamic law) as the basis for society and the state. It is also known as political Islam. The Islamist movement is made up of dozens of groups globally. Some are violent, but many are peaceful. ${ }^{1}$

The term "jihad" is most commonly understood in the West as holy war, or military action on behalf of Islam. ${ }^{2}$ But to most Muslims over the centuries, the term-which simply means "striving" or "to exert oneself" in Arabic — referred to a believer's spiritual struggle over the "base self," avoiding sin and attaining greater piety. Jihad also includes non-violent efforts at reform and activism. It is important to understand the contentious term's broader place within Islam as opposed to the exclusively militant connotation it has come to hold for radical Islamists more recently.

Among the other tenets and values of militant Islamism are takfir (the excommunication of other Muslims from the faith), the re-defining of Muslims' religious obligations, and the primacy and need for a caliphate to establish legitimacy of leadership and an authentic Islamic state. Militant Islamists-in their pursuit of a society governed by strict, orthodox Islamic principles-have implemented these concepts.

This chapter provides an evolution of Islamism. It begins with an overview of Wahhabism and Salafism, essential to understanding Islamist activism. It then reviews the historical support for these concepts, beginning with an examination of 13th-century scholar Ibn Taymiyya's historical role in shaping militant interpretations of Islam. The chapter then reviews the reformers and activists of the 19th and 20th centuries who revived Ibn Taymiyya's ideas to effect change in their societies. Finally, these earlier foundational movements are connected to the modern, militant jihadi groups like al-Qaida and the Islamic State that found rationales within them to carry out terrorist attacks. ${ }^{3}$

\section{Wahhabism and Salafism: an overview}

The terms Wahhabi and Salafi are widely employed in discussions of Islamism and terrorism, yet precise definitions for them, and how they differ, can be elusive. These two ideological movements, which are the most important and dominant strains of Islamism, had separate points of origin and differing trajectories 
of development. While there is much overlap between the two, particularly in matters of Islamic law and jurisprudence, their critical distinction is in regard to political activism.

Wahhabism is a puritanical Sunni Islamic reform movement founded by the Hanbali scholar Muhammad ibn Abd al-Wahhab (1703-1792) in the Arabian Peninsula and is today the dominant form of Islam in Saudi Arabia. The term "Wahhabi," however, is employed in a polemical or pejorative usage, and adherents of this movement instead call themselves Salafi, muwahhidin (supporters of monotheism), or simply Sunni Muslims. Ibn Abd al-Wahhab criticized many popular Islamic practices as idolatrous and called for a return to Islam as practiced during the Prophet Muhammad's lifetime and that of the first three generations of the Prophet's followers, who make up the Salaf al-Saliheen, or "pious predecessors."

Both Wahhabis and the Egyptian-descendant Salafis argue that the Quran and the hadith (the sayings and recorded actions of the Prophet Muhammad) should be the only sources of religious conduct, and they reject Western influence and other forms of Islam such as Sufism and Shiism. While Salafism is also a puritanical movement within Sunni Islam that calls for a return to the traditions of the Salaf al-Saliheen, after which it is named, it emerged in a very different political environment. Wahhabis long held a pact with the Saudi ruling family to remain quiet in political affairs, while the Salafi movement that arose out of 19th and 20th century Egypt is expressly political in its activism. ${ }^{5}$

Salafi-jihadism, then, is a third, distinct category into which groups like al-Qaida and the Islamic State fall. Salafi-jihadis generally agree with the political ambitions and awareness of the Salafi movement but differ on methodology and strategy. While most Salafi groups since the 19th century have largely eschewed violence, Salafi-jihadis went to lengths to justify their use of violence, ${ }^{6}$ including against unarmed civilians, to further the cause of reinstating their interpretation of God's law.

\section{Ibn Taymiyya and the foundations of modern militancy}

To understand the theological rationale underpinning the militancy of al-Qaida and other Islamist terrorist groups, one must begin in 13th-century Mesopotamia with the scholar Taqi al-Din Ahmad ibn Taymiyya. Ibn Taymiyya is considered a key figure in the evolution of the Salafi movement, establishing the concept of takfir. ${ }^{7}$

Ibn Taymiyya was a proponent of strict textualism (athari) and is widely considered the foundational thinker of the contemporary Salafi movement. He opposed the theory of textual rationalism (kalam) prevalent in his day in favor of a fundamentalist interpretation of the Quran and hadith.

Ibn Taymiyya was born in the Mamluk Islamic Sultanate in 1263, growing up under the constant threat of pagan Mongol encroachment from the east. Only five years before his birth, the Mongols had conquered the neighboring Abbasid Caliphate and sacked its capital, Baghdad. When he was six years old, his village fell to the Mongols, forcing his family to flee to Damascus.

With the battle-hardened Mongols on their eastern doorstep, the Mamluks, who ruled Egypt and Syria from their headquarters in Cairo, had cause for concern. The sultan promptly called for a jihad against the pagan invaders. The Mamluk army, imbued with religious fervor, began to wage a brutal defensive war. ${ }^{8}$ Mahmoud Ghazan, the Mongol leader, presented the Mamluk authorities with a dilemma in 1295, when he and his tribesmen converted en masse to Sunni Islam. The defensive war against Mongol aggression, which had until then been characterized as a jihad, suddenly became an intra-faith conflict. ${ }^{9}$

This put the Mamluk sultan in a precarious position. According to Sunni orthodoxy, any individual is considered a Muslim if he or she recites the shahada (declaration of faith) - "there is no god but God and Muhammad is His messenger"- in front of witnesses. ${ }^{10}$ Furthermore, no matter how undesirable or cruel a Sunni leader might be, as long as he fulfills this minimum criteria, surrendering to his authority is incumbent upon Muslims. Creating fitna (discord) in the umma (Islamic community) is considered a serious sin. Rebellion against a Sunni ruler, regardless of the motivations or context, is forbidden. 
In 1303, however, Ibn Taymiyya issued a fatwa (religious edict) that challenged, and for subsequent generations of militants destroyed, the orthodox classification of a true Muslim. Ibn Taymiyya argued that an essential indicator of belief and acceptance was left out of the traditional orthodox understanding of what defined a true Muslim: the individual must strictly adhere to, and a ruler must strictly enforce, Sharia. ${ }^{11}$

Despite the Mongols' official conversion to Islam, they continued to promulgate their Yasa code, a blend of various elements from the Islamic, Christian, and Jewish legal traditions, along with aspects of the Mongols' own longstanding customs. This led Ibn Taymiyya, then an official of the Mamluk sultanate, to issue his famous fatwa, specifically directed toward a Muslim prince named Muzaffar who governed a city on behalf of the Mongols. His fatwa effectively pronounced takfir against the Mongols, labeled them apostates, and argued that their blood was then licit in warfare. It thus became obligatory for "true" Muslims to wage jihad against the apostate Mongol leaders and those Muslim citizens who had accepted the Yasa code. ${ }^{12}$

Ibn Taymiyya's other major theological mission, which modern militants have enthusiastically embraced, was to assert the primacy of militant jihad in the Islamic faith. Along with total, literal adherence to Sharia, he considered waging martial jihad a fundamental part of Muslims' religious obligation and a primary duty of all believers. He argued that by the Middle Ages, Muslims only acknowledged the personal spiritual connotation of jihad (as expressed in Sufism, prominent in his time), and this was a blasphemous misunderstanding of what he viewed as a central component of Islam. ${ }^{13}$

He is most revered by modern Islamist militants for the fatwa he issued in 1303 that labeled the Mongols apostates, despite their conversion to Islam five years earlier. The ruling challenged the accepted identifiers of a true Muslim - namely the simple profession of faith (shahada) - and would be a foundation for 20thand 21st-century militants to justify militant jihad against political leaders in the Muslim world through the practice of pronouncing takfir. ${ }^{14}$

Muhammad ibn Abd al-Wahhab advanced some of Ibn Taymiyya's 13th-century ethos in 18th-century Arabia, developing what would later become known as Wahhabism. Notably, he and his movement were religious reformers before all else. They sought to "purify" the practices of fellow Muslims by returning to the ways of early and "unadulterated" Islamic society. His purification process also included a heavy emphasis on excommunicating members of the faith, elucidated in works such as Nawaqidh al-Islam (Things That Nullify One's Islam) and perhaps his best-known writing, Kitab al-Tawhid (Book of Monotheism).

Salafis, however, would turn their focus outward by the 20th century. For Wahhabis, the need to enforce strict interpretations of Islamic law — such as death for those labeled kuffar, or unbelievers, and corporal punishments for other transgressions of creed—was essential to the project of purifying Muslim society. Significantly, these practices and principles would be seen in action two centuries later with the Islamic State.

\section{Egypt and the Muslim Brotherhood}

There is a clear lineage running from the teachings of Ibn Taymiyya, through the cleric Ibn Abd alWahhab in 18th-century Arabia, to reformers like Muhammad Abduh in late 19th-century Egypt. This lineage culminated in the emergence of 20th-century political and militant Islamist groups, which drew upon these arguments to justify opposition to local Muslim governments. For Egypt, the 19th and early 20th century was a period of renewal and revival of Ibn Taymiyya's brand of fundamentalism and generated the first Islamist reformers. Indeed, Egypt would serve as a wellspring for Islamism, as it saw more than 100 years of evolving Salafi thought and activism.

Muhammad Abduh (1849-1905) was one of the first reformers to use the term Salafi as it is understood today. By the 1960s, it would be co-opted by more radical elements like Sayyid Qutb and his followers. Yet Abduh, an Egyptian religious scholar and liberal reformer, sought to demonstrate Islam's compatibility with European rationalism using the model practiced by the earliest Muslim generations, the Salaf. He 


\section{Rudder and Heffelfinger}

argued they had created a vibrant and thriving community and state because they creatively interpreted the Quran and hadith to solve new challenges as they arose. Among the primary goals of Abduh's activism was the rejection and defiance of Western imperialism. ${ }^{15}$

Following World War I and the fall of the Ottoman Empire, Egypt would become a laboratory for the evolution and development of political and militant Islamist ideology. In 1928, a teacher named Hassan al-Banna founded a religio-political movement in Egypt called the Muslim Brotherhood (al-Ikhwan alMuslimin).${ }^{16}$ It would influence scores of subsequent Islamic organizations across the globe, both militant and non-violent. Al-Banna became increasingly disturbed by Egypt's political, economic, and social crises, all of which had facilitated the British occupation of his country. He believed that the root cause of these crises was Egypt's rejection of Islam in favor of Western secularism and materialism. ${ }^{17}$

For al-Banna, Islam represented a panacea for all that ailed Egypt. He believed in the purity of the Islam practiced during the "golden age" of the Prophet Muhammad, argued that modern Muslims had strayed from God, and thus established the Brotherhood to guide society back to the right path. ${ }^{18}$ Like Abduh, alBanna blamed Western secularism as a core cause of the Muslim world's decay and straying from its roots. Although the specifics of the state the early Brotherhood sought to create were vague, al-Banna consistently argued that sovereignty did not belong to the people or their leaders but to God alone. Any political system that failed to acknowledge this essential truth was unacceptable and destined for failure. Al-Banna argued that Egypt must abandon its secular and Western nature and adopt the Quran as its constitution and Sharia as the law of the land. ${ }^{19}$

To realize such a transformation on the political level, al-Banna believed in reforming the hearts and minds of the people so that the government would eventually have no choice but to change to reflect the masses' religio-political vision. To this end, the Brotherhood created a vast network of social services-such as schools, health clinics, and neighborhood clubs - through which its members propagated their vision of a pure Islam. In this regard, the Brotherhood's efforts at mobilizing the masses was a novel one and a divergence from the many other Islamist reformers who primarily worked through the publication of their writings.

At the same time that the Brotherhood developed its network of social services, it engineered a covert program to infiltrate its members into the military and police. It also established a militia. The militant wing of the Brotherhood became active in 1948 by attacking British and Jewish businesses throughout Egypt. They also participated in the unsuccessful military effort to block the establishment of Israel in $1948 .{ }^{20}$

The Brotherhood was linked to the assassination of Cairo's police chief, which led the government to ban the activities of the Brotherhood and to arrest and imprison many of its members. In retaliation for the government's crackdown, the Brotherhood assassinated Egyptian Prime Minister Mahmoud Fahmi al-Nuqrashi in 1948. Responding in kind, the government's secret police killed al-Banna on February 12, 1949. Prior to his death, the Brotherhood had grown to an estimated 300,000 to 600,000 members within Egypt. $^{21}$

By the time of his death, al-Banna had helped to create affiliates of the Muslim Brotherhood beyond Egypt's borders. The most prominent branches were located in Palestine, Jordan, Syria, and Saudi Arabia. Members of these affiliates would eventually create their own offshoots, thereby rapidly increasing the number of radical groups in the region.

Many of these splinter groups would become far more militant than al-Banna's organization. In Palestine, for example, Brotherhood leader Ahmed Yassin formed his own militant Brotherhood splinter group called Hamas in 1987. Abdullah Azzam, a former senior member of the Jordanian Muslim Brotherhood, partnered with Usama bin Ladin during the Afghan-Soviet war to establish the organization that would become al-Qaida.

The Egyptian Muslim Brotherhood survived the death of its founder and established a tacit partnership with Lieutenant Colonel Gamal Abd al-Nasser and his Free Officers group during the last years of Egypt's 
monarchy. It was a marriage of convenience as both groups sought the ouster of a corrupt and ineffective monarchy. Their association quickly dissolved, however, once al-Nasser began to consolidate his rule following his successful 1952 revolution. The Brotherhood discovered that he neither intended to establish an Islamic state nor to share power with them. ${ }^{22}$

In 1954, a member of the Brotherhood shot at al-Nasser in a sloppy, unsuccessful attempt to kill him. The new Egyptian government immediately enforced a ban on the group, executed much of its leadership, and imprisoned thousands of its members. Those who remained at large were either forced underground in Egypt or were exiled. During these purges, a great number of the Brotherhood's members found refuge in Europe, particularly in the United Kingdom and Germany, and influenced the development of Islamist activism in those countries. Likewise, those who immigrated to the United States would prove highly influential in the formation of the nascent Islamist organizations in America.

For those who stayed in Egypt, al-Nasser's brutal crackdown divided the Brotherhood. The majority of al-Banna's disciples emerged cautiously and resolved to avoid clashing with the regime. They evolved into a political party, renounced violence, and sought to work within the system to gradually effect change. This faction became an active force in Egyptian politics, holding seats in parliament beginning in 1976 and ultimately enjoying a short stint as the leaders of Egypt following the fall of President Hosni Mubarak in $2011 .^{23}$

A smaller faction, sharply opposed to any accommodation with Cairo, coalesced around the ideologue Sayyid Qutb in the 1950s. Like al-Banna, Qutb believed that a return to the Islam practiced during the time of the Prophet and the Salaf was the only cure for the ills of the Muslim world. For Qutb, however, the creation of an Islamic state became imperative, an endeavor for which true Muslims needed to be willing to fight and die.

\section{The ideology of Sayyid Qutb}

Like al-Banna, Sayyid Qutb was also born in northern Egypt in 1906. During the 1930s and 1940s, Qutb worked for the Egyptian Ministry of Education. In 1948, he went to the United States on a scholarship to study the American educational system, earning a master's degree in education from the Colorado State College of Education and taking courses at Wilson Teachers College in Washington, DC. ${ }^{24}$ Qutb returned to Egypt in 1950, disillusioned with the United States and more conservative in his religious beliefs. He would become one of the most militant voices of his era, calling for a vanguard to lead Muslims to establish a political state ruled by Islamic law, a quest that would result in his execution.

In 1951, he published a magazine article called, "The America I Have Seen: In the Scale of Human Values," which contained passages such as:

I fear that a balance may not exist between America's material greatness and the quality of its people. And I fear that the wheel of life will have turned and the book of time will have closed and America will have added nothing, or next to nothing, to the account of morals that distinguishes man from object, and indeed, mankind from animals. ${ }^{25}$

While al-Banna sought to effect socio-political change by cultivating citizens' piety so that the state would eventually be transformed from below, Qutb would demand that a vanguard force wage war against apostate governments to effect socio-political change from the top down. Once the character of the state was changed, Qutb believed, the hearts and minds of the people would follow.

Qutb took Ibn Taymiyya's anti-Mongol, epoch-specific ruling and interpreted it to apply to modern conditions, offering a fresh take on Muslims' right to rebel against apostate rulers. Qutb believed that the dominant ideologies of his day-capitalism, democracy, socialism, and communism-had failed the people. In his groundbreaking work, Milestones (Ma'alim fi 'l-Tariq), Qutb wrote that "mankind today is on the 


\section{Rudder and Heffelfinger}

brink of a precipice . . . because humanity is devoid of those vital values which are necessary not only for its healthy development but also for its real progress. . . It is essential for mankind to have new leadership!"26

This "new leadership," he argued, was signified by a wholehearted embrace of Islamic law, the perfect alternative to the failed ideologies of the West. Viewing the promulgation of Sharia as a divine commandment, Qutb believed that it was incumbent upon all Muslims to work toward implementing it in their own societies. Since the repressive nature of the governments in the Islamic world prevented Muslims from fulfilling this religious obligation, it would be futile to try to work peacefully and constructively from within the system to effect political change. ${ }^{27}$

With no other recourse, a vanguard of dedicated individuals should be created to, as Qutb wrote,

establish the reign of God on earth and eliminate the reign of man, to take power out of the hands of those of His worshippers who have usurped it and return it to God alone, to confer authority upon divine law alone and to eliminate the laws created by man. ${ }^{28}$

Qutb demanded an international revolution with the goal of creating Islamic states throughout the Muslim world. In his call to arms, Qutb pronounced takfir against the leaders of "so-called" Muslim countries. They were apostates, he claimed, and therefore legitimate objects of martial jihad. Qutb updated Ibn Taymiyya's argument by substituting the West for the Mongols as the enemy of Islam, an evil adversary that uses "Muzaffars" - the prince whom Ibn Taymiyya accused of apostasy-to prevent the Muslim community from following the true word of God. ${ }^{29}$

When Qutb's death sentence was announced to him in 1965, he responded, "Thank God, I performed jihad for 15 years until I earned this martyrdom." ${ }^{30}$ Fixated on sacrificing his life for this movement, his words continue to inspire contemporary generations of Salafi-jihadis. Indeed, Milestones' literal interpretations of the Quran and hadith, and of the lives of the Salaf, are frequently found in their modern literature. ${ }^{31}$

Despite his recognition of the existential threat posed by the West, Qutb focused his revolutionary rhetoric on apostate regimes in the Islamic world. Just as he had built upon the thoughts of Ibn Taymiyya, the ideologues of the transnational Islamist militant movement would later build upon his views years after his death in 1966. By that time, the West—and specifically the United States-would be in the crosshairs.

\section{The Arab Cold War}

During the 1950s and 1960s, Egypt and Saudi Arabia engaged in a bitter ideological contest to define the identity of the Arab world. During the conflict, known as the Arab Cold War, Egypt propagated a panArab ideology that placed primacy on Arab identity over religious or national affiliations and argued for unity among all Arabs. It attacked the Saudi royal family with propaganda, relentlessly seeking to expose its improprieties.

The Saudis responded with a vision of their own, pan-Islamism, which viewed all other identities as subordinate to religious affiliation and sought to shore up their credentials as leaders of the Islamic world. The doctrine of pan-Islamism first emerged as a means to resist Western encroachment during the late 19th century. It essentially argued that unity among Muslims is not only central to Islam but is critical to the strength of the Muslim world. Yet through the creation of various Saudi-funded institutions intended for the propagation of Islam around the world, it became clear this ideology was little more than a rebranding of Wahhabism.

In May 1962, Saudi Arabia hosted a conference of Islamic states to formulate ways to fight secularism in the Arab and Muslim world. The meeting created the Muslim World League, which was funded by the Saudi monarchy with its permanent headquarters in Mecca. ${ }^{32}$ The league would become one of the Saudis' main weapons against secularism, and it proved instrumental in providing an Islam-focused alternative to 
the secular pan-Arab ideology of al-Nasser. Through its establishment, the Saudis created an extremely well-funded center for Salafi outreach and education based around the teachings of Ibn Abd al-Wahhab.

Saudi Arabia's King Faisal recognized that to realize his dream of a unified Islamic community and to strike a decisive blow against pan-Arabism, there had to be a standardized reading of Islam-namely the Wahhabi variety - that would supplant the wide variety of Islamic interpretations. By paying the salaries of imams (prayer leaders) at mosques throughout the world, offering scholarships to Saudi universities, and funding the printing and dissemination of topical literature, the Muslim World League sought to establish a standard that was ultra conservative and fundamentalist to inform how the contemporary Muslim world should be ordered. ${ }^{33}$

The Muslim World League engaged in a wide range of charitable activities, such as the funding of health clinics, soup kitchens, and other relief activities to aid needy Muslims-often in conflict zones. But along with these publicly charitable actions, the Muslim World League and its subsidiaries regularly spread militant ideology, provided arms to militants, and funded jihadi training. Some of these operations would also later be undertaken by Saudi charities such as the Benevolence International Foundation and the alHaramayn Foundation, which were both designated by the United States as supporters of terrorism. ${ }^{34}$ Like the league's offer to pay foreign imams' salaries, however, these humanitarian endeavors came with strings attached. Local beliefs and customs, which had long been integral parts of Muslims' religious practices, began to be suppressed, and the humanitarian facilities were used as propagation bases.

Offering safe haven to Egypt's Muslim Brotherhood marked another significant component of the Saudis' political and ideological offensive against al-Nasser. Bitter enemies of the Egyptian government, members of the Brotherhood were welcomed into Saudi Arabia en masse by King Faisal during the late 1950s and 1960s. This was a pragmatic move to put pressure on al-Nasser. Faisal also saw his embrace of the Brotherhood-a group that many Muslims viewed favorably for challenging the secularism of al-Nasser's regime - as a way to advance his credentials as the leader of the Muslim world.

While many members of the original Muslim Brotherhood, such as Qutb, had stayed in Egypt after al-Banna's assassination, once relations between Egypt and Saudi Arabia began to sour in the late 1950s, the Saudis courted many of these disaffected men. Saudi Arabia gave sanctuary and generous stipends and encouraged them to spread anti-Nasser propaganda from Saudi soil.

Two particularly noteworthy members of the Brotherhood who found refuge and became professors in Saudi Arabia were Muhammad Qutb, brother of Sayyid Qutb, who had fled Egypt in the mid-1960s, and Abdullah Azzam. They both worked at King Abd al-Aziz University in Jeddah, another popular institution for Saudi and foreign students, established in 1967. They both also taught an undergraduate Usama bin Ladin at the university. ${ }^{35}$

Azzam, a Palestinian member of the Brotherhood, had taught Islamic law at the University of Jordan. He moved to Cairo, where he completed a master's degree and PhD in Islamic Jurisprudence at al-Azhar University. Saudi Arabia subsequently offered him a job at King Abd al-Aziz University in the late 1970s. The fact that Azzam dedicated himself to fomenting martial jihad notwithstanding, the Saudi government made him the head of the Muslim World League's education division while he was in residence at King Abd al-Aziz University. ${ }^{36}$

Yet Saudi Arabia also understood the importance of preventing rebellious splinter groups from taking hold in their country, both out of self-protection and to guard against endangering their goal of worldwide Islamic unity. Toward that end, in 1971 a formal initiative to protect and promote a "pure" Salafi doctrine was created: the Permanent Committee for Islamic Research and Guidance. The committee has been composed of a body of clerics consistently loyal to the Saudi royal family who issue fatwas on matters of belief, worship, and society.

It is difficult to overestimate the effect of Brotherhood members on Saudi society. Some obtained jobs as imams in mosques, while others worked as teachers, professors, and top officials in the Ministry of 


\section{Rudder and Heffelfinger}

Education, designing school textbooks and syllabi. They had a tremendous impact on an entire generation of Saudi youth, as well as on thousands of foreign Muslims who flocked to the kingdom for subsidized schooling.

The Saudis had largely been cut off from the outside world and had been conditioned to leave political considerations to their rulers in the House of Saud, in line with the pact formed by Ibn Abd al-Wahhab nearly two centuries ago. Their worldview was generally devoid of any political considerations. But this began to change when the Brotherhood arrived. The Brotherhood's activist ideology mixed with the indigenous fundamentalism of the Saudis. While the doctrine of Wahhabism was largely apolitical, the political activism of emigrant Brotherhood members threatened to upend that status quo. ${ }^{37}$

In 1961, King Faisal seized on al-Nasser's decision to place the revered al-Azhar University in Cairo under government control by creating a rival religious university in Saudi Arabia. Under the leadership of Brotherhood members, the Saudi government opened the Islamic University of Medina, designed to be an alternative to al-Azhar following its loss of legitimacy through its association with the secular al-Nasser regime.

As Saudi Arabia used its vast wealth to enable the Muslim World League-and several other organizations under its umbrella such as the International Islamic Relief Organization and the World Assembly of Muslim Youth - to globally propagate its religio-political vision on a massive scale, the next generation of militant groups emerged in Egypt.

By the late 1960s, the Egyptian economy was in ruins, the people suffered at the hands of the elite, and an acute identity crisis had developed. Secularism, with a focus on Arab solidarity, was seen to have failed the Arab world. Egyptians and other Arabs began to reconnect with their Islamic heritage with renewed vigor. It was in this context that the arguments of Sayyid Qutb provided a bridge from the gradual bottomup approach of al-Banna's Muslim Brotherhood to the more immediate and violent approaches of the post-1967 militant groups.

The most important of these groups that emerged in the post-war period were the Egyptian Islamic Group and Egyptian Islamic Jihad. The significance of these groups is two-fold. First, they were trailblazers in locally focused terrorism and were relatively successful in waging war against their government. Second, these two groups were among al-Qaida's earliest and most militarily effective feeder groups and affiliates. Their eventual alliance with Bin Ladin's organization drastically expanded al-Qaida's operational and logistical capabilities and greatly enhanced Bin Ladin's role as a major player in the world of transnational terrorism.

\section{Muhammad Abd al-Salam Faraj and The Neglected Duty}

Muhammad Abd al-Salam Faraj became an influential facet of the Egyptian, and later global, Salafi movement by the 1960s. His embrace and advocacy for violent jihad came in succession to the prominent Salafi reformers before him-Abduh and his student Rashid Rida, Hassan al-Banna, and finally Sayyid Qutb.

Egyptian Islamic Jihad, an alliance of several small clandestine groups, emerged in the late 1970s under the leadership of Faraj. Unlike the Egyptian Islamic Group, which focused on universities for recruitment, many of Islamic Jihad's members were underprivileged urbanites. Ayman al-Zawahiri would later become the head of Islamic Jihad before he began to merge it with al-Qaida in 1998.

Heavily influenced by Ibn Taymiyya, Faraj published Islamic Jihad's manifesto in 1981. Called The Neglected Duty, it was a call for action that focused on the primary importance of martial jihad. It became one of the most significant treatises of the militant Islamist movement and impacted the thinking of Bin Ladin and al-Zawahiri. ${ }^{38}$ Like Qutb, Faraj classified jihad against the Egyptian state as an individual obligation, requiring the participation of all Muslims. Faraj sought to establish martial jihad as the sixth pillar of Islam. ${ }^{39}$ 
For Faraj, jihad was not just the most important method for establishing an Islamic state but the only method, the essential means for reinstating the glory of Islam. In The Neglected Duty, Faraj rejected a number of strategies favored by other militants that he felt were counterproductive to the umma's realization of God's rule on earth.

Faraj had watched as the approaches of al-Banna and Qutb failed to bring about the creation of an Islamic state. He knew that it would be playing with fire to challenge the Egyptian authorities. Accordingly, the longer that one waited to attack the state, the more likely one was to be arrested or killed. The execution of a rapid and violent blow against Cairo was the only path.

In The Neglected Duty, as in the works of Qutb and Ibn Taymiyya, Faraj embraced the argument that implementation of Sharia was the most critical indicator of a political leader's piety and of whether a particular community could be considered truly Islamic. Faraj wrote that

one of the necessary conditions to make a state Muslim is that it be governed by the laws of Islam. Yet the laws regulating the life of the Muslims are infidel laws-laws conceived by infidels and imposed by them upon Muslims... . The situation of Muslims [today] resembles that of the believers under the yoke of the Mongols. ${ }^{40}$

Accordingly, Faraj pronounced takfir against Egypt's leaders, quoting the Quranic verse, "Whoso judgeth not according to what God hath revealed, they are the transgressors." ${ }^{11}$ The solution was martial jihad, and Islamic Jihad dedicated itself to targeting those who were responsible for the governing of the country, the leaders who acted as a wedge between the people and true Islam.

Faraj formulated a three-step strategic plan toward his ultimate goal of the restoration of the caliphate.

Step 1: The Near Enemies. Faraj was unflinching in his assertion that groups must begin their struggle by overthrowing their local governments and overseeing the promulgation of Islamic law in their own countries. ${ }^{42}$

Step 2: The Far Enemies. Once the near enemies have been subdued, Muslims should attack outside, far enemies who aided and abetted the local apostate rulers.

Step 3: The Caliphate. The newly established Islamic states, free of interference from their far enemies, should unite to reinstate the caliphate and restore the glory of the transnational Muslim community.

Faraj's thinking marked a significant step in the evolution of militant Islamist movements as they moved along the path from a local to a global focus. While other earlier thinkers, such as Qutb, addressed the treachery of Israel and the West, they did not present any explicit program for waging war against them. Thus, on this subject, Faraj represents a middle point between Qutb and later leaders such as Bin Ladin, who agitated for a permanent shift in targeting priorities from the near to the far enemy.

After Islamic Jihad's members assassinated Egyptian President Anwar Sadat, Egyptian authorities executed Faraj on April 15, 1982. Islamist activists, including members of the groups that fell under the Islamic Group's umbrella, were arrested by the thousands. Among them was Omar Abd al-Rahman, known as the "blind sheikh," who was later acquitted of all charges and released, and an Islamic Jihad member who would rise to prominence with al-Qaida, al-Zawahiri.

\section{The formation of al-Qaida}

With the creation of al-Qaida, the evolution of Salafi thought culminated in a movement centered around militant uprising against the United States and its allies. Its leaders and the contemporary Salafi-jihadi scholars that they used for legitimacy, such as Abu Qatada and Abu Muhammad al-Maqdisi, came at the 


\section{Rudder and Heffelfinger}

end of a Salafi lineage stretching back two centuries, greatly influenced by Ibn Taymiyya, Ibn Abd alWahhab, Sayyid Qutb, and other prominent 20th-century Egyptian Islamists.

Usama bin Ladin would ultimately become the leader and chief spokesman of the transnational Islamist militant movement known as al-Qaida and its most recognizable face. The 17th of 24 children fathered by an extraordinarily wealthy construction magnate, Bin Ladin's religious awakening is said to have begun while he was a student at King Abd al-Aziz University in Jeddah. Also influential to Bin Ladin was the preaching of Abdullah Azzam. ${ }^{43}$

Often called the "amir of jihad," Azzam was unyielding in his advocacy of holy war. "Jihad and the rifle alone: no negotiations, no conferences, and no dialogues," was one of his more well-known catchphrases. ${ }^{44}$ Azzam had also moved to Peshawar in the early 1980s to support the Afghan jihad. He was a fervent advocate of martial jihad, viewing it as a primary duty of all Muslims. ${ }^{45}$

Azzam traveled the world to set up fundraising and propaganda offices. He issued a number of fatwas categorizing the Afghan struggle as a defensive jihad. In the United States, Azzam established al-Kifah Refugee Center, which had its headquarters inside the al-Farooq Mosque on Atlantic Avenue in Brooklyn, New York. The Brooklyn center quickly became a hotbed of militant activity, attracting the so-called "blind sheikh," Omar Abdel Rahman, and many of the individuals involved in the 1993 World Trade Center bombing, as well as El Sayyid Nosair, the assassin of Jewish Defense League leader Rabbi Meir Kahane.

In 1984, Bin Ladin and Azzam established the Afghan Services Bureau (Maktab al-Khidamat) in Peshawar, which was designed to provide a wide range of services to the anti-Soviet jihad, including generating propaganda to encourage recruits and donations.

Meanwhile, al-Zawahiri relocated to Pakistan and Afghanistan in 1986. He had spent three years in an Egyptian jail for his alleged involvement in the assassination of Sadat. He was routinely tortured, but that only enhanced al-Zawahiri's militant fervor. In the tradition of Faraj, he believed that only rapid strikes executed by a vanguard could bring about revolutionary change and impose a pure Islam upon a spiritually awakened populace. Al-Zawahiri saw no need to involve the masses in his revolution, believing-like Qutb - that a vanguard would lead the umma to this end. Once in South Asia, al-Zawahiri began to nurture a relationship with Bin Ladin.

In early 1988, the Soviets announced their intention to fully withdraw from Afghanistan by the following year. The senior figures among the foreign fighters agreed that the jihad should not end with the liberation of Afghanistan. They supported Azzam's move to establish a network of loosely affiliated militant Islamist groups and individual mujahidin to wage a global holy war. Writing in al-Jihad, the journal of record for foreign fighters in Afghanistan, Azzam described the function of the new militant coalition: "This vanguard constitutes the strong foundation (al-Qaida al-Sulbah) for the expected society." ${ }^{6}$ It would become known as al-Qaida.

In August 1996, Bin Ladin released his first major statement outlining his religio-political agenda. In the document, called "Declaration of Jihad Against the Americans Occupying the Land of the Two Holiest Sites," Bin Ladin was highly critical of the Saudi government, castigating it for trading some aspects of Sharia for secular law.

Furthermore, he accused the Saudi royal family of siding with infidels against Muslims by inviting the American military into the Saudi kingdom in 1990 after Iraq invaded Kuwait. Despite his hatred of the Saudi royal family, Bin Ladin saved most of his ire for the United States, the greater enemy that he believed lurked behind the Saudis, just as the Mongols lurked behind the prince Muzaffar in the days of Ibn Taymiyya.

Deeply concerned about Saudi Arabia's growing financial troubles, Bin Ladin complained about the amount of money the United States had taken from Saudi Arabia to finance its military presence and to arm and train the ineffective Saudi military. He also railed against Saudi oil policy, which he argued was 
controlled by the United States to suit its pricing needs to the detriment of Muslims. He blamed Saudi Arabia's economic decline on the United States. ${ }^{47}$

The "Declaration of Jihad" is perhaps the first formal and articulate call for Muslims to switch their focus from the near to the far enemy: "The occupying American enemy is the principal and the main cause of the situation. Therefore efforts should be concentrated on destroying, fighting and killing the enemy until, by the grace of Allah, it is completely defeated." ${ }^{\prime 8}$ Prioritizing the far enemy was critical because

the situation cannot be rectified (the shadow cannot be straightened when its source, the rod, is not straight either) unless the root of the problem is tackled. Hence it is essential to hit the main enemy who divided the umma into small and little countries and pushed it, for the last few decades, into a state of confusion. ${ }^{49}$

On February 23, 1998, Bin Ladin and al-Zawahiri, along with several other militant and religious leaders, announced the creation of the World Islamic Front for Jihad Against the Jews and the Crusaders. The coalition was a conglomerate of numerous militant groups that had until this point been primarily focused on their local struggles. On many levels, the content of the World Front's statement was similar to that of Bin Ladin's "Declaration of War," but it expanded Bin Ladin's call for martial jihad from one that sought to simply expel the U.S. military from Saudi Arabia into one that called for indiscriminate attacks on Americans wherever they might be found.

The statement gave the United States a taste of the new campaign being waged against it by militants operating around the world. As the document made clear, the diverse signatories had firmly shifted their targeting priorities from the near to the far enemy. No longer would Bangladeshis solely fight the Bangladeshi government or Saudis exclusively target the Saudi state. The efforts of all members of this new alliance, irrespective of their national origin, would be employed to wage war first and foremost against the United States.

By asserting that "all these crimes and sins committed by the Americans are a clear declaration of war on God, his messenger, and Muslims," the Front argued that jihad against the Americans must be waged out of necessity: "and ulama [Islamic religious scholars] have throughout the Islamic history unanimously agreed that jihad is an individual duty if the enemy destroys the Muslim countries."

Therefore, the statement concluded,

the ruling to kill the Americans and their allies — civilians and military-is an individual duty for every Muslim who can do it in any country in which it is possible to do it . . . in order for their armies to move out of all the lands of Islam, defeated and unable to threaten any Muslim.

To be clear, the goals of the transnational Islamist militant movement remained the overthrow of local regimes in the Muslim world and the re-establishment of the caliphate. Al-Qaida viewed the United States as a roadblock on the path to the realization of those objectives. Thus, attacks on the United States were not necessarily intended to destroy or conquer it for Islam in the short term but rather to remove American support for local governments so that the Muslim world could once again be ruled by "true believers." Bin Ladin and al-Zawahiri argued that this fundamental obstacle must be destroyed before the movement could address its primary goal of defeating local leaders.

It was this view that led directly to the most spectacular terrorist attack in world history: a series of four coordinated strikes in the United States on September 11, 2001, that killed nearly 3,000 people, destroyed New York City's World Trade Center, damaged the Pentagon, and caused billions in damages to property and infrastructure.

While 9/11 was the single bloodiest and most damaging attack in al-Qaida's history, it also effectively marked the beginning of the end of the group. Its leaders would be driven deep into hiding and many of 


\section{Rudder and Heffelfinger}

its lieutenants killed. Over the next decade, a number of regional affiliates would emerge, among them: al-Qaida in the Arabian Peninsula, al-Qaida in the Islamic Maghreb, al-Shabaab, Hayat Tahrir al-Sham (formerly Nusra Front, also known as al-Qaida in Syria), al-Qaida in the Sinai Peninsula, al-Qaida in Gaza, and al-Qaida in Iraq.

\section{The Islamic State}

The Islamic State is the re-incarnation of the al-Qaida affiliate in Iraq initially led by the Jordanian militant Abu Musab al-Zarqawi. Al-Zarqawi had studied under Abu Muhammad al-Maqdisi, the prominent Jordanian Salafi-jihadi scholar whose work al-Qaida leaders frequently cited to bolster their legitimacy.

The Islamic State has focused on retaliation of perceived grievances through gruesome displays of violence as their primary modus operandi. The group's leadership has explicitly labeled their fighters as part of "the current of Jihadi-Salafism." ${ }^{50}$ But to a large extent, they set aside the complex questions of theology and ideology that al-Qaida's leadership — and the Egyptian Islamists before them-delved into. Their tactics have earned them the condemnation of not only mainstream Muslim clerics but also hardline Salafi ones like al-Zawahiri and the prominent cleric Abu Basir al-Tartusi. ${ }^{51}$

The Islamic State wholly embraced the theology of Ibn Abd al-Wahhab, widely distributing Wahhabi textbooks among schools it controlled. Many Islamic State publications, such as al-Taghut (the Tyrants), for example, contain extensive Wahhabi quotes, making clear their place within Salafi and Wahhabi traditions. ${ }^{52}$ The Islamic State even created a religious police akin to that of Saudi Arabia (the Mutawwa), which corralled citizens to worship at prayer time, enforced dress codes and the separation of genders, and sought to stop any public vices..$^{53}$

Unlike most other Wahhabi adherents, however, they have militarized and politicized Ibn Abd al-Wahhab's calls for the purification of Islamic practices and taken the punishment of offenders to nearly unimaginable extremes. ${ }^{54}$ Significantly, the Islamic State also condemns Saudi Arabia's leaders as illegitimate Islamic rulers unfit to preside over the Two Holy Mosques of Mecca and Medina.

In this regard, the Islamic State created a new brand of Wahhabi Islam, which had changed little since its inception in Arabia in the late 18th century. This blend of the creed of Wahhabism-marked by puritanical obsession over concepts such as shirk (associating partners with God) and rooting out bida (theological or legal innovation) - and the political ambitions of 20th-century Salafism marks a significant turn in the development of Islamism. No longer did adherents of Wahhabi Islam need to remain quiet politically and demonstrate obedience to the Saudi monarchy in exchange for patronage; instead, there became what was essentially a new habitat for Wahhabi thought to imprint on a very different political and social environment that was to become their caliphate.

In 2014, the Islamic State's announcement of a caliphate- under which all Muslims across the globe were to be subject - was dismissed almost universally. Nevertheless, the viability of such an enterprise was established. The Islamic State declared previous Islamic states, such as the Ottoman Empire that ruled from North Africa to western Asia for over six centuries, illegitimate and un-Islamic.

In the language for which Salafis and Wahhabis are best known, the Islamic State demanded a return to early Islamic practices and principles as the sole means of reviving a pure Islamic society and state. In this sense, the Islamic State went beyond the ambitions of al-Qaida and the Egyptian Salafi activist groups of the past century, essentially putting the end goal of establishing a caliphate up front.

\section{Conclusion}

From its earliest days with Ibn Taymiyya, Islamism has been defined by its response to the political environment and how the reformers who took up this ideological endeavor attempted to address the issues of their times. Throughout the 19th and 20th centuries, Islamist reformers of Salafi or Wahhabi persuasion 
did the same, attempting to "purify" their society from elements that diverged from the earliest Muslim generations. This has often meant violent upheaval, at times for Western countries like the United States but most often for Muslims themselves.

Today, despite the deaths of some of these foundational jihadi leaders-including Bin Ladin, al-Zarqawi, and Abu Bakr al-Baghdadi-the legacy of militant Islamist ideology persists. Just as the Islamic State built on previous jihadis' actions and made strides toward establishing a caliphate that would govern Muslims under the strict and exclusionist standards they embody — an outgrowth of Ibn Taymiyya, Ibn Abd alWahhab, and the other early Salafi scholars and activists who established the ideological underpinnings of militant Islamism — one must expect new generations to take up the mantle of this unfinished work.

\section{Notes}

1 For more, see Francois Burgat, Face to Face with Political Islam (London: I.B. Tauris, 2003); William McCants, "Understanding Islam and Islamism," in Terrorism and Political Islam: Origins, Ideologies and Methods, ed. Christopher Heffelfinger and Erich Marquardt (West Point: Combating Terrorism Center, 2008).

2 David Cook, Understanding Jihad (Berkeley: University of California Press, 2015).

3 Note: this chapter focuses exclusively on Sunni-based Islamist militancy, which is by far the dominant form. Shia militant activism, which can be labeled Islamist but is not Salafist, is treated in subsequent chapters.

4 Bernard Haykel in The Princeton Encyclopedia of Islamic Political Thought, ed. Gerhard Bowering (Princeton: Princeton University Press, 2012).

5 David Commins, The Wahhabi Mission and Saudi Arabia (London: I.B. Tauris, 2006).

6 William McCants, ed., Militant Ideology Atlas (West Point: Combating Terrorism Center, 2005).

7 Gilles Kepel, Muslim Extremism in Egypt: The Prophet and the Pharaoh (Berkeley: University of California Press, 1993).

8 Ibid.

9 Denise Aigle, The Mongol Empire Between Myth and Reality (Leiden: Brill, 2014).

10 Some scholars and schools of thought say a witness is not necessary for conversion.

11 Aigle, The Mongol Empire.

12 Albert Hourani, Arabic Thought in the Liberal Age: 1798-1939 (New York: Cambridge University Press, 1983).

13 Aigle, The Mongol Empire.

14 Ibid.

15 Christopher Heffelfinger, Radical Islam in America: Salafism's Journey from Arabia to the West (Lincoln: Potomac Books, 2011).

16 For further reading on the Muslim Brotherhood, see Richard Mitchell, The Society of Muslim Brothers (New York: Oxford University Press, 1993).

17 Heffelfinger, Radical Islam in America.

18 Mitchell, The Society of Muslim Brothers.

19 Ibid.

20 "Profile: Egypt's Muslim Brotherhood," BBC, December 25, 2013, www.bbc.com/news/world-middle-east12313405.

21 Ziad Munson, "Islamic Mobilization: Social Movement Theory and the Egyptian Muslim Brotherhood," Sociological Quarterly 42, no. 4 (2002): 487-510.

22 Mitchell, The Society of Muslim Brothers.

23 David D. Kirkpatrick, "Islamists Win 70\% of Seats in the Egyptian Parliament," New York Times, January 21, 2012, www.nytimes.com/2012/01/22/world/middleeast/muslim-brotherhood-wins-47-of-egypt-assembly-seats.html.

24 The Colorado State College of Education, located in Greeley, Colorado, has been called the University of Northern Colorado since 1970. Wilson Teachers College is now part of the University of the District of Columbia. Some reports have also claimed that Qutb studied at Stanford University in California. See Sayyid Qutb, "The America I Have Seen: In the Scale of Human Values," 1951, www.cia.gov/library/abbottabad-compound/3F/3F56ACA47 3044436B4C1740F65D5C3B6_Sayyid_Qutb_-_The_America_I_Have_Seen.pdf.

25 Ibid.

26 Sayyid Qutb, Milestones (Damascus, Syria: Dar al-Ilm, 1964).

27 Quintan Wiktorowicz, “A Genealogy of Radical Islam,” Studies in Conflict and Terrorism 28, no. 2 (2006): 75-97.

28 Kepel, Muslim Extremism in Egypt.

29 Mitchell, The Society of Muslim Brothers. 


\section{Rudder and Heffelfinger}

30 Lawrence Wright, The Looming Tower: Al-Qaeda and the Road to 9/11 (New York: Knopf, 2006).

31 McCants, Militant Ideology Atlas.

32 Madawi al-Rasheed, A History of Saudi Arabia (New York: Cambridge University Press, 2002).

33 Ibid.

34 Matthew Levitt, Charitable Organizations and Terrorist Financing (Washington, DC: The Washington Institute, 2004).

35 Lawrence Wright, "The Man Behind Bin Laden," New Yorker, September 9, 2002, www.newyorker.com/ magazine/2002/09/16/the-man-behind-bin-laden.

36 Andrew McGregor, " Jihad and the Rifle Alone': Abdullah Azzam and the Islamist Revolution," Journal of Conflict Studies 23, no. 2 (2003): 92-113.

37 This phenomenon was manifest in the al-Nahda, or Awakening, movement led by Safar al-Hawali and Salman alAwda in the decades that followed. For more, see Heffelfinger, Radical Islam in America.

38 Wiktorowicz, "A Genealogy of Radical Islam."

39 Kepel, Muslim Extremism in Egypt.

40 Emmanuel Sivan, Radical Islam: Medieval Theology and Modern Politics (New Haven: Yale University Press, 1990$), 128$.

41 Quran, verse 5:47.

42 Marc Sageman, Understanding Terror Networks (Philadelphia: University of Pennsylvania, 2004).

43 Wright, "The Man Behind Bin Laden."

44 Peter L. Bergen, Holy War, Inc.: Inside the Secret World of Osama Bin Laden (New York: Touchstone Books, 2002).

45 Abdullah Azzam, Join the Caravan (London: Azzam, 1996).

46 Jason Burke, Al-Qaeda: The True Story of Radical Islam (London: I.B. Taurus, 2004).

47 Usama bin Ladin, Declaration of War Against the Americans Occupying the Land of the Two Holy Places (London: al-Quds al-Arabi, August 1996).

48 Ibid.

49 Ibid.

50 Cole Bunzel, From Paper State to Caliphate: The Ideology of the Islamic State (Washington, DC: Brookings, 2015).

51 "The Slow Backlash-Sunni Religious Authorities Turn against Islamic State," The Economist, September 6, 2014.

52 Bunzel, From Paper State to Caliphate, 10.

53 "Crime and Punishment in Saudi Arabia: The Other Beheaders," The Economist, September 20, 2014 ; David D. Kirkpatrick, "And 'ISIS' Harsh Brand of Islam is Rooted in Austere Saudi Creed," New York Times, September 24, 2014, www.nytimes.com/2014/09/25/world/middleeast/isis-abu-bakr-baghdadi-caliph-wahhabi.html.

54 Karen Armstrong, "Wahhabism to ISIS: How Saudi Arabia Exported the Main Source of Global Terrorism," New Statesman, November 27, 2014, www.newstatesman.com/world-affairs/2014/11/wahhabism-isis-howsaudi-arabia-exported-main-source-global-terrorism. 


\title{
3 \\ THE EVOLUTION OF AL-QAIDA 1988 to present day
}

\author{
Seth G. Jones
}

Nearly three decades after the establishment of al-Qaida, a fiery Ayman al-Zawahiri addressed rebel fighters in Syria in 2017. "You are those who have taken up the path of jihad in the way of Allah to raise the flag of Islam and jihad," the al-Qaida leader said. "Unite and close your ranks with your Muslim brothers and mujahidin not just in [Greater Syria], but the entire world, for it is a single crusader campaign being waged against Muslims the world over." ${ }^{1}$ For al-Qaida's leaders, the war in Syria was part of a broad campaign across multiple regions designed to institute an extreme version of Sharia (Islamic law) and overthrow existing ruling regimes.

Al-Qaida's push into Syria, which started in earnest in 2011, was the fourth in a series of historical waves of activity by the group since its establishment in 1988. These waves have been characterized by surges in terrorist violence, along with "reverse waves" distinguished by decreases in terrorist activity. ${ }^{2}$ As political scientist David Rapoport explained, a wave

is a cycle of activity in a given time period-a cycle characterized by expansion and contraction phases. A crucial feature is its international character; similar activities occur in several countries, driven by a common predominant energy that shapes the participating groups' characteristics and mutual relationships. ${ }^{3}$

Using Rapoport's "wave" theory, this chapter reviews the evolution of al-Qaida, beginning with its formation in 1988. It finds that despite some key successes along the way, al-Qaida is no closer to achieving its ambitious goal of a pan-Islamic caliphate three decades after its creation. In addition, al-Qaida has been unable to successfully perpetrate a major terrorist attack in the United States since 9/11.

At least two major challenges plagued al-Qaida's leaders. First, al-Qaida failed to hold territory because of poor leadership, incompetent governance, excessive violence, and internal tensions. Second, al-Qaida suffered from little popular support in the Muslim world, which hampered its ability to recruit fighters, secure funding, conduct operations, and inspire attacks in the West.

\section{Al-Qaida's four waves of activity}

Fatality data provides a useful measure of al-Qaida activity. Figure 3.1 illustrates al-Qaida's major activity waves, using the number of fatalities from attacks perpetrated by al-Qaida across the globe. The data includes total attacks per year from the core al-Qaida organization and its formal affiliates. 


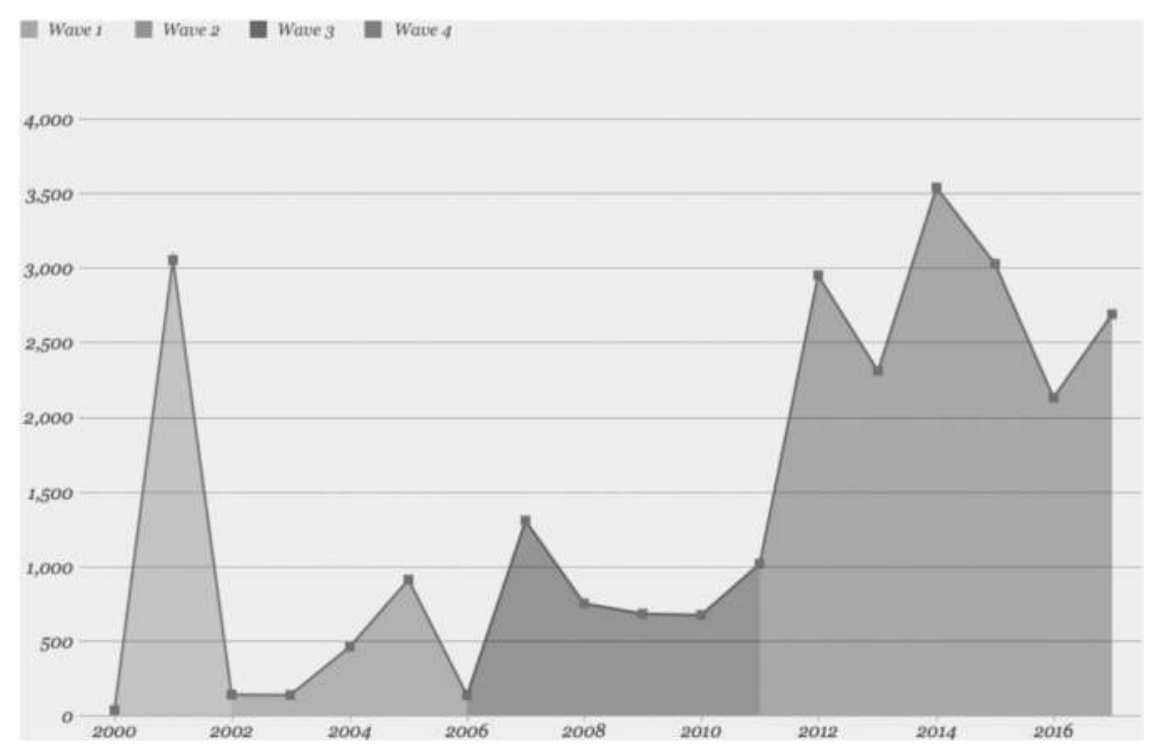

Figure 3.1 Al-Qaida waves of activity measured by fatalities, 2000-2017. ${ }^{4}$

Source: The data is from the Global Terrorism Database at the University of Maryland. Retrieved on May 15, 2018, from www. start.umd.edu/gtd/.

These affiliates included al-Qaida in Iraq (AQI), which became a formal member in 2004 and then left the organization in 2014; al-Qaida in the Islamic Maghreb (AQIM), based in Algeria and neighboring countries, which became a formal member in 2006; al-Qaida in the Arabian Peninsula (AQAP), based in Yemen, which became a formal member in 2009; al-Shabaab, based in Somalia, which became a formal member in 2012; Jabhat al-Nusra (the Nusra Front) and successor groups based in Syria, such as Hurras al-Din, which became a formal member in 2013; and al-Qaida in the Indian Subcontinent, based in Afghanistan and Pakistan, which became a formal member in September 2014. ${ }^{5}$ What distinguishes affiliates from other types of jihadi groups is the decision by their amirs (leaders) to swear baya (oath of loyalty) to al-Qaida, which was then accepted by al-Qaida's leaders.

The data in Figure 3.1 includes those attacks each year between 2000 and 2017 by al-Qaida core and affiliates. Most of these attacks occurred in countries or regions where al-Qaida had sanctuaries - such as Iraq, Yemen, and Somalia - rather than in the West. After 9/11, al-Qaida's leaders failed to orchestrate a major attack on U.S. soil despite numerous attempts, such as the foiled plot to bomb the New York subway by Najibullah Zazi in 2009.

The first wave began in the late 1980s as Usama bin Ladin, Ayman al-Zawahiri, and other jihadi leaders established al-Qaida in Pakistan during the anti-Soviet war. It peaked in 2001 following the 9/11 attacks and was followed by a reversal as al-Qaida leaders and operatives were captured or killed in Afghanistan, Pakistan, the United States, and across the globe.

A second wave emerged in 2003 after the U.S.-led invasion of Iraq and was characterized by spectacular attacks across Iraq and in Casablanca, Madrid, London, and other major cities. Yet it was followed by a reverse wave by 2006 as AQI suffered major setbacks in Iraq, British and American intelligence agencies foiled several plots, and U.S. drone strikes killed senior al-Qaida operatives in Pakistan.

A third wave surged from 2007 to 2009 following the rise of AQAP but was followed by a reverse wave with the death of Bin Ladin in 2011 and the loss of other senior leaders. 
Finally, the Arab Spring helped create the conditions for a fourth wave of activity as al-Qaida affiliates established a foothold - or expanded their presence - in countries such as Syria, Yemen, Afghanistan, and Somalia.

\section{First wave}

Al-Qaida's first wave of terrorist activity began in the late 1980s along the Afghanistan-Pakistan border. In August 1988, a group of foreign fighters, who had trekked to the region to fight the Soviet Union in Afghanistan, gathered in Peshawar, Pakistan, to form a new organization. Initially called al-Qaida al-Askariyya (the military base), the group included an advisory council and membership requirements for those interested in joining. ${ }^{6}$ Among the participants were Bin Ladin, Abu Hasan al-Madani, and Abu Ubaidah al-Banshiri.

According to notes taken during the meeting by one of the participants, the group decided that "alQaida is basically an organized Islamic faction, its goal is to live the word of God, to make His religion victorious." Al-Qaida's leaders divided recruits into two factions: 1) "limited duration" fighters, who would receive training and then fight in Afghanistan; and 2) "open duration" fighters, who would become full members of al-Qaida and would eventually deploy across the globe to conduct violent jihad. ${ }^{7}$

By the early 1990s, Afghanistan deteriorated into a civil war following the departure of Soviet forces and the end of U.S. support to the Afghan mujahidin (Islamic resistance fighters). Pakistan also arrested foreign fightersincluding al-Qaida operatives - who stayed behind. Some fighters dispersed to countries such as Bosnia, Algeria, Sudan, and Egypt, where they attempted to transform domestic conflict into the armed jihad that Bin Ladin and other al-Qaida leaders had urged them to do. ${ }^{8}$ Egypt, Saudi Arabia, Jordan, and other countries established border controls to capture those who tried to enter, as well as to deter others from even trying. ${ }^{9}$

Al-Qaida leaders such as Bin Ladin and al-Zawahiri were strongly influenced by Abdullah Azzam, a Palestinian who argued that fighting in Afghanistan against the Soviets was a requirement for all good Muslims. ${ }^{10}$ Another influential figure was Sayyid Qutb, an Egyptian and a leading member of the Muslim Brotherhood.

In his book Milestones, Qutb argued that Western values hindered humanity's progress. Modernday Islam had become corrupt, he wrote, and he compared the contemporary modern Muslim states with jahiliyya. As used in the Quran, jahiliyya describes the age of ignorance in which Arabs were supposed to have lived before the revelation of Islam to the Prophet Muhammad at the beginning of the 7th century. ${ }^{11}$ Qutb urged Muslims to build a new Islamic community, much like the Prophet Muhammad had done a thousand years earlier. ${ }^{12}$ Qutb argued that the only legitimate ruler is one who establishes Islamic law "without any question and rejects all other laws in any shape or form." ${ }^{13}$ He also sanctioned offensive jihad against governments that stand in the way of Islam. ${ }^{14}$

Inspired by the writings and examples of individuals like Azzam and Qutb, al-Qaida's leaders aimed to overthrow successive regimes in the Middle East (the near enemy) to establish a pan-Islamic caliphate, as well as to fight the United States and its allies (the far enemy) who supported them. ${ }^{15}$ As al-Zawahiri wrote, the "establishment of a Muslim state in the heart of the Islamic world is not an easy or close target. However, it is the hope of the Muslim nation to restore its fallen caliphate and regain its lost glory." ${ }^{16}$ Figure 3.2 highlights the envisioned caliphate, which ranged from West Africa through the Middle East and South Asia to the Asia-Pacific region.

For al-Qaida, the United States was the most significant far enemy. Al-Qaida's leaders argued that the United States was a corrupting influence due to its Christian roots, aid to Arab regimes, support to Israel, and predilection toward democratic governance rather than Islamic law. To reestablish a caliphate, al-Qaida had to target the supporters of Muslim regimes. The conflict with the United States, then, was a "battle of ideologies, a struggle for survival, and a war with no truce." ${ }^{17}$

In February 1998, Bin Ladin, al-Zawahiri, and others published a fatwa (religious ruling) to kill Americans: "The ruling to kill the Americans and their allies—civilians and military—is an individual duty for 


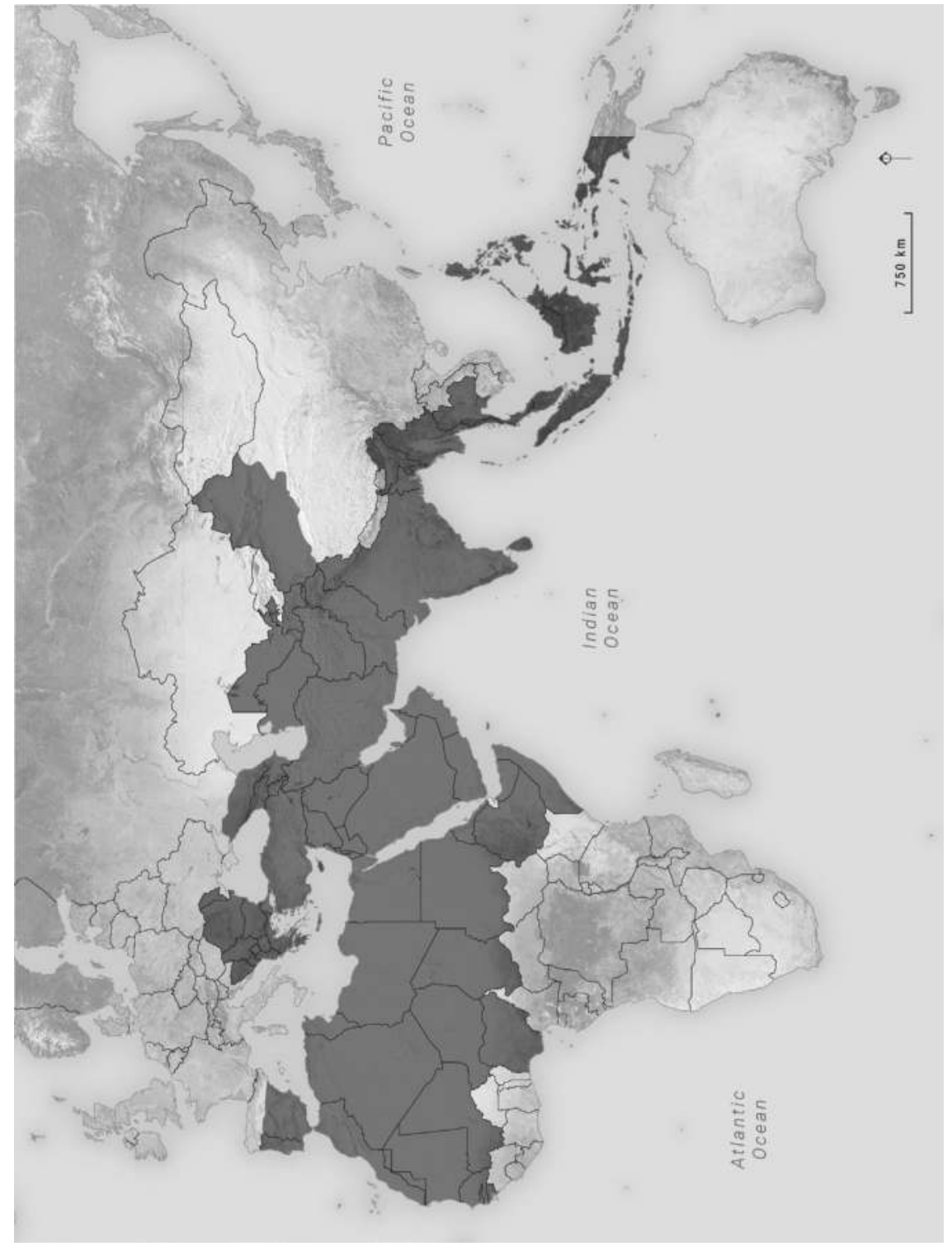

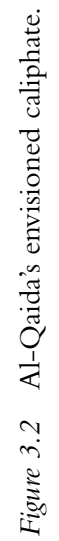


every Muslim who can do it in any country in which it is possible to do it." ${ }^{18}$ The fatwa cited three main grievances against the United States: the presence of U.S. troops in the Arabian Peninsula, America's intention to destroy the Muslim people of Iraq through sanctions, and the U.S. goal of incapacitating the Arab states and propping up Israel. Bin Ladin accused the United States of plundering the Muslim world's riches, dictating to its rulers, humiliating its people, and terrorizing its neighbors.

Following a decade of preparation and organization, al-Qaida launched its first wave of violence in earnest in 1998. At 5:35 AM on August 7, 1998, National Security Advisor Sandy Berger woke President Bill Clinton to inform him that there were simultaneous attacks against the U.S. Embassies in Nairobi, Kenya, and Dar es Salaam, Tanzania.

The destruction was horrific. In Nairobi, the blast leveled a three-story building, gutted the rear half of the U.S. Embassy, and incinerated dozens of people in their seats in nearby buses. The al-Qaida operatives had packed 400 to 500 cylinders of TNT (each about the size of a soda can), aluminum nitrate, and aluminum powder into specially designed wooden crates that were sealed and placed in the bed of a truck. The area around the U.S. Embassy was a maze of narrow streets and alleys, which trapped and intensified the blast. Shards of flying concrete, steel, glass, furniture, and other debris battered pedestrians, motorists, and embassy workers from multiple directions. ${ }^{19}$

On August 20, 1988, President Clinton ordered cruise missile strikes against al-Qaida targets in Afghanistan and Sudan in what was codenamed Operation Infinite Reach. As one of Bin Ladin's sons explained following the U.S. strikes in Afghanistan, "The air was suddenly full of menace, with bright flashes and crashes so loud that their eardrums were bursting. .. . Wherever the missiles hit, life was obliterated. Buildings evaporated and large craters opened the earth." ${ }^{20}$

Although U.S. missiles struck their intended targets in Afghanistan, neither Bin Ladin nor any other senior terrorist leader was killed. ${ }^{21}$ Two years later, al-Qaida operatives bombed the guided-missile destroyer USS Cole on October 12, 2000, while it was refueling in Yemen. The attack killed 17 U.S. soldiers and injured 39 others. $^{22}$

On September 11, 2001, al-Qaida executed its most audacious terrorist attack when 19 operatives hijacked four airplanes in the United States: United Airlines Flight 175, American Airlines Flight 11, American Airlines Flight 77, and United Airlines Flight 93. Al-Qaida operatives called the attacks the "blessed double raid" since they targeted sites in New York City and Washington, DC. ${ }^{23}$

Al-Qaida terrorists flew one of the planes into the Pentagon and two others into the World Trade Center towers in New York City, which caused both of the nearly 1,400-foot-high buildings to collapse. The fourth plane crashed into a field in Pennsylvania after passengers stormed the cockpit. The September 11 attacks killed nearly 3,000 people and wounded thousands more. ${ }^{24}$

In response, U.S. military and Central Intelligence Agency (CIA) forces took aim at al-Qaida and the Taliban regime in Afghanistan, which had provided sanctuary to Bin Ladin and other al-Qaida leaders. ${ }^{25}$ It was a remarkably effective campaign. Approximately 100 CIA officers, 350 Special Operations Forces, and some 15,000 Afghans_-running as many as 100 combat sorties per day—defeated a Taliban army estimated at 50,000 to 60,000 soldiers plus several thousand al-Qaida fighters. ${ }^{26}$

Al-Qaida was severely weakened. The United States seized more than 20 terrorist training camps, killed thousands of enemy fighters, and forced hundreds of al-Qaida members and thousands of Taliban to flee across the borders of Pakistan and Iran. By December 2001, three months after the attacks, al-Qaida was in disarray. One quarter of Bin Ladin's top commanders had been killed or captured. ${ }^{27}$ Al-Qaida's first wave was on the wane.

\section{Second wave}

By 2003, the U.S.-led invasion of Iraq and the subsequent insurgency that developed gave al-Qaida new life. America's invasion galvanized al-Qaida sympathizers and helped launch al-Qaida's second wave. One 
of al-Qaida's strongest allies in Iraq was Abu Musab al-Zarqawi, a Jordanian who had arrived in northern Iraq in 2002. He was not a member of al-Qaida but was the leader of a jihadi group called Jamaat al-Tawhid wal Jihad (Organization of Monotheism and Jihad).

Nationalist groups led by former regime officers, Sunni religious figures, and Baathists dominated the insurgency after the U.S. invasion. Yet al-Zarqawi and his group orchestrated a lethal campaign of car bombs and gruesome beheadings. On August 8, 2003, a cell allied with al-Zarqawi helped plan and carry out a car bombing at the Jordanian Embassy in the al-Andalus district of Baghdad, which killed 17 people.

On August 19, al-Zarqawi's organization bombed the United Nations headquarters in Iraq, which killed United Nations Special Representative Sergio Vieira de Mello. ${ }^{28}$ On August 29, al-Zarqawi's network exploded a car bomb outside the Imam Ali mosque in Najaf, killing the Shia chairman of the Council for the Islamic Revolution in Iraq, Ayatollah Muhammad Baqr al-Hakim.

On October 17, 2004, al-Zarqawi swore allegiance to Bin Ladin, and he was accepted into al-Qaida. Al-Zarqawi's terrorist campaign was intense, widespread, and effective. ${ }^{29} \mathrm{He}$ advocated the subjugation of Shia Muslims — whom he considered apostates (those who have abandoned religion) — and the creation of a worldwide caliphate governed by Sharia. He called for a "total war" against Shia in hopes of rallying Sunni Muslims to his side and countering the growing role of Iran and Shia militias in Iraq. Shia were increasingly dominating the new Iraqi Army, al-Zarqawi contended, and Shia power would continue to grow if they were not opposed.

By this time, al-Zarqawi's organization, which he renamed AQI, had roughly 15 brigades operating under its banner, including two "martyrs" brigades dedicated to suicide operations. The group released daily communiqués, ran two official websites, and published two magazines. ${ }^{30}$ Bin Ladin welcomed al-Zarqawi into al-Qaida and identified Iraq as al-Qaida's central battleground against the United States. ${ }^{31}$ Al-Zarqawi's organization brought in foreign fighters at unprecedented levels, mostly through Syria. ${ }^{32}$ According to documents captured in a raid near Sinjar, along Iraq's border with Syria, AQI's foreign contingent came primarily from Saudi Arabia, Libya, Yemen, Algeria, and Syria. ${ }^{33}$ Al-Qaida's second wave of terrorism was underway.

In May 2003, a group with ties to al-Qaida killed 45 people in Casablanca during a series of suicide bombings. The same week, al-Qaida operatives conducted multiple attacks in Riyadh, Saudi Arabia, killing 34 people. In August, a suicide car bomber detonated explosives in front of a Marriott hotel in Jakarta, Indonesia, killing 12. In November, there were multiple attacks in Istanbul, which killed more than 40 people.

Then, in 2004, a potentially al-Qaida-linked terrorist attack shook Europe. North African terrorists brought 13 improvised explosive devices concealed in blue sports bags into the Alcalá train station in Madrid, Spain, on March 11. They placed the bombs in the luggage and seating areas in four trains. The first train left Alcalá de Henares station on the C-1 track at 7:01 AM, headed for downtown Madrid. The other three followed shortly thereafter. After placing the bombs and setting the timers, the terrorists exited the trains.

The Madrid attacks left 191 dead and 1,755 injured, up to that point the largest number of casualties from an attack in continental Europe since World War II. The operatives were not members of al-Qaida, but they were inspired by its ideology and activities. In addition, some of the Madrid attackers had connections to al-Qaida operatives like Hamza Rabia, al-Qaida's head of operations in Europe and North America. $^{34}$

The following year, al-Qaida attacked London. Beginning at 8:50 AM on July 7, 2005, four suicide bombers trained by al-Qaida operatives in Pakistan conducted attacks in central London. Three bombers targeted London's subway system, the Underground, and one bomber detonated explosives on the \#30 double-decker bus traveling east from Marble Arch. The attacks killed 56 people, including the four suicide bombers. The ringleader, Mohammad Sidique Khan, had trained in al-Qaida-affiliated camps in Pakistan. ${ }^{35}$ 
By this time, UK security agencies, such as the country's domestic intelligence agency MI5, were overwhelmed due to threats from al-Qaida and other terrorist networks. According to MI5's estimates, the spy agency could cover 6\% of its targets fairly well (but with gaps), 33\% fairly (with even bigger gaps), and $42 \%$ inadequately, and $19 \%$ had no coverage at all. ${ }^{36}$

To make matters worse, the terrorist threat appeared to be growing more serious. In 2001, MI5 knew of approximately 250 primary investigative targets within the United Kingdom. There were more than 500 targets by July 2004 and 800 by July 2005. To deal with the threat, UK government agencies increased their coverage of Islamic extremists. Roughly $56 \%$ of MI5's resources went to Islamic groups in July 2005 , up from $23 \%$ in $2002 .{ }^{37}$

Much like during the first wave, however, the tide eventually began to turn. Al-Zarqawi's brutality in Iraq was too much even for some al-Qaida leaders. In 2005, al-Qaida second-in-command Ayman al-Zawahiri sent a note to al-Zarqawi criticizing him for conducting a ruthless campaign of violence that was undermining al-Qaida's support among local Iraqis. "In the absence of this popular support," argued al-Zawahiri, "the Islamic mujahid movement would be crushed in the shadows." 38

By 2006, AQI's violence had triggered a revolt among Anbar Province's tribal sheikhs. ${ }^{39}$ Members of the U.S. Army's 1st Brigade of the 1st Armored Division, Marines from the I and II Marine Expeditionary Force, CIA operatives, U.S. Special Operations Forces, and a host of agencies provided intelligence, firepower, and ultimately trust in local Iraqis to defend themselves. The widespread Sunni Arab Iraqi revolt against AQI became known as the Sunni Arab Awakening, or sahwa in Arabic.

The Awakening, which punctuated the end of al-Qaida's second wave, resulted from a complex range of factors such as egregious al-Qaida abuses against the Sunni population, tribal infighting, criminal disputes, U.S. engagement, elite payoffs, and the surge of U.S. military forces. ${ }^{40}$ Sunni Arabs joined anti-al-Qaida militia groups and helped identify al-Qaida leaders for targeting. The sahwa's results were clear: al-Qaida lost control of the Sunni population in Iraq, and it was forced into internal exile in the most remote areas of the country. ${ }^{41}$

\section{Third wave}

Al-Qaida, however, began to mount a comeback - a third wave. Al-Qaida established a new front in Yemen, and a charismatic Yemeni-American operative named Anwar al-Awlaqi aided the group. He was born on April 22, 1971, in Las Cruces, New Mexico, where his father was studying on a Fulbright scholarship. ${ }^{42} \mathrm{Al}$-Awlaqi spent much of his childhood in Yemen and eventually moved to the United States.

Fluent in English and adept at giving eloquent talks on Islam, al-Awlaqi's stirring lectures earned him a growing cadre of followers. Perhaps most importantly, he understood the intricacies of the internet, using it to broadcast his messages well before the Islamic State began to dominate this medium beginning in 2014 . Al-Awlaqi's fluency in vernacular English, support for al-Qaida, unabashed advocacy of jihad, and websavvy approach were a powerful combination. His lectures could be accessed on the internet, and Islamic bookstores around the world sold his compact discs.

Al-Awlaqi operated his own blog and was active on several social networking sites. His supporters established sites on Facebook and MySpace devoted to proselytizing his sermons and praising him. Al-Awlaqi envisioned himself as a vanguard figure among English-speaking Muslims. It was his mission to spread the word.

Most of al-Awlaqi's online English lectures were non-violent and centered on traditional religious themes, but some of his most stirring sermons blended the former Muslim Brotherhood ideologue Sayyid Qutb's rigid dogmatism with al-Qaida's sweeping ambition to overthrow Arab regimes and weaken their Western supporters. Al-Awlaqi's sermon, "The Constants of Jihad," mesmerized would-be radicals. He urged listeners: "Jihad will . . . carry on until the Day of Judgment since we are told to wipe out [nonMuslims] from the world." 43 
Al-Awlaqi was not the only influential jihadi. A growing number of would-be jihadis were also inspired by Abu Musab al-Suri’s online publication, “The Global Islamic Resistance Call.” Al-Suri was a naturalized Spanish engineer who argued that Muslims should encourage a civil war in the West, including in Europe.

In January 2009, al-Qaida publicly announced that Saudi and Yemeni operatives had unified under the banner of a single group in Yemen, which they named AQAP. Al-Awlaqi pledged baya, or loyalty, to the group's amir (leader). ${ }^{44}$ Al-Awlaqi settled in Shabwa Governorate of Yemen and ran his global jihadi enterprise. ${ }^{45}$ He developed an online blog, which was later shut down. He also improved his Facebook and MySpace pages, as well as adding postings on YouTube and other social media forums to proselytize his jihadi message. "The internet has become a great medium for spreading the call of jihad and following the news of the mujahidin," al-Awlaqi wrote. ${ }^{46}$

By 2009, al-Qaida — with operatives inspired by individuals such as al-Awlaqi — was plotting attacks in the United States. In June 2009, Abdulhakim Mujahid Muhammad, who changed his name from Carlos Bledsoe, opened fire with a semi-automatic rifle on a military recruiting center in Little Rock, Arkansas, killing one soldier and wounding another. He had listened to al-Awlaqi's sermons and spent time in Yemen. ${ }^{47}$

On November 5, 2009, a U.S. Army major, Nidal Malik Hasan, gunned down 13 people and wounded 43 others at Fort Hood, Texas. Hasan had first met al-Awlaqi in 2001 at the Dar al-Hijra mosque in Falls Church, Virginia, where al-Awlaqi was the imam. ${ }^{48}$ Hasan and al-Awlaqi exchanged at least 18 e-mails that discussed the afterlife, the appropriate time for violent jihad, and how to transfer funds abroad without triggering law enforcement attention. ${ }^{49}$

Hasan was then promoted to the rank of major in the U.S. Army and received deployment orders to Afghanistan. That served as a catalyst. At approximately 1:30 PM on November 5, Hasan walked into the Soldier Readiness Center at Fort Hood, a facility that processed soldiers before and after deployment. $\mathrm{He}$ bowed his head for several seconds and then stood up and opened fire, shouting "Allahu Akbar!" 50

In December 2009, al-Qaida struck again. Umar Farouk Abdulmutallab, who was born in Nigeria, met with al-Awlaqi several times and attended a training camp in the Shabwa region of Yemen. In late 2009, Abdulmutallab met again with al-Awlaqi. The cleric asked if the young Nigerian would conduct a suicide mission. Abdulmutallab agreed. ${ }^{51}$

Al-Awlaqi revealed that the mission would take place in the United States and provided some basic guidance. He requested that Abdulmutallab conduct the attack on a U.S. airline, carry out the attack only when he was ready, travel through an African country to avoid suspicion, and detonate the bomb over U.S. airspace. In early December, Abdulmutallab prepared a wasia, or last will and testament, in a hand-written letter addressed to his parents. A video later released by AQAP's media arm showed Abdulmutallab engaged in training in the Yemeni desert.

On December 24, 2009, Abdulmutallab boarded Northwest Airlines Flight 253 in Amsterdam, Netherlands, which was scheduled to arrive in Detroit, Michigan, the next day on December 25. The flight carried 279 passengers and 11 crew members. ${ }^{52}$ Abdulmutallab wore a bomb in his underwear. The main explosive charge consisted of pentaerythritol tetranitrate (also known as PETN), although forensic analysis also found traces of triacetone triperoxide (also known as TATP). ${ }^{53}$ The initiator consisted of a plastic syringe, possibly filled with ethylene glycol, which was supposed to be inserted into a chemical mixture stored in a cloth pouch in Abdulmutallab's underwear. ${ }^{54}$ The flame produced by the reaction was designed to be sufficient to initiate the TATP a few seconds later, which would initiate the PETN main charge.

The explosion, al-Qaida's leaders hoped, would bring down the airplane. The bomb did not include large pieces of metal, such as wires and batteries, making it difficult for airport screeners to detect. In the end, the bomb ignited, injuring Abdulmutallab and two other passengers. The main charge, however, failed to ignite and the airplane landed safely at Detroit Metropolitan Airport. It was a close call.

The failure did not deter al-Qaida. In August 2008, Najibullah Zazi, a U.S. citizen from New York, met with senior al-Qaida operatives in Pakistan. Zazi agreed to execute one of al-Qaida's boldest plots since 
9/11: a suicide attack on the New York City subway modeled, in part, on the successful 2005 attack in London. The plot involved two other Americans: Adis Medunjanin and Zarein Ahmedzay. Zazi conducted training at al-Qaida camps in Pakistan. ${ }^{55}$

Zazi's training was critical for several reasons. It provided him technical expertise necessary to assemble a bomb, which would have been more difficult had he only used internet-based instructions. Zazi was trained in peroxide-based detonators and explosives. He also received two or three days of classroom training on firearms, followed by hands-on training that involved weapons assembly, cleaning, and handling of handguns, rifles, and other weapons. Due to the efforts of UK and U.S. intelligence and law enforcement agencies, Zazi's plot was thwarted. The Federal Bureau of Investigation (FBI) arrested Zazi on September 19, 2009. On January 10, 2010, the FBI arrested Medunjanin and Ahmedzay.

By late 2010, however, al-Qaida's third wave of terrorism began to decline because of persistent U.S. action across the globe. U.S. strikes killed a number of al-Qaida leaders: external operations chief Saleh al-Somali in Pakistan in December 2009, general manager Sheikh Said al-Masri in Pakistan in May 2010, senior al-Qaida operations officer Abu Abd al-Rahman al-Najdi in Pakistan in September 2010, Abu Hamza al-Muhajir in Iraq in April 2010, and Anwar al-Awlaqi in Yemen in September 2011.

The pace of U.S. drone strikes had increased under the Obama administration and involved multiple U.S. intelligence agencies that recruited human assets, intercepted electronic communications, and analyzed satellite and other imagery. The drone strikes, however, were controversial. ${ }^{56}$

On May 2, 2011, U.S. military and intelligence operatives killed al-Qaida chief Usama bin Ladin in Pakistan. ${ }^{57}$ Shortly after the U.S. invasion of Afghanistan, Bin Ladin had trekked through the Afghan mountains near Tora Bora and entered Pakistan in December 2001. He then moved among a number of homes in Pakistan's Khyber Pakhtunkhwa Province. In 2005, he settled into his safe house in Abbottabad, Pakistan, where U.S. operatives would eventually find and kill him. Ayman al-Zawahiri replaced Bin Ladin as the new leader of al-Qaida.

The third wave was over. The United States implemented a light-footprint approach in countries such as Yemen and Pakistan, where it effectively targeted al-Qaida's leaders. The United States increased drone strikes, which severely disrupted al-Qaida's command-and-control by killing most of its senior leaders, hampered communications, decreased morale, limited freedom of movement, and delayed the planning cycle of terrorist operations. ${ }^{58}$

\section{Fourth wave}

Beginning around 2012, a fourth wave began as al-Qaida attempted to take advantage of the Arab Spring uprisings and escalating wars in countries such as Syria, Yemen, Somalia, Iraq, and Afghanistan. Al-Qaida also found itself in competition with the Islamic State. By the fourth wave, core al-Qaida had been severely weakened from persistent U.S. drone strikes. Ayman al-Zawahiri remained al-Qaida's leader, and a small number of al-Qaida leaders were located in nearby Iran with ties to the leadership, including Saif al-Adel. ${ }^{59}$

The core leaders, however, had limited legitimacy and power over al-Qaida's affiliates in Africa, the Middle East, and Asia. Most of al-Qaida's power and influence had trickled down to its affiliates. ${ }^{60} \mathrm{Al}-$ Qaida's core also suffered several major losses. In August 2020, for example, Israel's spy agency, the Mossad, allegedly assassinated Abu Muhammad al-Masri in Tehran in cooperation with the United States. ${ }^{61}$

In Syria, al-Qaida's main allies were Hayat Tahrir al-Sham and Tanzim Hurras al-Din, which were primarily located in northwestern Syria. These groups - particularly Tanzim Hurras al-Din-plotted external attacks against Western targets, although they failed to perpetrate any major attacks against the United States. The United States killed several al-Qaida veterans in Syria, including Abu Mohammed al-Sudani in October 2020. ${ }^{62}$

In Yemen, AQAP tried to expand its foothold in such governorates as Abyan, Marib, and Shabwa as a civil war raged in the country. In April 2017, for example, former AQAP leader Qasim al-Raymi-who 
was killed in January 2020 by a U.S. airstrike-outlined his strategy of fighting the Houthis and building broad and deep support among Sunni groups and tribes in Yemen.

Outside of Yemen, AQAP's leaders also called for "easy and simple" attacks against the United States and other Western countries, such as small-arms attacks. ${ }^{63}$ In December 2019, Second Lieutenant Mohammed Saeed Alshamrani, a Saudi air force cadet training with the American military in Pensacola, Florida, killed three U.S. sailors and injured three others in a shooting attack. He was inspired by al-Qaida's ideology, communicated with leaders of AQAP up until the attack, and joined the Saudi military in part to carry out a "special operation" for al-Qaida. ${ }^{64}$ Nevertheless, AQAP still struggled to orchestrate attacks against the United States and other Western countries.

In South Asia, al-Zawahiri announced the creation of al-Qaida in the Indian Subcontinent (AQIS) in September 2014 as a regional affiliate, taking advantage of sanctuaries in Afghanistan, Pakistan, and Bangladesh. By 2020, AQIS boasted several hundred members and had cells in the southern and eastern provinces in Afghanistan.

Al-Qaida's overall size and presence in Afghanistan was almost certainly larger and more expansive than five or even 10 years before. ${ }^{65}$ This expansion was due, in part, to Taliban advances in Afghanistan. As a U.S. Department of Defense assessment concluded in 2020, "Despite recent progress in the peace process, AQIS maintains close ties to the Taliban in Afghanistan, likely for protection and training." ${ }^{66}$ Contacts between al-Qaida and the Haqqani Network-including the Taliban's deputy leader, Sirajuddin Haqqani-remain particularly close. They shared long-standing personal relationships, intermarriage, a shared history of struggle, and sympathetic ideologies. ${ }^{67}$

Al-Qaida was also active in other regions. In West Africa, for example, Jamaat Nusrat al-Islam wa al Muslimeen was one of al-Qaida's most active affiliates, controlling territory and conducting attacks in Mali, Burkina Faso, Côte d'Ivoire, Senegal, and other countries. In East Africa, al-Shabaab conducted attacks in Somalia and neighboring countries, especially Kenya, despite military operations led by the United States and the African Union Mission in Somalia. Al-Qaida also suffered notable losses, such as the death of Abdelmalek Droukdel, the longtime head of AQIM, in June 2020. ${ }^{68}$

\section{Conclusion}

Following its establishment in 1988, al-Qaida evolved during four major waves of activity from a small network of individuals in Pakistan to a pan-Islamic movement that would eventually try to compete with the Islamic State for legitimacy and the resources of violent jihadis across the globe. Over three decades after its establishment, al-Qaida included four main tiers.

The first tier was a weak leadership structure based mostly in Pakistan and Afghanistan that was decimated by U.S. and partner attacks. Core al-Qaida had little power over its affiliates but attempted to provide overall guidance about the group's goals, which included respect the tawhid, or oneness of God; support governance by Islamic law; unite Muslims across the world around the tawhid; revive the duty of armed jihad to "liberate" countries across the Middle East, Africa, and Asia and target their supporters, including the United States; and strive to build a caliphate. ${ }^{69}$

The second tier included formal affiliates. These affiliates swore baya to al-Qaida's leader who, in turn, accepted their loyalty pledge. Examples included AQIM, AQAP, al-Shabaab, Jamaat Nusrat al-Islam wa al Muslimeen, Hurras al-Din, and AQIS.

The third tier involved allied violent jihadi groups that established a relationship with al-Qaida, such as the Afghan Taliban. They were not created by core al-Qaida, they did not become formal members, and their leaders did not swear baya to al-Qaida. This arrangement allowed the groups to remain independent and pursue their own goals but still work with al-Qaida for specific operations or training purposes when their interests converged. There were a number of allied groups across Africa, Asia, the Middle East, and the Caucasus. 
The fourth tier comprised individuals and networks that had no direct contact with core al-Qaida but who were inspired by al-Qaida's ideology and outraged by perceived oppression of Muslims across the globe. They were often motivated by a hatred of the West and its "apostate" regimes in the Muslim world. Without direct support, these individuals and networks tended to be amateurish. ${ }^{70}$

The existence of these tiers made it difficult for al-Qaida or any other violent jihadi group, including the Islamic State, to establish command-and-control over all Muslim extremists. Indeed, al-Qaida was plagued by several challenges. One was a repeated failure to hold territory where the group or its allies could impose their extreme interpretation of Islamic law and ultimately its hoped-for caliphate. Al-Qaida's leaders developed a close relationship with Mullah Omar's Taliban in the 1990s and established a sanctuary in Afghanistan, only to lose it after the $9 / 11$ attacks.

Al-Qaida affiliates in Yemen, Syria, Somalia, and African countries like Algeria and Mali also consistently failed to hold territory because of poor leadership, incompetent governance, limited support from local populations, excessive violence, internal tensions, and other factors-including aggressive targeting by the United States and its local and international allies.

Another problem was a lack of support. In a brusque letter to Abu Musab al-Zarqawi in 2005, Ayman al-Zawahiri remarked that "we are in a media battle in a race for the hearts and minds" of Muslims. ${ }^{71}$ Yet Bin Ladin, al-Zawahiri, and other al-Qaida leaders consistently failed to translate this statement into practice. Public opinion polls showed that Muslim views of al-Qaida were consistently negative. "Strong majorities in most countries have unfavorable opinions of the group," concluded one poll conducted in 14 Muslim countries in 2014. ${ }^{72}$ Another survey found that Bin Ladin had been "largely discredited" and there was "little support for the al-Qaida leader."73

Al-Qaida's lack of popular support has been a chronic problem for the group. Over three decades after its establishment, al-Qaida is no closer to fulfilling its grandiose vision of a pan-Islamic caliphate, and there is little prospect that this trend will change.

\section{Notes}

1 Ayman al-Zawahiri, "Sham Will Submit to None Except Allah," As-Sahab Media Foundation, April 2017. The transcript and translation are courtesy of the SITE Intelligence Group.

2 See David C. Rapoport, "The Four Waves of Modern Terrorism," in Attacking Terrorism: Elements of a Grand Strategy, ed. Audrey Kurth Cronin and James M. Ludes (Washington, DC: Georgetown University Press, 2004), 47. For more on al-Qaida waves, see Seth G. Jones, Hunting in the Shadows: The Pursuit of Al Qa'ida Since 9/11 (New York: W.W. Norton, 2012).

3 Rapoport, "The Four Waves."

4 The data is from the Global Terrorism Database at the University of Maryland, accessed May 15, 2017, www.start. umd.edu/gtd/.

5 These dates refer to the year in which the affiliate publicly announced that their amir had sworn baya (allegiance) to core al-Qaida leaders.

6 Peter Bergen, The Osama bin Laden I Know: An Oral History of Al Qaida's Leader (New York: Free Press, 2006); Lawrence Wright, The Looming Tower: Al-Qa'ida and the Road to 9/11 (New York: Alfred A. Knopf, 2006), 133.

7 The quotes are from the exhibit by "Tareekh Osama” (Osama's history) document presented in U.S.A. v. Enaam M. Arnaout (Northern District of Illinois, 2002).

8 Thomas Hegghammer, "The Rise of Muslim Foreign Fighters: Islam and the Globalization of Jihad," International Security 35, no. 3 (2010): 53-94.

9 Gilles Kepel, Jihad: The Trail of Political Islam (Cambridge, MA: Harvard University Press, 2002), 159-184, 237253, 254-275.

10 Abdullah Anas, The Birth of the Afghan Arabs (London: Dar al-Saqi, 2002); Mohammed Salah, Narratives of the Jihad Years: The Journey of the Arab Afghans (Cairo: Unknown Publisher, 2001).

11 Sayyid Qutb, Milestones, reprint ed. (New Delhi: Islamic Book Service, 2007), 7-11.

12 On Qutb's work, see Gilles Kepel, The Prophet and Pharaoh: Muslim Extremism in Egypt (Berkeley: University of California Press, 1985); Olivier Carré, Mystique et politique (Paris: Presses de la FNSP et Cerf, 1984); Ibrahim M. Abu Rabi, Intellectual Origins of Islamic Resurgence in the Muslim Arab World (Albany: SUNY Press, 1996). 
13 Qutb, Milestones, 36.

14 See, for example, Kepel, Jihad, 25-27.

15 On the establishment of a caliphate, see, for example, Abu Bakr Naji, The Management of Savagery: The Most Critical Stage Through Which the Ummah Will Pass, trans. John M. Olin (Cambridge, MA: Institute for Strategic Studies at Harvard University, May 23, 2006).

16 Ayman al-Zawahiri, Knights Under the Prophet's Banner, trans. Laura Mansfield (Old Tappan, NJ: TLG, 2002$), 201$.

17 Ibid., 111.

18 The text is the second fatwa to declare a holy war, or jihad, against the West and Israel. Usama bin Ladin et al., "Jihad Against Jews and Crusaders," February 23, 1998, www.fas.org/irp/world/para/docs/980223-fatwa.htm.

19 On the Nairobi attack, see National Commission on Terrorist Attacks, The 9/11 Commission Report: Final Report of the National Commission On Terrorist Attacks Upon the United States (New York: W.W. Norton, 2004), 68-70.

20 Najwa bin Laden, Omar bin Laden, and Jean Sasson, Growing Up Bin Laden: Osama's Wife and Son Take Us Inside Their Secret World (New York: St. Martin's Press, 2009), 240.

21 See National Commission on Terrorist Attacks, The 9/11 Commission Report, 116-118.

22 Ibid., 190-197.

23 See, for example, Gilles Kepel, Terror in France: The Rise of Jihad in the West (Princeton: Princeton University Press, 2015), 127.

24 National Commission on Terrorist Attacks, The 9/11 Commission Report.

25 On the overthrow of the Taliban regime, see Gary Schroen, First In: An Insider's Account of How the CIA Spearheaded the War on Terror in Afghanistan (New York: Ballantine Books, 2005).

26 Gary Berntsen and Ralph Pezzullo, Jawbreaker: The Attack on Bin Laden and al-Qaeda (New York: Crown, 2005), 312 .

27 George Tenet and Bill Harlow, At the Center of the Storm: My Years at the CIA (New York: HarperCollins, 2007), 187.

28 Jim Clancy and Pam Benson, “Tape: Al-Zarqawi Claims Responsibility for Wave of Attacks,” CNN, April 6, 2004, www.cnn.com/2004/WORLD/meast/04/06/us.zarqawi/.

29 Robert A. Pape and James K. Feldman, Cutting the Fuse: The Explosion of Global Suicide Terrorism and How to Stop It By (Chicago: University of Chicago Press, 2010).

30 See, for example, International Crisis Group, In Their Own Words: Reading the Iraqi Insurgency (Brussels: International Crisis Group, 2006).

31 Statement from Usama bin Ladin, December 27, 2004.

32 Brian Fishman et al., Bombers, Bank Accounts, and Bleedout: Al Qaida's Road in and Out of Iraq (West Point: Combating Terrorism Center, 2008), 50, 70.

33 Joseph Felter and Brian Fishman, Al Qa'ida's Foreign Fighters in Iraq: A First Look at the Sinjar Records (West Point: Combating Terrorism Center, 2007).

34 Fernando Reinares, “The Madrid Bombings and Global Jihadism,” Survival 52, no. 2 (2010): 83-104; "Islamist Website Confirm Death of Key Player in Spanish Train Bombing," El Pais, May 8, 2010.

35 Intelligence and Security Committee, Report into the London Terrorist Attacks on 7 July 2005, Cm 6785 (London: The Stationery Office, 2006); Intelligence and Security Committee, Could 7/7 Have Been Prevented? Review of the Intelligence on the London Terrorist Attacks on 7 July 2005, Cm 7617 (London: The Stationery Office, 2009); House of Commons, Report of the Official Account of the Bombings in London on 7th July 2005, HC 1087 (London: The Stationery Office, 2006).

36 Intelligence and Security Committee, Could 7/7 Have Been Prevented?, 41.

37 Intelligence and Security Committee, Report into the London Terrorist Attacks, 8, 33.

38 Ayman al-Zawahiri, "Letter from Ayman al-Zawahiri to Abu Musab al-Zarqawi," Combating Terrorism Center, July 9, 2005, https://ctc.usma.edu/harmony-program/zawahiris-letter-to-zarqawi-original-language-2/.

39 Mitchell B. Reiss, Negotiating with Evil: When to Talk to Terrorists (New York: Open Road, 2010), $177-220$.

40 For better insight into the Awakening, see Niel Smith and Sean MacFarland, "Anbar Awakens: The Tipping Point," Military Review 88, no. 2 (2008): 65-76.

41 Myriam Benraad, “Iraq’s Tribal 'Sahwa': Its Rise and Fall,” Middle East Policy Council Journal 18, no. 1 (2011): 121-131.

42 Nasser al-Awlaki v. Barack H. Obama et al., "Declaration of Dr. Nasser al-Awlaki,” 10-1469 (District of Columbia, 2010).

43 Anwar al-Awlaqi, Sermon on "Thawaabit "ala darb al Jihad" ("Constants on the Path of Jihad), online lecture series, 2005.

44 Statement of James R. Clapper, Director of National Intelligence, in Support of Formal Claim of State Secrets Privilege, Response to Nasser al-Awlaki v. Barack H. Obama et al., 10-1469-JDB, Document 15-2 (District of Columbia, 2010). 
45 Counterterrorism Bureau, Special Analysis: Anwar al-Awlaki (New York: New York City Police Department, 2009). 46 Anwar al-Awlaqi, "44 Ways to Support Jihad," February 2009.

47 Detective Tommy Hudson, "Officer's Report, Arrest of Abdulhakim Mujahid Muhammad," Federal Bureau of Investigation, June 1, 2009; Kimberly Brunell, “Arrest of Abdulhakim Mujahid Muhammed," Federal Bureau of Investigation, June 2, 2009, https://archives.fbi.gov/archives/littlerock/press-releases/2009/lr060209.htm.

48 Evan Perez and Keith Johnson, "Hasan, Radical Cleric Had Contact," Wall Street Journal, November 10, 2009, www.wsj.com/articles/SB125778227582138829.

49 Counterterrorism Bureau, Special Analysis.

50 Independent Review Related to Fort Hood, Protecting the Force: Lessons from Fort Hood (Washington, DC: U.S. Department of Defense, 2010).

51 Scott Shane, "Inside Al Qaeda's Plot to Blow Up an American Airliner," New York Times, February 22, 2017, www. nytimes.com/2017/02/22/us/politics/anwar-awlaki-underwear-bomber-abdulmutallab.html.

52 U.S.A. v. Umar Farouk Abdulmutallab, Criminal Complaint (Eastern District of Michigan, 2009).

53 Select Committee on Intelligence, Unclassified Executive Summary of the Committee Report on the Attempted Terrorist Attack on Northwest Airlines Flight 253 (Washington, DC: U.S. Senate, 2010).

54 Wayne County EMS Report, Patient Name: Umar Farouk Abdulmutallab, December 25, 2009; U.S.A. v. Umar Farouk Abdulmutallab, Criminal Complaint.

55 "Zarein Ahmedzay Pleads Guilty to Terror Violations in Connection with Al-Qaeda New York Subway Plot," U.S. Department of Justice, April 23, 2010, www.justice.gov/opa/pr/zarein-ahmedzay-pleads-guilty-terror-viola tions-connection-al-qaeda-new-york-subway-plot.

56 New America, Public Opinion in Pakistan's Tribal Regions (Washington, DC: New America, 2010), 9.

57 See, for example, Peter L. Bergen, Manhunt: The Ten-Year Search for Bin Laden from 9/11 to Abbottabad (New York: Crown, 2012).

58 On the effectiveness of drone strikes, see Patrick B. Johnston and Anoop K. Sarbahi, "The Impact of U.S. Drone Strikes on Terrorism in Pakistan," International Studies Quarterly 60, no. 2 (2016): 203-219.

59 On the history of al-Qaida in Iran, see Seth G. Jones, "Al Qaeda in Iran: Why Tehran is Accommodating the Terrorist Group," Foreign Affairs, January 29, 2012, www.foreignaffairs.com/articles/iran/2012-01-29/al-qaeda-iran.

60 United Nations Security Council, Twenty-Sixth Report of the Analytical Support and Sanctions Monitoring Team Submitted Pursuant to Resolution 2368 (2017) Concerning ISIL (Da'esh), Al-Qaida and Associated Individuals and Entities (New York: United Nations, July 23, 2020).

61 Adam Goldman et al., "Al-Qaeda's No. 2, Accused in U.S. Embassy Attacks, Was Killed in Iran," New York Times, November 13, 2020, www.nytimes.com/2020/11/13/world/middleeast/al-masri-abdullah-qaeda-dead.html.

62 Eric Schmitt, "Al Qaeda Feels Losses in Syria and Afghanistan but Stays Resilient," New York Times, November 13, 2020, www.nytimes.com/2020/10/27/world/middleeast/al-qaeda-afghanistan-syria-somalia.html.

63 Thomas Joscelyn, "AQAP Leader Calls for 'Simple' Attacks in the West," Long War Journal, May 8, 2017, www. longwarjournal.org/archives/2017/05/aqap-leader-calls-for-simple-attacks-in-the-west.php.

64 "Attorney General William P. Barr and FBI Director Christopher Wray Announce Significant Developments in the Investigation of the Naval Air Station Pensacola Shooting," U.S. Department of Justice, May 18, 2020, www. justice.gov/opa/pr/attorney-general-william-p-barr-and-fbi-director-christopher-wray-announce-significant.

65 Richard Esposito, Matthew Cole, and Brian Ross, "President Obama's Secret: Only 100 al Qaeda Now in Afghanistan," $A B C$ News, December 2, 2009, https://abcnews.go.com/Blotter/president-obamas-secret-100al-qaeda-now-afghanistan/story?id=9227861.

66 Department of Defense, Enhancing Security and Stability in Afghanistan (Washington, DC: U.S. Department of Defense, 2020), 28.

67 Antonio Giustozzi, The Taliban at War: 2001-2018 (New York: Oxford University Press, 2019), 81-83; United Nations Security Council, Eleventh Report of the Analytical Support and Sanctions Monitoring Team Submitted Pursuant to Resolution 2501 (2019) Concerning the Taliban and Other Associated Individuals and Entities Constituting a Threat to the Peace, Stability and Security of Afghanistan (New York: United Nations, 2020), 3.

68 United Nations Security Council, Twenty-Sixth Report of the Analytical Support and Sanctions Monitoring Team.

69 See, for example, Ayman al-Zawahiri, "To Other Than Allah We Will Not Kneel," As-Sahab Media Foundation, January 2016. The transcript and translation are courtesy of the SITE Intelligence Group.

70 Brian Michael Jenkins, Stray Dogs and Virtual Armies: Radicalization and Recruitment to Jihadist Terrorism in the United States Since 9/11 (Santa Monica: RAND, 2011).

71 Al-Zawahiri, "Letter from Ayman al-Zawahiri to Abu Musab al-Zarqawi."

72 "Concerns about Islamic Extremism on the Rise in the Middle East," Pew Research Center, July 1, 2014, www. pewresearch.org/global/2014/07/01/concerns-about-islamic-extremism-on-the-rise-in-middle-east/.

73 “Osama bin Laden Largely Discredited among Muslims in Recent Years," Pew Research Center, May 2, 2011, www.pewre search.org/global/2011/05/02/osama-bin-laden-largely-discredited-among-muslim-publics-in-recent-years/. 


\title{
4 \\ THE HISTORY OF THE ISLAMIC STATE
}

\section{From Abu Musab al-Zarqawi to Abu Bakr al-Baghdadi}

\author{
Brian Fishman
}

The world awoke to the Islamic State on June 29, 2014, when it declared itself the caliphate, a transnational Islamist state led by a single ruler with supposed global authority. Empowered by the Syrian civil war, the Islamic State had just captured Mosul, Iraq's third-largest city. As the Iraqi army melted away, the jihadi militia overran much of Iraq's Sunni Arab northwest and declared a new era in regional and global politics.

The Islamic State's territorial expansion terrified observers around the world and proved deadly for thousands of people in its path. But the Islamic State's geographic expanse was only one aspect of its multifaceted character. Even as the Islamic State built a military and administrative capability for its new caliphate, the group prepared terrorist attacks around the globe and used insurgent tactics to counter an ever-growing list of enemies. The group did not fit neatly into traditional analytical categories: it was a pseudo-state, a terrorist group, and an insurgency simultaneously. This complexity both complicated analysis of the organization's rise and challenged traditional metrics for determining progress and victory in the war against them.

The Islamic State's enemies sought to blunt its appeal to recruits, but disillusioned locals joined it and foreign fighters flowed into Islamic State territory regardless. A variety of motivations drew these recruits, among them a religious passion for jihadi violence, disillusionment with governance and society in their home country, and an apocalyptic vision that the group's claim to be the caliphate was the fulfillment of God's will.

For all of the Islamic State's dramatic growth in 2014, however, many of its core weaknesses were apparent concurrently with its most dramatic successes. The group only sought Sunni Muslims as followers, and its brutality alienated and angered most of its natural constituents. ${ }^{1}$ Rifts between intransigent religious radicals and would-be bureaucrats instigated internal purges and disillusionment. The Islamic State's leaders genuinely believe they have divinely ordained authority to govern and therefore are usually unwilling to create alliances with other groups that do not completely accept their right to lead.

The Islamic State's unwillingness to build sustainable alliances both hardened its enemies and contributed to a slowly crippling resource drain that has furthered its steady decline from the peak of its power in the fall of 2014. Moving forward, the Islamic State's organizational complexity and ideological rigidity offer strength in some respects and weakness in others.

As of 2020, the Islamic State has lost most of its ability to hold and administer wide swaths of territory, but it appears prepared to maintain a capability to disrupt societies in the Middle East and project terrorism globally. Such persistence is unsurprising. In many ways, operating as a terrorist group is the Islamic State's 
natural state. The world awoke to the group in 2014, but the organization-originally under the guise of al-Qaida in Iraq-had declared itself the Islamic State of Iraq in 2006 and went on to conduct a campaign of terrorist violence that made its future gains possible. That past speaks to the group's future: the caliphate is waning, but the Islamic State will remain.

\section{The Islamic State's godfather: Abu Musab al-Zarqawi}

What the world knows as the Islamic State would not exist without Abu Musab al-Zarqawi. Born Ahmad Fadeel al-Khalayleh to a single mother in the dusty Jordanian town of Zarqa, the man who would eventually establish both the organizational underpinning and hyper-violent ethos of the Islamic State did not show early signs of a future in Islamist militancy. ${ }^{2}$

Instead, he was a petty criminal. ${ }^{3}$ As a teenager, al-Zarqawi smoked, drank, and worked in a video store. ${ }^{4}$ To counter his life of crime, al-Zarqawi's mother urged him to embrace religion, and he eventually did so with a zealot's lust, ultimately using a razor to meticulously scrape a tattoo from his forearm. ${ }^{5}$

The Soviet Union invaded Afghanistan in 1979, setting off a decade-long war that attracted Muslim fighters from around the world during the 1980s. Al-Zarqawi eventually joined the fight, but he waited until 1989 as the Soviets withdrew and the war increasingly devolved into an internecine battle among various Afghan factions. ${ }^{6}$

Al-Qaida sputtered to life in 1988 as an effort to keep united the foreign fighters who had joined the Afghan resistance. Nonetheless, most foreigners drifted home to normal lives once the Soviets withdrew. As those fighters departed, al-Zarqawi arrived. Although he reputedly participated in some battles among the various resistance factions on his first trip to Afghanistan, little is known in detail. ${ }^{7}$

Al-Zarqawi and hardline jihadi scholar Abu Muhammad al-Maqdisi, also a Jordanian, journeyed back to Jordan and founded a short-lived jihadi group known as Bayt al-Imam in 1993, but they were quickly arrested and imprisoned. ${ }^{8}$

The jihadi prisoners in al-Jafr prison initially selected al-Maqdisi as their amir (leader) because of his reputation as a scholar, but al-Maqdisi's powerful prose and intellect did not translate into natural leadership skills. ${ }^{9}$ For example, the jihadis soured on al-Maqdisi's unwillingness to challenge the prison guards; al-Zarqawi, on the other hand, preened "like a peacock" and challenged the guards repeatedly, resulting in beatings that only bolstered his credibility with other prisoners. ${ }^{10}$ Before long, the jihadi prisoners replaced al-Maqdisi with al-Zarqawi as amir. ${ }^{11}$

After al-Zarqawi's release from prison, he aimed to join the jihad in Chechnya, where international fighters flocked to oppose Russian dominance over a predominately Muslim population. To reach Chechnya, al-Zarqawi needed money and connections, which could be acquired in South Asia. Along with two friends, al-Zarqawi arrived in Kandahar, Afghanistan, in December 1999. ${ }^{12}$

Al-Zarqawi arrived at a perfect time to strike a deal with al-Qaida, primarily because of intra-jihadi politics. Al-Qaida was the leading jihadi organization among 13 other jihadi groups in Afghanistan. ${ }^{13}$ Many allied with al-Qaida, but some disagreed on strategy. In 1998, al-Qaida embraced a strategy focused on attacking the United States, but most jihadis prioritized striking governments in predominately Muslim regions of the world. ${ }^{14}$ Both sides of the debate aimed to overthrow local governments, but al-Qaida chief Usama bin Ladin argued that it was too difficult to overthrow Muslim rulers if they were supported by the United States. ${ }^{15}$ Bin Ladin's goal was to keep striking the United States with terrorist attacks until Washington ended its support to local governments that were in al-Qaida's crosshairs. ${ }^{16}$ Once Muslim governments lost U.S. support, then it would be al-Qaida's time to seek revolution. ${ }^{17}$

$\mathrm{Al}-$ Zarqawi was both ideologically radical and favored direct strikes on near enemies. ${ }^{18} \mathrm{Al}-\mathrm{Q}$ aida valued long-term strategic planning, while al-Zarqawi relied on instinct to survive and thrive. Al-Zarqawi sided with jihadis who believed the Taliban were illegitimate ${ }^{19}$ because they accepted "un-Islamic" Afghan cultural practices, such as decorating the graves of ancestors. Al-Zarqawi also disagreed with al-Qaida's focus 
on the United States. He hated the United States, but he wanted to attack hard and soon, which meant focusing on the closer targets of governments in the region. These disagreements would return years later.

Despite his immediate distaste for al-Zarqawi, Bin Ladin ultimately offered the younger jihadi training and start-up funds. ${ }^{20} \mathrm{Al}$-Zarqawi set up camp outside the western Afghan city of Herat, not far from the Iranian border. ${ }^{21} \mathrm{Al}$-Zarqawi recruited widely among Jordanian, Palestinian, and Syrian fighters, many of whom brought their families with them to Afghanistan. In a decade, he had transformed from a forgettable, low-level foot soldier into a leader.

After the 9/11 attacks, al-Zarqawi immediately fled to Kandahar, which was the center of the Taliban resistance to the U.S. counterattack after 9/11. Ultimately, Taliban chief Mullah Omar ordered his supporters to retreat from Kandahar. ${ }^{22}$ Like many others, al-Zarqawi then slipped out of Afghanistan to seek safety in Iran. ${ }^{23}$ Yet he already had his eyes fixed on the next big prize: Iraq.

\section{The Islamic State's predecessor: al-Qaida in Iraq}

Al-Zarqawi crossed into northern Iraq in mid-2002, where he was welcomed by a primarily Kurdish jihadi group called Ansar al-Islam. ${ }^{24}$ Al-Zarqawi hoped to confront a U.S. invasion of Iraq violently, but he was not content to wait for that moment. Using a broad network of Levantine jihadis, al-Zarqawi built the framework for a regional terrorist organization before a shot was fired in Iraq. Indeed, the Islamic State's "Godfather" fired first at the United States in Jordan. On October 28, 2002, gunmen in Amman assassinated Laurence Foley, an American diplomat with the Agency for International Development, an operation funded by al-Zarqawi. ${ }^{25}$

The U.S.-led coalition invaded Iraq on March 20, 2003, with a series of devastating strikes against Ansar al-Islam's jihadi camps in Iraqi Kurdistan. ${ }^{26}$ Cruise missiles rained down, and U.S. Special Operations Forces killed and captured survivors. ${ }^{27}$ Kurdish and jihadi survivors fled in all directions, including across the border into northern Iran. ${ }^{28}$

Al-Zarqawi was already ensconced in Baghdad when the invasion began. ${ }^{29} \mathrm{He}$ was joined by a range of foreign jihadis, many of whom had arrived in Iraq on buses from the Syrian cities of Damascus and Aleppo. Perhaps the most important, however, was an Egyptian known as Abu Ayyub al-Masri, who would take the nom de guerre Abu Hamza al-Muhajir. Al-Masri had a history of working with Egyptian jihadi groups as a bombmaker, but he was an ideological extremist like al-Zarqawi and would eventually become one of the most important figures in Islamic State history.

The foreign jihadis quickly built ties with officials from Saddam Hussein's regime who undergirded the early stages of the Iraqi insurgency. Saddam had delegated planning for the resistance to a senior general named Izzat al-Douri, who aimed to broaden resistance to the U.S.-led invasion by enabling groups with a wide variety of ideological dispositions. Some of the early insurgent groups in Iraq were secular Baathist nationalists, others embraced a Muslim Brotherhood-like Islamism, and others reflected the jihadi disposition of foreigners like al-Zarqawi.

Prior to the U.S.-led invasion, al-Douri had led Saddam's "Faith Campaign," which worked to reconfigure Iraq's traditional secularism into an "Iraqi Islam." ${ }^{30}$ Saddam hoped this would both mitigate Iranian influence among Iraq's Shia population and staunch the influence of foreign Muslim Brotherhood and Salafis among Iraq's Sunnis. ${ }^{31}$ This history meant al-Douri was theoretically well positioned to co-opt extremism in the insurgency. In the end, however, it did not work. Although the Baathists served as the backbone of the early insurgency, the most diehard fighters were eventually co-opted by the foreign jihadis.

Al-Zarqawi's first major attack in Iraq embodied the early collaboration between Baathists and foreign jihadis. On August 7, 2003, a truck bomb exploded at the Jordanian Embassy in Baghdad. ${ }^{32}$ Two weeks later, a similar bomb exploded at the United Nations headquarters in Baghdad. ${ }^{33}$ Al-Zarqawi's allies, in conjunction with former Iraqi officers, organized both attacks. While the attacks served both Baathist and jihadi goals, al-Zarqawi's movement ultimately claimed the strikes and gained the most attention. 
Al-Zarqawi's most important attack early in the insurgency came later in 2003 when he sent his father-inlaw on a suicide mission to kill the prominent Shia cleric Ayatollah Muhammad Bakir al-Hakim in Najaf. ${ }^{34}$ After the U.S. invasion, al-Hakim had returned to Iraq from exile in Iran and advocated productive engagement with U.S. forces. The attack both killed a potentially unifying figure in Iraq's Shia community and illustrated the strategy of sectarian war that would come to be al-Zarqawi and the Islamic State's calling card.

Al-Zarqawi's penchant for brutality and sectarianism disturbed al-Qaida's leadership. Throughout 2003, al-Zarqawi communicated via messenger with al-Qaida's leaders, who argued against a strategy of unremitting attacks on Iraqi Shia. ${ }^{35}$ Ideologically, al-Qaida argued that everyday Shia were lapsed Muslims who should be reformed, not killed. Al-Qaida agreed that the jihadis would eventually need to confront organized Shia groups, including Iran, but they hoped first to win over everyday Shia and worried that brutally killing Shia would alienate less radical Sunnis.

Practically, al-Qaida's leaders also worried that many al-Qaida leaders lived in Iran and, though they were sometimes able to communicate externally during this period, were also under house arrest-style restrictions and could be killed or traded by the regime if push came to shove.

Despite the early attacks, the leadership council of al-Zarqawi's group, Jamaat al-Tawhid wal-Jihad, was upset when they gathered in early 2004. They had conducted many attacks but made few tangible gains. To change that, the group pledged to seize territory and confront the United States and the Iraqi Security Forces directly.

The location for this showdown was Fallujah, a city of 200,000 people 80 miles up the Euphrates River from Baghdad. The city had a long reputation for religious conservatism, and it was there that a collection of militant groups, including al-Zarqawi's Jamaat al-Tawhid wal-Jihad, asserted absolute control. ${ }^{36}$ After this militant coalition repelled an initial attack by U.S. troops in April 2004, al-Zarqawi's legend ballooned.

Al-Zarqawi seized that moment to close his longstanding negotiations with al-Qaida. Despite their strategic disagreements, al-Zarqawi publicly pledged allegiance to Bin Ladin in October 2004 and thereby created a new entity called al-Qaida in Iraq (AQI). ${ }^{37}$

Al-Zarqawi praised the al-Qaida leader and stated his willingness to follow orders, although he explained that he was swearing allegiance only after al-Qaida "came to understand our approach, and their hearts warmed to it." ${ }^{38}$ In reality, however, future discord between al-Qaida diehards and al-Zarqawi's intellectual descendants suggest the differences between al-Zarqawi and al-Qaida were never fully resolved.

In November 2004, U.S. forces successfully pushed the jihadi-led coalition of insurgents out of Fallujah. A seminal moment, however, occurred in the interim: al-Zarqawi had joined al-Qaida and became the undisputed leading figure among foreign jihadis in Iraq. Moreover, the jihadis had a taste of what it meant to control territory. They had established the precedent that would eventually be reflected as true jihadi governance in the future Islamic State.

AQI conducted many atrocities while in control of Fallujah. One was particularly public. On a grainy video distributed globally online, al-Zarqawi personally beheaded a captured American businessman named Nicholas Berg. The video displayed Berg dressed in an orange jumpsuit like those worn by American prisoners at Guantanamo Bay. After making a brief statement reiterating jihadi goals, al-Zarqawi beheaded the victim. ${ }^{39}$ Ten years later, Islamic State beheadings would loyally follow this basic script.

The video also reflected new modes of propaganda distribution. Capitalizing on newly available broadband technology, which increased the size of a file that could be placed online, duplicate copies of the video were uploaded across the internet. The numerous links to these sites were subsequently distributed in messages on dedicated jihadi web forums.

Even as al-Zarqawi planted the jihadi flag in Fallujah, he and Sayf al-Adl, a prominent al-Qaida operative who managed al-Zarqawi's ties to the network, aimed to develop a shared vision for the newly created AQI. This was no easy task: they needed to shape al-Zarqawi's brutality into a framework that al-Qaida's leaders recognized as strategy rather than nihilism. The result was a seven-stage plan for taking over the world by $2020 .{ }^{40}$ 
The plan aimed to extend the fighting in Iraq and discredit the governments of Muslim-majority countries by forcing them to endorse the U.S. invasion. Over the long run, the plan sought to establish an Islamic State, but it looked to do so not in Iraq but in Syria. Stage five of the plan indicated that the caliphate would be re-established in Syria between 2013 and 2016, a prediction that turned out to be accurate; the Islamic State declared itself the caliphate in $2014 .{ }^{41}$

The precision of that prediction was luck more than calculated strategy, but the so-called "master plan" was revelatory in identifying why Syria, not Iraq, was the best locale for reestablishing the caliphate. Most important were demographics. Iraq's population is $60 \%$ Shia, and only about $20 \%$ of the population are Sunni Arabs. Syria, on the other hand, is 70\% Sunni Arab and was governed by Bashar al-Assad, who came from a small offshoot sect of Shia Islam known as Alawites.

The world awoke to the Islamic State in 2014, but a decade earlier, Sayf al-Adl and the "Zarqawists" recognized that even as they fought in Baghdad, their long-term path to geopolitical power ran through Damascus, Aleppo, and Raqqa.

\section{Tensions increase between al-Zarqawi and al-Qaida}

Al-Zarqawi's decision to formally join al-Qaida represented the high point of cooperation between the two movements, but this marriage was never built to last. As 2005 wore on, al-Qaida's leadership grew increasingly frustrated with al-Zarqawi's growing reputation for brutality. ${ }^{42} \mathrm{Al}-Z$ awahiri also questioned whether Iraqis would be more amenable to have an Iraqi leading jihadi forces in the country.

Al-Zawahiri, and al-Qaida generally, maintained that the jihadi movement would eventually need to win over the Muslim masses globally to assert political power. Al-Zarqawi disagreed with that notion. Whereas al-Qaida's leadership felt that Sunni Muslims needed to be led back to what they considered the truth path of Islam, al-Zarqawi was more inclined to simply write off intransigent Sunnis—and kill them. For al-Zarqawi, publicizing brutal killings was not just a way to spread fear, but he believed that Muslims who rejected that violence revealed themselves as apostates.

The breakdown occurred in November 2005 when suicide bombers dispatched by al-Zarqawi detonated explosives inside Western-branded hotels in the Jordanian capital of Amman. One bomb exploded in the middle of a wedding celebration, killing dozens. ${ }^{43}$ Al-Zarqawi initially hailed the attacks as a blow against a key American ally in the region, but the Jordanian public was aghast. As with most of al-Zarqawi's attacks, the vast majority of victims were Muslim. Al-Qaida was furious.

Al-Qaida's response to al-Zarqawi's intransigence was swift. Multiple senior officials sent alZarqawi letters urging him to limit the violence. ${ }^{44}$ In January 2006, al-Qaida dispatched one of its most senior commanders, Abd al-Hadi al-Iraqi, from Pakistan to Iraq on a mission to muzzle the young Jordanian. ${ }^{45}$

Al-Zarqawi must have understood the frustration and took some steps to manage it. In January 2006, AQI announced that it would begin operating within an umbrella group called the Mujahidin Shura Council, which ostensibly would be led by an Iraqi and endeavored to present itself as a vehicle for Iraqfocused militant groups. ${ }^{46}$ One of those organizations was a small, highly sectarian group that operated primarily in Iraqi's Diyala Province. Its religious leader was a young man named Ibrahim Awad Ibrahim al-Badri, who would eventually become infamous as Abu Bakr al-Baghdadi, supposed caliph and leader of the Islamic State.

Al-Baghdadi's day in the limelight was still far off, but the jihadi environment in Iraq was shifting dramatically. On February 22, 2006, a team of jihadis broke into the al-Askariyya Mosque in Samarra and wired the entire shrine with explosives. The shrine is considered the third-holiest site for Shia Muslims in Iraq and was known globally for its shimmering gold-tiled dome. No one was killed by the bomb blast itself, but the explosion devastated the building — and precipitated an unprecedented sectarian backlash by Shia militias. ${ }^{47}$ Consistent with al-Qaida's guidance, al-Zarqawi and AQI did not claim credit for the attack, 
but his aim was achieved regardless. Al-Zarqawi had been trying for years to provoke an all-out sectarian war in Iraq. After the al-Askariyya Mosque bombing, he got it.

Al-Zarqawi did not have long to celebrate this achievement. On June 8, 2006, a U.S. Special Operations Command Task Force tracked one of al-Zarqawi's clerical advisors to a safehouse west of Baquba. ${ }^{48}$ Watching the scene via real-time drone footage, analysts caught sight of a man who looked like al-Zarqawi, and commanders approved an airstrike on the safe house. Al-Zarqawi rushed out of the safe house just before two 500-pound bombs plunged into it, but the blast was devastating. American Special Operations Forces were on the ground at the safe house in time to watch al-Zarqawi die. ${ }^{49}$

Al-Zarqawi's death was a dramatic blow to the jihadi movement in Iraq, but it was not a death knell. AlZarqawi's supporters even celebrated his martyrdom, claiming that images of his body revealed that he was smiling in death. Al-Zarqawi was no longer a commander, but he would continue to inspire a generation of jihadis. His replacement was no legend, but he was a capable militant. Abu Ayyub al-Masri had joined al-Zarqawi prior to the U.S. invasion. He kept the AQI military machine humming, but as the summer of 2006 wore on, he faced an extraordinary political challenge: American troops began to experiment with counterinsurgency techniques designed to win over the Sunni population in western Iraq.

Many Sunni tribal leaders were tired of AQI's draconian proclamations and unremitting violence, and the outbreak of full-on sectarian war left them vulnerable. Al-Zarqawi's strategy had been to provoke Shia attacks on Sunnis to push those Sunnis into the arms of AQI. The strategy, however, was too clever; the Sunni tribal leaders were looking for someone to defend them against the empowered Shia militias, but many turned to the U.S. military rather than AQI for that security.

\section{The formation of the Islamic State of Iraq}

In September 2006, the first coalition of Sunni tribal leaders formally announced their opposition to AQI. For al-Masri, this must have been a severe crisis. AQI had created a sectarian war, but it was not reaping the political and strategic benefits.

On October 15, 2006, al-Masri moved dramatically to rectify the problem. Without informing alQaida, the Mujahidin Shura Council announced that it was dissolving, and instead it would establish the Islamic State of Iraq (ISI). The ISI would be a true Islamic state designed to govern and build the foundation of a caliphate. ${ }^{50}$ The new "state" quickly announced a government structure with ministries—ranging from "War" to "Fisheries"-led by the equivalent of cabinet officials. It described leadership succession procedures and explained in detail the state's obligations to its "citizens."

Yet even as the ISI moved to collect garbage and manage low-level public works projects, it made clear that imposing its understanding of Islamic law took priority. If there was ever a tradeoff between imposing divine punishments and bettering people's lives, the state declared that "improving their conditions is less important than the condition of their religion." 51

The ISI's close supporters embraced it, but the new state did not gain wide currency among Muslims. Indeed, even most jihadis declared the group illegitimate. The jihadis complained about a range of issues: the ISI did not actually control that much territory, which many jihadis thought was necessary for an Islamic state to be valid, and the group could not even rally most Muslims in Iraq to its side. The ISI responded that territory was not critical and described a feudal system of government in which local leaders swore allegiance to the ISI's amir and would govern whatever territory they could. They pointed to the Prophet Muhammad's first "state" as a reference point because it had also been quite weak compared to its enemies.

In the end, the most important criticism of the ISI was its choice of amir. The man was largely unknown, which raised tremendous alarm among jihadis globally. His name was Hamid Dawud Khalil al-Zawi, but he was known as Abu Omar al-Baghdadi. Prior to declaring the ISI, the Zarqawist movement in Iraq had explored the qualifications required of a future amir and potential caliph. Among relatively standard 
leadership qualities, they pointed to one very specific characteristic: anyone selected as amir must be a direct descendent of the Prophet Muhammad's tribe of Quraysh. ${ }^{52}$

Across the Middle East, many people claim to descend from Quraysh, but the criteria excluded many logical candidates in Iraq, including al-Masri. Abu Omar, on the other hand, fit the bill. He was Iraqi and had briefly served within the Baathist state as part of the security services. Abu Omar was purged from the Iraqi state because of his extreme Salafi views and, according to jihadi biographies, served as a mechanic and a small-time preacher during Saddam's reign. ${ }^{53}$

Jihadis outside of Iraq had never heard of him. Al-Qaida's leaders had not been forewarned that AQI was going to declare an Islamic state or given an opportunity to opine about the leader of the new institution. After Abu Omar's appointment, al-Qaida's leadership repeatedly pressed its partners in Iraq for information on the new amir. To complicate matters, the ISI went to great lengths to keep Abu Omar's true identity a mystery. ${ }^{54}$ The deception was effective; a disillusioned defector from the ISI arrived in Pakistan to brief al-Qaida and claimed that Abu Omar was a fabricated persona and not a real person. American interrogators heard the same story — and repeated it publicly—after capturing the ISI's media chief in $2007 .^{55}$

The ISI's trickery reflected unique and careful operational security measures, but their disregard for alQaida was more important. After its establishment, the ISI clearly declared that al-Qaida no longer existed in Iraq. It was not until 2007-a year after the group's declaration-that al-Qaida's leadership publicly agreed. Despite this messaging, however, there clearly was still engagement between the two groups, which was notable in the alignment between their political statements in late 2007. Al-Qaida's leadership later claimed that the ISI continued to operate as one of its affiliates despite the public disavowal. Whatever the backroom deals, the ambiguity was real for many of the groups' supporters, and both sides would tell their own versions of this history when the two groups ultimately split violently in 2013.

Despite its bold claims, the ISI went into headlong retreat shortly after announcing the establishment of the so-called state. By the spring of 2007, it was clear that the declaration—far from being a triumph—was turning into a disaster. As Sunni tribal groups rebelled and U.S. troops flowed into Iraq, the ISI was losing. Even then, however, the group's long-term vision and persistent commitment to its vision were clear. In April 2007, Abu Omar described the group's intent to "remain," a concept that is still a core element of the Islamic State's rhetoric today.

Over the following three years, the ISI was battered and bruised by U.S. troops, Sunni militias, and the Iraqi government. When al-Masri announced the state in October 2006, he claimed to have 12,000 men under arms and another 12,000 waiting in the wings. ${ }^{56}$ By 2011, the U.S. military estimated that their numbers were down to about $1,000 .{ }^{57}$ Despite these setbacks, however, the ISI's commitment to "remain" was not just talk; the group modified its structure and operational model and survived despite massive losses.

The group survived by evolving from an insurgent movement that held territory to a terrorist group that operated underground. It reduced attacks against U.S. forces but assassinated Sunni leaders who had opposed it and conducted bombings and hit-and-run attacks against Iraqi troops. Iraq's Anbar Province had been al-Zarqawi's most important stronghold early in the war, but the ISI withdrew most of its surviving forces to Ninawa Province and the city of Mosul, in Iraq's far north. Mosul had several advantages: the U.S. surge never reached Mosul, and it was close to the group's support networks across the border in Syria, where a trickle of foreign fighters still entered Iraq even at the group's weakest point.

Throughout this period, the ISI laid the groundwork for resurrection. It operated like a criminal mafia to raise money and maintained a strict organizational structure that gathered intelligence and spread propaganda. The group's media apparatus was not as active as during the group's high point, but it continued to release statements and videos of attacks. Indeed, the ISI remained a very potent terrorist organization during this period of decline: there were more suicide bombings in Iraq between 2008 and 2010 than in any other country in the world. ${ }^{58}$ The U.S. surge damaged the ISI significantly, but it was never defeated. 
The U.S. military did not see it that way at the time. In early 2010, American and Iraqi troops surrounded and killed both Abu Omar al-Baghdadi and al-Masri, al-Zarqawi's immediate successor and the ISI's minister of war. That spring, many of the group's top leaders were killed or captured. This was a tremendous success for counterterrorism officials, and to many of them, it looked like the military defeat of the ISI. They were wrong.

\section{The ISI returns with a vengeance: Abu Bakr al-Baghdadi takes the helm}

The ISI's leadership was devastated in the spring of 2010, but the group's position in Iraq strengthened in other ways. The United States had agreed to withdraw from Iraq by the end of 2010 per a Status of Forces Agreement signed by President George W. Bush, and the Obama administration failed to negotiate a new agreement that may have left a residual U.S. force in the country. As troops prepared to leave Iraq, they were less active in pursuing ISI operatives.

Meanwhile, Sunni frustration with the Iraqi government grew. As a primarily Shia country, the Iraqi government was generally led by Shia religious parties, some of which had close ties to Iran. Many Sunnis resented the government in Baghdad and complained that it aggressively targeted Sunni tribal and political leadership. The tension rose as tribal groups that once sought partnership with the United States to ensure their security had to fend for themselves. As the Iraqi government began to look like more of a threat to Sunni leaders than the weakened ISI, some turned to the jihadi group to push back on Baghdad. Al-Zarqawi was long dead, but to a limited extent, the strategic vision he sketched in 2004 started to become a reality.

Despite the shifting political sands in Iraq, the ISI did not have a smooth path back to power. A core problem was replacing Abu Omar al-Baghdadi as amir. Back in 2006, the ISI described three legitimate processes for selecting an amir: the previous amir could select a successor, leading figures in the state could choose a new leader by consensus, or, in worst-case scenarios, a new leader could assert control by force. Unlike the selection of al-Masri as al-Zarqawi's successor, which took days, selecting the replacement for Abu Omar took weeks. This suggests that Abu Omar's successor seems to have been chosen via some combination of the latter two methods.

Like Abu Omar al-Baghdadi, Abu Bakr al-Baghdadi was unknown outside Iraq. He had been raised in Samarra, north of Baghdad, in a prominent tribal family, and received a $\mathrm{PhD}$ in Islamic history. ${ }^{59} \mathrm{Abu} \mathrm{Bakr}$ joined the Iraqi insurgency in the early years and quickly became a follower of al-Zarqawi.

Abu Bakr had been imprisoned for his support of the insurgency, where he gained a reputation among guards as a skilled negotiator between various factions in the prison yard and among prisoners as an ideological extremist. After his release from prison, Abu Bakr returned to the insurgency and eventually served as the ISI's governor in Mosul when it was the group's center of gravity after the U.S. troop surge. ${ }^{60}$ Like Abu Omar, Abu Bakr was unknown to the international jihadi community, but his stronger resume as a scholar, militant, and manager was perfect for the leadership role.

Abu Bakr was named amir of the ISI on May 16, 2010. ${ }^{61}$ His organization was battered, but he quickly seized on the political climate in Iraq. Abu Bakr rebuilt relationships with Sunni tribes and embraced former Saddam-era military officials. The world had stopped paying close attention to Iraq, but the largescale car bombs in Baghdad had resumed, and the rate of foreign fighters entering Iraq ticked up. The ISI targeted banks, government ministries, and key officials. The group also began a series of prison breaks, which served to bolster its ranks. The ISI was no longer a territorial entity as it had been in 2006, but as Abu Bakr stepped into command, it was a highly effective terrorist organization. ${ }^{62}$

Even as the ISI strengthened in Iraq, there was a surge of optimism across the Middle East about the prospect of democratic revolution. In Tunisia, Egypt, Libya, and Bahrain, protest movements exploded against their autocratic regimes. Known colloquially as the Arab Spring, it was a halcyon moment full of hope for everyone in the region. Inevitably, that revolution arrived in the ISI's backyard: not in Iraq but in Syria. 
In February 2011, Syrian authorities arrested a group of young boys for scrawling a slogan from the Egyptian Arab Spring movement - "the people want to topple the regime"- on a wall in the southern town of Deraa. When the community erupted to protest their arrest, regime snipers opened fire. The violence was returned almost immediately and the slow, inexorable slide toward a Syrian civil war began.

The ISI quickly took notice. In April 2011, an ISI shura council member released a statement that noted "the good news about the Muslim people in some Syrian cities starting to mobilize" and pledged the ISI's "support." ${ }^{33}$ In the ISI's lexicon, "support" had only one meaning: the ISI was coming to Syria, and not just to protest but to fight.

Indeed, the ISI had longstanding networks in Syria that had previously been used to funnel fighters in and out of Iraq, but many of those were known to the Syrian regime, which had enabled jihadi logistics networks for moving fighters into Iraq. Yet now the tactical accommodation between jihadis and the Syrian regime was breaking down. In response, Abu Bakr sent a Syrian deputy named Abu Muhammad alJolani to serve as his primary delegate in Syria in August 2011. ${ }^{64}$

Al-Jolani quickly gained legitimacy with a wide range of Syrian militants who had emerged to fight the Syrian regime. Unlike al-Baghdadi and the Zarqawists around him, al-Jolani took a constructive approach to other Islamist militant groups. He did not demand their immediate allegiance and instead thought that a cooperative relationship with other militants was prudent. Al-Jolani's group in Syria did not initially acknowledge its ties to the ISI, but it soon announced itself as Jabhat al-Nusra (or the Nusra Front) in January 2012. ${ }^{65}$

The Nusra Front's ideological vision for an Islamic state contradicted the secular objectives of many early Syrian revolutionaries. Yet Syrian militants also welcomed experienced fighters who could strike the Syrian regime and were willing to overlook the group's ideological extremism in exchange for tactical victories. At the same time, the Syrian regime conducted false flag attacks and released jihadis and Islamists from prisons to bolster its claim that the rebellion was dominated by jihadis - an attempt to weaken international support for the rebels. ${ }^{66}$

Sunni states in the region-Saudi Arabia, Qatar, and the United Arab Emirates-sponsored militants who worked closely with Nusra and perhaps the group itself. The regional powers did not have good options for militants to support. They wanted to overthrow the Iranian-backed regime in Damascus to counter Iranian influence, but the secular and nationalist elements of the Free Syrian Army rebel coalition were not nearly as effective as the various Islamist militants.

Even the United States was slow to draw a direct link between the ISI and the Nusra Front in Syria. The U.S. State Department did not formally link Nusra to the ISI and its forefather AQI until December 2012, nearly 18 months after it first appeared in Syria and almost a year after it formally announced itself. ${ }^{67}$

The Supreme Joint Military Council, an umbrella movement for Syrian rebel groups, swiftly denounced the State Department's designation and rejected the suggestion of "extremist forces" in Syria. The Nusra Front, however, was bolstered both by the Syrian regime and many of the Syrian revolutionaries opposed to it. Both factions would eventually regret their decisions to do so.

Despite the Nusra Front's manifest ties to the ISI, many observers of the early Syrian civil war did not recognize the link. Two potential reasons stand out. First, the ISI was erroneously believed to be defunct because of the defeats it suffered between 2007 and 2010. Second, observers were rightfully critical of the al-Assad regime in Syria and believed in the righteousness of the rebellion against it. Acknowledging that jihadis had infiltrated the rebellion seemed to fall directly into the political trap that al-Assad hoped to set to discredit it.

\section{The Islamic State in Iraq and Syria}

In April 2013, the ISI removed any doubt about the Nusra Front's origins. Abu Bakr reportedly ordered al-Jolani to attack secular Syrian rebel groups or be dissolved. Al-Jolani ignored the directive. On April 9, 
2013, the ISI announced the "abolition of both names, the Islamic State of Iraq and Jabhat al-Nusra, and we merge them under one name: the Islamic State in Iraq and al-Sham (ISIS)." ${ }^{68}$

The merger was a nonstarter for al-Jolani. The next day he acknowledged the ISI's initial support but rejected the merger and announced that he would only take orders from Ayman al-Zawahiri, the leader of al-Qaida, not Abu Bakr and the ISIS leadership in Iraq. The discord between al-Jolani and Abu Bakr revealed a deeper and longer-standing tension between the ISI and al-Qaida. When Bin Ladin was killed in May 2011, al-Zawahiri assumed leadership of al-Qaida. Al-Zawahiri was a longstanding jihadi in good standing but did not command the same respect among jihadis globally as Bin Ladin — and he did not have the ability to rein in Abu Bakr as an increasingly independent leader. The tripartite conflict played out publicly, as well as through a series of private letters between the al-Qaida leadership and the ISI. The dispute spanned years of intra-jihadi politics. Al-Jolani acknowledged the Nusra Front's origins in the ISI but asserted that Nusra was a direct affiliate of al-Qaida, on par with ISIS. Al-Zawahiri agreed with this assessment and asserted that he therefore had the authority to mediate the dispute between Abu Bakr and al-Jolani. Abu Bakr not only rejected that formulation as guidance for 2013, but he argued that when the ISI was established in 2006, it had formally separated from al-Qaida. From Abu Bakr's perspective, the implications of this history were two-fold: both that Nusra Front was exclusively a product of the ISI and that al-Zawahiri had no authority to mediate the dispute with al-Jolani. ${ }^{69}$

It is hard to know the exact sequence of events. On the one hand, al-Qaida publicly acknowledged the ISI's independence in 2007, but that statement seems to have been coordinated with the ISI leadership at the time to bolster the former's legitimacy. Meanwhile, al-Zawahiri subsequently asserted that Abu Bakr had secretly sworn allegiance to al-Qaida. He produced letters suggesting that al-Qaida leaders believed this to be true but did not show a record of the actual pledge. The ISI's most important decisions were made without input from al-Qaida, most notably the decision to declare the "state" in the first place and the selection of both Abu Omar and Abu Bakr. Whether it had secretly sworn allegiance to al-Qaida's leadership or not, the ISI operated independently from the time of its original announcement. ${ }^{70}$

In 2013, the dispute grew more heated and eventually devolved into open warfare between ISIS and al-Qaida, including the Nusra Front. Al-Zawahiri publicly denounced both al-Jolani and Abu Bakr for airing their grievances publicly, but he basically accepted al-Jolani's position that the two organizations were peers. In doing so, al-Zawahiri asserted al-Qaida's institutional authority over both groups, but he also was backing al-Jolani's strategic approach.

Abu Bakr had a Zarqawist insistence that other groups fall in line behind his leadership- - he genuinely saw ISIS as the locus for a future caliphate and the most legitimate Islamic authority on earth - but alJolani was willing to work more cooperatively with other militant groups. Like Abu Bakr, al-Jolani and al-Zawahiri aimed to build a caliphate eventually, but their strategy was much more protracted.

The Syrian civil war was the greatest political opportunity for jihadis since the Soviet invasion of Afghanistan in 1979. Yet ISIS and al-Qaida would not seize that opportunity together. Al-Zawahiri claimed that the Nusra Front was indeed independent of ISIS and, unsurprisingly, al-Jolani accepted that position. Abu Bakr rejected it, at which point open warfare erupted on the ground between the Nusra Front and ISIS. Entire military units switched sides overnight, sometimes killing their commanders in the process. It was a new phase in the Syrian civil war and the death knell for the long, uncomfortable accommodation between al-Qaida and the Zarqawist movement that had begun in Kandahar in 1999. ${ }^{71}$

\section{The Islamic State and the caliphate}

Despite their dispute, both ISIS and the Nusra Front initially thrived in Syria. As 2013 wore on, it became clear that the Syrian regime did not have the military strength to quickly suppress the rebellion, which remained a diverse hodgepodge of ideologies and groups. The Syrian war became a magnet for foreign fighters from abroad. 
In early 2007, more than 100 foreign fighters a month joined the ISI in Iraq, but that was nothing compared to the flow of foreigners entering Syria. ${ }^{72}$ Hundreds of fighters entered Syria every month, primarily through Turkey, which did little to stop the flow. Eventually, tens of thousands of people would join the fight in Syria from more than 80 countries, most of them joining either ISIS or the Nusra Front.

Some of the foreign groups were quite powerful. Central Asian jihadis arrived with years (even decades) of experience fighting Russia in the Caucasus and quickly became a center of military expertise for ISIS. When a group led by the veteran Chechen fighter Abu Omar al-Shishani defected from the Nusra Front to ISIS, it was a major coup for the more radical group.

In Syria, ISIS seized the city of Raqqa when fighters previously loyal to the Nusra Front defected. Raqqa became the symbol of ISIS territorial control and effectively served as the group's capital until 2017. In 2013, ISIS territorial gains in Syria drew most of the world's attention, but the group also reasserted control over major parts of Iraq. Ever since the U.S. troop surge destroyed the ISI's territorial holdings in Iraq, the group had worked silently and systematically to assassinate local governors and tribal leaders and rebuild networks across the country. That long-term effort started to pay off.

The heart of ISIS's project in Iraq was in Mosul, but the most dramatic early shifts occurred in Anbar Province. ISIS fighters seized neighborhoods in Fallujah and Ramadi, often with the help of local tribal officials fearful of the Shia-dominated government in Baghdad and the Iranian-sponsored militias that bolstered it. Iran had sponsored militias in Iraq since before the fall of Saddam, and they had played a major role attacking U.S. troops during the occupation. By 2013, those same networks were diverted to support the al-Assad government in Syria. When ISIS seized Raqqa in Syria and towns in Iraq's Anbar Province, they considered it all part of a single battle against a transnational Shia enemy.

Despite ISIS's dramatic growth and history in Iraq, the international community did not immediately recognize the threat. The perceived virtue of the Syrian rebellion colored assessments of anyone opposed to the Syrian regime, but this was bolstered by the erroneous belief that ISIS was less likely than al-Qaida to conduct attacks against the West. After all, al-Qaida explicitly prioritized attacks against the so-called "far enemy" - the West-and Zarqawists like ISIS focused on attacks against the "near enemy" of local governments.

This view was short sighted. The Zarqawists always aimed to confront the West eventually, and ISIS had strengthened so much that it could focus on local violence while still having capacity to invest in attacks abroad. Moreover, ISIS's focus on the "near enemy" was not nearly as absolute as some claimed. Dating back to 2008, the ISI's minister of war, al-Masri, claimed responsibility for a 2007 bomb plot in London. ${ }^{73}$ Indeed, ISIS's network outside of Iraq and Syria grew active in early 2014. In May, a French ISIS supporter opened fire at the Jewish Museum in Brussels. It was a hallmark of attacks to come. ${ }^{74}$

Before ISIS's international campaign gained full steam, the group continued to grow in Iraq and Syria. In early June 2014, ISIS fighters struck across Iraq. In Ramadi, they took over a local university, and in Baghdad, suicide car bombs detonated across the city. These attacks, however, were just a diversion for the real blow, which was coming farther north.

Mosul had been ISIS's stronghold in Iraq since the U.S. troop surge pushed the group out of Anbar Province in 2007. ISIS had deep underground networks, cooperative relationships with many politicians, and short supply lines to its rear base in Syria. Moreover, Mosul was a primarily Sunni city that was riven by disputes between Arab and Kurdish factions. It was far from Iraq's Shia population centers that provided most of the troops for the Iraqi army. Many soldiers felt they were defending a city that did not want them. Iraqi units in the city had been hollowed out by deserters and corrupt commanders who enlisted "ghost soldiers" that only existed to collect a salary that could be shared with officers. Official numbers suggested there were as many as 25,000 soldiers defending Mosul, but the actual number was closer to half that. ${ }^{75}$

ISIS began its attack by further undermining the defenders. It released propaganda claiming that its spies were everywhere in the city, including within the police and army; soldiers might fight, but they would never know whether the soldiers on either side of them were loyal. These messages were effective 
at undermining morale. When ISIS fighters entered Mosul in force, ISIS sleeper cells within the city rose up, confusing and terrifying the Iraqi army. Although ISIS only had a small number of fighters, the Iraqi defenses collapsed and soldiers scattered south. In a matter of days, a city of 1.8 million people had fallen into the hands of ISIS.

The offensive did not stop there. As Iraqi troops fled, ISIS fighters attacked in Fallujah and Ramadi and charged south from Mosul. Some observers even worried that Baghdad itself was in danger. ISIS's Mosul offensive shook the world out of its complacency. A terrorist group once left for dead now controlled major sections of both Syria and Iraq and was close enough to Baghdad to cause real concern. This was no longer a threat that could be wished away by the virtue of the broader Syrian revolution. ISIS was redrawing the borders of the Middle East.

ISIS had bigger aspirations than just Iraq and Syria. On June 29, 2014, Abu Muhammad al-Adnani, the group's spokesman, announced that the movement al-Zarqawi started a decade earlier was changing its name yet again. This announcement was different. Instead of simple nomenclature, al-Adnani announced that ISIS was declaring itself the caliphate, with global authority. Instead of limiting itself to "Iraq and alSham," the new entity would simply be called the "Islamic State." ${ }^{\prime 6}$ Abu Bakr al-Baghdadi, whom al-Qaida considered an unknown when he was announced as amir of the ISI in 2010, was named caliph. To punctuate the announcement, Abu Bakr led prayers at the Grand Mosque in Mosul on July 4, 2014. ${ }^{77}$

For its supporters, declaring the caliphate seemed to validate the group's propaganda and ideological disposition. Islamic State leaders had long claimed that their small, embattled group would one day rise to govern a new caliphate-and now they could point to that actually happening.

The Islamic State capitalized on this success to recruit even more. They appealed for people from all over the world to emigrate and join the caliphate, arguing that it was religiously required despite the risks. Islamic State propagandists also advanced a vision of impending apocalypse. They argued that reestablishing the caliphate was not simply a re-codification of jihadi power and authority, but it marked the beginning of a final eschatological battle between good and evil.

Apocalyptic rhetoric had been common in the Zarqawist movement since before the declaration of the ISI in 2006. It was a powerful motivational tool and allowed the group's leadership to imbue a sense of religious immediacy to their actions. For the Islamic State's leaders, it was not enough to support the concept of the Islamic State; would-be supporters urgently needed to take action because the end of the world was imminent. Their case was bolstered because Islamic prophecy suggested that apocalyptic battles would occur in northern Syria, precisely in the areas where its troops were engaged. ${ }^{78}$

The Islamic State's eschatological vision contrasted with its effort to build sustainable governing structures. If the end times were really evident, then establishing robust bureaucracies to pick up garbage and manage fisheries seemed strange. The concepts could be reconciled to the same violent ideological vision, but they suggested different resourcing priorities. Whatever Abu Bakr al-Baghdadi's true religious conviction, the group deftly used both its progress in governance and the specter of an apocalyptic fight to recruit and motivate supporters.

\section{The Islamic State targets the West, but falters in Iraq}

Even as Abu Bakr climbed the minbar (pulpit) in Mosul, the earliest signs of the Islamic State's future setbacks were already visible. Islamic State fighters who had rushed south toward Baghdad were stopped and shortly thereafter pushed back by a combination of Iraqi troops, Iranian-backed militias, and U.S. airpower. They had substantially overreached by pushing into the Iraqi heartland and would eventually pay the price.

By the standards of a jihadi terrorist group, the Islamic State was almost incomprehensibly powerful, but it thrived most when underestimated by its enemies. After the capture of Mosul, no one underestimated the Islamic State, and the results were predictable: it was slowly and steadily pushed back. 
The Islamic State's decline as a geographic entity began in late 2014, but it was a slow process. In the meantime, the Islamic State rebuilt a sophisticated governance structure modeled after the original framework announced in 2006. It established a leadership cadre; cabinet offices addressing everything from military affairs, immigrants, and health care; and federated authority to wilaya (provinces) in both Iraq and Syria and beyond. Over time, these sprouted globally, in regions as disparate as Libya, the Caucuses, Afghanistan, and the Philippines.

Functional wilaya replicated the overarching structure with governing bodies of their own, complete with distinct social service functions and propaganda distribution networks. This geographic and structural federation was necessary to manage the Islamic State's sprawling territory, but it also created resilience. The Islamic State could lose leadership and territorial control in a particular locale and still have functional organizations elsewhere in the world.

In the wake of declaring the caliphate, the Islamic State also announced its intention to conduct terrorist attacks around the globe. In September 2014, al-Adnani exhorted followers to attack in the West. "If you cannot find an [improvised explosive device] or a gun," he explained, "then find a disbelieving American or Frenchman . . . and smash his head with a rock or slaughter him with a knife." ${ }^{79}$ The Islamic State's predecessors had threatened Europe previously, and al-Zarqawi had conducted attacks outside Iraq and Syria, but this was the first time that an Islamic State leader put external attacks at the center of the group's political vision.

The core of the Islamic State's external operations fell within the Amniyat. This unit identified foreign fighters upon their arrival in Syria for specialized training and then sent them back to their home countries. It also engaged with supporters remotely and urged them to conduct simple attacks in their home countries. ${ }^{80}$

In 2015, the Amniyat campaign infrastructure started to emerge. In January, Belgian officials disrupted a large cell in the Belgian city of Verviers that hinted at an extensive operational capability in Europe. This network emerged in full force in the autumn, when the Islamic State bombed a Russian airliner flying out of the Egyptian resort town of Sharm el-Sheikh; bombed a Shia neighborhood in Beirut; and conducted a complex attack in Paris involving suicide attackers, small arms, and a hostage-taking operation at the Bataclan Theater. ${ }^{81}$

Moreover, the Islamic State catalyzed a distributed network of supporters to conduct attacks with little or no connection to the core organization that further advanced its overall goals. Al-Qaida had conducted attacks globally but did not generate a continuous campaign of violence like that produced by the Islamic State. None of the Islamic State's attacks approached the sophistication of 9/11, but a seemingly endless line of unsophisticated attacks threatened multicultural societies around the globe, especially in Europe.

The Islamic State's global reach sharpened the focus of political leaders around the world. Indeed, just before the Paris attacks, President Barack Obama announced that the Islamic State was losing territory in Iraq and Syria. The Iraqi army was slowly pushing north toward Mosul and retaking the major cities in Anbar Province. Key Islamic State provinces further afield were under pressure as well, especially in Libya, where the government and various Islamist militias routed Islamic State-linked groups.

Progress was slower in Syria despite Russia's intervention on behalf of the al-Assad regime and a more aggressive Western campaign against the Islamic State. Russia prioritized attacking militants that directly threatened the Syrian regime (which often did not include the Islamic State), and American intervention was limited to airstrikes and Special Operations Forces. Nonetheless, the basic strategic shift had occurred; the Islamic State was playing defense in Syria and Iraq while directing and inspiring terrorist attacks around the globe.

At times, the Islamic State made deeply counterproductive military decisions. Its enthusiastic charge toward Baghdad after capturing Mosul is a key example, but another was the 2015 campaign to capture the city of Kobane along the Syrian-Turkish border. The Islamic State tried for months to capture the city despite intense American air support for its defenders. The assault seemed suicidal to many, which led 
observers to speculate it was motivated in part by an Islamic prophecy that the final battle between good and evil would take place nearby. Whatever the motivation, the Islamic State's attack on Kobane was a military disaster.

The Islamic State was steadily rolled back in 2016 and 2017 despite a series of terrorist attacks abroad. The group had global reach, as it conducted attacks in Europe, the United States, North Africa, Central and South Asia, and in Southeast Asia. Some of the attacks involved fighters who had received direct training in Syria or Iraq and returned home, but other terrorists simply were inspired by the Islamic State's example and followed al-Adnani's exhortation to attack with a rock, knife, or car. ${ }^{82}$

Critically, the Islamic State emerged as the world's leading jihadi brand, which allowed it to attract fighters with a jihadi disposition but not a distinct position on the ideological and political divisions between al-Qaida and the Islamic State.

By mid-2017, the Islamic State was in serious decline. After a brutal siege, the Iraqi army retook Mosul, and Raqqa fell to U.S.-backed fighters. The number of foreign fighters entering Syria dropped precipitously, and many of the group's leaders were killed, including Abu Muhammad al-Adnani. The Islamic State was a shadow of its former self, but it would still fight on.

On October 26, 2019, the Islamic State faced another significant loss. Its longtime leader, Abu Bakr al-Baghdadi, was killed after he detonated a suicide vest during a U.S. Special Operations Forces military operation in Syria's Idlib Province. ${ }^{83}$

\section{Conclusion}

The decline of the Islamic State after its zenith in 2014 is reminiscent of the setbacks it faced in 2006 and 2007. Now, as then, the Islamic State faces tremendous military pressure in the areas it controls or once controlled, and it simply does not have the military capability to resist those forces conventionally.

Yet the imbalance today is not nearly as lopsided as it was in 2007 when 150,000 U.S. troops were concentrated against the ISI in Iraq. Indeed, the Islamic State today operates on an entirely different scale than the ISI did then. American commanders have suggested that the Islamic State has fighters measured in the low thousands, which is comparable to its reported numbers in early 2011. Today's Islamic State, however, also has a much broader set of affiliate organizations around the world and has many times more alumni who have fought in core combat zones and then drifted home or to other locations.

As the Islamic State suffers further military setbacks in Iraq and Syria, it is likely to adopt an operational approach similar to the ISI between 2008-2011. The group will probably shift to underground terrorist networks rather than an overt conventional force; focus on iterative large-scale terrorist attacks; and work to undermine the various forces arrayed against it via assassinations, bribery, and threats. The group will maintain a robust communications wing to sustain the commitment of true believers around the globe, and it will encourage supporters globally to continue to conduct terrorist attacks against civilian targets in Western countries.

This operational model is likely to be resilient for the Islamic State. Neither the Iraqi or Syrian government is well positioned to assert strong authority over their territories, which means that Islamic State cells will remain active. Indeed, Islamic State affiliates further afield will remain functional, as uprisings by supporters in Libya, Afghanistan, and the Philippines attest. None of these groups are likely to assert broad territorial control in the near term, but they represent a disruptive spoiler force in many places and a distinct terrorist threat.

The Islamic State's greatest advantages are the fractures among the coalition arrayed against it. In Iraq, Sunni tribal groups have once again rejected the Islamic State, but they are not necessarily supporters of the government in Baghdad or the Iranian-backed militias that support it. In Syria, the Russian-backed government, Western-backed rebels, and the Turkish government have all fought the Islamic State, but they eye each other warily. Governments around the Middle East agree that the Islamic State is a threat, 
but they continue their traditional geopolitical rivalries that threaten to distract from their focus against the group. Western governments are dedicated to defeating the Islamic State as well but are loath to maintain longstanding, semi-permanent military operations in the Middle East.

Nevertheless, the group is still a dangerous terrorist organization, and it will continue to threaten regimes in the Middle East and people all over the globe. It is hard to imagine that world leaders could ever underestimate the Islamic State after the tremendous damage it has done, but inattention helped the group rebuild underground after its setbacks in 2007. The Islamic State is a shadow of its former self, but it will wait, prepare, and hope for another political opportunity to emerge more forcefully again. The odds are against the Islamic State reasserting itself as a major territorial force, but there are no guarantees. After all, it has managed just such a resurrection act before.

\section{Notes}

1 Graeme Wood, "What ISIS Really Wants," The Atlantic, March 2015, www.theatlantic.com/magazine/ archive/2015/03/what-isis-really-wants/384980/.

2 Mary Anne Weaver, “The Short, Violent Life of Abu Musab al-Zarqawi," The Atlantic, June 8, 2006, www.theatlantic.com/magazine/archive/2006/07/the-short-violent-life-of-abu-musab-al-zarqawi/304983/; "Key Events in the Life of al-Zarqawi," New York Times, June 8, 2006, www.nytimes.com/2006/06/08/world/08timeline-zarqawi. html.

3 Ibid.

4 Ibid.

5 Joby Warrick, The Black Flags: The Rise of ISIS (New York: Doubleday, 2015).

6 Brian Fishman, The Master Plan: ISIS al-Qaeda and the Jihadi Strategy for Final Victory (New York: Yale University Press, 2016).

7 “Iraq: A Timeline of Abu Mus'ab al-Zarqawi," RFE/RL, June 9, 2006, www.rferl.org/a/1069045.html.

8 Weaver, "The Short, Violent Life of Abu Musab al-Zarqawi."

9 Ibid.

10 Ibid.

11 Fu'ad Husayn, “Al-Zarqawi: The Second Generation of al-Qa'ida,” al-Quds al-Arabi, May 13, 2005.

12 Warrick, The Black Flags.

13 Umar Abd al-Hakim (Abu Musab al-Suri), “The Global Islamic Resistance Call. Part I: The Roots, History, and Experiences," and "Part II: The Call, Program and Method," location and publisher unknown, December 2004.

14 Steven Brooke, "Strategic Fissures: The Near and Far Enemy Debate," in Self-Inflicted Wounds: Debates and Divisions within al-Qa'ida and its Periphery, ed. Assaf Moghadam and Brian Fishman (West Point: Combating Terrorism Center, 2010).

15 Ibid.

16 Ibid.

17 Ibid.

18 Daniel L. Byman and Jennifer R. Williams, ISIS vs. Al Qaeda: Jihadism's Global Civil War (Washington, DC: Brookings, 2015).

19 Mustafa Hamid and Leah Farrall, The Arabs at War in Afghanistan (London: Hurst Publishers, 2015$), 183$.

20 Byman and Williams, ISIS vs. Al Qaeda.

21 Hamid and Farrall, The Arabs at War in Afghanistan.

22 Muhammad al-Turayri, "Saudi al-Qaeda Member Relays His Experience of the 9/11 Attacks Alongside Bin Laden," al-Hayah, September 20, 2006.

23 Weaver, "The Short, Violent Life of Abu Musab al-Zarqawi."

24 Ibid.

25 Jeffrey Gettleman, “Zarqawi’s Journey: From Dropout to Prisoner to an Insurgent Leader in Iraq," New York Times, July 13, 2004, www.nytimes.com/2004/07/13/world/reach-war-profile-terror-zarqawi-s-journey-dropout-prisoner-insurgent-leader.html.

26 Karl Vick and Daniel Williams, “U.S. Strikes Alleged Al Qaeda Allies,” Washington Post, March 22, 2003 , www. washingtonpost.com/archive/politics/2003/03/22/us-strikes-alleged-al-qaeda-allies/5a2661d1-9b1a-4417-931ed9b0fc12c59e/.

27 Ibid.

28 Scheherezade Faramarzi, Iran's Salafi Jihadis (Washington, DC: Atlantic Council, 2018). 


\section{The history of the Islamic State}

29 Joby Warrick, “ISIS, With Gains in Iraq, Closes in on Founder Zarqawi’s Violent Vision,” Washington Post, June 14, 2014, www.washingtonpost.com/world/national-security/isiss-gains-in-iraq-fulfill-founders-violent-vision/2014 /06/14/921ff6d2-f3b5-11e3-914c-1fbd0614e2d4_story.html.

30 Samuel Helfont, Compulsion in Religion: Saddam Hussein, Islam, and the Roots of Insurgencies in Iraq (New York: Oxford University Press, 2018).

31 Amatzia Baram, Saddam Husayn and Islam, 1968-2003 (Washington, DC: Johns Hopkins University Press, 2014).

32 Dexter Filkins, "At Least 11 Die in Car Bombing at Jordan's Embassy in Baghdad," New York Times, August 7, 2003, www.nytimes.com/2003/08/07/international/worldspecial/at-least-11-die-in-car-bombing-at-jordans-embassy. html.

33 Dexter Filkins and Richard A. Oppel, Jr., “Top Aid Official Are Among 17 Killed,” New York Times, August 19, 2003, www.nytimes.com/2003/08/19/international/worldspecial/top-aid-officials-are-among-17-killed.html.

34 Bruce Riedel, Al Qaeda Strikes Back (Washington, DC: Brookings, 2010).

35 Vahid Brown, Cracks in the Foundation: Leadership Schisms in Al-Qa ida From 1989-2006 (West Point: Combating Terrorism Center, 2007).

36 Margaret Warner, “Marines Say New Fight for Fallujah Sparks Anguish Over Iraq War,” PBS News Hour, June 3, 2016, www.pbs.org/newshour/world/column-marines-say-latest-fight-for-fallujah-reignites-anguish-over-iraq-war.

37 Dexter Filkins, "Wanted Rebel Vows Loyalty to Bin Laden, Web Sites Say," New York Times, October 18, 2004, www.nytimes.com/2004/10/18/world/middleeast/wanted-rebel-vows-loyalty-to-bin-laden-web-sites-say.html.

38 "Letter from Tawhid w'al Jihad (Zarqawi Bayah)," Mu'askar al-Battar, October 17, 2004.

39 Dexter Filkins, "Iraq Videotape Shows the Decapitation of an American," New York Times, May 12, 2004, www. nytimes.com/2004/05/12/international/middleeast/iraq-videotape-shows-the-decapitation-of-an.html.

40 Fishman, The Master Plan.

41 “ISIS Rebels Declare 'Islamic State' in Iraq and Syria,” BBC, June 30, 2014, www.bbc.com/news/av/worldmiddle-east-28091637.

42 In July 2005, al-Qaida's second-in-command at the time, Ayman al-Zawahiri, wrote al-Zarqawi urging him to tone down the level of violence. "More than half of this battle is taking place in the battlefield of the media," al-Zawahiri wrote, urging al-Zarqawi to at least stop publicizing globally the atrocities he was committing in Iraq. For more, see "Zawahiri Letter to Zarqawi," July 9, 2005, https://fas.org/irp/news/2005/10/letter_in_english.pdf.

43 "Hotel Blasts Kill Dozens in Jordan," CNN, November 10, 2005, www.cnn.com/2005/WORLD/meast/11/09/ jordan.blasts/.

44 "Atiyah's Letter to Zarqawi," Combating Terrorism Center, no date, accessed November 15, 2020, https://ctc.usma. edu/harmony-program/atiyahs-letter-to-zarqawi-original-language-2/.

45 Brian Fishman, "The Man Who Could Have Stopped the Islamic State," Foreign Policy, November $23,2016$.

46 Ibid.

47 Robert F. Worth, "Blast Destroys Shrine in Iraq, Setting Off Sectarian Fury," New York Times, February 22, 2006, www.nytimes.com/2006/02/22/international/middleeast/blast-destroys-shrine-in-iraq-setting-off-sectarian.html.

48 Sean Naylor, Relentless Strike: The Secret History of Joint Special Operations Command (New York: St. Martin's Press, 2016), 279-289.

49 Ibid.

50 Fishman, "The Man Who Could Have Stopped the Islamic State."

51 Uthman bin Abd al-Rahman al-Tamimi, "Informing the People About the Islamic State of Iraq," Islamic State of Iraq Ministry of Sharia, 2007.

52 Haroro J. Ingram and Craig Whiteside, "Caliph Abu Unknown: Succession and Legitimacy in the Islamic State," War on the Rocks, November 25, 2019, https://warontherocks.com/2019/11/caliph-abu-unknown-successionand-legitimacy-in-the-islamic-state/.

53 Ibid.

54 Bill Roggio, Daveed Gartenstein-Ross, and Tony Badran, "Intercepted Letters Shed Light on State of Network in Iraq," Foundation for Defense of Democracies, September 12, 2008.

55 Dean Yates, "Senior al-Qaeda Figure in Iraq a Myth: U.S. Military," Reuters, July 18, 2007, www.reuters.com/ article/us-iraq-qaeda/senior-qaeda-figure-in-iraq-a-myth-u-s-military-idUSL1820065720070718.

56 "Al Qaeda Claims 12,000 Iraq Fighters," CBS, November 10, 2006, www.cbsnews.com/news/al-qaeda-claims12000-iraq-fighters/.

57 Jim Garamone, "Bombings Bear Signs of al-Qa'ida in Iraq, General Says," American Forces Press Service, August 15, 2011.

58 Brian Fishman, Redefining the Islamic State: The Fall and Rise of al-Qa'ida in Iraq (Washington, DC: New America, 2011).

59 William McCants, The Believer (Washington, DC: Brookings, 2015). 


\section{Brian Fishman}

60 Fishman, The Master Plan, 150-152.

61 "The Life and Death of Abu Bakr al Baghdadi," Wilson Center, October 28, 2019, www.wilsoncenter.org/article/ timeline-the-life-and-death-abu-bakr-al-baghdadi.

62 Brian Fishman, Redefining the Islamic State.

63 "Interview with Abu Ubaydah Abd al-Hakim al-Iraqi," Jihadist Media Elite and al-Furqan Media Establishment, April 11, 2011.

64 Rania Abouzeid, “The Jihad Next Door,” Politico, June 23, 2014, www.politico.com/magazine/story/2014/06/ al-qaeda-iraq-syria-108214.

65 "Announcing Jabhat al-Nusrah for the People of the Levant," al-Manarah al-Bayda Media Establishment, January 23, 2012.

66 The purpose of these prisoner releases is disputed. Some argue they were purely designed to strengthen extremist elements of the rebellion, but the first prisoner releases occurred even before violence had broken out writ large and were likely ill-advised attempts to placate the early revolutionary movement.

67 Jonathan Landay and Hannah Allam, "U.S. Might Name Syrian Rebel Nusra Front a Foreign Terrorist Group," McClatchy Newspapers, December 4, 2012, www.mcclatchydc.com/news/nation-world/world/article24741223. html.

68 Al-Sham generally refers to "Greater Syria," or the Levant. For the ISI's statement, see Abu Bakr al-Baghdadi, "Declaring the Establishment of the Islamic State of Iraq and al-Sham," al-Furqan Media Establishment, April 9, 2013.

69 Charles Lister, Profiling Jabhat al-Nusra (Washington, DC: Brookings, 2016), 5-13.

70 Ibid.

71 Ibid.

72 “The Rise, Spread, and Fall of the Islamic State," Wilson Center, October 28, 2019, www.wilsoncenter.org/article/ timeline-the-rise-spread-and-fall-the-islamic-state.

73 "Audio Interview with Abu Hamzah al-Muhajir, Minister of War of the Islamic State of Iraq," al-Furqan Media Establishment, October 24, 2008.

74 "Brussels Jewish Museum Murders: Mehdi Nemmouche Guilty," BBC, March 7, 2019, www.bbc.com/news/ world-europe-47490332.

75 Ned Parker, Isabel Coles, and Raheem Salman, "How Mosul Fell," Reuters, October 14, 2014, www.reuters. com/article/us-mideast-crisis-gharawi-special-report/special-report-how-mosul-fell-an-iraqi-general-disputesbaghdads-story-idUSKCNOI30Z820141014.

76 Sylvia Westall, “AfterIraq Gains, Qaeda OffshootClaims Islamic 'Caliphate,'”Reuters, June 29, 2014, www.reuters.com/ article/us-syria-crisis-iraq/after-iraq-gains-qaeda-offshoot-claims-islamic-caliphate-idUSKBNOF40SL20140630.

77 Hannah Stranger, "Islamic State Leader Abu Bakr al-Baghdadi Addresses Muslims in Mosul," Telegraph, July 5, 2014, www.telegraph.co.uk/news/worldnews/middleeast/iraq/10948480/Islamic-State-leader-Abu-Bakr-al-Baghdadiaddresses-Muslims-in-Mosul.html.

78 For more on the Islamic State's apocalyptic vision, see William McCants, The ISIS Apocalypse (New York: St. Martin's Press, 2015). For criticism of the notion that the Islamic State's apocalyptic vision drove its original declaration of an Islamic state in 2006, see Fishman, The Master Plan.

79 Abu Muhammad al-Adnani, "Indeed Your Lord Is Ever Watchful," al-Furqan Media Establishment, September 22, 2014.

80 Jean-Charles Brisard and Kevin Jackson, “The Islamic State's Eternal Operations and the French-Belgian Nexus," CTC Sentinel 9, no. 11 (2016): 8-15.

81 Jason Hanna et al., "ISIS Publishes Photo of What It Says Is Bomb That Downed Russian Plane," CNN, November 19, 2015, www.cnn.com/2015/11/18/middleeast/metrojet-crash-dabiq-claim/index.html; "Paris Attacks: What Happened on the Night," BBC, December 9, 2015, www.bbc.com/news/world-europe-34818994.

82 Yara Bayoumy, “ISIS Urges More Attacks on Western 'Disbelievers'," Independent, September 23, 2014, www. independent.co.uk/news/world/middle-east/isis-urges-more-attacks-western-disbelievers-9749512.html.

83 Joby Warrick, “Abu Bakr al-Baghdadi, Extremist Leader of Islamic State, Dies at 48," Washington Post, October 27, 2019, www.washingtonpost.com/local/obituaries/abu-bakr-al-baghdadi-islamic-states-terrorist-in-chief-dies-at48/2019/10/27/0d004abc-663d-11e7-8eb5-cbccc2e7bfbf_story.html. 


\title{
5 \\ CONTEMPORARY CONFLICT AND POLITICAL VIOLENCE IN THE LEVANT
}

\author{
Benedetta Berti
}

In its contemporary use, the term "Levant" commonly refers to the eastern Mediterranean countries of Israel, Jordan, Lebanon, Syria, Palestine, ${ }^{1}$ and, in some accounts, Iraq (see Figure 5.1). Its territory rests at the center of the Middle East, itself characterized by great geostrategic importance due to its natural resources - chiefly oil and natural gas - and its location at the crossroads between Africa, Europe, and Asia, which contributes to its political and military significance.

In the post-World War I period, European colonial powers drew the national borders of the countries that make up the Levant. This externally driven state-building process contributed to the rise of unstable and fragile countries and, in some cases, conflict and violence.

This chapter offers a brief introduction to an especially complex and diverse region of the world. It briefly assesses the Levant's historical, geographic, and political significance while also providing a concise political overview of the main countries that make up this part of the Middle East. The chapter then examines the contemporary history of political violence in the region, specifically the ArabIsraeli conflict and the impact of internal violence and civil wars. In accounting for the region's conflict dynamics, the chapter emphasizes the role played by non-state armed groups, focusing specifically on the development of Hamas and Hezbollah, two of the most prominent armed political movements active in the Levant.

\section{Framing the Levant}

The Levant holds a rich historical legacy. Mesopotamia — the lands between the Tigris and Euphrates rivers-is an integral part of the Fertile Crescent and is often referred to as the cradle of civilization. ${ }^{2}$ From the establishment of the world's first cities to the development of written legal codes and early systems of governance, the early history of mankind is intrinsically linked to the Levant. ${ }^{3}$ Just as importantly, the birth and development of both Judaism and Christianity occurred along the southern shores of the Eastern Mediterranean, while the Levant was later central to the evolution and growth of Islam and early Islamic civilization. ${ }^{4}$

The Levant is home to approximately 80 million people-with Iraq and Syria being the two most populous states. ${ }^{5}$ An important demographic characteristic is the high percentage of young people. Approximately $53 \%$ of the population is 24 years or younger, a trend commonly referred to as the "youth bulge." ${ }^{6}$ 


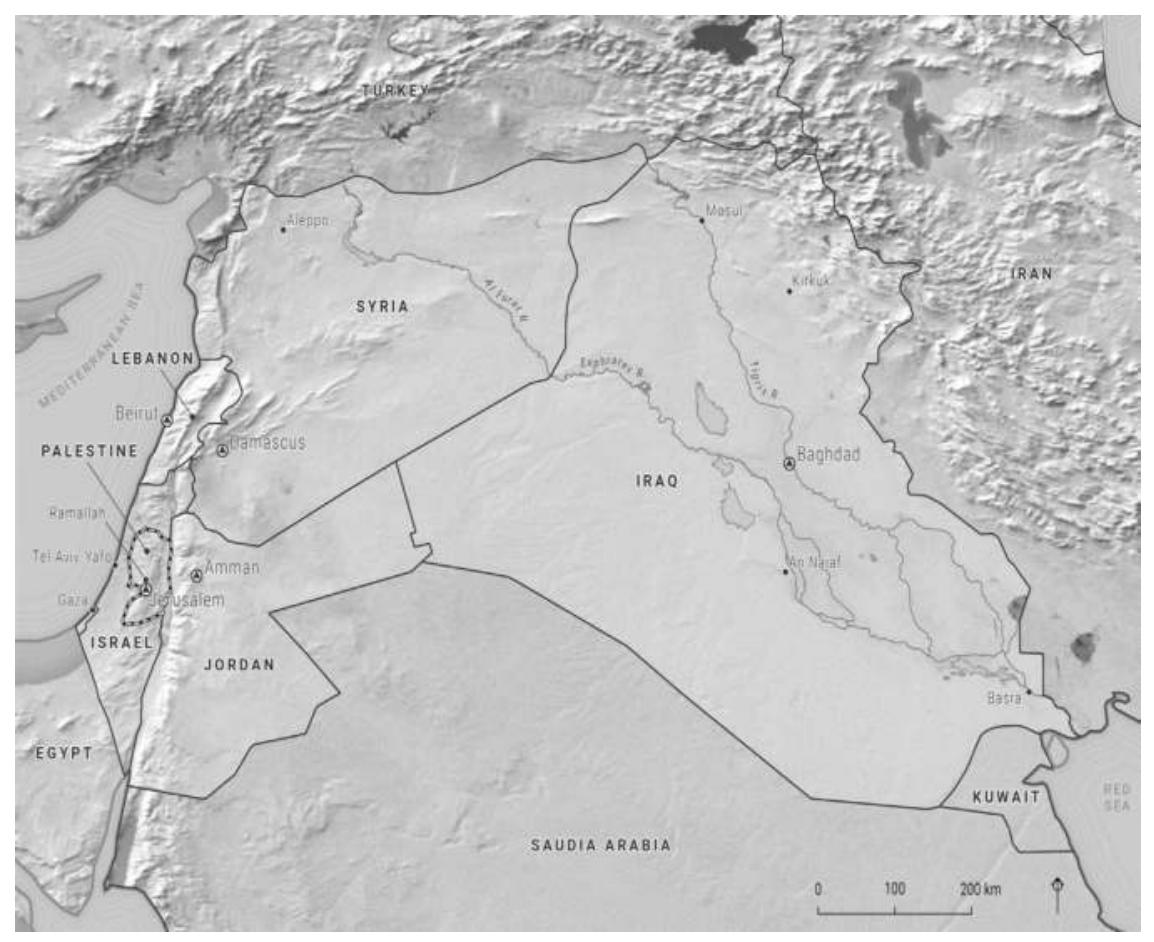

Figure 5.1 Countries constituting the Levant

The Levant is diverse religiously, linguistically, and ethnically. The majority of the population is Sunni Muslim, and Sunni Islam has deeply shaped the region both historically and culturally. There are, however, important exceptions. Approximately $60-65 \%$ of Iraq is Shia Muslim, while roughly three quarters of the population in Israel is Jewish.?

Sizeable religious minorities and Islamic sub-sects have historically been present in the Levant, including Druze communities across Israel, Lebanon, and Syria; Alawites in Syria; and Christian minorities in all the countries of the region. The majority of the population is Arab, and the largest non-Arab populations are Jews in Israel and Kurds between Syria and Iraq (as well as in Iran and Turkey). ${ }^{8}$

Lebanon is itself characterized by great diversity - recognizing 18 different religious, ethnic, and sectarian groups - but it is dominated by three main confessional groups: Maronite Christians, Sunni Muslims, and Shia Muslims. ${ }^{9}$

\section{State formation and development in the Levant (1916-1948)}

External nation-states - and especially the European colonial powers- had an inordinate impact in shaping the current political order in the Levant. Although the role and influence of Western powers dates further back to the 19th century, the current state-based order came into existence in the post-World War I period on the ashes of the Ottoman Empire.

The Ottomans, from their seat in Istanbul, had ruled over the lands of the modern-day Levant for more than 400 years, eventually establishing a flexible system of local administration. The Ottomans not only often preserved local customs and power structures, but they granted a level of autonomy to different religious communities in the region. ${ }^{10}$ 
The Levant's political landscape changed dramatically after the Ottoman Empire's fateful decision to side with Germany and Austria in World War I. The Ottomans' military defeat in the war worsened its decline and precipitated its final collapse. On the ruins of the once glorious empire, victorious European powers - specifically, France and the United Kingdom-established spheres of control over the Levant and in the process began to draw borders and establish new states.

The foreign powers' geostrategic interests largely shaped this externally imposed process. Accordingly, policies such as including local actors in decision-making, or establishing strong and legitimate states, were low on the European powers' list of priorities for the region. The Sykes-Picot Agreement, authored in 1916 by British official Mark Sykes and his French counterpart Francois Georges-Picot, was central to the formation of the modern-day Middle East. In this document, the two diplomats essentially distributed the Levant between France and the United Kingdom. ${ }^{11}$

The Sykes-Picot Agreement, with some amendments, served as the basis for the post-World War I distribution of power expressed through the League of Nations' mandate system. Former Ottoman lands were divided into mandates and distributed between France, which was assigned the lands corresponding to present-day Syria and Lebanon, and the United Kingdom, which was allocated the mandates of Iraq and Palestine $^{12}$ (later divided into two areas, Palestine and Transjordan). ${ }^{13}$ The mandate concept stipulated that each territory would be ruled on an interim basis with a commitment by the mandatory power to "guide" those states toward their own independence.

\section{Lebanon and Syria}

France shaped the formation of Lebanon and Syria, including their border demarcations. France's desire to recognize the Maronite Christian minority's claims to statehood led to the rise of the Lebanese state. ${ }^{14}$ To fulfill those aspirations and to make the new Christian protectorate viable and independent, the French administration expanded the territory of this proto-state beyond the Christian-dominated Mount Lebanon area, incorporating coastal areas from Tyre to Sidon, Beirut, Tripoli, and the Bekaa Valley. ${ }^{15}$

Present-day Lebanon thus emerged in the 1920s as "Greater Lebanon," changing its name in 1926 to the Lebanese Republic and finally obtaining independence from France in $1943 .{ }^{16}$ Yet with the expansion beyond Mount Lebanon, the new state effectively abandoned the possibility of becoming a Christianmajority country and emerged as a multi-confessional state, dominated by three main sectarian groups: Maronite Christians, Sunni Muslims, and Shia Muslims.

Lebanon's political system developed around this dynamic, regulating the polity on the basis of the principle of power-sharing between the country's distinct communities and establishing Lebanon's unique sectarian system, which allocates a fixed quota of high political posts and parliament seats to each confessional group according to their estimated size. Since then, Lebanon has over time repeatedly struggled to find a stable resolution to its sectarian divisions, a normalization of its inter-community relations, and a formula to ensure cohesive and strong central political institutions.

France also oversaw the administration of Syria, although it faced significant local resistance. It tinkered considerably with the political system, experimenting with the notion of a federation and with the idea of maintaining separate statelets for Syria's main ethnic-religious minorities, such as the Druze and Alawite communities. ${ }^{17}$ Eventually, however, a centralized Syrian state emerged and gained full independence in 1946.

The end of the French mandate in Syria did not spell the end of Syria's troubles. In subsequent years, Syria faced extreme internal instability and volatility, marked by a series of internal conflicts, coups, and counter-coups. After a brief and largely failed experiment to form a political union with Egypt in 1958, Syria's path toward "authoritarian consolidation" began in the early 1960s with the rise to power of a group of military officers hailing from a current of the secular-nationalist Baath Party. This process eventually led 
to the ascent of Alawite military officer Hafez al-Assad, along with that of an Alawite military-political elite, leading to a period of stable yet deeply authoritarian rule. ${ }^{18}$

During his years in power as the president of the Syrian Arab Republic from 1971 until his death in 2000, Hafez al-Assad relied on a combination of repression and co-optation to ensure his permanence in power, maintaining a strong grip on all government institutions and on Syria's highly coercive security apparatus. ${ }^{19}$ After his death, the presidency passed to his son Bashar al-Assad, who ruled largely uncontested until the beginning of the Syrian revolution in 2011 - a watershed event that challenged the regime and precipitated the country's descent into a protracted and bloody civil war.

\section{Iraq, Jordan, Israel, and Palestine}

The other mandatory power, the United Kingdom, became just as involved in the process of state formation, resulting in the creation of Iraq, Jordan, Israel, and the non-establishment of a Palestinian state.

Iraq emerged out of the three Ottoman provinces of Basra, Baghdad, and Mosul, which Britain consolidated into one multi-ethnic and multi-sectarian state characterized by an Arab-Shia majority and two sizable Arab-Sunni and Kurdish (largely Sunni) minorities. ${ }^{20}$ After becoming the mandatory power in 1920, the British backed the ascent of the Hashemite dynasty under King Faisal to ensure influence over this complex territory even after Iraq obtained independence in 1932.

The Hashemite family's rise to power in Iraq was itself a byproduct of Britain's regional power games. Hailing from the Arabian Peninsula and acting as sharif (custodians to the holy cities of Mecca and Medina), the Hashemites had allied with Britain against the Ottoman Empire, leading to what came to be known as the Arab Revolt of 1916-1918. ${ }^{21}$ The British-Hashemite alliance had been forged based on the expectation that the United Kingdom would support Emir Husayn ibn Ali's political plans to establish a united Arab state to rule the Arab provinces of the Ottoman Empire, from Palestine to Iraq and from the Mediterranean Sea to the Arab/Persian Gulf. ${ }^{22}$

British support, however, was short lived. The Hashemites only succeeded in ruling over a portion of their desired lands. They briefly took control of Damascus before France, backed by Britain, evicted them in $1920 .{ }^{23}$ In the following years, the Hashemites not only saw their hopes for a united Arab state fade away, but they also eventually lost the struggle for control of the Arabian Peninsula to the al-Saud family, which would later consolidate its power and give rise to modern-day Saudi Arabia where they continue to rule today. In this context, Iraq became a consolation prize awarded to the Hashemite family despite their lack of strong local roots or support.

The Hashemite family's reign in Iraq would last until 1958. To rule over what was essentially an unfamiliar country, the monarchy entrenched a system of governance that strongly relied on the Sunni minority to control the key political and military posts, largely marginalizing other parts of Iraqi society. A military coup in 1958 eventually overthrew the Hashemites, precipitating a decade of instability.

This lasted until 1968, when the Baath Party rose to power under the leadership of Ahmad Hasan alBakr and Saddam Hussein. ${ }^{24}$ Much like the case of Syria, during the following decade, Saddam Hussein emerged as a strong, secular, nationalist, socialist, and deeply despotic ruler. He eventually assumed control of the presidency and ruled Iraq between 1979 and 2003, until his regime was brought down following the U.S.-led invasion of the country.

On the other side of the Levant, the British role was just as central in the birth of the modern-day states of Jordan and Israel, as well as in shaping the beginning of what would later be known as the Arab-Israeli conflict (or the Israeli-Palestinian conflict).

As the mandatory power, Britain separated the Palestine territory into two separate areas-Palestine and Transjordan - with the latter encompassing the lands on the eastern banks of the Jordan River. This 
territory, oddly and artificially shaped between Israel-Palestine, Syria, Iraq, and Saudi Arabia, was to be ruled first as the Emirate of Transjordan and then, after 1946, as the Hashemite Kingdom of Jordan — serving essentially as an additional compensation prize, in addition to Iraq. ${ }^{25}$

During the next three decades, King Abdallah I of the Hashemite dynasty consolidated the crown's power over the new kingdom by building strong relationships with prominent tribal families and with key power-brokers hailing from the East Bank of the Jordan River. ${ }^{26}$ Thus, while the monarchy in Iraq did not stand the test of time, its counterpart in Jordan thrived, with the crown still in power today.

The Kingdom of Jordan extended its borders following the 1948 war against the newly formed state of Israel, with Jordan gaining control over the areas of Palestine known as the West Bank, stretching to East Jerusalem. As a result, Jordan altered its demography and became a country of both "east-banker" Jordanians and "west-banker" Palestinians, with separate political and national identities. ${ }^{27}$ Even though Jordanian control over the West Bank ended in 1967, the country's social basis was forever transformed.

In addition to establishing Transjordan, Britain's role would be consequential in shaping the future of mandatory Palestine. The Sykes-Picot Agreement of 1916 had already recognized the interests of the United Kingdom over the lands corresponding to present-day Israel and Palestine. British policy in mandatory Palestine took shape in those years.

On the one hand, the United Kingdom developed a favorable attitude toward the possibility of seeing a Jewish settlement and the development of a "national home" for the Jewish people in Palestine, influenced by advocacy from the emerging Zionist movement in Europe. This policy was expressed in the famous 1917 Balfour Declaration. ${ }^{28}$

On the other hand, as the direct ruler in mandatory Palestine, Britain also had an interest in preventing mass-based unrest and conflict in the areas under its control. Britain soon discovered that finding a balance between these two interests was not simple, as supporting the Zionist movement in Palestine produced consistent local opposition from the Arab majority on the ground, resulting in unrest, protests, and tensions. ${ }^{29}$

During the 1920s and 1930s, a series of local rebellions put the "Palestine question" high on the British foreign policy agenda. Britain initially took distinct options into consideration during the 1930s, including the idea of partitioning the land to solve the struggle between the Jewish and Arab national movements. Yet by 1939 , the country opted to restrict Jewish immigration and appeared to move toward placing the idea of a Jewish State on indefinite hold. ${ }^{30}$

These policy changes did not, however, produce a more stable situation for the mandatory power. Instead, they led to active armed struggle by Zionist non-statutory armed groups against the British presence in mandatory Palestine. These groups employed a strategy based on sabotage, guerrilla warfare, and, in some cases, terrorism.

The operational tempo of anti-British operations further escalated in the immediate aftermath of World War II, along with the unrest between Arab and Jewish communities on the ground, contributing to the mandatory power's decision to refer the "Palestine question" to the newly formed United Nations. With the notion of a Jewish State gaining fresh momentum after the end of the war, the United Nations endorsed the idea of the partition of mandatory Palestine, a decision also shaped by the tragedy of the Holocaust.

This process eventually led to the end of British rule over Palestine and to the United Nations General Assembly's adoption of Resolution 181 in November 1947, recommending a partition plan that would establish both a Jewish and Arab state in mandatory Palestine. ${ }^{31}$ While leaders of the Zionist movement and the Jewish communities in Palestine cheered the decision, it triggered widespread protests within the Arab population, as well as vehement rejection from the established Arab states in the region-precipitating the 1948 Arab-Israeli War. ${ }^{32}$ 


\section{Contemporary political violence in the Levant before the Arab Spring}

The process of state formation in the Levant is intrinsically related to foreign intervention, violence, and conflict. This legacy continued to shape political dynamics in the region long after the colonial powers' direct control waned and the states emerged as independent countries.

For example, the post-independence process of authoritarian consolidation in both Syria and Iraq between the 1950s and 1960s was fraught with internal violence, coups, and uprisings. Under Saddam Hussein in Iraq, the country went to war twice, first against the newly established Islamic Republic of Iran between 1980 and 1988 and then again in the 1990-1991 Gulf War. The Gulf War led to Saddam Hussein's defeat and to more than a decade of international sanctions placed on the Iraqi regime. ${ }^{33}$ Elsewhere in the Levant, Lebanon's fragile sectarian system would produce two civil wars in 1958 and between 1975 and 1989.

At the same time, the other dynamic that helps explain the past decades of political violence and war in the Levant-both conventional/inter-state and non-conventional/intra-state violence-is the Arab-Israeli conflict.

Israel's contested independence inaugurated two-plus decades of regional conventional wars between the state of Israel and its Levantine as well as Middle Eastern neighbors. Following the adoption of Resolution 181 that partitioned Palestine into Arab and Jewish states, armed confrontation ensued between the Arab and Jewish populations in mandatory Palestine. These clashes became a fully fledged regional war following Israel's proclamation of independence in May 1948, leading military units from Egypt, Transjordan, Lebanon, Syria, and Iraq to invade the newly born state under the umbrella of the Arab League. ${ }^{34}$

The war concluded with a series of armistices in 1949, leaving the situation on the ground profoundly altered: Israel managed to withstand the attacks and expand its territory, Transjordan advanced to take control of the West Bank of mandatory Palestine and parts of Jerusalem (including its old city), and Egypt gained the region of mandatory Palestine known as the Gaza Strip. ${ }^{35}$ Israel viewed the 1948 war as a victorious fight for independence, whereas the Palestinian population saw it as their nakba (catastrophe), depriving them of an independent state and making many of them stateless and refugees within the Levant. ${ }^{36}$

After 1949, the conflict between Israel and its neighbors was never fully resolved. Open hostilities resurfaced in the 1956 Suez Crisis, which pitted Israel against the Egyptian regime of Gamel Abd al-Nasser within the broader context of the Cold War. The regional tensions gradually built until an explosive war in 1967. ${ }^{37}$ The June 1967 war-also known as the Six-Day War-involved another conventional confrontation between Israel and its neighbors. The brief hostilities, ending with a United Nations-brokered cease-fire, led to an overwhelming Israeli victory, with the country taking over the Jordanian-controlled West Bank and Jerusalem, the Egyptian-administered Gaza Strip and Sinai Peninsula, and the Syrian region of the Golan Heights. ${ }^{38}$

These military achievements were yet again challenged in October 1973 when an Egyptian and Syrian surprise attack managed to taint Israel's reputation of military invincibility. Egypt and Syria sought to retake the Sinai Peninsula and the Golan Heights. Yet after early gains, the October War (also known as the Yom Kippur War or the Ramadan War) turned in favor of the Israeli military. When the conflict ended abruptly through a U.S.-USSR-brokered cease-fire agreement, Israel's control of the territories acquired in 1967 was all but unchallenged, while its opponents were deeply on the defensive.

The 1973 war concluded this period of conventional inter-state wars waged in the context of the ArabIsraeli conflict and opened the door to the beginning of a diplomatic process between Egypt and Israel, resulting both in Israel's withdrawal from the Sinai Peninsula as well as a peace treaty between the two states in 1979. 


\section{Irregular warfare, insurgency, and terrorism in the Levant}

Whereas 1948-1973 marked a period of conventional wars linked to the Arab-Israeli conflict, the following decades brought a shift to a series of unconventional confrontations pitting mostly the Israeli state against non-state actors waging war on behalf of the Palestinian people, often using terrorism as a tactic.

This shift resulted from the dramatic political and military defeat inflicted to Arab states and their leaders-who, until then, aspired to represent the Palestinian cause - in the 1967 war. $^{39}$ A new generation of Palestinian political and military leaders also proved instrumental to these changes, especially through the creation of Fatah - under the leadership of Yasser Arafat — and by working to increase the autonomy of the Palestine Liberation Organization (PLO) ${ }^{40}$

The shift began gradually, first with Palestinian armed units - known as fedayeen — undertaking hit-andrun, cross-border operations against Israeli targets, chiefly from Jordan and, to a lesser extent, from Syria and Egypt. ${ }^{41}$ After 1967, an insurgent strategy based on terrorism and guerrilla warfare became the backbone of the Palestinian armed strategy, with the PLO leading a "war of attrition" inspired by the National Liberation Front in Algeria. ${ }^{42}$

In parallel, the PLO began relying on "publicity terrorism" in the international arena, including hijacking civilian airliners or assassinating Israeli officials and civilians abroad. These tactics served the strategy of putting the Palestinians front and center as a global issue and to elevate the status and power of the PLO and its leaders. ${ }^{43}$ Internationally, the strategy was successful, consecrating the rise of Arafat and the PLO as the sole legitimate representative of the Palestinian people, a status endorsed by the Arab League in $1974 .^{44}$

The PLO's unconventional tactics employed against Israel led to internal tensions within the countries from where they operated. Regional governments that harbored Palestinian militants increasingly resented the PLO's autonomy and freedom of action, as well as the Israeli counterattacks against the PLO on their own territory. A dramatic example of this dynamic occurred during the 1970 conflict between Palestinian armed factions and the Jordanian army, known as "Black September." On that occasion, violent clashes between the Jordanian government and the PLO led to the latter's permanent ouster from Jordan. ${ }^{45}$

Lebanon, where the PLO relocated after its expulsion from Jordan, represents another example of the negative impact Palestinian armed operations had on the host country's stability. Indeed, in the 1970s, the double impact of the PLO's armed struggle in southern Lebanon and Israeli counterattacks only contributed to the further militarization and destabilization of Lebanon, eventually contributing to the country's descent into a prolonged civil war between 1975 and 1990. ${ }^{46}$

The Lebanese civil war quickly became a proxy war, with extensive regional and international involvement. Israel, for example, intervened militarily in Lebanon in 1978 and 1982. The 1982 operation, dubbed "Operation Peace for Galilee," went well beyond the objective of eliminating the PLO's presence from southern Lebanon. Israel became involved in Lebanon's civil war and eventually established a "security zone" in southern Lebanon, an area that would be controlled by the Israel Defense Forces (IDF) until its withdrawal in $2000 .{ }^{47}$

By the time the civil war ended in 1989, the PLO had lost its strong operational base, and Lebanon was de facto divided, with the "security zone" under IDF control and the rest of the country under strong Syrian control. After the war, the Syrian government became- under the terms of Lebanon's internationally brokered peace agreement- the official "guarantor" of the peace, a role the country used to consolidate its military and political influence over Lebanon until 2005..$^{48}$

After Lebanon, the map of conflict shifted again. In the following decades (1982-2003), Israel would be simultaneously involved in two major irregular conflicts against Hezbollah in Lebanon and against distinct Palestinian armed factions, eventually led by Hamas, in the West Bank and Gaza. 


\section{Hezbollah}

Hezbollah ("The Party of God") was officially established as an umbrella military group in the early 1980s, largely as a response to the Israeli invasion of Lebanon in 1982. The organization had the initial goal of unifying the anti-IDF military actions of armed Shia factions that had emerged in the midst of the Lebanese civil war and had found common inspiration in the 1979 Iranian Revolution and its ideals. ${ }^{49}$

With active Iranian help, ${ }^{50}$ Hezbollah's military capabilities evolved throughout the civil war, with the group relying chiefly on asymmetric tactics-including car bombings, suicide attacks, and kidnappings of Israelis and other foreigners - to implement a strategy of attrition aimed at driving Israel out of Lebanon by inflicting a high number of casualties, especially through a series of "self-martyrdom," or suicide, attacks. ${ }^{51}$

In parallel, Hezbollah's strategy also sought to expel foreign peacekeeping troops from Lebanon in the early 1980s, which led to a number of high-profile terrorist attacks, including the April 1983 suicide operation against the U.S. Embassy in Beirut and the infamous barracks bombing in October 1983 that killed 241 U.S. service personnel. ${ }^{52}$ Due to these and other operations, Hezbollah has been regarded as the armed group responsible for putting suicide bombing as a tactic on the map, leading to its more widespread adoption by other non-state armed groups in the following years. ${ }^{53}$

After 1989, with the end of the civil war in Lebanon, Hezbollah redefined its identity as Lebanon's self-proclaimed "national resistance," preserving its military apparatus and directing its military campaigns chiefly against the Israeli presence in the Israel-controlled "security zone." Hezbollah's actions triggered recurrent escalations, including the short-lived 1993 and 1996 armed confrontations. ${ }^{54}$ Hezbollah also developed its social and political outreach in the post-civil war period, becoming both an active political party involved in the Lebanese political system as well as a major welfare and social services provider for the Lebanese Shia community at large. The group still maintains these roles today. ${ }^{55}$

Following the Israeli withdrawal from the security zone in 2000, Hezbollah's military strategy began to gradually shift from high mobility to holding ground, creating a complex system of underground tunnels and bunkers and investing in more conventional training. ${ }^{56}$ These changes became especially clear in the July 2006 war with Israel, which revealed that Hezbollah had further transitioned from a non-conventional militia to a hybrid army. ${ }^{57}$

In the July 2006 war, Hezbollah effectively relied on a combination of sub-conventional and conventional tactics, including defending and holding ground, ${ }^{58}$ while also propping up its small guerrilla units with standoff weapons normally associated with conventional military forces. ${ }^{59}$ These trends have only increased since 2006, with the group growing in size, upgrading its arsenal and infrastructure, and improving its war-fighting capabilities. ${ }^{60}$

Since becoming involved in the Syrian civil war on the side of the ruling regime, Hezbollah's role has encompassed direct military support to conduct both offensive as well as defensive operations, including key artillery support to the Syrian army, confirming its hybrid warfare capabilities and its "beyond insurgency" status. ${ }^{61}$

\section{Palestinian armed groups and the rise of Hamas}

In parallel with the Israel-Hezbollah conflict, the other major theater of confrontation in the 1980s-2000s became the West Bank, Gaza, and Israel proper. Palestinian protests against Israel's presence and control over Gaza and the West Bank-territories it took over in the 1967 war-grew and eventually found a collective, political, and organized expression in the first intifada, a cycle of Palestinian popular protests centered on civil resistance, in 1987. ${ }^{22}$ The convergence between the protests in Gaza and the West Bank, and the rising international role acquired throughout the 1970s by the PLO and its chairman Yasser Arafat, prepared the ground for a political process that would take place in the early 1990s between Israel and the PLO. 
Eventually, this political process resulted in a set of agreements between Israel and the PLO commonly referred to as the Oslo Accords. The agreements established a principle of mutual recognition between the parties - with the PLO accepting the principle of a "two state solution" to resolve the Israeli-Palestinian conflict - and were intended to pave the way for a final status agreement. ${ }^{63}$ This process also led to the establishment of the Palestinian Authority as an interim political entity exercising political control over parts of the West Bank and Gaza, allowing the Palestinian political leadership of the PLO and Fatah to return to Palestine from exile. ${ }^{64}$

Hamas emerged out of the backdrop of the first intifada. Hamas, or the Islamic Resistance Movement, was officially founded in 1987-1988 during the outbreak of the first intifada. Its mission was to serve as the armed military wing of the Gaza branch of the Muslim Brotherhood. Even though the group was established with this relatively narrow mandate, Hamas evolved over the following decades into a complex and multifaceted organization, combining a political movement and a party, as well as an armed military wing and an extensive network of social service institutions. ${ }^{65}$

Hamas' status and role evolved further following the group's victory in the 2006 Palestinian Legislative Council elections and the subsequent clashes with Fatah, leading to the Hamas takeover of the Gaza Strip. ${ }^{66}$ Since 2007, Hamas has been in de facto control of Gaza. In previous decades, Hamas, much like Hezbollah, engaged in a series of direct confrontations with Israel, in the process refining its reliance on terrorism, insurgency, and also hybrid or semi-conventional tactics. ${ }^{67}$

From an operational perspective, Hamas transformed from a relatively unsophisticated violent faction perpetrating individual stabbings against Israelis to being able to carry out both large-scale terrorist attacks and rocket strikes against Israel. The group's political and military capabilities developed in the 1990s when Hamas emerged as the main Palestinian group opposing the Oslo Accords and when it relied on suicide bombings as a key element in its strategy of attrition against Israel.

Hamas' status rose further in the early 2000s with the sinking of the political process set forward by the Oslo Accords and the outbreak of the second intifada, characterized by high-profile suicide attacks in the West Bank, Gaza, and Israel. With the winding down of the second intifada and the death of historic Palestinian leader and Palestinian Authority President Yasser Arafat in 2004, Hamas' role increased further, culminating with the group's takeover of Gaza in 2007.

Since then, Hamas has simultaneously ruled Gaza while being involved in cyclical violent confrontations with Israel. In parallel, Hamas' military wing, the Izz ad-Din al-Qassam Brigades, has grown in size and capabilities. Inspired by Hezbollah's operational concept in the 2006 war with Israel, Hamas's military wing developed into a hybrid actor with sophisticated combat skills that rely more on standoff tactics - in combination with ambushes, improvised explosive devices, and suicide missions-while developing defensive tactics, including the limited holding of ground. ${ }^{68}$

\section{Conclusion}

The Arab-Israeli conflict has accounted for a large part of the conventional and unconventional inter-state conflict that has occurred in the Levant in the post-World War II period. At the same time, it is important to note that political violence in the region has by no means only been limited to the Arab-Israeli conflict. Indeed, as illustrated throughout the chapter, internal conflicts have occurred in virtually all the states that make up the Levant.

For example, Lebanon's internal conflicts are largely a byproduct of its complex internal political makeup, difficult inter-community relations, and often inadequate political institutions. Nevertheless, there is no question that strong and repeated foreign interference-including by its southern neighbor, Israel, and by Syria-have substantially contributed to internal instability during the previous decades.

In Syria, armed clashes and internal violence occurred repeatedly before the beginning of the civil war in 2011. Iraq's contemporary history even prior to the overthrow of Saddam Hussein in 2003 had been 
fraught with both internal unrest and violence, as well as clashes with other regional states. Moreover, in authoritarian countries like Iraq and Syria, a great share of political violence has been perpetrated by the state against its own citizens in the form of violent repression and crackdowns on any internal opposition.

The lens of internal instability and fragmentation, along with that of the Arab-Israeli conflict, reveals the dynamics of political violence in the Levant during the previous decades. Both issues are themselves at least partially a byproduct of the problematic and externally driven process of state formation in the region that largely began a century ago.

\section{Notes}

1 The terms "Palestine" and "Palestinian Territories" (or "Palestinian Occupied Territories") will be used interchangeably to designate the territory corresponding to the Gaza Strip and West Bank.

2 Charles K. Maisels, Early Civilizations of the Old World: The Formative Histories of Egypt, the Levant, Mesopotamia, India and China (London: Routledge, 2001).

3 Tareq Y. Ismael and Jacqueline S. Ismael, Government and Politics of the Contemporary Middle East: Continuity and Change (London: Routledge, 2011).

4 William L. Cleveland, A History of the Modern Middle East (Boulder: Westview Press, 2000).

5 United Nations Development Program, Arab Human Development Report (New York: United Nations, 2016). The data concerning Israel is collected through Israel's Central Bureau of Statistics, accessed August 23, 2017, www.cbs. gov.il/reader/cw_usr_view_Folder?ID=141.

6 Department of Economic and Social Affairs, Population Division, World Population Prospects: The 2015 Revision (New York: United Nations, 2015).

7 Central Intelligence Agency, "World Factbook: Middle East," World Factbook, accessed August 23, 2017, www.cia. gov/library/publications/the-world-factbook/wfbExt/region_mde.html.

8 Ibid.

9 Benedetta Berti, The Ongoing Battle for Beirut: The Role of Foreign Powers in Lebanon Between Old Dynamics and New Trends (Tel Aviv: Institute for National Security Studies, 2011), 18.

10 William L. Cleveland and Martin Bunton, A History of the Modern Middle East (Boulder: Westview Press, 2013).

11 Malcolm Yapp, The Making of the Modern Near East 1792-1923 (London: Routledge, 2013).

12 The province of Palestine then included modern-day Israel, Jordan, and the Occupied Palestinian Territories.

13 Yapp, Making of the Modern Near East.

14 Hafeez Malik, "Lebanon as An Experiment in Multicultural Independence," in Lebanon's Second Republic: Prospects for the Twenty First Century, ed. Kail C. Ellis (Gainesville: University Press of Florida, 2002), 14-22.

15 Kamal Salibi, A House of Many Mansions: The History of Lebanon Reconsidered (Berkeley: University of California Press, 1990).

16 Ibid.

17 Philip Khoury, Syria and the French Mandate. The Politics of Arab Nationalism, 1920-1945 (Princeton: Princeton University Press, 1987).

18 Patrick Seale, Asad of Syria: The Struggle for the Middle East (London: I.B. Tauris, 1988).

19 Ahed Al Hendi, "The Structure of Syria's Repression: Will the Army Break With the Regime?" Foreign Affairs, May 3, 2011, www.foreignaffairs.com/articles/middle-east/2011-05-03/structure-syrias-repression.

20 Charles Tripp, A History of Iraq (New York: Cambridge University Press, 2002).

21 Ibid.

22 Mary C. Wilson, King Abdullah, Britain and the Making of Jordan (New York: Cambridge University Press, 1987).

23 Tripp, A History of Iraq.

24 Kanan Makiya, Republic of Fear: The Politics of Modern Iraq (Berkeley: University of California Press, 1998).

25 Philip Robins, A History of Jordan (New York: Cambridge University Press, 2004).

26 Ibid.

27 Ibid.

28 Rashid Khalidi, The Iron Cage: The Story of the Palestinian Struggle for Statehood (Boston: Beacon Press, 2006).

29 Ibid.

30 Baruch Kimmerling and Joel Migdal, The Palestinian People: A History (Cambridge, MA: Harvard University Press, 2003).

31 Ibid.

32 Ibid.

33 Cleveland and Bunton, History of the Modern Middle East. 
34 Ibid.

35 Mehran Kamrava, The Modern Middle East: A Political History Since the First World War, 3rd ed. (Berkeley: University of California Press, 2013).

36 Nur Masalha, The Politics of Denial: Israel and the Palestinian Refugee Problem (London: Pluto Press, 2003); Benny Morris, The Birth of the Palestinian Refugee Problem Revisited (New York: Cambridge University Press, 2004).

37 Malcom Kerr, The Arab Cold War: Gamal 'Abd al-Nasir and His Rivals, 1958-1970 (New York: Oxford University Press, 1971).

38 Michael Oren, Six Days of War: June 1967 and the Making of the Modern Middle East (New York: Oxford University Press, 2002).

39 Sadik Azm, Self-Criticism after the Defeat (London: Saqi Books, 2011).

40 In 1964, the Arab League established the Palestine Liberation Organization as a representative of the Palestinian people. The PLO's role would increase after 1967, especially after Fatah movement leader Yasser Arafat assumed its chairmanship in 1969. Eventually, the Arab League recognized the PLO as the sole representative of the Palestinian people in 1974. For more, see Cleveland and Bunton, History of the Modern Middle East.

41 Yezid Sayigh, Armed Struggle and the Search for State: The Palestinian National Movement, 1949-1993 (New York: Oxford University Press, 1997).

42 Gerard Chaliand and Arnaud Blin, The History of Terrorism From Antiquity to Al Qaeda (Berkeley: University of California Press, 2007).

43 Ibid.

44 Cleveland and Bunton, History of the Modern Middle East.

45 Robins, A History of Jordan.

46 Charles Winslow, Lebanon: War and Politics in a Fragmented Society (London: Routledge, 1996); Berti, The Ongoing Battle for Beirut.

47 Laurie Eisenberg, "History Revisited or Revamped? The Maronite Factors in Israel's 1982 Invasion of Lebanon,” in Conflict, Diplomacy and Society in Israeli-Lebanese Relations, ed. Efraim Karsh, Michael Kerr, and Rory Miller (London: Routledge, 2010), 54-78. The security zone was an area constituting about $10 \%$ of Lebanon's territory that after 1982 had been under the military control of the IDF, with the assistance of the Southern Lebanese Army, a Christian militia that acted as an Israeli proxy in the occupied areas. See Augustus Richard Norton and Jillian Schwedler, “(In)security Zones in South Lebanon,” Journal of Palestine Studies 23, no. 1 (1993): 61-79.

48 The Taif Agreement was signed on October 22, 1989, and ratified on November 4, 1989.

49 Naim Qassem, Hizbullah: The Story From Within (London: Saqi, 2005).

50 Augustus Richard Norton, "Changing Actors and Leadership Among the Shiites of Lebanon," Annals of the American Academy of Political and Social Science 482, no. 1 (1985): 109-121.

51 Ahmad Nizar Hamzeh, In the Path of Hizbullah (Syracuse: Syracuse University Press, 2004).

52 Martin Kramer, "Hizbullah: The Calculus of Jihad," Bulletin of the American Academy of Arts and Sciences 47, no. 8 (1994): 20-43; Augustus R. Norton, Hezbollah (Princeton: Princeton University Press, 2007).

53 Michael Horowitz, The Diffusion of Military Power: Causes and Consequences for International Politics (Princeton: Princeton University Press, 2010), 174-176.

54 Benedetta Berti, Armed Political Organizations: From Conflict to Integration (Washington, DC: Johns Hopkins University Press, 2013).

55 Ibid.

56 Iver Gabrielsen, "The Evolution of Hezbollah's Strategy and Military Performance, 1982-2006," Small Wars and Insurgencies 25, no. 2 (2014): 257-283.

57 Ralph Peters, "Lessons from Lebanon: The New Model Terrorist Army," Armed Forces Journal International 144, no. 3 (2006): 38-43.

58 Stephen Biddle and Jeffrey A. Friedman, The 2006 Lebanon Campaign and The Future of Warfare: Implications for Army and Defense Policy (Carlisle: Strategic Studies Institute, 2008), 52.

59 David E. Johnson, Hard Fighting: Israel in Lebanon and in Gaza (Santa Monica: RAND, 2011).

60 Richard Beeston and Nicholas Blanford, "Hezbollah Stockpiles 40,000 Rockets Near Israel Border," The Times, August 5, 2009, www.thetimes.co.uk/article/hezbollah-stockpiles-40000-rockets-near-israel-border-wdx776ph8qp; Jeffrey White, If War Comes: Israel vs. Hizballah and Its Allies (Washington, DC: The Washington Institute, 2010).

61 Jeffrey White, "Hizb Allah at War in Syria: Forces, Operations, Effects and Implications," CTC Sentinel 7, no. 1 (2014): 14-17.

62 The term "first intifada" refers to the cycle of organized protests beginning in December 1987. It is commonly understood to have concluded when the Oslo Accords were signed on September 13, 1993. See Mary E. King, "Palestinian Civil Resistance Against Israeli Military Occupation," in Civilian Jihad: Nonviolent Struggle, Democratization, and Governance in the Middle East, ed. Maria J. Stephan (New York: Palgrave Macmillan, 2009), $131-156$. 


\section{Benedetta Berti}

63 Itamar Rabinovich, Waging Peace: Israel and the Arabs, 1948-2003 (Princeton: Princeton University Press, 2004).

64 Ibid.

65 Berti, Armed Political Organizations.

66 International Crisis Group, Enter Hamas: The Challenge of Political Integration (Brussels: International Crisis Group, 2006).

67 Johnson, Hard Fighting.

68 Yoram Cohen and Jeffrey White, Hamas in Combat: The Military Performance of the Palestinian Islamic Resistance Movement (Washington, DC: The Washington Institute, 2009); Eitan Shamir and Eado Hecht, "Gaza 2014: Israel's Attrition vs Hamas' Exhaustion," Parameters 44, no 4 (2014): 81-90. 


\title{
6 \\ JIHADI MILITANCY AND HOUTHI INSURGENCY IN YEMEN
}

\author{
Elisabeth Kendall
}

Yemen has long been plagued by conflict. The main fault line is between northern and southern Yemen, which were separate countries before they signed an awkward union in 1990. Within four years, they were already at war, and tensions remain high to the present day. Numerous other divides exist, which tend to fall along tribal lines. Tribal leaders, laws, and customs continue to occupy important positions in Yemeni society, exacerbated by the lack of strong state institutions. Former Yemeni President Ali Abdullah Saleh famously likened dealing with Yemen's tribal elites to dancing on the heads of snakes. ${ }^{1}$

Politicians are not alone in exploiting Yemen's fault lines. Yemen's main terrorist group, al-Qaida in the Arabian Peninsula (AQAP), has tried to frame north-south tensions as a holy war between Sunnis (southerners) and Shia (northerners). Yemen attracts terrorists in a number of ways. Its topography of deserts, mountains, and wadis (valleys) makes it easy to lie low and engage in paramilitary training. Moreover, its civil war chaos, government exodus, disillusioned population, and critical humanitarian crisis make it a rich recruitment ground for vulnerable and angry young men.

This chapter provides an overview of Yemen's modern history, which is necessary to understand the origins of today's conflicts. It then explains the emergence and development of AQAP and the Islamic State in Yemen, assessing their respective goals and strategies and the extent of their success. Finally, it examines how the Houthi insurgency managed to take over the reins of government and overrun much of the country in 2014.

\section{Overview: the modern history of Yemen}

A brief background of Yemen is essential for contextualizing the conflicts and power struggles shaping the country today. The contemporary unrest that erupted into all-out civil war in 2015 was neither new nor binary. It was the product of a complex web of conflicts rooted in history and exacerbated by clashing local, regional, and international agendas.

In the centuries preceding unification in 1990, Yemen was a loose patchwork of different sheikhdoms, sultanates, emirates, and an imamate ${ }^{2}$ in the north that at times expanded into the south and east. Yemen was technically part of the Ottoman Empire until 1918, although the Ottomans only exercised weak control over this mass of disparate rulers scattered across distant and difficult terrain.

In 1839, the British quickly seized the southern port of Aden, developing it into a trading colony where its importance gradually increased, boosted by the opening of the Suez Canal in 1869. The British struck 
alliances with the various sultans, sheikhs, and amirs (leaders) who controlled Aden's tribal hinterlands and also extended British influence further east toward Oman.

The result was that large areas of Yemen's south and east became British protectorates, while the northwest of the country continued to be ruled separately as an imamate, as had been the case since the late 9th century with some ebb and flow. Yemen's north-south divide was always problematic. The north never fully accepted the dividing line drawn in 1904 by the Ottomans and British. ${ }^{3}$

Profound changes occurred in both the north and the south during the 1960s with the emergence of nationalist sentiment fueled by simmering resentment and deep-seated grievances. Power struggles ensued. In the north, the imamate was toppled in 1962 and the Yemen Arab Republic proclaimed in its place. A civil war followed in which regional powers became entangled. Egyptian President Gamal Abd al-Nasser dispatched thousands of Egyptian soldiers to Yemen to bolster the nascent republic in line with blossoming pan-Arab nationalist sentiment. On the other side, Saudi Arabia, Jordan, and the British helped those who wanted to reinstate the imamate. ${ }^{4}$

It was only in 1967 that Egypt finally withdrew its struggling forces from Yemen, having suffered a crippling defeat closer to home in the Six-Day War against Israel. By 1968, Saudi Arabia agreed to recognize the Yemen Arab Republic in the north, and a governing council formed in Sanaa. Egypt's costly and disastrous military experience in Yemen in the 1960s may have contributed toward its decision not to contribute troops to the Saudi-led coalition's intervention in Yemen in 2015.

In southern Yemen, meanwhile, Britain attempted to secure its interests in the face of growing turbulence by establishing the Federation of South Arabia in 1959. It was unable to rein in the growing wave of nationalist sentiments, which the Egyptians had taken the opportunity to stoke in the south. A series of violent independence movements finally led the British to withdraw from Yemen entirely in 1967. That same year, the National Liberation Front swept to power and formed the People's Republic of South Yemen.

South Yemen became the People's Democratic Republic of Yemen in 1970. But not all southern regions were integrated willingly into the new southern state, ${ }^{5}$ which was the Arab world's first and only Marxist regime. ${ }^{6}$ Following the untimely British withdrawal, ${ }^{7}$ and with it any hope of protection, dissenters were either crushed or fled to neighboring Gulf countries. There was also a mass exodus of southerners to Yemen's north, a shift that was to exacerbate north-south tensions in coming decades.

Years of political turbulence ensued. Clashes erupted along the north and south border several times in the 1970s, most seriously in 1979 with a two-month war. A military coup in 1974 allowed the north to consolidate power into a command council dominated by the military. Power struggles persisted, and two council chairs were assassinated in quick succession before Ali Abdullah Saleh took over in 1978. Through a mixture of carrot and stick tactics, ranging from harsh repression to generous patronage, coupled with blatant nepotism, particularly in the military and security sectors, Saleh was able to remain in power for more than three decades. ${ }^{8}$

During the 1980s, as Saleh consolidated his power in the north, the socialist south was sharply divided, with competing political factions jockeying for control. The power struggles erupted into armed conflict in 1986 known as the South Yemen Civil War. With the economy in ruins and Moscow's support receding as the Soviet Union disintegrated, the southern People's Democratic Republic of Yemen eventually united with the north in 1990. Saleh became president of the United Republic of Yemen. Significantly, however, the northern and southern militaries were never merged, and simmering disputes over the allocation of power and resources were never resolved. ${ }^{9}$

Just four years later, in 1994, the pro-union north and the socialist separatist south were again at war. Although the hostilities ended after two months with a victor's peace for the north, the repercussions can still be felt today. After the war, the military personnel of the former southern Yemeni state were demobilized and deprived of their pensions. Many of them became activists who formed the backbone of the southern secessionist movement that coalesced in 2007. 
The movement, known as the Hirak, won widespread support among a population seething with resentment against the north, which it accused of monopolizing political power, seizing land, and exploiting southern resources. It was also during the 1994 war that Saleh mobilized jihadis to help him fight the southerners, whom he framed as godless socialists. Usama bin Ladin gave Yemeni members of al-Qaida permission to rush home to join the war. ${ }^{10}$

As a result of this historical legacy, Yemen's “Arab Spring” in 2011 was not simply an opportunistic uprising inspired by the popular unrest in Tunisia and Egypt. Rather, it was the crescendo of widespread tensions that had been gathering steam for years. ${ }^{11}$ Popular grievances included corruption, nepotism, preferential patronage, economic underdevelopment, political marginalization, collaboration with the controversial U.S. drone program, and an unpopular and blatantly undemocratic succession plan by which Saleh's son, Ahmad, would inherit power. ${ }^{12}$

When Yemeni security forces fired live rounds on crowds of protestors on March 18, 2011, Saleh's regime broke into factions, and the Yemeni army fractured. ${ }^{13}$ Saleh was deserted by powerful figures, including Army General Ali Muhsin al-Ahmar. ${ }^{14}$ In 2016, al-Ahmar would become vice president and commander of the armed forces fighting against Saleh.

A Gulf Cooperation Council transition plan arranged for Saleh to be replaced. Although Saleh eventually agreed, there were significant flaws in the plan. ${ }^{15}$ Not only was the new president, Abdu Rabbu Mansour Hadi, Saleh's direct deputy, but he was also the sole candidate permitted to stand in the February 2012 elections. Moreover, transitional justice was entirely absent. Saleh was kept on as head of the ruling party and granted immunity from prosecution. Crucially, this gave him a free hand to pursue spoiler activities. Meanwhile, Hadi's largely cosmetic attempts at military reform left Saleh in a strong position of military influence. This was a key factor in facilitating the Houthi power grab in 2014.

Yemen proceeded to unravel after the Houthis took over Sanaa in 2014 and began to march south the following year. President Hadi fled in March 2015, prompting Saudi Arabia to intervene, leading an alliance of Sunni Arab states. ${ }^{16}$ Saudi Arabia declared three main war aims: contain Iran, restore the Hadi government, and prevent Yemen from fragmenting. Since launching its bombing campaign, Saudi Arabia has failed in all three aims and in all likelihood exacerbated the very situation it sought to defuse. The Houthis, who are part of the Zaydi sect of Shia Islam, have become more dependent on Iran and have increasingly employed more sophisticated weaponry of Iranian origin. ${ }^{17}$

Following the 2019 Riyadh agreement between the Hadi government and the separatist Southern Transitional Council, a new power-sharing cabinet relocated from Riyadh to Aden in late 2020. This arrangement remains fragile. Meanwhile, the Houthis' Supreme Political Council continues to govern most of North Yemen from Sanaa.

"Counterterrorism" remains a convenient justification for all sides in their ongoing battles. The Hadi government characterizes the Houthis as Iran-sponsored terrorists, while the Houthis frame their expansion into central Yemen as a counterterrorism campaign. The Southern Transitional Council justifies its use of force against government forces-including a devastating aerial bombardment by the United Arab Emirates in August $2019^{18}$ — as counterterrorism on the basis of the government's close links to the Islamist Islah Party.

Despite agreements signed by the Hadi government with the Houthis in Stockholm in 2018 and with the Southern Transitional Council in Riyadh in 2019, cease-fires continue to be broken, and peace remains elusive. Meanwhile, numerous other armed groups and tribal militias patrol their own pockets of Yemen in a complex web of shifting loyalties. In short, Yemen is fragmenting.

\section{The emergence of AQAP}

Militant jihad in Yemen, as elsewhere in the Middle East, was fueled by war and civil unrest. President Saleh forged pragmatic ties with radical clerics in the 1980s and 1990s to enlist Islamist extremists for his 
ongoing power struggle with the south. The continuing dominance of Marxist ideology among southern political elites made them easy to frame as godless infidels in an obvious parallel to Usama bin Ladin's jihad against the Red Army in Afghanistan throughout the 1980s. ${ }^{19}$

As the 1994 civil war brewed, Tariq al-Fadhli, a leading southern tribal figure who had fought with al-Qaida in Afghanistan, was promoted to colonel in the Yemeni army and sent to rally his men in Abyan, a coastal governorate northeast of Aden. ${ }^{20}$

Yemen's civil war in 1994 also coincided with growing intolerance toward Arab jihadi fighters in Afghanistan both by local warlords and the neighboring Pakistani government, as well as a crackdown on Ayman al-Zawahiri's Islamic Jihad group in Egypt. Yemen-with its civil strife, low cost of living, and ungoverned spaces - seemed like an ideal place for them to regroup and train. ${ }^{21}$ Al-Zawahiri himself reportedly relocated to Yemen for a year in 1994, joining his brother Muhammad and other Egyptian jihadis who had already relocated there. ${ }^{22}$

In the mid-1990s, a militant jihadi group known as the Aden-Abyan Islamic Army formed in south Yemen under the leadership of a local veteran of the Afghan jihad, Zayn al-Abidin al-Mihdar. The group operated with support from a high-ranking military commander, Ali Muhsin al-Ahmar, who had married Fadhli's sister. ${ }^{23}$ Ali Muhsin would later become Yemen's vice president and commander of the armed forces in 2016. This history is relevant because it lends credence to reports of informal alliances between AQAP and parts of the Saudi-backed Yemeni military during the current war. ${ }^{24}$ Indeed, by 2016, the United Arab Emirates felt compelled to recruit new, separate fighting forces in key southern governorates to help shift the focus in those areas back to counterterrorism.

The Aden-Abyan Islamic Army began releasing statements in 1998, specifically criticizing increased Western influence on the Arabian Peninsula. In 1998, it kidnapped 16 Western tourists, four of whom were killed in a clumsy rescue operation. ${ }^{25}$ The incident led to al-Mihdar's execution and the end of the group, in theory at least. In practice, the group was subsequently linked to several al-Qaida attacks. The most notable of these were the attempted attack on the USS The Sullivans in 2000, the suicide boat bombing of the USS Cole in 2000 in which 17 U.S. sailors were killed, and the suicide boat attack on the French oil tanker MV Limburg in 2002.

Since 2000, jihadi militancy in Yemen has been dominated by al-Qaida. Anger over the U.S.-led invasion of Iraq in 2003 contributed to its growth. This coincided with the release of many jihadis from jail in the early 2000s to attend a poorly conceived re-education program that prisoners treated more like an exit strategy. ${ }^{26}$ Those who remained in jail—including future AQAP leaders Nasir al-Wuhayshi and Qasim alRaymi-exploited their captivity to recruit fellow prisoners and build a strong jihadi network.

Saleh cracked down on Yemenis attempting to travel to Iraq or neighboring countries without formal government permission. This may have mollified the Americans, but it created longer-term problems in Yemen. Once locked up in Yemen, these thwarted fighters were easy recruitment targets for the jihadi networks forming in prisons. ${ }^{27}$ On the surface, al-Qaida in Yemen appeared to be dwindling in numbers in the early to mid-2000s, but behind locked doors, it was growing. Meanwhile, the international focus on combating al-Qaida had shifted to Iraq and Saudi Arabia.

The international community was caught off guard when al-Qaida in Yemen dramatically resurged following a major jailbreak in 2006 in which 23 jihadis escaped from a high-security prison in Sanaa. ${ }^{28}$ Among the escapees were al-Wuhayshi and al-Raymi, both of whom would in turn become overall leader of al-Qaida in Yemen.

Al-Wuhayshi was the immediate choice, owing to his origin, schooling, charisma, and experience. Born in Abyan, he had the local touch with regard to tribal interaction and recruitment. His religious grounding was strong, as he had graduated from one of the hundreds of religious institutes that had sprung up in Yemen in the 1970s and 1980s. ${ }^{29}$ Moreover, as a veteran of the Afghan jihad, where he had acted as Bin Ladin's personal secretary, he had clear credibility and experience. ${ }^{30}$ 
The jailbreak proved a watershed moment for al-Qaida. Several high-profile attacks followed that demonstrated a step change in technical expertise and coordination. These included a suicide bomb attack on a Spanish tour group that killed 10 people in 2007 and an audacious double car bombing against the U.S. Embassy in 2008 that killed 20, including six attackers. ${ }^{31}$

Al-Qaida in Yemen also benefited from the crackdown on Islamist extremism inside Saudi Arabia. Saudi jihadis fled across the border into Yemen. In January 2009, the Saudi and Yemeni branches of al-Qaida merged to form AQAP. Attacks continued apace, focusing on both Yemeni military and international targets, such as the 2009 suicide bombing of a South Korean tour group, followed a few days later by a second on the grieving relatives and investigators newly arrived from Korea to sort matters out. ${ }^{32}$ Most attacks occurred inside Yemen, but there were also several attempts to strike outside Yemen. ${ }^{33}$

Key to such operations was AQAP bombmaker Ibrahim al-Asiri, whose unwavering dedication to the group is perhaps best exemplified by his construction of a suicide bomb to insert in the rectum of his own brother in 2009. He succeeded in blowing his brother to pieces, but the target of the bomb, Saudi Prince Muhammad bin Nayif, was reportedly unharmed. Al-Asiri is also thought to have been the mastermind behind the underwear bomb that an AQAP-trained Nigerian man tried to detonate in a plane over Detroit on Christmas Day 2009, as well as two bombs hidden in printer cartridges and found on cargo planes in $2010 .{ }^{34}$

AQAP has also been able to inspire international attacks without the need for direct operational links. Online sermons by Yemeni-American AQAP ideologue Anwar al-Awlaqi, who was killed in a U.S. drone strike in 2011, and AQAP's English-language magazine Inspire have been linked to numerous international acts of terrorism. These include the Boston Marathon bombings in 2013, the Charlie Hebdo massacre in Paris in 2015, and the shooting at a naval base in Pensacola, Florida, in 2019. Such attacks highlight the enduring ability of AQAP's figureheads to inspire aspiring militants long after their own deaths. ${ }^{35}$

Lone wolf attacks in the West continue to be incited through bulky, if now highly infrequent, issues of Inspire. This has been supplemented since 2016 with a series of occasional Inspire Guides that offer brief analysis of the pros and cons of various terrorist attacks in the West, including the Orlando gun attack in 2016, the Nice truck massacre in France in 2016, and the Westminster attack in the United Kingdom in 2017.

\section{AQAP's key objectives}

AQAP has two core goals: expelling infidels from Muslim lands and introducing an Islamic regime to rule in accordance with Sharia (Islamic law). While these goals have remained constant, AQAP's approaches to engaging local populations and achieving these objectives have been refined according to experience and prevailing conditions.

During the instability of the Arab Spring in 2011, AQAP exploited the turmoil to establish Islamic emirates in Abyan and Shabwa. AQAP held and administered territory in these southern governorates for more than a year. It established a Sharia court and enthusiastically implemented punishments among local populations.

Although AQAP tried to undertake community projects, its overbearing governance style alienated local communities and tribal leaders. Local tribal militias, known as Popular Committees, formed and collaborated with the Yemeni military in eventually ousting AQAP from its governance role. AQAP learned from its mistakes during this short period of rule in 2011-2012. When the next governance opportunity presented itself in 2015-2016, it revised its approach.

AQAP's influence and power peaked after a Saudi-led coalition of nine Sunni Muslim countries-supported by the United States and United Kingdom-entered the Yemen conflict to restore the internationally recognized government of President Hadi in March 2015. The security and governance vacuum created by the war allowed AQAP to gain strength in the eastern governorate of Hadramawt. 
As the coalition campaign began, AQAP increased its number of fighters and its war chest by staging another jailbreak, this time freeing an estimated 300 jihadis, seizing military hardware, and robbing the central bank of an estimated $\$ 100$ million. ${ }^{36}$ By April 2015, it had established a de facto state in Hadramawt's coastal capital of Mukalla for an entire year, until United Arab Emirates special forces, with help from the United States, forced it to withdraw in April 2016. ${ }^{37}$

AQAP entrenched its position using a number of parallel strategies that were at once practical, tactical, and ideological. This combination of strategies was key to its success, since populations in Yemen's east could not simply be terrorized into submission. Tribal communities in particular are well armed and highly practiced at resisting intruders. AQAP's success did not lie in the recruitment of what might be considered fighting "members." Even at its peak, its core fighters likely numbered no more than $4,000 .{ }^{38}$ Rather, success lay in winning enough toleration that it could continue to exist, operate, and over time expand.

AQAP revised its dictatorial governance style of 2011-2012. Just as it had rebranded itself as Ansar al-Sharia (Partisans of Islamic Law) in 2011 to distance itself from any negative baggage attached to the al-Qaida label, it again rebranded in 2015. This time it chose the name Abna' Hadramawt (the Sons of Hadramawt) for more local appeal, and it struck power-sharing deals with existing local governance structures. ${ }^{39}$ It could thus share the glory with local communities when their prospects improved but also the blame if the situation deteriorated.

AQAP carefully avoided alienating tribes and local populations in areas under its influence. When AQAP accidentally killed innocent tribesmen in operations that targeted the Yemeni military, AQAP published formal apologies and negotiated with the relevant tribes to pay blood money. ${ }^{40}$ AQAP was also mindful to invoke and praise the glorious history and courage of various tribes in several statements, videos, poems, and anashid (anthems). This framed their contemporary jihad as a natural continuation of the proud struggles of their forefathers, such as those who fought to win independence from British colonialists in the 1960 s. ${ }^{41}$

AQAP regularly exploited U.S. drone strikes, airstrikes, and raids, particularly when they resulted in the deaths of women and children or the destruction of village property. Thus, U.S. lethal action, while yielding short-term successes, can also generate long-term cycles of violence because it enables AQAP to position its jihad as justifiable revenge and to frame local misfortune as part of a global battle between believers and infidels.

AQAP also courted local populations by spearheading community development projects, such as improving utility infrastructure, building roads, and renovating schools. Approximately 56\% of tweets from AQAP's governance Twitter feed during 2016 were about its hands-on development activities. In contrast to the war raging in Yemen's west, where bombs dropped by the Saudi-led coalition destroyed civilian infrastructure as well as Houthi military targets, AQAP's territory looked like a haven of stability and security. ${ }^{42}$ AQAP financed its activities through oil imports and smuggling operations along Yemen's porous eastern coastline.

It was probably the outbreak of internationalized war in 2015 that proved the biggest boon to AQAP. The jihadis increased their relevance by framing the anti-Houthi war effort as part of their program of global jihad. Widespread fear among southerners of occupation by the Houthi northerners could be slotted directly into existing jihadi narratives of sectarian battles between Sunni believers and Shia infidels. Disputes that were in essence political were manipulated to take on a new religious significance.

\section{The Islamic State in Yemen}

The Islamic State announced its expansion into Yemen on November 13, 2014, following Islamic State leader Abu Bakr al-Baghdadi's acceptance of an oath of allegiance sworn to him by "Yemen's mujahidin." ${ }^{43}$ AQAP faced some early defections of members who joined the Islamic State. Al-Baghdadi's group 
proclaimed various Islamic State provinces around Yemen and undertook several high-profile attacks in 2015 and 2016.

Nevertheless, the Islamic State did not usurp AQAP as Yemen's primary jihadi group. On the contrary, the arrival of the Islamic State on the world stage actually worked to AQAP's advantage in two significant ways. First, it distracted international attention away from both al-Qaida and Yemen and shifted it to Iraq and Syria. Second, the Islamic State's indiscriminate brutality allowed AQAP to position itself as the "good guy." AQAP highlighted the Muslim death toll and civilian ravages wrought by the Islamic State's devastating bombing campaign in Yemen and pledged that, unlike the Islamic State, it would not target "mosques, markets and crowded places." ${ }^{4}$

At the same time, AQAP apologized for its own previous excesses, such as the storming of a military hospital in Sanaa in 2013 and the beheading of 14 soldiers in Hadramawt in 2014, which it implicitly blamed on the negative influence of Islamic State propaganda. ${ }^{45}$

The Islamic State's inability to gain traction in Yemen, particularly among the tribes, can be attributed to several factors. Unlike AQAP, the Islamic State did not produce a narrative that was culturally specific to Yemen aside from disparaging the Houthis as infidel agents of Iran. Nor did the Islamic State engage in AQAP-style community development projects in Yemen, despite its early efforts in this regard in Syria and Iraq.

The ability to form tribal alliances has been as central to al-Qaida's success as it has to the Islamic State's relative failure in Yemen. Pro-AQAP channels on the messaging application Telegram have taken pride in AQAP's readiness to engage tribes, support community projects, and work in conjunction with local structures. ${ }^{46}$ Some Islamic State fighters in Yemen defected back to AQAP and became highly critical of the irreligious, brutal, and dictatorial behavior of its leaders. ${ }^{47}$

In fact, the Islamic State never succeeded in holding territory in Yemen and became confined largely to a single front in the Qayfa region of al-Bayda Governorate. Even this front was severely dented in October 2017 when the United States bombed its two main training camps, killing dozens of Islamic State fighters. Although a new version of the Islamic State sprang to life again in the same location in 2018, it likely did so with outside help ${ }^{48}$ and failed to gain much traction among local Yemenis. ${ }^{49}$

From mid-2018 onwards, the rivalry between AQAP and the Islamic State in Yemen erupted into all-out war, and for the next two years, they focused overwhelmingly on killing each other. Additional challenges for the Islamic State included weak communications, infiltration by spies, poor leadership, factionalism, a concerted counterterrorism campaign spearheaded by the United Arab Emirates, and a dramatic uptick in U.S. drone strikes. ${ }^{50}$ By 2020, Yemen's jihadi groups were severely degraded, held no territory, and had fragmented.

\section{The Houthi insurgency}

The Houthis derive their name from their former leader Hussein al-Houthi, but they are not a homogenous tribal group. Instead, the Houthis are a conglomeration of miscellaneous political and tribal groupings from Yemen's north, whose rhetoric has acquired increasingly religious overtones. They are predominantly Zaydi, a branch of Shia Islam but one that is markedly different from Iran's "Twelver Shiism" and closer in practice to Sunni Islam. Religious conviction played an important role in the formation of Houthi identity politics. Even their political arm is known as Ansar Allah (Partisans of God). Zaydis make up over one-third of Yemen's population of 30 million. ${ }^{51}$ As of 2020, the Houthis control territory in which two thirds of Yemen's population lives. ${ }^{52}$

The Houthis' mobilization began in the late 1980s as a cultural revivalist campaign seeking to win cultural recognition for Zaydis and to end their economic and political marginalization. They were also religiously motivated by the need to push back against influence activities conducted by Saudi-backed 
Wahhabis and local Salafis. ${ }^{53}$ This campaign led to six rounds of war between the Houthis and the Yemeni government between 2004 and 2010. ${ }^{54}$ Saudi Arabia entered into direct war with the Houthis in the last of these in 2009. ${ }^{55}$

The conflict was exacerbated by the Yemeni government's initial knee-jerk response of mass arrests and collective punishment across the Zaydi population. Previously neutral tribesmen flocked to the Houthi cause. There is some evidence that President Saleh may have deployed the Republican Guard under the command of his son Ahmad to deliberately foment the Houthi insurgency to discredit General Ali Muhsin al-Ahmar, who had been tasked with putting down the insurgency. This would weaken any potential future bid by Ali Muhsin for the presidency, which Saleh had earmarked for his son Ahmad. ${ }^{56}$

The Houthi hostilities receded between 2011 and 2014 as the Houthis joined in the Arab Spring uprising and the subsequent National Dialogue Conference sponsored by the United Nations. ${ }^{57}$ The National Dialogue, which included 565 delegates from all around Yemen, was hailed at the time by Western governments as a successful model of transition. Ultimately, however, it failed. Crucially, the National Dialogue avoided tackling the most controversial issues relating to the future shape of Yemen and the division of power, territory, and resources ${ }^{58}$ Moreover, despite the laudable inclusion of some women and youth, the Dialogue's delegates were less representative than the Dialogue's official website implied.

The Houthis, meanwhile, had become increasingly disillusioned at a transition process led by a president born in the south, backed by their former adversaries, appointed in a sham election in which he was the sole candidate, and now extended beyond his two-year term that had been due to end in early 2014 . In September 2014, the Houthis flooded the capital and took over key buildings. The final trigger for their comprehensive takeover came in January 2015 with the tabling of a federal plan that left the Houthis without access to a seaport or oil. ${ }^{59}$ In response, the Houthis placed President Hadi under house arrest and abducted his chief of staff.

The Houthi "coup" was thus generated by domestic concerns relating to the control of resources and power rather than by ideological principles externally nurtured by Iran. As international embassies closed and United Nations staff evacuated, the Houthis continued their march south to Aden. President Hadi escaped and fled to Saudi Arabia in March 2015. ${ }^{60}$ It was at this point that Saudi Arabia led a coalition of nine states into the Yemen conflict, anticipating a swift end to the Houthi insurgency.

\section{How did Sanaa and Aden fall to the Houthis?}

The Houthis' military alliance with former President Saleh proved crucial to their success in advancing swiftly south with little initial resistance from government forces. Saleh hoped to regain the presidency that he had been forced to cede to his deputy, Hadi, in 2012. Saleh had the advantage of retaining the loyalty of many of the better-trained and equipped factions of the Yemeni military, including the Republican Guard. The Houthis, therefore, had access to both military hardware and well-trained personnel. ${ }^{61}$

There is evidence of Iran and its Lebanese proxy, Hezbollah, providing weapons and military advisors to the Houthis. This was likely not as significant at this point in the conflict as their opponents claimed, and there is little evidence of Iran supplying the Houthis with heavy weapons in the early stages of the war. ${ }^{62}$ It was not Iranian assistance that explains the Houthi success; it was the collaboration with former President Saleh.

The Yemen conflict has been framed as both a sectarian battle and a proxy war between Sunni Saudi Arabia on the side of the Hadi government and Shia Iran on the side of the Houthis. The Houthis do fit into the broad orbit of Iranian influence alongside Hezbollah, significant factions of the Iraqi government, and the Syrian regime of Bashar al-Assad. ${ }^{63}$ All profess their admiration for Shia leaders and their hatred for Israel and the United States.

But the Houthis are not a direct proxy of Iran. They will work with Iran as long as it suits them, much as they worked with Saleh as long as it achieved their objectives (they eventually murdered him in 2017) ${ }^{64}$ 
The Houthi relationship with Iran is based on pragmatism rather than command and control, but it has become increasingly ideological as the war has dragged on.

Yemen has proven a relatively cheap option for Iran. It has benefited Iran to play up its role in Yemen for several reasons related to regional power politics, but it is important to distinguish between Iran's rhetoric and its tangible activities. Iran can be linked to limited military assistance to the Houthis beginning in $2011^{65}$ and to more sophisticated military assistance beginning in late 2014. ${ }^{66}$

Iran, however, did not need to supply the Houthis with large quantities of expensive weaponry and training; it needed only to create the perception of doing so. This was enough to concern international audiences; please domestic hardliners; elevate Iran's standing as an important regional stakeholder; and antagonize Saudi Arabia into an expensive, unpopular, and unwinnable war. It has succeeded in damaging Saudi Arabia financially and reputationally, and it has distracted Riyadh's attention away from Syria, where it opposes the Iran-backed al-Assad regime.

Moreover, contrary to what Saudi Arabia hoped, Iran's influence in Yemen increased rather than decreased as the war escalated. Whereas in January 2017, the United Nations panel of experts on Yemen concluded there was insufficient evidence of direct large-scale supply of arms from Iran, ${ }^{67}$ a year later it reported strong indications that the Houthis had received new ballistic missile technology and drones originating in Iran.$^{68}$ Since 2020, the frequency of Houthi drone and missile attacks inside Saudi Arabia has increased dramatically ${ }^{69}$ It is unlikely that this could have occurred without significant external assistance.

Overall, the Houthi insurgency was neither the direct product of Islamic sectarianism nor simply a manifestation of the broader proxy war between Saudi Arabia and Iran.

\section{Conclusion}

It is reasonable to conclude that the rise of the Houthis' political arm Ansar Allah over the past decade and the growing regional influence of Iran have occurred in tandem rather than being inextricably linked. ${ }^{70}$ While the Houthi alliance with Iran sprang more from necessity than ideological alignment, the longer the conflict has dragged on following the internationalization of Yemen's civil war in 2015, the more vulnerable the Houthis have become to Iranian influence. This is of obvious concern to the Saudiled coalition of Sunni states fighting to restore Yemen's internationally recognized government. A war that essentially grew out of a domestic political dispute has turned into a drawn-out international power struggle with sectarian overtones using proxy forces in Yemen.

Yemen looks to be in the process of fragmenting. The north-south divide remains a potent issue. In 2017, a well-organized political body known as the Southern Transitional Council emerged in Aden, the capital of the former South Yemen, with aspirations for the south to secede. Funded by the United Arab Emirates, it recruited and trained local forces across the south. These forces have clashed multiple times with the formal Yemeni military, which holds firm to the concept of a united Yemen. Although the southern secessionists and the Hadi government signed a peace deal in Riyadh in 2019 and a power-sharing cabinet was formed in late 2020, violent clashes persist.

There are also fragile fault lines inside Yemen's former South, where significant sectors of the population oppose the notion of secession, control by Aden, or influence by the United Arab Emirates. In the eastern governorates of Hadramawt and al-Mahra in particular, regional independence movements have emerged. There is, therefore, the potential for new fronts to open in Yemen. As a result, even if a peace deal is reached in the main war between the Houthis and the Yemeni government, translating this into peace on the ground has become increasingly difficult.

There are some parallels between the respective rises of the Houthi and Sunni jihadi insurgencies in Yemen. The Houthis originally attempted to win support much as al-Qaida had done during its zenith of 2015-2016: by plugging into widespread discontent and claiming to stand against ineffective government and endemic corruption. ${ }^{71}$ Similarly, both the Houthi and the Sunni jihadi insurgencies then 
attempted to re-frame their popular appeal in religious terms that would accord with their respective sectarian narratives. ${ }^{72}$

The Houthis have characterized themselves increasingly as true Muslims battling an infidel government that collaborates with both al-Qaida and the Islamic State as agents of the United States and Israel. ${ }^{73}$ Conversely, al-Qaida fighters characterize themselves as true Muslims battling infidel Houthis who collaborate-however improbably - with both Iran and the Islamic State as agents of the United States and Israel. Finally, Yemen's Islamic State fighters characterize themselves as true Muslims battling infidel Houthis who collaborate - even more improbably — not only with Iran but also with the Hadi government and al-Qaida as agents of the United States and Israel.

While the Houthis have retained a strong position during the ongoing war, both AQAP and the Islamic State in Yemen are shadows of their former selves. At the start of the war, AQAP in particular had been able to exploit the security vacuum, humanitarian crisis, and booming smuggling economy to bolster its support, influence, and funding. The Islamic State did not fare as well as AQAP in Yemen, partly owing to its weak understanding of tribal dynamics, inability to construct locally attuned narratives, weak religious credentials, and overbearing leadership style.

Nevertheless, although the jihadi groups were by 2020 weaker than they have ever been, the ideas and motivators that underpin the Salafi-jihadi movement in Yemen persist. Moreover, while the groups may recede and move underground, they do not fully disappear. By early 2021, there are signs that AQAP may be regrouping in the south. Yemen's jihadi militancy should therefore be seen as dormant or managed rather than absent or defeated.

\section{Notes}

1 "Yemen's Saleh, 'Dancing on the Heads of Snakes'," Reuters, September 23, 2011, www.reuters.com/article/ us-yemen-saleh/newsmaker-yemens-saleh-dancing-on-the-heads-of-snakes-idUSTRE78M20X20110923.

2 A Zaydi Shia imamate ruled Yemen for hundreds of years until 1962. The imams claimed authority to rule Yemen based on being descendants of the Prophet Muhammad.

3 Noel Brehony, Yemen Divided: The Story of a Failed State in South Arabia (London: I.B. Tauris, 2011$), 3$.

4 The British, however, assisted covertly. See Duff Hart-Davis, The War That Never Was: The True Story of the Men Who Fought Britain's Most Secret Battle (London: Arrow Books, 2012).

5 Elisabeth Kendall, “The Mobilisation of Yemen's Eastern Tribes: Mahra's Self-Organisation Model," in Yemen and Search for Stability, ed. Marie-Christine Heinze (London: I.B. Tauris, 2018), 78.

6 Brehony, Yemen Divided.

7 Peter Hinchcliffe, John T. Ducker, and Maria Holt, Without Glory in Arabia (London: I.B. Tauris, 2006).

8 Stephen Day, Regionalism and Rebellion in Yemen (New York: Cambridge University Press, 2012).

9 Ibid.

10 Gregory D. Johnsen, The Last Refuge: Yemen, al-Qaeda, and the Battle for Arabia (New York: Oneworld, 2012).

11 Day, Regionalism and Rebellion in Yemen.

12 Steven Erlanger, "In Yemen, U.S. Faces Leader Who Puts Family First," New York Times, January 4, 2010 , www. nytimes.com/2010/01/05/world/middleeast/05saleh.html.

13 Mohamed Sudam and Mohammed Ghobari, "Yemen in State of Emergency After Protest Massacre," Reuters, March 18, 2011, www.reuters.com/article/us-yemen/yemen-in-state-of-emergency-after-protest-massacre-idUSTRE72H2Z720110318.

14 “Top Yemen General, Ali Mohsen, Backs Opposition,” BBC, March 21, 2011, www.bbc.com/news/world-middleeast-12804552.

15 Ginny Hill, Yemen Endures (London: Hurst, 2017).

16 "Saudi Arabia Launches Air Strikes in Yemen," BBC, March 26, 2015, www.bbc.com/news/world-us-canada32061632 .

17 Jonathan Saul et al., "Iran Steps Up Support for Houthis in Yemen's War-Sources," Reuters, March 21, 2017, www.reuters.com/article/us-yemen-iran-houthis/exclusive-iran-steps-up-support-for-houthis-in-yemens-warsources-idUSKBN16S22R.

18 Andrew England and Simeon Kerr, "UAE Attacks on Yemen Reveal Fractures in Saudi-Led Coalition,” Financial Times, August 29, 2019, www.ft.com/content/48f44b08-caa5-11e9-a1f4-3669401ba76f. 
19 Mustafa Hamid and Leah Farrall, The Arabs at War in Afghanistan (London: Hurst, 2015).

20 Johnsen, The Last Refuge.

21 Formal confession of Ahmad Ibrahim al-Naggar, an Islamic Jihad leader. Cited in Montasser al-Zayyat, The Road to al-Qaeda: The Story of Bin Laden's Right-Hand Man (Biography of Ayman al-Zawahiri by his Egyptian lawyer) (London: Pluto Press, 2004; original Cairo, 2002), 56-58.

22 Laurent Bonnefoy, Yemen and the World: Beyond Security (London: Hurst, 2018), 84.

23 International Crisis Group, Yemen's Al Qaeda: Expanding the Base (Brussels: International Crisis Group, 2017).

24 Ibid., 15.

25 "Yemen: Troops Raid Militants' Hide-Out," Associated Press, June 26, 2003, www.nytimes.com/2003/06/26/ world/threats-and-responses-briefly-noted-yemen-troops-raid-militants-hide-out.html.

26 Johnsen, The Last Refuge.

27 Ibid.

28 Gregory D. Johnsen, “A Profile of AQAP’s Upper Echelon,” CTC Sentinel 5, no. 7 (2012): 6-9.

29 Ibid.

30 For a brief assessment of al-Wuhayshi's skills relative to those of his successor, Qasim al-Raymi, see Elisabeth Kendall, Death of AQAP Leader Shows the Group's Fragmentation-And Durability (Washington, DC: Washington Institute, 2020).

31 "Profile:Al-Qaedainthe ArabianPeninsula,"BBC,June 16,2015,www.bbc.com/news/world-middle-east-11483095.

32 “South Koreans Urged to Flee Yemen," BBC, March 19, 2009, http://news.bbc.co.uk/2/hi/middle_east/7952303. stm.

33 "Profile: Al-Qaeda in the Arabian Peninsula."

34 "Chief Al-Qaeda Bomb Maker 'Killed in Yemen Strike'-US Reports," BBC, August 21, 2018, www.bbc.com/ news/world-middle-east-45257631.

35 Scott Shane, "The Enduring Influence of Anwar al-Awlaki in the Age of the Islamic State," CTC Sentinel 9, no. 7 (2016): 15-19.

36 Yara Bayoumy, Noah Browning, and Mohammed Ghobari, "How Saudi Arabia's War in Yemen Has Made alQaeda Stronger-And Richer," Reuters, April 8, 2016, www.reuters.com/investigates/special-report/yemen-aqap/.

37 Phil Stewart, "Small U.S. Military Team in Yemen to Aid UAE Push on al Qaeda," Renters, May 6, 2016, www. reuters.com/article/us-usa-yemen-pentagon/small-u-s-military-team-in-yemen-to-aid-uae-push-on-al-qaedaidUSKCNOXX1ZJ.

38 Bureau of Counterterrorism and Countering Violent Extremism, Country Reports on Terrorism 2015 (Washington, DC: U.S. Department of State, 2016). Higher estimates have been reported, but there is little evidence to support them.

39 Joana Cook, "Their Fate Is Tied to Ours": Assessing AQAP Governance and Implications for Security in Yemen (London: ICSR, 2019), 19.

40 See, for example, AQAP Statement "Tawdih Hawla Qadiyat Qutla Qabilat Al Bu Bakr bin Daha wa-Ibn al-Hayj" (Clarification about the Issue of Killings of the Al Bu Bakr bin Daha Tribe and Ibn al-Hayj), October 20, 2016.

41 Elisabeth Kendall, Contemporary Jihadi Militancy in Yemen: How is the Threat Evolving? (Washington, DC: Middle East Institute, 2018), 7.

42 Specific instances of Saudi airstrikes on civilian targets can be found in: Panel of Experts on Yemen, Final Report of the Panel of Experts on Yemen (New York: United Nations Security Council, 2017), 47-48; Panel of Experts on Yemen, Final Report of the Panel of Experts on Yemen (New York: United Nations Security Council, 2018), 46-47.

43 Yasir Yosef Kuoti, "Islamic State in Yemen," Terrorism Monitor 14, no. 24 (2016).

44 "Bayan Nafy al-'Alaqa bi-Tafjirat Masajid al-Huthiyyin fi San'a" (Statement Denying Links to the Bombings of Houthi Mosques in Sanaa), Al-Qaida in the Arabian Peninsula, March 20, 2015.

45 "Al-Mu'tamar al-Suhufi al-Duwali al-Awwal, ma' al-Shaykh Nasr bin 'Ali al-Anisi” (First International Press Conference, with Sheikh Nasr bin Ali al-Anisi), al-Malahim Media, December 2014; "Ta'liq 'ala Istihdaf Wizarat alDifa' bi-San'a' li-l-Qa'id Qasim al-Raymi" (Commentary on the Targeting of the Ministry of Defense in Sanaa, by Commander Qasim al-Raymi), al-Malahim Media, December 2013.

46 For a fuller comparison of AQAP and Islamic State local engagement strategies in Yemen, see Elisabeth Kendall, "Al-Qaeda and Islamic State in Yemen: A Battle for Local Audiences," in Jihadism Transformed: Al-Qaeda and Islamic State's Global Battle of Ideas, ed. Simon Staffell and Akil Awan (London: Hurst, 2016), 103-108.

47 Elisabeth Kendall, "The Failing Islamic State Within the Failed State of Yemen," Perspectives on Terrorism 13, no. 1 (2019): 80.

48 Counterterrorism Committee, Twenty-Fifth Report of the Analytical Support and Sanctions Monitoring Team (s/2020/53) (New York: United Nations Security Council, 2020), 8.

49 Elisabeth Kendall, ISIS in Yemen: Caught in a Regional Power Game (Washington, DC: Center for Global Policy, 2020). 


\section{Elisabeth Kendall}

50 Elisabeth Kendall, "Impact of the Yemen War on Militant Jihad," in Politics, Governance E Reconstruction in Yemen, ed. Marc Lynch and Stacy Philbrick Yadav (Washington, DC: POMEPS, 2018).

51 “Who Are Yemen's Houthis?” Reuters, May 20, 2015, www.reuters.com/article/idUS312582283620150520.

52 Helen Lackner and Raiman al-Hamdani, Talking to the Houthis (Berlin: European Council on Foreign Relations, 2020).

53 Several early examples of such campaigns can be found in Shelagh Weir, A Tribal Order: Politics and Law in the Mountains of Yemen (Austin: University of Texas Press, 2007); International Crisis Group, Yemen: Defusing the Saada Time Bomb (Brussels: International Crisis Group, 2009), 8.

54 A detailed history of the Houthi conflict can be found in Marieke Brandt, Tribes and Politics in Yemen: A History of the Houthi Conflict (London: Hurst, 2017).

55 Mai Yamani, "Saudi Arabia Goes to War," Guardian, November 23, 2009, www.theguardian.com/commentis free/2009/nov/23/saudi-arabia-yemen-houthi-war.

56 Additionally, Ali Muhsin was given inferior forces and denied both new hardware and support from the Republican Guard and central security services. See Sarah Phillips, Yemen and the Politics of Permanent Crisis (New York: Routledge, 2011), 93-95.

57 Gabriele von Bruck, "Saada: Ground Zero," London School of Economics (blog), June 19, 2017, https://blogs.lse. ac.uk/mec/2017/06/19/saada-ground-zero/.

58 Charles Schmitz, Yemen's National Dialogue (Washington, DC: Middle East Institute, 2014).

59 Stephen W. Day, "What's Behind Yemen's Recent Political Turmoil," Washington Post, February 23, 2015, www. washingtonpost.com/news/monkey-cage/wp/2015/02/23/whats-behind-yemens-recent-political-turmoil/.

60 "President Hadi Leaves Yemen as Saudi-Led Raid Continues," BBC, March 27, 2015, www.bbc.com/news/ world-middle-east-32078817.

61 Panel of Experts on Yemen, Final Report on Yemen (2017), 34. Note that there are also claims that Republican Guard units defected from Saleh early in the uprising, as did many military commanders. However, it is unclear whether the Yemeni military under President Hadi was able to consolidate these alleged shifts in allegiance away from Saleh.

62 Elisabeth Kendall, Iran's Fingerprints in Yemen: Real or Imagined (Washington, DC: Atlantic Council, 2017).

63 International Institute for Strategic Studies, Iran's Networks of Influence in the Middle East (London: International Institute for Strategic Studies, 2019).

64 Shuaib Almosawa and Ben Hubbard, "Yemen's Ex-President Killed as Mayhem Convulses Capital," New York Times, December 4, 2017, www.nytimes.com/2017/12/04/world/middleeast/saleh-yemen-houthis.html.

65 W. Andrew Terrill, Iranian Involvement in Yemen (Philadelphia: Foreign Policy Research Institute, 2014).

66 Thomas Juneau, "Iran's Policy Towards the Houthis in Yemen: A Limited Return on a Modest Investment," International Affairs 92, no. 3 (2016): 647-663.

67 Panel of Experts on Yemen, Final Report on Yemen (2017), 26.

68 Panel of Experts on Yemen, Final Report on Yemen (2018), 24 and 32.

69 Statement by the Acting UK Deputy Permanent Representative to the United Nations, United Nations Security Council, November 11, 2020.

70 Emile Hokayem and David Roberts, “The War in Yemen,” Survival 58, no. 6 (2016-2017): 157-186.

71 In 2016, Transparency International's Corruption Perceptions Index ranked Yemen 170 out of 176 countries.

72 For a brief account of AQAP and Islamic State-Yemen sectarian narratives, see Kendall, "Al-Qaeda and Islamic State in Yemen."

73 There is some evidence that the Houthis, or a faction within them, may themselves have collaborated with the Islamic State in Yemen. See Kendall, ISIS in Yemen. 


\title{
7 \\ THE ROOTS OF TERRORISM IN NORTH AND WEST AFRICA AQIM and Boko Haram
}

\author{
Alice Hunt Friend
}

North and West Africa comprise a region of vast and sparsely populated territories covering some of the most rugged landscapes on earth. Its geographic complexities pose numerous challenges to governance and the extension of security. As an operating environment for both state security forces and terrorist groups, it presents urban and desert terrain that puts intelligence collection and logistics to the test. For the region's under-resourced governments, lasting counterterrorism offensives have often relied on political suppression and brutality rather than security operations integrated with comprehensive law enforcement, development, and political co-optation.

The most prominent terrorist groups operating in North and West Africa today are historical products of domestic insurgencies in Algeria and Nigeria. Algeria's violent anti-secular Salafist Group for Preaching and Combat (GSPC) later rebranded itself to become al-Qaida in the Islamic Maghreb (AQIM). Nigeria's Boko Haram evolved from a fringe sect of religious radicals to a full-blown militant organization attacking the legitimacy of the Nigerian state.

Yet neither AQIM nor Boko Haram has ever focused primarily on confrontation with the West. To a great degree, the causes and conduct of these two groups have been largely independent phenomena, with little to suggest that AQIM and Boko Haram will join forces in the future. To better understand AQIM and Boko Haram today, this chapter examines their roots, the political conditions that motivated their historical and contemporary manifestations, and how regional governments-in particular Algeria and Nigeria- have acted to combat them.

\section{From the party to the guerrilla: Algeria and the rise of violent political Islamism}

Although not all extremists in West Africa have their roots in Algerian domestic politics, Algeria's history of tension between secularism and Islamism casts a long shadow over political violence in the region. Having lost the fight over the religiosity of the Algerian state, Islamist factions have proven tenacious, adaptive, and migratory, spreading into the broader region without ever abandoning hope for a theocratic Algeria. In response, the Algerian government has tried a variety of strategies to defeat their Islamist opponents, from suppression to amnesty to a regional policy designed to crush terrorism at home and abroad.

Foundational to its history is Algeria's experience as a French colony, when repression of Islamic institutions and cultural practices helped to galvanize a defiant sense of Muslim identity. ${ }^{1}$ Independence led to 
26 years of a single-party system, but a struggle over the composition of the Algerian state erupted in 1988, with Islamic identity serving as a natural organizing principle.

After activists pressured the government to allow the formation of political parties, the Islamic Salvation Front became the most significant player. The Islamic Salvation Front won approximately a third of local seats in the 1990 election and performed well again in the first round of national parliamentary elections in $1991 .^{2}$ Fearful that the party would take total control of the government, the secularist military regime canceled the second round of elections, arrested many of the Front's leaders, and installed a Higher Executive Committee to run the government. ${ }^{3}$

The new military regime systematically dismantled every Islamic Salvation Front connection to Algerian politics, catching them off guard. The party was split over the best way to respond to their sudden expulsion from national politics. Some advocated continued peaceful political organization, while others viewed the military's actions as imposing war-like conditions. ${ }^{4}$ Violent events swiftly overcame those advocating a return to legitimate politics, as extreme repression at the hands of the government pushed many Islamists into a guerrilla mindset and the advocacy of "violent rejectionism." ${ }^{5}$ Under pressure from security forces, a number of resistance groups sprang up and eventually coalesced under the general moniker of the Armed Islamic Group (GIA), resulting in a civil war. ${ }^{6}$

Despite the common enemy, the solidarity of the GIA was not guaranteed, and different opinions over strategic purpose and tactics began to unfold almost immediately. In particular, Islamists launched what would become the movement's perennial debate over the merits of privileging domestic or "pan-Islamic" goals. ${ }^{7}$ This debate echoed the Islamic Salvation Front's earlier differences over the use of violence, with the nationally focused GIA members hoping for an eventual return to mainstream Algerian politics and the pan-Islamists seeing in those same politics the corruption and evil of Western governing models-evidence that only the total destruction of the state could make Islamic governing possible. The pan-Islamist faction saw their purpose as connecting with the broader Islamist movement.

To a great extent, the debate also echoed the divide between core jihadis and the bulk of Algeria's Muslim population, which was motivated not by a global religious ideology but by economic and cultural interests and relied upon Islamic identities to reinforce national and local solidarity. Algerian Islamists returning from the Afghan-Soviet war added their voices to the civilizational arguments, inspired by the notion that the world is divided between believers and the takfir (those whom extremists have deemed apostates and no longer Muslim). ${ }^{8}$

Such a division allowed GIA hard-core members to include Muslim Algerians in their growing list of enemies. They argued that any individual willing to embrace Western practices was detrimental to the cause of Islamic purity. Put simply, there were those who believed the struggle was for Algeria's identity and those who believed it was just a battleground in a wider war. ${ }^{9}$

The GIA eventually espoused the latter, emphasizing Muslim identity over Algerian identity, and as a result saw no hypocrisy in targeting Algerian Muslims who embraced nationalist or secular values. Yet in practice, the group remained largely focused on the Algerian state and any institutions that buttressed it. ${ }^{10}$ Under the anti-Western and anti-secular rubric, the GIA destroyed infrastructure and schools, killed teachers, and raped and tortured its victims. ${ }^{11}$ The targets were almost always Algerian, especially concentrated in the capital city and, counterproductively, in many communities that "formed the backbone of the Islamic opposition."12

It is instructive that Usama bin Ladin made a brief foray into supporting the GIA financially at this juncture, but the GIA was too embroiled in its own agenda to prioritize cooperation with the wider jihadi movement. ${ }^{13}$ Although the GIA did undertake a few spectacular attacks against foreigners, including the hijacking of an Air France jet in 1994, the vast majority of their offensives focused on Algerians. ${ }^{14}$

Perhaps because of these internal contradictions, or due to its own brutality, the GIA struggled to gain real traction inside Algeria. The GIA became famous not so much for its cause but for its violence. With a "notorious reputation for mayhem and murder," the GIA made its mark beheading journalists, killing 
women who refused to wear the hijab (veil), and murdering women and children related to members of the military. ${ }^{15}$

Some argue that although the group was organized as a response to the economic and social failures of the socialist regime, it did not offer any realistic solutions, instead promoting ruthless social engineering at the expense of stability. ${ }^{16}$ Although political Islam still resonated with the population, the GIA's nihilistic experiment with destroying the state did not appeal to those who saw integration of Islamic and secular governing institutions as a possible outcome.

In the end, the moderates were too numerous, and those on the fence turned away from the GIA's vicious tactics. With a narrow public base of support, pressure from the security forces-coupled with a government amnesty and reconciliation program-further picked off members and delegitimized the group. ${ }^{17}$

As the civil war wound down, many Algerian Islamists adapted by relaxing their views toward Muslims who did not actively oppose the government. Some members of the GIA began to peel away, and they organized themselves into a new entity in 1998: the GSPC. The GSPC carved out a middle path between the "bloodthirsty" GIA and the "apostate" Islamic Salvation Front, rejecting violence against civilians and focusing its energy on the Algerian state. ${ }^{18}$ Operating in the mountains and deserts rather than in urban areas, the GSPC primarily targeted military officials. Their most common tactic was to combine a false roadblock with an ambush, with pursuant attacks once local security forces responded to the initial call for help. ${ }^{19}$

Under persistent pressure from security forces, the GSPC divided itself into regional commands, none of which seemed to have a fixed base of operations. ${ }^{20}$ The group struggled to appeal to a war-weary public because of its distance from population centers and its inability to offer a meaningful alternative to the government. As a result, the GSPC began to emphasize its links with international jihadi groups to build credibility.

\section{The birth of al-Qaida in the Islamic Maghreb}

The GSPC leadership reached out once again to al-Qaida, an overture both sides considered carefully. Although the GSPC appeared to be the new center of Islamist gravity in North Africa, Bin Ladin opposed privileging operations against the "near enemy" over the Western "far enemy." Meanwhile, the GSPC's senior leadership cadre could not decide whether an al-Qaida affiliation would help or harm their domestic political goals.

In the end, they compromised: the GSPC would attack a mix of Western and Algerian government targets, implementing tactical elements of al-Qaida's global agenda, while continuing to threaten the integrity of the Algerian state. ${ }^{21}$ Al-Qaida's second-in-command, Ayman al-Zawahiri, announced the merger on September 11, 2006, and the GSPC's head, Abdelmalek Droukdel, made a subsequent statement of loyalty. ${ }^{22}$ Four months later, Droukdel announced that the GSPC would change its name to al-Qaida in the Islamic Maghreb.

The old group, now operating under the new AQIM moniker, undertook a spate of deadly terrorist attacks in Algiers designed to leverage the credibility bestowed by its new relationship. Targeting government buildings, security forces, and the United Nations, AQIM reintroduced suicide bombings in Algeria, killing hundreds of people. Dual suicide car bombings — one outside the Algerian prime minister's homein April 2007 took 23 lives, with speculation that AQIM employed methods learned in, or transferred from, the insurgency in Iraq. ${ }^{23}$

Droukdel also expanded operations into the wider region, adopted al-Qaida's media style, and encouraged Algerians to join al-Qaida's efforts abroad. ${ }^{24}$ The result was the appearance of transnational terrorist solidarity and aggrandizement for both groups. Yet there is no evidence that al-Qaida exercised any direct control over AQIM, and some analysts have concluded that the so-called merger was simply a "marriage of 
convenience" for both sides. ${ }^{25}$ The adoption of the AQIM title was thus more of a rebranding of the GSPC than a true "expansion" of al-Qaida. The leadership and members of the former GSPC were unchanged, and its essential preoccupation with the Algerian government did not waver.

AQIM's area of operations did shift, however, and its survival mechanism became blending in with Sahelian populations, particularly those also aggrieved by their own governments. Chief among these groups are the Tuaregs of northern Mali, to which AQIM brought a fresh supply of resources. ${ }^{26}$ As the Algerian government pushed GSPC cells out of Algeria into the Sahelian and Saharan zones that straddle ancient trade routes, the network discovered that kidnapping for ransom and various forms of smuggling were highly lucrative activities. ${ }^{27}$

AQIM members brought this wealth to their new communities, married into poorer families in the region, and acted as an "Islamic charity"-effectively becoming an integral element of society. ${ }^{28}$ These profit-making ventures muddied AQIM's commitment to its ideological goals and at times turned AQIM into an extremist criminal cartel. One of its senior commanders, Mokhtar Belmokhtar, was even known by the nickname "Marlboro Man" for smuggling such a high volume of cigarettes around the Sahel. ${ }^{29}$

The influx of cash may have exacerbated existing tensions, and a splinter group calling itself the Movement for Oneness and Jihad in West Africa was established in 2011. ${ }^{30} \mathrm{~A}$ spate of subsequent divisions and mergers continued, when the remnants of the Movement and other groups, including al-Murabitoun, merged to form yet another organization called Jamaat Nusrat al-Islam wal-Muslimin (Group to Support Islam and Muslims). ${ }^{31}$

The Algerian state's success at infiltrating and quashing Islamist groups within its own territory has pushed extremists to the fringes of the Sahara and Sahel. Combined with recent counterterrorism operations by other regional states and France, Algeria's long-term fight against AQIM and its predecessor organizations means the group today is fractured and searching for ways to survive- perhaps by re-joining splinter groups and competitors. ${ }^{32}$

AQIM has a shown a resiliency possible in part by its ability to shift focus on Mali's border regions with Niger and Burkina Faso. Although the group remains contained to the Sahel, it continues to menace Sahelian countries. The group also still struggles to hold territory when confronted with law enforcement or military operations. ${ }^{33}$ Time will tell whether the loss of its long-time leader, Droukdel, in June 2020 will degrade AQIM's operations.

Al-Qaida's Sahel affiliates also have continued to experience several rounds of splintering and re-alignment. For one splinter group, al-Mourabitoun, this process included a complete shift in loyalties to the Islamic State, which now recognizes al-Mourabitoun's successor organization, the Islamic State in the Greater Sahara, as one of its regional affiliates. ${ }^{34}$

\section{Boko Haram: act locally, align globally}

If AQIM proved surmountable operationally, the theocratic and ideological sources of its agenda appear to be more durable and resonant in other contexts. In 2002, some 4,000 kilometers away, a man named Mohammed Yusuf began preaching against the secularism and corruption of the Nigerian state from his mosque in the northeastern city of Maiduguri. ${ }^{35}$

Although his message contained an inherent tension between opposition to so-called Western culture and opposition to Nigerian politics, Yusuf focused on Nigerian targets. Echoing the earlier fundamentalist ideology of the GIA in Algeria, Yusuf and his followers began to use violence to punish Muslims whom they accused of indulging in apostasy, often relying on quick hit-and-run tactics using light arms and traveling by car or motorcycle. ${ }^{36}$ These attacks drew police attention, and over the next several years, the group's engagement with law enforcement escalated into ever-deadlier exchanges. The violence spread into neighboring Nigerian states and culminated in a conflagration in 2009 that left Boko Harem leader Yusuf and several hundred other adherents dead, with hundreds more captured by police. ${ }^{37}$ 
The group seemed to be in full retreat and was inactive for almost a year until Yusuf's second-incommand, Abubakar Shekau, released a video and a manifesto announcing his leadership of Boko Haram and threatening revenge on the Nigerian state as well as its Western supporters. A one-time theology student, Shekau took pride in extreme violence and appears to have cheated death at the hands of security forces multiple times. ${ }^{38}$ Although it is unclear how directly he commands the whole of Boko Haram's forces, much of the terror Boko Haram inspires is rooted in Shekau's ruthless personality.

Often expressing common cause with al-Qaida, Boko Haram launched a series of improvised explosive device attacks at the end of 2010 and the beginning of 2011, targeting government installations, religious leaders, and politicians. In mid-June 2011, the group executed its first suicide bombing inside Nigeria against the police inspector-general, and in August, the group launched another suicide bombing against the United Nations offices in the country's capital, Abuja. ${ }^{39}$

Attacks escalated throughout 2013 and 2014, when Boko Haram expanded its array of targets, frequently engaged Nigerian forces directly, and overran border towns and increasing swathes of Nigerian territory. The attacks became numbing in their frequency. ${ }^{40}$ The group so succeeded at cowing security forces and terrorizing local populations that Shekau declared it had enough territorial control to establish a "caliphate" in northern Nigeria. ${ }^{41}$

By the end of 2014, Boko Haram had earned the dubious honor of being called the world's deadliest terror group by the Institute for Economics and Peace..$^{42}$ In its 2015 report on global terrorism, the institute noted that in 2014 Nigeria "witnessed the largest increase in terrorist deaths ever recorded by any country, increasing by over 300\% to 7,512 fatalities." ${ }^{43}$ It also reported that Boko Haram was responsible for 10 of the 20 most fatal terrorist attacks worldwide in $2014 .^{44}$

The bloody campaign that included more Muslim than non-Muslim victims did not sit well with every Boko Haram member, and a splinter group known as Ansaru formed in 2012 partially in response to this concern. Loosely affiliated with al-Qaida, and guided by leaders who had received training in Algeria, Ansaru focused its operational energies on kidnapping foreigners in the northern and northwestern regions of Nigeria. ${ }^{45}$

With a much smaller member base than Boko Haram, Ansaru served to slightly widen the scope but not the scale of militant Islamic activity in the country. In a video from 2015, for example, the group argued that Boko Haram "launches physical and bomb attacks at Muslims and public places. . . These acts are contrary to the teachings of Islam." ${ }^{46}$ Eventually, the Ansaru-Boko Haram divide came to reflect the competition between al-Qaida and the Islamic State. Regardless, the divisions among Islamist groups in the Sahel reveal a variety of competing goals and ideologies that prevent the modest numbers of militants from massing into a truly formidable challenge to established governments like in Nigeria.

\section{The state response to Boko Haram}

The initial Nigerian government response to Boko Haram was swift and brutally executed, imposing a series of setbacks on the organization, including the death of its leader, Mohammed Yusuf, in 2009. Under the new leadership of Shekau, however, Boko Haram regrouped and pushed back with increasing lethality, leveraging their reconstituted numbers, training, and often-superior equipment. ${ }^{47}$

In this second phase of the group's development, Boko Haram's boldness and tactical dominance throughout 2012 and 2013 largely pushed government forces out of much of the northeast. Declaring a state of emergency in the northern states of Borno, Adamawa, and Yobe, the Nigerian government launched a Joint Military Task Force and stationed divisions in the north to push back against the group. ${ }^{48}$

Security forces reportedly responded to Boko Haram's brutality in kind, using ruthless tactics and indiscriminate violence to intimidate both the terrorists and any possible sympathizers. ${ }^{49}$ In its 2014 Country Report on Human Rights, the U.S. State Department noted, "observers asserted that the climate of impunity for serious crimes led to the victimization of the civilian population by both Boko Haram and 
government forces." ${ }^{50}$ Despite international pressure and a renewed effort to professionalize the military forces, accusations of extrajudicial killings continued to follow Nigerian forces. ${ }^{51}$

Meanwhile, Boko Haram was organizationally displaced, if undeterred. Much of the group withdrew from northeastern towns and villages into the Sambisa Forest in Borno State and frequently sought haven across the border in northern Cameroon, as well as in Niger and Chad. Their will did not appear to suffer, as they continued to conduct coordinated attacks in Nigerian and Cameroonian territory, signaling an enduring commitment to threatening local populations and government forces. ${ }^{52}$

Upon his election in 2015, Nigerian President Muhammadu Buhari pledged to defeat Boko Haram by the end of the year and took several actions to advance this goal, including moving the army's command center from Abuja to Maiduguri and dismissing several senior military officers suspected of corruption. ${ }^{53}$ The government also increased resources for the military after years of underinvestment.

The reinvigorated effort, coupled with regional pressure on the group, paid operational dividends. Nigerian forces successfully routed Boko Haram from all of the territory it previously held, seized weapons caches, and destroyed former hideouts. At the same time, the Buhari administration announced renewed efforts to investigate and prosecute military human rights violations.

Nigeria's revitalization of its counterterrorism operations was preceded by a regional push for collaboration to combat the Boko Haram threat in the wake of the Chibok kidnappings in 2014. The Chibok incident - in which Boko Haram kidnapped more than 200 female students—served as a wake-up call for the Nigerian government. ${ }^{54}$ International pressure on Abuja mounted, and U.S. Congressional pressure on the Barack Obama administration to conduct a rescue operation also inspired a renewed American effort to assist the Nigerian security services. ${ }^{55}$

Meanwhile, representatives from Benin, Chad, Cameroon, Niger, and Nigeria met in Paris in May 2014 with officials from the United States, United Kingdom, and the European Union and conducted a series of follow-on meetings to reactivate a long-standing but disused Multinational Joint Task Force originally organized through the Lake Chad Basin Commission. Member countries pledged troops to the fight against Boko Haram, and by January 2015, the African Union endorsed plans for an 8,700-strong force and requested a United Nations trust fund to resource the effort. ${ }^{56}$

The tasks include targeted operations against Boko Haram, capturing members of the terrorist group, border security, recovery of abductees, regional coordination, and intelligence sharing. ${ }^{57}$ Coupled with Nigeria's renewed offensive, regional efforts paid real dividends: under this pressure, Boko Haram split into two factions, presumably also dividing resources and fighters in a move likely to weaken terrorist efforts operationally. ${ }^{58}$

Despite the international diplomatic and political support for the mission, the task force frequently suffers from materiel and logistics shortfalls. Task force members focus largely on their own border regions, and it is unclear how much tactical, operational, or strategic coordination actually occurs. ${ }^{59}$ Boko Haram also refuses to fade away despite the increased pressure, demonstrating its withering, if episodic, ability to overtake military bases. Boko Haram's capture of Baga along with the town's task force headquarters in early 2015 marked an early setback for regional efforts. ${ }^{60}$ Militants are continuously able to regroup after task force operations, since the offensives are typically not sustained. ${ }^{61}$

Like the GSPC, Boko Haram has demonstrated its ambitions to benefit from connections with global Islamist terrorist movements since at least 2009. Shekau began by emulating al-Qaida's propaganda style and tried to connect to its core leadership. Yet rather than substantive loyalty, Shekau's interest seems to have been more in affiliating with whomever's public profile loomed larger. After 2011, for example, as core al-Qaida seemed to be in retreat, Shekau shifted his attentions to the Islamic State. Boko Haram began to refer to the territory seized in northern Nigeria as a caliphate and expressed support for Islamic State leader Abu Bakr al-Baghdadi. ${ }^{62}$

By March 2015, Shekau had publicly declared Boko Haram's allegiance to the Islamic State, a fealty that appeared unsolicited but which al-Baghdadi eventually accepted. ${ }^{63}$ The effect on Boko Haram, at least in 
terms of its media profile, was stark. Gone were the fuzzy videos. In their place were slick video techniques, a social media presence, a new logo, and the Islamic State flag branding. ${ }^{64}$

In 2016, however, Boko Haram split into two factions. Shekau continued to lead one faction, but the second faction came under the leadership of Abu Musab al-Barnawi, the purported son of Boko Haram's original founder Mohammed Yusuf. ${ }^{65}$ Al-Barnawi's faction, the Islamic State West Africa Province, claimed it split from Shekau because it disapproved of his rampant attacks on other Muslims. ${ }^{66}$ The Islamic State appeared to withdraw its official support to Shekau's faction and instead recognized the al-Barnawi-led faction as an official affiliate. The Islamic State West Africa Province prioritizes attacks on state security forces and is more discriminate in its targeting selection, while Shekau's Boko Haram continues to conduct more indiscriminate attacks. The degree to which the two factions coordinate remains unclear. ${ }^{67}$

\section{Conclusion}

The Algerian and Nigerian experiences with Islamist terrorism demonstrate the fundamentally parochial concerns that animate members of global jihadi networks and the extent to which capable government institutions make the difference in terrorists' success or failure. In the case of the GSPC and AQIM, the durability of the Algerian state and pressures from Western countries have proven formidable obstacles to Islamism in the Sahel. Yet for Nigeria, government fecklessness allowed an initially surmountable extremist group to flourish and expand.

Local terrorist organizations benefit in terms of recruitment and respect when they affiliate with internationally recognized groups such as al-Qaida and the Islamic State. Strategically, these affiliations are meaningful: the ideological commonalities between far-flung groups and their tendency to share motivational grievances against Western actors and cultures do indicate a broad challenge to U.S. and European security and freedom of engagement. Operationally, groups such as AQIM and Boko Haram remain grounded in their immediate political and social surroundings.

These surroundings, however, matter. After the civil war, the Algerian state consolidated political power once again and maintained a robust security capacity. AQIM fled into the Sahara because it could not find reliable havens in Algeria. In contrast, Nigeria systematically divested in its military and engaged in transparent corruption, supplying ripe political and operational targets for an anti-state insurgency. Only when Abuja began to reinvest in its security capacity and welcome more regional cooperation did Boko Haram face setbacks.

Throughout the lifecycle of these two movements, links to global jihadi groups have proven more cosmetic than structural. This is in part due to history. Violent Islamism in North and West Africa has leveraged global narratives to serve local goals in part because it springs from an anti-colonial framework that is itself about local action referencing a transnational movement. ${ }^{68}$ This sense of common history squares the circle between domestic politics and global jihad, and minimizes rivalry among groups on the continent while keeping them fixated on their own capitals.

They also suggest an increasing appreciation among these groups for a common purpose: the rejection of decades of failed governance in their home countries and an effort to replace those failures with a rigid form of Islamist authority. ${ }^{69}$ To the extent that the West is perceived as connected to those governance failures, that is where these groups consider themselves global actors-but the actions themselves are nevertheless still against proximate targets, such as AQIM's attack against the United Nations compound in Algiers.

In the end, groups such as AQIM, Boko Haram, and its offshoots pose a limited threat to North and West African stability. When they succeed in launching attacks and holding territory, they provide a demonstration effect-a kind of warning to those who do not invest in governing institutions and fail to comprehend the structural role Islam plays in the politics of North and West African states. 


\section{Notes}

1 Graham E. Fuller, Algeria: The Next Fundamentalist State? (Santa Monica: RAND Corporation, 1996), 6-8.

2 Andrew J. Pierre and William B. Quandt, The Algerian Crisis: Policy Options for the West (Washington, DC: Carnegie Endowment for International Peace, 1996), 7-8.

3 Ibid., 10.

4 David B. Ottaway, “Algeria: Bloody Past and Fractious Factions," Wilson Center, August 27, 2015, www.wilsoncenter.org/article/algeria-bloody-past-and-fractious-factions.

5 James D. Le Sueur, Between Terror and Democracy: Algeria Since 1989 (Black Point, NS: Fernwood Publishing Ltd, 2010), 54-58.

6 Ottaway, "Algeria."

7 Le Sueur, Between Terror and Democracy, 122.

8 John M. Nomikos and Aya Burweila, "Another Frontier to Fight: International Terrorism and Islamic Fundamentalism in North Africa," International Journal of Intelligence and CounterIntelligence 22 (2008): 52.

9 Dalia Ghanem, The Shifting Foundations of Political Islam in Algeria (Washington, DC: Carnegie Endowment for International Peace, 2019).

10 Ibid.

11 Ray Takeyh, "Islamism in Algeria: A Struggle Between Hope and Agony," Journal of Middle East Policy 10 , no. 2 (2003): 62-75.

12 Ibid.

13 Le Sueur, Between Terror and Democracy, 140.

14 Alan Riding, "Hijacked Airliner Forced to France," New York Times, December 26, 1994, www.nytimes. com/1994/12/26/world/hijacked-airliner-forced-to-france.html.

15 Lauren Vriens, "Backgrounder: Armed Islamic Group,” Council on Foreign Relations, May 27, 2009, www.cfr.org/ backgrounder/armed-islamic-group-algeria-islamists.

16 Takeyh, "Islamism in Algeria."

17 Ghanem, The Shifting Foundations.

18 Le Sueur, Between Terror and Democracy, 145.

19 Lianne Kennedy Boudali, The GSPC: Newest Franchise in al-Qa'ida's Global Jihad (West Point: Combating Terrorism Center, 2007), 3.

20 Ibid.

21 Christopher S. Chivvis, The French War on al-Qa'ida in Africa (New York: Cambridge University Press, 2016), 22-23.

22 Nomikos and Burweila, "Another Frontier to Fight," 51.

23 Boudali, The GSPC, 7.

24 Chivvis, The French War, 23.

25 Christopher S. Chivvis and Andrew Liepman, North Africa's Menace: AQIM's Evolution and the U.S. Policy Response (Santa Monica: RAND, 2013), 4.

26 Morten Boas, "Guns, Money, and Prayers: AQIM's Blueprint for Security Control of Northern Mali," CTC Sentinel 7, no. 4 (2014): 1-5.

27 Modibo Goita, West Africa's Growing Terrorist Threat: Confronting AQIM's Sahelian Strategy (Washington, DC: Africa Center for Strategic Studies, 2011), 1-4.

28 Boas, "Guns, Money, and Prayers," 4.

29 Andrew Wojtanik, Mokhtar Belmokhtar: One-Eyed Firebrand of North Africa and the Sahel (West Point: Combating Terrorism Center, 2018), 10-11.

30 “MUJAO/al-Mourabitoun," European Council on Foreign Affairs, accessed November 18, 2020, www.ecfr.eu/ special/sahel_mapping/mujao.

31 Jama'at Nasr al-Islam wal Muslimin (JNIM) (Washington, DC: Center for Strategic and International Studies, 2018).

32 Thomas Joscelyn, “Al Qaeda Groups Reorganize in West Africa,” The Long War Journal, March 13, 2017, www. longwarjournal.org/archives/2017/03/analysis-al-qaeda-groups-reorganize-in-west-africa.php.

33 Human Rights Watch, "We Found Their Bodies Later That Day": Atrocities by Armed Islamists and Security Forces in Burkina Faso's Sahel Region (New York: Human Rights Watch, 2019); "Mapping Armed Groups in the Sahel," European Council on Foreign Relations, accessed November 10, 2020, www.ecfr.eu/mena/sahel_mapping/aqim.

34 Jason Warner, “Sub-Saharan Africa's Three 'New' Islamic State Affiliates," CTC Sentinel 10, no. 1 (2017): $28-32$. The Islamic State has also been involved in attacks in the border regions of Mali, Niger, and Burkina Faso, including a significant ambush of U.S. Special Operations Forces outside a Nigerien village in 2017. For more, see Alice Hunt Friend, DoD's Report on the Investigation into the 2017 Ambush in Niger (Washington, DC: Center for Strategic and International Studies, 2018). 
35 Jacob Zenn, "Leadership Analysis of Boko Haram and Ansaru in Nigeria," CTC Sentinel 7, no. 2 (2014): 23-29.

36 J. Peter Pham, "How Boko Haram Became the Islamic State's West Africa Province," The Journal of International Security Affairs 30 (2016): 17-26.

37 Zenn, "Leadership Analysis," 23.

38 Terrence McCoy, "The Myth of the Unkillable Abubakar Shekau: Is the Feared Boko Haram Leader Dead, or Was It a Double?" Washington Post, September 25, 2014, https://nationalpost.com/news/the-myth-of-the-unkillable-abubakar-shekau-is-the-feared-boko-haram-leader-dead-or-was-it-a-double; "Man Claiming to be Boko Haram's Abubakar Shekau Surfaces in Video," Voice of America, September 25, 2016, www.voanews.com/africa/ man-claiming-be-boko-harams-abubakar-shekau-surfaces-video.

39 Senan Murray and Adam Nossiter, "Suicide Bomber Attacks UN Building in Nigeria," New York Times, August 26, 2011, www.nytimes.com/2011/08/27/world/africa/27nigeria.html.

40 Bureau of Democracy, Human Rights, and Labor, Nigeria Country Report on Human Rights (Washington, DC: U.S. Department of State, 2014).

41 Robert Windrem, "While World Watches ISIS, Boko Haram Declares Its Own Caliphate in Nigeria," NBC News, September 15, 2014, www.nbcnews.com/storyline/missing-nigeria-schoolgirls/while-world-watches-isisboko-haram-declares-its-own-caliphate-n202556.

42 Institute for Economics and Peace, Global Terrorism Index 2015: Measuring and Understanding the Impact of Terrorism (Sydney: Institute for Economics and Peace, 2015).

43 Ibid.

44 Ibid.

45 Connor Gaffey, "What Is Ansaru, the Other Military Islamist Group in Nigeria Besides Boko Haram?” Newsweek, April 4, 2016, www.newsweek.com/what-ansaru-nigerias-other-militant-group-443785.

46 Thomas Joscelyn, "Jihadist Divisions Grow in Nigeria," Long War Journal, February 23, 2015, www.longwarjournal.org/archives/2015/02/jihadist-divisions-grow-in-nigeria.php.

47 Zenn, "Leadership Analysis," 23-28.

48 Korva Coleman, "Nigeria Declares State of Emergency in 3 States," National Public Radio, May 15, 2013, www.npr. org/sections/thetwo-way/2013/05/15/184201332/nigeria-declares-emergency-in-3-states-over-terrorism.

49 Amnesty International, Stars on Their Shoulders, Blood on Their Hands: War Crimes Committed by the Nigerian Military (New York: Amnesty International, 2015).

50 Bureau of Democracy, Human Rights, and Labor, Nigeria Country Report on Human Rights.

51 Michelle Faul and Ibrahim Abdulaziz, "Nigeria: People Detained by Military Disappear in Northeast," Washington Post, February 20, 2016, https://apnews.com/article/80b83de26e3040ebb94fe7f37849f32e.

52 Scott Menner, "Boko Haram's Regional Cross-Border Activities," CTC Sentinel 7, no. 10 (2014): 10-15.

53 Julian Borger, "Muhammadu Buhari Pledges to Defeat Boko Haram," Guardian, February 26, 2015, www.theguardian.com/world/2015/feb/26/nigerian-election-muhammadu-buhari-pledges-defeat-boko-haram.

54 Lesley Stahl, "The Chibok Girls: Survivors of Kidnapping by Boko Haram Share Their Stories," 60 Minutes, February 17, 2019, www.cbsnews.com/news/the-chibok-girls-survivors-of-kidnapping-by-boko-haram-sharetheir-stories-60-minutes/.

55 Ernesto Londono and Anna Gearan, "U.S. Prepares to Dispatch Small Team to Nigeria to Assist in Search for Kidnapped Girls," Washington Post, May 7, 2014, www.washingtonpost.com/world/national-security/us-preparesto-dispatch-small-team-to-nigeria-to-assist-in-search-for-kidnapped-girls/2014/05/07/bd9f8094-d604-11e395d3-3bcd77cd4e11_story.html.

56 Maïa de la Baume and Alissa J. Rubin, "West African Nations Set Aside Their Old Suspicions to Combat Boko Haram," New York Times, May 17, 2014, www.nytimes.com/2014/05/18/world/africa/west-african-nations-setaside-their-old-suspicions-to-combat-boko-haram.html.

57 Ionel Zamfield, “At a Glance: African-Led Counterterrorism Measures Against Boko Haram," European Parliamentary Research Service, March 2015, www.europarl.europa.eu/RegData/etudes/ATAG/2015/551302/EPRS_ ATA\%282015\%29551302_EN.pdf.

58 Margaret Besheer, "Regional Task Force Battles Boko Haram," Voice of America, March 14, 2017, www.voanews. $\mathrm{com} /$ africa/regional-task-force-battles-boko-haram.

59 Thomas Fessy, “Boko Haram: Can Regional Force Beat Nigeria’s Militant Islamists?” BBC, March 3, 2015, www. bbc.com/news/world-africa-31695508.

60 "The Massacre Nigeria Forgot: A Year After Boko Haram's Attack on Baga," Guardian, January 9, 2016, www.the guardian.com/world/2016/jan/09/nigeria-baga-massacre-boko-haram-1-year-on; Pham, "How Boko Haram," 23.

61 John Campbell, "Mixed Results in Evaluation of Multinational Effort Against Boko Haram," Council on Foreign Relations, July 16, 2020, www.cfr.org/blog/mixed-results-evaluation-multinational-effort-against-boko-haram.

62 Pham, "How Boko Haram," 23. 
63 “Nigeria's Boko Haram Pledges Allegiance to Islamic State," BBC, March 7, 2015, www.bbc.com/news/ world-africa-31784538.

64 Rukmini Callimachi, "In Newly Sophisticated Boko Haram Videos, Hints of Islamic State Ties," New York Times, February 20, 2015, www.nytimes.com/2015/02/21/world/africa/in-newly-sophisticated-boko-haram-videoshints-of-islamic-state-ties.html.

65 International Crisis Group, Facing the Challenge of the Islamic State in West Africa (Brussels: International Crisis Group, 2019).

66 Ibid.

67 John Campbell, "Suspected Leadership Changes to IS-Backed Boko Haram Faction Continue," Council on Foreign Relations, March 12, 2019, www.cfr.org/blog/suspected-leadership-changes-backed-boko-haram-faction-continue.

68 Chivvis makes the point that the GSPC/AQIM grew out of a struggle against French colonization and continues to target France as an expression of its opposition to the form of government Algeria inherited. See Chivvis, The French War, 25.

69 For a further exploration of this phenomenon, see Yaroslav Trofimov, "Jihad Comes to Africa," Wall Street Journal, February 5, 2016, www.wsj.com/articles/jihad-comes-to-africa-1454693025. 


\title{
8 \\ AL-SHABAAB AND THE HORN OF AFRICA
}

\author{
Ken Menkhaus
}

The Horn of Africa is a region plagued by crisis. Its many challenges have created conducive conditions for criminal and terrorist networks and have led to extensive international intervention. The region's troubles have produced an exceptionally difficult operating environment for its residents, governments, and external actors seeking to promote stability and development.

Today, the Somali militant group al-Shabaab remains the most dangerous terrorist organization operating in the Horn. It became an official al-Qaida affiliate in 2012, and it has conducted a number of major international terrorist attacks in the region, including in Kampala in 2010 and Nairobi in 2013 and 2019. It remains the main source of political violence in Somalia.

This chapter provides general background on the Horn of Africa but primarily focuses on Somalia due to ongoing U.S. military action against al-Shabaab. After providing an overview of the modern history of Somalia, the chapter recounts the evolution of al-Shabaab and how it gained strength in the country. It also examines the factors that have been instrumental to al-Shabaab's survival despite persistent U.S. and international opposition.

\section{Background of the Horn}

The Horn of Africa is home to hundreds of different ethno-linguistic groups. Some, such as the Oromo, number close to 40 million and are better described as nations. The region is diverse religiously, with inhabitants practicing Islam, Orthodox Christianity, Catholic and Protestant Christianity, and indigenous religions. Islam and Orthodox Christianity have existed in much of the Horn for more than 1,000 years and are deeply embedded in local culture and identity. ${ }^{1}$ For most of that history, Muslim and Christian populations generally co-existed peacefully. In more recent times, however, tensions between the region's faith groups have spiked, reflected in growing intolerance and occasional communal violence.

The region's states-Sudan, South Sudan, Ethiopia, Eritrea, Somalia, Djibouti, Uganda, and Kenyacount among the poorest and least developed in the world (see Figure 8.1). ${ }^{2}$ Most of the population lives at or near subsistence levels, and basic development indicators such as infant mortality, literacy, and life expectancy are extremely low. The region is prone to recurring humanitarian crises and even periodic famine. Pressures on the land have strained carrying capacity and have led to deforestation, degraded rangelands, desertification, and in some areas serious long-term water shortages.

Population growth and fertility rates are among the highest in the world. This contributes to pressure on education, housing, land, and employment, fueling urban drift and intensifying the Horn's high levels 


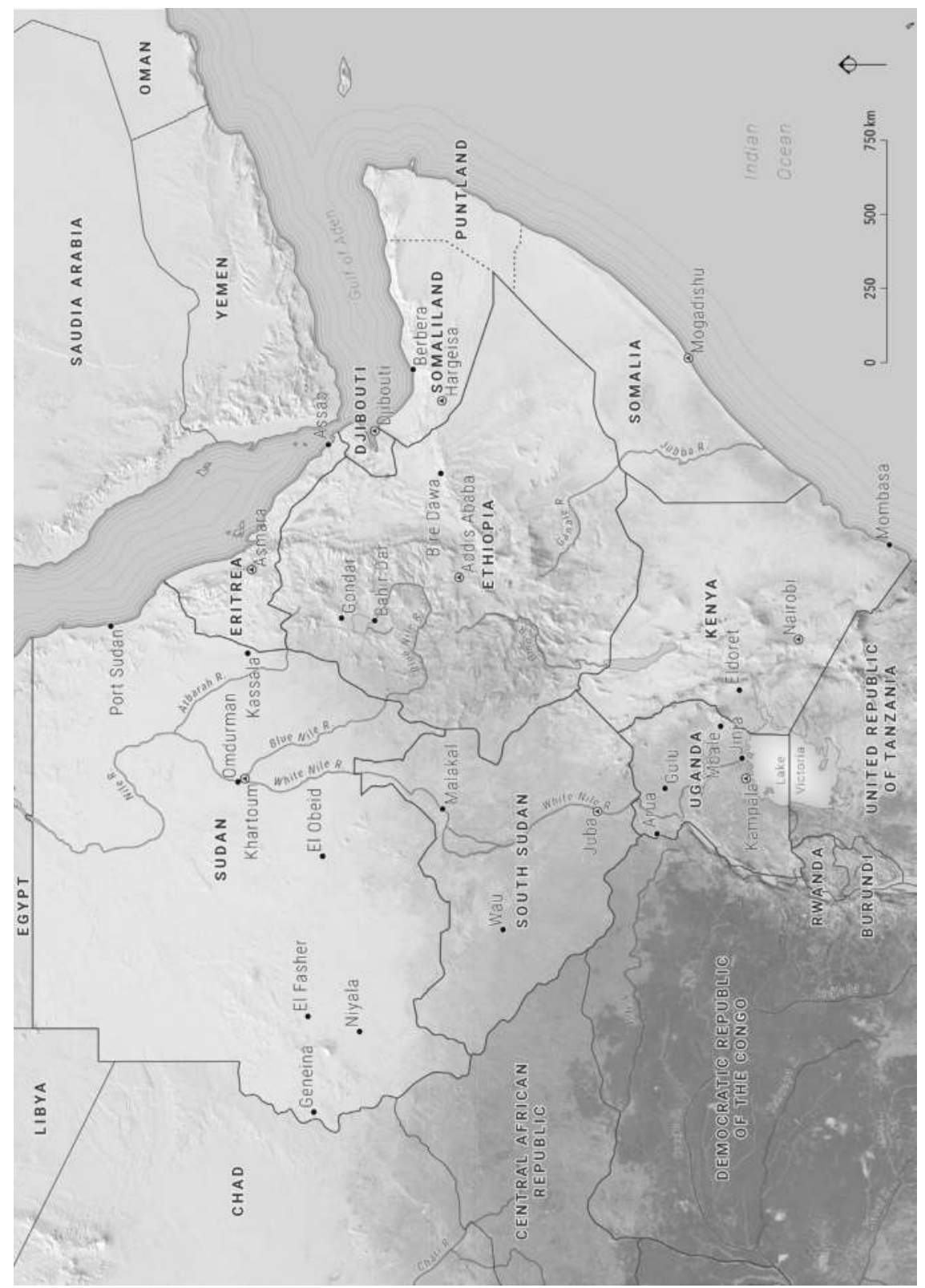

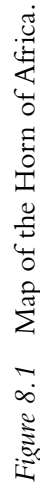


of urbanization. Although several of these countries-most notably Ethiopia, Kenya, and Uganda-have enjoyed strong economic growth rates in recent years, most of the economic benefits are concentrated in a few of the region's major urban centers. Urban unemployment is high.

Tens of millions of people live in remote areas more or less beyond the reach of state authority, which leads to informal or hybrid governance arrangements, such as local protection forces, protection rackets, and tribal or clan customary authorities. Where governments are functional, some are beset by high levels of corruption. Somalia, South Sudan, Sudan, and Yemen are ranked among the six most corrupt governments in the world. ${ }^{3}$

States in the Horn generally feature center-periphery dynamics, in which a core region comprising the capital and economically valuable land is the center of political attention and services, while remote peripheral or border areas have been marginalized, with little infrastructure and basic services. This has created grievances in some peripheral communities that armed movements exploit. In Ethiopia, Eritrea, and Kenya, core-periphery dynamics partially correspond to religious divisions, with Muslim populations concentrated in peripheral zones. Armed groups, including terrorists, have exploited the region's hinterlands and now pose serious security threats at both the national and global levels.

The formal security sector is often responsible for predation on the citizenry rather than a source of protection and rule of law. ${ }^{4}$ In some cases, security forces are controlled by a dominant ethnic group and hence feared by other groups. ${ }^{5}$ In other cases, security forces are unpaid or irregularly paid, so they prey on local populations as a source of livelihood. These dynamics reduce the ability of the state to provide protection, security, and rule of law and can create complications for external actors engaged in support to regional security forces. ${ }^{6}$

Across the entire region, national and local politics are dominated by ethno-politics. Many governments reflect a form of ethno-hegemony, with one empowered ethnic group using control of the state to advance its elite's political and economic interests. Where multi-party democracy exists, parties tend to be strongly associated with an ethnic group, reducing elections to a form of ethnic census. Where political decentralization has been instituted, sub-national states or counties have been drawn more or less along ethnic or tribal lines. ${ }^{7}$

Nationalist movements and sentiments exist but are generally not as strong as affiliation to sub-national identity. Clannism has been particularly persistent and divisive in Somalia, and even al-Shabaab-which has been a vocal critic of clannism and is the political actor most committed to transcending clan-has failed to overcome it. ${ }^{8}$

Few borders in the region are actively patrolled. As a result, movement of goods, people, weapons, and contraband across borders is common, as is the spillover from violent conflicts. Al-Shabaab, for example, has exploited the poorly policed Kenya-Somalia border zone. The waters of the Gulf of Aden in the northern Horn do not serve as a barrier but instead are a maritime highway with ample movement of people, livestock, and goods across to Yemen, which is deeply enmeshed in the commercial economy of the Horn.

The Horn has been host to some of the world's costliest and longest-running wars. Sudan's civil war lasted several decades and cost an estimated two million lives. The civil war that erupted in South Sudan in December 2013 has led to the deaths of somewhere between 50,000 to 300,000 people and displaced over one million. ${ }^{9}$ The Somali civil war of 1991-1992 triggered a famine that cost 250,000 lives and produced a million refugees. War between Eritrea and Ethiopia in 1998-2000 led to 100,000 lives lost. ${ }^{10}$ Many other zones of the region suffer from chronic low-intensity warfare and flare-ups of communal violence.

Somali nationalists have long sought to unify all Somalis into a single nation-state and hence have rejected the colonially imposed borders with Kenya and Ethiopia, as ethnic Somalis inhabit most of eastern Ethiopia and northern Kenya, as well as half of Djibouti. These irredentist claims led to the Ogaden War of 1977-1978 between Somalia and Ethiopia, a war Somalia lost.

Today, the irredentist agenda is weak, but it can still be invoked to good effect by Somali nationalists and Islamo-nationalists and is an enduring preoccupation for the Ethiopian government. This has been a major 
factor in the long history of distrust and animosity between Ethiopia and Somalia, a tension that is likely to endure despite much improved relations between the two countries since 2017.

Al-Shabaab, which became an official al-Qaida affiliate in February 2012, remains the most dangerous terrorist group operating in the Horn. It continues to organize major terrorist attacks on both soft and hard targets in Somalia and the wider region. Most of its attacks outside Somalia have been in Kenya, but it has also successfully executed terrorist operations in Uganda and Djibouti, has links to violent terrorist networks in Tanzania, and has sought unsuccessfully to wage a war of terror on Ethiopia. ${ }^{11}$

\section{Somalia overview}

In Somalia, multiple clan liberation movements led to the fall of the Siad Barre regime in January 1991 and the collapse of the state. Somalia remained without a functional central government for 22 years. The civil war of 1991-1992 destroyed the capital Mogadishu, and the economy of plunder that ensued triggered a massive famine. A U.S.-led multinational peace enforcement effort, Operation Restore Hope, began in December 1992, and it immediately imposed some stability and ended the famine. Yet attempts to revive the central government failed.

A Mogadishu warlord, General Aideed, directed an attack on United Nations peacekeepers, and a fourmonth effort led by U.S. Special Operations Forces to capture Aideed culminated in a bloody raid in 1993 known as the Battle of Mogadishu, or Black Hawk Down, in which 18 U.S. troops and an estimated 500 Somalis were killed. The peace operation failed, and the United Nations withdrew in $1995 .{ }^{12}$

In the north, a breakaway region, Somaliland, declared independence from Somalia in May 1991 and gradually built up an internationally unrecognized, but effective, government. Somaliland has since been a zone of relative peace, security, and economic recovery in the eastern Horn.

Efforts to negotiate a revived state in Somalia succeeded in 2004 with the declaration of the Transitional Federal Government led by President Abdullahi Yusuf of the Majerteen/Darood clan. Yet armed groups associated with Hawiye clans in Mogadishu never accepted the Transitional Federal Government, and the governing body was unable to relocate to the capital from the southwestern town of Baidoa.

In 2006, the Islamic Courts Union (ICU), a broad umbrella group of Sharia (Islamic law) courts, came into conflict with U.S.-backed militias in Mogadishu. In June 2006, the ICU consolidated control over all of Mogadishu and quickly expanded its authority across most of southern Somalia in an attempt to govern.

Somalis largely welcomed the peace and security provided by the ICU, but it was short lived. The ICU's main source of military strength was a small but disciplined set of Islamist fighters, some ex-mujahidin veterans from the war against the Soviets in Afghanistan. These committed fighters would later be called al-Shabaab. ${ }^{13}$ Hardliners in that group pushed the ICU into confrontation with neighboring Ethiopia, and Ethiopia launched a cross-border offensive in December 2006, quickly crushing the ICU and forcing its leaders to flee to Eritrea. ${ }^{14}$

The Ethiopian military occupation of Mogadishu prompted armed resistance. Al-Shabaab regrouped and emerged as the lead faction in the insurgency. It succeeded in retaking most of southern Somalia and Mogadishu in 2007 and 2008, a period of destructive insurgency and counterinsurgency violence. AlShabaab was significantly more radical than the ICU and had direct ties to al-Qaida, to which its leaders pledged loyalty. The Ethiopian intervention was intended to quash an emerging Islamist threat on its borders, but its actions ended up producing the opposite effect. ${ }^{15}$

Ethiopia withdrew from Mogadishu in early 2009, and a large African Union peacekeeping force known as the African Union Mission in Somalia (AMISOM), composed mainly of Ugandan and Burundian troops, replaced the Ethiopian contingent. From 2009-2012, a violent stalemate ensued. The Transitional Federal Government moved back to the capital from Baidoa but remained a failed and corrupt government with virtually no capacity but protected by AMISOM. 
In 2012, under international pressure, Somalia held indirect elections that produced a post-transitional government called the Federal Government of Somalia (FGS) led by President Hassan Sheikh Mohamud. For a short period, optimism reigned. ${ }^{16}$ Somalis had public confidence in the new government, and alShabaab weakened and withdrew from major cities. Security improved, and Somali investments in business and real estate increased in the capital. The international community threw its full support behind the FGS and aid agencies, and diplomatic missions relocated from Nairobi, Kenya, to the large, protected Mogadishu International Airport zone.

Between 2013 and 2016, the situation deteriorated. Al-Shabaab regrouped yet again and began launching frequent, highly destructive terrorist attacks on soft and hard targets in Somalia and Kenya. The FGS was paralyzed by political in-fighting and high levels of corruption. Regional states such as Jubaland and South West State formed to advance the nascent federal system and became modestly functional as administrations.

In early 2017, indirect elections produced a new bi-cameral parliament and the selection of President Mohamed Abdullahi Mohamed as the new head of state. AMISOM troop-contributing countries announced their intent to begin withdrawing forces starting in 2018, adding urgency to the need to build up the capacity of the weak and clan-riven Somali National Army.

\section{6-2013: al-Shabaab's rise and fall}

Al-Shabaab began as a small circle of committed Somali jihadis who served as police in two of 14 Sharia courts in Mogadishu in or around 2002. A few of these jihadis had returned from Afghanistan as veteran mujahidin and maintained ties to al-Qaida's core organization and the East Africa al-Qaida cell in Kenya. They first came to the attention of the outside world through a string of political assassinations of exintelligence and military officers in Mogadishu in what was described as a "dirty war." 17

They also provided safe haven to a small number of East Africa al-Qaida figures who moved in and out of Mogadishu, prompting the U.S. government to partner with local militias in an attempt to apprehend the East Africa al-Qaida cell members. Although al-Shabaab numbered only a few hundred fighters at the time, it was disciplined, well-trained, and decisive in the ICU's rapid military victory in Mogadishu in 2006.

Al-Shabaab suffered heavy losses in the initial Ethiopian military intervention in southern Somalia in 2006, but it had regrouped by April 2007 and emerged as the lead armed resistance against the Ethiopian army and the Transitional Federal Government. It quickly attracted broad support from Somalis at home and abroad, even from those who despised its radicalism. It was widely viewed by Somalis as a legitimate form of resistance to an illegal foreign occupation.

Thousands of Somalis joined the group, and many hundreds of Somali youth in the diaspora, including Somali-Americans, traveled to Somalia to join as well. Other Somalis from the diaspora engaged in fundraising for al-Shabaab. ${ }^{18}$

During the 2007-2012 period, al-Shabaab paid its fighters a regular salary, which served as a major incentive to join because most militias were unpaid in Somalia. It generated funding from contributions, taxes, and especially revenues from control of seaports such as Kismayo, where lucrative charcoal exports contributed substantially to what the United Nations estimated was the group's total annual budget of $\$ 70-\$ 100$ million per year. ${ }^{19}$

By early 2008, al-Shabaab succeeded in retaking almost all of southern Somalia and controlled most of the capital Mogadishu. This was the group's high-water mark.

From the outset, al-Shabaab has been attentive to public relations, focusing on four main targets of influence: Somalis in country, Somalis in the diaspora, the global Islamic umma, and al-Shabaab's enemies.

In country, the group relies primarily on radio broadcasts, sermons, and speeches delivered to assemblies in its area of control. For external public relations-which is directed at Somalis in the diaspora, the global 
Islamic umma, and the group's non-Somali enemies - the group has relied on a combination of internet chat rooms, videos, affiliated online news sites, and Twitter. Its periodic videos were initially crude and amateurish in 2007-2008 but have since become significantly more sophisticated. Its real-time use of Twitter to mock Kenyan security forces and implore Muslims worldwide to take up the call to jihad during its attack on the Nairobi Westgate Mall in 2013 revived its reputation in global jihadi circles. ${ }^{20}$

During the 2007-2012 period, al-Shabaab always framed its objectives more by what the group opposed rather than promoting a vision for the future. For example, it opposed Ethiopian and then African Union peacekeepers in Somalia and sought to drive them out; it opposed the Somali transitional government, regardless of who held power in it; and it opposed any and all behavior and actors deemed un-Islamic.

Its strategic goals remained the subject of internal dispute. Some of its leaders embraced al-Qaida's vision of an eventual global Islamic caliphate, but the majority of the group's members and leaders were focused on an Islamo-nationalist agenda: the formation of an Islamic state in Somali-inhabited areas of the Horn, including northern Kenya and eastern Ethiopia. ${ }^{21}$

From 2009-2012, al-Shabaab entered a period of stalemate and decline. Designation of the group as a terrorist organization by the United States and other major governments had a chilling effect on diaspora support and fundraising. Al-Shabaab's rule in areas it controlled and its interpretations of Sharia were harsh and unpopular. Its use of suicide bombers against civilian targets shocked and angered Somalis, and its seeming indifference to heavy casualties sustained by its own young fighters led to blowback from angry clans.

Recruitment during this period was initially voluntary, but reports that al-Shabaab was forcibly conscripting boys and young men emerged in 2009. ${ }^{22}$ In some cases, they pressured and coerced families into providing a young male as a fighter in lieu of taxes-a practice that has intensified in recent years. In other cases, they went to schools to conscript boys.

The costs of association with al-Shabaab mounted, causing leaders of two large and powerful clans - the Haber Gedir Ayr and the Ogaden - to break with the group. ${ }^{23}$ The Ayr shifted support to an armed Sufi Muslim group, called Ahlu Sunnah Wal Jama, to oppose al-Shabaab, while the Ogaden Ras Kamboni militia flipped to an alliance with Ethiopia and Kenya and eventually captured Kismayo seaport from alShabaab in 2013 - an important strategic victory. Once al-Shabaab lost Kismayo seaport, it relied more aggressively on extortion of monthly "taxes" from Somali citizens and taxes collected at checkpoints on commercial traffic. ${ }^{24}$

Al-Shabaab was unable to fight against the heavy armor of AMISOM forces and found it difficult to hold territory in conventional battles. The group also struggled with mounting internal divisions over clan, tactics, goals, and links to al-Qaida. ${ }^{25}$ Finally, al-Shabaab's standing in Somalia was tarnished when it blocked food aid into areas it controlled — part of the group's campaign against international aid groupsduring the 2011 famine that claimed 260,000 lives. ${ }^{26}$

The regional response to al-Shabaab's ascent has been robust but not always effective. Ethiopia's initial two-year military occupation of southern Somalia in 2007-2008 succeeded in driving the ICU out of power, but al-Shabaab regrouped in the countryside and assumed the role as the lead resistance movement against the Ethiopian occupation. The Ethiopian intervention ended up as a quagmire and handed al-Shabaab an easy rallying point to mobilize anti-Ethiopian support among Somalis. In fact, by 2008, alShabaab had already retaken most of southern Somalia and much of the capital Mogadishu.

Yet in 2011, under pressure from AMISOM, al-Shabaab withdrew from most of Mogadishu and other towns it had controlled, retreating into the countryside. It shifted tactics, opting for a campaign of asymmetric warfare featuring greater use of hit-and-run ambushes, remote-controlled improvised explosive devices, and assassinations. The selection of a new, post-transitional government in August 2012 - the FGS - was greeted with significant public support and expectations, draining support from al-Shabaab.

By the summer of 2013, tensions inside al-Shabaab exploded in a bloody purge that left a number of top figures dead, triggered an exodus of most foreign fighters out of Somalia, and consolidated 
power into the hands of hardliner Ahmed Godane. ${ }^{27}$ Many observers felt that al-Shabaab was spiraling into terminal decline.

\section{3-2020: al-Shabaab remains resilient}

Despite the series of disastrous setbacks in 2011-2013, al-Shabaab remained resilient by adjusting its tactics, reinventing itself, and thus reviving its fortunes. Today, al-Shabaab still struggles with profound problems, and some of its tactics can be construed as signs of weakness or desperation rather than strength, but it has coped with its vulnerabilities and remains a dangerous terrorist threat to both Somalia and the wider region. $^{28}$

Al-Shabaab's revival can be attributed to a combination of key factors: redirection, asymmetric warfare tactics, fear and extortion, collusion, exploitation of grievances, and a strategy of stalemate.

\section{Redirection}

Faced with setbacks and fading fortunes inside Somalia, al-Shabaab redirected its violence at Kenya. For years, the group had used Kenya for recruitment, fundraising, and transit but had been restrained in its use of terrorist attacks on Kenyan territory. Kenya's decision to launch a military offensive in southern Somalia to drive al-Shabaab out of the border area in October 2011 angered and humiliated many Somalis and gave al-Shabaab an easy pretext for expanding its campaign of violence against Somalia's neighbor.

Its first major terrorist attack in Kenya, targeting the popular Westgate Mall in Nairobi in September 2013, was devastatingly successful. The terrorist operation dealt a heavy blow to Kenya: it exposed the country's inept and corrupt security forces, made al-Shabaab the top news story in the global media for a week, and recast al-Shabaab from a defeated insurgency to a major jihadi threat.

The attack also predictably baited the Kenyan government into launching a heavy-handed and indiscriminate law enforcement response that appeared to target all Somalis in Kenya-whether refugees, visitors, or Kenyan citizens. The Kenyan mass detentions and abusive police behavior angered Somali Kenyans and risked pushing some into al-Shabaab's arms. ${ }^{29}$

Al-Shabaab followed the Westgate Mall attack with a series of terrorist operations in Kenya, all focused on soft civilian targets and designed to drive a wedge between Kenyan Muslims and Christians that alShabaab hoped to exploit. Its tactic was to spare Muslims and massacre Christians. Al-Shabaab's propaganda videos called the attacks retribution for infidel invasion and occupation of Muslim lands, striking a chord with some Somalis. It increasingly drew on Somali and other recruits from within Kenyan society, leading many to conclude that its jihadi violence in Kenya was no longer only a cross-border affair but had become an internal Kenyan problem. ${ }^{30}$

In April 2015, al-Shabaab launched a bloody and brutal attack on Garissa University in the Somaliinhabited portion of northeast Kenya. The attack amounted to a cold-blooded massacre: al-Shabaab killed 148 students, picking out the Christians for execution while allowing Muslims to go free. The attack was so shocking that it may have worked against al-Shabaab by producing a backlash in Somali Kenyan society.

Improved Kenyan security and intelligence, supported by external allies, has also made Kenya a more difficult environment for al-Shabaab. Terrorist attacks in Kenya dropped off dramatically in 2016. By then, however, al-Shabaab had already shifted its energies back into Somalia.

\section{Asymmetric warfare tactics}

Al-Shabaab's tactical retreat from holding major towns and neighborhoods in Mogadishu allowed it to focus exclusively on asymmetric warfare, which played to its strengths. Guerrilla warfare has been implemented in two ways, both equally effective. 
One type is low risk, small-scale hit-and-run attacks, which include ambushes on convoys, remotecontrolled improvised explosive devices, grenade or mortar attacks, and assassinations. Al-Shabaab launches several of these on a daily basis. They are designed to harass, frighten, and demoralize Somalis in the FGS and AMISOM and make them engage in costly risk-averse countermeasures. AMISOM forces, for example, have been accused of indiscriminate firing on civilians, leading to significant civilian casualties and local anger.

The second type are more complex terrorist attacks aimed at high-visibility, hard targets such as government installations, AMISOM bases, Mogadishu International Airport, or heavily secured hotels frequented by Somali political figures and international diplomats. They typically involve a car bomb that destroys the entry gate, followed either by a vehicle filled with suicide fighters who swarm into the compound or a larger truck bomb that is detonated inside the compound.

Both variations of the model are difficult to counter and have resulted in major attacks with high casualties. In a few cases, where attacks target AMISOM forward bases, casualty levels have exceeded 100 people. ${ }^{31}$ The tactic requires capacity in bombmaking, which al-Shabaab possesses, and a ready supply of vehicle drivers and fighters who are prepared to die as martyrs. The latter is a potential weakness for the group, and evidence exists that al-Shabaab has resorted to coercing or duping young men into the role.

Not all of these complex terror attacks succeed, but enough are successful, and they have had a major impact on morale and security protocols for AMISOM, the FGS, and the international community. The expansive Mogadishu International Airport complex - where nearly all of the United Nations staff, AMISOM officers, embassies, contractors, military trainers, and other international visitors are concentratedis heavily fortified and bunkered.

The total loss of life in AMISOM is unknown due to a lack of transparency by troop-contributing countries on an issue they consider politically sensitive, but it is high and has produced public outcries in AMISOM member states. AMISOM's response to these attacks has been to prioritize force protection, including withdrawal from forward bases. AMISOM has been frustrated by Somali army clannism, collusion with al-Shabaab, failure to hold recovered space, and predatory behavior toward local communities, some of whom turn to al-Shabaab for protection.

Since 2014, AMISOM has ceased launching offensives against al-Shabaab. AMISOM is not fit for purpose to pursue a mobile, decentralized al-Shabaab in remote rural areas. ${ }^{32}$ This has allowed al-Shabaab to reenter villages and towns it had lost without a shot.

\section{Fear and extortion}

Al-Shabaab's most powerful tool is the Amniyat, a surveillance and intelligence network with operational capacity that has deep reach into all Somali institutions, including the Somali government, the Somali National Army, and many foreign aid agencies. The Amniyat's penetration of the government and security sector makes it difficult for Somali security forces to launch an operation without al-Shabaab having advance knowledge, which gives the group a significant advantage planning attacks.

The Amniyat tracks the employment and income of Somalis in its areas of operations and facilitates alShabaab's systematic taxation or extortion of money from citizens and businesses. Recent evidence exposed the fact that al-Shabaab's ability to extort money from Somalis extends into parts of northern Kenya. ${ }^{33}$

Those who refuse to pay are threatened with assassination and their businesses bombed. The Amniyat is responsible for planning and executing suicide bombings as well as hit-and-run attacks. ${ }^{34}$ The Amniyat instills fear, discourages Somalis from cooperating with the FGS and AMISOM, and pressures Somalis to collude with it. Its organization and tactics mimic those of an effective mafia. It is entirely possible that portions of the Amniyat network could outlast al-Shabaab itself and morph into a criminal extortion racket. 


\section{Collusion}

Somalis have become experts at risk management, and one means of managing risk in an uncertain political environment is to keep doors open to all sides. Al-Shabaab exploits this impulse and has forged a dense set of relations across Somali society involving collusion with al-Shabaab. Collusion even extends to individuals in the FGS and Somali army and touches most businesses and international agencies, whether their top officials are aware of it or not. ${ }^{35}$

\section{Exploitation of grievances}

Al-Shabaab recruits from across all Somali clans, but it has become adept at understanding and exploiting grievances of clans that have been marginalized in national or regional politics or preyed upon by dominant clans. These aggrieved clans turn to al-Shabaab as a tactical ally, as a means of resisting the Somali army or improving their bargaining position with regional or national authorities. The extent of grievances in Somalia, whether justified or not, has given al-Shabaab ample traction in some lineages, although the group has not been able to truly transcend the pervasive clannism in Somali society. The woeful performance and public unhappiness with the FGS since 2012 has been a gift to al-Shabaab, allowing it to contrast the corruption, clannishness, and paralysis of the government with its own more competent and clean record of local governance.

\section{Stalemate strategy}

Since 2011, al-Shabaab appears to be content to play for a draw in Somalia while expanding its recruitment and operational reach in East Africa. In Somalia, its strategy is to block progress by the FGS, demoralize Somali and international supporters of the FGS, consolidate its extortion network to collect taxes on people and businesses, and inflict enough losses on AMISOM to prompt it to withdraw. Al-Shabaab believes that time is on its side and that eventually a war of attrition will result in an AMISOM withdrawal and new opportunities for al-Shabaab to exploit.

AMISOM's troop-contributing governments have declared their intent to gradually withdraw from Somalia. While this process is likely to take years and may not result in a complete redeployment (some peacekeepers may stay on in a support role to the Somali National Army), the prospect of an eventual AMISOM withdrawal will produce a seismic change in the overall security environment in southern Somalia. If the Somali army is not able to insert itself and assume its proper role, the security vacuum that results will be exploited by al-Shabaab, and the entire FGS could be at risk.

Al-Shabaab's wider regional ambitions, especially in Kenya, have involved a much more aggressive strategy involving terrorist attacks aimed at high-visibility civilian sites and expanded recruitment across a large swathe of Kenyan society.

Despite its impressive revival in Somalia since 2012, al-Shabaab continues to face problems that continually risk plunging the group into crisis. Its tactics, especially suicide car bombings and assassinations, are deeply unpopular with Somalis and have shrunk the group's public support. The group's vigorous taxation is increasingly viewed as extortion and is being met in some locations by armed clan resistance. Al-Shabaab has been put on the defensive in the Lower Shabelle region as a result of offensives by a combination of the Somali army, AMISOM, and clan militias backed by U.S. drone attacks.

The group has lost a number of top officials - including its leader Ahmed Godane in 2014- to American airstrikes. ${ }^{36}$ Its current leadership has faced defections by important figures. The group is also facing a mounting challenge from groups professing allegiance to the Islamic State. In some regions of Somalia, violent campaigns between al-Shabaab and the Islamic State resemble mafia turf wars over control of taxation of local businesses. 


\section{Al-Shabaab's future}

Al-Shabaab has demonstrated tremendous resilience in the face of serious external pressures and internal crises. If past performance is an indication of future trends, the group is likely to continue to be a major armed spoiler in the near to mid-term. It faces a weak, dysfunctional, and penetrated Somali army; a Somali government of questionable legitimacy and weak capacity; foreign peacekeepers with stated intentions to begin to withdraw in 2021; and a fearful, risk-averse Somali population. Its asymmetric military tactics allow it to choose the time and place of attacks and armed engagements, and its Amniyat network affords it superior intelligence. For all of its weaknesses, it faces relatively little resistance. The most dangerous immediate threat to the group at present is U.S. military operations against its leaders.

Continued stalemate is the most likely scenario in the coming years. Al-Shabaab possesses ample capacity to harass the FGS and launch terrorist attacks but not necessarily the ability or even the desire to hold major cities and make itself a fixed target of external counterterrorism strikes.

If AMISOM withdraws from Somalia completely, it is possible that al-Shabaab will overrun the Somali army and take most or all of Mogadishu, leading to the fall of the FGS. This worst-case scenario would pose enormous challenges for the United States and regional states and would likely precipitate a mass exodus of Somali refugees.

Somali civic and political figures, and some external diplomats and advocacy groups, frequently raise the prospect of a negotiated settlement between al-Shabaab and the FGS. Quiet efforts have been made for years but have not borne fruit. There are extensive lines of communication between al-Shabaab and the FGS as a result of clan affiliations that bridge the two, so the problem is not a lack of good offices.

For now, this scenario seems unlikely, as al-Shabaab believes time is on its side, and key external actors, most notably Ethiopia and Kenya, and quite possibly the U.S. government, would seek to veto any negotiations. Yet variations on this scenario are plausible. If strikes on al-Shabaab continue to weaken it and worsen internal fissures, the leadership could look to strike a deal, or breakaway factions could defect.

A final scenario is an al-Shabaab collapse. If the FGS administration makes real progress in combating corruption, professionalizing the Somali army, and making governance more inclusive and effective, al-Shabaab will find itself with little support among war-weary Somalis. Its many fault lines make it quite susceptible to another round of internal feuding and defections. In this event, rump portions of al-Shabaab could degenerate into a dangerous mafia extortion racket that would take time to marginalize.

Overall, al-Shabaab is likely to remain a significant and chronic threat to the FGS, regional member states in Somalia, regional states in the Horn of Africa, and Western and international agencies working in the Horn. Soft targets such as hotels and shopping malls will continue to be vulnerable to complex suicide bombings in the Horn and in Somalia. Despite its many internal weaknesses, al-Shabaab is able to conduct terrorist attacks with relative ease, at low cost, and with little risk. It has also proven effective at exploiting local grievances to secure tactical alliances and recruits. The enduring threat posed by al-Shabaab ensures that Ethiopia and Kenya will remain deeply involved in Somalia for the foreseeable future, as will other external actors concerned about the wider security threats posed by the group.

\section{Notes}

1 Terje Ostebo and Patrick Desplat, eds., Muslim Ethiopia: The Christian Legacy, Identity Politics, and Islamic Reformism (New York: Palgrave MacMillan, 2013); Haggai Erlich, Islam and Christianity in the Horn of Africa: Somalia, Ethiopia, Sudan (Boulder: Lynne Rienner Press, 2010).

2 There is no uniform definition of which states constitute the Horn of Africa region. Some studies limit the Horn to Ethiopia, Eritrea, Somalia, and Djibouti. Others encompass the "Greater Horn of Africa" and include Kenya, Uganda, Sudan, South Sudan, and Yemen. 
3 Transparency International, Corruption Perceptions Index 2016 (Berlin: Transparency International, 2017).

4 Bureau of Democracy, Human Rights, and Labor, 2019 Country Reports on Human Rights Practices: Somalia (Washington, DC: U.S. Department of State, 2019).

5 “Shortages, Clan Rivalries Weaken Somalia's New Army," The New Humanitarian, May 28, 2014, www.thenewhumanitarian.org/news/2014/05/28/shortages-clan-rivalries-weaken-somalia-s-new-army; Clemence Pinaud, "South Sudan: Civil War, Predation, and the Making of a Military Aristocracy," African Affairs 113, no. 451 (2014): 192-211.

6 Paul Williams, Understanding US Policy in Somalia: Current Challenges and Future Options (London: Chatham House, 2020).

7 International Crisis Group, Ethiopia: Ethnic Federalism and its Discontents (Brussels: International Crisis Group, 2009).

8 Stig Hansen, “An In-Depth Look at Al-Shabab's Internal Divisions," CTC Sentinel 7, no. 2 (2014): 9-12.

9 "South Sudan Is Dying, and Nobody Is Counting," News24, March 11, 2016, www.news24.com/news24/africa/ news/south-sudan-is-dying-and-nobody-is-counting-20160311-4.

10 Bronwyn Bruton, "Ethiopia and Eritrea Have a Common Enemy," Foreign Policy, July 12, 2018, https://foreignpolicy.com/2018/07/12/ethiopia-and-eritrea-have-a-common-enemy-abiy-ahmed-isaias-afwerki-badme-peacetplf-eprdf/.

11 Matt Bryden and Premdeep Bahra, "East Africa's Terrorist Triple Helix: The Dusit Hotel Attack and Historical Evolution of the Jihadi Threat," CTC Sentinel 12, no. 6 (2019): 1-11; International Crisis Group, Al-Shabaab Five Years Africa Westgate: Still a Menace in East Africa (Brussels: International Crisis Group, 2018).

12 Todd South, "The Battle of Mogadishu 25 Years Later," Army Times, October 2, 2018, www.armytimes.com/ news/your-army/2018/10/02/the-battle-of-mogadishu-25-years-later-how-the-fateful-fight-changed-combatoperations/.

13 International Crisis Group, Somalia's Islamists (Brussels: International Crisis Group, 2005).

14 Ken Menkhaus, "The Crisis in Somalia: Tragedy in Five Acts," African Affairs 106, no. 424 (2007): 357-390.

15 Ken Menkhaus, "Somalia: 'They Created a Desert and Called It Peace (Building)',' Review of African Political Economy 36, no. 120 (2009): 223-233.

16 Laura Hammond, "Somalia Rising: Things Are Starting to Change for the World's Longest Failed State," Journal of Eastern African Studies 7, no. 1 (2013): 183-193; International Crisis Group, Somalia: An Opportunity That Should Not Be Missed (Brussels: International Crisis Group, 2012).

17 International Crisis Group, Counter-Terrorism in Somalia: Losing Hearts and Minds? (Brussels: International Crisis Group, 2005).

18 Stig Hansen, Al-Shabaab in Somalia: The History and Ideology of a Militant Islamist Group (New York: Oxford University Press, 2013).

19 Monitoring Group on Somalia and Eritrea, Report of the Monitoring Group on Somalia and Eritrea Pursuant to UN Security Council 1916 (2010) (New York: United Nations, 2011), 27.

20 Ken Menkhaus, "Al-Shabaab and Social Media: A Double-Edged Sword," The Brown Journal of World Affairs 20, no. 2 (2014): 309-327.

21 International Crisis Group, Somalia's Divided Islamists (Brussels: International Crisis Group, 2010).

22 Human Rights Watch, No Place for Children: Child Recruitment, Forced Marriage, and Attacks on Schools in Somalia (New York: Human Rights Watch, 2012).

23 Not all members of these clans supported al-Shabaab before 2008, and not all supporters from these clans defected, but as a group, the clans shifted positions.

24 Personal interviews, Kismayo, Somalia, December 2016.

25 Christopher Anzalone, "Al-Shabab's Tactical and Media Strategies in the Wake of Its Battlefield Setbacks," CTC Sentinel 6, no. 3 (2013): 14.

26 Ken Menkhaus, “No Access: Critical Bottlenecks in the 2011 Somali Famine," Global Food Security 1, no. 1 (2012): $29-35$.

27 Matt Bryden, The Re-invention of Al Shabaab: Strategy of Choice or Necessity? (Washington, DC: Center for Strategic and International Studies, 2014).

28 Matt Bryden, The Decline and Fall of al-Shabaab? Think Again (Minneapolis: Sahan, 2015).

29 David M. Anderson and Jacob McKnight, "Kenya at War: Al-Shabaab and Its Enemies in Eastern Africa," African Affairs 114, no. 454 (2015).

30 Bryden, The Re-invention of Al Shabaab.

31 Harun Maruf and Dan Joseph, "No End in Sight for the Al-Shabaab Threat to Somalia," CTC Sentinel 11, no. 11 (2018): 16-20.

32 Paul Williams, Fighting for Peace in Somalia: A History and Analysis of the African Union Mission (AMISOM), 20072017 (New York: Oxford University Press, 2018). 
33 "Mandera Locals Warned Against Playing Tax to al-Shabaab," The Nation, October 21, 2016, https://nation.africa/ kenya/videos/news/mandera-locals-warned-against-paying-tax-to-al-shabaab-318982.

34 Bryden, The Re-Invention of Al Shabaab.

35 Ken Menkhaus, "Managing Risk in Ungoverned Space: Local and International Actors in Somalia," SAIS Review 36, no. 1 (2016): 109-120.

36 Helene Cooper, Eric Schmitt and Jeffrey Gettleman, "Strikes Killed Militant Chief in Somalia, U.S. Reports," New York Times, September 5, 2014, www.nytimes.com/2014/09/06/world/africa/somalia-shabab.html. 


\title{
9 \\ THE HISTORY OF TERRORISM IN SOUTHEAST ASIA
}

\author{
Peter Chalk
}

Terrorism and sub-state political violence have a long legacy in Southeast Asia that dates to the struggles of ethno-nationalist and religious groups fighting for minority self-determination during the Cold War. Since the late 1990s, however, the residual challenge posed by militant extremism has risen in reaction to both the force of modernization pursued by many Southeast Asian governments and the political influence of Islam-which has itself been further amplified by the contemporary force of jihadi radicalism.

In the southern Philippines, an ongoing Bangsamoro insurgency continues to disrupt stability, investment, and local development. In stark contrast to its original inception, it now has an explicitly religious bent. Further complicating matters in the country is an entrenched communist terrorist insurgency that is seeking the creation of a Maoist state through protracted people's war and which continues to draw sustenance from popular disillusionment born out of government corruption and the existence of sharp socio-economic inequalities.

In Indonesia, Islamic extremism has emerged as an increasingly salient threat since the demise of the Suharto regime in 1998. In particular, a dramatic reawakening of historical Muslim identity has combined with a more fluid domestic environment to dangerously exacerbate and radicalize popular sentiment across the archipelago. This has helped feed and foster a newer generation of jihadi militancy that is variously dedicated to the genesis of a fundamentalist order in Indonesia or a wider caliphate in Southeast Asia.

Finally, in southern Thailand, violence associated with Malay-Muslim separatism has been a recurrent problem since the late 1960s. The overall scale of unrest, however, has risen dramatically since 2004 to the point that the so-called "deep south" is now in the throes of what amounts to a full-scale ethno-religious insurgency.

This chapter examines the evolving scope and dynamic of terrorism in Southeast Asia, drawing on the undercurrents of unrest summarized previously. It delineates groups by country, profiling both historical and active terrorist groups.

\section{Philippines}

The Republic of the Philippines is an archipelagic state that consists of 7,107 islands scattered across 1,295,000 square kilometers of territory. The largest are Luzon in the north and Mindanao in the south. The country has a population of more than 110 million, the vast bulk of which (estimated at $81 \%$ ) adhere to Catholicism, with Islam at $5 \%{ }^{2}$ 


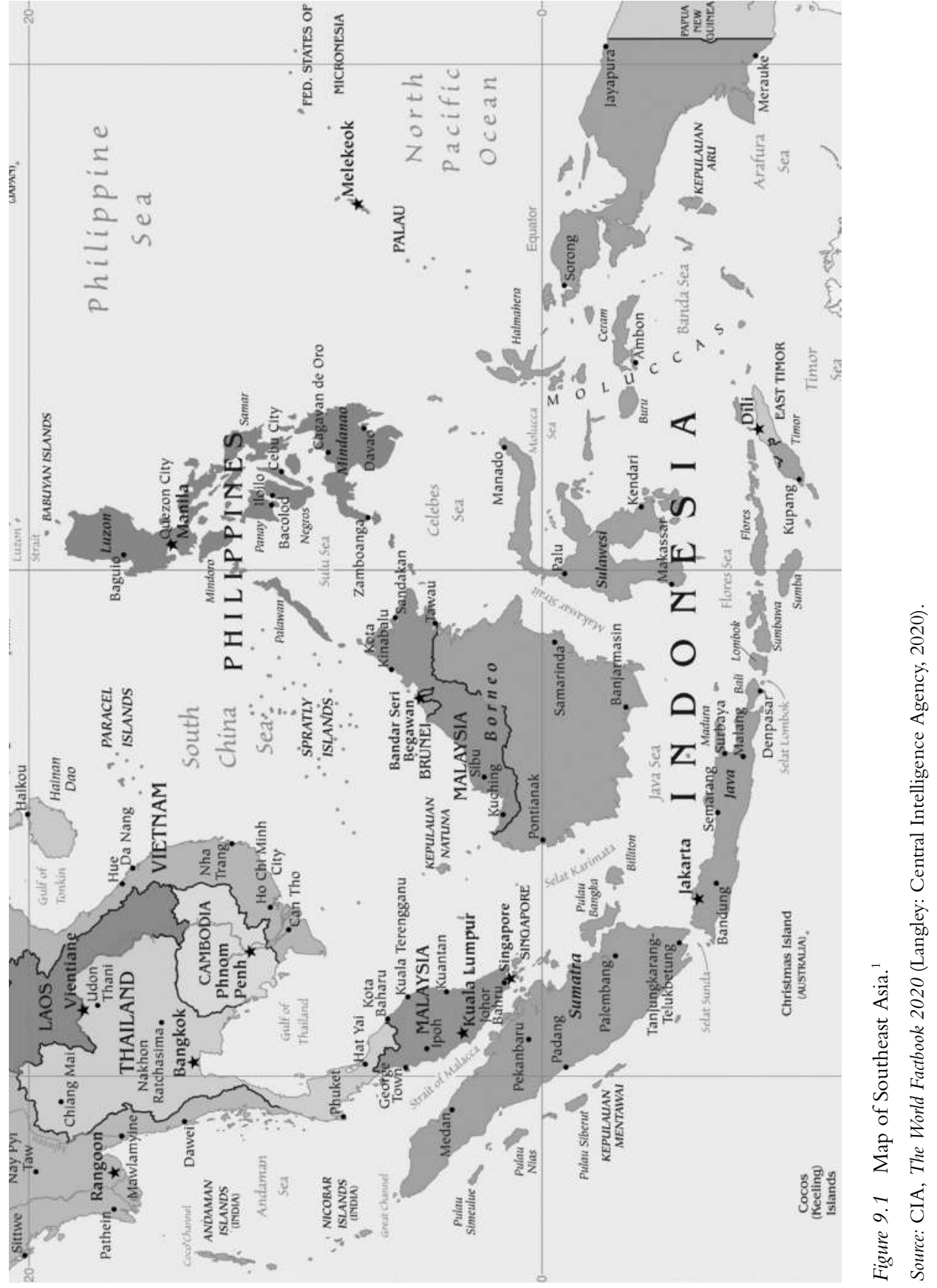


The Philippines has a turbulent history. The archipelago fell under Spanish colonial administration in the 16th century, which lasted until 1898, when it was ceded to the United States following the SpanishAmerican War. In 1935, the country became a self-governing commonwealth as a prelude to independence after a 10 -year transitional period. This was interrupted by the outbreak of the Pacific War and the Japanese occupation of the Philippines in 1942. American and Filipino forces fought together to regain control, which was achieved in 1945.

The Philippines finally achieved its full independence on July 4, 1946, when Manuel Roxas was sworn in as the first president of the new republic. Since then, the country has experienced 14 years of martial law (under Ferdinand Marcos), two mass "people power" movements that have removed elected leaders from office (one in 1986 and one in 2001), several coup attempts, and numerous corruption scandals. Persistent problems that continue to plague the country include poverty, social inequality, rural stagnation, and ethno-religious marginalization. ${ }^{3}$

Against this backdrop, the Philippines has confronted an extremely diverse mosaic of internal security challenges that have spanned the spectrum of Bangsamoro separatism, Islamist extremism, and communistinsurgent war. Much of the country's internal violence has stemmed from Moro Muslim grievances in Mindanao, a region that has never viewed itself as part of an integrated Catholic Philippine state. Combined with economic neglect and poverty, the people on this southern island have long harbored a sense of oppression and victimization that has given rise to and sustained a range of rebel groups, including the Moro National Liberation Front (MNLF), the Moro Islamic Liberation Front (MILF), the Abu Sayyaf Group, and the Bangsamoro Islamic Freedom Fighters. ${ }^{4}$

Apart from militants in Mindanao, the Philippines faces an ongoing communist terrorist insurgency, the origins of which date back to the Huk rebellion of the late 1940s and early 1950s but the modern manifestation of which has been the campaign waged by the New People's Army since 1968. Underscoring and feeding this particular internal security challenge, which Manila regards as its most serious, have been severe social inequalities (especially in the countryside), poor governance, economic stagnation, and the political opportunity afforded both by Philippine leader Ferdinand Marcos' declaration of martial law and agreements allowing the United States to maintain military bases in the country. ${ }^{5}$

\section{Moro National Liberation Front}

The MNLF was initially the main vehicle for pursuing the Muslim Moro struggle in Mindanao and its surrounding islands in the southern Philippines. Nur Misauri, an ethnic Tausug and former university professor, established the group in 1972. The movement adopted an overtly nationalist ideological agenda that was aimed at achieving self-determination for the Bangsamoro people through armed struggle. Such an outcome was enshrined as an essential precondition for the implementation of Islamic institutions in a future independent republic. To this effect, the MNLF created a dedicated guerrilla wing, the Bangsa Moro Army, to directly confront the Filipino military. ${ }^{6}$

Benefiting from alleged training in Malaysia and drawing on weapons and money supplied by Islamic states in the Middle East (predominantly Libya), the group rapidly expanded. By the mid-1970s, it had grown into a sizeable rebel force of 30,000 fighters. ${ }^{7}$ The MNLF's struggle lasted until 1996, when it signed a peace accord with President Fidel Ramos. The agreement led to the creation of a limited Autonomous Region of Muslim Mindanao that was to remain within the constitutional parameters of the Philippine state.

The 1996 deal ended the MNLF's campaign of violence. Despite sporadic clashes against the security forces, the movement has largely adhered to the terms of the peace accord and is not designated as a terrorist entity by either the European Union or the United States. Nevertheless, its war with Manila, which 
cost the lives of some 100,000 people, continues to have an enduring legacy in the Philippines and remains one of the bloodiest episodes in the country's history. ${ }^{8}$

\section{Moro Islamic Liberation Front}

The MILF is the largest and best-equipped Islamist militant group in Mindanao. It was officially established in 1984, largely in reaction to the MNLF's more ethno-centric character. Under the hardline leadership of Hashim Salamat, it pursued an explicitly Islamist agenda aimed at creating an independent state based on Sharia (Islamic law) in all areas of the southern Philippines where Muslims have traditionally been the majority. The group was highly critical of MNLF leader Misuari’s 1996 deal with Manila, charging that he was a traitor who had deviated from the correct Islamic line in both war and peace. ${ }^{9}$

Salamat died in 2003 and was succeeded by Al Haj Murad Ebrahim. Under the pragmatic leadership of the new chairman, the goal of outright independence was gradually moderated in growing recognition that a guarantee of comprehensive autonomy rather than full statehood was the most realistic concession that could be extracted from Manila. To this end, Murad committed to a mutual cessation of hostilities agreement in 2003 and has since participated in Malaysian-sponsored talks aimed at resolving a broad array of concerns about a future self-governing Moro homeland..$^{10}$ Most of these issues have been resolved, and despite periodic clashes with Filipino forces, ${ }^{11}$ the group has settled for the establishment of the Bangsamoro Autonomous Region in Muslim Mindanao, which formally came into being following two plebiscites held in 2019. ${ }^{12}$

Organizationally, MILF is split between an executive and a dedicated armed wing known as the Bangsamoro Islamic Armed Forces. The armed wing can call upon some 40,000 fighters, 30\% of which will be decommissioned as part of the creation of the Bangsamoro Autonomous Region in Muslim Mindanao. ${ }^{13}$

Most of MILF's violence has taken the form of classic guerrilla warfare against the Philippine military rather than indiscriminate attacks against civilians. That said, they are widely suspected of having a special operations group that has carried out deniable urban bombings and random shootings when it believes such actions will have value in refocusing national and regional attention on the Bangsamoro struggle. ${ }^{14}$

MILF has also been linked to the activities of Jemaah Islamiyya (JI), which between 1998 and 2007 was the most dangerous cross-border terrorist entity in Southeast Asia. For much of JI's earlier inception, the movement enjoyed free access to the MILF's main headquarters, Camp Abu Bakar, in Maguindanao, where it was allowed to establish an autonomous militant outpost known as Wakalah Hudaibiyah. After the central base fell to the Philippine military in 2000, MILF reportedly assisted JI in setting up a new facility deeper inside the province that remained operational until 2003. ${ }^{15}$

Despite these early links with JI, MILF has, for the most part, not been intimately involved in violent jihadi extremism. The group formally renounced the use of terrorism in 2003 and the following year effectively cut all connections with JI-realizing that in the context of peace talks with Manila, any perceived association with the Indonesian network would be counterproductive. There is no indication that MILF has been influenced by the ideology of the Islamic State. MILF leader Murad has vociferously denounced the "savagery and barbarism" of the Islamic State and has also pledged a ready willingness to actively work with the government of the Philippines-in the context of the Bangsamoro Autonomous Region in Muslim Mindanao-to prevent the Islamic State's ideology from taking hold in Mindanao. ${ }^{16}$

\section{Abu Sayyaf Group}

The Abu Sayyaf Group was founded on the island of Basilan in 1991 under the leadership of Abdurajak Janjalani, a veteran of the Afghan mujahidin during the 1980s. The group's stated objectives are the eradication of all Christian influence in the southern Philippines and the creation of an Islamic state of 
Mindanao. ${ }^{17}$ From the outset, however, this local agenda was tied to transnational extremist designs—notably the regional and global supremacy of Islam through the force of arms-mostly rhetorically but also on occasion substantively.

Toward that end, the group actively sought to establish ties with international extremist groups. During its early years, when it operated as a cohesive and explicitly religious jihadi outfit, Abu Sayyaf was linked to several transnational terrorist plots. One of the most infamous was Oplan Bojinka, which was hatched in 1995 by Ramzi Yousef, a "freelance" Islamist militant and the convicted mastermind behind the 1993 World Trade Center bombing.

The multi-pronged plot was to have included the assassinations of the Pope and President Bill Clinton while they visited the Philippines in 1996, coordinated attacks against the U.S. Embassies in Manila and Bangkok, and the mid-air detonation of commercial aircraft flying trans-Pacific routes from the U.S. western seaboard. Authorities foiled the plot only after volatile explosives ignited a fire in an apartment Yousef rented in Manila, forcing him to flee to Pakistan, where he was subsequently detained and extradited to the United States. ${ }^{18}$

From the late 1990s onwards, however, the group steadily deteriorated into a fractured, largely criminalized entity due to the loss of several senior commanders and the influx of a new generation of cadres motivated more by money than Islamist zeal. Compounding its weakness was a sustained Filipino military offensive that proved decisive in blunting Abu Sayyaf's operational capabilities. This effort received important backing from the United States under Operation Enduring Freedom-Philippines, which was instituted in 2002 and was primarily aimed at ensuring the group was not allowed to emerge as an active beachhead for al-Qaida-style extremism in Southeast Asia.

Today, the group numbers in the hundreds, split between roving kidnap-for-ransom bands operating across the small islands of the Sulu Archipelago. The largest and most active factions are based on Basilan and Sulu. Even though in its current configuration, the Abu Sayyaf Group operates mostly as a criminal entity, there are indications that the group is attempting to redefine itself as a more integrated and credible Islamist militant force. Perhaps the clearest sign of this - and in direct contrast to the stance of the MILFhave been moves to identify more closely with the international Islamist cause, particularly as personified by the Islamic State's struggle in Iraq and Syria.

In 2014, the now-deceased Abu Sayyaf leader Isnilon Hapilon uploaded a video on YouTube in which he read an Arabic statement that pledged full "loyalty and obedience in adversity and comfort" to the Islamic State. ${ }^{19} \mathrm{He}$ was consequently declared the Islamic State's leader, or amir, in Southeast Asia and in May 2017 was at the forefront of the dramatic seizure of Marawi City, which dragged on for five months, led to the deaths of 1,200 people and the displacement of a further 350,000 and, ultimately, set the stage for the establishment of a new Islamic State province in East Asia. ${ }^{20}$

\section{Bangsamoro Islamic Freedom Fighters}

The Bangsamoro Islamic Freedom Fighters, also known as the Bangsamoro Islamic Freedom Movement, is a splinter faction of MILF that emerged under the leadership of Ameril Umbra Kato, a Middle Easterntrained scholar and the former leader of MILF's 105th Command. He accused MILF of departing from the original goals of the Bangsamoro struggle and selling out the Moro Islamic cause by entering into negotiations for Mindanao's autonomy rather than full independence. ${ }^{21}$ Kato died from pneumonia in April 2015 after which command passed to the more radical Ismael Abu Bakar, also known as "Bonmgos."22

Its strength is estimated to be less than 1,000 fighters, although these cadres have increasingly been divided between two main factions: one led by Sheikh Muhedeen Animbang and one under the charge of Ismael Abu Bakar. The former is stronger both in terms of numbers and in its capacity to steal weapons as well as manufacture its own. As with the Abu Sayyaf Group, neither represents a threat beyond the conflict 
zones of the southern Philippines, where they mostly target police and army outposts. These confrontations typically escalate in the run-up to the holy month of Ramadan and frequently involve attacks against civilian communities. ${ }^{23}$

Despite being relatively small and disaggregated, the group carries important implications for both the MILF peace process and general stability in Mindanao and its surrounding islands. The group has shown itself both willing and capable of engaging Philippine security forces, targeting both military and police outposts. In line with its original raison d'etre, the stated objective of these attacks is to sabotage the peace process as part of the long-term goal of achieving Bangsamoro independence. ${ }^{24}$

In common with Abu Sayyaf, the Bangsamoro Islamic Freedom Fighters pledged support to the Islamic State in a YouTube video aired on August 13, 2014. Although not as strong as Abu Sayyaf leader Hapilon's baya - in the sense of articulating full obedience to Islamic State leader Abu Bakr al-Baghdadi—the recording established that a mutually beneficial alliance had been forged. ${ }^{25}$

\section{The New People's Army}

The New People's Army acts as the armed wing of the Communist Party of the Philippines, which José María Sison launched in 1968. Its stated aim is to replace the current political and economic order in the Philippines with a socialist system through a strategy of protracted people's war. To accomplish this objective, the movement employs all tactical means at its disposal, including insurgent warfare, urban sabotage, mass mobilization, political lobbying, and international solidarity work with other like-minded left-wing groups. ${ }^{26}$

At the height of its strength, the communist guerrilla force could call on 28,000 fighters who were organized into 87 combat fronts that were mainly scattered across the Visayas, eastern Mindanao, the Compostela and Surigao valleys, Davao Oriental, Davao Central, Davao Norte, Misamis, and Zamboanga del Norte. ${ }^{27}$ Through the Communist Party of the Philippines' legitimate arm, the National Democratic Front, the New People's Army/Communist Party of the Philippines also penetrated key sectoral organizations that were then leveraged to support the "people's war." Notable in this regard were youth groups, labor unions, churches, university student bodies, and even political parties (mainly by buying off corrupt congressional representatives). ${ }^{28}$

The basic strategy employed by the Philippine government to defeat the movement is to combine "hard" coercive offensives with "soft" incentive programs. The New People's Army/Communist Party of the Philippines is weaker today than at any time in the past. By 2016, the organization had fewer than 5,000 cadres at its disposal, suffered from the capture of key operational leaders, and has been driven from many towns and hamlets, retaining a presence in a mere 1,190 barangays (the smallest municipal government unit), which equates to only $5 \%$ of the country's total. ${ }^{29}$

Reflecting its degraded capacity, only a small amount of the group's activity currently takes the form of classical guerrilla warfare, with the bulk of its actions comprising sporadic and opportunist attacks on Philippine security forces, government officials, and infrastructure, as well as kidnap and extortion schemes. ${ }^{30}$

\section{Summary}

The persistence of terrorist and insurgent groups in the Philippines reflects the inability of the state to exert its writ over Mindanao and its surrounding islands, weak governance, social inequalities, and an uneven distribution of economic wealth. These interrelated conditions have generated a sense of alienation and resentment in certain segments of the country's local population (especially evident in the south) and contributed to gaps in governance that have acted as a magnet for competing poles of power of both Bangsamoro Muslim and communist varieties. ${ }^{31}$ 
Of the various principal groups that have operated in the country, however, Manila has always regarded the New People's Army/Communist Party of the Philippines as its primary internal security threat. Military, police, and government officials have consistently prioritized the battle against the communist insurgency on account of its motivational goals (the overthrow of the existing political architecture), geographical spread (nationwide), and infiltration of key state institutions.

By contrast, the Abu Sayyaf Group and the Bangsamoro Islamic Freedom Fighters have historically been small entities, and neither has demonstrated the ability to operate beyond purely local theaters. Although the MILF has presented a greater challenge, under the leadership of Al Haj Murad Ebrahim, the group has exhibited a steadily growing willingness to negotiate with the government and settle its conflict on terms considerably short of its original goal.

The Philippine experience with terrorism demonstrates how ungoverned spaces can quickly translate into hubs of militant activity that can take years to root out. Even if these zones of militancy never develop into threats that fundamentally erode the underlying fabric of the state, they can still manifest in a manner that requires the allocation of scarce resources.

\section{Indonesia}

Indonesia straddles the equator, occupies a strategic location astride major sea lanes that connect the Indian and Pacific oceans, and shares land borders with Timor-Leste, Malaysia, and Papua New Guinea. It is the world's largest archipelagic state, consisting of 13,466 islands (of which 922 are permanently inhabited). The country has a total population of 258 million, the majority of which (approximately 87\%) are Muslim. Christians and Roman Catholics form the next largest denominations. Ethnically, Indonesia is predominantly Javanese (approximately 40\%), although there is also a relatively large Sundanese community (15.5\%). ${ }^{32}$

The Dutch colonized Indonesia in the early 17th century, remaining in control until 1942, when the Japanese invaded the country and commenced a three-and-a-half-year period of occupation. Following the end of the Pacific War in 1945, Indonesia declared its independence, but it took four years of fighting, negotiations, and mediation by the United Nations before the Netherlands finally agreed to a transfer of sovereignty in $1949 .{ }^{33}$ Darul Islam, a theologically driven movement that was committed to the creation of a fully fledged Islamic state, refused to recognize the legitimacy of the new secular-oriented post-colonial government and during the next decade launched a series of rebellions that for a time challenged the writ of the central administration in Java. ${ }^{34}$

In 1957, President Sukarno declared martial law and instituted his concept of "guided democracy"-in effect authoritarian rule- to both cripple Darul Islam and forge a wholly unified political system based on the traditional hierarchical organization of Indonesian villages. After an abortive communist coup in 1965, Sukarno was eased from power, and Suharto assumed leadership in what effectively amounted to a military putsch. Dubbing his government the "New Order," Suharto's increasingly dictatorial regime took hold in the country and lasted until 1998, when a popular uprising toppled Suharto and paved the way for elections the next year. ${ }^{35}$

Although hailed as a landmark in Indonesia's history, the sudden transition from rigid and uncompromising rule to an open political democracy removed the lid on simmering ethno-religious tensions that had previously been contained. Combined with poverty, inflation, unemployment, and the re-awakening of dormant Islamist identity, a highly fluid, if not freewheeling, domestic threat environment materialized that hardened communal divisions and radicalized popular sentiment across the archipelago.

These developments fueled a growing fundamentalist undercurrent that has provided fertile ground for an assortment of radical groupings with militant tendencies. ${ }^{36}$ Three in particular have attracted attention: $\mathrm{JI}$, which is now largely defunct as a militant movement, and two that are currently active, Jamaah Ansharut Tauhid (JAT) and Mujahidin Indonesia Timor (MIT). ${ }^{37}$ 


\section{Jemaah Islamiyya}

$\mathrm{JI}$ is an Indonesia-based jihadi organization with links to al-Qaida. The movement was established in January 1993 under the combined leadership of Abdullah Sungkar and Abu Bakar Bashir. It defined its objectives in both local and regional terms. The immediate goal was to fully realize Darul Islam's original agenda of instituting Sharia in Indonesia, which was then to be enshrined as part of a wider vision that sought the creation of a pan-Southeast Asian caliphate embracing Brunei, Malaysia, southern Thailand, and the southern Philippines.

JI has been described as al-Qaida's operational wing in Southeast Asia. While the group is known to have established loose ties with Usama bin Ladin's movement in the years immediately before 9/11 and continued to accept funding and technical expertise after the $9 / 11$ attacks, it never subsumed itself under al-Qaida. By contrast, the group evolved as a distinct entity, developing an organizational and operational character that was specifically designed to further its own regional Islamist agenda. ${ }^{38}$

At its height in 1999-2000, estimates placed JI's hard-core membership at around 2,000 activists supplemented by a wider support pool of 5,000 passive sympathizers. ${ }^{39}$ These cadres were organized into four regional divisions (mantiqis) that were defined along both geographic and functional lines. ${ }^{40}$ Between 2002 and 2005, JI was recognized as the most dangerous terrorist organization in Southeast Asia. Unlike its early militant activity, when the group mostly worked with other Islamist groups in carrying out attacks against Christian communal targets in Maluku and Sulawesi, this period was characterized by an operational agenda that was exclusively aimed at causing mass civilian casualties.

Suicide attacks marked the hallmark of this violence. Some of the more lethal attacks include the 2002 Bali bombings, the 2003 assault on the JW Marriott in Jakarta, and the 2004 attack against the Australian Embassy. ${ }^{41}$ All of these operations demonstrated considerable skill in terms of bomb construction and pre-attack planning and surveillance and were mostly justified under the twin umbrella of fighting the "far enemy" (the United States and its Western allies) while fostering the supremacy of Islam across Southeast Asia. ${ }^{42}$

Although Indonesia based and regionally networked, JI also enjoyed a strong presence in the southern Philippines. The group both benefited from open access to militant camps run by MILF and established robust operational and logistical ties with the movement. For at least five years, Mindanao acted as a strategic rear-base for JI where attacks were planned, munitions procured, and cell members trained. ${ }^{43}$

The threat emanating from JI-regionally and to the southern Philippines—started to diminish following the second Bali bombings in 2005. Three main factors accounted for this demise.

First, Indonesia's highly effective counterterrorism efforts successfully eliminated some of the group's most lethal and proficient commanders. Densus 88 (Detachment 88 ), an elite national police rapid response team established with U.S. assistance in 2003, was at the forefront of these neutralizations, which proved decisive in breaking and disrupting jihadi cells across the country.

Second, many were uncomfortable with the large number of Muslims killed in JI's attacks—which was particularly true of the Marriott Hotel and Australian Embassy attacks in Jakarta. Ensuing Islamic criticism not only deprived the movement of vital grassroots support, but it also triggered an internal split between so-called pro-bombing hardliners and traditionalists who viewed the use of such indiscriminate tactics as counterproductive.

Third, the MILF peace process, which placed considerable pressure on the MILF to ensure they had no outward association with any outside extremist organizations, deprived JI of what had hitherto been a highly useful external safe haven.

By 2008-2009, JI had essentially disappeared as an effective militant entity in its own right. The final death knell of the group came when its founding leader, Abu Bakar Bashir, defected and established a separate group, JAT. Although the group remains intact and continues to espouse the full institution of Sharia in 
Indonesia, it has continually stressed that this objective will now be pursued through dawa (preaching and religious outreach) rather than violence. ${ }^{44}$

\section{Jamaah Ansharut Tauhid}

Bashir founded JAT in the city of Solo in July 2008. The group's basic ideology is articulated in a booklet entitled Aqidah \& Manhaj Kami (Our Faith and Method) and essentially draws upon the historical Darul Islam aspiration of creating a hardline caliphate in Indonesia. All members take an oath pledging an unbending commitment to the enduring struggle against musrik (defenders of evil), apostates, and other perceived enemies of Islam, including followers of secularism, pluralism, liberalism, communism, socialism, and democracy. ${ }^{45}$ Bashir established the organization as an alternative to $\mathrm{JI},{ }^{46}$ from which he had increasingly become estranged on account of the large number of Muslims killed in its attacks, and which by 2006 had in any case largely ceased to act as an effective entity in its own right.

JAT is a hierarchical, vertically integrated movement. Below its ruling council is an administrative office that oversees five departments: finance, morality enforcement, religious outreach and media, education, and a secretariat. The group also maintains a network of branch offices that are divided into provinces, districts, and local cells. ${ }^{47}$

The group can call upon hundreds of supporters and members. Tactics focus on bombings, assassinations, armed assaults, and rocket strikes. In addition to these traditional terrorist methods, JAT also makes extensive use of the internet and social media-both for recruitment and general communication and propaganda purposes. ${ }^{48}$

Although formed in 2008, JAT only came to the attention of Indonesian authorities as a potential domestic security threat following a raid on a suspected terrorist training camp in the northwestern province of Aceh in February 2010. Although police found the facility vacant, they uncovered scores of weapons, bomb-making equipment, and other logistics that could be leveraged for militant purposes. Subsequent investigations tied this materiel to JAT, and three months later, a trio of senior commanders were charged with directly financing the camp. Although Bashir was not one of those originally detained, he was apprehended that August. In June 2011, Bashir received a 15-year jail term for inciting terrorism (after which control of the group passed to Mochammad Achwan). ${ }^{49}$

Despite this loss in leadership, JAT continues to actively recruit and conduct attacks. Its main targets have included Indonesian governmental and security personnel and local civilians; Western nongovernmental organizations; Australian and American aid workers and contractors; and soft, civilian-centric venues such as churches..$^{50}$

Several prominent members of the movement have also sworn allegiance to the Islamic State, including Bashir. Bashir proclaimed that it was obligatory for all members of JAT to both respect and obey his oath, declaring that anyone who refused to do so would be expelled from the group. This was an explicit attempt to bind the organization as a whole to the ideological and operational precepts of the Islamic State. Although some members rebuffed Bashir's call for allegiance to al-Baghdadi, many did not, arguably reflecting the continued influence that JI's former spiritual leader retains among radical Indonesian Islamists. ${ }^{51}$

\section{East Indonesian Mujahidin/Holy Warriors}

The East Indonesian Mujahidin/Holy Warriors is the most active terrorist group currently operational in Indonesia. Abu Wardah (also known as Santoso, or Abu Musab al-Zarqawi al-Indonesi), a former field commander in JAT, established the group in 2010. The group appears to act as an umbrella movement for militants based in the simmering conflict zones of Poso, Palu, and Bima. ${ }^{52}$ 
The group has been portrayed as representing a new generation of jihadis in Indonesia that has been able to attract a level of grassroots support that JI failed to secure. Whereas the latter movement predominantly appealed to radicals who resonated with the al-Qaida emphasis on attacking the United States and its regional allies, the East Indonesian Mujahidin leader Santoso introduced a specific indigenous dimension to his group's cause, both ideologically and operationally. ${ }^{53}$ The target set shifted from the United States to a more discrete focus on the central government's security apparatus (particularly the police), and the priority switched from forming a regional caliphate to championing the Islamic struggle against the secular-oriented administration in Jakarta.

Despite an intense crackdown on its activities that has seen its numerical strength cut in half, as well as the loss of Santoso, who was shot and killed in July 2016, the group continues to threaten domestic stability in Indonesia, carrying out repeated strikes on law enforcement personnel and facilities in Poso. According to intelligence officials, the group retains a high potential to perpetrate acts of terrorism and is now actively seeking to supplement its ranks by recruiting fighters from the international jihadi network, including Uighurs associated with the Eastern Turkestan Islamic Movement in Xinjiang, China. ${ }^{54}$ The group has also allegedly sought to recruit individuals proficient in information technology who have reportedly been instrumental in urging Indonesians to wage a domestic war via visual propaganda disseminated over the internet. ${ }^{55}$

Although primarily domestically oriented, the East Indonesian Mujahidin has pledged allegiance to the Islamic State. The pledge may have been aimed at regional jihadis who were fighting in Iraq and Syria under the banner of the Khatiba Nusantara Lid Daulah Islamiyya, a special Malay-speaking unit of roughly 100 cadres, in the hopes that they will join the group's struggle upon returning to Southeast Asia.

\section{Summary}

The Indonesian internal threat environment improved considerably with the demise of JI. Nevertheless, the archipelago continues to confront an array of terrorist-related challenges that draw sustenance from radical Islamist sentiment that remains an integral component of the archipelago's domestic political landscape. Of particular importance is the ongoing legacy of Darul Islam, the wellspring of jihadi militancy in Indonesia that has yet to be fully expunged. Indicative of this predisposition to extremist beliefs has been indigenous support for the Islamic State, which more than any other Southeast Asian state has retained theological prominence at the grassroots level.

The future driving force and center of gravity for religious fanaticism in Indonesia will be contingent on a range of historic, political, and economic factors, some of which may well be beyond central government control (such as the outbreak of the civil war in Syria). Despite a general improvement in the country's overall terrorist risk profile, a latent potential for radicalism persists, which under the right circumstances could trigger a return to the type of chronic instability that characterized the immediate post-Suharto era. ${ }^{56}$

One major concern centers on Indonesians who have volunteered to fight with the Islamic State in the Middle East. Between 300 and 500 nationals are thought to have joined the Islamic State, where they operated alongside Malays and Uighurs in a dedicated unit known as Khatiba Nusuntara. ${ }^{57}$ With the group's territorial defeat in Iraq and Syria in 2019, it is likely that some of these experienced, battle-hardened veterans will look to return home.

Such a development could have dangerous ramifications. Within Indonesia, they could breathe new life into a weakened East Indonesian Mujahidin and, by drawing on the tactics used in Syria and Iraq, spearhead attacks on Shia Muslims to incite sectarian hatred and violence. Regionally, they could work to rekindle transnational Islamic extremism by conducting cross-border strikes in the same manner as did JI-the group responsible for the worst terrorist atrocities to have ever been perpetrated in Southeast Asia. ${ }^{58}$ 


\section{Southern Thailand}

The Kingdom of Thailand lies in the heart of mainland Southeast Asia bordering Burma (Myanmar), Laos, Cambodia, and Malaysia. Known as Siam until 1939, it is the only Southeast Asian state never to have been colonized by a European power. Thailand has a landmass that covers 513,120 square kilometers of territory and enjoys important maritime outlets to the Gulf of Thailand and the Andaman Sea. It has a total population of 68 million, 90\% of whom practice Theravada Buddhism. Mahayana Buddhists, Muslims, Hindus, Sikhs, and Christians make up the remaining 10\%. Ethnically, the country is almost exclusively Thai $(97 \%) .{ }^{59}$

A unified Thai kingdom has been in existence since the mid-14th century. It was not until 1932, however, that a constitutional monarchy replaced absolute rule, a transition that was ushered in on the back of a bloodless coup instigated by a small group of middle-ranking officials. The Japanese briefly invaded the country in 1941, and it fought against the Allies during the Pacific War but later became a U.S. treaty ally after sending troops to assist American forces in Korea. It similarly supported Washington's campaign in Vietnam, and in 2003, its status was elevated to that of a major non-NATO ally. ${ }^{60}$ Thailand has since enjoyed close defense relations with the United States, although these have been periodically disrupted by coups-first in 2006 and then in 2014.

Militant activity in Thailand centers on the violent campaign for independence in the "deep south" provinces of Yala, Narathiwat, and Pattani. Three interrelated factors have traditionally framed separatist sentiment in this particular region: a belief in the historical greatness of the ancient Kingdom of Pattani, an ethnic orientation with the Malay race, and a religious credo based on Islam.

During the 1930s, these core "ingredients" were woven together and used to advance a doctrine of selfdefense that emphasized the right and duty to resist any form of persecution that placed communal survival in jeopardy. The specific stimulus for this development was the central government's assimilationist and modernization program that was aimed at eliminating "backward" Islamic customs and dialects, enforcing uniformity in language and social behavior, and phasing out the local institution of Sharia. These moves were undertaken in accordance with the so-called "Thai way" that has since delineated three main pillars for defining state identity: chat (nation), sasana (religion, in effect Buddhism), and Kasat (monarchy).

It is against this background that ethno-religious resistance in Yala, Narathiwat, and Pattani has taken seed and evolved. Initially, these zones of dissidence were characterized by intermittent attacks that did not represent a genuine challenge to local security. Over the years, however, the situation in the three provinces has steadily deteriorated to the extent that the so-called "deep south" is now beset by what amounts to almost daily violence and internecine communal conflict.

Despite this, the terrorist insurgency does not compare with the jihadi campaigns in the Philippines and Indonesia in the sense that the militant focus has always remained highly localized and parochial in nature. While unrest has been a feature of southern Thailand for more than 50 years, it is possible to single out two distinct phases of violence: $1960-1998$ and 2004 to the present.

\section{Historical groups}

Between 1960 and 1998, around 60 extremist movements operated across the Malay-Muslim provinces of Thailand's deep south, many of which benefited from a relative safe haven in the northern Malaysian state of Kelantan. Collectively, these groups have come to be known as the "old guard," and although each exhibited a different ideological and operational outlook, they all shared a common desire to carve out an independent Muslim state with Pattani as the center.

Violent action in pursuit of this objective typically fell into a standard pattern of low-intensity conflict and terrorism oriented around arson, ambushes, kidnappings, assassinations, extortion, sabotage, and bomb attacks. The overall aim was to present Pattani, Yala, and Narathiwat as provinces that remained beyond 


\section{Peter Chalk}

the sovereign writ of Bangkok; to undermine the security of ethnic Thais and Buddhists living in the region; and to place additional pressure on Bangkok to accede to the political demands of Malay-Muslim separatism. ${ }^{61}$

In August 1997, the scale of unrest spiked sharply after a number of militant groups forged a tactical alliance to refocus national and regional attention on the "southern question." The groups undertook a coordinated campaign of bombings, shootings, and incendiary assaults that resulted in nine deaths, several dozen injuries, and considerable economic damage. At the time, the jointly orchestrated strikes, which were codenamed "Falling Leaves," marked the most serious upsurge of Malay-Muslim separatist action since the early 1980 s. $^{62}$

The coordinated campaign of attacks proved to be highly instrumental in heightening the overall visibility of the Muslim cause in southern Thailand. The operation, however, also heightened regional pressure on Malaysia to step up surveillance and monitoring of its northern border, with Bangkok arguing that Falling Leaves could neither have been planned nor executed without the benefit of a secure militant safe haven in Malaysia's Kelantan State.

Malaysian Prime Minister Mahathir Mohamad responded, marking a significant shift in his government's hands-off approach to what it had traditionally referred to as a purely domestic Thai problem. Malaysia carried out a series of raids along the northern Malaysian border that both deprived the primary old guard militant groups of an important source of external sanctuary and resulted in the detention of several prominent separatist leaders and mid-level commanders. These setbacks proved definitive in disrupting and hemorrhaging their internal operational structures. By 1998, the old guard separatist movement in southern Thailand had been essentially crippled. ${ }^{63}$

\section{Active groups}

Unlike the earlier phase of the southern Thai conflict, there does not appear to be a centralized organizational nucleus of defined groupings behind the current bout of terrorist and insurgent activity. Attacks are the work of an amalgam of militants consisting of a newer generation of Islamists operating under the banner of the Barisan Revolusi Nasional-Koordinasi; co-opted criminal elements; and a random collection of disaffected youths, unemployed farmers, laborers, and tradespeople. ${ }^{64}$

Estimates of the number of people actively engaged in violent attacks vary greatly, from 5,000-6,000 to as many as 20,000-30,000 - although the consensus suggests that the figure remains at the lower end. Thai officials believe the militant base is loosely organized around urban-based cells, each numbering between three and four cadres who are then grouped together to form independent teams of up to 18 operatives that function at the tambol (sub-district) level. ${ }^{65}$

Armed actions are reportedly carried out by dedicated military wings known as Runda Kumpulan Kecil (small patrol groups), the members of which are between 16 and 24 years old, religiously pious, and trained in a range of skills including unarmed combat, bombmaking, weapons handling, and sharpshooting. A range of munitions is available to these squads, most of which seem to be locally made, stolen from the security forces, or procured from the stocks of old guard militant groups. ${ }^{66}$

The ostensible objective of the current manifestation of the insurgency continues to emphasize the creation of an independent Malay-Muslim state, although there is a higher emphasis on the religious aspect of the end goal. Beyond this basic objective, the "new guard" does not seem to be guided by any overarching master plan other than fostering animosity between Muslims and Buddhists and generally making the southern border regions ungovernable. ${ }^{67}$

Despite lacking clear strategic direction, rebels fighting in Yala, Pattani, and Narathiwat have taken their campaign of violence to a level of sophistication and ruthlessness not seen in the past. Between January 2004 and the end of 2015, incidents occurred on an almost weekly basis in the three provinces, 
leaving more than 6,500 dead. ${ }^{68}$ For a population that numbers only 1.8 million, these figures represent a considerable toll.

Besides this higher intensity, the sophistication of the insurgents has increased. Larger bombs are routinely deployed and detonated using an array of delayed and remote-controlled triggering mechanisms. In addition, attacks have become increasingly integrated. Typically embracing explosions, arson, assassinations, and random shootings, these assaults have been deliberately engineered to maximize overall impact. ${ }^{69}$

An explicit jihadi undertone has also characterized the current bout of instability in the south, which was not apparent in the past. Reflective of this have been frequent attacks against establishments associated with secular decadence (such as bars and discotheques); the distribution of leaflets warning locals of reprisals if they do not adopt traditional religious dress and respect the Friday holiday; and the increased targeting of monks and other Buddhist civilians, often through highly brutal means such as immolations and decapitations. ${ }^{70}$

The growing religious nature of the Malay-Muslim struggle has generated fears of it metastasizing into a more serious terror campaign that is exacerbated by operational and ideological links with international extremist networks such as the Islamic State and al-Qaida. As of 2020, however, there was no indication that this had occurred.

\section{Summary}

The scale, scope, and intensity of Malay-Muslim militancy have increased significantly since 2004. Bombings, shootings, and arson occur on an almost daily basis, and the number of people caught in the middle of this unrest has risen to unprecedented levels. While there does not appear to be a clearly defined strategy behind these attacks, militants have demonstrated that they are capable of conducting large-scale attacks on a relatively consistent basis. ${ }^{71}$

Despite the seriousness of the insurgency, there is no evidence to suggest that the Islamic State or other outside jihadi extremists have been able to hijack or otherwise co-opt the conflict. The terrorist insurgency remains localized, and even though a more Islamist orientation has been evident, it is not apparent that this has altered, much less superseded, underlying ethno-religious militant imperatives. This distinguishes the southern Thai insurgency from Indonesia's experiences with JI and the Philippines with the Abu Sayyaf Group.

In many ways, the failure of outside jihadis to hijack the southern Thai insurgency is not surprising. An overriding sense of self-identity characterizes the Malay-Muslim border provinces, which suggests the existence of an in-built barrier to external penetration. In contrast, in Indonesia and the Philippines, it is the religious component of militant extremism that is dominant in terms of self-identity. While there is an Islamist component in southern Thailand, it is ethno-nationalism that takes precedence; thus, externally based jihadi groups face a more difficult challenge in terms of proselytism and indoctrination.

Just as importantly, the types of radical Sunni teachings that have been sourced to jihadi strongholds in Syria, Iraq, Yemen, and Libya are at odds with the Shafi-based socio-religious orientation of Thailand's Muslim minority. For this community, the prime concern is restoring the historic glory of the Pattani Kingdom, not on ensuring the transnational supremacy of puritanical Islam. ${ }^{72}$

\section{Conclusion}

The outlook in Southeast Asia has improved considerably from the years immediately following 9/11, when there was a genuine concern that the region could morph into a new beachhead for transnational terrorism.

In the southern Philippines, MILF has settled its political differences with Manila, acceding to the Bangsamoro Autonomous Region in Muslim Mindanao in 2019, and has vowed to act as a bulwark against 


\section{Peter Chalk}

spreading Islamic State influence in the wider Mindanao basin. The Bangsamoro Islamic Freedom Fighters and the Abu Sayyaf Group are small, and despite swearing allegiance to the Islamic State, they do not have the capacity to operate beyond purely local theaters in Mindanao. The once-powerful communist New People's Army has been significantly degraded to the point that the movement is weaker today than at any time in the past.

In southern Thailand, although the tempo of the terrorist insurgency remains high, there has been no noticeable sign that outside jihadis have been able to hijack the local struggle for independence and co-opt it for other cross-border Islamist purposes.

Nevertheless, risks remain. Indonesia remains a particular cause for concern. Not only has the country emerged as the prime focal point for recent Islamic State-inspired extremism, but it could yet revert to a regional hub for cross-border jihadi extremism if volunteer fighters start returning home from Iraq and Syria.

On a wider level, it is also important to note that in many ways, Southeast Asia offers an ideal theater for terrorists, both logistically and operationally. Poor governance, weak states, corruption, porous borders, a relatively sophisticated communication and transport infrastructure, and an abundance of small arms all help to create fertile ground for militant non-state entities to clandestinely rest, train, move, plan, and conduct attacks. As long as this physically enabling environment exists, Southeast Asia will remain vulnerable to outbursts of extremist violence, especially when such a setting serves to aid and abet pre-existing domestic conflicts. ${ }^{73}$

Reflective of this reality, the United States has and continues to work closely with the Philippines, Indonesia, and Thailand - the three states that have historically been the main sites of terrorism in Southeast Asia. Support has primarily been channeled to boost inter- and intra-agency cooperation (especially in terms of intelligence fusion); promote accountability and professionalism in police, naval, and military forces; strengthen the rule of law; and heighten land and maritime border security.

These initiatives fall under the wider U.S. global partner nation capacity-building program that since 2019 has been managed by the U.S. Department of Defense's Institute for Security Governance. Assistance is aimed at consolidating national and regional contexts that are hostile to violent extremism and will continue to act as a central component of Washington's unilateral and bilateral engagement efforts in Southeast Asia.

\section{Notes}

1 CIA, The World Factbook 2020 (Langley: Central Intelligence Agency, 2020).

2 Derek McDougall, Studies in International Relations (Melbourne: Edward Arnold, 1991), 64-65; CIA, The World Factbook 2020.

3 CIA, The World Factbook 2020; Jeremy Atiyah et al., The Rough Guide to Southeast Asia (New York: Rough Guides, 2005), 764-767.

4 Peter Chalk et al., The Evolving Terrorist Threat to Southeast Asia: A Net Assessment (Santa Monica: RAND, 2009), 33-34.

5 Ibid., 36; Tom Marks, Maoist Insurgency Since Vietnam (London: Frank Cass, 1996), 95-96.

6 Peter Chalk, "The Davao Consensus: A Panacea for the Muslim Insurgency in Mindanao?" Terrorism and Political Violence 9, no. 2 (1997): 79-98.

7 Christopher Paul et al., Paths to Victory: Detailed Insurgency Case Studies (Santa Monica: RAND, 2013$), 347$.

8 David Wiencek, "Mindanao and Its Impact on Security in the Philippines," in The Unraveling of Island Asia? Governmental, Communal, and Regional Instability, ed. Bruce Vaughn (Westport, CT: Praeger, 2002), 49; Claude Buss, Cory Aquino and the People of the Philippines (Stanford: Stanford Alumni Association, 1987), 109.

9 Peter Chalk, Grey-Area Phenomena in Southeast Asia: Piracy, Drug Trafficking and Political Terrorism (Canberra: Strategic and Defence Studies Centre, 1997), 70.

10 Chalk et al., The Evolving Terrorist Threat to Southeast Asia, 38-39. For further information on the evolution of these talks, see International Crisis Group, Southern Philippines Backgrounder: Terrorism and the Peace Process (Brussels: 
International Crisis Group, 2004); U.S. Institute of Peace, The Mindanao Peace Talks (Washington, DC: U.S. Institute of Peace, 2005).

11 Floyd Whaley, "Scores of Philippine Police Killed in Clash with Islamist Rebels," New York Times, January 26, 2015, www.nytimes.com/2015/01/27/world/asia/scores-of-philippine-police-officers-killed-in-firefight-withrebels.html.

12 Miyoko Taniguchi, "From Rebels to Rulers: The Challenges of the Bangsamoro Government in Mindanao," The Diplomat, August 12, 2020, https://thediplomat.com/2020/08/from-rebels-to-rulers-the-challenges-of-the-bangsa moro-government-in-mindanao/; Ferdinandh Cabera, "Top Army, Ex-MILF Commanders Trained on Disaster Response," Minda News, August 17, 2020, www.mindanews.com/top-stories/2020/08/top-army-ex-milf-comman ders-trained-on-disaster-response/.

13 Taniguchi, "From Rebels to Rulers"; Manuel Canyon, "Decommissioning of MILF Fighters to Continue," Business Mirror, February 19, 2020, https://businessmirror.com.ph/2020/02/19/decommissioning-of-milf-fighters-to-con tinue/; Carolyn Arguillas, "Decommissioning of 12,000 MILFCombatantsStarts September7,"Minda News, August 15, 2020, www.mindanews.com/peace-process/2019/08/decommissioning-of-12000-milf-combatants-starts-sept-7/.

14 Peter Chalk, "Militant Islamic Extremism in Southeast Asia," in Terrorism and Political Violence in Southeast Asia: Transnational Challenges to States and Regional Stability, ed. Paul J. Smith (London: M.E. Sharpe, 2005), 22; Eric Schmitt, "Asian Gains Seen in Terror Fight," New York Times, June 9, 2008, www.nytimes.com/2008/06/09/ world/asia/09terror.html.

15 Jim Gomez, "Al-Qaeda Trained in the Philippines," Associated Press, September 22, 2004, www.cbsnews.com/ news/al-qaeda-trained-in-philippines/; Zachary Abuza, "The Moro Islamic Liberation Front at 20: State of the Revolution" (paper prepared for the National Intelligence Council-U.S. Department of State Bureau of Intelligence and Research, Bureau of East Asian and Pacific Affairs Conference on Mindanao, Washington, DC, July 9, 2004).

16 Peter Chalk, Black Flag Rising: ISIL in Southeast Asia and Australia (Canberra: ASPI, 2015), 14; Shaul Shay, The Islamic State and Its Allies in Southeast Asia (Herzliya: International Institute for Counter-Terrorism, 2014), 3; "Philippine Muslim Rebels Oppose Islamic State 'Virus',' Associated Federated Press, August 28, 2014, www.businessstandard.com/article/pti-stories/philippine-muslim-rebels-oppose-islamic-state-virus-114082800340_1.html.

17 International Political Violence Terrorism Research Center, "Abu Sayyaf Group Profile" (unpublished document, Nanyang University, January 1, 2006).

18 "Plane Terror Suspects Convicted on All Counts," CNN, September 5, 1996, www.cnn.com/US/9609/05/terror.plot/.

19 Chalk, Black Flag Rising, 15; Shay, The Islamic State and Its Allies, 5; C. Joaquin, "Daesh and the Philippines: Distant But Virulent Inspiration," in The Geopolitics of Extremism: ISIS in Asia (Geneva: Geneva Centre for Security Policy, 2015), 15.

20 Philippine police intelligence officials, interviews with author, Manila, December 2018. See also Peter Chalk, Jemaah Islamiyah: An Uncertain Future (Canberra: ASPI, 2019), 15.

21 Chalk, Black Flag Rising, 15; Jacob Zenn, "Rebel With a Cause in Mindanao," Asia Times, September 13, 2011; International Crisis Group, The Philippines: Back to the Table, Warily (Brussels: International Crisis Group, 2011), 6; Ikhwah Al-Mujahidun, “A Day with the Mujahideen of the BIFF," EsinIslam, May 13, 2012, www.esinislam.com/ Articles201205/WritersArticles_IkhwahAl-Mujahidun_0515.htm.

22 Philippine security analyst and subject matter expert, interviews with author, Manila, January 2016.

23 Ibid.

24 Rene Acosta, "Philippines Rebel Group Bangsamoro Islamic Freedom Fighters Undermines Peace Talks," Asia Pacific Defense Forum, September 24, 2012; International Crisis Group, The Philippines: Breakthrough in Mindanao (Brussels: International Crisis Group, 2012), 16.

25 Peter Chalk, "The Islamic State in the Philippines: A Looming Shadow in Southeast Asia?" CTC Sentinel 9, no. 3 (2016): 10-13.

26 "Celebrate the 38th Anniversary of the People's Army!" Philippine Web Central, accessed February 16, 2016, www.philippinerevolution.net/npa/npa; "25 Years of the New People's Army," Liberation International, MarchApril 1994; Office of the Presidential Advisor on the Peace Process, CPP-NPA-NDF (Manila: Republic of the Philippines, 2007).

27 Chalk et al., The Evolving Terrorist Threat to Southeast Asia, 58.

28 National Security Council, interviews with author, Manila, January 2008.

29 Peter Chalk, National Security in the Philippines Under Duterte: Shooting From the Hip or Pragmatic Partnerships Beyond the Noise? (Canberra: ASPI, March 2018), 6.

30 Bureau of Counterterrorism, Country Reports on Terrorism 2019 (Washington, DC: U.S. Department of State, 2020), 255, www.state.gov/wp-content/uploads/2020/06/Country-Reports-on-Terrorism-2019-2.pdf.

31 Chalk et al., The Evolving Terrorist Threat to Southeast Asia, 63-64. 


\section{Peter Chalk}

32 CIA, The World Factbook 2020.

33 Ibid.; Atiyah et al., The Rough Guide to Southeast Asia, 252.

34 Michael Leifer, A Dictionary of the Modern Politics of Southeast Asia (London: Routledge, 1996), 93-94; Adam Schwartz, A Nation in the Waiting: Indonesia in the 1990s (Boulder: Westview Press, 1994), 169.

35 Atiyah et al., The Rough Guide to Southeast Asia, 252-253.

36 Chalk et al., The Evolving Terrorist Threat to Southeast Asia, 67-68.

37 It should be noted that a wide range of Islamic nationalist, anti-statist, and nascent jihadi movements have operated in Indonesia since the fall of the Suharto regime. However, a full accounting of these movements is beyond the scope of this chapter.

38 Chalk et al., The Evolving Terrorist Threat to Southeast Asia, 92.

39 International Crisis Group, Indonesia: Jemaah Islamiyah's Current Status (Brussels: International Crisis Group, 2007), 13.

40 Ministry of Home Affairs, White Paper: The Jemaah Islamiyah Arrests and the Threat of Terrorism (Singapore: Ministry of Home Affairs, 2003), 10.

41 “The 12 October 2002 Bali Bombing Plot," BBC, October 11, 2012, www.bbc.com/news/world-asia-19881138.

42 Chalk et al., The Evolving Terrorist Threat to Southeast Asia, 99.

43 International Crisis Group, Southern Philippines Backgrounder, 13-17; Zachary Abuza, State of Jemaah Islamiyah: Terrorism and Insurgency in Southeast Asia Five Years After Bali (Medford, MA: Jebsen Center for Counter-Terrorism Studies, 2007).

44 Bilveer Singh, "Jemaah Islamiya: Still a Latent Threat," RSIS Commentary, April 24, 2017, www.rsis.edu.sg/ rsis-publication/cens/co17075-jemaah-islamiyah-still-a-latent-threat/.

45 International Crisis Group, Indonesia: The Dark Side of Jama'ah Ansharut Tauhid (Brussels: International Crisis Group, 2010), 4; Chris Rottenberg, Jamaah Ansharut Tauhid: The Perpetual Threat (Washington, DC: Osgood Center for International Studies, February 2012), 2-3.

46 It should be noted that Bashir was willing to accept JI members if they were prepared to accede to his authority and accept his Islamic worldview.

47 International Crisis Group, Indonesia: The Dark Side of JAT, 5.

48 Bureau of Counterterrorism, Country Reports on Terrorism 2019, 278; Chalk, Black Flag Rising, 13.

49 Ibid., 10-11; Rottenberg, Jamaah Ansharut Tauhid, 3.

50 Rottenberg, Jamaah Ansharut Tauhid, 3-4; Bureau of Counterterrorism, Country Reports on Terrorism 2019, 277; Karima Anjani, "Indonesian Church Bomber Linked to Radical Islamic Group," Reuters, September 27, 2011, www.reuters.com/article/idINIndia-59574320110927.

51 Chalk, Black Flag Rising, 13; Rohan Gunaratna, “The Rise of Islamic State: Terrorism's New Face in Asia," in From the Desert to World Cities: The New Terrorism, ed. Wilhelm Hofmeister et al. (Singapore: Konrad Adenauer Stiftung and S. Rajaratnam School of International Studies, 2015), 12.

52 Chalk, Black Flag Rising, 13. Wardah was killed in July 2016 during a shootout with members of the Indonesian Army's Alpha 29 Taskforce at the village of Tambarana in Poso.

53 "Mujahidin Indonesia Timur," Terrorism Research and Analysis Consortium, September 16, 2016, www.trackingterrorism.org/group/mujahidin-indonesia-timur-mit-isea.

54 Freelance investigative journalist, interview with author, Manila, November 2016.

55 Chalk, Black Flag Rising, 13; Gunaratna, "The Rise of Islamic State," 15-16; Rommel Banlaoi "Uyghur Militants in Southeast Asia: Should PH Be Worried?” Rappler, July 13, 2016, www.rappler.com/voices/thought-leaders/ uyghur-militants-southeast-asia-philippines; Jacob Zenn, "A Closer Look at Terrorism in Southeast Asia," War on the Rocks, August 19, 2014, https://warontherocks.com/2014/08/a-closer-look-at-terrorism-in-southeast-asia/.

56 Chalk et al., The Evolving Terrorist Threat to Southeast Asia, 85-86.

57 Freelance investigative journalists and Thai military officials, interviews with author, Manila, November 2016.

58 Chalk, Black Flag Rising, 14.

59 CIA, The World Factbook 2020.

60 Ibid.; Atiyah et al., The Rough Guide to Southeast Asia, 952-953.

61 Chalk et al., The Evolving Terrorist Threat to Southeast Asia, 8. See also R.J. May, "The Religious Factor in Three Religious Minority Movements," Contemporary Southeast Asia 14, no. 4 (1992): 307-320; Omar Farouk, "The Historical and Transnational Dimensions of Malay-Muslim Separatism in Southern Thailand," in Armed Separatism in Southeast Asia, ed. Lim Joo-Jock and S. Vani (Singapore: Institute of Southeast Asian Studies, 1984).

62 Peter Chalk, "The Evolving Dynamic of Terrorism in Southeast Asia," Terrorism and Political Violence 10, no. 2 (1998): 122.

63 Peter Chalk, The Malay-Muslim Insurgency in Southern Thailand (Santa Monica: RAND, 2008), 8.

64 Thai officials and journalists, interviews with author, Bangkok, January 2016. See also Tony Davis, "No End in Sight for Southern Thailand's Escalating Insurgency,' Jane's Intelligence Review, March 2005. 
65 Chalk, The Malay-Muslim Insurgency, 11.

66 Chalk et al., The Evolving Terrorist Threat to Southeast Asia, 18-19.

67 Chalk, The Malay Muslim Insurgency, 11.

68 James Rothwell and Chiara Palazzo, "Four Killed and at Least 20 Injured in String of Explosions in Southern Thailand," Telegraph, August 12, 2016, www.telegraph.co.uk/news/2016/08/11/one-dead-and-ten-injuredafter-bombs-hit-thailand-resort-town-of/.

69 Freelance investigative journalists and Thai military officials, interviews with authors, Bangkok, November 2005 and September 2006.

70 Chalk, The Malay-Muslim Insurgency, 12.

71 Chalk et al., The Evolving Terrorist Threat to Southeast Asia, 29-30.

72 Chalk, Black Flag Rising, 16.

73 Paul Smith, "Introduction," in Terrorism and Violence in Southeast Asia: Transnational Challenges to States and Regional Stability, ed. Paul Smith (Armonk, NY: M.E. Sharpe, 2005), xii. 


\title{
10
}

\section{THE TALIBAN AND THE MODERN HISTORY OF AFGHANISTAN}

\author{
Rob Johnson
}

Since the 1970s, Afghanistan has been a country in conflict. It has often been asserted that violence among Afghans is endemic and this "natural" belligerence, along with the mountainous terrain of the country, accounts for the defeats of successive waves of invaders. ${ }^{1}$ This simplistic interpretation is used to explain why guerrilla resistance in Afghanistan wore down the Soviet Union and forced their withdrawal in 1989 and why the United States and its allies continue to struggle with establishing peace long after their military intervention was officially ended in 2014. The argument is often made that no foreign military force can ever win in Afghanistan, with additional references to the British in the 19th century. This history has led to Afghanistan earning the nickname of the "graveyard of empires."

These simplistic judgments, however, are misleading. The British regarded Afghanistan as a security zone, a region that would be denied to its enemies to protect the landward approaches to its possessions in India and which would be controlled through its rulers rather than permanently occupied. The tactical setbacks the British suffered did not affect their strategic or operational control of the country. Moreover, several empires controlled Afghanistan in similar ways without significant problems-including the Persians and Mughals - by co-opting local Afghan leaders as their intermediaries. Nevertheless, the tendency is to assume that the unsuccessful Soviet experience is the norm.

There have also been romantic ideas that Afghanistan should be returned to its "natural" tribal or medieval state. While seemingly fossilized in parts of the country, Afghanistan's social structure and culture are changing rapidly. Young Afghans refuse to allow their country to remain in the past. The majority of Afghans are eager for change, looking for new opportunities, and interested in the future. They do not embrace a "medieval" conception of their country, even where they accept the values of their faith and their traditions. ${ }^{2}$

While traditions and culture thrive among impoverished populations in much of rural Afghanistan, a brief tour around the major cities reveals just how much the country has changed since $2001 .{ }^{3}$ Afghanistan is making the important transition from a hierarchical and agrarian society to a modern, bureaucratic state, but state building is never a smooth process, and the conflicts that have lasted for decades have distorted the country's development. Afghanistan failed to achieve its transformation in the 1980s and 1990s, while insurgency has stunted and arrested the development of the country for an additional two decades.

Afghan citizens have had to face the reality of marauding banditry by gunmen and by undisciplined, corrupt police, as well as the intimidation of narco-gangsters. Afghans are caught in a struggle for survival where guns and money replace clan allegiances and codes of honor. Yet this has also been a conflict about the form that a new Afghanistan should take: one ideological and atavistic, while the other is based on 
economic modernization. The unfortunate consequences of the conflict between these world views is the survival of patronage and an unbridled search for profit and power, as well as considerable violence.

This chapter identifies the challenges facing Afghanistan, with a particular emphasis on the post-2001 period. It focuses on the key themes of the conflict, specifically insurgency, terrorism, narcotics, governance, and security. It also includes an analysis of the Taliban, the organization whose association with international terrorists provoked Western military intervention and has driven Afghanistan's insurgency ever since.

\section{From the anti-Soviet insurgency to the civil war: 1978-1996}

The Afghanistan insurgency of the early 21st century is the legacy of a civil war that began in 1978 . When communists seized power in Kabul that year, the coercion and violence that accompanied their unpopular social and economic reforms sparked resistance. The communists' purges and factional fighting provoked open revolt, and this in turn prompted Soviet military intervention a year and a half later. The Soviets did not consider the possibility of a growing insurgency, and Moscow struggled to comprehend the conflict. ${ }^{4}$

To halt what appeared to be Soviet expansionism, the United States, Pakistan, and the Gulf states intervened indirectly by supporting the mujahidin resistance fighters. ${ }^{5}$ As the fighting intensified, millions of Afghans became refugees, most seeking sanctuary in Pakistan's tribal belt and the borderlands of Iran. Crucially, the Pakistan border area provided a safe haven for the insurgents and their families from the 1980s onward. Pakistani tribal leaders and authorities exploited this situation for their own interests, seeking to control the government in Kabul and prevent it from falling under the influence of its rival, India, or any faction it considered a threat. ${ }^{6}$

The fighting proved deadly to the population, with millions killed during the war. ${ }^{7}$ Insurgents made extensive use of mines and improvised explosive devices, and the communists retaliated with extreme measures. ${ }^{8}$ Both adversaries proved especially deadly to a people largely dependent on agriculture and confined to limited areas of settlement and routes because of the mountainous terrain.

When the Soviets withdrew in 1989, optimism reigned. Observers hoped that the Afghans could settle their differences and rebuild the country. Such hopes, unfortunately, were short lived. Instead, the mujahidin resistance factions fought each other, and the central government collapsed when funding from the Soviet Union ended abruptly in 1991. ${ }^{9}$ State institutions withered and virtually disappeared. Gunmen and warlord-led clans battled it out on Kabul's streets, reducing the city to ruins, while roadside robberies and taxation at the muzzle of an assault rifle became the norm. ${ }^{10}$

After two years of chaos, the Taliban - largely Pashtun southerners who attracted Pakistan's supportbegan to overrun factions around Kandahar. The Taliban then seized Herat before bombarding Kabul with artillery and launching rockets into the city center. ${ }^{11}$ Pakistan's military backed the Taliban because Islamabad wanted a compliant, pro-Pakistan authority in Kabul. ${ }^{12}$ Pakistan's Inter-Services Intelligence, its main intelligence agency, swung its full weight behind the Taliban and supported its assault on the capital in September $1996 .{ }^{13}$ Still divided, the other factions abandoned Kabul in the face of the Taliban onslaught. ${ }^{14}$

Afghans in the south initially welcomed this austere, puritanical, and militant sect because it promised to end the civil war. ${ }^{15}$ While the ethnic composition of Afghanistan is complex, the Pashtun population, broadly observing Sunni and conservative Islam, dominates the south and east, with significant enclaves in the northwest (Badgheis Province) and northeast (Kunduz Province)..$^{16}$ The northern and central populations of Afghans are a mixture of Sunni Uzbek, Tajik, Shia Muslim Hazarajat, and other minorities, each representing waves of historic migration and settlement. ${ }^{17}$

Afghans in regions with sectarian or ethnic differences to the Taliban reacted in horror to the group's ultra-conservative and coercive policies. Northern communities resisted from the outset because the Taliban exhibited intolerance and brutality toward them. ${ }^{18}$ In time, the Taliban subjected all Afghans, not just northerners, to draconian restrictions, executions based on spurious evidence, and random torture. ${ }^{19}$ Many 
suspected that such untypical behavior must be foreign inspired, from the more extreme Deobandi tradition of Pakistani madrasas (religious schools) or from purist Arabs who looked down on bucolic Afghan culture. ${ }^{20}$

In theory, the Taliban was a militaristic organization eager to turn the clock back to an idealized version of Islamic society. ${ }^{21}$ In practice, however, many Taliban recruits were disaffected and angry young men, strengthened by veterans of the war against the Soviets, including the so-called "Arab Afghans"-foreign fighters from across the Middle East, Africa, and Europe who had fought alongside the Afghan mujahidin. ${ }^{22}$

Repudiating politics, the Taliban's leader, Mullah Muhammad Omar, referred to himself as Amir alMomineen (leader of the faithful) and sought exclusive power legitimized as a "divine right." ${ }^{23}$ Mullah Omar employed the props and rhetoric of Islam, impressing his followers with a dignified piety. ${ }^{24}$ In reality, he ruled with an oligarchy of friends and allies.

The Taliban made use of their Pakistani intelligence and military contacts, but they also relied on the support of drug barons and provincial governments. ${ }^{25}$ For recruits and influence beyond the country, they accessed networks of Deobandi madrasas in Pakistan. ${ }^{26}$ Taliban fighters found themselves among idealistic comrades who shared radical ideas and were fed a heady cocktail of religious dogmatism and militant doctrine.

Despite their righteousness and self-confidence, the Taliban never fully controlled Afghanistan. Groups gradually united against the Taliban under the banner of the National Islamic United Front for the Salvation of Afghanistan, more commonly known as the Northern Alliance. ${ }^{27}$ The northerners' resistance drove the Taliban to greater brutality against the Afghan people.

In August 1998, the Taliban overran Mazar-i-Sharif and massacred large numbers of civilians, mainly Shia Hazaras. ${ }^{28}$ Survivors state that the killing went on for three days, led by foreign Taliban fighters under the direction of Mullah Omar's loyal lieutenant, Mullah Abdul Manan Niazi. The Taliban reportedly killed people in unimaginable ways, including asphyxiation by locking people in metal containers in the sun. Firing squads toured the streets, and decrees forbade the inhabitants from moving or burying the bodies. Eyewitnesses spoke of dogs tearing at corpses. ${ }^{29}$

In the northern province of Badakhshan, the anti-Taliban forces of Ahmad Shah Massoud were the most successful in defying Mullah Omar's attempts to coerce all Afghans into submission. His resistance inspired a generation. Although Massoud was killed in 2001, he has been venerated ever since. ${ }^{30}$

The Taliban's primary objective was "security." They claimed to be asserting Sharia (Islamic law) and restricted private and public life under the auspices of protecting the Afghan people. They expressed a desire to continue the jihad until there were no opponents left, and they aimed for a "strong" Afghanistan. The Taliban made sure their laws were strictly enforced, often by a "religious police," the Amr bil-Maroof wa Nahi An il-Mukir (Department for the Promotion of Virtue and Suppression of Vice). ${ }^{31}$ Those who fell foul of the religious police in Kabul could be stoned to death or executed publicly by firing squad. ${ }^{32}$

The Taliban targeted any element of liberal culture: they banned television and only tolerated radio as a means of propaganda, prayers, and the broadcast of new decrees. They outlawed music, dancing, playing games, flying kites, drumming, and all visual representations of animals or people. ${ }^{33}$ On March 10, 2001, the Taliban destroyed 1,500-year-old Bamiyan Buddha statues. ${ }^{34}$

International opinion, already angered by the cultural destruction, soon focused on the Taliban mistreatment of women. The Taliban argued the "face of a woman is a source of corruption for men." ${ }^{35}$ Women often had to forego medical treatment and were denied education, forced into marriages, and prevented from traveling. ${ }^{36}$ They were rendered invisible with decrees on dress and kept out of public view. Denied employment, many war widows were left destitute. ${ }^{37}$

Under the Taliban, Afghanistan became a springboard for al-Qaida's terrorist operations. ${ }^{38}$ On August 7, 1998, al-Qaida operatives detonated suicide car bombs outside the U.S. Embassies in Kenya and Tanzania. ${ }^{39}$ The coordinated bombings killed 224 people. The United States retaliated by launching cruise missiles 
against al-Qaida camps in Afghanistan and Sudan. ${ }^{40}$ Washington froze Taliban assets in the United States, and the United Nations followed with sanctions, demanding that al-Qaida chief Usama bin Ladin be handed over to U.S. custody. In December 2000, the United Nations imposed military sanctions, increasing the pressure on the Taliban. ${ }^{41}$ Meanwhile, al-Qaida, harbored by the Taliban, issued statements advocating "global jihad."

\section{9/11 and the fall of the Taliban}

The Taliban's decision to allow al-Qaida to base itself in the country and mount the 9/11 attacks on the United States marked their greatest strategic error. After 9/11, the U.S. military retaliated. Overwhelming American air power guided by Special Operations Forces, working alongside the Northern Alliance, defeated the Taliban in a matter of weeks. After what served effectively as an ultimatum, President Pervez Musharraf of Pakistan declared himself in favor of U.S.-led action in Afghanistan. Pakistan's policy of creating a compliant state on its western border had failed spectacularly, but their national interest in creating a pro-Pakistani state would not disappear entirely.

The U.S.-led coalition deployed thousands of bombs and missiles in the space of a few weeks. Even seasoned Taliban veterans broke under the intensity of the attacks. Many fighters later explained that they could not even see the aircraft that attacked them. ${ }^{42}$ The Taliban especially feared the 15,000-pound BLU82 "Daisy Cutter," although it was only dropped on four occasions. ${ }^{43}$ The CBU-103 "Combined Effects Munitions," colloquially known as a "cluster bomb," were also highly effective, although the debris of unexploded ordnance attracted criticism. ${ }^{44}$

Despite fears of indiscriminate bombing, 6,700 of the weapons used were precision-guided. Special Operations Forces could lay down carpets of explosions a few hundred yards in front of their own positions without inflicting civilian or friendly casualties.

The Taliban collapsed swiftly because they did not have much legitimacy to govern. ${ }^{45}$ They had demonstrated that they were just as ruthless and uncompromising as previous regimes, all of which had managed to alienate substantial sections of the Afghan people. ${ }^{46}$ The Taliban were forced to depend on their original Pashtun heartland in the south and east, cut deals with other groups in the facilitation of narcotics, and then play on the idea of a foreign occupation or corrupt government to garner support. ${ }^{47}$

When Mullah Omar fled Kandahar, he spoke in terms of an approaching apocalypse, but this only exposed the fact that the Taliban had little to offer except violence and coercion. ${ }^{48}$ Under the Taliban, the country had remained in ruins, and its people lived in intolerable conditions, held in check only by repression. Like the Islamic State in the period of 2014-2017, the promises of an idealized Muslim polity turned out to be no more than political extremism, torture, summary execution, and, for its adherents, a cult of martyrdom.

The Bonn Conference of October 3, 2001, marked the beginning of a long and difficult process of reconstruction. Six neighboring countries plus the United States and Russia (known as the "Six plus Two") agreed that Afghanistan should enjoy a multi-ethnic, freely elected government. Nevertheless, at the subsequent meeting of Afghans that December, important continuity figures were not present: warlord Abdul Rashid Dostum; Taliban leaders; and the former king, Zahir Shah. Even so, participants agreed on a "road map" for peace starting with the formation of an interim administration. An emergency loya jirga (Grand Council) was created. ${ }^{49}$

In addition, an international peacekeeping force, the International Security Assistance Force (ISAF), would be deployed. ISAF had the task of restoring confidence in Kabul and protecting the leaders of the new administration from terrorist groups. ${ }^{50}$ Meanwhile, U.S. and allied Special Operations Forces continued to hunt down al-Qaida operatives. ${ }^{51}$

Most encouraging about the peace process were the early steps taken to hand over authority to the Afghans. The first priority was security, so the presence of ISAF was crucial. There was no question of 
permanent occupation, nor was there an opportunity, as had occurred in 1989, for Pakistan to intervene in Afghan politics for its own ends. ISAF's presence meant warlords could not resume their violent campaigns.

Expectations, however, proved impossible to fulfill, and it did not take long for criticisms of the Western effort to develop. Afghans needed to feel the effects of material prosperity as a peace dividend, and they looked eagerly toward the wealth of the West for assistance. Unfortunately, Afghan hopes for immediate recovery and development could not be met, and the U.S. administration did not commit to "nationbuilding." There was certainly an expectation in the United Nations that reconstruction of Afghanistan would take place, but the American military priority was the pursuit and defeat of al-Qaida.

Specialists also pointed out that Afghanistan's “construction," rather than "re-construction," would actually take decades. ${ }^{52}$ The overriding problem was that lawless armed groups held Afghanistan at their mercy, and too few troops had been dedicated for the security tasks that had emerged after 2001.

In 2006, a steady stream of American and NATO troops arrived, taking over responsibility for the eastern and southern provinces. At its peak, Western combat troops across the country numbered nearly 130,000, with especially heavy concentrations in the south and east where the Taliban had the strongest presence.$^{53}$ Special Operations Forces augmented conventional troops, who were all supported by complete control of the air through both manned and unmanned armed aircraft.

There were evident problems with the initial strategy for Afghanistan. Afghans complained about a lack of human security, a precarious economy, vulnerable agricultural yields, and corrupt officials; Afghans often found those issues more pressing than the Taliban threat. ${ }^{54}$ Yet United Nations and military officials, lacking the experience of development work but drafted in to cover the absence of government advisors and non-governmental organizations, took a patronizing approach and failed to engage Afghans at a local level..$^{55}$

Contract workers went unchecked, and a practice of sub-contracting and exorbitant costs reached epidemic proportions. ${ }^{56}$ The result was patchy development work, often of a low standard, with investment in buildings and short-term projects rather than people.

The lack of qualified police officers further exacerbated the weak national Afghan criminal justice system. ${ }^{57}$ An auxiliary police, created from militiamen, proved corrupt and too small to be effective. The police training program in Kabul, operated by Germany, was too slow and unable to furnish sufficient numbers to meet demands beyond Kabul..$^{58}$

There were significant rifts in the approaches of NATO members who participated in ISAF, particularly over their mission, rules of engagement, and attitude toward risk. ${ }^{59}$ Locals who might have provided security personnel and development workers, in the style of the traditions of village arbakai (militias), were disarmed because of a fear of private armies. ${ }^{60}$ From a legal point of view, there were disputes about whether Sharia should take precedence over secular law, and there were protests from Western governments who wanted to see Afghanistan built more in their own image. ${ }^{61}$

Reconciliation was also a contested area. The proximity of the Taliban to al-Qaida in ideological terms meant that Western states had no appetite for talks with the Taliban. Conversely, the Afghan government decided against criminalizing the Taliban in the hopes of a rapprochement and was determined to remain in control of all negotiations, even if that meant derailing any foreign initiatives in the short term. ${ }^{62}$ Any suggestion of power sharing between Pashtuns and non-Pashtuns seemed to anger or disappoint every faction.

There were some aspects of the Western-led stabilization effort in Afghanistan that moved in the right direction, needing only time, manpower, and money to sustain them. Unfortunately, the diversion of resources to Iraq in 2003 checked progress in security and reconstruction at a critical time. Nevertheless, the recruitment of a new Afghan security force proved essential, and the Afghan National Army began to grow from 2001 and soon became an evident source of pride..$^{63}$ Yet the strategic priority of the Western powers was to deny Afghanistan as a base for further operations by al-Qaida and its allies, and that meant less interest in developing Afghanistan as a whole. ${ }^{64}$ 


\section{The Taliban resurgence}

After the U.S.-led invasion in 2001, the Taliban used Pakistan's border area as a relative safe haven. The Taliban strategy sought to recreate an emirate, win over more Afghans to their cause, impose Sharia, and maintain Pashtun supremacy. ${ }^{65}$ Their method focused on undermining Western efforts, using force to demoralize and weaken Western forces to keep resistance alive, sustain the idea of a liberation struggle, and wage a war of "national" defense. Their tactics were not just military-style attacks but the intimidation and murder of Afghans. ${ }^{66}$

In 2006, a blend of al-Qaida and Taliban forces re-emerged, conducting a campaign of insurgency and terrorism. Their objective was to "discipline" the Afghan people, to co-opt and recruit local fighters, and to wage unrelenting hit-and-run warfare to make Afghanistan ungovernable. They sought to pressure the United States and its NATO allies to leave the country, believing they could do the same to the Americans as they had to the Soviet Union. ${ }^{67}$

One rural interviewee gave a vivid impression of the low-key character of intimidation by insurgents:

One night around midnight someone knocked on the door of our house. We were terrified, fearing that the police had come back to arrest me or my brother once again. But when we opened the door, it was one of my father's former students. He had a Kalashnikov on his shoulder and was a Taliban sub-commander already. The two other Taliban he was with also carried AKs and had several hand grenades attached to their belts. This was my first encounter with the Taliban since the defeat. We invited them to spend the night. Early the next morning I accompanied them to the mosque. My father's former student read out the names of those he accused of having betrayed Islam by following [Afghan President Hamid] Karzai and the infidels. He warned them to cease all contact and to quit any job they may have had with the government or the Americans. He ended by saying he would return in one week. ${ }^{68}$

Each year, the insurgents would attempt to build up their forces in the late winter and early spring, and conduct a "fighting season" of attacks from March to October. This would be followed by a lull as they attempted to regenerate forces and restore command and control. Weapons and ammunition passed along "main supply routes," many of which were traditional smuggling trails.

The Taliban have had diverse sources of income, ranging from donations from wealthy Gulf businessmen, ideologues in Pakistan, extortion from haulage firms taking goods into Afghanistan, racketeering within Afghanistan, and roadside intimidation. ${ }^{69}$ The Taliban invests in security in local areas, providing for the safe passage of goods and extracting a fee. This system allows them to generate more revenue while expanding their influence, building relationships, and dominating the lives of Afghans at a local level. ${ }^{70}$

The Taliban also derived significant sums of money from narcotics. Notoriously, Afghanistan produces over $90 \%$ of the world's opium. ${ }^{71}$ Refined into heroin, a portion remains in the region to supply a growing regional addict population, especially in Iran and Afghanistan, and the rest is exported, primarily to Western Europe via Africa or Central Asia. For farmers, opium is

a miracle crop. . . [maturing] quickly, allowing double cropping . . . it is more weather-resistant than wheat, is easy to store, transport, and sell. . [and] can easily be stored . . . as a form of savings in a country that until recently was wracked by inflation. ${ }^{72}$

The Taliban recognized the importance of opium to Afghan farmers, and they were careful to frame support for the trade against government eradication and corruption. They offered financial backing to those whose fields were being eradicated in exchange for support against the government, and they assisted 
in the guarantee of production by ensuring that payments were delivered to the farmers even before the crop had been harvested. ${ }^{73}$ By providing security and safe passage, they made the opium trade viable.

Crucially, the opium trade has produced national and international networks of production, refinement, and export that have changed social relationships within Afghanistan. It offers a powerful few enormous influence, enabling them to dispense with traditional forms of governance and to buy off interfering government officials. The insurgents, criminal groups, and government remain locked in a struggle for this critical part of the Afghan economic ecosystem. But the opium trade also distorted the Taliban itself, setting up resentment between southern Pashtuns and the central "Quetta Shura" headquarters. ${ }^{74}$

When under significant pressure from ISAF or the Afghan security forces, the Taliban and other insurgent groups, like the Haqqani network on the Pakistan border, resorted to more significant acts of terrorism, often in urban areas. ${ }^{75}$ Large scale vehicle-borne improvised explosive devices or suicide raids by small groups of men were designed to demoralize the Afghan government and persuade Western coalition forces to withdraw. ${ }^{76}$ The Taliban rejoiced at the announcement in 2009 that the West would begin its drawdown and transition, and they believed they had "brought down the elephant." Their objective was to finish the process with a sustained campaign of violence.

In 2009, General Stanley McChrystal, the ISAF commander, announced a modification to the West's strategy in Afghanistan. ${ }^{77}$ The objective remained the defeat of al-Qaida and the stabilization of the country under the leadership of the government in Kabul, but McChrystal argued that the method was of vital importance. McChrystal believed that Afghans needed to play a bigger role.

As part of this strategy, McChrystal and other military commanders convinced the White House that they needed to "surge" more U.S. troops into Afghanistan. The Obama administration authorized 33,000 more troops, which would be used to assist the expansion of the Afghan National Security Forces, hold critical areas of the south against Taliban advances, and boost support to local government structures. ${ }^{78}$

McChrystal immediately demanded a rapid increase in numbers of Afghan National Security Forces personnel. He urged the reprioritization of resources to signal the West's long-term commitment to Afghanistan. McChrystal also made clear, somewhat controversially, that he intended to protect the Afghan population not only from the Taliban but also from the corrupt and coercive elements of the Afghan government. In short, he wanted to implement a classic counterinsurgency doctrine to win the "hearts and minds" of the population and to drive a wedge between the people and the insurgents. ${ }^{79}$

The relatively small scale of coalition manpower available, especially compared with concurrent operations in Iraq, meant that there was a greater incidence of airstrikes to protect units. Those planning coalition military operations in Afghanistan showed an awareness of the dangers of reliance on air powerespecially the accidental and adverse consequences of killing civilians. ${ }^{80}$ The intention was to prevent civilian casualties altogether, but while this aim went further than the strict laws of international armed conflict, in practice, it was not achieved.

Many factors prevented its realization, such as poor intelligence and target selection, the proximity of military targets and civilians, weapons malfunctions, and periodic misunderstandings between ground and air forces ${ }^{81}$ President Karzai, whose authority had been diminishing, felt compelled to increase demands on the coalition, criticizing airstrikes and insisting on terminating the arrests of Taliban suspects and their supporters in night raids. ${ }^{82}$

ISAF wanted to tackle the insecurity of the population by neutralizing the insurgents and reassuring the Afghan people with an overt military presence. The insurgents, however, were determined to maintain resistance; terrorist attacks in the cities were a means to divert public attention whenever the insurgents came under pressure in rural areas. ${ }^{83}$ Taliban attacks on aid organizations also increased, as the Taliban believed that aid groups furthered the government's interests. The Taliban attacks forced some aid agencies to leave.

ISAF's answer was to develop more effective Afghan National Security Forces. Despite predictions that service would be unpopular, a large volunteer army was created. There were initially criticisms that Tajik 
Afghans retained most positions of command despite provincial quotas that allowed for ethnic groups to be represented proportionally, but the dynamic was in part a legacy of the Northern Alliance victory in 2001. While Pashtuns were encouraged to enlist, literacy and competency levels were lower among southerners, even by Afghan national standards. In some cases, Pashtun recruits feared Tajik-dominated forces, and promotion appeared to be influenced by patronage networks more than merit.

The Afghan National Security Forces had a variety of other problems. Some soldiers sold their equipment for personal profit; those absent without leave rose in number but went unpunished; and, despite screenings, there were concerns about narcotics abuse. ${ }^{84}$ But there were positive developments as well. Abuse against civilians declined rapidly as training improved, a new pay system reduced ghost pay-rolling, and rumors of the killing of Taliban prisoners declined as the criminal justice system improved after $2010{ }^{85}$ Recruit training was extended, and contracts lasted three years to improve service conditions. ${ }^{86}$

Inevitably, there were still concerns that insurgents might intimidate, torture, or kill the families of Afghan National Security Force members. ${ }^{87}$ Initially, there was little troop rotation out of the danger zones, the best units were often over-worked, and casualties ran as high as $15 \%$. The most significant ongoing challenge, however, was leadership. ${ }^{88}$

Western mentors embedded with Afghan troops to assist in the development of experienced junior commanders. ${ }^{89}$ This proved an excellent interim measure, although there were complaints on both sides about expectations. ${ }^{90}$ There were several "green-on-blue" incidents where Afghan soldiers, or disguised insurgents, turned their guns on their coalition mentors. ${ }^{91}$ Yet as larger Afghan units formed, and specialist leadership training developed, advisors replaced the embedded teams, allowing Afghan formations to operate independently.

There were, as one would expect for a new army, limitations in their capabilities, especially in intelligence, logistics, vehicle maintenance, air mobility, heavy weapons, and transport. By 2010, however, the Afghan military took control over more areas of Afghanistan, allowing the establishment of political control. The Afghan government set up an Afghan Air Corps (and later an air force) and also established pay facilities, training institutions, and a medical evacuation chain. ${ }^{92}$

In insurgencies, there are always individuals who exploit the presence of military forces for their own ends. Some provincial groups and leaders tried to acquire U.S. or foreign development funding while keeping open links with the insurgents. In Kunar Province in 2008, one group of local leaders manipulated both insurgents and ISAF by inviting fighters to "defend" their valley against foreigners, knowing that Western troops would clear the area and then commence development work as part of the "shape, clear, hold and build" tactic. Once the insurgents had served their purpose, the locals drove them out and embraced the construction projects but expressed the hope that the foreigners would also leave. ${ }^{93}$

Local security forces, or irregular forces, were considered vital to building local governance because they provided the link between local leaders, local justice, and the national government. Local security forces could be kept accountable to their own communities while being licensed by the central authorities, which could be considered a form of social contract. ${ }^{94}$ Although local forces were distrusted because of the fear of large, unregulated militias, the fact was that everything in Afghanistan required tailoring to local needs. ${ }^{95}$ Throughout the campaign, the West's aim was consistent in wanting to improve security, which meant, ultimately, getting Afghans into a position where they could sustain themselves.

The conflict in Afghanistan would have been far easier to resolve had it not been for the activities across its borders. Iranian leaders perceived that they had been encircled by the United States with its troops in Iraq and Afghanistan. Iranian intelligence made every effort to maintain links to the Afghan government, to the leaders of Herat, and to some insurgent groups. Nevertheless, Iran suffered the effects of Afghan opium trafficking, and Tehran grew concerned about the assertiveness of Baloch insurgents within its borders. ${ }^{96}$

Pakistan had its own agenda, pursuing a form of hybrid warfare against Western interests while denying any involvement in the conflict. ${ }^{97}$ Pakistan's main goal was preventing Indian influence in Kabul, but 
it also wished to persuade the United States to abandon the Afghans to foster its own relationship with the Afghan Pashtun population, a group it regards as a potential paramilitary asset against India and other rivals. ${ }^{98}$ Afghanistan's various insurgent groups could cross the "Durand Line" that demarcates Afghanistan and Pakistan and find sanctuary in Pakistan's Federally Administered Tribal Areas, where they could purchase weapons and ammunition, recruit refugees, indoctrinate trainees, select suicide bombers, rehearse operations, arrange command appointments, rest their fighters, and plan missions.

The United States recognized the problem of operating across a sovereign border, and in time they orchestrated a campaign of drone strikes. Pakistan cooperated when it suited their interests, but it protected certain militant groups. The greatest humiliation for Pakistan was the discovery of Bin Ladin in a compound in Abbottabad, well inside Pakistan's borders. Knowing that Pakistan would not cooperate, the United States launched a daring and successful Special Operations Forces mission to kill the al-Qaida leader. Pakistan retaliated by closing ground lines of communication across its borders and withdrawing its "support," but it had been exposed as an unreliable ally.9

The death of Bin Ladin had in effect ended the raison d'être of the U.S. intervention in Afghanistan. Al-Qaida was scattered, many of its operatives had been killed, Afghanistan was a sufficiently stable if financially dependent nation-state, and there was no strategic interest in fighting the Taliban in perpetuity.

After the end of Western combat operations in 2014-the extra troops from the "surge" had left in 2012 - the insurgents stepped up their attacks and inflicted significant losses on Afghan security forces for two years. Then, in late 2014, a new threat emerged in the eastern province of Nangarhar, inspired by the Islamic State movement in Syria. Known as the "Vilayet Khorasan," or Islamic State Khorasan, these fighters emulated the tactics and brutalities of the Islamic State, murdering their opponents and terrorizing the population. The United States led the effort to neutralize this emerging threat while being careful not to permit itself to be drawn into yet another "large footprint." The emphasis was on enabling the Afghan security forces. ${ }^{100}$

After a series of "spectacular" mass casualty terrorist attacks - including the massacre of patients and staff in a Kabul maternity unit in May 2020, murders of police officers, attacks on funeral gatherings, and other acts of depraved violence - the Islamic State Khorasan movement suffered a steady and mounting stream of casualties. These terrorist attacks appeared to attract radical recruits, but the extreme violence had already alienated the Afghan and Pakistani Taliban, al-Qaida, and the Haqqani network. There were also unconfirmed reports of pitched battles between the Taliban and Islamic State Khorasan.

The U.S. announcement in 2017 that it would sustain Afghanistan's funding and support for at least four more years dealt a serious blow to the Taliban and other militant groups in Afghanistan. The Taliban made a full U.S. withdrawal a condition for negotiations to end the conflict. Yet the Taliban also knew that they had not inspired a nationwide resistance, as had been the case against the Soviets. In some southern areas, the Pashtun population resented the Taliban insurgency, especially when terrorists targeted much-needed schools and infrastructure.

This eventually compelled the Taliban to reverse its policy against the education of girls. ${ }^{101}$ None of the urban areas had fallen, and even Taliban attempts to wrest control had been temporary, lasting only a few days. The Americans seemed resolute in their support to the Afghan government, and the country continued its faltering progress toward statehood.

As a result of leadership quarrels in the Taliban, the Haqqani network has emerged as the more effective adversary of the Afghan government. ${ }^{102}$ The Haqqanis draw their lineage from across the AfghanistanPakistan border area, and, with the backing of the Pakistani intelligence services, they proved a useful tool for deflecting militancy from North Waziristan in Pakistan's Federally Administered Tribal Areas into Afghanistan. ${ }^{103}$ For Pakistan, the cohesion of the Haqqanis made them an attractive partner compared with the larger but more factional Taliban.

When the leadership of the Taliban became divided in 2017-2018, Sirajuddin Haqqani, the leader of the Haqqani network, offered an effective alternative movement to weaken the government of Afghanistan. 
Hostage-taking became a useful method to deter drone strikes, while terrorist attacks in Kabul were the means to maintain pressure on the Afghan government and tie down its security personnel. While Islamic State Khorasan and the Taliban have the higher profile, it is the Haqqani network that is likely to have the most lasting influence in Afghanistan's conflict going forward, particularly if Islamabad believes it is the most worthy of its support.

\section{Conclusion}

Afghanistan is a case study of the consequences of both state collapse and uninhibited state power. The process that began with the communist coup of 1978 resulted in the gradual erosion of the Afghan state. Those who propagated ever more radical solutions were, like so many revolutionary zealots, consumed by the forces they had unleashed. Without public support, radicals were forced to turn to terror to enforce their new utopia, and the result was brutality, coercion, atrocities, and failure.

The Taliban, backed by their external allies, are convinced of the righteousness of their ideology, but they have perpetrated the very crimes they claimed to have come to eradicate. While the Islamists believed that they had to destroy the Western presence and Western values, these same values proved essential requirements for social groups to coexist and are shared by both Western and Islamic societies.

Since 2001, despite all the doubts and commitments the West faced, the insurgents failed to overrun or dislodge U.S. forces as they expected. Their major offensives in the south and east from 2006 to 2014 were all defeated militarily. They failed to overturn the Afghan government after the drawdown of Western forces. They failed to prevent elections or the people from voting. Politically, they remained outside the mainstream processes.

After 2014, there was increasing factionalism among insurgent groups in Afghanistan. There was some suggestion that insurgent field commanders would rather be free of the constraints imposed by the command councils based in Pakistan. It is also clear, however, that the Deobandi and Wahhabi doctrines that have sustained their motivation have drawn closer together, and many Taliban fighters now identify with a pan-Islamic ideology, not just a Pashtun-Afghan one.

The peace talks that were supposed to end the conflict in Afghanistan have suffered a number of false starts. ${ }^{104}$ The Karzai administration often accused the United States and its allies of trying to settle a deal that would not be in Kabul's interests. American officials often expressed concern about with whom they could negotiate and whether the representatives who came forward were, in fact, the "authentic voice" of the Taliban. In 2018, however, the Taliban "office" in Qatar seemed to be more serious about a peace process.

On February 29, 2020, the Trump administration concluded a preliminary peace agreement with the Taliban, offering that American forces would withdraw from Afghanistan over a 14-month period if the Taliban ended their campaign of violence. ${ }^{105}$ But the Ashraf Ghani administration rejected a set of proposals that accompanied the deal, whereby there would be a release of Taliban prisoners. Likewise, the Taliban quickly added that their promise was to "reduce violence" for a period of seven days and was in no way intended to be lasting. Thus, it seems that the Taliban intends to continue its war against the Kabul government.

\section{Notes}

1 Keith Stanski, “'So These Folks Are Aggressive': An Orientalist Reading of 'Afghan Warlords', Security Dialogue 40, no. 73 (2009): 73-94.

2 Thomas Barfield, “Is Afghanistan 'Medieval'?” Foreign Policy, June 2, 2010, https://foreignpolicy.com/2010/06/02/ is-afghanistan-medieval-2/.

3 M. Nazif Shahrani, "The Future of the State and the Structure of Community Governance," in Fundamentalism Reborn? Afghanistan and the Taliban, ed. William Maley (London: Hurst, 1998). 
4 Artemy M. Kalinovskii, "A Long Goodbye: The Politics and Diplomacy of the Soviet Withdrawal From Afghanistan, 1980-1992" (thesis, London School of Economics, 2009).

5 Edward Giradet, Afghanistan: The Soviet War (London: Taylor \& Francis, 1985).

6 Seth G. Jones, The Insurgent Sanctuary in Pakistan (Washington, DC: Center for Strategic and International Studies, 2018).

7 Alexander Lyakhovski, Tragedia i doblest Afgana (Moscow: Éksmo, 2009), 1,018; Rodric Braithwaite, Afgantsy: The Russians in Afghanistan, 1979-89 (London: Profile Books, 2012).

8 Giradet described Soviet tactics as inducing a migratory genocide by extensive bombing and reducing areas to rubble. See also Braithwaite, Afgantsy.

9 Ahmed Rashid, Taliban (New Haven: Yale University Press, 2001).

10 William Maley, The Afghanistan Wars, 2nd ed. (New York: Palgrave Macmillan, 2009).

11 Ibid.

12 Gilles Dorronsoro, The Taliban's Winning Strategy in Afghanistan (Washington, DC: Carnegie Endowment for International Peace, 2009).

13 Matt Waldman, The Sun in the Sky: The Relationship Between Pakistan's ISI and Afghan Insurgents (London: Crisis States Research Centre, 2010).

14 "Taliban Poised to Overrun Afghan Capital," Guardian, September 26, 1996, www.theguardian.com/theguardian/ 1996/sep/26/fromthearchive.

15 There was a long tradition of resistance to the authority of the capital. See David Edwards, "Pretexts of Rebellion: The Cultural Origins of Pakhtun Resistance to the Afghan State" (PhD diss., University of Michigan, 1986).

16 For more details on Afghanistan's historical ethnic groups, see Henry Walter Bellew, The Races of Afghanistan: Being a Brief Account of the Principal Nations Inhabiting That Country (Calcutta: Thacker and Spink, 1880).

17 Katharine Adeney, "Constitutional Design and the Political Salience of 'Community' Identity in Afghanistan," Asian Survey 48, no. 4 (2008): 535-557.

18 Neamatollah Nojumi, The Rise of the Taliban in Afghanistan (New York: Palgrave Macmillan, 2002); Kamal Matinuddin, The Taliban Phenomenon: Afghanistan, 1994-1997 (New York: Oxford University Press, 1999).

19 James Fergusson, Taliban (London: Bantam Press, 2010).

20 Barnett R. Rubin, The Fragmentation of Afghanistan: State Formation and Collapse in the International System (New Haven: Yale University Press, 2002).

21 Abdul Salam Zaeff, My Life With the Taliban (London: Hurst, 2011).

22 Mohammed M. Hafez, "Jihad After Iraq: Lessons From the Arab Afghans Phenomenon," CTC Sentinel 1, no. 4 (2008).

23 Michael Semple, Rhetoric, Ideology, and Organizational Structure of the Taliban Movement (Washington, DC: U.S. Institute of Peace, 2014).

24 Zaeff, My Life With the Taliban.

25 See, for example, Rob Johnson, "Managing Helmand From Bost to Bastion," International Area Studies Review 15, no. 3 (2012): 279-300.

26 Zaeff, My Life With the Taliban; Nojumi, The Rise of the Taliban, 154, 180 and 189.

27 Rob Johnson, The Afghan Way of War (New York: Oxford University Press, 2012), 256.

28 Kenneth J. Cooper, “Taliban Massacre Based on Ethnicity," Washington Post, November 28, 1998, www.washington post.com/archive/politics/1998/11/28/taliban-massacre-based-on-ethnicity/efe15f81-abed-4e57-96f1-046cc $59 \mathrm{~d} 1 \mathrm{~d} 48 /$.

29 Maley, The Afghanistan Wars, 230.

30 Quil Lawrence, "In Afghanistan, Assessing a Rebel Leader's Legacy," National Public Radio, September 9, 2011, www.npr.org/2011/09/09/140333732/in-afghanistan-assessing-a-rebel-leaders-legacy.

31 John F. Burns, "Stoning of Afghan Adulterers: Some Go to Take Part, Others Just to Watch," New York Times, November 3, 1996, www.nytimes.com/1996/11/03/world/stoning-of-afghan-adulterers-some-go-to-take-partothers-just-to-watch.html.

32 Ibid.

33 "Who Are the Taliban?" BBC, February 27, 2020, www.bbc.com/news/world-south-asia-11451718; Nicholas Wroe, "A Culture Muted," Guardian, October 13, 2001, www.theguardian.com/world/2001/oct/13/afghanistan. books; Matinuddin, The Taliban Phenomenon.

34 Barry Bearak, "Over World Protests, Taliban Are Destroying Ancient Buddhas," New York Times, March 10, 2001, www.nytimes.com/2001/03/04/world/over-world-protests-taliban-are-destroying-ancient-buddhas.html.

35 Amnesty International, Women in Afghanistan: The Violations Continue (London: Amnesty International, 1997).

36 Bahaar Joya, "Invisible Taliban Child Brides, Widows Trapped as Sex Slaves," Reuters, August 23, 2017, https:// fr.reuters.com/article/us-afghanistan-rights-women-idUSKCN1B31PL. 
37 M.J. Gohari, The Taliban (New York: Oxford University Press, 2000), 108-110.

38 Zaeff, My Life With the Taliban, 136-144; Fergusson, Taliban, 87.

39 James C. McKinley, Jr., "Bombings in East Africa," New York Times, August 8, 1998, www.nytimes.com/1998/08/08/ world/bombings-east-africa-overview-bombs-rip-apart-2-us-embassies-africa-scores.html.

40 James Bennet, “U.S. Fury on 2 Continents," New York Times, August 21, 1998, www.nytimes.com/1998/08/21/ world/us-fury-2-continents-overview-us-cruise-missiles-strike-sudan-afghan-targets.html.

41 UNSCR 1333, December 19, 2000, reinforced by UNSCR 1363, allowed for measures of counterterrorism. The Taliban vowed to kill any UN officials it found in either Afghanistan or Pakistan. See Rashid, Taliban, xi.

42 Sami Yousafzai and Ron Moreau, "The Taliban in Their Own Words," Newsweek, October 5, 2009.

43 Richard Norton-Taylor, “Taliban Hit by Bombs Used in Vietnam," Guardian, November 6, 2001, www.theguardian.com/world/2001/nov/07/afghanistan.terrorism6.

44 See, for example, Human Rights Watch, Fatally Flawed: Cluster Bombs and Their Use by the United States in Afghanistan (New York: Human Rights Watch, 2002).

45 James Dobbins, After the Taliban (Washington, DC: Potomac Books, 2008).

46 Olivier Roy, Islam and Resistance in Afghanistan (New York: Cambridge Middle East Library, 1986), 224.

47 Zaeff, My Life With the Taliban,

48 Antonio Giustozzi, Empires of Mud (London: Hurst, 2009).

49 Steven Erlanger, "Talks in Bonn End With Deal On Leadership For Afghans," New York Times, December 5, 2001, www.nytimes.com/2001/12/05/world/nation-challenged-negotiations-talks-bonn-end-with-deal-leadershipfor-afghans.html; Dobbins, After the Taliban.

50 Antonio Giustozzi, Koran, Kalashnikov and Laptop: The Neo-Taliban Insurgency in Afghanistan 2002-2007 (London: Hurst, 2007), 11-32.

51 Declan Walsh, “In Hiding, Bin Laden Had Four Children and Five Houses," New York Times, March 29, 2012, www.nytimes.com/2012/03/30/world/asia/on-run-bin-laden-had-4-children-and-5-houses-a-wife-says.html.

52 Ivan Arreguin-Toft, "The Country as a Whole: Imagined States and the Failure of COIN in Afghanistan," in War and State-Building in Afghanistan: Historical and Modern Perspectives, ed. Scott Gates and Kaushik Roy (New York: Bloomsbury, 2015), 220-221 and 236-237; Thomas Barfield, Afghanistan: A Cultural and Political History (Princeton: Princeton University Press, 2012), 274-275.

53 "NATO and Afghanistan," North Atlantic Treaty Organization, July 8, 2020, www.nato.int/cps/en/natohq/topics_8189.htm.

54 Sippi Azarbaijani-Moghaddam et al., Afghan Hearts, Afghan Minds (London: BAAG, 2008).

55 Arreguin-Toft, "The Country as a Whole," 236.

56 Rajiv Chandrasekaran, "US Military Dismayed by Delays in 3 Key Development Projects in Afghanistan," Washington Post, April 28, 2011, www.washingtonpost.com/world/us-military-dismayed-by-delays-in-3-key-development-projects-in-afghanistan/2011/04/22/AFD6jq8E_story.html.

57 Antonio Giustozzi and Mohammed Isaqzadeh, Policing Afghanistan: The Politics of the Lame Leviathan (London: Hurst, 2013).

58 Giustozzi, Koran, Kalashnikov and Laptop.

59 See, for example, Elizabeth Bumiller, “West Point Divided on a Doctrine's Fate," New York Times, May 27, 2012, www. nytimes.com/2012/05/28/world/at-west-point-asking-if-a-war-doctrine-was-worth-it.html?_r=1\&pagewanted=all.

60 "Tribal Security System (Arbakai) in Southeast Afghanistan," Government of the United Kingdom, January 1, 2008, www.gov.uk/research-for-development-outputs/tribal-security-system-arbakai-in-southeast-afghanistan.

61 Azarbaijani-Moghaddam et al., Afghan Hearts, Afghan Minds.

62 Michael Semple, Reconciliation in Afghanistan (Washington, DC: U.S. Institute for Peace, 2009).

63 Antonio Giustozzi, The Army of Afghanistan: A Political History of a Fragile Institution (London: Hurst, 2016).

64 Anthony Cordesman, The Ongoing Lessons of the Afghan and Iraq Wars (Washington, DC: Center for Strategic and International Studies, 2008); Anthony Cordesman, The Afghan War: Key Developments and Metrics (Washington, DC: Center for Strategic and International Studies, 2017).

65 Robert D. Crews and Tarzi Amin, The Taliban and the Crisis of Afghanistan (Cambridge, MA: Harvard University Press, 2008).

66 Giustozzi, Koran, Kalashnikov and Laptop.

67 Zaeff, My Life With the Taliban, 34; Fergusson, Taliban.

68 Yousafzai and Moreau, "The Taliban in Their Own Words."

69 Dawood Azami, “Afghanistan: How Does the Taliban Make Money?” BBC, December 22, 2018, www.bbc.com/ news/world-46554097.

70 Antonio Giustozzi, The Taliban at War, 2001-2018 (London: Hurst, 2019). Giustozzi, Empires of Mud, covers the contrasting tactics and approach of patronage by warlords. 
71 Office on Drugs and Crime, Afghanistan: Opium Survey 2015 (New York: United Nations, 2015).

72 Chris Johnson and Jolyon Leslie, Afghanistan: The Mirage of Peace (London: Zed Books, 2008), 130.

73 Giustozzi, Koran, Kalashnikov, and Laptop, 86; Giustozzi, The Taliban at War, 77-108.

74 Giustozzi, The Taliban at War, 77-108 and 197-236.

75 Don Rassler and Vahid Brown, The Haqqani Nexus and the Evolution of al-Qa ida (West Point: Combating Terrorism Center, 2011). For an example, see "Kabul: Gunmen Attack Intercontinental Hotel," BBC, January 2018, www. bbc.co.uk/news/world-asia-42761881.

76 See, for example, Carlotta Gall, “9 Americans Die in Afghan Attack," New York Times, July 14, 2008, www.nytimes. com/2008/07/14/world/asia/14afghan.html.

77 Peter Baker, "How Obama Came to Plan for 'Surge' in Afghanistan," New York Times, December 5, 2009, www. nytimes.com/2009/12/06/world/asia/06reconstruct.html.

78 “Afghanistan Surge Achieved Its Mission, Dempsey Says," The Nation, September 12, 2012, https://nation.com. pk/19-Sep-2012/afghanistan-surge-achieved-its-mission-dempsey-says; Doug Mataconis, "Was Obama’s 'Afghan Surge' A Failure?" Outside the Beltway (blog), August 26, 2012, www.outsidethebeltway.com/was-obamas-afghansurge-a-failure/; Victor Davis Hanson, "Iraq and Afghanistan: A Tale of Two Surges," CBS News, December 1, 2011, www.cbsnews.com/news/iraq-and-afghanistan-a-tale-of-two-surges/.

79 Stanley McChrystal, Commander's Initial Assessment (Kabul: NATO ISAF Headquarters, August 30, 2009), 1-2.

80 Scott Gates et al., "Continuity and Change in Asymmetric Warfare in Afghanistan: From the Mughals to the Americans," in War and State-Building in Afghanistan: Historical and Modern Perspectives, ed. Scott Gates and Kaushik Roy (New York: Bloomsbury, 2015), 35; Personal interviews, Oxford, names omitted, March 2012.

81 Thom Shanker, “At Odds With Air Force, Army Adds Its Own Aviation Unit," New York Times, June 22, 2008, www.nytimes.com/2008/06/22/washington/22military.html.

82 President Hamid Karzai, interview published in the New York Times, April 26, 2008.

83 Peter Beaumont, "Fear, Disillusion and Despair: Notes From a Divided Land as Peace Slips Away," Guardian, June 7, 2008, www.theguardian.com/world/2008/jun/08/afghanistan.

84 Giustozzi, The Army of Afghanistan; Antonio Giustozzi, “The Afghan National Army Unwarranted Hope?” RUSI Journal 154, no. 6 (2009): 36-42.

85 Anthony Cordesman, Afghan National Security Forces: Shaping the Path to Victory (Washington, DC: Center for Strategic and International Studies, 2009).

86 Anthony Davis, "Home-Grown Army: Afghan National Army," Jane's Defence Weekly, December 12, 2008.

87 Antonio Giustozzi, "Auxiliary Force or National Army? Afghanistan's 'ANA' and the Counterinsurgency Effort, 2002-2006," Small Wars and Insurgencies 18, no. 1 (2007): 45-67.

88 Mark Moyar, “Afghanistan and Leadership," Wall Street Journal, October 5, 2009, www.wsj.com/articles/SB10001 424052748703298004574454810540018326.

89 Anthony Cordesman, Winning in Afghanistan: Creating Effective Afghan Security Forces (Washington, DC: Center for Strategic and International Studies, January 2008).

90 Jan E. Haug, "The Operational Mentoring and Liaison Team Program as a Model for Assisting the Development of an Effective Afghan National Army" (master's thesis, U.S. Army Command and General Staff College, 2009).

91 Bill Roggio and Lisa Lundquist, "Green-on-Blue Attacks in Afghanistan: The Data," Long War Journal, June 17, 2017, www.longwarjournal.org/archives/2012/08/green-on-blue_attack.php.

92 Richard Andrade, "U.S. Pilots Advise, Assist Fledgling Afghan Air Corps," U.S. Army, September 30, 2010, www. army.mil/article/45886/u_s_pilots_advise_assist_fledging_afghan_air_corp.

93 Seth G. Jones, Counterinsurgency in Afghanistan (Santa Monica: RAND, 2008).

94 Rob Johnson, True to Their Salt: Indigenous Personnel in Western Armed Forces (New York: Oxford University Press), 337-371.

95 Roggio and Lundquist, "Green-on-Blue Attacks."

96 Office on Drugs and Crime, Afghanistan: Opium Winter Assessment (New York: United Nations, 2009); Amin Tarzi, "Afghanistan: Kabul Mulls Relations with Iran," RFE/RL, March 17, 2007, www.rferl.org/a/1075333. html; "Iran and Afghanistan," Institute for the Study of War, accessed October 15, 2020, www.understandingwar.org/ iran-and-afghanistan.

97 Richard Haass, “The Pakistan Conundrum," Project Syndicate, January 12, 2018, www.project-syndicate.org/ commentary/united-state-pakistan-relations-aid-cutoff-by-richard-n-haass-2018-01.

98 Avinash Paliwal, My Enemy's Enemy: India in Afghanistan from the Soviet Invasion to the US Withdrawal (London: Hurst, 2017), 274-279.

99 “Osama bin Laden Killed in Pakistan,” Al Jazeera, May 2, 2011, www.aljazeera.com/news/2011/5/2/osama-binladen-killed-in-pakistan; "Pakistan PM Imran Khan Says Osama Bin Laden Was 'Martyred' When Killed During US Army Raid," London Evening Standard, June 26, 2020, www.standard.co.uk/news/world/osama-bin-ladenmartyred-pakistan-imran-khan-a4480806.html. 
100 Abdul Sayed and Colin P. Clarke, "The Islamic State in Afghanistan Is Down, but Not Out," RAND (blog), September 14, 2020, www.rand.org/blog/2020/09/the-islamic-state-in-afghanistan-is-down-but-not-out.html.

101 Emran Feroz and Abdul R. Lakanwal, "In Rural Afghanistan, Some Taliban Gingerly Welcome Girls Schools," Foreign Policy, May 4, 2020, https://foreignpolicy.com/2020/05/04/afghanistan-taliban-girls-schools/.

102 Farzad R. Bonesh, "Factors Affecting Divisions Among Afghan Taliban: Internal and External Forces Are Keeping the Taliban Split Into Two Factions," Asia Times, May 22, 2020, https://asiatimes.com/2020/05/ factors-affecting-divisions-among-afghan-taliban/.

103 Jeffrey A. Dressler, The Haqqani Network: From Pakistan to Afghanistan (Washington, DC: Institute for the Study of War, 2010).

104 Richard Haas, “How Not to Leave Afghanistan," Project Syndicate, March 3, 2020, www.project-syndicate.org/ commentary/trump-us-taliban-agreement-poor-prospects-by-richard-n-haass-2020-03?barrier=accesspaylog.

105 Sarah Dadouch et al., "U.S. Signs Peace Deal With Taliban Agreeing to Full Withdrawal of American Troops from Afghanistan," Washington Post, February 29, 2020, www.washingtonpost.com/world/asia_pacific/afghanistan-ustaliban-peace-deal-signing/2020/02/29/b952fb04-5a67-11ea-8efd-0f904bdd8057_story.html. 


\title{
11
}

\section{THE MODERN HISTORY OF IRAN AND THE BIRTH OF THE SHIA PROXY MODEL}

\author{
Alex Vatanka
}

In February 2019, the Islamist political system in Tehran turned 40 years old. In 1979, Iran's ancient monarchy was replaced by the modern world's first theocracy, led by Supreme Leader Ayatollah Ruhollah Khomeini. Unlike his predecessor, the pro-Western Mohammad Reza Pahlavi (the shah), Khomeini had only vague notions about his preferred foreign policy agenda and Iran's place in the world.

Then came the seizure of the U.S. Embassy in Tehran in November 1979 at the hands of Islamist militants. By endorsing the seizure, Ayatollah Khomeini unleashed a process that soon upended the close economic, military, and strategic ties that Iran had enjoyed with the United States since 1941. American presidents from Franklin D. Roosevelt to Jimmy Carter had viewed Iran as an anchor of American influence in the Middle East and in particular a key frontline state against the Soviet Union and the expansion of communism.

With the arrival of the Islamist regime in Tehran, the once-close relations-where at one point some 50,000 Americans lived and worked in Iran — came to an abrupt end. ${ }^{1}$ Instead, the United States has functioned as the primary ideological target of enmity for Iran's Shia Islamist leadership since 1979.

This chapter provides a short history of contemporary Iran before outlining the challenges that the Iranian Islamist regime poses from an American perspective. The evolution of Iranian foreign policy behavior is then tracked through Tehran's posturing over the last 42 years during a number of military conflicts where Iran has either been a direct participant or an influential actor. As such, it discusses the birth of the Shia proxy model and Iranian-sponsored Hezbollah. Finally, the chapter concludes by identifying key domestic drivers that shape Iranian foreign policy and what this reality signals for Tehran's future priorities on the regional and international stages.

\section{The 1979 Islamic revolution}

Reza Khan propelled himself to power after a coup against the Qajar Dynasty in 1921 fueled by popular anger in Iran about the country's general decline and vulnerability to the British and Russian colonial powers in the period immediately following World War I. He pronounced himself shah, or monarch, of Persia. With this proclamation, the Pahlavi Dynasty began. ${ }^{2}$

Reza Khan advertised modernization as his foremost approach to improving the dynasty and its welfare. In 1935, the dynasty underwent a formal name change from Persia to Iran. Public schools, modern universities, and Westernized clothing were all hallmarks of Reza Khan's guise of modernization, and with it came a swifter approach to dictatorial rule. 
Reza Khan's son and successor, Mohammad Reza Shah, succeeded to the throne in 1941. Over the next 38 years, his links to the United States would eventually drive the country to a revolution. The Central Intelligence Agency's active participation not only propelled the overthrow of the country's prime minister, Mohammad Mossadeq, in 1953, but the United States also contributed significant military aid toward the development of the Shah's secret police force-the SAVAK. ${ }^{3}$

In 1963, the shah essentially tried to force a series of Western economic and social reforms on the Iranian people, known as the White Revolution. ${ }^{4}$ Many traditionalist Iranians found comfort for their many economic, social, and political grievances in the clergy, who would soon play a large role in the overthrew of the Pahlavi regime in 1979.

By 1979, the political unrest had grown into a revolution, and the shah was ultimately forced to flee to Egypt in January. On February 1, after 14 years in exile, the Ayatollah Ruhollah Khomeini returned to lead the country. This would be known as the 1979 Iranian Revolution.

Within months after coming to power in February 1979, Ayatollah Khomeini was deliberately but inconspicuously employing the Islamic Revolutionary Guards Corps (IRGC) — the organization that he authorized and which subsequently became the regime's political-military vanguard to protect the new Islamic government from threats - to marginalize the appointed Prime Minister Mehdi Bazargan and the so-called "liberal," or moderate, current by using the IRGC as an instrument to undermine Bazargan. ${ }^{5}$ The U.S. Embassy in Tehran had initially welcomed Khomeini's appointment of Bazargan. ${ }^{6}$ Then, on November 4, 1979, a group of Khomeini-backed radicals stormed the U.S. Embassy, taking 66 Americans hostage. Khomeini supported the seizure, but Bazargan's government opposed it.

Bazargan's first split with the ayatollah, however, had appeared a number of months earlier over an issue that would prove equally far reaching. In March 1979, a nationwide referendum was held about the coming post-shah political system. ${ }^{7}$ Bazargan and his liberal faction sought to have the ballot ask if the voters wanted a "democratic Islamic republic." ${ }^{8}$ Khomeini overruled them, and the word "democratic" was dropped as the ayatollah maintained that "Islam itself was democratic." Following the March vote, Iran became an "Islamic Republic," and Khomeini and his inner circle began to formulate its characteristics and neutralized those who opposed the new constitutional arrangement.

It was an ominous sign of what would follow. It was also a prime example from the earliest days of postshah Iran about a struggle to define, own, and defend the "revolution" and "Iranian interests" by various regime personalities, factions, and institutions ever since. In the realm of foreign policy, a few concepts at first emerged as unshakable creed, including opposition to the United States, Israel, and a belief that armed struggle was the way forward. Meanwhile, Khomeini saw his revolution as borderless.

\section{0-1988: The Iran-Iraq War and the birth of the Shia proxy model}

In 1980, next door in Iraq, Sunni strongman Saddam Hussein had for months been weighing his options following Iran's revolution and Khomeini's rise to power. The new Shia Islamist revolutionary government in Tehran was determined to undermine Saddam's rule by inciting Iraq's Shia majority against him. ${ }^{10}$ Yet Baghdad did not know if the new political reality in Tehran would be a lasting one. Would the exiled shah, backed by the United States, ultimately return, as had been the case in 1953 ?

The answer to that critical question came on July 27, 1980. That was the day the shah passed away while in exile in Cairo. ${ }^{11}$ Saddam interpreted the shah's death to mean that Khomeini and his Shia Islamist revolutionaries were in power to stay, and he opted to act before they could take the fight to him.

As it turned out, Saddam's invasion of Iran on September 22, 1980, was a blessing for the radical clergy in Tehran. As with the U.S. Embassy hostage incident, it acted as a major distraction for the Iranian public and an opportunity for a further Islamist power grab. For the ordinary Iranian and almost all political strands of the time, the war became a case of country before politics or ideology. ${ }^{12}$ The notable exception 
was Khomeini's camp. They invariably came to regard the anti-Saddam war as an event to proliferate Khomeini's ideas about "Islamic Government," a concept they flaunted as universal in its mission. ${ }^{13}$

In its most exorbitant vocalization, it was a messianic narrative. Earliest slogans of the war-such as "War, War Until Victory" against Iraq-soon shifted to an open-ended agenda of promising a global revolution. "War, War until the Removal of Intrigue from the Whole World" or "The Road to Jerusalem Goes Through Karbala" became the favored alternative chants of Ayatollah Khomeini's martyrdom-hungry foot soldiers. ${ }^{15}$ It was more than just bombast.

The fanaticism pouring out of Tehran was quickly turning the Arab world, as well as most of the international community, against Iran. Those killed had become shahid, or martyrs. The militant clergy and their accomplices from the IRGC had turned the defense of the motherland into the defense of Islam. This, however, meant that the war was to be endless, given the breadth of Islamic lands and the many conflicts where Tehran could choose to implant itself. As it turned out, this is exactly what happened.

Short on military expertise but full of religious and ideological zeal, Khomeinists would drag Iran through a war that ultimately lasted eight years (1980-1988) and cost billions of dollars of damage. Meanwhile, official figures show some 190,000 Iranian military forces and tens of thousands of civilians died. ${ }^{16}$ It was also in this period that Khomeini's young Islamist followers began to seek ways to spread the message of the Iranian Revolution. The model they created would prove to have a long shelf life and remain expedient in decades to come.

Early in the war effort against Iraq, Tehran and the IRGC leadership looked to take advantage of significant numbers of Iraqi Islamist-minded Shia who were abandoning Iraq because the anti-Islamist regime of Saddam Hussein proved to be a harsh suppresser of their political aspirations. ${ }^{17}$ In Khomeini's Iran, these same Iraqi Shia Islamist dissidents were welcomed with open arms.

Iran quickly invested significant resources to indoctrinate these Iraqi Shia and in many cases armed and deployed them against the Saddam regime they had fled. ${ }^{18}$ It was to be the birth of the proxy model in Iran, which the country has relied on as a key projector of its power across a number of arenas in the Middle East. For example, the now-famous external operational branch of the IRGC - the Quds Force-was initially established with heavy reliance on Iraqi Islamist exiles who as ethnic Arabs could operate behind enemy lines inside Iraq much more freely than ethnic Iranians. ${ }^{19}$

By 1982, the IRGC formed the anti-Saddam Badr Corps from dissident Iraqi Islamists with its operational headquarters in Iran. ${ }^{20}$ Also in the early 1980s, Tehran created a new organization from Lebanese Shia dissidents: Hezbollah. ${ }^{21}$ Both Hezbollah and the Iraqi Badr Corps embraced Khomeini's doctrine of sweeping political resistance. ${ }^{22}$ It was an agenda that was not only focused on a domestic agenda or rivals but also very much anti-U.S. and anti-Israeli in its ideological disposition.

Hezbollah would engage in a number of terrorist attacks against Westerners, such as kidnappings and car bombings. One of its most prominent attacks resulted in the deaths of 241 U.S. service personnel—including 220 Marines-from a truck bomb at a Marine compound in Beirut, Lebanon. ${ }^{23}$

Some four decades later, Hezbollah has become a state-within-a-state in Lebanon, while Badr is one of the most influential political actors in Baghdad. Badr's present-day leader, Hadi al-Amiri, was an early recruit by the Iranians, and his star has risen ever since, as he has enjoyed Iranian patronage. ${ }^{24}$ Following the Iraqi elections in 2018, al-Amiri was even in contention to become Iraqi prime minister as head of the renamed Badr Organization. ${ }^{25}$

In the case of Hezbollah, its leader Hassan Nasrallah does not seek to downplay his ideological dependency on the Iranian Islamist regime. As he has repeatedly said, Nasrallah considers himself a follower and a servant of Iran's Supreme Leader Ayatollah Ali Khamenei. ${ }^{26}$

Both Hezbollah and Iraq's Badr Organization remain to this day the most successful Shia militant proxies aligned with Tehran. Meanwhile, throughout the 1980s, Iranian-inspired political radicalism and acts of violence were not limited only to the Iraqi or Lebanese theaters. Acts of political violence at the hands 
of groups that looked to Iran for ideological guidance were also witnessed in Bahrain, Kuwait, Pakistan, and Saudi Arabia. ${ }^{27}$

Still, not everyone in Tehran in the 1980s believed the role of championing the array of Arab militants was the best way to promote Iranian national interests. This was most notably the case with the powerful speaker of the Iranian parliament, Ayatollah Akbar Hashemi Rafsanjani, who was sensitive to the damage such sponsorship might impose on Iran's standing as a "normal" country. ${ }^{28}$

The advances the Islamists in Tehran made on this front during the 1980s is what Iranian hardliners to this day view as highly valuable in the geopolitical struggle, where a number of Middle Eastern states engage in proxy conflict to extend their regional power in countries such as post-Saddam Iraq and later in Syria. Nonetheless, by the time of Khomeini's death in 1989, the intra-regime debate in Tehran about the utility of the export of the Islamic revolution via the proxy model ended the more excessive Iranian behaviors that had been evident in the early part of that decade.

\section{The few opportunities of the 1990s}

In comparison to the 1980s, which Iran's present-day Supreme Leader Ayatollah Ali Khamenei touted as the "golden revolutionary age," the 1990s witnessed retrenchment in Tehran's use of the proxy model. ${ }^{29}$ There were two principal factors that resulted in Iran cutting back its use of Arab Islamist proxies.

First, the key lesson learned by the moderates inside the Iranian regime was that dabbling in revolutionary rhetoric and action — such as sponsoring non-state militant actors-is inherently damaging to Tehran's reputation as a political and economic partner. This was based on Iran's experience in the Iran-Iraq war. Moderates argued that Iran should return to the international mainstream by moving away from some of the most reckless expressions of the regime's revolutionary agenda. ${ }^{30}$

Second, for most of the 1990s, there were few opportunities for Tehran to deploy its proxy model. The war with Iraq had ended in 1988. This left Iran with a handful of theaters where it could advance its foreign policy by relying on foreign militant proxies. One major exception was Iran's role in the wars that followed the breakup of Yugoslavia in 1992. The Iranians, along with Arabs and the Turks, were quick to send arms, funds, and volunteers to aid the Muslim Bosnians against their Croat and Serb adversaries. ${ }^{31}$ The Quds Force spearheaded Iran's armed operations in the Balkans in the 1990s, and it was here that, for the first time, they came to operate alongside Sunni jihadi groups, including the forerunners to al-Qaida. ${ }^{32}$

In the 1990s, the most obvious theater for Iran to operate was next door in Afghanistan. In a struggle that Tehran considered of strategic importance against the Saudi- and Pakistani-backed Sunni radicals of the Taliban, the Iranians put enormous effort into supporting the Afghan anti-Taliban forces. The Iranians directed most of this support to the Northern Alliance led by Ahmad Shah Massoud until his death in $2001 .{ }^{33}$ Unlike its use of an Islamist and often-sectarian message to mobilize Iraqi Shia recruits, Tehran kept its options open in Afghanistan, pursuing both an activist policy but also a pragmatic one that was only sometimes Islamist or sectarian.

Tehran wanted to carve out the western Afghan provinces on its border as part of its unquestionable "zone of influence" and to link Afghanistan to the Iranian sphere of economic power through pan-regional initiatives. ${ }^{34}$ Above all, the Iranians sought to avoid an Afghan central government under the thumb of the Pakistanis or the Sunni Arab Gulf states, such as Saudi Arabia. ${ }^{35}$ The Iranians opted to expand both hard and soft power in Afghanistan and did not let political affinity be the only litmus test after which Afghan groups could receive arms, financial aid, and political support.

In terms of grassroots support, the bulk of Iran's assistance went to the ethnic Shia Hazara Afghans, ${ }^{36}$ but the fact that ethnic Tajik are mostly Sunni did not stop Iran from sponsoring many of the political leaders from this community, including prominent figures such as Abdullah Abdullah, the future chief executive in the Ashraf Ghani government in Kabul. ${ }^{37}$ 
This reality did not end criticism among Afghans then or now. A common complaint from Afghan secular-leaning officials is that Tehran has essentially squandered many opportunities to constructively attract ordinary Afghans by failing to appeal to the common cultural values shared between the populations of the two countries as historic members of the Iran Zamin (Land of Iran). ${ }^{38}$

Some secular-leaning Afghan leaders instead view the Islamic Republic as either overly selective in its approach by focusing on just the Afghan Shia or the ethnic Tajiks or opting to use controversial ideological or sectarian (and often anti-U.S.) messaging that is aimed at only a minority of Afghans while making the majority anxious about ultimate Iranian intentions. ${ }^{39}$ Such fears in Kabul multiplied following the outbreak of the Syrian civil war in 2011 and after Iran began to recruit Afghan Shia to join its military campaign in support of the beleaguered Syrian President Bashar al-Assad. ${ }^{40}$

Some observers have argued that while sectarian factors play a role in Iran's strategic calculations, it is not in the single-minded, all-encompassing way that Iran's critics suggest. According to this line of thinking, the Islamic Republic, as enshrined in its constitution from 1979, ideologically committed itself to a mission of mobilizing so-called downtrodden Muslims against what Tehran labeled unjust rulers. This refers to Muslims in general and did not distinguish between Shia and Sunni. ${ }^{41}$

Nevertheless, some aspects of the Iranian political model are strikingly sectarian. For example, it is enshrined in the constitution of the Islamic Republic that only a Shia Muslim can hold the office of supreme leader and the presidency in Iran, a rigid stipulation that Iran's Sunni minority-about 10\% of the country's population - find discriminatory. ${ }^{42}$ This does not mean Iran is an outlier in this regard. Similar sectarian policies are evident across the region where Sunni-majority states exclude minority Shia from political equality. ${ }^{43}$ The central point is to underscore that Iran, too, has its own sectarian biases and is sensitive to them.

\section{The impacts of the Iraq and Syria conflicts and the Arab Spring}

If the 1990s presented few opportunities for Iran to expand its Shia proxy model of the 1980s, the U.S.-led military invasion of Iraq in 2003 and the outbreak of the Arab Spring from 2011 onwards created a number of opportune security vacuums. Accordingly, in a number of cases such as Iraq and later in Syria, Tehran looked to protect and expand its interests through the use of proxy forces under its general leadership.

Once the United States invaded Saddam's Iraq in March 2003, which led to the political rise of the Iraqi Shia, Iran stood among the top beneficiaries of the political transformation in that country. Many of Tehran's close Iraqi Islamist allies_-groups and individuals that the Iranians had sponsored since the early 1980 s - were suddenly at the heart of Iraqi power politics. ${ }^{44}$ By the time Iraq was engulfed in a sectarian conflict between the Shia majority and the Sunni minority, Iran was ready to play the role of a facilitator for many of the Shia Iraqi groups.

Put simply, the security vacuum in Iraq since 2003 paved the way for Tehran to expand its reach by either further increasing its assistance to its existing Iraqi allies or in some cases forming new militant groups that could act as Iranian surrogates. It is in this timeframe that a number of new militant Shia entities emerged on the Iraqi scene, including Asaib Ahl al-Haq (League of Righteous People) and Kataib Imam Ali (Imam Ali Brigades). ${ }^{45}$ These Shia Islamist militant groups were invariably close to Tehran and the IRGC in particular. In fact, in a couple of cases, Iraqi militants would openly declare their primary allegiance to Iran's supreme leader, Ayatollah Ali Khamenei. The most notable case was that of Saraya alKhorasani (Khorasani Brigades). ${ }^{46}$

Still, such expressions of fealty were the exceptions. Tehran's interest was not to "Iranize" the Iraqi militants that operated under its tutelage; it wanted above all to exercise ideological mentoring over these recruits who overwhelmingly came from humble social backgrounds and were looking for a political tent to call home. 
Moreover, from the U.S. perspective, one reality was undeniable: the long list of Iraqi militant groups with ties to Iran would also end up in direct conflict with U.S. forces in Iraq. This resulted in many American casualties as the IRGC aided its Iraqi minions in conducting asymmetric warfare through the use of more sophisticated improvised explosive devices and other tactics. ${ }^{47}$

Only a few years later, the eruption of a number of Arab Spring popular uprisings in 2011-from Yemen to Syria to Tunisia - and the subsequent emergence of the Islamic State became yet another reason for Tehran to stay devoted to the use of non-state militant actors. They considered it the best way to defend Iranian interests outside of the country's borders. This campaign was relatively inexpensive compared to a full-out conventional military response. In comparison, for example, the Saudi and Emirati military interventions in Yemen since 2015 have by all accounts cost far more in monetary terms for those intervening countries.

In terms of justifying such policies in an ideological framework, the Iranian hardliners intellectually traveled back to the zealous revolutionary days of the 1980s and came up with the concept of "Axis of Resistance." ${ }^{48}$ It is essentially a catchall phrase that can be cited by Tehran as a way of justifying a range of actions. This includes the constant ideological enmity toward the United States and its regional alliesnamely Israel and the Gulf Sunni Arab states - to rationalize the formation of non-Iranian, non-state militant entities that act as Tehran's collaborators. ${ }^{49}$

As had been the case in Afghanistan and in Yugoslavia in the 1990s, Tehran would not let sectarian realities prevent it from pursuing its strategic goals. In Syria, the Iranian mobilization in the defense of the Bashar al-Assad regime was presented not as a Shia cause - since the regime of al-Assad is and has always been a secular entity-but as an effort against what Tehran called an American and Israeli plot to weaken the hand of those states and groups in the "Axis of Resistance" that oppose American hegemony in the Middle East. ${ }^{50}$

From the outside, it might seem to be the case of local actors (in places such as Iraq or Syria or among the Palestinians) looking for foreign patronage and hence a client-patron relationship. The association is less than a marriage of convenience and more the case of a mothership (Iran) on a distinct ideological trajectory; its goal is to cause fellow travelers (proxy groups) to come with it on the ride, even though the final destination is less than clear even for many in Tehran.

In fact, there has been far more clarity and consistency in terms of Tehran's modus operandi in operationalizing the militant proxies that have come under its wings. With the experiences of the early 1980s still relatively fresh - when Tehran was instrumental in founding Hezbollah and Iraqi Badr-the generals from the IRGC only had to return to the past blueprint to expand the proxy model that they were about to help spread in the Middle East.

The rewards for such a policy have been readily measurable. According to Nick Heras, 40 out of the estimated 67 Popular Mobilization Forces militias in Iraq in 2018 shared close links with the IRGC. ${ }^{11}$ By the end of 2017, an estimated 50,000 fighters from Popular Mobilization Forces mobilized against the Islamic State were in units under direct or indirect Iranian control. ${ }^{52}$

To put this number in perspective, the total number of fighters from Popular Mobilization Forces was at the time estimated at $110,000-122,000 .{ }^{53}$ The hardline generals from the IRGC pointed to this fact as an Iranian strategic success. ${ }^{54}$ From their vantage point, the use of non-Iranian proxies provided Tehran with strategic depth at a low cost. Not everyone in Tehran viewed it the same way.

\section{The fight over foreign policy in Iran}

Since 2011, the IRGC has pushed to maintain and expand its militant proxy model as an inherent instrument of power projection in the region. As a country, however, Iran's political, diplomatic, and economic needs and interests go far beyond the mere question of carving out and nurturing ostensible strategic depth in a handful of Arab states via the proxy model vehicle. 
There is another way of looking at this Iranian predicament. Put simply, Iran's recent successes on the battlefields in Iraq and Syria have translated into some political capital but only at a steep cost. It is not clear whether these victories are permanent or reversible. For example, as the al-Assad regime moved toward total military victory against the Syrian opposition by 2018 , the Iranians suddenly found themselves wondering if they could remain a dominant actor in the post-war future of Syria.

Most importantly, the Russians-Iran's principal tactical collaborators in Syria on the side of al-Assad since September 2015- began to show signs of wanting to part ways with Tehran. ${ }^{55}$ At a minimum, Tehran felt the Russians were working hard to minimize Iran's future role in post-war Syria, an outcome that Moscow could only seek because of general Iranian estrangement from other key actors-principally the United States and the Arab states of the Persian Gulf-who have a voice in the long-term normalization of Syria.

In other words, thanks to Iran's weak international diplomatic hand, its otherwise significant military victories on the battlefield via the militant proxies it controls in Syria quickly showed themselves to be hardly a guarantee of long-term broader strategic successes as the generals from the IRGC claimed. Iran's proxy model delivered results during the stages of military conflict, but it struggled to convert battlefield wins into firm political victories.

Internal critics of the militant proxy model in Iran's foreign policy have instead argued it is an unsustainable way to project Iranian power. It might have been relatively inexpensive as compared to other military campaigns occurring at the same time in the region, but the indirect costs and consequences were considerable and potentially lethal to the staying power of the Islamic Republic's grip on power in the region. ${ }^{56}$

In terms of domestic political ramifications, it was abundantly clear that many Iranians viewed the military interventions in Iraq and in Syria as ideologically driven wars of choice that were not critical to Iranian national security. In a number of nationwide socio-economic protests that Iran experienced in 2017 and 2018, the top slogans of the demonstrators were aimed at Tehran prioritizing foreign ideological pursuits over the everyday needs of the Iranian population. ${ }^{57}$ Such incidents highlighted the gap between the ruling elite in Tehran - particularly the hardline elements - and the Iranian public. This is the sort of grievance that if left unaddressed could fundamentally put the political future of the Islamic Republic in question.

The May 2018 decision by the Trump administration to abandon the 2015 nuclear deal and reimpose sanctions also provided further debate in Tehran, since its controversial and costly regional policies are explicitly responsible for U.S.-led international isolation. ${ }^{58}$ That being said, while the Trump administration's pursuit of a "maximum pressure" campaign damaged Iran economically through sanctions, it did little to counter Tehran's most objectionable policies: the expansion of Iranian hard power via its control of political and militant groups aligned with the Islamic Republic.

A year after the assassination of Quds Force leader Qassem Soleimani in January 2020, which was arguably the most lethal step the U.S. military has taken against Iran's Shia proxy model, Tehran's regional footprint had not diminished. ${ }^{59}$ Iran was still pursuing its policy aims in Lebanon, Syria, and Iraq. In October 2020, after a five-year absence, Iran even sent an ambassador back to war-stricken Yemen, a country where Iran has backed the Houthi rebels against the U.S.-backed Saudi and Emirati forces. In other words, while putting sanctions on Iran cost the United States relatively little, pushing back against Iranian efforts militarily in the region will require far more U.S. commitment and investment.

\section{Iran's choice: to be a "normal" or "revolutionary" state?}

When Iranian President Hassan Rouhani was elected in 2013 and re-elected in 2017, many in the West hoped it might be a moment of Iranian introspection. Tehran, it was thought, might not stop only at compromising over its nuclear program but extend its concessions to include its future relationship with Islamist militant groups that it had sponsored in one way or another since 1979. That was not to be. The hardliners 
in the Iranian regime, not least Supreme Leader Ayatollah Ali Khamenei and the IRGC generals, remained deeply suspicious of Western intentions, and especially of the United States and Israel.

The rise of the Islamic State in Syria and then in Iraq from early 2014 militarized Tehran's response to the vehemently anti-Iranian group. The IRGC was, by default, Tehran's first line of defense. The March 2015 Saudi intervention in Yemen in the name of fending off an Iranian presence in southern Arabia further exacerbated the zero-sum game of regional rivalry between Iran and Saudi Arabia. The IRGC's stated objective of preserving the al-Assad regime in Damascus while neutralizing the Islamic State in Iraq faced no genuine pushback from the Rouhani government.

The arrival of the presidency of Donald Trump also put the brakes on efforts to reduce IRGC powers. Supreme Leader Ali Khamenei, who sets the fundamental course in Iranian foreign policy, chose not to give in to American pressure in regard to Tehran's regional interventions. This meant that the Iranians doubled down on their investments in places such as Iraq and Syria. For the IRGC, it was again convenient and imperative to stress the value of the cherished militant proxy model and point to the depth it gives Iran in various theaters in the Middle East as a deterring factor in a potential American decision to attack Iran militarily.

Nor does Khamenei believe more concessions will satisfy Washington's demands. He has repeatedly stated that compromising with the United States will not be possible, as Washington's basic strategic goal is to bring about regime change in Tehran. ${ }^{60}$ To deter the United States from seeking this objective, Khamenei and his hardline supporters believe the Islamic Republic should remain "revolutionary" and double down on efforts to spread its message both ideologically and operationally. Iran's continued support for foreign militant proxies, and particularly those from the Arab countries, has to be viewed in this context.

\section{Conclusion}

Iran, a country of 82 million people and a considerable amount of political competition within the ranks of the Islamist ruling elite, will continue to be a critical policy challenge for the United States. There is no doubt that the two principal factions in the Islamic Republic - the so-called "pragmatists" and the "hardliners" - have differences of opinion in regard to Iran's foreign policy agenda. The trajectory of this foreign policy competition will be greatly shaped by a number of factors, including the outcome of the succession process already underway to replace Supreme Leader Ayatollah Ali Khamenei and American policy toward Tehran in the next few years.

The "pragmatists" insist that Tehran should and can seek some kind of accommodation with the United States, which will prevent Iran from becoming internationally isolated or entirely beholden to Russia or China for its diplomatic or trade needs. In opposition, the "hardliners" believe that an accommodation with the United States is not only impossible but unadvisable, since this faction believes Washington's bottom-line objective is to bring about the end of the Islamic Republic.

In the midst of this policy competition, the "hardliners" have emerged as the undisputed handler of Iran's foreign policy agenda. Iran's Arab policy is seemingly overwhelmingly shaped and implemented by the IRGC.

The IRGC's overall success, however, is still far from universally accepted in Iran. Not only is it a deep source of resentment for the Iranian public, but the IRGC's modus operandi for the Arab world is even questioned at the most senior ranks within the regime. As described in this chapter, Iran's "forward defense" has evolved and is a relatively nimble concept in its application as long as it can advance Tehran's regional agenda. In a nutshell, the pitch has been as simple as the argument that Iran is better confronting its Arab rivals and the Americans outside of Iran's borders than inside them.

Hence, the strategists behind this Iranian approach to the Arab world and Tehran's geographic vicinity in general have tended to defend "forward defense" as not only protecting Iran from possible foreign invaders but as a vanguard against Western and secular political influences in the broader Middle East. 
Tehran's Arab strategy from 2003 highlights two basic realities. First, Iran has demonstrated agility in defining and implementing security policy in the region. Second, Iran's activities in the Arab world reveal a consensus among Iranian policymakers that the appetite of the Iranian public for "forward defense" is finite. On the other hand, Tehran's mobilization of non-Iranian forces has been a double-edged sword. It helped resolve Iran's manpower problems, but in strengthening appeals to transnational ideological claims, Iran provided its regional rivals with a convincing argument that Tehran was indoctrinating, funding, and arming a new generation of Shia militants and fueling a regional Shia-Sunni sectarian divide.

Iran, a non-Arab and Shia majority country with aspirations to lead the Islamic world, has always been highly sensitive to the charge of acting as a Shia sectarian power, and it has invested heavily in countering this criticism. Nevertheless, the priority of keeping al-Assad in power superseded Tehran's wish to maintain its credibility in the eyes of the Sunni street. As a result, Iran's approach helped mobilize opposition to Iranian policy and stoked fears that Iran was seeking more revisionist aims.

It is far from clear whether Iran can sustainably pursue this strategy. Iranian society is showing unmistakable signs of concern regarding the limits of forward defense and all the direct and indirect costs associated with it. Iran's rivals appear to have assessed that those strains are sufficient and that Iran will fold when confronted. What is clear, however, is that this uncertainty brings with it the risk of repeated crises with the potential for escalation.

\section{Notes}

1 Suzanne Maloney, “1979: Iran and America," Brookings, January 24, 2019, www.brookings.edu/opinions/ 1979-iran-and-america/.

2 Michael P. Zirinsky, "Imperial Power and Dictatorship: Britain and the Rise of Reza Shah, 1921-1926," International Journal of Middle East Studies 24, no. 4 (1992): 639-663.

3 John P. Miglietta, American Alliance Policy in the Middle East, 1945-1992: Iran, Israel, and Saudi Arabia (Lanham, MD: Lexington Books, 2002); Bethany Allen-Ebrahimian, "64 Years Later, Central Intelligence Agency Finally Releases Details of Iranian Coup," Foreign Policy, June 20, 2017; Nasser Karimi and Jon Gambrell, “Torture Still Scars Iranians 40 Years After Revolution," Associated Press, February 6, 2019, https://apnews.com/article/072580b 5f24b4f8ea2402221d530257e.

4 Maloney, "1979: Iran and America."

5 Ali Alfoneh, Iran Unveiled: How the Revolutionary Guards Is Turning Theocracy Into Military Dictatorship (Washington, DC: American Enterprise Institute, 2013).

6 Kenneth M. Pollack, The Persian Puzzle: The Conflict Between Iran and America (New York: Random House, 2005). Others, too, had welcomed the appointment, including Iran's Arab neighbors to the south. For more on this, see F. Gregory Gause III, The International Relations of the Persian Gulf (New York: Cambridge University Press, 2009).

7 Ronald Koven, "Khomeini Decrees Islamic Republic After Vote in Iran," Washington Post, April 2, 1979 , www. washingtonpost.com/archive/politics/1979/04/02/khomeini-decrees-islamic-republic-after-vote-in-iran/ c4d11a54-8981-4b91-8ca0-7d9771a8cf2c/.

8 Muhammad Sahimi, “The Ten Days That Changed Iran,” PBS Frontline, February 3, 2010, www.pbs.org/wgbh/ pages/frontline/tehranbureau/2010/02/fajr-10-days-that-changed-iran.html.

9 Ervand Abrahamian, A History of Modern Iran (New York: Cambridge University Press, 2008).

10 Bruce Riedel, “What Iran's Revolution Meant for Iraq,” Brookings, January 24, 2019, www.brookings.edu/blog/ order-from-chaos/2019/01/24/what-irans-revolution-meant-for-iraq/; Lyse Doucet, "Legacy of Iran-Iraq War Lives On,” BBC, October 5, 2015, www.bbc.com/news/world-middle-east-34444337.

11 Benedicte Rey, "Forty Years Ago, the Shah of Iran Died in Exile," Agence France-Presse, July 25, 2020, www.barrons. com/news/forty-years-ago-the-shah-of-iran-died-in-exile-01595683205.

12 Ali Ansari, “Iranian Nationalism Rediscovered," Middle East Institute, January 29, 2009, http://education.mei.edu/ content/iranian-nationalism-rediscovered.

13 Ayatollah Khomeini, "New Year's Speech: We Shall Confront the World With Our Ideology," Middle East Research and Information Project, March 21, 1980.

14 "Khomeini Rebuffs Iraq and Urges War Until 'Victory'," New York Times, January 29, 1981, www.nytimes. com/1981/01/29/world/khomeini-rebuffs-iraq-and-urges-war-until-victory.html. 
15 Behrouz Alikhani, "Popular War Songs and Slogans in the Persian Language During the Iran-Iraq War," Cambio. Rivista Sulle Trasformazioni Sociali 3, no. 6 (2013): 211-217.

16 The number of dead is still contested, although this figure is generally accepted.

17 Samir F. Ghattas, "President Saddam Hussein, Locked in a 7-Year-Old War With Neighboring Iran," Associated Press, September 30, 1987, https://apnews.com/article/ff8a42896ec185f3fdade03321e02e36.

18 Ibid.

19 Morad Veisi, "A Look at Three Decades of Iran's Secretive Quds Force," RFE/RL, January 8, 2020, www.rferl. org/a/iran-quds-force-soleimani-explainer/30366930.html.

20 Borzou Daragahi, "Badr Brigade: Among Most Consequential Outcomes of the Iran-Iraq War," Atlantic Council, August 16, 2018, www.atlanticcouncil.org/blogs/iransource/badr-brigade-among-most-consequential-outcomesof-the-iran-iraq-war-2/.

21 "Nasrallah Says Khamenei Heavily Involved in Establishment of Lebanon's Hezbollah," al-Arabiya, October 1, 2019, https://english.alarabiya.net/en/News/middle-east/2019/10/01/Nasrallah-says-Khamenei-heavily-involvedin-establishment-of-Lebanon-s-Hezbollah.

22 Matthew Levitt, Hezbollah The Global Footprint of Lebanon's Party of God (Washington, DC: Georgetown University Press, 2015).

23 Radhika Chalasani, "A Look Back at the Deadly 1983 Marine Barracks Bombing in Beirut," ABC News, October 23, 2017, https://abcnews.go.com/International/back-deadly-1983-marine-barracks-bombing-beirut/story? id $=50663026$.

24 Maher Chmaytelli, "Iranian-Backed Shi'ite Militia Chief Aims to Lead Iraq," Reuters, May 8, 2018, www.reuters. $\mathrm{com} /$ article/us-iraq-election-amiri/iranian-backed-shiite-militia-chief-aims-to-lead-iraq-idUSKBN1I91NL.

25 "Iraq Shi'ite Paramilitary Leader al-Amiri Withdraws Candidacy for PM," Reuters, September 18, 2018, www. reuters.com/article/iraq-politics-amiri/iraqi-shiite-paramilitary-leader-hadi-al-amiri-withdraws-candidacy-forpm-idUSL2N1W4067.

26 "Hezbollah Leader Reaffirms Loyalty to Iran, Khamenei," al-Arabiya, September 10, 2019, https://english.alarabiya.net/en/News/middle-east/2019/09/10/Hezbollah-leader-reaffirms-loyalty-to-Iran-Khamenei.

27 Daniel L. Byman, "How Terrorism Helps—And Hurts-Iran," Brookings, January 6, 2020, www.brookings.edu/ blog/order-from-chaos/2020/01/06/how-terrorism-helps-and-hurts-iran/.

28 In 1985, Rafsanjani was critical of the hijacking of the TWA Flight 847 by Hezbollah and wanted to work with President George H.W. Bush to release hostages from Kuwait Airways Flight 422 in 1988. See David Crist, The Twilight War (London: Penguin Books, 2012); Alan Cowell, "Ayatollah Ali Akbar Hashemi Rafsanjani, Ex-President of Iran, Dies at 82," New York Times, January 8, 2017, https://cn.nytimes.com/world/20170109/ ayatollah-rafsanjani-dead/en-us/.

29 For more details, see Alex Vatanka, Iran's Use of Shi ${ }^{i}$ Militant Proxies (Washington, DC: Middle East Institute, 2018).

30 For a discussion, see Behbod Negahban, "Who Makes Iran's Foreign Policy? The Revolutionary Guard and Factional Politics in the Formulation of Iranian Foreign Policy," Yale Journal of International Affairs 12 (2017): 33-48. See also Farhad Rezaei, Iran's Foreign Policy After the Nuclear Agreement: Politics of Normalizers and Traditionalists (New York: Palgrave Macmillan, 2018).

31 Michael R. Gordon, "Iran Said to Send Arms to Bosnians," New York Times, September 10, 1992, www.nytimes. com/1992/09/10/world/iran-said-to-send-arms-to-bosnians.html.

32 Golnaz Esfandiari, "Iranian Media Confirm Quds Force Involvement in Foreign Conflicts," RFE/RL, January 30, 2020, www.rferl.org/a/iranian-media-confirm-quds-force-involvement-in-foreign-conflicts/30408664.html.

33 Vinay Kaura, "Iran's Influence in Afghanistan," Middle East Institute, June 23, 2020, www.mei.edu/publications/ irans-influence-afghanistan.

34 Sajjan M. Gohel, “Iran's Ambiguous Role in Afghanistan," CTC Sentinel 3, no. 3 (2010): 13-16; Saurav Sarkar, “Iran's Afghanistan Balancing Act," Stimson Center, July 27, 2020, www.stimson.org/2020/irans-afghanistan-balancing-act/.

35 Mohsen M. Milani, "Iran’s Policy Towards Afghanistan,” Middle East Journal 60, no. 2 (2006): 235-256.

36 Ibid.

37 Obaidullah Obaid, "How Iran's New Quds Force Commander Could Hurt the US in Afghanistan," Atlantic Council, March 11, 2020, www.atlanticcouncil.org/blogs/iransource/how-irans-new-quds-force-commander-couldhurt-the-us-in-afghanistan/.

38 Davood Moradian, the chief of Presidential Programs for President Hamid Karzai, interview with author, Kabul, Afghanistan.

39 Ibid.

40 Kathy Gannon, "Iran Recruits Afghan and Pakistani Shiites to Fight in Syria," Associated Press, September 16, 2017, https://apnews.com/article/4731b95dae684f77b27d83c26e72a276. 


\section{Alex Vatanka}

41 “Iran (Islamic Republic of)'s Constitution of 1979 with Amendments Through 1989," Comparative Constitutions Project, PDF generated February 4, 2020.

42 Central Intelligence Agency, “World Factbook: Iran,” World Factbook, accessed September 16, 2020, www.cia.gov/ library/publications/the-world-factbook/geos/ir.html.

43 For a comprehensive overview, see "Sectarianism in the Middle East and Asia," Middle East Institute, November 1, 2019, www.mei.edu/publications/sectarianism-middle-east-and-asia.

44 Vatanka, Iran's Use of Shi i Militant Proxies.

45 Ibid.

46 Nafiseh Kohnavard, “Tikrit: Iran Key in Fight to Wrest City From IS,” BBC, March 3, 2015, www.bbc.com/news/ world-middle-east-31705600.

47 Office of the Spokesperson, "Department Press Briefing-April 2, 2019," U.S. Department of State, April 2, 2019, www.state.gov/briefings/department-press-briefing-april-2-2019/.

48 Robin Wright, “Iran Entrenches Its 'Axis of Resistance' Across the Middle East,” New Yorker, September 20, 2019, www.newyorker.com/news/our-columnists/iran-entrenches-its-axis-of-resistance-across-the-middle-east.

49 Ibid.

50 Ibid.

51 Nicholas A. Heras, Iraq's Fifth Column: Iran's Proxy Network (Washington, DC: Middle East Institute, 2017).

52 Ibid.

53 Ibid.

54 For a discussion, see "Reasons Behind the Successes of Iran's Regional Policies," Mashregh News, December 11, 2019.

55 Sirwan Kajjo, “Tensions Grow Between Russia, Iran in Syria,” Voice of America, May 27, 2019, www.voanews.com/ extremism-watch/tensions-grow-between-russia-iran-syria.

56 In its defense, strategists from the Revolutionary Guards constantly have to defend the model from critics. See, for example, "Iran's Defense Doctrine has Changed From 'Mere Defense' to 'Increasing the Threat to the Enemy', Tasnim News, October 1, 2016.

57 “Iranian Deputy Minister Outlines Reconstruction Projects Funded by Tehran in Syria," Radio Farda, October 6, 2020, https://en.radiofarda.com/a/iranian-deputy-minister-outlines-reconstruction-projects-funded-by-tehran-insyria-/30878768.html.

58 Mark Landler, “Trump Abandons Iran Nuclear Deal He Long Scorned,” New York Times, May 8, 2018 , www. nytimes.com/2018/05/08/world/middleeast/trump-iran-nuclear-deal.html.

59 Michael Crowley, Falih Hassan, and Eric Schmitt, "U.S. Strike in Iraq Kills Qassim Suleimani, Commander of Iranian Forces," New York Times, January 2, 2020, www.nytimes.com/2020/01/02/world/middleeast/qassemsoleimani-iraq-iran-attack.html.

60 "The Leader of the Revolution: We Will Not Negotiate with the Americans," Khabar Online, July $31,2020$. 
12

\title{
TERRORISM, INSURGENCY, AND CRIMINAL INSURGENCY IN LATIN AMERICA
}

\author{
Román D. Ortiz
}

Latin America has been fertile ground for irregular warfare since its independence from the Spanish monarchy in the early 19th century. With few inter-state wars, the military history of the region has been dominated by conflicts between governments and irregular adversaries. The motivation, shape, and tactical range of these actors-from bandits and insurgents to vigilantes and drug traffickers- have been extremely diverse, but all of them shared the view of the "state" as the enemy and the use of unconventional means to defeat it.

The evolution of insurgency and violence in Latin America can be traced through a set of waves of violence resulting from clashes between governments and irregular groups. Whether profit-driven criminals or politically motivated rebels, the key strategic fault lines fueling conflict in Latin America have always run between government and anti-state forces.

This chapter analyzes the evolution of irregular threats in Latin America, describing the context in which non-state violent actors emerge and operate. It will discuss the differing motivations and military capabilities of the various groups, focusing on El Salvador's Farabundo Marti Liberation Front (FMLN), Peru's Shining Path, the Revolutionary Armed Forces of Colombia (FARC), the United Self-Defense Forces of Colombia, and Mexico's Los Zetas. The chapter also touches on the activities of Islamist terrorist organizations in Latin America, specifically Hezbollah and the Islamic State.

\section{The Latin American strategic context}

The profile of Latin America's irregular armed actors and their occasional success—such as in Cuba in 1959 and Nicaragua in 1979- has much to do with the context in which they have emerged and operated. In this respect, Latin America's physical landscape has played a vital role. The region has sharp contrasts in terms of population and wealth distribution. Latin America contains several megacities, each near large empty spaces such as the Andes Mountains or the Amazon rainforest. The contrast is even clearer when comparing population density. Bogota, for example, concentrates 4,277 inhabitants per square kilometer, while the department of Putumayo in Colombia's south has 14.2. ${ }^{1}$ Regional wealth inequality is also extreme. The gross domestic product per person in Mexico City is $\$ 20,782$ but just $\$ 3,146$ in the state of Chiapas. $^{2}$

The combination of huge, densely populated cities and extensive and empty rural spaces has obvious strategic implications. Both present significant obstacles for economic development and governance. Cities include high-crime areas such as gang-controlled slums and enclaves of radicalization at some universities. 
Rural areas include deep jungles and rugged mountains that present governments with challenges on the provision of basic services and security while providing effective sanctuary for guerrillas and criminals.

The strategic relevance of these spaces has changed over time. While jungles and mountains have partially lost their value as safe havens due to improvements in intelligence and mobility of the state security forces, Latin American cities have become more difficult to control due to the complexity and thickness of the physical and human terrain.

The human factor fueling rebellion has also evolved. In the earlier years, the urban middle class served as drivers for insurrection. They provided leaders, ideologues, and cadres for the region's various revolutionary attempts, from Fidel Castro and Ernesto Che Guevara for Cuba's July 26th Movement in the 1950s to Abimael Guzman for the Shining Path in the 1980s. ${ }^{3}$ Even when the number of militants of middle class origin was small, their political and strategic roles were critical. This was the case with the FARC, a group mainly composed of peasants whose political and military strategy was disproportionally influenced by a small core of urban intellectuals close to the Colombian Communist Party.

Although Latin America's urban middle classes have remained fertile ground for the emergence of revolutionary cadres, other social sectors have played an increasing role in political violence. Middle and large landowners have provided some leaders to the vigilante groups — defined as private security militias - that developed illegal counterinsurgent campaigns in Central America and Colombia starting in the 1980s.

Bandits and criminals have also fed the ranks of violent extremist groups. Many of the leaders of the Colombian paramilitary movement that founded the United Self-Defense Forces of Colombia were drug traffickers. Likewise, the FARC recruited criminal gangs to beef up some of its key units, such as the Daniel Aldana Mobile Column operating in the Colombian port of Tumaco. ${ }^{4}$

Insurgent and vigilante leaders have used a variety of networks as bridges between their armed organizations and their social bases to provide militants, supporters, and financiers. During the 1980s, the Colombian Communist Party served that role in some regions where it enjoyed strong political influence. Educational institutions have also become hubs for mobilization, such as the National University of San Cristóbal de Huamanga from where Shining Path leader Guzman led the initial effort to expand the reach of the group in the Central Andes. ${ }^{5}$ Likewise, landowner associations have played key roles as networks to organize and finance vigilante groups. The Rural Association of Farmers and Ranchers of Magdalena Medio, for example, provided support for the creation of vigilante groups in Colombia in the 1980s. ${ }^{6}$

Beyond these established networks, the sustainability of long-term armed activity - such as the Colombian and Central American insurgencies and more recently the systematic violence displayed by the Mexican cartels-would not be possible without the existence of social bases that provide a continuous flow of foot soldiers and sympathizers.

The specific profile of these social niches has evolved as the nature of the armed groups has changed, but they have always been characterized by collective dispossession and frustration. They are usually marginalized groups whose options for social mobility have been dashed in the face of a variety of obstacles, including lack of access to property, inadequate education, ethnic discrimination, or poor economic prospects. Consequently, many have remained trapped in poverty with little hope of progress, a situation that has made outreach from illegal groups more attractive.

At the same time, the failure of the government to provide basic services such as justice or security has produced ungoverned social spaces. The result has been a power vacuum from which armed groups have profited. This combination of factors facilitated the recruitment of FARC among informal settlers and coca growers in southeastern Colombia, as well as the rapid growth of the Shining Path in the marginalized indigenous communities of the Peruvian department of Ayacucho. The same could be said with the enlistment of young slum dwellers by self-defense groups and criminal gangs in Central America, Mexico, Colombia, and Brazil.

The development of Latin American armed organizations has also required a strategic roadmap frequently provided by Marxist-Leninist revolutionary doctrine. This was the case with Che Guevara's 
foquismo (foco theory), which guided the 1960s insurrectionist wave, and the Maoist people's warfare theories that led to the rebellions of the 1980s, from El Salvador to Peru.

These theories defined two different approaches to revolution. On the one hand, foco theory proposed that a small armed vanguard could act as a catalyzer for general insurrection even when there are no sociopolitical preconditions for revolution. ${ }^{7}$ On the other hand, the concept of Maoist people's warfare argued the importance of building an extensive structure of professional cadres as a tool for political-military mobilization and emphasized the need for adapting revolutionary strategy to preexisting social conditions as a key factor for success. ${ }^{8}$

These doctrines played critical roles in providing guidelines for organization, popular mobilization, and campaign design. Without these ideas, Latin American rebels would have been just partisans without political direction. With them, they became the heads of well-organized political-military movements conducting an assault against the state.

The influence of leftist revolutionary techniques went beyond the politically motivated groups. Marxist militants and common criminals who joined forces while in Candido Mendes prison in Rio de Janeiro in the 1970s created the notorious Brazilian gang "Red Command." Likewise, the Peasant Self-Defense Groups of Cordoba and Uraba, a Colombian vigilante organization, expanded rapidly in the 1980s by recruiting a group of former Maoist guerrillas who brought with them broad experiences in organization building and mass mobilization.

Nevertheless, the most transformative factor in the evolution of Latin American armed organizations has been booming illicit economies, including drug trafficking, illegal mining, oil theft, kidnapping for ransom, and extortion. The emergence of this economic opportunity provided armed groups with strategic autonomy, since they could self-finance their operations, and it gave them the possibility of developing a base of popular support among the social sectors connected to the illegal economies, such as coca growers or informal miners.

The illicit business also changed the nature of Latin America's violent groups. ${ }^{10}$ The flow of criminal money modified the drivers shaping the behavior of the irregular fighters, replacing ideological zeal with hunger for profit. The profile of militants mutated progressively, with middle-rank positions within the insurgent organizations becoming occupied by individuals less committed to the group's original political ideology and more interested in crime for profit. ${ }^{11}$

The best example of this transformation is how the FARC filled its ranks with figures involved in the drug business to the extent that the leadership of communist origin became increasingly isolated from the rest of the organization. Similar processes of criminalization took place in other groups such as the Colombian National Liberation Army, the remains of the Shining Path, and other smaller groups such as the Paraguayan People's Army.

At the same time, a new generation of armed criminal organizations emerged as key players in a fresh wave of anti-state violence that most of the region has experienced since the mid-1990s. These new criminal enterprises were still motivated by profit, but they progressively developed military-grade capabilities and performed para-state functions such as security and justice in the communities under their control.

The combination of economic motivation, political functions, and military capabilities applies to groups such as the Brazilian First Command of the Capital, the Mexican Jalisco New Generation Cartel, and the Colombian Gulf Clan, which are best described as "criminal insurgencies." 12

\section{Insurgents, vigilantes, and criminal insurgents: organization and tactics}

The three key types of irregular armed actors in Latin America-political insurgents, vigilantes, and criminal insurgents - have been driven by three different motivations: revolution, defense of the status quo, and illegal profit. Their differences, however, have gone beyond these motivations and include two other key issues: organizational structure and strategic behavior. 
In terms of organization, two factors have defined the shape of the armed actors: the level of centralization/decentralization of their command and control system and the mix of full-time, uniformed combatants and part-time, clandestine collaborators within each group. Traditional insurgents developing a guerrilla strategy have tended to build more centralized organizations and have a higher proportion of fulltime militants, even if their ranks have always included part-time collaborators. The best example of this model has been the FARC, which kept a considerable level of unity of action and a high proportion of uniformed combatants during most of its history until the years before its partial demobilization in 2016 .

At the other end, vigilante groups and criminal gangs have been characterized by a highly decentralized structure and a major proportion of part-time, clandestine collaborators. This tendency is a result of the informal leadership of these actors; the key role of family, clan, and community ties to maintain internal cohesion; and the type of violence practiced, usually involving terrorism. This characterization omits some exceptions, but overall the majority of these groups - from the Salvadorian "death squads" to the Medellin Cartel-operated according to the described model of decentralized networks.

Between both extremes, criminal insurgents have evolved toward hybrid organizational models that involve three different interconnected rings: a hardcore of militarized followers under the direct control of the leadership, a second layer of clandestine networks of collaborators, and a final ring of allied gangs. Even if these three components have been common in many Latin American armed groups, the mix among them is more balanced in the criminal insurgency-type organizations. This is a result of the hybrid nature of these actors who have integrated some military capabilities — brought by former members of insurgent organizations or government security forces - into ordinary gang-style groups.

This has been the case with the infamous Los Zetas cartel, which was created as a paramilitary organization by former Mexican military personnel, but it is also true with the Jalisco New Generation Cartel and Gulf Clan.

In terms of tactical repertoire, Latin American irregulars have employed a broad variety of lethal and non-lethal tools. With force application, they have combined guerrilla, terrorist, and mass violence tactics to varying degrees depending on their capabilities and the operational context. During the 1980s and 1990s, guerrilla warfare was the dominant option, with terrorism playing a secondary role; the main effort of the revolutionary groups took place in the rural areas, and the vigilante gangs limited the majority of their actions to attacks against civilians accused of being insurgent sympathizers or members of leftist parties.

There were some significant exceptions to this pattern, however. The Shining Path transitioned from a declining rural insurgency to an intense urban terrorist campaign that nearly brought the Peruvian state to the brink of collapse. In parallel, a coalition of Colombian self-defense groups created the United SelfDefense Forces of Colombia and built a vigilante army that combined terrorist and guerrilla tactics in a set of successful offensives against FARC and National Liberation Army insurgents.

Latin American anti-state violence has changed significantly during the past two decades. Rural insurgencies have declined, while revolutionary organizations have taken a more urban approach. That has been the case of the Colombian National Liberation Army, which has maintained a significant presence in rural areas, but it has emphasized its operations in large cities. This is also true for the more recent and smaller groups such as the Chilean anarchist cells that carried out a set of terrorist attacks against urban infrastructure between 2005 and 2019. ${ }^{13}$ This change in setting has been accompanied by a shift in tactics, particularly an emphasis on terrorism and violent protests.

As a result, political violence has returned to Latin American cities. The bombing of the police academy in Bogota in 2019 that killed 23 people is an indication of this change ${ }^{14}$ Likewise, the set of violent protests in Quito, Santiago, and Bogota between 2019 and 2020 evinced the capability of groups of extremists to disrupt social life, radicalize peaceful demonstrators, and destabilize governments. ${ }^{15}$

At the same time, the emergence of criminal insurgencies has been accompanied by dramatic changes in terms of force application. These groups have been able to sustain irregular warfare not only through the 
recruitment of former members of insurgent groups and security forces but also by the introduction of new military hardware. This has included anti-materiel rifles (rifles designed for use against military equipment as opposed to people), anti-tank rockets, improvised armored vehicles, and drones.

The combination of military expertise and new equipment has produced exponential growth in tactical capabilities. Mexican cartels, for instance, are able to coordinate swarming maneuvers with columns of armored sports utility vehicles and execute commando raids against key rivals. ${ }^{16}$ Their tactical resources have provided them with clear superiority over local law enforcement agencies and some state police forces. This has created ever-expanding "no-go" areas that remain beyond government control.

On a more limited scale, a similar scenario is emerging in Brazil, where some gangs have gained control over the periphery of some cities, but instead of superior equipment, they combine terrain exploitation with a certain degree of popular support to keep security forces away.

As a complement to violence, Latin American irregular armed actors have made extensive use of non-lethal tools such as propaganda and political action. During the 1980s and 1990s, the FARC built a complex propaganda apparatus including publications and a network of regional radio stations. At the same time, the organization maintained political ties with the Communist Party and developed a number of front organizations.

This classical use of communication tools as a part of an insurgent campaign has evolved as technology has offered new channels to reach key audiences. In particular, insurgent groups have displayed an increasing presence in social media and expanded their political messaging to topics such as environmentalism or gender issues to gain influence over the urban youth. ${ }^{17}$

Criminal groups and gangs have also developed communications efforts. Mexican cartels have deployed a systematic effort to shape the information environment. To this end, they have systematically intimidated and attacked journalists and media outlets to control information. Furthermore, cartels have developed their own means to disseminate messages, such as the so-called narcocorridos (popular songs on the drug business) and narcomantas (banners used by the criminal groups), through which they launch threats, send messages, and explain actions. Likewise, they release videos-from public statements to gruesome executions - through conventional and social media with the objective of reasserting their power and sowing fear among communities and security forces.

Among non-lethal means, corruption has become a key ingredient as insurgents and vigilantes have a long tradition of exploiting graft and treason to their gain. During the 1990s, the Colombian National Liberation Army enjoyed the complicity of local officials to develop a scheme of extortion and embezzlement in the department of Arauca. ${ }^{18}$ In parallel, vigilante gangs partnered with businesspeople to profit from corruption in public works in the neighboring department of Casanare.

The strategic importance of corruption has grown dramatically after its "weaponization" by cartels and gangs. In fact, its systematic use has had three key effects. First, it has operated as a defensive layer protecting criminal structures. Second, it has damaged the credibility of the government and reduced its popular support. Finally, it has facilitated the efforts of criminal groups to expand their economic interests and political influence.

Cases such as those involving bribes by the Sinaloa Cartel to Genaro Garcia Luna, Mexican secretary of public security under President Felipe Calderon, are the best illustration of the critical impact of corruption. $^{19}$

\section{From Marxists to drug kingpins: the evolution of Latin American anti-state violence}

The emergence of Latin America's criminal insurgencies is the latest chapter in a long history of internal violence. Successive groups have profited from previous experiences while introducing changes to better 
adapt to the evolving strategic scenario. This section will profile several key insurgent and vigilante groups that played a critical role in the evolution of irregular warfare in Latin America in recent decades.

\section{Farabundo Martí National Liberation Front: the last Cold War insurgency}

Any analysis of the recent evolution of anti-state violence in Latin America must start with the insurgent campaign launched by the FMLN in El Salvador between 1980 and $1992 .{ }^{20}$ Created as a coalition of four different groups, the FMLN would become the most sophisticated version of Cold War-era Latin American guerrillas. El Salvador presented some serious challenges for an insurgent campaign. The small size of the country and the high population density reduced the maneuver space for any rural-based armed group.

At the same time, the Salvadorean armed forces, initially characterized by poor training and unrestricted violence, became an increasingly professional counterinsurgent force under the intense training and equipment program developed by the U.S. government in the 1980s. ${ }^{21}$

In this context, the FMLN enjoyed two advantages. First, it received a massive amount of support and technical assistance from the Soviet Union and other Eastern Bloc countries. Allies provided large quantities of weapons, including assault rifles, rocket launchers, machine guns, mortars, and, during the last period of the war, surface-to-air missiles. ${ }^{22}$ They also provided critical communications gear and medical equipment. Furthermore, the FMLN developed a significant capability to manufacture improvised weapons such as landmines and anti-air rockets.

Second, the FMLN had safe havens in Cuba and Nicaragua that played key roles as logistical hubs and training bases. Cuba, and on a smaller scale Vietnam, also provided training and advisory assistance.

This allowed the Salvadorean insurgents to build a sophisticated guerrilla army. FMLN recruited, trained, deployed, and sustained a number of full-time semi-regular combat battalions and developed the capability to plan and coordinate a nationwide strategy. In parallel, they built commando-type unitsknown as "Special Purpose Forces"- and used them as a spearhead for complex operations such as assaults on military bases and area ambushes.

These military tools allowed the FMLN to develop an extremely effective campaign that did not cause the collapse of the Salvadorian armed forces only due to sustained support from the United States. The resulting strategic stalemate led to peace negotiations between the insurgents and the Salvadorean government, ending in an agreement that established the disarmament of the FMLN in exchange for its legalization as a political party and the drafting of a new constitution.

\section{Shining Path: drug trafficking and urban terrorism}

As the Salvadorian civil war progressed, the Shining Path in Peru tested a completely different insurrectional model. While it has gone down in history as a particularly extremist and brutal group, the Maoist organization introduced two key innovations in its strategic behavior that made it possible to challenge the Peruvian state even if it had limited resources and was internationally isolated: the development of an autonomous economic base and the transition from a rural guerrilla project to an urban terrorist network.

Based on a particularly radical version of Maoism that accused the Chinese Communist Party of betraying Mao's legacy, the Shining Path could not rely on foreign support to acquire the resources required for revolution. As a consequence, Shining Path leader Abimael Guzman and his followers opted for a low-tech insurrection based on the mobilization of the indigenous communities of Ayacucho armed with makeshift weapons and a continuous supply of dynamite diverted from the extensive and poorly controlled Peruvian mining industry.

This lack of resources - a key difference compared to the FMLN-remained a permanent handicap for Guzman's plan to escalate the war against the state. The expansion of insurgent operations toward the Upper Huallaga Valley, an area with extensive coca plantations, provided an alternative source of financing 
to the Shining Path. The Peruvian Maoists took on the role of regulators of the drug business, guaranteeing a minimum price to the coca growers. They also offered military protection to the Colombian traffickers, allowing the Shining Path to profit from both sides of the market. ${ }^{23}$

Furthermore, the Colombian connection provided a source of modern weapons that were badly needed. ${ }^{24}$ But getting involved with drug trafficking was a mixed blessing for Guzman. It became a key source of much-needed money and weapons, but it also had a deleterious effect on the group's cohesion by providing financial autonomy to the insurgent columns operating in the Upper Huallaga region.

Even with the additional resources, the Shining Path's campaign in the rural areas faced increasing difficulties. The organization's attempts to impose its radical platform in the rural areas under its control stirred up hatred among the indigenous communities that sought government support to expel the insurgents from their territories. The result was the creation of state-sponsored Self-Defense Committees and the progressive weakening of the Shining Path in the rural areas. ${ }^{25}$ Guzman's response was to turn the group's main effort on the capital, Lima. ${ }^{26}$

Two factors facilitated this transition. First, many of the Shining Path's cadres were from cities and familiar with the urban operational environment. Second, the rural terror campaign caused a massive displacement of population toward Lima, which led to the emergence of new settlements in the cities. These emerging neighborhoods became perfect environments for the infiltration of rural guerrillas or the recruitment of new militants. In this context, Guzman launched a terrorist escalation in Lima that stoked fear among the population and cornered the government. ${ }^{27}$

Nevertheless, the Shining Path's organizational structure was too weak and its social base too narrow to win its war against the Peruvian state. The arrest of Guzman in Lima in 1992 dealt a decisive blow to the organization. It collapsed quickly and remained reduced to a small group isolated in the coca-growing regions.

\section{FARC: a new model of insurgency}

During the 1980s and 1990s, the FARC's expansion in Colombia was the result of a combination of the FMLN's operational sophistication and the Shining Path's financing model. In particular, the FARC's military modernization was closely connected with their learning from the Salvadorian experience.

As part of its Seventh Conference in 1982, FARC insurgents approved the so-called "New Form of Operation." As such, the group made a leap from guerrilla-style operations to mobile warfare, including the execution of complex actions such as assaults on fortified bases and area ambushes. ${ }^{28}$ To develop these capabilities, the FARC took inspiration from the FMLN's modernization. This involved the formation of battalion-size units called "Mobile Columns" and the creation of special forces groups such the "Teofilo Forero Mobile Column."

A key step in this modernization was the creation of the "Hernando González Acosta Military School" in which future middle-rank commanders received training, some of it developed by Chilean and Salvadorean insurgents. ${ }^{29}$ The result of these efforts was clear during the 1990s when the FARC launched a general offensive that destroyed a set of key army bases in the south and the east of Colombia, allowing the "de facto" control of extensive areas of the country. ${ }^{30}$

This military escalation would have been impossible without the involvement of the FARC in the drug business, which dramatically improved its financial resources. In this respect, the FARC's strategy was similar to the Shining Path: the search for financial autonomy to sustain its insurgent campaign.

Initially, the FARC operated as a regulator of the industry and a provider of military protection, taxing coca growers and receiving payments from drug traffickers. ${ }^{31}$ But the incentives for Colombian guerrillas to become more deeply involved in the production of narcotics grew as they sought to maximize profit and prevent the vigilante groups, such as the United Self-Defense Forces of Colombia, from attacking their intermediaries and disrupting their access to the market. 
As a consequence, some FARC units developed their own cocaine laboratories and became fully embedded in the drug business by the mid-1990s. Additionally, the FARC, like other Colombian groups, turned to kidnapping for ransom as a source of income, kidnapping more than 1,000 people at its peak in $2000 .{ }^{32}$

As in the case of the Shining Path, drug trafficking was a mixed blessing. It made the FARC one of the wealthiest armed groups in the world and allowed it to acquire huge amounts of military equipment in the black market. ${ }^{33}$ But it also unleashed a rapid process of criminalization that weakened the internal cohesion of the group and diminished its military effectiveness. ${ }^{34}$ Some guerrilla commanders began to increasingly operate independently and became more concerned about keeping drug money flowing into their pockets than fighting government troops.

The FARC leadership implemented a set of measures to prevent the dissolution of the group, including strict rules to maintain control over the narcotics money as well as harsh punishment for any member found guilty of embezzlement. These efforts, however, could not prevent the increasing decentralization of the organization, which ultimately led to its fragmentation and the emergence of a set of dissident gangs after its top commanders signed a peace agreement with the Colombian government in 2016.

\section{United Self-Defense Forces of Colombia: between vigilantism and organized crime}

In parallel to the FARC expansion, the United Self-Defense Forces of Colombia emerged as a hybrid actor: half criminal enterprise, half vigilante group. The roots of the organization were in the Medellin Cartel and the internecine war between its infamous leader, Pablo Escobar, and a dissident faction that became known as "Persecuted by Pablo Escobar" (or "Los Pepes"). ${ }^{35}$ This infighting contributed to the death of Escobar and the dismantling of his network of collaborators, but the winning side reshaped the cartel's operations.

With a more militaristic view on how to control the drug business, this group of former Medellin Cartel members built an illegal army to assault the main coca-growing areas that remained under guerrilla control. This project increased its military force and geographical reach with the incorporation of vigilante groups created by big landowners in some Colombian regions to protect their interests and fight the guerrillas. This mix of criminal gangs and illegal anti-guerrilla groups was the cornerstone of the United Self-Defense Forces and defined its composition and strategic behavior. ${ }^{36}$

As a way to grow in stature and political influence, the United Self-Defense Forces leadership emphasized its profile as a political force with the use of uniforms, the dissemination of propaganda, and the development of a political platform. Even if these efforts did not change the fact that the group was composed of gangs driven by criminal motivations, it cannot be ignored that the organization played the role of an armed wing of the Colombian extreme right in much the same way as the Salvadorian "death squads." 37

After its creation in the mid-1990s, the organization grew quickly as it integrated groups from different areas of Colombia. The result was a loose coalition of very different actors, including urban criminal networks such as "The Terrace" in Medellin and rural armed groups such as the Peasant Self-Defense Groups of Cordoba and Uraba. This organizational diversity resulted in a broad variety of operational behavior. In many Colombian regions, the United Self-Defense Forces behaved as a traditional vigilante gang, executing terrorist attacks against both individuals suspected to be guerrilla sympathizers and members of legal leftist parties.

In other parts of the country, however, the group executed more complex operations involving the deployment of hundreds of combatants in offensive operations to take over key areas for drug production and trafficking. At the same time, the organization used corruption and coercion to gain control over government bodies. In particular, it developed a massive scheme of voter fraud through which it guaranteed the election of a number of rightist representatives and gained significant influence over the Colombian Congress. ${ }^{38}$ 
Ultimately, the organization went into a crisis as a result of the contradictions within its leadership and reached a demobilization agreement with the government in $2005 .{ }^{39}$ The reintegration of its members into civil life was considerably difficult, however, since many of them were common criminals. Consequently, a significant proportion of the group left the organization to join the criminal gangs that took its place in the Colombian drug business. ${ }^{40}$

\section{Los Zetas: the rise of a criminal army}

The United Self-Defense Forces of Colombia's role as a hybrid actor-a criminal coalition operating as a political player in Colombia's internal conflict - offered a clear precedent for a new generation of Latin American armed actors that combined the control of an extensive illegal economy, a strong military apparatus, and a significant level of political influence. This new model of armed organized crime became visible with the creation of the Los Zetas cartel in Mexico in the late 1990s.

Los Zetas was initially formed by the Gulf Cartel as a military arm to fight rival gangs. Its founding group consisted of former special operators belonging to the Mexican Army's Airborne Group of Special Forces and then expanded with defectors from other security agencies. Inevitably, the growth of Los Zetas led to a conflict with their bosses in the Gulf Cartel and its consolidation as an independent criminal enterprise. ${ }^{41}$

In this process, the organization introduced two key changes to the Mexican drug business. First, it increased the sophistication and intensity of the violence in the fight against rival gangs. Los Zetas brought their military expertise on issues such as intelligence and direct action to the Mexican cartel wars but also displayed a complete disregard for human life—committing atrocities on a scale like never before.

Second, they expanded their economic portfolio much beyond drug trafficking to include extortion, kidnapping, human trafficking, and other illegal business. At the same time, Los Zetas developed a broad network of corruption involving police chiefs, prosecutors, and high-ranking officials, particularly in the states of Tamaulipas and Coahuila. According to some sources, this involvement in politics included the illegal funding of political campaigns. ${ }^{42}$

Although Los Zetas became the most powerful Mexican cartel in the early 2010s, two factors led to the group's decline. First, the notoriety of the organization and its use of extreme violence made it a priority target for the Mexican authorities and, particularly, the army. Second, a set of internal disputes led to the group's fragmentation. As a result, Los Zetas was reduced to a set of independent and rival networks by 2015.

Nevertheless, the group's strategic legacy has had a critical influence on Mexico's security environment. After Los Zetas, all of the other criminal organizations were forced to develop a more effective military apparatus. The diversification of the criminal economy became a new normal, with cartels and gangs going beyond the drug business into a variety of economic activities.

Likewise, even if drug-related corruption preceded Los Zetas, its weaponization to gain control over parts of Mexican territory became a more extended practice. This combination of military sophistication, diversification of the economic portfolio, and massive use of corruption has been the recipe for strategic success pursued by the criminal groups that have replaced Los Zetas as the main threat to Mexico's stability today.

\section{The global dimension: Islamic terrorism in Latin America}

The anti-state violence in Latin America has been mainly the result of regional dynamics more than global tendencies. Latin American irregular actors have enjoyed international support, and outside terrorist and criminal groups have developed connections with the region for political, financial, or logistics reasons, although they have usually refrained from attacks on its soil. That has been the case for both the Provisional 
Irish Republican Army and the ultranationalist Basque organization Euzkadi Ta Askatasuna. The same can be said about criminal networks such as the Calabrian Ndrangheta or the Russian mafia.

Hezbollah has been the main exception to this pattern, executing three major terrorist attacks in a short period of time: the bombing of the Israeli Embassy in Argentina in 1992 (resulting in 29 deaths), the suicide van bombing of a Jewish center in Argentina in 1994 (resulting in 85 deaths), and the blowing up of Alas Chiricanas Airlines Flight 901 in Panama the same year (resulting in 21 deaths). ${ }^{43}$

This series of attacks underscored the extent of Hezbollah's infrastructure in Latin America as well as its role as a proxy for Iran, which has used the Lebanese terrorist group as a tool for foreign action. As the subsequent investigation demonstrated, the bombings in Buenos Aires were purportedly authorized by Iran as a reprisal for the decision of the Argentinian government to suspend nuclear cooperation. ${ }^{44}$

Operationally, Hezbollah proved its capabilities by executing three suicide attacks thousands of kilometers away from its bases in Lebanon and closely coordinated two of them. This was partly possible due to Hezbollah's ability to build an international network leveraging the Lebanese diaspora scattered all over the world..$^{45}$ In the case of Latin America, the key hub was the Tri-Border Area, a region where the boundaries among Argentina, Paraguay, and Brazil converge and where there is a well-positioned Shia community.

Since the attacks, Hezbollah's presence in the region has only grown. Venezuelan President Hugo Chavez and his successor, Nicolas Maduro, not only assisted Tehran in the development of political relations in Latin America but also made Venezuelan territory available for a broad set of Iranian-sponsored projects.

As a result, Venezuela became a new operating area for Hezbollah in Latin America, as Hezbollah could count on the support of the Venezuelan government. ${ }^{46}$ The former Venezuelan vice president and current minister of petroleum, Tareck El Aissami, has been central to this relationship. El Aissami is a dedicated Chavista with extensive family connections in the Middle East and has been sanctioned by the U.S. Treasury Department for his involvement in drug trafficking and money laundering. ${ }^{47}$

Consequently, Hezbollah found a favorable environment to expand its activities. It maintained its illegal economic infrastructure in Paraguay, as the arrest of Assad Ahmad Barakat in Brazil in 2018 proved. ${ }^{48}$ At the same time, it took advantage of its presence in Venezuela to expand its operations in the Caribbean basin, including drug trafficking and money laundering. ${ }^{49}$

In this respect, Operation Titan in 2008-executed jointly by Colombian and U.S. law enforcement agencies - revealed the relations between the Shia group and a Medellin-based drug trafficking ring known as the Envigado Office. Further investigations revealed that individuals connected to Hezbollah developed a scheme to transfer Colombian cocaine to the Los Zetas cartel in Mexico and then laundered the profits through the Lebanese Canadian Bank. ${ }^{50}$

As a part of Hezbollah's Latin America strategy, Venezuela became a hub for terrorist financing and training. The Shia Islamic Center, several travel agencies, and other types of companies in Caracas and Margarita Island became a network used for money laundering and the recruitment of sympathizers who were brought from all over Latin America for ideological indoctrination on Venezuelan soil and, if selected, further training in Iran. ${ }^{51}$ Additionally, the Venezuelan National Office of Identification and Foreigners, in charge of the issuance of national identification, provided passports to Middle Eastern individuals with Hezbollah ties and other violent extremist organizations. ${ }^{52}$

The result of Venezuela's cooperation with Hezbollah has been an expansion of its clandestine infrastructure in Latin America. The Lebanese group has not been limited to just building its financial and logistical resources; it has also developed plans and preparations to commit terrorist attacks. That was the case with the arrest of Muamad Amadar, a Lebanese citizen connected to Hezbollah, who collected intelligence on potential Jewish and Israeli targets in Lima in $2014 .{ }^{53}$

The most notorious terrorist plot planned by Iranian agents in the region was the so-called "Cafe Milano Plot" in 2011. It involved an attempt to assassinate Adel al-Jubeir, the Saudi ambassador to the United States, in a bombing in Washington, DC. An Iranian agent connected to a high-ranking officer of 
the Quds Force, the branch of the Islamic Revolutionary Guards Corps in charge of external clandestine operations, tried to contact the Los Zetas cartel in Mexico to hire them to carry out the assassination. ${ }^{54}$

The plot was discovered when the Iranian envoy inadvertently contacted a Drug Enforcement Administration confidential informant who notified the agency. The "Cafe Milano Plot," however, demonstrated the operational potential of Hezbollah's network in Latin America and how aggressive Tehran's agents can be when attempting to achieve their objectives.

In comparison with Hezbollah, Sunni terrorist groups have had a lighter footprint in the region. Contradictory news has emerged on al-Qaida's activities in a variety of Latin American countries, from Honduras to Brazil. ${ }^{55}$ Likewise, there have been indications of contacts between Latin American drug trafficking groups and al-Qaida in the Islamic Maghreb to guarantee transport and protection for drug shipments coming to Europe through West Africa and the Sahara desert. ${ }^{56}$ Yet the most significant presence of radical Sunni groups in the region is connected to the Islamic State, which engaged in considerable recruitment of individuals from Trinidad and Tobago.

These islands have a long history of Islamic radicalism that includes a coup attempt carried out by the extremist group Jamaat al-Muslimeen in $1990 .{ }^{57}$ After the failed coup, the organization became fragmented and many of its members involved in criminal activities. Radical preachers, however, continued to operate on the island. That was the context in which the Islamic State developed an extremely successful recruitment campaign.

Around 240 citizens of Trinidad and Tobago — including women and children - traveled to Syria and joined the Islamic State's self-proclaimed caliphate, where they performed a variety of functions but became particularly visible in the propaganda apparatus. ${ }^{58}$ While fighting to retain the group's now lost territory, more than 65 were killed or remain missing, another 50 or more remain in Syrian and Iraqi prisons, and a few continue in the Islamic State's ranks. ${ }^{59}$ The future return of some of these militants to the islands and the persistence of their radicalization networks represent a challenge to the security of Trinidad and Tobago and the hemisphere.

\section{Conclusion}

The evolution of Latin American anti-government violence in the last 40 years offers some key conclusions. First, there is a blurred line between organized crime and political violence. In case after case, it is possible to identify how politically motivated insurgent groups like the Shining Path or the FARC resort to criminal activities for self-financing, while criminal groups such as the Sinaloa Cartel or the First Command of the Capital assume para-state functions, providing justice and security services to those communities under their control.

At the same time, the movement of people between criminal organizations and extremist groups is frequent. Brazilian leftist insurgents were critical in the foundation of the Red Command, and the FARC recruited criminal gangs to beef up its urban networks in some Colombian cities.

A second key lesson is how tactical and operational knowledge has circulated from organization to organization, overcoming political and geographical barriers and facilitating an ever-increasing sophistication of Latin American irregulars. The methods for inter-group learning have varied, from pure imitation to the incorporation of members of other organizations who brought with them new expertise. The effect, however, has always been similar: the acquisition of new capabilities and the increase of effectiveness and resilience. The role played by the Salvadorian FMLN in the military modernization of the FARC is a good example.

Finally, a third conclusion is the ambiguous nature of the strategies deployed by the Latin American irregular actors. The traditional assumptions that guerrilla warfare and mass mobilization are the weapons of choice of insurgents, while criminals prefer corruption and assassination, are no longer valid. Corruption has become a common tool for insurgent organizations such as the Colombian National Liberation 
Army, while organized criminal groups such as the Jalisco New Generation Cartel have demonstrated their capability to execute combat operations and use propaganda effectively.

The result is the emergence of a generation of hybrid actors capable of combining lethal and non-lethal tools into strategies that are more difficult to anticipate and contain. These tendencies should be taken into consideration to understand the future profile of Latin American irregular threats.

\section{Notes}

1 Colombian statistics are author's calculations based on Colombia's Statistics Department DANE population's census for 2019, www.dane.gov.co/index.php/estadisticas-por-tema/demografia-y-poblacion/proyecciones-de-poblacion.

2 Figures are author's calculations based on Mexico's Institute of Statistics, accessed December 28, 2020, http://cuentame.inegi.org.mx/monografias/informacion/bc/default.aspx?tema=mee=02\#: :text $=$ Resumen.,Baja $\% 20 \mathrm{Califo}$ rnia\&text $=$ Extensi $\%$ C3\%B3n $\% 3$ A $\% 20$ Representa $\% 203.65 \% 25 \% 20$ del $\% 20$ territorio, 2.8\%25\%20del $\% 20$ total $\% 20$ del $\% 20 \mathrm{pa} \% \mathrm{C} 3 \%$ ADs.

3 Timothy P. Wickham-Crowley, Guerrilla \& Revolution in Latin America. A Comparative Study of Insurgents and Regimes Since 1956 (Princeton: Princeton University Press, 1992).

4 Fundación Ideas para la Paz, Trayectorias y dinámicas territoriales de las disidencias de las FARC (Bogota: Fundación Ideas para la Paz, 2018).

5 Carlos Ivan Degregori, Que difícil es ser dios: Ideología y violencia política en Sendero Luminoso (Lima: El zorro de abajo ediciones, 1989).

6 Carlos Medina Gallego, Autodefensas, Paramilitares y Narcotráfico en Colombia. Origen Desarrollo y Consolidación: El Caso Puerto Boyacá (Bogotá: Editorial Documentos Periodísticos, 1990).

7 Che Guevara, Guerrilla Warfare (Lincoln, NE: University of Nebraska Press, 1998).

8 Mao Tse-Tung, On Guerilla Warfare (Eastford, CT: Martino Fine Books, 2017).

9 Ben Penglase, "The Bastard Child of the Dictatorship: The Comando Vermelho and the Birth of 'Narco-Culture' in Rio de Janeiro," Luso-Brazilian Review 45, no. 1 (2008).

10 Chris Dishman, "Terrorism, Crime, and Transformation," Studies in Conflict and Terrorism, 24, no. 1 (2001): $43-58$.

11 Michael Lohmuller, "Guerrilla Leader Exemplifies Possible Criminalization of Colombia’s FARC,” Insight Crime, August 21, 2015, www.insightcrime.org/news/brief/colombia-guerrilla-leader-emblematic-of-farc-criminalization-fears/.

12 For more on the concept of "criminal insurgency," see John Sullivan, From Drug Wars to Criminal Insurgency: Mexican Cartels, Criminal Enclaves and Criminal Insurgency in Mexico and Central America, and Their Implications for Global Security (Bogota: Vortex Foundation, 2012). For details on the Colombian Gulf Clan, see Jeremy McDermott, "The Evolution of the Urabeños," Insight Crime, May 2, 2014, https://new.insightcrime.org/investigations/ the-victory-of-the-urabenos-the-new-face-of-colombian-organized-crime/.

13 Gideon Long, "Chileans Baffled by Persistent Bomb Attacks," BBC, August 20, 2014, www.bbc.com/news/ world-latin-america-28850708; "Atentado terrorista en el metro de Santiago de Chile," CNN, September 8, 2014, https://cnnespanol.cnn.com/2014/09/08/atentado-terrorista-en-el-metro-de-chile/; Fernanda Paul, "Qué es ITS, el grupo eco-extremista al que el gobierno de Chile acusa de 'actos terroristas' y que tiene presencia en otros países de América Latina?” BBC Mundo, May 14, 2019, www.bbc.com/mundo/noticias-america-latina-48258275.

14 Amy Held and Ian Stewart, "Deadly Blast at Bogota Police Academy Stokes Fears of Return to Colombia's Dark Past," National Public Radio, January 17, 2019, www.npr.org/2019/01/17/686299973/ deadly-explosion-at-bogota-police-academy-stokes-fears-of-return-to-dark-past.

15 Camila Lucero and Ignacio Guerra, "Presidente Piñera: 'Estamos en guerra contra un enemigo poderoso que no respeta a nada ni a nadie'," El Mercurio, October 20, 2019, https://web.archive.org/web/20191021142741/ www.emol.com/noticias/Nacional/2019/10/20/964954/Pinera.html; Unidad Investigativa y Justicia, "Lo que hay detrás de las horas de zozobra que se vivieron en Bogotá,” El Tiempo, September 13, 2020, www.eltiempo.com/ unidad-investigativa/bogota-vandalos-eln-y-disidencias-detras-de-jornadas-violentas-537552.

16 John Sullivan and Adam Elkus, "Tactics and Operations in the Mexican Drug War," Infantry 100, no. 4 (2011): 20-23.

17 Matthew Bristow, “Twitter Suspends Accounts as Colombia Rebels Declare Curfew,” Bloomberg, February 15, 2016, www.bloomberg.com/news/articles/2016-02-15/twitter-suspends-guerrilla-accounts-as-marxists-declare-curfew.

18 JavierDuqueDaza, “Arauca: elsaqueo delas regalías entre elELN,los paramilitaresylos políticos,”Razon Publica, March6, 2017, https://razonpublica.com/arauca-el-saqueo-de-las-regalias-entre-el-eln,-los-paramilitares-y-los-politicos/.

19 Mary Beth Sheridan and Shayna Jacobs, "Former Mexican Anti-Drug Official Charged With Taking Bribes from 'El Chapo' Cartel,' Washington Post, December 10, 2019, www.washingtonpost.com/world/the_americas/ 


\section{Terrorism in Latin America}

former-mexican-anti-drug-official-charged-with-taking-bribes-from-el-chapo-cartel/2019/12/10/b39f9e5a1b70-11ea-977a-15a6710ed6da_story.html.

20 Hugh Byrne, El Salvador's Civil: A Study of Revolution (Boulder: Lynne Rienner, 1996).

21 See Cecil Bailey's chapter in this handbook.

22 David E. Spencer and Jose Angel Moroni Bracamonte, Strategy and Tactics of the Salvadorean FMLN Guerrillas: Last Battle of the Cold War. Blueprint for Future Conflicts (Westport, CT: Praeger, 1995).

23 T. David Mason and Christopher Campany, "Guerrillas, Drugs and Peasants: The Rational Peasant and the War on Drugs in Peru," Terrorism and Political Violence 7, no. 4 (1995): 140-170.

24 Jose E. Gonzalez, "Guerrillas and Coca in the Upper Huallaga Valley," in Shining Path of Peru, ed. David Scott Palmer, 2nd ed. (New York: Palgrave Macmillan, 1994).

25 Carlos Tapia, Las fuerzas armadas y Sendero Luminoso: Dos estrategias y un final (Lima: IEP, 1997).

26 Gordon H. McCormick, From the Sierra to the Cities: The Urban Campaign of Shining Path (Santa Monica: RAND, 1992).

27 Michel L. Smith, "Shining Path's Urban Strategy: Ate Vitarte," in Shining Path of Peru, ed. David Scott Palmer, 2nd ed. (New York: Palgrave Macmillan, 1994), 145-166.

28 Román D. Ortiz, "La guerrilla mutante," in Colombia en la encrucijada, ed. Francisco Leal (Bogota: Norma-Uniandes, 2006).

29 "Las escuelas de las FARC," Verdad Abierta, February 22, 2013, https://verdadabierta.com/las-escuelas-de-las-farc/.

30 David Spencer, “A Lesson for Colombia,” Jane's Intelligence Review 9, no. 10 (1997); David Spencer, “Bogota Continues to Bleed as FARC Find their Military Feet," Jane's Intelligence Review 10, no. 11 (1998).

31 Juan Guillermo Ferro and Graciela Uribe, El orden de la guerra: Las FARC-EP entre la organización y la política (Bogota: CEJA, 2002).

32 "Kidnapping and Extortion," Colombia Reports, July 20, 2019, https://colombiareports.com/colombia-kidnappingand-extortion-statistics/.

33 Román D. Ortiz, "Renew to Last: Innovation and Strategy of the Revolutionary Armed Forces of Colombia (FARC)," in Teaching Terror: Strategic and Tactical Learning in the Terrorist World, ed. James Forest (Lanham: Rowman \& Littlefield, 2006).

34 Jeremy McDermott, “The FARC and the Drug Trade: Siamese Twins?” Insight Crime, May 26, 2014, www.insightcrime.org/investigations/farc-and-drug-trade-siamese-twins/.

35 Natalia Morales and Santiago La Rotta, Los Pepes: Desde Pablo Escobar Hasta Don Berna, Macaco y Don Mario (Bogota: Planeta, 2000).

36 Juan Carlos Garzón, “La complejidad paramilitar: una aproximación estratégica," in El poder paramilitary, ed. Alfredo Rangel (Bogota: Planeta, 2005).

37 Centro Nacional de Memoria Histórica, Paramilitarismo. Balance de la contribución de la Comisión Nacional de Memoria Histórica al esclarecimiento histórico (Bogota: Centro Nacional de Memoria Historica, 2018).

38 Claudia López Hernández, Y refundaron la patria? De como mafiosos y políticos reconfiguraron el Estado colombiano (Barcelona: Random House Mondadori, 2010).

39 Cynthia J. Arnson et al., The Peace Process in Colombia With the Autodefensas Unidas de Colombia-AUC (Washington, DC: Woodrow Wilson Center, 2005).

40 International Crisis Group, Colombia's New Armed Groups (Brussels: International Crisis Group, 2007).

41 Guillermo Valdés, "El nacimiento de un ejército criminal," Nexos, September 1, 2013, www.nexos.com. $\mathrm{mx} / \mathrm{p}=15460$.

42 David Agren, "Mexico Drug Cartel's Grip on Politicians and Police Revealed in Texas Court Files," Guardian, November 10, 2017, www.theguardian.com/world/2017/nov/10/mexico-drug-cartels-grip-on-politicians-andpolice-revealed-in-texas-court-files.

43 “Argentina Freezes Hezbollah Assets, 25 Years After AMIA Attack," Al Jazeera, July 18, 2019, www.aljazeera.com/ economy/2019/7/18/argentina-freezes-hezbollah-assets-25-years-after-amia-attack; "Panama Says New Evidence Shows 1994Plan Crash “Terrorist'Incident,'BBC,May22,2018,www.bbc.com/news/world-latin-america-44207991.

44 Damian Pachter, “Exclusive: IAEA Expert Details Argentina's Early Support of Iran Nuclear Program,” I24 News, November 17, 2017, www.i24news.tv/en/news/international/middle-east/160477-171117-exclusive-iaea-expertdetails-argentina-s-early-support-of-iran-nuclear-program.

45 Ioan Pop and Mitchell D. Silber, "Iran and Hezbollah's Pre-Operational Modus Operandi in the West," Studies in Conflict and Terrorism 44, no. 2 (2021): 156-179.

46 Colin P. Clarke, "Hezbollah Is in Venezuela to Stay," Foreign Policy, February 9, 2019, https://foreignpolicy. com/2019/02/09/hezbollah-is-in-venezuela-to-stay/.

47 "Treasury Sanctions Prominent Venezuelan Drug Trafficker Tareck El Aissami and His Primary Frontman Samark Lopez Bello," U.S. Department of Treasury, February 2, 2017, www.treasury.gov/press-center/press-releases/Pages/ as0005.aspx. 
48 Emanuele Ottolenghi, "Hezbollah Operative Assad Ahmad Barakat Extradited to Paraguay," Foundation for Defense of Democracies, July 22, 2020, www.fdd.org/analysis/2020/07/22/hezbollah-operative-extradited-to-paraguay/

49 Josh Meyer, "The Secret Backstory of How Obama Let Hezbollah off the Hook," Politico, no date, www. politico.com/interactives/2017/obama-hezbollah-drug-trafficking-investigation/; Hannah Stone, "US Alleges Zetas-Hezbollah Funding Link," Insight Crime, December 14, 2011, www.insightcrime.org/news/brief/ us-alleges-zetas-hezbollah-funding-link/.

50 Jo Becker, "Beirut Bank Seen as a Hub of Hezbollah's Financing," New York Times, December 13, 2011, www. nytimes.com/2011/12/14/world/middleeast/beirut-bank-seen-as-a-hub-of-hezbollahs-financing.html.

51 “Venezuelan Ties to Hezbollah," International Institute for Counter-Terrorism, August 14, 2008, www.ict.org.il/Article. aspx?ID=307\#gsc.tab=0; Martin Arostegui, "New Air Bridge Reflects Iran's Growing Influence in Venezuela," Voice of America, April 15, 2019, www.voanews.com/americas/new-air-bridge-reflects-irans-growing-influence-venezuela

52 Emili J. Blasco, "EE.UU. investiga el uso de pasaportes venezolanos por radicales islamistas," $A B C$, January 4, 2016, www.abc.es/internacional/abci-eeuu-investiga-pasaportes-venezolanos-radicales-islamistas-201601031047_noticia.html.

53 “Report: Peru Arrested Hezbollah Operative Planning Attacks on Israelis, Jews," Jerusalem Post, October 30, 2014, www. jpost.com/International/Report-Peru-arrests-Hezbollah-operative-planning-attacks-on-Israelis-Jews-380369.

54 Office of Public Affairs, "Two Men Charged in Alleged Plot to Assassinate Saudi Arabian Ambassador to the United States," U.S. Department of Justice, October 11, 2011, www.justice.gov/opa/pr/two-men-charged-allegedplot-assassinate-saudi-arabian-ambassador-united-states.

55 "Qaeda Eyeing Honduras?” CBS News, August 23, 2004, www.cbsnews.com/news/qaeda-eyeing-honduras/; Jaime Daremblum, “Al Qaeda in Brazil?” Hudson Institute, April 7, 2011, www.hudson.org/research/7889-alqaeda-in-brazil-.

56 Yaya J. Fanusie and Alex Entz, Al-Qaeda in the Islamic Maghreb (Washington, DC: Foundation for Defense of Democracies, 2017); Mohammad-Mahmoud Ould Mohamedou, The Many Faces of Al Qaeda in the Islamic Maghreb (Geneva: Geneva Center for Security Policy, 2011).

57 “Trinidad Marks 1990 Coup Attempt," BBC, July 27, 2010, www.bbc.com/news/world-latin-america-10774647.

58 "The ISIS Phenomenon in Trinidad and Tobago," Caribbean Investigative Journalism Network, December 5, 2019, www.cijn.org/the-isis-phenomenon-in-trinidad-and-tobago/.

59 Rukmini Callimachi and Eric Schmitt, "Teenager Captured With ISIS Fighters Is From Trinidad, Not the U.S., Officials Say,” New York Times, January 11, 2011, www.nytimes.com/2019/01/11/world/middleeast/teenager-isissyria-trinidad.html. 


\section{PART II}

Operational case studies 
- Taylor \& Francis

Taylor \& Francis Group

http://taylorandfrancis.com 
13

\title{
EL SALVADOR
}

\section{Operations and Planning Assistance Training Teams and a minimalist approach to counterinsurgency}

\author{
Cecil E. Bailey
}

Ever since El Salvador's long counterinsurgency ended in a negotiated peace in 1992, military and political practitioners continue to review the war for insights relevant to current and future conflicts. Although the role of the United States in El Salvador has its detractors, many consider it a successful counterinsurgency campaign and occasionally refer to a "Salvador Model." Popular descriptions include the "minimalist" approach to military aid or negotiations as an objective.

The case of El Salvador, like any counterinsurgency, was like twisting Rubik's cube: there were many influences, and action with any one of them affected all the others. Nevertheless, one can single out a rarely examined piece of the "model" to find lessons worth learning: the U.S. military advisory program to the El Salvadoran Armed Forces (ESAF).

Key political and economic components of U.S. counterinsurgency strategy played prominently to get the protagonists to negotiate an end to the conflict. At the U.S. Embassy in San Salvador, the dominant policy themes were democracy and development. U.S. counterinsurgency strategy had tools for both. El Salvador, however, was a special case in the desperate throes of a violent leftist insurgency on the verge of overthrowing the government and seizing power imminently, an outcome inimical to U.S. security interests in Central America.

At the same time, U.S. policymakers resisted any meaningful role with the only key player capable of preventing that outcome: the Salvadoran military. Prime among U.S. objections was the ESAF's record of political intervention and abusive repression, either of which was reason enough to withhold aid as a matter of policy. Decision-makers were thus stuck with the quandary of how to support a quasi-political, unprofessional, and repressive military ally when U.S. policies and values advocated against it.

Ultimately, the United States relied on small teams of advisors, known as Operations and Planning Assistance Training Teams (OPATTs), to assist El Salvador with its counterinsurgency. But political resistance to sending them and restrictions on their numbers and how they operated provide valuable lessons for a military advisory role in a counterinsurgency.

This chapter begins with a brief overview of the policy and doctrine that existed at the time. It discusses the Arms Export Control Act and the War Powers Resolution of 1973 and the impact both had on the security assistance mission. It describes why El Salvador mattered to the United States in the late 1970s and early 1980s. The chapter then explains how the field advisory mission evolved with the creation of the OPATTs, a wholly unique organization at the time. ${ }^{1}$ It concludes with lessons offered by the U.S. experience in El Salvador. 


\section{Policy and doctrine}

None of the counterinsurgency doctrine extant at the time appeared to fit the circumstances in El Salvador. ${ }^{2}$ Internal defense and development, for example, was in considerable disrepute due to its perceived failure in Vietnam. ${ }^{3}$ Post-Vietnam low-intensity conflict was part of a larger doctrinal construct to deal most with Europe's Fulda Gap and less with third-world insurgency. ${ }^{4}$ U.S. Southern Command (SOUTHCOM) in Panama, in whose area of responsibility El Salvador was situated, established a directorate in 1986 to develop solutions for Central America's "small wars"; principal among them at the time was the insurgency in El Salvador. ${ }^{5}$ It published its first study in 1988 when the war was all but over. ${ }^{6}$

The most relevant doctrine at the time was the new foreign internal defense doctrine. Foreign internal defense had its trial run in El Salvador and has remained part of U.S. counterinsurgency doctrine since. At the time, however, U.S. doctrine offered little guidance for the counterinsurgency campaign in El Salvador.

With little doctrinal basis, the campaign in El Salvador came to be driven primarily by the U.S. Security Assistance Program. This program, designed to aid allied host nations to provide for their own security, had historically been a tool to promote U.S. security objectives abroad. In Latin America, those objectives typically included a military component to modernize host nation militaries while promoting democratic ideals. ${ }^{7}$ The program, however, had never been used as the core of a counterinsurgency campaign against a full-scale revolution. ${ }^{8}$

In El Salvador, the program was used as early as 1981 to deploy U.S. Army Special Forces detachments to train ESAF units. For the next two years, this and other deployments focused on small unit tactics and force expansion to counter early insurgent advantage. Training and weapons modernization gradually had their effect as new U.S. trained battalions were fielded and battlefield advantage tilted away from the insurgents.

Yet fundamental reform among El Salvador's officer corps, one of the program's objectives, lagged combat advances. The ESAF became a more effective fighting force, but the military's unprofessional and abusive behavior on and off the battlefield stunted other counterinsurgency objectives of political legitimacy and popular support for the government.

Unfortunately, the United States had no effective way to influence how the ESAF conducted combat operations against insurgents. In 1979, the United States sent a small group of senior officers to advise the ESAF at the national level in San Salvador. Among others, this team had officers at the air force, logistics services, and at the ESAF command and staff headquarters (Estado Mayor). But none were assigned to field units where fighting was among the population and abuses routinely alleged. No sustained field advisory program with a strategic view was established until 1985, when advisory teams were finally assigned to ESAF brigade headquarters. Once established, that mission developed into one of the longest running of the war but was rarely coordinated into the overall U.S. campaign.

This experience was not a plan according to doctrine or model but rather a case of "make it up as you go" with the only tool acceptable to a U.S. Congress that wanted no part of a military adventure in El Salvador. ${ }^{9}$

\section{Security assistance, the Arms Export Control Act, and the War Powers Resolution}

Congressional resistance stemmed from the experience in Vietnam and how an early advisory mission there escalated into the United States taking over the war. In 1980, the tools to prevent a recurrence in El Salvador were powerful. Principal among them were the Arms Export Control Act of 1976 and the War Powers Resolution of 1973. The Arms Export Control Act was significant because it provided that Congress approve funding for all security assistance programs annually. For El Salvador, that meant Congress was empowered to control whether the program was funded each year. ${ }^{10}$ 
The War Powers Resolution limited presidential authority to commit U.S. forces abroad. A product of the Vietnam experience, the resolution gave Congress the authority to require the president to withdraw forces from "hostile situations" after 60 days unless Congress approved. ${ }^{11}$ In 1981, the resolution's language was unavoidable given nightly news of guerrilla attacks across the country and riot and repression in San Salvador's streets. There would have been little purpose in deploying U.S. military forces to El Salvador knowing Congress would likely order them withdrawn.

The solution was to avoid the War Powers Resolution altogether and send small teams to train and advise Salvadoran forces under provisions of the Arms Export Control Act. Within that legislation, training and advice was available from a list of choices, one of which was the mobile training team (MTT).

MTTs were limited to six-month deployments; if the mission required a longer commitment, the Extended Training Services Support (ETSS) ${ }^{12}$ allowed for deployments of a year or longer. As a result, most of the early missions to El Salvador were MTTs designed to quickly patch the most immediate combat skill needs within the six-month term of their deployment. As combat capabilities improved, objectives shifted to more complex planning and coordination assistance, which predictably required longer-term ETSS deployments. The ETSS was the tool used to deploy the OPATTs to the ESAF brigades.

\section{The insurgency and why it mattered to the United States}

El Salvador's war was typical of Latin American insurgencies. From the colonial period, a culture of radically skewed economic and political systems developed throughout Central America. Military intervention in government was the norm and commonly had the purpose of preserving the social and economic status quo as wealth and power accrued to an elite economic class while systemically disenfranchising an impoverished majority.

Described "as one of the sickest and most repressive societies in Latin America," ${ }_{13}^{13}$ El Salvador's condition was in part due to its distinction as the most densely populated nation in the Western hemisphere. ${ }^{14}$ The consequences of that alone for an agro-export economy in which land was scarce and labor abundant were inescapable: El Salvador's economy required exploitation of the powerless. Any uprising that threatened this status quo was put down by force, as brutally as necessary, by military and security forces.

In that way, the Salvadoran military, the very institution the U.S. military proposed to aid, was a significant part of the "problem." These features, combined with revolutionary fervor of the 1960s-fueled by Marxist movements, liberation ideology, and other forces-made revolution in El Salvador all but inevitable.

This inevitability became reality in the late 1970s. From Fidel Castro's march into Havana in 1959, leftist movements throughout Latin America were increasingly inspired to violence as the only path to social, political, and economic reform. In Central America, armed rebellion that had simmered in Nicaragua since the 1930s erupted into open revolt in 1979. Extreme violent suppression by Nicaragua's National Guard sufficiently disgusted President Jimmy Carter that he withdrew all support for the long-time ally at the height of the insurgent assault. The regime collapsed within days. Sandinista rebels seized government control in July 1979, and shortly afterward Nicaragua's new revolutionary junta allied with Cuba and the Soviet Union.

Within a year, El Salvador looked as though it would fall next. Only months after events in Nicaragua, El Salvador's capital city of San Salvador was a wild déjà vu cycle of violence as military crackdowns on protesters ignited more protests, which, in turn, escalated to ever more extreme brutality to quell them. By the end of 1980, conditions had worsened to a crisis, and the United States had limited leverage to influence the situation. Military aid available to El Salvador, for example, was less than $\$ 6$ million and restricted to spending on non-lethal purposes.

Timing for Washington was bad. The crisis in El Salvador straddled the administrations of outgoing President Carter and President-elect Ronald Reagan, and they differed considerably in how to respond. 
President Carter withheld military aid because of human rights abuses. By withholding aid, however, Carter risked El Salvador going the way of Nicaragua. ${ }^{15}$

At the same time, Reagan campaigned on an aggressive policy to curb communist expansion in Central America. Reagan's landslide election forecast significant military aid for El Salvador. ${ }^{16}$ But as Reagan prepared to implement his plans, Congress found ways to condition U.S. aid on ESAF human rights observance, a high hurdle at the time.

These policy differences during the transition muddled the political environment in ways that shaped assistance operations for the entire war. With Carter, for instance, aid came halting and lurching based on the latest report of a government atrocity or rebel surge, a persistent pattern throughout the war. Just before Carter turned over the presidency to Reagan, two events offered a preview of how this pattern precipitated chaotic swings in military aid.

The first was the murder of four U.S. churchwomen by Salvadoran security forces in December 1980. Carter immediately suspended all military aid. ${ }^{17}$ The second came barely a month later, when the January 1981 guerrilla "final offensive" staggered the ESAF. ${ }^{18}$ Carter reinstated the suspended aid and added another $\$ 5$ million. ${ }^{19}$

The failed offensive is less the story than how it made clear to the Salvadorans that they needed substantial help quickly and that only the United States stood to provide it. Aid expected to flow on Reagan's inaugural was tenuous at best and would remain so as the new administration's containment agenda clashed with an opposition Congress anxious to avoid military involvement in El Salvador's troubles. ${ }^{20}$

In response, the Reagan administration crafted extraordinary rules for how military personnel sent to El Salvador would operate to placate fears of a Vietnam redux. To deflect language in the War Powers Resolution and the Arms Export Control Act, they would only be "trainers" and specifically not "advisors," even though the Arms Export Control Act made no distinction between the two terms.

To address worries about escalation to a combat role, a State Department letter to the House Committee on Foreign Affairs described how trainers would be confined to "safe" garrisons to diminish risk of their exposure to "hostilities" and would be limited to sidearms for personal protection with strict rules on circumstances under which they could use them. ${ }^{21}$ The letter concluded that "a small training team whose members have sidearms would have no meaningful combat capability, and [therefore] is not a force equipped for combat" and ipso facto could not be in a hostile situation. ${ }^{22}$

In addition to these innovative maneuverings, the "55-man limit" initiated at the end of the Carter administration severely constrained incoming President Reagan. ${ }^{23}$ The genesis of the limit can be traced to a December 1980 meeting headed by Carter's secretary of state, Zbigniew Brzezinski, in which one of the issues to be decided was how many U.S. military personnel would be in El Salvador when Carter transitioned to Reagan. The number projected for transition day was 55, a number Brzezinski approved. ${ }^{24}$

This decision might have faded away as an uninteresting historical tidbit except that in March 1981, just months after Reagan's inauguration, Undersecretary of State Walter Stoessel Jr., in testimony before the Senate Appropriations Committee, affirmed that the administration would not exceed that limit without first consulting Congress. ${ }^{25}$ That set the limit in stone and became a dominant factor in both personnel and mission planning for the duration of the war.

The U.S. military thus joined El Salvador's war with its first ground deployment in March 1981—just months after the January guerrilla "final offensive" — as a training mission armed only with sidearms, confined to safe garrisons, and admonished from any advisory or combat function.

This first deployment, loosely organized in three Special Forces MTTs, consisted of 26 "trainers," as those were the only positions available after factoring in other U.S. military personnel already in El Salvador-a preview of the meticulous character this war would have. ${ }^{26}$ With such a small force, the immediate priority was combat training almost exclusively for one unit-a thousand-man immediate reaction battalion named the Atlacatl - an occurrence that would shadow U.S. military assistance throughout the war and beyond. 


\section{Strategy and elections}

After the initial MTT, the United States did not plan any further training missions until the "Woerner Report" at the end of 1981. The Pentagon directed senior staff officer General Frederick Woerner Jr. to assess what could be done to turn the course of the war. In his report, he laid out a five-year, $\$ 300$-million program to triple ESAF ground forces. Nearly the entire plan focused on immediate combat capability. ${ }^{27}$

Strategically, force expansion intended to buy time for El Salvador's two critical elections: the election of the 1982 Constituent Assembly and the 1984 presidential election. Then, along with a constitutionally elected president, a new popularly elected government would form. ${ }^{28}$ Support and legitimacy for the new government would flourish, and the insurgency would wither.

The interim, however, was bleak. In January 1983, SOUTHCOM Commander General Wallace Nutting observed, "government forces are losing enough weapons to equip a new guerrilla company every two to four weeks." ${ }^{29}$ The U.S. Military Group (MILGP) commander at the U.S. Embassy, Colonel Joseph Stringham, described entire battalions mauled in head-to-head combat with Farabundo Martí National Liberation Front (FMLN) insurgents. ${ }^{30}$ Euphoria over the 1982 election had worn off in a milieu of government corruption and ineptitude, unabated rightist terror, and economic drift. FMLN insurgents were wrecking infrastructure nationwide.

Against this background, with the critical March 1984 presidential election only months away, U.S. Ambassador to El Salvador Thomas Pickering arranged the pivotal December 1983 demarche by Vice President George H.W. Bush to add clout to Pickering's position that the Salvadorans either get control of rightist violence or lose U.S. support. Furthermore, Bush demanded that the military guarantee the presidential election, and, in a quo to the quid, he pledged increased and sustained military aid. ${ }^{31}$

\section{Elections and advisors}

How to know the military would guarantee the election worried Pickering. Even though international observers were planned, Pickering wanted his own guarantors and proposed to SOUTHCOM Commander General Paul Gorman to detail U.S. military officers to monitor the ESAF during the elections and then to stay on in the brigades as advisors. ${ }^{32} \mathrm{~A}$ three-man OPATT would be assigned to each brigade composed of a lieutenant colonel team chief, a captain as training officer, and a military intelligence officer. ${ }^{33}$ To bring the ESAF on board with Pickering's proposal, Gorman promised intelligence and other support.

The impact opportunity of this mission was lost from the start as team members trickled in and were piecemealed to the brigades, some arriving after the election. The mission suffered further when the team chiefs were ordered out of the brigades as Salvadoran commanders made it clear they were not interested in advice. ${ }^{34}$ Without the colonels, the two remaining officers were poorly used. Although the training officers were tasked to help the Salvadorans develop training programs, they spent most of their time conducting the actual training, a wasteful under-utilization of a combat arms captain. When the six-month MTT tours for the intelligence officers ended, no replacements were requested, and Pickering's OPATT dwindled in most brigades to a lone training officer.

The presidential election was nevertheless a success and dramatically impacted the assistance program. When newly elected President Jose Napoleon Duarte promised to carry out reforms and investigate rightwing violence, support in Congress soared on the view that democracy had taken root in El Salvador. ${ }^{35}$ Congress approved the highest annual military assistance appropriation of the war in 1984 at \$197 millionmore than double the year before. In 1985, appropriations for economic aid ballooned to $\$ 434$ million.

Woerner's force expansion was nearly complete. El Salvador had the most formidable military in Central America, with a ground force of over 40,000 backed by a more modern air force refurbished after a crippling FMLN raid destroyed half its fleet in January 1982. ${ }^{36}$ The Bush effect had inspired something of 
a shakeup as moderate officers were assigned to key positions, and senior leadership publicly declared they would end abuses. ${ }^{37}$

As for the FMLN, international support flagged after the elections, and guerrilla ranks declined from combat losses, recruiting difficulties, and desertion. From hotly contested Usulután Department came an assessment describing demoralized guerrillas "drifting away in onesies and twosies" at a desertion rate higher than the brigade was capturing or killing them. ${ }^{38}$ The MILGP searched for ways to seize the initiative.

\section{OPATT revival: fielding the right teams}

These were the circumstances when the moribund OPATT concept was salvaged by the opportunity of two only tenuously related events. First, when the intelligence officers to the brigades were not replaced, the MILGP requested two Special Forces operations and intelligence sergeants from Panama to keep intelligence support alive in the two high-threat departments of San Vicente and San Miguel. They arrived within weeks, both veterans of earlier missions.

The second event came in June 1985 when a letter from U.S. Army Captain Michael A. Sheehan requested assignment to an OPATT. The fourth brigade training officer was near the end of his tour with no replacement planned, and here was an officer asking for the job. ${ }^{39}$

With Sheehan's letter in hand, the MILGP requested his assignment by name, and he arrived in September. The ease and speed of this action outside routine personnel processes were surprising. Combined with the quick deployment of the two operations and intelligence sergeants, this set in motion an initiative to give the OPATT concept one more try.

The sputter of the 1984 OPATT made getting the mission off to a solid start a priority. To do that, the MILGP exploited the discovery that it could summarily select specific officers and expedite their assignment. Officers in El Salvador proposed candidates they believed would be "right" for OPATT leadership, and the MILGP requested their assignment by name- a collegial and unorthodox pull approach in which incumbents, at least for several years, could select their successors.

To further control the process, the SOUTHCOM personnel officer suggested that the embassy declare OPATT assignments "nominative," meaning that candidates required embassy approval. In practice, that gave the MILGP the unusual prerogative to determine team chief assignments outside routine personnel management channels. Most came from a narrow field of officers from the forward-based Special Forces battalion in Panama. The selection for Marine Corps team chiefs was similar.

By the end of 1985, every brigade had a complete team on the ground. The new teams, one for each of the six brigade headquarters, were composed of three men: a major and two operations and intelligence sergeants. The one exception was the 6th Brigade, where the Marines provided the OPATT. Lacking operations and intelligence sergeants, Usulután was staffed with a major, a military intelligence lieutenant, and a gunnery sergeant.

Assignments were established as year-long ETSS tours. Team chiefs were screened to have experience and education equivalent to their advisory duties, company-level command, battalion or higher staff experience, and Spanish language fluency. ${ }^{40}$ The Special Forces sergeants brought additional capabilities—such as communications, engineering, and medical - that contributed to their counterinsurgency assistance.

The real launch of the new mission came with the noncommissioned officers who replaced the nowdeparted military intelligence lieutenants. For a good start, the MILGP requested immediate MTT deployment of 10 Special Forces operations and intelligence sergeants from Panama to fill those positions. This MTT, composed of veterans of earlier missions, arrived in June 1985, and an ESAF-wide coherent training and advisory effort surged for the first time. As the startup MTT ended, their ETSS replacements arrived. From there grew the repetitive noncommissioned officer assignments that became the backbone of the OPATTs as the same men returned year after year-a boon for a long-lasting war. 
This process for OPATT selection and assignment continued under MILGP control until Special Forces was established as a career management field in 1987. Afterwards, the process in El Salvador normalized into routine personnel administration. For the critical early period to establish the mission, however, assignments were selective in a way that the formal personnel system could not hope to replicate.

The MILGP - in consort with the SOUTHCOM personnel office, security assistance administrative offices at Fort Bragg and Fort Monroe, a committed forward-based Special Forces battalion in Panama, and an eager Marine Corps headquarters - found that it could get the right man in the right assignment and on time. Everyone involved in this process understood that manpower restrictions dictated that no position could afford less rigor.

The revived 1985 OPATT construct was essentially an improved version of the Pickering-Gorman scheme for the 1984 elections: three-man teams deployed to each of the six brigade headquarters. The ESAF traditionally consisted of 14 military departments as autonomous commands, each reporting directly to the Estado Mayor in a flat organization. Designating six of them as brigades changed little. Nevertheless, in 1985, the new OPATTs were assigned to the brigade headquarters, even though functionally, each was still just another military department. ${ }^{41}$

Part of the reason for this was that military department boundaries were the same as political department boundaries, which historically endowed department commanders with a quasi-political role. ${ }^{42}$ This feature complicated coordination between the departments because commanders found it difficult to overcome the autonomy of departmental authority and resisted coordinating operations with neighboring departments. Notably, the FMLN had no such boundaries and routinely exploited this weakness.

Force expansion presented other frustrations. For instance, immediate-reaction battalions assigned to brigade zones were under command of the Estado Mayor in San Salvador and had no obligation to coordinate with brigade commanders in whose zones they operated. The National Guard and National Police fielded battalion-size units that also operated in brigade zones and also under their own national level authorities. The MILGP never considered that these commands might fall within the OPATT mission or whether the brigades were even the right place or best use for field advisors. Their title had become Brigade OPATTs as early as 1981, and there was no consideration to use them otherwise.

The foundation of the new OPATT was thus built on decisions from years earlier with little thought to contemporary circumstances. The OPATTs, with limited direction from the embassy or any other authority, spent the rest of the war defining and expanding their role and influence on their own initiative.

\section{OPATT support to counterinsurgency}

When the 1985 OPATTs deployed, they were tasked to help develop ESAF counterinsurgency capabilities across the board. This included human rights, a concern that gave Congress pause from the beginning. Human rights observance, as the Congressional linchpin to continued U.S. aid, became an overriding edict for the OPATTs to monitor-no small task, which carried considerable risk. Their mission also included developing civil-military operations capabilities with the objective to integrate all Salvadoran and U.S. counterinsurgency capabilities into a coordinated campaign.

With the OPATTs in place, the opportunity to form a national to local coordinated U.S. counterinsurgency campaign was at its apex. Manpower was finally available and in most of the right places. Several of the jobless colonels banished from the brigades were assigned national-level civil-military operations responsibilities: one as coordinator for civic action, another for civil defense. A psychological operations advisor had been assigned to the Estado Mayor since mid-1984. These and others worked almost exclusively with agencies in the capital, with scant attention beyond the city limits. The OPATTs had arrived, but commands outside San Salvador continued to operate largely on their own initiative and with local resources. National-level resources remained distant. 


\section{Intelligence}

U.S. intelligence support was relatively advanced when the OPATTs arrived. It included C-130 signals intelligence overflights, which could detect locations of guerrilla units on the move. The 470th Military Intelligence Brigade in Panama provided analytic support and occasional short-term assignments of intelligence specialists to support the advisory teams. The Central American Joint Intelligence Task Force operated from the Pentagon to coordinate intelligence activities supporting El Salvador. At the Estado Mayor intelligence section, a U.S. intelligence advisory team worked to coordinate all of these activities. ${ }^{43}$

Central Intelligence Agency (CIA) teams of as many as four intelligence specialists set up regional intelligence centers in the brigades to expedite information gathered by brigade units to the Estado Mayor intelligence staff for analysis and regeneration as "actionable intelligence." Since the regional intelligence centers were CIA teams, they did not count against manpower limits, even though they roughly doubled U.S. intelligence support in the brigades.

Intelligence was the counterinsurgency linchpin for the OPATTs, yet it was a top-down-driven program supported by far-flung analysts, sometimes so operationally focused that it provided little immediate tactical value. The high-level, high-tech resources were important, but for all the U.S. investment in Salvadoran intelligence, the most actionable tactical intelligence typically came from capabilities developed by the OPATT operations and intelligence sergeants.

\section{Psychological operations and civic action}

Psychological operations were an important part of the strategy to influence public support to the government, but U.S. doctrine and capabilities were inadequate for the task. Early U.S. psychological operations assistance at the national level, mostly MTTs from SOUTHCOM and Fort Bragg, generally lacked continuity and direction. ${ }^{44}$ In 1984, General Gorman had assigned Major Dennis Keller, a qualified and experienced psychological operations advisor, to the ESAF Estado Mayor staff as a two-year ETSS to turn things around. ${ }^{45}$

When Keller left two years later, the Salvadorans had "the rudiments of a true organic capability to design, produce, and disseminate psychological operations campaign products." ${ }^{46}$ It was a success story soon adrift as subsequent psychological operations advisors arrived having little more qualification than brief orientations and, in the better cases, completion of Fort Bragg's six-week Psychological Operations Officer Course.

By this time, the education and experience of the Salvadoran officers heading the psychological operations staff eclipsed that of the U.S. "advisor," relegating the inexperienced advisor to providing little utility beyond funding and equipment. ${ }^{47}$

A resurgent interest in civil-military operations in 1988 prompted the MILGP to pull all related advisors under a single office to unify and coordinate civil-military assistance activities from the national to local level. As part of this initiative, the MILGP attached a liaison officer to the U.S. Agency for International Development (USAID) office in San Salvador to coordinate military activities with USAID programs. ${ }^{48}$ This evolution of organization achieved an effective level sometime in 1989, when the war was essentially over. ${ }^{49}$

Operationally, the OPATTs encouraged coordination of locally generated civic action events and psychological operations with intelligence activities. ${ }^{50}$ The symbiosis of these relationships gave advisors the bonus opportunity to fit human rights behavior into dialogue with their counterparts. In rural areas, this symbiosis was most evident when civic action followed combat operations.

Seemingly small things mattered immensely. Resources such as food distribution, soccer balls, water containers, and other enticements-including medical and dental care and haircuts-attracted people to attend the events and provided the audience for psychological operations. Intelligence operators used the events to establish relationships with local citizenry and to develop human intelligence resources. ${ }^{51}$ The 
FMLN obviously opposed these events and where the ESAF did not secure populations afterwards, local guerrillas countered with their own psychological operations. The advantage, said one advisor, was that "we could do Civic Action and they could not." 52

\section{Civil defense}

Civil defense was a program of U.S. advocacy for a nationwide rural security plan with local citizenry organized as self-defense units for their communities. The program fell into the OPATTs' portfolio because of general ESAF disinterest in it. ${ }^{53}$ U.S. involvement in El Salvador's civil defense program began with the National Campaign Plan in 1983 during which performances of civil defense units in the San Vicente Department had been encouraging. ${ }^{54}$ But responsibility for civil defense still effectively belonged to military department commanders, most of whom had little enthusiasm for it. As a result, the OPATTs tended to assume responsibilities - including training, inspecting, and certifying civil defense units- to keep the program operational and viable. ${ }^{55}$

Once the OPATTs were behind the program, active civil defense units accelerated to more than 300 nationwide. The program nevertheless suffered where commanders failed to provide weapons and equipment or refused to reinforce them when threatened or attacked. The test of U.S. commitment to civil defense came in 1987 when National Civil Defense Coordinator Lieutenant Colonel Gilberto Tijerina completed his ETSS tour and departed. For the next year and a half, the MILGP requested civil defense coordinators as six-month MTTs in the grade of captain — an enormous step backwards, as it signaled low U.S. interest for a vital program in which the ESAF had almost none.

In 1989, the MILGP reversed course and requested Major Andrew Angelacci and Sergeant Major Michael Hitcho as an ETSS team to salvage the program, but it was too late to impact the war.

\section{Interagency civil-military operations}

Where psychological operations, civic action, and civil defense were military led, USAID directed assistance for war damage restoration and economic development. USAID programs were active nationwide but rarely coordinated with either U.S. advisors or ESAF commands. Accounts of interagency cooperation reported at the national level were not evident in the brigade zones. ${ }^{56}$

National civil-military operations coordinator Hitcho observed that, by 1989, civil-military operations were "left to the departmental level and even then, there seems to be a lack of coordination and cooperation between agencies. Each agency was doing its own thing, sometimes working against each other." ${ }^{57}$ The ETSS liaison officer attached to USAID to remedy this situation had come too late to meaningfully contribute except for post-war reconstruction.

U.S. agencies were certainly committed to reconstruction and development throughout the countryside but with little focus on overarching counterinsurgency objectives. That was partly because no system for routine interagency coordination existed for programs below the national level. This disconnect left the field advisors largely outside any strategic counterinsurgency direction of other U.S. agencies. In 1986, Ambassador Edwin Corr prodded embassy agencies to coordinate their programs with brigade OPATTs, as they were the only continuous U.S. presence in most of the country outside San Salvador. ${ }^{58}$ Later that year, the OPATT team chiefs raised the same issue in a meeting with SOUTHCOM Commander General John Galvin. ${ }^{59}$ Yet the disconnect remained.

A prime example was how projects lavished on insurgent-infested communities often ignored those with dedicated pro-government civil defense units. That presented the OPATTs an inconsistency impossible to explain away. USAID declared its position in a 1987 memorandum that read, "[USAID] neither gives assistance to [communities with] Civil Defense nor refuses assistance to communities that resist forming Civil Defense units." 60 
Had the one counterinsurgency principle of interagency coordination been embraced, leverage for U.S. programs with the OPATT as the focal point in the brigade zones would have been incalculable. A flourish in psychological operations and civic action with human intelligence byproducts is easily imagined. The effect on civil defense could only have been positive. Pressure on the insurgency would have intensified, and their freedom of movement would have shriveled. The war might well have ended years earlier.

As the war wound down with the negotiated peace in 1992, the OPATTs were redirected as monitors for demobilization and peace plan compliance because they were already there, known, and generally trusted by both ESAF and FMLN leaders and had the capabilities to fill the role. The security assistance program supported that mission, too, mostly with Special Forces officers and noncommissioned officers.

\section{Lessons learned: security assistance in a counterinsurgency}

The U.S. security assistance system is a large body of programs designed to accomplish a broad range of U.S. policy objectives, discussion of which is beyond the scope of this chapter. Suffice it to say, as long as the Arms Export Control Act and the War Powers Resolution exist, military planners may need to be prepared to work within the constraints of this legislation. Regardless of the doctrinal void when El Salvador's crisis called, much was known about how to counter insurgencies, yet principles like interagency coordination were ignored and military theorem cast aside. Programs known to be critical to counterinsurgency operations were relegated to low priority. Principles known as essential to counterinsurgency were consciously disregarded.

\section{A field advisory mission should have started earlier}

Deploying advisors to ESAF field units was repeatedly considered dating back to 1979, yet nearly four years lapsed after the United States joined the war before a coherent field advisory force deployed. That was a significant opportunity lost. The intervening years saw some of the most intense fighting, when the Salvadoran government teetered and U.S. assistance policy wavered.

The ETSS as an instrument for advisory missions was well known, having been used as early as 1980 for advisors to the Estado Mayor. That same sense of priority was not accorded to field assignments where the fighting took place, right-wing terrorism ruled, and daily human rights abuses occurred along with the occasional atrocity—all crucial matters with consequences for U.S. policy objectives. ${ }^{61}$

When the United States commits to a genuinely desperate counterinsurgency campaign, knowing neither the cost nor duration, field advisors close to the action are essential to influence not only the pursuit of the war but whether U.S. objectives are even achievable. The later they are deployed and the farther they are from the action, the less effective they will be and the less known about the efficacy of policies and objectives.

\section{Stringent selection criteria for advisors was critical}

After earlier efforts failed to establish a viable field advisor mission, prospects for any future mission seemed poor. Had it not been for the MILGP initiative to resort to selecting personnel on its own and directly managing their assignments, the advisor mission would have likely plodded along until it died for lack of priority and interest. A sustained advisory program might have never existed.

The 1985 mission demonstrated how one can succeed when others fail: in a minimalist counterinsurgency strategy, the quality and dedication of people become the key assets. Middle-grade to senior ranks for both officer and noncommissioned officer were required for the OPATTs because they had the necessary education, training, and experience for field advisory duty. ${ }^{62}$ Skills that did not come with the off-the-shelf 
soldier — such as language fluency and cultural awareness - were essential, hence the reliance on the special operations community. Compromising advisor qualifications or relying on generic selection will put such a mission at grave risk.

\section{Tour length for advisors should have been longer}

How much can an advisor accomplish in a year, and would longer make a difference? For the advisors to El Salvador, planning and conduct of counterinsurgency operations presented little challenge-that was their forte. Their real challenge was influencing how their counterparts thought about small unit operations against nimble insurgents, the value of a noncommissioned officer corps, why a captured intelligence source is better than a dead guerrilla, what the military's human rights behavior and its relationship with the citizenry mean to winning the war, and more. Such subjects were the ingredients to promoting individual and institutional reform in El Salvador's case and required long-term influence. ${ }^{63}$

Continuity of effort is vital. There were about four iterations of OPATT advisors to the various brigades on one-year assignments, and none reported their jobs "done" after a year. As they finished their tours, most agonized over tour brevity relative to task magnitude. How long is long enough? Most who opined suggested that an advisor was only beginning to become effective after a year; two years would have been more realistic, and even that commitment would be meaningful only if their replacement had the background to pick up where they left off. ${ }^{64}$

Tour length, however, provokes a separate discussion about how the services regard assignment of their personnel to missions outside normal career progression patterns - or put bluntly, when career becomes more important than mission. ${ }^{65}$

\section{Commands that should have sought a stake in the advisory program often did not}

Special operations and intelligence communities were prime supporters of the advisor mission. ${ }^{66}$ The Marine Corps aggressively sought advisor assignments and deserves applause. Some commands that should have been vital players, however, were only reluctant participants. Psychological operations assistance, given the oft-cited doctrinal tenet about the importance of popular support and government legitimacy, is worth comment. El Salvador offered the psychological operations and civil affairs communities a rare opportunity for high-profile, real-world experience. Where those commands were expected to lean forward to get into the war, they leaned the other way. The low priority they assigned to El Salvador was reflected in reluctant MTT support and the difficulty in providing qualified and experienced psychological operations and civil affairs advisors. ${ }^{67}$

\section{Manpower limits narrowed U.S. influence}

The 55-man limit continues to garner praise for saving the United States from a ground combat role in El Salvador. The limit is occasionally awarded status as a counterinsurgency model. ${ }^{68}$ The brigade advisor mission, however, the largest of the security assistance programs in manpower terms, owned only 18 positions deployed throughout the ESAF. Other advisors to combat units added about another six. Such limited manpower spread advisors very thin, and much of the ESAF remained outside their influence. The immediate-reaction battalions illustrate the point: after they were trained, equipped, and deployed to the field, U.S. influence all but ended. This had consequences.

The preeminent example is the case of the Atlacatl, the first immediate-reaction battalion trained by U.S. Special Forces. In December 1981, less than a year after its activation, the Atlacatl was charged with one of the war's worst atrocities at El Mozote, a village in the country's northeast, where the battalion allegedly 
killed more than 700 civilians. ${ }^{69}$ That event laid a stigma on all the immediate-reaction battalions and, by extension, the U.S. Special Forces who trained them. ${ }^{70}$

Eight years later, during the November 1989 FMLN urban offensive, a unit assigned to the Atlacatl was credited with the Jesuit murders during the heat of the offensive. ${ }^{71}$ That singular event abruptly changed the course of the war and marked the ESAF as incorrigible after nearly a decade of U.S. effort to reform it. The question is whether U.S. military assistance can afford to train units like the immediate-reaction battalions and then not assign them advisors.

The difference with other high-risk units to which advisors were assigned makes the point. The Special Operations Group, for example, grew out of a 1982 initiative to provide the ESAF a strategic reconnaissance capability to go deep into guerrilla held areas for intelligence purposes and, importantly, to control the use of artillery and air attacks near civilian populations. ${ }^{72}$ This unit also developed specialized commando capabilities that carried considerable opportunity for abuse. ${ }^{73}$ By the end of the war, the unit's reputation for professionalism ranked among the highest in the ESAF. A hand-selected noncommissioned officer had advised the unit continuously for four years.

Another was the Special Antiterrorist Command, formed in 1984 in response to rising urban insurgent terror. This was a unit of Congress' nightmares - an organization operating in secrecy within the Treasury Police, long known for its collusion with right-wing terror groups. Sufficient reforms within the military and police, however, convinced the MILGP that such a unit could be effectively influenced by an appropriate advisor - another hand-selected noncommissioned officer who advised the unit for more than four years. These units were identified from the beginning for their important capability but also their potential for misuse, the solution for which was to assign long-term advisors to manage the risk.

\section{Advisors effectively promoted human rights objectives}

The effect that brigade advisors had on Salvadoran human rights conduct is too easily overlooked. ${ }^{74}$ Notably, data gathered by the post-war United Nations Truth Commission determined that units that had U.S. advisors assigned had a greater decline in human rights abuses than units without advisors. The study concluded that advisor impact on human rights, one of the most important U.S. objectives, was effective and positive but only where advisors were present. ${ }^{75}$

\section{Conclusion}

Observations from this case study are both encouraging and disappointing. The advisory mission to El Salvador contributed to the fundamental objective of military reform and to U.S. regional security objectives. This can be attributed to careful selection of advisors with specific qualifications at a turning point in the war. Such rigorous personnel management can help a minimalist approach to counterinsurgency succeed, but policymakers must consider what a small mission can realistically accomplish.

Political considerations that established manpower and other constraints offered little on how to organize and deploy a small advisory mission. They offered even less for how to fight an insurgency. Even so, while the litany of rules and restrictions may have been necessary to get the assistance program started, making those constraints rigidly inflexible obstructed pursuit of policy objectives and very likely prolonged the war.

The most important conclusion to be taken from this experience is the exigency to plan for an advisory mission as early as military assistance becomes an option. In El Salvador's case, the delay in getting a ground advisory mission in place was indeed a lost opportunity. The reaction to the experience of Vietnam was too severe. The Salvadorans received a small U.S. training and advisory mission that was too tightly reined. 
Security assistance will probably be a U.S. counterinsurgency option in the future for the same reasons it was in El Salvador - a politically acceptable, flexible, economical, and low-profile choice that can be tasked with a broad range of objectives from imparting basic soldier skills to promoting sensitive political objectives.

The U.S. experience in El Salvador offers considerable insight into opportunity and risk for small advisory missions, especially those for counterinsurgencies. As a practical counterinsurgency model, however, making it up as you go relies too heavily on fortuity. Quality professional talent eager for advisory duty may not be readily available or easily deployed. Commands may not be willing to commit their best and brightest on a moment's notice.

A counterinsurgency doctrine that incorporates and encourages the kind of flexibility, imagination, and independent action exhibited in the case of El Salvador-and that resolutely mandates campaign coordination down to the lowest and most remote advisor-would be more effective.

\section{Notes}

1 The OPATT was an unofficial term created in 1980 to disassociate the planned advisory mission from the term "advisor."

2 David H. Ucko, "Small Is Beautiful: El Salvador's Lessons and Non-Lessons for the Indirect Approach," War on the Rocks, May 15, 2014, https://warontherocks.com/2014/05/small-is-beautiful-el-salvadors-lessons-and-nonlessons-for-the-indirect-approach/; Steven Metz, "New Challenges and Old Concepts: Understanding 21st Century Insurgency," Parameters 37, no. 4 (2007); Alfred A. Valenzuela and Victor M. Rosello, “The War on Drugs and Terrorism: El Salvador and Colombia," Military Review 84, no. 2 (2004): 28-39.

3 John T. Correll, “The Second Coming of Counterinsurgency," Air Force Magazine, September 2013, www.airforcemag.com/article/0913counterinsurgency/.

4 Richard D. Downie, Learning From Conflict: The U.S. Military in Vietnam, El Salvador, and the Drug War (Westport, CT: Praeger, 1998), 57-59.

5 John T. Fishel and Max G. Manwaring, "The SWORD Model of Counterinsurgency: A Summary and Update," Small Wars Journal, December 20, 2008.

6 Small Wars Operational Requirements Divisions J-5 Directorate, Strategic Country Assessment El Salvador (Quarry Heights, Panama: U.S. Southern Command, 1988).

7 Abraham F. Lowenthal, ed., Exporting Democracy: The United States and Latin America (Washington, DC: Johns Hopkins University Press, 1991).

8 Steven Metz, "Counterinsurgency and American Strategy, Past and Future," World Politics Review, January 24, 2012, www.worldpoliticsreview.com/articles/11248/counterinsurgency-and-american-strategy-past-and-future.

9 Interview by Kalev I. Sepp with General Paul F. Gorman, Cardinal Point, Virginia, December 4, 1998. Sepp: "Was there any doctrine, either related to low intensity conflict, or operational doctrine, that you directly templated to your situation?" Gorman: "No, I think it was the other way around. We did it, and then we wrote about it, and then we tried to get others to adopt it . . I'm not aware of any corpus of advice that we pulled out of manuals."

10 Arms Export Control Act, 22 U.S.C. \2751 (1979).

11 War Powers Resolution, 50 U.S.C. \ 1541-1548 (1973).

12 At the time, ETSS referred to Engineering and Technical Services Support, but since engineering and technical specialists were not required for the El Salvador mission, the same acronym was used, but it was used to refer to Extended Training Services Support. The term now refers to Extended Training Services Specialists.

13 Benjamin C. Schwarz, American Counterinsurgency Doctrine and El Salvador: The Frustrations of Reform and the Illusions of Nation Building (Santa Monica: RAND, 1991).

14 Department of Economic and Social Affairs, Population Division, Department of Economic and Social Affairs, World Population Prospects Dataset (New York: United Nations, 2019), https://population.un.org/wpp/Download/Standard/ Population/.

15 Paul F. Gorman, “Operational Art in a Low Intensity Theater,” in On Operational Art, ed. Clayton R. Newell and Michael D. Krause (Washington, DC: Center of Military History, 1994), 153-170.

16 Cynthia J. Arnson, Crossroads, Congress, The President, and Central America (University Park: Pennsylvania State University Press, 1993), 41-42.

17 William M. LeoGrande, Our Own Backyard (Chapel Hill: University of North Carolina Press, 1998), 60-62. 
18 Brian J. Bosch, The Salvadoran Officer Corps and the Final Offensive of 1981 (Jefferson, NC: McFarland, 1999).

19 Arnson, Crossroads, 51.

20 LeoGrande, Our Own Backyard, 149-152.

21 Department of State correspondence from Belden Bell, deputy assistant secretary for Congressional relations to Clement J. Zablonski, chairman, Committee on Foreign Affairs, House of Representatives, March 6, 1981.

22 Ibid.

23 National Security and International Affairs Division, El Salvador Extent of Military Personnel in Country (Washington, DC: General Accounting Office, 1990).

24 National Security Council memorandum minutes of Special Coordination Committee Meeting, Subject: U.S. Policy to El Salvador, December 11, 1980.

25 Arnson, Crossroads, 64-74.

26 Ibid.

27 Frederick F. Woerner, "Report of the El Salvador Military Strategy Assistance Team (Draft)," National Security Agency Archive, September 12, 1981.

28 LeoGrande, Our Own Backyard, 21-24.

29 Nutting Papers, U.S. Army Military History Institute, Carlisle Barracks, PA, SECDEFQR, January 6, 1983.

30 Brigadier General Joseph S. Stringham interview with Colonel Charles A. Carlton, May 29, 1985, Senior Officers Oral History Program, El Salvador, Project 85-7, U.S. Army Military History Institute, 1985.

31 LeoGrande, Our Own Backyard, 230-231.

32 James Roach, e-mail to author, April 11, 2003.

33 Colonel John D. Waghelstein, interview with Colonel Charles A. Carlton, Senior Officers Oral History Program, El Salvador, Project 85-7, U.S. Army Military History Institute, 1985, 56.

34 Roach, e-mail to author.

35 Lydia Chavez, "Duarte Declared Salvador Winner with 54\% of Vote," New York Times, May 12, 1984, www. nytimes.com/1984/05/12/world/duarte-declared-salvador-winner-with-54-of-vote.html.

36 Downie, Learning from Conflict, 109; James S. Corum, “The Air War in El Salvador," Aerospace Power Journal 12, no. 2 (1998): 31-32.

37 James LeMoyne, "A Salvador Police Chief Vows an End to Abuses," New York Times, July 1, 1984, www.nytimes. com/1984/07/01/world/a-salvador-police-chief-vows-an-end-to-abuses.html.

38 Author's recollection of a report by USMC Major Jeffery Cole, team chief to the sixth brigade.

39 Captain Michael A. Sheehan, interview with Kalev Sepp, June 24, 1996.

40 Ibid.; Mark A. Meoni, “The Advisor From Vietnam to El Salvador” (master's thesis, University of Scranton, 1992), 59.

41 Bosch, Salvadoran Officer Corps, 17-22.

42 Shirley Christian, "EI Salvador's Divided Military," in El Salvador: Central America in the Cold War, ed. Marvin E. Gettleman et al. (New York: Grove Press, 1986), 94.

43 The team assigned to the Estado Mayor intelligence section typically consisted of a senior U.S. advisor and two military intelligence officers, all as ETSS.

44 John Page, A History of Psychological Operations in El Salvador: Lessons Learned and Prospects for the Future (Fort Bragg: 4th Psychological Operations Group, 1995), 24-25.

45 Ibid., 29.

46 Unidentified source paper in author's possession, "PSYOP: Major Events," no date.

47 Lieutenant Colonel Alfred E. Lunt III, interview with author, October 3, 2003.

48 Lieutenant Colonel Calvin C. Seybold, interview with author, May 17, 2003; Sergeant Major Michael Hitcho, interview with author, June 20, 2003.

49 Lunt, interview with author; Hitcho, interview with author.

50 Colonel Christopher St. John, e-mail to author, May 20, 2003. Haircuts, for instance, "were a surprise . . . even more popular than medical and dental care."

51 Chief Warrant Officer Jefferey D. Dahlby, interview with author, November 26, 2003.

52 St. John, e-mail to author.

53 Bosch, Salvadoran Officer Corps, 124-125.

54 Colonel Peter Stankovich, interview with author, May 18, 2003.

55 Tijerina, Memorandum, Civil Defense, 1987.

56 Scott W. Moore, "Gold, Not Purple: Lessons From USAID-USMILGP Cooperation in El Salvador, 1980-1982" (master's thesis, Naval Postgraduate School, 1997); Agapito De La Garza, "Memorandum, Lessons LearnedNational Plan" (1986); William C. Council, “1st BDE OPATT Report (May 89-Jun 89)” (1st BDE OPATT, 1989).

57 Sergeant Major Michael Hitcho, personal notes, no date. 


\section{El Salvador}

58 The author was present for this meeting.

59 General Galvin called this meeting to hear unfiltered field operations reports directly from OPATT team chiefs.

60 “El Salvador, The National Plan,” USAID Information Paper, 1987.

61 Meoni, “The Advisor," 145-149.

62 Meoni believed advisors must meet all of these requirements and others to be effective and that it was better not to have an advisor than have one who was unqualified.

63 Robert Thompson, Defeating, Communist Insurgency: The Lessons of Malaya and Vietnam (New York: Praeger Publishers, 1966), 155.

64 Meoni, “The Advisor,” 97-98.

65 Meoni, "The Advisor," is a well-toned discussion on the subject, concluding that the U.S. Army did a discreditable job in supporting the advisor mission to El Salvador.

66 Ibid., 166-167.

67 Page, PSYOP in El Salvador, 24-41.

68 Victor M. Rosello, “Lessons From El Salvador,” Parameters 23, no. 4 (1993): 100-108.

69 Inter-American Court of Human Rights Case of the Massacres of El Mozote and Nearby Places v. El Salvador, Judgment of October 25, 2012.

70 Lieutenant Colonel Frederick F. Ruoff, interview with author, April 23, 2003.

71 An Atlacatl unit killed six Jesuits in their residence at the University of Central America in San Salvador. See Kevin Clarke, "State Department Sanctions 13 Suspected in 1989 Slayings of Jesuits in El Salvador," America The Jesuit Review, February 21, 2020, www.americamagazine.org/politics-society/2020/02/21/ state-department-sanctions-13-suspected-1989-slaying-jesuits-el.

72 Colonel John D. Waghelstein, telephone interview with author, October 23, 2003.

73 Sergeant Maror Michael Kim, telephone interview with author, March 23, 2004.

74 Andrew J. Bacevich et al., American Military Policy in Small Wars: The Case of El Salvador (Cambridge: Pergamon Brassey's, 1988); Michael Childress, The Effectiveness of U.S. Training Efforts in Internal Defense and Development-The Cases of El Salvador and Honduras (Santa Monica: RAND, 1995), 22.

75 Chris Lukasevich, U.S. Training and Advisory Assistance to the Armed Forces of El Salvador from 1981-1991 and the Resulting Decline of Human Rights Abuses (no city: Chris Lukashevich, 2013), 22-27. 


\title{
14 \\ PLAN COLOMBIA AND THE U.S. ARMY'S 7TH SPECIAL FORCES GROUP
}

\author{
Kevin M. Higgins ${ }^{1}$
}

"If I could live my life over again, I would come back as a captain in the 7th Special Forces Group," Lieutenant General Wayne Downing said. "There is no better job in the world." Downing made these remarks in October 1991, as the two of us ran down the sand trails and through the pine forest of Fort Bragg's "MATA Mile" fitness trail. ${ }^{2}$ This is how Ranger Downing did annual performance counseling. No office chat for him. It was a 10-kilometer run at dawn. ${ }^{3}$

Downing commanded U.S. Army Special Operations Command from August 1991 to April 1993. As the second commander of the relatively new headquarters, he was responsible for all of the Army's Special Operations Forces, including the Special Forces Groups, the 75th Ranger Regiment, the 160th Special Operations Aviation Regiment, and civil affairs and psychological operations forces. ${ }^{4}$

As commander, he traveled the globe to see his units in action. He was particularly impressed by the 7th Special Forces Group and its 12-man detachments, deployed throughout Central and South America to support the "War on Drugs." The teams trained and advised the antinarcotics police in the source zone countries from where virtually all of the world's cocaine originated. The Special Forces teams had autonomy, responsibility, and a critical mission in high-threat areas. "This is where the rubber meets the road," Downing remarked as the UH-60 helicopter skimmed the treetops of the Peruvian jungle on his way to visit a 7 th Group detachment. ${ }^{5}$

This chapter recounts how the 7th Special Forces Group deployed to Latin America to train the Andean Ridge police units from 1987 to 2003. It describes the relationship of the 7th Group with U.S. Southern Command (SOUTHCOM), the Department of State, and the Drug Enforcement Administration (DEA), covering the creation of the Special Forces Tactical Analysis Teams and Joint Planning and Assistance Teams.

It then provides a detailed case study of Colombia, providing the inside story of how the 7th Group helped to organize, train, equip, and advise a new Colombian Army counterdrug brigade. In 2000, this support evolved into Plan Colombia, a \$1.3-billion program that ultimately contributed to a successful end of the 50-year war with the Revolutionary Armed Forces of Colombia (FARC). ${ }^{6}$

\section{7th Group deploys to train Andean Ridge police units}

In 1986, the U.S. State Department requested help from the Department of Defense to establish and train the Andean Ridge antinarcotics police units. These Bolivian, Peruvian, Ecuadoran, and Colombian police units would interdict cocaine and precursor chemical shipments, destroy cocaine labs, and eradicate coca 
fields. ${ }^{7}$ Attacking cocaine in the source zone was a vital pillar of President Ronald Reagan's strategy for the "War on Drugs." The White House considered source zone operations a high-impact, economy-of-force mission. In 1989, DEA Special Agent Larry Leveron explained the importance of the source zone:

We added up the cost of all the man-hours and resources that the U.S. local and federal law enforcement officers spend to interdict cocaine domestically, inside the USA. It averaged out to $\$ 16,000$ for every gram of cocaine seized. Here in Bolivia, the DEA can pay an informant $\$ 2,500$ to take the antinarcotics police to a cocaine lab or cache site. We can seize upwards of two tons of pure cocaine on a single operation. This is much easier than hunting cocaine down in the USA. The narcos split that ton up into a thousand packets and spread it over 10 counties. ${ }^{8}$

SOUTHCOM's force of choice to train the Andean Ridge police units was the 7th Group. The 7th Group's principal mission in Latin America was foreign internal defense. In the 1980s, the Group successfully advised El Salvador, Honduras, and Costa Rica in their counterinsurgency efforts against armed Marxist subversive movements. During this time, the Group had honed Spanish language capabilities, cultural awareness, and instructor skills.

At the time, some members of the United States Congress and other critics questioned the appropriateness of an elite military unit like the 7th Group training civilian police forces. During the 1970s, some Latin American military and police forces had used harsh repressive measures against their citizens. Critics did not want the United States to encourage Latin American governments to militarize their police. ${ }^{9}$

Proponents of the 7th Group option countered that this training would complement the host nation's own formal police training. The Andean Ridge antinarcotics forces were first police, trained in their country's laws and police procedures. The 7th Group training would provide the forces the additional skills they needed to be successful against armed criminals operating in remote rural areas or high-risk urban neighborhoods. ${ }^{10}$

The Group's training focused on patrolling, marksmanship, immediate-action drills, land navigation, river crossings, mountaineering, first aid, survival skills, airmobile operations, mission planning, and human rights. These subjects were not part of police training, but they were necessary for the counterdrug mission, and the expertise resided within U.S. Special Forces. The Group designed training and practical exercises to conform to the host nation police's laws, protocols, use of force, and rules of engagement.

\section{Prelude to Colombia: 7th Group a key component of counternarcotics efforts in the Andean region}

In April 1987, Captain Charles T. Cleveland, the commander of Special Forces Operational Detachment Alpha (ODA) $774,{ }^{11}$ began the first mission into the Andean Ridge. His mission was to "to train an existing Bolivian counternarcotic police force in jungle light infantry operations; build a base camp to support sustainment, training, and operations; and [make them an] effective unit" and "assist the DEA in putting pressure on the drug networks in Bolivia's main coca-growing area, the Chapare region." ${ }^{2}$

To accomplish the mission, Cleveland traveled down dirt roads deep into the Chapare coca-growing region with officers from Bolivia's Mobile Police Unit for Rural Areas, the Unidad Móvil Policial para Áreas Rurales. Cleveland pulled up to an open field and threw his rucksack down. "This is our training camp," he said. "We start tomorrow."."13

Cleveland named the 40-day course Garras de Leopardo (Claws of the Leopard) after the jungle leopard indigenous to the Chapare. ${ }^{14}$ As ODA 774 taught the first iterations of the Garras course, the U.S. State Department built the school's barracks, mess hall, classrooms, and warehouses on Cleveland's empty field. Over the next few years, the 7th Group transitioned from teaching the course to training the trainers. By 
1991, the Bolivians were running the Garras center under 7th Group mentorship. ${ }^{15}$ Today, the site, now known as Garras de Valor, is an International Training Center, boasting graduates from 13 Latin American countries. ${ }^{16}$

The Garras course made the mobile police unit the best-trained and equipped unit in Bolivia. They were an ideal strike force for the DEA intelligence-driven counternarcotics operations. Many of the 7th Group captains and their ODAs would follow in Cleveland's footsteps over the years. They would establish training centers and elite units throughout the hemisphere.

In 1989, Captain Bennet Sacolick, commander of ODA 773, and Captain Ed Reeder, commander of ODA 784, deployed to Mazamari, Peru, to train the Peruvian National Police Sinchis. The Sinchis, Latin America's only airborne police unit, operated in the jungle highlands of Junin Department. The Maoist insurgent group, Shining Path (Sendero Luminoso), controlled Junin's extensive coca cultivations. Sacolick and Reeder taught the Sinchis a series of courses modeled after Cleveland's Garras de Leopardo. The DEA worked with the Sinchis on several successful counternarcotics operations. ${ }^{17}$

At the same time, Captain Bob Closson conducted an assessment of the Colombian National Police's counternarcotics bases. Closson developed a unit training strategy and recommendations for security upgrades. He laid the groundwork for 7th Group's 30-year relationship with the Colombian Antinarcotics Police, the Jungla Comandos. By 1992, the 7th Group soldiers were deploying on 135 missions a year to 17 countries in Latin America. Half of these missions focused on developing special counternarcotics police forces.

\section{Special Forces Tactical Analysis Teams}

In Bolivia, the DEA and the 7th Group developed a successful partnership model that was later implemented in more than 10 Latin American countries. The DEA attaché in Cartagena, Colombia, best described the relationship between the DEA and the Special Forces teams: "The DEA focuses on doing good things. Special Forces focuses on doing things good." ${ }^{18}$ The DEA wanted success in the drug war, and the 7th Group sought to produce a unit capable of achieving success.

The DEA helped the host nation with intelligence, analysis, investigations, judicial arrest, and search warrants. The DEA put the "X" on the map. The 7th Group ensured that the strike force could select the best route, navigate, move in a tight formation, cross obstacles, achieve surprise, and capture (or kill, if necessary) the target. After each mission, the 7th Group trainers conducted an after-action review with their counterparts. The trainers incorporated these lessons into the next training course. The Group discovered that missions most often failed due to faulty or incomplete information in the target folders as opposed to training shortfalls.

"We can help with that," exclaimed Master Sergeant Stan Brown to the DEA team in Chapare, Bolivia, in 1989. "We have [intelligence sergeants] on our team. They are well trained in preparing target folders and analyzing information." ${ }^{19}$ Brown assigned two members of the training team to the DEA planning cell. The Special Forces assistant operations and intelligence sergeants helped the DEA construct target folders, which included imagery, coordinates, threat assessment, and terrain study. This gave the Bolivians the tools needed to plan a successful mission. As a result, mission success increased, and the DEA asked SOUTHCOM to formalize and expand this intelligence planning support to all the Andean countries.

These teams were named Tactical Analysis Teams (TATs), which were defined as "an ad hoc organization developed with the mission associated with U.S. interests with a particular country or region in mind." ${ }^{20}$ They were "the focal point of the fusion of tactical intelligence from national, theater, and local assets" and their primary mission was to funnel "intelligence support to the host government." ${ }^{21}$ In addition to training counternarcotics units, the 7th Group support expanded to include two-man TATs in more than 10 Latin American countries. 


\section{Special Forces Joint Planning and Assistance Teams}

As counternarcotics training and operational missions increased, the Military Groups - the military component of the country team at the U.S. Embassies-were soon overwhelmed. The Military Group is the liaison between the Department of Defense and the host nation. It serves as the military advisor to the U.S. ambassador and the central coordinating agency for military operations and training.

The rapid surge in counternarcotics training and support was too much for the small Military Group offices to handle, so they turned to the 7th Group for help. The Special Forces soldiers had demonstrated a mature, professional, can-do attitude in the hinterlands, so the Military Groups asked SOUTHCOM for a six-man Special Forces element to augment their staff as the Joint Planning and Assistance Team (JPAT). The JPAT would coordinate the deployments for all U.S. military service members and typically rotate every six months.

In the early 1990s, the U.S. Marine Corps launched teams to develop a riverine interdiction capability in the Andean region. The narcos built their cocaine labs along riverbanks and used small boats and canoes to move precursor chemicals and cocaine up and down the rivers. The rivers served as the roads in the undeveloped territories. Like the 7th Group, the small Marine Corps training teams created these riverine units from scratch. SOUTHCOM provided the boats, weapons, fuel, and field gear, while the U.S. Army Corps of Engineers constructed the docks and the riverine outposts.

The U.S. Navy and Coast Guard partnered with host nation naval forces to interdict maritime traffic. The narcos moved loads of more than 500 kilograms of cocaine using go-fast boats and semi-submersible craft. Two-man crews piloted these small fiberglass vessels. The go-fasts achieved speeds of more than 40 knots while maintaining a low surface profile to avoid visual or radar detection.

The U.S. Air Force helped create the Air Bridge Denial program beginning in 1995. They enhanced the host nation air force's ability to detect and interdict illegal aircraft moving coca paste from Bolivia and Peru to the Colombian cocaine refineries. Small narco planes flew drugs out of clandestine airstrips, usually at night. The U.S. Air Force deployed ground-based radar teams to remote areas in Peru, Colombia, and Venezuela. When the host nation radar operators detected an illegal track, they would launch an interceptor aircraft to force the narco plane to land. The U.S. Air Force helped upgrade the host nation interceptor planes as well as the cargo planes flying supplies out to the counternarcotics units. ${ }^{22}$

The Special Forces JPATs worked out of the Military Group offices inside the embassy. They walked all counternarcotics mission paperwork around to the U.S. country team offices for interagency clearance. They coordinated memorandums of understanding with the Ministry of Defense, visited the police academies to verify the selection and assessment processes, and assisted with the planning for counternarcotics operations. They hunted down supplies and equipment for the teams in the jungle camps, coordinated the airlift to move the loads, briefed incoming teams on force protection, and found them secure lodging in the local hotels. They acted as the eyes and ears for the special operations command component of SOUTHCOM, known as Special Operations Command South (SOCSOUTH), which commanded the mission.

Soon, the Special Forces TATs and JPATs became indispensable. They were the glue that held the U.S. Embassy efforts together. The Special Forces soldiers used their rapport-building skills to improve contacts at the highest levels of the armed forces and the police, which would pay dividends over the next 30 years.

\section{Case study: Colombia}

By 1997, the Air Bridge Denial program had degraded the air movement of cocaine base from Bolivia and Peru into Colombia. The interceptor aircraft interdicted more than 100 planes a year. Most narco planes were intercepted while offloading on clandestine airstrips, but they were also occasionally shot down while in flight. ${ }^{23}$ The narcos adapted by ramping up the coca field cultivations in Colombia, from 44,000 hectares 
in 1994 to 163,000 hectares by $2000 .{ }^{24}$ As a result, the air movement from Peru was no longer essential. The farmers in Colombia could now grow the coca, make the cocaine base, and move the product to the labs by river, road, or mule.

Growing coca in Colombia had advantages. The country had a plentiful 1.6 million hectares of land suitable for coca cultivation, far beyond world demand, which could be met with only 225,000 hectares. ${ }^{25}$ The best coca-growing areas in Colombia were also in ungoverned or under-governed spaces, far away from the Colombian security forces, who were preoccupied with the 37-year conflict against the 15,000-strong leftist FARC; the 5,000-strong National Liberation Army; and the 20,000 members of the right-wing paramilitary group, the United Self-Defense Forces of Colombia, also known as the "paramilitaries." ${ }^{26}$ The Colombian security forces had few resources and little energy remaining to counter the narcotrafficking surge.

The FARC, the National Liberation Army, and the United Self-Defense Forces seized the opportunity to extort the coca farmers in their areas of operation. They encouraged farmers to grow coca and provided the farmers with fertilizer and farm equipment. These groups also controlled the cocaine and chemical precursor shipping routes. The DEA estimated that the FARC alone was making more than $\$ 600$ million a year taxing the narcotraffickers. ${ }^{27}$ These additional funds gave the FARC the ability to double in size from 7,000 to 15,000 combatants in five years. ${ }^{28}$ Drug trafficking financed the illegal armed groups.

While centralization might have been viewed as a good business decision, Luis Moreno, the director of the U.S. State Department's Narcotics Affairs Section at Embassy Bogota, saw this as a golden opportunity to hit the narco trade head-on. "They have all their eggs in one basket," Moreno explained. "They have made it easy for us. We no longer have to fight a narcotrafficking operation dispersed over several borders. We can surge here in Colombia and hit them with a knockout punch." 29

The U.S. government lacked new foreign assistance funding, but the Defense Department and State Department creatively moved funds from other programs to Colombia. The embassy's Narcotics Affairs Section set up a second aerial fumigation spray base. The Military Group brought in more training teams for maritime, riverine, and ground interdiction.

This U.S. aid, however, was not without restrictions. The U.S. government limited assistance to Colombia for counternarcotics only. It prohibited the embassy from helping Colombia in their fight against the illegal armed groups: the FARC, the National Liberation Army, and the United Self-Defense Forces. The U.S. government did not want to go down a "slippery slope" and become locked in an internal conflict, another Vietnam. Any help the embassy provided had to be related to counternarcotics.

The U.S. government monitored the embassy for compliance. When the Colombians requested training or equipment upgrades, they had to show that more than $50 \%$ of the operational hours for that entity were for antinarcotics activities. Likewise, any intelligence that the U.S. government provided had to be related to narcotics activity. ${ }^{30}$

\section{Getting the Colombian Army into the fight}

The 180,000-strong Colombian Army was the largest component of the Colombian security forces. They were, however, the only service not supporting the counternarcotics effort. This was not unique to Colombia. None of the Andean Ridge armies were keen on supporting counternarcotics missions: counterinsurgency was their mission, while counternarcotics was viewed as a police mission. The army wanted to portray itself as the "friend of the people" and did not relish alienating farmers by eradicating their coca crops. ${ }^{31}$ This attitude, unfortunately, turned out to be short sighted. By the 1990s, the insurgent groups were using the coca trade to finance their operations, and the two activities could no longer be separated.

In 1997, the Military Group tried to open the door to the Colombian Army for counternarcotics participation. The Military Group sent 7th Group teams to train the Colombian Army's 12th and 24th brigades in the southern coca-growing departments of Caqueta and Putumayo. Because coca cultivations 
carpeted the brigades' operational areas, the embassy could make the case for the counternarcotics nexus. During patrols, the brigades often found and destroyed coca base labs and precursor chemicals.

The 7th Group teams only had limited success, because $70 \%$ of the Colombian Army were draftees on one- to two-year enlistments. It was not uncommon for enlistments to expire only days after graduating from their eight-week light infantry courses. Additionally, the small 350-man Colombian Army battalions had only three officers: the commander, one dual-hatted as the intelligence and operations officer, and one as the personnel and logistics officer. Likewise, their noncommissioned officer ranks were also thin. Thus, the 7th Group trainers found it impossible to implement a "train the trainer" concept.

On December 3, 1998, SOUTHCOM Commander General Charles Wilhelm approached General Fernando Tapias and the Colombian Joint Staff while at the Conference of Ministers of Defense of the Americas in Cartagena. "How about creating an elite Army counterdrug battalion?" Wilhelm asked. "This unit would be all professional career soldiers. It would be properly staffed." 32

"We will have to think about that," replied Tapias. The Colombian Army was still reluctant to be pulled into the counternarcotics mission, and they also worried that any U.S. government assistance to a new counterdrug battalion might come with "strings attached" and impinge on their sovereignty. ${ }^{33}$

"The FARC are getting stronger every day from the narco trade," said Wilhelm. "You can't keep fighting this conflict like business as usual. What you are doing now is not working." Tapias agreed. "I can provide some training and some non-lethal field gear," said Wilhelm. "That is all I can promise. The rest will be up to you." 34

\section{Mission planning}

With Tapias' support, SOUTHCOM set out to help build the counterdrug battalion, modeling it after a U.S. Army Ranger battalion. The battalion would include 938 professional soldiers, including a staff of 46 officers and senior noncommissioned officers. The unit would be like no other Colombian unit. SOUTHCOM wanted to start building the force by April 20, 1999, which was less than 90 days away. It was a very ambitious timeline, but Wilhelm wanted to strike while Colombian interest was still high.

SOCSOUTH tasked the 7th Group with the mission. Its deputy commander, Lieutenant Colonel Bruce Yost, led the planning effort. He had recently returned from a two-year tour in the Military Group Colombia as the Army mission chief, and he knew all the key players in the country. Yost needed every bit of his rapport-building skills to overcome the resistance he met.

The compressed timeline and the size of the project took the Colombian military and U.S. Embassy officials by surprise. Yost convinced them to agree that Tolemaida, the Colombian National Training Center, would be the ideal training location. Ultimately, the Colombians agreed to train the 938-strong counterdrug battalion in three nine-week iterations of 300 students, from April through December 1999.

To fund training, the SOCSOUTH commander canceled other missions: 7th Group's remaining 1999 training missions to the 12th and 24th brigades and two Navy SEAL deployments to Cartagena. It leveraged "free" airlift to Colombia thanks to Chief Warrant Officer Larry Plesser, the 7th Group air planner, who had forged a special relationship with Air National Guard units around the United States. Plesser acquired the sizable airlift of C-17 and C-141 cargo planes to transport the 7th Group trainers and their equipment from Fort Bragg to Colombia.

"Instead of punching holes over the skies of North Carolina for your annual pilot qualification testing, why don't you fly our men down to Colombia?" Plesser asked..$^{35}$ The Air National Guard loved the excitement of landing on new airfields and supporting an important mission, all the while fulfilling their annual training requirements. Plesser performed similar coordination for all 7th Group missions into Latin America. As a result, SOUTHCOM could afford to double the 7th Group's operational tempo from 75 to 150 missions annually. Plesser singlehandedly expanded military-to-military contacts with all 26 countries in the region. ${ }^{36}$ 
SOCSOUTH planners flew to Camp Shelby, Mississippi, in February 1999 to meet with the 7th Group commander. Colonel Ed Phillips ran a national-level special operations training exercise covering five states and involving 2,000 soldiers, sailors, and airmen. He was a meticulous planner and often had to defend his 18-month training calendar against outside encroachment, and the counterdrug battalion mission would be a major disruption. But Phillips understood the importance of the mission. "Give me two hours," said Phillips, after listening to the planning team before disappearing behind a curtain on the gymnasium stage. Soon, he emerged with the nine-month training calendar that included the rotation plan for the three Special Forces companies.

“This mission needs to be done by an entire Special Forces company, all six ODAs," said Phillips.

We will divide the initial 300 students into six 50-man groups. Each ODA will run a training committee. The student groups will do a round-robin rotation through each committee. We will have committees for weapons, medical skills, land navigation, patrolling, communications, and operations planning. For the last three weeks we will bring everyone together for full mission profile exercises. ${ }^{37}$

Phillips understood the mission, having executed similar ones in 15 Latin American countries in the past. He had commanded at every level in the Group: detachment, company, battalion, and now group. Special Forces emphasizes regional focus, and Phillips was a product of that system.

By April 1999, the 7th Group was ready to launch from Fort Bragg, but General Hugh Shelton, the chairman of the Joint Chiefs of Staff, had not yet signed the deployment order. The Joint Staff was awaiting confirmation that all Colombian Army soldiers slated for the training had been vetted under the provisions of the "Leahy Law" in the United States..$^{38}$ Under the 1997 law, Congress banned the United States from providing training or aid to a foreign military unit whose members had violated human rights. Three days prior to the proposed deployment date, the State Department completed the vetting.

Days later, the first Special Forces company landed on the 10,000-foot runway of Tolemaida, the "Fort Benning of Colombia," home of their International Lancero School, Airborne School, and National Training Center. Captain Eric Valentzas, a 7th Group veteran, was on a two-year assignment as an instructor at the Lancero School. Together, Valentzas and the JPAT paved the way for the incoming Special Forces company. They performed the advance work of coordinating the billeting, office space, firing ranges, and maneuver areas for the company and their 300 students.

The Colombian Army created the Lancero School in 1955. Captain Ralph Pucket and First Lieutenant John Galvin helped establish the school. ${ }^{39}$ Modeled after the U.S. Army Ranger School, the Colombian Army sends officers and noncommissioned officers to the 73-day course. Since 1955, there have been more than 17,000 graduates and 581 international graduates from 18 different countries, including more than 100 from the 7th Group (including this handbook's co-editor, Michael A. Sheehan). Those who wear the coveted Lancero badge establish instant bona fides in Colombia. Four of the incoming 80 trainers were Lancero graduates. ${ }^{40}$

\section{Training the counterdrug battalion and the move to Tres Esquinas}

Initially, the Tolemaida base proved an ideal learning environment. Everything went according to schedule. The students were motivated, and the Colombian Army leadership was engaged. But Lieutenant Colonel Jeff Waddell, the commander of 7th Group's 1st Battalion, had concerns about the last phase of the course. "This Tolemaida cow-pasture is like walking around a golf course," Waddell said. "We need to take the final exercise down south to the Putumayo jungle, where these boys are going to have to fight."

In response, the Colombian Air Force shuttled the students and their trainers from the pleasant meadowlands of Tolemaida to the Amazon rainforests of the Tres Esquinas Air Base, 418 kilometers away, for 
the final training exercise. The base had been carved out of the jungle during the Colombia-Peru War of 1932. It sits at the junction of two great rivers and is accessible only by air or a three-day river trip through FARC territory.

The hot, humid air blasted the Special Forces trainers as the plane's ramp opened after landing. There were no structures available to occupy; it was a bare-bones field situation. Tres Esquinas had a few Colombian Air Force office buildings, a Colombian Riverine Marine outpost, and the Colombian Joint Intelligence Center tent. The 400-man Colombian Air Force airbase defense force lived in their foxholes, scattered around the porous six-kilometer perimeter.

The Special Forces soldiers savored the challenge. Constructing the base would be time consuming and would negatively impact training, but the trainers would not let it be a distraction. This was an opportunity to show the new students how to thrive in an austere environment.

They needed to establish better security because the 48th FARC Front, and its estimated 4,000 fighters, sat just outside the base's perimeter. The area was a major coca-producing region, and the 48th Front's primary mission was to manage the extensive coca trade in the Putumayo Department. They not only taxed the coca growers, but they controlled the entire production chain. These drug funds helped sustain 15,000 FARC guerrillas. Estimates of the FARC's annual income ranged from $\$ 200$ million to $\$ 3.5$ billion. ${ }^{42}$ The coca trade accounted for the majority, but kidnapping and extortion were also significant sources of revenue, with kidnapping accounting for $\$ 300$ million at its peak. ${ }^{43}$

The 7th Group knew the FARC viewed the counterdrug battalion as a serious threat to their financial operations and concluded that a FARC attack on Tres Esquinas was imminent. The FARC could exploit a successful attack against the U.S. trainers to gain international credibility and derail U.S. government assistance efforts.

\section{Special Forces engineers and weapons sergeants strengthen the perimeter}

Waddell was not going to make it easy for the FARC. His Special Forces engineers and weapons sergeants strengthened the defenses. The Group needed barrier material to improve the perimeter and build fortifications but lacked the supplies or funds to purchase them. Major General Phillip Kensinger, commander of U.S. Army South in Panama, came to the rescue. A former 7th Group officer, Kensinger had led the mission to train and equip the Honduran Army against the Sandinistas in 1982. He caught wind of the plight of his former comrades and had excess barrier material.

After 88 years in Panama, U.S. Army South was relocating to Fort Buchanan, Puerto Rico. Kensinger made use of the Defense Department's Excess Defense Articles program. He sent kilometers of concertina and razor wire and tons of sandbags, stakes, and pickets to Tres Esquinas. Excess defense articles are Department of Defense-owned articles that are no longer needed. The United States can give this surplus equipment at no cost to foreign recipients on an "as is, where is" basis in support of U.S. national security and foreign policy objectives. ${ }^{44}$ Once again, Plesser contracted the Air National Guard to help move the material.

Special Forces engineer sergeants are demolitions experts and skilled builders, and they led the effort to harden the perimeter. They designed field fortifications that could withstand machine-gun and mortar fire. They strung wire, built bunkers, cut down trees for observation towers, and marked trench lines. It was hard work in the tropic sun, but few complained.

The Special Forces weapons sergeants established a Guard Operations Center, and a 30-man truckmobile quick reaction force. They went from fighting position to fighting position and developed range cards for crew-served weapons. They also formed an interior guard force to protect the flight line and sensitive locations inside the perimeter. They developed a patrolling plan and emplaced listening and observation posts outside the perimeter to detect and thwart FARC attacks. They ran full-blown, no-notice live fire rehearsals of the base defense plan. These exercises included mortars, the Colombian Air Force AC-47 Fantasma gunship, and the Colombian Marines Piranha patrol boats. 
The base defense has withstood the test of time. Since 1999, the FARC has failed to penetrate the perimeter despite several attempts, and Colombian Army commanders around the country have copied many of the techniques that were employed at Tres Esquinas.

\section{Special Forces medics protecting the force}

The 48th Front was a threat, but an immediate danger was already "inside the wire": insects, wildlife, and bacteria. The Special Forces medics developed and supervised the preventive medicine plan. Clouds of mosquitoes appeared at dawn and dusk, carrying dengue, malaria, and yellow fever. The Brazilian wandering spider, the most venomous arachnid in the world, roamed the base camp. ${ }^{45}$ The poison dart frog lay hidden in the rotting wood, waiting for a student patrol to pass by. The bullet ant, named for its potent sting, made victims wish they had been shot with a bullet.

The Orteguaza River flowed with surprises. The electric eel could deliver a massive electric shock, enough to stun the victim into drowning. The black caiman prowled the riverbanks, and schools of piranhas glided past the base.

Most aggravating was the tiny, biting, bloodsucking sand fly. The "no-see-ums" could penetrate the fine mesh of the mosquito nets. The sand fly carried Leishmaniasis, causing ulcers on the skin, mouth, and nose; fever; enlargement of spleen and liver; and a lower red blood cell count. As the students ran through the jungle, they brushed against poisonous plants, triggering strong allergic reactions and severe skin rashes. Thorns punctured their skin and caused infections.

The Special Forces medics provided classes on the native species. They swept the camp to eradicate likely hiding spots, standing water, and breeding areas. They treated the bed nets with insecticide and distributed anti-malarial pills. Men shook out their clothes in the morning and kept their sleeves rolled down and hats on. The medics forced the men to drink water as they acclimated to the humidity and heat.

There was also the invisible enemy: the deadly bacteria that transmit giardia, diphtheria, typhoid fever, cholera, and dysentery. The medics erected burn-out latrines, urinal pipes, hand-washing stations, field showers, and water purification systems. Good personal hygiene would reduce the infestation of body lice and mites. It was a point of pride for the medics to keep the non-battle injury rate to zero. The medics supervised the kitchen to identify spoiled or undercooked food, and they treated the river water with their reverse osmosis water purifiers. They moved garbage and rubbish to a landfill outside the camp.

The medics and the counterdrug battalion also ran a medical civic action in the nearby village of Solano. This was a common 7th Group practice in Latin America. ${ }^{46}$ They would win the goodwill of the people, learn about the local attitudes, and possibly gain valuable information from the satisfied villagers.

In its first three days, the civic action saw more than 800 patients. The medics performed minor surgeries, optometric evaluations, pediatrics, and health screening referrals. For the next 20-plus years, the counterdrug battalion would be operating in similar inhospitable environments, and the Special Forces medics taught them how to stay healthy.

\section{The formation of Plan Colombia}

Back in Bogota, Colombian President Andres Pastrana was meeting with the "big four": General Barry McCaffrey, the director of the Office of National Drug Control Policy; Brian Sheridan, assistant secretary of defense for special operations and low-intensity conflict; General Wilhelm, SOUTHCOM commander; and Rand Beers, assistant secretary of state for international narcotics and law enforcement affairs. ${ }^{47}$

Pastrana lamented that his daring peace overture to the FARC was proving disastrous. A year earlier, Pastrana had created a 42,000-square-kilometer demilitarized zone for negotiations to bring an end to the 
conflict, but the FARC did not honor the agreement and instead used the sanctuary to refit and rearm. The FARC's ranks swelled to $15,000 .^{48}$ In the previous year, there had been more than 2,800 kidnappings, ${ }^{49} 176$ police station attacks, ${ }^{50} 1.8$ million people displaced, ${ }^{51}$ and the cocaine trade had erupted. ${ }^{52}$

Pastrana proposed a comprehensive "Plan Colombia" aid package. He needed increased U.S. support to stabilize the situation. His integrated strategy would secure help for counternarcotics projects, bolster economic development, strengthen the government's presence in outlying areas, and increase humanitarian aid.

The "big four" led the U.S. interagency effort to promote Plan Colombia to President Bill Clinton and the U.S. Congress. By limiting the plan to counternarcotics, they alleviated concern that the United States would get pulled into Colombia's internal conflicts. The proposal included reinforcing all ongoing counternarcotics programs: Riverine, Air Bridge Denial, Maritime, Aerial Eradication, Antinarcotics Police, and Alternative Development.

The Plan Colombia program would bolster the new and heretofore unfunded counterdrug battalion. The "big four" flew to Tres Esquinas to consult with the 7th Group trainers and to determine what kind of support the battalion needed. As Wilhelm landed, the students had just returned from a three-day field exercise to burn three coca base labs. They had walked day and night through dense jungle for five kilometers. While a short distance on the map, it was a grueling walk in real life.

Three coca base labs were not much to show for three days of work, when considering there were an estimated 10,000 base labs and 150 cocaine labs in Colombia. At this rate, the battalion would not make a dent in the drug supply. Air mobility was the answer. It was prescient that Waddell chose to move the training to the dense jungle. There, the government visitors got a clear sense of the challenges facing the Colombians. Thus, indirectly, the 7th Group helped shape Plan Colombia.

Senator John McCain believed in Plan Colombia and visited the training in Tres Esquinas. "Do we need more than one [counterdrug] battalion? If so, how many?" McCain asked. "How about a [counterdrug] brigade? Three battalions? Let's not nickel and dime this. The Colombians need our help. Let's go in hard and make a difference."

"How about air mobility?" inquired McCain. "How many Blackhawks would it take to move this [counterdrug] brigade around to get the job done?" The Military Group aviation advisor quickly responded, "30 Blackhawks, sir." He already knew the answer and was hoping to be asked. ${ }^{53}$

\section{Plan Colombia officially begins}

President Clinton signed Plan Colombia in July 2000. It was a $\$ 1.3$-billion program ${ }^{54}$ that would exceed $\$ 7$ billion over the next decade..$^{55}$ The plan aimed at fighting the illicit drug trade, increasing the rule of law, protecting human rights, expanding economic development, and instituting judicial reform. The cornerstone of Plan Colombia was the counterdrug brigade and the Army aviation brigade. Murray's "30 Blackhawks" would ultimately become 72 helicopters. ${ }^{56}$

The first counterdrug battalion became operational on December 15, 1999, and the next two in 2000 and 2001. The counterdrug brigade headquarters was activated on December 8, 2000. The brigade focused its operations in the departments of Putumayo, Caquetá, and Nariño, all centers for coca production. With the benefit of air mobility, the brigade inflicted casualties on guerrilla forces and disrupted coca harvesting and processing. The brigade worked with the National Police to secure coca-producing areas for spraying as part of the aerial eradication program, dramatically reducing ground fire incidents.

The brigade strengthened the Colombian government's ability to extend its authority throughout Colombia and played a key role in attacking the sources of insecurity in Colombia in the remote rural areas. The brigade became the "force of choice" for the government of Colombia to capture high-value targets, such as narcotrafficking and criminal organization leadership. 


\section{7th Group and the Colombian National Police}

In addition to the Colombian Army Counterdrug Brigade, the 7th Group worked closely with the National Police. After building the counterdrug brigade, the 7th Group modified its footprint in Colombia to four ODAs - two working with the National Police and two with the Army-and expanded the JPAT into a 15-man Special Forces Operational Detachment Bravo, led by a Special Forces company commander, that formed an advanced operations base in Bogota. The advanced operations base controlled the team missions and interfaced with the Military Group, SOCSOUTH, the Embassy's Narcotics Affairs Section, and the Colombian Army and National Police.

Since 1989, an ODA had been assigned to train and assist the National Police's elite Jungla Comandos. Under Plan Colombia, the Junglas would expand from one company to four, a total of 600 men. The Narcotics Affairs Section provided an annual budget of $\$ 5$ million, and the ODA supervised the training of the Jungla training cadre and the three Jungla airmobile companies. The Junglas' primary missions were the destruction of cocaine labs and the capture of the narcotraffickers. The Jungla operations relied heavily on police aviation, which enabled them to reach their remote and inaccessible targets. The Junglas seized over 50 metric tons of cocaine and destroyed hundreds of laboratories annually. ${ }^{57}$

The ODA helped the Colombian government establish a police presence in the rural areas. Over the course of the decades-long conflict, the National Police had abandoned many towns in the remote areas due to FARC attacks. The FARC subsequently assassinated mayors, impressed minors into their ranks, kidnapped for ransom, extorted business owners, and forced farmers to grow coca. Civilians often fled to the safety of the urban areas.

In April 2002, President Alvaro Uribe directed that Colombia's security forces reestablish a police presence in the 158 unmanned municipalities (of the country's 1,098 municipalities). The Narcotics Affairs Section Bogota provided $\$ 1.5$ million to equip each squadron, and the 7 th Group trainers helped design and train the 10,000-man rural police force, the Carabinero Mobile Squadrons. These Mobile Squadrons were trained to operate in high-threat areas and included civil affairs, agricultural, and veterinarian officers to interface with the local population.

From April 2003 through September 2004, the National Police installed detachments, ranging from 45 to 250 police, in the 158 unmanned municipalities. The simultaneous deployment of the Carabinero Squadrons and Municipal Police detachments provided a fine net of security over Colombia's countryside. The FARC attacks, kidnappings, extortion, and narcotrafficking all drastically dropped. Mayors and displaced civilians returned to the towns, and nongovernmental organizations and U.S. Agency for International Development workers now operate safely in many of these zones.

\section{Conclusion}

On November 30, 2016, the Colombian government ratified a peace agreement with the FARC. ${ }^{5}$ With a relatively small footprint, the 7 th Group trainers made a significant contribution to ending the 50 -year conflict. Most notably, the 7th Group-trained counterdrug brigade and the Antinarcotics Police Jungla Comandos captured (or killed) hundreds of FARC rebels, seized hundreds of tons of cocaine, and dismantled thousands of processing laboratories, which severely disrupted narcotrafficking organizations and drove the FARC to the bargaining table.

But the groundwork was laid more than a decade prior, starting with Captain Cleveland's first mission in Bolivia in 1987. This long-term investment provided the 7th Special Forces Group with the language proficiency, cultural skills, expertise, and rapport to both shape and execute Plan Colombia years later. The Special Forces trainers taught the fieldcraft skills that the Colombians needed to make high-risk arrests of heavily armed criminal elements operating in difficult terrain. 
The Special Forces trainers shared their hard-earned experiences in counternarcotics operations in the Andean Region with the Colombian security forces. They showed devotion, patience, and attention to detail in forming the leaders. They were superb role models. The 7th Group training program in Colombia is an example of how a long-term yet modest investment can have outsized results and the wisdom of investing in partner nations before crises erupt.

\section{Notes}

1 Kevin Higgins served as the Military Group commander, U.S. Embassy Bogota, from 1999-2001, and helped design and execute Plan Colombia.

2 The Military Assistance Training Advisor course, established in the 1960s at Fort Bragg, included the "MATA mile," a circuit training course in the training area at Fort Bragg. Although the course ceased to exist decades ago, the fitness trail is still referred to as the MATA mile.

3 Author served as Wayne Downing's deputy inspector general for inspections from 1990-1992.

4 Special Operations Command, ARSOF Fact Book (Fort Bragg: U.S. Army, no date).

5 Author recollection of the 1995 flight.

6 Rand Beers, "Plan Colombia Is Well Worth U.S. Support,” Boston Globe, July 9, 2001.

7 White House, National Drug Control Strategy: Progress on the War on Drugs, 1989-1992 (Washington, DC: White House, 1993) 27-28.

8 Author recollection of story frequently told by Leveron.

9 Author experience based on Congressional delegations, Congressional staff delegations, and journalist visits.

10 Ibid.

11 A detachment, or "A Team," consists of 12 Special Forces soldiers or "Green Berets": The commander (an officer), an assistant detachment commander (a warrant officer), a team sergeant, an intelligence sergeant, two weapon sergeants, two engineering sergeants, two communications sergeants, and two medical sergeants.

12 Charles Cleveland, The American Way of Irregular War: An Analytical Memoir (Santa Monica: RAND), 31-32.

13 Author recollection of story recounted by Master Sergeant Stan Brown in August 1989.

14 The course was renamed Garras de Valor, or Claws of Valor, in 1990. See www.felcn.gob.bo/CEIAGAVA/QuienesSomos.aspx.

15 Author supervised the transition.

16 Guillermo Bullaín Iñiguez, " “Claws of Valor' in the Jungle," Correo del Sur, October 10, 2016.

17 Author visited Sacolick at the Sinchis camp in 1989.

18 Author recollection of conversation with DEA agent in 1989.

19 Author recollection of conversation with Stan Brown in Bolivia in 1989.

20 Army Intelligence Center, Student Handbook (Fort Huachuca: U.S. Army Intelligence Center, 1995).

21 Ibid.

22 Matthew Bates, "U.S., Colombian Governments Work to Deter Drug Trafficking," Air Force Print News, September 21, 2016, www.af.mil/News/Article-Display/Article/129685/us-colombian-governments-work-toto-deter-drug-trafficking/.

23 U.S. Government Accountability Office, Air Bridge Denial Program in Colombia Has Implemented New Safeguards, but Its Effect on Drug Trafficking Is Not Clear (Washington, DC: U.S. Government Accountability Office, 2005).

24 Office on Drugs and Crime, Colombia: Coca Survey for December 2002 (New York: United Nations, 2003), 3.

25 "Colombia-Arable Acres," Trading Economics, accessed October 25, 2020, https://tradingeconomics.com/colom bia/arable-land-hectares-wb-data.html; Office on Drugs and Crime, World Drug Report 2010 (Washington, DC: United Nations, 2011), 66.

26 These are widely accepted estimates of each group's size.

27 “The World's 10 Richest Terrorist Organizations," Forbes, December 12, 2014, www.forbes.com/sites/forbes international/2014/12/12/the-worlds-10-richest-terrorist-organizations/.

28 Alfredo Rangel Suárez, Colombia: guerra en el fin de siglo (Bogotá: Tercer Mundo, 1998), 12.

29 Author recollection of conversations with Luis Moreno.

30 Author experience as Military Group commander from 1999-2001.

31 Joseph Treaster et al., "Battle Against Cocaine Traffic Is Languishing in South America," New York Times, January 1, 1990, www.nytimes.com/1990/01/01/world/faltering-drug-war-flow-latin-american-special-report-battle-againstcocaine.html.

32 Author recollection of meeting. 
33 Ibid.

34 Ibid.

35 Author recollection of conversation with Larry Plesser.

36 SOUTHCOM is now responsible for 31 countries. See "Area of Responsibility," U.S. Southern Command, accessed September 16, 2020, www.southcom.mil/About/Area-of-Responsibility.

37 Author recollection of event.

38 Bureau of Democracy, Human Rights, and Labor, "Leahy Law Fact Sheet," U.S. Department of State, January 22, 2019.

39 John Galvin, Fighting the Cold War, A Soldier's Memoir (Lexington: University Press of Kentucky, 2015), 63-83.

40 Charles Briscoe, "Colombian Lancero School Roots," Veritas 2, no. 4 (2006): 30-37.

41 Author recollection of conversation with Jeff Waddell.

42 Mimi Yagoub, "What the FARC's Elusive Finances Mean for Peace," InSight Crime, April 20, 2016, www.insightcrime.org/news/analysis/what-the-farc-s-elusive-finances-mean-for-peace/.

43 "The FARC's Finances: Unfunny Money," The Economist, April 14, 2016, www.economist.com/the-americas/ 2016/04/14/unfunny-money; “The FAR C's Riches: Up to \$580 Million in Annual Income,” InSight Crime, September 16, 2017, www.insightcrime.org/news/analysis/farc-riches-yearly-income-up-to-580-million/.

44 “Excess Defense Articles (EDA)," Defense Security Cooperation Agency, accessed September 16, 2020, www.dsca.mil/ programs/excess-defense-articles-eda.

45 Tim MacWelch, "The 10 Most Dangerous Spiders in the World," Outdoor Life, November 11, 2019, www.out doorlife.com/photos/gallery/survival/2011/10/10-most-dangerous-spiders-world/.

46 Steve Balestrieri, "Civic Action Projects Very Important in Special Operations Missions," SOFREP, August 1, 2017, https://sofrep.com/specialoperations/civic-action-projects-important-special-operations-missions/.

47 Author helped coordinate this meeting.

48 Suárez, Colombia, 12.

49 U.S. Bureau of Citizenship and Immigration, Colombia: Kidnapping and Extortion by Armed Groups in Urban and Suburban Areas (Washington, DC: U.S. Bureau of Citizenship and Immigration, 2000).

50 "Cómo va la guerra," Cambio, June 19-26, 2000.

51 Francis Deng, Internal Displacement in Colombia (Washington, DC: Brookings, 2000).

52 "Cocaine Production in Colombia Is at Record Highs," The Economist, July 6, 2019, www.economist.com/ the-americas/2019/07/06/cocaine-production-in-colombia-is-at-historic-highs.

53 Senator John McCain visited Colombia three times when the author was the Military Group commander.

54 Marc Lacey, "Clinton Defends the Outlay of \$1.3 Billion to Colombia," New York Times, August 24, 2000, www. nytimes.com/2000/08/24/world/clinton-defends-the-outlay-of-1.3-billion-to-colombia.html.

55 Rafael Romo, "Plan Colombia Revisited: Mixed Results for US-Anti-Drug Initiative," CNN, January 17, 2011, https://edition.cnn.com/2011/WORLD/americas/01/17/colombia.us.drugs/.

56 U.S. Government Accountability Office, Drug Reduction Goals Were Not Fully Met, but Security Has Improved (Washington, DC: U.S. Government Accountability Office, 2008), 29.

57 Author experience; "Run Through the Jungle," Small Wars Journal, November 22, 2011, https://smallwarsjournal. $\mathrm{com} / \mathrm{blog} /$ run-through-the-jungle-colombia's-jungla-commandos.

58 Nicholas Casey, "Colombia's Congress Approves Peace Accord With FARC," New York Times, November 30, 2016, www.nytimes.com/2016/11/30/world/americas/colombia-farc-accord-juan-manuel-santos.html. 
15

\title{
THE STORY OF THE U.S. ROLE IN THE KILLING OF PABLO ESCOBAR
}

\author{
Mark Bowden
}

American military interventions overseas frequently have the inadvertent side effect of mobilizing antiAmerican sentiment. In Vietnam, Somalia, Nicaragua, Afghanistan, Iraq, and elsewhere, the presence of uniformed American soldiers has energized propagandists who portrayed the American effort-including humanitarian missions like the one in Somalia in the early 1990s - as imperialist, an effort to impose Western values or American rule. In some instances, this blowback can severely undermine and even defeat U.S. objectives.

As a result, it is often preferable for interventions to remain covert, even if they are successful. The killing of Colombian drug kingpin Pablo Escobar in 1993 offers a good example of both the virtues and hazards of working undercover with indigenous foreign forces.

This chapter provides background on Pablo Escobar and his Medellin Cartel, including how Escobar achieved notoriety and power in Colombia. It then details Centra Spike, a U.S. Army signals intelligence unit that assisted the National Police of Colombia in finding Escobar and other Colombian drug lords. Although American assistance eventually led to the deaths of Escobar and other drug kingpins, it raised a number of legal and ethical challenges that are discussed in this chapter.

\section{Pablo Escobar and the Colombian drug trade}

During the 1970s and early 1980s, there was an increasing flow of cocaine from Colombia to the United States. A sizeable portion of an American generation reared on smoking dope and dropping acid had matured with an appetite for "uppers" and cocaine, which briefly became fashionable with young white professionals.

Although it was illegal, many considered "coke" harmless fun. A 1981 Time Magazine cover-a far more significant platform at the time than now-featured a martini glass filled with the white powder. ${ }^{1}$ The Time Magazine story sounded all the right alarms about the drug's addictive properties, but it also described coke as "an emblem of wealth and status" and "the all-American drug." Beginning in 1984, the popular television series Miami Vice outfitted law enforcement battles with drug traffickers with sleek speedboats and, stylizing the violence, draped its settings and characters in shades of cool pastel, glamorizing the growing illicit enterprise.

Along with Colombia's other rich traffickers, Pablo Escobar, head of the Medellin Cartel, had become a person of interest to U.S. authorities during the Ronald Reagan administration. Escobar was a celebrated figure in Colombia, which had at best an ambivalent attitude toward drug trafficking. No matter 
how much the U.S. government wanted to stop it, cocaine had been a tremendous boon to Colombia's economy. The tide of American dollars had employed thousands, enriched whole communities, and lifted many to positions of power.

This growth of opportunity weighed heavily against the violence of narco-traffickers, who frequently warred against each other and the police. Escobar's policy of plato o plamo (silver or lead) either frightened or "bought" many police officers and judges. ${ }^{3}$ Authorities largely tolerated his illicit business. His infamy, wealth, and status grew. At his cartel's height, Escobar would be ranked as the seventh richest man in the world by Forbes. ${ }^{4}$

Escobar cultivated popular support in Medellin, a major Colombian city, by building housing for the poor and investing in soccer clubs and stadiums. These efforts, along with his personal charm, led to his election first to the city's governing council and then as an alternate to the Camara de Representantes (House of Representatives of Colombia). ${ }^{5}$ Escobar was just getting started. He had ambitions to be president and to turn Colombia into a narco state.

Yet then came crack, cocaine's cheaper, street version, which triggered an epidemic of addiction, violence, and crime in the United States. The drug lost its cool and became a serious problem. In April 1983, U.S. Ambassador to Colombia Lewis Tambs made curbing cocaine trafficking his number-one priority, and American pressure started to change the climate in Bogota. ${ }^{6}$ When Representative Pablo Escobar tried to take his seat in El Congreso (Congress of Colombia), he was publicly confronted by its leaders, called out as a thug, and effectively chased from its halls. ${ }^{7}$ Insulted and outcast, Escobar was from that day forward at war with the state.

Although the government of Colombia was now officially committed to bringing Escobar to justice, it was not yet ready to invite its American allies into the fight. The country was reluctant to concede that it needed American help to police its own country, so Americans were mostly on the sidelines during the bloody war that raged in the 1980s. During this war, Escobar and his allies killed politicians, judges, journalists, and others who criticized him, which contributed to Medellin becoming one of the most violent cities in the world at the time.

In 1989, Escobar's men assassinated Luis Galan, the front-runner in the Colombian presidential race (and an outspoken enemy of the narcos). ${ }^{8}$ Then, in a failed attempt to kill Galan's successor, Cesar Gaviria, they downed an Avianca airliner, killing 110 people. ${ }^{9}$ Gaviria had been warned and skipped the flight. $\mathrm{He}$ was subsequently elected president. ${ }^{10}$ Bombing the plane was not even the worst of Escobar's atrocities during those bloody years, but it did give the U.S. government the opening it needed to step directly into the fight.

The downing of the Avianca flight came a year after the terrorist attack on Pan Am Flight 103 over Lockerbie, Scotland. In the wake of the Pan Am attack, the United States and other world powers elevated threats to air travel as a primary concern. Despite the importance of international air travel, it remained vulnerable to terrorism. The global counterterrorism community prioritized deterring and punishing any actor who would target commercial airliners.

Two Americans were among those killed on the Avianca flight. As a result, the George H.W. Bush administration viewed Pablo Escobar, José Rodríguez Gacha, and other cartel leaders as direct threats to U.S. citizens. Weeks after the Avianca bombing, President Bush released an opinion by the U.S. Justice Department's Office of Legal Counsel concluding that it would not violate the Posse Comitatus Act for the U.S. military to be employed against criminal suspects overseas. ${ }^{11}$ From the perspective of the Bush administration, the narcos could now be legally killed.

The following year, in 1990, worries about the Medellin Cartel grew even greater when some of Escobar's men attempted to buy 120 Stinger anti-aircraft missiles and other military hardware in Florida. As stated by the Washington Post at the time,

The two Colombian nationals, one allegedly associated with cartel chief Pablo Escobar, were charged with offering undercover agents more than $\$ 1$ million in cash in exchange for Stingers, 
M-16 automatic rifles, night-vision goggles and other weaponry that was to be stolen from U.S. military bases. ${ }^{12}$

Mindful of Executive Orders dating back to 1976 prohibiting the U.S. government from assassinating foreign citizens, President Bush ordered a clarification, which was drafted by the Defense Department counsel:

[The Order's] intent was not to limit lawful self defense options against legitimate threats to the national security of the United States or individual U.S. citizens. Acting consistent with the Charter of the United Nations, a decision by the president to employ clandestine, low visibility or overt military force would not constitute assassination if the U.S. military forces were employed against the combatant forces of another nation, a guerrilla force, or a terrorist or other organization whose actions pose a threat to the security of the United States. ${ }^{13}$

The U.S. military could now target Escobar and other Colombian drug lords. It still had to work with the government of Colombia, however, which in 1989 held a dim view of the American military operating within its borders. Newly elected President Gaviria nevertheless allowed a covert U.S. Army signals intelligence unit to help Colombian police track the narcos down. It was code-named Centra Spike.

\section{Centra Spike}

Centra Spike's primary purpose was to find people, although it was designed to offer an array of support intelligence. By eavesdropping on radio and telephone conversations from the air, Centra Spike's members could pinpoint the origin of a radio or cell phone call within a few hundred meters in seconds. It was incredibly accurate.

As described in this author's book Killing Pablo:

What was more remarkable was the electronic package now used to accomplish that feat. Instead of triangulating from three receivers on the ground, they did it from one small aircraft. The airborne equipment substituted the three separate ground locations by taking readings from different points along the plane's flight path. As soon as a target signal was received, the pilot would begin flying an arc around it. Using computers to do precise, instantaneous calculations, they were able to begin triangulating off points in that arc within seconds. If the aircraft had time to complete a half circle around the signal, the location of its origin would be known to within two hundred meters. This could be done regardless of weather conditions or preventative measures taken by targets on the ground. Even a coded radio signal could not disguise its point of origin. ${ }^{14}$

President Gaviria had recruited Colonel Hugo Martinez to head the Colombian National Police's Bloque de busqueda (Search Bloc), a special unit devoted to finding, arresting, or killing the country's top narcos. ${ }^{15}$ The problem, of course, was finding them. Escobar had nearly unlimited resources, and he also had many friends in the country. Many Colombians perceived him as a Robin Hood figure, given his financial spending in his home city to win support during his election campaigns.

Escobar had also cloaked his cause in the Colombian flag, accusing President Gaviria and Colonel Martinez of selling out to the United States. He turned the issue of extradition into a nationalist cause. Aware that the Colombian judiciary had been intimidated and corrupted, Washington pressed for top narcos to be flown to the United States for trial and imprisonment. Escobar rightly saw extradition as the end of the line for him, so he rallied public support behind banning the practice, which he characterized as an insult 
to Colombia's sovereignty. The argument was popular enough that some Colombians helped hide Escobar or tipped him off when the Search Bloc planned a raid.

The advantage of Centra Spike was that the unit's presence was all but invisible, and its capabilities generally unknown. Additionally, Centra Spike's eavesdropping process was not what Colombians might expect from a state-of-the-art American listening operation. As explained in Killing Pablo,

Anyone looking for America's most sophisticated eavesdropping equipment would be watching for something high-flying and fancy, something with great bulbous features on the top or bottom, probably bristling with antennae. They wouldn't be searching for two perfectly ordinary-looking Beechcraft, an older model 300 and a newer $350 .{ }^{16}$

On both the inside and outside of the Beechcraft, they appeared as standard two-propeller commercial planes, no different from what charter services or major companies would use to transport their executives. ${ }^{17}$ Transport via aircraft was common in a country such as Colombia, which had many unreliable mountain roads.

The Beechcraft, of course, were not standard. They were $\$ 50$-million spy planes outfitted with sophisticated, state-of-the-art electronic eavesdropping and direction-locating equipment. ${ }^{18}$ As stated in Killing Pablo,

If someone looked very closely - for instance, with a tape measure - they would discover the Beechcrafts' wing-spans to be about six inches longer than that of the normal models, because the plane's two main eavesdropping antennae were installed inside. Five more antennae could be lowered from the belly of the plane once it was in flight. Inside, until they took off, the planes looked like standard models. Centra Spike's operators would board carrying laptop computers, and set up for listening only after the plane had reached an altitude of twenty to twenty-five thousand feet. Then antennae would be lowered, panels folded down from the inner walls, and the computers plugged into the plane's mainframe and power center. The two operators wore headsets with earphones, one in each ear, so they could monitor four frequencies simultaneously. The computer screens before them displayed graphically the plane's position and the estimated position of the signals they locked on to. Since the plane flew so high and could listen through cloud cover, there was no tip-off below. ${ }^{19}$

Another incredible capability of Centra Spike was that the team could power on a cell phone remotely, provided that the battery was left in the phone. ${ }^{20}$ The phone could be activated to emit a low-intensity signal, enough for the unit to acquire its general location, without activating the phone's lights or sound. Centra Spike operators would generally power on a phone when the target was likely sleeping, then position the aircraft into position to monitor any phone calls the target might make when they awoke.

Over the early months of 1990, Centra Spike armed Colonel Martinez with critical information concerning the whereabouts of the narco kingpins and also the structure of their organizations. Charting the pattern of Medellin Cartel phone calls, the unit could draw maps of the organization's inner workings, its links not only with Escobar's inner circle and criminal enterprises but with the network of bankers, accountants, lawyers, and other "civilian" associates who managed its investments, accounts, and payrolls.

It became increasingly hazardous, legally speaking, for anyone supporting Escobar to conceal their activities. By the end of 1990, Escobar's once-comfortable life had turned into a nightmare. He was on the run constantly, often escaping minutes before the Search Bloc swept through his latest hideout. Increasingly desperate, Escobar found a new way to pressure President Gaviria. Colombian politics had always been dominated by an incestuous group of affluent families centered in Bogota. He began kidnapping the sons and daughters of some of the nation's preeminent families, threatening to kill them-at times making good on the threat. ${ }^{21}$ 
He demanded that Gaviria back off the pursuit and promise to never extradite him to the United States and in return offered to negotiate a compromise. Under tremendous pressure from some of his most powerful friends, and desperate to lower the level of violence in Colombia, Gaviria finally ignored the entreaties of U.S. Ambassador Tambs and struck a deal with Escobar in 1991.22

In return for a promise that he would not be extradited, Escobar agreed to surrender. ${ }^{23}$ The murders and kidnappings would cease. He would plead guilty to one relatively minor crime-acting as a middleman in a single drug deal — and serve a short term in a prison on a hilltop outside Medellin that Escobar had built himself and for which he had hired all of the guards. ${ }^{24}$ The Colombian National Police were not allowed to even approach this sanctuary, which Escobar had furnished with every luxury.

As infuriating as the deal was, Gaviria hoped that his prosecutors would be able to find new charges against Escobar that would eventually lock him up in a real prison permanently. It did not play out that way. Escobar continued to manage his business from his cushy jail cell. He frequently made trips into Medellin, even appearing at soccer matches and waving to the crowd.

For the most part, Colombian authorities looked the other way, but when Escobar began executing members of his organization inside the prison whom he suspected of stealing from him, it was too much for even Gaviria to stomach. As authorities moved in to arrest Escobar and transfer him to a real prison in July 1992, he escaped and resumed his life on the run. ${ }^{25}$

Having tried and failed to strike a deal with Escobar, Gaviria now abandoned his concerns about Colombian sovereignty. Centra Spike returned to the country and resumed hunting. This time it came with a squadron of Delta Force Special Operations Forces.

\section{U.S. Special Operations Forces join Centra Spike}

The melding of this American special operations unit and the Colombian National Police did not go smoothly at first. Due to some cultural missteps, the Delta role was pared down. Left behind were a small number of Delta personnel who could speak Spanish fluently and who were better suited temperamentally to manage the tricky partnership. ${ }^{26}$

Colonel Martinez and his men had suffered a great deal in their pursuit of Escobar, and they resented the idea that a crack American military unit had arrived to show them how to do their job more effectively. ${ }^{27}$ Yet they were willing to concede that catching Escobar, who always seemed to stay one step ahead, would require not only Centra Spike's magic but a mobile strike force capable of reacting swiftly and securely when new targeting information arrived. This was Delta's specialty.

In short order, Escobar's world got smaller. Delta worked closely with the Search Bloc, improving its reaction time and tactics. ${ }^{28}$ Steered in part by intelligence from Centra Spike, the Search Bloc kept closing the ring around Escobar. Nevertheless, even as cooperation improved, problems arose. It is hard to tie the hands of skilled soldiers engaged in dangerous work thousands of kilometers from home. In theory, American personnel were barred from participating in raids, but the line between advising and acting began to blur.

The Search Bloc's methods were also problematic. In June 1990, the Search Bloc killed John Arías, one of Escobar's most trusted sicario (hitman) leaders. ${ }^{29}$ One month later, the Search Bloc captured Hernan Henao, Escobar's brother-in-law and a trusted associate. ${ }^{30}$ Then, on August 9, they killed Escobar's longtime partner in crime Gustavo Gaviria, his cousin and friend from his first days of skipping school and stealing cars. ${ }^{31}$ The Search Bloc claimed Gaviria was killed in a shoot-out, yet the expression "killed in a shoot-out with police" was regarded as a euphemism for summary execution.

Escobar claimed that there had been no shoot-out, that his cousin had been captured, tortured, and then executed by Colonel Martinez's men. These two losses deeply affected Escobar both emotionally and professionally: Henao had been the cartel's treasurer and main moneyman, and Gustavo had been one of Escobar's most trusted confidants. ${ }^{32}$ 
It was easy to rationalize these abuses. Escobar authored many atrocities. The Colombian National Police had borne the brunt of his violence for years and were inclined to meet fire with fire. The scale of the narco's threat to Colombia had long ago transcended law enforcement. This was war, and Escobar was a threat to the state. Yet American involvement in these aggressive tactics undermined basic moral and legal principles.

\section{Legal and ethical challenges grow}

A bigger problem soon arose with the appearance of Los Pepes (Perseguidos por Pablo Escobar, or People Persecuted by Pablo Escobar), an anti-Escobar death squad that began targeting even non-criminal associates, including Escobar's wife and children, extended family members, lawyers, bankers, and accountants.

In one case, the teenage son of a lawyer who had represented Escobar was slain with his father. ${ }^{33}$ Los Pepes members were supposedly composed of family members of those who had been killed by Escobar and his men. This encompassed a large group of people, including the wealthy, government and industry figures, policemen (including members of the Search Bloc itself), and, notably, members of rival criminal cartels. This partnered the Search Bloc with known criminals and implicated it in extrajudicial killings.

Clearly a violation of U.S. policy, there was not adequate pressure to curb these excesses. Although Los Pepes' actions were immoral and illegal, they were effective, and U.S. personnel in Bogota expended little effort to stop them. A U.S. Drug Enforcement Administration cable from the period pointed out:

The attacks by Los Pepes further demonstrate their resolve to violently retaliate against Escobar each and every time Escobar commits a terrorist attack against the [Government of Colombia] and/or the innocent citizens of Colombia. Although the actions are not condoned nor approved by the [Colombian National Police] nor the [U.S. Embassy] they may persuade Escobar to curb such behavior for fear of losing members of his own family. Too, these types of attacks will seriously cut into those assets owned by Escobar and his associates. ${ }^{34}$

Escobar complained bitterly about the tactics used against him, even though he recognized no legal or moral limits to his own actions. Los Pepes were merciless, often signing its handiwork by draping crudely lettered signs around the necks of its victims with taunting messages for Escobar. ${ }^{35}$ If the Search Bloc had for years been trying to pluck Escobar from the top of his mountain of personal and business associates without success, this new more determined effort was taking down the mountain itself.

The institutional charts generated by Centra Spike's surveillance-which not only mapped Escobar's personal and business ties but which could pinpoint the location of most people on it - was clearly being employed to devastating effect. As stated in Killing Pablo,

Up in their vault at the embassy, Centra Spike analysts weren't missing the distinct pattern in Los Pepes' hits. The death squad was killing off the secret white-collar infrastructure of Pablo's organization, targeting his money launderers, bankers, lawyers, and extended family, as if using the very charts that Centra Spike and the CIA had painstakingly assembled over the previous six months. ${ }^{36}$

In fact, Los Pepes' hits were often correlated with new targeting information that Centra Spike turned over to CIA Chief of Station Bill Wagner, who then provided that information to the Search Bloc. Even more instructive was whom Los Pepes chose not to kill. As explained in Killing Pablo,

There were certain key individuals in Pablo's inner circle who were monitored constantly by the Americans, often with video as well as audio surveillance. Not only were these people key to 
intelligence gathering, but anyone paying them a visit, threatening them, or killing them would likely show up in the American monitoring. These were the people Los Pepes left alone. ${ }^{37}$

Providing intelligence that would later be used to assist a murder - such as supplying the street address of a target who was subsequently killed - seemed to be in violation of Executive Order 12333, which stated: "No person employed by or acting on behalf of the United States Government shall engage in, or conspire to engage in, assassination." ${ }^{38}$ The Americans in Bogota were generally unwilling to risk their careers and freedom on the legal opinion issued by the Defense Department's legal counsel in 1989. As a result, they acted carefully on intelligence they collected. Major Steve Jacoby turned his Centra Spike intelligence over to Wagner; how that intelligence was later acted on was, as far as Jacoby was concerned, outside of his purview. ${ }^{39}$

Wagner supplied the Colombian government the intelligence he thought would be the most useful, but an unofficial channel also existed. The complete daily intelligence reports were kept in a red book that could be checked out by official U.S. Embassy visitors. Colombian police officers visited the embassy regularly. ${ }^{40}$

The link was clear enough that the new U.S. ambassador in Bogota, Morris Busby, cabled his concerns to Washington in August 1993, after Colombia's attorney general, Gustavo de Grieff, threatened to expose it (referring to himself in the third person):

The [Government of Colombia] has long been worried that police officials may have been cooperating with Los Pepes, and that [a Colombian official] has now told Ambassador Busby that he has new, "very good" evidence linking key members of the police task force in Medellin charged with capturing Pablo Escobar to criminal activities and human rights abuses committed by Los Pepes. Our own reporting since early February has also suggested that the police were cooperating with the group at some level, including sharing information. ${ }^{41}$

The methods crossed moral and legal boundaries, but they worked. By late 1993, Escobar had grown completely isolated. He was hiding with one bodyguard in a small house in Los Olivos, a neighborhood in Medellin, cut off from money and allies. The one link he retained was a satellite phone connection to his wife and children, which he used regularly even though he was now aware those hunting him could use the signal to track his location.

He was ordinarily careful to keep his conversations short and often made calls while being driven around Medellin in a taxi. Yet in a long conversation with his son on December 2, 1993, Escobar neglected his usual precautions. His location was pinpointed to a specific neighborhood, and using an Americanprovided portable locating device, the Search Bloc identified it precisely. Colonel Martinez's men closed in, and the Search Bloc gunned down both Escobar and his bodyguard as they attempted to flee the house across a back roof. ${ }^{42}$

Officially, Search Bloc shots fired from a distance felled Escobar. He was hit three times. The shot that killed him cleanly entered his right ear and passed directly through his brain. It was either administered as a coup de grace after he fell, or, as one of the Delta Force operators told this author, "It was some pretty nice shootin'., 43

\section{Conclusion}

The role played by Centra Spike and Delta Force in the successful hunt for Pablo Escobar was not fully revealed until years later, when Killing Pablo was published in 2001. While Escobar himself complained repeatedly that Americans were behind the effort, the U.S. military role was kept quiet to the point that it 
never colored the Search Bloc's efforts. The hunt was seen strictly as a Colombian National Police operation. Secrecy enabled President Gaviria to avoid the embarrassment and political repercussions he might have faced if it were known that he had invited American military forces to operate inside his own country. In that sense, it was a complete success.

The success, however, came at a cost that the U.S. military is duty-bound to avoid. Working closely with a foreign military force (in Colombia, the National Police function as a branch of the military) with looser standards than its own implicated U.S. soldiers in operations that violated American ethical and legal constraints. In some cases, innocent people were targeted and killed.

It will never be known if Pablo Escobar could have been brought to justice without these tactics, but it is likely he would have. It might just have taken longer, but it would have been for good reason: the U.S. military is held to higher standards than those in many other countries and certainly higher than those employed by criminal organizations.

\section{Notes}

1 Michael Demarest, “Cocaine: Middle Class High,” Time, July 6, 1981, http://content.time.com/time/magazine/ article/0,9171,922619,00.html.

2 Ibid.

3 Patrick L. Clawson and Rensselaer W. Lee III, The Andean Cocaine Industry (New York: Pallgrave Macmillan, 1996), 51; Simon Strong, Whitewash: Pablo Escobar and the Cocaine Wars (London: Pan Books, 1996), 34-65.

4 Amanda Macias, "10 Facts Reveal the Absurdity of Pablo Escobar's Wealth," Independent, December 29, 2017, www.independent.co.uk/news/people/pablo-escobar-worth-wealth-money-how-much-a8133141.html.

5 Robert D. McFadden, "Head of Medellin Cartel Is Killed by Troops in Colombia," New York Times, December 3, 1993, www.nytimes.com/1993/12/03/world/head-of-medellin-cocaine-cartel-is-killed-by-troops-in-colombia. html.

6 Alan Riding, "Shaken Colombia Acts at Last on Drugs," New York Times, September 11, 1984, www.nytimes. com/1984/09/11/world/shaken-colombia-acts-at-last-on-drugs.html.

7 McFadden, "Head of Medellin Cartel Is Killed."

8 Christine Armario, "Pablo Escobar's Hit Man, Known as 'Popeye,' Dies of Cancer," Associated Press, February 6, 2020, https://apnews.com/article/9435a29de481dd47f8c73c1e42899d8b.

9 Chris Dyer, "That Bomb as a Work of Art," Daily Mail, December 27, 2018, www.dailymail.co.uk/news/article-6532649/Pablo-Escobars-hitman-Jhon-Jairo-Vasquez-tells-blew-airliner-killing-110-people.html.

10 Ibid.

11 Michael Isikoff and Patrick E. Tyler, "U.S. Military Given Foreign Arrest Powers," Washington Post, December 16, 1989, www.washingtonpost.com/archive/politics/1989/12/16/us-military-given-foreign-arrest-powers/9ff56a099271-4778-ae99-03c60b3b1f0b/.

12 Michael Isikoff, "2 Colombians Held in Missile Scheme," Washington Post, May 8, 1990, www.washingtonpost.com/ archive/politics/1990/05/08/2-colombians-held-in-missile-scheme/f80616f7-03fc-4b44-b566-9ca2c01c7c18/.

13 Office of the Judge Advocate General of the Army, "Memorandum of Law: Executive Order 12333 and Assassination" (official memorandum, Washington, DC: Department of the Army, November 2, 1989).

14 Mark Bowden, Killing Pablo (New York: Atlantic Monthly Press, 2007). This information is based on the author's interviews with a Centra Spike member and with Colonel Hugo Martinez.

15 For more on Hugo Martinez, see Mark Bowden, "Killing the King of Cocaine," The Observer, May 5, 2001, www. theguardian.com/theobserver/2001/may/06/life1.lifemagazine2.

16 Bowden, Killing Pablo.

17 Ibid.

18 Ibid.

19 Ibid.

20 This information is based on the author's personal conversations with a member of Centra Spike.

21 James Brooke, "Cocaine Ring's Latest Campaign: Kidnapping Wealthy Colombians," New York Times, January 7, 1990, www.nytimes.com/1990/01/07/world/cocaine-ring-s-latest-campaign-kidnapping-wealthy-colombians.html.

22 Joseph B. Treaster, "Drug Baron Gives Up in Colombia as End to Extradition Is Approved," New York Times, June 20, 1991, www.nytimes.com/1991/06/20/world/drug-baron-gives-up-in-colombia-as-end-to-extraditionis-approved.html. 


\section{U.S. role in the killing of Pablo Escobar}

23 Ibid.

24 Joseph B. Treaster, "Colombian Drug Baron Escapes Luxurious Prison After Gunfight," New York Times, July 23, 1992, www.nytimes.com/1992/07/23/world/colombian-drug-baron-escapes-luxurious-prison-after-gunfight.html.

25 Ibid.

26 This information is based on the author's personal interviews with Delta personnel; DEA agents Steve Murphy, Javier Pena, and Joe Toth; Hugo Martinez Sr.; and Hugo Martinez, Jr.

27 This information is based on the author's personal interviews with Hugo Martinez and Hugo Martinez Jr.

28 Michael Harris, "Simple Tale of How U.S. Helped Bring Down a Drug King," Los Angeles Times, July 3, 2001, www.latimes.com/archives/la-xpm-2001-jul-03-cl-18006-story.html; Bowden, Killing Pablo.

29 “Drug Cartel Figure Is Slain in Medellin," Associated Press, June 15, 1990, www.nytimes.com/1990/06/15/world/ drug-cartel-figure-is-slain-in-medellin.html.

30 Douglas Farah, "Drug Lord's Base Hurt, Officials Say,” Washington Post, July 15, 1990, www.washingtonpost.com/ archive/politics/1990/07/15/drug-lords-base-hurt-officials-say/46f8e1ac-69ef-45a5-8962-0310a993d403/.

31 Stan Yarbro, "Key Medellin Cartel Figure Killed in Gunfight with Police," Associated Press, August 12, 1990, https://apnews.com/article/ac5fd2d878de4f99b28a0e9b51a308c8.

32 This information is based on the author's personal interviews with members of the Medellin Cartel, as well as from recordings of Escobar's interviews and intercepted (and recorded) phone calls.

33 “Angry Over Blast, Colombia Vigilantes Kill Escobar Lawyer," Los Angeles Times, April 17, 1993, www.latimes. com/archives/la-xpm-1993-04-17-mn-24040-story.html.

34 Bowden, Killing Pablo. The author obtained this cable.

35 Steve Murphy and Javier F. Pena, Manhunters: How We Took Down Pablo Escobar (New York: St. Martin's Press, 2019)

36 Bowden, Killing Pablo.

37 Ibid.

38 “Executive Order 12333 of December 4, 1981 United States Intelligence Activities," Code of Federal Regulations, title 3 (1981): 200 (Washington, DC: National Archives, 1981).

39 This information is based on the author's interviews with Steve Jacoby.

40 This information is based on the author's interviews with Steve Jacoby, Steve Murphy, Javier Pena, Joe Toth, Hugo Martinez Sr., and Hugo Martinez Jr.

41 "Unraveling the Pepes Tangle Web" (Embassy cable to Washington, Bogota: American Embassy Bogata, August 6, 1993), https://nsarchive2.gwu.edu/NSAEBB/NSAEBB243/19930806.pdf.

42 This information is based on the author's interviews with Hugo Martinez Sr. and Hugo Martinez Jr., as well as intercepted (and recorded) phone calls made by Escobar to his family.

43 This information is based on the author's interview with a Delta Force member. 


\title{
16
}

\section{THE IRAN-CONTRA AFFAIR AND THE AFGHAN TASK FORCE}

\author{
Lessons in covert action
}

\author{
Jack Devine and Amanda Mattingly
}

When President Ronald Reagan came to office in 1981, he brought with him a new national security team with a focus on defeating the Soviet Union and winning the Cold War. For Reagan and his team, this meant taking the fight to the Soviets, their surrogates, and the nation-states they threatened. The Cold War saw several proxy wars, but none were as consequential as those fought on Reagan's watch, including the conflicts in Nicaragua and Afghanistan.

Both conflicts involved the arming of rebel militias - the Contras in Nicaragua and the mujahidin in Afghanistan-against a communist threat. The similarities end there. These conflicts and the handling of them could not have been more different. The Afghan Task Force was regarded as a great success, and driving the Russians from Afghanistan was the last real battle of the Cold War. In contrast, U.S. efforts in Nicaragua were much less effective, and the mistakes made and legal lines crossed in arming the Contras against the Sandinista National Liberation Front almost led to the undoing of Reagan's own administration.

The Central America operation-turned-scandal, which will forever be known more broadly as the "Iran-Contra Affair," underscores the importance of "good" covert action and is a cautionary tale about what happens when it is not executed properly. This chapter examines these two covert action case studies. It then explores key lessons learned in why covert action largely failed in Nicaragua but succeeded in Afghanistan.

\section{Taking the fight to the Soviets}

President Reagan entered the White House with the conviction that the United States needed to take a tougher line with its enemies. This meant bringing in a national security team composed of three main heavyweights: Secretary of State George Schultz, Secretary of Defense Casper "Cap" Weinberger, and Central Intelligence Agency (CIA) Director William "Bill” Casey. While they sparred among themselves over turf issues, they all had a close relationship with Reagan and shared his foreign policy vision.

All three had served in senior positions during the Nixon and Ford administrations. In addition, Casey had served as chief of staff for Reagan's campaign, playing a major role in his victory. During World War II, he worked for the Office of Strategic Services - the CIA's predecessor organization-where he served as the head of its Secret Intelligence Branch in Europe.

Reagan's national security team moved quickly to assert American resolve and shift the balance of power, especially as it related to the Soviet Union, with the clear intention to bring the fight to the Soviets. Casey immediately began to push for robust covert action activities and tougher, more pointed National 
Intelligence Estimates on the USSR. He made important personnel changes more in line with his aggressive approach to intelligence, not all of which sat well at the CIA, Congress, and the White House. It was clear Reagan intended to take the battle to the Soviets and their allies, and Casey did not want to become bogged down in debate over the president's foreign policy objectives- he too wanted to bleed the Soviet Union dry. ${ }^{1}$

Consistent with Reagan's goals, Casey sought to press hard on the Soviets in Central America and Afghanistan. This provided a boost in morale to the CIA work force, but it also came with downside risks, which later surfaced in the case of Central American operations.

\section{Outsized focus on Central America}

President Reagan's national security team held the strong conviction that the Soviet Union had plans to penetrate the governments of Central America and to bring the region into the Soviet sphere of influence as a way of undermining the United States. ${ }^{2}$ They also believed that the Cubans planned to foment revolution throughout the region, starting with Nicaragua, where leftist Sandinista revolutionaries overthrew long-time dictator Anastasio Somoza Debayle in July 1979.

Right from the start, Reagan and his team fixated on the proximity of Central America to the United States and thus focused on defending it from the Soviet threat. Casey looked upon the Sandinista government as a serious risk to U.S. national security, and Ambassador to the United Nations Jeane Kirkpatrick concurred with the assessment, famously stating, "Central America is the most important place in the world for the United States today."3

Casey's assertions were supported by a Special National Intelligence Estimate, entitled "Soviet Policies and Activities in Latin America and the Caribbean," published by the CIA in June 1982. In this report, the intelligence community spelled out clearly their judgment that the Soviet Union had begun to target Central America, and Nicaragua in particular, as an area of increased interest and activity. ${ }^{4}$

Furthermore, the report asserted that the Soviet objective in the region was to help their Cuban allies to successfully penetrate Nicaragua and aid the Sandinistas and their leader, Daniel Ortega. The Soviet strategy, per the document, included sending hundreds of Russians to assist their Cuban counterparts; training the Nicaraguan military and intelligence service; and committing millions to finance farming, infrastructure, and communications projects in Nicaragua. ${ }^{5}$ For Reagan's national security team, evidence of Soviet interest and activity in Nicaragua was clear, and their intentions to fight against Soviet influence intensified as a result.

In 1982, Reagan also signed National Security Decision Directive 17, authorizing the CIA to recruit and support rebels known as the "Contras" against the Sandinistas. ${ }^{6}$ In December 1982, Congress approved $\$ 19$ million in aid to support the Contras in a classified appropriations bill. ${ }^{7}$ This program became an integral part of the "Reagan Doctrine" in rolling back communism and giving military support to groups opposing communist, leftist governments.

Later that year, Reagan delivered a speech in Costa Rica that was broadcast throughout the region calling on the countries of Central America to join in a "peaceful revolution for democracy." The pointed statements came as a warning to the communists in the region and amid questions about CIA agents in Honduras. Reagan would not confirm it at the time, but consistent with this policy line, Casey was quickly setting in motion a major covert action operation in Central America that became the hallmark of his tenure as director of central intelligence.

Significantly, Casey replaced a highly respected and experienced Latin American operator, Nestor Sanchez, with Duane "Dewey" Clarridge as chief of the Latin America Division. Sanchez apparently was too cautious for Casey's taste. Clarridge was a Middle East hand who matched Casey's WWII-era Office of Strategic Services style of operating and had a reputation for pushing the envelope. Although Clarridge had no area knowledge or Spanish language skills, he was a strong leader and developed a loyal following among 
many Latin America Division officers. For his part, Clarridge was only too eager to accept Casey's vision about the Soviet-Cuban threat and energetically threw himself into organizing an exile force in opposition to the Sandinistas based in Honduras. ${ }^{9}$

This Casey-Clarridge covert action operation began as an authorized effort to prevent arms from being shipped from Nicaragua into surrounding countries, specifically to the leftist rebels in El Salvador, but quickly morphed into support for the Contra rebels to oust the Sandinistas in Managua. Casey and others in the administration subscribed to the "Domino Theory" and feared that if Nicaragua fell prey to communism, then it would be the first of many other Central American countries to fall. This same theory led to the U.S. intervention in Grenada in $1983 .^{10}$

The theory was not unique to the Reagan administration. In the early 1970s, for example, President Richard Nixon, Secretary of State Henry Kissinger, and CIA Director Richard Helms feared that a socialist satellite in Chile could be contagious in the region. Indeed, fear of the "falling domino" 11 had been part of the U.S. foreign policymaking lexicon in Latin America going back to the John F. Kennedy administration — when Fidel Castro proclaimed Cuba a communist state in 1961 — and arguably before that in Guatemala in the 1950s.

As a result, providing support to the Contra rebels in opposition to the Sandinistas became a top priority for the Reagan administration in the 1980s. Based on the intelligence viewed by Casey, it was clear that the Sandinistas had close ties to Fidel Castro in Cuba and that many Cuban and Soviet advisors were assisting in Nicaragua. ${ }^{12}$

Additionally, the Cuban Missile Crisis of 1962 was never far from mind. The fear that the Soviets would deliver fighter jets and other military aircraft to Nicaragua by way of the Punta Huete airfield northeast of Managua — an airfield that was constructed in the early 1980s with Soviet and Cuban funds-was very real at the time, and the intelligence community monitored the movements at the airfield closely. ${ }^{13}$

The prevailing sentiment regarding Central America was clear: "If we can't stop Soviet expansionism in a place like Nicaragua, where the hell can we?" ${ }^{14}$ This made sense to Clarridge, but others in the Latin America Division of the CIA had differing views from the beginning about how to block the Sandinistas, how best to pursue a covert action program, and whether it would be more productive to apply political and economic pressure on Nicaragua.

Nevertheless, the Latin America Division focused on building up an exile, rebel force made up of disparate groups-including ex-Somoza National Guard soldiers and disillusioned ex-Sandinista insurgentswho would be trained by Argentine military forces in Honduras. They would be known as the Contras, and Clarridge continued to maintain that they "would be in Managua by Christmas" of 1983, as Honduran General Gustavo Alvarez had said to Senator Patrick Leahy during a trip to the region. ${ }^{15}$

\section{Covert action case study: arming the Contras of Nicaragua}

As time went on, the Central America covert action program became increasingly controversial, with growing opposition to supporting the Contras. In a speech in early 1985, President Reagan pushed back against these critics, arguing that the Nicaraguan rebels were "our brothers" and "freedom fighters" and that they needed "proof that we care as much about the fight for freedom 700 miles from our shores as the Soviets care about the fight against freedom 5,000 miles from theirs." ${ }^{16}$ Again, the proximity of Nicaragua to America's doorstep loomed large for Reagan and his national security team.

Still, lack of public support and Congressional opposition eventually led to the Boland Amendments (1982-1984) that prevented CIA assistance to the Contras "for the purpose of overthrowing the government of Nicaragua" and ultimately outlawed providing any U.S. government funds to them. ${ }^{17}$ Casey's and Clarridge's briefings to the House and Senate Intelligence Committees did not help their cause. The committee members soon came to distrust Casey and Clarridge and felt that they were not telling the truth, or at least routinely holding back under questioning. ${ }^{18}$ 
The plan was for the Argentines to train the Contras in Honduras on the border with Nicaragua, which offered easy in-and-out access to the country for small to medium-sized attacks on critical infrastructure or political and economic targets. ${ }^{19}$

Support for these exiles within Nicaragua, however, was minimal-comparable to the lack of support in Cuba for the Cuban exiles involved in the doomed Bay of Pigs invasion in 1961. ${ }^{20}$ Lack of support inside Nicaragua meant that they were not able to provide the best on-the-ground intelligence necessary for a successful covert operation. Furthermore, they were accused of corruption and human rights abuses and should not have been considered viable partners for the CIA. ${ }^{21}$

Nevertheless, with the United States providing the funding for the Contras, the number of attacks on Sandinista targets grew. ${ }^{22}$ Some ended successfully, while others ended in disaster. The mining of Nicaragua's harbors in 1983 was among the types of ill-conceived attacks led by the Contras. The Wall Street Journal broke the story in April that year about the harbor mining, and it became the clearest example of what Congress felt were half-truths coming from the CIA and the State Department about the U.S. intervention in Nicaragua.

The CIA-led operation to mine the harbors was designed to support the Contras by cutting off weapons flows and fuel to the Sandinista government, but instead the operation became a fiasco as commercial shipping vessels continued to use the harbors. At one point, Republican Senator Barry Goldwater wrote a letter to Casey letting him know just how "pissed off" he was about the CIA-led actions in Nicaragua. ${ }^{23}$ Both Republican and Democratic members grew increasingly unhappy with what they viewed as the CIA officials' disdainful and dishonest behavior in supporting the Contras and covering it up. Congress was left in the dark.

At the end of 1983, Reagan had approved an internal authorization of 3,000 additional weapons to support the Nicaraguan Democratic Opposition, a Contra group. ${ }^{24}$ Increases in the number of forces, weapons, and funding, however, were not fully disclosed to lawmakers. This behavior virtually guaranteed that lawmakers would take punitive action against the Central American Task Force. Although in the early stages Congress permitted assistance to the Contras for other purposes such as arms interdiction, Congress shut off the entire funding as time went on, and CIA operational activity was forced to come to a halt. Casey should have listened to former CIA Director Helms' advice that "the only thing you can't tell Congress about are operations you shouldn't be doing in the first place." 25

Reagan's national security team was unwilling to take no for an answer. Caught up in the conviction of their cause, they sought other ways to support the Contras. The White House and Casey reached out to third countries and private donors to arrange funding and military supplies for the Contras, which was technically legal even though it ran against the spirit of the Boland Amendments. They obtained about $\$ 34$ million through this process. ${ }^{26}$

Since the operational program ceased to be managed by the CIA, Lieutenant Colonel Oliver North of the National Security Council (NSC) took charge. The NSC running operations was unheard of before then. North appropriately called the project "The Enterprise," which became the secret arm of the NSC staff, and for the first time in history had control over its own airplanes, ships, operatives, and Swiss bank accounts. The idea that the NSC on its own would run clandestine operations out of the White House in an effort to "work around" Congress was doomed to failure. ${ }^{27}$

At this point in 1985, a disreputable Iranian arms dealer named Manucher Ghorbanifar stepped into the picture, having won over key officials at the NSC, including North, with a poorly prepared plan to free U.S. hostages held by Hezbollah in Lebanon by arranging for the sale of U.S. arms (specifically missiles) to the Iranians. What was not clear to those at the CIA-with the possible exception of Casey-was that the proceeds from the steep markups on the weapons sales would go to supporting the Contras, in contravention of the Boland Amendments that prohibited such assistance. ${ }^{28}$

Despite strong objections to working with Ghorbanifar from those within the CIA, including from the head of the Directorate of Operations Clair George, and an insistence that Ghorbanifar be polygraphed 
(which he then failed), the NSC went ahead with their plan, and Reagan signed an executive directive to trade the missiles. ${ }^{29}$ That decision began the biggest scandal of the Reagan administration, which engulfed the CIA and threatened to take down the White House.

Now known as the Iran-Contra Affair, the plan was stunning on several levels, starting with the fact that trading missiles for hostages contradicted long-standing U.S. policy of not dealing with terrorists. At the same time, Ghorbanifar was a problematic partner. A few years earlier, the CIA had put out a "burn notice" on him, saying that he was a serial fabricator who could not be trusted. CIA field offices were prohibited from having any relationship with him. ${ }^{30}$

Moreover, continued funding of the Contras was against U.S. law. The majority of those involved in the execution of the authorized arms-for-hostages trade did not know that the money made on the deal was then being diverted to the Nicaraguan rebels. But North knew, and he implicated many others in the process. Who else had knowledge about the illegal transfer of funds in violation of the Boland Amendments is a matter of continuing controversy. Despite various investigations, it still remains unclear exactly what Reagan, Vice President George H.W. Bush, and Casey knew about the funds transfer. ${ }^{31}$

In January 1986, Reagan authorized the direct shipment of arms from the United States to Iran without informing Congress. The Pentagon's fee for the missiles was $\$ 3,500$ each, but Ghorbanifar charged the Iranians $\$ 10,000$ for the same items. The profits from the upcharge- $\$ 6.5$ million after the first 1,000 of the planned 4,000 anti-tank TOW missiles were delivered to Iran in February 1986-went to the same account that funded the Contras. ${ }^{32}$

By the summer of 1986, the Iranians began complaining about the huge markup for the missiles. In November, a pro-Syrian magazine in Lebanon, Ash-Shiraa, published a piece about the secret arms deal with Iran, and the American press began to investigate the story. ${ }^{33}$ U.S. Justice Department investigators found a memo describing a diversion of $\$ 12$ million from Iran arms sales to the Contras. On November 25 , Reagan said that he had not been fully informed about the sale of arms to Iran and that up to $\$ 30$ million had been used to support the Contras.

One of the many sad truths about the arms deal is that few hostages were released. In fact, in September 1986, radical Shia militants took two more American hostages in Lebanon, effectively replacing those they had freed, all while the United States was funneling arms to the Iranians. ${ }^{34}$ Nearly everyone involved within the U.S. government, and especially in the CIA, came to realize what a disaster the operation had been. The operation came with a significant cost in terms of Congressional and public trust. In the end, several top officials were indicted for their involvement in the Iran-Contra Affair, including North, George, Clarridge, and others who were implicated in the illegal activity.

The Nicaraguan side of the equation was not much better, considering that despite all of the money that the Reagan administration funneled to the Contras, the objectives were never met. The Contras were divided politically, accused of corruption, human rights violations, and drug trafficking, and made little impact in Nicaragua despite years of covert funding. Efforts to make the Contras into a viable military force were ultimately unsuccessful. The many setbacks for the Contras - and the fact that they were never able to secure ground-also meant that the rebel forces were removed from the key battles in Nicaragua, which were political and economic. ${ }^{35}$

It is possible that U.S. support to the Contras kept the Cubans and Russians more engaged in Nicaragua than in other countries in Central America, which allowed for modest U.S. success elsewhere. For example, efforts against the leftist Farabundo Martí National Liberation Front (FMLN) in El Salvador might have been more difficult if Sandinista leader Ortega had the opening to send weapons and trainers freely.

Nevertheless, in Nicaragua, the reality was that once the United States cut off military support for the Contras, the rebels agreed to negotiations with the Sandinistas. Under pressure from the international community, particularly from neighboring Central American countries, the Contras eventually demobilized in $1989 .{ }^{36}$ This came just ahead of elections in 1990 that resulted in a surprise win for opposition 
candidate Violeta Chamorro from the National Opposition Union over incumbent Sandinista National Liberation Front leader Daniel Ortega. ${ }^{37}$

How much of an influence the Contras ultimately had in creating the conditions for a resolution to the conflict and a democratic transition in Nicaragua is debatable. It is not unreasonable, however, to believe that the failed socialist economic policies of the Sandinistas, coupled with the collapse of the Soviet model on the other side of the globe, had much more to do with the defeat of the Sandinistas in the polls in 1990 than did U.S. support to the Contras.

\section{Covert action case study: arming the mujahidin in Afghanistan}

The Reagan Doctrine of rolling back communism and bringing the fight to the Soviets played out elsewhere in the world at the same time- - with very different results in Afghanistan than in Nicaragua. Russian troops invaded Afghanistan in December 1979, and by the time President Reagan took office, the international reaction to the invasion was already swift and negative.

According to then-NSC Director Zbigniew Brzezinski, the Reagan administration immediately launched a two-fold process to counter the Soviets. First, the United States coordinated a joint international response involving sanctions focused on the Soviet Union. Second, the United States provided weapons to the anti-Soviet Afghan mujahidin fighters. These weapons came from various sources but especially from the Egyptians and the Chinese. ${ }^{38}$ Ultimately, the effort to arm militants through the Pakistani intelligence service, the Inter-Services Intelligence, to fight off the Russians became the CIA's longest and most successful covert operation to date.

Unlike the Central American Task Force, the Afghan Task Force was low profile and did not hold the headlines like the activities in Central America. While George Crile's 2003 book Charlie Wilson's War played up the drama as well as Representative Charlie Wilson's role in supporting the mujahidin in Afghanistan, the truth is less sensational. In reality, it was a traditional CIA covert action program run in a professional manner consistent with past programs, albeit on a larger scale and with a clear and positive outcome in the context of the Cold War.

President Jimmy Carter first authorized the covert war in late 1979. In 1981, President Reagan reauthorized the program. Congressional appropriates grew from $\$ 30$ million in 1981 to $\$ 200$ million in 1984 with the purpose of funneling weapons to the mujahidin fighters. ${ }^{39}$

By 1984, it became clear that the effort was doing significant damage to the Soviet military in Afghanistan. A critical few in the administration recognized that the covert action in Afghanistan was paying off and started to question conventional wisdom that the Soviets could not be beat - a notion held even by the CIA's top Russian analysts. In 1985, Reagan signed National Security Decision Directive 166 authorizing the CIA to ramp up efforts. ${ }^{40}$ With bipartisan Congressional support, the budget tripled that year, and the relatively small Afghan office was turned into a large task force.

At the beginning of the Soviet invasion of Afghanistan, the Soviets believed that they could succeed with only limited support to the Afghan military. They thought it would be enough to just provide communications and transport support. It became clear fairly quickly that they would have to take to the battlefield themselves and engage the enemy directly in firefights.

The Afghan resistance began to grow in proportion to the Soviet troops on the ground. By 1985, the Soviet forces had increased to about 110,000 troops, including elite Spetsnaz Special Forces and the lethal Mil Mi-24 attack helicopters. On the other side of the battlefield, however, the mujahidin fighters were estimated to be about 120,000 strong. ${ }^{41}$

The Soviets' biggest miscalculation was their belief in nation-building. They thought they could build another communist country despite the tribal nature of Afghanistan and their inherent distaste of foreign occupation. The Soviet-supported Afghan army faced a high desertion rate throughout the war, and their soldiers were reluctant to engage the Afghan mujahidin in combat because they simply did not identify with 
the creation of a communist government. In fact, they only signed up on a temporary basis for a paycheck, which meant they would "duck" when the firing started.

As the war developed, a pattern unfolded with the Soviets occupying the cities and communication centers, while the mujahidin formed bands to conduct an insurgency throughout the countryside. By the end of the war, Kabul had lost control of most of the countryside.

Many experts and policymakers had underestimated the determination of the mujahidin as well as the impact of the CIA's massive military weapons buildup, including, above all, the game changing surface-toair Stinger missile. The Stinger missile was deployed to counter Soviet aircraft, especially the Mil Mi-24 helicopter, which arguably led the Kremlin to withdraw its forces from Afghanistan in early 1989 as it forced the Russians to greatly curtail their air battle and left the playing field open to the mujahidin.

The American buildup had been a full-court press. With a budget increasing to $\$ 350$ million in the summer of 1986, the Afghan Task Force managed to undertake a sizeable increase in its arms purchases from the Chinese and maintain purchase levels with the Egyptians. ${ }^{42}$ Early in the program, it was decided that the CIA would use only Soviet-type weapons to reduce the U.S. presence on the battlefield and provide the mujahidin with weapons that were interchangeable with arms seized from Soviet and Afghan storage. This is a common practice in organizing insurgencies.

By purchasing weapons from the Chinese and the Egyptians, the task force avoided becoming overly dependent on one country, reducing the risk of being shut down if the local political situation changed suddenly and restricted procurements. At the same time, the task force increased the purchase of fourwheel-drive Toyota trucks needed for the rough terrain in Afghanistan. When these trucks could not finish the last leg of the haul over the mountains, the task force then turned to mules herded across China and delivered to camps in Pakistan. As the pressure built on the battlefield in 1986, it became clear that the Soviets would have to pull up stakes if the mujahidin could maintain the pressure. Recently declassified Russian documents support this analysis. ${ }^{43}$

The timing of this build-up roughly coincided with the selection of Mikhail Gorbachev as secretary general of the Communist Party of the Soviet Union and the initiation of his reformist policies, which contributed significantly to the Soviets' decision to withdraw from Afghanistan. Gorbachev "inherited a deteriorating war in Afghanistan" and the major setbacks in 1986 only intensified Gorbachev's desire for withdrawal. ${ }^{44}$ Soviet military and intelligence services started planning their exit from Afghanistan. In 1988, serious negotiations concluded with the Geneva Accords and the establishment of a United Nations program to monitor the withdrawal. ${ }^{45}$ On July 20, 1987, Moscow formally announced the departure of Soviet troops, and the last troops left Afghanistan on February 15, 1989.

The success of the covert action in Afghanistan was the result of a large and strategic effort that involved many partners - not just within the U.S. government and Congress but also international partners such as Pakistani and Saudi intelligence. Some critics of the program have argued that CIA officers on the Afghan Task Force were absentee managers to Pakistani intelligence or the mujahidin, but it was the close collaboration among these partners that led to success.

It is also important to emphasize that there is no evidence any weapons or support from the CIA ever went to Usama bin Ladin, who would establish al-Qaida in 1988. Critics who believe the CIA's covert war in Afghanistan created al-Qaida are incorrect, although the group likely benefited, even if indirectly, from the U.S. support. In fact, what made it possible for the CIA and U.S. Special Operations Forces to topple the Taliban within months of the $9 / 11$ terrorist attacks were, in large part, the tribal networks that the CIA established in Afghanistan and Pakistan in the 1980s. ${ }^{46}$

When the Islamabad CIA chief of station wrote the well-known message, "We Won," ${ }^{47}$ as the final Soviet troops crossed the Friendship Bridge on their way out of Afghanistan in 1989, the "we" meant a large number of unsung heroes in the United States and abroad who were engaged for nearly a decade in executing the CIA covert war. 


\section{Lessons learned}

The situations in Nicaragua and Afghanistan in the 1980s were quite different, but contrasting the two covert action operations is worthwhile. Why did one go so terribly awry, while the other proved successful and helped end the Cold War? Arming the Contras was not exactly like arming the mujahidin, and the attention on the issue by Reagan administration officials was not the same either. Certainly, the role of Congress could not have been more different. Yet the lessons learned from the two operations clearly demonstrate the differences between "good" and "bad" covert action.

The two case studies help to underscore the need for certain conditions for covert action to succeed. Such conditions include the following: ${ }^{48}$

Viable partners: The United States needs partners who share U.S. goals and objectives within the host nation where the covert action is targeted. The United States cannot rely on exiles outside of the country, as this can lead to miscommunication and mistakes. A base of operations contiguous to the target is also critical.

Real-time, accurate information: Covert action requires real-time information collected by foreign agents directed by the CIA. Reliance solely on spy satellites, communications intercepts, and other technologies can result in missing contextual details that can make or break an operation.

Adequate resources: Small sums of money and limited capability are at best ineffective and at worst dangerous. "Dabbling" is not enough. When policymakers direct the CIA to conduct covert action, they must equip the agency to succeed with ample funding and personnel.

Bipartisan political support: Covert action should reflect, in general terms, the wishes of the American people even if they are unaware of the operation. Like war, covert action needs support in Congress, and if there are significant detractors on either side of the aisle, then it is unlikely the covert action will succeed.

A direct threat to U.S. security: To garner support domestically and internationally, the White House must demonstrate that its adversary poses a real threat to U.S. national security and needs to be eliminated.

Proportionality: The desired outcome must be relatively commensurate with the cost and the collateral damage, particularly with regard to the possibility of civilian casualties.

A reasonable prospect for success: Before the CIA launches a covert action operation, policymakers have to possess a clear objective and have confidence-based on fact, not desire- that accomplishing the operation is possible.

With respect to the covert action operation in Nicaragua, several of the aforementioned conditions were not met, although it was not for lack of attention from the White House. The most obvious "red flag" was poor support from Congress. When the Reagan administration failed to obtain support for funding and arming the Contras, they sought alternative and illegal methods to pursue their objectives, which were therefore bound to fail. Going around Congress makes for bad covert action.

Bipartisan support in Congress is key to another required condition: adequate resources. The Boland Amendments meant that the Reagan administration did not have the funds that they would otherwise have put into the effort. Unfortunately, key officials still stuck to what was a bad plan while at the same time keeping others in the dark about illegal actions taken to fund these objectives.

In the end, the Iran-Contra Affair took down several career CIA operatives who were implicated in this illegal activity. In contrast, the Afghan Task Force had significant bipartisan support on Capitol Hill. Representatives in Congress were largely supportive of the U.S. objectives in Afghanistan and willing to provide the funding to meet those objectives.

Another major "red flag" in the failed covert action in Nicaragua was reliance on exile forces in the form of ex-Somoza National Guard soldiers and disillusioned ex-Sandinista insurgents along the border 
in Honduras. Support for these exiles within Nicaragua under the Sandinistas was minimal and has been compared to the lack of support in Cuba for those Cuban exiles who backed the failed Bay of Pigs invasion decades earlier. These exiles were seen largely as corrupt human rights abusers and thus not viable partners for the United States.

Given the lack of support inside Nicaragua for the Contras, they were also unable to provide the best real-time information to the CIA directing the operation. The fiasco in Nicaragua's harbors is an example of poor intelligence provided to those planning the operation.

In contrast, there were significant numbers of Afghan fighters and civilians who were sympathetic to the Afghan mujahidin efforts to drive out the Soviets from their country. The mujahidin were not just an exile force seeking to regain power from an opposing tribal or political force, but they wanted to take back their country from foreign occupation. This was a stark contrast to the situation in Nicaragua, but it speaks to the fact that the mujahidin proved viable partners with access and real-time information as well that helped to drive the program.

Despite the focus on Nicaragua and Central America more generally, the Reagan administration struggled to compel the public or Congress to see the threat the same way. Casey and others in the administration, including Reagan himself, were fixated on the proximity of Nicaragua to the United States. They viewed Central America as a clear and present danger on the doorstep to the United States, but they had trouble communicating this threat effectively enough to build support. Not being able to articulate the direct threat to U.S. security necessary to garner support spelled doom for the covert action plan.

In contrast, the Soviet invasion of Afghanistan was seen as a clear and direct threat to U.S. interests and security. The mujahidin's fight against the Russians in Afghanistan had strong public support, and the Afghan Task Force had bipartisan Congressional support and funding to match. Ultimately, fighting the Russians directly in Afghanistan held much more sway than fighting them indirectly in Nicaragua.

One of the most important components necessary for success in covert action is the reasonable prospect for success. Setting aside the misguided arms-for-hostages trade and the illegal diversion of funds to the Contras, the covert action program in Nicaragua was still bound to fail because the White House did not have reasonable prospects for success on the ground. Their analysis and policy decisions were shaped more by desire and fear than facts on the ground. In contrast, the Afghan Task Force ramped up significantly when real-time intelligence suggested Soviet casualties and Afghan desertions, which greatly improved the prospects for success.

Overall, the cases of Nicaragua and Afghanistan demonstrate the complexity of the secret covert action programs of the Cold War. They were costly in human and financial resources and fraught with risks to U.S. allies and interests. The results of these programs differed greatly, but the comparisons between the two case studies and the important lessons learned from both should help to craft covert action programs in the future.

\section{Notes}

1 Stephen S. Rosenfeld, “The Reagan Doctrine: The Guns of July,” Foreign Affairs, 1986.

2 Evan D. McCormick, "Introduction: Latin America and the Legacy of Ronald Reagan's 1980s," in Policy Roundtable: Reagan and Latin America (Austin: Texas National Security Review, 2018).

3 Walter LaFeber, Inevitable Revolutions: The United States in Central American (New York: W.W. Norton, 1993$), 5$.

4 CIA, Soviet Policies and Activities in Latin American and the Caribbean (Langley: Central Intelligence Agency, 1982).

5 Ibid.

6 White House, National Security Decision Directive on Cuba and Central America, NSDD 17 (Washington, DC: White House, 1982).

7 "Nicaraguan Decade: War, Ruin and Turnabout," New York Times, February 20, 1990, www.nytimes. com/1990/02/27/world/turnover-in-nicaragua-nicaraguan-decade-war-ruin-and-turnabout.html.

8 Steven R. Weisman, "Reagan Denounces Threats to Peace in Latin America," New York Times, December 5, 1982, www.nytimes.com/1982/12/05/world/reagan-denounces-threats-to-peace-in-latin-america.html. 
9 Jack Devine, Good Hunting: An American Spymaster's Story (New York: Farrar, Straus and Giroux, 2014), 71-72.

10 Sam Tanenhaus, "The Rise and Fall and Rise of the Domino Theory," New York Times, March 23, 2003, www. nytimes.com/2003/03/23/weekinreview/the-world-from-vietnam-to-iraq-the-rise-and-fall-and-rise-of-thedomino-theory.html.

11 The "falling domino" reference, and ultimately what became the "Domino Theory," originally came from an April 7, 1954, speech by Dwight D. Eisenhower explaining the importance of Vietnam to the United States.

12 William J. Casey, "Address to the Harry J. Sievers Lectures Series" (New York City: Center for the Study of the Presidency, Fordham University, February 25, 1986).

13 Robert Vickers, "Intelligence and Punta Huete Airfield: A Symbol of Past Soviet/Russian Strategic Interest in Central America," Studies in Intelligence 60, no. 2 (2016): 13.

14 Joseph E. Persico, Casey: The Lives and Secrets of William J. Casey: From the OSS to the CIA (New York: Viking, 1990), 264.

15 William M. LeoGrande, Our Own Backyard: The United States in Central America, 1977-1992 (Chapel Hill: University of North Carolina Press, 1998), 311.

16 Gerald M. Boyd, "Reagan Terms Nicaraguan Rebels 'More Equal of Founding Fathers', New York Times, March 2, 1985, www.nytimes.com/1985/03/02/world/reagan-terms-nicaraguan-rebels-moral-equal-of-founding-fathers.html.

17 Boland Amendment, www.brown.edu/Research/Understanding_the_Iran_Contra_Affair/documents/d-nic-7.pdf.

18 Fox Butterfield, "Senior Official in C.I.A. Is Linked to North's Effort on Contra Arms," New York Times, January 21, 1987, www.nytimes.com/1987/01/21/world/senior-official-in-cia-is-linked-to-north-s-effort-on-contraarms.html.

19 Stephen Engelberg, "U.S. and the Nicaraguan Rebels: Six Years of Questions and Contradictions," New York Times, May 3, 1987, www.nytimes.com/1987/05/03/world/us-and-the-nicaraguan-rebels-six-years-of-questions-andcontradictions.html.

20 Tad Szulc, "Nicaragua, An Echo of the Bay of Pigs," New York Times, March 16, 1986, www.nytimes. com/1986/03/16/opinion/nicaragua-an-echo-of-the-bay-of-pigs.html.

21 Michael Freitag, "Sandinistas and Contras Accused of Rights Abuses," New York Times, November 18, 1987, www. nytimes.com/1987/11/18/world/sandinistas-and-contras-accused-of-rights-abuses.html.

22 White House, "CIA Covert Operations in Nicaragua" (secret presidential finding, Washington, DC: White House, September 19, 1983).

23 Doyle McManus and Robert C. Toth, "Setback for Contras: CIA Mining of Harbors 'a Fiasco'," Los Angeles Times, March 5, 1985, www.latimes.com/archives/la-xpm-1985-03-05-mn-12633-story.html.

24 Robert McFarlane, "Support for the Nicaraguan Democratic Opposition" (Memorandum to the President, Washington, DC: November 7, 1983).

25 Persico, Casey, 492.

26 Richard Sobel, "Contra Aid Fundamentals: Exploring the Intricacies and the Issues," Political Science Quarterly 110, no. 2 (1995): 287-306.

27 Devine, Good Hunting, 89.

28 Ibid., 86. "The various [Congressional] committees and commissions called dozens of witnesses but they were never able to resolve a central question about Iran-Contra: What was Bill Casey's role? Casey suffered a stroke in his office on December 15, 1986, the result of a brain tumor, which left him unable to talk and caused his death a short time later."

29 Bob Woodward and Charles R. Babcock, "CIA Warned of Ghorbanifar as 'Fabricator'," Washington Post, January 31, 1987, www.washingtonpost.com/archive/politics/1987/01/31/cia-warned-of-ghorbanifar-as-fabricator/ 22de69d3-1da0-4a9e-bdb1-03eb1c447dfb/.

30 James Bamford, “Iran: The Next War," Rolling Stone, July 24, 2006.

31 Bob Woodward, Veil: The Secret Wars of the CIA 1981-1987 (New York: Simon \& Schuster, 1987). In Woodward's book, he claims that on Bill Casey's deathbed, he told Woodward that he knew that the funds from the arms sales to Iran were used to support the Contras in Nicaragua. However, as Jack Devine wrote, "There has been much conjecture over the years about whether he [Casey] helped the NSC orchestrate the [Iran-Contra] operation." See Devine, Good Hunting, 86.

32 Bamford, "Iran: The Next War."

33 Melissa B. Mahle, Denial and Deception: An Insider's View of the CIA From Iran-Contra to 9/11 (New York: Nation Books, 2004), 29.

34 Micah Zenko, "Revising President Reagan's Iran Arms-for-Hostages Initiative," Council on Foreign Relations, August 3, 2016, www.cfr.org/blog/revisiting-president-reagans-iran-arms-hostages-initiative.

35 Editorial Board, "Why the Contras Failed," New York Times, August 20, 1989, www.nytimes.com/1989/08/20/ opinion/why-the-contras-failed.html. 
36 Mark A. Uhlig, "Five Latin Presidents Defy U.S. and Urge Contras' Eviction," New York Times, August 8, 1989, www.nytimes.com/1989/08/08/world/5-latin-presidents-defy-us-and-urge-contras-eviction.html.

37 Mark A. Uhlig, "Turnover in Nicaragua; Aristocratic Democrat; Violeta Barrios de Chamorro," New York Times, February 27, 1990, www.nytimes.com/1990/02/27/world/turnover-in-nicaragua-aristocratic-democrat-violetabarrios-de-chamorro.html.

38 Robert Pear, "Arming Afghan Guerrillas: A Huge Effort Led by U.S.," New York Times, April 18, 1988, www. nytimes.com/1988/04/18/world/arming-afghan-guerrillas-a-huge-effort-led-by-us.html.

39 Devine, Good Hunting, 25.

40 White House, U.S. Policy, Programs and Strategy in Afghanistan, NSDD 166 (Washington, DC: White House, 1985).

41 Devine, Good Hunting, 27.

42 Ibid., 37.

43 Alan J. Kuperman, "The Stinger Missile and U.S. Intervention in Afghanistan,” Political Science Quarterly 114, no. 2 (1999): 219-263.

44 Steven Coll, "Gorbachev Was Right," New Yorker, September 29, 2009, www.newyorker.com/news/steve-coll/ gorbachev-was-right.

45 Phillip Taubman, "Soviet Sets May 15 as Goal to Start Afghanistan Exit," New York Times, February 9, 1988, www. nytimes.com/1988/02/09/world/soviet-sets-may-15-as-goal-to-start-afghanistan-exit.html.

46 Devine, Good Hunting, 104.

47 Steve Coll, Ghost Wars (New York: Penguin Books, 2004), 185.

48 This list of conditions first appeared in Devine, Good Hunting. 


\title{
THE HORSE SOLDIERS
}

\section{Lessons from expeditionary unconventional warfare}

\author{
Mark E. Mitchell
}

At 9:59 AM on September 11, 2001, as the soldiers of the U.S. Army's 5th Special Forces Group watched the stunning and unforgettable collapse of the South Tower of the World Trade Center, they knew instinctively that their lives would soon change dramatically. As the Army Special Forces group designated to support U.S. Central Command (CENTCOM) - the geographic combatant command with an area of responsibility stretching from Egypt to Pakistan - they would surely be involved in any response to the terrorist attacks. President George W. Bush pledged to "find those responsible" for the most devastating attack against the United States since Pearl Harbor and "bring them to justice.".

In the weeks following the attacks, the 5th Group began deploying to Uzbekistan to serve as the vanguard for America's response to these horrific events. On the night of October 19, 2001, with support from the 160th Special Operations Aviation Regiment and U.S. Air Force Special Operations aircraft, the first Special Forces Operational Detachment Alphas (ODAs), or detachments, infiltrated Afghanistan and linked up with Afghan resistance forces and elements from the Central Intelligence Agency (CIA).

A mere 102 days after the 9/11 attacks, the Taliban and their al-Qaida "guests"-including Usama bin Ladin and hundreds of his supporters - had been routed by a motley collection of tribally and ethnically based resistance forces supported by U.S. Special Operations Forces (SOF) and coalition air power. The Afghan Interim Administration assumed power in Kabul, while the men and women of Task Force Dagger - a joint task force built around the 5th Special Forces Group and commanded by the group commander, Colonel John Mulholland-celebrated a hard-fought victory whose swiftness defied all predictions. $^{2}$

The stunning success of the Afghan resistance forces-who on September 10, 2001, had been near collapse-was enabled by an international effort spearheaded by the CIA and SOF supported by U.S. airpower. The combination of lethal aid supplied by the CIA and the precision airstrikes directed by SOF stunned the Taliban and sent them into headlong retreat. Major cities fell to the Northern Alliance and other resistance forces in rapid succession. The image of U.S. soldiers, airmen, and intelligence officers riding on horseback with their Afghan partners rapidly became the iconic picture of this initial phase of the long war in Afghanistan. ${ }^{3}$

The achievement of this in-extremis effort was widely and rightly celebrated. A few hundred Americans on the ground in Afghanistan helped indigenous forces vanquish a mutual enemy and pursue a hated foe who had killed nearly 3,000 Americans, inflicted serious damage to the U.S. economy, and dealt a blow to America's sense of security. ${ }^{4}$ From afar, the rapid if imperfect ${ }^{5}$ success of this operation made it 
seem almost effortless and preordained. The reality, especially for those on the ground in Afghanistan, was decidedly different.

This chapter describes the author's experience conducting unconventional warfare in the aftermath of $9 / 11$. It starts with a brief overview of unconventional warfare, how the U.S. Army drifted away from it, and the strategic focus of the United States prior to 9/11. Next, it describes the author's experience planning, infiltrating, and fighting with the Northern Alliance to defeat Taliban and al-Qaida forces near Mazar-i-Sharif in northern Afghanistan. Finally, it provides some lessons for unconventional warfare operations.

\section{Army Special Forces and unconventional warfare}

Since its inception, a core activity of U.S. Army Special Forces has been unconventional warfare, defined as "activities conducted to enable a resistance movement or insurgency to coerce, disrupt, or overthrow a government or occupying power by operating through or with an underground, auxiliary, or guerrilla force in a denied area." ${ }^{\prime}$ Although the doctrinal definition has changed over several decades, ${ }^{7}$ the essential components have remained the same: enabling an indigenous movement in a denied area to coerce or overthrow an established government or occupying power. The doctrine, organization, training, and equipment of the Special Forces are all designed to ensure that detachments can successfully execute this mission anywhere in the world.

Every prospective Green Beret ${ }^{8}$ must first pass a rigorous assessment and selection course before training begins. They then must complete the Special Forces Qualification Course, language training, and special skills $^{9}$ training before assignment to an operational group. The training, which can take up to two years, produces a disciplined, mature, and highly capable Special Forces soldier.

The capstone exercise of the qualification course is known as Robin Sage. This unique two-week exercise replicates an unconventional warfare environment. ${ }^{10}$ It is remarkably effective in preparing Special Forces soldiers for the challenges they may soon face. Nevertheless, the Department of Defense, CENTCOM, and the 5th Group were still unprepared for unconventional warfare in Afghanistan, because the demand for it was practically non-existent prior to $9 / 11$. In seeking to understand why, it is necessary to review the preceding decades and the strategic forces that shaped the mission focus.

\section{Drifting away from unconventional warfare}

U.S. Special Forces trace their lineage to multiple organizations from World War II: the 1st Special Service Force, Merrill's Marauders, and the Office of Strategic Services. In June 1952, the first Special Forces group, the 10th Group, was activated. It focused on preparing for guerrilla warfare behind enemy lines in the event of a Soviet invasion of Western Europe. By 1957, additional Special Forces began training Vietnamese Army commandos. ${ }^{11}$

Their role later shifted to advising irregular forces and supporting counterinsurgency missions. By the time they were withdrawn from Vietnam in 1971, the Special Forces had achieved significant success on the battlefield and a level of notoriety in popular culture. ${ }^{12}$

Nevertheless, their fortunes declined precipitously for the next decade. The U.S. Army deactivated several Special Forces groups, and attention quickly turned from counterinsurgency and irregular warfare to focus on the Soviet threat in Europe. During the 1980s, small numbers of Special Forces deployed to El Salvador to assist the government in combating a socialist insurgency. Special Forces also participated in counternarcotics efforts in South and Central America in the 1980s and the invasion of Panama in 1989.

In 1990, the Pentagon reactivated the 3rd Special Forces Group. In 1990-1991, the 5th Group played a critical role in the operations Desert Shield and Desert Storm: monitoring Saudi Arabia's border, conducting deep reconnaissance in Iraq, and acting as liaisons with Arab forces in the U.S.-led coalition. ${ }^{13}$ 
Following the liberation of Kuwait from Saddam Hussein's Iraq, the 5th Group assumed a permanent, rotational presence in Kuwait, advising and training the Kuwaiti Army.

Additionally, the 10th Group supported humanitarian relief operations in Turkey and northern Iraq after the conclusion of the Gulf War. ${ }^{14}$ Special Forces elements also supported United Nations peacekeeping operations in Somalia and Haiti and the implementation of the Dayton Accords following the civil war in Bosnia-Herzegovina. ${ }^{15}$

In short, for nearly five decades after their establishment, Special Forces units participated in just about every type of operation imaginable, except bona fide unconventional warfare. Instead, Special Forces performed foreign internal defense and an array of ancillary missions. The unique skills of the Special Forces soldier were in high demand, and the budget and size of the Special Forces grew substantially throughout the 1990s. Nevertheless, demand for Special Forces to conduct unconventional warfare did not exist.

The dearth of unconventional warfare missions was not due to the absence of opportunities. The United States provided significant support to Afghan tribesmen in their efforts to drive Soviet forces from their country in the 1980s under President Ronald Reagan, but this was accomplished through a successful covert action program run by the CIA. Special Forces played a minor supporting role, at best.

Even as the threat from al-Qaida in Afghanistan grew in the late 1990s, the Department of Defense and the executive branch were reluctant to employ Special Forces to overthrow the Taliban. ${ }^{16}$ A variety of factors contributed to the aversion of using Special Forces to conduct their core mission: concern over risk (strategic, political, tactical), especially after the October 1993 debacle in Mogadishu; a paucity of political will; and the existence of similar capabilities in the intelligence community.

These factors also influenced a perception among some in the Special Forces and the larger special operations community that the United States would never again engage in unconventional warfare. This perception had real consequences. Although training in the qualification course was inextricably linked to unconventional warfare, there was little emphasis on it in the Special Forces groups and no interest whatsoever in the rest of the Department of Defense or the U.S. government.

\section{Strategic focus}

The last decade of the 20th century marked the end of the Cold War. In a span of less than two years, Germany reunified, the Soviet Union collapsed, and the Warsaw Pact dissolved. Discussion focused on how to invest the anticipated "peace dividend" in this new, peaceful era. President Bill Clinton's National Security Strategy in December 2000 focused on adapting Cold War alliances, engaging with former adversaries, advancing democracy and human rights, and promoting economic prosperity. ${ }^{17}$ The strategy mentioned Afghanistan in the context of abuses of religious freedom, illegal drug trafficking, and sheltering Bin Ladin and other terrorists, but the response focused on "energetic diplomatic efforts" rather than military options. ${ }^{18}$

Simply put, the U.S. government did not envision any possibility of military action in Afghanistan to overthrow the Taliban. The 5th Special Forces Group had trained in Pakistan, Uzbekistan, and Tajikistan, but Afghanistan was the one country in the region where it never expected to operate. The Soviets and the British before them had invaded Afghanistan with massive, well-equipped forces only to later withdraw from the "graveyard of empires" after ignominious years of casualties and calamities. The United States had no intention of ever getting directly involved in the country.

As a result, CENTCOM had no contingency plans for operations in Afghanistan on 9/11. The 5th Group had soldiers trained in Arabic, Farsi, and even in Urdu, but none specifically trained in Pashto or Dari, the dominant languages in Afghanistan. Also, few were trained on the employment of horses and pack animals. Few could identify any of the major political figures in the Taliban, resistance groups, or specific tribes. The average soldier knew little about Afghan culture or history. No one in the 5th Group had any personal relationships with anyone of importance in Afghanistan. 
Yet by mid-morning on 9/11, the impossible had become the inevitable, and the 5th Special Forces Group - and the rest of the U.S. national security apparatus - began an urgent effort to prepare.

\section{Horse soldiers}

In 1998, President Clinton ordered Tomahawk cruise missile strikes against al-Qaida training camps in Afghanistan, but air power alone could not drive the Taliban and al-Qaida from Afghanistan. ${ }^{19}$ After the 9/11 attacks, it was immediately clear to the 5th Group soldiers that any response to the attacks would involve Army Special Forces. Although ignorant of the specifics on the ground in Afghanistan, the group understood the strategic situation in the region.

\section{Planning}

The United States had no conventional forces deployed in Central Asia. Moreover, the United States did not have permanent military bases in any of Afghanistan's neighboring countries from which it could launch and sustain a conventional campaign. Establishing such bases and deploying conventional forces would take months. Even then, the mountainous terrain posed a substantial challenge.

Additionally, Afghanistan was landlocked, with the nearest seaport hundreds of kilometers away in Karachi, Pakistan. Given Pakistan's sponsorship of the Taliban and the population's deep distrust of the United States, it was clear that Pakistan would not allow the basing of U.S. military forces to strike the Taliban and their al-Qaida guests.

Planning for operations in Afghanistan began immediately and unfolded simultaneously at the strategic, operational, and tactical levels. At the strategic level, the United States made futile overtures to the Taliban government to apprehend and turn over Bin Ladin while also negotiating with surrounding countries for staging, basing, and overflight rights and permissions to launch attacks on a neighboring country. ${ }^{20}$ For a variety of reasons, diplomatic efforts focused on Uzbekistan, which granted access to Karshi-Khanabad ("K2"), an old Soviet airfield in southern Uzbekistan-but only for search and rescue operations.

At the operational level, CENTCOM, under the command of General Tommy Franks, was designated as the "supported command" for all operations. Within days, planners from other defense organizations and government agencies descended on the CENTCOM headquarters and its subordinate headquarters, Special Operations Command Central (SOCCENT), both at MacDill Air Force Base in Tampa, Florida.

At the tactical level, the 5th Special Forces Group struggled with the implications of being designated the core of Joint Special Operations Task Force-North (JSOTF-N), which later came to be known as Task Force Dagger. Per the joint and Army doctrine in effect at the time, the 5th Group would have normally been designated as an Army Special Operations Task Force, while SOCCENT would function as the JSOTF, controlling all SOF in the Afghanistan theater. ${ }^{21}$

SOCCENT Commander Rear Admiral Bert Calland, however, eschewed this role, preferring instead to retain control of all SOF in the CENTCOM area of responsibility. In an interview with an Army historian, Calland defended this decision by pointing to his other responsibilities across the CENTCOM area of responsibility, stating, "My job is [CENTCOM] wide." 22

Although the actual plan was still under development, the 5th Group placed four detachments in "isolation"- a strictly controlled planning environment designed to ensure operational security - to begin familiarizing themselves with Afghanistan. ${ }^{23}$ Issues developed almost immediately at every level. The peacetime staffs at SOCCENT and 5th Group were insufficiently manned or untrained to perform many of the joint functions that the mission demanded. Each staff required substantial augmentation and training about joint staff procedures.

New personnel ("augmentees") had to be identified, integrated, and trained at the same time that these already stretched staffs planned and directed combat operations. Additionally, the equipment on 
hand - especially critical communications systems like local area networks — was inadequate for the assigned missions. Worse, the various headquarters competed against each other for these limited resources.

The detachments in isolation at Fort Campbell, Kentucky, quickly discovered that the United States lacked military maps of Afghanistan. Luckily, they were able to obtain Soviet-era maps to support their planning. They also discovered that many detachment members lacked the Top Secret clearances needed to access some of the information concerning potential operations.

The detachment planning also exposed another serious deficiency: a lack of leadership profiles. In a classic unconventional warfare scenario, a "pilot team" would link up with and assess the resistance movement's leaders and overall readiness. This information would be gathered in a dossier passed on to the detachments during isolation so that they could conduct detailed planning. But pilot teams and dossiers for resistance leaders whom they would most likely advise- Mohammed Fahim Khan and Abdul Rashid Dostum-did not exist. They would have to rely on CIA intelligence officers to introduce them and on their Robin Sage training to carry them forward.

The staffs and detachments also recognized that standard military-issued equipment might not be suitable for the environment in Afghanistan, which set off a mad scramble to procure needed items from stores such as REI, Bass Pro Shop, and other specialty outfitters. It was only the first of many logistical problems that the detachments would encounter in the early days of Operation Enduring Freedom.

\section{Organizing for combat}

As planning furiously continued, an advance party deployed to Uzbekistan's K2 airbase in late September 2001 to begin the assessments and coordination necessary to receive additional forces. Soon afterward, other forces began to move to K2 in accordance with a hastily developed deployment plan, but ongoing negotiations and a lethargic Uzbek bureaucracy stalled their arrival. This caused a significant backlog of C-17 aircraft at airfields across Europe. At this point, Secretary of Defense Donald Rumsfeld personally intervened and on October 5, 2001, received permission from Islam Karimov, the president of Uzbekistan, to use $\mathrm{K} 2$ for search and rescue operations. ${ }^{24}$

On October 6, C-17s began arriving at K2 approximately every two hours. Over the course of the next week, the American population at the base swelled from 100 to more than 2,000. The following day, Operation Enduring Freedom officially began with airstrikes on key Taliban targets across Afghanistan. ${ }^{25}$

Twelve days later, on October 19, the first U.S. forces set foot on the ground in Afghanistan. ${ }^{26}$ Other U.S. SOF conducted an airborne assault on an airstrip outside Kandahar and an airmobile assault on the compound of Mullah Muhammad Omar, the elusive Taliban leader, in Kandahar, while helicopters from the 160th Special Operations Aviation Regiment inserted two 5th Group ODAs (595 and 555) in the mountains of northern Afghanistan to link up with Khan and Dostum. ${ }^{27}$

The former Soviet airbase may have been ideal in terms of geographic proximity, but it was deeply flawed in many ways. Littered with abandoned Soviet equipment, trash dumps, contaminated soil, and an absence of functional latrines, it made for squalid living conditions. The constant stream of personnel, aircraft, equipment, and supplies from multiple units, headquarters, and services made it chaotic. The limited space and poorly defined command relationships between the Air Force and Army personnel at the base also added to the confusion.

Ultimately, the Air Force Joint Special Operations Aviation Component responsible for the combat search and rescue mission merged into the JSOTF-N commanded by Mulholland. This unique, nondoctrinal arrangement set off another round of headquarters and staff integration and adaptation on the fly.

I arrived at K2 on the night of October 26, 2001. As the operations officer for 5th Group's 3rd battalion, I had been tasked to establish the tactical operations center for an Army Special Operations Task Force. Within minutes of my arrival, however, I was directed to report to the isolation facility for planning. I discovered that Mulholland had decided to insert his battalion commanders as liaisons to the senior resistance 
commanders. My commander, Lieutenant Colonel Max Bowers, had been assigned to assist Dostum and provide command and control for detachments operating with Northern Alliance forces in the vicinity of the Darya Suf Valley.

Bowers had assembled an ad hoc team-including me and a Special Forces communications sergeantto accompany him. We were designated as Special Forces Operational Detachment Charlie (ODC) 53. Three of the other team members came from the battalion's Bravo Company. Since I had commanded the company until June 2001, I was intimately familiar with them. The last two members of our team were two U.S. Air Force Joint Terminal Attack Controllers to control aircraft essential to the mission. They were highly trained and competent patriots, but none of us had ever met, trained, or operated with them. It was, to say the least, a highly unusual situation.

The decision to send battalion commanders "into the box," ostensibly to provide more senior advisors, had several important consequences.

First, although the ODC had been part of Special Forces doctrine in the Vietnam era, it was no longer part of our doctrine. We simply were not organized or equipped for the mission, and, more importantly, we had never trained specifically for it. Now, with an ad hoc and hastily assembled "team," we prepared to go deep into Afghanistan to wage unconventional warfare against the Taliban.

Second, it disrupted the task organization of the battalion headquarters and one of the company headquarters; it left the battalion executive officer in command and split up a company headquarters. Large portions of the battalion staff were then conscripted as augmentees to the JSOTF.

Third, it altered the entire command and control structure. Lieutenant colonels on the ground with limited communications and focused on advising an Afghan commander were in no position to exercise command and control; the environment was too fluid and dynamic. Instead, the ODAs and ODCs ended up reporting directly to Task Force Dagger in contrast to doctrine that called for two intermediate headquarters between the ODAs and the JSOTF. Mulholland, through his fledgling JSOTF staff, now had a large and growing span of control.

This had a tertiary effect on an already stretched logistical system. Typically, the company and battalion headquarters would handle the logistics support for the detachments. Dedicated teams of individuals familiar with each detachment and their mission, known as area support teams, were supposed to shepherd the detachments' resupply requests. In conjunction with the battalion staff, they would build and inspect resupply bundles to ensure the teams had what they needed.

Unfortunately, most of the logistics support came from Incirlik, Turkey, under the command of Special Operations Command Europe, and there were no area support teams there to assist. The combination of untested staffs, extremely long supply lines, and poor communications would lead to a high number of unfilled requests and immense frustration.

Irrespective of the unusual situation, everyone on ODC 53 recognized the importance of the mission and diligently attempted detailed mission planning. Much like the other teams, there was a great deal of information that the ODC lacked, so assumptions and contingency plans had to be made. After several days of planning and preparation, the ODC was ready to go.

\section{Infiltration and planning with the Northern Alliance}

The harsh and unpredictable weather in the Hindu Kush Mountains posed a significant challenge for infiltration. The conditions limited the amount of cargo the MH-47E helicopters could carry, and we had to abandon a plan to take a small pickup truck for mobility. In its place, the ODC requested two John Deere "Gators," six-wheeled all-terrain vehicles, from an infantry battalion of the 10th Mountain Division that provided base security at K2. They obliged.

The weather also caused multiple delays. For three consecutive nights, the ODC loaded onto helicopters with engines running only to disembark two hours later. At one point, Task Force Dagger's energetic 
executive officer came up with a plan to conduct an airborne infiltration using "rough terrain suits" on a short, narrow drop zone on a mountain plateau.

Typically, only Army airborne engineer units use rough terrain suits. These heavily padded canvas suits, with a helmet resembling those worn by National Football League linebackers, were designed to allow the engineers to jump in wooded terrain to clear landing zones. None of us were confident that they would protect us if we missed the landing zone and tumbled down the mountain. Moreover, none of the team had ever parachuted with one. The idea was quickly abandoned, and luckily the weather cleared enough on the night of November 2 to complete the infiltration.

ODC 53 infiltrated using MH-47 helicopters. The flight to Landing Zone Burro-which included aerial refueling, low-level "nap-of-the-earth" flying, and a false insertion-took three and a half hours. Dostum would later tell us that his forces had alerted him to helicopters long before we arrived.

Landing Zone Burro was a relatively small but level area along the Darya Suf River, approximately 120 kilometers south of Mazar-i-Sharif. The ethnic Uzbek militia of Dostum's Junbesh-i-Milli political party had sought refuge in these mountains after the Taliban seized control of Mazar-i-Sharif in 1998. Three years in this wilderness had taken its toll, and they were in dire need of assistance.

Our pulses quickened as the helicopters set down on Landing Zone Burro. Even though we knew that ODA 595 and CIA officers would be there to meet us, we were unsure of what to expect. It was around 3 AM local time. The moon had set, and the remote valley was devoid of electricity or ambient light. As we began to off-load our extremely heavy rucks (military backpacks), hands reached out of the total blackness and grabbed them.

Due to the darkness, the roar of the engines, and the rotor wash, we could not see the faces of those grabbing our gear, but we continued to offload. After about a minute on the ground, the helicopters departed into the darkness. To our relief, we soon discovered that a couple of the helping hands belonged to members of ODA 595.

Dostum was asleep, and we all agreed that there was no need to wake him. During the Afghan Civil War, Dostum had gained a reputation as a ruthless warlord, and we did not know what to expect. Unverified stories of his cold-blooded deeds and perfidy seemed to dominate what little information we received before infiltration. It was difficult to sort fact from fiction. Yet ODA 595 had been on the ground with Dostum for two weeks and had suffered no harm. In fact, ODA 595 found that Dostum had been especially protective of them, fearing that any harm to the Americans would destroy his relationship with the United States and his opportunity to defeat the Taliban.

After receiving a detailed update on the situation, we established security and initiated our sleep plan. We met Dostum later that morning and began efforts to build rapport. It was a complex task, since ODA 595 had already been on the ground with Dostum for two weeks, earning his trust, confidence, and a certain fondness. He was reluctant to see that bond broken and remained closer to the ODA 595 commander than any other American.

My initial impression was that while Dostum was deadly serious about defeating the Taliban, he was also gregarious, with a quick wit and sense of humor. Standing well over six feet tall, he seemed a giant in comparison to his subordinates and rode a white stallion that was also much larger than the other horses. In conversation through translators, he came across as intelligent and insightful, even if not particularly well educated.

At any rate, he had earned the respect and loyalty of his forces and the affinity of ODA 595. The feelings were mutual, and he seemed perturbed that a new group of Americans now imposed themselves on their happy marriage. He insisted on keeping the detachment commander at his side and only reluctantly accepted ODC 53. His indifferent attitude toward ODC 53 would have real consequences later during the offensive up the Darya Suf Valley.

The local portion of the Northern Alliance comprised Uzbek forces under Dostum, Tajiks under Mohammed Atta, and Hazaras under Haji Mohaqqeq. They were united by a shared hatred of the Taliban, 


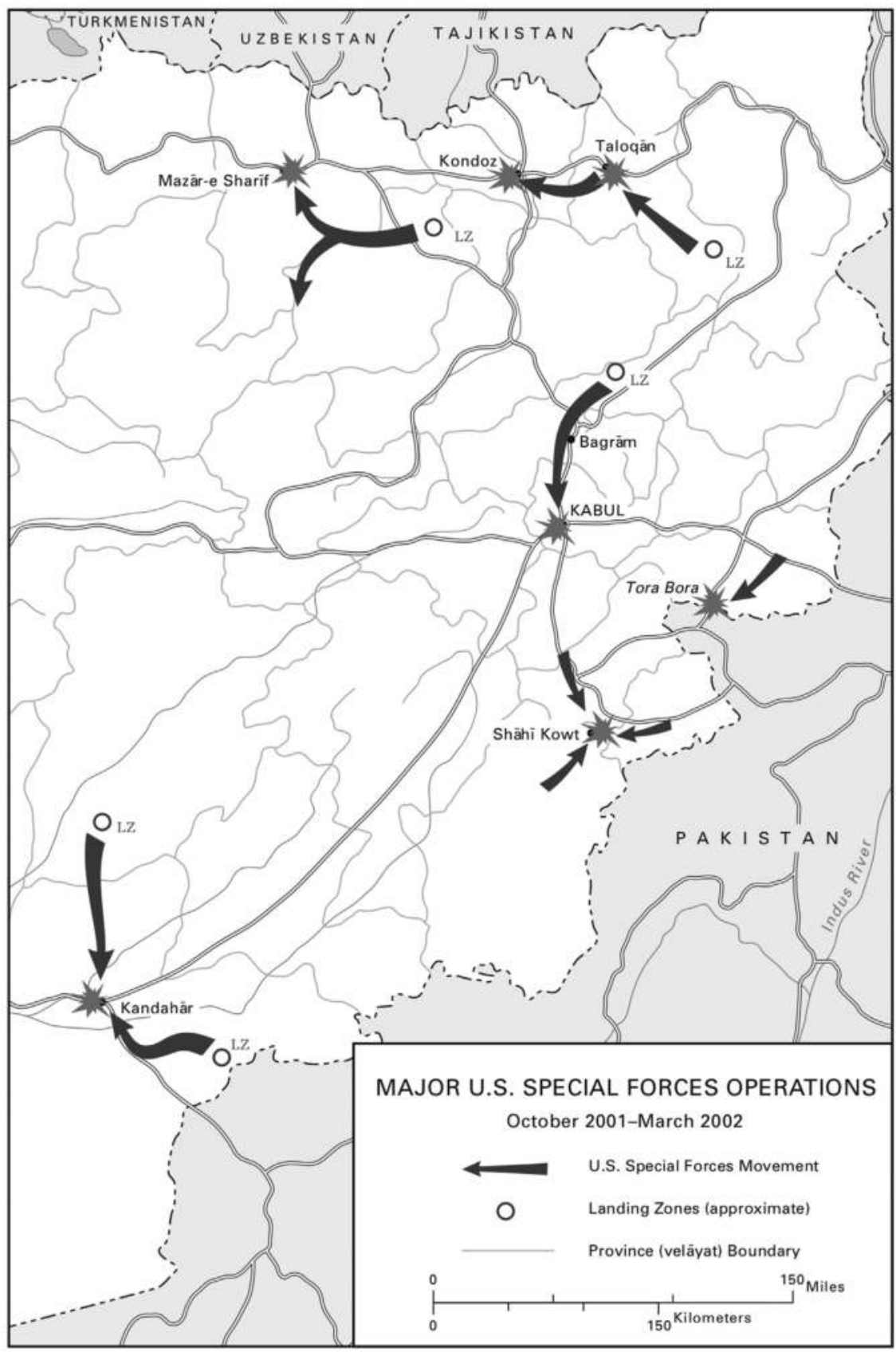

Figure 17.1 Major U.S. Special Forces operations in Afghanistan, 2001-2002. ${ }^{28}$

Source: This map appears in Operation Enduring Freedom (Washington: Center of Military History, no date), 9, retrieved from https://history.army.mil/html/books/070/70-83/cmhPub_70-83.pdf. 
but little else, and were already planning a major offensive to recapture the strategically important city of Mazar-i-Sharif. A detachment provided advice and assistance to each faction. ODC 53 was responsible for coordinating and synchronizing the detachments and the Northern Alliance forces and deconflicting the U.S. airpower essential to their success.

We spent the next several days near Landing Zone Burro establishing rapport, which included providing medical treatment to Afghans who had been wounded in battle. We also conducted battlefield reconnaissance on horseback and coordinated for delivery of small arms and ammunition, as well as blankets, horse feed, and cold weather clothing and gear.

Dostum was frustrated and anxious with the pace of support. General Franks had personally promised aid, but it had yet to arrive. Dostum's forces were desperately short of arms and ammunition, and their ability to launch an offensive was contingent on receiving enough supplies to carry them to Mazar-i-Sharif.

Dostum asked us directly, "Why does [General Franks] promise things he can't deliver?" Franks, however, did not share the same sense of urgency, because CENTCOM was operating on a much different timeline. The initial plan envisioned Special Forces training and equipping the Northern Alliance during the winter months and conducting a coordinated offensive in the spring. Dostum, however, was ready to launch the offensive now.

Another fact that Dostum did not fully grasp was that the Department of Defense did not have stocks of weapons and ammunition to provide to indigenous forces. It did not matter that a core part of the Special Forces' unconventional warfare mission specified equipping and training indigenous forces. The U.S. military had neither the Congressional authorization nor funding to purchase and maintain weapons stockpiles for use by foreign irregular forces.

Our team did not fully understand this reality, either. In training, we used the Army's communications standard operating procedures, which included codes for prepackaged sets of weapons and ammunition, ${ }^{29}$ and we assumed that there were warehouses with stockpiles from which these prepackaged sets would be drawn. But these stockpiles, as well as backup equipment for our own gear, did not exist. As a result, we had to rely on the CIA to provide necessary aid. Our backup equipment was stripped from units not committed to the fight.

Ultimately, Dostum's initial aid was delivered on November 4. Unfortunately, not one of the 20 bundles landed on the drop zone (the same small area associated with the rough terrain suits). Wind blew many of the bundles over the side of the rugged cliffs. Some of the bundles came crashing down very close to our encampment, sending us scrambling into the caves where we had been living. Other bundles ended up suspended on the cliffs when the parachutes snagged on the rocks.

Using the John Deere Gators, ODA 595 and a coterie of Afghans retrieved what they could in the darkness, and retrieved some, but not all, of the suspended bundles the following day. In a typical snafu, the cold-weather clothing and boots came in a range of sizes typical for an average American unit, but not a typical Afghan militia. The average Afghan was of slighter stature, and the clothing and boots were generally too large. Thus, it was not uncommon to see an Afghan wearing a Gortex parka that went down to his knees.

Planning and executing a synchronized offensive by three independent and geographically dispersed militias from multiple avenues of approach is a difficult task under any conditions. It was made even more difficult by the arduous mountains, poor communications, and language barrier.

For communications with Task Force Dagger, we relied principally on data burst transmissions using a high-frequency radio. We had satellite phones and a satellite communications radio for voice communications, but the phone was unreliable, and the radio could only be used from a stationary location. For intrateam communications, we used secure FM radios, although the terrain limited their range. There were long periods of time when we had no direct communications with anyone but our Afghan counterparts. 
With the assistance of intelligence officers and a handful of Afghans who spoke English, the ODAs and ODC 53 assisted the Northern Alliance in developing a reasonably coherent plan to retake Mazar-i-Sharif. If successful, it would set the stage for liberating all of northern Afghanistan from the Taliban.

During planning, Dostum requested additional aid and "true" close air support. As a countermeasure against man-portable air defense systems, U.S. aircraft could not fly lower than 15,000 feet above ground level. Dostum, a former general in the Afghan army, believed it was necessary to fly lower to hit smaller and rapidly dispersing Taliban forces. He also wanted close air support continuously available on short notice to take advantage of fleeting opportunities. Neither request was granted, but Dostum did receive some additional air support for the offensive to seize Mazar-i-Sharif.

The offensive on Mazar-i-Sharif began on November 5, with the delivery of two BLU-82 15,000 pound conventional bombs, known as the "Daisy Cutter," by a special operations MC-130 aircraft. Originally designed to clear jungle landing zones in Vietnam, we chose to use this unguided weapon mainly for its psychological effect. With Dostum's input, we selected a previously abandoned village that the Taliban had occupied. Yet out of a misplaced concern for civilian casualties where there were no civilians, the target was moved to an open area several kilometers from the original target. If it had any effect on the Taliban, it was not discernable.

The offensive immediately encountered stiff resistance from Taliban forces reinforced by al-Qaida volunteers. Eventually, ODA 595 successfully directed precision airstrikes on Taliban positions, allowing Northern Alliance forces to break through the initial resistance. Every U.S. soldier and airman, except for a handful using the John Deere Gators, received horses to ride during the offensive. There were no "extra" horses available, so for each horse ridden by an American, an Afghan soldier had to walk.

The saddles were made of wood with remnants of Oriental rugs tacked on for "cushioning." As hard as the saddles were on us, they could be much harsher on the horses, which were not accustomed to bearing American soldiers loaded with our individual gear, such as radios, batteries, ammunition, and water.

The stirrups on the saddles were also too small for our large boots, making it difficult to firmly position our feet in the stirrups. We had to learn how to jam the toe of our boots into the stirrups while mounted. An experienced horseman on ODA 595 had requested proper saddles for the horses, but due to the extended and chaotic logistical support, the saddles would not arrive until long after we had liberated Mazar-i-Sharif and transitioned to vehicles.

For the most part, we had little, if any, experience riding horses, especially in the rugged mountains of Afghanistan. We had to learn and adapt quickly if we wanted to keep up with our experienced hosts. The Afghans navigated these trails not by maps but by memory. They had difficulty describing our destinations, so we had to follow them. Once the offensive began, we would ride for hours at a time, sometimes up to 10 hours, along narrow and winding mountain trails.

Some of the night rides were especially harrowing as we traversed trails on the edge of deep canyons. The canyons were so deep at times that we could not see the bottom even with our night vision goggles. Rest halts could be troublesome as well. Due to the complete lack of ambient light, upon which our night vision depended, it was difficult to see when the group began moving again. We experienced multiple "breaks in contact" during our rides, but we miraculously always managed to link up again.

\section{Combat offensive to seize Mazar-i-Sharif}

With ODA 595 directing effective airstrikes on Taliban positions, the offensive managed to reach its designated objectives on the first day but encountered more heavy resistance at the final objective: the village of Boi Becha. With an effective defense employing well-placed machine guns, the sizeable Taliban force repelled several assaults by Dostum's forces. 
In a last-ditch effort to seize the critical terrain on which the village sat, Dostum massed nearly 1,000 mounted riflemen in three ranks behind a small ridge not far from the village. On command, the three ranks lurched forward and moved over the ridge. As they cleared the ridge, they charged the village, breaking into a full gallop and firing their rifles at the Taliban positions. They routed the Taliban, with survivors fleeing further up the valley. We had witnessed the first cavalry charge of the 21 st century.

Fighting continued in the Darya Suf Valley for five more days. Despite some fierce resistance, the Northern Alliance troops, flush with new arms and ammunition and energized by the effectiveness of American airpower, steadily drove the Taliban and their al-Qaida allies northward. Whenever we stopped, Dostum's staff would pull out a 12-volt car battery and a citizens band radio that the general would use to contact the Taliban and supporting militia leaders. In a typical Afghan scheme, Dostum skillfully used the threat of American airstrikes to cut deals with some militia leaders allied with the Taliban. As his forces neared, some of these militias abandoned the Taliban and switched sides.

At one point during the drive to Mazar-i-Sharif, irritation with the ODC 53 commander turned Dostum's indifference to enmity. While stopped for several hours at one of their mountain redoubts, Dostum was apparently insulted by the tone and content of the advice he received from the commander. He advised us that he was going on a reconnaissance mission with members of ODA 595 and needed our horses. He left us with an interpreter and vowed to send the horses back to us in a few hours. Thirty-six hours later, it was abundantly clear that the horses would not be returning; he had abandoned us on the mountaintop. A pointed discussion with our interpreter confirmed our suspicions: it was a deliberate decision by Dostum. We were now on our own.

With the reluctant help of our interpreter, we rented local burros using $\$ 100$ bills. We had carried tens of thousands of dollars in cash, called an "operational fund," for just such an emergency. We used the burro to carry our gear off the mountaintop and set out to regroup, hopefully with friendly forces. The night was pitch black, and once again our night vision goggles were of limited utility. We followed a heavily rutted trail that we hoped would lead us to the valley below. During the march, one of the burros stumbled in a rut and ended up on its back unable to move due to the weight of our gear. It was hard not to laugh at the plight of this unfortunate animal, but we unstrapped the hapless and frustrated beast, got it back on its feet, remounted all the gear, and moved out again.

Passing quietly through several unmarked villages, so as not to provoke gunfire from frightened residents, we eventually reached the river valley. With the moon now lighting the sky, we crossed to the road on the east side of the river and began marching northward. We were fortunate enough to find a group of Hazara militia waiting for transportation to the front lines. After several hours, a convoy of jinga ${ }^{30}$ trucks arrived, and we piled into the back with what seemed to be 100 Hazaras.

Just after dawn, we reached the town of Shulgera where Dostum had halted his advance and linked up with ODA 595 and the CIA officers-almost two full days since we had last seen them. If Dostum was surprised to see us, he never let it show, and we continued as if nothing had happened.

On November 10, the Northern Alliance forces seized control of the gateway to Mazar-i-Sharif, the Tangi Gap. Beyond this gap lay open plains to the city of Mazar-i-Sharif, a mere 30 kilometers away by road. The battle for the gap was not without cost. The Taliban had heavily mined the gap, which led to the deaths of numerous Northern Alliance soldiers and horses, as well as destroyed vehicles. In the small villages along the road to Mazar-i-Sharif, thankful crowds lined the road and cheered on the Northern Alliance as they pursued fleeing Taliban into the heart of Mazar-i-Sharif.

A contingent of nearly 200 Taliban and al-Qaida fighters seized the Sultan Razia Girls School in the heart of Mazar-i-Sharif, where they chose to make a stand. Located only one-quarter mile from the famed Blue Mosque at the center of the city, the multistory building provided a good vantage point for the Taliban defenders. ODA 595's request for airstrikes on the school caused significant concern at Task Force Dagger, which worried about civilian casualties in the surrounding areas and the possibility of 
damaging the Blue Mosque. Given the exigency of the circumstances, ODA 595 received permission and carried out a series of airstrikes around the school before the Northern Alliance routed the remaining Taliban.

Once in Mazar-i-Sharif, we moved to Qala-i-Jangi, an 18th-century British mud fortress about 5 kilometers southwest of the city. The fortress had served as Dostum's headquarters until the Taliban seized control in 1998. It was stocked with all manner of arms and munitions, including cases of World War I-era bayonets for the 1903 version of the Springfield rifle. The security situation in the city was still tenuous as Taliban sympathizers went into hiding.

The unsteady alliance of Uzbeks, Tajiks, and Hazaras started to show strains almost immediately as the factions staked out territory and competed for post-conflict influence and control. After two weeks at the fortress, the commander of ODC 53 decided to establish an independent U.S. compound on the east side of the city, much nearer to the airfield that would become essential to continued operations. We occupied the Turkish School, a five-story concrete building surrounded by a 10 -foot wall.

Although the Northern Alliance now controlled Mazar-i-Sharif, the Taliban was reportedly massing forces for a counteroffensive in the city of Kunduz, 170 kilometers east of Mazar-i-Sharif. As Northern Alliance forces began to move eastward, they encountered a convoy of trucks with approximately 600 Taliban and foreign al-Qaida fighters. After a standoff and negotiations, which included a suicide bomber that killed Dostum's intelligence chief, the group surrendered. A small force, consisting of soldiers who were not fit to fight at Kunduz, escorted the trucks to Qala-i-Jangi. But they failed to search the trucks or prisoners because they "had given their word" that they would no longer fight.

The next day, using smuggled weapons, the prisoners staged an uprising, killing CIA officer Mike Spann and seizing control of the fortress, including its stockpile of weapons. ${ }^{31}$ An unknown number of prisoners escaped into the surrounding area, and local villagers captured and killed some of those fleeing. The large majority, however, remained in the fortress, and a three-day battle ensued with members of ODC 53 directing "danger-close" airstrikes with 2,000-pound guided bombs and AC-130 gunships against the former prisoners.

One bomb mistakenly struck a U.S. position, wounding five Americans and four members of a United Kingdom Special Boat Service detachment that had arrived the prior day. The errant strike also killed several Afghans and destroyed a T-55 tank, but all of the Americans and Brits survived. ${ }^{32}$

The battle concluded when the survivors, who had barred themselves in the basement of a building, were forced out after Dostum's men flooded the basement with water. Of the original 600 prisoners, only 85 survived. Among the survivors was Johnny Walker Lindh, an American convert to Islam who had made his way into Afghanistan via Yemen and Pakistan. He was not discovered until several days after the battle, but was eventually returned to the United States, convicted in federal court of providing support to terrorists, and sentenced to 20 years in prison. ${ }^{33}$

After the battle, our attention turned to re-opening the Mazar-i-Sharif airport, which had been heavily damaged by the U.S. Air Force during the opening salvos of the war. Five large craters, each about 30-40 feet wide and 15-20 feet deep, were neatly spaced down the length of the runway and, for good measure, another four bombs created a single large crater that ran perpendicular to the runway. Hazardous munitions also littered the airport.

The road to Uzbekistan, however, was heavily mined and would take months to clear. With the onset of winter, the internally displaced persons living in squalid camps around Mazar-i-Sharif faced not only the harsh weather but also starvation. The only way to move enough relief supplies to Mazar-i-Sharif was by air, and Task Force Dagger ordered that we repair the runway.

Repairing a deliberately cratered airfield is a challenge even under the best of conditions. With no heavy equipment, asphalt, gravel, concrete, or engineers available, it seemed impossible. But no one should doubt the creativity and determination of the Green Berets. We accomplished the mission with assistance 
from one Air Force "RED HORSE" engineer sergeant, ${ }^{34}$ some talented U.S. Army mechanics, local labor, and Uzbek smugglers.

Our mechanics repaired an abandoned Soviet steamroller, while we used our operational fund to pay locals to haul smooth river rock from nearby creek beds. We then purchased 55-gallon drums of tar from smugglers. Under the supervision of the RED HORSE engineer, we filled the craters with river rock and then compacted the holes with the steamroller. We used an open fire to melt the tar, which we then poured over the rocks.

We repeated the process until the surface was level and we had enough runway to land a C-130 cargo plane. The Air Force Joint Terminal Attack Controllers were trained in air traffic control, and over the course of the next few weeks, we landed over 200 aircraft, including American C-17 and Russian IL-76 cargo jets. The Red Cross delivered humanitarian aid, which we helped distribute to the refugee camps, ameliorating some of their suffering and avoiding starvation.

In the weeks after the fall of Mazar-i-Sharif, Taliban resistance crumbled in city after city, including Kabul. By early December, the Taliban had ceased to exist as an effective fighting force or government. On December 22, an interim Afghan government was inaugurated in Kabul. ${ }^{35}$

Although it would be a decade before the United States finally found and killed Bin Ladin, and the Taliban would eventually reconstitute in the tribal areas of Pakistan, the men and women of Task Force Dagger and our brethren in the intelligence community had accomplished a stunning victory. We had achieved what many considered impossible: a force of several hundred Americans and disparate militias, backed by airpower, had outmaneuvered, outfought, and defeated the Taliban, driving them from power in a matter of weeks. In late January 2002, we handed over the mission of rebuilding Afghanistan to conventional forces and returned to Ft. Campbell the following month.

\section{Lessons learned}

\section{The lengthy Special Forces training is worth the investment}

We succeeded in an extremely difficult environment. Simply put, our training in the qualification course was spectacular. The Special Forces assessment and selection had identified the soldiers with the necessary determination, ingenuity, and adaptability. The qualification course, especially Robin Sage, had equipped us with the required skills to tackle all the situations we encountered. It is difficult to count the number of times that we remarked to each other, "This is just like Robin Sage!” Whether establishing rapport, dealing with a mercurial guerrilla chief, or sorting out factional rivalries, we had experienced it all in our training. In the case of ODC 53, individual skill and determination overcame a lack of prior collective training. The success as a collective organization was a testament to the Special Forces training and selection process.

\section{Logistics must be tested prior to combat}

Although we had great individual and collective training at the battalion level and lower, it relied on a fictional logistical concept and acquisition authorities that had never been truly exercised. When higher headquarters did participate in multi-echelon training, it focused on command and control, not unconventional warfare logistics with intercontinental supply lines. Had we participated in such an exercise, or tried to, we would have realized that the equipment and warehouses on which we expected to rely did not exist; the U.S. government did not have stockpiles of weapons and ammunition for guerrilla forces.

Additionally, we had never exercised logistical interoperability with other U.S. government departments and agencies. Consequently, we did not really understand the limits of their ability to support our operations. This led to an embarrassing incident after the Northern Alliance turned to Iran out of frustration 
with our inability to supply them with uniforms. We were shocked and dismayed when an Iranian C-130 landed bearing new police uniforms for the fledgling force.

While Special Forces operating in denied areas can sometimes rely on local procurement for resupply, this was not viable in the mountains of Afghanistan. Prior to our arrival, the Northern Alliance had exhausted their own supplies and were under pressure, barely subsisting, and losing territory to the better equipped and supplied Taliban forces. Consequently, our resupply of food, ammunition, equipment, and other supplies was wholly dependent on aerial delivery by parachute.

We once made the mistake of using the same drop zone twice in Mazar-i-Sharif, and we found ourselves in a foot race to the bundles with the locals. The drop contained a mixture of equipment for the U.S. teams and general supplies for the Northern Alliance, but there was no way to distinguish the bundles in the darkness. In the chaos, the local pillagers absconded with important equipment and supplies. Worse, Task Force Dagger could not provide a complete inventory of the equipment, making it nearly impossible to determine what had been lost. Thanks largely to luck, we determined that some locals had absconded with a box of equipment containing weapons sights and other components. Although the equipment was eventually recovered, it was a painful reminder of our logistical frailty.

Had we truly tested the logistics system in training, we might have realized that we did not maintain a sufficient system of operational "floats"—radios, weapons, and other types of equipment - to replace our operational losses or the legal authority to purchase police uniforms.

\section{The lack of war plans or war games negatively impacted operations}

There was a complete absence of plans to go to war in Afghanistan under any conditions, resulting in a massive whole-of-government crisis planning after 9/11. Our diplomats negotiated basing rights and authorities on the fly, causing delays and adding uncertainty to our planning efforts. The crisis planning also meant that parallel planning was initiated without the benefit of war gaming, synchronization, deconfliction, and integration that would normally occur in sequential planning.

The consequences of the highly compressed planning timeline were significant. For example, even though the Taliban did not pose a real threat to U.S. air superiority, the Air Force planners nonetheless chose to destroy the runway at Mazar-i-Sharif because that is what they always do. Even a single war game conducted prior would have shown this was unnecessary.

\section{Command and control must be rigorously designed and tested in peacetime}

An effective command and control system is essential for success in a multi-dimensional, joint (multiservice), and combined (multinational) combat environment. This conflict, however, exposed a significant disconnect between our doctrine and peacetime organization and the demands of expeditionary warfare. For various reasons, we abandoned our Army and joint doctrine regarding command and control in several important ways. In the middle of a crisis, we created command and control structures and relationships with which we had never experimented in peacetime, including the ODCs. The combined staffs had not trained together and had no standing operating procedures.

Moreover, since the units involved were not designed to support either the new structures or 24-hour operations, commanders had to rely on large numbers of individual augmentees. Most of these augmentees had little or no familiarity with the unconventional warfare mission, the units involved, the commanders, or the environment. They were nevertheless called on to perform critical staff and liaison functions. These hybrid organizations effectively eliminated multiple levels of command, destroyed unit integrity, and left the ad hoc Task Force Dagger staff with an overwhelming span of control. All of this reflected a combination of outdated doctrine and faulty assumptions about the strategic environment and a failure to rigorously design, test, and evaluate our command and control structures in peacetime. 


\section{Notes}

1 George W. Bush, Statement by the President in His Address to the Nation (Washington, DC: White House, 2001).

2 Leigh Neville, Special Operations Forces in Afghanistan (Oxford: Osprey, 2008), 8.

3 See, for example, Center for Military History, Operation Enduring Freedom: October 2001-March 2002 (Fort McNair: Center of Military History, no date), 12.

4 Gary Berntsen and Ralph Pezzullo, Jawbreaker: The Attack on Bin Laden and al-Qaeda (New York: Crown, 2005), 312.

5 Usama bin Ladin escaped to Pakistan, and it would be a decade before he was finally found and killed by the United States.

6 Joint Chiefs of Staff, Special Operations, JP 3-05 (Washington, DC: Joint Chiefs of Staff, 2011), II-9.

7 See, for example, Joint Chiefs of Staff, Doctrine for Joint Special Operations, JP 3-05 (Washington, DC: Joint Chiefs of Staff, 1998), II-6.

8 Special Forces soldiers are commonly referred to as "Green Berets" for the distinctive headgear that they are awarded upon completing the long and arduous Special Forces Qualification Course.

9 Two examples of special skills training include military free fall parachuting or underwater operations.

10 Mark Price, "Unconventional Warfare Training Being Staged in 21 North Carolina Counties," Charlotte Observer, August 21, 2019, www.charlotteobserver.com/news/local/article234211482.html.

11 Francis J. Kelly, U.S. Army Special Forces, 1961-1971 (Washington, DC: Department of the Army, 2004).

12 The Green Berets, Rambo, The Deer Hunter, and Apocalypse Now portrayed Green Berets as rogues at best and renegade, mentally unstable killers at worst.

13 "5th Special Forces Group (Airborne) History," U.S. Army Special Operations Command, accessed October 15, 2020, www.soc.mil/USASFC/Groups/5th/5thSFGHistory.html\#: :text=The $\% 205$ th\%20SFG\%20(A)\%20added, and\%20returned\%20in\%20April\%201991.

14 It was called Operation PROVIDE COMFORT. See "10th SFG(A) History," U.S. Army Special Operations Command, accessed October 15, 2020, www.soc.mil/USASFC/Groups/10th/history.html.

15 "5th Special Forces Group (Airborne) History," U.S. Army Special Operations Command.

16 Micah Zenko, Between Threats and War: Discrete Military Operations in the Post-Cold Era (Stanford: Stanford University Press, 2010), 66.

17 White House, A National Security Strategy for a New Century (Washington, DC: White House, 1999).

18 Ibid.

19 James Bennet, "U.S. Cruise Missiles Strike Sudan and Afghan Targets Tied to Terrorist Network," New York Times, August 21, 1998, www.nytimes.com/1998/08/21/world/us-fury-2-continents-overview-us-cruise-missiles-strikesudan-afghan-targets.html.

20 “Taliban Again Refuses to Turn Over Bin Laden," Associated Press, October 2, 2001, www.nytimes.com/2001/10/02/ international/taliban-again-refuses-to-turn-over-bin-laden.html.

21 Joint Chiefs of Staff, Doctrine for Joint Special Operations.

22 Charles H. Briscoe et al., Weapon of Choice: U.S. Army Special Forces in Afghanistan (Fort Leavenworth: Combat Studies Institute Press, 2003), 41.

23 Department of the Army, Special Forces Detachment Mission Planning Guide (Washington, DC: Department of the Army, 2012), 2.

24 C.J. Chivers, “2nd Wave of Troops Arrives in Uzbekistan,” New York Times, October 8, 2001, https://movies2. nytimes.com/2001/10/08/international/asia/08UZBE.html.

25 Patrick E. Tyler, "U.S. and Britain Strike Afghanistan, Aiming at Bases and Terrorist Camps; Bush Warns 'Taliban Will Pay a Price'," New York Times, October 8, 2001, www.nytimes.com/2001/10/08/world/nation-challengedattack-us-britain-strike-afghanistan-aiming-bases-terrorist.html.

26 "U.S. Special Operations Troops in Commando Raid," CNN, October 22, 2001, www.cnn.com/2001/WORLD/ asiapcf/central/10/19/ret.afghan.attacks/index.html.

27 Neville, SOF in Afghanistan, 11-14.

28 This map appears in Operation Enduring Freedom (Washington, DC: Center of Military History, no date), 9, https:// history.army.mil/html/books/070/70-83/cmhPub_70-83.pdf.

29 The Army's Standard Audiovisual Services Supplement (SAV SER SUP).

30 A jinga truck is a highly decorated cargo truck common in South Asia.

31 Richard A. Serrano, "Detainees Describe CIA Agent's Slaying," Los Angeles Times, December 8, 2004, www. latimes.com/archives/la-xpm-2004-dec-08-fg-prison8-story.html.

32 Carlotta Gall, "A Nation Challenged: Mazar-i-Sharif; U.S. Bomb Wounds G.I.'s as Battle Rages at Fort," New York Times, November 27, 2001, www.nytimes.com/2001/11/27/world/a-nation-challenged-mazar-i-sharif-usbomb-wounds-gi-s-as-battle-rages-at-fort.html. 
33 Katharine Q. Seelye, "Regretful Lindh Gets 20 Years in Taliban Case," New York Times, October 5, 2002 , www. nytimes.com/2002/10/05/us/threats-responses-american-taliban-regretful-lindh-gets-20-years-taliban-case.html.

34 The U.S. Air Force Rapid Engineer Deployable Heavy Operational Repair Squadron Engineer (RED HORSE) squadrons are "civil engineering SWAT teams." See Peter Grier, "The RED HORSE Way," Air Force Magazine, February 1, 2003, www.airforcemag.com/article/0203redhorse/.

35 "New Afghan Government Takes Control," ABC News, December 22, 2001, https://abcnews.go.com/Inter national/story? $\mathrm{id}=80300 \&$ page $=1$. 
18

\title{
SPECIAL OPERATIONS FORCES AND AFGHAN LOCAL POLICE PROGRAMS
}

\author{
Donald C. Bolduc and Chris Hensley
}

U.S. Special Operations Forces (SOF) deployed to Afghanistan in October 2001 to topple the Taliban regime. With the fall of the Taliban and the establishment of a new Afghan government in December 2001, the SOF campaign quickly transitioned from unconventional warfare to counterinsurgency and foreign internal defense employing regular and irregular Afghan forces to improve security.

Security forces are considered "irregular" when they do not fall within the formal security establishment, even if sanctioned and supported by the state. They are more of a militia as opposed to a standing and professional police or military force. ${ }^{1}$ The fall of the Taliban left a security void, and the coalition and new Afghan government determined they had to build Afghanistan's security apparatus from scratch. As a result, they often had to rely on irregular forces to provide security in the more remote areas of the rugged country.

Over the next decade, SOF attempted to address rural insecurity and instability through the integration of regular and irregular forces. Unfortunately, multiple attempts to create irregular security forces ended in failure. The lack of success for an "integrated" approach resulted from two dynamics: Afghan national, provincial, and district governance dysfunction exacerbated by corruption and a rural population characterized by fierce independence and a historical pattern of fighting against the centralization of authority.

But these earlier experiences slowly revealed the costs, benefits, and risks associated with irregular force constructs. Lessons learned from earlier attempts—along with support from academics, innovative SOF leaders, and geopolitical conditions-coalesced in 2009 to enable the development and application of the Village Stability Operations (VSO) and Afghan Local Police (ALP) program, the first truly successful irregular security force since the war's start. It was a balanced "bottom up" and "top down" counterinsurgency approach, with the objective of connecting traditional tribal governance at the village level to the central government at the district and provincial levels.

Key to this objective was empowering rural populations to govern and defend themselves while stabilizing and improving the basic functions of district governance. The approach was unique in that it attempted to integrate security, development, and governance through a balanced, mutually supportive method that would address the underlying sources of instability in rural Afghanistan. The VSO/ALP construct may not be a panacea for all security and stability issues, but this chapter presents it as an effective construct in Afghanistan.

This chapter highlights the evolution of irregular forces in selected areas of Afghanistan in hopes that the lessons learned may prove valuable when considering irregular force employment in similar environments. It starts by discussing some of the implications of a parochial-based security force design. Next, it describes 
some of the earlier irregular security forces: Afghan Security Force, Afghan highway patrolmen, Afghan National Auxiliary Police, and the Afghan Public Protection Program. It then details the development of the Village Stability Operations program and the Afghan Local Police.

\section{Implications of a parochial-based security force design}

Following the defeat of the Taliban, Afghan stakeholders signed the Bonn Agreement authorizing statebuilding efforts by the international community. ${ }^{2}$ It requested support building a security force but did not specify size or type. The international community decided upon a large, centralized Western military design intended to support a strong, democratically elected central government.

Although well intended, this decision failed to fully appreciate the unique nature of Afghanistan's polity, culture, and social structure. Moreover, the force was not designed to counter the Taliban's rural-based insurgency. As a result, the operational performance of the newly created Afghan National Security Forces was inadequate to deal with the re-emerging insurgent threat.

The only successful attempts at relative central authority in Afghanistan's history were those that employed what Thomas Barfield called the "Swiss Cheese" model. He explained that successful rulers and their succeeding dynasties understood that only the most populated and economically prosperous segments of Afghanistan could be centrally governed. Other geographically disconnected areas had to be left to their own tribal and clan forms of governance. ${ }^{3}$

In contrast, central authority is "universal and absolute" in his "Processed American Cheese" model. ${ }^{4} \mathrm{He}$ explained that central authority was never historically extended to distant and remote areas in Afghanistan unless they posed a direct challenge to the state. When they posed a challenge, successful rulers confronted these distant threats by empowering their rival clans and tribes, preventing their access to urban markets, or attacking these challengers to demonstrate the cost of their actions. All of the regimes that tried to govern these distant locals-Amanullah Khan from 1919-1929, the People's Democratic Party of Afghanistan from 1978-1992, and the Taliban from 1996-2001—were ultimately overthrown. ${ }^{5}$

Both Afghan and coalition political representatives, as well as senior military leaders, viewed irregular forces as antithetical to the Western model of a stable democratic state. They were perceived as proxies for warlords or other malevolent actors and a potentially lethal threat to democracy. Critics pointed to the rise of warlords after the Soviet withdrawal as setting conditions for the Taliban takeover of Afghanistan.

Opposition to employment of irregular forces and the lack of a corresponding counterinsurgency strategy strangled attempts at pursuing "bottom-up" irregular force approaches. Some military units attempted to create local, irregular security forces, but these programs slowly deteriorated due to a lack of financial, material, or political support from the international community, the Afghan central government, and those in the military community who believed that a counterterrorism approach was the solution to Afghanistan's problems.

Coalition efforts initially focused on building the Afghan National Army and Afghan National Police. As the Taliban and other insurgent groups grew from 2003-2005, however, coalition operational priorities began to shift toward countering the insurgent threat, which came at the expense of training the army and national police. Regardless, the national army and national police were never going to be large enough to adequately address a rural-based and geographically dispersed insurgent threat.

As a result, United States and coalition efforts to counter insurgent threats and train their partners simultaneously produced an operational methodology focused on short-duration combat operations to clear the enemy with no ability to hold terrain. This led to a counterproductive cycle: coalition and Afghan army elements would clear an area and return to their bases, and then the Taliban would return and eventually reseed the previously cleared territory. The Afghans living in these rural areas recognized that neither the Afghan government nor the Taliban were winning, which resulted in "fence sitting" by a majority of the rural populace. Neutrality ensured their survival. 
The absence of a comprehensive counterinsurgency strategy and long-term vision created a cycle of frustration: American units rotated into Afghanistan, observed the current situation, and formulated plans that would support their tactical priorities, at least for the duration of their stay. This produced objectives and end-states that were tactical and short term: clear a particular geographic area of insurgents, improve a few tactical capacities of a partner, and sprinkle in civil-military development efforts.

Conventional forces would complete their respective rotations and either never return to Afghanistan or return many years later. This cycle prevented senior leaders from recognizing and altering the approach. Conversely, many SOF elements returned year after year. It was not uncommon for some SOF units and leaders to have completed as many as six or eight rotations. This rotational frequency helped reveal the lack of an effective counterinsurgency campaign strategy, assessment framework, and operational progress.

\section{Afghan Security Force (2004-2005)}

Special Forces detachments operating in 2003-2004 recognized a need for Afghan forces to expand their combat power, protect outposts, and gather intelligence, so they began recruiting and employing irregular forces. Over time, these irregular forces became increasingly capable. By 2004, they were labeled the Afghan Security Force. Together with coalition SOF, these forces effectively targeted and neutralized many insurgent fighters and facilitators. Unfortunately, they could not hold terrain, and coalition forces did not focus sufficient attention on the development of the Afghan army. Compounding the challenge was the U.S. invasion of Iraq that made Afghanistan a supporting effort.

Afghan President Hamid Karzai and other government officials became increasingly averse to irregular forces. The Afghan Security Force, however, filled a critical operational need for coalition SOF operating in remote rural areas. The Special Forces detachments developed trust and formed close bonds with their Afghan Security Force partners by living, eating, laughing, and sharing with them. This directly translated into greater security and operational effectiveness. In time, however, the detachments were redirected to partner with the Afghan National Army, and the Afghan Security Force was restricted to base security functions. By early 2006, the 2,000-man force was demobilized. ${ }^{6}$

\section{Afghan highway patrolmen (2006-2007)}

When Lieutenant Colonel Donald C. Bolduc returned to Kandahar in July 2006 to take command of Task Force-31 (TF-31), which had responsibility for southern Afghanistan, some of his Special Forces detachments were on their fourth or fifth rotations. ${ }^{7}$ Predictably, the task force found itself having to regain lost terrain it had secured just months earlier. Having participated in the capture of Kandahar and Karzai's reintroduction to the country in 2001, Bolduc implicitly understood the critical role tribal alliances played in the effort then and what that meant now.

Recognizing the weight of the task ahead, Bolduc encouraged his company and detachment commanders to leverage tribal structures during their rotation in Kandahar, Uruzgan, Zabul, Helmand, Nimroz, Farah, and Herat provinces. This section will focus on the efforts in Uruzgan Province.

Beyond the organic TF-31 elements, coalition forces in Uruzgan Province included 150 Texas National Guard soldiers, U.S. civil-military personnel, Australian special operations elements, and 200 Afghan army soldiers. These units would have to reorganize, unify, and synchronize efforts to improve security conditions. Luckily, the leaders figured out a way to complement each other to achieve a "unity of effort" despite the lack of a "unity of command." Additionally, the 30-day area assessment determined that tribal alliances and power brokers would prove instrumental.

Jan Mohammed, the Karzai-appointed Uruzgan governor, had supported SOF's entry into the country in 2001 but subsequently established a kleptocracy, severely alienating the provincial population. This only fed the Taliban's narrative, enabling them to expand their influence in the province exponentially. 
Conditions were so adverse that coalition forces could not travel safely to the governor's mansion a quarter of a mile from their outpost, and local Afghan security guards hired by the Provincial Reconstruction Team ${ }^{8}$ were found diagramming the coalition bases. Recognizing that significant manpower would be required to alter these conditions, the task force engaged with local officials and tribal leaders.

The advanced operations base (AOB), the name for a deployed Special Forces company, discovered that the governor's right hand-man, Matiullah Khan-who was a member of the Pashtun subtribe known as the Popalzai-was also the provincial tribal leader. By 2005, SOF had learned that capable leaders were critical to making security and stability improvements, so the AOB immediately set out to partner with Khan. Replacing Mohammed was necessary to establish government legitimacy and improve security. The SOF relationship with Khan would be the decisive factor in marginalizing the governor and accomplishing this delicate task.

Khan, the illiterate son of a farmer who had inherited his tribal appointment, maintained power by crushing challengers. He was a product of the conditions and society around him. But Khan had close ties to Karzai, who was also a member of the Popalzai subtribe. ${ }^{9}$ Khan had personally helped Karzai reach Kandahar in 2001. His relationship with Karzai and role as the provincial tribal leader ensured formal and informal governance connectivity. For these reasons, Khan was best positioned to help the United States achieve its objectives in Afghanistan.

Khan certainly recognized that a relationship with U.S. and coalition forces could render legitimacy, financial gain, and political power. His loyalties rapidly realigned with the coalition. Soon, he openly defied Mohammed's requests that ran counter to SOF interests. He reported the governor's attempts to discredit the coalition politically, his leaking of intelligence concerning SOF missions to the Taliban, and his narcotics trafficking. Eventually, in 2006, Karzai removed Mohammad from office.

While developing this relationship with Khan and the various Popalzai district elders, coalition SOF pressured Taliban networks using lethal and non-lethal means to create the time and space necessary for governance development efforts. Coalition and Afghan forces pushed the Taliban out of population centers and persistently targeted them in the surrounding countryside. This enabled Khan to establish rings of security checkpoints around Tarin Kowt, Uruzgan's provincial capital.

As this Popalzai security force demonstrated an increased ability to secure the province, SOF sought approval from the Afghan central government to designate Khan and his men official "Afghan highway patrolmen." The short-lived Afghan Security Force program demonstrated the need to formalize an irregular force to ensure its long-term viability.

Unlike the Afghan National Army, the highway patrolmen came from the province and provided needed access to and support from the local population. In addition to building trust between the Afghan government and the local population, it also provided better intelligence to the coalition. As security improved, it also allowed the Provincial Reconstruction Team to take on more reconstruction efforts.

Khan and the highway patrolmen provided a tribal-based means to secure and hold terrain and maintain civil order. Yet Khan still lacked sufficient control in more distant parts of the province. Additionally, power struggles continued. Smaller subtribes-the Barakzai and Alokazai-complained of being threatened, attacked, or mistreated by the Popalzai.

Economic development remained slow. Some large-scale infrastructure projects occurred, but investment in micro-development was lacking. Bolduc attempted to create village reconstruction teams to work hand in hand with the Provincial Reconstruction Teams, but he lacked the implementation time before the battalion rotated out of Afghanistan.

While the approach certainly had its faults, traditional and formal governance finally began to intersect in central Uruzgan. The effort simply needed to be nurtured and codified. In the years to come, Khan continued to support coalition SOF until he was assassinated by a Taliban suicide bomber in Kabul in 2015. ${ }^{10}$ 
The experiment also reinforced the theory that a counterinsurgency strategy that balances counterterrorism operations with formal and informal partner development efforts is effective in setting conditions for partner operational independence. Unfortunately, given the lack of a governing long-term theater strategy, after TF-31 departed, its replacements reverted to a counterterrorism centric approach. This ultimately ceded terrain and popular influence back to the Taliban.

\section{The Afghan National Auxiliary Police (2006-2007)}

During the 2006 deployment, it became clear to Bolduc that the national police could not hold ground won during clearing operations, nor could the Afghan National Army, as they were needed for clearing operations elsewhere in the country. Thus, Bolduc sought out Kandahar Governor Asadullah Khalid to build a tribal force - the Afghan National Auxiliary Police - that would partner with TF-31 Special Forces detachments to ensure the long-term security of Panjwai, a district in Kandahar Province.

This plan would leverage traditional local governance structures to establish governance, protect the populace, separate the threat from the populace and their operating areas, and force an elusive enemy to expose itself. The governor agreed to support the proposal and even traveled with the detachments in Panjwai and surrounding districts to help get the program started.

Tribal elders, the national police, and Governor Khalid were responsible for vetting the tribal candidates. The governor held shuras (traditional tribal meetings) with local elders to gain their support. He also served as the conduit with the Ministry of Interior and President Karzai to obtain national support for the program. Formal and informal governance began to intersect as top-down support was assured.

Despite the support, the program did not necessarily go smoothly; International Security Assistance Force (ISAF) elements responsible for providing official police training resisted and disparaged the program, alleging it would compete with provincial police forces for funding and equipment. In their view, it was an illegitimate militia that would damage the Afghan government in the long term. As a result, funding for the program was temporarily delayed.

TF-31 immediately turned to their partners in the Central Intelligence Agency, who agreed to fund the program until a formal system could be instituted through the Ministry of Interior. One detachment was assigned responsibility for designing a three-week training program, which included human rights and law of war training. Within five months, TF-31 had generated approximately 1,000 Afghan National Auxiliary Police. The detachments lived with this force to improve operational functionality.

From the onset, it was designed as a temporary force to hold key terrain in and around Kandahar, allowing the national police and the national army to focus elsewhere. Eventually, National Auxiliary Police members were permitted to attend formal police and army training to become part of the formal Afghan security architecture. The ISAF Regional Command South commander, Dutch Major General Van Loon, commended TF-31 for this initiative and advocated its formalization.

Over time, the program expanded into Helmand, Zabul, Nimroz, and Herat provinces, with the force growing to 9,000 officers. ${ }^{11}$ Yet the lack of a formal, overarching ISAF counterinsurgency strategy prevented rotating units from focusing on long-term objectives. As a result, after TF-31 departed, incoming SOF units returned once more to a counterterrorism-centric strategy, focused more on targeting the Taliban directly and less on building partner capacity.

The program also suffered from a lack of national-level ministerial and ISAF oversight and support. When the Afghan government deployed the National Auxiliary Police beyond their geographical areas of tribe, clan, and qawm (a social unit in Afghanistan) linkage, it began to collapse as National Auxiliary Police elements began to create more problems than they resolved. The same set of circumstances that had negatively affected the Afghan Security Force contributed to the collapse of the Auxiliary Police. 


\section{The Afghan Public Protection Program (2009-2010)}

The abandonment of the National Auxiliary Police program in 2008 prevented the Afghan security architecture from holding terrain and protecting local populations in rural areas. ISAF and SOF elements continued to clear terrain of insurgents only to have them return. In essence, units were fighting a decade-long war one year at a time. Since the ISAF leadership and some SOF units continued to ignore the underlying causes of instability and failed to build an Afghan-based capacity to hold key terrain, conditions necessitated another irregular force solution. Thus, Special Forces in Wardak Province, led by Major Brad Moses, initiated the Afghan Public Protection Program in March 2009.

Given the proximity of the Taliban to Kabul (Wardak Province is directly west of Kabul), ISAF, the Ministry of Interior, the Ministry of Defense, and the National Defense Services backed the program. As a result, the Ministry of Interior formalized the Public Protection Program from the start. Moses established an Afghan-led vetting process and a three-week training program and fought for resources through the Ministry of Interior.

By 2010, it had grown to approximately 1,200 personnel with a target of 8,000 (200 per district), and it secured the major roads running south and southeast from Kabul, critical infrastructure (bridges, dams, district centers), and the home villages of the participants. ${ }^{12}$ This bottom-up local security organization complemented Afghan National Security Forces and succeeded at holding terrain and developing stability in villages and districts. The security environment in Wardak soon began to improve. It appeared the program might succeed, but a few factors emerged that would negatively affect it.

First, the international community and human rights organizations held its controversial leader, former Taliban member Ghulam Mohammed Hotak, in contempt. Instead of viewing this as a potential opportunity for reintegration, many asserted he was recruiting active Taliban. ${ }^{13}$ Some could not discern that local villagers joined any group that presented the greatest opportunity for their personal survival. Changing sides was part and parcel of tribal culture and a survival mechanism. Whatever their previous allegiances may have been, Hotak and his men aligned with the Afghan government.

Second, the lack of consistent resourcing facilitated the decline and eventual closure of the program.

Third, ISAF redirected SOF from the Public Protection Program to the Afghan National Civil Order Police program. The Civil Order Police was an expeditionary formal police unit that was designed to deploy throughout the country in response to instability. It was created as an elite gendarmerie and initially conceived of as a riot control force but was also assigned to replace district-level police who were away for collective training. ${ }^{14}$ SOF mentoring was seen as indispensable to the program's success. Thus, ISAF transferred the Public Protection Program mission to the conventional forces.

Given the nascent nature of the Public Protection Program and lack of capacity of the conventional forces to mentor and adequately train the force, logistical support degraded, pay became irregular, and coalition support during enemy engagements eroded. The Public Protection Program's distrust with the Afghan government and coalition grew, and they were left wondering why they had been abandoned. Eventually, Public Protection Program leader Ghulam Hotak quit out of frustration.

In hindsight, it is clear that operational conditions in Afghanistan demanded the employment of an irregular force and traditional governance approaches, but senior leaders did not hear calls for change. Yet a growing chorus called for change. ${ }^{15}$ Seth G. Jones noted, "Some of America's most seasoned diplomats and military commanders in Afghanistan did understand the country, but they could not get through to their leaders, who were initially uninterested in nation building and distracted by Iraq." 16

Jones compared the American experience to previous ones. He described the common challenges foreign invaders in Afghanistan have faced since Alexander the Great in $330 \mathrm{BC}$. The challenges were surprisingly similar to those of the United States in 2009. Jones outlined some of the specific causes of American stagnation: insufficient coalition manpower, diversion of U.S. forces and resources to Iraq, corruption, poor Afghan leadership, Taliban exploitation of a religious ideology, and a safe haven in Pakistan. Jones helped persuade senior leaders that a greater balance was needed regarding bottom-up and top-down approaches. ${ }^{17}$ 
At this time, international resolve to stay the course in Afghanistan began to wane; calls for withdrawal and frustration over the lack of progress mounted. ${ }^{18}$ After eight years of fighting, most Afghans polled viewed their government as generally ineffectual and corrupt. ${ }^{19}$ The coalition continued to pursue an enemy-focused operational approach, development efforts were marginally effective, and Afghan governance and security capacities stagnated. There were some successes: cities expanded, more children attended school, medical care improved, and some Afghan special operations units demonstrated success. On the whole, however, the Taliban grew in strength and influence.

\section{Village Stability Operations and the Afghan Local Police (2009-2014)}

Beginning in 2009-2010, U.S. Special Operations Command's (SOCOM) initiative to embed SOF detachments in contested villages across Afghanistan proved one of the most effective engagement methods employed in the theater. The Local Defense Force initiative, which morphed into Village Stability Operations, placed highly trained SOF units in rural villages to live and work among the villagers and advance stability in the region.

Village stability worked "backwards": first establishing stability in the villages and then connecting village governance to the districts and the provinces. Investing in villages required rigorous analysis and a long-term commitment; it was also socially tiring. But the rewards were worth the risk: the central government could not create stability without support from the villages.

\section{The Local Defense Initiative (2009)}

In mid-2009, General Stanley McChrystal assumed command of ISAF. An innovative problem solver, ${ }^{20}$ he rapidly redefined how to fight the campaign. He directed the creation of a population-centric campaign strategy and prioritized coalition efforts toward Afghan security and governance capacity development. He drove unification of U.S. and coalition SOF efforts. This forced the coalition to focus more on long-term objectives and encouraged new approaches to that end. ${ }^{21}$

With supportive ISAF leadership, it appeared that an irregular force redux might finally succeed. This time it was Special Forces officer Scott Mann who presented the idea to Brigadier General Ed Reeder, the Combined Forces Special Operations Component Command-Afghanistan (CFSOCC-A) commander. Reeder supported the approach, and through his leadership and vision, the Local Defense Initiative was born.

The Local Defense Initiative concept was straightforward: Special Forces detachments would attempt to gain the trust of local elders, live in their villages, develop local security forces, and support tribal council governance reformation and local economic development. It was hoped that this would permit the reemergence of rural governance to manage security and ultimately provide conflict resolution and development opportunities.

The coalition effort in Afghanistan was at a pivot point. Success required a full-court press, as well as proven, innovative leaders. With McChrystal at the helm, a SOF commander was finally in charge of the campaign in Afghanistan, a campaign that was from the beginning an unconventional one. To round out the SOF team, Brigadier General Scott Miller replaced Reeder to lead CFSOCC-A, and Bolduc returned to assume command of Combined Joint Special Operations Task Force-Afghanistan (CJSOTF-A) underneath him. This partnership transformed SOF operational progress and ultimately defined how U.S. and coalition SOF would organize and operate in Afghanistan for years to come.

Three weeks prior to assuming command, Bolduc conducted a comprehensive operational assessment of the command across Afghanistan. One of the shortcomings that it identified was the need for a more uniform focus on consistent partnership development across all operating units regardless of how far flung or disparate the environment. 
The Local Defense Initiative lacked operational level command emphasis, resulting in the absence of a codified operational methodology; organizational supporting framework; and a formalized narrative explaining its purpose, intent, and benefit to the aggregate Afghan security architecture. CJSOTF-A simply had not developed a larger organizational supporting plan or strategy that prioritized efforts in relation to McChrystal's design.

Bolduc designated the Local Defense Initiative program as CJSOTF-A's main effort. This realigned CJSOTF-A's operational priorities more effectively with McChrystal's population-centric campaign strategy. Additionally, it served to communicate to all subordinates what was paramount to organizational operational success. As the staff shifted its effort from deliberate attack planning to the Local Defense Initiative, development gaps and shortfalls became readily apparent. The training of formal security force partners such as the Afghan Commando Corps, their special forces detachments, and special police units had never received sufficient attention. ${ }^{22}$

The Commandos played a critical role in establishing and maintaining the conditions necessary for large-scale development and sustainment of Afghanistan's irregular forces. But they remained incapable of managing force management administration, logistics, and command and control functions independently, so the coalition SOF elements managed these institutional functions for them in large measure. CJSOTF-A took a number of steps to address these shortfalls and recognized that the Local Defense Initiative program would not be self sustaining until institutional reforms with the formal SOF units were addressed.

Organizational restructuring helped address some institutional challenges. No longer could the training of Afghan SOF be an additional task for one of the operational SOF battalions; it required a dedicated training command. Bolduc selected Lieutenant Colonel Miguel Howe to design and build the Afghan Special Operations School. ${ }^{23}$ CFSOCC-A required the Afghan Ministry of Defense to participate in the school's design and development to inculcate a sense of responsibility for its management and to facilitate an eventual seamless transition.

It became apparent that the evolving Special Operations School would require a significant amount of support and coordination with the Ministry of Defense and the Afghan government. Bolduc requested that the school be re-aligned from the CJSOTF-A to the CFSOCC-A, given Miller and his staff maintained the relationship with the Ministry of Defense. This allowed the CJSOTF-A to focus more attention on the Local Defense Initiative.

To be successful, Bolduc would have to leverage the support of multiple Afghan ministries and a host of U.S. interagency actors and non-governmental organizations. His command eventually integrated these stakeholders into a global network to help analyze causes of rural instability and address them. It leveraged students from the Naval Postgraduate School in Monterey, California, to help draft the Local Defense Initiative's operational methodology. Lessons from the previous attempts had also demonstrated the importance of early Afghan branding to the longevity of the program. While the program had a name, the forces needed a name other than "Local Defense Forces."

\section{Establishing VSO/ALP (2010)}

Bolduc and Miller worked with ISAF and the Afghan government to determine an acceptable name for the program. President Karzai was uncomfortable with militias and insisted on an Afghan government connection to a local defense force. CJSOTF-A effectively communicated the program's purpose and demonstrated to the Karzai administration that there were no connections to non-governmental militias. ${ }^{24}$ In August 2010, Karzai signed a presidential decree authorizing Village Stability Operations and the Afghan Local Police. ${ }^{25}$ This decree was essential for securing the Afghan government's buy-in.

CFSOCC-A selected the highest-priority locations for VSO, which included an assessment of the human terrain to determine whether a particular village would accept the proposition of defending themselves. Once selected, the village held a jirga or shura (tribal meetings) to decide whether to accept the 
proposition. If accepted, a Special Forces detachment was sent to live among the population to build the security force and promote governance and development. Village elders hand-selected the ALP members, intentionally selecting a group to represent the ethnic and tribal cross-section of the local populace.

The initial implementation strategy resembled the operational phases used in 2005-2007- "shape, clear, hold, build, and transition" - although in practice, the "clear" area may have initially been very small. The detachments "shaped" the security environment, which allowed them to "hold" the village and surrounding territory through influence, deterrence, and the advent of a local police or militia. ${ }^{26}$ When a VSO site was first established, the vast majority of SOF efforts were directed toward understanding the threat while simultaneously training the ALP force. Over time, units conducting VSO found themselves in the unique position to expand their involvement with the local populace from one narrowly focused on security to include governance and economic development.

In the build phase, the detachment connected the village or villages under its control with the district and provincial government. This phase resembled the larger control hub or civic action platform utilized in the Civilian Irregular Defense Group from Vietnam. ${ }^{27}$ The villages, local population, and local police had to feel that they were part of the larger national government. This in turn established a sense of ownership in the legitimacy of the system and feelings of nationalism and created the impression that the local villagers are firmly committed to a goal greater than themselves - in essence, the establishment of the social contract.

The final phase of the VSO strategy was the transition phase. This phase was one of the most delicate of the operation and can be compared to the latter stages of the civilian defense strategy when Vietnamization occurred. During the transition phase, after certain metrics of success were met, the Special Forces detachment would hand the local defense force over to the national police or the Afghan National Army - or the local forces would disband, disarm, and reintegrate into society. It is important to place the same level of emphasis on this phase of the operation to avoid the fate of the Montagnards and their treatment by the South Vietnamese army. By the summer of 2010, CFSOCC-A had established 20 VSO sites. ${ }^{28}$

Codifying all aspects of the program and having a "brand" with the approval of the Afghan government proved essential in winning the support of the ISAF commander, the U.S. Agency for International Development, the Department of State, and ultimately funding from the U.S. Congress. Bolduc also adapted CJSOTF-A's organizational structure to provide the top-down support that had always been missing or unsustainable in previous programs. He formed a cell in the plans section of his staff to help with the logistics, administration, and resourcing of the program. This cell was directly linked to the CFSOCC-A headquarters in Kabul and coalition liaison officers in the Ministry of Interior. It eventually integrated liaisons arrayed at provincial and district centers as well.

Bolduc also directed his staff to develop a 24-month campaign support plan to establish continuity and unity of effort for the VSO/ALP program and partner development efforts; he sought to mitigate some of the friction from units rotating every six months. The 24-month campaign plan established clear lines of effort, intermediate military objectives, and supporting effects. The assessment cell applied the appropriate metrics to determine what was and was not working, which improved operational level decision-making. It marked the first time that population-centric metrics were provided to demonstrate clear progress in security, governance, and development. As a result, General David Petraeus, who had replaced McChrystal as the ISAF commander, made VSO/ALP a top priority. ${ }^{29}$

Bolduc also transformed the CJSOTF-A operations center into a situational awareness room. This reflected his view that the purpose of the command was to enable its subordinate elements. This allowed the headquarters to move valuable manpower and intellectual capital from the arguably bloated headquarters to subordinate units where they were desperately needed.

Bolduc invited coalition and Afghan special operations forces to join the CJSOTF-A staff. He gave each a desk in the situational awareness room: Emirates, Australians, Canadians, Afghan Commandos, and French personnel. Bolduc extended the same invitation to the U.S. interagency community. This 
broadened operational synchronization and improved effectiveness. It also resulted in an expansion of combat (and non-combat) power. As allies felt more involved, they increasingly volunteered to support various missions and initiatives. NATO SOF targeted Taliban networks in areas that complemented CJSOTF-A operations, while the United Arab Emirates even volunteered to conduct VSO.

The command's collective partner development and operational efforts improved dramatically. Miller and his staff in Kabul rapidly effected change for detachments on the ground across Afghanistan. For example, ineffective district police chiefs and governors were now removed in a month or two; previously, it took six, if they were removed at all. Equipping and pay issues were now resolved within days versus months.

Improved reporting helped to reveal that the planned re-vetting of the ALP and other Afghan partners had not occurred. Although they had been thoroughly vetted during the recruiting process, they had not been re-vetted later. The initial vetting began with tribal elder recommendation, national police endorsement, biometric enrollment, drug/medical screening, psychological testing, and interviews. The names of individuals who passed initial screening were then forwarded to the Ministry of Interior in Kabul for final approval before training commenced. But after initial screening, the Afghans had no mechanism to weed out individuals who later became liabilities.

More emphasis should have been placed on re-vetting given the high threat of insurgent infiltration. Due to the need to rapidly build the ALP capability, Special Forces detachments were often operating as split teams. Instead of all 12 detachment members being located together, which is the norm, they were split to double the ALP capacity. But given the remoteness of their locations, it brought additional risk.

Beyond helping to identify potential insider threats, the re-vetting also served to verify accurate ALP accounting for pay, which limited the potential for graft and helped cleanse the program of those violating drug and behavioral standards. The re-vetting process took one month to complete, and while it eliminated only a small percentage of participants, it improved force capability and management accounting.

Due to better information flow, another gap was identified: detachments encountered difficulty acquiring intelligence from women and children in communities in which they resided. Given that women and children represented over $50 \%$ of the population, detachments were missing valuable intelligence on insurgent activities and insights into tribal and political matters. They were also the ones most impacted by development efforts: schools, clinics, security, and improvements in agricultural production.

As a result, CJSOTF-A attached experienced female medical service non-commissioned officers to the SOF detachments in Uruzgan and Kandahar provinces. The results proved promising: team situational awareness improved, and micro-economic development expanded. In time, SOF formalized the program into what became Cultural Support Teams, and the initiative would ultimately influence the Pentagon's thinking regarding the roles of women in combat. The program had its share of ups and downs as it evolved, but it did validate the operational advantages to integrating female service members for counterinsurgency and stability operations. ${ }^{30}$

\section{VSO/ALP progammatics, structure, and enablers}

As organizational structures and supporting initiatives were refined, the command's supporting capacities expanded as well. The enterprise learned the importance of cultural demographic analysis, persistent stakeholder engagement, liaisons partnered with district and provincial authorities, and the need to control program growth to ensure quality. CJSOTF-A conducted a deliberate tribal analysis, often lasting weeks or months, to select VSO/ALP sites based on their potential. The assessments were critical to understand every aspect of social structure, stakeholder influence, geography, and threat conditions.

Over time, a number of recurring characteristics emerged, such as: evolution occurred more rapidly when existing tribal structures existed, tribal homogeneity acted as a growth catalyst, and living between 


\section{Special Operations and Afghan police}

competing subtribes avoided negatively impacting natural balances of power. Codifying these and other findings helped optimize the program's methodology.

The command developed a comprehensive information operations plan and a structured media engagement plan. Another element vital to the expansion and success of the program was a tiered engagement strategy. At the tactical level, detachments conducted radio broadcasts and face-to-face engagements with local stakeholders and populations. At the operational level, CJSOTF-A briefed interagency and Afghan ministerial elements. Opening the program to media scrutiny, early and often, enabled the command to help drive the narrative versus having to spend significant amounts of time defending the program.

As the program expanded, it became glaringly apparent that most Afghan district officials, and some provincial officials, were woefully inept at executing the responsibilities of their offices. Yet the program was dependent on these officials to succeed. Thus, CJSOTF-A embedded liaison teams-Provincial Advisory Teams and District Advisory Teams - to improve the various district and provincial offices.

These liaison officers mentored district governors and police chiefs on security issues and helped them develop processes and mechanisms to ensure the ALP were adequately equipped and paid on time. A capable district office was critical to transferring control of the ALP to the Afghans so the detachment could transition to a new location to expand the program. If the Afghan government consistently supported the ALP, and district representatives and tribal elders routinely met with them, then success had been achieved. Some sites still failed, but in a majority of cases, the advisory teams managed to improve performance of district and provincial centers.

To avoid the fate of earlier security efforts, CJSOTF-A sought to institutionalize the program. While some stakeholders did not fully recognize or agree with the ALP/VSO construct, they could not argue with its success on the ground. It was so effective that the Taliban viewed the ALP program as a direct threat to their strategic success and their number-one priority to attack. ${ }^{31}$

Likewise, Miller wanted to ensure institutional success, so he established a senior leader mentoring program where he and other senior leaders directly mentored their Afghan counterparts. The multilateral engagement strategy that was formed months earlier and had advocated support for the program produced dividends. Popular opinion of Afghan provincial governance improved. ${ }^{32}$

When Petraeus took command of ISAF in 2010, the ALP program had already improved security in some areas. He visited VSO sites in Kandahar and Kunar, and he was so impressed with the potential of the program that he personally advocated for its expansion. Petraeus called it a "game changer" and characterized it to the U.S. Congress as an essential piece of the Afghan security architecture necessary to improve security and stability. ${ }^{33}$

In June 2011, Petraeus and Afghan officials agreed to increase the authorized strength of the ALP from 10,000 to 30,000 despite only having 6,500 police at 41 sites. ${ }^{34}$ Without Petraeus' support, the program certainly would not have evolved to become a pillar of the Afghan security architecture. Once the new target had been established, CFSOCC-A and CJSOTF-A furiously analyzed how to accomplish this in a manner consistent with the program's tenets. It was fortuitous that the 24-month campaign support plan was already in place because it provided the framework; however, the mechanics of the expansion required significant analysis. Most importantly, how would the command maintain program standards, a quality over quantity conundrum?

Probably the greatest determinate of program success was direct, long-term SOF mentorship. A RAND study would later reveal that successful sites required an average of 15 months of direct mentoring. ${ }^{35}$ Longterm SOF partnering improved both combat skills and behaviors. This did as much to legitimize the force as successfully defending against Taliban incursions. CFSOCC-A requested an additional Army Special Forces battalion to meet growth demands, but SOCOM was unable to fulfill the request due to other requirements in Iraq and Afghanistan.

Ultimately, SOCOM approved an additional Special Forces battalion headquarters, but it did not answer the need for operational teams. After studying the issue, Bolduc and the battalion commanders agreed to 
"split team" operations to double the operational capacity of Special Forces, although it increased tactical and operational risk. SOCOM also provided Navy SEAL teams and Marine Special Operations Teams. This may not sound unusual in today's context, but at the time, it was contentious at senior command levels in the special operations community.

CFSOCC-A also requested a conventional infantry battalion to augment the CJSOTF-A. ${ }^{36}$ This was unprecedented and led to a shift in conventional forces and SOF interoperability. The intent was to further split the Special Forces detachments and augment them with infantry squads to maximize growth, maintain program standards, and ensure adequate force protection. But this was not a mission for which infantry forces had ever been trained.

The concept was ultimately approved, although grudgingly by some senior conventional force leaders worried that the unit would be relegated to fire base guards and taken advantage of by SOF. In the summer of 2011, Lieutenant Colonel Curtis Buzzard and an infantry battalion from the 82nd Airborne Division deployed to support the VSO mission in northern Afghanistan. ${ }^{37}$

The skeptics were proven wrong, as it proved a success. It demonstrated that non-traditional SOF and conventional forces command and control relationships can work. In northern Afghanistan, the infantry battalion headquarters, supported by an Army Special Forces company headquarters, commanded multiple Special Forces detachments, a SEAL platoon, an infantry rifle company, a heavy weapons company, and elements of a forward support company and a headquarters company.

It worked remarkably well and validated the value of an adaptive methodology in a complex and dynamic environment. The combined effects of such force restructuring and employment methodology enabled the VSO/ALP mission to advance and more importantly redefine future SOF and conventional forces operational constructs and command and control approaches. ${ }^{38}$

The program's operational success fueled additional support for the program. The VSO program was a relative bargain when compared to the cost of other security programs. The development and employment of an ALP officer cost one-fourth that of a national police officer and one-sixth that of an Afghan National Army soldier. ${ }^{39}$ It proved an effective and economical approach to rural security, a significant advantage in an economy where $76 \%$ of its gross domestic product came from international donors. ${ }^{40}$ Security solutions needed to be cost effective to be viable in the long term.

Unlike the national police and national army, the ALP demonstrated sustained improvements in rural security. According to the 2011 Afghan National Safety Office, insurgent attacks dropped 42\% in Kunduz, $64 \%$ in Baghlan, and $76 \%$ in Takhar. ${ }^{41}$ Seeing this data and the projected $\$ 180$ million a year price tag for 30,000 ALP, the U.S. Congress approved multi-year funding. ${ }^{42}$

The rapid expansion and success of the ALP required a significant amount of logistical support. Lieutenant Colonel Ron Reagan, the CJSOTF-A support battalion commander, contracted small fixed-wing aircraft to support troop movements, air dropped thousands of tons of supplies and materials each month, and contracted and acquired a fleet of ground and all-terrain vehicles.

Simultaneously, Mann designed an innovative and enhanced SOF pre-deployment training and education program. Detachments learned about Afghan history and culture from Afghans and esteemed academicians, gaining insight into causes of rural instability. They heard from recently returning VSO SOF operators on what does and does not work. Mann transformed pre-deployment training from basic combat skill training to something more akin to a graduate-level course. Operators routinely commented that it was the best pre-deployment education that they had received in their careers. ${ }^{43}$

As Bolduc and Miller rotated out of Afghanistan in the summer of 2011, the program had a solid foundation and a long-term supporting plan, significant improvements in security had been achieved, and U.S. and coalition SOF were more operationally integrated. Institutional evolution advanced with Afghan special operations partners, and they were more effectively recruiting, training, resourcing, and executing command and control responsibilities. 
Bolduc returned in the summer of 2012 for his ninth deployment to Afghanistan to command CFSOCC-A. By the end of 2012, the program had grown to 18,000 and was operational at 92 sites, ${ }^{44}$ but Bolduc was in a race against the clock. He was trying to build VSO/ALP capability to mitigate the effects of the U.S. drawdown while trying to transition the program to the Afghans at the same time.

Since the program's inception, the Barack Obama administration had surged forces into Afghanistan, and in 2011, their withdrawal began. With the signing of the strategic partnership agreement between the United States and Afghanistan in May 2012, it was expected that nearly all U.S. forces would be out by the end of 2014. ${ }^{45}$ This decision forced U.S. military leaders to make hard choices on the prioritization of efforts.

Bolduc hurried to ensure that the Ministry of Interior could independently manage the program. Due to the success of the program and unprecedented security gains, there were calls, even in the midst of the transition, to expand the ALP to $45,000 .{ }^{46}$ But it was clear to all parties that SOF would no longer be able to live in the villages with the ALP and mentor them, and the Ministry of Interior would have to assume this role with the help of Afghan special forces. By the end of 2014, the transition was complete.

Unfortunately, without SOF mentorship and support, the program could not sustain the gains it had made. By 2019, many of the security gains achieved by the program had been lost, with the Taliban controlling $14 \%$ of the country's districts and another $29 \%$ remaining contested-controlled by neither the Taliban nor the government. ${ }^{47}$

\section{Conclusion}

Developing successful irregular force programs is an exceedingly difficult and complex process, but, as demonstrated in Afghanistan, it can be an extremely effective and economical way to fill a security gap. But building an effective program is not easy, as demonstrated by the failures of the Afghan Security Force, the Afghan highway patrolmen, the Afghan National Auxiliary Police, and the Afghan Public Protection Program. These failures, and the success of the VSO/ALP program, demonstrate that success requires three essential elements: international support, government support, and a willing populace. Village stability is a building-block component that ultimately contributes to security at the district, provincial, and national levels.

The VSO/ALP model demonstrates the importance of possessing an in-depth historic and cultural understanding of the operational environment. The VSO/ALP program highlights the advantage of outlining a comprehensive supporting framework that integrates bottom-up and top-down efforts seamlessly. It evidences the vital need for a multi-dimensional engagement strategy. The program succeeded because it addressed rural security and instability challenges through the reformation of tribal governance and security mechanisms supported through a central authority at the district and provincial levels as part of a population-centric counterinsurgency strategy.

$\mathrm{VSO} / \mathrm{ALP}$ represents the quintessential SOF counterinsurgency and irregular warfare mission, combining both direct and indirect approaches in a balanced and integrated approach. It played to SOF organizational strengths: adaptability, fungibility, small-unit decentralized execution, and specialized skill-set and tradecraft capabilities. Additionally, it demonstrated the effectiveness of a command and control construct, where SOF is supported by conventional forces, interagency partners, international partners and organizations, and non-governmental organizations.

\section{Notes}

1 The U.S. Department of Defense first defined irregular forces as "Armed individuals or groups who are not members of the regular armed forces, police, or other internal security forces" in 2009 in Joint Chiefs of Staff, 
Counterinsurgency Operations, JP 3-24 (Washington, DC: Joint Chiefs of Staff, October 5, 2009), GL-7, but rescinded the definition with the 2013 edition of the joint publication.

2 Lisa Saum-Manning, VSO/ALP: Comparing Past and Current Challenges to Afghan Local Defense (Santa Monica: RAND, 2012), 2.

3 Thomas Barfield, Afghanistan: A Cultural and Political History (Princeton: Princeton University Press, 2012).

4 Ibid., 338.

5 Ibid.

6 Saum-Manning, VSO/ALP, 3.

7 A Special Forces battalion has three Special Forces companies, each with six detachments.

8 A Provincial Reconstruction Team is a "civil-military team designed to improve stability in a given area by helping build the legitimacy and effectiveness of a host nation or local provincial government in providing security to its citizens and delivering essential government services," Joint Chiefs of Staff, Civil-Military Operations, JP 3-57 (Washington, DC: Joint Chiefs of Staff, 2018), GL-7.

9 “Kandahar Provincial Overview," Naval Postgraduate School, accessed December 28, 2020, https://nps.edu/web/ $\mathrm{ccs} /$ kandahar.

10 Azam Ahmed, "Powerful Afghan Police Chief Killed in Kabul," New York Times, March 20, 2015, www.nytimes. com/2015/03/20/world/asia/powerful-afghan-police-chief-killed-in-kabul.html.

11 Mathieu Lefevre, "The Afghanistan Public Protection Program and the Local Defence Initiative," in Snapshots of an Intervention: The Unlearned Lessons of Afghanistan's Decade of Assistance (2001-2011), ed. Martine van Bijlert and Sari Kouvo (Kabul: Afghanistan Analysts Network, 2012).

12 Saum-Manning, VSO/ALP, 5.

13 Human Rights Watch, "Just Don't Call It a Militia": Impunity, Militias, and the "Afghan Local Police" (New York: Human Rights Watch, 2011).

14 Robert M. Perito, Afghanistan's Civil Order Police: Victim of Its Own Success (Washington, DC: United States Institute of Peace, 2012).

15 See, for example, Donald C. Bolduc, "Organizing Counterinsurgency Operations in Afghanistan," Small Wars Journal, August 5, 2008, https://smallwarsjournal.com/jrnl/art/organizing-counterinsurgency-operations-inafghanistan; Jim Gant, One Tribe at a Time: The Paper That Changed the War in Afghanistan (New York: Black Irish Entertainment, 2009).

16 Seth Jones, In The Graveyard of Empires: America's War in Afghanistan (New York: Norton, 2009).

17 Ibid.

18 Malou Innocent, "Five Reasons to Withdraw From Afghanistan," National Interest, March 21, 2012, https://nationalinterest.org/blog/the-skeptics/5-reasons-withdraw-afghanistan-6673.

19 Office on Drugs and Crime, Corruption in Afghanistan: Recent Patterns and Trends (Vienna: United Nations, 2012).

20 Liam Collins, "Military Innovation in War: The Criticality of the Senior Military Leader" (PhD diss., Princeton University, 2014), 306-412.

21 Stanley McChrystal, ISAF 2009 Comprehensive Counter Insurgency Strategy (Kabul: ISAF, 2009); Kenneth Katzman, Afghanistan: Post-Taliban Governance, Security, and U.S. Policy, CRS Report No. 30588 (Washington, DC: Congressional Research Service, 2009).

22 For more on the Commando Corps, see Eric Sof, "ANA Commando: An Elite Afghanistan Special Operations Forces," SPEC OPS Magazine, December 3, 2020, https://special-ops.org/afghanistan-ana-commando-special-forces/.

23 Eventually the school became the Afghan National Army Special Operation Advisory Group.

24 Yochi J. Dreazen, “Going Native," National Journal 42, no. 46 (2010).

25 Department of Defense, Report on Progress Toward Security and Stability in Afghanistan (Washington, DC: Department of Defense, 2011), 68.

26 A shaping operation is "an operation that establishes the conditions for decision operation through effects on the enemy, other actors, and the terrain." See Department of the Army, Operations, ADRP 3-0 (Washington, DC: Department of the Army, 2016), 4-6.

27 See, for example, Eugene G. Piasecki, “Civilian Irregular Defense Group: The First Years: 1916-1967,” Veritas 5, no. 4 (2009): 19-28.

28 Mark Moyer, Village Stability Operations and Afghan Local Police (MacDill AFB: JSOU, 2014), 9-10, www.socom. mil/JSOU/JSOUPublications/JSOU14-7_Moyar_VSO_FINAL.pdf.

29 Ibid., 12-13.

30 Megan Katt, "Blurred Lines: Cultural Support Teams in Afghanistan," Joint Forces Quarterly 75, no. 4 (2014): 106-113.

31 This came from various intelligence reports. 


\section{Special Operations and Afghan police}

32 Keith Shawe, Afghanistan in 2013: A Survey of the Afghan People (Kabul: The Asia Foundation, 2013), 9, https:// asiafoundation.org/resources/pdfs/2013AfghanSurvey.pdf.

33 Bill Roggio, “Full Text of General Petraeus’ Testimony to Congress,” Threat Matrix (blog), March 15, 2011, www. longwarjournal.org/archives/2011/03/full_text_of_general_petraeus.php.

34 Moyar, VSO and the ALP, 51.

35 Saum-Manning, VSO/ALP, 2012.

36 Moyar, VSO and the ALP, 14.

37 Curtis Buzzard, e-mail, October 8, 2020.

38 Ibid.

39 Gerald Fulcher and Alec Mackenzie, "Building a Viable Local Security Force," Diplomatic Courier, February 12 , 2012, www.diplomaticourier.com/posts/building-a-viable-local-security-force.

40 OECD, Aid Effectiveness 2011: Progress in Implementing the Paris Declaration (Paris: OECD, 2012).

41 Afghan NGO Safety Office, ANSO Quarterly Data Report, Q.4 2011 (London: INSO, 2011).

42 Fulcher and Mackenzie, "Building a Viable Local Security Force."

43 David H. Petraeus, conference remarks, CFSOCC-A Village Stability/Afghan Local Police Conference, April 9, 2011.

44 Anthony Cordesman, The Afghan War in 2013: Vol III: Security and the ANSF (Washington, DC: Center for Strategic and International Studies, 2013), 115.

45 Enduring Strategic Partnership Agreement between the Islamic Republic of Afghanistan and the United States of America, May 2, 2012, https://obamawhitehouse.archives.gov/sites/default/files/2012.06.01u.s.-afghanistanspasignedtext.pdf.

46 Cordesman, The Afghan War, 115.

47 Alia Chughtai, “Afghanistan: Who Controls What," Al Jazeera, June 24, 2019, www.aljazeera.com/news/2019/6/24/ afghanistan-who-controls-what. 
19

\section{U.S. CIVILIAN ARCHITECTURE FOR STABILIZATION AND COUNTERINSURGENCY IN NORTHERN AFGHANISTAN (2012-2013)}

Keith Mines

While attending the loya jirga (grand council) during my first State Department tour in Afghanistan in the spring of 2002, I befriended a grizzled but young ex-mujahidin fighter from the mountain village of Gayan on the Pakistani border. Arif was a man of the land whose focus was prayer, farming, and fighting. He could have been transported back 100 years and life would have been little different.

We saw each other several times over the next month and developed a close friendship. He was both curious and hopeful about these foreigners who had appeared, seemingly out of nowhere, and he summarized for me a good deal of what would play out for the next decade: anger over civilian casualties, a periphery almost completely cut off from the center, fierce factional and ethnic conflict, a flat economy, and a willingness and ability of local forces to fight the central government when developments did not go their way. It indicated a good deal of work ahead for the reborn nation, an observation a female delegate to the loya jirga expressed when she answered the question "What do you need?" by simply saying, "We need everything."

The international coalition anxiously sought to provide a new beginning for Afghanistan, acting under the self-interested notion that a stable Afghanistan would fend off the kinds of intrusions that allowed international terrorists safe haven in the lead up to the $9 / 11$ attacks. From the earlier concept of Afghanistan as a platform from which Western forces would be able to pursue al-Qaida, the model that gradually emerged was one of a partner that would contain terrorism through its own capacity.

For a country starting from such a low bar, it was to be a long-term, resource-intensive project across the three standard counterinsurgency lines of effort: economy, security, and governance. ${ }^{1}$ The size of the required effort brought in much of the international community, and on the U.S. side nearly the whole of the interagency. This chapter provides a snapshot of this capacity-building effort from the perspective of the author's experience while serving as the senior U.S. State Department official in Mazar-i-Sharif from 2012-2013 and offers several lessons about civil-military cooperation.

\section{Diplomatic field architecture}

By statute, the U.S. Department of State takes the lead on the civilian side of a stabilization effort under the direction of an ambassador. Most civilian employees (and uniformed service members not under a 
major command such as U.S. Central Command) fall under the ambassador's authority, and their presence in country is with his or her approval. Significant military efforts fall directly under the combatant commander, but military commanders coordinate closely with the ambassador, and successful ambassadors and commanders go to great lengths to ensure their lines of effort are fully synchronized. There is by now a well-understood principle that any discord between the ambassador and military leadership, or among their respective subordinates, is a recipe for disaster.

A good part of the State Department's role overseas is managing the U.S. platform itself: the embassy if in a capital, or consulate or "regional platform" if outside the capital. The State Department's management branch is staffed and resourced to provide a secure location from which outreach, reporting, and programs can be safely and productively supported. In a country as geographically inaccessible as Afghanistan, policymakers saw the need to extend the embassy's reach into the country's regions even beyond consulates, where issues could be more directly managed.

U.S. Ambassador Ryan Crocker, who led the U.S. mission from 2011-2012, told me there was no substitute for physical presence in counterinsurgency and nation-building, and that his goal was to establish a robust civilian presence throughout the country. He posted senior Foreign Service Officers to Herat, Mazar-i-Sharif, Jalalabad, Kandahar, and Helmand to manage a regional platform. Between two and six Provincial Reconstruction Teams (PRTs) - which included more junior State Department and interagency officers-would work under this platform. All of these teams worked from a provincial capital or from a military base nearby.

\section{The operating environment and Provisional Reconstruction Teams}

The nine provinces of northern Afghanistan and their approximately nine million inhabitants make up nearly one third of the country. ${ }^{2}$ The north remains the heartland for Afghan Tajiks, Uzbeks, and Turkmen. There are also "Pashtun belts" in some parts of the north, which remain a constant source of instability because of their tendency to support local Taliban groups. Due to a constellation of cultural, military, and geographic factors, northern Afghanistan has traditionally had a strong natural alignment with the United States. In general, the region was relatively secure when I arrived in Mazar-i-Sharif in 2012 and was less supportive of insurgent activity. It was a giant "ink-spot" of stability, to use a counterinsurgency theory analogy.

The German Bundeswehr (German Armed Forces) led the International Security Assistance Force's (ISAF) Regional Command North at Camp Marmal just outside Mazar-i-Sharif. The base was a collection of international diplomats, soldiers, and contractors who contributed to build partner capacity and combat terrorism. The camp included 3,000 German soldiers, 4,000 American soldiers, and 1,000 soldiers from 14 other countries. The United States provided "enablers"- primarily intelligence support and aviation-for the coalition force and a sprinkling of officers throughout the Regional Command North staff, including the deputy commander.

While the military constituted the largest component of the international mission in the north, officials from other agencies contributed to the development of Afghanistan's economy, security, and governance. Due to the challenging security environment, these other agency officials were partnered with military personnel to create PRTs, "an interim civil-military organization designed to operate in semi-permissive environments usually following open hostilities."3 PRTs improve stability by "helping to build the host nation's capacity; reinforcing the host nation's legitimacy and effectiveness; and bolstering that the host nation can provide security to its citizens and deliver essential government services." ${ }^{4}$

The first PRT was established in Gardez in 2002 and expanded into Bamyan, Kunduz, Mazar-i-Sharif, Kandahar, and Herat throughout 2003. ${ }^{5}$ When I arrived in Afghanistan in 2012, there were nine coalition PRTs in northern Afghanistan (see Figure 19.1). The size of the civilian component of each PRT varied, but in the north, it was generally between 6-20 individuals. The civilian side of the team came with special 


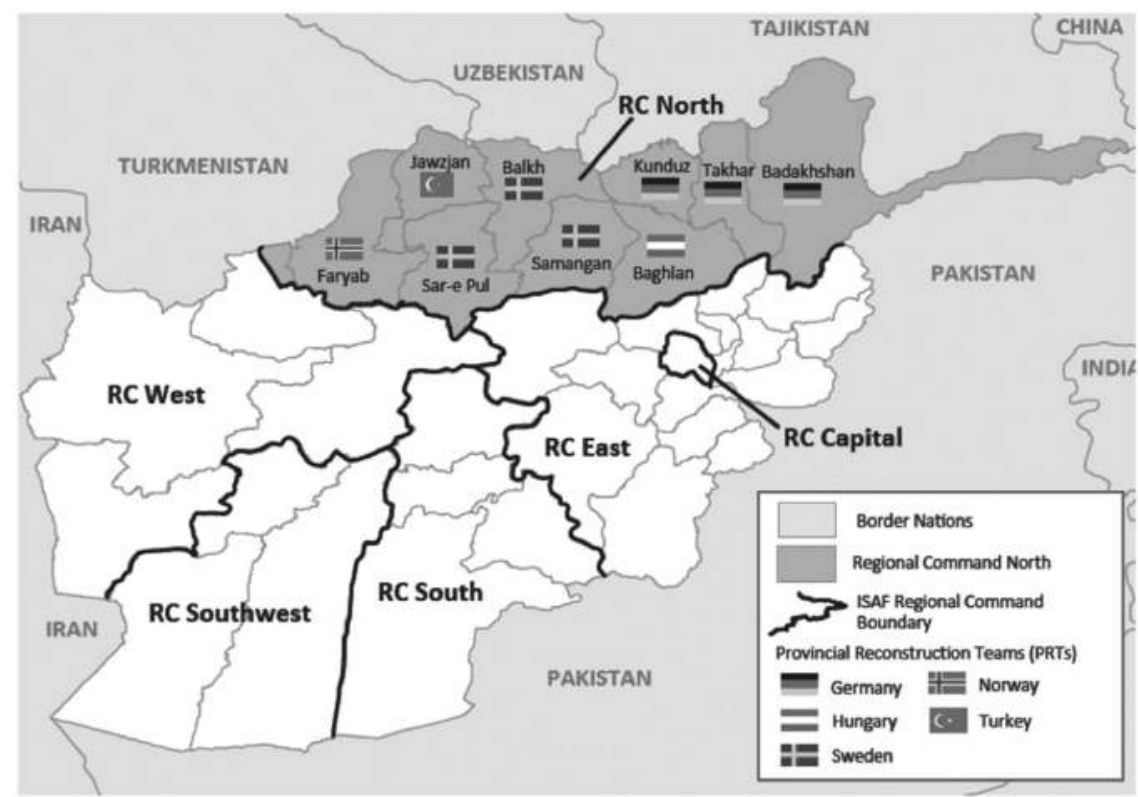

Figure 19.1 Map of PRTs in northern Afghanistan, $2012 .^{6}$

Source: Christian Karsner and Sarah Kopczynski, “Through and With: Reintegration in Northern Afghanistan,” Special Warfare 25, no. 1 (2002): 37.

skills in agriculture, economic development, justice and the rule of law, and political stability and was charged with building host country institutions and administering economic and development assistance.

The PRTs were located on military bases, with the host military unit providing base security, conducting counterinsurgency operations, and training or advising local security forces. A military commander was generally the overall leader of the PRT, and the civilian component fell under his authority. ${ }^{7}$

In addition to the international contingent, a U.S. civilian team consisting of a State Department political or economic officer, an agricultural advisor, and a U.S. Agency for International Development (USAID) program officer joined their European counterparts but worked separately from them-in practice, a PRT within a PRT. While they lacked "unity of command," they maintained "unity of effort."

They were positioned with Norway in Faryab, Sweden and Turkey in Jowzjan, Sweden in Mazar-iSharif, Germany in Kunduz and Badakhshan, and Hungary in Baghlan. They conducted political and economic reporting and engagement; public outreach; agricultural assistance; rule of law support; and assistance programs in education, health, infrastructure, and governance. The local officials found it reassuring to know that the United States remained invested in areas under the control of other NATO partners.

The U.S. teams were all well received by their European and Afghan hosts, who welcomed all the help they could get, especially when they came with project or budgetary support. Sitting atop the six U.S. PRTs was an interagency regional headquarters team that I led consisting of officers from the State Department, USAID, and the Department of Agriculture. In addition to overseeing the efforts of American PRTs, I provided senior U.S. political engagement with the governors and other prominent Afghan leaders and conducted extensive public outreach to explain the overall effort to the Afghan populace within Regional Command North.

At the national level, however, there were questions with the PRT construct, and Afghan President Hamid Karzai himself had become critical. In February 2011, Karzai raised a question in a NATO forum as to whether these "parallel structures" should be ended. ${ }^{8}$ The notion undoubtedly had its genesis 
in something Karzai had experienced, possibly a PRT that overstepped its bounds or an honest feeling that after 10 years, the local governments should be more functional.

Afghan governors, however, did not share Karzai's sentiment. They knew that PRTs were always intended to be temporary and their withdrawal, euphemistically described as "transition," would begin in 2012. One governor described the imminent pullout of the PRT as his "Y2K." He recognized the value of the PRT serving as a backstop for the provincial government when it stumbled, especially in emergencies, and in mentoring and training government officials in technical fields such as budgeting. The PRT's military component also actively worked with local security forces to ensure stability, providing a higher level of intelligence support and operational planning. The governor was in no hurry to see it end.

Nurturing cooperation in this environment required infinitely more time and patience than in a setting where one understood intuitively the players and their motivations. Nevertheless, many PRTs effectively delivered stability and progress. Success was achieved through good cross-cultural skills, empathy for the positions of others, some joint projects that bound the various foreign and host country elements together, and an effective force that was known but not visible, all under good civilian and military leadership.

\section{The economy}

The three broad lines of effort in State Department planning for stabilization, as in most similar operations, were economic development, security and the rule of law, and governance. Of the three, my team believed the economic piece to be the most urgent.

Afghanistan needed a stable economy prior to the impending coalition departure or risked what one governor described as a "fiscal and economic cliff." One researcher noted that most Afghans "judge the country's contending powers in terms of their ability, or inability, to improve the economic lot of ordinary people. ... An awareness of economic progress will do more than anything else to advance political stability." 10 Every member of the international team in the north understood the urgency of building a sustainable economy that could outlast the coalition presence. Silver bullets did not exist; instead, a long slog was required.

Progress in Afghanistan from my first tour in 2002 to my return in 2012 had been dramatic: the number of children in school had grown from one million boys to 4.6 million boys and 2.9 million girls, ${ }^{11}$ access to health care had increased from $9 \%$ to $57 \%,{ }^{12}$ gross domestic product (GDP) had increased from $\$ 4$ billion to $\$ 20$ billion with growth averaging more than $17 \%$ a year, ${ }^{13}$ mobile cellular subscriptions had increased from 25,000 to over 15 million, ${ }^{14}$ and life expectancy had increased by $9 \% .{ }^{15}$ While impressive, the gains were the result of starting from a very low bar and remained tenuous, and some, like GDP growth, were the product of unsustainable foreign investment. Still, when I showed these metrics to my Afghan counterparts, even the most skeptical official found them difficult to challenge.

Our strategy was to build a self-sustaining export-oriented economy that was organized in the short term around agricultural derivatives and transportation while simultaneously working to develop the north's more lucrative mineral wealth that could underwrite higher-level progress. The Department of Agriculture advisors, typically farmers or extension agents, ${ }^{16}$ focused on training farmers, spreading new techniques, assessing agricultural potential, steering infrastructure projects dealing with irrigation, and helping connect farmers with markets and their own government. ${ }^{17}$

State Department economic officers provided reporting to guide resource allocation and programs while engaging with local business partners. USAID directed infrastructure projects and private-sector development as well as support for governance, health, and education. The Pentagon-run Task Force for Business Stability Operations led a parallel operation intended to quickly reduce unemployment, stabilize the economy, and attract foreign investment. ${ }^{18}$

U.S. military units also supported economic development through the Commanders Emergency Response Program, which enabled "local commanders during contingency operations to respond . . . to 
urgent, small-scale, humanitarian relief, and reconstruction projects and services that immediately assist the indigenous population within their area of responsibility." 19

Given the centrality of agriculture to the economy, we hoped to expand agricultural production and build an export-oriented economy that would employ the most people across the longest employment chain. There were serious hurdles to getting products into international markets where they would draw the biggest yield: transit challenges, phytosanitary issues, lack of investment capital, poor infrastructure, and the absence of a marketing culture. Nevertheless, there were several early successes in fruits and nuts and some non-agricultural products, including carpets and skins.

Other sectors of the economy were similarly challenging, but teams found creative ways to spark development. Mazar-i-Sharif was a hub for transit across Afghanistan, and Balkh Province- of which Mazari-Sharif serves as the capital—was the country's gateway to Central Asia and Europe, a key part of the "New Silk Road" concept. By piggybacking on the military's redeployment scheme, which required the development of a world class "port" and rail line in Hairaton, a town on the Uzbek border, this transit hub could anchor the local economy.

The project brought in additional players: U.S. Army logisticians and a small team of border experts from the U.S. Department of Homeland Security's Border Management Task Force, who mentored, trained, and advised the Afghan team in effective border management. The crossing looked more and more functional each month.

Underground natural resources were more pieces of the economic puzzle. They included 59 trillion cubic feet of natural gas reserves; 1.9 billion barrels of crude oil ${ }^{20}$ and a smattering of gold, aluminum, iron, and other precious minerals conservatively estimated at $\$ 1.5$ trillion. ${ }^{21}$ They offered the promise of jobs, tax revenues, and other economic development that follows from resource extraction development. USAID and the Pentagon's Task Force for Business Stability Operations worked in parallel to develop the natural gas fields, which had thrived under the Soviet Union..$^{22}$ The overall project continues today, with Turkish investment and some progress, albeit still years away from reaching its full potential. ${ }^{23}$

There were also a handful of highly functional factories in the north, primarily around Mazar-i-Sharif. The Sadat bottling factory employed more than 100 workers and produced thousands of bottles of water daily under an extremely talented chief executive officer who had spent years abroad and operated at a level commensurate with any Western executive. The Ghazanfar brothers had built up an impressive business focused on fuel delivery, refining, and real estate. The biggest issue for both, along with other businesses that had grown up alongside them, was their dependence on a substantial international presence. They were attempting to transition to an Afghan-only economy, but it was not clear how it would be sustained when the tens of thousands of coalition members departed.

Elsewhere across the north, when advising economic development, we often found efforts lacking at least one critical component. I spent several days in Baghlan Province and found that their agricultural sales were constrained because of a lack of cold storage. Cold storage was not available because of a shortage of electricity. Electricity was not available because the dam in Pul-i-Kumri was functioning at a quarter of its capacity since the Ukrainian-built turbines broke down years earlier and the company that produced them went out of business. There was no specific culprit, just a very broken infrastructure and a mishmash of actors and interests that rarely aligned with a clear track record of production and marketing. Our teams did what they could to piece it all together.

The Afghan government, which would soon have full responsibility for economic development, was an energetic partner in some provinces and indifferent in others. Governor Atta Muhammad Nur of Balkh Province was the most visionary of the northern governors, seeking new markets in India, Iran, Uzbekistan, and the Gulf. He traveled widely, just as any American governor would to develop business. Governors of most other provinces were supportive of our efforts but did little to foster the self-sustainment of their economies. 
In the spring of 2013, the minister of finance and future president, Ashraf Ghani, spoke at a conference in Kunduz about the region's development. He said the fundamental challenge facing the north was not security but jobs and suggested it was time to move beyond production to a full competition strategy that would connect producers to exporters. He reminded the audience that there was much the country could do without the international community.

When I left Afghanistan in 2013, the economic project was unfinished. I knew that once most NATO forces left in the coming years, the support on which the Afghans depended would be gone. In my final message to Washington, I judged that the modest gains we had made were all tentative and we were a long way from bringing northern Afghanistan even to the periphery of the global economy. I suggested most of our contribution could have gone better.

I also concluded, however, that it was always going to be the work of a generation, and we needed to be realistic about the limitations of what a rural, mountainous, disjointed economy with a largely rapacious leadership could bring about. In my view, it was just enough for continued development engagement. It was clear that without continued outside assistance, any residual progress would be lost.

\section{Security and the rule of law}

The development of a lasting and viable security system had been through the same ups and downs as the economy, but, like the economy, was marked by steady progress. In 2012, the north had only 3\% of the nation's security incidents, making it a "permissive" environment, but there remained dangerous areas that could unravel at any moment. Over the previous decade, the United States and other NATO member-states had invested almost $\$ 450$ million into the security force-basing infrastructure in Balkh alone. ${ }^{24}$ This investment produced training facilities and a robust logistical system, but it was all still very dependent on ISAF.

Building on a Kabul-directed recruiting and training system that provided the initial security forces, each PRT did what it could to train, advise, and mentor the forces in its sector while conducting what missions and patrolling it could within the limits of its national caveats. ${ }^{25}$ But for the most part, security remained the primary focus of the military component of the NATO mission, with the PRTs playing a supporting role. U.S. Special Operations Forces (SOF) operated throughout Regional Command North, carrying out missions to kill or capture terrorists and insurgents, as well as building local security forces through the Village Stability Operations and Afghan Local Police program.

State Department officers and SOF worked closely in most areas, knowing that they each possessed one piece of the puzzle. State Department officers had day-to-day contact with local government officials and were building a system for local governance and the economy that would create the stable environment required to improve security over the long term. SOF teams, for their part, operated in places where State Department officers could only access with great difficulty, and they knew the local political structure and its key power brokers. SOF and State Department officers exchanged information, synchronized strategies, and often found places where their direct cooperation could make a difference between success and failure.

I saw this play out even more clearly in Anbar Province in Iraq on a previous deployment. As a division of labor, I managed the formation of the new provincial government, and a team from the Central Intelligence Agency engaged with tribes who were losing influence with the current local leadership, while SOF teams contained nefarious actors. We met frequently to compare notes and share information. When it became clear to the intelligence team that one major tribal grouping was left behind in the provincial government formation, I struck a deal with the other members to include them, while the SOF teams kept potential spoilers at bay through direct action raids. It was one of the clearest examples of positive unity of effort I have seen.

In the north, containing spoilers was one primary mission for SOF, and the diplomats helped build trust and relationships with local strongmen and leaders to ensure they understood the purpose of the SOF raids 
and helped mitigate blowback when a "night raid" went awry. Based on our extensive relationship building, the local governors greatly appreciated the SOF raids. I asked several governors what they would select if they had to choose among a one-year extension of the PRT, $\$ 1$ million for their security forces, or an indefinite extension of night raids. They invariably opted for night raids. They knew the Afghan national forces could not confront and control the terrorist threat alone, and they accepted the occasional fallout from collateral damage.

In the midst of these efforts, the Afghan National Army, Afghan Border Force, and Afghan National Police made progress. In March 2013, to ensure a safe Nowruz Festival for hundreds of thousands of pilgrims coming into Balkh, Governor Atta consolidated local and national security forces in Mazar-i-Sharif under a single command, with even the Afghan National Army commanders deferring to his leadership. The event would bring hundreds of thousands of pilgrims and other visitors to his province, and he was determined to ensure it would occur without incident.

Atta assembled 6,200 security personnel from the police, border guards, and army, and developed four cordons of successively tighter security. It ran like clockwork and with no visible coalition presence. It was a good example of how the security system could come together when properly led.

Such leadership was not initially available several weeks later in Badakhshan Province. A band of insurgents - a curious mix of criminals and religious extremists - in the Wakkan corridor ambushed an Afghan army column, killing more than a dozen soldiers. ${ }^{26}$ The attack set off a month-long scrum by the army and police to re-establish their presence in some of the country's toughest terrain and laid bare the security forces' lack of cohesion, planning skills, morale, air power, and leadership. Above all, it raised questions about the division of labor, with the army wanting to be the "clear" force to the police's "hold" force but the police arguing they lacked capability to hold anything. To their credit, the security forces collectively clawed their way back in and reestablished the government's presence.

Across the north, the security forces adjusted to changing conditions. The Afghan army came in when called, and they largely muddled through. The local PRTs took more and more of a hands-off approach but tried to support the force with training, advising, and mentoring, increasingly staying out of the perpetual appeals for logistical support, something the Afghans never quite mastered.

One perpetual problem was that the national security system was never able to fully overcome the local security architecture that had existed for so long under warlords, strongmen, and ethnic leaders. These leaders maintained their private security forces through either informal or formal networks, and there was continued space for insurgent groups to operate. ${ }^{27}$ The governor of Faryab Province told us he was in a "bidding war" with insurgent leaders for the loyalty of the province's young men. The governor of Talibanheavy Baghlan Province conversely believed that the police worked for money, while the Taliban worked for faith, claiming that "100 Talibs could overcome 1,000 police."

It was a continuing struggle to establish the primacy of the national government throughout the country, not unlike what Colombia has largely achieved after its nearly 50-year fight with the Revolutionary Armed Forces of Colombia. Establishing governance and security in a rugged nation like Afghanistan or Colombia is often a resource-intensive, lengthy, and bloody battle.

One of the programs the United States and the United Kingdom implemented to overcome this lack of security in the countryside was the Afghan Local Police, a federally funded local force for rural areas that many worried would become just another armed group. State Department officers often worked closely with SOF teams who conducted the training mission to ensure a tribal balance and good political landing for the new force.

Beyond investing in the development of Afghan security forces, several countries, notably the Netherlands but also the United States, had modest programs for rule of law and judicial support. In most of the provinces, we found that there was some NATO investment in improving judicial systems in the provincial capital but little in the districts. The supporting U.S. effort funded a network of advisors and defense 
attorneys and attempted to improve both the quality of the judicial system and the ability of the police, courts, and other local officials to coordinate their actions through better case management.

There were the occasional cases where the system worked, including in June 2012, when four Afghan Local Police members received sentences of 16 years in prison for the rape of a young girl. ${ }^{28}$ Unfortunately, this was the exception. Many Afghans turned to the Taliban to seek justice from the predations of local strongmen. Sustaining the new system would be difficult, and we knew we were only working on the margins.

Corruption was one of the many negative outcomes resulting from a poor judicial system - the one constant across most sectors and provinces. Unfortunately, corruption actually worsened over time. When Transparency International first ranked Afghanistan on its corruption perceptions index in 2005, it ranked 117 out of 159. By 2012, Afghanistan had fallen to 174 out of 198 and has failed to improve since. ${ }^{29}$

Sarah Chayes, who spent years in Afghanistan and became one of the leading voices on corruption, said in a 2015 interview after a trip to Kunduz: "In an arid place like Afghanistan, almost entirely dependent on high-end agriculture . . stealing someone's land is worse than murdering them." The ability of local strongmen to take land, she went on, means that "years of built-up grievances and no avenue of recourse drive people to extremes," with a "thoroughly corrupt" government implicated on the wrong side of the issue. ${ }^{30}$

We did what we could with local authorities to support anti-corruption programs, one of which was run by Shamshullah Jawid, the head of the local Afghan High Office of Oversight and Corruption. Jawid was part of the new class of bureaucrats in the government, not connected through birth or tribe to power but hopeful of having influence through professionalism, technical competence, and fairness. He was working on an awareness campaign that had reached 2,700 people through seminars and conferences and had dozens of ongoing corruption cases. ${ }^{31}$

The security forces and the judiciary still had a long way to go. Yet in 2013, a rudimentary infrastructure was in place, a new generation of leaders had been trained, and with political will and consistent outside resources, continued progress was conceivable. Of the two, the judiciary was to be the most difficult, and we knew it would likely end up with a much more localized flavor.

\section{Governance}

Nadia Schadlow noted that "to wage war effectively, civilian and military leaders must operate as successfully on political battlefields as they do on the physical." ${ }^{32}$ Fareed Zakaria added that "in almost every situation that U.S. forces are involved in, the solutions are more political than military. . . Military force without a strategy or deeply engaged political and diplomatic process is destined to fail." 33

Getting regional warlords to lay down their weapons and support a national government was at the center of Afghanistan's many transitions. One key factor was the traditional disconnect between the central government and the regional and local governments in Afghanistan, whose tough terrain has always made strong local autonomy a political fact of life.

Both post-9/11 leaders-Hamid Karzai from 2002-2014 and Ashraf Ghani since 2014-have struggled to channel power away from regional strongmen into national institutions. They have appointed governors from outside the regions who could implement national policies independent of local actors, deployed security forces led by outsiders, alternatively withheld and offered resources, and attracted some regional leaders to Kabul with ministerial positions to take them away from their center of gravity.

But they were competing with regional strongmen who had a firm local power base that derived from various revenue streams (often from border crossings in the north), a place of prominence in their ethnic group, their martial prowess proven in the various wars of the last decades, and at times sheer brutality and thuggery. In many provinces, the regional power brokers resembled a firmly entrenched mafia family. ${ }^{34}$ 
Our challenge in dealing with these regional leaders, who could not legitimately be ignored and who on matters of security and counterterrorism were often active on the right side of the equation, was how to bring them under the national umbrella. We did so by engaging them actively and respectfully but channeling all our resources through the representatives of the central government.

By 2012, the reality of the impending transition from NATO to Afghan forces, which would occur in phases between 2013 to 2015, when only a residual force at Camp Marmal would be left across the north, began to sink in for local leaders. I found this in a visit to Abdul Rashid Dostum, the Uzbek leader who had fought with the United States in ousting the Taliban. Over a lavish lunch in his compound in the spring of 2013, Dostum showed us a large map with his electoral strategy for the 2014 election. He summed it up by saying "the election is the new AK for the Afghan family." ${ }^{35}$ From here on out we will fight through politics, not force, he suggested.

It would be a long road for the government to consolidate power, knowing that the strongmen would maintain their informal networks of influence even as they cautiously supported the developing formal government networks. The hope was that leaders like Dostum would move away from militias and toward the transparent amassing of wealth, media influence, and coalition building, paving the way for a postwarlord society.

The electoral system since then has become more decentralized. For the first time, voters chose district councils in 2018 that had some resources and authority retained locally, as opposed to the prior system of pushing all electoral energy to Kabul with resources returning at the discretion of the federal government. Against this backdrop, governance capacity at the provincial level progressed slowly if unevenly. The centrally chosen and placed governors in many cases were quite capable and connected to their province, especially if they were from the area and not sent from Kabul to quell any moves toward autonomy.

The provincial and local levels were less capable, however, and international donors sought to help develop a rudimentary capacity to budget, plan, and deliver services. Military civil affairs units also stepped into the breach, often bringing critical skill-sets that were not otherwise available for training, advising, and mentoring a local civil service. Local officials generally accepted the assistance as long as it was respectfully delivered and consistent.

Effective PRTs realized that they were key political players themselves and therefore needed to devote resources and effort to building their own influence. But with 9,000 villages and very little television and internet penetration in the north, it was a challenge. We decided radio would be our best tool, and several local stations that were tired of the poor international perception of Afghanistan were open to our more positive message. We fed them a steady stream of interviews and events.

We messaged especially heavily on the transition issue, which we saw as a game of confidence. Left to their own devices, few Afghans seemed to believe that they could develop into a functional democracy and market economy, but with the continuation of some form of international support, they saw the odds shifting in their favor. I believed we needed to be visible, present, and proactive.

As diplomats and soldiers conducted engagement, religious leaders were also high on the list of those to be engaged. In early November 2012, a negative video about the Prophet Muhammad was about to be published on the internet, and we wanted to stave off a violent reaction. The previous year, protesters overran a United Nations compound in Mazar-i-Sharif, killing seven employees after an obscure pastor burned Qurans at his Florida church. ${ }^{36}$

I met with the governor and both of the Sunni and Shia imams to warn them of the imminent video release, and the imams promised to do their part. The Sunni imam, having spent time in Kentucky on a State Department program, promised to take a firm message to the mosque that this single incident did not represent the American people he had come to know. Governor Atta was similarly determined not to allow another round of violence over the incident, and he directed the security forces to ban demonstrations outside of compounds. 
It reminded us again of the criticality of local leadership but also of taking the time to develop the relationships that would ensure that Afghan leaders remained on our side. There is no substitute for faceto-face encounters and for experiencing American culture firsthand.

Both local and national politics continued to progress, albeit unsteadily, but the real test of their progress, as with the economy and security forces, would be the withdrawal of the bulk of the international force across the sector during 2013-2014.

\section{Transition: a testing of what the partnership yielded}

From the day I arrived, one of our primary objectives was preparing for "transition," which required handing over security responsibilities to Afghan forces and political responsibilities to local officials. Regional Command North Commander Major General Vollmer likened it to conducting a "relief in place"-turning over bases and operating space to Afghans while in many cases under fire. I recall him reminding his staff that this was one of the most difficult missions a unit can conduct, directing that we would go out with our heads held high, not rushing to the door, but not lingering.

In October 2012, several NATO ambassadors held a discussion in Mazar-i-Sharif with local governors and security commanders. The message of the Afghans was one of a vast unfinished project that was on track but needed continued attention and resources to conclude successfully. They stressed the importance of ongoing support to the security forces but even greater importance to a steady flow of development assistance that would lead to jobs and poverty reduction.

The closure of PRTs was one of the most visible parts of the transition. Over the course of eight months in late 2012 to 2013, the Norwegians, Swedes, Germans, and Hungarians decamped nearly every PRT. By the summer of 2013, the only PRT remaining in the north was at Mazar-i-Sharif. Even with months of preparation, the process was inconsistent. In November 2012, well into the transition, one senior allied military advisor told me, "when we take the training wheels off, we sometimes find there wasn't a bicycle there to begin with."

In some provinces, we were not sure what would happen after the PRTs withdrew, because it was extremely difficult to assess the PRT's impact. In many places, international forces had stopped actively patrolling months ahead of the withdrawal, and in some cases, their national "caveats" had prevented them from ever having conducted combat operations anyway. But it soon became apparent that the mere presence of an international force, and especially of NATO SOF, had positively impacted security.

The early withdrawals went well enough, and some violence was expected. For example, in October 2012, a suicide bomber killed 45 people at a mosque in Maimana, the capital of Faryab Province. ${ }^{37}$ In some districts in Baghlan Province, the Taliban's "shadow government" squeezed out the poorly financed legitimate government and outmatched its security forces. The continued corruption and the predatory nature of some local officials also pushed some citizens to view the Taliban as the lesser of two evils. ${ }^{38}$

The Taliban strategy involved more than just being marginally less corrupt; they had been building a multi-ethnic coalition including Hazaras and Tajiks and presented a softer touch than the previous Taliban regime.

Our challenge was devising a way to keep our presence visible enough to support the Afghans in the transition after the withdrawal of military forces. In a January 2013 report to the embassy, I offered that "the Afghans are slowly gaining confidence in their own abilities, but always with a backward glance to see that we are still with them." I suggested that "the United States can play a decisive supporting role in maintaining the generally positive trajectory of the north, but only if we are here. . . We need to be visible, present, and engaged." 39

We explored several ways to remain engaged, at least with some peripheral tasks, including key leader engagement, support for the rule of law, anti-corruption efforts, and economic development, even if carried out through local partners with only occasional face-to-face encounters. Yet after the unfortunate 
politicization of the Benghazi incident, there was little appetite to assume the risk that would have been required for even such indirect engagement. In the end, the Afghans started to realize that in most places, transition meant withdrawal.

\section{Conclusion}

As I left Mazar-i-Sharif, I wrote to Kabul that the ball was still much in play in the north. Without our continued focus, however, it could quickly end up out of bounds or more likely somewhere in the bleachers. In a final cable, I concluded:

In urban areas there is a post-warlord political culture developing that is being buttressed by a postwar generation to create exciting new possibilities for the future. But rural areas, especially those that are cut off geographically from cities, are not part of this progressive picture, and even some more connected areas such as Kunduz are still at the mercy of the guy with the most shooters. The [Afghan National Security Forces] has its work cut out for it, and will need to pick up the pace if it is not to be outrun by the devolving security environment. Economically we are seeing the fruits of 10 years of rebuilding but increased agricultural and physical production must now be matched with internal and external markets to create jobs, something that will require extensive international assistance. The United States and the international community continue to play a vital role in all this both through continued direct assistance, and through beating back the chilling narrative of abandonment. . . . Going forward, showing up will be at least half the job here.

It was a bit on the optimistic side, although I sensed that pessimism was in such rich supply that there was no point in adding to it. In the end, the setbacks have been worse than I would have thought, while the progress has been less obvious. Still, it would be impossible to write the project off just yet. The Afghan National Security Forces continue to make progress, and hundreds of Afghans feel strongly enough about their country to give their lives in its defense. Elections, imperfect as they are, continue to yield democratically elected leaders. Education continues to edge along, and health care is ever improving.

The roots for economic progress are in place. The lesson might be that it is simply hard to pull a severely underdeveloped country into the modern age. But it is nearly guaranteed to fail without continued focus and resources from the international community, and given the threats emanating from ungoverned spaces of late, it may be worth staying the course. Adapting U.S. government architecture for engagement to draw out the skills and resources of the American interagency at the proper level and for the appropriate amount of time will be essential to success.

\section{Notes}

1 Department of the Army, Insurgencies and Countering Insurgencies, FM 3-24 (Washington, DC: Department of the Army, 2014), 7-9.

2 Bijan Omrani and Matthew Leeming, Afghanistan: A Companion and Guide (Hong Kong: Odyssey Books and Guides, 2011), 234.

3 Center for Army Lessons Learned, Afghanistan Provincial Reconstruction Team: Observations, Insights, and Lessons (Fort Leavenworth: U.S. Army Combined Arms Center, 2011), 1.

4 Ibid.

5 Ibid., 3.

6 Christian Karsner and Sarah Kopczynski, "Through and With: Reintegration in Northern Afghanistan," Special Warfare 25, no. 1 (2002): 37.

7 The Swedes, wanting to emphasize the primacy of the civilian effort, put an ambassador in charge of both the military and civilian components in their sector. 


\section{Stabilization in Afghanistan}

8 Judy Dempsey, “Karzai Seeks End to NATO Reconstruction Teams,” New York Times, February 6, 2011, www. nytimes.com/2011/02/07/world/asia/07munich.html.

9 Y2K, short for the year 2000, referred to the computer shortcut that was expected to wreak havoc when the year changed from 1999 to 2000.

10 S. Frederick Starr, Finish the Job: Jump-Start Afghanistan's Economy, a Handbook of Projects (Washington, DC: CentralAsia Caucasus Institute Silk Road Studies Program, 2012), 11.

11 "Education in Afghanistan," World Education News \& Review, September 6, 2016, https://wenr.wes.org/2016/09/ education-afghanistan; UNICEF, UNICEF Annual Report 2012 for Afghanistan (New York: UNICEF, 2013$), 2$.

12 "Afghanistan Health Sector Fact Sheet," U.S. Agency for International Development, accessed October 30, 2020, www.usaid.gov/sites/default/files/documents/1871/AFG\%20Health\%20Sector\%20Fact\%20Sheet $\% 20$ FINAL $\% 20$ 06.14.2014.pdf.

13 “Afghanistan," World Bank, accessed October 30, 2020, https://data.worldbank.org/country/AF.

14 Sam Gollob and Michael E. O’Hanlon, Afghanistan Index (Washington, DC: Brookings, 2020), 36.

15 "Life Expectancy at Birth, Total (Years)_Afghanistan," World Bank, accessed October 30, 2020, https://data. worldbank.org/indicator/SP.DYN.LE00.IN?locations=AF.

16 An extension agent is an agriculture expert and mentor.

17 The agricultural advisors were among the most effective, best exemplified by the simple statistics of the wheat harvest, which had increased from an average of 2.67 million metric tons in 2002 to 5.0 million metric tons in 2012. Although good rains played a part, it also had much to do with the advisors overseeing the systematic replacement of the wheat seed across the country to develop a more resilient and higher yielding strain. See "Afghanistan: Wheat Production Quantity," Knoema World Data Atlas, accessed December 10, 2020, https://knoema.com/atlas/ Afghanistan/topics/Agriculture/Crops-Production-Quantity-tonnes/Wheat-production.

18 S. Rebecca Zimmerman, Daniel Egel, and Ilana Blum, Task Force for Business and Stability Operations (Santa Monica: RAND, 2016).

19 Department of the Army, The Commanders' Emergency Response Program, ATP 1-06.2 (Washington, DC: Department of the Army, 2017), 1-1.

20 Amie Ferris-Rotman and Ramya Venugopal, “Exxon Explores 'Very Promising'Oiland Gas Fieldsin Afghanistan,”Reuters, September 7, 2012, www.businessinsider.com/this-energy-company-hopes-to-find-oil-in-afghanistan-2012-9.

21 Eltaf Najafizada, "Study Finds Mineral Deposits Worth \$3 Trillion in Afghanistan,” Bloomberg, January 29, 2011, www.bloomberg.com/news/articles/2011-01-29/u-s-afghan-study-finds-mineral-deposits-worth-3-trillion.

22 Amity Shlaes, "Afghan Resources Flowing to U.S.S.R. Despite the War; Hungary Seeks Dollars," Wall Street Journal, January 17, 1984.

23 Shadi Khan Saif, “Afghanistan Starts Gas Extraction After 4 Decades,” Anadolu Agency, April 2, 2020, www.aa.com. tr/en/asia-pacific/afghanistan-starts-gas-extraction-after-4-decades/1789496.

24 This number is based on the author's recollections from a meeting with a member from the U.S. Corps of Engineers in Afghanistan in 2012.

25 The Hungarian forces in Baghlan, for example, were prohibited from firing weapons except in self-defense, and most NATO allies had similar restrictions, often extremely detailed. See Regeena Kingsley, Fighting Against Allies: An Examination of 'National Caveats' Within the NATO-Led International Security Assistance Force (ISAF) Campaign in Afghanistan and Their Impact on ISAF Operational Effectiveness, 2002-2012, Volume II: Appendices (PhD diss., Massey University, 2014), 125, https://mro.massey.ac.nz/xmlui/bitstream/handle/10179/6984/03_appendices. pdf? sequence $=4 \&$ is Allowed $=\mathrm{y}$.

26 Rod Nordland, “Taliban Kill 17 Afghan Soldiers in Once-Quiet Region,” New York Times, March 6, 2013 , www. nytimes.com/2013/03/07/world/asia/taliban-kill-17-afghan-soldiers.html.

27 Dipal Mukhopadhyay, Warlords, Strongman Governors, and the State in Afghanistan (New York: Cambridge University Press, 2014).

28 Jawad Sukhanyar and Alissa Rubin, "4 Members of Afghan Police Are Found Guilty in Rape," New York Times, November 7, 2012, www.nytimes.com/2012/11/08/world/asia/afghan-militia-members-found-guilty-in-rape.html.

29 "Transparency International Corruption Perceptions Index," accessed November 10, 2020, www.transparency.org/en/.

30 Theresa Riley, "Sarah Chayes on Why Afghanistan Is Going to Fall to the Taliban Again," Moyers and Company, Perspectives, October 5, 2015.

31 Based on the author's notes from conversations with Shamshullah Jawid.

32 Nadia Schadlow, War and the Art of Governance: Consolidating Combat Success Into Political Victory (Washington, DC: Georgetown University Press, 2017), 2.

33 Fareed Zakaria, “The United States Is Stumbling Into Another Decade of War,” Washington Post, June 22, 2017, www.washingtonpost.com/opinions/global-opinions/the-united-states-is-stumbling-into-another-decade-ofwar/2017/06/22/7cd589f2-5796-11e7-a204-ad706461fa4f_story.html. 
34 Mukhopadhyay, Warlords, Strongman Governors, and the State in Afghanistan.

35 AK refers to the AK-47 rifle, which was the most common rifle in Afghanistan dating back to the Soviet-Afghan War.

36 Mohammad Bashir, "Worst Attack on U.N. in Afghanistan Kills at Least 7," Reuters, April 1, 2011, www.reuters. com/article/us-afghanistan/worst-attack-on-u-n-in-afghanistan-kills-at-least-7-idUSTRE7306JP20110401.

37 Alissa J. Rubin and Sangar Rahimi, "Suicide Bomber Kills Dozens of Worshipers in Afghanistan," New York Times, October 26, 2012, www.nytimes.com/2012/10/27/world/asia/afghanistan-suicide-bombing.html.

38 Joseph Goldstein, "A Taliban Prize, Won in a Few Hours after Years of Strategy," New York Times, September 30, 2015, www.nytimes.com/2015/10/01/world/a-taliban-prize-won-in-a-few-hours-after-years-of-strategy.html.

39 Quarterly report from senior civilian representative RC-North to Embassy Kabul, January 15, 2013, in possession of the author. 


\title{
20 \\ DISMANTLING AL-QAIDA IN IRAQ
}

\author{
Liam Collins ${ }^{1}$
}

When Major General Stanley McChrystal took command of Task Force 714 (TF 714) in October 2003, he found a unit that was highly proficient at conducting raids but not one capable of dismantling a terrorist network. The Special Operations Forces (SOF) "operators" were extremely capable at kill or capture (finish) operations, but the task force lacked the ability to exploit and analyze intelligence in an effective manner required to find and fix new targets. McChrystal recognized that the task force could be much more effective, and he quickly developed the idea that "it takes a network to defeat a network."'

Over the next three years, McChrystal oversaw the remarkable transformation of the task force into a highly efficient and effective network. In April 2004, the task force conducted only 10 operations in Iraq in the entire month; two years later, the task force conducted 10 operations on any given night, totaling more than 300 a month. $^{3}$

This chapter describes the development and evolution of the find, fix, finish, exploit, and analyze (F3EA) targeting cycle and the network that McChrystal built to combat al-Qaida in Iraq (AQI). It also provides an operational vignette of how F3EA led to the death of AQI's infamous leader, Abu Musab al-Zarqawi.

\section{Taking command of Task Force 714}

TF 714 originated after 9/11 when its early predecessor, Task Force Sword, was established in Afghanistan. It was a combined (multinational), joint (multi-service) task force under the direction of U.S. Special Operations Command (SOCOM) that deployed to Afghanistan in September 2001 to conduct direct action missions against high value al-Qaida and Taliban targets. ${ }^{4}$

In April 2003, the task force was directed to support the invasion of Iraq. TF $16,{ }^{5}$ composed of U.S. Army Rangers and other SOF units, was tasked with seizing key targets, including airfields deep in Iraq; capturing high-value targets; providing long-range special reconnaissance; and searching for weapons of mass destruction. ${ }^{6}$

After the fall of Baghdad, the task force's mission changed to capturing former regime members, carrying out sensitive site exploitations at facilities suspected of being used to store or process weapons of mass destruction, and hunting down Baath Party leadership attempting to flee the country. On July 22, 2003, TF 16 led a raid that killed Saddam Hussein's sons, who were two and three on the U.S. most wanted list. ${ }^{7}$

When McChrystal assumed command of TF 714 in October 2003, TF 16's primary mission had shifted almost exclusively to hunting the former regime leadership. ${ }^{8}$ Teams were located with TF 16 's headquarters 
in Baghdad, with General David Petraeus's 101st Airborne Division in Mosul, and with General Raymond Odierno's 4th Infantry Division in Tikrit. TF 714 also had a sizable presence in Afghanistan, a small number of personnel elsewhere in the region, and a few liaison officers at critical headquarters in the region and at a small number of partner agencies in Washington. ${ }^{9}$

Shortly after taking command, McChrystal took his first trip overseas, arriving in Iraq on October 24, 2003. He visited his task force headquarters in Baghdad before continuing to his "outstations," or teams, at other locations in Iraq. Both Petraeus and Odierno complimented the work of his teams, but McChrystal found the teams to be "largely cut off from the rest of [the] force." The teams and the task force had a clear mission but lacked a common strategy and "real-time links" to one another. The most glaring shortcoming was the way in which the teams handled raw intelligence. ${ }^{10}$

His task force understood the need to collect documents and electronic media for its intelligence value and worked on mastering "sensitive site exploitation," but the captured material was rarely exploited. Teams would grab everything they could find on target, stuff it in garbage bags or burlap sacks, load it on the helicopter with anyone they captured, and send it off to the headquarters for analysis. But teams never received anything back; it was a black hole. ${ }^{11}$

When McChrystal inspected the intelligence processing facility at the headquarters at Baghdad International Airport, he opened a door to a spare room and found it "filled with piles of these plastic and burlap bags stuffed with captured material" that appeared to be unopened. ${ }^{12}$ To be fair, the headquarters attempted to exploit the captured media and documents, but it lacked capacity. The media exploitation cell consisted of a single individual attempting to exploit the more than 75 computers that had been recovered. ${ }^{13}$

After his overseas visit, McChrystal concluded that his task force had five significant shortfalls: a lack of a common strategy; a lack of intelligence, surveillance, and reconnaissance (ISR) assets; a lack of human intelligence; a lack of interrogators; and a lack of document exploitation capability. McChrystal realized there was no common strategy and the headquarters was irrelevant to the forward teams, with each team fighting its own, independent campaign. He saw that he needed to tie the forward teams and the rear headquarters into a single fight. ${ }^{14}$

Two months later, TF 16 captured Saddam Hussein, but the team based in Tikrit, not at headquarters, conducted the exploitation that led to his capture. Starting with a seemingly low-level and distant lead, the team conducted a series of raids and interrogations that ultimately led them to Saddam on December $14 .{ }^{15}$

\section{The start of find, fix, finish, exploit, and analyze}

Despite the capture of Saddam Hussein in December 2004, TF 16's mission was far from over. It quickly transitioned from capturing former regime elements to AQI, with its leader, Abu Musab al-Zarqawi, replacing Saddam Hussein as its top target.

McChrystal understood the importance that al-Zarqawi had in Iraq, but he also recognized where Iraq fit in the larger fight against al-Qaida. With most of al-Qaida's senior leaders believed to be increasingly isolated in Pakistan, al-Qaida needed to remain relevant. It was difficult for the al-Qaida core to conduct operations, so it became reliant on its affiliates in Algeria, Libya, Saudi Arabia, Yemen, Somalia, and Iraq to remain active. These groups were largely cut off from the al-Qaida leadership, and the local groups often acted on their own, with little guidance or direction. ${ }^{16}$

Communication, when it did occur, was slow, often through couriers carrying compact discs or letters; the leaders simply did not communicate using e-mail or phone. ${ }^{17}$ Given this decentralized network, McChrystal concluded that there was "no single person or place" that the United States could strike that would cause al-Qaida to collapse. ${ }^{18}$ So he developed a strategy to target "two of the enemy's surfaces": alQaida's senior leadership and its regional affiliates. If successful, the al-Qaida brand would suffer, as onlookers who might consider joining or supporting the group would think twice after seeing the organizational losses. ${ }^{19}$ 
In the summer of 2004, Colonel Bennet Sacolick, the TF 16 commander, came into McChrystal's office and put a single PowerPoint slide on the monitor that read "FIND-FIX-FINISH-EXPLOIT-ANALYZE." ${ }^{20}$ The words represented the targeting cycle that his deputy, Colonel Scott Miller, had outlined earlier in the year.

Sacolick's brief captured what the task force referred to as the "blink" problem. ${ }^{21}$ A blink was anything that slowed or degraded the targeting process. This process often involved at least a half dozen units or agencies working in separate locations. Between and within each step of the process, information crossed organizational lines, cultural barriers, physical distances, or time zones.

Sacolick summarized the ineffectiveness of the process that existed at the time: "By the time we're ready to go after another target it's often days later, the situation has changed, and we're essentially starting from square one." McChrystal described this process as "[feeling] slow at the time. In retrospect, it was glacial." 22

The task force could sense AQI growing. They wanted to hit targets but lacked the actionable intelligence of where to find them. Most nights, they were stuck sitting in their base. It would take a new approach to defeat the enemy; it would take a network to defeat a network.

\section{Building the network and expanding F3EA capability}

Over the next two years, TF 714 would build the aircraft while in flight. Simultaneously, McChrystal flattened the organization with the help of video teleconferences (VTCs), established a robust liaison network, created two Joint Interagency Task Forces (JIATFs), expanded and improved interrogation capability, expanded ISR capability, and improved the document exploitation capability.

\section{Flattening the organization}

McChrystal's first task was flattening the organization-a rigid hierarchy could not keep pace with a networked enemy. What happened in one region impacted others, so the subordinate teams had to have a complete picture to wage an effective campaign. A rigid hierarchical structure impeded the flexibility of subordinate commanders to execute time-sensitive operations and their ability to rapidly share information.

To increase situational awareness, McChrystal expanded the use of VTCs within TF 714. He forced all his deployed teams to take part in daily operations and intelligence meetings and purchased the required communications packages to make it possible. This provided the dispersed elements situational awareness to everything within the command and allowed each element to understand how they contributed to the larger campaign plan. ${ }^{23}$ Many task force members were initially opposed to attending daily meetings, but they soon saw the value. The daily VTCs provided the forum to synchronize the task force's efforts so that everyone knew the priorities. ${ }^{24}$

McChrystal took another measure by establishing a "portal"- - one-stop shop on the task force's internal network to find all the task force's operations and intelligence information. It served as a repository of information and a venue to manage important staff actions. To force its use, McChrystal and his staff would constantly emphasize the importance of using the portal, and his chief of staff was well known for remarking, "you are either a martyr or a zealot" to anyone who did not fully embrace it. Eventually, McChrystal expanded portal access to his conventional military and interagency partners. ${ }^{25}$

A final measure that McChrystal implemented to flatten the task force was changing the e-mail protocol. If information was meant for McChrystal and his staff, subordinates were mandated to send it directly to him and his staff rather than going through multiple layers of command, which both delayed and filtered the information that was necessary for McChrystal to understand both the enemy situation and his own command. Yet to make this system function, everyone needed to understand what McChrystal and his primary staff needed and what someone else could handle. Otherwise, the volume of e-mail would cripple McChrystal and his primary staff. ${ }^{26}$ 


\section{Expanding the liaison network}

McChrystal's next task was to expand his liaison network. In April 2004, TF 714 supported Major General James Mattis and his Marines in the first battle of Fallujah. Yet McChrystal was caught by surprise when Mattis informed him that Washington had halted the attack when they were on the verge of taking the city. McChrystal had not realized that Washington had concerns with the attack, and he blamed himself for having established too few links with the Marines. He described it as "a mistake I worked hard not to repeat." ${ }^{27}$ Soon thereafter, McChrystal sent liaison officers to as many units and commands as he could and would soon expand the liaisons to relevant agencies in Washington. ${ }^{28}$

McChrystal believed eliminating the "blinks" would have a dramatic payoff, but it required significant physical, organizational, procedural, and cultural changes from his interagency partners. It required everyone in the network to believe in the network premise and trust their counterparts throughout the network, including those they would never meet in person or with whom they might not have otherwise communicated. ${ }^{29}$

To bring the task force and interagency partners closer together, he greatly expanded the TF 714 operations and intelligence VTCs. Until this time, they primarily served as a synchronization tool for his staff. But McChrystal's newly formatted operations and intelligence meeting differed from those conducted by most units by "its regularity; the size, diversity and dispersion of the forum; and the richness of the information discussed." ${ }^{30}$ The VTC occurred six days a week: at 4 PM in Baghdad, which was still several hours prior to the start of many of the task force's night raids, and 9 AM in Washington, which was the start of the work day for many agencies.

In the winter of 2004, the VTC's audience was relatively small. It included some of the larger bases in Afghanistan and Iraq and the conference room of a few key agencies in Washington. By the summer of 2005, the VTC had grown to include even the most remote bases thanks to the development of pre-packaged communication bundles that could connect from anywhere in the world. Eventually, anyone with access to the portal could watch the daily operations and intelligence meeting from their computer. ${ }^{31}$ By 2007 , the daily meeting was a worldwide forum of thousands of people associated with the mission, with up to 72 distinct locations participating daily. ${ }^{32}$

Beyond the value the operations and intelligence meetings provided in terms of sharing information, McChrystal described it as the "single most powerful tool I had at my disposal in leading a dispersed force." It provided him nine hours each week to "influence, inspire and learn" from the diverse force that he led. ${ }^{33} \mathrm{He}$ established a culture where "everyone knows everything . . . all the time." ${ }^{34}$ Situational awareness was centralized, while decision-making was decentralized. ${ }^{35}$ The culture encouraged initiative and free thinking, liberating subordinates to act without hesitation.

Everyone left the daily operations and intelligence meeting knowing the task force's current intent, strategy, rules, and approvals. Outside of the military members of the task force, the operations and intelligence meeting helped animate the Washington beltway for critical support despite the fact that it was a nine-to-five job for many of them. It served as a daily reminder that the United States was at war. ${ }^{36}$

\section{Forming the JIATFs}

Given the geographical dispersion of al-Qaida, McChrystal understood that the military alone could not defeat the group, but he recognized that "early on, counterproductive infighting among the [Central Intelligence Agency (CIA)], [Department of State], [Department of Defense] and others back in Washington threatened that campaign." ${ }^{37}$ Likewise, General John Abizaid, the CENTCOM commander, grew increasingly frustrated with the U.S. government's lack of a "unity of effort" and convened a conference in January 2004 to focus key organizations for the war on terrorism. Abizaid argued that two years after 9/11, the United States had lost its focus on al-Qaida. ${ }^{38}$ 
McChrystal sought to leverage the enthusiasm from the conference into real gains by bringing all potential intelligence sources to bear and followed the recommendation of Rear Admiral Bill McRaven, his deputy, to form a JIATF. ${ }^{39}$ A JIATF is an interagency element that is formed when the close integration of two or more agencies is required for a specific task and purpose. TF 714 required a JIATF focused on al-Qaida to leverage the CIA's human intelligence, the National Security Agency's signals intelligence, the Federal Bureau of Investigation's (FBI) forensic and investigative expertise, the Defense Intelligence Agency's military reach, and the National Geospatial-Intelligence Agency's mapping ability. ${ }^{40}$

While the concept was not new, McChrystal described it as a "transformative" step for TF 714 . McChrystal understood that to be effective, the JIATF had to be physically located in Afghanistan or Iraq because

the Beltway culture compelled, or allowed, the agencies to be less collaborative. Valuable information that might slide across a table downrange had to cross miles and clear bureaucratic hurdles back in Washington where the myriad of essential but compelling priorities, from bureaucracy to family life, always slowed action. ${ }^{41}$

Having everyone in the same tent allowed the analysis to be processed faster, which was essential for fleeting targets. Less obvious but even more important, having them live and work together decreased the gravitational pull back to their respective headquarters in Washington and increased "the sense of shared mission and purpose." ${ }^{42}$

McChrystal established a JIATF in a tent in Bagram, Afghanistan, and the seats slowly filled over the ensuing weeks and months. Most of the JIATF was resourced from outside of his command-only the director, deputy director, and a handful of analysts came from his stateside special operations unit. Success was not measured by how many reports an individual produced; instead, it was measured by the impact of the reports. ${ }^{43}$ McChrystal described the establishment of the JIATF as beginning the process of "turning TF 714 from a collection of niche strike forces into a network able to integrate diverse elements of the [U.S. government] into a unified effort." ${ }^{44}$

Al-Zarqawi's network had grown more sophisticated and more powerful since the U.S. invasion in 2003, and the steady increase of foreign fighters was one measure of effectiveness that indicated that alZarqawi was perceived to be winning. At the time, the task force estimated that 100-150 foreign fighters entered Iraq each month; by comparison, the coalition estimated insurgent numbers at 12,000-20,000 fighters. ${ }^{45}$ But the strategic effect of the foreign fighters was significant. They accounted for roughly $75 \%$ of all suicide bombers in Iraq, and since they had no stake in a stable Iraq, they were not afraid to hit infrastructure targets that only made the situation worse. ${ }^{46}$

In December 2004, McChrystal created a second JIATF, JIATF-West, to reverse engineer the flow of foreign fighters into Iraq. The JIATF in Bagram, focused on al-Qaida leaders in the Afghanistan-Pakistan region, was renamed JIATF-East. Like JIATF-East, JIATF-West had its own weekly VTC, which focused primarily on the foreign fighter network. The VTC quickly grew to include station chiefs from across the region and three dozen agencies back in Washington. This improved our understanding of the enemy network, as each agency could contribute its piece to the larger puzzle to help "connect the dots." ${ }^{7}$

\section{Improving the interrogation capability}

Among the task force's various shortfalls, its interrogation capability was McChrystal's most urgent priority. On the day he took command, his deputy, Air Force Brigadier General Lyle Koenig, called from Iraq and told McChrystal, "We need to close the screening facility. . . We don't have the expertise or experience to do this correctly." ${ }^{8}$ McChrystal called it "our Achilles' heel" and remarked that "if we don't do 
this right, we'll be taken off the battlefield." ${ }^{49}$ Everyone recognized that detainees were a critical source of intelligence, so he resolved to keep the facility open but made fixing it a priority. ${ }^{50}$

At the time, the task force had a skeletal staff of about 13 people working in inadequate facilities, and they rarely provided the teams any intelligence of value from the detainees they captured. ${ }^{51}$ But they were only partially to blame. The teams would simply throw anyone they captured onto a helicopter with bags full of captured material with no explanation as to who they were or the contents of the bags. The interrogation team did not know where to start and lacked the time to conduct enough interrogation sessions to extract anything of value.

Out of necessity, the operators, who lacked formal training, were sometimes forced to conduct their own interrogations..$^{52}$ In one instance, headquarters finally sent a formally trained interrogator to a team to use at their location; however, the interrogator was trained as a "strategic debriefer" and had no experience as a tactical interrogator. After a week of disappointing results, the team sent him back to the screening facility so he could be paired with an experienced interrogator to conduct on-the-job training. The final straw came after the team discovered the "interrogator" had never heard of "Stockholm syndrome."

Improvements only came when the operators started accompanying their detainees back to the tactical screening facility instead of sending the detainees to the screening facility blindly. This allowed the operators to learn what the interrogators needed to be effective and vice versa. They soon learned that providing the interrogators with detailed information of what they learned on target helped the interrogator refine his or her questioning and hasten the exploitation process. ${ }^{53}$

Likewise, the operators educated the interrogators on what they needed from the detainees. The screening facility quickly became so effective that instead of the teams resisting transferring their detainees until after they had interrogated them, they could not get them transferred fast enough. ${ }^{54}$ In 2004 , TF 16 built a professional screening facility that provided a clean, sterile environment with the appropriate oversight to include cameras in every room. ${ }^{55}$

\section{Expanding intelligence, surveillance, and reconnaissance capability}

Over the course of the war, TF 16's ISR capability increased exponentially in terms of platforms, sensor packages, and employment. When McChrystal took command in October 2003, he had access to only a single Predator unmanned aerial vehicle that was augmented by a helicopter outfitted with a camera. ${ }^{56}$

By June 2004, the task force had gained access to a few more Predators, but the process for controlling them remained awkward. The Air Force controlled the platforms and viewed them as a strategic collection platform and tried to manage them this way, but the task force required tactical surveillance to watch people or vehicles for the subtleties required for man hunting or network operations. ${ }^{57}$ Eventually, the task force gained control of dozens of platforms.

The expanded use of ISR started to pay off when the U.S. military's ground operations into Fallujah were halted. While watching a Predator feed, one of the task force's intelligence analysts noted that a tractor appeared to be blocking a street to keep out foot traffic, so he directed the Predator, through its controller thousands of miles away, to investigate. There he observed what looked like men loading suspicious crates onto flatbed trucks that they covered with canvas. When the first truck pulled away, the analyst followed it with the Predator. When it entered Baghdad, the task force commander launched the finish force to intercept the vehicle. As expected, they found it full of munitions: machine guns, grenade launchers, rockets, and explosives for car bombs. ${ }^{58}$

After the operation, they flew the Predator back to the second truck and followed it to a house at the edge of Fallujah that they assessed to be a bomb-making factory. With ground operations into Fallujah still on hold, the TF 16 commander called an airstrike on the house. Seconds after the bomb detonated, the munitions in the house started to cook off and continued to burn for the next 20 minutes-this 
confirmed they had indeed hit a large weapons cache. Sources in Fallujah and signal intercepts indicated that 20 people, most of them Tunisian foreign fighters, had been killed when the house exploded. This operation validated the task force's ISR techniques that would be replicated hundreds of times in the following years. ${ }^{59}$

After visiting Israel in February 2004, McChrystal asked SOCOM to bypass the slow acquisition process and buy ready-made Israeli platforms. The Air Force rejected SOCOM's attempt and instead promised to quickly field more Predators. After the Air Force failed to follow through on its promise, SOCOM purchased six commercial single-engine turboprop planes and gutted the insides of all amenities, stripping them down to metal frame to reduce weight - the lighter the aircraft, the more fuel it could carry and the longer it could fly and collect intelligence. Only essential communication and surveillance equipment was installed. This fleet was soon dubbed the "Confederate Air Force."

In addition to expanding the fleet itself, the sensor packages continued to improve. In the spring of 2004, a couple operators briefed McChrystal and his staff about a technology they encountered that, if slightly modified, could prove game changing by allowing the task force to capitalize on the enemy's own increasing use of newer technologies. The potential of the product was obvious, and McChrystal directed them to produce the capability. ${ }^{61}$

After several months of working with interagency partners and technology experts, their innovation was ready to field. To complement the technology, the operators also developed software that "revealed the relationships among the owners of captured equipment," which provided the task force a vivid understanding of the enemy's organization. McChrystal described it as an "accelerant to F3EA that had a distinct impact on [the al-Zarqawi network], forcing them to modify how they communicated and making it much harder to hide in the expanses of Anbar." 62

\section{Expanding document and media exploitation capability}

The lack of adequate document and media exploitation capability was one of the last significant shortfalls to be addressed. Several solutions were developed early on, but none were particularly effective. Most teams identified one or two computer-savvy operators to exploit the computers they captured, since they never received anything back after shipping them off. It was slow, however, and even if they pulled the data, they lacked the linguists to analyze the exploited material. Another solution was to ship them back to the United States for exploitation, but since it required more than 30 days to ship and process, any information recovered was rarely "actionable." 63

To better triage and exploit captured documents, the task force created the Joint Exploitation Team. Given the massive amount of media that was captured, it was impossible for such a small element —it started with four reservists - to exploit media quickly. It could only triage. The task force hired Arabic linguists to improve its exploitation and analysis capacity, but exponential improvement only occurred after the National Media Exploitation Center contributed a "powerhouse" capability that the task force could not generate internally. ${ }^{64}$

The National Media Exploitation Center's 30-40 people had the ability to download the contents of locked or damaged computers and could extract phone numbers, names, messages, images, and, using its software, process and store the data and link it to other information that would not only find individual targets but also illuminate large portions of the network. ${ }^{65}$

By this time, the task force possessed an effective triage capability in Iraq, so the solution was to leverage the National Media Exploitation Center's capability through reach back. ${ }^{66}$ This required pushing large amounts of data to Washington, so the task force purchased huge satellite dishes and paid for commercial satellite bandwidth to push the data. ${ }^{67}$ Luckily, the dot-com bust created a glut in commercial satellite pipelines, and there was excess capacity available for the task force to buy. The task force was reported to have spent close to $\$ 1$ million a day on commercial bandwidth early in the war. ${ }^{68}$ 
The payoff was almost immediate. The National Media Exploitation Center saw instant value of their contributions and soon started working 24/7 operations to support TF 714. The exponential growth of document and media exploitation served as another significant accelerant to the F3EA cycle. ${ }^{69}$ Since the exploitation of captured battlefield material exceeded the capability of forward-deployed intelligence professionals, "exploitation VTCs" were created where specialists in Washington could weigh in on material only minutes after capture. ${ }^{70}$

\section{The results}

By the end of McChrystal's first year in command, TF 714 had grown from disparate strike teams into a budding network. McChrystal provided a common strategy; developed the F3EA targeting cycle; flattened his organization; expanded his liaison network; established two JIATFs; and expanded interrogation, ISR, and media exploitation.

In Iraq, however, the task force conducted only 18 operations in August 2004, little more than the 10 it conducted in April. At the same time, insurgent attacks were up five-fold to more than 2,500 a month, casualties had more than doubled to more than $750 \mathrm{a}$ month, and coalition fatalities nearly doubled to just under 80 a month. ${ }^{71}$ McChrystal had built his interagency network, but it had yet to mature.

Over the winter of 2004-2005, the task force's main effort shifted from finish to exploit and analyze. By the summer of 2005, the operators had mastered the F3EA cycle, and it became a true operations-intelligence cycle. ${ }^{72}$ Operators were now involved in all phases of the cycle, not just the finish phase. They were watching ISR video, taking notes, directing drones, reading interrogation and other intelligence reports, and mapping the enemy network on dry-erase boards. ${ }^{73}$ Because they understood the network and the intelligence picture, it accelerated the F3EA process; the operators could ask pointed questions on targets, which could immediately lead to subsequent targets and further accelerate the F3EA cycle. ${ }^{74}$

By the summer of 2005, the task force was finally pressuring AQI. The task force became so effective that many enemy leaders, even mid-level ones, started sleeping with suicide vests or barricading themselves in basements and firing through the floorboards when the task force entered. ${ }^{75}$ Their desperation was on display.

Despite the shortfall of adequate interrogators, by late 2005, TF 16 had what Lieutenant General Michael Flynn called "industrial-scale, capture-interrogation-exploitation operations." Just as ISR assets were "massed" to provide an unblinking eye, exploitation capabilities were massed to exploit detainees and find subsequent targets in record time. As a result, when interrogators entered the booth to interrogate a detainee for the first time, they had a wealth of knowledge on the individual, which made them more effective and efficient at pulling information. Interrogation booths were next to the rooms where document and media exploitation occurred. Analysts were paired with interrogators in teams that worked together from start to finish for each detainee. ${ }^{76}$

Operators who captured detainees often joined the interrogation team and provided detailed sketches showing where detainees were captured and where documents and media were recovered, which was necessary to determine what equipment belonged to whom and to help identify the most significant members captured on target. While the operator was debriefing the interrogation team, other members of the network were exploiting the media and documents. ${ }^{77}$

By the end of 2005, McChrystal had fully transformed his command. The operators fully embraced F3EA, making it an effective operational cycle. He had flattened the organization by pushing out communications packages. Running effective daily operational and intelligence VTCs together with other VTCs provided an environment where situational awareness was centralized, but decision-making decentralized. With the help of the JIATFs, ISR, document and media exploitation, interrogations, and new signals intelligence collection capabilities, the F3EA cycle had been accelerated from a process that took days and weeks to a process that took hours, minutes, and seconds. 


\section{Operational Vignette: the killing of Abu Musab al-Zarqawi}

TF 714's ability to find and ultimately kill AQI leader Abu Musab al-Zarqawi demonstrates the amazing evolution of the task force. The first lead for the operation came on January 6, 2006, from a liaison officer who reported that Iraqi forces had captured Abu Zar, a high-value target on TF 16's target list. Abu Zar was subsequently transferred to the task force screening facility, where the expanded interrogation capability paid off. ${ }^{78}$ Abu Zar identified a group of buildings in Yusufiyah, a rural area on the outskirts of Baghdad, that AQI used for planning and staging and that Abu Ayyub al-Masri, al-Zarqawi's deputy and the amir of the foreign fighter network, used for shelter. TF 16 immediately redirected ISR to Yusufiyah. ${ }^{79}$

For eight weeks, the TF 16 intelligence analyst directed spare ISR to watch Yusufiyah. The patient and robust use of ISR paid off on April 8, 2006, when the analyst observed a convoy of vehicles approaching the house. The task force loaded helicopters and launched for a daytime raid. While airborne, one of the vehicles departed, but having multiple ISR platforms allowed the task force to continue to observe the house and follow the car to another location. Meeting resistance at the house, the finish force killed five insurgents and conducted a thorough sensitive site exploitation. The finish force then launched for the second location, where, encountering little resistance, they detained the 12 men that they found. ${ }^{80}$

The interrogations of the 12 individuals produced nothing of value until the 51st interrogation of a detainee named Mubassir. Had it not been for the task force's new detention facility and additional capacity, it never would have been able to conduct the necessary number of interview sessions required to discover this critical intelligence. Mubassir provided information that Abd al-Rahman, al-Zarqawi's spiritual advisor, lived in Baghdad and met with al-Zarqawi every 7-10 days. ${ }^{81}$ After reading the tactical interrogation report, the TF 16 intelligence analyst directed ISR to fly to the address that Mubassir had provided. The ISR fleet had grown to such a point that the analyst had several assets at his level of control. ${ }^{82}$

Only minutes after arriving, the ISR platform observed a silver sedan pull up in front of the house. The driver exited the vehicle and entered the house before returning to the car with a second individual and proceeding to drive away. The analyst directed the ISR operator to stay on the car and followed it to another house that was one of five locations that the task force believed was part of al-Masri's courier network. ${ }^{83}$

What he observed matched the information from Mubassir's tactical interrogation report. If it was al-Rahman that they were observing and if the intelligence was correct, he would meet with al-Zarqawi within the next 7-10 days. Over the next few days, the analyst directed much of the task force's ISR to watching the targets. After further interviews, Mubassir provided 14 sites in Baghdad related to al-Rahman's movement routine. ${ }^{84}$

To develop al-Rahman's pattern of life-necessary to identify signs that he was meeting al-Zarqawithe task force dedicated $70 \%$ of its ISR fleet to the effort. The tradeoff, however, was that the number of raids conducted by the task force dropped significantly because the ISR, which was critical to finding and fixing new targets, was focused on a single target. ${ }^{85}$

McChrystal was concerned about the decrease in the operational tempo because he wanted to keep constant pressure on the network. The decision to focus on a single target was controversial within the command. Some wanted to detain al-Rahman for questioning, believing that if they did, he would provide information on al-Zarqawi. Others thought he was their only lead to al-Zarqawi and would be unlikely to talk, and his capture would spook al-Zarqawi and cause him to flee. ${ }^{86}$

A new TF 16 commander arrived on June 1 . He had previously served as a JIATF director and was firmly in the camp that believed it was best to continue to wait and follow al-Rahman in the hopes that he would lead to al-Zarqawi. ${ }^{87}$

On June 7, after some 19 days of heavy ISR coverage, moving trucks showed up at al-Rahman's house. While watching the ISR feed the following day, the task force commander and intelligence analyst noticed more strange behavior. As usual, al-Rahman entered the silver sedan at his brother-in-law's house, but 
instead of driving to his house as he usually did, he circled around the neighborhood and returned to his brother-in-law's house, driving as if he was worried about being followed. ${ }^{88}$

From there, developments really diverged from al-Rahman's normal pattern of life that they had observed over the past 19 days. This time when the vehicle departed, it took a highway out of Baghdad toward Baqubah. The vehicle pulled over to the side of the six-lane highway, dropped off al-Rahman, and then drove off. Al-Rahman started walking against traffic and put a cell phone to his ear. A few seconds later, a blue truck stopped, picked him up, and then accelerated away. ${ }^{89}$

One ISR platform stayed with the silver sedan while a second followed the truck. An hour later, the truck arrived in Baqubah and pulled into a parking area in front of what appeared to be a restaurant in a commercial part of town. Al-Rahman exited the vehicle and entered the building. A minute later, a white

pickup truck with a red stripe pulled up and parked nose to nose with the truck. A man exited the vehicle and entered the building.

Minutes later, when a couple of men exited the building, the intelligence analyst quickly identified one as al-Rahman even though he had changed his clothing. After watching al-Rahman for 19 days, he could identify al-Rahman by his gait. At this point, the task force had nine ISR platforms following four targets: the silver sedan in Baghdad, the way station in Baqubah, the blue truck parked there, and the white pickup driving out of town. ${ }^{90}$

The pickup drove three miles northwest of Baqubah toward the small town of Hibhib. Outside of Hibhib, the truck turned off a frontage road and stopped halfway up the driveway of a secluded house. Al-Rahman exited the vehicle and entered the house. The TF 16 commander had no way of knowing if al-Rahman was meeting al-Zarqawi, but he determined he was and decided to bomb the house. ${ }^{91}$

Bombing was the finish option of last resort since it limits intelligence exploitation-a dead enemy cannot be interrogated, and destroyed electronic media cannot be exploited - but a manned operation was deemed too risky. The task force had hit hundreds of targets over the past two years, but this target offered al-Zarqawi too many escape routes, and he had narrowly evaded capture too many times before. Additionally, being isolated, the risk of collateral damage and civilian casualties from large bombs was almost negligible. A little more than an hour after al-Rahman entered the house, two F-16s dropped two 500-pound bombs on the building. ${ }^{92}$

Already airborne, the assault force was 18 minutes away when the first bomb fell. By the time they arrived, Iraqi police were already on the scene, and they had loaded a single person into an ambulance. The police claimed not to know his identity, yet he was the only person they evacuated from the house. The task force believed he was al-Zarqawi. He was barely alive, and despite attempts to resuscitate him, he died within the hour. After securing al-Zarqawi, the task force launched on the other targets they had built over the past three weeks. Later that night, the FBI agent assigned to the JIATF confirmed through a fingerprint match that they had killed al-Zarqawi. ${ }^{93}$

\section{Conclusion}

The death of al-Zarqawi demonstrated the effectiveness of the F3EA targeting cycle and the network that supported it. It all started with information from one of McChrystal's many liaison officers. Throughout the multi-week operation, the improved screening facility and its interrogator and analyst teams pulled valuable intelligence from detainees and disseminated their reports on the portal for everyone to analyze. The growing ISR fleet was critical in determining al-Rahman's pattern of life. In total, more than 600 hours of ISR were dedicated to finding and fixing al-Zarqawi during the operation. ${ }^{94}$

The operators had learned patience and understood the role that intelligence played in finding their top-priority targets. Years earlier, they might have grown impatient with the low operational tempo and launched on al-Rahman prematurely, blowing the opportunity to finish al-Zarqawi. By this time, they operated more like the law enforcement community and put much more time into gathering intelligence 
and developing targets than they did in the raid itself. From start to finish, it looked more like an operation to take down an organized crime ring than a military raid.

The development of the F3EA cycle and the evolution of the task force was significant. It went from being able to conduct 10 operations in a month to 10 each night in only two years. From 2005-2007, the task force sent more than 2,000 Iraqis to trial. ${ }^{95}$ By early 2010, AQI was decimated. What had once been a broad terrorist network was now an underground group with only a few cells remaining.

The task force, with their Iraqi counterparts, killed or captured most of AQI's top leadership between January and March of 2010, including its amir for northern Iraq, the amir for operations, the amir of Mosul and his successor, the amir for east Mosul, the economic security amir, the amir for Baghdad, and an operative responsible for Baghdad's first major suicide attack in the summer of $2003 .{ }^{96}$

On April 18, 2010, in a raid near Tikrit, Iraqi Forces and TF 714 killed Abu Ayyub al-Masri, who had succeeded al-Zarqawi as AQI's leader, and Abu Omar al-Baghdadi, the head of the Islamic State of Iraq. ${ }^{97}$ The F3EA targeting cycle proved instrumental in nearly taking AQI off the battlefield in Iraq.

\section{Notes}

1 Some of the text in this chapter is drawn from a much longer chapter in the author's dissertation. For more, see Liam Collins, "Military Innovation in War: The Criticality of the Senior Military Leader" (PhD diss., Princeton University, 2014), http://arks.princeton.edu/ark:/88435/dsp01br86b3727.

2 Stanley McChrystal, “It Takes a Network," Foreign Policy, February 21, 2011, https://foreignpolicy.com/2011/02/21/ it-takes-a-network/.

3 Michael Flynn, interview with author, April 2, 2013; Stanley McChrystal, My Share of the Task (New York: Penguin, 2013), 145.

4 Leigh Neville, Special Operations Forces in Afghanistan (Oxford: Osprey, 2008), 8; "Task Force 11-Task Force Sword," Global Security, accessed January 26, 2013, www.globalsecurity.org/military/agency/dod/tf-11.htm.

5 The task force went through several name changes. For simplicity, I will use one number for each component: TF 714 for the overarching task force and TF 16 for the subordinate task force in Iraq. See Leigh Neville, SOF in Iraq (London: Bloomsbury Publishing, 2011), 26-42.

6 Ibid., 9, 30-31.

7 Rym Brahimi et al., "Saddam's Sons Killed in Raid,” CNN, July 22, 2003, www.cnn.com/2003/WORLD/ meast/07/22/sprj.irq.sons/; Neville, SOF in Iraq, 41-42.

8 McChrystal, My Share of the Task, 101.

9 Collins, "Military Innovation in War," 325.

10 Ibid.

11 Former JIATF deputy director, interview with author, January 29, 2013; McChrystal, My Share of the Task, 106.

12 McChrystal, My Share of the Task, 106. The unexploited captured material was confirmed during interviews by many others.

13 Former TF 714 field artillery officer, interview with author, April 12, 2013.

14 McChrystal, My Share of the Task, 106-107.

15 Eric Maddox, Mission: Black List \#1 (New York: HarperCollins, 2008).

16 McChrystal, My Share of the Task, 115-116.

17 Nelly Lahoud et al., Letters from Abbottabad: Bin Ladin Sidelined (West Point: Combating Terrorism Center, 2012); Liam Collins, "The Abbottabad Documents," CTC Sentinel 5, no. 5 (2012): 1-4; McChrystal, My Share of the Task, 115-116.

18 McChrystal, My Share of the Task, 115-116.

19 Ibid.

20 Stanley McChrystal, interview with author, April 1, 2013; McChrystal, My Share of the Task, 153.

21 Scott Miller, e-mail message to author, March 26, 2013; McChrystal, My Share of the Task, 153-154.

22 McChrystal, My Share of the Task, 154.

23 Former TF 16 commander, interview with author, February 1, 2013; Former JIATF deputy director, interview, January 29, 2013.

24 Ibid.

25 Dana Priest and William M. Arkin, Top Secret America (New York: Little, Brown and Company, 2011).

26 Former TF 16 commander, interview, February 1, 2013; Former JIATF deputy director, interview, January $29,2013$. 


\section{Liam Collins}

27 McChrystal, My Share of the Task, 131.

28 Ibid.

29 Ibid., 154-155.

30 Ibid., 163.

31 Former JIATF deputy director, interview, January 29, 2013; McChrystal, My Share of the Task, 163.

32 Former JIATF director, interview with author, February 7, 2013; Former JIATF deputy director, interview, January 29, 2013.

33 McChrystal, My Share of the Task, 163.

34 Miller, e-mail message to author, March 26, 2013.

35 Flynn, interview.

36 McChrystal, My Share of the Task, 164.

37 Ibid., 116.

38 John Abizaid, interview with author, April 12, 2013; McChrystal, My Share of the Task, 117-177.

39 McChrystal, My Share of the Task, 117-177.

40 Ibid., 117.

41 Ibid.

42 Former JIATF deputy director, interview, January 29, 2013; McChrystal, My Share of the Task, 117.

43 Former JIATF director, interview with author, April 5, 2013.

44 McChrystal, My Share of the Task, 119.

45 McChrystal, My Share of the Task, 170-171; John Burns, "Iraq's Ho Chi Minh Trail," New York Times, June 5, 2005, www.nytimes.com/2005/06/05/weekinreview/iraqs-ho-chi-minh-trail.html.

46 Joseph Felter and Brian Fishman, Al-Qa'ida's Foreign Fighters in Iraq: A First Look at the Sinjar Records (West Point: Combating Terrorism Center, 2007), 18.

47 Former JIATF director, interview with author, February 1, 2013; Former JIATF director, interview, February 7 , 2013; Former JIATF director, interview, April 5, 2013; McChrystal, My Share of the Task, 162-166.

48 Ibid., 199.

49 McChrystal, interview; McChrystal, My Share of the Task, 200.

50 Former TF 16 intelligence officer, interview with author, March 6, 2013.

51 Priest and Arkin, Top Secret America, 246.

52 Former TF 16 commander, interview, April 8, 2013.

53 Former JIATF director, interview, April 5, 2013; Former TF 16 commander, interview, April 8, 2013.

54 Flynn, interview; Former TF 16 intelligence officer, interview, March 6, 2013.

55 McChrystal, My Share of the Task, 200-201.

56 Ibid., 37.

57 Ibid., 138.

58 Ibid., 139-143.

59 Ibid.

60 Ibid., 157-158.

61 Ibid.

62 Ibid.

63 Former TF 16 commander, interview, April 8, 2013.

64 Flynn, interview.

65 Priest and Arkin, Top Secret America, 244-245.

66 Flynn, interview.

67 Former JIATF director, interview, February 7, 2013; Former JIATF deputy director, interview, January 29, 2013; Priest and Arkin, Top Secret America, 244-245.

68 Priest and Arkin, Top Secret America, 246.

69 Flynn, interview.

70 Priest and Arkin, Top Secret America.

71 U.S. Department of Defense, "Measuring Security and Stability in Iraq," 27; "U.S. Military Casualties—Operation Iraqi Freedom (OIF) Casualty; and Iraq Coalition Casualty Count, "Iraq Coalition Casualties," accessed November 19, 2012.

72 Former JIATF director, interview, February 1, 2013; Former JIATF director, interview, April 5, 2013.

73 Former TF 16 commander, interview, April 8, 2013.

74 Former JIATF director, interview, February 1, 2013.

75 McChrystal, My Share of the Task, 184. 


\section{Dismantling al-Qaida in Iraq}

76 Former TF 16 commander, interview, February 1, 2013; Former JIATF deputy director, interview with author, March 19, 2013.

77 Flynn, interview; Priest and Arkin, Top Secret America, 248.

78 McChrystal, My Share of the Task, 204.

79 Ibid.

80 Ibid., 206.

81 Ibid., 204-216.

82 Former TF 16 intelligence analyst, interview with author, April 15, 2013; McChrystal, My Share of the Task, 216-221.

83 Ibid.

84 Ibid.

85 Ibid.

86 Ibid.

87 Former TF 16 commander, interview, February 1, 2013

88 Ibid.

89 Ibid.; McChrystal, My Share of the Task, 223-234.

90 Ibid.

91 Ibid.

92 Ibid.

93 Ibid.

94 Glenn W. Goodman, “ISR Now Synonymous with Operations,” Journal of Electronic Defense 30, no. 7 (2007): 19.

95 Priest and Arkin, Top Secret America, 248-249.

96 Bill Roggio, “Iraq Forces Capture Two Senior al Qaeda Leaders in Mosul,” Long War Journal, April 7, 2010 , www. longwarjournal.org/archives/2010/04/iraqi_forces_capture.php; Bill Roggio, "Iraqi Forces Detained al Qaeda's 'Ruler of Baghdad',' Long War Journal, April 22, 2010, www.longwarjournal.org/archives/2010/04/iraqi_forces_ detaine.php.

97 Tim Arango, “Top Qaeda Leaders in Iraq Reported Killed in Raid,” New York Times, April 19, 2010 , www. nytimes.com/2010/04/20/world/middleeast/20baghdad.html; Michael Gordon and Bernard Trainor, The Endgame (New York: Pantheon Books, 2012), 623. 


\title{
21
}

\section{OPERATION ENDURING FREEDOM-PHILIPPINES \\ Lessons in special warfare}

\author{
David S. Maxwell
}

U.S. Army doctrine lists two core competencies for its Special Operations Forces (SOF): surgical strike and special warfare. ${ }^{1}$ The doctrinal definition of surgical strike is "the execution of capabilities in a precise manner that employ Special Operations Forces in hostile, denied, or politically sensitive environments to seize, destroy, capture, exploit, recover or damage designated targets, or influence threats." ${ }^{2}$ It is perhaps the more visible and well-known of the two competencies. An example of surgical strike is the raid into Abbottabad, Pakistan, that killed Usama bin Ladin in 2011.

Special warfare is the special operations competency that has as its foundation persistent engagement with the intention to achieve long-term effects. The doctrinal definition of special warfare is

the execution of capabilities that involve a combination of lethal and nonlethal actions taken by a specially trained and educated force that has a deep understanding of cultures and foreign language, proficiency in small-unit tactics, and the ability to build and fight alongside indigenous combat formations in a permissive, uncertain, or hostile environment. ${ }^{3}$

It may be less visible and well known than surgical strike, but is by far the more commonly executed competency.

U.S. involvement in the Philippines is an excellent example of a successful special warfare mission. It demonstrates that counterterrorism operations can be effective with a small U.S. presence that is based on an effective campaign plan and a fairly capable host-nation security force. It is based on the author's personal experiences as the battalion commander of the 1st Special Forces Group's 1st Battalion from 2000-2002 and as the commander of the Joint Special Operations Task Force-Philippines (JSOTF-P) executing Operation Enduring Freedom-Philippines from 2006-2007.

This chapter begins with an overview of security threats as well as historical background on the U.S.Philippines security relationship. It then offers analysis of a pre-9/11 special warfare mission and an examination of the effort to establish a JSOTF in the aftermath of $9 / 11$. The chapter then jumps to 2006, when the author returned as the JSOTF-P commander to examine special warfare from 2006-2007. Finally, it concludes with some short vignettes and lessons learned from the operations in the Republic of the Philippines.

\section{The U.S.-Philippine security relationship}

The Philippines has a long history of insurrection, having been occupied or controlled by a foreign power from the 1500s until its independence in 1946. It has confronted myriad threats over the course of its 
history, from Japanese occupation during World War II, to the Huk rebellion, ${ }^{4}$ to communist and Moro insurgencies, to multiple modern-day terrorist groups.

Recent threats to the Philippines include separatist insurgencies from the Moro population in the southern region of Mindanao and the Sulu Archipelago. These include remnants of the Moro National Liberation Front, which signed a peace agreement establishing the Autonomous Region of Muslim Mindanao in 1996; the Moro Islamic Liberation Front (MILF), which continued the insurgency until signing a tenuous peace agreement in 2015; and splinter groups such as the Bangsamoro Islamic Freedom Fighters and the Musari Breakaway Group. Other significant terrorist and insurgent groups include the Abu Sayyaf Group (ASG) and Jemaah Islamiyya. Additionally, the New People's Army/Communist Party of the Philippines seeks to overthrow the Philippine government.

The Philippines also suffers violent election conflict and clan conflict (known as ridos). All of these groups represent the varied forms of revolution, resistance, terrorism, insurgency, and criminal violence that have created a difficult and dangerous security situation for the Philippine government and its citizens.

Due to the Philippines' strategic location in the Pacific Ocean, the United States has long had an interest in the nation. The United States granted the Philippines independence on July 4, 1946, but has maintained a close security relationship ever since. ${ }^{5}$ In 1951, the two countries signed a Mutual Defense Treaty, with each country agreeing to come to the defense of the other if attacked. ${ }^{6}$ The United States maintained two large military bases on the islands until the closure of Clark Air Base in 1991 and Naval Base Subic Bay in 1992. ${ }^{7}$ Following the closure of the bases, the United States engaged in military exercises with the Philippines to maintain interoperability and regional expertise. These include the Balikatan exercise, ${ }^{8}$ the COPE series of Air Force exercises, ${ }^{9}$ and the CARAT naval exercises. ${ }^{10}$ Additionally, SOF has conducted persistent engagement through Joint Combined Exchange Training programs.

\section{Special warfare before $9 / 11$}

In the late 1990s and early 2000s, the terrorist threat in the region intensified. In April 2000, the ASG captured 20 hostages, including 10 tourists from the Middle East and Europe. ${ }^{11}$ The hostage crisis and other emerging threats drove Ambassador Michael A. Sheehan, the U.S. Department of State coordinator for counterterrorism, to initiate a security assistance program to establish a Philippine national counterterrorist force: the Light Reaction Company. ${ }^{12}$

Air Force Brigadier General Donny Wurster, commander of Special Operations Command Pacific (SOCPAC), directed the 1st Special Forces Group's 1st Battalion, based in Okinawa, to deploy a mobile training team to organize, train, and equip the Light Reaction Company. The company was modeled on the U.S. Pacific Command (PACOM) commander's in-extremis force, a specially trained and resourced Special Forces company from the 1st Battalion focused on direct action and counterterrorism missions. ${ }^{13}$ The training mission began in relatively short order.

On May 27, 2001, during the initial training of the Light Reaction Company, the ASG kidnapped 20 people, including three Americans, from a beach resort in western Palawan Province. From there, they moved the hostages to Basilan Island in the Sulu Archipelago in southern Mindanao (see Figure 21.1 for a map of the Philippines). ${ }^{14}$ Weeks later, the militants beheaded one of the Americans, Guillermo Sobero, while demanding ransoms for the hostages. ${ }^{15}$ The Philippine government wanted to immediately deploy the Light Reaction Company despite the fact it had not completed its training; U.S. leadership, however, convinced them otherwise. On July 8 , only two days after graduating, the company deployed.

U.S. advisors were not permitted to deploy with them, although the U.S. trainers maintained contact with the company leadership through e-mail and text messages. This limited contact revealed that the company was misemployed, something the U.S. trainers feared and had forecast during their initial mission analysis. ${ }^{17}$ Ultimately, the Light Reaction Company successfully recovered the hostages 11 months later 


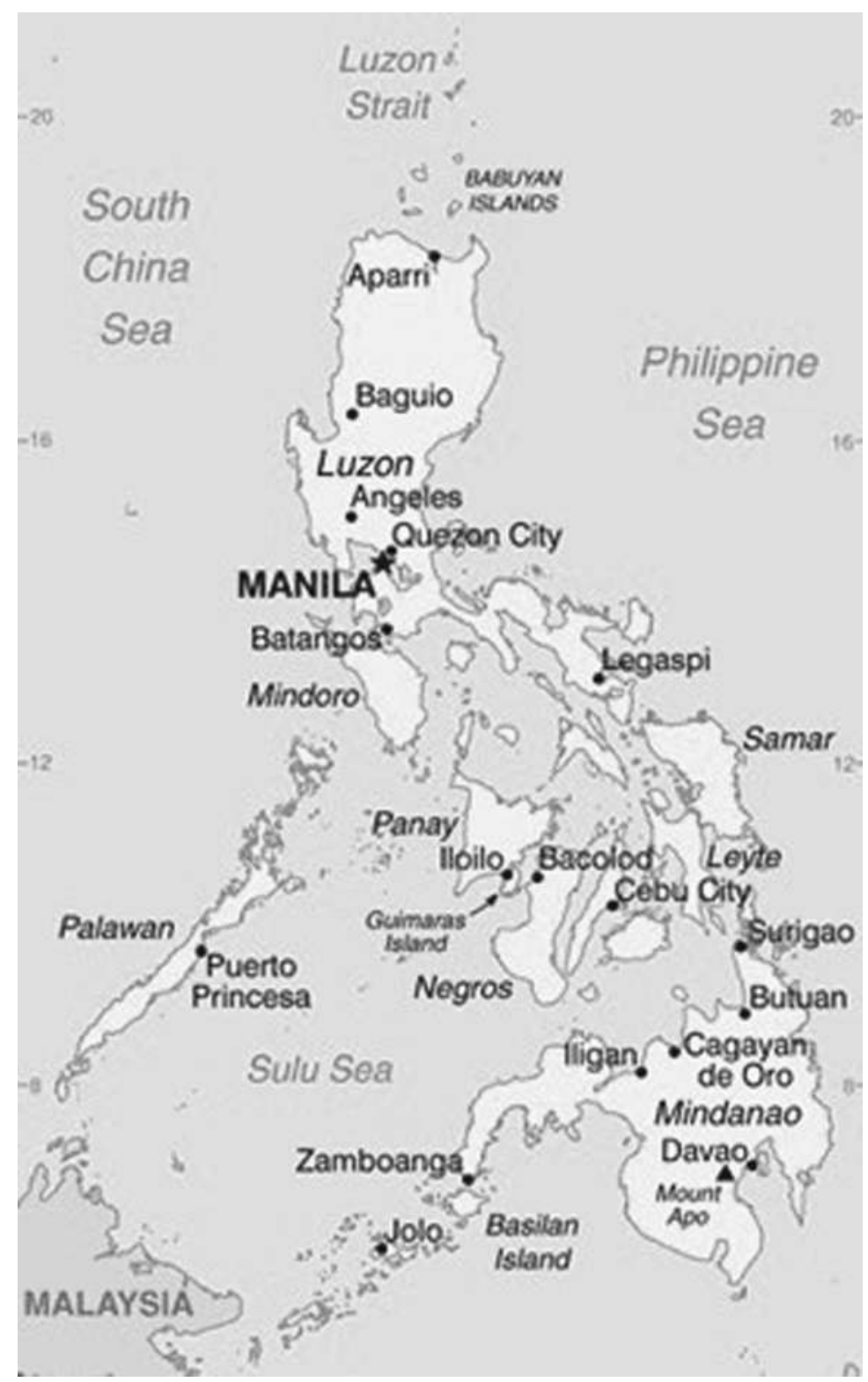

Figure 21.1 Map of the Philippines. ${ }^{16}$

Source: CIA, The World Factbook 2020 (Langley: Central Intelligence Agency, 2020).

during a night raid when it was finally employed properly. Unfortunately, American Martin Burnham and Filipino nurse Ediborah Yap were killed during the rescue attempt. ${ }^{18}$

A few lessons emerged from this experience. First, forming good relationships is critical. At the first planning meeting between the U.S. planning team and the Armed Forces of the Philippines, a senior Special Forces noncommissioned officer attended the meeting. Some PACOM officers did not believe a noncommissioned officer should attend a meeting with the senior officers of the Philippines' general staff, 
but they reluctantly allowed him to participate. When the master sergeant entered the meeting room, a number of Philippine generals greeted him warmly, as they had trained with U.S. Special Forces — and this particular master sergeant - for nearly two decades. During the meeting, they turned to him numerous times for his expert advice on how to conduct the mission. This example demonstrates the importance of building relationships and long-term engagement in special warfare.

A second lesson is to avoid building a partner force in the U.S. image. During planning, Special Forces soldiers developed an equipment list that included everything from weapons and body armor to night vision devices and radios. They recommended that the Light Reaction Company be equipped with .45-caliber pistols instead of 9-mm pistols, the caliber widely used by the U.S. military. This conflicted with the desires of the embassy's security assistance office, but the Special Forces soldiers were adamant and ultimately won the argument. Their rationale was that the Philippines produced .45-caliber ammunition indigenously, which would allow them to be self sufficient and not dependent on U.S. ammunition supplies.

This is just one example of fielding equipment that is best for the host nation even though it might run counter to the normal practice of providing equipment identical or similar to that of U.S. forces. It is important to understand the broader situation and host nation capabilities and provide self-sustaining solutions as opposed to creating a force in the U.S. image, which, unfortunately, is all too common.

A third lesson is that specialty units are likely to be improperly employed if engagement is limited to tactical-level training and does not also include training at the organizational level to ensure operationallevel commanders know how to resource and employ these units. While the U.S. advisors were confident in the Philippines' ability to create a tactical counterterrorism capability, they correctly assessed that this force would not be properly employed or supported because it required intelligence and command-andcontrol structures that were not being developed in parallel.

This led to conventional commanders employing the company improperly and ineffectively during its first deployment. Instead of using the specialty trained and equipped force for its designed mission, they initially wasted it, employing it like a traditional infantry company in a traditional movement-tocontact operation. Too often, advisory missions focus on the development of tactical combat capabilities, while command-and-control, intelligence, and sustainment capabilities that are also necessary are ignored.

One final lesson is that Special Forces trainers should always strive to "work themselves out of the job." From the beginning, the Special Forces trainers planned for the Philippines to become self sufficient. Over the next three years, the Light Reaction Company grew from a company to a battalion and ultimately a regiment. The Special Forces advisors served as the training cadre for the first training course. For the second course, they partnered with Philippine Special Forces to conduct the training. By the third iteration, the Philippines were capable of conducting the course without any U.S. advisors. To this day, the Filipinos continue to provide the training cadre without U.S. supervision. Thus, the Special Forces trainers effectively worked themselves out of a job, but it is important to note that it often takes more than two iterations of a course before the host nation is fully able to run quality training. It cannot be rushed.

\section{Special warfare after $9 / 11$}

Due to the employment issues, the 1st Special Forces battalion commander received permission from SOCPAC to deploy to Zamboanga, Mindanao, to meet with the Light Reaction Company leadership to assess the issues. The meeting was scheduled for September 12, but the events of $9 / 11$ delayed the meeting by several days. Concurrently, SOCPAC started to develop contingency plans, anticipating that U.S. action might be ordered against the ASG and Jemaah Islamiyya, since both were known to have direct links to al-Qaida.

In October 2001, SOCPAC directed the 1st Special Forces Group to conduct an assessment and develop a campaign plan to support the Philippine government and military. Colonel David Fridovich, the Group's commander, assembled a team of operations, intelligence, and logistics planners along with naval special 
warfare and air force SOF planners and deployed them to the Philippines for a "Terrorism Coordination and Assistance Visit." ${ }^{19}$ The Group developed a campaign plan following a detailed mission analysis that included frank and detailed discussions and assessments with the Philippine military leadership. Fridovich presented the plan to SOCPAC and PACOM, who brought it to the secretary of defense for ultimate approval. $^{20}$

This campaign plan formed the foundation for operations that started in 2002 and continue today. The plan was regularly updated and adjusted based on ongoing assessments and changing conditions, but the basic concepts identified during the October 2001 Terrorism Coordination and Assistance Visit remain.

PACOM, however, made a number of modifications to the campaign plan developed by Fridovich and his team. For one, Fridovich's plan took a holistic approach to the security challenges faced by the Philippine government. It accounted for the Moro insurgency, the ongoing peace negotiations, and recognized the communist threat, which the Philippine government viewed as the more serious risk.

Yet the PACOM-approved campaign plan limited operations to Basilan Island, the ASG stronghold. Furthermore, the plan prohibited operations that might impact peace negotiations with the MILF. Finally, it limited U.S. support to countering only groups associated with al-Qaida; thus, SOCPAC could not provide support to the Philippine military in its fight against the communist New People's Army. This, unfortunately, demonstrated a myopic counterterrorism focus rather than the holistic security approach required to address the multiple threats against a longstanding ally.

A couple of anecdotes from the planning are worth noting. When the assessment team first landed in Zamboanga, Colonel Alexander Yano, the Philippines Task Force Zamboanga commander, greeted us at the ramp of our C-130 aircraft. We had been in the same small group at the Infantry Officers Advanced Course at Fort Benning in 1985. Yano had attended the course through the International Military Education and Training program, which is managed by the Defense Security Cooperation Agency. Some of the program's goals include "[establishing] a rapport between the U.S. military and the country's military to build alliances for the future" and "[enhancing] interoperability and capabilities for joint operation."21

In this case, the program had achieved its goal, as the relationship that I developed with Yano years earlier not only paid dividends during the Terrorism Coordination and Assistance Visit, but it also proved critical in subsequent years as Yano was later promoted to Army commander and ultimately to commander of the Armed Forces of the Philippines.

A second anecdote relates to personnel numbers. During planning, the SOCPAC commander received constant pressure from PACOM to identify how many U.S. forces were needed to conduct the operation. SOCPAC wanted to avoid a "manpower limit," as SOF leaders remembered all too well the 55-man limit in El Salvador. ${ }^{22}$ SOCPAC attempted to focus on required capabilities as opposed to required number of personnel.

SOCPAC determined that operations on Basilan Island required 13 Special Forces detachments to advise the 13 Philippine battalions, three advanced operations bases (Special Forces company headquarters) to advise the three Philippine brigades, and one Special Forces battalion headquarters to advise the task force (division-level) command.

SOCPAC thought that this would prevent a manpower limit; however, a PACOM staff officer looked at the doctrine for a Special Forces detachment and learned it consisted of $12 \mathrm{men}$. He then multiplied that by 13 and came up with 156 personnel. He rounded that up to 160, and that became the initial manpower limit for the deployment to Basilan Island. Thus, the campaign planners were unable to outsmart the "personnelists" who demanded specific personnel numbers.

In January 2002, SOCPAC deployed Joint Task Force 510, a rapidly deployable headquarters within its command, to Zamboanga to start the advisory mission. ${ }^{23}$ Realizing this was a long-term mission, SOCPAC established JSOTF-P to replace Joint Task Force 510 in July $2002 .{ }^{24}$ The scale, scope, and duration of the mission had exceeded the ability of SOCPAC to command with its organic task force. 


\section{The JSOTF mission}

In 2006, the author returned to the Philippines, this time as the JSOTF-P commander. Its mission statement read,

JSOTF-P, in coordination with the Country Team, builds capacity, and strengthens the Republic of the Philippines security forces to defeat selected terrorist organizations in order to protect [Republic of the Philippines] and U.S. citizens and interests, while preserving [Republic of the Philippines] sovereignty.

The mission statement had evolved over time, and the new statement eloquently captured what the task force needed to accomplish.

This short mission statement identified critical elements in the overall campaign plan. First, it acknowledged that operations must be conducted in coordination with the country team-the "interagency group made up of the head of each State Department section in the embassy and the heads of the other U.S. government agencies represented at [the embassy]." ${ }^{25}$ Although this was a "Title 10" named operation in support of the global war on terrorism-meaning embassy approval for operations was not requiredJSOTF-P and SOCPAC leadership recognized that the military effort had to be nested within the embassy's strategic plan.

The mission statement also emphasized building capacity and strengthening security forces rather than an exclusive focus on military forces. This was an important distinction. From the initial assessment, it was clear that the security problem could not be solved by the application of military power alone. Southern Mindanao lacked sufficient police and law enforcement capability as well as operational courts and judges. The limited police that did exist wore military-style uniforms, carried rifles, and required military support to conduct law enforcement operations due to the high threat. The campaign plan identified the need to take a holistic approach, so the order authorizing the Operation Enduring Freedom-Philippines mission included the necessary authorities to train, advise, and assist law enforcement forces.

Several initiatives focused on law enforcement. A simple one was influencing law enforcement personnel to wear their blue uniforms rather than military uniforms. Another was for them to assume control of checkpoints from the military and move the military into supporting roles. A major effort emphasized the rule of law, which meant getting the courts to function and putting judges back into their communities.

By 2006, this investment paid dividends when rogue elements of the Moro National Liberation Front, MILF, and the ASG committed numerous atrocities. On Basilan Island, the MILF and ASG fighters beheaded 10 Philippine Marines in a MILF-controlled area. ${ }^{26}$ Rather than conducting "scorched earth" or "scouring operations" as were common prior to 2002, the Philippine military requested and were granted warrants for the arrests of the perpetrators and proceeded to conduct highly surgical military operations with special operations and law enforcement personnel.

Most importantly, in regard to policing, Federal Bureau of Investigation personnel, as well as members of the U.S. intelligence community, performed some of the best work. One of the most critical skills taught to the security forces, both military and police, was sensitive site exploitation. There was an inherent tension between the law enforcement community, which focused on evidence protection, chain of custody, and bringing perpetrators to justice, and the intelligence community, which sought intelligence for immediate and future follow-on operations. Yet U.S. law enforcement and intelligence personnel cooperated to reduce the friction between evidence and intelligence so that intelligence could be exploited immediately, while evidence was protected for later prosecution.

Unfortunately, the mission statement still restricted targeting to select terrorist organizations. This was in response to directives and concept plans that directed operations against only al-Qaida-linked terrorist 
groups. ${ }^{27}$ Although Philippine leaders wanted a broader mandate, this limitation did not adversely affect the partnership because trust had been established through years of persistent engagement.

\section{JSOTF-P campaign plan lines of effort}

The doctrinal basis for JSOTF-P's campaign plan was foreign internal defense, defined by joint doctrine as the

participation by civilian and military agencies of a government in any of the action programs taken by another government or other designated organization to free and protect its society from subversion, lawlessness, insurgency, terrorism, and other threats to its security. ${ }^{28}$

Advising on counterinsurgency was a large part of the JSOTF-P mission, yet the U.S. military lacked counterinsurgency doctrine until December 2006. ${ }^{29}$ Luckily, SOF has a long history with foreign internal defense, and its education and training in unconventional warfare helped compensate for the lack of doctrine.

Conducting accurate assessments was critical to JSOTF-P designing an effective campaign plan. The Special Forces soldiers conducted area studies prior to deployment, and once deployed, they conducted continuous area assessments. The psychological operations forces developed their engagement strategy using audience analysis, among other assessments. The civil affairs forces developed their plans based on the large amounts of data that they collected, including assessing local conditions as part of their civil information management process.

On Basilan, one of JSOTF-P's first tasks was to conduct a structured assessment of the security situation; the training level of security forces; and the economic, historical, and cultural conditions. JSOTF-P surveyed nearly 30 "barangays," or villages, using a 67-item questionnaire to gather data necessary to prioritize efforts. Fridovich directed their use based on his experience in Haiti. JSOTF-P used this information to synchronize efforts among military forces as well as efforts with other U.S. government agencies, such as the U.S. Agency for International Development.

The campaign also relied on basic counterinsurgency fundamentals: deny insurgent/terrorist sanctuary, deny insurgent/terrorist mobility, deny insurgent/terrorist access to resources, and separate the insurgent/terrorist from the population. ${ }^{30}$ These easily understandable fundamentals guided the planning and execution of the campaign plan. Although they are simple to articulate, it is mindful to turn to influential military theorist Carl von Clausewitz who said, "Everything is very simple in war, but the simplest thing is difficult." 31

The campaign's four lines of effort were: 1) Philippine security forces, 2) civil-military operations, 3) intelligence, and 4) influence operations.

The objective for the first line of effort was to develop a secure and stable environment. The training cycle flowed as follows: assess, train, rehearse, execute the operation, conduct an after-action review, identify strengths and weaknesses, train to correct deficiencies, rehearse, and execute the next operation. U.S. advisors shifted training away from large-scale battalion-size movement-to-contact (or "scouring operations," as the Philippine soldiers called them) to aggressive small-unit tactics that were more effective at finding and fixing enemy forces and conducting planned attacks.

U.S. advisors could not accompany their partners for any tactical operations, but they could often observe the forces in the field and on targets if the battalion commander was near enough. U.S. political leaders were unwilling to accept U.S. casualties, so they restricted U.S. service members from operating below the battalion level under the flawed assumption that the battalion commander would be away from the front lines. But in this type of warfare, there were no frontlines. The SOF soldiers overcame this 
restriction by working closely with and collocating with the battalion commander and his tactical command post, even if it placed them at risk.

While improving ground tactical operations was a priority, the advisory mission extended beyond ground operations. One important improvement was providing the Philippine Air Force the ability to fly at night. Ground forces were reluctant to conduct night operations because their wounded could not be medically evacuated until daylight. JSOTF-P helped to get the Philippine helicopter pilots night vision goggles and facilitated extensive training by the U.S. Air Force's 6th Special Operations Squadron, which had aviation foreign internal defense as a mission.

Improving Philippine close air support was also important. By rigging gun cameras in Philippine OV-10 aircraft and MD-500 attack helicopters and using the overhead imagery capability of the U.S. P3 Orion, air advisors trained Philippine fixed and rotary wing pilots in rudimentary joint air attack tactics that significantly improved their ability to provide close air support. The film provided by the P3 flying overhead allowed the advisors to critique the training. After demonstrating the greatly improved capability to senior Philippine leadership and ground commanders, commanders had much greater confidence in their air support.

The JSOTF-P advisory mission extended to support activities as well. JSOTF-P logisticians identified critical joint logistics shortfalls that resulted from stovepiping and a lack of inter-service cooperation. By leveraging the U.S. ambassador to engage with senior leaders in Manila, the team transmitted recommendations for how to improve logistics and overcome some of the traditional inter-service rivalries.

Finally, another non-standard or overlooked activity fell to JSOTF-P lawyers. Philippine military lawyers' main focus was on administrative law and advising commanders on the enforcement of military regulations. They had little, if any, operational law training or experience unless they had participated in the International Military Education and Training program. JSOTF-P lawyers assessed the problem and developed training programs to provide operational law capabilities. This also offered another method to provide human rights and the law of land warfare training.

The second line of effort was civil-military operations. Informed by assessments, these operations focused on short- and long-term projects. In terms of long-term projects, civil affairs collaborated with the U.S. Agency for International Development to work with the Philippine government's Mindanao Economic Development Council on development projects that could address some of the root causes of the insurgency. Schools, medical facilities, roads, livelihood programs, and business development are all examples of development that can drive long-term change.

The United States also supported smaller civil-military operations activities such as medical and engineering civic action programs to provide the military access to contested areas. They supported a classic "ink spot" counterinsurgency strategy. Based on a threat assessment, Philippine forces would move into areas with a strong insurgent and terrorist presence. Next, they would engage the population to identify projects that would improve local conditions. They would then build the projects to help gain the trust of the local populace, which, if successful, would provide access to information on the insurgents; this was critical to denying insurgents and terrorists sanctuary, mobility, and access to resources.

The local political and military leadership recognized the value of civil-military operations. For example, the governor of Sulu Province had a problem with absentee barangay chiefs (village mayors) who lived off the island and only periodically visited the villages that elected them. JSOTF-P constructed "area coordination centers," which provided the barangay a place for town meetings and a central farmer's market and a location for the U.S. advisors to coordinate civil-military operations projects with local stakeholders. The Sulu governor asked the Philippine and U.S. militaries to only build area coordination centers where the mayor pledged to live full time in his barangay. Building these fairly basic centers thus improved local governance.

The third line of effort was intelligence. The JSOTF helped establish fusion centers at the Philippine combatant command and task force headquarters and tactical intelligence liaisons at the battalion level. 
Releasable U.S. national-level and technical intelligence from both the military and other government agencies was fused with the extensive human intelligence capabilities of the Philippine military and government to improve targeting. U.S. intelligence personnel assisted their Philippine counterparts in terrorist targeting and developing target intelligence packages.

Like the ground operations, intelligence operations greatly improved over time. One of the many successes was the destruction of the ASG's auxiliary network on Jolo Island that provided weapons and safe houses to the group. The group's legitimate activities provided cover for its auxiliary support. Analysts determined that they were communicating via citizens band radio using codes in indigenous dialects. Once the code was broken and communications monitored, the Philippine military conducted a simultaneous joint special operation to take down much of the network in a single night.

Intelligence operations were complex, frustrating, and difficult with different military and civilian intelligence agencies having varying authorities and restrictions. Weekly coordination meetings with the various intelligence agencies at the U.S. Embassy, however, greatly facilitated overcoming the friction and allowed the JSOTF to provide quality intelligence to Philippine forces.

The final line of effort was influence operations. Philippine and U.S. psychological operations forces worked to sow dissent and discord among the ASG fighters and their supporters. Likewise, public affairs and public diplomacy officials at the U.S. Embassy worked to ensure transparency of U.S. activities and helped build trust between the Philippines and the United States. The collaboration produced a number of positive outcomes: the development of a comic book series in multiple dialects focusing on local heroes and their heroic actions, influencing the youth toward productive lives, tip lines, and effective use of the Department of State's Rewards for Justice Program. ${ }^{32}$

A priority for influence operations was enhancing the legitimacy of the Philippine government and its security forces. Although the United States employed extensive psychological operations products in print and electronic media, as well as through face-to-face contact, legitimacy was best enhanced through action and occurred over time. From a U.S. perspective, it was imperative that the JSOTF avoid taking any action that would undercut Philippine legitimacy. This was an important part of all planning.

\section{Operational vignettes}

What follows are four short vignettes that illustrate the effectiveness of special warfare operations during Operation Enduring Freedom-Philippines. The examples demonstrate the creative thinking required to accomplish the mission, the individual initiative of SOF personnel, that conventional forces have a role in counterinsurgency, and the importance of information operations.

\section{Road building on Basilan Island}

During the initial assessment and deployment to Basilan, one of the key infrastructure shortfalls the assessment team identified was the lack of a paved road to circumnavigate the island. Of the 130 kilometers of road, 84 kilometers remained unimproved. This hindered the ability of local farmers to move food to market, impeded economic development, and constrained the mobility of Philippine security forces. Because the mission had developed comparatively swiftly, humanitarian assistance funding required to complete the road was unavailable at the start of the mission in 2002.

PACOM decided that the best way to finish the road would be to bring in U.S. Navy Seabees ${ }^{33}$ and U.S. Marine and Philippine Army engineers to build the road as part of a military exercise. The U.S. Navy conducted an amphibious landing on Basilan and offloaded Philippine and U.S. engineer equipment, and the engineers started paving the road using "assault road" techniques that would be used in any military situation. 
Since PACOM lacked the authorities to build the road for humanitarian purposes, the legal justification to build it was for force protection purposes so that Philippine and U.S. military forces would have sufficient mobility for operations. Mobility was especially important for quick reaction force operations if any military units had any difficulties with the enemy. The completion of the road not only improved military mobility but also served the needs of locals and improved economic development.

\section{Providing water to a village}

The second vignette demonstrates the initiative of the Special Forces detachment. One particular detachment advised a battalion that did not have access to water in its camp. The Special Forces engineering sergeant identified a water source 2 kilometers away and developed a plan to place a sump pump at the source and then build a pipeline to the camp using PVC pipe. In between the water source and the camp was a small barangay that also lacked water. The villagers had to haul water using jugs from the same water source. A failed development project that had been attempted years earlier left a cistern on high ground next to the village.

The Special Forces engineers assessed that the pipeline they had built could also fill the cistern, and gravity could be used to carry water from the cistern to the village. They connected the pipeline to the cistern and built a connecting pipeline to the village for less than $\$ 1,000$. Two weeks later, the barangay mayor invited Philippine and U.S. military leadership to the village for the unveiling of the project. The project took place unbeknownst to the military leadership, and the villagers' outpouring of gratitude pleasantly surprised them.

The Special Forces detachment lacked humanitarian assistance funding, as well as the authorization to provide humanitarian assistance to the village (approximately $\$ 2$ million in humanitarian assistance funding was finally authorized six months after the initial deployment). They knew, however, that the village was strategically located and could provide valuable information about the insurgent and terrorist presence, which would enhance both Philippine military operations and force protection. They justified their actions because they were authorized to improve the conditions of Philippine and U.S. forces and, through creative engineering, also made allies of the local villagers who ultimately provided information to the Philippine military.

Both projects illustrate the slow pace of funding, resourcing, and authorities required to accomplish necessary activities and actions in support of a campaign plan. They also demonstrate how SOF often find creative ways to accomplish the mission and achieve desired effects in spite of the bureaucracy.

\section{Advising counterinsurgency operations}

The third vignette demonstrates that conventional units have a role in counterinsurgency. After the ASG lost their sanctuary in central Mindanao due to a cease-fire agreement between the Philippine government and the MILF, U.S. advisory operations expanded from 2005-2007. While requested as part of the original campaign plan, this broader mission had been initially denied. U.S. advisors deployed to these new locations, assessed the situation, identified the ASG sanctuaries, and provided operational advice to the Philippine military.

Because the ASG's auxiliary provided information on the Philippine military's movements, the only way for the military to achieve surprise in one particular area was to conduct an amphibious assault at night, so the U.S. advisors helped them plan and prepare for the operation. This technique was highly successful and resulted in the elimination of three sanctuaries, the destruction of a major bomb-making factory, and the death of ASG leader Khadaffy Janjalani. ${ }^{34}$ This forced the ASG to disperse throughout the island and has prevented them from massing forces ever since. 
This vignette illustrates two lessons. First, classic counterinsurgency methods do have modern applicability. Second, conventional military action also has a role in special warfare. The JSOTF was fortunate to have both surface warfare naval officers and Marines assigned as individual augmentees. They were instrumental in assisting the Philippine forces plan and execute the amphibious operations.

\section{Producing lethal effects through influence operations}

The fourth vignette demonstrates the importance of information operations. Abu Sulaiman replaced Janjalani as ASG commander, but his tenure in this position was relatively short lived, as an 11-month operation led to his death in January 2007. ${ }^{35}$ His killing was a classic special warfare operation in support of the Philippine military.

In March 2006, the ASG bombed the Sulu Cooperative store on Jolo Island, killing 5 and wounding another 40, most of them Muslims. ${ }^{36}$ One of the low-level ASG members became disgruntled over the killing of fellow Muslims and was significantly persuaded by his wife to provide information on Sulaiman. His wife had been influenced by both psychological and civil-military operations.

The dissent and discord program emphasized not only the poor ASG leadership but also the Rewards for Justice program, which offered a $\$ 5$ million reward for information leading to the capture or killing of Abu Sulaiman. ${ }^{37}$ The low-level ASG member's wife was also influenced by the care she and her children had received from the Philippine government through medical civic action and the construction of schools and clinics. She challenged her husband, arguing that the ASG had done nothing for her family and that he should not support the group and instead help the government. She argued that she could not even put milk on the table for her children, yet there was a $\$ 5$ million reward available.

This convinced him to become an informant, and he eventually provided valuable intelligence on Abu Sulaiman. National-level intelligence assets later located Abu Sulaiman in the jungles on Jolo Island, and an intelligence officer immediately provided the information to Staff Sergeant Crysta Kovach, an intelligence analyst in JSOTF-P.

Kovach recognized this as actionable intelligence and knew that a U.S. Special Forces detachment was advising the 6th Philippine Special Forces Company that was planning to conduct an operation in the vicinity that night. She provided the information, developed a target intelligence package, and then transmitted it to the detachment so they could help their counterparts plan the mission.

Kovach received that information at 3 PM, and by 6 PM, the Philippine 6th Special Forces Company had started its movement into the jungle. At dawn, they arrived at the ASG camp. When Abu Sulaiman left the perimeter of the camp to use the bathroom, they attempted to capture him, but rather than surrender, he resisted and was shot and killed. The company cleared the camp, killing a number of ASG militants. They conducted a sensitive site exploitation, recovering computers, cell phones, and weapons. They sent a digital photo of Sulaiman over the radio to the task force headquarters and had the informant make a positive identification. In June 2007, the informant, along with others who played a role, received a portion of the reward. The informant and his family were placed in witness protection.

This last vignette illustrates how all the lines of effort in this special warfare campaign-advise and assist, intelligence, civil-military operations, and influence operations - came together and resulted in the death of the ASG leader. Although it took months to develop, when JSOFT-P received actionable intelligence, the Philippine forces were prepared to rapidly act and exploit it. This is the nature of special warfare.

\section{Conclusion}

This chapter examined a few of the many operations that occurred during Operation Enduring FreedomPhilippines, and they offer some important insights for future operations. 
First, SOF doctrine and training prior to $9 / 11$ was effective. Foreign internal defense conducted by personnel grounded in unconventional warfare is an important part of a special warfare campaign.

Second, persistent engagement over time allows relationships to develop. Continued engagement-including International Military Education and Training - are investments in people. It is impossible to predict when or if they will pay off, but they did in the Philippines, and they have in many cases around the world.

Third, the importance of host nation sovereignty cannot be over-emphasized. While some future operations will be conducted in failed states and ungoverned spaces, the majority of U.S. operations will likely be conducted in a sovereign nation in support of a host nation government. It is critical to build and train the host nation forces in their own image and have them plan and execute their own operations while providing the appropriate mentorship.

Finally, special warfare and operations in a country like the Philippines require personnel and leaders who can truly practice the art of leading without being in charge. They must be able to exercise presence, patience, and persistence to deal with the political friction and complexity to focus on achieving long-term effects rather than simply short-term gains.

In February 2015, a ceremony in Zamboanga marked the deactivation of JSOTF-P but not necessarily the end of U.S. support. At its height, the task force had up to 600 U.S. military personnel in country. Additionally, it is important to note that even advisory missions carry inherent risks, as 17 U.S. troops died as part of the mission. ${ }^{38}$ Yet the mission was widely viewed as a success.

One RAND study assessed that JSOTF-P contributed to a "reduced transnational terrorist threat" and "increased [Philippine security forces] capabilities at the tactical, operational, and institutional levels." 39 Kurt Hoyer, the U.S. Embassy press attaché, remarked, "Our partnership with the Philippine security forces has been successful in drastically reducing the capabilities of domestic and transitional terrorist groups in the Philippines." ${ }^{40}$ In the end, JSOTF-P was an efficient and effective use of SOF for special warfare.

\section{Notes}

1 A competency is an essential and enduring capability. See Department of the Army, Special Operations, ADP 3-05 (Washington, DC: Department of the Army, 2019), 1-3.

2 Ibid.

3 Ibid., 9.

4 The Huk Rebellion, also known as Hukbalahap Rebellion, was a communist-led peasant uprising in the Philippines from 1946-1954.

5 Bureau of East Asian and Pacific Affairs, "U.S. Relations With the Philippines," U.S. Department of State, January 21, 2020, accessed September 28, 2020, www.state.gov/u-s-relations-with-the-philippines/.

6 "Mutual Defense Treaty Between the United States and the Republic of the Philippines," The Avalon Project, https://avalon.law.yale.edu/20th_century/phil001.asp.

7 Bob Drogin, “Americans Bid Farewell to Last Philippine Base," Los Angeles Times, November 25, 1992, www. latimes.com/archives/la-xpm-1992-11-25-mn-1038-story.html.

8 The Balikatan exercise "has been the cornerstone of the U.S.-Philippine military alliance since the United States closes its [bases] and pulled out of the country in 1991." It is a U.S. and Philippines joint military exercise that is conducted annually. See Travis J. Tritten, “U.S. Philippines Wrap Up Annual Balikatan Exercise," Stars and Stripes, April 15, 2011, www.stripes.com/news/u-s-philippines-wrap-up-annual-balikatan-exercise-1.141114.

9 COPE is a long-standing exercise designed to enhance multilateral air operations among the U.S., Japan, and Australia. See Pacific Air Force Public Affairs, "COPE North 2019 Strengthens Partnerships, Sharpens Lethality, Improves Interoperability," Pacific Air Forces, February 13, 2019, www.pacaf.af.mil/News/Article-Display/Article/ 1757382/cope-north-2019-strengthens-partnerships-sharpens-lethality-improves-interopera/.

10 The Cooperation Afloat Readiness and Training (CARAT) exercise is the U.S. Navy's "oldest and longest continually running exercise in South and Southeast Asia." See Commander, Logistic Group Western Pacific, "U.S. and Bangladesh Navies Conclude Cooperation Afloat Readiness and Training 2019," U.S. IndoPacific Command, November 8, 2019, www.pacom.mil/Media/News/News-Article-View/Article/2012418/ us-and-bangladesh-navies-conclude-cooperation-afloat-readiness-and-training-2019/. 
11 Thomas Fuller, “20 Kidnapped From Malaysian Resort Island,” New York Times, April 25, 2000, www.nytimes. com/2000/04/25/news/20-kidnapped-from-malaysian-resort-island.html.

12 Michael A. Sheehan, Crush the Cell: How to Defeat Terrorism Without Terrorizing Ourselves (New York: Crown, 2008$), 123$.

13 "Special Forces CIF Companies," American Special Operations, accessed September 29, 2020, www.americanspecialops.com/special-forces/cif/.

14 “Rescue Raid Ends in Hostage Deaths," CNN, June 8, 2002, www.cnn.com/2002/WORLD/asiapcf/southeast/06/07/phil.hostages/index.html.

15 "Philippines Kidnappers Who Beheaded US Hostage Jailed," Guardian, December 6, 2007, www.theguardian. com/world/2007/dec/06/terrorism.philippines.

16 CIA, The World Factbook 2020 (Washington, DC: Central Intelligence Agency, 2020), www.cia.gov/ the-world-factbook/.

17 Linda Robinson et al., U.S. Special Operations Forces in the Philippines, 2001-2014 (Santa Monica: RAND, 2016$), 15$.

18 "U.S Hostages Killed in Raid in the Philippines," PBS, June 7, 2002, www.pbs.org/newshour/politics/ asia-jan-june02-philippines_06-07.

19 Robinson et al., U.S. SOF in the Philippines, 16.

20 An interesting side note is that in the meetings in the Oval Office with his national security staff, President George W. Bush overruled Secretary of Defense Donald Rumsfeld's objections to executing the plan because he had told President Arroyo he would support her in the fight against terrorism. This was relayed to this author at West Point by the late General Wayne A. Downing, who was present at the meeting as the counterterrorism advisor to National Security Advisor Condoleezza Rice.

21 “International Military Education \& Training (IMET)," DSCA, accessed September 29, 2020, www.dsca.mil/ programs/international-military-education-training-imet.

22 For more on the 55-advisor limit, see Cecil E. Bailey's chapter in this handbook.

23 Robinson et al., U.S. SOF in the Philippines, 23.

24 Geoffrey Lambert et al., "Operation Enduring Freedom-Philippines: Civilian Harm and the Indirect Approach," Prism 3, no. 4 (2012): 121.

25 Shawn Dorman, Inside a U.S. Embassy: Diplomacy at Work (Washington, DC: Foreign Service Books, 2011), 69-70.

26 "Militants Kill 14 Philippine Marines, Behead 10," Agence France-Presse, July 11, 2007.

27 Many of the authorities stem from Authorization for Use of Military Force, Pub. L. No. 107-40 \1, 115 Stat. 225 (2001).

28 Joint Chiefs of Staff, Foreign Internal Defense, JP 3-22 (Washington, DC: Joint Chiefs of Staff, 2018), ix.

29 Department of the Army, Counterinsurgency, FM 3-24 (Washington, DC: Department of the Army, 2006).

30 See, for example, David Galula, Counterinsurgency Warfare: Theory and Practice (Westport, CT: Praeger, 1964).

31 Carl Von Clausewitz, On War, ed. Michael Howard and Peter Paret (Princeton: Princeton University Press, 1984).

32 Rewards for Justice, "Counter-Terrorism Rewards Program," in Flyer (Washington, DC: Department of State, 2019), www.state.gov/wp-content/uploads/2019/05/Misc_Rewardsforjustice.pdf.

33 Seabees are engineers from Navy construction battalions.

34 "Success Story," Rewards for Justice, accessed September 29, 2020, https://rewardsforjustice.net/english/khadaffy_ janjalani.html.

35 "Philippine Military Kills Abu Sayyaf Leader," Guardian, January 17, 2007, www.theguardian.com/world/2007/ jan/17/alqaida.terrorism.

36 Human Rights Watch, Lives Destroy: Attacks Against Civilians in the Philippines (New York: Human Rights Watch, 2007), 20, www.hrw.org/reports/2007/philippines0707/philippines_lives_destroyed.pdf.

37 “Abu Sayyaf Senior Leaders Designated," Department of Treasury, November 30, 2005, www.treasury.gov/presscenter/press-releases/Pages/2005113013165523877.aspx.

38 Sam LaGrone, "U.S. Officially Ends Special Operations Task Force in the Philippines, Some Advisors May Remain," USNI News, February 27, 2015, https://news.usni.org/2015/02/27/u-s-officially-ends-specialoperations-task-force-in-the-philippines-some-advisors-may-remain.

39 Robinson et al., U.S. SOF in the Philippines, xvii.

40 LaGrone, "U.S. Officially Ends JSTOF-P." 


\title{
22 \\ OPERATION SERVAL
}

\section{A swift intervention with a small footprint in Mali}

\author{
Michael A. Sheehan and Pascale C. Siegel
}

In January 2012, Tuareg separatists from the National Movement for the Liberation of Azawad (MNLA), backed by Salafi-jihadi groups al-Qaida in the Islamic Maghreb (AQIM) and Ansar Dine, attacked government outposts in northern Mali, kicking off a separatist insurgency. By early April, the coalition of separatist and jihadi fighters had forced the retreat of the Malian military, captured the towns of Kidal, Gao, and Timbuktu (the major population centers in northern Mali), and imposed a harsh form of Sharia (Islamic law). Although the rebel offensive was predictable, not enough was done to prevent it.

While the international community dithered, the rebels gained strength in the north. In early January 2013, perhaps as a preemptive strike before an effective international force could be mustered, Tuareg rebel leader Iyad Ag Ghali ${ }^{1}$ sent a column of fighters south toward the capital, Bamako. To the credit of French President Francois Hollande, the French immediately sought and gained permission from the government in Bamako to launch Operation Serval on January 11, 2013.

The U.S.-French intervention in Mali in 2013 is notable for its fast, measured, and efficient approach. About 4,000 French troops - supported by U.S. intelligence, aerial refueling, and strategic lift for heavy combat forces - saved the capital city of Bamako from collapse and effectively quelled a jihadi-backed separatist uprising. ${ }^{2}$ Intent on keeping a small footprint and avoiding the impression of a European occupational force, Operation Serval succeeded on both counts. The integration of a pursuant United Nations peacekeeping force (largely composed of African nations) in the major cities along the Niger River and a European Union training mission to rebuild the Malian Army-along with continued U.S.-French operations in northern Mali-effectively contained the threat of AQIM remnants in Mali and throughout North Africa.

This chapter discusses the causes of the crisis in Mali in 2012-2013. It then details the multiple phases of the French operation to halt the jihadi advance, reclaim control of northern Mali for the central government in Bamako, and weaken the jihadi threat in the country. U.S. support to the French, augmented by important roles played by the United Nations and the European Union, provides a model of allied and multilateral cooperation.

\section{The 2012 crisis: collapse of the government and the early international response}

Mali has long been a fragile state weakened by a recurring separatist problem in the north and Islamist infiltration from Algeria. The alliance of convenience between Tuareg nationalists and Salafi-jihadi groups led to a separatist offensive in 2012 and the collapse of the Malian military and government. ${ }^{3}$ 
On January 17, 2012, Tuareg separatists from the MNLA, opportunistically backed by AQIM and Ansar Dine, attacked a government outpost in Ménaka, a town in the Gao region in eastern Mali, forcing the military to retreat. ${ }^{4}$ The rebels pursued their offensive against government bases in Tessalit and Aguelhok near the Algerian border, where the military-which did not receive adequate logistical support and ammunition from the central government-lost 50 soldiers. ${ }^{5}$ Fighting intensified and spread south to Anderamboukane, near the Niger border, and Léré, south of Timbuktu. By March 11, Tessalit fell, followed by Aguelhok. ${ }^{6}$ On March 30, Kidal fell, Gao fell the following day, and Timbuktu a day later. ${ }^{7}$

On April 6, the MNLA declared independence for Azawad-the name they gave to the territory they claimed in the northern half of Mali-and proclaimed a unilateral cease-fire. ${ }^{8}$ In less than three months, a small force of about 2,000-6,500 militants belonging to disparate groups with divergent goals took over half of Mali. ${ }^{9}$

The reigniting of the Tuareg rebellion and the rapid collapse of the Malian military caused consternation in Bamako, Paris, and Washington, not least of which because the Malian Army had received extensive counterterrorism training from the United States. They had failed to perform under pressure. The sudden defeat of the army also ignited popular and army discontent in Bamako. Wives of soldiers slaughtered in Aguelhok stormed the presidential palace, and troops became restive. ${ }^{10}$

On March 22, the unrest culminated in a coup against the sitting president, Amadou Toumani Touré, led by Malian Army Captain Amadou Haya Sanogo. ${ }^{11}$ In his inaugural speech, Sanogo denounced the lack of resources, leadership ineptitude, and political corruption. Sanogo also promised a government of national unity and a return to democracy as soon as possible. The coup drew widespread condemnation from the United States, France, the European Union, the African Union, and the United Nations, leading to the cessation of all U.S. assistance programs. ${ }^{12}$ The coup did not, however, slow or stop the rebels' advance; army units fled, leaving tons of American-provided weapons, ammunition, and equipment to the enemy.

Meanwhile, the jihadi factions turned on the MNLA. Through combat operations, intimidation, and subornation, the jihadi factions managed to marginalize the more secular fighters and wrest control of Azawad - the rebel-claimed portion of Mali. By the summer of 2012, three Salafi-jihadi factions controlled the major northern cities: AQIM controlled Timbuktu and its region, Ansar Dine controlled Kidal, and the Movement for Oneness and Jihad in West Africa (MUJAO) controlled Gao. ${ }^{13}$

The jihadi factions imposed a brutal version of Sharia, contrary to the recommendation of AQIM's leader, Abdelmalek Droukdel. Droukdel had recommended imposing Sharia gradually to keep the population's support or at least complacency. ${ }^{14} \mathrm{He}$ also feared that the quick implementation of a harsh version of Sharia would provoke the international community into intervening. ${ }^{15}$

Several factors led to the crisis in 2012, beginning with Mali's ongoing struggle with Tuareg nationalism. The Tuaregs - a large Berber ethnic confederation who inhabit the Saharan regions of North Africaare a small minority within Mali, but they are well organized politically. ${ }^{16}$ The nomadic pastoralist Tuaregs live in the north and have been in recurring conflict with Bamako since Mali gained independence from France in $1960 .{ }^{17}$ Bamako's agricultural policies—such as land privatization and irrigation-diverge from the Tuaregs' nomadic traditions, leading to conflicts over land usage. ${ }^{18}$

The central government failed to properly expand services, economic opportunities, and investment in the north. ${ }^{19}$ As Bamako agreed to greater autonomy, the government felt even less incentive to provide services, creating resentment among the local population. Investment plans designed to jumpstart economic development in the north never fully materialized.

The Libyan Civil War in 2011 boosted the Tuaregs' prospects across North Africa. Many Tuareg nationalists who had fled Mali for Libya after several failed revolts dating back to the 1960s returned to Mali as Muammar Gaddafi's Libyan regime collapsed. ${ }^{20}$ Battle hardened and well armed with weapons and ammunition, they saw an opportunity to take revenge on Bamako. "With our new arms and equipment, 


\section{Operation Serval}

we have a military capability that is superior to the Malian Army," said a spokesman for the Tuaregs in Paris in December 2011. ${ }^{21}$

Compounding the threat, Algerian Salafi-jihadi fighters had found refuge in the sparsely populated regions of northern Mali in the aftermath of the Algerian Civil War that ran from 1991-2002. Lacking the resources to remove these fighters from Malian territory, President Touré's government entered into a tacit "pact of non-aggression" with the jihadis because it considered the jihadi threat less of a risk than Tuareg nationalism. ${ }^{22}$

With this mindset, Toure agreed to the 2006 Algiers Accord to put an end to the third Tuareg rebellion. By the terms of the accord, the Malian Army was to drastically reduce its presence in northern Mali out of respect for Tuareg local rule. This, in effect, allowed AQIM greater freedom of movement. In 2009, when Touré decided to reestablish control over the north, the operation failed. Touré reverted to his stance that jihadis did not pose a serious threat to Mali, stating, "These threats are not born in Mali, and they do not target Malians. These people are not even from Mali." ${ }^{23}$

As both camps strengthened, they also moved closer. AQIM pushed its members to marry into the most prominent Tuareg tribes to co-opt their loyalty, protection, and support. ${ }^{24}$ Meanwhile, Iyad ag Ghali, a long-time secular-leaning leader of the Tuareg movement, came back from his mission at the Malian Consulate in Jeddah converted to extremist Wahhabist orthodoxy. ${ }^{25}$ After losing his bid for the direction of the MNLA, he founded Ansar Dine in accordance with his newfound religious beliefs and reestablished ties to his purported relative Abd al-Karim at-Targui, leader of a small AQIM katiba (military brigade) ${ }^{26}$ Such ties helped these disparate groups push the Malian military out of northern Mali but were not enough to build a lasting coalition.

The international community proved unable to assist Mali's government in developing a coherent and decisive response. The French government was eager to respond but wary that unilateral action would be perceived as neo-colonialist and backfire. The French told their American counterparts they wanted to keep an "African face" on the mission as much as possible but were hoping for a United Nations-assessed peacekeeping operation that was not forthcoming. It thus settled on a lead-from-behind-strategy by supporting a poorly supported African-led military response. ${ }^{27}$

Algeria refused to support any form of international intervention, as it viewed the region as within its sphere of influence. ${ }^{28}$ By far the most capable army in the region, the Algerians also refused to take any significant military action against the rebels. The Algerian government thought it could control Iyad Ag Ghali and split Ansar Dine from the rest of the jihadi factions. ${ }^{29}$ Algeria launched unilateral diplomatic talks for that purpose, which achieved little to nothing. Meanwhile, the new Malian government, under the leadership of Sanogo, did not think a foreign intervention was warranted, as it suspected an intervention would eventually lead to his ouster. ${ }^{30}$

The United States government, led by its ambassador in Bamako and its African Affairs Bureau of the State Department in Washington, blocked U.S. contact with any part of the army while coup leader Sanogo was still the "power behind the throne," even as the AQIM threat steadily increased in the north. ${ }^{31}$ The ineffectiveness of the African Union mission allowed AQIM to strengthen its forces.

Michael A. Sheehan, the assistant secretary of defense for special operations and low-intensity conflict, traveled to the region in the spring of 2012 and met with the U.S. ambassador in Mali in an attempt to get U.S. advisors back into the country to prepare trusted army units (such as the loyalist Red Berets) to combat the coming AQIM threat. The ambassador and the State Department made it clear that it was not possible under the current political conditions. The priority was to move forward with new elections and install a legitimate government before reengaging with the military. ${ }^{32}$

Frustrated in Mali, Sheehan had more success in Niger. In discussion with Ambassador Bisa Williams about the growing AQIM threat, Sheehan used a map of North Africa to describe how Niger was at the center of a gathering storm and would be an ideal location for U.S. intelligence aircraft. Williams agreed 
and told Sheehan that the Nigerien prime minister was very concerned about AQIM and Boko Haram forces in and around Mali and might be amenable to supporting U.S. efforts. ${ }^{33}$

A meeting was arranged the next day, and the prime minister agreed. None of the discussion had been pre-approved by Washington or by lower-level officials in the government of Niger; the idea was raised by the senior diplomat in Niger and immediately accepted by the prime minister. It is unlikely that the government bureaucracies of either nation, if given the chance to provide input on the concept, would have approved the idea so rapidly. Within months, the United States deployed surveillance aircraft to Niamey International Airport. These drones would be instrumental in providing the French with invaluable intelligence from the start. ${ }^{34}$

In July 2012, while addressing a security conference at the Aspen Institute in Colorado, Sheehan stated that "we cannot allow al-Qaida to sit in ungoverned places," arguing that the United States needed to accelerate its efforts to support the government in Mali as well as its army. ${ }^{35}$ No decisions were forthcoming in Washington, however, and the State Department position prevailed, resulting in the continued isolation of the Malian Army.

In December 2012, as the crisis grew, Sheehan traveled with Deputy Secretary of State William Burns to Algeria. The Algerian government made it clear that it was unwilling to move, either unilaterally or as part of a regional force, outside of its borders-notwithstanding that many of the rebel groups leaders were Algerian. ${ }^{36}$

Yet the U.S. government doubted the capabilities of an African-led force. To unmistakably convey her point, U.S. Ambassador to the United Nations Susan Rice reportedly called the French plan "crap." ${ }^{37}$ To be fair to the French, they were quite aware of the weaknesses of the African-led International Support Mission to Mali but were unable to get a United Nations peacekeeping operation approved by the Security Council as the United States objected on budgetary concerns.

In addition to U.S. budget concerns, the United Nations secretary general also expressed his apprehension about a potential counterterrorism mission that might be more than the United Nations could handle. The African Union and Economic Community of West African States remained concerned about the deteriorating situation and continued to agitate for an international response to the crisis while they put together an ill-equipped and poorly trained International Support Mission that was clearly not up to the task.

It took nine months for the United Nations to adopt Resolution 2085, authorizing the African-led International Support Mission to Mali under United Nations Chapter 7 on December 20, 2012. ${ }^{38}$ This operation was not a United Nations-assessed operation, however, which meant it would not guarantee funding and support to the ground forces. The force, supported by voluntary contributions, was a model doomed to fail and never became a significant factor.

In April 2013, after the complete collapse of the Malian Army, the United Nations established the Multidimensional Integrated Stabilization Mission in Mali. The United Nations force deployment allowed the French to focus their U.S.-supported effort in the sparsely populated north while maintaining an "African face" to the mission in the more populated south.

\section{Operation Serval}

After the United Nations authorized the International Support Mission to Mali in December 2012, Ansar Dine sought to preempt the foreign intervention. It broke off diplomatic talks with the Algerian government and sent a column of fighters toward Sévaré, near Mopti, a town located near the border of southern Mali and the self-declared Azawad state and on the only major road connecting the two. ${ }^{39}$

French intelligence identified dissent among the rebel groups concerning the wisdom of moving south. Ghali favored the move, but Droukdel preferred to consolidate gains in the north. ${ }^{40}$ The French also knew that the jihadis were massing forces but were unsure of the rebels' intent. The rebel force was not 
large enough to hold a city the size of Bamako. They could, however, try to terrorize the city and foment instability. Interim President Dioncounda Traoré, to whom coup leader Sanogo officially ceded power in April 2012, worried the jihadis would activate supporters inside the city. Moreover, if jihadis entered the city, a counterattack would become much more complex, and the fragile United Nations consensus might collapse.

On January 11, 2013, after a formal request from President Traoré, French President Hollande ordered French troops into action. ${ }^{41}$ Hollande laid out the following military objectives: "Stop the jihadi advance, assist the government of Mali in retaking the country, destroy the terrorists, seek and secure the hostages." ${ }^{42}$ At the time, AQIM and MUJAO held seven French civilians hostage, a situation that could have easily turned into a political liability had the terrorist groups decided to release videos of the hostages or their executions. ${ }^{43}$

The sudden change of plans forced the military to recalibrate the requisite force at the last moment under the first Joint Tactical Task Group. ${ }^{44}$ French Defense Minister Jean-Yves Le Drian called his American counterpart, Secretary of Defense Leon Panetta, on January 12, asking for logistics and intelligence support. ${ }^{45}$ Panetta immediately agreed to the request, and the Joint Staff swung into action to provide the support. The support was critical to success, especially with the deployment of C-17 aircraft capable of moving heavy tracked vehicles into the theater. In addition, U.S. aerial refueling of French Mirage jets over the battlefield was instrumental to the success of French air attacks against AQIM targets. ${ }^{46}$

The U.S. reconnaissance aircraft (MQ-1 and MQ-9 drones) stationed in Niamey, Niger-a relatively short distance to the battlefield in Mali-were instrumental in providing immediate intelligence on AQIM positions to the French. ${ }^{47} \mathrm{~A}$ joint intelligence fusion center of French and U.S. intelligence personnel was quickly established and began working seamlessly to provide even more detailed intelligence reports as the battle ensued.

Operation Serval consisted of four phases: 1) halt the jihadi advance, 2) reclaim territory for the central government in Bamako, 3) pursue the militants into their mountain strongholds, and 4) begin the process of political reconciliation and stabilization (see Figure 22.1 for associated movements).

\section{Phase 1: halting the jihadi advance}

Phase 1 began within hours of the presidential announcement to stop the jihadi advance and disrupt their logistical tail. French special forces from the 4th Special Forces Helicopter Regiment stationed in Burkina Faso struck jihadi columns moving from Konna to Sévaré (near Mopti), halting their advance. ${ }^{49}$ The Gazelle attack helicopters that flew directly to the battle zone from their bases in Burkina Faso were the most effective in stopping the column. ${ }^{50}$ One French aviator was killed in the initial assault after his helicopter crashed. ${ }^{51}$ But the combination of attack helicopters and French ground forces stopped the column of jihadi fighters dead in their tracks.

As French troops arrived in Sévaré, they discovered that the Malian Army had fled, dropping its weapons and equipment into the hands of AQIM (similar to what the Iraqi Army would do in the face of the Islamic State a year later). Within 24 hours, airstrikes commenced against militant training camps and weapons and ammunition depots in the north. Mirage 2000D jets stationed in N'Djamena, Chad-later joined by Rafales flying from Saint-Dizier airbase in France-conducted the strikes. ${ }^{52}$

Meanwhile, pre-positioned French conventional forces arrived in Bamako to protect French and European citizens and prepare for the arrival of reinforcements from France. Within a week, French and Malian troops took positions in Markala, Mopti, Diabaly, and Douentza to prevent the jihadis from marching south again.

Operation Serval benefited from intelligence assets pre-positioned in Mali. France's General Directorate for External Security had gathered significant intelligence on French hostages, the armed groups, their leaders, and their logistical support networks. This intelligence was shared with the Directorate of 


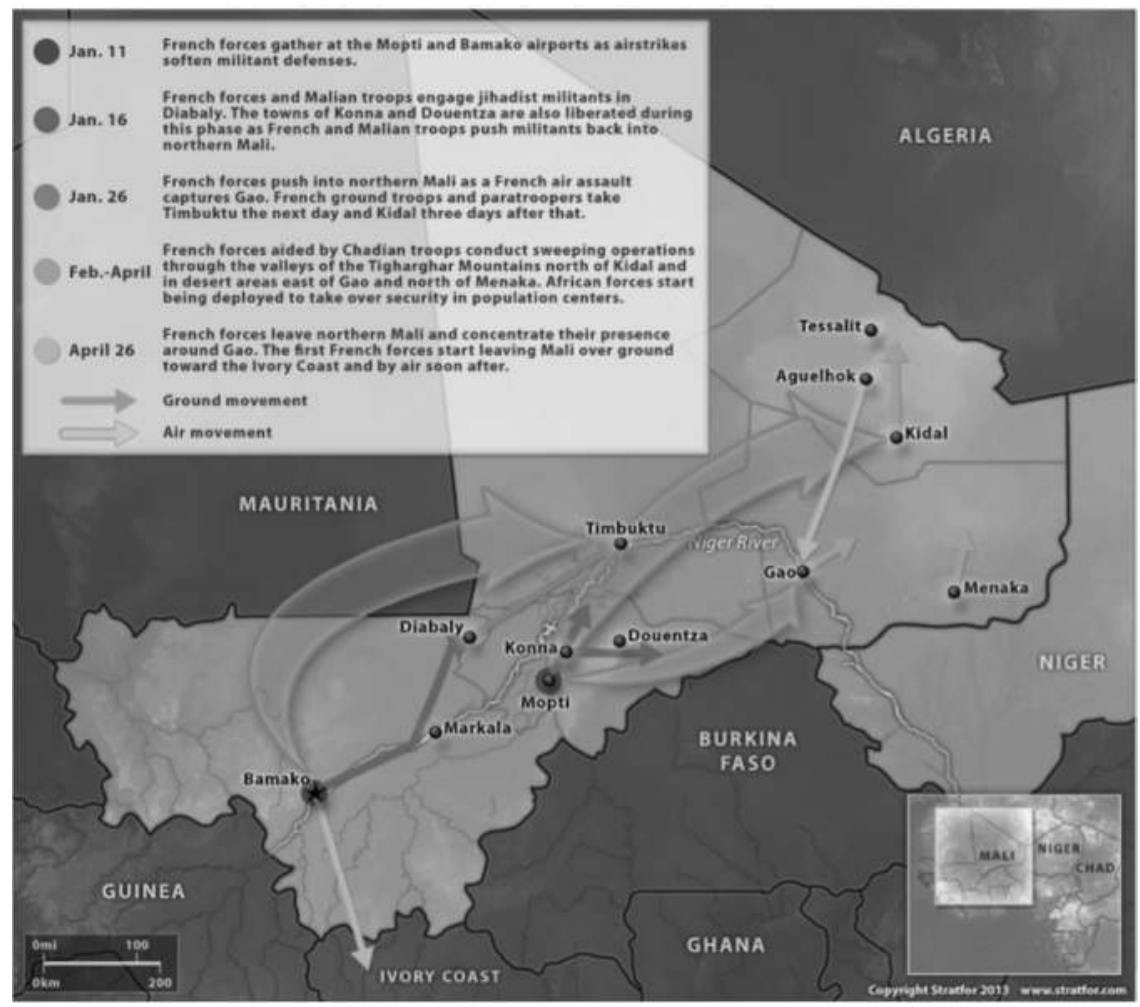

Figure 22.1 Phases of French operations in Mali, 2013. ${ }^{48}$

Source: This map comes from "French Operations in Mali: A Look Back," which is republished with the permission of Stratfor Worldview, a leading global geopolitical intelligence and advisory firm.

Military Intelligence at the outset of the operation and was instrumental in generating the list of targets to strike or seize. ${ }^{53}$

Operation Serval also benefited from France's pre-positioned forces in the region. France's Special Forces Command had troops in the Sahel as part of a multinational counterterrorism effort called Operation Sabre. These units deployed to Sévaré on January $11 .{ }^{54}$ Additionally, pre-positioned forces in Gabon, Djibouti, and Senegal, along with forces deployed in several long-term operations in Chad, Ivory Coast, and the Central African Republic, facilitated the rapid deployment of conventional forces into theater.

These bases, in close proximity to ports or airports, formed essential logistical hubs, receiving reinforcements or projecting forces and equipment forward. The strategic reserve-which can project 2,300 men from pre-identified units at a distance of 3,000 kilometers within seven days ${ }^{55}$ - was mobilized to complement the pre-positioned forces. France successfully mobilized both army and navy elements of the strategic reserve.

Strategic and refueling capacity deficits were expected, well known, and caused by repeated delays in acquisition programs. Between January 10 and February 11, 2013, 362 flights carried 10,000 tons of freight in theater. ${ }^{56}$ Some $75 \%$ of these flights were contracted out to civilian transporters. ${ }^{57}$ British, Canadian, Swedish, Hungarian, and American allies flew most of the remaining 25\%.

The situation was similarly dire in terms of in-flight refueling capacity. France had an aging fleet of refuelers that could not meet mission requirements, so allies again filled the gaps. By January 27 , after some 


\section{Operation Serval}

procedural delays, the U.S. military provided three air tankers. In the end, Americans, Spaniards, Germans, and British provided $30 \%$ of the refueling missions. ${ }^{58}$

Nonetheless, with outside assistance, the force ramped up quickly. By January 18, 1,800 French troops had arrived..$^{59}$ By early February, that number exceeded 5,000. ${ }^{60}$ The U.S. assisted by bringing in another contingent from Chad. Unlike many peacekeeping contingents, the Chadian unit came prepared to fight alongside its French allies and would soon find itself in the largest engagement of the intervention.

In light of the rapid progress, President Hollande decided to press the military advantage and ordered the troops to push north as quickly as possible to "not let [the jihadis] believe that the front line was becoming a border." ${ }^{1}$ Jihadi groups posted statements on the internet exhorting their supporters to carry out attacks against France and their interests around the world. This was a source of concern in Paris, as such attacks could have dampened the French public's enthusiasm for the operation.

\section{Phase 2: reclaiming territory}

Phase 2 began on January 24. Conventional troops and French special forces crossed the Niger bend to retake control of the north and liberate the major cities. There were inherent risks in moving quickly. Concerns included the nationalist or Islamist sympathies of many northern inhabitants; the threat of improvised explosive devices, as intelligence indicated that an Algerian explosives expert had traveled to Mali; the threat of man-portable air defense systems; and the sheer size of the region that had to be cleared of militants, which meant operating across long distances with logistical lines extending over 1,500 kilometers.

Phase 2 became a war of speed and rapid engagements over long distances in punishing heat in a type of military expeditionary mobility not widely practiced by the French military in decades. Troops were often out of communications for up to 10 hours a day. They carried only one day's supply of fuel, water, and food. This put significant strains on logistics. ${ }^{62}$

That terrain made logistical support extremely challenging. The size of the force (over 5,000 by February), the distance between the theater command post and the advanced units (up to 1,800 kilometers), the extreme climate, the poor conditions of the roads, and the lack of local resources made it particularly challenging to provide 4,500 daily rations, 45,000 liters of water, 10 tons of ammunition, 30,000 liters of gas, and 200,000 liters of kerosene. ${ }^{63}$

In Mali, logistics constrained maneuver. Several operations had to be canceled, rescheduled, or modified to accommodate the logistical requirements. This could have led to serious setbacks had the jihadis chosen to slow down the French advance by attacking the logistical lines.

The French planned to retake Timbuktu and Gao with a combination of airborne assault followed by armored units. But this plan was modified out of fear that airborne elements would be too vulnerable once they landed in the absence of other friendly forces on the ground. Instead, French special operators first seized key installations (airfields), and then conventional troops and paratroopers moved in.

For the most part, as the French advanced, the jihadis chose to disperse rather than put up a serious fight. Yet the speed at which the enemy abandoned the terrain came as a surprise. By January 28, French forces successfully controlled both Timbuktu and Gao. ${ }^{64}$ Overall, the situation was deemed secure enough for President Hollande to meet with President Traoré in Mali on February 2, where thousands cheerfully showed their gratitude to the French head of state. ${ }^{65}$

In Gao, however, resistance persisted as MUJAO regrouped and launched hit-and-run and suicide bombing attacks against French and Malian troops. MUJAO's resistance forced the French to maintain a larger footprint in the region than it preferred (more than 1,700 French troops) to conduct clearing operations in the villages and towns stretching all the way to Menaka (300 kilometers west of Gao). By mid-April, French and Malian forces had killed some 200 jihadis in the Gao region and seized 75 tons of equipment, and the frequency of attacks receded. ${ }^{66}$ 
The expanse of the operational area stretched French intelligence, surveillance, and reconnaissance capabilities, requiring more allied support. The French deployed intelligence, surveillance, and reconnaissance assets, including Mirage F1, Rafale, Atlantique-2, special forces, and Harfang drones ${ }^{67}$ They also leveraged the Hélios and Pléiade surveillance satellites and pooling arrangements with German and Italian satellites. ${ }^{68}$ Yet this still proved inadequate, so France turned to its American and British allies. Starting January 11, the United States provided drone flights operating out of nearby Niamey airport, which allowed for long "dwell time" over the area of operations; the drones also provided precision intelligence on enemy locations. ${ }^{69}$

In addition, France lacked the requisite level of satellite mobile connections to allow satisfactory communications between forward units and rear headquarters. The French first compensated for this deficit by buying commercial Thuraya and Inmarsat satellite phones before moving the VAB VENUS system-a wheeled satellite communication vehicle-from Afghanistan to Mali. ${ }^{70}$ Overall, the system suffered from limited bandwidth, so the Americans provided critical support once again.

As operations subsided in Gao and Timbuktu, French forces continued to press north. At the end of January, French Army special forces took over the airstrip in Kidal, allowing the paratroopers to land safely. They relieved the French special forces and secured the city.

On February 6, a similar scenario played out in Tessalit. French special forces secured the airfield before handing it over to paratroopers reinforced by an armored company diverted from Gao and Chadian reinforcements from Kidal. ${ }^{71}$ By early February, the French had the fourth task group paratroopers, the third task group of (aging) AMX-10RCs light reconnaissance vehicles equipped with a 105-mm cannon, 155mm howitzer cannons mounted on a truck, a logistical sub-group, a medical unit, and a command post ready to move into the Adrar des Ifoghas mountains. ${ }^{72}$

\section{Phase 3: the battle of the Ifoghas}

Phase 3 lasted from mid-February to the end of March and was designed to clear AQIM's defensive positions in the Adrar des Ifoghas mountain range. The Adrar is the cradle of the separatist movement in Mali. It is from the town of Kidal, on the southern side of the range, that many separatist insurrections began. As the mountain range straddles Mali and Algeria, it is also where Algerian Islamist fighters took refuge at the end of that country's civil war, regrouped, and later pledged allegiance to al-Qaida. For a decade, AQIM had used the Ifoghas to entrench itself into the social fabric (by marrying into Tuareg tribes), to run various smuggling operations (drugs, weapons, hostages), and to stockpile weapons and ammunition. ${ }^{73}$

Unlike earlier phases, the French and Chadian forces faced small groups of hardened combatants dispersed over large swaths of inhospitable territory but well organized and hunkered in defensive positions. While conventional forces systematically cleared AQIM's hideouts, French special forces searched for the remaining French hostages and hunted down key terrorist leaders. By this time, AQIM had regrouped from the initial French assault and, led by its southern amir Abu Zeid, began to fight back.

As the French sought to enter the Ametetai Valley (which runs east-west through the northern side of the Ifoghas), a violent firefight erupted, forcing the French to withdraw. ${ }^{74}$ Intelligence had correctly identified the logistical depots but failed to clearly identify AQIM's presence and intent. The French set up close watch on the valley, brought in hundreds of reinforcements, and expanded the logistical support first by air-bridge and then by a time-consuming road trek.

On February 22, the French began clearing the valley from the west, with Chadian forces moving in from the east. An intense firefight ensued in which 26 Chadians were killed. ${ }^{75}$ It was the first deadly combat on any significant scale of the war and the bloodiest day of the intervention. The French and Chadian troops forced the jihadis into the center of the valley, where French paratroopers subsequently killed many of them. ${ }^{76}$ 
For the following month, French and Chadian troops continued combing through the Ifoghas valley, encountering fierce resistance. The tenacity and fanaticism of AQIM's foot soldiers surprised French officers, which French officials attributed to the widespread use of a drug called ketamine, an anesthetic reducing fear. ${ }^{77}$ By official French accounts, the operation killed close to 400 jihadis, ${ }^{78}$ including the local amir, Abu Zeid. Chadian troops thought they had killed key AQIM operative Mokhtar Belmokhtar during the battle, but that assessment proved to be premature. ${ }^{79}$

Entering the Ifoghas and the Kidal region posed political challenges at the strategic and operational levels. The question was how local populations-who had long supported Tuareg nationalism, tolerated jihadi groups, and intermarried with their members - would react to the presence of French troops and the return of Malian central authority. In that uncertain context, would troops be welcomed, tolerated, or harassed?

France's primary objective was to destroy the jihadi groups and prevent the establishment of a safe haven in northern Mali. The secondary objective was restoring Malian government sovereignty over the entire territory to prevent northern Mali from becoming a terrorist safe haven again. In support of that objective, promoting national reconciliation was a means to that end.

France had decided to officially remain neutral in the conflict between the nationalist MNLA and the government of Mali. On the ground, France forbade troops at the operational and tactical levels from entering into any local negotiations with the nationalists. But at the onset of the operation, the MNLA pledged allegiance to France, hoping to gain an ally in their negotiations with Bamako. ${ }^{80}$ It worked, as France pressed for including the armed secular-leaning groups in the reconciliation process.

In addition, France pressured the Malian government not to send its forces north immediately so as not to provoke those with separatist sympathies. ${ }^{81}$ Bamako only reluctantly accepted, which placed the responsibility for the crisis on the Tuareg political leadership. These political decisions facilitated the reconquest of the north by neutralizing potentially hostile actors.

Yet considering the fluid relations between nationalists and jihadis, tactical incidents could easily have occurred, potentially with negative consequences. Moreover, in Kidal, which remained under the control of the MNLA, the security situation remained uncertain and the political situation tense. The arrival of Malian troops led to clashes with the MNLA in the fall of 2013. ${ }^{82}$ Jihadi groups continued to interfere.

\section{Phase 4: stabilization and political reconciliation}

Phase 4 started in early May, as residual combat operations continued, notably in the region of Gao. Stabilization operations were designed to secure the liberated areas. International partners helped to alleviate the burden on French forces and allowed France to focus on building a regional force to combat violent Islamists and jihadis throughout the Sahel.

The French government undertook Operation Serval unilaterally (albeit with limited support from a handful of allies), in stark contrast with recent operations under the banner of the European Union or NATO. Yet Paris always intended to transition to a multilateral framework led by African peacekeeping forces for legitimacy reasons (a former colonial power intervening in its former colony would see its legitimacy erode quickly) and for operational reasons (the French committed up to 5,300 troops to Operation Serval and needed relief). ${ }^{83}$

The first pillar was to restore the constitutional order by holding elections. Although Traorés interim government had functioned, the French believed that it lacked the legitimacy required to enter into fruitful negotiations with the separatists. ${ }^{84}$ In addition, without an elected government, U.S. support for stabilization would be limited.

In July and August 2013, Mali held presidential elections. Ibrahim Boubacar Keita won in a landslide. In November, legislative elections commenced peacefully, handing Keita's party another landslide victory. 
African troops from the Multidimensional Integrated Stabilization Mission in Mali, backed by forces from Operation Serval, were in charge of securing the elections. ${ }^{85}$

The second pillar of the stabilization program was to rebuild the Malian forces into a large and tactically proficient enough force to hold the north to avoid a repeat of the 2012 debacle. By 2013, the Malian military was in complete disarray, "badly trained, badly paid, and under-equipped" according to General Lecointre, chief of the European Union training mission. ${ }^{86}$ The European Union led a dual-track mission of tactical counterterrorism training for eight unified, self-supported battalions (focused on reconnaissance, area control, and operations for eliminating isolated pockets of resistance) and capacity building at the ministerial level to ensure that the force had effective administrative support.

The European Union mission was extended in 2014 and again in 2016. Under the third mandate, the European Union training mission in Mali trained, advised, and educated the Malian military to contribute to the restoration of their military capacity and enable them to conduct military operations aimed at restoring Malian territorial integrity, protecting the population, and reducing the threat posed by terrorist groups. As part of the third mandate, the mission area was extended toward the Niger River loop, including the municipalities of Gao and Timbuktu. Kidal, the most restive region, remained outside of the purview of the mission.

The third pillar sought to ensure that an African-led force would be able to take over from the Frenchled operation to maintain a long-term presence to keep the jihadi threat in check. The Economic Community of West African States had been a useful mediator during 2012, but its military arm was predictably ineffectual. Its troops began deploying to Mali in the first months of 2013 and grew to about 6,000 soldiers, but they largely stayed away from the fighting. The exception was the previously mentioned Chadian forces.

In April 2013, the United States supported United Nations Resolution 2100, creating a United Nations peacekeeping force. The International Support Mission troops transitioned to a United Nations command on July 1 under their new "blue helmets" and began to deploy to the major cities in Mali in the second half of 2013. Eventually, the Multidimensional Integrated Stabilization Mission in Mali mission would grow to over 11,000 troops, but it took longer than the French had anticipated. ${ }^{87}$ In early November 2013, there were still 3,000 French soldiers in Mali, much more than they preferred-but compared to similar U.S.-led interventions, this was a much smaller force. ${ }^{88}$

The fourth pillar was to facilitate the reconciliation process between the Tuaregs and the government in Bamako. In mid-June, the government and the separatists signed the Ouagadougou Political Accords, an interim agreement calling for an immediate cease-fire, cantonment of rebel forces, the return of government authority in the north (with an exception for Kidal), national elections, and reconciliation talks. ${ }^{89}$ The cease-fire became effective immediately. The reconciliation process proved arduous, however, and faltered repeatedly, with Tuaregs and Malian forces clashing regularly in late 2013.

In spring 2014, the Tuaregs launched a successful offensive against government troops and expelled them from Kidal, Menaka, Andéramboukane, and Anéfis. ${ }^{90}$ Renewed diplomatic efforts by the Algerian government helped broker a new peace agreement, the Algiers Accord, in June 2015. Implementation, however, has been uneven. As a result, residual violence both at the hands of nationalist Tuaregs and jihadis regularly resurfaces, although not on the scale seen in 2012 or with the same dramatic consequences for government control.

\section{Conclusion}

The separatist and jihadi attack into southern Mali was foreseeable, but little was done to thwart the offensive until it was launched in January 2013. The Malian Army fled without their weapons during the 2012 offensive, which led to jihadi control of the north. A coup in March 2012 then left the government without any U.S. support until the French intervention. Efforts to establish a United Nations peacekeeping 


\section{Operation Serval}

operation floundered amid U.S. budget concerns. The French wanted to ensure that any assistance they provided would not be perceived as neo-colonial, and it was not until the AQIM-affiliated militants pushed south in January 2013 that they decided to intervene. Maintaining political legitimacy at the strategic and tactical levels, as well as domestically, became a top French priority that shaped operations. It was also a key factor in the French success.

The French response to the crisis of January 2013 was exemplary and demonstrated how effective a relatively small but swift intervention can be. Operation Serval achieved its primary objectives: it halted the jihadi advance, assisted the government of Mali in reclaiming control over the country, killed terrorists, and secured hostages - all with a relatively small footprint. Within a few months of the intervention, the operation denied a jihadi safe haven in the north, reversed their alliance with the separatist Tuaregs, curtailed their links to the social fabric of the Ifoghas tribes, and secured the Malian capital.

While degraded, the threat of AQIM has not been eliminated. U.S. and French Special Operations Forces continue to work together in the region, training local forces and targeting the radical jihadi groups in the remote regions across North Africa. As recently as October 30, 2020, a French airstrike killed more than 50 AQIM fighters. ${ }^{91}$ The United Nations peacekeeping force, numbering more than 13,000 troops in $2020,{ }^{92}$ continues to patrol the major cities, occasionally facing attacks and suffering casualties at the hands of resilient jihadis in the region.

Moreover, despite international support, the Malian Army capitalized on popular discontent surrounding elections widely believed to be fraudulent, the resurgent Islamist insurgency, corruption, and economic disruption to overthrow the government in August 2020. ${ }^{93}$ It marked Mali's fourth coup since independence in 1960. Nonetheless, AQIM and other jihadi militants have failed to return to the level of control they achieved in 2012.

\section{Notes}

1 Iyad Ag Ghali, a prominent Tuareg leader in Mali, was the leader of the Islamist militant group Ansar Dine. In 2017, Ag Ghali merged Ansar Dine with the Saharan branch of AQIM and other Salafi-jihadi groups to form Jamaat Nusrat al-Islam wal-Muslimin.

2 Angelique Chrisafis, "France May Begin Mali Withdrawal Within Weeks," Guardian, February 6, 2013, www. theguardian.com/world/2013/feb/06/france-mali-withdrawal.

3 Adam Nossiter, "Soldiers Overthrow Mali Government in Setback for Democracy in Africa," New York Times, March 22, 2012, www.nytimes.com/2012/03/23/world/africa/mali-coup-france-calls-for-elections.html.

4 "Rebels Attack More Towns in Northern Mali," Reuters, January 18, 2012, https://news.trust.org/item/20120 118171200-juh2d/.

5 Ibid.; Christopher Chivvis, The French War on Al Qa'ida in Africa (New York: Cambridge University Press, 2016), 65.

6 “Tuareg Rebels Take Mali Garrison Town, Say Sources,” Reuters, March 11, 2012, www.reuters.com/article/ ozatp-mali-rebellion-tessalit-20120311-idAFJOE82A04U20120311.

7 “Rebels Seize Desert Capital Kidal," BBC, March 30, 2012, www.bbc.com/news/world-africa-17562066? templatestyle=one_recipe\&; "Mali Tuareg Rebels Control Timbuktu as Troops Flee," BBC, April 2, 2012, www. bbc.com/news/world-africa-17576725.

8 “Tuareg Rebels Declare Independence in Northern Mali," BBC, April 6, 2012, www.bbc.com/news/av/ world-africa-17637637.

9 Laurent Touchard, "Mali: De quelles forces disposent les jihadistes," Jeune Afrique, November 12, 2012, www.jeuneafrique.com/173468/politique/mali-de-quelles-forces-disposent-les-jihadistes/; Alain Rodier, "Mali: Point sur les forces rebelles," Cf2R, January 2013, https://cf2r.org/actualite/mali-point-sur-les-forces-rebelles/.

10 Chivvis, The French War, 67.

11 Nossiter, "Soldiers Overthrow Mali Government."

12 Ibid.

13 The Movement for Oneness and Jihad in West Africa (MUJAO) formed in 2011 as an offshoot of AQIM. In 2013, one faction of MUJAO merged with Mokhtar Belmokhtar's al-Mulathameen group to form al-Murabitoun. In 2017, al-Murabitoun would later merge with three other groups to form Jamaat Nusrat al-Islam wal-Muslimin, an al-Qaida affiliate. 
14 Chivvis, The French War, 72.

15 Ibid.

16 Grégory Chauzal and Thibault Van Damme, The Roots of Mali's Conflict: Moving Beyond the 2012 Crisis (The Hague: Clingendael, 2015).

17 Ibid.

18 Thomas Krings, "Marginalisation and Revolt Among the Tuareg in Mali and Niger," GeoJournal 36, no. 1 (1995): 57-63.

19 Chauzal and Van Damme, The Roots of Mali's Conflict.

20 "Return of Tuareg Fighters from Libya Worries Mali Authorities," France 24, November 11, 2011, https://observers.france24.com/en/20111111-mali-return-tuareg-fighters-libya-worries-mali-authorities-government-aqmiazawad-movement-.

21 Isabelle Lasserre and Thierry Oberlé, Notre Guerre Secrète (Paris: Fayard, 2013), 151.

22 Anouar Boukhars, The Paranoid Neighbor: Algeria and the Conflict in Mali (Washington, DC: Carnegie Endowment for International Peace, 2012).

23 “Faiblesse de L’Armee: Les Cinq (5) Evenements Qui Ont Conduit Le Mali Au Chaos," Bamada, March 29, 2013, http://bamada.net/faiblesse-de-larmee-les-cinq5-evenements-qui-ont-conduit-le-mali-au-chaos.

24 Morten Bøås, "Guns, Money and Prayers: AQIM's Blueprint for Securing Control of Northern Mali," CTC Sentinel 7, no. 4 (2014): 1-6; Andrew Lebovich, "The Local Face of Jihadism in Northern Mali," CTC Sentinel 6, no. 6 (2013): 4-10.

25 Leela Jacinto, "Mali’s Whisky-Drinking Rebel Turned Islamist Chief," France 24, June 12, 2012, www.france24. com/en/20120612-northern-mali-peace-dealer-or-wrecker-nine-lives-ansar-dine-chief-iyad-ag-ghali.

26 Robyn Dixon, “Al Qaeda-linked Militia Says It Killed Two French Journalists in Mali,” Los Angeles Times, November 7, 2013, www.latimes.com/world/worldnow/la-fg-wn-mali-journalists-killed-20131107-story.html.

27 Peter Hille, "West African Forces Begin Mali Mission," Deutsche Welle, January 18, 2013, www.dw.com/en/ west-african-forces-begin-mali-mission/a-16533491.

28 Boukhars, The Paranoid Neighbor.

29 Ibid.; Laurence Aida Ammour, "Algeria's Role in the Sahelian Security Crisis," Stability: International Journal of Security and Development 2, no. 2 (2013): 1-11.

30 Leela Jacinto, “Is Mali’s Captain Sanogo Losing Control of the Ship?" France 24, January 16, 2013, www.france24. com/en/20130116-mali-captain-amadou-sanogo-army-coup-power-france-intervention.

31 Co-author Michael Sheehan's experience as ASD (SO/LIC) from 2011-2013.

32 Ibid.

33 Ibid.

34 Ibid.

35 Adam Entous and Drew Hinshaw, "U.S. Sets Sights on al Qaeda in Mali," Wall Street Journal, July 26, 2012, www. wsj.com/articles/SB10000872396390444840104577551434209691426.

36 Michael R. Gordon and Eric Schmitt, "U.S. Officials Propose Sharing Drone Surveillance Data with Algerians," New York Times, February 26, 2013, www.nytimes.com/2013/02/27/world/middleeast/john-kerry-diplo matic-trip.html; co-author Michael Sheehan's experience as ASD (SO/LIC) from 2011-2013.

37 Colum Lynch, "Rice: French Plan for Mali Intervention Is 'Crap', Foreign Policy, December 11, 2012, https:// foreignpolicy.com/2012/12/11/rice-french-plan-for-mali-intervention-is-crap/.

38 "Security Council Authorizes Deployment of African-Led International Support Mission in Mali for Initial YearLong Period," United Nations, December 20, 2012. https://www.un.org/press/en/2012/sc10870.doc.htm

39 Adam Nossiter, "Mali Government Is Left Reeling After Islamists Take Village Long Held by Army," New York Times, January 10, 2013, www.nytimes.com/2013/01/11/world/africa/islamists-take-mali-village-forcing-army-intoretreat.html.

40 Nicolas Champeaux, "Le projet du chef d'AQMI pour le Mali," Radio France International, October 6, 2013, www. rfi.fr/fr/afrique/20131006-mali-vade-mecum-droukdel-mali-aqmi-terrorisme-al-qaida-sanguinaire; Jean-Christophe Notin, La guerre de la France au Mali (Paris: Tallandier, 2014), 155.

41 John Irish and Bate Felix, "Malian Army Beats Back Islamist Rebels With French Help," Reuters, January 10, 2013, www.reuters.com/article/us-mali-rebels/malian-army-beats-back-islamist-rebels-with-french-help-idUSBRE90912Q20130111.

42 Notin, La guerre de la France, 155.

43 Ségolène Allemandou, "Al Qaeda Silent on French Hostages in Mali," France 24, February 2, 2013, www.france24. com/en/20130201-france-mali-hostages-al-qaeda-threat-execution-human-shield.

44 Chivvis, The French War, 101.

45 Serge Daniel, “Mali Attacks Islamists With Foreign Help," Agence France-Presse, January 11, 2013, www.thedailystar. net/news-detail-264891?amp. 


\section{Operation Serval}

46 "US Military Sending Air Tankers to Refuel French Jets Over Mali," Associated Press, January 27, 2013, www.theguardian.com/world/2013/jan/27/us-military-tankers-french-mali.

47 Eric Schmitt, "Drones in Niger Reflect New U.S. Tack on Terrorism," New York Times, July 10, 2013, www. nytimes.com/2013/07/11/world/africa/drones-in-niger-reflect-new-us-approach-in-terror-fight.html.

48 This map comes from "French Operations in Mali: A Look Back," which is republished with the permission of Stratfor Worldview, a leading global geopolitical intelligence and advisory firm.

49 Chivvis, The French War, 99.

50 Ibid.

51 "French Pilot Killed in Mali Fighting," Deutsche Welle, January 12, 2013, www.dw.com/en/ french-pilot-killed-in-mali-fighting/a-16517183.

52 Chivvis, The French War, 100.

53 Antoine d'Evry, L'opération Serval à l'épreuve du doute: Vrais succès et fausses leçons (Paris: French Institute of International Affairs, 2015), 25-26.

54 Michael Shurkin, France's War In Mali: Lessons for an Expeditionary Army (Santa Monica: RAND, 2014), 7.

55 Ministry of Defense, French White Paper on Defence and National Security-2013 (Paris: French Ministry of Defense, 2013), 91.

56 d'Evry, L'opération Serval, 31.

57 Ibid.

58 Ibid.

59 Chivvis, The French War, 102.

60 d'Evry, L'opération Serval, 33.

61 Notin, La guerre de la France, 222.

62 Chivvis, The French War, 115.

63 Philippe Nauche, Rapport d'information de l'Assemblée (Paris: French National Assembly, 2013), 45.

64 Lydia Polgreen and Scott Sayare, "With Timbuktu Retaken, France Signals It Plans to Pull Back in Mali," New York Times, January 28, 2013, www.nytimes.com/2013/01/29/world/africa/timbuktu-mali-france-conflict.html.

65 David Lewis and Richard Valdmanis, "Mali Hails 'Savior' Hollande, He Says Fight Not Over," Reuters, February 2, 2013, www.reuters.com/article/us-mali-rebels-hollande/mali-hails-savior-hollande-he-says-fight-notover-idUSBRE91104320130202.

66 Chivvis, The French War, 137.

67 Ibid., 123.

68 "Hélios and Pléiade Trained on Mali," Intelligence Online, July 16, 2013.

69 Nauche, Rapport d'information de l'Assemblée, 61.

70 d'Evry, L'opération Serval, 33.

71 Chivvis, The French War, 131.

72 Ibid.

73 Adam Nossiter and Peter Tinti, "Mali War Shifts as Rebels Hide in High Sahara," New York Times, February 9 , 2013, www.nytimes.com/2013/02/10/world/africa/new-focus-in-mali-is-finding-militants-who-have-fled-intomountains.html; Lebovich, "The Local Face of Jihadism in Northern Mali."

74 Derek H. Flood, "A Review of the French-Led Military Campaign in Northern Mali," CTC Sentinel 6, no. 5 (2013): 5-9; Matthieu Mabin, "Exclusive Report from Jihadist Stronghold in Mali," France 24, March 7, 2013 , www.france24.com/en/20130307-exclusive-report-jihadist-stronghold-mali.

75 Drew Hinshaw and David Gauthier-Villars, "Chad Claims Killing of al Qaeda Commander," Wall Street Journal, March 1, 2013, www.wsj.com/articles/SB10001424127887324662404578333971047215246.

76 Ibid.

77 Nauche, Rapport d'information de l'Assemblée, 52-53.

78 Laurent Lagneau, "Mali: Les défis de l'après Serval," Zone Militaire, April 18, 2013, www.opex360.com/2013/04/18/ mali-les-defis-de-lapres-serval/.

79 Missy Ryan, “The U.S. Still Doesn't Know if It's Killed this Legendary One-Eyed Militant,” Washington Post, February 17, 2016, www.washingtonpost.com/news/checkpoint/wp/2016/02/17/the-u-s-government-thoughtit-had-killed-this-legendary-militant-now-its-not-so-sure/.

80 Peter Tinti, "Tacit French Support of Separatists in Mali Brings Anger, Charges of Betrayal," Christian Science Monitor, March 20, 2013, www.csmonitor.com/World/Africa/2013/0320/Tacit-French-support-of-separatistsin-Mali-brings-anger-charges-of-betrayal.

81 Nauche, Rapport d'information de l'Assemblée, 111-112.

82 "Malian Troops in First Clash with MNLA Rebels Since Truce," BBC, September 12, 2013, www.bbc.com/news/ world-africa-24058524. 
83 Michael Shurkin, "What It Means to be Expeditionary: A Look at the French Army in Africa," Joint Forces Quarterly 82, no. 3 (2016): 76-85.

84 d'Evry, L'opération Serval, 40.

85 Morten Boas, "Mali 2013: A Year of Elections and Further Challenges," E-International Relations, December 22, 2013, www.e-ir.info/2013/12/22/mali-2013-a-year-of-elections-and-further-challenges/.

86 “'Ramshackle' Mali Army Needs Training: EU Mission Chief,” Daily News Egypt, January 29, 2013, https://dailynewsegypt.com/2013/01/29/ramshackle-mali-army-needs-training-eu-mission-chief/.

87 Tiemoko Diallo, "France Vows to Strengthen Cooperation With U.N. Mission in Mali," Reuters, June 22, 2015, www.reuters.com/article/uk-mali-france/france-vows-to-strengthen-cooperation-with-u-n-mission-in-maliidUKKBNOP222A20150622.

88 Shurkin, France's War In Mali.

89 Adam Nossiter, "Rebels in North Mali Sign Peace Deal Allowing in Government Troops," New York Times, June 18, 2013, www.nytimes.com/2013/06/19/world/africa/mali-and-rebels-reach-peace-deal.html.

90 "Tuareg Rebels 'Defeat Government Army in Kidal'," BBC, May 22, 2014, www.bbc.com/news/ world-africa-27511448?SThisFB.

91 "French Airstrikes Kill Over 50 Qaeda-Linked Jihadists in Mali," The Defense Post, November 3, 2020, www.thedefensepost.com/2020/11/03/french-airstrikes-kill-jihadists-mali/.

92 "UN Renews Mali Peacekeeping Force MINUSMA Without Personnel Cuts," Al Jazeera, June 29, 2020, www. aljazeera.com/news/2020/6/29/un-renews-mali-peacekeeping-force-minusma-without-personnel-cuts.

93 "Why Mali Is in Turmoil Again," Reuters, August 18, 2020, https://uk.reuters.com/article/uk-mali-politicsprotests-factbox-idUKKCN25E1LA. 


\title{
23
}

\section{U.S. COUNTERTERRORISM POLICY IN YEMEN FROM 2010-2020}

\author{
Luke Hartig
}

In January 2009, al-Qaida's affiliates in Yemen and Saudi Arabia announced a merger and the formation of a new, more formidable group called al-Qaida in the Arabian Peninsula (AQAP). Al-Qaida's Yemen branch had been ratcheting up pressure over the previous year, with attacks on foreign tourists and the U.S. Embassy in Sanaa. But the newly merged group went further, attempting to assassinate one of the closest U.S. counterterrorism partners in Saudi Arabia and partially inspiring two terrorist shootings in the United States. Washington was thrust into action.

Shortly after taking office, the Barack Obama administration moved to lay the groundwork for counterterrorism in Yemen. The administration engaged in intense diplomacy with Yemen's leader, President Ali Abdullah Saleh, to win his unequivocal cooperation in combating the threat. U.S. officials promised extensive aid to Yemeni security forces and other support needed by the impoverished state. In December 2009, the United States reportedly launched multiple airstrikes against AQAP camps in Yemen. ${ }^{1}$ The strikes likely killed dozens of AQAP fighters but also more than three dozen civilians, according to human rights groups. ${ }^{2}$

On Christmas Day 2009, AQAP struck again when Umar Farouk Abdulmutallab attempted to destroy a commercial airliner over Detroit using an explosive device concealed in his underwear. ${ }^{3}$ The device did not detonate, but the failed attack underscored the importance of counterterrorism efforts in Yemen.

As Elisabeth Kendall has outlined earlier in this volume, there were historical and organizational reasons, as well as strong ties to al-Qaida's core organization, that allowed AQAP to become dangerous so quickly. There is no doubt that the political and human terrain also aided AQAP's incubation; the group maintained ties to local tribes and formed in the vacuum created by weak Yemeni security forces. Moreover, Yemen's leader, Saleh, had a spotty record of combating extremism and had ruled for more than 30 years by setting his opponents against one another.

By 2009, Saleh's governing strategy, which he famously called "dancing on the heads of snakes," became unsteady. Sub-national actors, particularly the northern Houthi rebels, increasingly agitated against the central government. AQAP exploited Yemen's environment-its vast ungoverned spaces, traditional role in regional smuggling routes, lingering animosity among the country's disparate regional and sectarian groups from a lengthy civil war in the 1990s, and long borders with Saudi Arabia and Oman-to create an ideal safe haven.

Although the counterterrorism community had long focused on Yemen, it was the failed Christmas Day plot in 2009 that brought the threat home to the American people and fortified the will of policymakers to aggressively combat AQAP. As the government investigated the failed attack, the wheels of U.S. 
policy were set in motion, with senior leaders convening to discuss a wide range of operations and programs the United States could undertake.

U.S. policymakers would focus on five core policy imperatives that would largely define U.S. policy in Yemen for years to come: promoting political and economic reform, developing Yemeni counterterrorism capabilities, disrupting AQAP plotting with lethal action, leveraging regional support for Yemen and counterterrorism efforts, and avoiding over-commitment.

This chapter examines the U.S. campaign against AQAP over four time periods that correspond with the key strategic phases of the conflict: dysfunctional partnership with Ali Abdullah Saleh (2010-2012), President Hadi and a new hope for Yemen (2012-2014), Yemen's unraveling (2014-2017), and a new administration and expanded U.S. military operations (2017-2020).

\section{0-2012: dysfunctional partnership with Ali Abdullah Saleh}

Between the failed Christmas Day attack in December 2009 and the overthrow of the Saleh government in February 2012, the fight against AQAP would reach a fever pitch. AQAP was at its zenith and pursued a multi-pronged strategy, seeking to establish itself as a regional jihadi leader, a top propagandist to disgruntled Muslims in the West, the head of a quasi-state in southern Yemen, and the foremost terrorist threat to the United States. The group called for a regional holy war and a blockade of the Red Sea to prevent shipments to Israel. ${ }^{5}$

AQAP capitalized on limited governance and lingering animosity about the country's predominately northern leadership in southern Yemen to establish a safe haven in the south and to increasingly administer its own territory. They released multiple editions of Inspire, a slick English-language magazine, calling for "lone wolf" attacks in the West and providing various levels of operational instruction to aspiring terrorists. ${ }^{6}$ They persisted in developing increasingly sophisticated concealed explosive devices, most notably a bomb hidden in printer ink cartridges that was intended to bring down a United Parcel Service aircraft en route to the United States in October 2010. ${ }^{7}$

American hopes for addressing the quickly growing threat were channeled through Sanaa and President Saleh, a challenging partner whose government was beset by factionalism, riddled with ties to extremist elements, and unable to provide basic services to its people. On the security side, Yemen needed assistance to build up its counterterrorism capabilities in the face of an emerging threat.

In 2011, the forces of democratization and uprisings against authoritarian governments that came to be known as the Arab Spring emerged in Yemen, leading to major protests in the streets of Sanaa and providing an opening for longstanding political opponents to move against the president. Saleh's long-time but uneasy political ally, Major General Ali Muhsin al-Ahmar, took Saleh's violent crackdowns against protesters as an opportunity to break with the president, ostensibly in support of the protesters but more likely as a way of fortifying his own power. ${ }^{8}$ By spring 2011, Saleh was bowing to the pressure mounting against him and making moves toward stepping down as president.

On June 3, a failed assassination attempt against Saleh, which he blamed on the al-Ahmar family, ${ }^{9}$ left him badly injured and forced him to seek medical treatment in Saudi Arabia. Saleh's politically weak vice president, Abdu Rabbu Mansour Hadi, assumed the presidency in an interim capacity.

During this period, U.S. counterterrorism efforts against AQAP struggled to keep pace with Yemen's political tumult. U.S. operations focused on building up Yemeni security forces and airstrikes against operatives who threatened the United States and its interests. ${ }^{10}$ One of the central priorities was establishing a comprehensive assistance program in support of Yemeni forces. ${ }^{11}$ The U.S. government reviewed and vetted Yemeni security and military units, prepared to deploy Special Operations Forces (SOF) as advisors, ${ }^{12}$ and provided a range of new equipment through the Department of Defense's Section 1206 Counterterrorism Train and Equip authority. 
There was no shortage of challenges. Yemeni forces were beset by factionalism, with different units and elements within units expressing loyalty to Saleh, Muhsin, and various other commanders, all of whom had their own unique relationships with Saleh. The most capable forces, including most of Yemen's fledgling commando units, reported to the president's son, Ahmed Saleh, commander of the Republican Guard, which had traditionally focused on regime protection. The United States would therefore likely achieve the greatest operational return by working with Ahmed, but in so doing, Washington risked empowering the forces most loyal to the Saleh family and the forces the president would most likely rely on to remain in power or suppress political opposition. ${ }^{13}$

Furthermore, Yemen's assistance needs went far beyond its commandos. The Air Force had a terrible record of aircraft maintenance and struggled to field airworthy planes and helicopters from its aging fleet. ${ }^{14}$ Border security was deficient, easing the flow of weapons and fighters into the country and the potential for AQAP to export terrorism far beyond the Arabian Peninsula. ${ }^{15}$ The army also struggled, with factionalism and political struggles undercutting effectiveness. ${ }^{16}$

The United States deployed dozens and eventually more than 100 advisors in the capital and with Yemen's Southern Regional Command. ${ }^{17}$ Washington also provided more than $\$ 200$ million of weapons and equipment to Yemeni forces during 2010-2012. ${ }^{18}$ Although Yemen desperately needed the equipment, the country's dysfunctional armed forces struggled to absorb this massive infusion of new gear. Personnel had to be trained, military leadership had to determine how to incorporate it, and U.S. officials had to push back on the tendency from some Yemeni leaders to keep the gear in pristine condition and not utilize it. The influx of U.S. advisors helped integrate the gear and new tactics into their daily operations.

Nevertheless, with Yemeni wariness of an elevated U.S. military presence and increasing U.S. policymaker concerns over the safety of its people in Yemen, the United States could never deploy enough advisors, dispersed across a wide enough area, to support the full range of forces who needed assistance. By the end of this period, as civil unrest wracked Yemen and removed Saleh from power in 2011, the United States suspended all of its security assistance programs and withdrew most of its advisors. Policymakers concluded that it was too dangerous, and it was too difficult to assess the political loyalty of partner units and whether they might be deployed against protesters or Saleh's political enemies.

At this time, the U.S. targeted killing program was still finding its footing. The U.S. government and Saleh faced significant blowback from the Yemeni public after the reports of civilian casualties from the U.S. airstrikes in December 2009. ${ }^{19}$ U.S. strikes subsequently slowed to a level that would be unlikely to inflict strategic harm on AQAP, with only a single strike against AQAP in $2010,{ }^{20}$ and that strike was reportedly another errant operation that accidentally killed a local official who was meeting with AQAP members in an attempt to negotiate and reconcile with the group. ${ }^{21}$ The Yemeni government had to take additional action to soothe the unrest. ${ }^{22}$

The United States did not conduct another strike until a year later. By the summer of 2011, with Sanaa in turmoil following the medical departure of Saleh, U.S. airstrikes surged, with 9 strikes reportedly conducted between May and September and 12 across the calendar year. Most significant was a strike that killed Anwar al-Awlaqi, AQAP's top propagandist, an increasingly powerful operative, and the first U.S. citizen reportedly targeted for lethal action in the war on terrorism. ${ }^{23}$ Another American operative, Samir Khan, who had produced AQAP's Inspire magazine, was killed alongside al-Awlaqi, ${ }^{24}$ although U.S. officials said he was not intentionally targeted. ${ }^{25}$

\section{2-2014: President Hadi and a new hope for Yemen}

As 2011 drew to a close, a new hope slowly emerged in the form of the acting president, Abd Rabbu Mansour Hadi. A military officer by training, Hadi had been chosen as Saleh's vice president in 1994 for 
two primary reasons: he was a southerner who could theoretically help Saleh claim he was committed to inclusively governing all of Yemen after the civil war, and he would pose no political challenge to Saleh. ${ }^{26}$

In his many years in Sanaa, Hadi had never developed a strong political base of his own. After years of living outside the south and a checkered history of support for southern causes, his ties to southern elites were weak. He quickly grew popular, however, despite his low profile and years of working with Saleh. Many viewed Hadi as a seemingly honorable man with limited ties to the elites who had controlled and exploited Yemen. ${ }^{27}$ Some thought Hadi could bring about change without plunging Yemen into further instability.

With Saleh sidelined from his injuries, and with Yemeni elites uniting to call for Saleh's ouster, Hadi quickly emerged as the best-or the least objectionable — candidate. The Gulf Cooperation Council, a political and economic union comprising Yemen's Arab Gulf neighbors, had become active in Yemen and brokered a deal in which Saleh would formally relinquish power after the 2012 elections and Hadi would be the sole candidate for the presidency to lead Yemen during a two-year transition period. The council committed to helping Hadi, financially and otherwise, through this period and structured a set of political reforms and assistance commitments designed to put Yemen on stronger footing and prepare for open elections in $2014 .^{28}$

As Yemen began to stabilize, however, AQAP continued to grow. AQAP likely saw an opportunity with the Yemeni government focused elsewhere and a small footprint of U.S. trainers and advisors. Throughout spring and summer of 2012, the group seized terrain in southern Yemen. In April 2012, reports emerged that another attempted bombing of an airliner using a concealed explosive device had been thwarted. ${ }^{29}$

Given Yemen's political reform and AQAP's resurgence, the United States made a new commitment to Yemen. Washington would strongly support Hadi, roll back AQAP, and develop a stable and capable partner in a troubled region. To achieve these aims, the top near-term priority was developing a comprehensive assistance program involving security, diplomatic, economic, and humanitarian aid to support the Hadi government and develop weak state institutions.

The United States resumed a comprehensive security assistance program that included a range of activities, from restarting counterterrorism capacity-building to supporting the restructuring of the Yemeni security sector. ${ }^{30}$ SOF returned, ${ }^{31}$ and the U.S. government proposed more than $\$ 37$ million in military aid to augment Yemen's airlift capacity and to equip Yemen's SOF and the Interior Ministry's counterterrorism unit. ${ }^{32}$

Resuming assistance, however, was not as straightforward as the U.S. government might have hoped. Yemen's Ministry of Defense remained deeply dysfunctional, plagued by mismanagement, and factionalized into two enduring camps-Saleh and Ali Muhsin loyalists. Many of the structural reforms proposed would require substantial and long-term commitment. De-factionalizing the ministry by removing Saleh and Muhsin loyalists presented substantial political risk to Hadi, who already lacked support from Yemen's elites and could scarcely afford to alienate Yemen's strong and well-armed political entities.

The Yemeni military had also become a political patronage machine, the dismantling of which presented additional challenges. Most notable were the thousands of Yemeni "ghost soldiers" who received payments despite not serving in the Yemeni military. ${ }^{33}$ Culling the ghost soldiers was critical to improving the ministry's finances but would likely provoke blowback from those losing the payments and their political patrons.

Re-engaging counterterrorism forces also had its challenges. Yemen's civil unrest had altered some of the partners with whom the United States had previously worked. The first task for U.S. advisors was to evaluate the new landscape and assess with whom they could actually work. A bigger challenge, however, was the reduced ability of the U.S. mission in Yemen to accommodate large numbers of personnel. During the 2011 civil unrest, the U.S. mission had consolidated personnel at the former Sheraton hotel to mitigate risk. ${ }^{34}$ 
In September 2012, just two days after the terrorist attack in Benghazi, Libya, protests in Sanaa ostensibly over the Innocence of Muslims film culminated in protesters storming the U.S. Embassy, burning vehicles, and vandalizing the compound. ${ }^{35}$ With the increased danger in Sanaa and a heavy focus from senior U.S. officials on embassy security everywhere in the region after Benghazi, the U.S. mission in Sanaa tightened its security and controlled its personnel levels even more. Each personnel increase was carefully scrutinized. Although the number of military advisors eventually returned to higher levels, late 2011 through most of 2013 were essentially lost years in terms of building Yemeni security capacity.

Nevertheless, the Yemeni military presented some hope. Although the organization was heavily focused on its own internal reforms, it began to take decisive action against AQAP in the south. In concert with southern tribal militias, the military conducted a campaign in 2012 that eventually wrested away AQAP territories and led to major battlefield losses for the group. ${ }^{36}$ It was a huge victory for Washington's Yemeni allies, and U.S. policymakers held out hope that a similar level of military action and local engagement could root AQAP out from its other strongholds.

Yemeni military efforts were complemented by an increase in U.S. airstrikes. The United States executed 56 strikes in 2012 - nearly five times the 2011 total-many of them against AQAP targets in its southern safe haven. ${ }^{37}$ Strikes continued apace in early 2013, reportedly killing the group's top deputy, a former Guantanamo Bay detainee named Said al-Shihri. ${ }^{38}$

Learning from its 2012 losses, AQAP no longer sought to control territory, and instead it regrouped in traditional tribal safe havens and sparsely populated areas. On the rare occasions that the Yemeni military confronted them in these locations, AQAP fought back with refined guerrilla tactics. The group conducted hit-and-run strikes against military bases, carried out an increasing number of terrorist attacks in Sanaa, and then blended back into the population. ${ }^{39}$

AQAP's renewed strength was matched by an elevated role within the global al-Qaida organization. In mid-2013, al-Qaida leader Ayman al-Zawahiri named AQAP amir Nasir al-Wuhayshi the deputy for al-Qaida's worldwide operations. In late July 2013, the U.S. government announced that due to a threat emanating from the Arabian Peninsula, the U.S. presence in Sanaa would be reduced and embassies would be temporarily closed in more than 20 countries. ${ }^{40}$ The losses AQAP had sustained in 2012 appeared to have been recouped. Beyond its own organizational and tactical adaptations, AQAP also seemed to have benefited from a decline in Yemeni military operations after the 2012 campaign, as well as a decline in U.S. airstrikes.

In May 2013, President Obama delivered a speech laying out a new framework that elevated the required standards that must be met before lethal action could be taken against terrorist targets outside areas of active hostilities. ${ }^{41}$ During its first term, the Obama administration grappled with the use of targeted strikes and drone aircraft, and the president believed it was important to establish a set of rules and principles that would address the range of legal and policy issues associated with these operations.

Obama wanted to put the program on a sustainable long-term footing, underpinned by U.S. values and with an eye toward reinforcing and setting new international norms with respect to using force against terrorist targets outside of active warzones. His Presidential Policy Guidance prescribed a detailed interagency process for reviewing proposals for lethal action and directed that lethal force only be used against targets that posed a "continuing, imminent threat to U.S. persons." Strikes were further restricted so that they could only be conducted when capture was assessed to be infeasible and if the relevant operational commander could assess with "near certainty" that civilians would not be harmed in the action. ${ }^{42}$ In practical terms, this meant that U.S. strikes could not be used to provide air support to Yemeni security forces or to attack AQAP elements that were not involved in active plotting against the embassy, the homeland, or other targets where U.S. persons would be present.

Whether due to the new elevated standards, AQAP's improved ability to detect and evade U.S. drones, or other reasons, strikes plummeted following the release of the policy guidance. Yet even the new targeting 
rules could not prevent tragedy. In December 2013, a strike was widely reported to have hit a wedding convoy. ${ }^{43}$ Bound by continued secrecy about specific strikes in Yemen, the U.S. government declined to officially acknowledge or comment on the strike, let alone refute the media accounts. ${ }^{44}$ As the Yemeni population and human rights groups reacted in outrage, the Presidential Policy Guidance reforms did not appear to have eliminated the risk of civilian casualties nor quelled the controversy surrounding the drone program in Yemen.

\section{4-2017: Yemen's unraveling}

By late 2013, it was clear that Yemen's political transition was not progressing according to plan. The twoyear transition period and the National Dialogue Conference, the forum designed to solve the country's political problems during the transition period, were far behind schedule, with major decisions about Yemen's constitutional structure, geographic governance, resource sharing, and economic system unresolved. Gulf economic, security, and technical assistance had not come through as planned, and while Hadi remained popular, the Yemeni population had begun to grow impatient.

During a trip to the United States in 2013, Hadi requested additional aid, and U.S. officials scrambled to increase Washington's support and mobilize international partners. ${ }^{45}$ Hadi leaned into the domestic political work on the transition, moving to quickly but haphazardly conclude the National Dialogue Conference in early 2014, and developed ambitious proposals for Yemen's future government. ${ }^{46}$ Lisa Monaco, Obama's counterterrorism advisor and point person on Yemen, traveled to Yemen and Saudi Arabia in early 2014 to underscore strong U.S. support for the Hadi government and to rebuild momentum around the Gulf Cooperation Council transition. ${ }^{47}$

The troubled transition had begun to alienate two of Yemen's traditionally marginalized groups—southerners and the Houthis - who felt that they had been inadequately represented in the National Dialogue Conference and the structures that would emerge from it. In February 2014, Hadi declared a new federal system for Yemen that organized the country into six regions. ${ }^{48}$ The Houthis objected vociferously that commitments made within the National Dialogue Conference had not been upheld and that they had been placed in a region that was attached to Sanaa and isolated from the Red Sea, virtually ensuring that they would have little autonomy. ${ }^{49}$

Saudi Arabia had also become increasingly antagonistic toward the Houthis, which it viewed as an Iranian-backed threat along its southern border. Yet the history of the Houthis and their relationship with Iran was more complicated than Riyadh alleged. The Houthis followed the Zaydi sect of Shia Islam, which has been described as more closely aligned with the brand of Sunni Islam practiced in Yemen than the Shia Islam practiced in Tehran.

Throughout Yemen's history, Zaydi Muslims have lived largely peacefully alongside their Sunni neighbors in northern Yemen. But spiraling confrontations between Saleh, who benefited from divisions in the country, and an emboldened Houthi movement resulted in multiple wars. The Houthis, perhaps in response to Riyadh's provocations and possibly looking to carve out a mutually advantageous relationship with Iranian government elements that saw opportunity in Yemen, launched rockets into Saudi Arabia and escalated tensions further. In March 2014, the Saudis declared the Houthis a terrorist organization. ${ }^{50}$

While political progress slowed, U.S. counterterrorism programming continued apace. Defense and State Department officials agreed on more than $\$ 69$ million of security assistance in 2014 to provide Yemen with enhanced aerial surveillance and precision strike capabilities. ${ }^{51}$ After the drawdown precipitated by the threat in the summer of 2013, U.S. advisors finally returned and reached personnel levels not seen since before the 2011 protests. Moreover, for the first time in two years, the Yemeni military launched a major offensive against AQAP positions, this time in the rugged al-Mahfid region of Abyan and Shabwa. ${ }^{52}$ 
Reports emerged of U.S. strikes against AQAP training camps, and Yemeni forces moved in shortly thereafter. ${ }^{53}$ The offensive proved far more difficult than the 2012 campaign. AQAP had refined its guerrilla tactics, the terrain was more hospitable to an entrenched insurgency, the local population was far less supportive of the Yemeni Army than the southern tribes had been, and there was no U.S. air support beyond the initial strikes.

Yet the mere fact that Yemeni forces engaged in operations against AQAP outside of Sanaa or Aden was significant and a testament to Hadi's willingness to prioritize counterterrorism even while facing so many other challenges. The United States also continued to conduct drone strikes against AQAP targets, although at a lower pace than before, a total of 17 strikes in 2014 killing 110 combatants and 10 civilians. ${ }^{54}$

Unfortunately, the counterterrorism gains could not conceal the slow-motion disaster developing on the political and economic fronts. The Houthis and southerners continued to simmer in resentment over the political process, and Hadi faced increased pressure from the international community over the crippling structural problems in the Yemeni economy. Clashes between Houthis and Salafis around the Dhammaj area had exacerbated Houthi anger. Yemen's Gulf allies were increasingly focused on the rise of the Islamic State in Iraq and Syria and the intensifying sectarian conflicts with Iran, distracting them from the aid and tremendous work still needed in Yemen.

The World Bank and the International Monetary Fund approved substantial assistance packages, but only if Hadi agreed to implement several economic reforms, the most important of which-an end to fuel subsidies - would ultimately precipitate Hadi's fall. Hadi was eventually convinced and formally ended the subsidies in July 2014. Protests broke out, and demonstrators streamed into the streets of Sanaa, and in some cases armed Houthi youth exploited them. ${ }^{55}$

Hadi was taken aback by the speed and intensity of the outrage, and he quickly moved to tamp down on the discord, reinstate the subsidies, and address the simmering political grievances. ${ }^{56}$ But it was too late. Seeing their opportunity, the Houthis cited Yemeni security force actions to disperse the protesters in early September as a pretense to send armed rebels to Sanaa.

Sanaa had long prepared for a Houthi move on the capital and protected the city with an armored brigade stationed in Amran, just north of Sanaa. ${ }^{57}$ The Houthis clashed with the brigade through the summer of 2014, eventually defeating the unit and killing its commander. Rumors swirled that elements within the Sanaa government or Saleh himself might have allowed for the unit's defeat. ${ }^{58}$ Many of the other reinforcements that Hadi might have called upon remained deployed against AQAP in the eastern part of the country.

The Houthis did not take over Yemen all at once. Their forces were ostensibly present in Sanaa to protect their people from Yemeni government aggression. In the weeks and months that followed, however, they were increasingly emboldened by the lack of concerted resistance and the ease with which they took over Yemen's streets, then its security institutions, and finally the country's national leadership.

The Houthi alliance with Saleh was unexpected as well. Saleh had waged multiple wars against the Houthis during his time in office, but Houthi leadership saw an opportunity in Saleh's overture and were willing to use him to advance their own political gains. Houthi forces, however, killed former President Saleh when he proved no longer useful or trustworthy in December 2017.

The United States scrambled to resolve the crisis. Obama again dispatched Monaco to Yemen and Saudi Arabia in September amid growing Houthi protests, and a United Nations-led process was formed to address the tensions, which would evolve into the United Nations-led political process supported by successive U.S. administrations. ${ }^{59}$ Nevertheless, political resolution proved elusive, and Hadi appeared to be facing a slow-motion coup.

As Hadi's hold on Sanaa weakened, the United States also conducted its first ground operation in Yemen, staging a hostage rescue in the remote deserts of Hadramawt to free American photojournalist Luke Somers. Concern for Somers had grown, particularly after the murders of U.S. hostages in Syria in 
2014. When an opportunity to rescue him materialized, U.S. forces quickly proposed an operation, which Obama approved.

The operation was executed nearly flawlessly, and several hostages held by AQAP were freed, but Somers was not present at the raid site. On December 4, about a week after the initial rescue attempt, AQAP released a video castigating the United States for the failed rescue and threatening to kill Somers if unspecified demands were not met. Facing the threat on Somers' life, U.S. forces developed a new fix on Somers' position and staged another rescue. This time, the operational conditions were more complicated. During the rescue, a firefight erupted, and AQAP captors shot and killed Somers and a South African hostage, Pierre Korkie. ${ }^{60}$

AQAP had failed to secure a ransom or any other concession from the United States or South Africa, but in producing a high-profile drama over the hostages' lives and ultimately murdering them in the face of a U.S. rescue attempt, AQAP had acquired some of the attention and notoriety that the Islamic State had developed with its execution of U.S. hostages several months prior. The possibility of future hostage scenarios and the dangers of trying to free them would remain central to U.S. policymaking and future considerations of in-country programming.

As the political crisis raged, U.S. counterterrorism efforts flagged. Sanaa became increasingly dangerous, with loosely controlled Houthi militants roaming the streets and manning checkpoints and in at least one case firing on a U.S. Embassy vehicle. ${ }^{61}$ Anti-U.S. Houthi rhetoric became increasingly pitched. ${ }^{62}$ Many of Yemen's elite counterterrorism units had come under Houthi influence ${ }^{63}$ or were desperately defending themselves against the Houthis. At the same time, the Houthis actively fought AQAP fighters in key contested areas outside of the capital. ${ }^{64}$

Throughout the fall of 2014, the United States reduced the number of personnel in Yemen out of a concern that the unrest could boil over into a mob siege on U.S. facilities, a violent mishap at a checkpoint, or an intentional Houthi assault on U.S. personnel. With most of the U.S. military's partner organizations in Yemen in crisis, there was little upside to keeping a substantial advisory presence.

In February 2015, the Houthis stormed Hadi's presidential palace, placed him under house arrest, and coerced his resignation (he rescinded his resignation upon later escaping the capital). ${ }^{65}$ Combined with the increasing danger on the streets of Sanaa, U.S. policymakers determined that the risk of maintaining a diplomatic presence in Sanaa outweighed any possible upside, and the United States evacuated all of its personnel from Sanaa in February $2015^{66}$ and all remaining personnel in March. ${ }^{67}$

Saudi and Emirati bombing ramped up within weeks, and it soon became clear that the Saudi war in Yemen was destined to become a quagmire that would lead to a humanitarian crisis for the Yemeni people. AQAP took advantage of the crisis to strengthen its own position. In a return to playbooks from earlier eras, AQAP again seized territory, this time in Hadramawt Governorate. The group established a stronghold in Mukallah in 2015, freeing an estimated 300 fighters ${ }^{68}$ from the local prison and pilfering an estimated $\$ 60$ million or more from the Central Bank in the process. ${ }^{69}$

The new AQAP governance of territory renewed longstanding concerns about geographic safe havens and suggested that it was following the Islamic State's lead by using territory to generate revenue, attract fighters, and plan operations. Islamic State elements also began to emerge in Yemen, presenting a threat to AQAP's monopoly and creating worries of a broader territorial safe haven.

With Yemen under siege from forces internal and external, and with the Saudi bombing campaign proving less discriminate than might have been anticipated given the substantial U.S. aid to Riyadh over the decades, there were certainly pitfalls to continuing with U.S. airstrikes against AQAP. Without a strong partner on the ground, however, the United States had virtually no other alternative.

In the nearly two-year period from the U.S. evacuation in February 2015 to the end of the Obama administration in January 2017, the U.S. government conducted 65 strikes in Yemen. The 43 strikes conducted in 2016 were more than in any year since 2012. ${ }^{70}$ They killed several top AQAP leaders-including 
its amir, Nasir al-Wuhayshi ${ }^{71}$ its religious chief, Ibrahim al-Rubaysh; ${ }^{72}$ and the head of its operations in the south, Jalal al-Balaidi. ${ }^{73}$

Over time, the Obama administration seemed to realize that lethal strikes alone would be insufficient to roll back AQAP's gains. The Saudis remained beset by the challenges of the war against the Houthis, but the United States demonstrated confidence in Emirati forces to take the fight to AQAP. Building on years of cooperation, the United States supported Emirati SOF in launching a campaign against AQAP, focusing on Mukallah, the strategically located capital of Yemen's restive Hadramawt Governorate. ${ }^{74}$

In April 2016, the United States conducted a strike on an AQAP training camp near Mukallah that killed dozens of fighters. Emirati and Yemeni forces-backed by U.S. personnel nearby and supported by Emirati fighter jets overhead-entered Mukallah, killed dozens of enemy fighters, and returned the city and the coastal Hadramawt area to the control of the Hadi government. ${ }^{75}$

Emboldened by their victory, the Emiratis proposed taking additional actions in other parts of the country. By the end of the Obama administration, the Pentagon was preparing options to provide the Emiratis further support in the form of additional military advisors and expanded operational assistance. In other parts of the country, the Saudi-Houthi conflict continued to rage, with the Houthis seemingly empowered with Iranian military materiel and the Saudis increasingly frustrated by the limits of its imprecise air war.

\section{7-2020: a new administration and expanded U.S. military operations}

Little changed on the ground in Yemen with the transition to the Donald Trump administration, but signs of shifts toward a more aggressive U.S. policy emerged almost immediately. Within a week of taking office, the Trump administration authorized a joint U.S.-Emirati ground raid to seize intelligence from an AQAP compound in Yemen. The raid was part of a broader U.S. Central Command plan to increase combined operations with Emirati SOF, both to enable Emirati counterterrorism action and to supplement intelligence collection that had been depleted since the Houthi takeover.

The operation resulted in the deaths of a U.S. Navy SEAL and a dozen or more civilians. ${ }^{76}$ Chief Petty Officer Ryan Owens was the first U.S. service member killed in Yemen in the campaign against AQAP, and although his death marked the beginning of several SOF mishaps that the Trump administration faced during its first several months, the administration was undaunted, and additional ground raids were authorized in subsequent months. ${ }^{77}$

Central Command conducted a surge of more than 80 strikes from February-April 2017 to "degrade the group's ability to coordinate external terror attack operations and limit their ability to hold territory seized from the legitimate government of Yemen and use it as a safe haven for terror plotting." ${ }^{78}$ Following Trump's decision to rescind the Obama drone strike policy and replace it with loosened targeting standards, drone strikes surged yet again, targeting both AQAP and Islamic State elements operating in Yemen. By year's end, the Pentagon reported in excess of 120 airstrikes in Yemen, more than double the number from 2012, the previous high-water mark. ${ }^{79}$

These moves deepened cooperation with partners, and more aggressive actions carried substantial pitfalls. In June, details emerged about what deepened cooperation with the Emiratis entailed. News reports outlined extensive torture of suspected terrorist detainees at Emirati-run facilities in Yemen ${ }^{80}$ Reports suggested that the U.S. military had at least some awareness of the Emirati abuses, and Congressional oversight committees called for investigations to understand the extent of U.S. knowledge or involvement. ${ }^{81}$

The Pentagon disputed reports and suggestions that U.S. forces were aware of the abuses committed by its partners, but the accounts resonated in the region and reinforced popular views of the United States being complicit. The Trump administration's warming relations with Riyadh and unwillingness to criticize the Saudi record in Yemen or its human rights record more broadly only reinforced the narrative against the United States. 
With the war in Yemen dragging into its seventh year and the humanitarian crisis worsening by the day, the U.S. government faced greater pressure than ever to lean on its Saudi and Emirati allies to end the war.

As of late 2020, the war in Yemen was estimated to have killed nearly a quarter of a million people, including more than 3,000 children, through a mix of direct violence and the indirect consequences of the war, according to United Nations assessments. ${ }^{82}$ The war has displaced 3.6 million more. The International Committee of the Red Cross considered Yemen the "world's single largest humanitarian crisis," with over 24 million people - out of a total population of 27 million — in need of aid. ${ }^{83}$

The United Nations Development Program completed a study in late 2019 noting that $75 \%$ of Yemenis were already living below the poverty line and assessing that Yemen was on track to become the poorest country in the world. To date, however, a political resolution to the conflict has proven elusive.

Yet amid all of the violence in the Yemeni civil war, U.S. counterterrorism operations have declined. A U.S. drone strike in late 2017 killed master bombmaker Ibrahim al-Asiri, a major victory that likely reduced AQAP's external attack capabilities and a capstone to a year of elevated strikes ${ }^{84}$ But strikes would slow in the years that followed. Throughout 2019-2020, U.S. strikes averaged fewer than one per month ${ }^{85}$ (although one of those killed AQAP's leader, Qasim al-Rimi). ${ }^{86}$

It is unclear whether the reduced pace of operations was due to a greatly weakened terrorist threat, declining U.S. capabilities, or more nefarious efforts carried out by the Emiratis. ${ }^{87}$ U.S. officials continued to warn of the potential for a terrorist safe haven in Yemen, given its history and high state of unrest, but amid the broader war and humanitarian crisis in Yemen, counterterrorism had become something of an afterthought. ${ }^{88}$

\section{What went wrong?}

Although the United States has successfully prevented AQAP from conducting a major attack against the United States or its allies, its counterterrorism-focused effort in Yemen has been eclipsed by a civil war that has inflicted immense human carnage on the country. The conflict has pushed the Houthis further into the arms of Iran, with financial and military support flowing into the country and threatening prospects for future stability.

America's reputation in the country and the region has been sullied by the Saudi-led bombing campaign, complicating U.S. involvement in post-conflict Yemen and aiding terrorist elements that might seek to capitalize on anti-U.S. sentiment for recruitment and radicalization purposes. The partners that the United States attempted to build within the Yemeni security forces are largely gone- disbanded, killed, or otherwise neutralized during the current conflict. The failure of U.S. policy in Yemen was not the result of any one action but many small missteps that aggregated into a catastrophe. Several key factors merit further examination.

\section{Political reform}

Since 2009, even while combating AQAP, the United States struggled to promote Yemen's long-overdue political, economic, and institutional reform agenda without destabilizing the central government in the process. Implementing such reforms was essential to long-term success in Yemen, and the failure to do so was ultimately the root of the country's undoing. Political and economic reform, however, must always be handled carefully, and Hadi and his international allies may have moved too quickly. At the same time, Hadi's inability to build a national consensus and address Houthi grievances through the National Dialogue Conference provoked their ire, and although the Houthis bear much of the blame for Yemen's collapse, Hadi's bungling of the political process only hastened their aggression.

More broadly, the United States and its international partners largely failed to provide Hadi the development and governance aid he needed. Although such support would not have directly solved Hadi's political 
problems with Yemen's elites, it might have allowed him to show progress and tout his goodwill with the international community to sustain what political progress he made. Yet several of the international pledges of commitment to Yemen as part of the 2012 transition agreement never materialized, and the international push for dramatic economic reforms went too far. When Hadi rolled back the fuel subsidies, the Yemeni streets reacted in outrage, and the Houthis saw their opening.

\section{Counterterrorism capacity building}

Ambitious U.S. capacity-building efforts fared better than political and economic reform efforts, but they also largely failed to meet Yemen's needs. The United States focused on sustainably developing Yemeni counterterrorism capacity without also enabling corrupt or abusive elements within Yemen's security services. But the problem was not one of focus or resources.

The fundamental problem with the capacity building program came down to Yemen's political instability and the difficult security environment. Sensitivity to risk was always at the forefront of policymakers' minds, but it was amplified after Yemen's 2011 political upheaval and the 2012 attack on U.S. personnel in Benghazi. Trainers constantly left; each time they returned, they had to reorient themselves to their Yemeni partners and recalibrate programming. The Yemeni security sector needed a decade-plus uninterrupted commitment. For political and security reasons, the United States was never able to provide that.

\section{Use of force}

If there is one area where the U.S. counterterrorism campaign in Yemen had greater success, it was through the direct action program. The fact that AQAP has been unable to execute a major attack on the West since 2009 is partially a testament to regional security collaboration, particularly with the Saudis. ${ }^{89}$ Credit must also be given to the role of U.S. airstrikes in removing AQAP's most dangerous and security conscious operatives, men who would have never been killed by the blunt, slow-moving Yemeni military. The death of the elusive master bombmaker Ibrahim al-Asiri in a U.S. airstrike in 2017 is a testament to the effectiveness of the U.S. drone program in Yemen in removing top leaders. ${ }^{90}$

This is not to suggest that U.S. operations were perfectly executed or always strategic. U.S. strike operations seemed to ebb and flow over time, with spurts of strikes followed by long periods without strikes. Sometimes the strikes seemed focused on removing top leadership, while at other times they were more targeted at lower-level fighters or combatants in training. Other times they were used in advance of Yemeni or Emirati military offensives, yet the United States did not provide the kind of sustained air support to ground operations that has proved decisive in supporting partner forces in other theaters, including Libya.

The United States conducted its campaign with increasing precision and discrimination, yet they could not prevent all civilian casualties, and the strikes grew increasingly unpopular. The inability to address Yemeni concerns or provide a transparent accounting of U.S. actions was a failure of policy. Minimal U.S. transparency and candor in response to persistent allegations of civilian casualties fueled popular outrage. The United States may have decreased drone strikes in recent years, but U.S. support to Saudi and Emirati operations in the civil war continues to fuel popular rage against the United States.

\section{Avoiding overcommitment}

Throughout the campaign, policymakers wanted to avoid committing the U.S. military to a third major ground war that would stretch its resources and which the American public would scarcely tolerate, so they relied on small groups of trainers and advisors combined with targeted airstrikes. U.S. officials touted the new approach as a small footprint and carefully scoped method of addressing terrorist threats. 
With a limited commitment, however, the United States never developed the level of infrastructure or range of programming to allow for a sustained, comprehensive, and multi-agency approach to counterterrorism. By the end of the Obama administration, Yemen had plunged deep into civil war with no clear end in sight and a decade or more of reconstruction ahead. Trump faced the same conundrum as Obama: small-footprint approaches to counterterrorism are preferable on a number of levels, but they leave the United States consistently frustrated in its inability to fully execute its objectives.

\section{Regional dynamics}

Throughout the campaign, the United States sought to leverage regional cooperation to support the Yemeni government and combat AQAP while preventing the Gulf states from turning Yemen into a sectarian battlefield over concerns about the Houthis. Yemen's undoing reflects a failure on this front. With the signing of the 2012 Gulf Cooperation Council transition agreement, the council partners all agreed to provide political, economic, or security assistance to the Hadi government. Most of those commitments were only partially or not at all realized.

Then there was the Saudi role in fanning the tensions that would consume Yemen. Saudi Arabia's antagonistic actions toward the Houthis, including designating them as a terrorist group in early 2014, exacerbated longstanding tensions between Saudi Arabia and the rebel group on its southwestern border. To the Saudis, the Houthis were another extension of Shia Iran's tentacles throughout the region-a tenuous proposition before 2015-but Saudi antagonism toward the group may have actually made this a selffulfilling prophecy.

Furthermore, it is not clear that the Saudis did everything they could to marginalize Saleh. The former president spent substantial time in the kingdom following his removal from office, and the Saudis could have potentially done more to convince or coerce him to stay out of Yemeni politics.

\section{Conclusion}

As the Yemen war stretches on, Saudi Arabia's deficiencies have been laid bare. Its political calculations in the run-up to the war were off base; its military, one of the best equipped in the region, has failed to execute even basic operations well; and its military and political leaders have shown little regard for the human consequences of the war.

With the horror of the Yemeni civil war stretching beyond six years and terrorist elements in the country remaining a concern to the United States, U.S. policymakers are in for a tough road ahead. Learning from the past decade is essential if the United States wants to bring about stability on the southern tip of the Arabian Peninsula and keep the American people safe.

\section{Notes}

1 Sudarsan Raghavan, "Yemen Asserts 34 Rebels Killed in Raid on Qaeda," Washington Post, December 18, 2009, http://archive.boston.com/news/world/middleeast/articles/2009/12/18/yemen_asserts_34_rebels_killed_in_ raid_on_qaeda/; “Al-Qaida Fighters Killed in Yemen Air Strikes,” Guardian, December 24, 2009, www.theguardian.com/world/2009/dec/24/yemen-strike-al-qaida.

2 Human Rights Watch, Between a Drone and Al-Qaeda: The Civilian Cost of U.S. Targeted Killings in Yemen (New York: Human Rights Watch, 2013).

3 Eric Schmitt and Eric Lipton, “Officials Point to Suspect's Claims of Qaeda Ties in Yemen,” New York Times, December 26, 2009, www.nytimes.com/2009/12/27/us/27terror.html.

4 "Newsmaker: Yemen's Salah, 'Dancing on the Heads of Snakes', Reuters, September 23, 2011, www.reuters.com/ article/us-yemen-saleh/newsmaker-yemens-saleh-dancing-on-the-heads-of-snakes-idUSTRE78M20X20110923.

5 "Yemen: Qaeda Affiliate Urges Joint Blockade of Red Sea," New York Times, February 9, 2010, www.nytimes. com/2010/02/09/world/middleeast/09briefs-Yemen.html. 
6 Marc Ambinder, “Al Qaeda’s First English Language Magazine Is Here,” Atlantic, June 30, 2010, www.theatlantic. com/international/archive/2010/06/al-qaedas-first-english-language-magazine-is-here/59006/.

7 Peter Finn, "U.S. Official Says 2 Package Bombs Were Intended to Detonate 'in Flight'," Washington Post, November 1, 2010, www.sfgate.com/news/article/Package-bombs-designed-to-detonate-in-flight-3168123.php.

8 “Top Army Commanders Defect in Yemen," Al Jazeera, March 21, 2011, www.aljazeera.com/news/2011/3/21/ top-army-commanders-defect-in-yemen.

9 Sarah Phillips, "Who Tried to Kill Ali Abdullah Saleh?” Foreign Policy, June 13, 2011, https://foreignpolicy. com/2011/06/13/who-tried-to-kill-ali-abdullah-saleh/.

10 Barack Obama, Presidential Letter-2012 War Powers Resolution 6-Month Report (Washington, DC: White House, 2012); Jane Ferguson, "U.S. Military Picks, Trains Yemeni Fighters," CNN, July 14, 2010, www.cnn.com/2010/ WORLD/meast/07/13/yemen.training/index.html.

11 “Gates Backs Big Boost in U.S. Military Aid to Yemen," Reuters, February 22, 2010, https://fr.reuters.com/article/ idUSN22208742.

12 Lolita Baldor, "U.S. Training in Yemen Reflects Wider Quest," Associated Press, September 8, 2010, www.nbcnews. com/id/wbna39062472.

13 Lucas Winter, “The Adaptive Transformation of Yemen's Republican Guard,” Small Wars Journal, March 7, 2017, https://smallwarsjournal.com/jrnl/art/the-adaptive-transformation-of-yemen's-republican-guard. Winter provides an excellent account of the origins and evolution of the Republican Guard, including in the Houthi era.

14 Robert Beckhusen, "The Yemeni Air Force Probably No Longer Exists," War is Boring (blog), March 27, 2015, https://medium.com/war-is-boring/the-yemeni-air-force-probably-no-longer-exists-49f838928670; "Yemen Air Force," Global Security, accessed December 9, 2020, www.globalsecurity.org/military/world/yemen/airforce.htm.

15 Robert F. Worth, "Saudi Border With Yemen Is Still Inviting for Al Qaeda," New York Times, October 26, 2010, www.nytimes.com/2010/10/27/world/middleeast/27saudi.html.

16 Winter, "The Adaptive Transformation of Yemen's Republican Guard."

17 Brian Dodwell and Marielle Ness, "A View From the CT Foxhole: An Interview with Captain Robert A. Newson, Military Fellow, Council on Foreign Relations," CTC Sentinel 8, no. 2 (2015): 1-4.

18 Comprehensive accounting of U.S. security assistance to Yemen is provided at Security Assistance Monitor: https:// securityassistance.org/data/program/military/Yemen/2009/2018/all/Global/.

19 Khaled Abdullah, "Drones Spur Yemenis' Distrust of Government and U.S.," Reuters, October 27, 2010, www.reuters.com/article/us-yemen-usa-qaeda/drones-spur-yemenis-distrust-of-government-and-u-s-idUSTRE69Q36520101027.

20 Peter Bergen et al., "In Depth: America's Counterterrorism Wars," New America, no date. For all discussion of airstrikes and other counterterrorism operations, this chapter relies on either specific media reporting or New America's compilation and analysis of reporting on operations against AQAP.

21 Abdullah, "Drones Spur Yemenis' Distrust."

22 “Air Raid Kills Yemeni Mediator,” Al Jazeera, May 25, 2010, www.aljazeera.com/news/2010/5/25/airraid-kills-yemeni-mediator.

23 Mark Mazzetti, Eric Schmitt, and Robert F. Worth, “Two-Year Manhunt Led to Killing of Awlaki in Yemen,” New York Times, September 30, 2011, www.nytimes.com/2011/10/01/world/middleeast/anwar-al-awlaki-is-killed-inyemen.html.

24 Robbie Brown and Kim Severson, "2nd American in Strike Waged Qaeda Media War," New York Times, September 30, 2011, www.nytimes.com/2011/10/01/world/middleeast/samir-khan-killed-by-drone-spun-out-of-theamerican-middle-class.html.

25 In May 2013, the United States publicly acknowledged its responsibility for killing al-Awlaqi and Khan, along with al-Awlaqi's son and one other U.S. citizen.

26 "Saleh's Successor: Low-Profile Warrior of Consensus in Yemen," Agence France-Presse, February $19,2012$.

27 Peter Salisbury, "Yemen's Quiet President," Al Jazeera, March 2, 2014, www.aljazeera.com/features/2014/3/2/ yemens-quiet-president.

28 International Foundation for Electoral Systems, Next Steps in Yemen's Transition (Washington, DC: International Foundation for Electoral Systems, 2012).

29 Greg Miller and Karen DeYoung, “Al-Qaeda Airline Bomb Plot Disrupted, U.S. Says,” Washington Post, May 7, 2012, www.washingtonpost.com/world/national-security/cia-disrupts-airline-bomb-plot/2012/05/07/gIQA9qE0 8T_story.html.

30 “CENTCOM 2013 Posture Statement," Department of Defense, April 6, 2013. For more details, see http://susris. com/2013/04/06/centcom-2013-posture-statement/.

31 Ken Dilanian and David S. Cloud, “U.S. Escalates Clandestine War in Yemen,” Los Angeles Times, May 26, 2012, https://latimesblogs.latimes.com/world_now/2012/05/washington-escalation-american-clandestine-war-yemenus-troops-.html. 


\section{Luke Hartig}

32 Comprehensive accounting of U.S. security assistance to Yemen is provided at Security Assistance Monitor: https:// securityassistance.org/data/program/military/Yemen/2009/2018/all/Global/.

33 Brian Palmer, "Why Is Yemen So Poor?” Slate, January 4, 2010, https://slate.com/news-and-politics/2010/01/ how-did-yemen-get-so-poor.html.

34 Sheila Carapico, "A New Green Zone in Sanaa," Middle East Report Online, January 1, 2013, https://merip. org/2013/01/a-new-green-zone-in-sanaa/.

35 Mohammed Ghobari, "Yemeni Protesters Storm U.S. Embassy Compound in Sanaa," Reuters, September 13, 2012, www.reuters.com/article/us-yemen-usa-embassy/yemeni-protesters-storm-u-s-embassy-compound-in-sanaaidUSBRE88C0AM20120913.

36 "Yemeni Military Seizes Jihadist Strongholds," Stratfor Worldview, June 13, 2012, https://worldview.stratfor.com/ article/yemeni-military-seizes-jihadist-strongholds.

37 Bergen, "In Depth."

38 Bill Roggio, “AQAP Confirms Deputy Emir Killed in US Drone Strike,” Long War Journal, July 17, 2013, www. longwarjournal.org/archives/2013/07/aqap_confirms_deputy.php.

39 Adrian Shahbaz, "Strategic and Tactical Shift Keeps al-Qaeda Insurgency Alive in Southern Yemen," Terrorism Monitor 10, no. 21 (2012): 4-5.

40 Barbara Starr, "Intercepted al Qaeda Message Led to Shuttering Embassies, Consulates," CNN, August 4, 2013, www.cnn.com/2013/08/04/politics/us-embassies-close/index.html.

41 Barack Obama, Remarks by the President at the National Defense University (Washington, DC: White House, 2013).

42 The Presidential Policy Guidance, with light redactions, was released in 2016, in response to a Freedom of Information Act request that the government had initially contested. For details, see www.justice.gov/oip/foia-library/ procedures_for_approving_direct_action_against_terrorist_targets/download.

43 Human Rights Watch, $A$ Wedding That Became a Funeral (New York: Human Rights Watch, 2014).

44 Lucy Draper, "The Wedding That Became a Funeral: U.S. Still Silent One Year on From Deadly Yemen Drone Strike," Newsweek, December 12, 2014, www.newsweek.com/wedding-became-funeral-us-still-silentone-year-deadly-yemen-drone-strike-291403.

45 Department of State, Remarks with President of Yemen Abdo Rabbo Mansur Hadi Before Their Meeting (Washington, DC: Department of State, 2013).

46 For a comprehensive analysis of the National Dialogue process, see Erica Gaston, Process Lessons Learned in Yemen's National Dialogue (Washington, DC: U.S. Institute of Peace, 2014).

47 Office of the Press Secretary, "Statement by NSC Spokesperson Caitlin Hayden on Assistant to the President for Homeland Security and Counterterrorism Lisa Monaco's Travel to Turkey, Yemen and Saudi Arabia," Obama White House, March 9, 2014, https://obamawhitehouse.archives.gov/the-press-office/2014/03/09/ statement-nsc-spokesperson-caitlin-hayden-assistant-president-homeland-s.

48 "Yemen to Become Six-Region Federation," Al Jazeera, February 10, 2014, www.aljazeera.com/news/2014/2/10/ yemen-to-become-six-region-federation.

49 Yara Bayoumy, "Yemen's Federal Plan a Bold Idea, but Many Hurdles Remain,” Reuters, February 23, 2014 , www. reuters.com/article/us-yemen-politics-analysis/yemens-federal-plan-a-bold-idea-but-many-hurdles-remain-idUS BREA1M05720140223? feedName $={ }_{\text {worldNews. }}$

50 "Saudi Arabia Designates Muslim Brotherhood Terrorist Group," Reuters, March 7, 2014, www.reuters.com/article/ us-saudi-security/saudi-arabia-designates-muslim-brotherhood-terrorist-group-idUSBREA260SM20140307.

51 Security Assistance Monitor.

52 "Yemen Launches Offensive Against al-Qaeda," Al Jazeera, April 29, 2014, www.aljazeera.com/news/2014/4/29/ yemen-launches-offensive-against-al-qaeda.

53 Mohammed Jamjoon, “Source: 'Massive' Attack Targets al Qaeda in Yemen,” CNN, April 20, 2014, www.cnn. com/2014/04/20/world/meast/yemen-drone-strike/index.html.

54 Bergen, "In Depth."

55 Peter Salisbury, “Yemen Rage Boils Over 'Unlivable' Price Hike,” Al Jazeera, August 1, 2014, www.aljazeera.com/ news/2014/8/1/yemen-rage-boils-over-unliveable-price-hike.

56 Danya Greenfield, Yemen: President Hadi's Gamble with the Houthis (Washington, DC: Atlantic Council, 2014).

57 "Yemen's Year of Destruction: The Houthi Takeover of Sanaa," The New Arab, September 21, 2015, https://eng lish.alaraby.co.uk/english/politics/2015/9/21/yemens-year-of-destruction-the-houthi-takeover-of-sanaa.

58 "The Road to Sanaa," Al Jazeera, June 24, 2015, www.aljazeera.com/program/al-jazeera-world/2015/6/24/ the-road-to-sanaa/.

59 Office of the Press Secretary, "Statement by NSC Spokesperson Caitlin Hayden on Assistant to the President for Homeland Security and Counterterrorism Lisa Monaco's Trip to Yemen," Obama White House, 
September 6, 2014, https://obamawhitehouse.archives.gov/the-press-office/2014/09/06/statement-nsc-spokes person-caitlin-hayden-assistant-president-homeland-s.

60 Mark Thompson, "Handicapping the SEAL Raid to Rescue Luke Somers in Yemen,” Time, December 7, 2014, https://time.com/3622579/navy-seal-raid-luke-somers-yemen/.

61 Josh Levs et al., "Yemen's President 'Has No Control' as Houthi Rebels Storm Palace," CNN, January 20, 2015, www.cnn.com/2015/01/20/world/yemen-violence/index.html.

62 Patrick J. McDonnell and Nabih Bulos, “'Death to America! Death to Israel!' Say Houthis in Yemen,” Los Angeles Times, February 20, 2015, www.latimes.com/world/middleeast/la-fg-death-to-america-death-to-israel-say-houthis-in-yemen-20150220-story.html.

63 Craig Whitlock, "Pentagon Loses Track of $\$ 500$ Million in Weapons, Equipment Given to Yemen," Washington Post, March 17, 2015, www.washingtonpost.com/world/national-security/pentagon-loses-sight-of-500-millionin-counterterrorism-aid-given-to-yemen/2015/03/17/f4ca25ce-cbf9-11e4-8a46-b1dc9be5a8ff_story.html.

64 Oren Adaki, "AQAP, Houthis Clash in Central Yemen," Long War Journal, October 16, 2014, www.reuters.com/ article/us-yemen-security/al-qaeda-and-houthis-clash-in-central-yemen-residents-idUKKCN0I41KG20141016.

65 "Yemen's Hadi Declares Houthi Power Grab Illegal," Al Jazeera, February 21, 2015, www.aljazeera.com/ news/2015/2/22/yemens-hadi-declares-houthi-power-grab-illegal.

66 Greg Miller, “U.S. Is Closing Its Embassy in Yemen as Security Concerns Mount,” Washington Post, February 11, 2015, www.washingtonpost.com/world/national-security/us-is-closing-its-embassy-in-yemen-as-security-concerns-mount/2015/02/10/47bf37dc-b16b-11e4-854b-a38d13486ba1_story.html.

67 Katharine Lackey, "U.S. Forces Evacuate Yemen Air Base," USA Today, March 21, 2015, www.usatoday.com/ story/news/world/2015/03/21/yemen-us-military/25138325/.

68 Harriet Alexander, "Al-Qaeda Frees 300 Prisoners in Yemen Jail Break," The Telegraph, April 2, 2015, www.telegraph.co.uk/news/worldnews/middleeast/yemen/11510765/Al-Qaeda-frees-300-prisoners-in-Yemen-jail-break. html.

69 Yaya Fanusie and Alex Entz, Al-Qaeda in the Arabian Peninsula Financial Assessment (Washington, DC: Foundation for the Defense of Democracies, 2017).

70 Bergen, "In Depth."

71 Thomas Joscelyn, “AQAP Confirms Death of Senior Leader,” Long War Journal, June 16, 2015, www.longwarjournal.org/archives/2020/02/white-house-confirms-death-of-aqap-leader.php.

72 Scott Shane, “U.S. Drone Kills a Top Figure in Al-Qaeda's Yemen Branch,” New York Times, April 14, 2015, www. nytimes.com/2015/04/15/world/middleeast/us-drone-kills-a-top-figure-in-al-qaedas-yemen-branch.html.

73 “Top al Qaeda Commander Killed in Yemen Drone Strikes," Reuters, February 4, 2016, www.reuters.com/article/ us-yemen-security/top-al-qaeda-commander-killed-in-yemen-drone-strikes-idUSKCNOVD0G6.

74 William Maclean, Noah Browning, and Yara Bayoumy, "Yemen Counter-Terrorism Mission Shows UAE Military Ambition," Reuters, June 28, 2016, www.reuters.com/article/us-yemen-security-emirates/ yemen-counter-terrorism-mission-shows-uae-military-ambition-idUSKCNOZE1EA.

75 Saeed al-Batati, Kareem Fahim, and Eric Schmitt, "Yemeni Troops, Backed by United Arab Emirates, Take City From Al Qaeda," New York Times, April 24, 2016, www.nytimes.com/2016/04/25/world/middleeast/yemenitroops-backed-by-united-arab-emirates-take-city-from-al-qaeda.html.

76 Eric Schmitt and David E. Sanger, "Raid in Yemen: Risky From the Start and Costly in the End," New York Times, February 1, 2017, www.nytimes.com/2017/02/01/world/middleeast/donald-trump-yemen-commandoraid-questions.html.

77 Eric Schmitt and Helene Cooper, "Navy SEALs Kill 7 Militants in Yemen Raid but Suffer Injuries,” New York Times, May 23, 2017, www.nytimes.com/2017/05/23/world/middleeast/navy-seals-yemen-raid.html.

78 Cheryl Pellerin, “Pentagon Spokesman Updates Iraq, Syria, Yemen Operations,” U.S. Central Command/DoD News, April 24, 2017, www.defense.gov/Explore/News/Article/Article/1161065/pentagon-spokesman-updates-iraqsyria-yemen-operations/.

79 “Update on Recent Counterterrorism Strikes in Yemen," U.S. Central Command, December 20, 2017, www.centcom.mil/MEDIA/PRESS-RELEASES/Press-Release-View/Article/1401383/update-on-recent-counterterrorism-strikes-in-yemen/; Bergen, "In Depth."

80 Maggie Michael, “Inside Yemen's Secret Prisons: 'We Could Hear the Screams',' Associated Press, June 23, 2017, https://apnews.com/article/b2a5ecfd1adb442a86df5bd05bc6599e.

81 "Senators Demand Investigation of Reports of Torture in Yemen," Reuters, June 23, 2017, https://fr.reuters.com/ article/us-yemen-prisons-usa-congress-idUSKBN19E2GZ.

82 “UN Humanitarian Office Puts Yemen War Dead at 233,000, Mostly From 'Indirect Causes',' UN News, December 1, 2020, https://news.un.org/en/story/2020/12/1078972. 


\section{Luke Hartig}

83 Shadi Abusneida, "For Yemenis on the Brink, Aid Funding Gap Spells Disaster," United Nations High Commissioner for Refugees, June 2, 2020, www.unhcr.org/en-us/news/stories/2020/6/5ed631574/yemenis-brink-aid-fundinggap-spells-disaster.html.

84 David Martin, “U.S. Officials Confident Drone Strike Killed Chief al Qaeda Bomb Maker," CBS, August 20, 2018, www.cbsnews.com/news/ibrahim-al-asiri-chief-al-qaeda-bomb-maker-killed-in-u-s-drone-strike/.

85 Bergen, "In Depth."

86 Christopher Miller, "Worldwide Threats to the Homeland," testimony before the U.S. House of Representatives Committee on Homeland Security, September 17, 2020.

87 Luke Hartig, "Full Accounting Needed of US-UAE Counterterrorism Partnership in Yemen," Just Security, December 7, 2018, www.justsecurity.org/61761/full-accounting-needed-us-uae-counterterrorism-partnership-yemen/.

88 Miller, "Worldwide Threats to the Homeland."

89 Greg Miller and Hugh Naylor, "CIA Scales Back Presence and Operations in Yemen, Home of Potent al-Qaeda Affiliate," Washington Post, February 11, 2015, www.washingtonpost.com/world/national-security/cia-scales-backpresence-in-yemen-base-for-potent-al-qaeda-affiliate/2015/02/11/9ad11c52-b219-11e4-827f-93f454140e2b_ story.html.

90 Martin, "U.S. Officials Confident Drone Strike." 


\title{
24
}

\section{DEFEATING THE ISLAMIC STATE Special Operations Forces in Syria}

\author{
Anthony Messenger, Nick Lewis-Walls, Mike Parker, \\ Bert Pedrigi, and David P. Kearns
}

In March 2018, Charlie Company from the 1st Battalion of the 5th Special Forces Group deployed to northeastern Syria to support the Syrian Democratic Forces (SDF) as part of Operation Inherent Resolve. ${ }^{1}$ The SDF was an alliance composed primarily of Kurdish and Arab militias who shared a goal of creating a secular, democratic, and decentralized Syria. The company's mission was to assist the SDF to defeat the Islamic State. The Islamic State controlled about one-third of Syria at its peak. By the time Charlie Company assumed the mission in March 2018, however, the SDF and pro-regime forces (PRF) aligned with Syrian President Bashar al-Assad had liberated much of the formerly Islamic State-controlled areas, relegating the group to a handful of small pockets. ${ }^{2}$

When Charlie Company deployed, the SDF had paused offensive operations against the Islamic State in northeastern Syria. Turkey had launched Operation Olive Branch into northwestern Syria, and the predominantly Kurdish SDF considered the defense of Afrin a higher priority than its anti-Islamic State operations. With the SDF moving forces to Afrin, they could only conduct defensive operations against the Islamic State. At the same time, four major external powers-Russia, Iran, Turkey, and the United Statescompeted for influence through their support to different Syrian forces, bringing additional complexity.

This chapter provides multiple first-hand accounts of Charlie Company's mission against the Islamic State in northeastern Syria. It begins with an overview at the company level by its commander, Major Anthony Messenger. The chapter then offers operational vignettes written from the perspectives of the three Special Forces Operational Detachment Alpha (ODA) ${ }^{3}$ commanders and a civil affairs team (CAT) commander. The chapter concludes with a series of lessons learned from Charlie Company's deployment.

\section{Company-level overview}

Major Anthony Messenger, commander of Charlie Company

When Charlie Company deployed to northeastern Syria in March 2018, the Islamic State maintained two pockets: the "Hajin Pocket" and "Dashisha" (see Figure 24.1). The Hajin Pocket, named for the largest town in the pocket, contained an estimated 60,000 people and 1,000-3,000 Islamic State fighters. ${ }^{4}$ The roughly 435-square-kilometer area spanned the last 45 kilometers of the north bank of the Euphrates River 


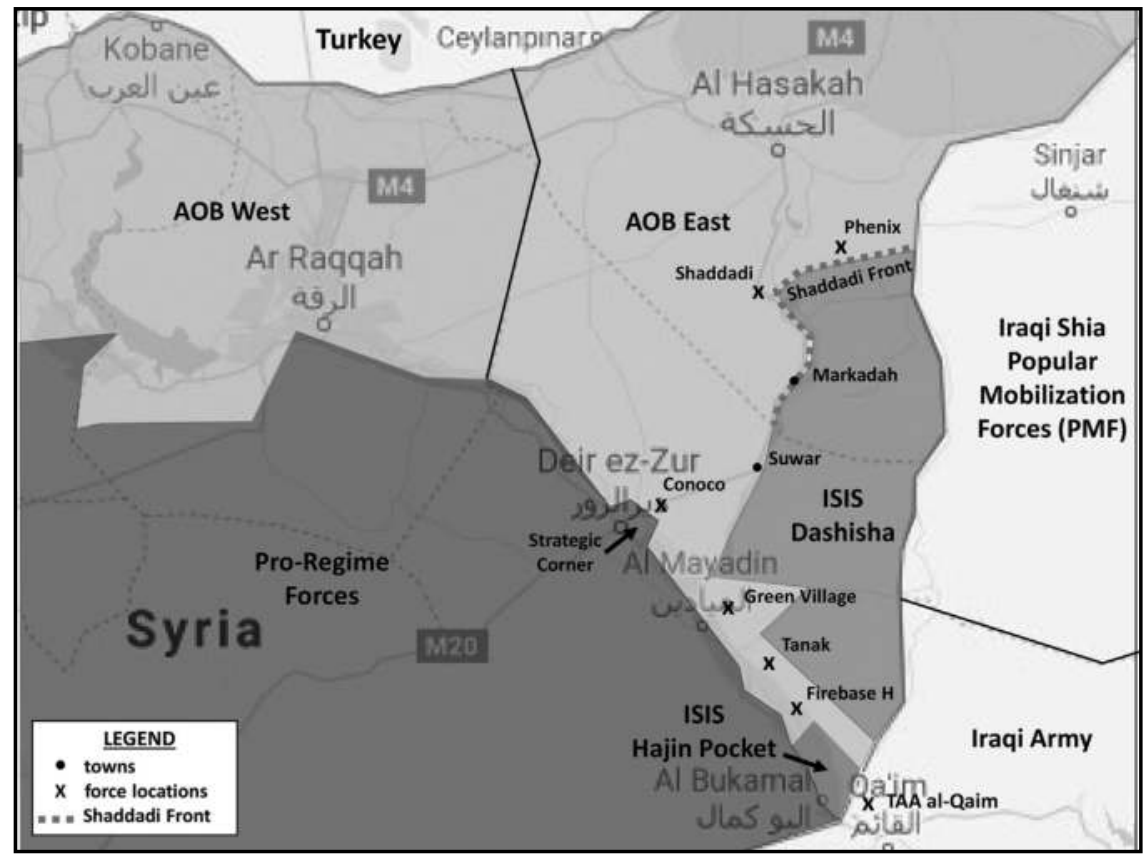

Figure 24.1 Initial disposition of forces in Syria, March 2018. ${ }^{5}$

Source: Map created using Google Maps.

to the Iraqi border. Hajin remained an Islamic State stronghold, where its fighters and supporters prominently displayed the extremist group's flags and enforced Sharia (Islamic law). Dashisha was a much larger 7,800-square-kilometer area, spanning east of the Khabur River to the Iraqi border.

The Islamic State still influenced populations in the recently liberated areas, including the major towns of Markadah and Suwar, which sat along the primary route between Charlie Company's headquarters and its detachments. Markadah was also a primary crossing point along the Khabur River for commerce from Islamic State-controlled territory to the recently liberated SDF-controlled areas. The population worried that the Islamic State might return, and the majority of the population had conservative (although not extremist) religious beliefs.

The SDF established a significant front line with fighting positions every kilometer along the Shaddadi front, the northernmost 100-plus kilometers of the Dashisha pocket. In some sections, the line was heavily fortified, while in others, it was largely void of troops. The SDF had also seized control of several oil fields north of the Shaddadi front line and infrastructure to the south, including the Conoco oil field near the city of Deir ez Zor.

There were additional strategic and operational complexities. Russia and Iran provided direct support to the embattled Bashar al-Assad government and its military operations against two different Syrian opposition forces: the Islamic State and the Free Syrian Army. The United States, Turkey, and other coalition partners supported various factions of the Free Syrian Army in different parts of Syria, but not all partners supported the same groups. All, with the exception of Turkey, supported the SDF.

American support to the SDF complicated relations with Turkey, since Ankara viewed the People's Protection Units and Women's Protection Units - components of the SDF-as an extension of the Kurdistan Workers' Party, a designated terrorist organization that has conducted attacks inside Turkey for decades. 
These geopolitical factors created a multifaceted strategic environment that resulted in significant challenges at the tactical level.

\section{Pre-deployment planning}

I assumed command of Charlie Company in October 2017, shortly after the company returned from its first deployment to Syria. At the time, I knew the company would return to Syria six months later for another six-month deployment. In those months, we had to recover from deployment, take post-deployment leave (vacation), and prepare for the next deployment. I was concerned six months would not be enough time, especially considering the repeated deployments over many years for some of my seasoned Special Forces soldiers. Ultimately, we were able to accomplish all of the critical pre-mission training.

After taking command, Charlie Company conducted a four-day operational planning process for its upcoming deployment. I broke the team leadership into planning teams with the goal of encouraging organizational teamwork and creating a shared understanding of the company's mission, commander's intent, and desired end state.

The detachment commanders studied all of the operations orders, from the combatant command to battalion level, and conducted detailed mission analysis for the advanced operations base (AOB) - the name of a Special Forces company when it deploys-mission. The detachments' assistant operations and intelligence sergeants conducted a thorough intelligence preparation of the battlefield and the warrant officers developed a strategic-level stakeholder analysis to understand the environment. Each planning team briefed the entire company on their outcomes, creating a shared understanding at the lowest level.

The planning teams then briefed my superior, the battalion commander, for approval. During planning, we identified pre-mission training tasks, helped the AOB visualize what we needed to resource, and focused our detachments on the pending deployment. At the end of the four-day process, I assigned missions to the detachments, and they initiated detailed planning. I could not, however, assign them specific areas of operations, or geographical sectors, since ongoing operations were fluid and the physical locations of the SDF and the company we would replace changed daily.

\section{Preparing for deployment}

Pre-mission training consisted of two AOB-run events: external evaluations (EXEVALs) and strike operations. The EXEVALs consisted of deployment-specific tasks derived from our consolidated planning. The company rotated each of the four detachments that would be deploying through a 36-hour EXEVAL. The tasks included employing 120-mm mortars, reacting to an improvised explosive device, conducting casualty evacuation, reacting to a chemical event, setting up a communications suite, and communicating using multiple modes.

At the end of EXEVALs, I assigned each detachment a sector within the AOB's area of operations, known as AOB East, to facilitate more detailed planning and coordination with the detachment they would replace. ODA 5136's mission, however, changed only three weeks prior to deployment when hundreds of PRF, including Russian private military contractors, attacked the U.S. position near the Conoco oil field on February 7.

Initially, ODA 5136 was to assume primacy on building partner capacity in support of stability operations, but after the attack, they were reassigned to assume control of the "strategic corner," build a partner force, and conduct a combined arms defense against a battalion plus of PRF with an overwhelming number of artillery tubes, tanks, and armored vehicles in support. The "strategic corner" earned its name because it was a physical location where risk to mission and men was highest, and loss of the location threatened the mission to defeat the Islamic State. 
The second part of pre-mission training focused on the AOB and detachment leadership. It was designed to train the $\mathrm{AOB}$ on sensor management, strike operations, and asset management. The leaders and critical enablers ${ }^{6}$ were all brought together to a simulations operation center to conduct strike operations. We conducted a detailed after action review following each iteration. This was the most beneficial training I received as the company commander. It trained me on the most critical aspect of my job: trust and patience. Trust and patience are essential when conducting complex operations with partners and allowing the detachment commanders time and space to problem-solve the challenges they face.

When we deployed, we would be working for a Special Operations Forces (SOF) headquarters element we did not typically work under. To build trust with our new headquarters, we invited them to train with us and validate our ability to conduct strike operations from the detachment and company level. The exercise built the trust necessary to enable quick execution, empowering leaders at the lowest level.

I knew the detachments would be ready. The biggest risk, from my perspective, would be the strategic situation. It was complex and constantly changing. I believed we needed to have a comprehensive understanding of the numerous actors and their equities.

\section{Strategic context}

Northeastern Syria represented a challenging strategic environment. In October 2017, the U.S.-backed SDF liberated Raqqa, the capital of the Islamic State's self-proclaimed caliphate, and subsequently raced the Russian and Iranian-backed PRF down the Middle Euphrates River Valley toward the border with Iraq, each side advancing against Islamic State elements toward the city of Deir ez Zor. ${ }^{7}$ The PRF remained on the south side of the Euphrates River, while the SDF remained on the north, leaving the river between them. The PRF, however, soon crossed to the north side of the river at Deir ez Zor, increasing the complexity of the tactical situation. ${ }^{8}$

To maintain momentum, the SDF bypassed the PRF position and continued its advance, leaving a PRF foothold on the north side of the river. Over time, the situation settled into an unsteady containment of the PRF, with minor skirmishes between the two forces. The containment remained effective largely due to the threat of coalition airstrikes. The United States would not support offensive operations against the PRF but maintained the right of self-defense and the defense of American partners against all combatants. Yet the risk of escalation was always present.

In mid-January 2018, the Turkish military and Turkish-supported elements of the Free Syrian Army initiated Operation Olive Branch, an air and ground campaign on the Kurdish-majority Afrin District in Syria. ${ }^{9}$ As a result, the Kurdish forces within the SDF halted offensive operations against the Islamic State and repositioned forces to defend Afrin, which it considered more important to Syrian Kurdish national identity. ${ }^{10}$

In February 2018, shortly before my arrival, a force of nearly 500 PRF-coupled with Iranian paramilitary and Russian private military contractors - conducted an attack from their position north of the Euphrates River near Deir ez Zor to seize the Conoco oil and gas facility in the SDF-controlled zone. The U.S. position was clearly marked, and U.S. SOF acted in self-defense to protect itself. The much smaller U.S. SOF element - supported by American airpower-defeated the PRF and Russian private military contractor attack, inflicting hundreds of PRF and private military contractor casualties. ${ }^{11}$

The situation left a capable adversary on the north side of the river. The PRF-with Russian and Iranian support - actively worked to undermine the SDF in the area and demonstrated a desire to seize critical oil and gas infrastructure. If the PRF conducted a successful breakout from this foothold and moved to the north or east, they could isolate U.S. SOF elements in the river valley to the southeast. This PRF location increased risk from the tactical through strategic levels and became the AOB's strategic corner.

We assumed our mission two weeks earlier than initially planned based on a tactical need to get our detachments in place quickly. But the flow of equipment into northeastern Syria was slow, even at the 
best of times. By conducting an early relief in place, the detachments lacked their organic equipment. We improvised in numerous ways and borrowed equipment from our partner force until our equipment arrived. I assumed a higher risk for the soldiers at the tactical level, but overall I thought I was reducing operational risk by displaying our resolve to support our partner and share the risk.

\section{Company deployment and mission overview}

In late February 2018, the company deployed and started occupying mission support sites (MSSs), or firebases, along the river valley and SDF front. We assumed primarily a defensive posture due to the tactical pause created by the SDF repositioning forces to Afrin but planned to resume offensive operations once conditions allowed. Ultimately, we re-established a complete cordon of the Hajin Pocket from May to June and cleared Dashisha from June to July. Additionally, the defense of the strategic corner was a constant concern and one that required me to surge other detachments to the area on occasion.

Within the first few weeks, the detachments occupied their MSSs, collocated with their SDF partners along the Islamic State front. This was intended to reassure our partners that while we would not provide combat support to their Afrin operation, we would remain committed to their fight against the Islamic State. One of my priorities was maintaining our partners' trust while urging them to resume offensive operations.

ODA 5131 was co-located at MSS Green Village with the forward SDF regional headquarters. ODA 5132 assumed responsibility of our northernmost sector along the Shaddadi front, which was the longest section of the SDF defense. ODA 5133 occupied a position near Tanak oil field, near the Hajin pocket, while ODA 5136 established a combined arms defense against the Russian and Iranian backed PRF threat at the strategic corner. We shared tactical operations centers with our SDF partners at each location to ensure clarity for operations and support.

I collocated the AOB with the SDF main regional headquarters near Shaddadi. I often met with my partner, the SDF regional commander, who commanded a division-sized force, to discuss our situation and influence his actions. The SDF's ultimate goal was to have an autonomous area within the Syrian government structure much like the Iraqi Kurds, yet no other actor had the desire to entertain this outcome. The SDF hoped that by partnering with the United States to defeat the Islamic State, the U.S. government would in turn help the SDF achieve its goal of an autonomous region within Syria.

The detachments had been in their MSSs for only a single week before I had to surge most of my forces to support the defense of the Conoco oil field due to PRF aggression. During this initial defense of the strategic corner, I requested additional support from our headquarters. In response, the headquarters sent another special operations element, with its supporting SDF, to assume responsibility for the defense.

As a result, I gave up tactical control of $50 \%$ of the AOB's combat power and moved into a supporting role as tensions ebbed and flowed. It was humbling to admit that I did not have the requisite combat power to conduct a full-scale deterrence of Russian-supported PRF while continuing with operations to defeat the Islamic State, and even more humbling to turn over the responsibility to another unit. But it was the correct call.

The defense of the strategic corner-albeit critical to the AOB's success-was a supporting effort to the AOB's primary mission: the destruction of the Islamic State's self-proclaimed caliphate. Nevertheless, if the threat in the strategic corner increased enough, operations to defeat the Islamic State would have to be halted to secure the corner, given the Conoco site protected the AOB's flank, ODAs 5133 and 5131's rear area, and the company's supply routes.

After successfully deterring the PRF forces, the SOF unit that had surged to take tactical control of the area returned to its primary mission elsewhere in Syria, and ODA 5136, with some technical assistance 
from a U.S. Army engineer officer, started to build a combined arms defense at the strategic corner to deter future incursions. We ultimately succeeded in deterring aggression along the strategic corner because of ODA 5136's efforts.

In late April 2018, as SDF troops repositioned from Afrin, we prepared for offensive operations along the desert and border axis (the strip of land between the Hajin and Dashisha pockets) led by ODA 5131 as the main effort. The operation kicked off beginning in May, and the SDF subsequently re-seized the desert and border axis they had lost earlier in the year. The axis separated the last two Islamic State strongholds and closed the Hajin Pocket.

Once complete, the AOB shifted its focus north. In July, we initiated the clearing of Dashisha with a series of airstrikes. ODA 5132 was the main effort, supported by ODA 5131, 5213, and a coalition SOF team. The operation took about one month, leaving the Hajin Pocket as the only Islamic State-controlled territory in our sector.

Logistics were a constant challenge. The SDF's defense of Afrin significantly decreased their logistics capability that the previous AOB had depended on for resupply and sustainment. This meant the AOB would need to assume a greater logistics responsibility than it had initially planned, which required a reallocation of its assets to supply the geographically dispersed elements.

The detachments relied on multiple methods of procurement that ranged from local sourcing to having food delivered to the AOB by Amazon and then delivered to them on resupply runs. The furthest MSS was a six-hour drive from the AOB. Some of these challenges were anticipated during mission analysis, and detachments filled boxes with mountain meals, protein bars, various forms of shelf-stable food, and MREs. ${ }^{12}$ Still, many of the soldiers lost significant weight during the first three months of the deployment.

\section{Task organization for combat operations}

The AOB's mission was to conduct partnered operations to destroy the Islamic State's self-proclaimed caliphate in Syria, an area of operations the size of Maryland. To do this, the company was heavily resourced. Beyond its organic detachments, the AOB also controlled CATs, psychological operations teams, coalition SOF, Army and civilian mechanics, cooks, a signal section, a robust intelligence section, Marine Corps Information Operations planners, Air Force Joint Terminal Attack Controllers, a Marine Corps heavy weapons company, an Army field surgical team, an Air Force Special Operations Surgical Team, a forward support company, 155-mm howitzers, multi-service engineers, and multi-service explosive ordnance disposal (EOD) teams.

Additionally, elements in direct support of the AOB included rocket artillery, counterfire radar systems, air weapons teams, fuelers, medevac aircraft, and a forward logistics element. The AOB also managed assigned intelligence, surveillance, and reconnaissance (ISR) platforms and close air support assets.

I assigned most of the non-organic elements to the detachments based on tactical requirements. The detachments integrated them into their joint (multi-service) and combined (multinational) teams. For example, when ODA 5136 built the defense at the strategic corner, they identified a need for responsive all-weather fires. The AOB requested and received howitzers from our headquarters and pushed them down to the detachment for employment.

Detachments rarely manage this level of fire support at their level, but they quickly learned the artillery drills and employment considerations. The detachment commander placed the howitzers north of the main defensive position, just out of range of the PRF artillery but within range to support the detachment and company fires plan. ${ }^{13}$

To ensure medical coverage across the sector, I split the field surgical team into two sections and positioned them with detachments to best support operations and "golden hour" requirements. ${ }^{14}$ The AOB maintained medevac aircraft for golden-hour coverage for three detachments, but ODA 5133, and later ODA 5131, maintained a surgical capability at their locations due to their distance from the AOB. 
Over the course of the deployment, the AOB supported up to seven sites at once. I transferred enablers, such as howitzers or surgical teams, from one detachment to another based on operational requirements. Generally, the detachments were expected to manage their own MSS and were provided Marine Corps infantry to assist with security.

The Marine Corps heavy weapons company attached to the AOB included organic armored vehicles, heavy mortars, and anti-tank guided missiles. This company was critical to building the combined arms defense, but it also reinforced the defense of the detachment MSSs.

We treated the Marine Corps company commander as a part of the team, and he was consulted on the employment of his forces to best support the detachment missions. Their integration was critical to mission success. They were able to provide timely support - such as additional anti-armor capability — and integrated seamlessly at all levels. Two detachments had Marine Corps mortar crews that were integral to operations. They brought the combat capability necessary to secure the MSSs and allowed the detachments to focus on their partner force.

\section{ODA 5133: the "Tip of the Spear" in the Middle Euphrates river valley}

\section{Major Nick Lewis-Walls, commander of ODA 5133}

In February 2018, ODA 5133 arrived to the AOB's most remote outstation, 130 kilometers from the AOB headquarters, with the mission of containing the Islamic State in the Hajin Pocket. The administrative structures of a non-functioning Tanak oil field served as the detachment's MSS (see Figure 24.2). The

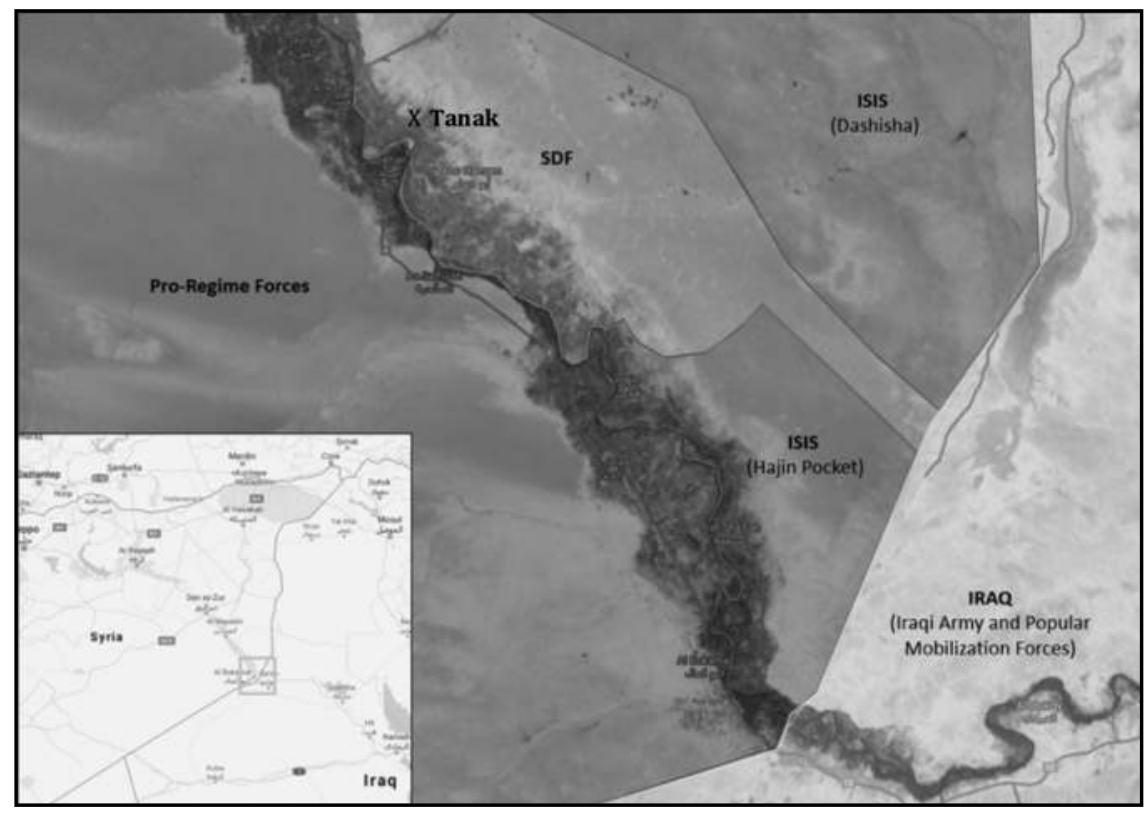

Figure 24.2 ODA 5133 containing the Islamic State in the Hajin Pocket, March 2018. ${ }^{15}$

Source: Map created using Google Maps. 
detachment's partner force consisted of 1,500 SDF fighters arrayed in 80 defensive fighting positions along a 65-kilometer front. An additional 1,300 SDF fighters provided wide-area security in the areas of the river valley that had been cleared from November 2017 to January 2018.

Islamic State elements in the river valley responded to the SDF's halt by consolidating and layering defensive positions in the Hajin Pocket, employing observation on static SDF positions, and conducting limited attacks during degraded weather conditions.

The detachment's initial position at the Tanak oil field MSS was not sufficient to support the SDF positions. Located 18 kilometers from the nearest point along the front, the detachment lacked organic unmanned aerial systems and weapon systems that could directly support SDF elements during times of degraded weather. Spring in northeast Syria generally brings several stretches of low clouds and poor weather, and the detachment could not rely solely on allocated ISR platforms to provide persistent coverage along the 65-kilometer front.

The detachment distributed its assigned ISR and close air support to the SDF defense along the front. The detachment also conducted multiple ground reconnaissance missions, ensuring familiarity with as many of the 80 positions as possible, timing routes, and designating suitable locations for mortar firing points.

In some cases, the detachment discovered that the SDF did not occupy positions reported by their commander. This initial reconnaissance paid dividends in gaining a more accurate understanding of the friendly situation. The detachment generated a refined common operational picture using off-the-shelf tactical applications to disseminate, synchronize, and update SDF disposition and operations.

The common operational picture was a living product, adjusted almost daily as new observations regarding enemy movement patterns, enemy activity, local patterns of life, and friendly disposition changed. While the detachment maintained a 24-hour strike cell with near-continuous close air support and ISR assets, the most useful characterization efforts came from the layering of ISR collection with long hours of direct ground observation.

During reconnaissance missions, small teams of Special Forces soldiers moved between the SDF positions during two- to three-day patrols, conversed with front-line SDF fighters, and spent "time on glass" (using optics for direct observation) to build a more complete picture of the enemy situation. Using these reports, the detachment generated an assessment of the enemy's concept of operations in the river valley, creating a geospatially arrayed product that tracked observed activity, intelligence reporting, and operational zones.

The detachment identified three types of Islamic State zones: employment zones, transition zones, and support zones. Employment zones were areas void of civilians in which Islamic State elements actively conducted visual observation of SDF positions, launched unmanned aerial systems, and conducted smallscale harassing attacks.

Transition zones were areas where Islamic State fighters transitioned between their support and employment zones.

Support zones were areas with high levels of civilian activity where Islamic State members could openly carry arms, fly flags, and enjoy relative freedom of movement by using the population as a shield against coalition airstrikes.

\section{Occupying Firebase " $H$ "}

From its first reconnaissance mission, the detachment searched for suitable locations for a new firebase. The most important operational considerations were proximity to SDF leaders and the enemy. Tactically, the prime considerations were adequate ranging to cover a significant portion of the front with 120 -mm mortar fire, employment of the detachment's unmanned aerial systems, and improved intelligence collection capabilities. The firebase's more proximate location to the front, however, would increase risk-to-force. 


\section{Defeating the Islamic State}

The detachment narrowed down promising locations, staying at sites over extended periods and conducting $120-\mathrm{mm}$ fire missions to gauge enemy reactions.

In the end, the detachment selected a location only 950 meters behind the front and approximately 2 to 3 kilometers from the nearest enemy position. From the firebase, the detachment could range $25 \%$ of the 65 -kilometer Hajin front with its $120-\mathrm{mm}$ mortars to include the most active section. Additionally, it could cover $50 \%$ of the front when employing mobile elements in pre-established mortar firing positions.

The detachment benefited from a number of attachments: an intelligence element, an Air Force Special Operations Surgical Team, a Navy EOD team, three Air Force Joint Terminal Attack Controllers, a 12-man Marine Corps security force, and a coalition SOF team. The attachments rotated in and out of theater on their own schedule, but they consistently accounted for roughly half of the combined 75-person force at the firebase.

The surgical team allowed the detachment to meet golden-hour evacuation requirements, since the farthest positions along the front were a 54-minute ground movement from the new firebase. After receiving approval to relocate, the detachment began a deliberate occupation. Upon occupation, the detachment chose to name its new position Firebase Hajin (Firebase "H").

\section{The defense}

As the detachment settled into the firebase and adjusted to its new operational tempo, the detachment devoted greater effort to understanding our partners so that we could become more effective combat advisors. While the Kurdish People's Protection Units and Women's Protection Units factions made up the bulk of the SDF, in our sector, the SDF instead consisted primarily of Arab-majority fighting units arrayed under the Deir ez Zor Military Council. Many of the fighters were from the nearby area and possessed a wealth of knowledge about local observations, local history, and tribal dynamics.

The SDF organized the front into three sectors. The sector commanders rotated their fighters out of their positions every two to three weeks, resulting in 100-300 fighters manning the positions in each sector at any given time. Additional SDF forces provided internal security in liberated areas to the rear of the front.

The front commander remained co-located with the detachment headquarters at Firebase " $\mathrm{H}$ " to synchronize operations. The assistant detachment commander maintained the prime relationship with the front commander, devoting considerable time to developing the relationship over lengthy discussions on politics, life, history, and the military situation in Syria.

This arrangement worked well. It allowed me, as detachment commander, to maintain a working relationship with the SDF commander while enabling broader visibility on external relationships, external assets, and higher-echelon reporting requirements. I could always step in to play the "bad cop" to provide leverage on critical issues and allow the assistant detachment commander to remain the "good cop" and maintain a high level of personal rapport. The detachment operations sergeant managed the day-to-day mission cycles, training cycles, and tactical employment of organic assets and systems.

With a firm relationship at the command level, the detachment worked to cement relationships at lower echelons. I assigned two to three Special Forces soldiers responsibility for each sector, enabling them to form relationships and become experts within their sector. With the SDF rotating every two to three weeks, the Special Forces advisors soon became the continuity on the defensive front, which improved SDF internal rotations.

Essential skills for these small advisory teams included both tactical skills—such as the ability to call for and adjust mortar fire, employ close air support, or engage targets with anti-tank weapons systems-and Arabic-language skills. The single linguist remained with the detachment headquarters at Firebase "H," so the Special Forces advisors employed their language training with the assistance of Google Translate and picture sketches to communicate with their partner force. Although the majority of the Special Forces 
soldiers had received Modern Standard Arabic or Levantine language training, a few of them spoke only French or Farsi and had to learn what they needed on the job.

The detachment also worked to build relationships between the SDF and their nearest adjacent unit: the Iraqi Security Forces. The detachment deemed improved Iraqi Security Forces-SDF coordination essential for both tactical and operational success in the river valley, particularly along the international border. By leveraging previous personal relationships with Iraqi officers and U.S. Army units across the border at Tactical Assembly Area al-Qaim, the detachment facilitated the first physical link-up between the SDF and Iraqi forces.

On the day of the meeting in May 2018, the detachment and its SDF counterparts drove to the international border and then walked across on foot to meet the Iraqi officers at a temporary collection of tables and chairs. As detachment members watched, the SDF commander, the Iraqi commander, and their staffs discussed operational plans, methods of coordination, and a desire to continue developing the relationship. The detachment paralleled this line of communication with the Iraqi Army and the coalition forces at Tactical Assembly Area al-Qaim.

I found credibility, rapport, and overall value to be the key characteristics for a successful advisory effort. The Special Forces soldiers shared long days and nights, meals, and stories with their counterparts but were quick to support the defense of the front with effective indirect fire, timely battlefield intelligence, and close air support.

\section{The cross-functional team}

The detachment became increasingly concerned about security and stabilization in the recently liberated areas of what we referred to as the "Green Blob" (the AOB's sector), 400 square kilometers of which fell within the detachment's sector. As early as April 2018, the detachment conducted limited civil reconnaissance and tribal engagement missions in the liberated area. Unfortunately, the limited civil affairs and psychological operations assets were not able to access the area as frequently as desired, but access improved over time.

The detachment worked through tribal connections to identify tribal influencers and power brokers for future relationships with the Deir ez Zor Civil Council. This process required a significant time commitment, but the detachment prided itself on talking to people. The detachment attempted conversations with anyone and everyone to find promising leads for tribal connections, from talking with Arab SDF/ Military Council members on the front with local connections, to conducting street-level engagements with merchants, to working through SDF commanders to arrange meetings.

The Deir ez Zor Civil Council had a tribal and local issue outreach center that the detachment frequently visited to meet with representatives from local groups. The detachment established and maintained contact with promising individuals — especially those with influence — using secure messaging applications. The detachment routinely vetted names of reliable contacts to gauge reactions and receive any additional or alternative views.

For the most part, the Arab tribal representatives were not evasive, nor did they seem insincere during engagements. They represented people trying to recover from a significant social and physical trauma over the past six years and sought to work with the coalition, SDF, and the Civil Council to build a "new normal." The detachment worked with its temporarily assigned CAT to connect recommended tribal interlocutors to the Civil Council and began facilitating Civil Council and SDF-led tribal engagements to build local cooperation for the liberation force and provide a pseudo-political outlet to air grievances and requests. The detachment moderated these engagements that rotated between local tribal leadership residences and the SDF headquarters.

Prior preparations were critical to productive meetings. The detachment rehearsed talking points with the SDF, while the CAT similarly advised the Civil Council participants. U.S. personnel served as the "honest brokers" in the room, and tribal leadership routinely commented that the American presence gave 
them the best opportunity for a better future, leading to their increased willingness to work with the SDF and the Civil Council.

After incorporating the CAT and tactical psychological operations team into the detachment's civic engagement in the Green Blob, the detachment's lobbying for the assets paid off. By late July 2018, the AOB moved a CAT and a tactical psychological operations team to Firebase "H," and the detachment fully integrated them into the mission. Eventually, this arrangement led to re-labeling the ODA a crossfunctional team, with the detachment commander serving as the cross-functional team commander and formalizing the relationship that had developed over the course of the deployment.

\section{ODA 5131: MSS occupation, desert operations, and containment}

\section{Major Mike Parker, commander of ODA 5131}

ODA 5131 spent six months training and preparing to partner with the SDF to conduct offensive operations against the Islamic State along the Middle Euphrates River Valley. During pre-deployment training, ODA 5131 was designated to replace the detachment that had recently established an MSS at the Omar oil field. Due to ongoing offensive operations in January and February, the previous detachment hastily established the MSS. The operational environment shifted nearly instantaneously as the SDF pivoted toward Afrin. Though frustrating in the moment, this pivot provided an opportunity to consolidate and reorganize for the final push to defeat the Islamic State in eastern Syria.

To prepare for offensive operations, the detachment needed a more suitable MSS- a scalable location that could serve as a logistics hub and support all of the company's detachments across the final 75 kilometers of desert to the Iraqi border. The MSS at Omar oil field was easily defendable, but the limited space provided no room for growth.

The SDF had already begun to occupy "Green Village," a community of abandoned apartment buildings adjacent to a field suitable for a helicopter landing zone. Green Village met all the requirements to serve as a logistics hub and facilitate the final offensive. It was scalable in size; could easily accommodate more than 250 personnel; adjacent to a helicopter landing zone and drop zone (a designated area into which troops or supplies are dropped by air); well defendable; and central in location to support AOB operations along the river valley.

Over the course of one week, two EOD technicians and one dog handler accompanied the SDF to clear the helicopter landing zone and approximately 20 three-story apartment buildings. Once clear, the detachment conducted a phased movement from the Omar oil field to Green Village. Although only a short five-minute drive, the detachment needed to move a field surgical team, counterfire radar, and rocket artillery assets that supported other detachments in the river valley.

The detachment occupied Green Village in March with approximately 50 personnel: ODA 5131, a marine infantry platoon, a rocket artillery platoon, a field surgical team, two EOD techs, and a military working dog. By the end of June, the MSS had grown to 220 personnel, including CATs, tactical psychological operations teams, forward arming and refueling point personnel (for aircraft), a second counterfire radar, a Special Operations Surgical Team, a howitzer platoon, other members of the international coalition, and transient visitors.

\section{Containment}

ODA 5131 was directed to contain the Islamic State within the Hajin pocket. ${ }^{17}$ The detachment's first task was to understand the nuances and challenges of the operational environment and then to 


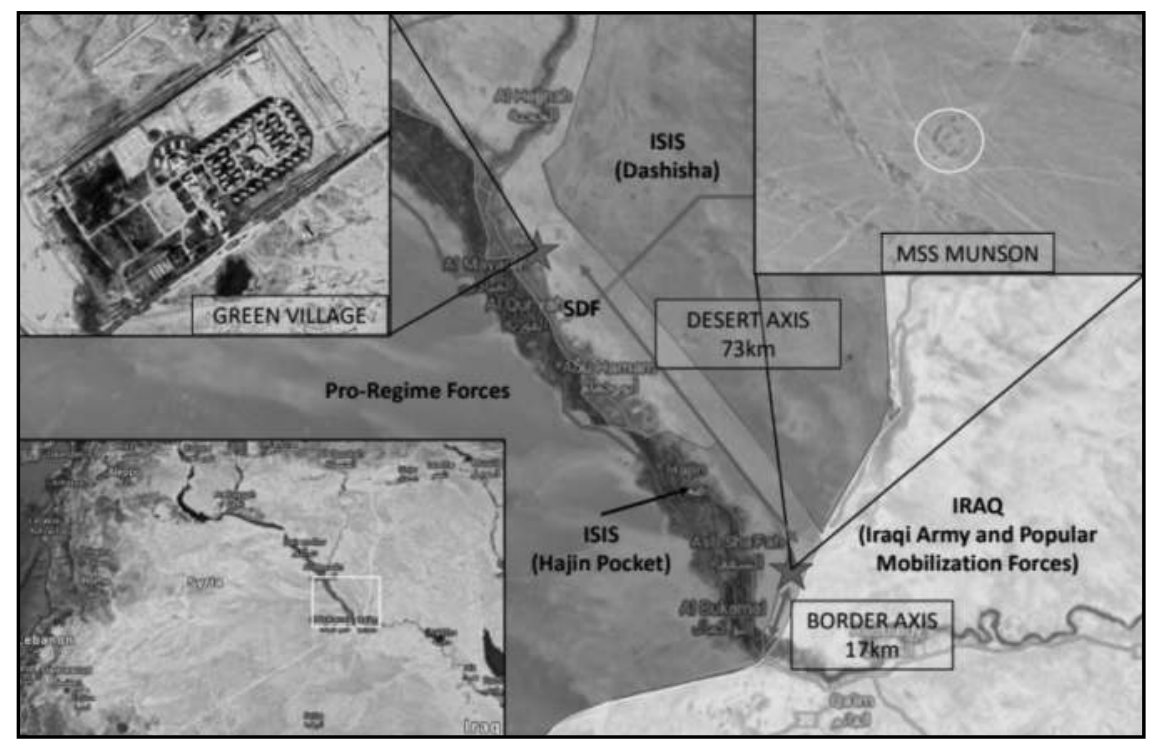

Figure 24.3 Green Village and the desert axis, April/May 2018. ${ }^{16}$

Source: Map created using Google Maps.

task-organize in a manner that would allow the detachment to partner most effectively with the SDF's chain of command.

The detachment began by validating its assessment of SDF positions along the desert axis (see Figure 24.3) - the stretch of desert with approximately 80 defensive fighting positions spaced nearly 1 kilometer apart. Fighting positions were constructed with dirt berms, sandbags, and small trenches to protect against vehicle-borne improvised explosive devices. The SDF positions included fighters armed with assault rifles (AK-47s), one to two machine guns (PKMs or variants), and occasionally rocket-propelled grenades. The SDF manned each fighting position with 8 to 12 SDF soldiers, who rotated every two weeks.

Defying traditional military tactics, the SDF frequently waited until 24-48 hours prior to an operation to establish the chain of command for tactical maneuver units. The SDF utilized a unique system of rotating field commanders (company to battalion equivalents) who were selected by senior SDF leadership based on considerations unknown to and with little influence from our detachment. The lack of unity of command at the lowest levels made it impossible for the detachment to conduct specific pre-mission training or rehearsals with the SDF prior to Operation Jazeera Storm (the SDF operation name for the final defeat of the Islamic State) or other operations. Flexibility in the time, location, and organic task organization were keys to success for operations with the SDF.

\section{Task organization}

Task organizing for Operation Jazeera Storm proved difficult, as the mission required the detachment to operate from three separate locations to effectively partner with the SDF. The detachment commander remained at Green Village to advise the operational commander, coordinate fires, and control ISR. The team sergeant also remained at Green Village to oversee logistics, run day-to-day operations, and oversee the MSS build-up.

Due to the distance from Green Village to ODA 5131's new area of operations, the detachment required a second MSS, so the assistant detachment commander led the rest of the detachment to establish MSS 
Munson near the Iraqi border. During offensive operations, the element at MSS Munson would split again. The assistant detachment commander remained at MSS Munson to advise the local SDF commander on operations and to de-conflict fires, while the senior weapons sergeant or senior engineer sergeant advised the SDF ground tactical commander on movement and maneuver, the de-confliction of local fires, and to provide updates on SDF locations as they inched toward Islamic State territory.

The detachment split operations into two primary categories: the "deep fight" and the "close fight." The "deep fight" was primarily a reconnaissance and artillery mission: to support the SDF using ISR capabilities controlled at Green Village to scan for threats, obstacles, or civilian activity ahead of SDF movement. ISR specifically conducted scans across wadis (river valleys), dead space (areas that cannot be covered with direct fire weapons), trench systems, and tunnel systems (by identifying tunnel entrances) and assessed Islamic State fighting positions.

The "close fight" was designed to provide the SDF with immediate tactical support using mortars and observation (small unmanned aerial systems and direct observation). Standing side by side with the SDF ground commander, the Special Forces soldier could observe the forward-most SDF element as they maneuvered from one position to another, reducing risk by quickly identifying Islamic State fighters and de-conflicting fires.

Technology proved invaluable during the initial phase of Operation Jazeera Storm. Rather than dedicating an ISR platform to track the SDF as they maneuvered toward Islamic State-controlled territory, the detachment tracked their position using direct observation and tracking devices. This technique allowed the detachment to dedicate all ISR platforms to actively scan for enemy threats.

\section{Supporting Operation Jazeera Storm from Iraq}

Given the proximity of Operation Jazeera Storm to the Iraqi border, the detachment requested to leverage assets located in Iraq. The detachment coordinated for ISR support from a Navy SEAL element located at Tactical Assembly Area al-Qaim. The SEALs maintained control of the ISR platform but provided scans in support of ODA 5131 priorities.

Relations with the SEAL element also led to tactical support from Task Force Thunder, the French field artillery task force also located at Tactical Assembly Area al-Qaim. Aside from language barriers, two challenges arose during fires planning. First, cross-border fires from Iraq into Syria had never been requested before and required approval. Second, the employment of French 155-mm howitzers required both French and U.S. rules of engagement.

To deny the Islamic State the use of the extensive wadi system that paralleled the Syria-Iraq border, the detachment provided the French officer a series of linear targets to cover the dead space between the SDF's axis of approach and the Islamic State's employment zone. French rules of engagement required a French "red card holder" to approve the release of fires. A red card holder was required to clear (approve) all coalition fires to ensure adherence to country-specific rules of engagement.

In this case, the U.S. and coalition rules of engagement were different. The Joint Terminal Attack Controller, or whoever else was controlling the fires, had to work through the red card holder-who was located in a headquarters and watching the ISR feed - to gain permission prior to using fires against any target. French rules of engagement mandated a 30-minute ISR "soak" of the target area to verify that no civilians were present prior to approving any fire mission. Eventually, the French reduced the requirement to five minutes, a duration that can still feel like an eternity for troops in contact.

Throughout the build-up and execution of Operation Jazeera Storm, the detachment assessed the priorities and level of investment of the SDF by reviewing the manning and equipping of fighters. When the SDF prioritized a mission, they employed experienced, primarily Kurdish fighters. These fighters were well equipped with several magazines for small arms and "technicals" (non-standard tactical vehicles mounted with heavy machine guns). The SDF also employed armored vehicles and mine rollers to clear 
roads from improvised explosive devices. In areas of lower priority, the detachment noted younger, primarily Arab fighters who were only lightly equipped with one or two magazines and lacked heavy machine guns.

\section{Operation Jazeera Storm: containment}

After securing the border axis, ODA 5131 transferred operations along the desert and border axis to ODA 5133. The detachment briefly consolidated and reorganized before splitting again to travel north to assist ODA 5132 and other coalition partners to clear Dashisha. Once the coalition secured Dashisha, ODA 5131 transitioned back to the desert and border axis. After a four-week absence, the detachment returned to MSS Munson and re-evaluated the SDF posture along the axis. The detachment noted that the SDF had not improved their defensive fighting positions. The most remote and vulnerable positions were not easily defendable, sand berms were small with few sandbags, no trench system existed to protect against vehicle-borne improvised explosive devices, and, most concerning, many positions lacked the ability to communicate with their sector commanders.

The detachment advised the SDF on how to improve their security posture, but the sector commanders showed little interest. Instead, they focused intently on radios and installation of radio repeaters. Although ODA 5131 quickly distributed radios, the additional equipment did little to improve communications, since the radios were nearly worthless without repeaters to amplify the signal. Unfortunately, due to competing requirements elsewhere in Syria, the repeaters could not be installed. To improve defensive posture in the short term, the detachment worked with the SDF to increase the number of roving mounted patrols.

Another challenge arose when the detachment established a mortar firing position to contain and deter the Islamic State. While observing an Islamic State engagement zone and scanning for movement in the wadi system, the mortar firing position received mortar fire from a concealed enemy position. Two Special Forces soldiers and one Marine suffered injuries, ultimately requiring medevac and treatment by the Special Operations Surgical Team.

A counterfire radar identified the location of the enemy position, which was confirmed by direct observation. But with the detachment focused on escaping the impact area and treating casualties, it was incapable of returning mortar fire. The detachment requested an immediate fire suppression mission from Task Force Thunder, but the French red card holder denied the request. Without the 30-minute ISR scan to ensure no civilians were present, the French red card holder would not approve the fires.

Eventually, an AC-130 gunship arrived and eliminated the Islamic State fighters. But given the unreliability of the French artillery, the AOB repositioned a platoon of U.S. 155-mm howitzers to the border MSS, which proved invaluable to containing the Islamic State along the desert and border axis.

Throughout the planning process, one of the greatest risks to the mission was the death of a U.S. service member. This was an "advise, assist, and enable" mission, so everyone recognized that American fatalities could lead to a U.S. withdrawal. ${ }^{18}$ This influenced all planning and operations. During operations, the SDF were always in the lead.

Nevertheless, it was an active combat environment, so the risk could never be completely eliminated. Two weeks after the mortar attack, the Islamic State successfully destroyed an RG-33 (a mine-resistant ambush-protected vehicle) belonging to one of our multinational partners with an anti-tank guided missile. Luckily, no one was killed.

To mitigate risk, the detachment practiced good tradecraft by varying its departure time, mission duration, observation locations, and mortar firing positions. During the war in Iraq, some American units became too predictable, as they reportedly conducted patrols based on the hours of the dining facility. ${ }^{19}$ We sought to avoid that.

By the summer, the SDF had surrounded the Hajin Pocket. But the Islamic State still managed to communicate with the outside world, receive supplies, and smuggle people through the gaps in the 
encirclement. Slowly, with effective intelligence analysis, the detachment began to identify locations where the Islamic State managed to slip through. One evening, prior to nightfall, the SDF reported significant vehicular movement at a suspected front crossing point. The detachment responded, establishing a mortar firing position and two observation positions and employing ISR to observe the area. As the detachment established its positions, the SDF engaged a large group of dismounted Islamic State fighters. ODA 5131 maneuvered quickly to support the SDF with direct and indirect fires.

Timely and accurate SDF reporting resulted in a direct engagement, with the U.S.-supported SDF killing approximately 30 Islamic State fighters who were actively trafficking across the front. After a similar incident two days later, the detachment provided the SDF with hundreds of meters of concertina wire to create obstacles along known crossing points and hinder Islamic State access to dead space.

\section{ODA 5132: reconnaissance, wide area disruption, defense, and clearing operations}

\section{Captain Bert Pedrigi, commander of ODA 5132}

ODA 5132 was tasked to contain the Islamic State within the Dashisha pocket until clearing operations commenced. The detachment was responsible for the northernmost portion of the AOB's sector, basing from MSS Phenix, northeast of the town of Shaddadi. The detachment spent the first few weeks validating its assessment of the front and meeting with SDF commanders. It was crucial to gather this information to ensure the detachment's efforts and future operations were nested within the overall campaign plan. As the detachment completed its validation, it started to develop courses of action on how to efficiently and effectively accomplish its mission.

Known Islamic State positions were approximately 7 to 10 kilometers from the SDF positions along the front, yet the SDF lacked permission to conduct offensive operations until forces had repositioned from Afrin. As a result, the detachment could not consistently pressure, actively target, or disrupt Islamic State activities. Depending on the allocation of assets, the detachment maintained a 24-hour ISR tactical controller at a strike desk to maintain surveillance, target acquisition, characterize villages within the Dashisha pocket, and sustain situational awareness on Islamic State activity. The detachment conducted limited airstrikes, but without ground operations, the airstrikes alone could not disrupt the enemy.

Lacking the ability to conduct offensive operations, the detachment planned and conducted disruption operations: "a tactical mission task in which a commander integrates direct and indirect fires, terrain, and obstacles to upset an enemy's formation or tempo, interrupt his timetable, or cause enemy forces to commit prematurely or attack in a piecemeal fashion." 20 This involved crossing the front and getting within direct fire range of known Islamic State locations.

The cross-front movement and destruction of cache sites and defensive battle positions were designed to disrupt the Islamic State. During planning, it was important to understand, in detail, areas within Islamic State-controlled territory where civilians lived so that civilian casualties could be minimized. This was achieved by requesting additional ISR assets and maintaining a detachment member on the strike desk to identify and record all observed activity.

The SDF commanders wanted to clear the pocket and discussed the situation with the detachment. Using intelligence assessments, targeting locations were prioritized prior to resuming offensive operations. The detachment also attempted limited deception by employing attack helicopters to clear known and suspected Islamic State improvised explosive device locations in areas where we planned to launch the offensive as well in other areas, to confuse Islamic State fighters as to where the primary attack would 
originate. The deception worked, as they repositioned high-value weapons systems to the areas where the deception operations occurred.

As deliberate planning continued for cross-front operations - consisting of mortar "raids" and reconnaissance missions - the detachment integrated its newly assigned Marine Corps mortar men by conducting battle drills and rehearsals to ensure the combined element was synchronized. Integration began as soon as the attachment arrived and was maintained throughout the entire deployment. Rehearsals and standard operating procedures would ultimately save lives.

\section{Disruption vignette}

In May 2018, after developing a plan and conducting rehearsals, our detachment conducted a cross-front operation. The plan was to establish a $120-\mathrm{mm}$ mortar firing point at the edge of the front, followed by the employment of a forward mortar firing point with an 81-mm mortar tube approximately 3 kilometers in Islamic State territory and a forward observer element that was 1 kilometer deeper. The forward observer element, operating from two vehicles, would consist of me, my Joint Terminal Attack Controller, some other American soldiers, and our SDF partners.

The operation started as planned. We established both mortar firing positions without incident. Soon, we received intelligence that the Islamic State was monitoring the movement of our forward observer element. We subsequently identified Islamic State fighters, vehicles, and weapons in locations corroborated through multiple reports and ISR platforms. We started to engage the Islamic State targets with both direct and mortar fire, while I worked with the Joint Terminal Attack Controller to integrate close air support.

As we were working with a red card holder to approve an airstrike, Islamic State fighters struck the other vehicle with an anti-tank guided missile, injuring the U.S. driver, gunner, and two passengers. The gunner and two passengers suffered only minor injuries, and they continued fighting, but the driver was seriously wounded

The gunner continued to engage Islamic State positions, while the passengers immediately started treating the driver. I moved our vehicle closer to theirs and tasked the Joint Terminal Attack Controller to utilize the fixed-wing aircraft overhead to do a "show of force" to intimidate our enemy. I also began to call in a 9-line medevac to evacuate the driver. ${ }^{21}$ Rather than dropping bombs, we had to settle for having the aircraft drop altitude and overfly the enemy positions as a "show of force" until the red card holder could approve the strike mission. The Islamic State also fired mortars at our location, with some landing as close as 20 meters away but none inflicting any injuries.

As the commander, I had to resist the urge to directly help with the care of the driver, as it was far more important for me to maintain command and control and get the medevac helicopter to our location. But I had unwavering trust in the individuals with me, and I knew the driver was getting the care he desperately needed.

After a few minutes, we abandoned the destroyed vehicle, loaded everyone on the remaining vehicle, and evacuated the driver to a secure location behind the SDF front. The driver was then transported by helicopter to the forward surgical team located with the AOB. ${ }^{22}$ I have no doubt that the rehearsals and shared understanding of standard operating procedures saved the life of the driver. Everyone reacted immediately, knew how to help, and knew what to do next to ensure he was transported as fast as possible. No matter the attachment, enabler, or partner, early integration into the team is vital to the mission success and soldiers' lives.

\section{The strategic corner vignette}

During disruption operations, there were three instances when the detachment had to respond to PRF aggression at the strategic corner. On each occasion, the detachment rapidly moved from our MSS to the strategic corner, two hours to our south, to reinforce SDF and coalition positions. 
In one particular case, the SDF reported PRF units engaging their positions, but due to chaotic partner force reporting and lack of clarity from unorganized ground forces, U.S. forces could not immediately assist with lethal strikes, as coalition commanders were unable to distinguish PRF from SDF. Within minutes, the detachment was tasked to identify and occupy a position near the SDF battle positions, link up with SDF commanders, delineate and accurately portray where PRF units and SDF units were located, and immediately report to the AOB to facilitate a potential strike on PRF units to deter further movement into SDF-controlled territory.

Within 30 minutes, the detachment started movement. Once in the general area, we confirmed their position and coordinated with SDF liaisons to facilitate the linkup with the local SDF commander. Within 15 minutes of arrival, the commander was at our location. Since the detachment was operating in the northeast, I had never met the commander. He was visibly upset and overwhelmed and immediately started yelling at me. I was instantly thrust into a heated conversation about why the United States was not assisting the SDF and how SDF soldiers were dying because of our lack of action. I was able to calm tensions and explain that I recently arrived to provide support but that support required detailed information on the location of his forces so that coalition forces would not strike the wrong target.

As soon as he realized I needed information to support him and his soldiers, he immediately called his front commanders to get reports and provide us an accurate picture of SDF locations. I also informed him to have all SDF soldiers remain in their confirmed locations, as that would assist us in distinguishing forces through ISR. While maintaining a calm demeanor, explaining my intentions and requirements clearly, we were able to develop a shared understanding as to why this information was so crucial. Once we obtained the requisite information and I was confident in it, I relayed the information to our AOB, which coordinated an airstrike that ultimately stopped the PRF attack.

After this incident, four more battalion-level SDF commanders, along with the regional SDF commander, arrived to question our interests. The SDF commanders were upset due to the length of time required to strike the PRF, as they believed this delay led to the deaths of multiple SDF soldiers. While I could not refute the claim, I had to convince them that protecting the SDF was in U.S. interests and explained that we did not want to strike the wrong positions and inadvertently kill SDF soldiers, which had happened in the past. This conversation lasted for over an hour and became tense at times.

I made several efforts to maintain rapport and credibility. This included demonstrating empathy toward their loss, acknowledging the delay of action, and continuing to explain that the SDF had the full support of the United States. Had I insisted on making excuses, it likely would have negatively impacted our relationship and U.S. interests in the region. In the end, we maintained a positive relationship with the SDF and came to understand the requisite information to receive more timely support.

\section{Offensive operations}

As offensive operations to clear Dashisha neared, the detachment continued to develop the plan with SDF commanders. The plan constantly changed based on available assets and Islamic State activity. The SDF regularly repositioned forces in anticipation of the operation. Despite our recommendations, the SDF commanders decided to clear from north to south. We had conducted multiple operations in the north to deceive the Islamic State into thinking the attack would commence from the north, so we had recommend attacking from the south.

The SDF also decided to establish a second command and control node, which we assessed as unnecessary. This entire process was frustrating, but at the end of the day, the detachment positioned itself in the best locations to support the partner force. We provided a forward element to control the 120 -mm mortars and close air support, and we co-located an element with the senior SDF commander to refine their plan and provide a 24-hour strike desk to conduct strikes in support of the clearing operations. 
In addition to concurrent planning with the SDF, the detachment also worked with other coalition partners. They brought capabilities that proved vital for intelligence collection and linguistic capability: one team leader was fluent in French, English, and Arabic. Nevertheless, working with coalition partners also brought challenges: the most significant was incompatible technology. Our coalition partners used a different system to battle-track and report to the $\mathrm{AOB}$, despite being required to report the exact same way. To fix this, the AOB resourced them with commercial off-the-shelf equipment.

During clearing operations, I spent a majority of my time at the SDF headquarters, talking with the SDF commander and the forward element. I also prioritized reporting to the AOB to ensure they had an accurate picture of the battle. Prior to conducting operations, I emphasized three priorities to the detachment: efficiency, effectiveness, and transparency. Transparency proved to be essential, as many requests for information came from a multitude of coalition units. Having the information up front was key to ensuring the forward element could focus on the fight.

When I was with the forward element, I spent a majority of my time with the front commander who controlled the maneuver elements. I advised him on how to conduct his operations and lethal strikes in support of the operations and ensured proper battle tracking. All lethal activities had to be deconflicted to avoid any friendly fire incidents. This required a great deal of tactical patience, but it paid dividends. As the SDF cleared the Islamic State from the Dashisha area, we did not inflict any friendly fire casualties on our SDF partners.

\section{CAT 613: governance and influence in irregular warfare}

\section{Captain David P. Kearns, commander of CAT 613}

CATs are a critical part of the Army SOF enterprise and are responsible for conducting civil affairs operations:

Actions planned, executed, and assessed by civil affairs forces that enhance awareness of and manage the interaction with the civil component of the operational environment; identify and mitigate underlying causes of instability within civil society; or involve the application of functional specialty skills normally the responsibility of civil government. ${ }^{23}$

The teams are often charged with supporting a breadth of operations, including shaping, combat, and stability operations. Given the small size of civil affairs elements in a given area of operations - in this case, two to three teams consisting of four soldiers each-a CAT must be prepared to support these various operations across a large geographical space, often simultaneously.

This section provides an example of how CATs wield influence and utilize civil affairs operations to support broader military objectives. Specifically, it will cover the use of civil affairs operations during offensive and stability operations. Moreover, it will discuss the importance of consolidating gains, which is critical to turning tactical success into victory at the operational and strategic levels.

\section{Task organization}

When CAT 613 arrived in Syria, the team was immediately paired with a tactical psychological operations team. In addition to allowing the team to meet the minimum force requirement of six U.S. personnel for operations outside of a firebase, this pairing enabled coordination and synchronization of all aspects of 
governance, information, and influence capabilities toward the campaign. The team consisted of six U.S. personnel: four civil affairs soldiers (team leader, team sergeant, civil reconnaissance soldier who also served as our lead engineer and communicator, and medic) and two psychological operations soldiers.

Additionally, the team frequently collaborated with other elements, including ODAs; EOD teams; foreign SOF elements; and a variety of other joint, interagency, inter-organizational, and multinational partners to leverage the appropriate personnel and capabilities. Finally, the SDF assigned two liaisons to the team, who were responsible for facilitating the team's movement and operations.

CAT 613 was responsible for the northern half of the AOB's sector, which included the northern half of Dashisha (see Figure 24.4). This area of operations encompassed portions of what the Syrian Kurds consider their traditional homeland, areas that had been liberated from the Islamic State years prior, areas that had only recently been liberated, and areas still under Islamic State control. This required the team to split its efforts between supporting offensive operations while simultaneously leading stability operations. The team primarily partnered with local civil councils, while the tactical psychological operations team mentored and supported local and regional media cells responsible for providing information support to both the civil councils and the SDF.

The AOB designated the combined civil affairs/psychological operations teams as the primary maneuver element in the Green Blob and made them responsible for leading efforts to consolidate gains. Impending offensive operations, however, competed for the team's limited capacity and led to a big decision: how and when to allocate efforts (people, time, equipment, funds, and other elements) across a large area in support of both offensive and stability operations.

\section{Civil Affairs in support of offensive operations}

CAT 613 participated in the planning, execution, and transition to offensive operations in Dashisha. Prior to the operation's start, the team participated in the AOB planning while simultaneously preparing the environment for the clearing operation. The team adopted an "outside-in" approach; rather than focusing exclusively on the areas within Islamic State control, the team focused on the recently liberated areas along the periphery. The team sought to ensure that these areas could both absorb the massive influx of people (internally displaced persons as well as fleeing Islamic State fighters and their families) and extend influence, especially security and governance, into enemy-held territory.

As the operation drew near, the team deliberately focused on preparing the surrounding civil councils and population centers to incorporate liberated villages and populations, including preparing them for the expected food, water, and medical requirements. Additionally, the team established relationships with other U.S. government agencies and non-governmental organizations to coordinate efforts.

Working with the SDF, the team identified several active and potential crossing points along the front line and helped establish permanent and mobile screening sites. This allowed the team to improve security while gaining access to civilians who had been under Islamic State control. The information collected at these sites increased operational understanding within Islamic State-held territory, helped the AOB refine its ground tactical plan, and hastened transition to stability operations. The sites also allowed the attached psychological operations team to disseminate messages by using local civilians crossing into enemy-held territory to spread information among the populace.

Once the SDF's clearing operation began, the team transitioned to a follow-and-support role, following roughly 36-48 hours behind and conducting civil reconnaissance and civil engagement in newly liberated areas. This allowed the team to gain the most updated understanding of the situation, both in liberated and enemy-held areas, and bring resources to help consolidate the SDF's gains.

During this time, the team worked closely with the civil councils, the U.S. Agency for International Development, and several local non-governmental organizations to extend the reach of governance and essential services (which consisted primarily of humanitarian aid in the early phases) to the newly liberated 
Anthony Messenger et al.

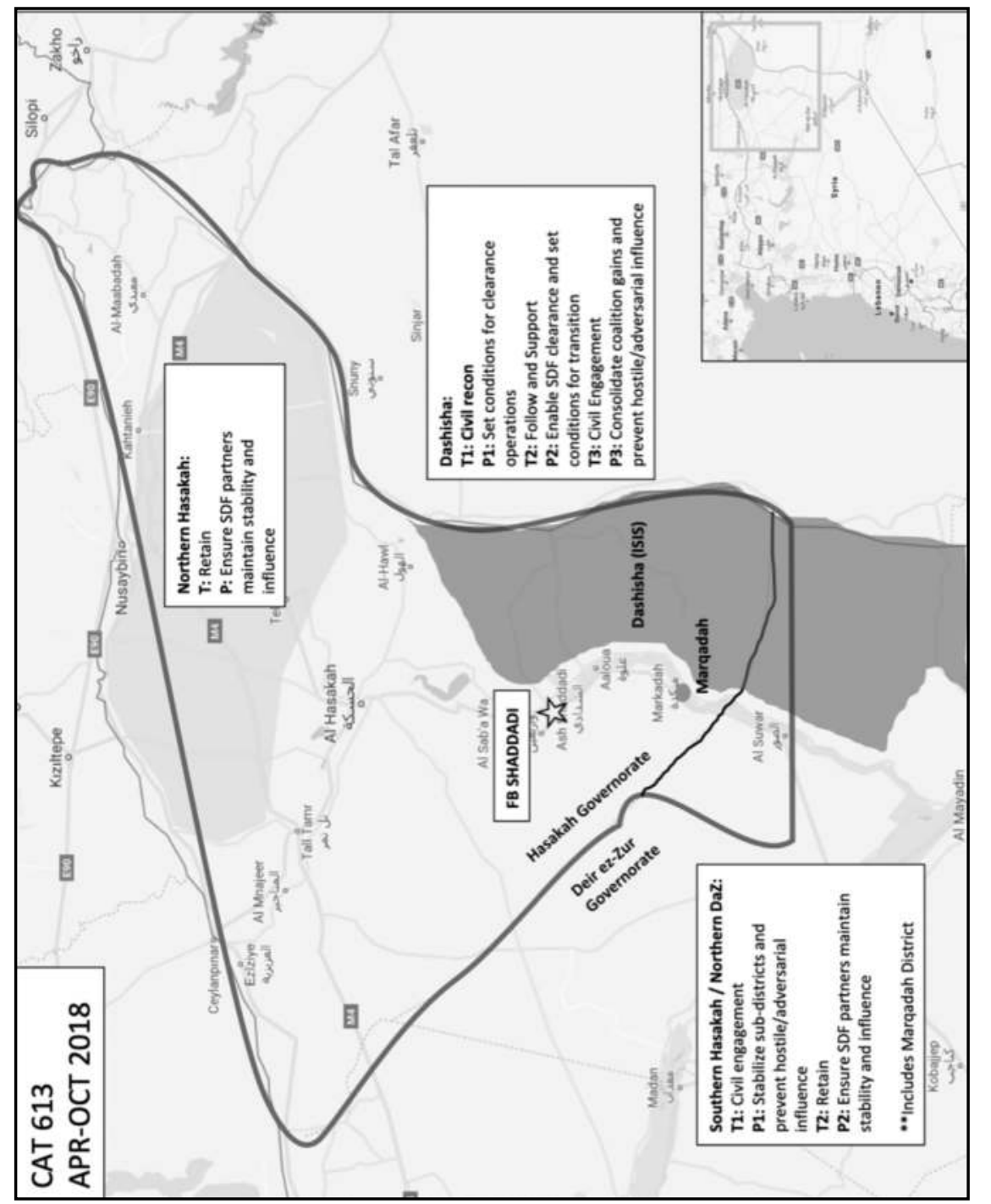

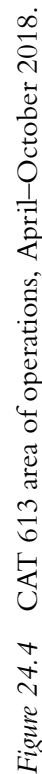


region. Although this improved the lives of those who had recently been under the control of the Islamic State, the primary purpose was to quickly stabilize the area under SDF control.

Numerous factions competed for influence and control in the region, which was historically undergoverned. The Syrian regime, Russia, Iran, and Iraqi Popular Mobilization Units all had, or desired, some degree of influence in Dashisha, and it was crucial for the SDF to be the first to establish control in the newly liberated area. Having governance, security, and humanitarian aid ready for injection into the vacuum was critical to ensuring the Islamic State could not return and other adversarial actors could not fill the gap they left behind.

Once the clearing operations completed, the team began transitioning to stability operations. In some cases, this transition occurred while offensive operations continued deeper in the enemy-held pocket. During this phase, the team, using the information gained while conducting civil reconnaissance, worked with the adjacent civil councils to create lasting security, governance, and stability in the area. While the first two phases of the clearing operation - preparation and execution - were heavily focused on the "outside" portion of the "outside-in" approach, stability operations were primarily focused inside the former Islamic State pocket.

During this time, the team and its partner force began work to establish new civil councils, transitioned from short-term humanitarian aid to longer-term stability assistance (e.g., clinics, bridge repairs, water infrastructure), and, alongside an ODA, began working with the force that would be responsible for securing the area, including the border with Iraq.

\section{Governance and influence in support of stability operations}

One particular district within CAT 613's responsibility, Marqadah, was liberated from the Islamic State in November 2017. After liberation, recovery of the district, including its administrative center, had stagnated as the counter-Islamic State offensive redirected resources elsewhere.

Six months later, when CAT 613 arrived, Marqadah showed little sign of progress: rubble, closed stores and clinics, and old and new Islamic State graffiti were easily visible throughout the towns. In line with its outward appearance, both the SDF and the locals claimed that Islamic State "sleeper cells" were prevalent throughout the area, threatening those who worked with coalition forces, attacking isolated SDF checkpoints, emplacing improvised explosive devices, and reporting on SDF and coalition movements-a particular problem given the upcoming offensive operations in Dashisha and Hajin.

Furthermore, established governance did not yet exist, which left a vacuum easily exploitable by hostile and adversarial actors. Although the SDF had seized the district with SOF support, it was clear that we had not yet consolidated the gains. The area remained unstable and rife for exploitation, civilians were scared and unwilling to hedge their bets on the coalition, and the Islamic State maintained the ability to disrupt future military operations. Having identified these issues, the team, working with multinational partners, planned and executed stability operations to create enduring security and governance in the area.

The initial priority for the team was to work with the provincial council to establish a plan for stability operations in the district. The team emphasized the need for the council to increase prioritization and resources for the area. At the time, the provincial council was governing remotely, having only recently established an "Emergency Services Committee" that was responsible for laying the groundwork for governance in the area. This body was both geographically and demographically separated from the population, as it was composed of Kurds and Arabs from towns further north. The council had a plan for the district, but for a variety of reasons - including a lack of funding and resources - it was not moving quickly.

The team began working closely with the members of the Emergency Services Committee to implement their governance and stability plans. The committee would serve as the primary executors while the team helped to provide the needed funding, resources, and security mechanisms. To support the process, the team established inroads into the local tribes-an effort the SDF and councils were often hesitant to 
do-to maximize local knowledge and ensure all key influencers were involved in the process. Ultimately, all parties agreed to expedite the establishment of a Marqadah Civil Council, which stood up approximately four months later.

The team implemented several projects and programs, alongside the civil council and SDF, to ensure security and enhance stability in the district. Unlike the team's initial projects during offensive operations, which primarily consisted of satisfying the immediate humanitarian assistance needs of the population, the activities in this district were all focused toward achieving enduring stability effects. They included renovating the council's headquarters, establishing a clinic, delivering potable water, and providing heavy equipment for rubble removal.

Additionally, the attached psychological operations team worked with the SDF to identify and remove Islamic State graffiti throughout the district. Finally, both the CAT and one ODA worked extensively with the local SDF to provide security for the region-including conducting combined presence patrols-to build their capacity and increase local confidence in the SDF and civil council. Whatever the project, program, or activity, the goal was to establish conditions favorable to U.S. and partner force interests and shape the environment to be untenable to hostile forces and adversarial actors.

\section{AOB lessons learned}

\section{Emphasize mission command}

Mission command is the Army's philosophy of command and control. It is built on trust, communicating clear commander intent and shared understanding of the end-state. ${ }^{24}$ The AOB executed successful mission command by ensuring all of the detachments understood the big picture and how they contributed to it. The AOB commander conducted video teleconferences five times a week, and the detachment commanders communicated directly for issues that crossed their sectors and shared resources to achieve the mission.

The video teleconference forced all players to talk about developments in their respective areas of operation. This, in turn, facilitated cross-talk and created a shared understanding among the various elements under the AOB umbrella. Shared understanding created the conditions for mutual trust. Trust is the bedrock that drives successful operations and enables decisions to be pushed down to the lowest level, which creates strategic effect.

\section{Big tent leadership makes effective teams}

The AOB did not have the luxury of conducting pre-mission training with all its supporting assets (artillery or medics, for example); the first time it saw many of these assets was when it conducted the relief in place with the previous $\mathrm{AOB}$. Thus, the $\mathrm{AOB}$ had to quickly incorporate these elements, which constituted close to $75 \%$ of the AOB's in-country personnel, into the team. As a part of relief in place and throughout the deployment, the AOB and its detachments conducted training with the elements to ensure everyone understood how to fight together.

\section{ODA lessons learned}

\section{Find opportunity in chaos}

The SDF's pivot toward Afrin completely derailed offensive operations. SDF partners were frustrated and upset that coalition forces would not intervene in Afrin to counter Turkish aggression and protect Kurdish families. In the midst of emotional turmoil and rough relations at the tactical level, including an incident where a Kurdish soldier threatened a detachment member, the detachment managed to take advantage of 
the tactical pause to consolidate previous gains and prepare for future offensive operations. Establishing a base the size of Green Village is not an easy task for a detachment, but the tactical pause allowed for a deliberate occupation and expansion that facilitated successful offensive operations. There is opportunity in chaos-even if it is just a tactical pause.

\section{Know the limitations of allied and partner forces}

The ultimate purpose of the detachment's varying missions was to destroy, or set conditions to destroy, the Islamic State's self-proclaimed caliphate. When conducting operations with allied or partner forces, even straightforward purposes often disintegrate into a murky pool of competing objectives, restrictive rules of engagement, and diverging tactics. To overcome the most ambiguous situations, commanders must understand and accept that partners may have a different way of operating and must have a thorough understanding of their partner's capabilities, limitations, restrictions, and desired end state.

\section{Constantly assess}

Partner force assessments should be conducted continuously and require an active effort to execute properly. Assessing a culminating exercise or event is an initial, not a final, assessment. They should occur more often, during less glamorous activities. Simple observations - such as how many fighters were in a defensive position, the ethnicity of fighters, the age of fighters, and type of weapons present-indicated the priority the SDF placed on different locations or missions. A small change from eight fighters per position to six may seem small, yet when multiplied across 100 positions, that seemingly insignificant change indicated a significant reprioritization.

\section{CAT lessons learned}

\section{Irregular warfare is about influence}

Joint U.S. doctrine defines irregular warfare as "a violent struggle among state and non-state actors for legitimacy and influence over relevant population(s)." ${ }^{25}$ It is more than "hearts and minds." Real influence is about successfully mobilizing a population in your desired direction. This requires creative application of lethal and non-lethal capabilities at the tactical and operational levels. It also requires participants to leverage the knowledge and capabilities of people and organizations outside of the direct chain of command, including members of other U.S. agencies, foreign governments, non-governmental organizations, local security forces, and civilians. Lethal and non-lethal efforts should always be mutually supporting, with a goal of influencing all relevant actors.

\section{Consolidate gains}

Consolidating gains translates short-term tactical and operational achievements into enduring conditions consistent with the desired end state. It is also one of the most challenging components. To succeed, leaders must re-evaluate their focus and priorities throughout the operation.

In Syria, successful clearing operations did not mean the work was complete in liberated areas; the Islamic State still maintained an underground presence, and significant threats to stability remained. As a result, the ultimate end state had not been achieved. CAT 613 applied the "outside-in" approach to consolidate gains. This involved focusing more attention on the liberated areas than the Islamic State-controlled areas. Not only did this help to establish desired conditions in the "green" (friendly-controlled area), but it also had the natural effect of supporting operations in the "red" (enemy-controlled area). This helped 
hasten the consolidation of gains in new areas because it positioned partners to project influence before, during, and after offensive operations. Regardless of the method, consolidation of gains is a military necessity. It is the only way to tie a series of winning battles into a winning war.

\section{Understand how a partner force operates: do not try to mirror image}

When conducting irregular warfare, indigenous partners bring a level of local knowledge and networks that far exceed the advising force. Often, they have been fighting for years or decades. It is probable that they have already developed their own way of doing business (fighting, governing, and messaging). The goal is to influence their behavior, as opposed to completely revamping their methods.

In Syria, the governing structures, networks, relationships, and underlying ideologies were set in place long before the civil war began. CAT 613's job was to assist the SDF in improving their legitimacy while simultaneously influencing their behavior to more closely align with U.S. interests. Rather than overhauling their systems or methods, the CAT tapped into their existing knowledge and structures while providing them the necessary resources, much of which they lacked. The mutually beneficial nature of the relationship helped the CAT to focus its partnership toward its shared end state. That said, the CAT's ability to provide something that its partners needed and lacked (funding and resources) gave it leverage, enabling the CAT to wield influence. In irregular warfare, influencing partners is as important as influencing the population and the enemy.

\section{Notes}

1 Operation Inherent Resolve was the U.S. military's operational name for its mission to defeat the Islamic State.

2 "Timeline: The Rise, Spread, and Fall of the Islamic State," Wilson Center, October 28, 2019, www.wilsoncenter. org/article/timeline-the-rise-spread-and-fall-the-islamic-state.

3 ODAs are also known as Special Forces A Teams or detachments. A detachment consists of 12 Special Forces soldiers, or "Green Berets": the commander (an officer), an assistant detachment commander (a warrant officer), a team sergeant, an intelligence sergeant, two weapons sergeants, two engineering sergeants, two communications sergeants, and two medical sergeants.

4 Rukimini Callimachi, "Fight to Retake Last ISIS Territory Begins," New York Times, September 11, 2018, www. nytimes.com/2018/09/11/world/middleeast/isis-syria.html.

5 Map created using Google Maps.

6 An enabler is "an organization or capability that supports a particular [course of action] and/or accomplishment of a particular objective." In this case, artillery and other elements were enablers that supported the AOB and its mission to defeat the Islamic State. See Colin Marcum, "How Enablers Shape the Deep Fight for the BCT," Fires (March-April 2017).

7 Anne Barnard and Hwaida Saad, "Raqqa, ISIS 'Capital,' Is Captured, U.S.-Backed Forces Say,” New York Times, October 17, 2017, www.nytimes.com/2017/10/17/world/middleeast/isis-syria-raqqa.html.

8 "Russia: Syria Government Forces Now on East Bank of Euphrates River," Reuters, September 15, 2017, www. reuters.com/article/us-mideast-crisis-syria-euphrates/russia-syria-government-forces-now-on-east-bank-ofeuphrates-river-idUSKCN1BQ2FQ.

9 Zeynep Yekeler, Understanding Turkey's Afrin Operation (Washington, DC: Center for Strategic and International Studies, 2018).

10 Liz Sly, "Kurds Pull Back From ISIS Fight in Syria, Saying U.S. 'Let Us Down', Washington Post, March 6, 2018, www.washingtonpost.com/world/kurds-pull-back-from-isis-fight-in-syria-say-they-are-let-down-by-us/ 2018/03/06/3fd2c2ca-2173-11e8-946c-9420060cb7bd_story.html.

11 Thomas Gibbons-Neff, "How a 4-Hour Battle Between Russian Mercenaries and US Commandos Unfolded in Syria," New York Times, May 24, 2018, www.nytimes.com/2018/05/24/world/middleeast/american-commandosrussian-mercenaries-syria.html.

12 MREs, or meals ready-to-eat, are self-contained, individual field rations packaged in small plastic bags.

13 The artillery platoon was deployed to a static location without its trucks, making shooting and moving very difficult. The AOB operations sergeant was tasked with finding the equipment to move the artillery after shooting counterfire and around the battlefield to best support the operations. 


\section{Defeating the Islamic State}

14 The golden hour is the hour immediately following traumatic injury in which medical treatment to prevent irreversible internal damage and optimize the chance of survival is most effective.

15 Map created using Google Maps.

16 Ibid.

17 Contain is "a tactical mission task that requires the commander to stop, hold, or surround enemy forces or to cause them to center their activity on a given front and prevent them from withdrawing any part of their forces for use elsewhere." Containment allows an enemy to reposition within the designated geographical area, whereas fixing an enemy does not. Geographic terms or time may express the limits of the containment. See Department of the Army, Terms and Military Symbols, ADP 1-02 (Washington, DC: Department of the Army, 2018), 1-22.

18 Eric Schmitt, Ben Hubbard, and Rukmini Callimachi, "ISIS Attack in Syria Kills 4 Americans, Raising New Worries About Troop Withdrawal," New York Times, January 16, 2019, www.nytimes.com/2019/01/16/world/ middleeast/isis-attack-syria-troops.html.

19 Brandon Colas, "Game Theory, Predictability and Route Selection,” Infantry 98, no. 3 (2009): 14-15; Liam Collins, e-mail to co-author, October 2, 2020.

20 Department of the Army, Terms and Military Symbols, 1-32.

21 A "9-line" MEDEVAC request is a standardized report to simplify and communicate injuries and pick up site information to facilitate rapid medical evacuation. See Eric Sof, "What Is a 9-Line MEDEVAC and Easy Procedures to Call It," Spec Ops, March 25, 2020, https://special-ops.org/what-is-a-9-line-medevac-and-how-to-properly-call-it/.

22 All individuals have since recovered from their injuries.

23 Department of the Army, Terms and Military Symbols, 1-16.

24 Department of the Army, Mission Command, ADRP 6-0 (Washington, DC: Department of the Army, 2012).

25 Joint Chiefs of Staff, Special Operations, JP 3-05 (Washington, DC: Joint Chiefs of Staff, 2014), II-1. 
- Taylor \& Francis

Taylor \& Francis Group

http://taylorandfrancis.com 


\section{PART III}

Government instruments in countering terrorism and waging irregular warfare 
- Taylor \& Francis

Taylor \& Francis Group

http://taylorandfrancis.com 


\title{
25 \\ THE JOINT TERRORISM TASK FORCE
}

\section{Investigating to disrupt and prosecute terrorists}

\author{
Ali Soufan
}

For years, military and civilian national security experts have called for a "whole-of-government approach" to fighting terrorism. ${ }^{1}$ The Joint Terrorism Task Force (JTTF) represents by far the most successful model for such an approach. The original JTTF, established in New York City in 1980, now brings together agents and officers from more than 50 U.S. intelligence and law enforcement organizations, as well as representatives from the equivalent agencies of America's staunchest allies overseas.

The New York JTTF has successfully investigated hundreds of cases, ranging from the 1993 World Trade Center bombing to the attack on the U.S. Consulate in Benghazi in 2012. The model pioneered in New York has been replicated elsewhere with comparable success; JTTFs now exist in nearly 200 cities in the United States, with hundreds of participating state, local, and federal agencies. ${ }^{2}$ The key to the JTTF's accomplishments lies in its seamless blending of apparently disparate resources, talent, and connections focused on a common purpose. Regardless of his or her parent agency—be it local, state, or federal—each officer and agent of the JTTF enjoys the same status within the organization.

Throughout its history, the men and women of the JTTF have made it their business to insist upon the highest standards of investigative integrity, embodied in the tried and true methods developed by the United States over generations in both military and civilian settings. Even after the worst attack on the U.S. homeland since Pearl Harbor, JTTF operatives refused to violate the Constitution, evade U.S. law, or turn to the exotic means of interrogation that unfortunately led some of their parent agencies astray. In the years immediately following $9 / 11$, this proved a hard line to maintain, but in hindsight, the record vindicates this rigorously constitutional approach.

This chapter outlines the history and achievements of the New York JTTF. It is a story that encompasses some of the biggest terrorist investigations of the past 30 years. As a result, the activities of the JTTF represent a fascinating lens through which to view the ongoing war against terrorism.

\section{The blind sheikh cell}

During the 1970s, the Federal Bureau of Investigation (FBI) and the New York City Police Department (NYPD) frequently found themselves running parallel investigations targeting terrorist groups such as the anti-Castro Omega 7, the anti-Yugoslav Croatian National Resistance, and the remains of left-wing extremist outfits like the Black Panthers and the Weather Underground. With so much criminal activity of local, national, and international concern occurring around New York City, jurisdictional rivalries sometimes became heated. 
Neil Herman, then a young FBI agent stationed in New York, recalled seeing police officers and FBI agents "almost come to blows over witnesses, crime scenes, and evidence collection." 3 The final straw came in 1978, when NYPD officers and FBI agents disputed access to a bomb factory run by Puerto Rican nationalists. In response, the FBI and the NYPD agreed to create a new joint unit that would initially bring together 10 agents and 10 detectives. The JTTF was born.

Throughout the 1980s, the JTTF successfully investigated domestic militants and the bank robberies that financed their activities. It was not until 1990 that the unit received its first major case with direct ties to the Middle East. Meir Kahane, the Israeli-American leader of the extremist Jewish Defense League, was assassinated in the ballroom of a Marriott hotel on Lexington Avenue in New York City. ${ }^{4}$ The perpetrator, arrested shortly thereafter, was an Egyptian-born U.S. permanent resident named El Sayyid Nosair, a follower of the extremist cleric Omar Abdel Rahman. ${ }^{5}$

The "blind sheikh," as Abdel Rahman was known, had once shared a jail cell with future al-Qaida leader Ayman al-Zawahiri. By the time of the Kahane assassination, Abdel Rahman had relocated to New York City, where he preached violence against the West from the pulpits of hardline mosques. ${ }^{6}$

Nosair's connections to extremism did not stop there. He had also worked at the Afghan Services Bureau (Maktab al-Khidamat), an organization originally set up by Usama Bin Ladin and others to channel funds to foreign fighters battling the Soviet Union in Afghanistan. Prior to Kahane's murder, a JTTF team had photographed Nosair and around a dozen others undergoing firearms training at a Long Island range. A raid on Nosair's apartment in Jersey City turned up a cornucopia of evidence, including bomb-making manuals, surveillance notes from prominent sites like Times Square and the World Trade Center, and a manifesto urging the destruction of the "tall buildings of which the Americans are so proud."

Most alarmingly of all, Nosair had somehow amassed a cache of military documents, including confidential messages to the Joint Chiefs of Staff. It would eventually become clear that a U.S. Army officer, Ali Mohammed, had been passing the secret documents to Nosair and other members of the blind sheikh's network. ${ }^{8}$ JTTF investigators soon realized that the cell around Rahman was financed via bank robberies carried out by a group of radical African American Muslims - the self-styled "Forty Thieves"-who worshipped at the same mosques as Nosair's Arab associates. ${ }^{9}$

There was compelling evidence of a potential terrorist conspiracy extending well beyond Nosair. Prosecutors, however, were not interested. They saw this wider political angle as introducing an unnecessary level of complication into what, in their eyes, ought to have been an open-and-shut murder case. The conspiracy angle was quickly shut down. The "Forty Thieves" aspect of the case was removed from the JTTF's jurisdiction and handed over to a sister unit, the Bank Robbery Task Force; the separation between the two halves of the case became so absolute that when authorities caught the leader of the "Forty Thieves," the JTTF team was barred from interrogating him, thus cutting off a potential route into the blind sheikh's inner circle. ${ }^{10}$

At trial, following the logic that Nosair's actions were a clear case of murder, the prosecutor adduced no evidence of the defendant's radical beliefs. Ironically, the jury in state court found Nosair not guilty of murdering Kahane, and he was jailed only for the aggravated assault of two bystanders he had shot in the process of escaping the scene, ${ }^{11}$ although later he would be found guilty of Kahane's murder in federal court.

Meanwhile, an FBI senior manager decided to put terrorism on the back burner. In 1992, the head of the bureau's Criminal Division in New York told two JTTF leaders that terrorism was "dead" and transferred them to chasing down gang members instead. FBI brass also shut down two successive informants the JTTF had been cultivating within the blind sheikh's orbit. ${ }^{12}$ During this period, Ramzi Yousef, a fiercely ambitious Pakistani trained by al-Qaida in Afghanistan, landed in the United States and joined the cell, rising quickly to become its de facto operational leader. ${ }^{13}$ The lack of informants blinded the JTTF both to Yousef's arrival on the scene and to the deadly bomb plot that he soon hatched. 
On February 26, 1993, a van-sized fertilizer bomb exploded under the World Trade Center's North Tower, killing six people, wounding over 1,000, and gouging a hundred-foot crater through the root of the building. ${ }^{14}$ The ensuing investigation galvanized the JTTF and knit its component agencies still closer together. Agents and officers finally had the freedom and resources to clamp down on the blind sheikh's cell. One of the previously fired informants was reinstated and, wearing a wire, recorded the cell preparing for what was to have been its next move- a series of bombings at New York landmarks, including the United Nations building and the Lincoln Tunnel. ${ }^{15}$

Yousef fled the country but was later hunted down and arrested in Islamabad. ${ }^{16}$ The main conspirators all eventually received life sentences. The blind sheikh, Abdel Rahman, died of natural causes in jail in 2017 at the age of 78, while Yousef remains incarcerated at the "Alcatraz of the Rockies," the supermaximum security prison in Florence, Colorado. ${ }^{17}$

In all of the JTTF's investigations into the blind sheikh's cell, there hovered one name: Usama bin Ladin. The shadowy Saudi apparently paid for the blind sheikh to live in exile in New York and some of Yousef's plane tickets. He bankrolled Nosair's criminal defense to the tune of $\$ 20,000$, leaving it with a surplus that later helped fund the 1993 World Trade Center bombing. ${ }^{18}$ Throughout the early 1990s, Bin Ladin was viewed as a financier rather than an operational leader, but that impression began to change in November 1995 when militants trained in al-Qaida's Afghan camps detonated a car bomb in Riyadh, Saudi Arabia, killing five U.S. military personnel. ${ }^{19}$

Two months later, the Bill Clinton administration declared Bin Ladin a threat to national security and ordered intelligence and law enforcement agencies to collaborate to bring him down. In response, the JTTF established a dedicated Bin Ladin desk with six full-time investigators, who soon went to work drawing up an indictment against the al-Qaida leader.

Jamal al-Fadl, a disgruntled former associate of Bin Ladin's, aided them in this task, after he walked into the U.S. Embassy in Eritrea in the summer of 1996 offering testimony that one intelligence official would later call "the Rosetta Stone.” Al-Fadl's defection would prove timely, for in August of the same year, Bin Ladin would publicly declare war on the United States and its allies. Over the months that followed, he would repeat that threat several times before finally converting it into action. ${ }^{20}$

\section{The prelude to the $9 / 11$ attacks}

In February 1998, Bin Ladin and the leaders of four other jihadi groups issued a fatwa calling on Muslims to kill Americans. ${ }^{21}$ I was a newly qualified FBI agent at the time, one of very few in the bureau who could read Arabic. I felt strongly that Bin Ladin posed a threat to the United States, and I wrote an internal memo outlining my concerns.

The memo brought me to the attention of the FBI's counterterrorism leadership, and ultimately onto the JTTF as a new agent. Around the time I joined in May 1998, Bin Ladin gave an interview to John Miller of ABC News. ${ }^{22}$ I told my superiors that this was his third and final warning of an imminent attack. Unfortunately, my call was correct. On August 7, near-simultaneous truck bombs exploded at the U.S. Embassies in Dar es Salaam, Tanzania, and Nairobi, Kenya.

Based on the methodology used in the attacks, the stream of threats emanating from Bin Ladin, and the language used in two early anonymous claims of responsibility, my colleagues and I quickly concluded that al-Qaida was to blame. Thanks to supervision from the JTTF and other American agencies, the law enforcement investigation into the bombings was meticulous from the start. Prosecutors from the Southern District of New York flew to the crime scenes in East Africa to establish a protocol for ensuring that every piece of evidence gathered would subsequently be admissible in U.S. courts. ${ }^{23}$

Within days, a JTTF team captured one of the bombers. FBI agent John Anticev extracted from him the telephone number for an operative in Yemen responsible for connecting members to each other by phone: 


\section{Ali Soufan}

in effect, al-Qaida's switchboard operator. Other lines of inquiry led to a raid on the office of a front charity, which turned up the passports of many al-Qaida operatives used for travel in and out of Somalia. The photographs from these passports became the basis for the first al-Qaida photobook, which would prove indispensable in future interrogations. ${ }^{24}$

On November 4, 1998, based on evidence gathered by the JTTF teams, a New York grand jury indicted Bin Ladin and other al-Qaida leaders on 238 counts of conspiracy to murder Americans and attack U.S. facilities. ${ }^{25}$ This step received scant media coverage because complex court proceedings could not compete for column space with the ongoing fallout from the Clinton-Lewinsky affair, Newt Gingrich's weak showing in the midterms, and the impending impeachment of President Clinton.

More seriously, there was little chance of following up on the indictment by arresting the defendant per normal protocol. Bin Ladin had been living in Afghanistan for more than two years, and he was on good terms with his hosts, the Taliban — a regime that the United States did not even recognize as a legitimate government.

Nevertheless, the JTTF's investigation continued. One allied country that figured prominently was the United Kingdom. In London, British authorities arrested Bin Ladin's media fixer, Khalid al-Fawwaz, a key conspirator in the embassy bombings. JTTF operatives helped Scotland Yard build a case that allowed for Fawwaz's detention pending extradition to the United States. He is now serving a life sentence in an American prison. ${ }^{26}$

In cooperation with the Greater Manchester Police, the team traced another conspirator, Anas al-Libi, to Manchester, England. He was arrested, but the evidence was not yet strong enough to detain him. Authorities released al-Libi, and he predictably fled the country. ${ }^{27}$ We did, however, raid al-Libi's home, where we uncovered a document that would become notorious as the "Manchester Manual," one of alQaida's principal playbooks. ${ }^{28}$

From interrogating al-Qaida suspects, I knew the torture methods that al-Qaida members were trained to expect if captured by a dictatorial Arab government, including being sodomized by dogs and seeing their mothers and sisters raped in front of them..$^{29}$ Evidently, our enemies were being trained to resist the most horrific violence, techniques the United States would not employ. Clearly, if the U.S. government was to get useful information out of any future al-Qaida captures, it would have to use a subtler and more intelligent method.

Luckily, U.S. military and civilian investigators had already spent decades developing just such a system. I refer to it as the Informed Interrogation Approach. It has three principal facets, all derived from insights into the psychology of individuals detained for questioning.

First, the interrogator uses the detainee's feelings of sudden dislocation and isolation to become the one person to whom the detainee feels he or she can talk. This leads into the second aspect: the need the detainee then feels to build a relationship with the interrogator. Third, the interrogator must give the detainee the impression of already knowing everything there is to know about him or her, so that any lies told by the subject will be easily identified. The interrogator can unleash a barrage of circumstantial detail or mention some nugget of intimate personal knowledge — as I did once when I asked an al-Qaida suspect if I could call him by his childhood nickname.

It should be noted that this technique is not about "being nice to terrorists," as a guard at Guantanamo Bay once complained to me. On the contrary, the best interrogators build rapport with subjects to undermine their inbuilt resistance. Our adversaries had been trained to expect the worst kind of torture, so when they instead received an outward show of respect and dignity, they lacked the psychological resources to deal with it. Caught off-guard, they became more likely to cooperate.

This approach has been proven to work over many years and thousands upon thousands of interrogations; I myself have seen it in action hundreds of times. It is no accident, therefore, that the Informed Interrogation Approach bears striking similarities to the techniques mandated by the U.S. Army Field Manual. ${ }^{30}$ 
My JTTF colleagues and I soon had a chance to put these methods to use in the embassy bombings investigation. We flew to Morocco to interview a local, L'Houssaine Kherchtou, who had once served as personal pilot to Bin Ladin. Having taken the time to do the requisite research, we knew that al-Qaida had treated Kherchtou poorly. When his wife needed a cesarean section, for example, the organization refused to pay, leaving her to beg for the money on the streets of Khartoum. ${ }^{31}$

By contrast, my colleagues and I outwardly treated Kherchtou with dignity, such as eating our meals together. All the while, we used his wife's ill treatment as a lever to pry him away from Bin Ladin. Kherchtou gave us chapter and verse on al-Qaida's activities in the three years since the previous star witness, Jamal al-Fadl, had defected. Today, having provided testimony that helped convict several key embassy plotters, Kherchtou resides in the U.S. witness protection program. ${ }^{32}$

During 1999, the approach of Millennium Eve-an obvious symbolic target for any number of terrorist groups-put authorities around the world on edge. When Jordanian intelligence learned of a plot to attack U.S. and Israeli interests in their country, I was sent with a JTTF team to Amman to assist with the investigation. On the last day of November, the authorities intercepted a call from Pakistan in which an al-Qaida commander named Abu Zubaydah apparently gave the Amman cell leader the order to begin operations. With our support, the Jordanians rounded up the plotters, uncovered their hideouts and bomb factory, and foiled the plot. ${ }^{33}$

Two other millennium-related plots failed thanks more to good luck than other factors. In December 1999, border patrol agents searched a car coming off the ferry from Canada at Port Angeles, Washington, and discovered a bomb intended to be used at Los Angeles International Airport. ${ }^{34}$

On January 3, a cell in Aden, Yemen's principal port city, attempted to blow up the U.S. naval destroyer The Sullivans, only to see their boat sink under the weight of explosives packed into it. Unfortunately, the Aden cell was determined to try again. The second time, they would have more luck. On October 12, 2000, the same small boat, having been recovered and refloated, hit the hull of the USS Cole as she was refueling in Aden. Seventeen American sailors lost their lives. ${ }^{35}$

Days later, I was sent to Aden with JTTF colleagues to investigate. Our relationship with the Yemeni authorities was delicate at best. The government of Yemeni President Ali Abdullah Saleh had supported Saddam Hussein in the Gulf War, and despite the best efforts of the Clinton administration (of which the policy of refueling in Aden was a part), Yemen was not yet ready to cooperate fully with the United States.

On the drive into the city, I opted to ride with the Yemenis on their truck instead of inside an airconditioned bus, partly as a show of friendship, but also partly to keep a wary eye on them. We eventually made some good friends among the Yemeni law enforcement and intelligence community, many of whom sympathized with America's loss. Other elements would remain obstructive, and we were forced to get tougher. For example, we criticized them for bugging our hotel room and a group of us bluffed our way into a local facility to retrieve a piece of physical evidence they were hoarding.

While in Yemen, the JTTF worked hand-in-glove with the Naval Criminal Investigative Service and in particular a very talented agent of theirs, Bob McFadden. The Central Intelligence Agency (CIA) would prove less accommodating. They refused to share information relevant to the case-including evidence the FBI had originally collected and shared with them-on the basis that the FBI was a law enforcement agency under the terms of the Foreign Intelligence Surveillance Act. ${ }^{36}$ This was a misreading of the law, as the same statute also designated the FBI an intelligence agency. ${ }^{37}$ Eventually, the $9 / 11$ Commission would vindicate the FBI's position. ${ }^{38}$

Politics, too, soon reared its head. We quickly established beyond any real doubt that al-Qaida had been behind the attack on the Cole and repeatedly briefed the White House, the CIA, the Department of Defense, and other agencies. We received no response. Sandy Berger, Clinton's national security advisor, would later say that there was no consensus that al-Qaida was responsible. ${ }^{39}$ That was simply not true. The 
reality was that, with the political situation back home so precarious in the wake of the knife-edge 2000 presidential election and the court proceedings that followed, neither the Clinton White House nor its successor wanted to spend political capital going after a foreign terrorist group.

After President George W. Bush took office in January 2001, Deputy Secretary of Defense Paul Wolfowitz described the Cole case as "stale," and Secretary of Defense Donald Rumsfeld agreed that too much time had passed to take action to punish al-Qaida. ${ }^{40}$ The 9/11 Commission would later find that the lack of an adequate response emboldened Bin Ladin to carry out an even more elaborate attack. ${ }^{41}$

\section{The 9/11 attacks and the aftermath}

Despite the lack of political support back home, the frequent clashes with Yemeni and American security agencies, and the daily death threats from local jihadis, the JTTF team continued to make progress on the Cole case. We interrogated captured members of the Aden cell and once again used the Informed Interrogation Approach to convince them to reveal information. Armed with significant knowledge about the detainees, and aware that lying was a grave sin according to their version of Islam, we were able to catch small inconsistencies in their stories and shame them into providing the truth. On other occasions, we used subterfuge of our own: we convinced one plotter to reveal his alias by claiming that we had a passport of his in another name.

In the course of these successful interrogations, a Yemeni named Fahd al-Quso imparted a nugget of information that, at the time, seemed to make little sense. During the planning phase of the Cole attack, he said that he and one of the designated bombers had been tasked with carrying some $\$ 36,000$ to a senior al-Qaida operative named Khallad. The exchange of funds took place in Bangkok. ${ }^{42}$

This was puzzling. Why, at the height of planning for a high-stakes operation in Yemen, would two of the principal plotters be sent halfway around the world to deliver money to another, seemingly unconnected, cell? It suggested that an additional plot could be underway, potentially one with much greater significance to al-Qaida. We asked the CIA and National Security Agency what they knew about Khallad's activities in Southeast Asia, but they refused to share information, still acting on their mistaken view that the law did not allow it. ${ }^{43}$

On September 12, 2001, with the twin towers a burning ruin in New York City, the CIA finally shared the intelligence we had requested months before: pictures of Khallad at a meeting in Kuala Lumpur with Khalid al-Mihdhar and Nawaf al-Hazmi, two of the hijackers of American Airlines 77, the plane that hit the Pentagon. The $\$ 36,000$ delivered to Khallad by the Cole plotters had apparently been destined to pay for al-Mihdhar and al-Hazmi's first-class flights to the United States, plus other expenses. Because the CIA had failed to alert any domestic agencies, these two known terrorists were able to enter the United States, obtain driver's licenses, open credit cards, and buy tickets on Flight 77, all under their real names. One of them had left the United States and re-entered, twice, with impunity. ${ }^{44}$

It is, of course, hard to prove the counterfactual, but the 9/11 Commission found that, by March 2000, the CIA knew that al-Mihdhar and al-Hazmi held valid U.S. visas. Had the CIA shared this knowledge, alMihdhar and al-Hazmi would most probably have been arrested or placed under surveillance. At the very least, al-Qaida would have lost two members of its $9 / 11$ cell. Those two could have led us to others-in which case, there is every possibility that we could have prevented the $9 / 11$ attacks.

As the Commission wrote:

We believe that if more resources had been applied and a significantly different approach taken, Mihdhar and Hazmi might have been found. . . . Investigation or interrogation of them, and investigation of their travel and financial activities, could have yielded evidence of connections to other participants in the $9 / 11$ plot. The simple fact of their detention could have derailed the plan. $^{45}$ 
As soon as we received the Kuala Lumpur pictures, we showed them to Cole plotter Fahd al-Quso. Al-Quso immediately identified one of the participants in the meeting as yet another hijacker, Marwan al-Shehhi, the man who piloted United Flight 175 into the South Tower of the World Trade Center. Al-Quso told us that he and al-Shehhi had met at a guesthouse in Afghanistan run by Bin Ladin's former bodyguard, a Yemeni named Abu Jandal (a nom de guerre meaning "father of death"). At that moment, Jandal just happened to be in the custody of the Yemeni security services. We demanded that Jandal be brought to us immediately.

Together with Bob McFadden of the Naval Criminal Investigative Service, we interrogated Jandal. Again, we used our knowledge of him, together with outward displays of kindnesses, to break down his resistance. Knowing he was diabetic, we brought him sugarless cookies to eat, and he started talking after being asked about his family and life. Like Kherchtou, Jandal had been treated by al-Qaida in ways he found demeaning: instead of being sent on the important mission he felt he had earned, Jandal had been made an errand boy, tasked with delivering a dowry to the family of a Yemeni teenager whom Bin Ladin had decided to marry. More importantly, Jandal opposed Bin Ladin's pledge of allegiance to Taliban leader Mullah Omar because he felt it made al-Qaida subservient to the Taliban.

We chatted about religion and the American Revolutionary War. Jandal was stunned to discover that the United States, a country he had spent his life hating, had itself been founded by rebels against unjust rule-which was precisely how many in al-Qaida perceived themselves. We pulled out the al-Qaida photobook and asked him to identify faces. He pointed to the most famous operatives, like Bin Ladin and al-Zawahiri. Then he prevaricated, saying he could not name any others.

“Are you claiming you don't know al-Sharqi?” I asked him, using the alias for Marwan al-Shehhi, the hijacker al-Quso had identified as having stayed in Jandal's own guesthouse. We had caught Jandal in a sinful lie. Embarrassed, he began to cooperate, and identified a number of other hijackers.

It was then that we hit him with the full horror of 9/11, including descriptions and photographs of the devastation in New York. Initially, he denied that Bin Ladin could have been behind it. "The sheikh is not crazy," he told us. ${ }^{46}$ After we showed him that some of the pictures he identified were of the hijackers, he recalled the truth and agreed to cooperate fully.

Jandal gave us reams of valuable detail on his own path into al-Qaida, Bin Ladin's inner circle, the training camps, the attack planning process, the methods al-Qaida militants used to conceal their identities, and much more. Jandal's statements proved central in securing Pakistan's cooperation in the war on terrorism and went on to be used in planning the U.S. invasion of Afghanistan.

When that invasion came, JTTF agents accompanied one of the first waves of U.S. ground forces. We brought with us the same investigative expertise that we had employed in the Cole case, the embassy bombings, and countless previous investigations. Over the border, at the U.S. Embassy in Islamabad, the JTTF created a center for processing terrorist suspects-taking their fingerprints, mugshots, and signed statements, all in accordance with U.S. laws. This was important work, for if there were ever to be a successful prosecution for $9 / 11$, the evidence gathered would have to live up to the rigorous standards of American justice.

In the ruins of Bin Ladin's Kandahar hideout, we recovered boxes upon boxes of evidence, including pictures, video, and other information about dozens of al-Qaida operatives and recruits. This evidence helped form the basis for the FBI's first ever Most Wanted Terrorists list. With everything we knew about al-Qaida, and with near global support behind us, it was tempting to believe that the only step left to complete was to round up the bad guys and bring them to justice. It would not be that simple.

\section{Failed experiments: enhanced interrogation techniques}

As the Taliban government collapsed, senior al-Qaida figures began streaming across the border into Pakistan. It was a logical move, as they had found sanctuary there before. After $9 / 11$, however, the paradigm 


\section{Ali Soufan}

had changed. Thanks in part to the damning statements we had extracted from Jandal in Yemen, the Musharraf regime was now a willing partner in the war on terrorism. Pakistani and U.S. agents fanned out across the country to apprehend al-Qaida members.

In March 2002, a joint team of FBI, CIA, and Pakistani forces cornered Abu Zubaydah, the commander who had given the go signal for the millennium plot. ${ }^{47}$ In the firefight that followed, Zubaydah was gravely wounded but stabilized enough to face interrogation. For security, Zubaydah was taken to a third country. He was surprised, to say the least, to find himself face-to-face with two Arabic-speaking JTTF agents: myself and my partner. As always, we did our homework and learned everything we could. When we went in, we asked his name, and he replied with a known alias.

"How about if I call you Hani?" I asked him. Zubaydah looked astonished. Hani was the nickname his mother had called him as a child. "OK," he said, and immediately started talking. Within hours, he had told us of Khalid Sheikh Mohammed's role as the mastermind of 9/11 - which we did not yet know at the time-and gave us information that led directly to the thwarting of a terrorist attack, the details of which can still not be discussed publicly. ${ }^{48}$

Our success reportedly upset CIA director George Tenet, who wanted his own agents running the interrogation. A CIA team soon arrived to take over, bringing with them a contractor who described himself as a psychologist. The CIA, they said, wanted to try "something new" with this interrogation. This set off alarm bells. Why try something new, we thought, when Zubaydah was cooperating? The contractor's "methods" included forced nudity, sleep deprivation, and extremes of temperature. Physical abuse, unlike psychological needling, was something Zubaydah understood and had been trained to resist. He simply stopped talking.

After a while, the team began to receive increasingly anxious messages from Washington wondering why our previously steady stream of information had suddenly dried up. My partner and I were put back in charge of the interrogation. With that, Zubaydah returned to cooperating, telling us, for example, about Jose Padilla, the would-be "dirty bomber" - information that led to Padilla's arrest in May 2002.49

Yet the CIA leadership continued to insist that Zubaydah was not cooperative. This claim emanated from the mistaken belief that Zubaydah had been al-Qaida's third in command, instead of what he really was: an independent operative who had only associated with al-Qaida for a handful of operations. He simply was not privy to discussions at the top of the organization. Yet the false idea that he was not cooperating was deployed as a justification for resuming the physical methods.

Zubaydah clammed up again. FBI Director Robert Mueller decided that the bureau could have no part in what was, at best, borderline torture, so I was ordered to return home. According to the Senate Intelligence Committee, Zubaydah was put in solitary confinement for 47 days shortly after I left without being asked a single question ${ }^{50}$ - a fact that suggests his captors realized that he did not have any more useful information to share, or at least nothing they needed urgently enough to ask.

In July 2002, still harsher methods were sanctioned and formalized into a list of "enhanced interrogation techniques." The CIA waterboarded Zubaydah 83 times. Khalid Sheikh Mohammed received the same treatment 183 times. ${ }^{51}$ Techniques such as these produced little if any valuable intelligence. The enhanced interrogation techniques, for example, clearly failed to extract actionable information about al-Qaida cells in Jakarta, Riyadh, London, Madrid, or Bali, all of which would strike within a couple of years of Khalid Sheikh Mohammed's arrest. Worse, torture would lead Ibn al-Sheikh al-Libi, a detainee interrogated in a third country, to concoct a story about a non-existent connection between al-Qaida, Saddam Hussein, and weapons of mass destruction, which formed part of the faulty justification for the 2003 invasion of Iraq. ${ }^{52}$

The failure of these methods should come as no surprise because they are deeply flawed in a number of ways. First, terrorists are specifically trained to resist torture. Second, the interrogator who relies on force does not typically take the time to become an expert on the subject matter pertaining to the detainee and so does not detect possible lies. 
Third, the techniques are desperately slow, taking place in a number of steps. One involved depriving a detainee of sleep for 180 hours at a time-in other words, over a week. Waterboarding a person 83 or 183 times takes even longer, because of the need to allow the detainee time to recover between sessions to keep him alive. In a genuine "ticking time bomb" situation, the device would have exploded before these techniques had a chance to work.

Fourth, even if useful evidence is recovered, it is irrevocably tainted and cannot be used in subsequent prosecution. This is why Khalid Sheikh Mohammed and others in U.S. custody whom we know to have been involved in 9/11 still cannot be convicted of any crime- a gross perversion of justice. ${ }^{53}$ Finally, by forcing the FBI to withdraw from participation in CIA-led interrogations, the techniques served to recreate the arbitrary barriers that blinded us to the $9 / 11$ plot.

I should make clear that, in my experience, the real professionals in the CIA - the seasoned interrogators and officers on the ground-wanted nothing to do with the contractors and their methods. They knew that enhanced interrogation techniques, apart from being abusive and un-American, represented a waste of time that our country could ill afford. During Abu Zubaydah's interrogation, in fact, one CIA psychologist left the location in protest, while the senior agency interrogator at the site repeatedly complained up the chain of command, only to be overruled from above.

\section{The JTTF as the gold standard}

Shortly after coming to office, the Barack Obama administration formally ended the use of enhanced interrogation techniques. ${ }^{54}$ These techniques lowered our standing among our allies even as they provided jihadis all over the world with a propaganda windfall that they are still exploiting today. Moreover, by degrading the quantity and quality of intelligence being extracted from detainees, the techniques actively hampered our counterterrorism efforts.

During his first term, President Obama also pursued a policy of closing the detention facility at Guantanamo Bay. The administration sought to build support for closure in part by showing that the detainees could be prosecuted successfully through the regular federal courts. To this end, a test case was selected: Ahmed Ghailani, a Tanzanian al-Qaida operative who helped build the bomb that killed 11 people outside the U.S. Embassy in Dar es Salaam in 1998. ${ }^{55}$ The New York JTTF, with its long history of bringing international terrorists to justice, was the natural choice for building the case against Ghailani.

Ghailani had been captured in Pakistan and held at an unidentified CIA "black site" prison before being transferred to Guantanamo Bay. The circumstances of his detention, and the harsh treatment to which he had been subjected, tainted much of the evidence against him. For example, the judge ruled inadmissible the testimony of a key prosecution witness - the man who had sold Ghailani the explosives used in Dar es Salaam-because investigators had obtained that witness's name during interrogation sessions in which enhanced interrogation techniques were used.

In 2010, a jury acquitted Ghailani of all but one of the nearly 300 charges against him. This was a disappointing result, but it is important not to lose sight of the fact that Ghailani's conviction on the one remaining charge was enough to imprison him for a life sentence. ${ }^{56}$

The 9/11 plot slipped past the U.S. intelligence apparatus in part because of a failure of communication between intelligence and law enforcement agencies. There is evidence that the situation has improved. A case in point is that of Najibullah Zazi, an immigrant from Afghanistan who was radicalized in Queens, New York, before moving to Colorado. In 2009, the National Security Agency intercepted an e-mail Zazi had sent to a known al-Qaida e-mail address in which he referenced an imminent "marriage"-common al-Qaida code for a suicide bombing. As it turned out, Zazi and two friends were planning to detonate devices on the New York subway on the anniversary of $9 / 11 .{ }^{57}$ 
The National Security Agency passed the e-mail to the CIA, which in turn shared it with the FBI. As a result, personnel from the New York and Denver JTTF offices were able to keep Zazi under near-continual surveillance as he drove from Colorado to Manhattan and contacted his co-conspirators. Eric Jergenson, a JTTF agent based in Denver, interrogated Zazi using the Informed Interrogation Method, bringing the suspect food and allowing him to talk until his story collapsed under the weight of the lies. ${ }^{58}$ As a result of casework, the two JTTF offices amassed enough evidence to indict Zazi and convince him to plead guilty in February 2010. ${ }^{59}$

Intelligence and law enforcement have also developed a framework for cooperation when it comes to terrorist suspects apprehended overseas. The April 2011 capture of Ahmed Warsame, a senior alShabaab commander and liaison to al-Qaida in the Arabian Peninsula, prompted a discussion among agencies as to whether he should be detained and interrogated for intelligence purposes or brought to the United States to stand trial. In the end, a compromise was reached: he was questioned by American intelligence aboard the USS Boxer. Then he was Mirandized and interrogated by JTTF law enforcement officials before being duly charged with rendering material aid to al-Shabaab and al-Qaida in the Arabian Peninsula — charges to which he would eventually plead guilty. ${ }^{60}$

During both phases of his interrogation, Warsame reportedly cooperated with the authorities, rendering valuable intelligence on senior figures from both al-Shabaab and al-Qaida in the Arabian Peninsula. Manhattan U.S. Attorney Preet Bharara later described this arrangement as "an intelligence watershed" and "a seamless orchestration by our military, intelligence, and law enforcement agencies that significantly furthered our ability to find, fight and apprehend those who wish to do us harm." ${ }^{61}$ The procedure has since become standard for terrorism suspects captured under battlefield conditions. ${ }^{62}$

Speed and efficiency remain hallmarks of the JTTF's work. After a crude bomb with a timing device was discovered smoldering in a vehicle in Times Square in May 2010, JTTF investigators were able to identify the would-be bomber, Faisal Shahzad, and arrest him at JFK airport as he attempted to flee the country a mere two days after planting the device. Later that year, Shahzad pleaded guilty to all charges and was sentenced to life imprisonment. ${ }^{63}$

The JTTF's successes are not limited to American courts. Following the 2010 bombings in Kampala, Uganda, during the World Cup final, JTTF operatives, together with colleagues from the U.S. Department of Justice, traveled to Uganda to assist the local authorities with their investigation and prosecutions. ${ }^{64}$ Ultimately, all seven members of the cell were convicted to life sentences ${ }^{65}$ The same model was later followed to support the investigation and prosecutions after al-Shabaab's attack on the Westgate shopping mall in Nairobi in 2013. ${ }^{66}$

Because it represents the gold standard in uniting disparate agencies for big investigations, the JTTF's caseload has sometimes extended beyond terrorism. For example, it put together the case against Abduwali Muse, the Somali pirate responsible for the violent capture of the container vessel Maersk Alabama in 2009-the incident dramatized in the movie Captain Phillips. Like many JTTF targets before him, Muse was prosecuted in the Federal District Court in Manhattan. He pleaded guilty and was sentenced to 33 years and nine months in prison, which he is now serving. ${ }^{67}$

Even in the harshest and most politically fraught environments, JTTF personnel have shown themselves able to operate effectively. In 2012, JTTF agents traveled to Libya to investigate the attack on the U.S. Consulate in Benghazi. The evidence they gathered pointed to Ahmed Abu Khattala. JTTF agents again joined forces with U.S. Special Operations Forces to capture him. In November 2017, a jury in the United States convicted Khattala of terrorism charges, although it acquitted him of murder, the most serious offense. ${ }^{68}$ Overall, the traditional investigative methods of the JTTF have proven the best tools for uncovering the truth.

\section{Conclusion}

The JTTF system, first pioneered in New York in 1980, remains the most effective model for joint counterterrorism law enforcement. Of the approximately 30 terrorist plots against New York City thwarted since $9 / 11$, the majority were disrupted by joint work through the New York JTTF. ${ }^{69}$ 
The JTTF model is the best we have, and it has led to some remarkable results. If there is one lesson to be gleaned from the failed experiments in "enhanced" interrogation techniques and extrajudicial detention, it is the power of adhering to our fundamental values - among them cultural pluralism, due process of law, and the avoidance of cruel and unusual punishments. The Informed Interrogation Approach and the JTTF's traditional investigation methods accord with each of these principles. Their success-and the failure of the alternatives proffered during the 2000s - shows that sticking to American principles is invariably not only the right route but also the smart one.

\section{Notes}

1 See, for example, White House, National Strategy for Counterterrorism (Washington, DC: White House, 2011).

2 "Joint Terrorism Task Force," Federal Bureau of Investigation, accessed September 30, 2020, www.fbi.gov/investigate/ terrorism/joint-terrorism-task-forces.

3 John Miller, Michael Stone, and Chris Mitchell, The Cell: Inside the 9/11 Plot, and Why the FBI and CIA Failed to Stop It (New York: Hyperion, 2002), 33.

4 John Kifner, "Meir Kahane, 58, Israeli Militant and Founder of the Jewish Defense League," New York Times, November 6, 1990, www.nytimes.com/1990/11/06/obituaries/meir-kahane-58-israeli-militant-and-founder-ofthe-jewish-defense-league.html.

5 Michael Sheehan, Crush the Cell: How to Defeat Terrorism Without Terrorizing Ourselves (New York: Crown, 2008), 103-104.

6 Miller et al., The Cell, 63.

7 Sheehan, Crush the Cell, 103-104.

8 Combating Terrorism Center, Ali Mohamed: A Biographical Sketch (West Point: Combating Terrorism Center, 2008).

9 David Herbert, "Prince of the Forty Thieves," The Atavist Magazine no. 63 (2016).

10 Miller et al., The Cell, 62.

11 Laurie Goodstein, "Muslim Acquitted in Kahane Slaying, Found Guilty of Weapons Charge," Washington Post, December 22, 1991, www.washingtonpost.com/archive/politics/1991/12/22/muslim-acquitted-in-kahane-slaying-found-guilty-on-weapons-charge/5994f3ca-2de3-4040-b588-5773d10cd837/.

12 Miller et al., The Cell, 69-75, 81-91.

13 National Commission on Terrorist Attacks, The 9/11 Commission Report: Final Report of the National Commission on Terrorist Attacks Upon the United States (New York: W.W. Norton, 2004), 71-72.

14 Ibid.

15 Miller et al., The Cell, 113-117.

16 National Commission on Terrorist Attacks, The 9/11 Commission Report, 73.

17 Alex Hannaford, “Alcatraz of the Rockies," The Times, March 18, 2012, www.thetimes.co.uk/article/ alcatraz-of-the-rockies-xw19bj0797v.

18 Miller et al., The Cell, 66.

19 John Lancaster, "Five Americans Killed by Car Bomb at Military Building in Saudi Capital," Washington Post, November 14, 1995, www.washingtonpost.com/archive/politics/1995/11/14/five-americans-killed-by-carbomb-at-military-building-in-saudi-capital/8e56b489-9b04-416a-996c-81138576ecc4/.

20 Jane Mayer, “The Clandestine Life of America's Top Al Qaeda Source,” New Yorker, September 4, 2006, www. newyorker.com/magazine/2006/09/11/junior.

21 World Islamic Front, "Jihad Against Jews and Crusaders," World Islamic Front, February 23, 1998, https://fas.org/ $\mathrm{irp} /$ world/para/docs/980223-fatwa.htm.

22 John Miller, “Osama Bin Laden Interview," ABC News, 1998, https://abcnews.go.com/2020/video/ osama-bin-laden-interview-1998-13506629.

23 Ali Soufan, The Black Banners: The Inside Story of 9/11 and the War Against al-Qaeda (New York: W.W. Norton, 2011), 82-84.

24 Ibid., 95.

25 U.S.A. v. Usama Bin Laden (and others), Grand Jury Indictment (Southern District of New York, 1998), https:// fas.org/irp/news/1998/11/98110602_nlt.html.

26 "Ex-Bin Laden Aide Sentenced to Life in Embassy Bombings," BBC, May 15, 2015, www.bbc.com/news/ world-us-canada-32757609.

27 “Profile: Ana al-Liby,” BBC, January 3, 2015, www.bbc.com/news/world-africa-24418327. 
28 The Al Qaeda Manual, U.S. Justice Department, accessed December 22, 2020, www.justice.gov/sites/default/files/ ag/legacy/2002/10/08/manualpart1_1.pdf.

29 Author's recollection from FBI interrogations.

30 Department of the Army, Human Intelligence Collector Operations, FM 2-22.3 (Washington, DC: Headquarters, Department of the Army, 2006).

31 Soufan, The Black Banners, 121-126.

32 Ibid., 130.

33 Ibid., 140.

34 Josh Meyer, “Man Convicted of Taking Part in Bomb Plot," Los Angeles Times, April 7, 2001, www.latimes.com/ archives/la-xpm-2001-apr-07-me-48100-story.html.

35 National Commission on Terrorist Attacks, The 9/11 Commission Report, 152-153 and 180.

36 Amy Davidson Sorkin, "Missed Opportunities," New Yorker, July 3, 2006, www.newyorker.com/ magazine/2006/07/10/missed-opportunities.

37 Office of the Inspector General, Review of Four FISA Application and Other Aspects of the FBI's Crossfire Hurricane Investigation (Washington, DC: U.S. Department of Justice, 2019).

38 National Commission on Terrorist Attacks, The 9/11 Commission Report, 423-427.

39 Ibid., 193.

40 Ibid., 202.

41 Ibid., 191.

42 Ibid., 191, 494.

43 Author's recollection of events.

44 Soufan, The Black Banners, 288-291.

45 National Commission on Terrorist Attacks, The 9/11 Commission Report, 272.

46 Soufan, The Black Banners, 320.

47 National Commission on Terrorist Attacks, The 9/11 Commission Report, 174-175.

48 Report of the Senate Select Committee on Intelligence, Committee Study of the CIA's Detention and Interrogation Program, Senate Report 113-288 (Washington, DC: U.S. Senate, December 9, 2014), 25.

49 Ibid., 29-30.

50 Ibid., $27-30$.

51 Ibid., 118.

52 Clive Smith, "Ibn al-Sheikh al-Libi: The Most Important Torture Story Never Told," Middle East Eye, November 7, 2018, www.middleeasteye.net/opinion/ibn-al-sheikh-al-libi-most-important-torture-story-never-told.

53 Sacha Pfeiffer, "A Legacy of Torture Is Preventing Trials at Guantanamo," National Public Radio, November 14, 2019, www.npr.org/2019/11/14/778944195/a-legacy-of-torture-is-preventing-trials-at-guant-namo.

54 Ibid.

55 Charlie Savage, “Terror Verdict Tests Obama's Strategy on Trials," New York Times, November 18, 2010, www. nytimes.com/2010/11/19/nyregion/19detainees.html.

56 Ibid.

57 Ibid.

58 Marshall Erwin, Connecting the Dots: Analysis of the Effectiveness of Bulk Phone Records Collection (Washington, DC: Hoover Institution, 2014).

59 A.G. Sulzberger and William Rashbaum, "Najibullah Zazi Pleads Guilty in Plot to Bomb Subway,” New York Times, February 22, 2010, www.nytimes.com/2010/02/23/nyregion/23terror.html.

60 Peter Finn, "Somali's Case a Template for U.S. as It Seeks to Prosecute Terrorism Suspects in Federal Court," Washington Post, March 30, 2013, www.washingtonpost.com/world/national-security/somalis-case-a-template-for-us-as-itseeks-to-prosecute-terrorism-suspects-in-federal-court/2013/03/30/53b38fd0-988a-11e2-814b-063623d80a60_ story.html.

61 U.S. Attorney's Office, Southern District of Washington, "Manhattan U.S. Attorney Announces Guilty Plea of Ahmed Warsame," Department of Justice, March 25, 2013, www.justice.gov/usao-sdny/pr/manhattan-us-attorneyannounces-guilty-plea-ahmed-warsame-senior-terrorist-leader-and.

62 Finn, "Somali’s Case."

63 U.S. Attorney's Office, Southern District of New York, "Faisal Shahzad Sentenced in Manhattan Federal Court to Life in Prison," Federal Bureau of Investigation, October 5, 2010, https://archives.fbi.gov/archives/newyork/pressreleases/2010/nyfo100510.htm.

64 New York Field Office, "FBI and Uganda Police Seek Assistance Identifying 7/11 Bombers," Federal Bureau of Investigation, July 19, 2010, https://archives.fbi.gov/archives/newyork/press-releases/2010/nyfo071910-1.htm. 
65 National Security Division, FY 2013 Performance Budget Congressional Submission (Washington, DC: U.S. Department of Justice, 2012), 17.

66 “NYPD Report Into Kenya Mall Attack Suggests Only Four Shooters Involved,” Fox News, December 11, 2013, www.foxnews.com/world/nypd-report-into-kenya-mall-attack-suggests-only-four-shooters-involved-and-allmay-have-escaped.

67 U.S. Attorney's Office, Southern District of New York, "Somalian Pirate Sentence in Manhattan Federal Court to 405 Months in Prison," Federal Bureau of Investigation, February 16, 2011, https://archives.fbi.gov/archives/ newyork/press-releases/2011/somalian-pirate-sentenced-in-manhattan-federal-court-to-405-months-in-prisonfor-hijacking-three-ships-and-for-hostage-taking.

68 Adam Goldman and Charlie Savage, "Libyan Convicted of Terrorism in Benghazi Attacks but Acquitted of Murder," New York Times, November 28, 2017. www.nytimes.com/2017/11/28/us/politics/benghazi-attacks-trialverdict-khattala.html.

69 Prepared Statement of John J. Miller, House Homeland Security Committee, May 6, 2019. 


\title{
26 \\ CREATING THE NYPD COUNTERTERRORISM BUREAU
}

\author{
Michael A. Sheehan ${ }^{1}$
}

Two months after the 9/11 attacks, while the World Trade Center was still smoldering, Michael Bloomberg was elected mayor of New York. Bloomberg, through his appointment of Police Commissioner Raymond Kelly, set into motion a process that would revolutionize the New York City Police Department's (NYPD) approach to counterterrorism.

This chapter tells the story of the creation of the NYPD's Counterterrorism Bureau (CTB) and its two principal components: the Counterterrorism Division (CTD) and the NYPD contribution to the Federal Bureau of Investigation's (FBI) Joint Terrorism Task Force (JTTF). The leadership and determination of the people who founded and staffed these units set the tone for an effective and reasonable post-9/11 approach to counterterrorism for a local police department.

\section{Laying the groundwork}

Mayor Bloomberg was a successful businessman with an unrelenting drive to accomplish tasks quickly and efficiently. He sought strong subordinate leaders to whom he could give general guidance but were expected to perform with excellence and autonomy. Bloomberg would turn out to be the ideal mayor for the NYPD. The department made great strides in both counterterrorism and crime fighting during Bloomberg's three terms. Even when it was not politically popular, Bloomberg remained a stalwart supporter of the NYPD.

One of Bloomberg's first and most important appointments was Police Commissioner Kelly. Kelly had been commissioner during the first World Trade Center attack in 1993, when the department had only a peripheral role in counterterrorism via a handful of detectives assigned to the FBI's JTTF. By the time Kelly took office, the implications of that bombing and its link to the 9/11 attacks convinced Kelly that New York City remained a principal target of al-Qaida's strategic ambitions.

The New York JTTF supported the Southern District of New York's prosecution of the perpetrators of the 1993 attack. Ramzi Yousef, the mastermind of that attack, was convicted in absentia and arrested in Pakistan in $1995 .^{2}$

In the interim, however, Yousef and his uncle, Khalid Sheikh Mohammed, plotted Operation Bojinkaa plan to blow up a dozen aircraft over the Pacific Ocean. A test run of their plan partially succeeded. Yousef left a small bomb on a Japan Airlines plane that exploded in midair on the Manila to Tokyo bound flight, killing one passenger and injuring another. The pilot skillfully landed the severely damaged aircraft at Naha Airport on Okinawa. ${ }^{3}$ Yousef and Mohammed managed to escape the Manila police, but Yousef 
was later arrested in Pakistan (thanks in part to the State Department's Rewards for Justice program), while his uncle made his way to Afghanistan. ${ }^{4}$

It was then, as a result of Mohammed's plotting with al-Qaida chief Usama bin Ladin, that the 9/11 operation was conceived - a hybrid of the 1993 World Trade Center attack and Operation Bojinka. ${ }^{5}$ Due to its experience with the 1993 attack, the Department of Justice's Southern District of New York took the lead for the investigation and prosecution of international terrorist attacks for the federal government. New York officials already had experience operating internationally. In the wake of al-Qaida's U.S. Embassy bombings in Kenya and Tanzania in 1998, the New York JTTF joined a team of intergovernmental specialists to investigate the attacks. In 2000, they joined a team sent to Yemen to investigate the bombing of the USS Cole. ${ }^{6}$

These interagency teams, known as Foreign Emergency Support Teams, were led by the State Department's Office of Counterterrorism—which by late 1998 was headed by Ambassador Michael A. Sheehan. ${ }^{7}$ John O'Neill, a special agent in charge of the New York JTTF, led the FBI contingent of the team, comprised of investigators and forensic experts. Concurrently, the Southern District of New York managed the U.S. government's prosecutorial expertise on al-Qaida.

By the mid-1990s, the Central Intelligence Agency (CIA) had begun to understand the developing threat of Bin Ladin and al-Qaida. In 1996, for the first time in its history, the CIA established a "virtual station" focused on an individual-Bin Ladin—as opposed to a country. This unique organization was established within the Directorate of Operations at the CIA under David Cohen, who would later become the NYPD's commissioner for intelligence. ${ }^{8}$

In 1998, in the immediate wake of the U.S. Embassy bombings in East Africa, Secretary of State Madeleine Albright appointed Sheehan as the State Department's ambassador-at-large for counterterrorism. At the suggestion of President Bill Clinton's counterterrorism czar, Richard Clarke, Sheehan visited John O'Neill within his first week on the job. Sheehan returned to Washington with a much fuller understanding of the pending al-Qaida threat.

At the same time, Kelly was appointed as the commissioner of the U.S. Customs Service. Under his watch, Customs conducted an extremely successful counterterrorism interdiction. In late December 1999, during the peak of the so-called millennium threat associated with the year 2000, authorities arrested the "Millennium Bomber," an al-Qaida operative named Ahmed Ressam who attempted to smuggle 130 pounds of explosive material into the United States. ${ }^{9}$ He planned to attack Los Angeles International Airport with a suitcase bomb around the millennium celebrations.

An alert customs agent foiled Ressam's plot. The agent viewed Ressam acting nervously and ordered him to a secondary inspection site where agents inspected his vehicle's trunk. Authorities subsequently arrested Ressam. Ressam had been trained, indoctrinated, and sent by al-Qaida from its camps in Afghanistan to Montreal, Canada, where he became part of an operational cell. ${ }^{10}$

At the same time, al-Qaida was planning to attack the USS The Sullivans in the port of Aden in Yemen. The attack faltered and was postponed until October 2000, when al-Qaida successfully attacked a different U.S. warship, the USS Cole, when it sailed into the port of Aden for resupply. ${ }^{11}$ The Ressam plot and other intelligence indicating that al-Qaida had planned a series of attacks around the millennial celebrations made clear to the Washington counterterrorism community that al-Qaida was a serious and growing threat. Nevertheless, even after the October 2000 attack on the Cole, few recognized that threat in its entirety.

Yet many counterterrorism officials who had experience with al-Qaida prior to 9/11, including the NYPD's future leadership-Kelly at Customs, Sheehan at State, and Cohen at the CIA-were part of a small number of counterterrorism officials who recognized both al-Qaida's dangers and limitations. In managing their counterterrorism programs, the NYPD sought to aggressively and relentlessly prevent a future al-Qaida attack while at the same time avoiding trampling the civil liberties of its citizens or instilling an overwrought fear that would inhibit people from visiting, living within, or investing in New York City. 


\section{The Counterterrorism Bureau}

Upon assuming leadership of the NYPD for the second time, Kelly quickly went to work to build the city's counterterrorism capability from scratch. He created two separate but complementary organizations: the Counterterrorism Bureau and a completely revamped Intelligence Division. Kelly tapped Frank Libutti, a retired Marine lieutenant general from the Pentagon's office of counterterrorism, to build and run the CTB and CIA veteran David Cohen to build and run the new Intelligence Division. ${ }^{12}$ Intelligence and operations would work together to protect the city from another attack.

Kelly was not alone in trying to figure out how the NYPD would evolve after 9/11. Among those were a young police captain, Michael O'Neil. Like many of his NYPD colleagues, O'Neil spent the first three months following the $9 / 11$ attack on "the pile," leading a portion of the rescue and recovery effort commonly referred to as the "Bucket Brigade." While working the pile, O'Neil thought about what could be done beyond cleaning up the attack site. He authored a white paper that envisioned the NYPD expanding its mission to include counterterrorism intelligence and training functions. His paper was forwarded up the chain of command around the time Kelly took charge. In short order, O’Neil was assigned to help develop the CTB.

Building the new capability would have been challenging under any circumstance, but Kelly had to build it while the NYPD was cutting 17\% of its force. In the last part of Rudy Giuliani's term as mayor, the police department had swelled to 41,000 uniformed police officers in an effort to decrease crime, but it was an unsustainable number of personnel. Kelly had to reduce the size to 34,000 officers while at the same time building a new counterterrorism capability. ${ }^{13}$ This is notable because most police departments wait until additional state or federal resources are provided before committing to counterterrorism functions. For local police, crime fighting is paramount, and they defer counterterrorism to the FBI. Kelly could not wait, and he managed to find the resources to establish the CTB while shrinking the NYPD.

The key to Kelly's success was his selection of personnel. He took the risk of going outside of the NYPD to hire veterans of the federal government as commissioners for the CTB and Intelligence Division. Below those commissioners, he picked maverick, aggressive NYPD officers who knew how to finish tasks and had strong track records of success.

\section{The Counterterrorism Division}

The two major components of the CTB were the Counterterrorism Division and the NYPD component of the JTTF. Kelly understood investigations were the heart of offensive counterterrorism operations. They are designed to detect or deter persons with violent intent before they can launch an attack. At the same time, Kelly also recognized he needed to "harden" the city with a defensive approach that would make it more difficult for terrorists to attack. Both became functions of O’Neil's Counterterrorism Division.

In January 2002, just days after Kelly's appointment, O’Neil was put in charge of the then non-existent Counterterrorism Division, a command at least two levels above his rank of captain. Kelly also assigned Inspector John Colgan, a talented officer with extensive logistics, administrative, and budgetary experience, to the CTD headquarters. Colgan was considered a renegade. He graduated from the elite Regis High School on Manhattan's Upper East Side and had attended the U.S. Coast Guard Academy.

Colgan spent most of his career in administrative and training assignments, and he was supremely efficient in navigating the complex world of government funding and budgets. He was the perfect fit for a bureau that started from scratch but needed to grow quickly. Colgan was single minded in his efforts, trampling over any obstacle in building the CTD.

As for a home for the new unit, O'Neil knew of a converted warehouse in the city's hinterlands that had been recently gutted and renovated. It had fluorescent lights, new chairs, computers, carpeting, and, perhaps most importantly, a huge parking lot. The unit now had a home, but it still needed to define its 
mission and recruit the right personnel. O'Neil sought the best talent from within the NYPD, and many were eager to join the new division after seeing 23 of their comrades killed on $9 / 11 .{ }^{14}$

Thousands applied. O'Neil established a rigorous interview process to identify the best and brightest. Former crime prevention personnel were assigned the new challenge of protecting critical infrastructure, the best police instructors became counterterrorism instructors, and uniformed officers who had military intelligence backgrounds became strategic threat analysts. As the unit and mission took form, O'Neil determined that it was going to take unusual organizational agility and the right people to get the job done.

The unit grew around a polyglot crew of cops with backgrounds as former narcotics detectives and military reservists. These cops were supplemented with new support provided by sharp, young civilian analysts, many with master's degrees from the most respected universities in the world. The new unit was established "on the fly" at a speed the federal government could only envy.

O'Neil also had connections to the growing number of reservists returning from Afghanistan (and later Iraq) and pulled them into the unit as well. One included NYPD Captain O'Rourke, who had recently completed his 12-month activation with the Air Force Office of Special Investigation's Counterterrorism Watch Center. As an Air Force reserve major, he had worked in a Sensitive Compartmented Information Facility reading Secret and Top Secret reports on Sunni Islamist terrorist groups. O'Rourke was set to return to a patrol precinct in the South Bronx, but O'Neil had other ideas. O'Neil told him to stop by the warehouse prior to his first day back in the Bronx, made a few calls, and O'Rourke was assigned to the unit within hours.

About one year into the development of the CTB, the Department of Homeland Security recruited away its first chief, Frank Libutti, to serve as an undersecretary in the new department. ${ }^{15}$ Michael A. Sheehan, who had recently served as the ambassador-at-large for the State Department's Office of Counterterrorism, replaced him.

In its first few years, the CTD developed seven units/functional areas: 1) Terrorism Threat Analysis Group; 2) Threat Reduction Infrastructure Protection Section; 3) Training Section; 4) the Chemical, Biological, Radiological, Nuclear, and Explosive (CBRNE) Preparedness Section; 5) Special Projects Unit; 6) NYPD Shield; and 7) the bomb section. Many functions crossed multiple sections and required the entire staff to be flexible and collaborative.

\section{Terrorism Threat Analysis Group}

Most armchair strategists are familiar with Sun Tzu's famous quote regarding the importance of knowing your enemy as well as yourself. ${ }^{16}$ Although Sun Tzu's wisdom seems obvious, many of the purported counterterrorism experts that proliferated on the cable news networks after 9/11 had only a superficial understanding of al-Qaida. New York City needed to strike a careful balance that warned people of the al-Qaida threat while at the same time promoting confidence for people to live, visit, and invest in the city.

To strike this balance, the NYPD needed a deep and nuanced understanding of al-Qaida - such as the group's strengths and weaknesses - to gain a realistic assessment of how the group might be able to attack New York City again. The NYPD's message to the public was clear: "There is a significant threat—but we are managing it. You can help us by communicating." In the weeks after 9/11, O'Neil set up a hotline with the now-ubiquitous saying: "If you see something, say something." 17

The detectives within the CTD and the JTTF were expected to become al-Qaida experts, which required detailed study of their modus operandi, leadership, and ideology. One of Kelly's other successful actions was to authorize the hiring of civilian analysts, many straight out of Ivy League graduate programs, since the NYPD lacked the expertise. Understanding the threat guided the CTD's defensive and "hardening" initiatives.

Until the civilian analysts arrived at the NYPD, detectives within the threat unit were primarily responsible for writing one-page Terrorism Awareness Bulletins that alerted police officers to evolving terrorist 
threats. The new civilian analysts were a diverse group, but all had experience studying and analyzing terrorism. They shared a similar mindset as well and did their best to integrate into the police culture. They were housed together in a small room at the warehouse, each with their own desk and quiet space to "think about terrorism."

From day one, it was a surprisingly easy assimilation. They became the Terrorism Threat Analysis Group and initially offered input and more pointed analysis for the Terrorism Awareness Bulletins. The detectives at the CTD welcomed them, and they appreciated the insight that the "smart kids" provided. For their part, the analysts readily consumed the street smarts and practical knowledge of the detectives. It seemed like both sides of the analyst-cop partnership had been eagerly awaiting one another, and together they figured out the pieces of the threat puzzle in New York City quickly, efficiently, and effectively.

With the "smart kids" on the team, the Terrorism Threat Analysis Group expanded beyond the onepage bulletins and started publishing longer reports that focused on how terrorists conducted their operations. The first volume covered eight of the major terrorist attacks against the United States, including the first World Trade Center attack, the Oklahoma City bombing, the Cole bombing, and the Madrid train attack. The second volume covered 14 additional attacks and plots against New York City, including plots against the Brooklyn Bridge and the subway system.

The third volume included a compendium of terrorist plots that involved improvised weapons of mass destruction (WMD), including the Aum Shinrikyo attack in the Tokyo subway system, the 2001 anthrax attacks in New York City, and a plot using ricin in the United Kingdom. It also included the chemical disaster in Bhopal, India, given the NYPD's concern with chemical storage facilities in the city and the desire to understand the dynamics of a potential attack on these facilities.

Daniel Rudder, a young scholar the NYPD hired from Colombia University, also published an in-depth report on the history of al-Qaida's ideology. ${ }^{18}$ This report dispelled cartoonish depictions of the jihadi narrative and described a much more sophisticated and compelling justification for religious violence in defense of the Islamic community that was purportedly under attack, particularly from the United States and Israel. The CTD used the volumes for training. ${ }^{19}$ O'Neil also tasked one of his new civilian analysts to create a counterterrorism library with the most up-to-date books on terrorism, physical security, and WMD. The library also included a media room that monitored international news outlets.

But perhaps the group's biggest coup was establishing a Sensitive Compartmented Information Facility at the Brooklyn headquarters. ${ }^{20}$ This enabled the analysts to have direct access to Secret-level government documents. The Department of Homeland Security was supportive but slow and bureaucratic, so a handful of NYPD reserve military officers with Top Secret clearances managed a deal with Naval Intelligence to certify the physical and operational standards of the facility before the Department of Homeland Security eventually certified it.

By acquiring a nuanced understanding of al-Qaida's true capabilities - both its strengths and weaknesses - the NYPD struck a balance in its counterterrorism posture. It was a delicate balance, encouraging people to continue to live, invest, and travel to New York City while asking them to stay vigilant. Some areas, like Wall Street, were hardened extensively, but in other areas, it was appropriate to put away the white concrete road barriers that were an eyesore, disrupted traffic, and did little to protect some buildings. The NYPD resisted turning Manhattan into a walled compound.

\section{Threat Reduction Infrastructure Protection Section}

The largest section in CTD was the Threat Reduction Infrastructure Protection Section. This was a new function for the NYPD. The department previously had a small unit that aided businesses on "lights and locks" to deter criminal activity, but this unit was repurposed with the goal of protecting the critical infrastructure of the city from a sophisticated terrorist attack-a task of enormous breadth. Its first function was to assess the city's critical infrastructure and establish levels of priority based on importance and 
vulnerability. After assessing more than 300 locations, they prioritized the top 40, which included Times Square, Wall Street, Broadway, and Grand Central Station.

Early on, Kelly decided that threat and risk assessments would be a core capability for the CTD, but it was a steep learning curve for the detectives. They had to gain expertise quickly, so they brought in blast mitigation experts from the Cooper Union, an elite engineering school with a surprising level of expertise on the physics of explosives and the best means to mitigate their effects. Detectives also went to classes to learn how to create computer-aided design drawings so they could develop detailed schematics for security plans.

Based on recommendations resulting from the Threat Reduction Infrastructure Protection Section's assessment of key commercial locations and iconic structures, bollards were emplaced to protect building lobbies, glass standards were raised, security perimeters were extended, and closed-circuit television camera coverage was vastly expanded and improved. The unit worked closely with the U.S. Army Corps of Engineers on a multi-year project to identify vulnerabilities in the aging fleet of city bridges and tunnels, and they worked on ways to harden them from various methods of attack.

At the same time, the unit created small teams to work with private-sector entities that had materials that could be converted into improvised WMD. The NYPD recognized the threat from homegrown terrorists - perhaps a radicalized employee with access to dangerous materials. Teams of detectives inspected and worked with chemical companies to reduce the risk of theft, sabotage, or commercial accidents. Others worked closely with engineering firms and hospitals to better safeguard radiological isotopes.

Another significant contribution involved the construction of the Freedom Tower. After reviewing the initial plans, Sheehan was surprised by the vulnerability of the building to a terrorist attack. In response, he directed Colgan and O'Neil to draft a white paper addressing its vulnerabilities. Weeks later, in a meeting prompted by the governor, the building owner notified the NYPD that they planned to revise the building and incorporate many of the NYPD's recommendations, despite the significant costs associated with modifying a building they had already started constructing.

\section{Training Section}

The Training Section provided a range of training - from general counterterrorism awareness training for cops on the beat to sophisticated training for personnel assigned to deal with WMD. Having the right personnel was key to the success of this program. O'Neil recruited some of the best police instructors from within the department, including some who were teaching undergraduates in criminal justice at John Jay College in their off-duty time. The late Lieutenant John Rowland, a gifted instructor and leader, led the team. ${ }^{21}$

The training section spent long hours researching and writing lesson plans that would form the basis of their presentations. The trainers exposed NYPD officers to the terrorist operational cycle, taught skills in surveillance and detection, recreated explosive devices and vehicle bombs to expose identifiable "tells," and began the research to provide officers with chemical and radiological protective measures and equipment. Word spread of the CTD "course book," and in short order, members of other law enforcement agencies from the region showed up to take classes in the warehouse. These impromptu courses developed into some significant joint counterterrorism efforts that stretched from Maine to Maryland.

The training unit constantly sought to expand its expertise, and they were fortunate enough to be able to recruit a wide range of experts to assist them. One program that proved important and popular was a course taught by former CIA specialists on law enforcement "solicitation" of Muslims. They instructed NYPD detectives on Arab and Islamic cultural issues so as to avoid offending friendly sources of information. They also provided tips and techniques for the interrogation of hostile suspects.

The detectives merged these concepts with their years of interrogating criminal "perps" of all types. Unlike Hollywood portrayals, the best NYPD interrogators were calm, methodical, and patient. They had 
a gift for getting people to talk. Sometimes it took many days, but these detectives would eventually break through and get the suspect to provide reliable information.

\section{Chemical, Biological, Radiological, Nuclear, and Explosive Preparedness Section}

The CTD was acutely aware of al-Qaida's intention to acquire and deploy WMD against the U.S. homeland, including a fledgling anthrax program they had experimented with in Afghanistan. ${ }^{22}$ With the 9/11 attack still fresh, the nation was hit by an anthrax attack only weeks later, with the contaminated letters ultimately killing five and sickening 17 more. Although these attacks were eventually traced to a single individual with experience in the U.S. military's biological warfare program, the source of the attack was unknown for several years. ${ }^{23}$ The fear of a terrorist attack using improvised WMD was a real concern.

In response, the NYPD created a series of programs to counter the threat. As noted earlier, NYPD detectives had to develop expertise in the types of threats that could reasonably be launched against the city: chemical, biological, radiological, and explosive. The Department of Homeland Security had a robust funding program for counter-WMD efforts and was happy to support New York's efforts as a pilot program.

Colgan was relentless in driving the training program, and within two years, the NYPD had built a formidable counter-WMD response capability. The entire department received a modicum of training that enabled every officer to provide perimeter security for any disaster or attack. Ten thousand cops received "Level Three" training that enabled them to operate on the edges of contaminated areas. Finally, over 600 cops received "Level Four" training-basically operating in a "space suit" - that enabled them to enter the blast area of some of the most challenging disaster sites.

\section{Special Projects Unit}

By 2003 and 2004, the CTD was a hotbed of innovation, as the teams tried to anticipate likely al-Qaida attack modes and means to deter the attacks or mitigate the damage if an attack slipped past the city's defenses. O'Neil created a Special Projects Unit to fill operational gaps, innovate new defensive measures, and conduct special operations to identify the city's vulnerabilities.

The unit managed some of the division's most innovative programs. When a threat or vulnerability was identified, the CTD created capability to mitigate that threat with personnel, programs, and technologies. Their work was most visible during the Republican National Convention in 2004, which saw a half-mile buffer of concrete and vehicle barriers around Madison Square Garden that kept the convention impervious to vehicle-born threats.

Working out of the back room of the CTD warehouse known as the SWAMP (Secret Works and Mysterious Projects), the unit also conducted "red cell" operations. In these operations, they acted in the manner of terrorists to determine vulnerabilities and corresponding mitigation strategies. One such project was called “Operation Kaboom.” Three detectives were provided a credit card with a $\$ 7,000$ line of credit and a civilian phone and told to build a large bomb based on information available on the internet, without identifying themselves as police officers.

Six weeks later, the trio had built a 2,400-pound ammonium nitrate and fuel oil truck bomb and surreptitiously delivered it to a department facility where they "lit the fuse," all of which was recorded for future briefing and training. ${ }^{24}$ They built the bomb at a leisurely pace at a rental storage facility in the Bronx. The unknowing facility manager sauntered by one day and even offered to help them haul some bags of ammonium nitrate until he was politely ushered away.

The operation exposed problems with ammonium nitrate laws. This information and coordination with Congressional staff helped the push for stronger federal laws on the regulation of volatile chemicals that could be built into massive, improvised bombs (as was the case in the first World Trade Center and 
Oklahoma City bombings). In addition, ammonium nitrate vendors were made more sensitive to sales of these volatile chemicals to suspicious persons. ${ }^{25}$

The Special Projects Unit organized tabletop exercises, managed directly by Kelly, for incidents, such as a dirty bomb attack in downtown Manhattan. They were followed by field exercises that deployed teams with their protective gear to manage a simulated chemical or radiological attack site. The NYPD's biggest concern was the creation of an improvised radiological device derived from locally sourced isotopes from cancer hospitals or engineering firms. There were no federal protocols, and a BBC documentary, with advisory support from the British security services, suggested that contaminated personnel from a radiological attack should remain close to the attack zone and be showered before being released. ${ }^{26}$

The NYPD had doubts about this protocol, and there was no federal guidance on how to react to a radiological attack, so the Special Projects Unit reached out to two of the nation's nuclear labs-Brookhaven in Long Island and Sandia in New Mexico-for help. Their engineers built a mock city in the desert in the southwestern United States and tested the explosion of an improvised radiological bomb. The bomb emitted chunks of metal with gamma radiation that remained fairly close to the explosive area, perhaps within a few blocks. In addition, the radiological bomb emitted alpha and beta particles that attached to dust particles and floated with the wind direction.

The studies in the desert showed both types of contaminated particles would not be propelled as far as originally thought — as the weight of the floating particles brought the contaminated dust particles down to earth. After extensive engagement with these scientists, the NYPD decided that the most productive course of action after an attack would be for all personnel to immediately move as far away from the attack zone as possible, away from the "radioactive shine" of the heavier gamma particles. New York would not attempt to decontaminate personnel close to the attack zone as depicted in the BBC documentary.

Instead, police officers would direct people away from the blast zone and into the wind, thereby minimizing exposure to alpha and gamma particles floating in the air. People would then be instructed to go home, take off their clothes, put them in a garbage bag, and then take a shower. Alpha particles can be stopped by a thin layer of material, including dead skin, so they are only harmful if swallowed, inhaled, or absorbed through an open wound. ${ }^{27}$

Beta particles can be stopped by a thin sheet of aluminum but can penetrate the dead skin layer, causing burns; they can also pose an internal radiation threat if ingested or inhaled. ${ }^{28}$ Most of this type of contamination could be washed away harmlessly. Gamma radiation from explosive chunks was different-more akin to getting a giant x-ray blast. But, again, the NYPD's conclusions were to move as far away from the blast of the explosion as quickly as possible and seek medical treatment.

\section{NYPD Shield}

On July 7, 2005, a terrorist attack in London, commonly referred to as "7/7," shocked the world. Four suicide bombers detonated three bombs on London's subway system and a fourth bomb on a double-decker bus, killing 52 and injuring more than $700 .{ }^{29}$ In the wake of the attack, the NYPD expanded its outreach to private sector security elements within the city. Recognizing that the private sector had a major role to play in securing the city, the CTD created NYPD Shield, "an umbrella program for a series of current and future Police Department initiatives that pertain to private sector security and terrorism." ${ }^{30}$ Shield is a "public-private partnership based on providing best practices, lessons learned, counterterrorism training opportunities and information sharing." 31

Local private security personnel are often the true first responders to an attack. Many of the city's major corporations invested heavily in enhanced security measures after 9/11, and they were hungry for information, best practices, training, and any other assistance the NYPD could provide. Private-sector firms expanded closed-circuit television coverage and established operations centers, and some even employed 
dog units. The more sophisticated, high-profile companies used low-profile counter-surveillance personnel to watch over their properties and their corporate leaders.

The new program kicked off in late July 2005, with CTD officers providing a briefing on the London bombings to the city's security managers. Hundreds came to learn about the attack and its implications for New York City. The department was happy to provide updates, including a description of a new program of random bag checks at subway stations.

The NYPD gave each security manager a booklet listing different services that the department could provide (such as emergency text messages, e-mails, best practices, and opportunities for training). Many sectors-such as financial services, hotels, Broadway playhouses, concert venues, ferry operators, and hospitals - created their own consultative bodies. The NYPD engaged with as many businesses as possible, often in meetings chaired by Kelly, who took a keen interest in trying to resolve their issues. The security managers received this well, as they were able to address their issues and concerns directly to the commissioner.

Due to the vulnerability of New York to a London-style attack, where the bombers had carried bombs onto the city's transit systems in personal backpacks, the CTD wanted to implement a bag check program to deter a similar attack in New York. Kelly liked the idea and started the program. The chiefs devised a workable program that was deployed to subway stations throughout the city.

The concept entailed stationing small police units around key subway entrances to conduct "random" bag checks on passengers before boarding the train. It was not a big shock to New Yorkers, as they had to undergo similar security checks prior to entering Yankee Stadium or the U.S. Open Tennis Championship. Moreover, the London bombings made the previously unpopular idea of random bag checks more palatable. The execution of the plan included perfunctory bag checks of random subway riders but was augmented with targeted bag checks when plainclothes officers observed indicators of any terrorist activity, such as people carrying unusual bags (containing wires or fluids), passengers acting nervous around security personnel, or other "tippers."

The New York American Civil Liberties Union sued the NYPD over the program, and both Sheehan and Cohen spent hours being challenged by American Civil Liberties Union lawyers. But in the end, the NYPD won the case. ${ }^{32}$

\section{Bomb section}

A separate bomb section was created within the Special Projects Unit when O'Neil recruited a recently returned reserve Special Forces engineer to the unit. This unit was not to compete with the legendary NYPD bomb squad that responds to bomb threats ${ }^{33}$ but to provide the CTD in-house expertise on terrorism-related improvised explosives. At the Brooklyn facility, the bomb section built important mock-ups for training and educational purposes.

The first was an exact replica of the Ryder rental truck bomb used in the 1993 World Trade Center attack. The second was a mock-up of the bomb-making facility used by the 2005 London bombers. While the mock-up of the Leeds apartment looked like a meth lab, it had some important differences, and the CTD did not want their cops to miss a bomb factory by mistaking it for a drug lab.

By 2005, the CTD was a well-oiled machine with true experts running programs within their respective areas of responsibility. The CTD depended upon the initiative of its detectives to find ways to keep the city safe. At one point, Kelly, pleased with the productivity of the CTD, offered Sheehan 20 additional detectives. When Sheehan informed O’Neil about the offer, O'Neil replied, "Boss, I don't need 20 random guys. They'll give me more of an administrative headache than they would be worth. Just give me five of the best." ${ }^{34}$ He then handed Sheehan the list. Kelly supported the re-assignment despite the grumbling of those NYPD precincts that lost some of their best crime fighters. Again, it was the quality of personnel that made the difference for the innovative measures initiated by the CTD. 


\section{The NYPD contingent within the FBI's JTTF}

The FBI has 56 field offices across the United States, with headquarters in the major metropolitan areas. ${ }^{35}$ Although each office has its own organization, the FBI field office is typically divided into several divisions. The New York field office is typical of a large office, with its four divisions: administration, criminal (for organized crime, white-collar crime, public corruption, and kidnappings), counterintelligence, and the JTTF. $^{36}$

New York City was the home of the first JTTF, created in 1980 when an NYPD official and a special agent from the FBI's New York field office met to discuss how to stop a terrorist organization that was responsible for a series of violent attacks in the city. They agreed to pool their resources, creating the first JTTF. $^{37}$ This ad hoc, multi-agency organization morphed into a unit charged with tracking all terrorist groups operating within the United States.

Since then, and especially after $9 / 11$, JTTFs have proliferated to roughly " 200 , including at least one in each of the 56 FBI's field offices." 38 They are composed of locally based investigators, analysts, linguists, and other specialists from dozens of U.S. law enforcement and intelligence agencies. JTTFs "chase down leads, gather evidence, make arrests, provide security for special events, collect and share intelligence, and respond to threats and incidents at a moment's notice." ${ }^{39}$ The New York JTTF has representatives from the State Police, Immigration and Customs Enforcement, the Port Authority Police, and other law enforcement agencies. Aside from the FBI, the NYPD contingent is by far the biggest contributor of personnel to the task force.

Prior to 9/11, the NYPD contingent of the JTTF included 16 detectives, two sergeants, and a lieutenant-mostly within the domestic terrorism division and surveillance units. This group was tiny, however, compared to the more than 120 detectives and supervisors Kelly would ultimately assign after 9/11. Within weeks, Kelly assigned some of his best detectives to the JTTF. In addition to the 120-plus detectives, Kelly also assigned a one-star chief and several other senior officers. As they acquired their security clearances, these detectives enabled the NYPD to participate on all JTTF operations.

Kelly recognized that many plots targeting New York City originated outside the city, so he wanted his team to understand the terrorist threat across the nation and their overseas roots, as it had immediate implications for New York. Thus, he needed to have a large team detailed to the JTTF. Sheehan ensured they obtained the requisite clearances so they could access the most sensitive national intelligence available. This enabled NYPD detectives to read raw intelligence from the various national intelligence agencies at the JTTF.

This team briefed Sheehan every morning, who in turn briefed Kelly and Cohen-all of whom were longtime consumers of the most sensitive intelligence from their time in the federal government. They were very familiar with al-Qaida's global operations and determined to stay on top of the latest developments.

In addition, Cohen used his CIA contacts to get the agency's top analysts to periodically visit New York City to brief Kelly, Sheehan, and himself. This global understanding of the terrorist threat shaped the development of the NYPD's global programs in counterterrorism and intelligence.

Kelly tracked all of the important investigations through a detailed, daily brief with his deputy commissioners for intelligence and counterterrorism. Sheehan would brief the FBI cases, and Cohen would brief details of the NYPD cases run out of his offices. Kelly would typically spend up to an hour each morning with his two deputy commissioners, discussing the case details and other initiatives that needed be implemented to strengthen the city's ability to deter an attack. As he did with his other counterterrorism initiatives, Kelly selected the most creative and aggressive NYPD veteran officials for the JTTF.

NYPD detectives and FBI special agents differ from one another in many ways. The average detective assigned to the JTTF typically had 12 to 18 years of experience on the streets of New York, and many had conducted hundreds of street arrests, including arrests of violent criminals. The special agents often lacked this street experience, but they were generally more educated, and some had years of experience investigating 
al-Qaida, dating back to the 1993 World Trade Center bombing, the East Africa embassy bombings, and the Cole bombing. Although the NYPD and FBI leadership clashed at times, relations were generally good at the squad level, and a mutual respect developed between the detectives and the special agents.

Investigations normally entailed collecting information on suspects by using surveillance, informants, undercover agents, or cops; analysis of their phone records (numbers called-not the substance of the conversation); and analysis of their social media. To use wiretaps on phones or computers, or to access information from the National Security Agency, a warrant is required from a special judge on the Foreign Intelligence Surveillance Court, which governs the use of these special tools. ${ }^{40}$ The department would typically seek this type of warrant only if the suspects had discussed taking violent action.

If the team had grounds for criminal charges, they could request a grand jury to review the case, which normally entailed prosecutors from the U.S. Attorney's Office. When investigations identified serious persons of interest who sought to conduct violence, the JTTF squad would often introduce an informant or undercover officer to infiltrate. This often resulted in arrests when the fledgling plot was disrupted. Suspects often claimed that informants or under covers entrapped them, but those arguments rarely held in court. ${ }^{41}$ Some critics claim that some of these plots were fanciful in nature and never would have been conducted..$^{42}$ But prior to $9 / 11$, many would have called the plot to hijack airplanes and crash them into buildings ridiculous and pure fantasy.

\section{Conclusion}

This chapter described the creation of the NYPD's Counterterrorism Bureau and its Counterterrorism Division and contribution to the JTTF. The fact that many of the capabilities that Kelly and his team began building in 2001 remain to this day is a testament to the foresight of this team.

The importance of public-private partnership for countering terrorism was one particularly important outcome. Over the past 15 years, Shield has trained more than 100,000 personnel in courses related to active shooter incidents, terrorism awareness, detecting hostile surveillance, suspicious mail and packages, and vehicle-borne improvised explosive device recognition. Shield continues to provide e-mail alerts, unclassified intelligence assessments, monthly liaisons, table-top exercises and live drills, and quarterly conferences to its large team of security professionals. ${ }^{43}$

While some of these efforts have not been without controversy, such as claims of entrapment, they have been effective and prevented dozens of potential attacks against the city. While terrorists have not been successful at conducting another major attack against New York since 9/11, it is important that the NYPD remain vigilant and resist the temptation to divest from the counterterrorism capabilities that it has built over the past two decades.

\section{Notes}

1 The author is indebted to Michael O'Neil for his extensive suggestions and contributions to this chapter.

2 "The Long Arm of the Law: FBI International Presence Key to Bringing Terrorists to Justice," Federal Bureau of Investigation, February 6, 2004, https://archives.fbi.gov/archives/news/stories/2004/february/law020604.

3 Christopher S. Wren, "Plane Bombing Is Described in Terror Trial," New York Times, June 4, 1996, www.nytimes. com/1996/06/04/nyregion/plane-bombing-is-described-in-terror-trial.html.

4 “Success Story: Ramzi Ahmed Yousef," Rewards For Justice, accessed September 30, 2020, https://rewardsforjustice. net/english/ramzi_yousef.html.

5 National Commission on Terrorist Attacks, The 9/11 Commission Report: Final Report of the National Commission on Terrorists Attacks Upon the United States (New York: W.W. Norton, 2004), 145-160.

6 Ibid., 74.

7 "Foreign Emergency Support Team," U.S. Department of State, accessed October 2, 2020, https://2001-2009.state. gov/s/ct/about/c16664.htm. 


\section{Creating the NYPD Counterterrorism Bureau}

8 National Commission on Terrorist Attacks, The 9/11 Commission Report, 109.

9 Josh Meyer, "Man Convicted of Taking Part in Bomb Plot," Los Angeles Times, April 7, 2001, www.latimes.com/ archives/la-xpm-2001-apr-07-me-48100-story.html.

10 U.S.A. v. Ressam, Petition (Supreme Court, 2007).

11 National Commission on Terrorist Attacks, The 9/11 Commission Report, 152-153 and 180.

12 Craig Horowitz, "The NYPD's War on Terror," New York Magazine, January 24, 2003, https://nymag.com/ nymetro/news/features/n_8286/.

13 Al Baker, "Crime Drops Despite Fewer Officers in Lean Times," New York Times, July 17, 2009, www.nytimes. com/2009/07/18/nyregion/18nypd.html.

14 “9/11 Tribute," New York City Police Department, accessed October 27, 2020, https://www1.nyc.gov/site/nypd/ about/memorials/9-11-tribute.page.

15 William K. Rashbaum, "Terror Expert With the City Police Is in Line for Federal Post,” New York Times, March 22, 2003, www.nytimes.com/2003/03/22/nyregion/terror-expert-with-the-city-police-is-in-line-for-federal-post. html.

16 Sun Tzu, The Art of War (London: Filiquarian, 2007).

17 For origin of the motto, see Hanson O'Haver, "How 'If You See Something, Say Something' Became Our National Motto," Washington Post, September 23, 2016, www.washingtonpost.com/posteverything/wp/2016/09/23/ how-if-you-see-something-say-something-became-our-national-motto/.

18 Patrice O’Shaughnessy, “New York's Secret War on Terror," New York Daily News, October 2, 2005.

19 Ibid.

20 Judith Miller, "FBI vs. the NYPD," New York Post, March 25, 2008, https://nypost.com/2008/03/25/fbi-vsthe-nypd/.

21 Roland died in January 2017 from an illness associated with his work on "the pile" after 9/11, another victim of the attack.

22 National Commission on Terrorist Attacks, The 9/11 Commission Report, 151.

23 Jackson Landers, "The Anthrax Letters That Terrorized a Nation Are Now Decontaminated and on Public View," Smithsonian Magazine, September 12, 2016, www.smithsonianmag.com/smithsonian-institution/ anthrax-letters-terrorized-nation-now-decontaminated-public-view-180960407/.

24 Al Baker, "Test Shows Ease of Buying Bomb Parts," New York Times, September 13, 2016, www.nytimes. com/2006/09/13/nyregion/13bomb.html.

25 Regulation of the Sale and Transfer of Ammonium Nitrate, 6 U.S.C. $\$ 488$ a (2007), www.law.cornell.edu/uscode/ text/6/488a\#: :text=The\%20Secretary\%20shall\%20regulate $\% 20$ the,Cybersecurity $\% 20$ and $\% 20$ Infrastructure $\% 20$ Security\%20Agency.

26 Dirty War, directed by Daniel Percival (2004, BBC One).

27 "Radiation Dictionary," Centers for Disease Control and Prevention, accessed November 14, 2020, www.cdc.gov/ nceh/radiation/emergencies/glossary.htm.

28 Ibid.

29 "July 72005 London Bombing Fast Facts," CNN, June 18, 2020, www.cnn.com/2013/11/06/world/europe/july7-2005-london-bombings-fast-facts/index.html.

30 “NYPD Shield," New York City Police Department, accessed December 10, 2020, www.nypdshield.org/public/.

31 Ibid.

32 Macwade v. Kelly, U.S. Court of Appeals, Second Circuit, August 11, 2006, https://caselaw.findlaw.com/us-2ndcircuit/1252582.html.

33 Richard Esposito and Ted Gerstein, "Inside the NYPD Bomb Squad," Police Magazine, September 1, 2007, www. policemag.com/339801/inside-the-nypd-bomb-squad\#: :text=The\%20Bomb\%20Squad\%20is\%20a,backed\%20 by $\% 20$ laboratory $\% 20$ forensic $\% 20$ science.

34 Quote is recollection of the author.

35 "Field Offices," Federal Bureau of Investigation, accessed September 30, 2020, www.fbi.gov/contact-us/ field-offices\#: : :text=Our\%20local\%20FBI\%20offices\%20are,the\%20U.S.\%20and\%20Puerto\%20Rico.

36 "FBI New York History," Federal Bureau of Investigation, accessed September 30, 2020, www.fbi.gov/history/ field-office-histories/newyork.

37 “Model Partnership: New York JTTF Celebrates 35 Years," Federal Bureau of Investigation, December 8, 2015, www. fbi.gov/news/stories/new-york-jttf-celebrates-35-years.

38 “Joint Terrorism Task Force," Federal Bureau of Investigation, accessed September 30, 2020, www.fbi.gov/investigate/ terrorism/joint-terrorism-task-forces.

39 Ibid. 
40 Elizabeth B. Bazen, The U.S. Foreign Intelligence Surveillance Court and the U.S. Foreign Surveillance Court of Review: An Overview, CRS Report RL 33833 (Washington, DC: Congressional Research Services, 2007), https://apps. dtic.mil/dtic/tr/fulltext/u2/a462105.pdf.

41 Francesca Laguardia, "Terrorists, Informants, and Buffoons: The Case for Downward Departure as a Response to Entrapment," Lewis \& Clark Law Review 17, no. 1 (2013): 171-214, https://law.lclark.edu/live/files/13718lcb171art4laguardiapdf.

42 Ian Cummings, "FBI Undercover Stings Foil Terrorist Plots-But Often Plots of the Agency's Own Making," Kansas City Star, March 2, 2017, www.kansascity.com/news/local/crime/article135871988.html.

43 Vincent Amadeo, "NYPD Shield and the Global Network: A Template for Law Enforcement Executives," Police Chief Online, February 26, 2020, www.policechiefmagazine.org/nypd-shield-and-the-global-shield-network/. 


\title{
THE INSIDE STORY OF HOW THE NYPD'S INTELLIGENCE DIVISION ADAPTED IN THE WAKE OF 9/11
}

\author{
David Cohen
}

In the aftermath of 9/11, the New York City Police Department (NYPD) made dramatic changes to respond to the new terrorist threat. The NYPD's ability to adapt to the evolving threat played a critical role in protecting New York City from subsequent terrorist attacks.

Through arrests and proactive intelligence-driven interventions, the NYPD and its partners foiled numerous plots. As NYPD deputy commissioner for intelligence from 2002 thru 2013, this is a firsthand account of how the NYPD re-engineered its intelligence structure, operations, and culture to address the post-9/11 threat to New York City.

\section{Re-engineering the Intelligence Division}

The NYPD Intelligence Division had a long and sometimes fabled history prior to $9 / 11$. Aside from a stable of extremely talented investigators and supervisors, it was not prepared for the intelligence mission of the post-9/11 environment. No organization was. Its re-engineering was unprecedented, unchartered, and profound. Members would be asked to take on responsibilities and roles that they did not expect to when they joined the NYPD.

Upon assuming office on January 1, 2002, New York City Mayor Michael Bloomberg appointed Raymond Kelly as police commissioner. Kelly immediately took action, tapping Frank Libutti, a retired Marine lieutenant general from the Pentagon's office of counterterrorism, to build and run the counterterrorism bureau and David Cohen, a 35-year veteran of the Central Intelligence Agency (CIA), to build and run the "new" Intelligence Division. Upon his appointment on January 25, 2002, Cohen immediately started the massive transformation of the division.

Three essential elements were required to achieve the desired transformation: leadership at the highest levels of the department, division, and line units; dramatic cultural change among investigators, analysts, and supervisors; and an environment that produced ideas, engagement, and integration.

\section{Leadership at the top}

An effective counterterrorism intelligence program at any level must receive its guidance from and have the ear of the organization's leader. For the NYPD Intelligence Division, this meant Kelly. His commitment to having a high-quality, effective, and responsible intelligence program was unambiguous, demanding, and unrelenting. These characteristics did not translate into micromanagement; rather, it required that his 


\section{David Cohen}

intelligence chief keep him informed, avoid surprises on matters on which he should be informed, and never withhold negative news or mistakes.

The mechanism that Kelly used to oversee the division's activities was a daily morning meeting with his deputy commissioner for intelligence and deputy commissioner for counterterrorism. He was briefed in substantial detail on what was known of the global and national terrorist picture, what the Division had learned about the threat locally, and the performance of individual programs. His strategy was broad gauged but also tightly focused. The strategy aimed to keep New York City as safe as possible within constitutional and legal bounds. At the tactical level, the goal was to decrease the odds of another terrorist attack against the city "a little bit, every day." "Thus, intelligence operations, investigations, and analysis demanded patience, persistence, and continuous improvement.

Regarding resources, Kelly never "taxed" the Intelligence Division, whether on personnel, technology, or funding, even when City Hall demanded "more with less." In terms of personnel, the city reduced the size of the NYPD by 7,000 uniformed personnel from 2002 to 2009 , a $17 \%$ reduction. ${ }^{2}$ Yet the Intelligence Division grew during this time. As the Division learned to absorb and effectively employ new technologies, it consistently received what Cohen requested. It led the department in building computer applications and communications technology, as well as information storage and retrieval systems.

\section{Changing the culture}

Law enforcement and counterterrorism intelligence operations are not necessarily a natural fit. NYPD detectives achieved success by making arrests. Many of these detectives found their way into the Intelligence Division prior to the $9 / 11$ attacks. Most came from the Narcotics Division, where success meant achieving a large number of arrests by quickly executed "buy-and-bust" operations. ${ }^{3}$ They were smart and energetic, but good intelligence operations demanded other qualities as well. Most importantly, patience in developing and testing assets and keeping them in place for long durations-sometimes years-and careful collection, documentation, and collation of intelligence information to be pieced together like a puzzle.

Blending these vastly different cultures required change at all levels. First and foremost, the detectives were weaned off making fast-moving arrests in large numbers. That meant an end to cigarette or drug cases that were traditionally used to build an inventory of confidential informants. New mechanisms were created to develop the confidential informants essential in addressing the rising threat of homegrown radicalization. In August 2004, for example, the NYPD arrested two homegrown jihadis-Shahawar Matin Siraj and James Elshafay-who plotted to blow up Manhattan's Herald Square subway station at East 34th Street and Sixth Avenue on the eve of the Republican National Convention to be held a block away. ${ }^{4}$

The transformation worked. Intelligence Division detectives soon blended their experience as investigators with the skills of the intelligence profession: different tradecraft, different use of informants, and the need for greater patience. Yet the pre-9/11 world of police intelligence required more change: how information was collected, combined, and shared. This meant automation.

In early 2002, the division still used a system in which debriefings were handwritten in triplicate using carbon paper; "forwarded" using an internal hand-carried mail delivery system; and kept in filing cabinets with limited chance of collation, integration, and analysis. Decades of operating this way had to change quickly. With the assistance of supervisors who recognized the need for change and persistence at all levels, automation was injected into the Division earlier than elsewhere in the NYPD.

The relationship between uniformed and civilian members of the Intelligence Division also impacted the effectiveness of its counterterrorism program. In almost any large organization, "silos" can easily emerge that impede effectiveness. At the CIA, for example, the challenge was linking operations officers with analysts. In the NYPD, the challenge was integrating uniformed personnel with civilian analysts. The Division hired its first of many civilian analysts in 2002 to help identify the "dots," connect those "dots," 
and then interpret what they meant and where they led. ${ }^{5}$ In short, bridging the cultural gap between the civilian and uniformed police was critical to the division's success.

The need for change never diminished. When the Division identified and fixed one issue, it often revealed a new set of issues requiring attention. Occasionally the layered constraints were a function of the 150-plus-year-old NYPD that served the department and the city well in addressing traditional crime. But if it impeded how intelligence addressed the terrorist threat, it was addressed. Identifying and fixing problems, or finding a better way to conduct intelligence, became an essential part of the division's DNAthe commitment to continuous improvement at every level and in every subordinate unit or program it undertook. For everyone in the Division, this was unrelenting and grueling and continued throughout its post-9/11 history.

\section{Ideas, engagement, and integration}

There was no roadmap, playbook, or consultants to tell the Intelligence Division how to reengineer itself to address the new terrorist threat. The NYPD had to figure it out on its own. The morning meeting between the police commissioner, the deputy commissioner of intelligence, and the deputy commissioner of counterterrorism helped drive the evolution. At the meeting, the leaders tossed around and decided on new ideas. Since almost all new initiatives involved a break or change from the past, communications among senior management, supervisors, and detectives were key to re-engineering the intelligence program.

The Division eventually established 16 separate units. Each had a unique responsibility, either in the intelligence collection, investigations, analysis, or support arena. Some overlapped on the edges, some dovetailed perfectly, and some were compartmentalized to protect the most sensitive sources and methods. The priority then became ensuring program managers—usually lieutenants—shared with colleagues their unit's activities, ensured that de-confliction was automatic, and enabled information to move seamlessly. To a person, they accomplished the task due to leadership from the captains, inspectors, and the most senior uniformed officer, Assistant Chief of the Intelligence Division Thomas Galati.

\section{Getting started: the NYPD hotline}

Prior to 9/11, all NYPD-produced terrorism-related intelligence was transferred for action to the Federal Bureau of Investigation's (FBI) New York Field Office Joint Terrorism Task Force (JTTF), where the NYPD had detailed a supervisor and a handful of detectives. The Intelligence Division had no role after passing the intelligence. After 9/11, its role expanded but only slightly; it ran down leads passed to them from the JTTF, as the JTTF lacked the capacity to personally investigate the growing number of leads.

By mid-February 2002, the Intelligence Division, as a matter of policy and practice, started to take a more assertive role in the growing number of terrorism-related cases. Three different sources now generated leads. First, the JTTF returned leads to the Division that it deemed unnecessary to pursue; the newly empowered Division would investigate if it determined there was reason. Second, the Division generated leads via its confidential informants. Third, the Division generated leads from its newly establish counterterrorism hotline.

Over a period of years, this hotline-located at the Division's 24-hour, seven-days-a-week operations desk-received thousands of calls from the public. The Division pursued each lead aggressively, and over the years, many calls resulted in full-scale investigations and arrests for matters related to terrorism. The rules were simple. When a call came in, the JTTF had first rights of refusal for follow-up; if they declined, the Division would act. The follow-up would be immediate, and the results would be documented in operational reports, filed, and a full investigative case initiated if warranted. 


\section{Expanding intelligence operations}

The Intelligence Division's ability to attract uniformed managers, supervisors, and detectives of the highest quality was a core strength of NYPD terrorism-related operations. With the strong support from Kelly, the Division brought on board some of the NYPD's best cadre. Every aspect of the Division benefited, none more so than the all-important undercover and confidential informant units.

\section{The deep undercover program}

The undercover program included the undercovers and their handlers and managers. The undercovers were young officers, in their early to mid-20s, almost all born abroad or first generation, and U.S. citizens with native fluency in languages ranging from Urdu to Bengali. The cadre grew to include men and women with roots in more than a dozen countries, mostly in South Asia, the Middle East, and North Africa. Instead of using experienced detectives who could not blend in with investigative subjects, these rookies entered the department through the Intelligence Division rather than the Police Academy. Hand selected, they were intelligent, highly motivated, and fully understood the complex challenges they would face.

As undercovers, they never entered an NYPD facility. They went through an intense six-month training program conducted by the undercover unit, usually in hotel rooms or locations far from New York City. The training class consisted of one student at a time, and instructors were often former undercovers who understood the professional and personnel issues that would arise living a full-time life under a different cover. The pressure on the undercovers, their handlers, and their managers was intense, as the stakes were high.

The undercovers blended naturally with the persons, clusters, and organizations that they were investigating. An undercover was instrumental in thwarting a case involving Mohamed Alessa and Carlos "Omar" Almonte, two New Jersey residents who were arrested as they attempted to depart New York to join the terrorist group al-Shabaab in Somalia. The pair had invited a remarkable 23-year-old undercover officer of Egyptian descent to join their cell after he spent months engaging with them. ${ }^{6}$ When the case became public, even the undercover officer's parents and girlfriend did not know that he had been living a separate life as an undercover for the previous four years.

While much of the deep undercover program cannot be discussed publicly due to case sensitivity and the safety of the undercovers involved, it can be said that they have been instrumental in dozens of cases. Their success is a direct result of the quality of the NYPD undercovers, their handlers, and their managers. One measure of the quality of the program is that when Samir Khan - the editor of al-Qaida in the Arabian Peninsula's Inspire magazine- - visited New York City before leaving for Yemen, NYPD undercovers were part of the welcoming party. ${ }^{7}$

\section{Confidential informants}

A confidential informant is "an individual requiring anonymity who provides useful information, directed assistance, or both, that enhance criminal investigations and furthers the mission of the agency, usually in exchange for financial or other consideration." ${ }^{8}$ They differ from citizens or witnesses who provide information in that the arrangement involves a relationship focusing on the trading of information for payment or prosecutorial considerations. ${ }^{9}$

Confidential informants served as the backbone of Intelligence Division operations, enabling the Division to get close to persons, clusters, or organizations under investigation. During these investigations, the Division understood and stayed firmly committed to avoiding any action that might be interpreted as entrapment. Division management at all levels knew this would be a first line of defense for defendants in a terrorist case. 
In one of many cases, the Division used two confidential informants and an undercover officer to investigate Jose Pimentel before arresting him in 2011 as he was constructing three bombs in his Washington Heights apartment. Pimentel, a self-radicalized internet disciple of al-Qaida in the Arabian Peninsula's Anwar al-Awlaqi, wanted to kill U.S. military personnel returning from Afghanistan. The case raised concerns of entrapment, ${ }^{10}$ and it was the lead argument in his defense. Nevertheless, he agreed to plead guilty to a single count on the indictment rather than go to trial and argue entrapment. ${ }^{11}$ Ultimately, the entrapment defense has almost always failed in post-9/11 terrorism cases, yet the Division remained committed to avoiding entrapping anyone. ${ }^{12}$

Having confidential informants who can gain access is essential; having detectives who can manage, control, and direct them is just as important. The intelligence units that worked with confidential informants were well trained. The Division often did well when it came to selecting confidential informants with access-sometimes too well. In one case, Najibullah Zazi and two other al-Qaida-trained associates from Queens, New York, planned multiple suicide attacks against the New York subway system in 2009. Asked by the FBI if it knew or could learn anything about Zazi, the Division appropriately approached one of its informants who happened to know Zazi's family well enough that he called Zazi's father, alerting him that law enforcement was asking about his son.

Zazi had terminated the plot the night before the alerting phone call. As Zazi stated at his trial, he realized he was under surveillance, especially when he faced an FBI-directed Port Authority vehicle stop at the George Washington Bridge following the 100-hour drive from Colorado to New York City. The case, with all its complications, demonstrates the depth of the NYPD informant cadre that it could call upon in time of need.

The Division developed and instituted an unparalleled vetting process for confidential informants used in the antiterrorism program. Operational testing was rigorous and continuous to ensure that informants were not merely reporting what they thought their investigator handlers wanted to hear or were trying to "dirty up" someone the informant wanted to harm. Their reporting streams were constantly reviewed for inconsistencies in what was already known about a target; a stringent mechanism was established that evaluated the ability of the investigators to manage their informants in the best way. Nothing was left to chance, as the review process itself consisted of the most experienced talent in the division. These reviews were critical and focused-it was not "checking the box."

\section{Adding civilian analysts to the division}

Commissioner Kelly wanted civilian analysts to be embedded in his divisions, so the NYPD recruited analysts with relevant backgrounds from the best schools. The Intelligence Division hired the first civilian analyst by early 2002. The Division was concerned about terrorist operatives entering the city from the port and needed expertise in this area, so they hired a Merchant Marine Academy graduate as their first analyst. In relatively short order, the civilian analyst program became a powerful force multiplier, and the analysts quickly became essential to the counterterrorism intelligence investigative program.

The blending of civilian analysts with investigators was neither automatic nor natural. The civilian cadre typically came from top graduate schools such as Harvard, Columbia, and Georgetown. While extremely intelligent, they often lacked intelligence experience; that came only with time on the job and an appreciation that ground-level analysis - what someone was saying to someone else in an apartment in Brooklyn, Queens, or Staten Island-was what mattered most. They learned quickly and played a powerful role in pursuing investigations and bringing perpetrators to prosecution.

Their intelligence, diligence, and creativity quickly won the respect of the investigative units with whom they worked. They were also helped by the management decision that, for operational security reasons, the operational reporting of each investigative unit was compartmented from one another. Within 
each unit, only the civilian analyst involved in the investigation was authorized to see all the reporting from the confidential informants and undercovers involved in the case.

Therefore, it fell to the analysts to collate the information, analyze it, identify gaps, and set requirements for both the undercover and confidential informant programs. Empowering the analysts helped make them full partners with the investigators, and the analyst and investigator always answered as a team. The integration of operations and analysis was now complete.

\section{The Cyber Unit}

Created in late 2002, the Cyber Unit's critical mission was to scour the internet to identify persons involved in planning or wanting to participate in terrorism-related actions. The Division was early to recognize the power of the internet in the context of terrorism; its concerns proved well founded.

First, al-Qaida and its affiliates increasingly communicated their ideology on the internet and via compact discs and videos, rapidly transforming the internet into a source of radicalization. Second, already radicalized individuals around the world used the internet to communicate with one another, forming "virtual" jihadi clusters, including with persons in the New York City area. Third, the internet had become a threatening source of information on bomb making, explosive devices of all kinds, and details on how to communicate securely.

The Intelligence Division, with the help of the Personnel Bureau, leveraged the Department's foreignlanguage capabilities to identify hundreds of NYPD members with foreign-language skills. It recruited some as cyber analysts to assess literature and conversations on jihadi websites and chat rooms, whether in Arabic, Farsi, Turkic, or Pashto. Their objective was to identify any mentions of New York City.

By scouring the internet, the Division began to identify organizations abroad that were known to be incubators of radicalization, or believed to be involved in terrorism, that might threaten New York. One example was al-Muhajiroon, an organization created by Omar Bakri Muhammad in the United Kingdom. Bakri, who was eventually expelled from the United Kingdom for extremist activity, sponsored a New York City chapter whose members included up to five people eventually arrested, convicted, and sentenced for various terrorism-related crimes. ${ }^{13}$ Other groups warranting attention included Lashkar-e-Tayyiba, Hezbollah, Hamas, and every other organization labeled as a terrorist group by the U.S. governmentwhether in South Asia, North Africa, the Middle East, or the Caucasus. ${ }^{14}$

The greatest impact resulted when cyber analysts-who included uniformed and civilian personnelcollaborated with civilian investigative analysts and investigative detectives. After the cyber team, always working in the unclassified world, identified a person of concern, the civilian analysts would conduct follow-up "forensic analysis," and, if needed, an investigation would begin involving the three (cyber, analyst, and detective) as a team.

As early as 2012, these teams started to assess how the Syrian rebellion attracted and produced radicalized persons in the New York area. In fact, even before the emergence of the Islamic State, the Division understood the risk and was preparing for its impact. It had a long record of looking for "lone wolves."

\section{The Demographics Unit}

One of the more controversial initiatives was the Demographics Unit, which was renamed the Zone Assessment Unit in 2010. Early in the Division's re-engineering process, it was clear that it lacked meaningful knowledge of either the demographic composition of the city or demographic concentrations. This was especially concerning during the post-9/11 period when there was alarm about al-Qaida cells or operatives establishing themselves in New York, New Jersey, and elsewhere in the United States. The importance of this knowledge is recognized in the Attorney General's Guidelines for Domestic FBI Operations that makes clear that such knowledge is an important FBI Field Office responsibility. ${ }^{15}$ 
With the risk of terrorism as the guidepost, the Division's concern included three points. First, if an adversarial operative, foreign or domestic, wanted to blend in so as not to be noticeable or appear suspicious, where are they likely to go? Where should intelligence or other policing efforts focus should the need arise?

Second, if an operative sought to recruit persons via their ability to associate or "hang out" with persons of similar background, where would the NYPD look if the Division received warnings from the federal government or elsewhere of such a risk?

Third, should events occur abroad — an attack on Hazaras in Pakistan, for example-where is the Hazara community in New York City concentrated, as they might need added police protection? Not knowing this in advance would be negligent in New York City.

From the NYPD's perspective, this knowledge was not frivolous, nor did it meet the definition of surveillance. Teams of plainclothes officers deployed to collect baseline knowledge about neighborhoods as opposed to individuals. The deployed teams were not involved in investigations or intelligence collection on persons or groups of persons. Nor did the NYPD send confidential informants or undercovers into mosques just to "listen." The rules were that a confidential informant or undercover could enter a mosque only if it were frequented by a person under investigation.

The American Civil Liberties Union still accused the NYPD of unlawful surveillance and unlawful profiling of Muslims. ${ }^{16}$ In the aftermath of Associated Press reports on the program, two major lawsuits were filed against the city: Hassan v. City of New York and Raza v. City of New York. As part of the settlements of both cases, which occurred several years after the unit had been disbanded in 2014, the NYPD was excused from any admission "that it has in any manner or way violated the rights of Plaintiffs or the rights of any other person or entity." Yet, the NYPD agreed to "establish a number of reforms designed to protect New York Muslims and others from discriminatory and unjustified surveillance" and a number of other requirements. ${ }^{17}$

\section{Creating an international program}

By the fall of 2002, the Intelligence Division deployed its first detective overseas. Eventually, the Division deployed personnel to 11 law enforcement organizations around the world, including, among others, London's Scotland Yard, Canada's Sûreté du Québec, and France's Paris Prefect. With few exceptions, these hand-picked assignees had native fluency in the language of the country assigned. The assignees to the Madrid Police, for example, spoke fluent Castilian Spanish, while those in the Middle East spoke Arabic. Their knowledge of terrorism and police intelligence made them welcome additions to the agencies that hosted them.

Their job was to represent the NYPD's interests, compare best counterterrorism practices, and ensure that questions that might show a nexus to New York City—a plot, group, or person, for example-were always asked by the host service when terrorism-related events or investigations occurred. Finally, they were expected to be on the site of any terrorist event as soon as possible to learn and report what and how the incident happened. It was vital that the NYPD learn from such events to improve its own counterterrorism initiatives.

It worked extremely well. For example, by having an accomplished lieutenant on site after the 2004 Madrid train bombings, the NYPD altered its critical response vehicle deployment strategy regarding subway stations. How it would handle terrorist crime scene material was also refined, having learned that the cell phone SIM card that ultimately led to the capture of the Madrid plotters was almost lost, as clean-up crews were about to discard the cell phone found at the scene.

Within 72 hours of the 2008 Mumbai attacks, the NYPD deployed a three-person team to India. In less than a week, the Division produced a 50-page report on what it learned from the incident and disseminated it to dozens of state and local U.S. law enforcement agencies, federal law enforcement agencies, and partners overseas. ${ }^{18}$ 
Commissioner Kelly also hosted a two-hour videoconference from Mumbai between the NYPD Mumbai team and 300 private-sector and law enforcement personnel. Based on what it learned, the NYPD quickly moved to train additional department personnel in the use of rifles, conducted internal hotel terrain mapping, established specialized hotel teams, and engaged in tabletop exercises using the Mumbai scenario.

Learning from the 2005 London bombings, Kelly initiated a random bag check program at some of New York's subway stations. This was the first of its kind in the United States, spearheaded by the NYPD Counterterrorism Bureau and its deputy commissioner, Michael A. Sheehan.

The information gathered from having officers on the scene during these various terrorist attacks abroad was vital, and sharing it with other police departments and agencies was standard operating procedure. Not surprisingly, it was not long before the Division had become a valuable source of information and insight for many of the foreign security services with which it worked.

The Division hosted hundreds of visits by foreign security services, provided training to some, and won their respect for the Division's professionalism and effectiveness. These meetings revealed the uniqueness of the NYPD. Few, if any, foreign security or intelligence services had their civilian intelligence analysts and investigators so thoroughly integrated. Few, if any, had an embedded undercover program staffed with full-time employees of their organization; more typically, they used only confidential informants or non-staff undercovers.

Many seemed to be constrained by unit-specific parochial perspectives that clearly interfered with the organization-wide integration of programs, people, and information. While they admired the NYPD's intelligence program, structural or cultural obstacles often prevented them from being able to replicate important elements of it.

\section{Sharing information and expanding partnerships}

Aside from leadership, information sharing was the single most important factor driving the Division's effectiveness in the years following 9/11. In its narrowest form, this meant sharing information between individual analysts and detectives, between teams of analysts and detectives, between the Division's 16 counterterrorism units, and ultimately between one organization and another. While easier said than done, information sharing was effective due to its leadership, culture, and technology.

Its leaders-Kelly, Cohen, and Sheehan - conducted daily meetings together and required their subordinates to be synchronized as well. Culturally, the department recognized that terrorism spanned not only jurisdictions but state and international borders, so it was important to expand its network to protect not only protect New York City but others around the world. Finally, technology was critical to digitizing reports and information that could be easily shared or searched.

Creating an environment of information sharing was made easier because its work was not U.S. government classified. The Division established its own classification standards based on the source of the reporting: undercovers, confidential informants, or cyber collection, for example. All intelligence reports/ memoranda produced by the Division carried an NYPD SECRET classification stamp.

\section{Operation Sentry: Expanding regional partnerships}

The NYPD is a vast organization by any measure. In 2002, when the process of restructuring it to address the terrorist threat began, there were 42,000 uniformed members and 15,000 civilians. Many organizations that large and powerful develop a view that they can accomplish what they need without outside assistance. But the Division rejected that perspective. It recognized that it needed partners to protect New York City from another attack.

This regional approach was the foundation of Operation Sentry, which was designed to build partnerships across the country. While New York City remained a primary target, the plotting, planning, training, 
and deployment often emanated from outside the city. In response, the Division started Operation Sentry by establishing special relationships with local law enforcement agencies surrounding the city.

Several features made Operation Sentry effective and attractive to each member. First, the Division explicitly called for assistance. Second, the Division committed some of its best detectives and analysts to the operation.

Third, the NYPD provided training, advice, and support to alliance members. This extended beyond counterterrorism matters and into traditional police issues. In this regard, the Division became the entry point for partners into the vast resources and expertise of the NYPD. When the Hoboken, New Jersey, police department needed scuba divers to assist in retrieving a body from the Hudson River, the first call for help came to the Division. ${ }^{19}$

Fourth, information sharing was complete, transparent, and based on a policy of "push" rather than "pull." Division policy and practice were to disseminate information quickly, in a useable form, to whomever needed it without waiting for a partner to request it. Fifth, Division leaders responsible for managing Operation Sentry were committed to a "no surprises" policy; any activity the Division undertook in a member's territory was always completed with the knowledge and, when needed, help of the partner in place. The policy was unambiguous and strongly supported by every Operation Sentry officer and partner.

The results of this collaboration were remarkable. Multiple terrorism-related investigations, arrests, and convictions resulted from joint efforts with the Suffolk and Nassau County police departments, and dozens of cyber leads produced by the Division's Cyber Unit were shared with local police departments around the country as well as the federal government.

A prime example of this successful collaboration is one of the few "illegal cigarette" cases given the greenlight by Cohen. Driving this decision was the fact that one of the targets in the case involved a financial associate of Omar Abdel Rahman (also known as the "blind sheikh") and an individual linked to Hamas' senior U.S. fundraiser. Another individual swept up in the "cigarette case" was the suspected sanctioner of Rashid Baz (who killed Jewish student Ari Halberstam on the Brooklyn Bridge in 1994). ${ }^{20}$ The case itself emerged from confidential informant leads obtained in conjunction with upstate New York police departments.

\section{Operation Nexus: expanding private sector partnerships}

Almost from the start, the Intelligence Division initiated a program to reach out to the private sector to engage it in "watching out" for any anomalous purchase that should raise concern about possible terrorist activity. A number of steps were taken to this end.

First, the Division identified material that could be used in a terrorist plot based on events overseas and a careful scrub of information available on the internet. Second, the Division identified all businesses in the tri-state area that bought, sold, inventoried, or transported such material. Third, it deployed teams of detectives to visit each of these locations, meet with managers or staff who were informed about how products in their possession had been used in terrorist attacks abroad, asked to remain vigilant for any purchases that were inconsistent with normal practices of their business, and advised to report that activity to the FBI and the NYPD counterterrorism hotline.

During what became known as Operation Nexus, detectives conducted more than 25,000 visits to area businesses. ${ }^{21}$ To raise awareness, they also spoke to industry conventions such as the aircraft spraying convention, the unmanned aerial vehicle convention, and firearms shows. Detectives also made special links with relevant firms. Intelligence detectives, for example, established a connection with the fuel trucking industry in the New York-New Jersey region to ensure that any missing fuel trucks would be immediately reported to Division's Operations Unit for response.

After the Boston Marathon bombings in 2013, Operation Nexus established a link with the country's largest fireworks company, headquartered in Pennsylvania. A company store, unknowingly, was the source of fireworks bought by Faisal Shahzad as part of his plan to detonate a bomb in Times Square in 2010.22 
The Tsarnaev brothers purchased fireworks from one of the company's New Hampshire stores to gain access to the black powder contained in the fireworks as part of the Boston Marathon bombings. ${ }^{23}$ According to the fireworks company, Operation Nexus outreach was the first time it had been contacted by any law enforcement agency. Unfortunately, this came only after the Boston Marathon bombings, when the Division connected the two purchases.

\section{Expanding federal government partnerships}

The NYPD leadership decision to carve out a role in defending New York City against another terrorist attack was not immediately understood or necessarily welcomed by all U.S. government agencies responsible for counterterrorism. Many believed NYPD intelligence should have a narrower, more traditional role that excluded terrorism issues. But the NYPD leadership believed that to defend the city, it could not rely solely on the federal government to find the dots, connect them, and pursue where or to whom they would lead. That system had failed in 1993 and 2001. Therefore, knowing its terrain better than the federal government, the mayor and commissioner directed the NYPD to take a much more active role than had been the case historically.

The greatest resistance came from the FBI, claiming the Intelligence Division was overeager and amateur. While there was much acrimony, that tension at no time interfered with either FBI or NYPD counterterrorism endeavors. Over time, these tensions diminished as old enmities faded. Today, the NYPD-FBI relationship remains strong.

The NYPD civilian analyst cadre were extremely important in this steadily improving relationship, as they carried the bulk of the information-sharing load with the FBI and other federal agencies. This took the form of briefings as well as extensive written documentation. Analysts conducted hundreds of briefings to FBI personnel and produced more than 1,000 special reports, referred to as "Sitreps," that were provided to the FBI. The Division also developed close partnerships with U.S. prosecutors as far afield as the Eastern District of Virginia that successfully prosecuted Division cases that others would not.

Throughout the 2002-2013 period, the Division posted highly qualified personnel to various U.S. government agencies in the New York City area and in Washington. These agencies welcomed the information and quality of personnel offered by the Division. Of greatest value to these agencies was the "view from the ground" provided by the NYPD analysts.

One point of media criticism focused on the NYPD-CIA relationship. ${ }^{24}$ The media focused on a portion of the CIA inspector general report that noted "a number of irregular personnel practices . . . [some] lack of formal documentation in some important instances, and varying degrees of management and legal oversight." ${ }^{25}$ Despite some unintentional administrative missteps, the six month review concluded that the CIA-NYPD relationship did not violate the 1947 National Security Act or Executive Order 12333, ${ }^{26}$ the relationship had been approved at the highest levels of both organizations, and no improprieties by either CIA or NYPD personnel had occurred. ${ }^{27}$

Despite these findings, the CIA ultimately terminated the relationship in 2012, perhaps due to the urging of the director of national intelligence, who stated in a public hearing that it is "not a good optic to have CIA involved in any city-level police department." ${ }^{28}$ Many in the NYPD believed that optics should not have been a deciding factor in the decision, considering that New York City remained a top terrorist target.

\section{Legal oversight of intelligence}

Given the sensitivity of the Intelligence Division's activities, legal oversight was crucial and welcomed. The U.S. Constitution and federal court guidelines - the Handschu guidelines ${ }^{29}$ - provided the boundaries that department and Division leadership was committed and obligated to work within. That said, it required 
a legal staff to determine whether an activity crossed those boundaries, came close to them and therefore needed to be avoided or altered, or was within the boundaries. The NYPD leadership treated these matters with the utmost conviction and did so openly for all staff members to see.

The Division was fortunate to have a vigorous and tough-minded civilian legal counsel, Assistant Commissioner Stuart Parker, who answered to Commissioner Kelly through the General Counsel rather than the Intelligence Division chain of command. Under such a structure, legal counsel could not be ignored. Legal oversight, however, required knowledge of the Division's actual activities. Thus, there was a need for complete transparency.

To ensure transparency, the deputy commissioner for intelligence implemented several mechanisms. First, the assistant commissioner for legal matters attended the Division's morning meetings, as that was where policy and operational guidance were surfaced, discussed, and decided upon. Second, the assistant commissioner for legal matters or his staff were authorized to attend any meeting held by any Division, team, unit, branch, or any combination of them, and the legal staff was to be informed of such meetings in advance. Third, the assistant commissioner or his staff reviewed operational reports prepared by Division detectives and analysts to ensure that activity on the ground comported with legal guidelines.

In short, the Division established mechanisms that ensured complete transparency and the legal oversight required by the court and the police commissioner.

\section{Conclusion}

While the re-engineered Intelligence Division had its critics, the results are tough to refute. Of the 16 known terrorist plots directed against the city by al-Qaida, its affiliates, or al-Qaida-inspired homegrown terrorists during 2002-2013, not a single one succeeded. The Division was responsible for stopping three of the plots and played a significant role in foiling three others. As discussed in the chapter, an undercover officer was central to the Alessa and Almonte cases, as well as in the arrests of individuals attempting to join al-Shabaab and al-Qaida in the Arabian Peninsula.

The Shehadah case is exemplary of what was accomplished. In 2008, Abdel Hameed Shehadah bought a one-way ticket to Pakistan to attend a terrorist training camp but was turned back by Pakistani officials based on intelligence provided by an NYPD undercover officer. He was subsequently arrested upon his return. ${ }^{30}$ Likewise, an NYPD undercover and confidential informant contributed to the arrest of Justin Kaliebe and Marcos "Ali" Zea, who were attempting to join al-Qaida in the Arabian Peninsula. ${ }^{31}$

There are many lessons to be drawn from the experience of the NYPD Intelligence Division during this post-9/11 era. The most central lesson is the overarching role of leadership in launching an endeavor never before taken on, in terms of scope and depth, by a local law enforcement agency. Commissioner Kelly's role was essential, critical, and overarching. None of this could have happened without his vision and strength of purpose. He seeded and then allowed the Division to thrive. Thus, strong, articulate leadership with unambiguous integrity at the top stands out as the single most important lesson.

The second lesson is the role of culture. Terrorism spans jurisdictions and nations, so counterterrorism must likewise span jurisdictions and nations. Civilian analysts were hired to partner with seasoned detectives. Partnerships were expanded through Operation Shield and Operation Nexus, and NYPD officers were even sent to overseas departments. Thwarting the many attempted attacks on New York City often involved multiple departments and agencies.

As the person who headed the NYPD Intelligence Division during this period, the third crucial lesson involves people. The Division came to be populated with smart, hard-working, highly motivated senior officers who were willing to learn and lead. Nobody filled this role or served as a better role model for others than Chief Thomas Galati, who had this author's complete confidence, shared in all decision-making, and had the trust of all concerned. 


\section{David Cohen}

The underlying lessons woven through this chapter have application for the challenges faced by Western European intelligence and security services in Mumbai, Tokyo, Bangkok, and other major urban centers. In brief, the Intelligence Division's key strengths involved more integrated intelligence and security programs; aggressive use of civilian analysts teamed with investigators; and support from a cadre of undercover officers who, while living a covert life, are fully embedded into the agencies for which they work. Yet it is important to operate within the rule of law. These are the minimum requirements for enhanced security and safety.

\section{Notes}

1 This quote is based on the author's recollections.

2 Al Baker, "Crime Drops Despite Fewer Officers in Lean Times," New York Times, July 17, 2009, www.nytimes. com/2009/07/18/nyregion/18nypd.html.

3 For more on buy-and-bust operations, see Michelle Mark, "Undercover New York Police Officers are Reportedly Targeting Addicts Instead of Drug Dealers," Business Insider, April 4, 2016, www.businessinsider.com/ undercover-new-york-police-officers-using-buy-and-bust-tactics-2016-4.

4 William K. Rashbaum, "Man Gets 30 Years in Subway Bomb Plot," New York Times, January 9, 2007, www. nytimes.com/2007/01/09/nyregion/09plot.html.

5 David Cohen, "NYPD's Intelligence Division: Answering the Terrorism Challenge Post 9/11," The Cipher Brief(blog), September 15, 2016, www.thecipherbrief.com/column_article/nypds-intelligence-division-answeringthe-terrorism-challenge-post-911-2.

6 U.S.A. v. Mohamed Alessa and Carlos E. Almonte, Criminal Complaint (District of New Jersey, 2010).

7 Jesse Morton and Mitchell Silber, "NYPD vs. Revolution Muslim," CTC Sentinel 11, no. 4 (2018): 1-7.

8 "Confidential Informants: Concepts and Issues Paper," IACP Law Enforcement Policy Center, August 2017, www. theiacp.org/sites/default/files/all/c/ConfidentialInformantsPaper2017.pdf.

9 Ibid.

10 William K. Rashbaum and Joseph Goldstein, "In Jose Pimentel Terror Case, FBI Worries Over Informer," New York Times, November 21, 2011, www.nytimes.com/2011/11/22/nyregion/for-jose-pimentel-bomb-plot-suspect-an-online-trail.html.

11 James C. McKinley Jr., "Judge Imposes 16-Year Term for Manhattan Man in Pipe Bomb Case," New York Times, March 25, 2014, www.nytimes.com/2014/03/26/nyregion/judge-imposes-16-year-term-for-manhattan-man-inpipe-bomb-case.html.

12 Jesse J. Norris, "Accounting for the (Almost Complete) Failure of the Entrapment Defense in Post-9/11 US Terrorism Cases," Law \& Social Inquiry 45, no. 1 (2020): 194-225.

13 Richard Esposito, "Feds Request Leniency for Terrorist Who Still Backs Killing of Americans," ABC News, March 7, 2011, https://abcnews.go.com/Blotter/mohammed-babar-convicted-aiding-al-qaeda-early-release/ story?id $=13078465$.

14 For a current list, see "Foreign Terrorist Organizations," U.S. Department of State, www.state.gov/foreignterrorist-organizations/.

15 Michael Mukasey, "Attorney General's Guidelines for Domestic FBI Operations," U.S. Department of Justice, September 29, 2008, www.justice.gov/archive/opa/docs/guidelines.pdf.

16 "The NYPD's Discriminatory Surveillance of Muslim Communities," ACLU, no date, www.aclu.org/other/ factsheet-nypd-muslim-surveillance-program.

17 Bridge Initiative Team, "Factsheet: The NYPD Muslim Surveillance and Mapping Program," Georgetown University, May 11, 2020, https://bridge.georgetown.edu/research/factsheet-the-nypd-muslim-surveillance-andmapping-program/.

18 Intelligence Division, Mumbai Attack Analysis (New York: New York City Police Department, 2008), https://info. publicintelligence.net/nypdmumbaireport.pdf.

19 A.G. Sulzberger and Al Baker, "Police Divers Recover Bodies and Plane Wreckage," New York Times, August 11, 2009, https://cityroom.blogs.nytimes.com/2009/08/11/police-divers-renew-effort-to-salvage-plane/?src=twt\&twt= CityRoom.

20 Mark Hosenball, “New York Says Breaks Cigarette-Smuggling Ring Linked to Militants," Reuters, May 16, 2013, https://fr.reuters.com/article/us-crime-cigarettes-mideast-idUSBRE94F1C320130516.

21 NYPD Shield, “Operation Nexus," New York City Police Department, November 10, 2020, www.nypdshield.org/ public/nexus.aspx. 
22 Cara Buckley, "Pennsylvania Fireworks Store Owner Recalls Shahzad," New York Times, May 6, 2010 , www. nytimes.com/2010/05/06/nyregion/06fireworks.html.

23 Lauren Dezenski, “Older Marathon Bombing Suspect Purchased Fireworks at N.H. Store,” Boston Globe, April 23, 2013, www.boston.com/uncategorized/noprimarytagmatch/2013/04/23/older-marathon-bombing-suspect-pur chased-fireworks-at-n-h-store-official-says.

24 See, for example, Charlie Savage, "CIA Report Finds Concerns With Ties to New York Police," New York Times, June 26, 2013, www.nytimes.com/2013/06/27/nyregion/cia-sees-concerns-on-ties-to-new-york-police.html.

25 CIA, "Review of the CIA-NYPD Relationship" (official memorandum, Langley, VA: CIA, December 27, 2011).

26 "Executive Order 12333 of December 4, 1981 United States Intelligence Activities," Code of Federal Regulations, title 3 (1981): 200.

27 CIA, "Review of the CIA-NYPD Relationship."

28 Mark Mazzetti, “CIA Examining Legality of Work With Police Dept.," New York Times, September 13, 2011, www.nytimes.com/2011/09/14/nyregion/cia-examining-legality-of-its-work-with-new-york-police.html.

29 The Handschu guidelines govern how the NYPD investigates political activity. These guidelines were a product of surveillance of political groups, like the Black Panthers, in the 1960s and 70s.

30 Tom Hays, "NYC Man Gets 13 Years in Terror Training Case," Associated Press, September 20, 2013, https:// apnews.com/article/eefbdb26a6b44f2f9a5c9b08556a25b4.

31 U.S. Attorney's Office, "Long Island Man Pleads Guilty to Attempting to Join Al-Qaeda in the Arabian Peninsula and Obstruction of Justice," U.S. Department of Justice, September 9, 2014, www.justice.gov/usao-edny/pr/ long-island-man-pleads-guilty-attempting-join-al-qaeda-arabian-peninsula-and. 
28

\title{
LESSONS LEARNED FROM FOUR HIGH-CASUALTY TERRORIST ATTACKS IN THE UNITED STATES SINCE 9/11
}

\author{
Paul Cruickshank
}

Almost two decades after 9/11, the United States has suffered four high-casualty Islamist terrorist attacks: the Fort Hood shooting in November 2009, the Boston Marathon bombings in April 2013, the San Bernardino attack in December 2015, and the Orlando nightclub shooting in June 2016. These attacks killed 80 people and injured almost $400 .^{1}$

This chapter tells the story about how the four attacks slipped through the cracks of the U.S. security apparatus and how, with the benefit of hindsight, warning signs were missed. In three of the plots (Fort Hood, Boston, and Orlando), the Federal Bureau of Investigation (FBI) previously had the perpetrator, or one of the perpetrators, on their radar for suspected terrorism-related activity. Official reviews have identified shortcomings in investigative protocols, management of leads, training, access to databases, information sharing, and human error.

Given the scale of the counterterrorism challenge faced by U.S. security agencies, and the difficult judgment calls they must continuously make on which probes to prioritize, the aim of this chapter is not to assign blame but to provide an overview of each case so that lessons can be learned. ${ }^{2}$

\section{The Fort Hood shooting}

Shortly after 1:30 PM on November 5, 2009, Major Nidal Malik Hasan, a 39-year-old Army psychiatrist who was soon due to deploy to Afghanistan, entered the Soldier Readiness Center at Fort Hood, Texas, with two guns, including an FN Five-seveN semi-automatic pistol, shouted the words "Allahu Akhbar" (God is Great), and began shooting. Singling out unarmed U.S. soldiers, Hasan killed 13 and injured an additional 32 people before civilian police shot and incapacitated him. In 2013, a military tribunal convicted Hasan and sentenced him to death. ${ }^{3}$

\section{Genesis of the plot}

Hasan, the son of Palestinian immigrants, began active duty in the Army in 1995. In the years after 9/11, Hasan transformed from a devout Muslim to embracing Islamist extremist views. These were on full display by 2007 when fellow officers at the U.S. Army's Walter Reed Medical Center in Maryland described him as having "fixed radical beliefs about fundamentalist Islam" that he shared at "every possible opportunity." 
During the same period, Hasan warned in writings several times that Muslim-Americans in the military could be prone to fratricide. ${ }^{5}$ At Walter Reed, Hasan had been exposed to soldiers traumatized by conflict in Iraq and Afghanistan, making it possible this later contributed to how he reacted when he received deployment orders.

Between December 2008 and June 2009, Hasan and Anwar al-Awlaqi, a Yemeni-American jihadi cleric based in Yemen, exchanged 18 e-mails focusing on a variety of issues, including the permissibility of suicide bombings. Hasan initiated 16 of the 18 e-mails. He was clearly in awe of the cleric, who previously led prayers at a mosque in Falls Church, Virginia, around 2001. ${ }^{6}$ During the course of their correspondence, Hasan wrote that they had met briefly when al-Awlaqi was the imam at the mosque but "I doubt if you remember me." In an e-mail in February 2009, Hasan spoke of paradise but did not appear to have necessarily envisaged carrying out an attack at that time because he told al-Awlaqi he wanted to find a wife. ${ }^{8}$

By the time the communications began, al-Awlaqi had already been publicly described by a Department of Homeland Security official as an "example of al-Qaida reach into the Homeland." Al-Awlaqi, who communicated with many followers around the world from Yemen, only sent Hasan two short and benign replies..$^{10}$ No evidence has emerged that the cleric directly encouraged or instructed Hasan to carry out an attack. In an interview with a Yemeni journalist shortly after the Fort Hood shooting, al-Awlaqi stated that while the attack was "permissible," he neither ordered nor pressured Hasan to harm Americans. ${ }^{11}$

While al-Awlaqi did not explicitly and publicly call for jihad against the United States until several months after the Fort Hood shootings, the cleric had for years released audio sermons supportive of al-Qaida's worldview, which likely influenced Hasan. ${ }^{12}$ Several days after Hasan's gun rampage, al-Awlaqi wrote on his blog that Hasan was a "hero [and a] man of conscience who could not bear living the contradiction of being a Muslim and serving in an army that is fighting against his own people." ${ }^{13}$

It is not clear exactly when Hasan began contemplating an attack, but he purchased the weapon he used in the shooting on August 1, 2009, after asking for the "most high-tech handgun" available at a gun store near the military base. In October 2009, the Army notified him that he would deploy to Afghanistan in November. It is possible this news served as the trigger for his attack. No evidence has emerged that Hasan told anyone ahead of time of his plans. ${ }^{14}$

\section{Missed warning signs?}

With the benefit of hindsight, there were two missed opportunities to identify Hasan as a serious threat. First, the Department of Defense failed to sufficiently examine obvious signs of radicalization. Second, the FBI could have scrutinized Hasan more intensively following discovery of his communications with al-Awlaqi.

\section{Signs of radicalization at Walter Reed}

According to a 2011 Senate Homeland Security Committee report into the shooting, Hasan's "radicalization to violent Islamist extremism came into plain view" while he studied and worked at Walter Reed Army Medical Center in Maryland from 2006-2008. He spoke favorably of suicide bombings and wrote in support of some of the actions of Usama bin Ladin and in one class caused such offense that one of his presentations had to be stopped. Hasan's superior officers received reports several times about his extremist utterances, yet "they failed to discipline him, refer him to counterintelligence officials or seek to discharge him." Instead, he was promoted to major in May 2009. In July 2009, Hasan was transferred from Walter Reed to Fort Hood, Texas, the Army's staging area for deployment to combat zones. ${ }^{15}$ 


\section{Paul Cruickshank}

\section{Communications with Anwar al-Awlaqi}

Hasan's communications with Anwar al-Awlaqi marked a second warning sign. As part of a continuing investigation into al-Awlaqi, the FBI monitored a large volume of online message traffic to/from the cleric as a "trip wire" for identifying persons of potential interest. ${ }^{16}$ On December 17, 2008, Hasan tripped the wire when he visited al-Awlaqi's website and sent him a first message, asking whether Muslim-American soldiers who died while killing, or trying to kill, their fellow soldiers to help Muslims fighting jihad were shaheeds (martyrs). ${ }^{17}$

Members of the Joint Terrorism Task Force (JTTF) in the FBI's San Diego Field Office, who were in charge of investigating al-Awlaqi, reviewed the message and a second message sent by Hasan. Concerned by the implications of the sender possibly being in the U.S. military, the JTTF sent a "routine discretionary action lead" to the International Terrorism Operations Section 1 at FBI Headquarters and the JTTF in the Washington, DC, Field Office on January 7, 2009. It attached both messages that Hasan sent to al-Awlaqi and noted that al-Awlaqi had not replied. ${ }^{18}$

The FBI supervisory special agent in the Washington Field Office did not assign the lead until about February 25, 2009, a delay the Webster Commission stated was likely due, in part, to the focus at the time on security concerns over President Barack Obama's inauguration. Informal FBI guidelines required work on routine leads to be completed within 90 days. The JTTF officer assigned in Washington waited until the 90th day, May 27, 2009, to read the lead and take action. The agent spent just four hours on the assessment. The Webster Commission judged the delay was "unreasonable" and "may have affected the shape, scope and outcome of [Washington Field Office's] assessment of Hasan, which took place in four hours on that ninetieth day." ${ }^{19}$

With the benefit of hindsight, the assessment at the end of those four hours that Hasan's e-mails were benign and he posed no threat was greatly consequential. According to the Commission, the JTTF officer in the Washington Field Office decided it was not necessary to interview Hasan or follow up with Hasan's superiors after seeing almost uniformly positive reviews in Army evaluation reports. For example, the department chair of psychiatry at Walter Reed wrote that Hasan's research on Islamic beliefs concerning military service during the global war on terrorism "has extraordinary potential to inform national policy and military strategy." ${ }^{20}$ According to the Webster Commission, "Based on what he read, [the Washington Field Office JTTF officer] believed that Hasan's communications with [al-Awlaqi] were relevant to his research on Islam and the military. . . [and] that Hasan was not involved in terrorist activities." 21

The Washington Field Office assessment frustrated the San Diego JTTF officer charged with the alAwlaqi investigation. One member of the San Diego team e-mailed the Washington JTTF officer on June 12, 2009, to inquire whether Hasan might even be an informant to the Washington Field Office:

The response looks a little slim. i.e. limited probing into this individuals background, no contact $\mathrm{w} /$ command and no interview of Hasan. We were wondering if we were missing something, i.e. we need to read between the lines (Hasan is a friend of [Washington Field Office])? ${ }^{22}$

The Washington Field Office agent e-mailed back stating that he had not contacted Hasan, nor his command, directly, but his Army-sponsored research was in line with the questions he sent al-Awlaqi. Additionally, the agent conveyed that Hasan was not a confidential human source. The agent concluded by asking "If you have additional information regarding HASAN's links to terrorism or request any specific action, please share and we will reassess." ${ }^{23}$

The San Diego team did not send such information. Despite the fact that they reviewed a trickle of new messages between Hasan and al-Awlaqi after first contacting the Washington Field Office, they never 
associated these messages with Hasan's initial two messages or the lead they sent to Washington. This may have been partly a function of the high number of electronic documents they needed to review in the al-Awlaqi investigation (as many as 70 per day) and partly a function of lack of access to the FBI's Data Warehouse System-Electronic Surveillance Data Management System database, ${ }^{24}$ which stored the AwlaqiHasan e-mails. According to the Webster Commission, one of the San Diego team did not even know about the FBI's database until after the attack, while two others involved in the al-Awlaqi lead in San Diego did not have access to it before the attack..$^{25}$

As a result, after Hasan sent the first two messages, the San Diego team did not flag any further messages to the Washington JTTF. According to the Webster Commission, the Washington Field Office was partly to blame. It found that the delay in Washington following up the lead "pushed Hasan further from the minds" of the San Diego agents. ${ }^{26}$ The Commission also judged that the Washington Field Office "erred in failing to search the [database] after the passage of five months since the initial e-mail from Hasan, if only to determine whether [al-Awlaqi] had replied to Hasan's messages." If they had searched the database, they could have seen additional communications, including al-Awlaqi's two e-mails to Hasan, yet the JTTF officer in Washington responsible for looking into the lead had not even been told about the existence of the database.

According to the Commission, if the Washington Field Office had seen the additional messages, it "could have undermined the assumption that Hasan had contacted [al-Awlaqi] simply to research Islam." The FBI's supervisory special agent who oversaw the handling of the case in Washington later said that, with the benefit of hindsight, the Washington Field Office would have opened a preliminary investigation into Hasan if he had seen all of the additional messages. ${ }^{27}$

In addition, the belief of the Washington Field Office "that the Army encouraged Hasan's research and would approve of his communications with [al-Awlaqi]" may have been different had they had access to files maintained locally by Hasan's command, which were far more critical of his performance. As the Senate report stated, "the FBI and [Department of Defense] together failed to recognize and to link the information that they possessed." If they had, Hasan would likely have been scrutinized more intensively. ${ }^{28}$ In fact, after the media began reporting on Hasan's attack, one of the FBI agents is said to have told his colleague in San Diego: "You know who that is? That's our boy." 29

In sum, the Senate committee and Webster Commission reviewing the circumstances around the Fort Hood shooting uncovered shortcomings in awareness and access to key databases, sharing information, a failure of either San Diego or Washington to take ownership of the lead, and a right hand not knowing what the left hand is doing dynamic within the FBI-JTTF structure. As a result, the FBI did not piece together the full scope of communications between Hasan and al-Awlaqi before the attack.

The Commission concluded that "individuals who handled the Hasan information made mistakes" and that the Washington Field Office "assessment of Hasan was belated, incomplete and rushed primarily because of their workload" and shortcomings in protocols, technology, and training "to navigate the everexpanding flow of electronic information." 30

While a more aggressive and coordinated probe, as well as an interview with Hasan, may have flagged him as a threat, it is not certain it would have prevented an attack. Even if Hasan had been dismissed from the Army, he would presumably have had other opportunities to target soldiers on U.S. soil. E-mails obtained by the FBI after the attack did not reveal any messages in the two weeks prior to the mass shooting suggesting Hasan was about to launch an attack. Moreover, as the Commission noted, "Other than his eighteen communications with Anwar [al-Awlaqi], he had no known contact and no known relationships with criminal elements, agents of foreign powers, or potential terrorists." ${ }^{31}$

Counterterrorism agencies on both sides of the Atlantic have found that it is difficult to intercept individuals who decide to conduct an attack if they fail to inform another individual about their plans. 


\section{The Boston Marathon bombings}

At 2:49 PM on April 15, 2013, two brothers-Tamerlan and Dzhokhar Tsarnaev-remotely detonated two pressure-cooker bombs they had just placed along the final stretch of the Boston Marathon route. The blasts, which were seconds apart, sent shrapnel across a wide area, killing 3 spectators and wounding 260 people.

Three days later, and just hours after the FBI released closed-circuit television images of the suspects, the Tsarnaev brothers shot dead Sean Collier, a Massachusetts Institute of Technology police officer who was sitting in his police cruiser, in a failed attempt to steal his firearm. They then hijacked a Mercedes sport utility vehicle so they could drive undetected to New York City to launch another attack using their remaining pipe bombs and a pressure-cooker bomb. The driver of the Mercedes, however, escaped during a stop at a gas station and called police. As a result, police located the brothers by tracking the vehicle's global positioning system to the Boston suburb of Watertown in the early hours of April 19.

The Tsarnaev brothers engaged the responding Watertown police officers in a gunfight and lobbed several pipe and pressure cooker bombs in their direction, some of which exploded. In the resulting melee, Dzhokhar Tsarnaev ran over his already wounded brother in an attempt to kill the police officers, contributing to his brother's death. Bleeding from gunshot wounds, Dzhokhar fled in the Mercedes and was arrested later that day hiding in a dry-docked boat in a residential area of Watertown. The owner of the boat discovered him and called 911. Dzhokhar Tsarnaev later told interrogators that he and his brother were planning a subsequent attack in New York City's Times Square. ${ }^{32}$

In 2015, Dzhokhar was convicted of the attacks after a trial in Boston. ${ }^{33}$ No terrorist group claimed responsibility, but the month after the bombings, al-Qaida's affiliate in Yemen-al-Qaida in the Arabian Peninsula—-praised the Tsarnaevs in its Inspire English-language magazine. ${ }^{34}$

\section{Genesis of the plot}

The Tsarnaev brothers entered the United States a decade before they bombed the Boston Marathon. Ethnic Chechens, they were born in Kyrgyzstan, where their father worked before the family moved to the United States. Tamerlan became a U.S. permanent resident in 2006, and authorities were processing his application for citizenship at the time of the attacks. Dzhokhar became a naturalized U.S. citizen in September 2012. At the time of the Boston bombings, Tamerlan was 26 years old, while Dzhokhar was a 19-year-old student at the University of Massachusetts-Dartmouth. ${ }^{35}$

Growing up, Dzhokhar idolized his older brother. Tamerlan had a volatile personality and increasingly turned to Islam as hopes of pursuing a career in boxing faded. Tamerlan became an avid consumer of Islamic content online and conspiracy-related websites and began to grow interested in the conflict in Chechnya. ${ }^{36}$

By 2011, Russian intelligence services had Tamerlan on their radar. In March 2011, the Russian Federal Security Service (FSB) sent the FBI a letter expressing concern that he had become radicalized and might seek to travel to Russia to join extremist groups. ${ }^{37}$ Moscow sent the same warning to the Central Intelligence Agency (CIA) that September. ${ }^{38}$ At some point the same year, Dzhokhar started to read terrorist writings and began posting online messages about the persecution of Muslims. ${ }^{39}$

In September 2011, Tamerlan, who had begun low-level drug dealing, may have participated in a brutal triple homicide in a Boston suburb in an apparent "drugs rip-off." Investigators gathered mounting evidence of his possible role in the killings after the Boston bombings. ${ }^{40}$ One of those murdered had been well known to him. Two of the homicide victims were Jewish. While being questioned about the murders, Ibragim Todashev, an associate of Tamerlan, was shot dead after he attacked an FBI agent during an interrogation a little over a month after the bombings. Todashev acknowledged he and Tamerlan carried out the murders. ${ }^{41}$ 
In January 2012, Tamerlan traveled to Russia, where he stayed with relatives in Makhachkala, the capital of Dagestan, a region that was at the time the center of the simmering jihadi insurgency in the Caucasus. ${ }^{42}$ But there is no evidence that he sought out jihadi groups or that he received terrorist instruction while in Dagestan. ${ }^{43}$

Upon his return to the United States in July 2012, Tamerlan grew a five-inch-long beard, and his radical views appear to have hardened. ${ }^{44} \mathrm{He}$ created a YouTube account, which showed he compiled playlists of jihadi videos, including "The Emergence of the Prophecy: The Black Flags of the Khorasan." The video detailed a prophecy about an army arising out of Afghanistan near the end of days, which has been cited by al-Qaida to justify its actions. At a Boston area mosque Tamerlan attended, he engaged in shouting matches with preachers, one of whom he accused of being a disbeliever. Congregants asked him to leave. ${ }^{45}$

The brothers appear to have started plotting the Boston bombings in late 2012. According to court documents, around Christmas that year, they accessed instructions on "making a bomb out of a pressure cooker filled with explosive powder and shrapnel" contained in al-Qaida in the Arabian Peninsula's Inspire magazine, which had been overseen by al-Awlaqi until his death in a U.S. airstrike in September 2011. ${ }^{46}$

Dzhokhar had nearly the complete set of Inspire magazines on his computer. When they built their bombs, the brothers used "improvised fuses made from Christmas lights and improvised, remote-control detonators fashioned from model car parts" and "filled the bombs with explosive powder emptied from ordinary fireworks, as well as nails, tacks, and BBs to make them more deadly." ${ }^{47}$ Like Hasan, the brothers consumed al-Awlaqi's propaganda. In March 2010, al-Awlaqi declared that jihad against the United States was binding on all Muslims. ${ }^{48}$

In the weeks leading up to the attacks, Dzhokhar created an online identity to spread radical ideas, and he obtained a handgun from a friend. The brothers purchased the materials necessary to make the bombs, with Tamerlan traveling to a fireworks store in New Hampshire in February 2013 to purchase 48 mortars containing low-explosive powder. The brothers "appeared to have crushed and emptied hundreds of individual fireworks containing black powder in order to obtain explosive fuel for the bombs." ${ }^{49}$ Around four weeks before the attacks, the brothers conducted target practice at a firing range in New Hampshire. ${ }^{50}$ Investigators did not establish where the brothers constructed the bombs. ${ }^{51}$

\section{Missed warning signs?}

With the benefit of hindsight, there were four missed opportunities to identify the brothers as serious threats. The first was the failure to make more headway in the investigation into the triple homicide in September 2011 in which Tamerlan (according to Todashev) participated, or even question Tamerlan about an attack that killed one of his close acquaintances. ${ }^{52}$ The second was that no one in the brothers' circle in Boston, including those at the Boston-area mosque who had witnessed Tamerlan's angry outbursts, appears to have ever reported any concerns about the brothers' state of mind to law enforcement. ${ }^{53}$

The third missed opportunity related to the actions of U.S. intelligence, border security, and law enforcement agencies following the Russian warnings. The fourth missed opportunity was that the brothers' extremist social media activities were not discovered until after the attacks, despite the fact that Tamerlan came onto the radar screen of counterterrorism agencies. The next sections examine the third and fourth potential missed opportunities in greater detail.

\section{The probe into Tamerlan Tsarnaev}

According to a 2014 Inspectors General report, the FBI legal attaché in Moscow received a memorandum in Russian from the FSB in March 2011 about Tamerlan and his mother. ${ }^{54}$ The memorandum alleged both were adherents of radical Islamist ideologies and that Tamerlan was preparing to travel to Russia to join 


\section{Paul Cruickshank}

unspecified "bandit underground groups" in Dagestan and Chechnya. The Russians requested the FBI give the FSB specific information about the pair, including possible future travel by Tamerlan to Russia. ${ }^{55}$

As a result of the Russian warning, the Boston JTTF conducted an assessment of Tamerlan, which involved an agent performing database searches, "drive-bys" of his residence, an on-site visit to his former college, and interviews with Tamerlan and his parents. ${ }^{56}$ In his interview, Tamerlan said he did not view extremist websites. ${ }^{57}$ In June 2011, the FBI closed its assessment, "finding no link or nexus" between Tamerlan and terrorism. ${ }^{58}$ Two months later, U.S. officials sent a letter to the FSB informing them that no derogatory information had been found about Tamerlan and requesting more information. ${ }^{59}$ There is no evidence the FSB ever responded before the Marathon bombings. ${ }^{60}$

The Inspectors General report noted that the JTTF agent in Boston conducting the assessment did not contact local law enforcement; visit the mosque Tamerlan attended; or interview Tamerlan's wife, his exgirlfriend whom he had been arrested for assaulting in 2009, or his friends and associates. ${ }^{61}$ The agent later said he did not find sufficient derogatory information to justify these additional steps. After the attacks, Tamerlan's former girlfriend revealed he had started shifting toward radical Islamist beliefs between 2006 and 2009, but it is not clear whether she would have revealed this before the bombings. ${ }^{62}$

In September 2011, the FSB provided the CIA with the same information that it had provided to the FBI. This resulted in the National Counterterrorism Center establishing a record for him in the Terrorism Identities Datamart Environment database, the U.S. government's central repository of the names known or "appropriately suspected" of involvement in international terrorism, which that year had over a half million entries. ${ }^{63}$

In the run-up to Tamerlan's travel to Russia in January 2012, the Boston JTTF agent was most likely informed of the upcoming travel by the Customs and Border Protection officer who received notification of Tamerlan's impending travel, according to the post-attack review by the Inspectors General. The Boston agent most likely then told the Customs officer the lead was closed and there was no interest in Tamerlan's travel. ${ }^{64}$

When Tamerlan departed from New York's John F. Kennedy International Airport on his trip to Russia, Customs did not review his record nor conduct an outbound inspection because he was judged a lower priority relative to other passengers of potential concern. When he returned to the United States in July 2012, Tamerlan was not identified as a potential subject of interest and therefore not directed to secondary inspection. While there had initially been instructions for Tamerlan to receive a secondary inspection when he re-entered the United States, by the time he flew back, this was apparently no longer deemed necessary. ${ }^{65}$

Given the FBI had shut down its probe into Tamerlan by this stage, it is impossible to know whether further questioning would have raised any additional red flags. Nevertheless, the Boston JTTF agent, if he was indeed alerted about Tamerlan's travel to Russia, never brought this to the attention of his supervisor. During the review by the Inspectors General, this supervisor stated that had he been informed of the travel, he would likely have re-opened the assessment. The JTTF agent, however, stated that he did not recall having a practice of notifying his supervisor of travel notifications in closed assessments. The head of the Boston JTTF said that if someone had "pinged" the JTTF agent about Tamerlan's travel, it would have "changed everything." The FBI legal attaché in Moscow between May 2011 and October 2012 stated he was never made aware of the travel, that it was "huge," and that normally this information would have led the FBI to reopen the assessment and seek additional information from the FSB. ${ }^{66}$ The Inspectors General report concluded that Tamerlan's travel to Russia was "significant in view of the FSB lead information and warranted further investigative action." ${ }^{67}$

Questions were raised in the aftermath of the attack over whether officials missed warning signs during Tamerlan's naturalization application process after he applied for U.S. citizenship in August 2012. Yet the Inspectors General report found that while Tamerlan's naturalization application was transferred for additional review because he had previously been flagged, the Boston JTTF agent informed the immigration 
services officer that "there is no national security concern related to [Tamerlan Tsarnaev] and nothing that I know of that should preclude issuance of whatever is being applied for." ${ }^{6}$

Another question mark concerns information sharing. According to then-Boston Police Commissioner Edward Davis, at no point before, during, or after the 2011 Boston JTTF assessment was the Boston Police Department alerted to the potential threat posed by Tamerlan Tsarnaev, but it is unclear whether this would have made any difference. ${ }^{69}$

\section{Extremist social media activities}

Despite the assessment that was opened into Tamerlan, U.S. counterterrorism agencies did not flag, as far as has been publicly stated, any of his online jihadi activity until after the attacks. In the two months leading up to the bombings, Tamerlan's own name was set as the "display name" on a YouTube account he maintained featuring jihadi videos, which likely would have been found through open-source searches had the probe into him still been open. He had previously maintained the account under a different "display name." ${ }^{, 70}$

Additional information on Tamerlan's online jihadi activities and download history that were subsequently obtained from analysis of a computer Tamerlan used would only have been discovered before the attacks if the FBI had opened a full investigation into him, according to the Inspectors General report. It was only after the attacks that authorities pieced together what type of websites the brothers had accessed online. $^{71}$

\section{The San Bernardino attack}

Shortly after 9 AM on December 2, 2015, Syed Rizwan Farook, a 28-year-old food safety inspector for the San Bernardino County Division of Environmental Health Services, arrived at a training session and holiday party for him and his coworkers in a conference room inside the Inland Regional Center in San Bernardino, California. While there, he placed a bag on a table before leaving the venue in a black sport utility vehicle at 10:37 AM. $^{72}$

Twenty minutes later, he returned with his wife, Tashfeen Malik. The two were dressed in dark, military-style clothing and opened fire on those in and near the conference room with powerful semi-automatic AR-15-style rifles, killing 14 and injuring 22. By the time police arrived minutes later, the couple had fled the scene. At 11:14 AM, Malik posted a pledge of allegiance on behalf of her and her husband to then-Islamic State leader Abu Bakr al-Baghdadi on Facebook. ${ }^{73}$

During their sweep of the building, authorities discovered a secondary explosive device Farook had placed in the bag to target arriving police officers. The bag contained three galvanized steel pipe bombs containing smokeless powder and a Christmas light initiator, which was wired to a remote-control toy car to create a radio-controlled improvised explosive device. The device was "switched on" and had close similarities to the explosive devices built by the Boston Marathon bombers. ${ }^{74}$

Shortly after 3 PM, investigators located the black sport utility vehicle which the couple had been driving around the area, and a high-speed pursuit and firefight ensued. Police killed both Farook and Malik. The two had fired over 80 rounds at officers. Afterwards, police recovered a Smith and Wesson AR-15-style rifle, an Oracle AR-15-style rifle, and two semi-automatic handguns near the vehicle. In the car, they found what they believed was the trigger apparatus for the secondary device left behind at the Inland Regional Center. ${ }^{75}$

The couple had been circling within seven miles of the attack site. Investigators believe they had been trying to remotely set off the explosive device they left behind. Three days after the attack, the Islamic State called the attackers "soldiers of the caliphate," a description it has used for those carrying out terrorist attacks in its name. No evidence has emerged the couple received any direction from terrorists overseas. ${ }^{76}$ 


\section{Genesis of the plot}

It is not exactly clear when Farook, the Chicago-born son of Pakistani immigrants to the United States, first became radicalized. An American citizen, Farook reportedly had a difficult childhood growing up in Riverside near San Bernardino, California. After attending Riverside City College and California State University San Bernardino, he held a series of jobs for San Bernardino County, including at its Department of Public Health between 2010 and the attack in December 2015. ${ }^{77}$

By 2005, Farook seems to have had some interest in the Tablighi Jamaat movement, a group with hundreds of thousands of members worldwide. Although largely apolitical and non-violent, its followers have a reputation for zealousness, which can make them vulnerable to radical influences. Like Nidal Hasan and the Tsarnaev brothers, Farook became increasingly influenced by the sermons and propaganda of alAwlaqi. Farook imparted this radical ideology to Enrique Marquez, a friend he introduced to Islam. In 2011, Marquez read Inspire magazine and other extremist content at Farook's residence. That year Farook expressed an interest in joining al-Qaida in the Arabian Peninsula in Yemen, Marquez revealed to FBI agents after the attack. ${ }^{78}$

Farook's terrorist plotting began in 2011 when he and Marquez started discussing becoming martyrs. ${ }^{79}$ According to what Marquez told the FBI after the San Bernardino attack, he and Farook discussed using firearms and pipe bombs to attack a library or cafeteria at Riverside City College (where they had both previously been registered as students) and to target traffic moving along a local highway during rush hour, with the intent being in both attacks to "maximize the number of casualties." ${ }^{80}$ They had been inspired by Nidal Hasan's shooting at Fort Hood in Texas two years prior and also studied the mass shooting carried out by Anders Breivik in Norway in 2011. ${ }^{81}$

In the months that followed, Marquez legally bought rifles, including the Smith and Wesson and Oracle rifles found near the black sport utility vehicle after the San Bernardino attack, and smokeless powder, which investigators established matched that inserted in the improvised explosive device Farook left behind at the Inland Regional Center.

In their later-abandoned 2011-2012 plot, Marquez revealed that he and Farook had consulted Inspire magazine for how to construct a bomb. ${ }^{82}$ It was decided Marquez should buy the firearms because "his appearance was Caucasian while Farook looked Middle Eastern.” Farook limited himself to buying ammunition and firearms components for use on the AR-15-style guns. The two took multiple trips to local firing ranges. ${ }^{83}$

Marquez told investigators he ceased plotting with Farook after the FBI made terrorism arrests near where they lived in late 2012. ${ }^{84}$ In February 2017, Marquez pleaded guilty to hatching the 2011-2012 plot and transferring the guns later used in the San Bernardino attack. Prosecutors said there was no evidence Marquez had advance knowledge of the attack. In October 2020, Marquez was sentenced to 20 years in prison..$^{85}$

Farook married Tashfeen Malik in 2014 after meeting online and traveling to see her in Saudi Arabia. During their online courtship in 2013, they made clear in direct private messages their shared commitment to jihadism and martyrdom. ${ }^{86}$ There is still much that is not clear about Malik's descent into extremism, but investigators have established that she was radicalized before she came into contact with Farook.

Born in Pakistan, Malik grew up in Saudi Arabia, where she was raised in a conservative interpretation of Islam before returning to Pakistan to study pharmacology at a university in Multan. While she was in the city, she enrolled in a Quran course run by an institute with conservative Islamic values. Malik entered the United States in July 2014 on a K-1 fiancé visa with a Pakistani passport, married Farook one month later, and was granted a conditional green card in July $2015 .{ }^{87}$

It is still not clear what triggered Farook and Malik to carry out an attack, but the Islamic State's calls for attacks in the United States presumably influenced them. In September 2014, the senior Islamic State leader Abu Muhammad al-Adnani called for attacks on U.S. soil. Investigators believe the married couple started planning an attack by late 2014, visiting gun ranges in the year leading up to their violent assault. 
Investigators have found no indication of any direct contact between the couple and any terrorist organization. Although the couple pledged allegiance to Islamic State leader Abu Bakr al-Baghdadi via Facebook shortly after the attack, they appear not to have had a deep knowledge of the terrorist organization. They reportedly had to search the internet earlier in the day of the attack for the name of al-Baghdadi. ${ }^{88}$

Six months before the attack, Malik gave birth to a baby girl. Three weeks before the attack, Farook stopped attending a local mosque. It is not clear what tipped the couple to turn their plotting into action. Just two weeks before the attack, Farook had a heated exchange about Islam at work with a co-worker. It remains unclear why the couple targeted Farook's work function in the conference room at the Inland Regional Center. According to the Los Angeles Times,

San Bernardino Police Lt. Mike Madden noted that in 2014, Farook attended another work event in that room, which was decorated for Christmas. Malik later stated on an online account something to the effect that she felt Muslims should not have to attend Christian events, Madden said. Madden added that she did not specifically mention the event in her posting and that it's far from clear that it played any role in the attack. ${ }^{89}$

\section{Missed warning signs?}

Unlike Nidal Hasan and Tamerlan Tsarnaev, neither Farook nor Malik came onto the FBI's radar screen. They also did not appear on any watchlists. ${ }^{90}$ One possible missed opportunity to detect a threat was Farook's reported digital contact with people suspected of links to overseas terrorist groups, but no suggestion has been made that these were known to U.S. intelligence before the attacks. ${ }^{91} \mathrm{~A}$ second potential missed opportunity was that U.S. agencies did not pick up private radical messages between the couple that were sent during their online courtship, nor their downloading of extremist materials. ${ }^{92}$

A third possible missed opportunity to uncover a threat was the fact that no signs of radicalization were detected during Malik's visa and green card applications. A fourth possible missed opportunity was that no one came forward to alert the government over concerns about the couple's radical views. A fifth potential missed opportunity was Farook's possible ties to the subjects of earlier terrorism arrests in the area, but any ties appear to have been only loose. This section now looks into each of these five potential missed opportunities.

\section{Communication with suspected terrorists}

It was reported that Farook had communicated with extremists inside and outside the United States a few years before the attack. He reportedly had contact with five people whom the FBI had investigated for possible terrorist activities, including "some kind of digital contact" with one associated with the Somali al-Qaida affiliate al-Shabaab and another associated with the Syrian al-Qaeda affiliate Jabhat al-Nusra, but in the aftermath of the attack, no evidence emerged that he had communicated with anyone of "significant investigative concern." ${ }^{93}$

It is not clear when U.S. agencies collected this information, but no suggestion has been made that it was flagged before the attack. U.S. officials have not publicly confirmed the communications. In a press conference two weeks after the attack, and after these media accounts were published, FBI Director James Comey said investigators had not seen indication of direct contact with foreign terrorist organizations. ${ }^{94}$

\section{Radical private messages}

Two weeks after the attack, Comey stated that "so far we've seen no indication that either of these two killers came across our screen, tripped any trip wires, anything that either brought them to our attention or should have brought them to our attention." 95 Thus, before the attack, U.S. agencies were not aware that 


\section{Paul Cruickshank}

Farook or Malik were downloading extremist content. They did not intercept or flag any of the private messages expressing support for jihad exchanged between Farook and his wife during their online courtship. These were only discovered after the attack once the FBI opened a full investigation. ${ }^{96}$

Although this was a possible missed opportunity to detect a threat, it is hard to see how U.S. security agencies could have previously known about the private messages exchanged by Farook and his wife or about their download history without other evidence leading to the opening of an investigation. It should be noted that even in the days after the FBI had opened an expansive investigation of the attackers, investigators did not uncover public social media messages in support of jihad by Farook or his wife. ${ }^{97}$

\section{The visa and immigration vetting of Malik}

It has been suggested that U.S. security agencies should have picked up signs Malik was radicalized during the vetting process for her visa and green card, but given neither she nor her husband publicly posted radical content online, this would have been difficult for the vetting agencies to discover. A senior State Department official told CNN that when a U.S. Consular official interviewed Malik for her fiancé visa in May 2014, she was not asked about jihadi leanings because no red flags were found in the application. Following the interview, Malik passed two other security database checks before her visa was granted. ${ }^{98}$

\section{No tips from the community}

U.S. counterterrorism agencies appear never to have received any tips the couple might pose a threat. As far as is known, Farook's circle of friends and family in California did not report any concerns to law enforcement. Some of his family members later said he was outspoken in his fundamentalist views, but said they had no idea Farook planned violence..$^{99}$ Farook was highly secretive, however, and it appears that only his wife was aware of his plan to carry out the San Bernardino attack. ${ }^{100}$

Malik wore the niqab (full veil) - a sign of very conservative but not violent extremist views - and mostly stayed at home once she arrived in California. In two private Facebook messages she sent in Urdu in 2012 and 2014 to a small group of friends in Pakistan, which were uncovered by investigators after the attack, she made clear her support for jihad and her hope to join the fight one day. ${ }^{101}$ Her family in Pakistan had grown concerned when she started posting radical messages via her Facebook page after she arrived in the United States, a family member there stated in an interview without specifying whether these were public or private messages. ${ }^{102}$ Yet, as far as is known, they did not alert authorities.

Although the couple assembled an arsenal of weapons and built bombs in the garage of their home, there is no evidence that neighbors or others were aware. ${ }^{103}$ There was subsequently a false claim that several witnesses saw explosives at the home of the attackers but did not alert law enforcement. ${ }^{104}$

\section{Loose ties to a jihadi terror travel cell}

One question is whether the loose connections that appear to have existed between Farook and a jihadi travel cell could or should have led to some scrutiny of Farook before the attack. The limited information that has been made public about these connections, and what was known when, make it a difficult question to answer, but no evidence has come to light that this was a dropped ball.

Investigators established after the San Bernardino attack that around the 2011-2012 period when Farook and his friend Enrique Marquez were plotting attacks, "Marquez had ties to a group of [California jihadis] who were arrested in 2012 when they attempted to travel to Afghanistan to join al-Qai'da." The criminal complaint in the Marquez case noted that one of those arrested was Ralph Deleon, a U.S. permanent resident from the Philippines who lived near the Riverside/San Bernardino area. ${ }^{105}$ The court documents further stated that "after the arrests of the California jihadists in 2012, Marquez distanced himself from Farook." 106 
In November 2012, authorities announced the arrest of four men, including Deleon-who were living or had resided in and around Riverside and who were inspired by the doctrines of Anwar al-Awlaqi-on suspicion of plotting to travel overseas to Afghanistan, join al-Qaida, and kill Americans. The ringleader of the group-Sohiel Omar Kabir, an Afghan-born American citizen-was arrested in Afghanistan after traveling there and encouraging others in the group to join him. Kabir and Deleon were convicted in 2014 for their roles in the jihadi terrorism travel plot. ${ }^{107}$

U.S. authorities have not yet provided clarity on the nature of the connection between Marquez and the four-man jihadi travel cell. According to the FBI, their investigations did not uncover any "direct ties" between Marquez and the four men. Officials told CNN that the San Bernardino attacker Farook was in Kabir's social circle but was not among those investigated at the time of the probe into Kabir's jihadi travel plot. ${ }^{108}$

\section{The Orlando nightclub attack}

Just after 2 AM on June 12, 2016, Omar Mateen, a 29-year-old American of Afghan descent, entered the Pulse gay nightclub in Orlando and started shooting, firing more than 200 rounds from a semi-automatic rifle and handgun in the initial minutes of his attack. Clubgoers fled for the exits and places to hide. ${ }^{109}$

An Orlando Police Department detective happened to be working an "off-duty detail" at the nightclub. He engaged Mateen almost immediately after the start of the attack and called for backup. At 2:08 AM, police first responders entered the club and drove Mateen to the rear of the venue, where he barricaded himself in a bathroom where some of those in the club had gone to hide.

A three-hour hostage standoff ensued, during which time Mateen called 911 to say he was responsible for the attack and to announce he was pledging allegiance to Islamic State leader Abu Bakr al-Baghdadi. In follow-up calls with negotiators, he also claimed falsely to have a suicide vest and to have placed bombs in vehicles outside the club. ${ }^{110}$

He also explained the motive for the attack:

You have to tell America to stop bombing Syria and Iraq. They are killing a lot of innocent people. ... What's going on is that I feel the pain of the people getting killed in Syria and Iraq and all over the Muslim Ummah [world]. . . The U.S. is collaborating with Russia and they are killing innocent women and children, okay. . . . My homeboy Tamerlan Tsarnaev ${ }^{111}$ did his thing on the Boston Marathon, my homeboy Moner Abu-Salha did his thing, okay, so now it's my turn, okay? ${ }^{112}$

In a follow-up call, Mateen stated that what triggered his attack was "the airstrike that killed Abu Wahib a few weeks ago." 113

After police learned that Mateen was threatening to place bomb vests on hostages, they breached the wall of the club just after 5 AM. As police prepared to move in, Mateen came out of the bathroom and engaged police in a firefight. Mateen was shot dead. His shooting rampage killed 49 people and injured 53 in what at the time was the deadliest terrorist attack on U.S. soil since 9/11.

The Islamic State claimed that Mateen was "one of the soldiers of the caliphate in America." 114 On May 21, 2016, one of its leading figures, Abu Muhammad al-Adnani, had called for attacks in the West during the Muslim holy month of Ramadan. Mateen's attack occurred almost a week after the start of Ramadan. No evidence has emerged that Mateen was in contact with the group. ${ }^{115}$

\section{Genesis of the plot}

Omar Mateen was a Queens, New York-born son of Afghan immigrants who grew up in Florida. His family was comfortably middle class, but like San Bernardino shooter Farook, Mateen had a troubled 


\section{Paul Cruickshank}

childhood, in his case exhibiting behavioral problems at school and often getting into fights. He was suspended from one school after $9 / 11$ for five days, because he reacted positively to the terrorist attacks. ${ }^{116}$

After graduating from a local community college, he was employed at the Florida Department of Corrections from which he was fired for making an off-color remark during training about bringing a gun "to school." ${ }^{117}$ He then took a job as a private security guard for security firm G4S, which employed him from 2007 onwards. Mateen obtained a firearms license in 2011, carried a gun as part of his duties, and would also obtain a concealed weapons permit. ${ }^{118}$

Mateen married his first wife in 2009 after meeting her online. She referred to him as bipolar. "He was not a stable person," she later said. "He beat me. He would just come home and start beating me up because the laundry wasn't finished or something like that." 119 When asked how he could have been capable of carrying out the attack, she said, "Emotional instability. Sickness. He was mentally unstable and mentally illthat's the only explanation that I could give. And he was obviously disturbed, deeply, and traumatized." 120

They separated after four months and divorced in 2011. That same year Mateen met his second wife, Palestinian-American Noor Salman, online. She would later be acquitted of charges of aiding and abetting the commission of a terrorist act and obstructing justice. In 2011 and 2012, Mateen traveled, like many Muslims from all around the world, to Saudi Arabia for the umrah pilgrimage. ${ }^{121}$

In 2013, while working for G4S at the St. Lucie County Courthouse, Mateen made inflammatory remarks to co-workers, which prompted the county sheriff's office to alert the FBI. Mateen made the bizarre and contradictory claim he had family connections to the Sunni terrorist group al-Qaida but was also a member of the Shia terrorist group Hezbollah, as well as telling his co-workers he hoped that the FBI would raid his family's home so that he could martyr himself. ${ }^{122}$

The FBI opened a preliminary investigation in May 2013 and placed Mateen in its Terrorist Screening Database (also known as the Terrorist Watchlist), ${ }^{123}$ but they were ultimately "unable to verify the substance of his comments." As a result, after 10 months, the FBI closed its investigation and removed him from the database in March 2014. ${ }^{124}$

A few months later, during the summer of 2014, the FBI again looked into Mateen after a man who prayed at the same mosque as he, Moner Abu-Salha, a recruit to al-Qaida's affiliate in Syria, became the first American to carry out a suicide bombing in the country. In the end, the FBI concluded that Mateen only knew the bomber casually. As already noted, Mateen in a call with negotiators during his attack described Abu-Salha as his "homeboy."125

Mohammed Malik, a Muslim acquaintance of Mateen, wrote in the Washington Post that after a posthumous video emerged in the summer of 2014 making clear Abu-Salha had been radicalized by al-Awlaqi's lectures, Mateen had told Malik that he also watched videos of al-Awlaqi and found them very powerful. Malik stated that while he did not think it likely at the time that Mateen would carry out any acts of violence, he informed the FBI that Mateen had been watching tapes of al-Awlaqi. A federal law enforcement officer confirmed Malik's cooperation to the newspaper. ${ }^{126}$

It became clear to investigators after the attack that Mateen had self-radicalized through the internet. Analysis of Mateen's electronic devices after the attack showed searches for jihadi propaganda, including videos of al-Awlaqi, as well as Islamic State beheading videos. Individuals who encountered him at the guard booth at PGA Village, the gated residential complex where he worked from 2014, recalled bizarre, aggressive behavior. ${ }^{127}$

It is not clear exactly when Mateen first began plotting an attack. On April 26, 2016, Mateen brought his wife to Disney World in Orlando. Investigators believed Mateen may have gone there to case it as a potential target. ${ }^{128}$ On May 9, 2016, the Pentagon announced that senior Islamic State leader Abu Wahib had been killed the previous week in an airstrike. The details appear to match the "Abu Wahib" whose death Mateen told police he sought to avenge. As noted by one analyst, since Abu Wahib did not have a big media profile in the West, only an "avid consumer" of Islamic State propaganda would likely have mentioned him. ${ }^{129}$ 
During their unsuccessful prosecution of Mateen's wife, prosecutors stated that Mateen intended to attack Disney World's shopping and entertainment complex by hiding a gun in a stroller but was spooked by the police presence and instead ultimately attacked the Pulse nightclub. Video footage from the Disney Springs complex that captured Mateen in the hours before the Pulse attack showed him looking behind at nearby police officers, forcing him, according to prosecutors, to choose a new target. ${ }^{130}$

Questions have been raised over whether Mateen targeted the Pulse venue in part because of homophobia or struggles with his own sexuality. ${ }^{131}$ Several clubgoers told reporters Mateen had been a regular at the Pulse nightclub and several men claimed sexual relations with him or sightings of him at gay bars, but the FBI has not independently corroborated that he was gay. ${ }^{132}$

Evidence emerged during the trial of Mateen's wife that points against the attack on the Pulse nightclub being premeditated. According to court documents, after leaving Disney Springs on the night of the attack, Mateen drove to another Walt Disney site before conducting a Google search for "downtown Orlando nightclubs.” He first headed to a different club after getting Google map directions for it, then did another Google search for clubs and got directions for Pulse. ${ }^{133}$

Around a week before the attack, Mateen bought the Sig Sauer assault-style rifle and a Glock 9-mm semiautomatic pistol he would use in the attack. He made the purchases at a licensed gun store in Florida. Mateen passed a background check and abided by the state's three-day waiting period in relation to the handgun. ${ }^{134}$

\section{Missed warning signs?}

In retrospect, given Mateen was twice looked into by the FBI, ${ }^{135}$ there were significant warning signs he could pose a threat. Thus far, no comprehensive official report has been released about the attack, making it difficult to identify in detail what different steps could have been taken, but several observations can be made.

\section{The preliminary investigation by the FBI}

The FBI launched a preliminary investigation into Mateen in 2013 after his incendiary remarks at the St. Lucie County Courthouse were flagged. According to Comey, this "involved introducing confidential sources to him, recording conversations with him, following him, reviewing transactional records from his communications, and searching all government holdings for any possible connections, any possible derogatory information. We then interviewed him twice." Because the preliminary investigation was never escalated to a full investigation, the FBI was not permitted to use its most aggressive tools (such as applying for Foreign Intelligence Surveillance Act or Title III warrants to read e-mails and listen to calls). ${ }^{136}$

The FBI sought help from Saudi intelligence with regard to his trips to Saudi Arabia but found no "derogatory" information. During the interviews with FBI agents, Mateen claimed he had made the remarks in anger because he thought his co-workers were discriminating against him and teasing him because he was Muslim. ${ }^{137}$

What seems clear is that Mateen received significantly more scrutiny from the FBI and was the subject of more invasive investigative methods than either Nidal Hasan or Tamerlan Tsarnaev. Although Mateen's social media accounts were not reviewed in the 2013 probe, the Los Angeles Times reported that more intensive monitoring of Mateen's social media accounts "wouldn't have changed the outcome. The postshooting review determined his social media accounts contained no ties to terrorist groups. He did not post radical statements until the night of the shooting, and then just to a group of friends, not the public."138

Under FBI guidelines at the time for the type of probe that was launched, monitoring a suspect's social media $24 / 7$ was not permitted, and authorities generally had to close preliminary investigations within six months if there was no evidence of a crime. The extension of the preliminary investigation to 10 months 


\section{Paul Cruickshank}

would have required sign-off from a special agent in charge and suggested the FBI believed there were more leads to track down at the end of the six-month period. ${ }^{139}$

There has yet to be a full accounting of why the FBI closed its investigation and why Mateen was removed from the Terrorist Watchlist, which resulted in his firearms purchases in the lead-up to the attack not being flagged. If his firearms purchases had been sent to authorities, it might have convinced the FBI to re-open its investigation of Mateen. ${ }^{140}$ Yet it is far from clear whether such a notification would have actually led to a reopening of the probe.

In another potential missed opportunity to stop the attack, one firearms store owner told reporters Mateen asked about high-end body armor and ammunition in bulk in May 2016. An employee grew suspicious, and the store alerted the local FBI office in West Palm Beach, but was not able to tell authorities the name of the prospective buyer because no sale had been made. Furthermore, the store only had grainy surveillance footage. ${ }^{141}$

\section{The tip from the community}

With the benefit of hindsight, one potential missed opportunity was the FBI not more extensively focusing on Mateen in the summer of 2014 after learning from a Muslim acquaintance that Mateen found alAwlaqi's videos "very powerful." Mateen reportedly denied having watched the videos when interviewed by the FBI that July. ${ }^{142}$ "We're going to look hard at our own work to see whether there is something we should have done differently," Comey stated after the attack. "So far, the honest answer is, I don't think so. I don't see anything, in reviewing our work, that our agents should have done differently." 143

\section{Conclusion}

In three out of the four high-casualty terrorist attacks on U.S. soil since 9/11, U.S. counterterrorism agencies had the attackers or one of the attackers on their radar prior to plot execution. In the case of the Fort Hood shooting and Boston Marathon bombings, certain investigators involved in the assessments should, with the benefit of hindsight, have more aggressively investigated leads.

Almost a year before the Fort Hood shooting, the FBI flagged Hasan after agents in San Diego learned he had been communicating with al-Awlaqi, but the Washington Field Office only followed up on the lead in May 2009. In the four hours a JTTF official spent reviewing Hasan's military records and other information, the official decided there was no need to interview or further investigate him. Although military personnel saw signs of Hasan's radicalization, he was never flagged for investigation, nor did the FBI learn about these concerns.

Despite opening an assessment into Boston Marathon bomber Tamerlan Tsarnaev two years before the attack after Russia's warning, the FBI closed the case after a three-month probe, which included an interview with Tamerlan. The Inspectors General review after the attack identified a key possible missed opportunity to prevent it: assuming that he himself was alerted, the JTTF agent handling the case in Boston did not tell his superiors or ask for the assessment to be reopened after Tamerlan traveled to Russia in January 2012. ${ }^{144}$

Authorities did not consider the San Bernardino shooters threats. There have not yet been official reviews or Congressional reports published about how their plotting evaded authorities, so it is not possible to identify any clear missed opportunities that would have prevented the attack. Yet officials after the attack told the media there were communications between Farook and suspected extremists in the United States and overseas. There has been no suggestion these were known to U.S. intelligence agencies before the attacks.

In the case of the Orlando nightclub attack, the FBI conducted a preliminary investigation into Mateen before the attack but terminated its inquiries and removed him from a terrorism watchlist. Why the FBI 
stopped looking into Mateen is not yet fully understood, but one key question is how the FBI evaluated the claim by an acquaintance of Mateen that Mateen was a fan of al-Awlaqi's videos.

U.S. authorities may have had opportunities to prevent some of the attacks if they had become aware of the attackers' private online communications (for example, the courtship messages of the San Bernardino attackers) or radical social media activity (for example, Tamerlan Tsarnaev's YouTube account) beforehand. Yet U.S. counterterrorism agencies cannot target the private messages of U.S. persons without a warrant, and despite increasing emphasis placed on monitoring "publicly available information," U.S. intelligence agencies do not and never will have the manpower to review anything but a fraction of the huge number of public social media postings made by inhabitants of the United States on Facebook, Twitter, and elsewhere. ${ }^{145}$

When asked during Congressional testimony in 2015 about the use of automated tools to flag concerning public jihadi extremist content, Comey stated "there are tools but they are limited in a way you would want them to be. The United States government, unlike some other governments in the world, does not monitor [the] internet." ${ }^{146}$ It should also be pointed out that if intercepting terrorist communications was hard for U.S. intelligence agencies in 2009, it has grown much harder in an age when encrypted messaging apps are so widely available.

From 2009, there was an uptick in the number of Islamist terrorist plots in the United States compared to previous years, partly because of the success of terrorists like al-Awlaqi in using the internet and social media to inspire extremists to attack inside the United States. ${ }^{147}$ The emergence of the Islamic State significantly worsened the threat outlook between 2013 and 2017, as there were more than 30 Islamic Statelinked attack plots in the United States. ${ }^{148}$ The defeat of the Islamic State as a territorial entity in 2019 did not end the jihadi threat to the United States.

The loss of 80 lives in four high-casualty attacks is tragic, and cumulatively there have been over a dozen more fatalities since 9/11 in other attacks by Islamist extremists, including the 2017 West Side Highway attack in New York City and the 2019 shooting at Naval Air Station Pensacola in Florida. Nevertheless, the larger story of U.S. counterterrorism efforts in the years since 9/11 is one of "many lives saved" because of the FBI and other agencies thwarting the large majority of Islamist terrorist plots in the United States since $9 / 11$.

At a time of enduring threats and finite resources, counterterrorism agencies across the Western world have been forced to do a certain amount of triage. Deciding which individuals of concern pose the greatest threat and need to be prioritized for scrutiny will involve making judgment calls. Creating smarter counterterrorism policies from the attacks that slipped through the security net will improve the ability of investigators to get the hard decisions right. As well as human error, reviews have unearthed shortcomings in investigative protocols, the management of leads, training, access to databases, and information sharing.

\section{Notes}

1 For the purpose of this chapter, high-casualty attacks are defined as fatal terrorist attacks that killed 10 or more people or injured dozens.

2 Various types of investigative action are referred to in this article. The attorney general's guidelines in relation to the FBI's domestic investigations "authorize three levels of investigation to address a potential threat to national security: 1) an assessment, which requires an authorized purpose but does not require any particular factual predication; 2) a preliminary investigation, which requires information or an allegation of a possible threat to national security; and 3) a full investigation, which requires an articulable factual basis of a possible threat to national security." Office of the Inspector General, Audit of the Federal Bureau of Investigation's Efforts to Identify Homegrown Violent Extremists Through Counterterrorism Assessments (Washington, DC: U.S. Department of Justice, 2020), 1.

3 Joseph Lieberman and Susan Collins, A Ticking Time Bomb: Counterterrorism Lessons From the U.S. Government's Failure to Prevent the Fort Hood Attack (Washington, DC: U.S. Senate Committee on Homeland Security and Governmental Affairs, 2011).

4 Ibid., 29. 


\section{Paul Cruickshank}

5 Ibid., 31.

6 Webster Commission, Final Report of the William H. Webster Commission on The Federal Bureau of Investigation, Counterterrorism Intelligence, and the Events at Fort Hood, Texas, on November 5, 2009 (2012), 1, 6, 41, 47, 50-52, 58, 68, 82; David Johnston and Scott Shane, "U.S. Knew of Suspect's Tie to Radical Cleric," New York Times, November 9 , 2009, www.nytimes.com/2009/11/10/us/10inquire.html.

7 Webster Commission, Final Report, 50.

8 Ibid., 51.

9 Lieberman and Collins, A Ticking Time Bomb, 20.

10 Ibid., 21; Webster Commission, Final Report, 34 and 50-51.

11 Sudarsan Raghavan, "Cleric Says He Was Confidant to Hasan," Washington Post, November 16, 2009 , www. theledger.com/news/20091116/cleric-says-he-was-confidant-to-hasan.

12 Paula Newton, "Purported al-Awlaki Message Calls for Jihad Against the U.S.," CNN, March 17, 2010, www. cnn.com/2010/WORLD/europe/03/17/al.awlaki.message/index.html; J.M. Berger, "The Enduring Appeal of Al-'Awlaqi's 'Constants on the Path of Jihad',' CTC Sentinel 4, no. 10 (2011): 12-15.

13 “Answers Sought on Fort Hood Suspect's Link to Imam,” National Public Radio, November 10, 2009, www.npr. org/templates/story/story.php?storyId=120266334.

14 Amanda Kim Stairrett, "Prosecutors End Case in Hasan Article 32 Hearing," Killeen Daily Herald, October 22, 2010, https://kdhnews.com/news/prosecutors-end-case-in-hasan-article-32-hearing/article_c2cea5e3-063c-5bb4a978-3cb69bae0501.html; Webster Commission, Final Report, 1.

15 Lieberman and Collins, A Ticking Time Bomb, 27-31; Webster Commission, Final Report, 61.

16 Webster Commission, Final Report, 34-40.

17 Ibid., 41.

18 Ibid., 34-46.

19 Ibid., 46, 53, 57, 77.

20 Ibid., 56-57, 80.

21 Ibid., 56.

22 Ibid., 58-59.

23 Ibid., 59-60.

24 The Webster Commission described the searchable electronic database as at the time being difficult to use and not effective in pinpointing information. Webster Commission, Final Report, 27-29, 36, 46, 82.

25 Ibid., 82.

26 Ibid., 76-77, 82 .

27 Ibid., 80-83.

28 Lieberman and Collins, A Ticking Time Bomb, 8; Webster Commission, Final Report, 80.

29 Lieberman and Collins, A Ticking Time Bomb, 39.

30 Webster Commission, Final Report, 71, 80, 82.

31 Ibid., 6, 68-69.

32 U.S.A. v. Dzhokhar A. Tsarnaev, Jury Trial Day Twenty-Seven, Opening Statement by William D. Weinreb (District of Massachusetts, 2015), 1-28; Committee on Homeland Security, The Road to Boston: Counterterrorism Challenges and Lessons from the Marathon Bombings House Homeland Security Committee Majority Report (Washington, DC: U.S. House of Representatives, 2014), 20-21.

33 "Boston Bomber Dzhokhar Tsarnaev Sentenced to Death," BBC, May 15, 2015, www.bbc.co.uk/news/av/ world-us-canada-32757084.

34 Jake Tapper, “Al Qaeda 'Inspire Magazine' Praises Boston Attack,” CNN, May 30, 2013, https://thelead.blogs.cnn. com/2013/05/30/al-qaeda-inspire-magazine-praises-boston-attack/.

35 Inspectors General, Unclassified Summary of Information Handling and Sharing Prior to the April 15, 2013 Boston Marathon Bombings (Washington, DC: Inspectors General for the Intelligence Community, 2014); Janet Reitman, “Jahar's World," Rolling Stone, July 17, 2013, www.rollingstone.com/culture/culture-news/jahars-world-83856/.

36 Reitman, "Jahar's World."

37 Inspectors General, Unclassified Summary of Information Handling, 1.

38 Ibid.

39 U.S.A. v. Dzhokhar A. Tsarnaev, Jury Trial Day Twenty-Seven, 10-11.

40 Serge F. Kovaleski and Richard A. Oppel, Jr., "In 2011 Murder Inquiry, Hints of Missed Chance to Avert Boston Bombing," New York Times, July 10, 2013, www.nytimes.com/2013/07/11/us/boston-bombing-suspect-is-saidto-be-linked-to-2011-triple-murder-case.html.

41 Ibid.; Committee on Homeland Security, The Road to Boston, 21-22; Ally Jarmanning, "Tamerlan Tsarnaev's Friend Told Police They Participated in Waltham Triple Homicide, New Documents Show," WBUR, November $15,2019$. 


\section{Lessons from four high-casualty attacks}

42 Committee on Homeland Security, The Road to Boston, 13.

43 Ibid., 13-15.

44 Ibid.; Reitman, "Jahar's World."

45 Committee on Homeland Security, The Road to Boston, 15; “Tsarnaev Mosque Outbursts Described," Associated Press, April 22, 2013, www.politico.com/story/2013/04/tamerlan-tsarnaev-mosque-outbursts-described-090474.

46 U.S.A. v. Dzhokhar A. Tsarnaev, Jury Trial Day Twenty-Seven, 12.

47 Ibid., 11-12; U.S.A. v. Dzhokar A. Tsarnaev, Government's Opposition to Defendant's Motion to Suppress Statements (District of Massachusetts, 2014), 3.

48 Paul Cruickshank and Tim Lister, "From the Grave, the Cleric Inspiring a New Generation of Terrorists," CNN, April 24, 2013, www.cnn.com/2013/04/24/us/boston-awlaki-influence/index.html; Margaret Coker, "Cleric Cited by Tsarnaev Lives On-Online," Wall Street Journal, May 5, 2013, www.wsj.com/articles/SB100014241278 87323687604578465023366949366; Newton, "Purported al-Awlaki Message."

49 U.S.A. v. Dzhokhar A. Tsarnaev, Jury Trial Day Twenty-Seven, 11-12; U.S.A v. Dzhokar A. Tsarnaev, Indictment (District of Massachusetts, 2013), 7; U.S.A. v. Dzhokar A. Tsarnaev, Government's Opposition, 3.

50 U.S.A. v. Dzhokar A. Tsarnaev, Indictment, 7.

51 Henry Gass, "Who Actually Built the Boston Marathon Bombs?” Christian Science Monitor, March 26, 2015, www. csmonitor.com/USA/USA-Update/2015/0326/Who-actually-built-the-Boston-Marathon-bombs.

52 Peter Bergen and Jennifer Rowland, "Four Things We Learned About the Boston Bombing," CNN, April 15, 2014, www.cnn.com/2014/04/08/opinion/bergen-boston-bombing-five-things/index.html.

53 Committee on Homeland Security, The Road to Boston, 16 and 35-36.

54 Inspectors General, Unclassified Summary of Information Handling, 7.

55 Ibid., 7-8.

56 Ibid., 8.

57 Eric Levenson, “Boston Bomber Tamerlan Tsarnaev Told FBI He Never Picked a Fight,” CNN, April 11, 2017, www.cnn.com/2017/04/11/us/tamerlan-tsarnaev-fbi-boston-marathon-interview/index.html.

58 Inspectors General, Unclassified Summary of Information Handling, 10.

59 Ibid., 10.

60 Ibid., 11.

61 Ibid., 9.

62 Ibid., 9, 18-19 and 22.

63 Ibid., 11; Committee on Homeland Security, The Road to Boston, 33; "Terrorist Identities Datamart Environment (TIDE)," Director of National Intelligence Fact Sheet, accessed December 22, 2020, www.dni.gov/files/NCTC/documents/features_documents/TIDEfactsheet10FEB2017.pdf.

64 Inspectors General, Unclassified Summary of Information Handling, 12-13.

65 Ibid., 13-14.

66 Ibid., 15-16.

67 Ibid., 21.

68 Ibid., 15-17; Henry Gass, "Boston Bomber's Application for US Citizenship Raises New Questions," Christian Science Monitor, February 29, 2016, www.csmonitor.com/USA/Justice/2016/0229/Boston-bomber-sapplication-for-US-citizenship-raises-new-questions.

69 Committee on Homeland Security, The Road to Boston, 25-26.

70 Inspectors General, Unclassified Summary of Information Handling, 19-20.

71 Ibid., 20.

72 Dan Flynn, "Syed Farook's Food Safety Inspection Reports Show Nothing Unusual," Food Safety News, December 4, 2015, www.foodsafetynews.com/2015/12/syed-farooks-food-safety-inspection-reports-show-nothingunusual/; U.S.A. v. Enrique Marquez, Jr., Criminal Complaint (Central District of California, 2015), 20-22; Megan Christie et al., "Christmas Party May Have Triggered San Bernardino Terror Attack: Police," $A B C$ News, December 1, 2016, https://abcnews.go.com/US/christmas-party-triggered-san-bernardino-terror-attackpolice/story?id=43884973; Frank Straub, Jennifer Zeunik and Ben Gorban, "Lessons Learned From the Police Response to the San Bernardino and Orlando Terrorist Attacks," CTC Sentinel 10, no. 5 (2017): 1-7; Mark Berman, "One Year After the San Bernardino Attack, Police Offer a Possible Motive as Questions Still Linger," Washington Post, December 2, 2016, www.washingtonpost.com/news/post-nation/wp/2016/12/02/ one-year-after-san-bernardino-police-offer-a-possible-motive-as-questions-still-linger/.

73 U.S.A. v. Enrique Marquez, Jr., Criminal Complaint, 20-22; Straub et al., "Lessons Learned”; Michael Martinez, Catherine E. Shoichet, and Pamela Brown, "San Bernardino Shooting: Couple Radicalized Before They Met, FBI Says," CNN, December 9, 2015, www.cnn.com/2015/12/09/us/san-bernardino-shooting/index.html.

74 U.S.A. v. Enrique Marquez, Jr., Criminal Complaint, 21-26; Straub et al., "Lessons Learned."

75 Ibid. 


\section{Paul Cruickshank}

76 Rukmini Callimachi, "Islamic State Says 'Soldiers of Caliphate' Attacked in San Bernardino," New York Times, December 5, 2015, www.nytimes.com/2015/12/06/world/middleeast/islamic-state-san-bernardino-massacre. html; Christie et al., "Christmas Party May Have Triggered San Bernardino Terror Attack: Police”; Al Baker and Marc Santora, "San Bernardino Attackers Discussed Jihad in Private Messages, F.B.I Says," New York Times, December 16, 2015, www.nytimes.com/2015/12/17/us/san-bernardino-attackers-discussed-jihad-in-private-messagesfbi-says.html.

77 Sarah Parvini, Matt Hamilton, and Corina Knoll, "Amid Farook Family Violence, Brothers Were a Study in Contrasts," Los Angeles Times, December 11, 2015, www.latimes.com/local/california/la-me-sb-farook-family20151211-story.html; Saeed Ahmed, "Who Were Syed Rizwan Farook and Tashfeen Malik?" CNN, December 4, 2015, www.cnn.com/2015/12/03/us/syed-farook-tashfeen-malik-mass-shooting-profile/index.html; U.S.A. v. Enrique Marquez, Jr., Criminal Complaint, 8-9; "San Bernardino Shooting: Suspect Graduated from Cal State," Press-Enterprise, December 3, 2015, www.pe.com/2015/12/03/san-bernardino-shooting-suspectgraduated-from-cal-state/; Rebecca Kimtich, "What We Know About San Bernardino Mass Shooting Killers Syed Farook and Tashfeen Malik," San Bernardino Sun, December 3, 2015, www.sbsun.com/2015/12/03/ what-we-know-about-san-bernardino-mass-shooting-killers-syed-farook-and-tashfeen-malik/.

78 U.S.A. v. Enrique Marquez, Jr., Criminal Complaint, 3-8.

79 Verified Complaint For Forfeiture [relating to Syed Farook's Life Insurance coverage by Minnesota Life Insurance Company] (Central District of California, 2016), 3-6.

80 U.S.A. v. Enrique Marquez, Jr., Criminal Complaint, 9-11.

81 Verified Complaint For Forfeiture, 5-6.

82 U.S.A. v. Enrique Marquez, Jr., Criminal Complaint, 4, 12-15, 17-18, 22, 25; Mike McIntire, "Weapons in San Bernardino Shootings Were Legally Obtained," New York Times, December 3, 2015, www.nytimes.com/2015/12/04/ us/weapons-in-san-bernardino-shootings-were-legally-obtained.html.

83 U.S.A. v. Enrique Marquez, Jr., Criminal Complaint, 3-4, 12, 18-19.

84 Ibid., 3-4, 12, 20; Kevin Dolak, "Four California Men Charged in Alleged Terror Plot," ABC News, November 20, 2012, https://abcnews.go.com/US/california-men-charged-alleged-terror-plot/story?id=17766529.

85 U.S. Attorney's Office Central District of California, "Enrique Marquez Jr. Agrees to Plead Guilty to Plotting Violent Attacks and Buying Firearms for Shooter in San Bernardino Terrorist Attack," U.S. Department of Justice, February 14, 2017, www.justice.gov/usao-cdca/pr/enrique-marquez-jr-agrees-plead-guilty-plotting-violent-attacks-and-buying-firearms; Michael Balsamo, "Records: Man to Plead Guilty to Aiding San Bernardino Attack," Associated Press, February 14, 2017, https://apnews.com/44e042ec473640b69c588e688dc98bc0/Records:-Man-to-plead-guiltyto-aiding-San-Bernardino-attack; U.S. Attorney's Office Central District of California, "Inland Empire Man Who Admitted Planning Mass Casualty Attacks and Purchasing Firearms Later Used in 2015 Terrorist Attack in San Bernardino Ordered to Serve 20-Year Federal Prison Sentence," U.S. Department of Justice, October 23, 2020, www.justice. gov/usao-cdca/pr/inland-empire-man-who-admitted-planning-mass-casualty-attacks-and-purchasing-firearms.

86 Baker and Santora, "San Bernardino Attackers"; Eyder Peralta, "San Bernardino Attackers Were Radicalized Before Meeting, FBI Director Says," National Public Radio, December 9, 2015, www.npr.org/sections/thetwoway/2015/12/09/459074323/san-bernardino-attackers-were-radicalized-before-meeting-fbi-director-says.

87 Martinez et al., "San Bernardino Shooting”; Declan Walsh, “Tashfeen Malik Was a 'Saudi Girl' Who Stood Out at a Pakistani University," New York Times, December 6, 2015, www.nytimes.com/2015/12/07/world/asia/in-conservative-pakistani-city-a-saudi-girl-who-stood-out.html; Salman Masood and Declan Walsh, "Tashfeen Malik, San Bernardino Suspect, Attended Conservative Religious School in Pakistan," New York Times, December 7, 2015, www.nytimes.com/2015/12/08/world/asia/tashfeen-malik-attended-conservative-religious-school-in-pakistan. html; Justin Fishel, Benjamin Siegel, and Emily Shapiro, "Inside the Immigration File of San Bernardino Shooter Tashfeen Malik," ABC News, December 22, 2015, https://abcnews.go.com/US/inside-immigration-file-sanbernardino-shooter-tashfeen-malik/story?id=35912170; Julia Preston, "San Bernardino Shooting: From Fiancé Visa to Green Card," New York Times, December 3, 2015, www.nytimes.com/live/san-bernardino-shooting/ from-fiance-visa-to-green-card/.

88 Baker and Santora, "San Bernardino Attackers"; Helen Davidson, "Islamic State's Call to Kill Westerners has Terrorism Experts Divided," Guardian, September 22, 2014, www.theguardian.com/world/2014/sep/23/islamicstates-call-to-kill-westerners-has-terrorism-experts-divided; "San Bernardino Shooters Were Radicalized for 'Quite Some Time': FBI,' CBS News, December 8, 2015, www.nbcnews.com/storyline/san-bernardino-shoot ing/san-bernardino-shooters-had-been-radicalized-quite-some-time-fbi-n475736; Pete Williams and Halimah Abdullah, "FBI: San Bernardino Shooters Radicalized Before They Met," NBC News, December 9, 2015, www. nbcnews.com/storyline/san-bernardino-shooting/fbi-san-bernardino-shooters-radicalized-they-met-n 476971.

89 Joel Achenbach and Sari Horwitz, "What Happens Next to the Baby Orphaned by the San Bernardino Shooters?" Washington Post, December 14, 2015, www.washingtonpost.com/news/post-nation/wp/2015/12/14/ 


\section{Lessons from four high-casualty attacks}

what-happens-next-to-the-baby-orphaned-by-the-san-bernardino-shooters/; Michael R. Blood and Eric Tucker, "Friends: Syed Farook Stopped Going to Mosque Weeks Ago," Associated Press, December 3, 2015, www. santacruzsentinel.com/2015/12/03/friends-syed-farook-stopped-going-to-mosque-weeks-ago/; "Friend of San Bernardino Shooting Victim Recalls Heated Conversation About Islam," CBS Los Angeles, December 3, 2015 , https://losangeles.cbslocal.com/2015/12/03/friend-of-san-bernardino-shooting-victim-recalls-heated-conversa tion-about-islam/; Richard Winton, "A Year After the San Bernardino Terror Attack, the FBI Is Still Struggling to Answer Key Questions," Los Angeles Times, December 1, 2016, www.latimes.com/local/lanow/la-me-sanbernardino-terror-probe-20161130-story.html.

90 Missy Ryan, Mark Berman, and Joel Achenbach, "Motive Elusive in Deadly San Bernardino Rampage as FBI Takes Over Probe," Washington Post, December 3, 2015, www.washingtonpost.com/news/post-nation/ $\mathrm{wp} / 2015 / 12 / 03 / \mathrm{fbi}$-takes-over-san-bernardino-investigation-as-authorities-seek-motive-for-attack-thatkilled-14-people/; Eric Tucker, Deb Riechmann and Tami Abdollah, "U.S. Officials Search for Missed Red Flags Ahead of San Bernardino Shooting," Associated Press, December 11, 2015, https://apnews.com/article/ c7c88283fb194dafaa109e7691d82245.

91 "Everything We Know About the San Bernardino Terror Attack Investigation So Far," Los Angeles Times, December 14, 2015, www.latimes.com/local/california/la-me-san-bernardino-shooting-terror-investigation-htmlstory. html.

92 Baker and Santora, "San Bernardino Attackers"; Eric Tucker et al., "U.S. Officials."

93 Los Angeles Times, "Everything We Know About the San Bernardino Terror Attack Investigation So Far"; Jennifer Medina et al., "San Bernardino Suspects Left Trail of Clues, but No Clear Motive," New York Times, December 3, 2015, www.nytimes.com/2015/12/04/us/san-bernardino-shooting.html; Christopher Goffard, "They Met Online, Built a Life in San Bernardino-And Silently Planned a Massacre," Los Angeles Times, December 5, 2015, https://graphics.latimes.com/san-bernardino-syed-farook-tashfeen-malik/.

94 Baker and Santora, "San Bernardino Attackers."

95 James Comey, "FBI Director James Comey Press Briefing at the New York Police Department on December 16, 2015," Washington Post, December 16, 2015, www.youtube.com/watch?v=exi1BuVZEFU.

96 Baker and Santora, "San Bernardino Attackers."

97 Adam Goldman and Mark Berman, "FBI: San Bernardino Attackers Didn’t Show Public Support for Jihad on Social Media," Washington Post, December 16, 2015, www.washingtonpost.com/news/post-nation/wp/2015/12/16/ fbi-san-bernardino-attackers-didnt-show-public-support-for-jihad-on-social-media/.

98 CNN Wire, Eric Spillman, and Chris Wolfe, "No Red Flags Found in Tashfeen Malik's Visa Application, So No Questions Asked About Her Learnings," KTLA5 Los Angeles, December 10, 2015, https://ktla.com/news/ local-news/san-bernardino-shooters-began-plotting-attack-before-their-marriage-fbi-director/ .

99 Winton, "A Year After the San Bernardino Terror Attack."

100 Ibid.; "Ex-Colleague: San Bernardino Killer 'Didn't Want to Be in the U.S.," CBS News, December 7, 2015, www.cbsnews.com/news/san-bernardino-shooting-ex-colleague-syed-rizwan-farook-reveals-new-insight/.

101 Parvini et al., "Amid Farook Family Violence”; Walsh, "Tashfeen Malik Was a 'Saudi Girl”"; Aoun Sahi, David S. Cloud, and Brian Bennett, "Exclusive: Tashfeen Malik was 'Modern Girl' Who Began Posting Extremist Messages on Facebook," Los Angeles Times, December 6, 2015, www.latimes.com/local/lanow/la-me-ln-tashfeen-malikfacebook-extremist-messages-20151205-story.html; Richard A. Serrano, "Tashfeen Malik Messaged Facebook Friends About Her Support for Jihad," Los Angeles Times, December 14, 2015, www.latimes.com/local/lanow/ la-me-ln-malik-facebook-messages-jihad-20151214-story.html.

102 Goffard, "They Met Online."

103 Winton, "A Year After the San Bernardino Terror Attack."

104 Matt Hamilton, "Donald Trump Repeats False Claim that Neighbors Saw 'Bombs All Over' Before San Bernardino Attack," Los Angeles Times, October 9, 2016, www.latimes.com/politics/la-na-pol-trump-debate-sanbernardino-20161009-snap-story.html.

105 Verified Complaint For Forfeiture, 6; U.S.A. v. Enrique Marquez, Jr, Criminal Complaint, 20; Office of Public Affairs, "Two Men Who Provided Material Support to Terrorists and Plotted to Kill American Targets in Afghanistan Receive 25-Year Prison Terms," U.S. Department of Justice, February 23, 2015, www.justice.gov/opa/ $\mathrm{pr}$ /two-men-who-provided-material-support-terrorists-and-plotted-kill-american-targets.

106 Verified Complaint For Forfeiture, 7.

107 Office of Public Affairs, "Two Men Who Provided Material Support to Terrorists"; Dolak, "Four California Men Charged in Alleged Terror Plot"; Steve Gorman, "Four Men Charged in California With Plot to Join al Qaeda," Reuters, November 20, 2012, www.reuters.com/article/us-usa-security-arrests/four-men-charged-in-california-withplot-to-join-al-qaeda-idUSBRE8AJ1JQ20121121; Dan Whitcomb, “Two Convicted in California of Conspiring 


\section{Paul Cruickshank}

to Join al Qaeda," Reuters, September 26, 2014, https://uk.reuters.com/article/us-usa-security-convictions/ two-convicted-in-california-of-conspiring-to-join-al-qaeda-idUKKCNOHL09320140926.

108 Joseph Serna, "Friend of San Bernardino Shooters Had Ties to 'Jihadists' Planning to Fight with Al Qaeda, Prosecutors Say," Los Angeles Times, June 1, 2016, www.latimes.com/local/lanow/la-me-ln-san-bernardino-marquezconnections-jihadists-20160601-snap-story.html; Evan Perez and Pamela Brown, "San Bernardino Shooting: Farook Tied to Jihadist Recruiter, Officials Say," CNN, December 11, 2015, www.cnn.com/2015/12/10/us/ san-bernardino-shooting/index.html.

109 Straub et al., "Lessons Learned"; Camilla Domonoske, Merrit Kennedy, and Emma Bowman, "Suspect Purchased Guns Legally Ahead of Deadliest Shooting in Modern U.S. History," National Public Radio, June 12, 2016, www. kut.org/2016-06-12/suspect-purchased-guns-legally-ahead-of-deadliest-shooting-in-modern-u-s-history.

110 Straub et al., "Lessons Learned"; Julian Hattem, "Orlando Gunman Claimed Shooting Was Motivated by Death of ISIS Operative," The Hill, September 26, 2016, https://thehill.com/policy/ national-security/297801-orlando-gunman-claimed-shooting-was-motivated-by-death-of-isis.

111 It was reported that Mateen had previously told coworkers he knew the Tsarnaev brothers, but investigators had at that earlier time established the claim was fabricated. Spencer Ackerman, "Orlando Shooter Investigated for False Claim of Ties to Boston Marathon Bombers," Guardian, June 13, 2016, www.theguardian.com/us-news/2016/ jun/13/omar-mateen-fbi-boston-marathon-tsarnaev.

112 Negotiation 1, Transcripts of calls with suspect 6-12-16, City of Orlando Pulse Tragedy Public Records; 16-242039 CNT 1, Suspect Calls Audio Files 6-12-16, City of Orlando Pulse Tragedy Public Records.

113 The official transcript of the call spells the name "Abu Wahid," but in the publicly available audio recording, it sounds to this author's ears like Mateen stated "Abu Wahib." A senior Islamic State leader going by the name "Abu Wahib" was killed in a U.S. airstrike in early May 2016. Negotiation 2, Transcripts of calls with suspect 6-12-16, City of Orlando Pulse Tragedy Public Records; 16-242039 CNT 2, Suspect Calls Audio Files 6-12-16, City of Orlando Pulse Tragedy Public Records; Thomas Gibbons-Neff and Joby Warrick, "Notorious Islamic State Leader Killed in Airstrike, Pentagon Says," Washington Post, May 9, 2016, www.washingtonpost.com/news/ checkpoint/wp/2016/05/09/notorious-islamic-state-leader-killed-in-airstrike-pentagon-says/.

114 "ISIS Claims Responsibility for Orlando Mass Shooting," CBS News, June 13, 2016, www.cbsnews.com/news/ mass-shooting-at-orlando-nightclub-pulse-isis-takes-responsibility/.

115 "Islamic State Calls for Attacks on the West During Ramadan in Audio Message," Reuters, May 21, 2016 , www. reuters.com/article/us-mideast-crisis-islamicstate/islamic-state-calls-for-attacks-on-the-west-during-ramadanin-audio-message-idUSKCNOYCOOG

116 Alan Blinder, Jack Healy, and Richard A. Oppel, Jr., "Omar Mateen: From Early Promise to F.B.I. Surveillance," New York Times, June 12, 2016, www.nytimes.com/2016/06/13/us/omar-mateen-early-signs-of-promisethen-abuse-and-suspected-terrorist-ties.html; Dan Barry et al., “'Always Agitated. Always Mad': Omar Mateen, According to Those Who Knew Him," New York Times, June 18, 2016, www.nytimes.com/2016/06/19/us/ omar-mateen-gunman-orlando-shooting.html; Mitch Weiss and Russ Bynum, "Records: Orlando Gunman Talked About Violence in 3rd Grade," Associated Press, June 17, 2016, www.seattletimes.com/nation-world/ apnewsbreak-woman-says-nightclub-shooter-stalked-her/.

117 Barry et al., "Always Agitated."

118 Blinder et al., "Omar Mateen”; Eyder Peralta, "What We Know So Far About the Orlando Shooting Suspect," National Public Radio, June 12, 2016, www.npr.org/sections/thetwo-way/2016/06/12/481787369/whatwe-know-so-far-about-the-suspected-orlando-shooter; Adam Goldman, Joby Warrick, and Max Bearak, “'He Was Not a Stable Person': Orlando Shooter Showed Signs of Emotional Trouble," Washington Post, June 12, 2016, www.washingtonpost.com/world/national-security/ex-wife-of-suspected-orlando-shooter-he-beat-me/ 2016/06/12/8a1963b4-30b8-11e6-8ff7-7b6c1998b7a0_story.html.

119 Zachary Fagenson, "Gunman in U.S. Massacre Described as 'Quiet' but Grew Hateful,” Reuters, June 12, 2016, https://br.reuters.com/article/us-florida-shooting-gunman-idUSKCNOYY11B.

120 Gregg Toppo, “Ex-Wife: Orlando Shooter 'Very Short-Tempered,' Violent," USA Today, June 12, 2016, www. usatoday.com/story/news/2016/06/12/ex-wife-orlando-shooter/85808768/.

121 Fagenson, "Gunman in U.S. Massacre Described as 'Quiet'”; Goldman et al., " “He Was Not a Stable Person””; Adam Goldman, "Orlando Gunman's Wife Breaks Silence: 'I Was Unaware,," New York Times, November 1, 2016, www.nytimes.com/2016/11/02/us/politics/orlando-shooting-omar-mateen-noor-salman.html; Patricia Mazzei, "Noor Salman Acquitted in Pulse Nightclub Shooting," New York Times, March 30, 2018 , www. nytimes.com/2018/03/30/us/noor-salman-pulse-trial-verdict.html; "Orlando Shooter Visited Saudi Arabia in 2011, 2012-Saudi Interior Ministry," Reuters, June 13, 2016, www.reuters.com/article/instant-article/ idINKCNOYZ1S8. 


\section{Lessons from four high-casualty attacks}

122 Nancy A. Youssef and Shane Harris, "FBI Tracked Orlando Killer Omar Mateen and Came Up Empty," Daily Beast, June 14, 2016, www.thedailybeast.com/fbi-tracked-orlando-killer-omar-mateen-and-came-up-empty; Mark Mazzetti, Eric Lichtblau, and Alan Blinder, "Omar Mateen, Twice Scrutinized by F.B.I., Shows Threat of Lone Terrorists," New York Times, June 13, 2016, www.nytimes.com/2016/06/14/us/politics/orlando-shoot ing-omar-mateen.html; Del Quentin Wilber, "The FBI Investigated the Orlando Mass Shooter for 10 Months and Found Nothing. Here's Why," Los Angeles Times, July 14, 2016, www.latimes.com/nation/la-na-fbi-investiga tion-mateen-20160712-snap-story.html; Adam Goldman, Matt Zapotosky, and Mark Berman, "FBI Had Closely Scrutinized the Orlando Shooter Before Dropping Investigation,' Washington Post, June 13, 2016, www.washing tonpost.com/world/national-security/fbi-had-closely-scrutinized-the-orlando-shooter-before-dropping-investig ation/2016/06/13/838e9054-3177-11e6-8ff7-7b6c1998b7a0_story.html.

123 Youssef and Harris, "FBI Tracked Orlando Killer"; Ron Johnson letter to Michael Horowitz, July 26, 2016, www.hsgac.senate.gov/media/majority-media/chairman-johnson-seeks-independent-review-of-why-orlandoterrorist-was-taken-off-terror-watchlist.

124 Johnson letter to Horowitz.

125 Barry et al., "Always Agitated"; Wilber, "The FBI Investigated the Orlando Mass Shooter"; Goldman et al., "FBI Had Closely Scrutinized the Orlando Shooter"; Blinder et al., "Omar Mateen”; Michael Edison Hayden and Julia Jacobo, "Gunman's Wife Says She Tried to Talk Him out of Attack, Officials Say," ABC News, June 14, 2016, https://abcnews.go.com/US/gunmans-wife-talk-attack-officials/story?id=39841580; Adam Taylor, "Omar Mateen May Not Have Understood the Difference Between ISIS, al-Qaeda and Hezbollah,” Washington Post, June 13, 2016, www.washingtonpost.com/news/worldviews/wp/2016/06/13/omar-mateen-may-not-have-understoodthe-difference-between-isis-al-qaeda-and-hezbollah/.

126 Mohammed A. Malik, "I Reported Omar Mateen to the FBI. Trump Is Wrong that Muslims Don't Do Our Part," Washington Post, June 20, 2016, www.washingtonpost.com/posteverything/wp/2016/06/20/i-reportedomar-mateen-to-the-fbi-trump-is-wrong-that-muslims-dont-do-our-part/.

127 Ralph Ellis et al., “Orlando Shooting: What Motivated a Killer?” CNN, June 14, 2016, www.cnn. com/2016/06/13/us/orlando-nightclub-shooting/index.html; Barry et al., "Always Agitated”; Joe Capozzi, “Exclusive: Madman at the Gate: A Community's Close Encounters With Omar Mateen,” Palm Beach Post, June 10, 2017, www.palmbeachpost.com/news/madman-the-gate-community-close-encounters-with-omar-mateen/oz96 cgJJvWl6tSbWjBjBeN/.

128 Evan Perez, Shimon Prokupecz, and Holly Yan, "Omar Mateen Scouted Disney Complex, Pulse, Official Says," CNN, June 15, 2016, www.cnn.com/2016/06/14/us/orlando-shooter-omar-mateen/index.html.

129 Gibbons-Neff and Warrick, "Notorious Islamic State Leader Killed in Airstrike"; Dan Frosch and Nicole Hong, “Transcripts Show ISIS Influence on Orlando Gunman,” Wall Street Journal, September 27, 2016, www.wsj.com/ articles/transcripts-show-isis-influence-on-orlando-gunman-1475023090; Caitlin Doornbos, “Transcripts of 911 Calls Reveal Pulse Shooter's Terrorist Motives," Orlando Sentinel, September 23, 2016, www.orlandosentinel.com/ news/pulse-orlando-nightclub-shooting/os-911-calls-released-orlando-shooting-20170922-story.html.

130 "Pulse Nightclub Shooter Intended to Attack Disney World, Prosecutors Say," Associated Press, March 28, 2018, www.nbcnews.com/news/us-news/pulse-nightclub-shooter-intended-attack-disney-world-prosecutors-sayn860786; Alanne Orjoux, "Pulse Nightclub Gunman Omar Mateen May Have Considered Disney Properties for Mass Shooting," CNN, March 6, 2018, www.cnn.com/2018/03/06/us/pulse-shooting-mateen-scouted-othersites/index.html.

131 Perez et al., "Omar Mateen Scouted Disney Complex."

132 Frances Robles and Julie Turkewitz, "Was the Orlando Gunman Gay? The Answer Continues to Elude the FBI," New York Times, June 25, 2016, www.nytimes.com/2016/06/26/us/was-the-orlando-gunman-gay-theanswer-continues-to-elude-the-fbi.html.

133 Orjoux, "Pulse Nightclub Gunman Omar Mateen."

134 Monivette Cordeiro, "Noor Salman's Trial Gave us the Best Glimpse of What Actually Led to the Pulse Shooting," Orlando Weekly, April 3, 2018, www.orlandoweekly.com/Blogs/archives/2018/04/03/noor-salmans-trial-gaveus-the-best-glimpse-of-what-actually-led-to-the-pulse-shooting; Jack Date, Allan Lengel, and Josh Margolin, "Orlando Shooter Bought Weapons at Nearby Gun Shop," ABC News, June 13, 2016, https://abcnews. go.com/US/orlando-shooter-bought-weapons-nearby-gun-shop/story?id=39817471; Bart Jansen, "Weapons Gunman Used in Orlando Shooting Are High-Capacity, Common," USA Today, June 14, 2016, www.usatoday.com/story/news/2016/06/14/guns-used-kill-49-orlando-high-capacity-common-weapons/85887260/; Michael Daly and Shane Harris, "How the Orlando Killer Omar Mateen Got His Guns," Daily Beast, June 13, 2015, www.thedailybeast.com/how-the-orlando-killer-omar-mateen-got-his-guns; Crimesider Staff, "Gun Shop: Orlando Shooter Passed Background Check," CBS News, June 13, 2016, www.cbsnews.com/news/ 


\section{Paul Cruickshank}

gun-shop-owner-orlando-nightclub-shooter-omar-mateen-passed-background-check/; David Fleshler, "Orlando Shooter Had Passed Background Checks," Orlando Sun Sentinel, June 13, 2016, www.sun-sentinel.com/news/sflgun-shop-owner-orlando-shooting-story.html.

135 Devlin Barrett, Adam Entous, and Alan Cullison, "FBI Twice Probed Orlando Gunman," Wall Street Journal, June 13, 2016, www.wsj.com/articles/orlando-gunman-was-twice-probed-by-fbi-1465761322.

136 James B. Comey, “Update on Orlando Terrorism Investigation,” Federal Bureau of Investigation, June 13, 2016 , www. fbi.gov/news/speeches/update-on-orlando-terrorism-investigation; Massimo Calabresi, "Why the FBI Dropped Its Previous Orlando Shooter Investigations," Time Magazine, June 14, 2016, https://time.com/4368439/orlandoshooting-omar-mateen-fbi-investigation-dropped/; Wilber, "The FBI Investigated the Orlando Mass Shooter."

137 Mazzetti et al., "Omar Mateen, Twice Scrutinized by F.B.I.”; Comey, "Update on Orlando Terrorism Investigation."

138 Johnson letter to Horowitz; Calabresi, "Why the FBI Dropped Its Previous Orlando Shooter Investigations"; Wilber, "The FBI Investigated the Orlando Mass Shooter."

139 Calabresi, "Why the FBI Dropped its Previous Orlando Shooter Investigations"; Youssef and Harris, "FBI Tracked Orlando Killer."

140 Johnson letter to Horowitz.

141 Brian Ross, Gerry Wagschal and Rhonda Schwartz, “Gun Store Owner: We Alerted FBI to 'Suspicious' Customer Weeks Before Orlando Shooting," ABC News, June 16, 2016, https://abcnews.go.com/US/orlandoshooter-turned-gun-store-suspicious/story?id=39901107.

142 Johnson letter to Horowitz.

143 Calabresi, "Why the FBI Dropped Its Previous Orlando Shooter Investigations."

144 Inspectors General, Unclassified Summary of Information Handling, 23.

145 Paul Cruickshank, "A View from the CT Foxhole: An Interview with Nick Rasmussen, Director, NCTC," CTC Sentinel 8, no. 9 (2015): 5-8; Oversight of the Federal Bureau of Investigation, Committee on the Judiciary, U.S. Senate (2015) (testimony by James Comey, FBI director on December 9, 2015).

146 Comey, testimony on Oversight of the Federal Bureau of Investigation.

147 See Chart 1 in Steven Bucci, James Carafano, and Jessica Zuckerman, 60 Terrorist Plots Since 9/11: Continued Lessons in Domestic Counterterrorism (Washington, DC: Heritage Foundation, 2013).

148 Committee on Homeland Security, “Terror Threat Snapshot: April 2017” (Washington, DC: U.S. House of Representatives, 2017), 1. 


\title{
29
}

\section{SOCIAL MEDIA RECRUITMENT OF AMERICANS}

\section{A case study from the Islamic State}

\author{
Alexander Meleagrou-Hitchens and Seamus Hughes
}

A new term has entered the counterterrorism lexicon in the past decade: the "virtual plotter."' This phrase, and variations of it, describe members of jihadi terrorist groups, mainly affiliated with the Islamic State, who use social media and applications with encryption technologies to reach out to and correspond with radicalized Westerners. In some cases, its members plot and direct attacks, helping to hone and focus the often-undisciplined zeal of potential lone actor terrorists to ensure that their eventual actions achieve either the maximum propaganda value or casualty impact. ${ }^{2}$

More frequently, however, these virtual plotters have acted in a more auxiliary capacity, plugging their Western contacts into wider extremist milieus (both online and offline) and encouraging radical beliefs while offering suggestions and options for mobilization. Indeed, because of the variety of roles they play, the authors have chosen to refer to these individuals as "virtual entrepreneurs," thus allowing for a broader encapsulation of the different categories of their involvement.

This chapter examines the impact of Islamic State ${ }^{3}$ virtual entrepreneurs in the United States. ${ }^{4}$ To present a broader and more accurate picture of how virtual entrepreneurs operate, the authors have categorized exchanges between U.S.-based Islamic State sympathizers and virtual entrepreneurs as either "direct plotting" or "encouragement and facilitation." " Out of a total of 38 Islamic State-inspired domestic plots and attacks in the United States between the period of March 1, 2014, and March 1, 2020, at least eight (21\%) involved some form of digital communication with Islamic State virtual entrepreneurs. ${ }^{6}$ In addition, virtual entrepreneurs have also been involved in at least six other terrorism-related cases, including assisting with logistics related to traveling to join the Islamic State. ${ }^{7}$ This brings the total number of U.S. terrorism cases linked to Islamic State virtual entrepreneurs to 14, involving 19 U.S.-based individuals, as of March 1, 2020.

\section{Background on virtual entrepreneurs}

The Islamic State's online contact with radicalized Westerners has given the group wider scope to claim ownership of attacks that in some cases it had little to do with in reality. This has inflated the Islamic State's impact and reach, which is crucial to the group's propaganda success. The emergence of Islamic State virtual entrepreneurs represents a hybrid between what are commonly seen as the two previous manifestations of the jihadi terrorist threat to the West: networked and inspired lone attacker plots. The former relies on direct involvement by an organization in terms of training, direction, financing, and indoctrination. The 
lone actor and now hybrid categories rely more on the creation of loosely connected milieus, often online, and the wide availability of an accessible form of global jihadi propaganda.

Law enforcement has understandably struggled to categorize this new development. In 2016, the Federal Bureau of Investigation's (FBI) executive assistant director for the National Security Division offered some measure of clarity. He described the current threat picture as "a hybrid between directed and enabled ... individuals overseas using encrypted communications to elicit some type of assistance from somebody in the U.S." He also pointed out that these figures often do not specifically direct attacks but rather help in "getting somebody ready to go . . getting them motivated, showing them a menu of targets and then saying, "hey, you take care of it."

While the use of this tactic has increased as the Islamic State continues to exploit social media and online encryption technologies, the phenomenon of jihadi entrepreneurs making virtual connections with unaffiliated radicalized Westerners is certainly not new. As is often the case when discussing innovative jihadis, one need only look at the activities of the late Yemeni-American al-Qaida ideologue and recruiter Anwar al-Awlaqi, who, via e-mail, was in contact with a number of radicalized individuals in the West and who, in at least one case, helped plot a potential attack. ${ }^{9}$

Social media and encrypted messaging apps, along with an expansion of jihadi territories across the globe, are all factors that have nonetheless added a new dimension to such virtual communications.

\section{Social media outreach to Americans}

In the United States, the impact of virtual entrepreneurs has not been as deadly as in Europe, but this is not for lack of effort. The most sustained attempts to import this type of terrorism to the United States came from a group that was based in Islamic State-held Raqqa, Syria, which the FBI nicknamed "the Legion." Composed of around a dozen English-speaking and mainly Western Islamic State operatives, the Legion systematically reached out to individuals in the United States using a mixture of direct messaging on Twitter and encrypted messaging. ${ }^{10}$ The group presented such a threat that three of its membersJunaid Hussain, Reyaad Khan, and Raphael Hostey-were killed in targeted airstrikes between 2015 and $2016 .{ }^{11}$

Hussain, the most prominent Legion member, was a British foreign fighter and former hacker. ${ }^{12}$ In 2013, while on bail for hacking charges, Hussain traveled to Islamic State-controlled territory and assumed the kunya (alias) Abu Hussain al-Britani. ${ }^{13}$ Before his death in August 2015, Hussain had achieved celebrity status among the online English-speaking Islamic State community. ${ }^{14}$ Both he and fellow British national Khan were identified by then-British Prime Minister David Cameron as being "involved in actively recruiting [Islamic State] sympathizers and seeking to orchestrate specific and barbaric attacks against the West." ${ }^{15}$ The other known British member of the Legion, Hostey (also known as Abu Qaqa), had traveled to Syria in 2013 and was mainly engaged in recruiting foreign fighters and creating Englishlanguage propaganda. ${ }^{16}$

The following vignettes reveal how members of the Legion actively sought to direct or encourage attacks in the United States. In some cases, Legion members were involved in direct plotting, instructing U.S. residents to commit attacks on behalf of the Islamic State, providing knowledge and guidance throughout the various elements of the plot. In others, Legion members simply encouraged and facilitated supporters in the United States to commit attacks without providing specifics or detailed instructions.

\section{Direct plotting}

Among the clearest examples of a Legion virtual entrepreneur directly plotting an attack is the case of Ohio resident Munir Abdulkader, who pleaded guilty to a plan to attack U.S. government officers. ${ }^{17}$ His flirtation with the Islamic State began in July 2014 when he established Twitter accounts to voice support 
for the group. ${ }^{18}$ Once he plugged himself into the online Islamic State community, it was not long until he came across and reached out to Legion figure Junaid Hussain, who largely became his handler in the spring of $2015 .{ }^{19}$

Initially, Abdulkader wanted to travel to Syria, but "Hussain helped push him to a different course" and turned his focus to a domestic attack "when they decided it simply had gotten too dangerous to go to an airport," explained Assistant U.S. Attorney Timothy Mangan, who prosecuted the case. ${ }^{20}$

Over the course of their communications, Hussain developed a terrorist plot for Abdulkader to implement. ${ }^{21}$ More specifically, he instructed Abdulkader to kidnap a U.S. soldier and record his murder on camera, providing him the target's name and address. The pair also discussed the best weapon to use and the need to record the attack for later propaganda dissemination. ${ }^{22}$ Following this conversation, Hussain suggested that Abdulkader attack a police station in Cincinnati, Ohio. Abdulkader also drew encouragement from Hussain that helped increase his determination to carry out a violent act. ${ }^{23}$ Abdulkader was ultimately sentenced to 20 years in prison for the thwarted plot. ${ }^{24}$

A second example relating to direct plotting also involved virtual entrepreneur Hussain. One of his main interests was inciting and planning attacks against people and groups seen as maligning the Prophet Muhammad. In mid-May 2015, David Daoud Wright, Nicholas Alexander Rovinski, and Usaamah Abdullah Rahim were in the advanced stages of a plan to kill an organizer of the "[Prophet] Muhammad Art Exhibit and [Cartoon] Contest," an event in Garland, Texas. Rahim, the senior member of the group, liaised with Hussain about possible attacks. The target was decided upon as a result of these conversations, during which "Hussain directly communicated instructions to Rahim with regard to the murder of [the] Intended Victim," which Rahim subsequently passed on to his accomplice, Wright. ${ }^{25}$

Due to the contact between Rahim and Hussain and subsequent activities by the plotters-including Rahim's purchase of combat knives at Hussain's recommendation "in case the 'feds' tried to arrest him" ${ }^{26}$ they soon became the subjects of law enforcement surveillance. On June 2, 2015, Rahim was approached by investigators while walking through a parking lot in Roslindale, Massachusetts, and he was shot dead after attempting to attack them with a knife. Rovinski was sentenced to 15 years in prison, ${ }^{27}$ and Wright was sentenced to 30 years. ${ }^{28}$

Legion members Hussain and Khan began their attempts to direct plots in the United States as early as 2014, when they used social media to solicit Minnesota resident Abdul Raheem Ali-Skelton to carry out an attack. ${ }^{29}$ During the previous months, Ali-Skelton had interacted and debated with Islamic State members on social media and was soon referred to the two Legion members. Ali-Skelton refused their request, however, but was later arrested and convicted for lying about his contact with the Legion. ${ }^{30}$

\section{Encouragement and facilitation}

While virtual entrepreneurs gain the most attention for their roles as direct plotters, much of their work has involved encouraging their contacts to take on more extreme positions or facilitating connections to real-world foreign fighter networks.

"Very soon carrying out 1st operation of Islamic State in North America," a user called "TheMujahid" texted to his online contact. The response was quick: "Can u make a video first?" Authorities determined that "TheMujahid" was North Carolina native Justin Sullivan, and his Islamic State contact was Legion member Hussain, who was writing under one of his several online monikers. ${ }^{31}$

According to documents from his case, messages found on Sullivan's cell phone showed that he "conspired and agreed with Hussain to commit such attacks on behalf of, and in support of, [the Islamic State] and in an effort to change United States policies against [the Islamic State] by avenging U.S.-coalition airstrikes against [Islamic State] fighters." ${ }^{32}$ Sullivan had converted to Islam in September 2014 and soon began reading Islamic State propaganda. In December 2014, he used his father's gun to murder his elderly neighbor, although the motive has never been fully established. ${ }^{33}$ 
By mid-2015, Sullivan had planned to buy an assault rifle at a local gun show and expressed a desire to kill up to 1,000 people. ${ }^{34}$ Perturbed by his son's behavior, which included destroying Buddha statues and other non-Islamic religious items, Sullivan's father called 911 and informed authorities of his suspicion that his son was becoming an Islamic State supporter. ${ }^{35}$

After subsequently entering into conversations with an FBI undercover agent in which he discussed his intentions to carry out an attack, he was arrested in June 2015 and pleaded guilty to providing material support to terrorism. Sullivan's case is indicative of the wider impact of virtual entrepreneurs in the United States beyond direct attack planning. ${ }^{36}$ Sullivan was not only provided with the encouragement, reassurance, and camaraderie he needed, but he also received specific advice on how to ensure his attack could provide the most benefit to the Islamic State.

Another U.S. case that sheds further light on the multifaceted role of virtual entrepreneurs is that of Jalil ibn Ameer Aziz of Pennsylvania. Prior to his arrest in December 2015 on charges of conspiracy to provide material support to the Islamic State, Aziz was heavily involved in online extremist networks, creating at least 57 pro-Islamic State Twitter accounts. ${ }^{37}$ When authorities searched his house, they discovered a tactical-style backpack with M4-style high-capacity magazines and a knife. ${ }^{38}$

Aziz helped connect aspiring American Islamic State foreign fighters with Legion members Hussain and Khan. According to court filings, Hussain provided Aziz with a Turkish telephone number, directing him to share it with a potential recruit so that he could communicate with them using encrypted messaging applications. Hussain also suggested to Aziz that if there were any problems, the recruit should contact another member of the Legion, Hostey, via a Twitter profile he provided. ${ }^{39}$

Legion member Hostey also communicated with at least two other Islamic State supporters. One of them, Avin Brown, was the first American to be arrested for trying to travel to join the Islamic State. ${ }^{40}$ Brown was friendly online with Hostey and helped connect him with another American Islamic State recruit, Mohammed Khan, from Chicago. ${ }^{41}$

Beginning in 2014, Khan initiated contact with Islamic State members overseas to seek guidance on traveling to Syria to join the group. ${ }^{42}$ In September 2014, Khan bought three airplane tickets from Chicago to Istanbul for himself and two siblings, but all three were arrested at O'Hare International Airport before boarding the flight. ${ }^{43}$ According to court documents, Hostey gave Khan information regarding routes to Syria, methods to avoid law enforcement suspicion, and the contact information of an individual in Istanbul who could take him into Islamic State-held territory in Syria. ${ }^{44}$

Between late 2015 and mid-2016, another domestic Islamist terrorist, Mohamed Bailor Jalloh, had been in communication with Islamic State virtual entrepreneur Abu Sa'ad al-Sudani. ${ }^{45}$ While not a member of the Legion, the Department of Defense identified al-Sudani as a "member, recruiter and external planner." ${ }^{46}$ Jalloh had traveled to Nigeria, via his native country of Sierra Leone, in June 2015, and he met an unnamed Islamic State facilitator with the intent of receiving assistance to join the group in Libya. He eventually decided against this and opted instead for a plan to attack the U.S. homeland. It was on his way back to the United States, while in Sierra Leone, that Jalloh first made online contact with al-Sudani. According to court documents, he was someone whom Jalloh "understood was an [Islamic State] figure engaged in plotting attacks in the United States." ${ }^{47}$

After his return to the United States, Jalloh communicated regularly with al-Sudani during the first half of 2016. On two separate occasions, al-Sudani arranged for a total of $\$ 700$ to be sent to him via a family member of Jalloh's in Sierra Leone, who gave the funds to a contact of al-Sudani's in the country. By March 2016, court records show that al-Sudani "was actively plotting an attack in the United States." As part of these efforts, he had put Jalloh in touch with another U.S.-based contact of his in the hope that they would plan an attack together. ${ }^{48}$

Unbeknownst to al-Sudani, his contact was an FBI informant. Jalloh first met the informant in April 2016 in Virginia and began discussing with him various options for an attack in the name of the Islamic State. During the meeting, Jalloh claimed that he was constantly thinking about conducting an attack, and when 
asked to elaborate, he said, "Nidal Hassan type of things. That's the kind of stuff I started thinking." ${ }^{49}$ As a result of the investigation, Jalloh was arrested in July 2016 after attempting to buy a weapon in North Carolina that he intended to use for an attack. He was later sentenced to 11 years in prison for conspiracy to provide material support to the Islamic State. ${ }^{50}$

Another example of virtual entrepreneur al-Sudani's involvement in encouragement and facilitation is the case of Aaron Daniels. Daniels, a 20-year-old resident of Ohio, was arrested in November 2016 for attempting to provide material support to the Islamic State. ${ }^{51}$ Federal agents apprehended Daniels as he left his hometown of Columbus. He intended to fly to Trinidad and Tobago to confuse authorities before attempting to continue onwards to join Islamic State affiliates in Libya or Syria. ${ }^{52}$ In addition to the attempted travel overseas, Daniels also sent \$250 via Western Union to an intermediary for al-Sudani in January $2016 .^{53}$

According to the criminal complaint, Daniels had been in contact with al-Sudani via social media before eventually sending him money and purchasing a plane ticket. ${ }^{54}$ In June 2016, Daniels told an undercover FBI agent that while he initially intended to join the jihad in Syria, "brother Abu Isa told me it was closed at that time . . . and suggested that I go to Libya." ${ }^{55}$ Later, Daniels clarified that he was in fact referring to al-Sudani. ${ }^{56}$ In a similar fashion to his other contacts with American would-be jihadis, al-Sudani provided advice and guidance about traveling overseas to join the Islamic State (for a fee) and additionally directed the recipient of his advice toward non-Syria battlefields. ${ }^{57}$

Al-Sudani was also involved in encouraging New York-based Islamic State supporter Emanuel Lutchman to plan an attack in the city. They began communicating online in December 2015 after Lutchman found al-Sudani's contact in an Islamic State-produced online document. ${ }^{58}$ During these discussions, Lutchman expressed his desire to travel to Libya to join the Islamic State, but he was told by al-Sudani that he first had to prove himself to the group by executing an attack in the United States.

Al-Sudani also pointed out that due to his location "behind enemy lines," Lutchman's real utility was as a domestic terrorist. ${ }^{59}$ He told Lutchman to plan an attack for New Year's Eve 2015, when he would have easy access to large crowds. He also offered Lutchman various pieces of advice both to ensure that the operation was as effective as possible and to avoid capture beforehand. Once the operation was complete, al-Sudani promised Lutchman he would vouch for him to the Islamic State after he arrived in Libya.

By late December, Lutchman-while maintaining regular contact with al-Sudani, who continued to offer advice and moral support - had begun plotting an attack with three accomplices. He was unaware, however, that all of these individuals were working for the FBI. On December 28, Lutchman identified a restaurant in Rochester, New York, as a target and began planning an attack that entailed taking hostages and executing them with a machete. ${ }^{60}$ Two days later, he recorded the video al-Sudani had requested of him. Holding his index finger aloft, he pledged allegiance to the Islamic State and announced that "the blood that you spill of the Muslim overseas, we gonna spill the blood of the kuffar [unbelievers]." ${ }^{61} \mathrm{He}$ was arrested immediately afterward, and in August 2016, Lutchman pleaded guilty to conspiracy to provide material support to the Islamic State and was sentenced to 20 years in prison. ${ }^{62}$ Al-Sudani died in a U.S. airstrike in Syria in April 2016. ${ }^{63}$

While Hussain provided instructions in a separate plot to attack the organizer of the Muhammad Art Exhibit and Contest, he was also, at the very least, on the periphery of a major conspiracy to attack the event itself. On May 3, 2015, Elton Simpson and his accomplice Nadir Soofi traveled to Garland, Texas, as part of a plot to use assault rifles to kill attendees. In the months preceding the attack, which ended in the deaths of both men before they could enter the venue, Simpson had been in direct contact with at least two virtual entrepreneurs using Twitter direct messages and SureSpot. ${ }^{64}$

Shortly before Simpson attempted the attack, he logged on to Twitter and urged users to follow@_ AbuHu55ain, one of the accounts operated by Legion member Hussain. ${ }^{65}$ In addition, an hour before the attack, Hussain himself tweeted a number of messages suggesting he was aware of the impending shooting, including: "The knives have been sharpened, soon we will come to your streets with death 
and slaughter!" 66 Two days later, the Islamic State released a statement taking credit for the attack in what amounted to its first of several claims of operations in the United States. ${ }^{67}$

While the clues certainly exist, there is no clear evidence that Hussain had a direct hand in plotting the attack in Garland, although there is no doubt he encouraged Simpson's extremism by offering moral support and helping validate his beliefs. While discussing Hussain's role in the Abdulkader case, however, Assistant U.S. Attorney Timothy Mangan told the judge that Hussain had boasted to Abdulkader about his involvement in directing the Garland attacks, telling him "there's more to come." ${ }^{8}$ Furthermore, in December 2015, FBI Director James Comey claimed that on the day of the attack, one of the gunmen and "an overseas terrorist" exchanged 109 encrypted messages. The overseas terrorist was reportedly thought to be Hussain. The details of these encrypted exchanges remain unknown, with the FBI unable to access them. ${ }^{69}$

Hussain was not the only virtual entrepreneur with whom Simpson had contact. Several years prior, Simpson attempted to join al-Shabaab in Somalia. ${ }^{70}$ Simpson's interest in this broader movement led him to Mohamed Abdullahi Hassan (a.k.a. "Mujahid Miski”), a Somali-American from Minnesota who joined alShabaab in 2009. ${ }^{71}$ Via direct messages on Twitter, Hassan and Simpson communicated about the Garland plot, with Hassan eventually re-tweeting a message from Simpson concerning the cartoon contest with a statement: "The brothers from the Charlie Hebdo attack did their part. It's time for brothers in the \#US to do their part." 72 This was a reference to the January 2015 al-Qaida-linked killings at the offices of French satirical magazine Charlie Hebdo, known for its frequent depictions of the Prophet Muhammad.

The virtual entrepreneurs of the Islamic State appear to be issuing similar sets of instructions to their American contacts, almost as if they are working from a common script. While it is unclear if Islamic State virtual entrepreneurs are sharing information and tradecraft among themselves, this certainly would appear to be the case.

Beyond their various degrees of direct contact with a myriad of radicalized Americans, the impact of virtual entrepreneurs, while significant, is difficult to measure. Their activities and the public profiles they cultivated have nonetheless made them beacons of inspiration for their fellow Western jihadis, many of whom have no doubt been motivated after witnessing their achievements.

\section{Implications of evolving social media and encryption technologies}

Social media, coupled with the ever-increasing availability of applications that offer encrypted messaging, has given virtual entrepreneurs the ability to both bypass Western counterterrorism measures and build close, trusted online relationships with recruits. Although jihadi propaganda has been easily accessible through various online platforms over the last decade, the advent of these social media applications has given would-be recruits access to real-time support and a stronger sense of belonging to the wider jihadi movement. This online support sustains and encourages a recruit's continued participation in the Islamic State.

In the past, American jihadis also sought religious justification and validation for their intended actions from recognized extremist leaders. Today, they can receive this from foreign fighters in Syria and Iraq. The deaths of figures like Hussain may help stem the number of homegrown attacks and plots, but the experience of the last six years points to an emerging online approach that is likely here to stay.

Along with helping to inspire radicalized Westerners, the work of Islamic State virtual entrepreneurs has given the group new ways to take ownership of attacks, ensuring that they continue to receive attention and media coverage. Crucially, virtual entrepreneurs require few resources and offer a favorable balance between cost and benefit. This is particularly pertinent, as the Islamic State lost ground in Iraq and Syria but retains its desire to remain relevant; by maintaining a significant online presence, its virtual entrepreneurs can give the group the capability to plot or encourage attacks on Western targets. ${ }^{73}$ 
It is, therefore, no surprise that this trend is on the rise. In Europe, the strengthening of security measures and increased military presence-after an initial period of lax oversight - has made it difficult for aspiring militants to travel and join the Islamic State as well as for the group to train and send operatives back to their home countries to conduct attacks. In the United States, it has never been easy to travel to Islamic State-controlled territory.

Three of the most influential members of the Legion-Hussain, Hostey, and Khan-were killed in 2015 and 2016, while Hassan was arrested in 2015 and al-Sudani was killed in 2016. Whether they can be replaced remains to be seen.

There are a number of factors that may influence this. The first is whether the Islamic State and other jihadi groups intent on striking the West are able to regain the territory needed to harbor individuals with the capability to inspire and plan attacks via the internet. While virtual entrepreneurs can technically be just as effective while operating outside of jihadi-held territory, it is more difficult. They may lose credibility in the eyes of Western jihadis gained by the likes of Hussain and Hassan who, due to their locations, were able to present themselves as legitimate members of terrorist organizations. This potential lack of safe havens would also likely make virtual entrepreneurs more vulnerable to interception by Western security services.

Second, much will depend on how both Western states and technology companies respond to this challenge. In August 2016, for example, Twitter announced that it had shut down 360,000 accounts for "promotion of terrorism." ${ }^{74}$ Nevertheless, it remains unclear how other companies that offer messenger apps with encryption services plan to respond. While Telegram announced in 2015 that it had shut down 78 Islamic State-related unencrypted channels, it also clarified that it had not interfered with any private, encrypted chats. ${ }^{75}$ Other encrypted messaging services echo this view.

In the traditional policy realm, Western states continue to struggle in their efforts to develop effective and coherent policies on combating terrorist use of the internet. In Europe, Europol has set up the Internet Referral Unit. According to Europol Deputy Director Wil van Gemert, it "detects terrorist and violent extremist online content, flags and refers such content to internet providers, and asks for its removal." ${ }^{, 76}$ It is not clear, however, if the Internet Referral Unit has begun to look into encrypted messaging applications.

In the United States, policy is still taking shape. Under the Barack Obama administration, government officials repeatedly met with senior technology company executives and through an initiative known as the Madison Valleywood Project urged them to police their platforms further and more aggressively enforce their terms of service. ${ }^{77}$ Overall, tensions are increasing between governments and companies that offer encrypted messaging platforms, with elected officials from both parties suggesting changes to Section 230 of the Communications Decency Act, which protects technology companies from being legally liable for the content on their platforms. ${ }^{78}$

The challenge of virtual entrepreneurs is intrinsically and inescapably entangled within the wider and overlapping issues of online privacy, countering violent extremism policies, and the ongoing tug of war between civil liberties and security. The future direction and shape of this debate, and the positions of tech companies and governments on censorship and monitoring of the internet, will ultimately decide how this new threat evolves.

As the response to this challenge develops, it is unlikely the world has seen the end of virtual entrepreneurs with the deaths of Legion members and others associated with them. Their recent successes could ensure that they will be central to jihadi groups' current and future efforts to strike the West while continuing to pose a complex challenge to counterterrorism authorities.

\section{Notes}

1 Rukmini Callimachi, "Not 'Lone Wolves' After All: How ISIS Guides World's Terror Plots From Afar,” New York Times, February 4, 2017, www.nytimes.com/2017/02/04/world/asia/isis-messaging-app-terror-plot.html; 


\section{Meleagrou-Hitchens and Hughes}

Daveed Gartenstein-Ross and Madeleine Blackman, "ISIL's Virtual Planners: A Critical Terrorist Innovation," War on the Rocks, January 4, 2017, https://warontherocks.com/2017/01/isils-virtual-planners-a-critical-terroristinnovation/; Bridget Moreng, "ISIS'Virtual Puppeteers," Foreign Affairs, September 21, 2016, www.foreignaffairs. com/articles/2016-09-21/isis-virtual-puppeteers.

2 The plots are often referred to as "Islamic State-enabled." While this typology is useful, it is also problematic, as it may suggest that the plots are planned by Islamic State leadership. It remains unclear if Islamic State virtual entrepreneurs are taking direction from senior Islamic State figures or acting independently.

3 While other jihadi groups, such as al-Qaida, have also made use of such platforms, the Islamic State is widely recognized as pioneering, or at least perfecting, the use of the internet to reach out to sympathizers around the world.

4 It is based on a review of court filings and interviews with law enforcement officials, reporters, and attorneys connected to these cases.

5 While such an approach is useful and necessary to better understand the threat, the levels of involvement of virtual entrepreneurs remain fluid and defy precise categorization.

6 The eight separate plots involved 13 individuals in total. They are Fareed Mumuni and Munther Omar Saleh (2015), David Daoud Wright and Nicholas Rovinski (2015), Munir Abdulkader (2015), Justin Nojan Sullivan (2015), Jalil Ibn Ameer Aziz (2015), Emanuel Lutchman (2015), Abdul Malik Abdul Kareem (2015), and Mohamed Bailor Jalloh (2016). The dates provided here reflect when the defendants were charged, as opposed to when the offense was carried out or contact was made with the virtual entrepreneur. Three individuals were killed either conducting their operation or during attempts to arrest them. Garland attackers Nadir Soofi and Elton Simpson were killed while conducting their operation. Usaamah Abdullah Rahim was killed when officers tried to arrest him. Soofi and Simpson committed the attack with assistance from Abdul Malik Abdul Kareem.

7 They are Avin Brown (2014), Mohammed Hamzah Khan (2014), Nader Elhuzayel (2015), Ardit Ferizi (2015), Aaron T. Daniels (2016), and Abdul Raheem Habil Ali-Skelton (2016).

8 Michael B. Steinbach, How Technology Has Transformed the Terrorist Threat Fifteen Years After 9/11 (Washington, DC: The Washington Institute, 2016).

9 This was the case of British Airways employee Rajib Karim. For more, see Alexander Meleagrou-Hitchens, As American as Apple Pie: How Anwar al-Awlaki Became the Face of Western Jihad (London: International Centre for the Study of Radicalisation and Political Violence, 2011); Scott Shane, Objective Troy (New York: Tim Duggan Books, 2016).

10 The membership of the Legion has yet to be fully identified. At the very least, it publicly consisted of British citizens Junaid Hussain (also known as Abu Hussain al-Britani) and his wife, Sally Jones (also known as Umm Hussain al-Britani); Reyaad Khan (also known as Abu Dujana); Raphael Hostey (also known as Abu Qaqa); and Trinidadian citizen Shawn Parson (also known as Abu Khalid al-Amriki). Based on conversations with individuals familiar with the group, the authors also strongly suspect that another British national, Omar Hussain (also known as Abu Sa'eed al-Britani), is also a member. Abu Sa'ad al-Sudani was not a member of the Legion but had close coordination with the group. For example, in at least one instance, Omar Hussain edited the online postings of al-Sudani. For more, see Adam Goldman and Eric Schmitt, "One by One, ISIS Social Media Experts Are Killed as Result of F.B.I. Program,” New York Times, November 24, 2016, www.nytimes.com/2016/11/24/world/middleeast/isisrecruiters-social-media.html.

11 Chris Cole, "Truth and Consequences: One Year on What We Know (and What We Don't) About the Khan Killing," Drone Wars, August 18, 2016, https://dronewars.net/2016/08/18/truth-and-consequences-one-year-onwhat-we-know-and-what-we-dont-about-the-khan-killing/.

12 U.S.A. v. Justin Nojan Sullivan, Factual Basis (Western District of North Carolina, 2016), 4.

13 Ibid., 4-5.

14 Hussain is thought to have been killed in a British operation codenamed "Illuminative" involving a U.S. airstrike.

15 "Cardiff Jihadist Reyaad Khan, 21, Killed by RAF Drone," BBC, September 7, 2015, www.bbc.com/news/ uk-wales-41406470.

16 William Watkinson, “Baby-Faced Isis Recruiter From Manchester Killed in Syria, Say Reports,” International Business Times, May 2, 2016, www.ibtimes.co.uk/baby-faced-isis-recruiter-manchester-killed-syria-say-reports-1557850.

17 U.S.A. v. Munir Abdulkader, Information (Southern District of Ohio, 2016); U.S.A. v. Munir Abdulkader, Affidavit in Support of a Criminal Complaint (Southern District of Ohio, 2015), 3.

18 U.S.A. v. Munir Abdulkader, Plea Agreement (Southern District of Ohio, 2016), 8; U.S.A. v. Munir Abdulkader, Information, 2; U.S.A. v. Munir Abdulkader, Criminal Complaint, 1.

19 According to court documents, Abdulkader "was in electronic communication with at least one member of ISIL overseas named Junaid Hussain, and placed himself under the direction of ISIL and its overseas leadership." See U.S.A. v. Munir Abdulkader, Sentencing Memorandum (Southern District of Ohio, 2016), 3.

20 U.S.A. v. Munir Abdulkader, Sentencing Minutes (Southern District of Ohio, 2016), 55. 


\section{Social media recruitment of Americans}

21 U.S.A. v. Munir Abdulkader, Sentencing Memorandum, 10.

22 U.S.A. v. Munir Abdulkader, Sentencing Minutes, 68 and 78.

23 U.S.A. v. Munir Abdulkader, Sentencing Memorandum, 13.

24 Office of Public Affairs, "Ohio Man Sentenced to 20 Years in Prison for Plot to Attack U.S. Government Officers," U.S. Department of Justice, November 23, 2016, www.justice.gov/opa/pr/ohio-man-sentenced-20-yearsprison-plot-attack-us-government-officers.

25 U.S.A. v. David Daoud Wright, Second Superseding Indictment (District of Massachusetts, 2017), 5.

26 Ibid.

27 Alanna Durkin Richer, “Man Guilty in Terror Plot to Be Released from Prison,” Associated Press, August 13, 2020, https://abcnews.go.com/US/wireStory/man-guilty-terror-plot-released-prison-72350803.

28 Joe Dwinell, "Convicted ISIS Terrorist out to Kill Boys in Blue Being Resentenced," Boston Herald, September 28, 2020, www.bostonherald.com/2020/09/28/convicted-isis-terrorist-out-to-kill-boys-in-blue-being-resentenced/.

29 U.S.A. v. Abdul Raheem Ali-Skelton, Defendant's Position on Sentencing Factors (District of Minnesota, 2016).

30 Laura Yuen, "Minnesotan Gets 3 Years for Lying About Contact with ISIS," MPR News, January 10, 2017, www. mprnews.org/story/2017/01/10/minnesotan-sentenced-lying-contact-isis.

31 U.S.A. v. Justin Nojan Sullivan, Factual Basis, 2, 5, and 15.

32 Ibid., 21.

33 Ibid., 2.

34 U.S.A. v. Justin Nojan Sullivan, Criminal Complaint (Western District of North Carolina, 2016), 4.

35 Ibid.

36 Office of Public Affairs, "North Carolina Man Pleads Guilty to Attempting to Commit an Act of Terrorism Transcending National Boundaries," U.S. Department of Justice, November 29, 2016, www.justice.gov/opa/pr/ north-carolina-man-pleads-guilty-attempting-commit-act-terrorism-transcending-national.

37 U.S.A. v. Jalil Ibn Ameer Aziz, Criminal Complaint (Middle District of Pennsylvania, 2015), 13.

38 Ibid., 14.

39 U.S.A. v. Jalil Ibn Ameer Aziz, Government's Opposition to Defendant's Motion in Limine (Middle District of Pennsylvania, 2017), 11.

40 U.S. prosecutors charged Brown with providing material support to terrorism in March 2014 after he attempted to board a flight in North Carolina bound for Turkey. See Office of Public Affairs, "Raleigh Man Pleads Guilty to Conspiring to Provide Material Support for Terrorism," U.S. Department of Justice, October 16, 2014, www.justice. gov/opa/pr/raleigh-man-pleads-guilty-conspiring-provide-material-support-terrorism.

41 Office of Public Affairs, "Illinois Man Pleads Guilty to Attempting to Provide Material Support to ISIL," U.S. Department of Justice, October 29, 2015, www.justice.gov/opa/pr/illinois-man-pleads-guilty-attempting-providematerial-support-isil.

42 U.S.A. v. Mohammed Hamzah Khan, Plea Agreement (Northern District of Illinois, 2015), 3-4.

43 Ibid.

44 Ibid.

45 Little is known about al-Sudani, who was better known online as Abu Isa al-Amriki, although he has been connected to a number of failed attacks and, under the name "HoneyNTea," used Telegram to run an Islamic State terrorist cell in India. See Callimachi, "Not 'Lone Wolves' After All."

46 Department of Defense, "Press Briefing by Pentagon Press Secretary Peter Cook," U.S. Department of Defense, December 19, 2016, www.defense.gov/Newsroom/Transcripts/Transcript/Article/1033978/ department-of-defense-press-briefing-by-pentagon-press-secretary-peter-cook-in/.

47 U.S.A. v. Mohamed Bailor Jalloh, Sentencing Memorandum (Eastern District of Virginia, 2016), 3.

48 Ibid., 4.

49 U.S.A. v. Mohamed Bailor Jalloh, Affidavit in Support of a Criminal Complaint (Eastern District of Virginia, 2016), 7.

50 Office of Public Affairs, "Former Army National Guardsman Sentenced to 11 Years for Attempting to Provide Material Support to ISIL," U.S. Department of Justice, February 10, 2017, www.justice.gov/opa/pr/ former-army-national-guardsman-sentenced-11-years-attempting-provide-material-support-isil.

51 Office of Public Affairs, "Ohio Man Arrested for Attempting to Provide Material Support to ISIL," U.S. Department of Justice, November 7, 2016, www.justice.gov/opa/pr/ohio-man-arrested-attempting-provide-material-support-isil.

52 U.S.A. v. Aaron Daniels, Criminal Complaint and Arrest Warrant (Southern District of Ohio, 2016), 7.

53 Ibid., 5.

54 Ibid., 6.

55 Ibid.

56 Ibid., 6-7. 


\section{Meleagrou-Hitchens and Hughes}

57 Ibid.

58 U.S.A. v. Emanuel L. Lutchman, Plea Agreement (Western District of New York, 2016), 4.

59 Ibid., 5.

60 Ibid., 6.

61 Ibid., 9.

62 Office of Public Affairs, "New York Man Sentenced to 20 Years for Conspiring to Provide Material Support to ISIL in Connection With Planned New Year's Eve Attack," U.S. Department of Justice, January 26, 2017, www.justice. gov/opa/pr/new-york-man-sentenced-20-years-conspiring-provide-material-support-isil-connection-planned.

63 Jennifer Rizzo, “ISIS Fighter, Wife, Killed in Airstrike, U.S. Says,” CNN, May 5, 2016, www.cnn.com/2016/05/05/ middleeast/isis-fighter-wife-killed/index.html.

64 Elton Simpson's online discussions with Hussain were presented as evidence for the prosecution in U.S.A. v. Abdul Malik Abdul Kareem (District of Arizona, 2016).

65 Rukmini Callimachi, "Clues on Twitter Show Ties Between Texas Gunman and ISIS Network," New York Times, May 11, 2015, www.nytimes.com/2015/05/12/us/twitter-clues-show-ties-between-isis-and-garland-texas-gun man.html.

66 Ibid.

67 Holly Yan, "ISIS Claims Responsibility for Garland, Texas, Shooting," CNN, May 5, 2015, www.cnn. com/2015/05/05/us/garland-texas-prophet-mohammed-contest-shooting/index.html.

68 U.S.A. v. Munir Abdulkader, Sentencing Minutes, 70.

69 James Eng, "FBI Director: Encrypted Messages Stymied Probe of Garland Shooting," NBC News, December 9, 2015, www.nbcnews.com/tech/security/fbi-director-encrypted-messages-stymied-probe-garland-shooting-n 477111.

70 Scott Shane and Fernanda Santos, "Elton Simpson Eluded U.S. Inquiry Before Texas Shootout," New York Times, May 6, 2015, www.nytimes.com/2015/05/07/us/elton-simpson-eluded-us-inquiry-before-texas-shootout. html.

71 Libor Jany, "Former Twin Cities Man and ISIL Recruiter Linked to Thwarted Terrorist Plots in U.S.," Star Tribune, July 3, 2015, www.startribune.com/former-twin-cities-man-and-isil-recruiter-linked-to-thwarted-terrorist-plotsin-u-s/311530601/.

72 Jim Sciutto et al., “Texas Attacker Tweeted with Overseas Terrorists," CNN, May 5, 2015 , www.cnn. com/2015/05/05/politics/texas-attack-terror-tweets/index.html.

73 For a comprehensive analysis of the Islamic State's plans to survive online, see Charlie Winter, Media Jihad: The Islamic State's Doctrine for Information Warfare (London: International Centre for the Study of Radicalisation and Political Violence, 2017).

74 “An Update on Our Efforts to Combat Violent Extremism," Twitter, August 18, 2016, https://blog.twitter.com/ en_us/a/2016/an-update-on-our-efforts-to-combat-violent-extremism.html.

75 The announcement was made on Twitter on November 18, 2015. Soon after, a user asked, "Oh, so do you intercept conversations?" to which the official Telegram twitter account responded, "No. Channels are public and available to everyone by default."

76 Paul Cruickshank, "A View From the CT Foxhole: Peter Edge, ICE Acting Deputy Director, and Wil van Gemert, Europol Deputy Director,” CTC Sentinel 10, no. 1 (2017): 11-16.

77 Cecelia Kang and Matt Apuzzo, "U.S. Asks Tech and Entertainment Industries Help in Fighting Terrorism," New York Times, February 24, 2016, www.nytimes.com/2016/02/25/technology/tech-and-media-firms-called-towhite-house-for-terrorism-meeting.html.

78 Kevin Breuninger et al., "Trump Is Trying to Link Stimulus Checks, Defense Spending to a Contentious Tech Protection," CNBC, December 29, 2020, www.cnbc.com/2020/12/29/why-trump-is-tying-section-230-to-stim ulus-checks-defense-bill.html. 


\section{0 \\ COUNTERING EXTREMIST ORGANIZATIONS IN THE INFORMATION DOMAIN}

Joseph Mroszczyk and Max Abrahms

Over the past 20 years, the frontlines in the fight against extremism have extended across the globe, leaving few corners untouched. This global effort has involved intelligence, law enforcement, and military operations to target extremist networks and prevent future attacks. Simultaneously, there has been a parallel battle in the information domain to shape opinions and change behaviors.

Terrorist and other violent extremist groups, commonly referred to as violent extremist organizations (VEOs), have leveraged 21st-century media and digital communication innovations to disseminate their propaganda instantly around the globe, allowing groups with limited military capabilities to achieve international notoriety and attention.

According to the U.S. Department of Defense, the information environment is "comprised of and aggregates numerous social, cultural, cognitive, technical, and physical attributes that act upon and impact knowledge, understanding, beliefs, world views, and, ultimately, actions of an individual, group, system, community, or organization." "This domain is characterized not by weapons of war but of communication designed to reach international audiences. Haroon Ullah describes this phenomenon as the "weaponization of information" where "the various ways in which information is disseminated are themselves part of the war."2

VEOs have long understood the importance of the information domain in their strategies. Brian Jenkins wrote in 1974 that "terrorism is theater." It is choreographed violence "aimed at the people watching, not at the actual victims." ${ }^{3}$ Indeed, a characteristic that distinguishes terrorism from other forms of violence is that it intends not only to harm the victims but also to signal to other groups and audiences the costs of noncompliance. ${ }^{4}$ As Martha Crenshaw notes, terrorism seeks to "create a psychological effect in a watching audience." ${ }^{5}$ Brigitte Nacos argues that focusing the attention of the public, the media, and government officials "is the raison d'être behind modern terrorism's increasingly shocking violence." ${ }^{\prime}$

This chapter argues that VEOs have advantages in information domain operations due to the inherently dispersed and distributed nature of the environment, complicating efforts to effectively combat the threat. First, it summarizes the major ways VEOs aim to instill fear in a targeted population, particularly by threatening violence and communicating through violence. Second, it discusses the various ways that groups generate appeal by cultivating a moderate image, which can help with recruitment efforts and public support. Third, it provides an overview of the various efforts to counter extremists in the information domain by targeting both messages and key nodes. This chapter is not an exhaustive discussion of the topic but rather explores some of the salient issues. 


\section{Putting the terror in terrorism}

VEOs strive to achieve their strategic goals partly by instilling fear into a targeted population. This objective is a key characteristic of extremist violence that distinguishes it from other types of criminal violence and plays out primarily in the information domain. Bruce Hoffman defines terrorism as "the deliberate creation and exploitation of fear through violence or the threat of violence in the pursuit of political change." " Peter Neumann argues "for an act of terrorism to be effective, it needs to actually terrorize people." ${ }^{8}$ VEOs aim to instill fear primarily through two mechanisms in the information domain: threatening violence and communicating violence.

\section{Threatening violence}

VEOs issue threats of violence even when they do not end up carrying it out. These threats, even if they do not come to fruition, can still achieve effects when it comes to a group's objective to frighten a targeted population and change their behavior. Since terrorists primarily seek to coerce a targeted population and government into accepting their demands, they can derive certain benefits from threatening the costs of noncompliance. ${ }^{9}$ These threats come at relatively low costs to the group and can be released through various media to reach the intended audience.

Joseph Brown finds that terrorists can use threats "to manipulate perceptions, induce fear, and obtain concessions," which can serve as a substitute for violence. When combined with acts of violence, threats can gain more legitimacy and allow a group to increase the longevity of their campaigns. Brown concludes that VEOs should "take full advantage of threats" because they are effective at intimidating civilians, shaping the impact of violence, and achieving limited concessions. ${ }^{10}$

Numerous VEOs stoke fear with threats even when they are not backed up by force. For example, the Islamic State has long promised that it will attack Rome and Vatican City, even depicting St. Peter's Square on the cover of Dabiq, its propaganda magazine. In August 2017, the commander of the Swiss Guards, the Vatican's security force, said it was only "a matter of time" before the group carried out an actual attack. Security measures at the Vatican have been increased in recent years in response to these threats. Although the Islamic State has not successfully attacked the Vatican to date, the threat alone has managed to modify the behavior of the Swiss Guards. ${ }^{11}$

Al-Shabaab has also regularly issued threats against the United States and its allies outside of Africa. In February 2015, for example, the al-Qaida affiliate threatened to attack malls in the United States, including the Mall of America, as well as malls in Canada and the United Kingdom. These threats were given additional credibility because of the group's attack on the Westgate Mall in Kenya that killed 67 people in 2013. Although the U.S. Department of Homeland Security said there was no "specific evidence" of this threat, it still warned Americans to be "particularly careful" if they visited the Mall of America. ${ }^{12}$

Lashkar-e-Taiba also routinely issues threats against targets in India, prompting heightened security measures and media coverage. VEOs understand that they can gain attention, stoke fear and other reactions in the target country through the information domain, even in the absence of physical attacks.

\section{Communicating violence}

Of course, VEOs are even more likely to elicit a response in the target country by carrying out physical attacks. As a form of communication, there is no substitute for violence, according to many militant leaders, who admit that they escalated to violence because their grievances had been ignored.

As the leader of the Tamil Tigers put it: "The Tamil people have been expressing their grievances ... for more than three decades. Their voices went unheard like cries in the wilderness." "13 The head of the United Red Army, an obscure offshoot of the Japanese Red Army, likewise admitted: "There is no other 
way for us. Violent actions . . . are shocking. We want to shock people everywhere. . . It is our way of communicating with the people." ${ }^{14}$ Usama bin Ladin and Ayman al-Zawahiri described 9/11 as a "message with no words," which is "the only language understood by the West." 15

For this reason, political scientists often describe terrorism as a political communication strategy. ${ }^{16}$ By using violence, terrorists reveal to the target that they possess the power to cause harm and are highly motivated to change the political status quo. ${ }^{17}$ VEOs select tactics and targets to maximize fear. ${ }^{18}$ Assaf Moghadam contends that VEOs use suicide tactics to elicit greater anxiety in the target. ${ }^{19}$ Diego Gambetta agrees that suicide tactics confer a "communicative benefit" compared to other types of attacks. ${ }^{20}$ Vehicular attacks are also a materially inexpensive method recommended by the leadership of al-Qaida and the Islamic State to maximize impact and gain publicity. ${ }^{21}$

Hostage-taking is another tactic that guarantees publicity. It has been described as "smart" terrorism because it can achieve a number of effects in the information domain, especially prolonged media coverage and the forced recognition of the group in negotiations. ${ }^{22}$ The communicative effect of hostage-taking was starkly displayed in 2016 when Islamic State terrorists seized an upscale bakery in Dhaka, Bangladesh, resulting in an 11-hour standoff with security forces. During the standoff, one attacker asked staff members to turn on the Wi-Fi so he could post images of the attack. ${ }^{23}$

The right-wing terrorist Brenton Tarrant also used modern technologies to livestream his March 2019 attack in real time on two mosques in Christchurch, New Zealand, which left 51 people dead. Prior to the attack, Tarrant announced on an extremist website that he would conduct an attack and would livestream it on Facebook. As Graham Macklin points out, Tarrant's video "was not so much a medium for his message insomuch as it was the message." Although less than 200 people watched the attack live, it received approximately 4,000 views before Facebook took the video down 12 minutes after the broadcast ended. ${ }^{24}$

Other terrorist attacks have also been livestreamed, such as an October 2019 attack at a synagogue in Germany in which the gunman killed two people and streamed a 35-minute video on Twitch, which gained 2,200 views before it was removed. ${ }^{25}$ Livestreaming attacks allows extremists to display their violence in an unfiltered manner to maximize its communicative impact.

Al-Qaida was among the first VEO to understand cyberspace as a critical component of the information domain. ${ }^{26}$ The group matured under the leadership of Bin Ladin, who prioritized perception. He was obsessed with messaging, image, and rapid dissemination of information, ${ }^{27}$ believing that "a huge part of the battle is in the media." ${ }^{28}$ His successor, Ayman al-Zawahiri, likewise noted that "more than half of this battle is taking place in the battlefield of the media." ${ }^{29}$

Al-Qaida in Iraq (AQI) was particularly notorious for its use of violence as a communication strategy. Following the U.S. invasion of Iraq in 2003, AQI, under the leadership of Abu Musab al-Zarqawi, embraced the art of publicizing violence. AQI's videos were "designed to shock, mortify, and instill absolute fear in its enemies" by showcasing beheadings and other forms of executions. ${ }^{30}$

In May 2014, AQI released a video displaying al-Zarqawi beheading American Nicholas Berg. The video received widespread international attention, and parts of the video were shown on major news outlets in the United States. ${ }^{31}$ In the following days, the most popular internet searches were related to the video. $^{32}$ This display of violence was staged to maximize its coverage while also demonstrating the willingness of the group to carry out horrific acts of violence in pursuit of its objectives.

More than any other VEO, the Islamic State distinguished itself by publicizing violence with modern technology. Charlie Winter's analysis of Islamic State propaganda videos confirms that brutality emerged as a primary theme. ${ }^{33}$ Judith Tinnes finds that the Islamic State conducted 2,281 camera-recorded killings from January 2015 through November 2020, with most involving shootings (60.13\%) and beheadings $(28.76 \%)$ but also other forms of brutal executions. ${ }^{34}$ The goal of these recorded killings is to maximize media attention and fear. ${ }^{35}$

Most analysts believe that the Islamic State's gory propaganda has a "strategic logic" and is indeed effective. ${ }^{36}$ According to Abdel Bari Atwan, the Islamic State "could never have achieved its territorial 
ambitions, nor could it have recruited such a large army in so short a time, without its mastery of the internet." ${ }^{37}$ Michael Weiss and Hassan Hassan add that the Islamic State's secret sauce has been its "slick propaganda machine," especially its "peerless ability to produce sleek, hour-long propaganda and recruitment films." 38

Charles Lister also attributes Islamic State success to its "slick propaganda media releases," as these "jihadists in particular proved especially adept at managing their use of social media and the production of qualitatively superior video and imagery output." ${ }^{39}$ The international media has promoted this interpretation, with the New York Times stating,

Where the Islamic State innovated the most was in carrying out increasingly gruesome violence explicitly to film it - to intimidate enemies and to draw recruits with eye-catching displays on social media. . . Those techniques have proved so effective. ${ }^{40}$

Wired magazine went so far as to say that "Islamic State has been singularly successful" because of its unique ability to "inspire dread" and "cultivate this kind of image." ${ }^{41}$ And yet, these assessments were made before the Islamic State group lost its caliphate and imploded.

\section{Benefits of a moderate face}

Terrorists must prioritize not only fear but also sympathy. ${ }^{42}$ For this reason, VEOs can benefit from restraint, particularly against civilians. ${ }^{43} \mathrm{~A}$ growing body of scholarship finds that extremism often backfires. By attacking civilians, VEOs risk strengthening the resolve of the target country, ${ }^{44}$ lowering the odds of government concessions, ${ }^{45}$ eroding popular support, ${ }^{46}$ and expediting organizational demise. ${ }^{47}$ For this reason, militant leaders often try to present their organizations as more moderate than the actual behavior of their members, especially when they kill civilians.

Militant leaders cultivate a more moderate image by denying organizational involvement or denying principal intent. ${ }^{48}$ In denial of organizational involvement, the leader refrains from claiming organizational credit when members attack civilians. In denial of principal intent, the leader acknowledges that his members attacked civilians but denies the violence reflects his intentions.

\section{Denial of organizational involvement}

The Taliban leadership eagerly assumes organizational responsibility for selective attacks against military targets. For instance, the Taliban quickly claimed responsibility when operatives ambushed Mohammad Qasim Fahim, the leader of the alliance that toppled the Taliban in 2001, on a road in northern Kunduz in July 2009. ${ }^{49}$ By contrast, Taliban leaders veil organizational involvement when operatives commit indiscriminate bloodshed.

The United Nations Assistance Mission in Afghanistan observes that Taliban attack denials are "frequently issued following civilian casualty incidents . . . perhaps highlighting the Taliban's continuous interest in gaining the Afghan people's support." ${ }^{50}$ For example, Taliban leadership released the following statement when operatives defied its orders by striking the International Committee of the Red Cross in Jalalabad: "The Islamic Emirate of Afghanistan wants to clarify to everyone that it was neither behind the May 29th attack on the [Red Cross] office in Jalalabad city nor does it support such attacks." ${ }^{1}$

According to Information Minister Mian Iftikhar Hussain of Pakistan's Khyber-Pakhtunkhwa Province, Taliban leaders eschew credit for civilian violence because "they are desperate to wash their tainted image among the public." ${ }^{52}$ In sum, anecdotal evidence abounds of the Taliban leadership denying organizational involvement when members attack civilians to enhance the image of the group. 
Quantitative research confirms that leaders are significantly likely to deny organizational responsibility when their members strike civilian targets versus military ones. Research finds that leaders are 41\% less likely to claim credit for attacks on civilian targets than military ones. ${ }^{53}$ Evidently, leaders become more careful about appearing too extreme with greater exposure to asymmetric conflict.

Groups are significantly less likely to claim credit over time, and the results strengthen for those groups that have survived at least a decade. The percentage of civilian attacks in particular for which groups claim credit also decreases over time, especially after a decade of fighting. ${ }^{54}$ The wisdom of moderate branding through denial of organizational involvement is at least partly a learned behavior. Over time, leaders gain knowledge about how to advance the cause even when their members subvert it.

Similarly, another study of VEOs finds that they tend to feature in their propaganda videos significantly fewer attacks against civilian targets than their members actually commit. By contrast, attacks on military targets are overrepresented. ${ }^{55}$ In these ways, militant leaders manage the marketing of their organization's violence to obscure its harm toward civilians and thereby gain sympathy, especially with locals.

\section{Denial of principal intent}

Denying organizational involvement is not always a realistic public relations strategy because sometimes leaders cannot credibly deny organizational responsibility when civilians are attacked. To distance the organization from the counterproductive attack, leaders often deny principal intent to demonstrate that the atrocity does not represent the values of the group, especially those at the top. Denial of principal intent is achieved through several image restoration techniques familiar to students of the communications literature.

Perhaps the most common face-saving technique is an apology. Militant leaders issue apologies surprisingly frequently. According to one study, leaders have apologized for $22 \%$ of attacks. Target selection is the key factor. Civilian casualties reportedly increase the odds four-fold of an apology on behalf of the group. ${ }^{56}$ The Irish Republican Army (IRA) leadership, for example, initially denied organizational responsibility for a December 1983 car bombing outside the Harrods department store in central London that killed two civilians and injured 14 bystanders.

But when denial of organizational involvement became implausible, the leaders pursued the denial of principal intent public relations strategy by issuing an apology. ${ }^{57}$ The IRA also apologized in 1987 when a bomb killed 11 bystanders at a memorial service for veterans in Northern Ireland. The public statement read: "The IRA admits responsibility for planting the bomb in Enniskillen yesterday which exploded with such catastrophic consequences. We deeply regret what occurred." ${ }^{58}$

In 2006, Hezbollah leader Hassan Nasrallah apologized for a rocket attack that killed two Israeli Arab children in Nazareth in northern Israel. "To the family that was hit in Nazareth, on my behalf and my brothers', I apologize to this family," Nasrallah said, apparently recognizing the political costs the attack had incurred. ${ }^{59}$

Over the years, al-Qaida leaders have increasingly issued apologies when members harmed civilians. In 2009, the American al-Qaida spokesman Adam Gadahn released a video message in English to "express our condolences to the families of the Muslim men, women, and children killed" in terrorist attacks in Afghanistan and Pakistan. ${ }^{60}$ In 2013, al-Qaida in the Arabian Peninsula struck a hospital that left dozens of people dead. Its leader Qasim al-Raymi released an apology through its media outlet. ${ }^{61}$

Following the massive truck bomb attack in Mogadishu in December 2019 that killed more than 80 people, al-Shabaab claimed credit for the blast but apologized that Somalis were killed, which the group said was meant to target a convoy of Turkish mercenaries. ${ }^{62}$ When civilians are struck, such apologies help militant leaders to project more positive intentions both personally and on behalf of their organization.

Militant leaders typically combine apologies with scapegoating to distance themselves from the offense. Essentially, the principal blames the unwanted attack on its agents. In their apology for the 
1983 Harrods attack, the IRA Army Council claimed it had "not authorized the attack" and blamed undisciplined operatives. ${ }^{63}$ Similarly, the IRA said that the Enniskillen attack was "not sanctioned by the leadership." ${ }^{64}$

The leader of Lashkar-e-Taiba, Hafiz Muhammad Saeed, blamed the 2008 Mumbai attacks and other instances of violence against the population on "rogue elements within the group." 65 Apologizing and scapegoating are often combined with corrective action, where the leader attempts to demonstrate the genuineness of his opposition to the unwanted violence against civilians by punishing the perpetrators for it. The IRA apology for the Enniskillen attack made a point to mention that the perpetrators would be subject to an "internal inquiry." ${ }^{66}$ Such public punishments are a form of crisis communications to help militant leaders distance themselves and their other members from the terrorism fallout.

\section{Converting support to action}

In sum, VEOs are not single-mindedly focused on fear maximization. Most leaders are sensitive to their organization's public image. Especially when civilians are harmed, they are known to practice both denial of organizational involvement and denial of principal intent. It explains why most VEOs around the world are significantly less likely to claim organizational responsibility for civilian attacks, and when organizational culpability is undeniable, the leaders maintain their image by apologizing, blaming it on wayward operatives and punishing them to signal to audiences that the terrorist carnage does not represent the values of the group. In these ways, VEOs are able to attract supporters and sympathizers.

VEOs must not only use the information environment to attract supporters, but they must convert these supporters into members to replenish its ranks. A group's longevity depends upon its ability to connect with candidates and convince them to join the group. ${ }^{67}$ In addition to strategically managing the effects of their violence through denial of organizational involvement and denial of principal intent, VEOs use the information domain to promote the quality of life their members enjoy ${ }^{68}$ distribute violent propaganda to appeal to certain individuals who find violence alluring, ${ }^{69}$ and position their group as more resolute than competing organizations. ${ }^{70}$

VEOs can reach a wider pool of candidates through the use of digital communications. As Sageman points out, prior to 2004, most Islamist terrorist networks developed as a result of face-to-face interactions among friends and family. After 2004, these interactions shifted to the internet as organizations adapted to the new information environment. ${ }^{71}$

Social media has emerged as a critical node of recruitment in the information domain, which has come to be known as this decade's version of the "radical mosque" in terms of its importance as a meeting space for the dissemination of radical ideologies. Though the social media ecosystem has become the meeting place for groups to connect with potential members, it is not the reason for radicalization and recruitment into VEOs. Rather, it functions as a meeting place for these processes to occur, just as mosques or bookshops once did. ${ }^{72}$ According to Weimann, social media offers VEOs a number of advantages in terms of their ability to recruit online, giving them free, reliable, and accessible platforms to reach their targeted audiences and disseminate material worldwide. ${ }^{73}$

\section{Government responses}

VEOs must be contested in the information domain, the critical battlespace in the war against extremism. Counterterrorism cannot be limited to killing extremists, capturing them, disbanding their networks, or hardening potential targets. For sustained success, governments must promote narratives to reduce the appeal of extremist messages and to delegitimize their voices across the information spectrum.

The U.S. government acknowledged this need early in the war on terrorism following $9 / 11$, and the effort has evolved into a larger international counterextremism enterprise composed of new bureaucracies, private 
sector cooperation, and expanded authorities. Two key aspects of winning the information domain are effective counternarrative messaging and cutting off the nodes through which messages are disseminated.

\section{Messages}

The United States lacked the bureaucratic infrastructure to organize an information war against extremism on 9/11, and it has continued to lag behind VEOs. Following the attacks, the George W. Bush administration acknowledged the need to enhance the image of the United States within the Muslim world. In October 2001, advertising executive Charlotte Beers was brought in to serve as undersecretary of state for public diplomacy. She led the Shared Values Initiative, an effort to promote the United States to Muslims abroad and to demonstrate that American values are not antithetical to Islam. The effort floundered due to resistance from diplomats within the Department of State who viewed the outreach as a transparent propaganda campaign. The Shared Values Initiative was canceled shortly after it began, with supporters contending that the effort was never given a chance to take root. ${ }^{74}$

The 2006 National Security Strategy highlighted the importance of winning the information war to counter terrorism. It noted that the war on terrorism was both a "battle of arms and a battle of ideas-a fight against the terrorists and against their murderous ideology." The document highlighted the ongoing war in Iraq had been "twisted by terrorist propaganda as a rallying cry" and that extremism was emanating from "sub-cultures of conspiracy and misinformation" and from an "ideology that justifies murder." Counterterrorism success, the document remarked, "means winning the battle of ideas, for it is ideas that can turn the disenchanted into murderers willing to kill innocent victims." 75

The Barack Obama administration attempted to enhance American "soft power" and public diplomacy in the information domain. Secretary of State Hillary Clinton subsequently developed in 2011 what became known as the Center for Strategic Counterterrorism Communications. Its task was to "coordinate, orient, and inform government-wide foreign communications activities targeted against terrorism and violent extremism."

The center grew to about 40 personnel within the first year, about half of whom were on the Digital Outreach Team charged with engaging in online debates about violent extremism. ${ }^{76}$ The center pursued a number of strategies to counter VEO messages, including reaching out to young people and extremists themselves on social media websites. Most of its efforts focused on countering messaging from the Islamic State, although the center also targeted VEOs in Somalia and Nigeria. ${ }^{77}$

The Obama administration replaced the Center for Strategic Counterterrorism Communications with the Global Engagement Center in 2016. The Global Engagement Center was charged with leading "the coordination, integration, and synchronization of Government-wide communications activities directed at foreign audiences abroad in order to counter the messaging and diminish the influence of international terrorist organizations." To these ends, the center sought to use the latest technologies, data analytics, and a whole-of-government approach to counter extremist narratives in the information domain. The center's stated goal is to expose the "true nature" of VEOs in order to reduce their appeal and diminish their influence among potential sympathizers and prospective recruits. ${ }^{78}$

The core mission of the center evolved under the Donald Trump administration with the National Defense Authorization Act of 2017, which codified the Global Engagement Center into law. Initially focused on countering messaging from VEOs, its mission expanded to include both "foreign state and non-state propaganda and disinformation efforts." ${ }^{79}$ This reflected a broadening of security threats to include adversarial states, particularly China and Russia.

Ingram highlights two additional changes that took place during the transition of the Center for Strategic Counterterrorism Communications to the Global Engagement Center. First, the new center prioritized coordination and capacity building across U.S. government agencies, non-government sectors, and international allies by enhancing data analytics capabilities. Second, the center moved away from its own 
messaging efforts and instead focused on strengthening the ability of these partners to engage in their own strategic communications. The center had transformed "from soloist to conductor," as one senior Department of State official put it. ${ }^{80}$

Despite these changes, the 2017 National Security Strategy acknowledged that U.S. efforts to counter its enemies in the information domain had been "tepid and fragmented." These initiatives "lacked a sustained focus" and suffered from a lack of properly trained professionals. The strategy called for the strengthening of "Information Statecraft" to counter the weaponization of information by U.S. enemies, including both state and non-state actors. Priority actions in the strategy included the need to improve understanding of "how adversaries gain informational and psychological advantages" and "craft and direct coherent communications campaigns to advance American influence and counter challenges from the ideological threats," such as those emanating from VEOs. ${ }^{81}$

The subsequent National Defense Strategy of 2018 similarly emphasized the role of the information domain and called for the need to "gain and maintain information superiority" in times of both peace and war. ${ }^{82}$ The 2018 National Strategy for Counterterrorism acknowledged that the United States had developed a robust counterterrorism architecture since the 9/11 attacks but had still "not developed a prevention architecture to thwart terrorist radicalization and recruitment." Toward those ends, the strategy listed a number of priority actions related to the information domain, including the need to combat extremist ideologies with strategic communications. ${ }^{83}$

In sum, nearly two decades after the $9 / 11$ attacks and the advent of the war on terrorism, the United States continues to play catch-up in the information domain. While tremendous strides have been made to disrupt terror networks, kill or capture leaders, and remove safe havens, there have not been parallel successes in the information environment. Many efforts are admittedly clandestine in nature, but it is nonetheless evident that the United States remains in a reactive posture in the information domain, struggling to link tactics and strategies to combat the influence of extremism online.

\section{Key nodes}

In addition to targeting VEO messaging, governments and private-sector partners can choke the spread of these messages through critical nodes — such as social media platforms - by limiting access and removing content. Technology companies have historically not been liable for the user content posted on their websites. Section 230 of the 1996 Communications Decency Act states that "no provider or user of an interactive computer service shall be treated as the publisher or speaker of any information provided by another information content provider," effectively protecting social media platforms, as well as companies that provide internet services, from liability for the content posted on their sites. Under Section 230, social media companies can choose to remove posts or content that are in violation of their own standards so long as they act in "good faith." 84

In recent years, however, there has been a renewed debate about whether "Big Tech" should bear some responsibility for the content posted on their platforms. The Department of Justice concluded in its June 2020 analysis of Section 230 that "reform is important now more than ever" with the growth of criminal activity on the internet. ${ }^{85} \mathrm{~A}$ reform proposed by the Department of Justice is to hold platforms accountable for a few types of particularly illicit content, such as child exploitation and abuse, cyberstalking, and terrorism. This reform would incentivize platforms to address these issues to stave off lawsuits from victims. ${ }^{86}$

Social media companies acknowledge that their platforms have been exploited by VEOs to spread extremist content and are taking steps to minimize this problem. In 2017, YouTube, Facebook, Microsoft, and Twitter founded the Global Internet Forum to Counter Terrorism to "prevent terrorists and violent extremists from exploiting digital platforms." It has since expanded to include more than a dozen other 
technology companies that work collaboratively to combat the dissemination of violent extremist content online.

Critics of this forum allege that-through the group's efforts to block or limit the dissemination of extremist content using algorithms - it has also removed other legitimate content that should be protected under free speech. More broadly, critics fear that government participation on a new Global Internet Forum to Counter Terrorism Independent Advisory Committee could increase the risk of what they see as extra-legal censorship. ${ }^{87}$

Facebook regularly shares metrics related to its efforts to remove extremist content from its platform. According to the company, it bans "groups that proclaim a hateful and violent mission from having a presence on our apps and we remove content that represents, praises, or supports them." Accordingly, it has developed automated techniques to detect content from groups like the Islamic State and al-Qaida.

In the first three months of 2020, Facebook removed 4.7 million pieces of content, an increase of over 3 million pieces compared to the previous three months. The company reported that it had increased its "proactive detection rate" - the content removed before it is reported-from $89.6 \%$ in the last quarter of 2019 to $96.7 \%$ in early $2020 .{ }^{88}$ The company recognizes the need not only to identify and remove extremist content but to also empower counter-narratives. ${ }^{89}$

While websites may have the ability to remove content, traditional media outlets, such as newspapers, still offer an outlet through which VEOs can publicize their message. There have been efforts to develop an ethical code of practice for media coverage of terrorism to limit its negative impact, such as fear, and enhance positive effects, like messages of resilience. ${ }^{90}$

The United Nations has also published a handbook for journalists covering terrorism "to explore some of the ethical dilemmas present in terrorism coverage, and start a conversation with media professionals as to how to respond appropriately and proportionately." ${ }^{11}$ At least in societies with a free press, measures such as these would need to emanate from the media itself, since governments generally lack legal authority to impose restrictions on how journalists report.

\section{Conclusion}

In sum, VEOs have demonstrated far greater adaptability, maneuverability, and innovation in the information domain in the past 20 years than the governments and organizations tasked with countering them. Extremist tactics and techniques are constantly evolving in parallel with the rapid transformation of the digital communication space, often leaving governments behind to develop bureaucracies and authorities to counter this threat. As Ingram concludes, strategic communications efforts against the Islamic State "have been dogged by bureaucratic disjointedness and instability," creating "a strategic-policy vacuum" that has hampered consistent messaging against the group. ${ }^{92}$

Governments have an inherent structural disadvantage when combating extremism in the information domain due to the sheer velocity at which innovation is taking place. Alberto Fernandez, former director of the Center for Strategic Counterterrorism Communications at the U.S. Department of State, notes that governments "with their sometimes elephantine decision-making processes, public oversight and multiple stakeholders, are often at a disadvantage compared to nimble, streamlined terrorist or insurgent forces in the field of propaganda." 93

Extremists have not only demonstrated innovation and creativity with the manner in which they conduct violence but have matured their information domain operations to deliver catered messages toward targeted audiences and for different effects, such as to instill fear or to generate support often by disassociating themselves from unpopular attacks. It is difficult to assess how effective extremist messaging has been due to a variety of methodological challenges, but more needs to be done to limit the capability of VEOs to exploit the information domain. 


\section{Notes}

1 Joint Chiefs of Staff, Joint Concept for Operating in the Information Environment (JCOIE) (Washington, DC: Joint Chiefs of Staff, 2018), 42.

2 Haroon K. Ullah, Digital World War: Islamists, Extremists, and the Fight for Cyber Supremacy (New Haven: Yale University Press, 2017), 3.

3 Brian M. Jenkins, International Terrorism: A New Kind of Warfare (Santa Monica: RAND, 1974), 4.

4 Boaz Ganor, The Counter-Terrorism Puzzle: A Guide for Decision Makers (New Brunswick, NJ: Transaction Publishers, 2005), 234-236; Brigitte L. Nacos, Mass-Mediated Terrorism: The Central Role of the Media in Terrorism and Counterterrorism (Lanham, MD: Rowman \& Littlefield, 2007), 14.

5 Martha Crenshaw, Explaining Terrorism: Causes, Processes and Consequences (New York: Routledge, 2011), 3.

6 Brigitte L. Nacos, Terrorism \& the Media: From the Iran Hostage Crisis to the Oklahoma City Bombing (New York: Columbia University Press, 1994), 8.

7 Bruce Hoffman, Inside Terrorism (New York: Columbia University Press, 2006), 40.

8 Michele McPhee and Brian Ross, "Official: American May Be Key in ISIS Social Media Blitz," ABC News, September 3, 2014, https://abcnews.go.com/blogs/headlines/2014/09/official-american-may-be-key-in-isis-socialmedia-blitz/.

9 Andrew H. Kydd and Barbara F. Walter, “The Strategies of Terrorism," International Security 31, no. 1 (2006): 49-80.

10 Joseph M. Brown, Force of Words: The Logic of Terrorist Threats (New York: Columbia University Press, 2020), $166-173$.

11 Jack Moore, “Pope's Swiss Guards Say ‘Only Matter of Time’Before ISIS Attacks Rome, Vatican,” Newsweek, August 25, 2017, www.newsweek.com/popes-swiss-guards-say-only-matter-time-isis-attacks-rome-vatican-655025.

12 Faith Karimi et al., "Al-Shabaab Threatens Malls, Including Some in U.S.; FBI Downplays Threat," CNN, February 21, 2015, www.cnn.com/2015/02/21/us/al-shabaab-calls-for-mall-attacks/index.html.

13 Louise Richardson, What Terrorists Want: Understanding the Enemy, Containing the Threat (New York: Random House, 2007), 50.

14 Gerald McKnight, The Mind of the Terrorist (London: Michael Joseph, 1974), 168.

15 Peter Bergen, "Interview with Osama bin Laden," CNN, 1997.

16 Robert A. Pape, Dying to Win: The Strategic Logic of Suicide Terrorism (New York: Random House, 2005). See also Max Abrahms, "Al Qaeda's Miscommunication War: The Terrorism Paradox," Terrorism and Political Violence 17, no. 4 (2005): 529-549.

17 Max Abrahms, "The Credibility Paradox: Violence as a Double-Edged Sword in International Politics," International Studies 57, no. 4 (2013): 660-671.

18 Nicholas J. O'Shaughnessy and Paul R. Baines, "Selling Terror: The Symbolization and Positioning of Jihad," Marketing Theory 9, no. 2 (2009): 227-228.

19 Assaf Moghadam, The Globalization of Martyrdom: Al Qaeda, Salafi Jihad, and the Diffusion of Suicide Attacks (Baltimore: Johns Hopkins University Press, 2008), 31.

20 Diego Gambetta, "Can We Make Sense of Suicide Missions," in Making Sense of Suicide Missions, ed. Diego Gambetta (New York: Oxford University Press, 2005), 266.

21 Brian M. Jenkins and Bruce R. Butterworth, "Smashing Into Crowds"-An Analysis of Vehicle Ramming Attacks (San Jose: Mineta Transportation Institute, 2019), 10.

22 Margaret G. Hermann and Charles E. Hermann, "Hostage Taking, the Presidency, and Stress," in Origins of Terrorism: Psychologies, Ideologies, Theologies, States of Mind, ed. Walter Reich (Washington, DC: Woodrow Wilson Center Press, 1998), 211-229.

23 Julfikar Ali Manik and Kai Schultz, "Bangladesh Sentences 7 to Death Over 2016 Bakery Attack," New York Times, November 27, 2019, www.nytimes.com/2019/11/27/world/asia/bangladesh-bakery-attack.html.

24 Graham Macklin, "The Christchurch Attacks: Livestream Terror in the Viral Video Age," CTC Sentinel 12, no. 6 (2019): 18-29.

25 Max Koslowski, "Social Media Companies Thwarted Spread of Latest Terror Livestream," Sydney Morning Herald, October 10, 2019, www.smh.com.au/politics/federal/social-media-companies-thwarted-spread-of-latest-terrorlivestream-20191010-p52zhk.html.

26 Malcom Nance and Chris Sampson, Hacking ISIS: How to Destroy the Cyber Jihad (New York: Skyhorse Publishing, 2017), 25-29.

27 Jim Michaels, "Bin Laden Was Obsessed with Media, Public Image," USA Today, March 1, 2016, www.usatoday. com/story/news/world/2016/03/01/bin-laden-obsessed-media-public-image/81164054/.

28 Peter Bergen, “Bin Laden’s Final Days—Big Plans, Deep Fears," CNN, March 19, 2012, www.cnn.com/2012/03/16/ opinion/bergen-bin-laden-final-writings/index.html. 


\section{The information domain}

29 Quoted in Akil N. Awan, "The Virtual Jihad: An Increasingly Legitimate Form of Warfare," CTC Sentinel 3, no. 5 (2010): 10.

30 Nance and Sampson, Hacking ISIS, 27.

31 Maria Newman, "Video Appears to Show Beheading of American Civilian," New York Times, May 11, 2004, www. nytimes.com/2004/05/11/international/middleeast/video-appears-to-show-beheading-of-american.html.

32 “Berg Video Dominates Net Searches," Sydney Morning Herald, May 20, 2004, www.smh.com.au/national/bergvideo-dominates-net-searches-20040520-gdiyj3.html.

33 Charlie Winter, The Virtual 'Caliphate': Understanding Islamic State's Propaganda Strategy (London: Quilliam, 2015), $22-23$.

34 Judith Tinnes, "Counting Lives Lost-Monitoring Camera-Recorded Extrajudicial Executions by the 'Islamic State'," Perspectives on Terrorism 10, no. 1 (2016): 78-82.

35 Ibrahim Al-Marashi, "The Truth About Beheadings," Al Jazeera, November 24, 2014, www.aljazeera.com/ opinions/2014/11/24/the-truth-about-beheadings/.

36 Steven T. Zech and Zane M. Kelly, "Off With Their Heads: The Islamic State and Civilian Beheadings," Journal of Terrorism Research 6, no. 2 (2015): 85.

37 Abdel Bari Atwan, Islamic State: The Digital Caliphate (Berkeley: University of California Press, 2015), 15.

38 Michael Weiss and Hassan Hassan, ISIS: Inside the Army of Terror (New York: Simon \& Schuster, 2016), XV and 171.

39 Charles R. Lister, The Syrian Jihad: Al-Qaeda, the Islamic State and the Evolution of an Insurgency (New York: Oxford University Press, 2016), 240, 244.

40 Anne Barnard and Neil MacFarquhar, "Paris and Mali Attacks Expose Lethal Qaeda-ISIS Rivalry," New York Times, November 20, 2015, www.nytimes.com/2015/11/21/world/middleeast/paris-and-mali-attacks-expose-a-lethalal-qaeda-isis-rivalry.html.

41 Brendan Koerner, "Why ISIS Is Winning the Social Media War-And How to Fight Back," Wired, March 2016, www.wired.com/2016/03/isis-winning-social-media-war-heres-beat/.

42 Martha Crenshaw, "The Causes of Terrorism,” Comparative Politics 13, no. 4 (1981): 387.

43 Max Abrahms, "Why Terrorism Does Not Work," International Security 31, no. 2 (2006): 42-78.

44 Claude Berrebi and Esteban F. Klor, "Are Voters Sensitive to Terrorism? Direct Evidence From the Israeli Electorate," American Political Science Review 102, no. 3 (2008): 279-301; Max Abrahms, "Does Terrorism Really Work? Evolution in the Conventional Wisdom Since 9/11," Defence and Peace Economics 22, no. 6 (2011): 583-594; Christophe Chowanietz, "Rallying Around the Flag or Railing Against the Government? Political Parties' Reactions to Terrorist Acts," Party Politics 17, no. 5 (2010): 673-698.

45 Anna Getmansky and Tolga Sinmazdemir, "Success Breeds Failure: The Effect of Terrorist Attacks on Land Control in the Israeli-Palestinian Conflict" (paper presented at the annual meeting of the American Political Science Association, New Orleans, LA, September 2012); Max Abrahms, "The Political Effectiveness of Terrorism Revisited," Comparative Political Studies 45, no. 3 (2012): 66-93; Max Abrahms and Matthew S. Gottfried, "Does Terrorism Pay? An Empirical Analysis," Terrorism and Political Violence 28, no. 1 (2016): 72-89; Khusrav Gaibulloev and Todd Sandler, "The Impact of Terrorism and Conflicts on Growth in Asia," Economics and Politics 21, no. 3 (2009): 359-383.

46 Martha Crenshaw, "The Logic of Terrorism: Terrorist Behavior as a Product of Strategic Choice," in Terrorism in Perspective, ed. Sue Mahan and Pamala L. Griset (London: Sage Publications, 2007), 24-34; Walter Reich, "Understanding Terrorist Behavior: The Limits and Opportunities of Psychological Inquiry," in Origins of Terrorism: Psychologies, Ideologies, Theologies, States of Mind, ed. Walter Reich (Washington, DC: Woodrow Wilson Center Press, 1998), 261-279.

47 Audrey Kurth Cronin, How Terrorism Ends: Understanding the Decline and Demise of Terrorist Campaigns (Princeton: Princeton University Press, 2009); Nelly Lahoud et al., Letters from Abbottabad: Bin Ladin Sidelined? (West Point: Combating Terrorism Center, 2012).

48 Max Abrahms, Rules for Rebels: The Science of Victory in Militant History (New York: Oxford University Press, 2018).

49 Whadat Afghan, "Afghan Vice-Presidential Candidate Survives Ambush," Reuters, July 26, 2009, www.reuters.com/ article/us-afghanistan-attack/afghan-vice-presidential-candidate-survives-ambush-idUSTRE56P0R 220090726.

50 United Nations Assistance Mission in Afghanistan, Afghanistan Annual Report 2013: Protection of Civilians in Armed Conflict (Kabul: United Nations, 2014), 32.

51 Azam Ahmed and Matthew Rosenberg, "Taliban Deny Responsibility for Attack on Red Cross," New York Times, May 31, 2013, www.nytimes.com/2013/06/01/world/asia/taliban-deny-responsibility-for-attack-onred-cross.html.

52 "Ashfaq Yusufzai, "Pakistan: Taliban Backs Off From Attacking Civilians," Inter Press Service, July 23, 2011, www. ipsnews.net/2011/07/pakistan-taliban-backs-off-from-attacking-civilians/. 
53 Max Abrahms and Justin Conrad, "The Strategic Logic of Credit Claiming: A New Theory for Anonymous Terrorist Attacks," Security Studies 26, no. 2 (2017): 279-304.

54 Max Abrahms et al., "Explaining Civilian Attacks: Terrorist Networks, Principal-Agent Problems and Target Selection," Perspectives on Terrorism 12, no. 1 (2018): 23-45.

55 Max Abrahms et al., "What Terrorist Leaders Want: A Content Analysis of Terrorist Propaganda Videos," Studies in Conflict \& Terrorism 40, no. 17 (2017): 899-916.

56 Ioana Emy Matesan and Ronit Berger, "Blunders and Blame: How Armed Non-State Actors React to Their Mistakes," Studies in Conflict \& Terrorism 40, no. 5 (2017): 376-398.

57 "IRA Says Harrods Bombing Was a Mistake," United Press International, December 30, 1983, www.upi.com/ Archives/1983/12/30/IRA-says-Harrods-bombing-was-a-mistake/2270441608400/?ur3=1.

58 Matesan and Berger, "Blunders and Blame," 388.

59 "Hezbollah Leader Apologizes for Attack's Child Victims," CNN, July 21, 2006, www.cnn.com/2006/WORLD/ meast/07/20/nasrallah.interview/.

60 "Al Qaeda Offers 'Condolences' for Innocent Victims," CNN, December 13, 2009, www.cnn.com/2009/ WORLD/asiapcf/12/12/afghanistan.alqaeda/index.html.

61 Yousuf Basil and Catherine E. Shoichet, "Al Qaeda: We're Sorry About Yemen Hospital Attack," CNN, December 22, 2013, www.cnn.com/2013/12/22/world/meast/yemen-al-qaeda-apology/index.html.

62 Graeme Baker, "Al-Shabaab Says Sorry for Killing Somalis With Huge Lorry Bomb," The Times, December 31, 2019, www.thetimes.co.uk/article/al-shabaab-says-sorry-for-killing-somalis-with-huge-lorry-bomb-kp6lcctpb.

63 Alan O’Day, Political Violence in Northern Ireland: Conflict and Conflict Resolution (Westport, CT: Praeger, 1997), 20.

64 Matesan and Berger, "Blunders and Blame," 388.

65 V.S. Subrahmanian et al., Computational Analysis of Terrorist Groups: Lashkar-e-Taiba (New York: Springer, 2013), 34.

66 Matesan and Berger, "Blunders and Blame," 388.

67 Hoffman, Inside Terrorism, 225.

68 Winter, The Virtual 'Caliphate,' 28-31.

69 Brian M. Jenkins, "The Allure of ISIS for Young Recruits," The RAND (Blog), March 20, 2015, www.rand.org/ blog/2015/03/the-allure-of-isis-for-young-recruits.html.

70 Kydd and Walter, "The Strategies of Terrorism," 51.

71 Marc Sageman, Leaderless Jihad: Terror Networks in the Twenty-First Century (Philadelphia: University of Pennsylvania Press, 2008), 109-123.

72 Winter, The Virtual 'Caliphate,' 7.

73 Gabriel Weimann, “Terrorist Migration to Social Media," Georgetown Journal of International Affairs 16, no. 1 (2015): 182. For more on the research challenges surrounding extremist recruitment activities via social media, see Maura Conway, "Determining the Role of the Internet in Violent Extremism and Terrorism: Six Suggestions for Progressing Research," Studies in Conflict \& Terrorism 40, no. 1 (2017): 77-98.

74 Margaret Seymour, "The Problem With Soft Power," Foreign Policy Research Institute, September 14, 2020, www. fpri.org/article/2020/09/the-problem-with-soft-power/.

75 White House, National Security Strategy (Washington, DC: White House, 2006), 9-10.

76 Richard Stengel, Information Wars: How We Lost the Global Battle Against Disinformation \& What We Can Do About It (New York: Grove Press, 2019), 60-61.

77 Brian Knowlton, "Digital War Takes Shape on Websites Over ISIS," New York Times, September 26, 2014, www. nytimes.com/2014/09/27/world/middleeast/us-vividly-rebuts-isis-propaganda-on-arab-social-media.html.

78 "Global Engagement Center," U.S. Department of State, accessed December 8, 2020, https://2009-2017.state.gov/r/ gec/index.htm.

79 “Global Engagement Center: Core Mission \& Mission,” U.S. Department of State, accessed December 8, 2020, www. state.gov/bureaus-offices/under-secretary-for-public-diplomacy-and-public-affairs/global-engagement-center/.

80 Haroro J. Ingram, Persuade or Perish: Addressing Gaps in the U.S. Posture to Confront Propaganda and Disinformation Threats (Washington, DC: The George Washington University Program on Extremism, 2020), 9.

81 White House, National Security Strategy (Washington, DC: White House, 2017), 34-35.

82 Department of Defense, Summary of the 2018 National Defense Strategy of the United States of America (Washington, DC: U.S. Department of Defense, 2018), 6.

83 White House, National Strategy for Counterterrorism (Washington, DC: White House, 2018), 21-22.

84 Barbara Ortutay, "AP Explains: The Rule That Made the Modern Internet," Associated Press, October 28, 2020, https://apnews.com/article/what-is-section-230-tech-giants-77bce70089964c1e6fc87228ccdb0618.

85 Department of Justice, Section 230-Nurturing Innovation or Fostering Unaccountability? Key Takeaways and Recommendations (Washington, DC: U.S. Department of Justice, 2020), 1.

86 Ibid., 3. 
87 “JointLetterto NewExecutiveDirector, GlobalInternetFormto CounterTerrorism,'HumanRights Watch,July30, 2020, www.hrw.org/news/2020/07/30/joint-letter-new-executive-director-global-internet-forum-counter-terrorism.

88 “An Update on Combating Hate and Dangerous Organization,” Facebook, May 12, 2020, https://about.fb.com/ news/2020/05/combating-hate-and-dangerous-organizations/.

89 Erin Saltman, "Countering Terrorism and Violent Extremism at Facebook: Technology, Expertise and Partnerships," Observer Research Foundation, August 27, 2020. www.orfonline.org/expert-speak/countering-terrorismand-violent-extremism-at-facebook/\#_edn1.

90 Jessica White, Terrorism and the Mass Media (London: Royal United Services Institute, 2020).

91 Moez Chakchouck, "Foreword" to Jean-Paul Marthoz, Terrorism and the Media: A Handbook for Journalists (New York: United Nations, 2017).

92 Haroro J. Ingram, A Brief History of Propaganda During Conflict: Lessons for Counter-Terrorism Strategic Communications (The Hague: International Centre for Counter-Terrorism, 2016), 32.

93 Alberto M. Fernandez, "Measuring the Unmeasurable: Evaluating the Effectiveness of US Strategic Counterterrorism Communications," in The Sage Handbook of Propaganda, ed. Paul Baines et al. (London: Sage, 2020). 


\section{1}

\section{THEATER SPECIAL OPERATIONS COMMAND}

\section{The operational employment of U.S. Special Operations Forces}

\section{Charles T. Cleveland and Liam Collins}

The U.S. Department of Defense divides the world into six geographical areas, with geographic combatant commanders (GCCs) responsible for nearly all missions within their assigned geographical area of responsibility. ${ }^{1}$ Central Command's area of responsibility includes 20 countries in the Middle East, Central and South Asia, and surrounding waterways; Africa Command includes all 54 African countries, with the exception of Egypt, and surrounding waterways; European Command includes Europe, Russia, and surrounding waterways; Northern Command includes the United States, Canada, Mexico, and surrounding waterways; Indo-Pacific Command includes 36 states in Asia and the Pacific Ocean and much of the Indian and Pacific Oceans; and Southern Command includes 31 countries in Latin and South America and surrounding waterways.

Subordinate to each GCC is a service component command for each service, including special operations. For example, Central Command includes U.S. Army Central, U.S. Naval Forces Central Command, U.S. Air Forces Central, Marine Corps Forces Central Command, and Special Operations Command Central (SOCCENT). These service component commands vary in size and composition but have essentially the same purpose: they execute the service's statutory requirements to provide administration and logistics to all service forces in the geographic combatant command. They may also conduct operations with forces that they receive when directed by the combatant commander. $^{2}$

In peacetime, these subordinate service headquarters are primarily administrative headquarters that command and control forces on exercise or conducting joint training events. They can, however, be augmented and tasked to serve as joint (multi-service) or combined (multinational) warfighting commands when directed by the combatant commander. ${ }^{3}$ Army Central, for example, became the Combined/Joint Land Component Command headquarters for the 2003 invasion of Iraq.

The Theater Special Operations Command (TSOC) performs a similar function for all service Special Operations Forces (SOF), with the exception of those assigned to the Joint Special Operations Command. Today's TSOCs have become an indispensable capability for a wide variety of missions ranging from combat operations against emerging threats to supporting humanitarian assistance missions. This chapter examines the history of the TSOCs and then provides two campaign vignettes to illustrate how they plan and execute operations in support of the GCC. 


\section{Establishing the TSOCs}

The TSOC is a critical component in the country's special operations arsenal. It is, however, a command construct that has had to fight for its existence from the start. The government is notorious for resisting new constructs, and this was especially true for the TSOCs.

Regionally oriented and largely independent from conventional forces, special operations have been a part of the American way of war since the revolution. Francis Marion, the "Swamp Fox," and his guerrilla campaign against the British in South Carolina is an early example. ${ }^{4}$ General Philip Sheridan's campaign against infrastructure in the Shenandoah Valley and the Army's experience in the Indian wars in the American West in the last half of the 19th century are others. In World War II, the Office of Strategic Services' work with the French resistance in Europe or its campaign in Burma are further examples. It can be argued that command and control of these efforts were the predecessors of today's TSOCs.

It was fighting against the Soviet and Chinese communist-supported insurgencies of the Cold War, however, where the United States saw the limits of conventional forces. The communists sought to weaken and discredit the ideals of free societies and the democratic system of government and to convince vulnerable populations that it was worth fighting for a communist way of governing. It was in the face of this persistent threat, often taking place below the threshold of conventional war, that the need to orchestrate special operations and irregular warfare activities became critical.

President John F. Kennedy recognized this new type of war in his Inaugural Address in 1961, and the Army became the leader for counterinsurgency within the U.S. Defense Department. ${ }^{5}$ It created the Institute for Military Assistance to promote learning on this new way of war. The Army created other organizations to fight the insurgent threat, and it expanded Special Forces, civil affairs, and psychological operations capabilities. ${ }^{6}$

The most radical and arguably best example of enlightened thinking was the U.S. Army Special Action Forces. The Special Action Forces was a brigade-sized element that consisted of regionally oriented Special Forces, military police, engineer, psychological operations, civil affairs, and medical units, primarily focused on counterinsurgency. The 8th Special Action Forces operated from Ft. Gulick, Panama, from 1963-1972. ${ }^{7}$ Coming out of Vietnam, the U.S. Army's priority shifted to conventional warfighting to counter the Soviet threat in Europe, and the Army largely purged counterinsurgency doctrine and training until Operations Enduring Freedom and Iraqi Freedom, more than a quarter century later. ${ }^{8}$

While conventional forces committed themselves to the plains of Europe and the Korean Peninsula, the need for regionally attuned forces and headquarters reemerged in the 1980s with the return to fighting communist insurgencies in Latin America. At the same time, troubled missions in the early 1980s spurred Congress to enact the largest reorganization of the Department of Defense since the National Security Act of 1947. As part of this reform, Congress directed the establishment of special operations headquarters to better prepare for and conduct the nation's special operations missions and irregular warfare campaigns.

The first troubled mission occurred on April 24, 1980. After six months of planning and preparation, the United States initiated Operation Eagle Claw, a raid to rescue the 53 American hostages who had been held in the U.S. Embassy in Tehran following the 1979 Iranian Revolution. The mission, however, was aborted at Desert One, a rendezvous in the Iranian desert roughly 650 kilometers southeast of Tehran, due to an insufficient number of helicopters required to continue the mission.

As the force departed, a helicopter collided with one of the C-130 aircraft carrying fuel, igniting an explosion that destroyed both aircraft and killed eight military personnel. ${ }^{9}$ The underlying problem that contributed to the failure was an inability of the services to work together. ${ }^{10}$ The Holloway Commission analyzed 23 issues and considered 11 of them major, including "command and control" and "overall coordination of joint training." 11 
Attempts at structural reform started shortly thereafter with the Ronald Reagan administration. Noel Koch, deputy assistant secretary of defense for international security affairs, made growing special operations capability a priority. The first step, in 1980, was creating the Joint Special Operations Command to "specifically focus on counterterrorist operations." 12 Koch later established a Special Operations Policy Advisory Group that included retired Admiral James Holloway. He also convinced Deputy Secretary of Defense Paul Thayer to sign a policy directive on October 3, 1983, which stated that "U.S. national security required the maintenance of special operations forces" and directed the services to complete several steps. ${ }^{13}$

An immediate effect of the "Thayer memorandum" was the establishment of the Joint Special Operations Agency within the Joint Staff. The Joint Staff and the services largely opposed the directive, and as a result, the agency was weak and generally ineffective. ${ }^{14}$

The Joint Special Operations Agency directed the GCCs to establish a TSOC within their operations directorates from their existing manpower authorizations. The creation of overhead in the form of a headquarters is usually contentious. In this case, it was doubly so. Pushback came from within the GCC staff, a fractious special operations community, and from the services themselves. Each GCC operations directorate, with the exception of European Command, lost 23 authorizations, 18 officers and five enlisted, to create the TSOC. European Command simply rebranded its existing Special Operations Task ForceEurope as its new Special Operations Command Europe. The Joint Special Operations Agency directive was not welcomed.

Furthermore, the U.S. Army had significant factions within its senior ranks who did not support the creation of a new special operations headquarters. Even though the new TSOCs were to address missions viewed as low priorities, the Army viewed any shift of mission to another organization as a budget threat and an unnecessary diversion of assets.

Only weeks after Thayer signed the policy directive, the United States invaded Grenada during Operation Urgent Fury. Fearing for the safety of the roughly 1,000 Americans in Grenada-many of whom were students at the island's medical school-President Reagan ordered several thousand troops to invade and secure their safety. ${ }^{15}$ The operation was deemed a success, but at the same time demonstrated the structural dysfunctions within the military.

The most glaring shortcoming was a "nearly crippling" lack of communications between the services. This problem became well known after an officer used a pay phone to call his headquarters in the United States in an attempt to get fire support from a naval ship that he could not communicate with but could see visually. In other cases, bureaucratic procedures presented obstacles. On the first day of the invasion, "a Navy commander disregarded orders that would have prevented him from refueling Army helicopters that were evacuating wounded soldiers 'because funding arrangements had not been worked out in Washington.", 16 A Senate study concluded that "URGENT FURY demonstrated that there are major deficiencies in the ability of the services to work jointly when deployed rapidly." 17

The terrorist bombings of the Marine Barracks in Lebanon the same month highlighted issues with the authorities and responsibilities of the combatant commanders. U.S. European Command had limited authority to direct service components within its area of responsibility. General William Smith, the European Command deputy, remarked,

I really felt the Marines didn't work directly for me. On paper, they were under our command, but in reality, they worked for the commander in chief, U.S. Naval Forces Europe, our naval component. They had their own operational and administrative command lines. . . We could advise, of course, but no more. ${ }^{18}$

These missions highlighted the weaknesses of the GCCs and the inability of the military to work jointly and provide effective military advice to its elected officials. 
As a result, Congress passed the Goldwater-Nichols Department of Defense Reorganization Act, signed into law by President Reagan on October 1, 1986. The law contained a number of objectives. For special operations, the law, as modified by the Nunn-Cohen Amendment, directed that segregated service special operations capacities - such as service funding for training and special operations peculiar equipment - be consolidated and created U.S. Special Operations Command (SOCOM) ${ }^{19}$ SOCOM was created from the U.S. Readiness Command, with General Jim Lindsay, an early member of the 10th Special Forces Group, as its first commander. ${ }^{20}$

SOCOM's purpose was to ensure investment in needed special operations capabilities, and this logically led to support for a similar component command for this newly assembled service-like, special operations capability. In fact, it was SOCOM's immediate and unpopular predecessor, the Joint Special Operations Agency, that had directed each of the GCCs to stand-up the TSOCs.

One of the main fallouts of this sequence of events was that the TSOCs were not originally included in SOCOM's constellation of assets, denying them a four-star special operations patron and its funding stream, leaving them organizationally orphaned. It would take nearly 30 years for the situation to change. ${ }^{21}$

The GCC received funds from the services, and as a subordinate command within the GCC, the TSOCs were required to do the same. Since SOCOM did not own the TSOCs, it could not provide funding as it did for other SOF units; that responsibility fell to the services. Thus, the level of service support depended largely on the personalities involved and the GCC support to their TSOC. SOCOM was not compelled to support the TSOC until 2014, when the secretary of defense assigned SOCOM combatant command of each TSOC. ${ }^{22}$ This meant that SOCOM finally had the responsibility to "organize, train, and equip TSOCs as it previously had for all assigned SOF units." 23

Also unique is the role that the TSOC commander plays as either an advisor to the GCC for special operations matters or as a sub-unified commander. Few special operations officers serve on GCC staffs, leaving these staffs deficient in planning and employing special operations capabilities. They have to rely on the TSOC to ensure these highly trained, strategic assets are appropriately employed.

The TSOCs share many characteristics with their service counterparts, but they also have several unique roles that reflect the fact that they are a joint headquarters, manned by special operations and support officers and enlisted personnel from all services. In simple terms, the TSOC has administrative control, or responsibility, for personnel actions, such as accountability, efficiency reports, good order and discipline issues, and SOF common requirements. ${ }^{24}$

While the SOCOM commander may "exercise command of selected special operations missions if directed to do so by the president or the secretary of defense," special operations are generally "conducted under the command of the [GCC]." ${ }^{25}$ Thus, whether special operations fall under the command of SOCOM or the GCC, the TSOC plays a critical role in the employment of nearly all SOF employed worldwide, either directly or through a subordinate task force.

Exercising operational control for special operations gives the TSOC a uniquely powerful and influential role. SOF capabilities range from the ability to conduct strike operations on short notice to special warfare operations, such as developing indigenous force options for local and regional challenges over the long term when large-scale U.S. military options are not feasible or desirable. The two parts of American SOF are not mutually exclusive capabilities; however, they do require very different formations and skill sets, and each has its own risks and payoffs. ${ }^{26}$

For each GCC, their TSOC develops campaigns (for example, plans that sequence operations of varying types such as raids, lethal strikes, partnered operations, capacity building, intelligence, psychological operations, or civil affairs missions) over time and in space to achieve GCC objectives. The TSOC is the primary author of SOF campaigns in the GCC's area of responsibility. ${ }^{27}$

To propose pertinent and supportable campaigns, the TSOC staff must study documents from the White House, National Security Council, Department of Defense, and Joint Staff, as well as those of the GCC and U.S. Embassy country plans. It views each through a "special operations lens," determining 
opportunities and requirements for which special operations are suited, and then seeks support for the development of a SOF campaign. It is important to note that no other command or staff element in the GCC is capable of this analysis. Furthermore, as of yet, there is no doctrine that prescribes what constitutes a SOF campaign, let alone one that exists below the threshold of traditional war.

Each campaign is different, often requiring nuance and understanding that uniquely resides within the TSOC. After a normally intense interaction with the GCC and SOCOM staffs to gain support for the proposed campaign, the TSOC commander seeks the GCC's approval. With GCC approval comes the authorities required or the support necessary to gain those authorities and resources from SOCOM and the Joint Staff to execute the plan.

The nature of each campaign varies based on the policy objectives: for example, counterdrug, counterinsurgency, counterterrorism, civil affairs, foreign internal defense, or, as is often the case, a combination of multiple activities. In all cases, the TSOC must maintain a campaign perspective while maintaining a crisis response capability to react to emergencies of all kinds-from earthquake relief, to noncombatant evacuations, to hostage rescue and recovery. ${ }^{28}$

SOF campaign development has the benefit of providing purpose, intent, and direction to subordinate elements, other components, Joint Task Forces, and embassy country teams. The process of developing SOF campaigns allows for detailed discussions with interagency partners in the affected region and countries, and it often requires coordination with Department of State Regional Bureaus, the Central Intelligence Agency, the U.S. Agency for International Development, and other players as required.

The Drug Enforcement Administration, for example, is a significant partner in U.S. Special Operations Command South's (SOCSOUTH) operations in the Andean Ridge of South America. A SOF campaign plan identifies needed forces, authorities, and support requirements. ${ }^{29}$ Once approved, it serves as a common point of departure for the various agencies impacted or supporting the campaign.

Last, SOF campaign doctrine and theory remains a developing and still controversial field. Work is underway at the U.S. Army Special Operations Command and at the John F. Kennedy Special Warfare Center and School at Fort Bragg, North Carolina. As the United States comes out of two of its longest wars in Afghanistan and Iraq, with special operations having played a significant role in each, these two commands have recognized the need to ensure they remain the subject matter experts in the application of special operations.

\section{TSOC campaign vignettes}

The following vignettes are prime examples of SOF campaigns, highlighting their multifaceted and strategic nature. Both were set in uncertain geopolitical situations and designed to provide options to policymakers should military operations become necessary. The TSOC's role was to develop, secure approval, resource, and ultimately execute long-term special warfare campaigns, such as foreign internal defense or unconventional warfare. These campaigns had, at their core, building and maintaining relationships with partner nations and indigenous groups to ensure their ability to secure or help secure objectives in the region.

In some cases, the relationship building was not necessarily directed at a specific objective but to set conditions for policy options using U.S. supported indigenous military or paramilitary operations. It is work that by necessity is long term, uncertain, and often without immediate payback.

\section{Operation Willing Spirit and the recovery of three American hostages (2003-2008)}

During a routine counternarcotics mission on February 13, 2003, Tommy Janis was at the controls of a single-engine Cessna Grand Caravan. Janis worked for Northrop Grumman on a contract to fly aerial 
surveillance missions for U.S. Southern Command (SOUTHCOM) in support of Plan Colombia. Three other Northrop Grumman contractors-Tom Howes, Marc Gonsalves, and Keith Stansell- joined Janis on the mission, as well as an intelligence sergeant from the Colombian Army, Sergeant Luis Alcides Cruz. ${ }^{30}$

When the plane's lone engine failed at 17,000 feet, Janis' only option was an emergency landing in the dense mountainous jungle. Surprisingly, he was able to crash-land the Cessna on a "postage-stamp-sized" clearing in the jungle, with all five escaping without major injury. Unfortunately, they landed in a Revolutionary Armed Forces of Colombia (FARC) stronghold, and shortly after landing, 50-60 heavily armed FARC soldiers captured them. For whatever reason, the FARC rebels separated Janis and Cruz from the rest of the crew and killed them "execution-style" near the wreckage. ${ }^{31}$

Working with Ambassador Anne Patterson, Brigadier General Remo Butler, the SOCSOUTH commander, made their recovery his top priority. The difficulty of the terrain and lack of immediately available resources made an immediate recovery effort impossible. Stansell had been in constant communication with Ed Trinidad, a member of the Tactical Analysis Team at the U.S. Embassy, during the four-minute descent. He relayed his position throughout the descent, but the FARC seized the crew before a rescue mission could be launched to the remote location. ${ }^{32}$

As the opportunity faded, so did the support for SOCSOUTH to maintain a forward presence dedicated to their recovery. It would take more than two years before the U.S. Embassy would have another opportunity to locate the hostages and consider a rescue attempt. As is often the case, fortune played a role.

In July 2005, a mobile training team of seasoned SOCSOUTH staff officers was training their counterparts in the Colombian Special Operations Command on contingency operations planning when the U.S. Embassy Intelligence Fusion Center determined that a key piece of intelligence could be exploited to possibly determine the precise location of the American hostages.

While intelligence operations ramped up, the SOCSOUTH planners realized that they lacked the necessary operational capability to act on any time-sensitive intelligence to conduct a rescue attempt. The SOCSOUTH commander presented his assessment to U.S. Ambassador Bill Wood and SOUTHCOM Commander General Bantz Craddock, and he recommended that SOCSOUTH be tasked with working with their Colombian counterparts to create a campaign to develop options for a military rescue. ${ }^{33}$

As a result, SOCSOUTH established SOC-Forward Colombia, a small headquarters with a staff of 8 to 10 SOF staff officers under the command of either a U.S. Army Special Forces colonel or U.S. Navy SEAL captain. The team worked as a supported command within the embassy, taking orders from the Florida-based SOCSOUTH commander but under instructions to comply with all guidance from the ambassador. The SOCSOUTH commander periodically deployed to Colombia to oversee capacity building and planning and to take charge of the SOC-forward when intelligence presented potential rescue opportunities. ${ }^{34}$

Working with the Colombian Special Operations Command, the SOC-forward began what would become a three-year campaign to build joint capacity, plans, and, most importantly, mutual trust and confidence. The campaign, named Operation Willing Spirit, eventually developed Colombian Army, U.S.Colombian, and unilateral U.S. rescue plans. The August 2005 intelligence lead did not pan out, but the changes in U.S. and Colombian collaboration that resulted from it had lasting effects and ultimately contributed to the successful recovery of the hostages years later.

The next potential rescue opportunity occurred in the summer of 2006. Colombian Army intelligence identified the tentative location for the transfer of the hostages as they were to be moved from one FARC regional command to another. The U.S. and Colombia quickly mounted a partnered operation to interdict the FARC column, with the intent to recover the hostages.

The U.S. secretary of defense authorized six U.S. Special Forces soldiers from the 7th Special Forces Group and U.S. helicopters from the 3rd Battalion, 160th Special Operations Aviation Regiment, to join the Colombian rescue. While this partnered force successfully infiltrated undetected and observed a FARC security detachment, they did not get "eyes-on" the hostages. It was later learned that the force 
was 24 hours too late, and the FARC force they observed was likely the rear security for the column main body that escorted the hostages. ${ }^{35}$

In 2008, the combined efforts finally paid off with one of the most masterful deception operations in special operations history. In January 2008, Colombian and U.S. intelligence determined that the hostages were once again on the move. The FARC planned to move the hostages by boat and over ground through an area about the size of Maryland. The Colombian Army knew that terrain, and the FARC would be vulnerable because of poor support infrastructure.

Over the next two months, the Colombian Special Operations Command and SOC-forward deployed 15 reconnaissance teams: 10 Colombian special operations teams and 5 U.S.-Colombian partnered teams. In total, 32 special operators from the United States 19th and 7th Special Forces Groups and SEAL Team Four infiltrated on U.S. special operations helicopters in the attempt to locate the hostages. ${ }^{36}$ Other U.S. national military rescue capabilities also deployed in a supporting role to SOCSOUTH, with the understanding that if conditions were to allow for a rescue, roles would reverse. The TSOC owned the relationship, and until the mission became a unilateral U.S. rescue, the Colombian government would remain in charge.

More than 1,000 U.S. service members deployed to Colombia from January through March 2008. At this time, the U.S. government and the hostages' families received the first positive proof of life since their captivity began five years earlier. A Colombian reconnaissance team observing a FARC site on the Apoporas River reported "eyes-on" the Americans when they were led to the river to bathe. Unfortunately, as was routine, the FARC moved positions before a rescue operation could be mounted safely. ${ }^{37}$

To block the FARC hostage movement into the heavy jungle area, which served as the group's sanctuary, the Colombians mounted a raid and occupied a critical choke point at the urging of their U.S. counterparts. The action worked, forcing the FARC to return with the hostages to the more vulnerable location that had prompted their move in the first place. While an immediate rescue opportunity slipped away, U.S. confidence in Colombian leadership was never higher. Remarkably, the mission was not compromised; the raid operation had been launched under the guise of a joint training exercise as opposed to a hostage rescue mission.

The campaign expanded to include the Colombian conventional army to put additional pressure on the FARC element. Over the next three months, an elaborate deception operation took shape. Operation Jaque (Checkmate) involved Colombian intelligence and special operations, through a series of intelligence deceptions, hustling the FARC into passing 15 hostages-including the 3 Americans - to a group of Colombian special operators posing as members of a non-governmental aid organization. The ruse was to have the fake non-governmental organization transport the hostages via helicopter to the area where the FARC had wanted to move the hostages earlier in the year.

With a strong recommendation of support from the ambassador and the SOCSOUTH commander, SOUTHCOM Commander Admiral Jim Stavridis sanctioned Operation Jaque and obtained approval from the highest level of the U.S. government to conduct the operation. Stavridis believed the plan would require operational and organizational precision, as well as finesse, given the uncertainty of the hostages' location in the dense jungle. ${ }^{38}$ To support the operation, SOCSOUTH deployed its Special Forces Contingency Response Force from the 7 th Special Forces Group as a quick reaction capability. ${ }^{39}$

On July 2, 2008, the FARC fell for the ruse, which had been initiated by a mole who had been planted within the group a year earlier. The FARC believed the mole was leading them to another FARC camp, but instead he led them into a trap. The ruse included Colombian troops disguised as aid workers, fellow guerrillas, and a cameraman and journalist from a fictitious pan-Latin American television station.

The FARC captors, along with their 15 hostages, boarded an Mi-17 helicopter for what they believed would be a short flight to rebel leader Alfonso Cano's camp. Instead, once the helicopter was airborne, the Colombian forces subdued the FARC rebels. ${ }^{40}$ The hostages were recovered without a single shot being fired. The three American hostages were finally free after 1,967 days in captivity. The rescued Americans 
served as guests of honor at the SOCSOUTH change of command in Homestead Air Force Base in south Florida less than one month later. ${ }^{41}$

The operation was a remarkable success, often compared to the U.S. raid in Pakistan that killed Usama bin Ladin in 2011. Yet this operation was significantly different. The Abbottabad raid was a unilateral raid by U.S. SOF. By contrast, Operation Jaque was largely a Colombian operation that was only possible because of the multi-decade investment by the United States to build Colombian capacity. ${ }^{42}$

U.S. Army Special Forces Major Russ Ames best summarized the success of this decades-long commitment when he remarked,

The highest praise for a [foreign internal defense] effort is when the host nation achieves a level of capability, that, when combined with their local knowledge and language, makes them more effective than [the United States] could ever hope to be. . . This is the holy grail of Special Forces work. ${ }^{43}$

\section{Lebanon (2008-present)}

There are few better examples of the long-term positive effects and the methodical development of options for policymakers and senior military leaders than SOCCENT's campaign to support the Lebanese Armed Forces. In 1976, Syrian troops entered Lebanon as part of an Arab peacekeeping force shortly after the Lebanese civil war broke out, but they soon transitioned from peacekeeper to occupier. They ultimately remained in Syria for 29 years, finally pulling out in $2005 .{ }^{44}$

Following Syria's withdrawal, the United States increased its assistance to Lebanon, providing $\$ 86$ million in fiscal year 2006, $\$ 843$ million in 2007 , and $\$ 73$ million in $2008 .{ }^{45}$ The large influx in 2007 was a result of the 2006 Lebanon War between Israel and Hezbollah, largely fought on Syrian soil. The war had highlighted the need for additional economic and military aid. ${ }^{46}$

In terms of military support, the United States had a near-continuous training program with Lebanese SOF and elite infantry units since the Syrian withdrawal. These units included the Lebanese Ranger Regiment, the 101st Airmobile Brigade, the Maritime Commando Regiment, and the Lebanese Commando Unit. By 2008, the training was routine, and the United States had developed strong relationships with the Lebanese Armed Forces at the tactical level. ${ }^{47}$

Yet the seizure of large swaths of western Beirut by Hezbollah fighters in May 2008 showed that much work was still needed for the Lebanese Armed Forces. ${ }^{48}$ As a result, SOCCENT reorganized its programs in Lebanon to accomplish three goals. The first was to posture U.S. forces in the region to contest the primacy of Lebanese Hezbollah, which served as an Iranian proxy group.

The second was to professionalize Lebanese SOF so they could conduct raids and, at the request of the U.S. ambassador, assist Lebanese SOF in the training of Lebanese Armed Forces conventional units, particularly the Intervention Brigades stationed south of the Letani River in southern Lebanon. It was important to show progress on United Nations Security Council Resolution 1701, which called for the cessation of all hostilities following the 2006 Lebanon War. It required Israel to withdraw from Lebanon, the disarmament of all armed groups (implying Hezbollah), and no armed foreign forces in Lebanon without the consent of the government. ${ }^{49}$

Yet Hezbollah had failed to disarm and still posed a significant threat to the government. Hezbollah, in effect, controlled parts of Lebanon..$^{50}$ It was important to build the Lebanese Armed Forces' capacity to replace Hezbollah as the guarantors of Lebanese security against external threats.

The third goal was to develop an enduring partner-building relationship with the Lebanese Armed Forces so that they could quickly conduct combined or joint operations against a growing terrorist threat emanating from Syria or the Bashar al-Assad regime. The United States sought to build Lebanese capacity to prevent another foreign invasion. 
Patterning from SOCSOUTH's success earlier in the year in Colombia, SOCCENT obtained approval to place two staff officers at the U.S. Embassy to develop and execute a SOF campaign on behalf of the ambassador and the CENTCOM commander. Although this new element initially authorized only two persons, it was designated a SOC-forward and was composed of a commander (a special operations colonel) and an operations officer from the SOCCENT staff. While small in number, they could task dedicated elements operating in direct support of their mission back at SOCCENT headquarters in Tampa, so its capability far exceeded the two officers in Beirut. Creating the small headquarters element (SOC-forward) greatly increased SOCCENT's ability to increase partner capability and provide options for the United States in future crises. It expanded engagement and influence up to the chief of defense level by providing the embassy a third senior officer in Beirut, supplementing the defense attaché and the security assistance officer. As a special operations officer, he provided expertise that the embassy lacked. He quickly integrated as a valued member to the permanently assigned military team at the embassy, especially when the tour of duty was extended to one year. ${ }^{51}$

This became important when the pro-Syrian Hezbollah-supported March 8 Alliance replaced the generally pro-U.S. March 14 Alliance government in June 2011. ${ }^{52}$ Calls in the U.S. Congress and even initial guidance from the Defense Department suggested terminating training with the Lebanese Armed Forces. ${ }^{53}$ Advising the ambassador to reject this position, the SOC-forward recommended that the United States retain these relationships. Withdrawing support would only concede influence to Hezbollah; by staying, the United States could still exert influence.

SOCCENT was also concerned that the Iranian Quds Force, a branch of Iran's Islamic Revolutionary Guards Corps that specializes in unconventional warfare and intelligence operations, ${ }^{54}$ would replace the U.S. training teams. To her credit, the ambassador took the recommendation and successfully fought off attempts to end the SOF mission.

The continued investment has paid dividends over the years. One such example was Lebanon's fight against the Islamic State. In 2017, an estimated 600 Islamic State fighters controlled roughly 120 square kilometers of Lebanese territory. On August 19, the Lebanese Armed Forces launched Operation Fajr al-Jur (Dawn of the Outskirts) to reclaim the territory. The operation was a resounding success and was regarded as "its most proficient [counterterrorism] operation since the end of the 1975-1990 civil war." 55

In less than two weeks, they had defeated the Islamic State fighters, expelling the defeated militants and their families from the country. It is doubtful they would have been so successful without the long-term TSOC campaign to build a capable Lebanese Armed Forces.

\section{Conclusion}

Today's TSOCs have come a long way since they were forced on the combatant commands in 1983. By 1986, for example, SOCSOUTH was down to only Seven of its authorized 23 personnel. But with the growth and expanding employment of SOF, by 2009, SOCCENT totaled more than 900 soldiers, sailors, airmen, marines, and civilians from the active and reserve components in either an assigned, attached, or temporary duty status - far beyond the 23 originally directed by the Joint Special Operations Agency back in $1983 .{ }^{56}$ The growth of the TSOC, however, should not be surprising given the explosive growth of SOF after $9 / 11$, from $\$ 3.7$ billion in $2001^{57}$ to $\$ 13.7$ billion in $2020 .^{58}$

Over the past several decades, SOF operations have grown not only in scale and scope but also in visibility. Earlier SOF operations, such as the Joint Planning and Assistance Teams in El Salvador or SOF support to the hostage recovery mission in Colombia in 2008, were smaller in scale and scope and less visible. But now SOF takes a much more active and visible role around the globe, from battling the Islamic State in Syria to Operation Enduring Freedom-Philippines in the Pacific. The TSOC remains a critical element in ensuring that SOF is properly employed to support U.S. policy objectives. 
In November 2020, as further evidence of SOF's growing role, Acting Secretary of Defense Christopher Miller ordered the assistant secretary of defense for special operations and low-intensity conflict, special operations' top civilian in the Pentagon, to report directly to him. In essence, this elevated him to the level of the service secretaries. Miller justified the change to "streamline information flow, enhance decisionmaking and more adaptively and adeptly support our commanders and their superb soldiers, sailors, airmen and Marines." ${ }^{59}$ Similar words could have been used 40 years ago to justify the establishment of the TSOCs.

\section{Notes}

1 Joint Chiefs of Staff, Doctrine of the Armed Forces of the United States, JP 1 (Washington, DC: Joint Chiefs of Staff, 2013), xvi.

2 Armed Forces, U.S.C. 10.

3 Joint Chiefs of Staff, Doctrine for the Armed Forces of the United States, JP 1 (Washington, DC: Joint Chiefs of Staff, 2017).

4 See, for example, Amy Crawford, “The Swamp Fox,” Smithsonian Magazine, June 30, 2007, www.smithsonianmag. com/history/the-swamp-fox-157330429/.

5 John F. Kennedy, “Inaugural Address of John F. Kennedy,” January 20, 1961, https://avalon.law.yale.edu/20th_century/kennedy.asp.

6 "U.S. Army Special Operations Center of Excellence," SOC, accessed November 1, 2020, www.soc.mil/SWCS/ about.html.

7 John Friberg, "History of the 8th Special Forces Group," SOFREP, July 9, 2016, https://sofrep.com/ news/8th-special-forces/.

8 Liam Collins, "Military Innovation in War: The Criticality of the Senior Military Leader" (PhD diss., Princeton University, 2014), 122-125, http://arks.princeton.edu/ark:/88435/dsp01br86b3727.

9 Mark Bowden, "The Desert One Debacle," The Atlantic 297, no. 4 (2006): 62-77.

10 James R. Locher III, "Has It Worked?-The Goldwater-Nichols Reorganization Act," Naval War College Review 54, no. 4 (2001): 10.

11 Holloway Commission, Holloway Commission Report (1980), https://nsarchive2.gwu.edu/NSAEBB/NSAEBB63/ doc8.pdf.

12 William Kernan, “The Holloway Report: Did It Reflect All the Facts and Lessons Learned” (essay, U.S. Army War College, 1987), 3, https://apps.dtic.mil/dtic/tr/fulltext/u2/a182845.pdf.

13 Susan L. Marquis, Unconventional Warfare: Rebuilding U.S. Special Operations Forces (Washington, DC: Brookings, 1997), 79-84.

14 Ibid., 84-86.

15 "United States Invades Grenada," History, accessed November 29, 2018, www.history.com/this-day-in-history/ united-states-invades-grenada.

16 John H. Cushman Jr., "Pentagon Study Faults Planning on Grenada," New York Times, July 12, 1986, www.nytimes. com/1986/07/12/world/pentagon-study-faults-planning-on-grenada.html.

17 Kathleen J. McInnis, Goldwater-Nichols at 30: Defense Reform and Issues for Congress, CRS Report R44474 (Washington, DC: Congressional Research Service, 2016), 4.

18 James R. Locher III, Victory on the Potomac: The Goldwater-Nichols Act Unifies the Pentagon (College Station: Texas A\&M University Press, 2002), 158.

19 The Nunn-Cohen Amendment was a rider to the 1978 National Defense Authorization Act that amended the Goldwater-Nichols Act. See Marquis, Unconventional Warfare, 107-147.

20 Ibid., 162-163.

21 The Nunn-Cohen Amendment designated SOF as a new major fund program with its own appropriation executed by SOCOM, but the TSOC was not included. See Marquis, Unconventional Warfare, 144-147.

22 Andrew Feickert, U.S. Special Operations Forces (SOF): Background and Issues for Congress, CRS Report RS21048 (Washington, DC: Congressional Research Service, 2020), 2.

23 Ibid. Note that the services were still required to provide all non-special operations peculiar administrative and logistical support to the TSOC consistent with their requirement for all SOF, but SOCOM could now provide SOF-peculiar material, supplies, and services to the TSOCs that it previously could not. See 10 U.S.C. $\$ 167(\mathrm{f})$ and Department of Defense, Support of the Headquarters of Combatant Commanders and Subordinate Unified Commands, DOD Directive 5100.03 (Washington, DC: Department of Defense, 2017), www.esd.whs.mil/Portals/54/Documents/DD/issuances/dodd/510003p.pdf. 
24 Joint Chiefs of Staff, Doctrine for the Armed Forces of the United States; Joint Chiefs of Staff, Joint Operations, JP 3-0 (Washington, DC: Joint Chiefs of Staff, 2018).

25 Armed Forces, 10 U.S.C. $\$ 167$ Unified combatant command for Special Operations Forces.

26 Department of the Army, Special Operations, ADP 3-05 (Washington, DC: Department of the Army, 2019).

27 Joint Chiefs of Staff, Special Operations.

28 Ibid.

29 Ibid.

30 Marc Gonsalves et al., Out of Captivity: Surviving 1,967 Days in the Colombian Jungle (New York: HarperCollins, 2009), xiii-25; Chris Kraul, "Slain U.S. Pilot May Be Honored," Los Angeles Times, September 24, 2008, www. latimes.com/archives/la-xpm-2008-sep-24-fg-janis24-story.html.

31 Ibid.

32 Gonsalves et al., Out of Captivity, xv.

33 This information is based on the co-author's experience as SOCSOUTH commander from 2005-2008.

34 Ibid.

35 Ibid.

36 Ibid.

37 Ibid.

38 Brian Petit, Going Big by Getting Small: The Application of Operational Art by Special Operations in Phase Zero (Denver: Outskirts Press, 2013), 135.

39 Each of the five active duty Special Forces Groups "keeps a company-sized element on a heightened state of readiness to serve as a direct-action, crisis response force for their specific command region." See Matthew Cox, "Pentagon to Decide if It Still Needs Green Beret Crisis Response Forces," Military.com, March 11, 2020, www.military. com/daily-news/2020/03/11/pentagon-decide-if-it-still-needs-green-beret-crisis-response-forces.html.

40 Tim Padgett, “Colombia’s Stunning Hostage Rescue," Time Magazine, July 2, 2008, http://content.time.com/ time/world/article/0,8599,1819862,00.html.

41 This information is based on the co-author's experience as SOCSOUTH commander from 2005-2008.

42 Petit, Going Big, 135.

43 Ibid., 136.

44 “Syrian Troops Leave Lebanon After 29-Year Occupation," New York Times, April 26, 2005, www.nytimes. com/2005/04/26/international/middleeast/syrian-troops-leave-lebanon-after-29year-occupation.html.

45 Casey L. Addis, Lebanon: Background and U.S. Relations, CRS Report R40054 (Washington, DC: Congressional Research Service, 2011), 4.

46 Ibid., 12.

47 This information is based on the co-author's experience as SOCCENT commander from 2008-2011.

48 Robert F. Worth and Nada Bakri, "Hezbollah Seizes Swath of Beirut From U.S.-Backed Lebanon Government," New York Times, May 10, 2008, www.nytimes.com/2008/05/10/world/middleeast/10lebanon.html.

49 Department of Public Information, Security Council Calls for End to Hostilities Between Hizbollah, Israel, Unanimously Adopting Resolution 1701 (New York: United Nations, 2006).

50 Nada Bakri and Hassan Fattah, "Clash Pits Hezbollah Against Rule in Lebanon," New York Times, January 24, 2007, www.nytimes.com/2007/01/24/world/middleeast/24lebanon.html.

51 This information is based on the co-author's experience as SOCCENT commander from 2008-2011.

52 Rebecca A. Hopkins, Lebanon and the Uprising in Syria: Issue for Congress, CRS Report R42339 (Washington, DC: Congressional Research Service, 2012), 1.

53 This information is based on the co-author's experience as SOCCENT commander from 2008-2011.

54 Miriam Berger, "What Is Iran's Revolutionary Guard Corps That Soleimani Helped to Lead?" Washington Post, January 4, 2020, www.washingtonpost.com/world/2020/01/04/what-is-irans-revolutionary-guard-corpsthat-soleimani-helped-lead/.

55 Nicholas Blanford, "The Lebanese Armed Forces and Hezbollah's Competing Summer Offensives Against Sunni Militants," CTC Sentinel 10, no. 8 (2017): 27-32.

56 This information is based on the co-author's experience as SOCCENT commander from 2008-2011.

57 Edward Bruner et al., Special Operations Forces in Operation Enduring Freedom: Background and Issues for Congress, CRS Report RS21048 (Washington, DC: Congressional Research Service, 2001), 3.

58 Feickert, U.S. Special Operations Forces (SOF), 6.

59 Corey Dickstein, “Acting Defense Secretary Orders Top Special Ops Civilian to Report Directly to Him,” Stars and Stripes, November 18, 2020, www.stripes.com/news/us/acting-defense-secretary-orders-top-special-ops-civil ian-to-report-directly-to-him-1.652557. 


\title{
32
}

\section{THEATER COMMAND IN AFGHANISTAN}

\section{Taking charge of "The Other War" in 2003-2005}

\author{
David W. Barno ${ }^{1}$
}

The war in Afghanistan from the period of 2003-2005 is a story of a theater in transition. Fought in the mountains and valleys of the Hindu Kush during those key years, the war was largely waged in the shadows, far away from news headlines. The U.S.-led invasion of Iraq in March 2003 absorbed nearly all of the American public's attention and dramatically shifted Afghanistan to a secondary war, designated as the "economy of force" theater.

The war presented a unique confluence of military, diplomatic, and economic challenges to those of us charged with its leadership. It little resembled the short combat operations of my previous experience in Grenada and Panama, ${ }^{2}$ nor the major conventional wars that I had spent years preparing for in Army schools. Commanding such a complex economy of force theater called upon every bit of my lifelong learning and professional preparation, beginning with my days as a cadet at West Point.

This chapter describes the requirements of theater command under those conditions and reinforces the necessity of adaptable leadership when faced with constrained resources, muddled interagency coordination, and limited guidance from Washington. Most of all, it is an account of adaptation and flexibility of command in war.

\section{Taking command}

In mid-2003, I was commanding one of the Army's largest training bases when I received a surprise phone call from General John Abizaid, the commander of U.S. Central Command. Abizaid discussed the possibility of me taking over command of our military mission in Afghanistan.

Earlier that year, I had assembled and led an ad hoc Army task force in Hungary to train Iraqi exiles for the looming invasion, and the effort had received positive attention in Washington and among senior Army leaders. ${ }^{3}$ Moreover, Abizaid and I had both served as company commanders in the 1st Ranger Battalion during the 1983 U.S. invasion of Grenada and remained good friends. This personal relationship would be crucial to my surprising new mission over the next two years: taking command of the overall U.S. effort in Afghanistan. I would be responsible for establishing a new three-star headquarters to run the war, located close to the hub of diplomatic efforts in Kabul.

Before that point, the military command in Bagram was 65 kilometers away and physically separate from the U.S. diplomatic effort in Kabul. The new headquarters in Kabul would be responsible for integrating the disparate U.S. diplomatic and military efforts, and it would be positioned to work more closely with the U.S. Embassy and the interim Afghan government of President Hamid Karzai. We would continue to 
fight the remnants of Taliban and al-Qaida forces scattered across the country but now through a much more integrated effort.

Soon after our first phone call, Abizaid asked me to visit Afghanistan to view our current efforts. My week-long visit in September 2003 began to reveal the full scope of the challenges that would confront a new commander arriving in Afghanistan. Force levels were small for a country substantially larger than Texas-only about 12,000 U.S. troops, along with about 1,500 coalition partners based in Bagram. ${ }^{4}$

Another 5,000 troops formed the International Security Assistance Force (ISAF) under a separate NATO command that was limited to peacekeeping operations in Kabul. U.S. troops were located on just a few dispersed bases, mostly in the country's volatile south and east.

Battalion-sized U.S. Army task forces sortied out on large-scale raids nearly every month to far-flung parts of the country, often patrolling for a week or more before returning to their bases to plan another mission. Warlords continued to dominate many remote areas of the country, and their private armies were often equipped with better heavy weaponry than the nascent Afghan National Army.

The transitional government in Kabul was less than two years old, and it exerted little influence outside of the capital despite having governors and administrators appointed at the provincial and district levels throughout the country. The United Nations led the international effort to rebuild Afghanistan and restore a functioning long-term government.

The United Nations Assistance Mission in Afghanistan (UNAMA) was the most important international body in the country, based in Kabul and led by the highly respected Algerian diplomat Lakhdar Brahimi. Seasoned ambassadors represented numerous countries in the capital, regularly interacting with the United Nations mission and the transitional government.

The United States maintained a modest diplomatic mission with about 200 personnel, guarded in its fortified embassy compound by a Marine infantry company. The Taliban and al-Qaida stayed largely out of sight; they were still reeling from the effects of U.S. operations in late 2001 and 2002, although they occasionally conducted surprise attacks on Afghan government facilities, especially in the south and east of the country. Both groups continued to find sanctuary in nearby Pakistan, a fact that deeply complicated the U.S.-Pakistan military relationship along the border. Pakistan was a significant portion of the U.S. command's operating area, ${ }^{5}$ which spanned four countries.

During my visit, I made several striking observations. As noted, the U.S. military effort was based at a former Soviet air base at Bagram, which was over an hour by road from the capital. The U.S. diplomatic effort operated out of the embassy in Kabul, led by a chargé d'affairs in the absence of a permanent U.S. ambassador.

The two efforts rarely interacted. I witnessed an exchange at the Kabul airport between the chargé and the senior U.S. commander discussing the upcoming visit of Secretary of Defense Donald Rumsfeld. The commander mentioned that he was going to brief Rumsfeld later that week on the U.S. military situation in Afghanistan, to which the chargé acidly replied, "I'd sure like to know the U.S. military situation in Afghanistan!" Civil-military relations were clearly fraught, which strongly shaped my thinking about the need to develop a unified U.S. interagency campaign.

I also saw various U.S. military efforts throughout the country, including Provincial Reconstruction Teams (PRTs) - a then-novel civil-military approach that posted small detachments of troops with foreign service officers and aid officials in provincial capitals. PRTs were designed to enhance both security and development by partnering international expertise with local Afghan government officials. I discovered that there were multiple "stovepiped" U.S. military chains of command directing the far-flung military units around the country. American PRTs were overseen by one chain of command, infantry units by another, aviation elements by a third, Special Operations Forces by yet another-a confusing arrangement with little apparent coordination or support.

We seemed to be fighting two largely unconnected wars-one aimed at finding and killing the enemy and another focused on security and reconstruction. I began to see the war as a classic counterinsurgency 
conflict and reflected upon some of the principles that succeeding in such a war would demand. Unifying these two efforts into a single endeavor was critical, both within the U.S. military and between the military and civilian components. Clearly, this would require some new partnerships and different thinking from the existing approach.

I was also surprised to learn that maneuver commanders were not assigned to a particular battlespace for more than a few weeks. Most missions were large-scale raids lasting one or two weeks in remote parts of the country, followed by a return to secure bases to plan another mission at a different location. While these tactics were useful as a narrow enemy-centric, counterterrorism approach, they struck me as out of step with the growing insurgency threatening Afghanistan's population and government.

Brief large-scale raids into remote areas seemed an unlikely way to engage the Afghan people or create confidence in the ability of international forces to protect the population. Our current approach seemed to be totally out of sync with what I saw unfolding in the country during my short visit. If I were tapped to take command, I believed that we would need to move in some bold new directions, shifting quickly toward an integrated civil-military counterinsurgency strategy. Only the U.S. military, in my judgment, could be the catalyst for such a holistic approach.

Abizaid called soon after my return and offered me command of the mission, along with some brief, if explicit, guidance: "Your job, Dave, is big Pol and little mil. . . . Get out there as soon as you can." With only a few days of advance warning, my time to prepare for this new job was scant-no more than a few days of briefings and meetings in Washington with key policymakers and experts. My formal transition with the outgoing U.S. commander, with whom I had spent some time during my earlier visit, was almost comically brief. We spoke for less than an hour over coffee at Ramstein Air Base in Germany as I headed into the theater, while he returned to the United States.

Less than four weeks after my short assessment visit, I found myself back in Afghanistan in charge of the U.S. military mission. I had much to learn, and all of it would now be on-the-job training. As I flew into Afghanistan that night, strapped in behind the pilots on the flight deck of a C-17 aircraft, the enormity of taking command of a war zone began to sink in. As we approached Afghan airspace in the dark, the flight crew and I donned body armor and helmets in case we encountered ground fire. Staring through the inky blackness of the night, I found it sobering gazing at the vast territory unfolding below with no visible lights for mile after mile.

Soon, tiny lights appeared in the distance marking the Kandahar airbase, where the only U.S. infantry brigade in the country was based. We landed just after 2 AM on the mostly blacked-out runway, and I was surprised to be met by the brigade commander and his command sergeant major. I knew both men well from my years in the 75th Ranger Regiment and 25th Infantry Division.

The next morning, we discussed the challenges they faced with too few troops and too many missions. This was the first of many times that my personal relationships with past subordinates quickly broke down the barriers of rank and distance, which repeatedly enabled me to receive unfiltered, candid feedback about the situation on the ground.

The next day, I flew to Kabul to join a non-existent headquarters- a challenge that no other U.S. commander in either Afghanistan or Iraq has ever faced. The U.S. military has used two combat theater models of command since 2001. The first is a rotational model, where senior commanders and their staff rotate in and out of theater together. These commanders train up for their new wartime mission with an augmented staff $^{6}$ for several months at home station, which usually includes a rigorous final certification exercise, and then they deploy together. Examples of this model include the XVIII Airborne Corps headquarters assuming theater command in Afghanistan as Combined Joint Task Force 180 (CJTF-180) in 2002 and the III Corps headquarters assuming command of Multi-National Corps-Iraq in early 2004.

The second model involves maintaining a headquarters permanently based in the combat zone, with individual commanders rotating in and out. Staff members also rotate individually, providing substantial headquarters continuity. This model has been used in Afghanistan since $2007^{7}$ and in Iraq from 2004-2011. ${ }^{8}$ 
Neither model applied to Afghanistan in 2003. I deployed to Kabul individually in October 2003 knowing there would be no existing staff. My job was to build one while simultaneously commanding a theater at war. The new headquarters, eventually called Combined Forces Command-Afghanistan (CFCA), officially stood up in February 2004 with approximately 100 staff members. ${ }^{9}$

The original plan envisioned the new headquarters in Kabul drawing entirely upon the existing CJTF$180^{10}$ staff in Bagram for "reachback" support, save a few senior officers sent forward to Kabul. In effect, this meant the CJTF-180 staff would have to work for two different commanders-one located in Kabul and one in Bagram - at the same time. Unsurprisingly, having two commanders direct one staff proved completely impractical, and I had no choice but to adapt to reality.

I began to build an ad hoc staff to address the many requirements of running a theater strategic headquarters in the capital. My headquarters would have much different responsibilities from our subordinate headquarters in Bagram, which I tasked with running the day-to-day operations of the war-from overseeing tactical actions to countrywide logistics.

As the theater headquarters, I wanted CFC-A to focus on the big picture of setting conditions for overall U.S. success in Afghanistan-including everything from teaming with the U.S. Embassy, meeting with Afghan ministers, and maintaining military ties with Pakistan. Our job at CFC-A was to be "up and out," while the CJTF at Bagram would focus on "down and in."

Almost all of the guidance on my role in Afghanistan came from phone conversations with Abizaid, often once or more per week, and his personal visits every few weeks. After about a week in Kabul, I updated him by phone. Sharing my first impressions, I observed that it was already obvious to me that my mission in Kabul could not simply be "big Pol" and "little mil" as he had directed. Instead, I argued that it needed to be "Big Pol, Big Mil, Big Econ, and Big Everything Else," and that I would need a full headquarters with a real staff to accomplish the sizable mission I faced.

Unfortunately, the combination of increasing personnel demands driven by the growing war in Iraq and bureaucratic inertia in Washington meant that it would take over a year for that process to begin in earnest and nearly six more months for CFC-A to reach full strength. ${ }^{11}$ In the meantime, more creative adaptation was the order of the day.

When I arrived, my initial staff of six included an aide I brought from my last command and four more leaders I drafted from the Office of Military Cooperation-Afghanistan, whose mission was developing and training the Afghan army-including a chief of staff, a pol-mil officer, and a communicator. By sheer chance, three of these six had served with me in the battalion I commanded 10 years earlier.

Personal relationships once again proved crucial. Since I had served with these officers for years at the tactical level, I trusted their judgment absolutely. They also knew me well, understood my basic philosophy of command, and could be painfully candid because they trusted me in return. In our earliest days, we held staff meetings in the hallway outside my prefab office. My ability to have total trust and confidence in this small group was a priceless advantage — all while shouldering a commander's responsibility for ongoing combat operations and simultaneously standing up a new theater headquarters.

CJTF-180 in Bagram slowly divested itself from the theater strategic functions it had previously been required to perform as we began to shift those tasks to our new headquarters in Kabul. We pulled several dozen of their staff members into our headquarters as we assumed those functions.

I soon drafted several more officers from the Office of Military Cooperation-Afghanistan, and we slowly began to receive individual augmentees from the United States as well. Many of these individuals were activated members of the Individual Ready Reserve, most of whom had been out of uniform for years.

\section{Building a new counterinsurgency strategy}

Some weeks after arriving in Kabul, I attended a small dinner for senior international diplomats hosted by Lakhdar Brahimi, the special representative of the United Nations secretary general in Kabul and the head 
of UNAMA. I sat at the table with Afghan ministers, a cluster of key foreign ambassadors, the ISAF commander, and several other senior United Nations representatives.

After the meal, Brahimi shared his strong concerns about the lack of security in the country and its impact upon the international reconstruction efforts. Brahimi publicly challenged me to devise a strategy to deal with what he viewed as a growing problem. It was a gauntlet thrown down that I could not ignore, but it was also a welcome catalyst to move ahead quickly with my plans to shift our approach to a broadbased counterinsurgency strategy. I never sought or received explicit permission to change our approach to a counterinsurgency strategy in Afghanistan. I went ahead while keeping Abizaid fully informed and with the understanding that, unless otherwise directed, I would reshape our efforts in this new direction.

I immediately told my small staff to produce what would become our new counterinsurgency strategy. Its "Five Pillar" framework would ultimately guide our integrated civil-military operations for the subsequent years (see Figure 32.1). As a simple diagram, it could be easily communicated to and understood by various audiences-from infantry platoons to visiting diplomats. It also captured in one chart all of the key objectives that we would need to meet to achieve success then and in the near future. It is important to note that the Army effectively lacked counterinsurgency doctrine at the time, as General David Petraeus' counterinsurgency manual was not published until December 2006. ${ }^{12}$

The new strategy was more than just a military approach, and it included plans to integrate all elements of power into a unified effort. We crafted the CFC-A mission statement to be broad enough to provide us the flexibility to accomplish a diverse range of tasks. To get widespread buy-in for this new strategy, we spent many hours briefing it and receiving feedback from as many key actors in Kabul as possible-including colleagues at the U.S. Embassy, ISAF, the Afghan government, UNAMA, and diplomats across the international community. We adjusted the plan and the language to accommodate concerns and rolled out the new strategy as 2004 arrived. ${ }^{14}$ We also developed seven detailed lines of operation to support the "Five Pillar" framework and a thorough operations plan for the coming year.

\section{CFC-A Counter-Insurgency Strategy}

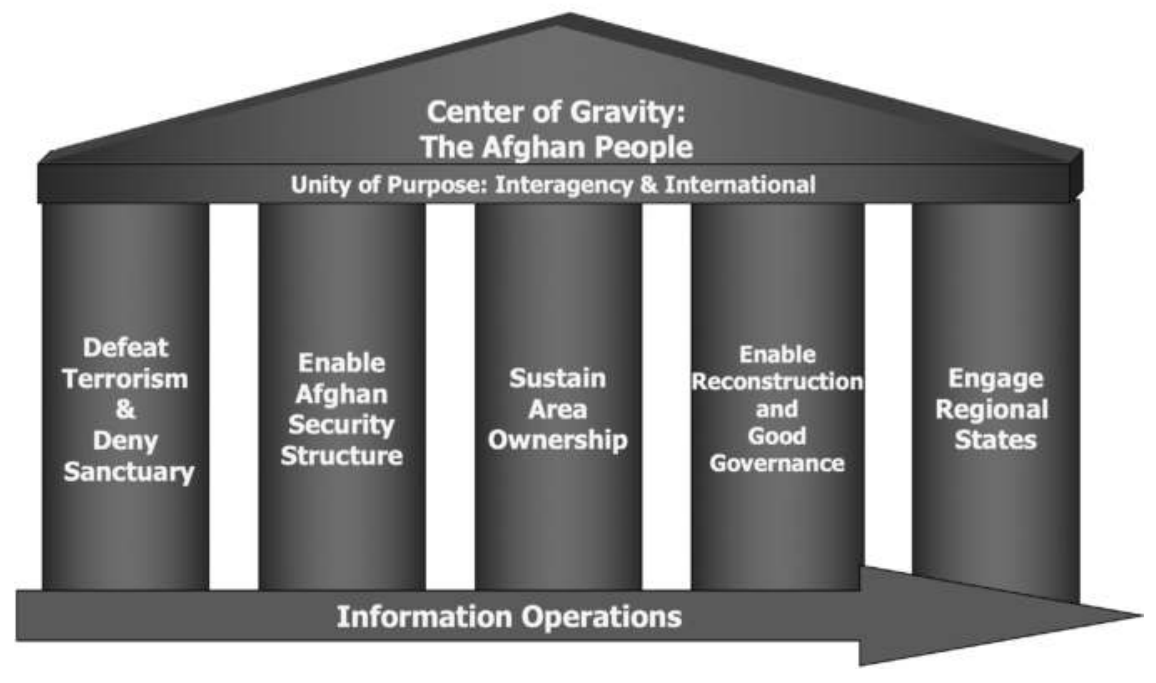

Figure 32.1 Five Pillar framework. ${ }^{13}$

Source: David W. Barno, "Combined Forces Command-Afghanistan” (Policy Forum, briefing to Center for Strategic and International Studies, Washington, DC, May 14, 2004). 
Two central elements of the "Five Pillar" strategy were strikingly new and marked a major departure from previous efforts. First, rather than focusing primarily on killing and capturing the enemy, I shifted our mission axis to a broad-based counterinsurgency approach with the Afghan population as the strategic center of gravity.

I realized that CFC-A would never have sufficient troops to secure the entire country and all of its citizens. Instead, my intent was to use our efforts to help align the population with the government rather than the insurgents and to do so in ways that would maintain Afghan support for the presence of international troops as long as possible.

I viewed Afghan popular support for foreign troops as a finite "bag of capital" to be spent frugally by the coalition. Every airstrike that killed Afghan civilians, or every night raid that kicked down doors of innocent households or unintentionally disrespected Afghan women, quickly spent down that precious capital of good will. We would now seek to operate in ways that would protect our troops ${ }^{15}$ but also respect the Afghan population to the greatest extent possible.

Second, we would quietly take ownership of helping to facilitate and integrate the U.S. interagency and international effort. The U.S. military was by far the largest and best-resourced organization in Afghanistan and could employ a vast range of capabilities. In part because of this fact, I viewed my job as doing everything possible to deliver success for the overall U.S. policy in Afghanistan, not simply narrowly trying to achieve an elusive military win.

I believed that if the U.S. Embassy failed, the United States would fail in Afghanistan-even if U.S. military operations succeeded. I did not see the war primarily as a military conflict but instead as a political conflict where the military effort was one of many lines of action-both for the coalition and for the Taliban. This was classic counterinsurgency theory. It was appropriate because in my judgment, the enemy strategy had shifted to become an insurgency.

Successfully countering such an insurgency would require an integrated effort that might be as much as $80 \%$ civil and only $20 \%$ military in nature. ${ }^{16} \mathrm{I}$ firmly believed that only the U.S. military in Afghanistan, with all its immense capabilities, could help push the disparate efforts toward a much more unified one. We would have to achieve this kind of unity if we had any hopes of defeating a relatively cohesive enemy.

I was complemented in taking on this new approach by the newly arrived U.S. Ambassador to Afghanistan Zalmay Khalilzad. He was born in Afghanistan but moved to the United States as a child and was an experienced defense expert. Khalilzad had close personal ties to the White House and Secretary of Defense Rumsfeld, and he could bypass layers of the bureaucracy through his lifelong personal contacts.

Khalilzad also spoke fluent Pashto and Dari, and he was able to establish rapport with senior Afghan political figures easily. ${ }^{17} \mathrm{He}$ and I shared nearly identical views about the road ahead in Afghanistan and pushed our staffs to cooperate fully. Although I had only met Khalilzad a few times before he arrived in Kabul, we immediately forged a close personal relationship. Even before his arrival, I had moved my personal quarters to the embassy compound to work more closely with the embassy staff. I lived in a spartanly furnished half-shipping container at the site, just yards from his only slightly more luxurious, multi-container "residence."

I made a point of starting my day at the embassy in an office just 10 feet from the ambassador's door, which was my "alternate command post" from my military headquarters and other office about a mile away. I spent the first few hours of every day attending the daily country team meeting and Khalilzad's follow-on small security core group huddle.

Spending most of the rest of the day at the military headquarters ${ }^{18}$ and traveling around the capital, I returned to the embassy in the evening and finished my workday there. This proximity allowed me to interact with the ambassador and his key staff on a regular basis, stay up to date on the ever-changing political and economic developments in the country, and physically demonstrate my commitment to a unified U.S. effort.

In addition, I assigned four very talented members of my bare-bones staff to the ambassador on a full-time basis to serve as his strategic planning team, a concept called the Embassy Interagency Planning 
Group. ${ }^{19}$ Over time, I also provided a small number of officers to augment chronically undermanned embassy sections we deemed necessary to advance our integrated strategy. Collectively, these many small steps enabled the U.S. military and the embassy to coalesce in ways that would previously have been unimaginable. We slowly grew a "One Team" approach, built on this shared physical co-location and our commitment to common goals.

My daily schedule also reflected the unique political-military nature of my command. With fewer than 14,000 U.S. troops in country, many of whom were based at Bagram, I traveled to visit field units only once or twice a week. These traditional battlefield circulation events allowed me to see how well our new policies were being adapted in the field, listen to field commanders and their troops, and make adjustments as necessary.

Early in my tenure, I chose to avoid joining the daily battlefield update briefs that the CJTF-180 commander and staff hosted twice a day from Bagram. These hour-long briefs featured commanders all across Afghanistan calling in via videoconference with reports from their far-flung units in the field. I received these updates in a daily update book, but I was convinced that participating in these discussions on a daily basis would drag me, as the theater commander, too far down to the tactical level.

In my view, those discussions were more appropriate for my subordinate two-star headquarters in Bagram that had direct operational warfighting responsibility. I never regretted this decision. It freed me, as the three-star theater commander, to remain focused at the strategic level-the ever-changing dynamics that affected U.S. national objectives in Afghanistan — rather than being flooded with tactical reports with great detail down to as low as platoon-level actions.

I often accompanied the ambassador to major events outside Kabul such as opening new PRTs and meeting Afghan officials; this not only provided the ambassador with helicopter transport, but it also presented to the Afghans a symbolically unified U.S. civil-military face. These frequent trips allowed me to meet and interact with Afghan governors, warlords, and military leaders in the provinces and take their measure. These wide-ranging visits in my first few months led me to view the conflict in Afghanistan in a new way. Early in 2004, I scribbled down a diagram I called the "Three Wars of Afghanistan" on the back of a piece of paper (see Figure 32.2). It attempted to visualize the environment I saw while traveling widely around the country.

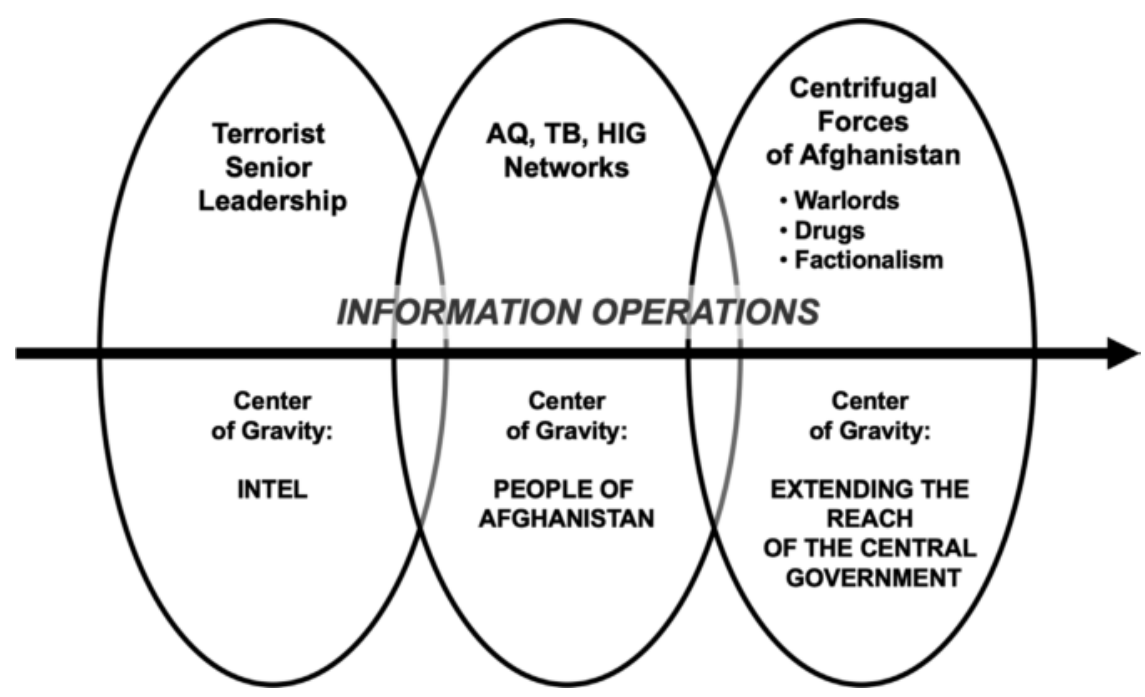

Figure 32.2 The Three Wars of Afghanistan. ${ }^{20}$

Source: Barno, "Combined Forces Command-Afghanistan." 
The first war was against terrorist senior leadership cells, particularly al-Qaida-a counterterrorism fight that relied exclusively on sound and actionable intelligence. Special Operations Forces largely fought this war.

The second was the counterinsurgency war against the networks of the various terrorist and insurgent groups (such as al-Qaida, Hizb-i-Islami Gulbuddin, and the Taliban): their fighters, active supporters, and passive enablers. Coalition and Afghan conventional forces mostly carried out this war. I saw its success rooted in the people of Afghanistan and finding ways to preserve their support for the national government.

The third war encompassed the enduring internal forces of Afghanistan that perpetually threatened to tear the country apart: drugs, crime, warlordism, poverty, and corruption. I believed that success would come from extending the reach and credibility of the central government to the distant corners of the country. In some ways, that would prove the most daunting task.

All of these efforts required effective communications with the Afghan people, which we mounted with information operations designed to highlight successes and explain setbacks and missteps quickly and honestly. ${ }^{21}$ My sketch soon became part of our formal strategy.

I frequently visited Pakistan, regularly engaging with the Pakistani Army chief, other senior commanders, and, at times, the head of the Pakistani intelligence service. I encouraged plans to conduct complementary counterinsurgency operations on both sides of the border and set up border coordination mechanisms to allow commanders on both sides to talk. I constantly pressured the Pakistanis to increase their counterinsurgency efforts in the Federally Administered Tribal Areas, a dangerous hotbed of insurgent activity. ${ }^{22}$

I hosted a quarterly Tripartite Commission that brought together senior military and security leaders from Afghanistan, Pakistan, and the United States - the only venue in which all three countries discussed issues of mutual security concern. These political-military tasks were complex and required diplomatic skills that stretched my capabilities. Nevertheless, they were key components of executing our overall regional policy and keeping pressure on terrorist and insurgent groups. ${ }^{23}$

Spending the majority of his time in Kabul, Ambassador Khalilzad visited President Karzai daily, often returning to the presidential palace at day's end and staying until late in the evening. These intensive interactions yielded priceless information on the relevant political cross-currents in Afghanistan. We learned critical information about how the president, provincial governors, and many ordinary citizens perceived our military operations. ${ }^{24}$

I also met often with numerous foreign diplomats in Kabul, building relationships with the growing number of nations that were supporting the rebuilding of Afghanistan. I leveraged these warm relations to help convince more countries to consider deploying PRTs to complement the surge of new U.S. PRTs I had directed in early $2004 .^{25}$ I began to chair a monthly PRT Executive Steering Committee meeting that brought together the Afghan minister of interior, the UNAMA deputy chief, the ISAF commander, the U.S. deputy chief of mission, and diplomatic representatives from all existing and potential PRTcontributing countries.

These meetings became an unofficial monthly international clearinghouse to share information, discuss a wide range of problems, and coordinate strategy. They served as an invaluable tool to promote shared awareness of the nationwide security and reconstruction situation and address its shortcomings in a collaborative fashion. The fact that they were always hosted by the senior U.S. military commander lent much weight to the discussions, in part because I had the wherewithal to implement our decisions.

Beyond my close bond with the U.S. ambassador, perhaps the most important relationship that I built in Kabul was with the special representative of the United Nations secretary general. UNAMA was unquestionably the most important international actor in the country, overseeing efforts for everything from rebuilding the shattered Afghan countryside, to reforming the security sector, to establishing a framework to conduct nationwide democratic elections. Brahimi served as the special representative of the secretary general until March 2004 when his deputy, a French diplomat named Jean Arnault, replaced him. 
Relations between UNAMA and the U.S. military had been fraught previously, exemplified by both sides heatedly contesting the monthly United Nations report that critiqued declining security across the country. It was clear to me that improving this relationship would be important, as the United Nations undergirded the diplomatic, military, and economic efforts of dozens of U.S. friends and allies supporting our efforts in the country.

Soon after taking office, Arnault invited me to have breakfast at his residence every Monday morning. U.S. diplomatic relations with France were at a low point at the time because of disagreements over Iraq. Our breakfasts, however, became an opportunity to build a personal relationship between two people with very different backgrounds who were leading organizations often at odds with one another.

Over time, Arnault and I shared our differing perceptions about events in the country, discussed upcoming plans for our organizations, and surfaced contentious issues, which we usually resolved. These meetings, week after week, slowly built mutual understanding and trust, and we eventually formed a close friendship.

Our bonds of trust proved instrumental to navigating several crises. In June 2004, when five aid workers from Doctors Without Borders were killed in a remote part of western Afghanistan, they pulled all of their staff from the country. ${ }^{26}$ The United Nations headquarters in New York pushed for the closure of the entire UNAMA mission as well, citing inadequate security. My relationship with Arnault helped to convince him of my view that the murders were an isolated local incident rather than a reflection of a nationwide breakdown in security.

As a result, Arnault convinced his superiors to leave UNAMA in place. If he had not done so, the pullout of UNAMA would have made it difficult if not impossible to hold the presidential election in October, and it would have jeopardized international support for a wide range of Afghan and U.S. programs across the country. This episode brought home once again how important it is for military leaders to build effective personal relationships with people much different from themselves.

\section{Implementing the counterinsurgency strategy}

In 2004, my primary challenge was to fully implement our new counterinsurgency strategy. Our staff grew at a painfully slow rate, while our mission expanded rapidly. With fewer than 100 people in our headquarters by the end of 2003, we were risking mission failure solely because we lacked staff capacity. It was time to find new and even more creative ways to adapt.

In early 2004, I dispatched one of my most experienced and trusted staff officers to fly to the headquarters of the 25th Infantry Division in Hawaii with two key missions. The first was to orient the senior leaders of the division to what they could expect in their imminent deployment to take over CJTF-180. His second mission was even more important from my perspective: to convince the division commander, Major General Eric Olson, to bring as many of his division's stay-behind leaders as he could spare ${ }^{27}$ and to put them on orders to join our struggling headquarters as staff augmentees.

Olson delivered. In March, he sent us more than 40 officers and noncommissioned officers whom we quickly merged into our battle staff. This unorthodox arrangement gave us the vital capacity to take on the urgent tasks of the coming year without being entirely overwhelmed.

During 2004, it became increasingly clear that the Afghan presidential election in October would be a "make or break" moment for the U.S. and international strategy for a post-Taliban Afghanistan. We might not win the war in Afghanistan in 2004, but failing to conduct free and fair elections that enabled the Afghan people to select their next president would certainly be seen as a major defeat.

The United Nations was responsible for conducting a nationwide voter registration effort as well as the election itself-a monumental task, since more than $80 \%$ of Afghanistan's 31 million residents were scattered across remote and inhospitable terrain. The Taliban vowed to disrupt the election, demonstrating their continuing control of the countryside. The year was shaping up to be a litmus test of progress in Afghanistan, a referendum on who was winning: the Taliban or the nascent national government. 
I viewed the election as an opportunity to defeat the Taliban politically and thus demonstrate its irrelevance. I believed that a successful Afghan presidential election in which large numbers of Afghans voted freely for their future could inflict a crushing defeat on the Taliban's aspirations that could not be achieved through military operations. The registration and election efforts would be the report card for U.S. policy goals in the entire war to date.

Given the stakes and potential crushing blow to the Taliban, I made the U.S. military's main effort for 2004 "setting conditions for a successful Afghan presidential election." This clear priority focused all U.S. and coalition military power on supporting this objective.

The "Five Pillar" counterinsurgency strategy supported this focus. We would continue to put military pressure on the Taliban and al-Qaida (Pillar 1) while building and buttressing Afghan security forces so they could provide security for the election (Pillar 2). With a second maneuver brigade headquarters arriving, we could finally assign battlespace across the country, so a single brigade-level commander would be responsible for each large region (Pillar 3). We greatly expanded the PRT presence across the south and east of the country, standing up eight new U.S. PRTs in areas contested by the Taliban to help enable local reconstruction and improve Afghan governance (Pillar 4). I continued to engage Pakistan to strengthen border security measures to stem Taliban infiltration before the election (Pillar 5).

We capped off this robust effort with a supporting information campaign-working together with the embassy and the international community - to highlight the value of free elections. All of these efforts were aimed at the security and allegiance of the Afghan people, which I was increasingly convinced constituted our strategic center of gravity. We also re-organized our command relationships to support these efforts.

Shifting from a raid-based military strategy to one built on long-term unit ownership of geographic areas immediately provided better awareness of the needs of the Afghan population, the Afghan security forces, and the enemy. Commanders now operated in a single territory throughout their tours and were responsible for addressing its unique challenges. We also put the growing number of PRTs under the command of the regional brigade commanders, which cleared up a fractured chain of command and restored unity of effort between the combat and reconstruction missions in each region. We provided manpower, security, and advice to UNAMA election efforts and helped open remote areas to voter registration. Across the country, our broad-based counterinsurgency enabled every aspect of the election preparations.

The results of these efforts were striking. More than 9.7 million Afghans registered to vote, and more than 8.1 million voted on election day $^{28}$ - a turnout rate of more than $83 \%$. Hamid Karzai handily won the field, defeating 17 opponents in a contest still viewed today as perhaps the most free and fair election in Afghanistan.

Karzai was peacefully inaugurated in December as Afghanistan's first democratically elected president. Those of us who had been deeply involved in ensuring a fair election that engaged all of the Afghan people in their budding democracy were ecstatic, and we could sense the euphoria that swept the country. Seen many years later, it seems a different and unabashedly optimistic time. In its original context, however, it was a watershed event, one we judged may have dealt a death blow to the Taliban.

The late winter of 2004-2005 saw security incidents across the country drop to a low point. Our intelligence analysts created a briefing chart with a checklist titled, "How Do You Know When Your Enemy is Defeated?" and checked off half of the blocks. Despite the apparent good news, I continued to ask my intelligence experts a question that had bedeviled them throughout the previous year: "Are we the boiling frog?" In other words, is the Taliban moving so slowly and subtly that their actions are below our threshold of detection? Have they simply lulled us into a false sense of security?

Our combat statistics from the previous year were striking: despite the enemy's goal of disrupting the Afghan election, only 900 security incidents occurred across the country in 2004-averaging fewer than 
three per day. ${ }^{29}$ The coalition had suffered 58 military fatalities, of which more than 20 occurred in aviation accidents. ${ }^{30}$ The coalition only dropped 86 bombs in Afghanistan throughout all of $2004^{31}$-another indicator of the diminished fighting power of the enemy.

Our staff assembled "then and now" comparisons of changes in the country since 2003. It was striking to see the significant progress in the Afghan political process, the growth of the Afghan army, the disassembly of warlord militias, and overall security. There was still a long way to go, but the forward momentum was palpable.

Khalilzad and I felt strongly that we were on the right path and were deeply pleased with our remarkably effective partnership. Chemistry matters, and for whatever reason, the two of us clicked as a team. The cooperation and integration between the U.S. military and the embassy had never been stronger or more effective. We began looking ahead to the parliamentary elections scheduled for September 2005. Nevertheless, we remained deeply concerned that the remarkable progress we had made in blending the military and diplomatic missions into a close team with strongly shared unity of purpose in Afghanistan would begin to break apart if either of us departed.

In the spring of 2005 , we began to put measures in place to institutionalize our unique politicalmilitary structure. We formalized our joint civil-military coordination structures and documented their procedures. ${ }^{32}$ The two of us worked to find every way to help sustain this unique mutual partnership between "Venus and Mars"- the embassy and the military—after one or both of our departures.

Unfortunately, Khalilzad and I both left Afghanistan in the spring of 2005 within a few weeks of each other. ${ }^{33}$ Losing both at nearly the same time was an unexpectedly disruptive blow to our unusual and successful joint efforts. An interim ambassador was assigned until the new chief of mission arrived in September. This created a crucial continuity gap in the political-military partnership during the height of the Afghan summer fighting season.

The incoming U.S. commander had a more traditional view of the relationship between civilian and military efforts and quickly revised the campaign plan. He removed the military from non-security lines of effort and narrowed the campaign plan to military and security efforts. He also decided to move out of the embassy compound and stop attending country team meetings except for special occasions. The new commander also removed military officers from the embassy who had previously augmented bare-bones embassy projects, and he disestablished the Embassy Interagency Planning Group.

The new U.S. ambassador shared the new commander's view. The carefully established joint governance mechanisms between the U.S. military headquarters and the embassy quickly evaporated as both new leaders shifted into their respective domains.

This proved particularly problematic because the Taliban began a multi-year resurgence in attacks across the country, which continued to grow for many years. The Taliban's resurgence proved so dangerous by 2009 that the United States began to surge tens of thousands of new troops into Afghanistan to reverse the tide, soon bringing the total numbers of U.S. forces to nearly 100,000 .

In 2011, however, the United States started a steady withdrawal of its forces. By November 2020, only 4,500 remained, with the Pentagon planning to reduce the number to 2,500 by mid-January $2021 .{ }^{34} \mathrm{Nev}-$ ertheless, the Afghan war continues unabated, with no clear end in sight.

\section{Notes}

1 The author is indebted to Dr. Nora Bensahel for her extensive editing and suggestions on this chapter.

2 I served in combat twice before arriving in Afghanistan: Operation Urgent Fury in Grenada in 1983 and Operation Just Cause in Panama in 1989, both with the 75th Ranger Regiment. Nearly all of my professional military education from Infantry Officer Basic until I attended the Army War College was focused on defeating the Soviet Union in a major European war. None of these were of great help in Afghanistan. 
3 See, for example, Jim Garamone, "Free Iraqi Forces Committed to Democracy, Rule of Law," American Forces Press Service, March 14, 2003.

4 Among the U.S. coalition partners were small contingents or staff from the United Kingdom, Canada, France, Australia, Germany, Norway, Italy, Romania, Denmark, New Zealand, Poland, Egypt, and the United Arab Emirates.

5 The Combined Joint Operating Area for U.S. forces headquartered in Bagram included Afghanistan, Pakistan (less Jammu and Kashmir), and the southern portions of Uzbekistan and Tajikistan. Most of our supply lines ran through Pakistan, and the Taliban operated relatively freely across many of the Pakistan-Afghanistan border areas. U.S. operations since 2001 often involved coordination with Pakistan's military, especially in patrols near the border. The United States, however, only conducted military operations in Afghanistan.

6 The augmented staff included staff officers from other services and other countries who deployed with them.

7 In 2007, ISAF became the overarching single NATO headquarters, which subsumed the U.S. command.

8 In Iraq, this permanent headquarters was Multi-National Forces-Iraq, which remained in Baghdad until 2011.

9 We operated as the de facto headquarters beginning shortly after my arrival in October 2003, but the pace of activities delayed our ability to host a formal activation ceremony until February 2004.

10 At the time, CJTF-180 was built on the headquarters of the Army's 10th Mountain Division, commanded by thenbrigadier general (promotable) Lloyd Austin.

11 When I departed command in May 2005, CFC-A was staffed by about 420 personnel—still remarkably small compared to subsequent theater headquarters in either Afghanistan or Iraq.

12 Conrad C. Crane, "United States," in Understanding Counterinsurgency: Doctrine, Operations, and Challenges, ed. Thomas Rid and Thomas Keaney (New York: Routledge, 2010), 75-86.

13 David W. Barno, Combined Forces Command-Afghanistan (Washington, DC: Policy Forum, briefing to Center for Strategic and International Studies, May 14, 2004).

14 Minor adjustments included making some of the language less military in nature to assuage some diplomats.

15 For example, commanders were always authorized to employ close air support while troops were in contact. After several civilian casualty incidents due to unobserved strikes, however, they were not allowed to drop ordnance unless they could see the enemy that was targeted.

16 See David Galula, Counterinsurgency Warfare: Theory and Practice (Westport, CT: Praeger, 1964); Department of the Army, Counterinsurgency, FM 3-24 (Washington, DC: Department of the Army, 2006).

17 Khalilzad had been serving as the special presidential envoy for Afghanistan under President George W. Bush from 2001 until he was appointed as the ambassador in November 2003.

18 The CFC-A headquarters was located in an area then known as the Kabul compound, which was separate from the U.S. Embassy compound. The Kabul compound was later renamed Camp Eggers after U.S. Army Special Forces Captain Dan Eggers, who was killed by an improvised explosive device in May 2004.

19 The ambassador quickly came to rely on these skilled officers for integrated planning with CFC-A and to devise and measure metrics for the U.S. effort.

20 Barno, "Combined Forces Command-Afghanistan."

21 This included, for example, conducting investigations on errant airstrikes and being forthcoming about the results.

22 These visits paid dividends. In May 2004, major combat units of the Pakistani army moved into Waziristan for the first time in their nation's history. The results were bloody for their forces but very disruptive to enemy elements using Waziristan as a launch point for operations into neighboring Afghanistan.

23 I also convened a regional security conference in January 2005 that brought together senior military leaders of Afghanistan, Pakistan, Uzbekistan, Tajikistan, and other Central Asian states to discuss ways to improve joint border security, counterterrorism, and counter-drug operations. This initiative was met with enthusiasm by the regional militaries. I hoped they would improve regional military cooperation on matters of shared concern. Further meetings were discontinued after my departure in May 2005.

24 I had many occasions to meet with Karzai and receive that feedback first-hand as well. Some of those meetings unavoidably involved explaining civilian casualties from coalition operations.

25 We dramatically expanded PRTs in Afghanistan to support our new strategy, growing from only two U.S. PRTs in 2003 to 10 by the spring of 2004, primarily placed in the Taliban-contested south and east of the country.

26 "Doctors Without Borders Condemns Fatal Attack on Aid Workers," Doctors Without Borders, June 3, 2004, www.doctorswithoutborders.org/what-we-do/news-stories/news/doctors-without-borders-condemns-fatalattack-aid-workers.

27 Less than one-half of the 25th Division was slated to deploy to Afghanistan. The remainder would be left behind in Hawaii awaiting other commitments.

28 This data is available at www.electionguide.org/elections/id/1939/.

29 Sadly, this marked one of the low points of violence in Afghanistan. See Department of Safety and Security, Half Year Review of the Security Situation in Afghanistan (Washington, DC: United Nations, 2007); Vigilant Strategic Services, “Country Wide Incidents By Week—2007” (Kabul: Vigilant Strategic Services Afghanistan, 2007). 
30 Coalition troop fatalities also showed a disturbing increase after 2004. See http://icasualties.org/.

31 Anthony Cordesman, U.S. Airpower in Iraq and Afghanistan: 2004-2007 (Washington, DC: Center for Strategic and International Studies, 2007).

32 Colonel Dave Lamm, my chief of staff from mid-2004 until my departure, was a driving force behind this effort.

33 Khalilzad took over as the U.S. ambassador to Iraq, and I was re-assigned to the Army Staff in the Pentagon.

34 Thomas Gibbons-Neff and Fatima Faizi, "As Pompeo Prepared to Meet Afghan Warring Parties, New Attack Struck Kabul," New York Times, November 21, 2020, www.nytimes.com/2020/11/21/world/middleeast/afghani stan-kabul-rocket-attack.html. 


\title{
33 \\ AMERICA'S DRONE WARS OUTSIDE OF CONVENTIONAL WAR ZONES
}

\author{
Peter Bergen and A.G. Sims ${ }^{1}$
}

On March 5, 2016, a large group of men gathered for a graduation ceremony in Raso, Somalia, a remote area 190 kilometers north of the capital, Mogadishu. U.S. intelligence assets had quietly observed for weeks as dozens of al-Shabaab militants trained for a large-scale attack against American troops in East Africa. ${ }^{2}$ In a bombardment of drone strikes and airstrikes, the United States decimated the al-Shabaab training camp, killing more than 150 militants. $^{3}$ The March 2016 strikes in Somalia were the most lethal attacks using drones outside of a traditional war zone.

In October 2001, the first armed drone strike in Afghanistan targeted Taliban leader Mullah Muhammad Omar. The strike was unsuccessful. ${ }^{4}$ After the failed attempt, drones emerged as a key U.S. counterterrorism tool. As of December 1, 2020, the United States has conducted 414 drone strikes in Pakistan, 374 counterterrorism operations in Yemen, and 253 operations in Somalia that include a mix of drone strikes, airstrikes, and ground raids, according to data from the New America think-tank. ${ }^{5}$

This chapter explains how armed drones targeting suspected terrorists outside of traditional war zones are changing the character of warfare while at the same time raising questions about the legality of drone strikes conducted far from recognized battlefields. It reviews how three different American presidents relied on armed drones to strike at hard-to-reach targets.

\section{The formation of the U.S. drone program}

The remotely piloted aircraft's novelty is its ability to stay aloft over locations for extended periods to gather real-time intelligence while also being able to act on this information immediately using precision munitions. Drone warfare is also taking place in an unprecedented information environment in which the U.S. government collects ever-vaster amounts of data.

Drones represent just one aspect of America's comprehensive international surveillance infrastructure. This data collection is so extensive that the National Security Agency can reportedly record every phone call that is made in a particular country. ${ }^{6}$ It is this merger of "big data" and drone technology, complemented by human intelligence about suspected terrorists, that has made drone warfare against al-Qaida and other jihadis so effective. ${ }^{7}$

Not long ago, killing a terrorist on the other side of the world with an armed drone would have been in the realm of science fiction. Before the 9/11 attacks, the United States had only a handful of experimental drones, and they had never been used to kill anyone. By 2012, however, the United States had some 7,500 
drones in its arsenal, more than 100 of which are armed drones that have killed thousands of suspected militants outside of traditional war zones. ${ }^{8}$

Over the course of the war on terrorism, the United States has used the drone program to extend its pursuit of al-Qaida and its affiliates, the Islamic State, and the Taliban beyond the conventional battlefields of Afghanistan, Iraq, and Syria to Pakistan, Somalia, and Yemen. The United States has also conducted air campaigns in Libya that included airstrikes and drone strikes. ${ }^{9}$

The United States is not in a formal state of hostilities in countries such as Libya, Pakistan, Somalia, and Yemen, but the post-9/11 Authorization for the Use of Military Force, which Congress passed just days after al-Qaida's attacks on the World Trade Center and Pentagon, authorized President George W. Bush to "use all necessary and appropriate force against those nations, organizations, or persons he determines planned, authorized, committed, or aided the terrorist attacks that occurred on September 11, 2001, or harbored such organizations or persons." ${ }^{10}$

Two presidents later, this is the same authorization that has been broadly interpreted to allow lethal military actions, including drone strikes, against groups such as the Islamic State, al-Qaida in the Arabian Peninsula (AQAP), al-Shabaab, and the Pakistani Taliban. Few of these strikes have any direct connections to the perpetrators of the $9 / 11$ attacks, but the Authorization for the Use of Military Force remains the critical piece of legislation approving lethal drone operations.

President Bill Clinton's counterterrorism coordinator, Richard Clarke, saw the promise of drones earlier than most. On a drone feed in 2000, Clarke saw a fuzzy glimpse of what might have been Usama bin Ladin in Afghanistan; Predator drone video feeds were not what they are now. Clarke was determined that the next time the United States had al-Qaida's leader, who masterminded the U.S. Embassy bombings in East Africa in 1998, in its sights, American drones would have the capability to kill him and the country's other enemies. ${ }^{11}$

The nascent technology's lack of sophistication was not the only barrier to arming drones. Legal and bureaucratic challenges existed as well. The Air Force did not want to strike Bin Ladin because the United States was not officially at war in Afghanistan or with al-Qaida. ${ }^{12}$ Questions about the Central Intelligence Agency's (CIA) covert action policies contributed to the reluctance of its leaders to arm drones for the purpose of targeted killing.

The original mandate for covert action, codified by President Harry Truman, was explicitly directed toward the communist threat. ${ }^{13}$ Even as the Bill Clinton administration authorized production of drones and tested this new intelligence tool in the Balkans, tensions persisted between the Air Force and the CIA about who should be responsible for the armed drone program. ${ }^{14}$

\section{Drone warfare under President George W. Bush}

In Nevada in June 2001, the CIA built a replica of Bin Ladin's four-room villa at Tarnak Farms, where he was living outside of Kandahar in southern Afghanistan. A Predator drone equipped with a missile obliterated the replica house in tests that the agency conducted with the Air Force.

National Security Council official Roger Cressey recalled that even this was not enough to convince the CIA and Pentagon to move forward with the armed Predator. "I was at the meeting at the agency afterwards," Cressey explained. "The data they got they said was inconclusive as to whether or not there was enough lethality in the explosion or the shrapnel to ensure that everybody inside would have been killed." ${ }^{15}$

Michael A. Sheehan, then the U.S. ambassador for counterterrorism, recalled that Richard Clarke "was pounding on the [CIA and Department of Defense] to more quickly develop—and use - the armed Predator, which was being tested, in Nevada, at the time." According to Sheehan,

both of them were dragging their feet in terms of money, and they also were uncomfortable with the use of the armed Predator. Can you imagine that now? Back then they were very slow 
to develop the capability, very slow in testing, they had lawyers wrapping them up in knots, and Clarke was apoplectic over it, because he wanted to introduce this asset into the Afghan theater. ${ }^{16}$

Even the 9/11 attacks did not end this bureaucratic infighting. On October 7, 2001, on the night of the beginning of the U.S.-led invasion of Afghanistan, a CIA-operated armed drone fired at the Taliban's leader, Mullah Omar, but missed, angering Air Force Lieutenant General Chuck Wald, who was coordinating military airstrikes in Afghanistan and had no prior knowledge of the strike. ${ }^{17}$

On November 13, Kabul fell to the anti-Taliban Northern Alliance. ${ }^{18}$ A few days later, a U.S. drone tracked top al-Qaida commander Mohammed Atef to a house in Kabul, where he was killed in an airstrike. Atef was al-Qaida's military commander and Bin Ladin's chief executive officer, working around the clock to manage al-Qaida's personnel and operations. A Saudi member of al-Qaida recalled that Atef's death "shocked us deeply, because this was the candidate to succeed Bin Ladin."19

After the Taliban were swept from power in Afghanistan, the CIA's secret drone war expanded to other countries. Marine Corps Lieutenant General Michael DeLong, the deputy commander of U.S. Central Command, recalled, "[CIA Director] George Tenet calls me one morning and said, 'We've got our target."' The target was Qaed Salim Sinan al-Harithi. The location was Yemen. Al-Harithi, who was killed by a Predator drone firing a Hellfire missile on November 3, 2002, was believed to have devised the 2000 attack on the USS Cole in Yemen that killed 17 American sailors. ${ }^{20}$

Two years later, the CIA's secret drone program expanded to Pakistan. On June 18, 2004, a CIA drone killed Nek Muhammad, a prominent Taliban leader, as the result of a secret negotiation between Pakistan's intelligence service and the CIA. ${ }^{21}$ The relatively slow pace of drone attacks quickened dramatically in the waning months of the Bush administration's second term after it had become clear that al-Qaida was reconstituting itself in Pakistan's tribal regions.

In July 2007, the 16 agencies that made up the U.S. intelligence community released a National Intelligence Estimate assessing that al-Qaida was resurging and warning that it "has protected or regenerated key elements of its Homeland attack capability, including a safe haven in Pakistan's Federally Administered Tribal Areas (FATA)." What particularly alarmed Bush administration officials was the mounting evidence that al-Qaida and affiliated groups were using the FATA to train Westerners for attacks on American and European targets. For example, the masterminds of the July 7, 2005, London bombings, which killed 52 people, had trained in Pakistan's tribal regions. ${ }^{22}$

In the face of the intense Pakistani opposition to American boots on the ground, the Bush administration chose to rely on drones to target suspected militants. Bush ordered the CIA to expand its drone attacks. A squadron of pilots stationed in Nevada operated the Predator and Reaper drones, which were equipped to drop Hellfire missiles and Joint Direct Attack Munition bombs (utilizing a control system that converts a "dumb bomb" into a guided munition), respectively. More than two dozen feet in length, the drones lingered over the tribal areas, gathering countless hours of video intelligence while seeking targets. ${ }^{23}$

In 2008, the Bush administration dramatically escalated the program, conducting 36 strikes in the president's final year in office- around nine times the highest number of strikes in any previous year. ${ }^{24}$ Overall, Bush authorized a total of 48 drone strikes in Pakistan during his two terms. According to Pakistani and U.S. officials and media reports, drone strikes in 2008 killed about a dozen senior or mid-level leaders from al-Qaida and the Taliban. They included top al-Qaida operative Abu Layth al-Libi, who had orchestrated a 2007 suicide attack at Bagram Air Base in Afghanistan during a visit by Vice President Dick Cheney. ${ }^{25}$

\section{Drone warfare under President Barack Obama}

As soon as he took office in January 2009, President Barack Obama quickly made drones one of his key national security tools. ${ }^{26}$ During the Bush administration, there was an American drone attack in Pakistan every 61 days. During the first two years of the Obama administration, there was a drone strike in Pakistan 
every four days. ${ }^{27}$ By the time he left office, Obama had authorized 353 drone strikes in Pakistan, seven times as many as were carried out during Bush's entire eight years in office. ${ }^{28}$

Under Obama, the targeted killing of al-Qaida leaders also evolved into a broader targeting of lowerlevel members of militant groups. The victims of drone strikes in Pakistan during the Obama era were mostly lower-ranking members of the targeted groups. Under Bush, about a third of all drone strikes in Pakistan killed a militant leader, compared to $14 \%$ under Obama. ${ }^{29}$

Drone attacks called "signature strikes"- attacks based on patterns of suspicious activity by a group of men, rather than "personality strikes" against particular militants—-were a hallmark of Obama's drone war. ${ }^{30}$ They decimated the ranks of lower-level combatants, killing somewhere between an estimated 1,659 and 2,683 suspected militants in Pakistan during Obama's tenure. ${ }^{31}$

In addition to signature strikes, Obama expanded targeting selection to include militant groups less directly threatening to the U.S. homeland compared to al-Qaida. More than a third of the Bush administration's strikes targeted al-Qaida; under Obama, that number stood at only $9 \%$. Under Obama, 47\% of drone strikes targeted the Taliban and the allied Haqqani network. ${ }^{32}$

An example of this shift in targeting came on October 11, 2012, when a drone strike killed a group of militants in Orakzai Agency in FATA believed to be loyal to Pakistani Taliban commander Hafiz Gul Bahadur. U.S. military officials had linked Bahadur's fighters to attacks on NATO troops in Afghanistan. ${ }^{33}$

This broadening of the target set coincided with a large surge of U.S. soldiers in Afghanistan. At the end of the Bush administration, there were more than 20,000 U.S. soldiers in Afghanistan. By mid-2010, there were 90,000..$^{34}$ Many of the drone strikes under Obama in the FATA occurred in the context of "force protection" of this larger contingent of U.S. soldiers.

The Obama administration's drone campaign in Pakistan peaked in 2010 but slowed considerably in 2011 as a result, in part, of deepening fissures in the U.S.-Pakistan relationship. The May 2011 raid by U.S. Navy SEALs on Bin Ladin's compound in Abbottabad in northern Pakistan, and a NATO airstrike six months later that inadvertently killed some two dozen Pakistani soldiers, greatly damaged relations between Washington and Islamabad, resulting in the closure of the CIA-controlled drone facility at Shamsi air base in Balochistan. ${ }^{35}$

At the same time, U.S. Ambassador to Pakistan Cameron Munter urged more judicious targeting of drone strikes as well as increased consultation with the Pakistanis. ${ }^{36}$ The drone strikes had long been unpopular among Pakistanis, who viewed them both as killing too many civilians and as violations of their national sovereignty. According to a Gallup poll from 2013, 70\% of Pakistanis surveyed opposed U.S. drone strikes in their country. ${ }^{37}$

A combination of the CIA drone base closure, State Department pressure to heed Pakistani sensitivities, greater scrutiny of the drone program by the American media and Congress, and a reduction of the U.S. military footprint in Afghanistan led to a 40\% drop in the number of strikes in 2011. There were 70 drone strikes in Pakistan in 2011, down from the record 122 in 2010 (see Figure 33.1).

Following this sharp drop, drone strikes in Pakistan continued to decline. The Obama administration conducted only three strikes in Pakistan in 2016. On May 21 of that year, the CIA conducted its final drone strike in Pakistan of Obama's presidency and the first outside of FATA, killing the Taliban's leader, Mullah Akhtar Mansour, in Balochistan. The administration then inaugurated a nine-month cessation of strikes in Pakistan, the longest such pause since Obama took office. ${ }^{39}$ It would remain the longest pause until President Donald Trump, who broke the pause but stopped conducting strikes following a strike on July 4, 2018, that initiated a more than two-year pause since the last known U.S. strike in Pakistan.

Even after the Obama administration halted drone strikes in Pakistan, the drone program continued in Yemen and Somalia, where two al-Qaida affiliates operated: AQAP and al-Shabaab. Umar Farouk Abdulmutallab, a Nigerian-born graduate student attending University College London, sought out the American cleric Anwar al-Awlaqi in Yemen. Al-Awlaqi, a leader of AQAP, directed Abdulmutallab to blow up an American passenger plane over U.S. soil. ${ }^{40}$ Deploying a hard-to-detect bomb secreted in his underwear, 


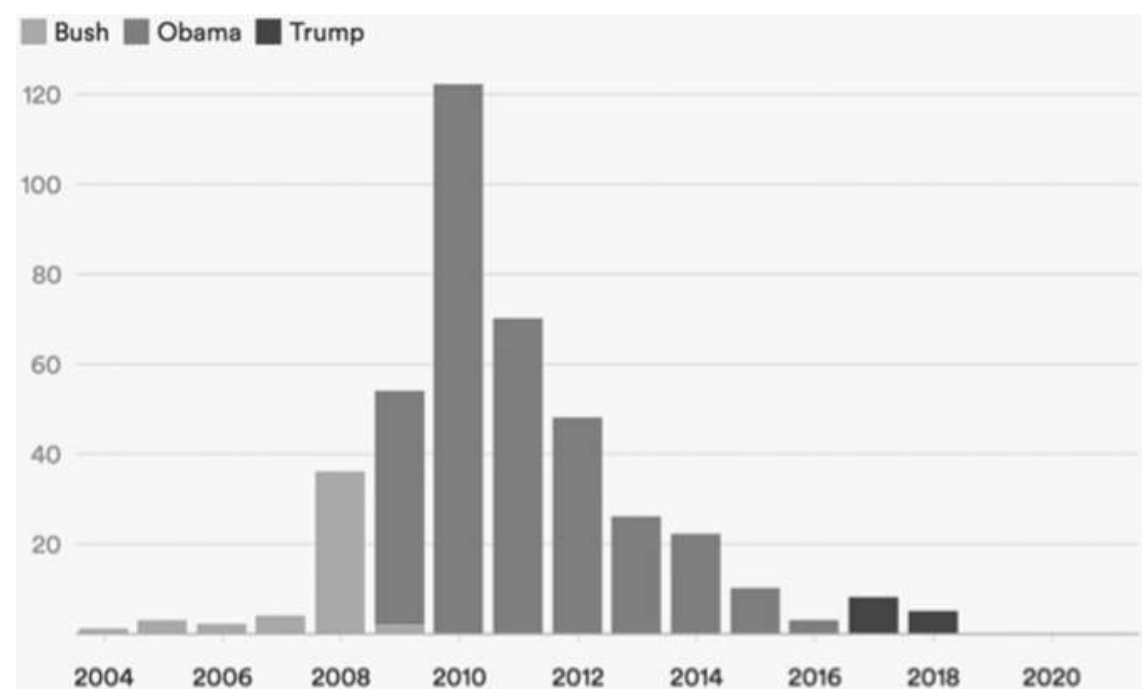

Figure 33.1 U.S. air and drone strikes in Pakistan, 2004-2020. ${ }^{38}$

Source: The data in this figure is drawn from research conducted by the authors and New America.

Abdulmutallab attempted to blow up Northwest Airlines Flight 253 as it flew over Detroit on Christmas Day 2009. The bomb did not detonate properly, saving the lives of the passengers and crew.

Obama first entered office not wanting terrorism to be a defining issue of his presidency, as it had been for his predecessor. Just as for President Bush, however, combating terrorist groups would become the dominant foreign policy issue for much of Obama's term. One of Obama's major campaign pledges was to end American involvement in both Iraq and Afghanistan, so he was not prepared to open a new war in the Arabian Peninsula. Obama explained his position: "We can't do in Yemen what we did in Afghanistan. We shouldn't have to spend tens of billions of dollars in Yemen because one scared kid from Nigeria was recruited to do something bad." ${ }^{41}$

While Obama did not want to launch a conventional war in Yemen after the Christmas Day incident, he still moved to take military action. The Bush administration had conducted only one drone strike in Yemen, while under the Obama administration, there were 185 strikes, ${ }^{42}$ resulting in an estimated 1,094 to 1,394 deaths. ${ }^{43}$ In Yemen, 56 drone and airstrikes took place in 2012, marking the first time that the number of drone strikes in Yemen and Pakistan had reached comparable levels. ${ }^{44}$

A controversial component of Obama's drone program was the use of so-called signature strikes, which he authorized for Pakistan's tribal regions and Yemen. ${ }^{45}$ Such strikes did not target militants identified as individuals but rather people deemed lawful targets for military action because they had displayed the behaviors of suspected militants. Stricter rules governed signature strikes in Yemen compared to Pakistan, and they were given a different name: Terrorist Attack Disruption Strikes. ${ }^{46}$

In addition to signature strikes, the Obama administration continued to target high-level leaders. U.S. national security officials began to portray the American-born AQAP leader Anwar al-Awlaqi as more threatening than even Bin Ladin. It was al-Awlaqi who was orchestrating al-Qaida's serious plots against American commercial jets.

Yet how could the U.S. intelligence community find someone hiding in a remote part of Yemen? Even if al-Awlaqi could be found, the administration could not send Federal Bureau of Investigation agents to arrest him. With only a few dozen U.S. Special Operations Forces in all of Yemen, mounting a ground operation had no guarantee of success. That left the drone option. 
Senior White House officials began debating whether they should target al-Awlaqi for death. Not since the Civil War had a president and his advisors seriously contemplated authorizing such a killing of an American citizen. The president and a small team of senior national security officials, including Attorney General Eric Holder, were in the unusual position of acting as al-Awlaqi's jury, judges, and de facto executioners. Just days after the Christmas Day plot, President Obama, the former constitutional law professor, gave his verbal approval to target al-Awlaqi for death. ${ }^{47}$

While the president had agonized over some of the decisions to target militants for death, the decision to kill al-Awlaqi was an "easy one." 48 In the president's mind, the weight of the evidence that al-Awlaqi was constantly plotting new ways to kill Americans was sufficient to order his death.

In July 2010, two lawyers at the Justice Department, David Barron and Marty Lederman, wrote a secret memo that established the legal rationale for why it was lawful under certain, specific circumstances for the president to authorize the killing of an American citizen. Merely being an American citizen, the memo argued, did not make one immune from being targeted. As an operational leader of al-Qaida actively working to kill Americans, al-Awlaqi posed an "imminent" threat of violent attack against the United States. Moreover, he was hiding in a remote area of Yemen where capture was simply not feasible. The Justice Department lawyers opined that if a drone operation were eventually used to kill al-Awlaqi, it would have to be conducted in such a manner that it comported with the "laws of war," such as avoiding civilian casualties. ${ }^{49}$

A confidential Justice Department "white paper" written around the same time introduced a broader concept of "imminence" than had previously been in use. An imminent threat no longer required the "United States to have clear evidence that a specific attack on U.S. persons and interests will take place in the immediate future." Instead, the memo argued that an "informed, high-level" U.S. official could lawfully target an American who had been "recently" involved in "activities" posing a threat of an attack on the United States and where there was "no evidence suggesting that he has renounced or abandoned such activities." ${ }^{50}$ In other words, an American could be targeted for death not only in the case where he was planning an imminent attack on the United States but if he had already been involved in such a plan and there was not a good reason to believe he would not try again.

In January 2011, demonstrations broke out in Yemen to protest against poor economic conditions and the regime of Yemeni President Ali Abdullah Saleh. This coincided with the Arab Spring revolts in other countries across North Africa and the Arabian Peninsula. AQAP made territorial gains amid the chaos, and the United States responded by substantially escalating drone strikes.

The U.S. government killed al-Awlaqi in a drone strike on September 30, 2011. ${ }^{51}$ It marked the first known case of the U.S. government targeting and killing a U.S. citizen since the Civil War. Samir Khan, another American jihadi, died alongside al-Awlaqi. Although Khan was not the target of the strike, he had risen to prominence as the editor of al-Qaida's Inspire magazine. Two weeks later, al-Awlaqi's American son, 16-year-old Abdulrahman al-Awlaqi, was killed during a strike that reportedly targeted an Egyptian al-Qaida leader, Ibrahim al-Banna. ${ }^{52}$

Drone strikes in Yemen continued to increase, peaking in 2012, but slowly began to drop through 2014 (see Figure 33.2). The decline would not last. In September 2014, Houthi rebels took the Yemeni capital, Sanaa, and AQAP exploited the discord, making a push for greater territory. The United States began to re-escalate its drone war due to AQAP's advances, including the group's seizure of the port city of Mukalla in April 2015..$^{54}$

Using the most conservative estimates, counterterrorism operations in Pakistan and Yemen authorized by the Obama administration killed more than 3,000 people. Using the most liberal estimates, the total number of people killed reached nearly $4,500 .{ }^{55}$ Put another way, using the most conservative estimates, the death toll from drone strikes under the Obama administration amounts to almost four times the number of prisoners (almost 800) placed at the Guantanamo Bay prison camp by the Bush administration. Obama told some of his aides drily: "Turns out I'm really good at killing people. Didn't know that was going to be a strong suit of mine." 56 


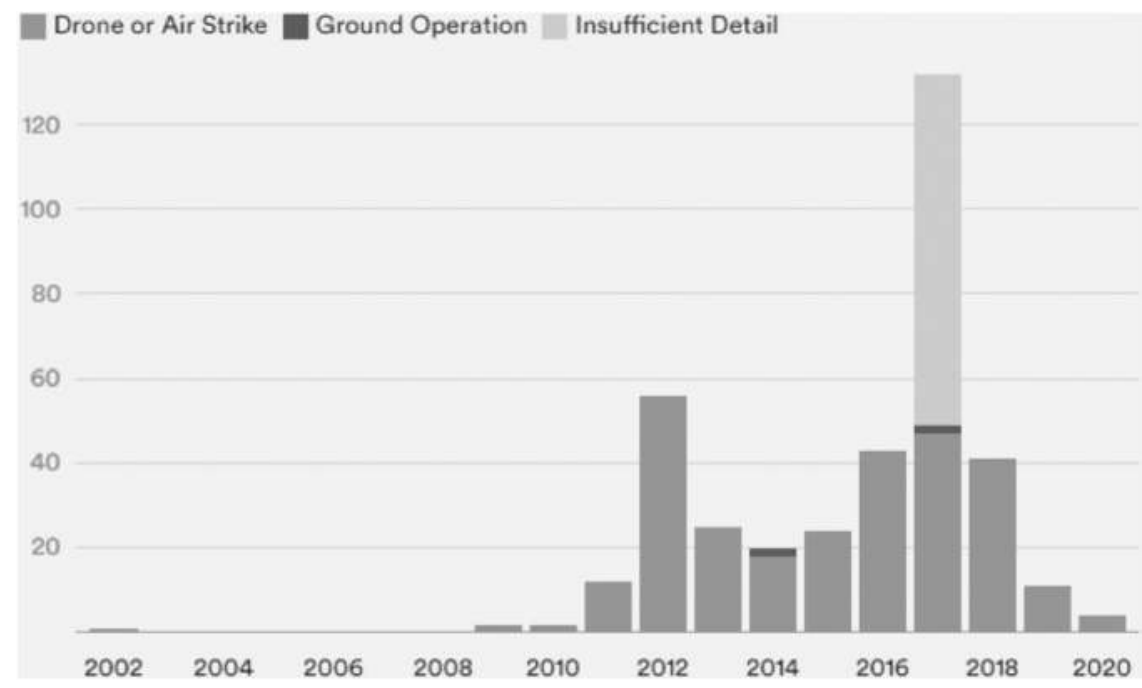

Figure 33.2 U.S. strikes in Yemen by type of strike, 2002-2020.53

Source: The data in this figure is drawn from research conducted by the authors and New America; data for 2020 is through December 1, 2020.

\section{Drone warfare under President Donald Trump}

In March 2017, President Donald Trump approved a Pentagon request to designate parts of three unnamed Yemeni provinces as "areas of active hostilities." The term has no clear, legal definition but authorizes the military to operate as it does in conventional war zones with broad authority to take action against terrorist targets at its own discretion. ${ }^{57}$

In the same month, Trump also granted the Pentagon's request to designate the entirety of Somalia as an "area of active hostilities" for six months. ${ }^{58}$ Marine Corps General Thomas Waldhauser, commander of U.S. Africa Command, confirmed in a press briefing:

We've been given authority to assist [African Union Mission in Somalia] forces that are on missions where, if they cannot take care of the situation on their own, then we are authorized to assist them there. We are also authorized to develop targets on our own and take appropriate action. ${ }^{59}$

Waldhauser also said that, despite the expanded rules of engagement, he was going to stick to the "near certainty" standard of no civilian casualties.

The Trump administration dramatically escalated the number of counterterrorism operations in Yemen in 2017 before substantially reducing the pace of strikes. The Trump administration conducted a total of 188 drone strikes, airstrikes, and ground operations in Yemen as of December 1, 2020. While strikes in Pakistan slowed, strikes in Somalia escalated significantly. The CIA conducted 13 drone strikes in Pakistan during the Trump administration, restarting the drone campaign in the country after a cessation of nine months under Obama.

The Trump administration again paused the campaign in Pakistan, however, and there has not been a U.S. strike in more than two years in the country. As of December 1, 2020, the Trump administration has conducted 193 airstrikes and ground operations in Somalia, the highest pace since the start of U.S. counterterrorism operations in Somalia in 2003 (see Figure 33.3). 


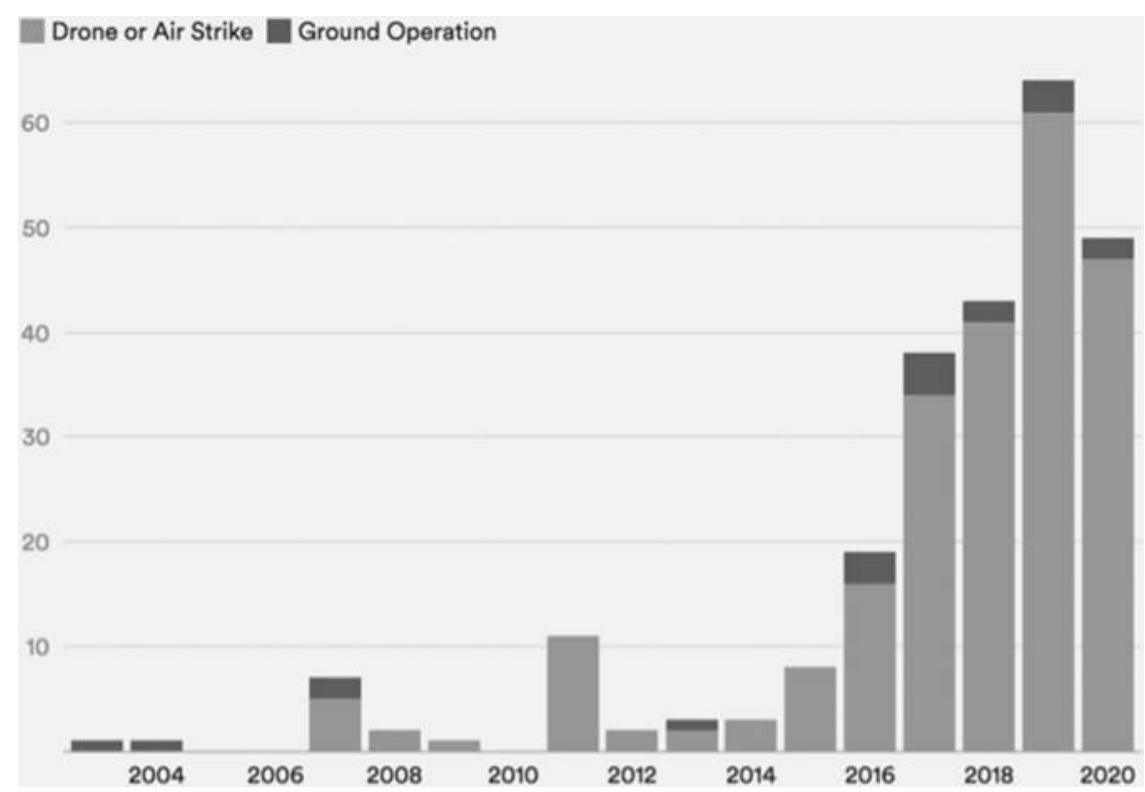

Figure 33.3 U.S. strikes in Somalia by type of strike, 2003-2020. ${ }^{60}$

Source: The data in this figure is drawn from research conducted by the authors and New America; data for 2020 is through December 1, 2020.

\section{Are CIA drone strikes effective at disrupting terrorist groups?}

U.S. drone strikes in Pakistan killed many top al-Qaida and Taliban leaders. Between 2004 and November 17, 2020, the drone campaign in Pakistan killed 95 militant leaders, according to New America data. It was so effective that before he was killed in the 2011 Navy SEAL raid, Bin Ladin considered moving al-Qaida's key figures out of Pakistan. ${ }^{61}$

In a lengthy October 2010 memo recovered from his Abbottabad compound after the raid, Bin Ladin wrote about the devastation that drones were inflicting on his organization and advised that his men leave the FATA region, where the drone strikes were overwhelmingly concentrated, and head to a remote part of Afghanistan. He also suggested that his son Hamza decamp from Pakistan's tribal regions for the wealthy Persian Gulf kingdom of Qatar. ${ }^{62}$

An account provided by David Rohde, a New York Times reporter who was held captive by the Haqqani network for months in 2009, provides additional evidence of the drone strikes' impact on Pakistan-based militants. In an essay reflecting on his captivity, Rohde said that his Taliban captors "feared drone strikes" and often tortured and executed villagers in Waziristan, an area of FATA, whom they suspected of secretly carrying global positioning system devices or otherwise providing guidance for U.S. drone strikes. ${ }^{63}$

The CIA drone attacks in Pakistan have undoubtedly degraded al-Qaida's core and hindered some of the Taliban's operations, killing many hundreds of each group's low-level fighters and many of their top commanders. After Abu Yahya al-Libi, the deputy leader of al-Qaida, was killed in a CIA drone strike in Pakistan's tribal region in 2012, senior U.S. counterterrorism officials concluded that only one leader of any consequence in al-Qaida's core group in the Afghanistan-Pakistan region remained: Ayman al-Zawahiri, the Egyptian surgeon who became the head of al-Qaida following Bin Ladin's death in $2011 .^{64}$

In April 2015, al-Qaida confirmed in an audio message that CIA drone strikes killed two of its leaders, Ustad Ahmad Farooq and Qari Abdullah Mansur, three months earlier in North Waziristan, near the 
Afghan-Pakistani border. ${ }^{65}$ Farooq, whose real name was Raja Mohammad Suleman, acted as the group's liaison to the Pakistani Taliban, and he was the deputy commander of al-Qaida's nascent South Asia branch. Mansur, whose real name was Qari Ubaidullah, oversaw suicide missions against U.S. and NATO troops in Afghanistan. ${ }^{66}$ The deaths of these two Pakistani al-Qaida leaders underlined the continuing decimation of the group's leadership in South Asia.

A 2015 RAND study, “The Impact of U.S. Drone Strikes on Terrorism in Pakistan,” used a statistical analysis based on New America's data and other datasets by non-governmental organizations to conclude that drone strikes reduced the threat posed by targeted groups in Pakistan through two mechanisms- the disruption of their operations and leadership decapitation. ${ }^{67}$

\section{Drone warfare and civilian casualties}

The U.S. drone campaign became increasingly controversial as it ramped up under the Obama administration. Human rights activists claimed that the attacks killed a substantial number of civilians, while Obama's top counterterrorism advisor, John Brennan, made the improbable claim in 2011 that there were no civilian casualties for nearly a year as a result of the strikes. ${ }^{68}$

How many civilians have actually been killed by drone strikes? This question is complicated by the fact that it is not always possible to differentiate precisely between militant and civilian casualties in Pakistan; the militants live among the population and do not wear uniforms, and they have the incentive to claim that all casualties are civilian, while government sources tend to claim the opposite. This can lead to conflicting media reports about whether the victims were militants or civilians, and in those unclear cases, New America added a separate category to its dataset of drone casualties: "Unknowns." Over the course of the drone war in Pakistan, an estimated 211 to 328 deaths are categorized as "unknowns." 99

By averaging the high and low casualty estimates of militant and non-militant deaths published in a wide range of reliable media outlets, New America estimates that the civilian death rate in U.S. drone strikes in Pakistan has declined dramatically since $2006 .^{70}$

Over the life of the CIA drone program in Pakistan, the estimated civilian death rate is $9 \%$, or between 245 and 303 individuals out of an estimated 2,366 to 3,700 total deaths. This civilian death rate average was $27 \%$ under Bush, while it was $6 \%$ under Obama. As of December 1, 2020, under Trump, it was approximately $4 \%$.

The civilian fatality rate from CIA drone strikes began to drop beginning in 2010 for a number of reasons. Three days after Obama took office, a drone strike killed at least five civilians on January 23, 2009, prompting the president to demand stricter targeting selection criteria from the CIA. Obama also wanted to personally authorize any strikes that the agency did not have "near certainty" would result in zero civilian casualties.

At the same time, technological innovations allowed the CIA to deploy much smaller munitions, and drones could circle over areas for longer periods, allowing them to target specific individuals with more precision and wait for an opportunity when no civilians were present. ${ }^{71}$ Figure 33.4 shows the annual number of fatalities from drone strikes in Pakistan, Yemen, Somalia, and Libya.

The drone program also came under increasing Congressional oversight. Since early 2010, members of the House Permanent Select Committee on Intelligence and the Senate Select Committee on Intelligence have held monthly meetings at CIA headquarters to watch video recordings of specific drone strikes, as well as to review the intelligence upon which CIA agents on the ground in Pakistan based their target selection. ${ }^{73}$

Even Pakistani security officials acknowledged during background interviews with the Washington Post in 2010 that better technology, a deeper network of on-the-ground informants, and better coordination between U.S. and Pakistani intelligence officials had all contributed to a significant drop in civilian deaths in drone strikes. ${ }^{74}$ In March 2011, Pakistani Major General Ghayur Mehmood acknowledged that 


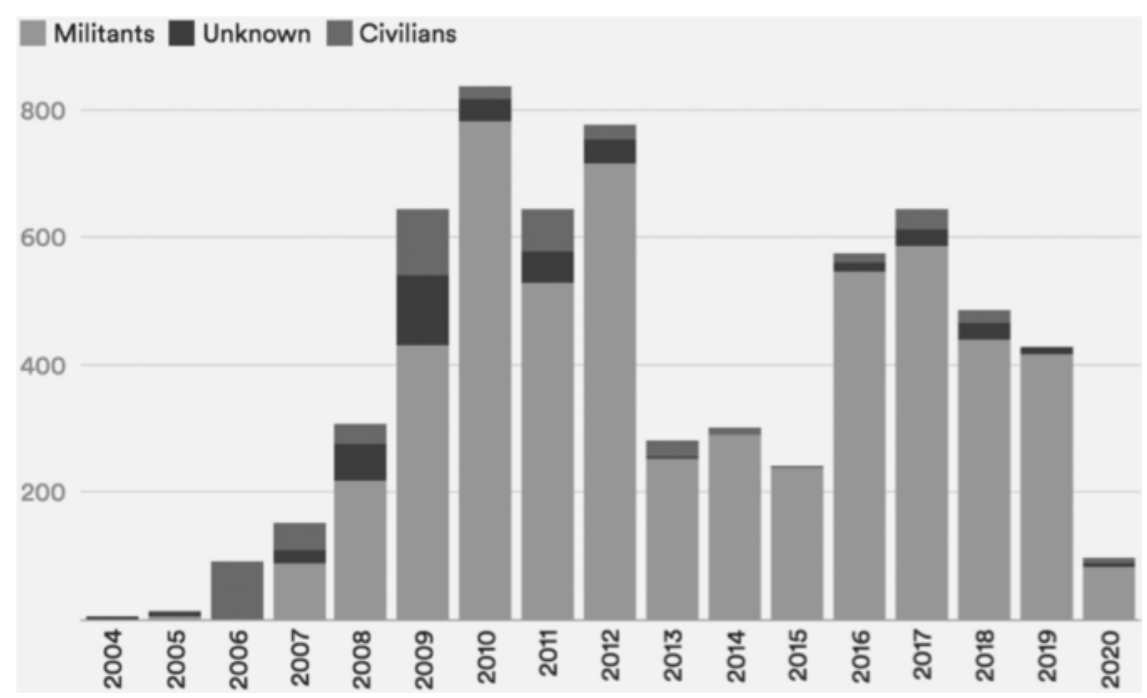

Figure 33.4 Deaths from drone strikes in Pakistan, Yemen, Somalia, and Libya, 2004-2020. ${ }^{72}$

Source: The data in this figure is drawn from research conducted by the authors and New America. This graphic likely undercounts the number of deaths in Yemen in 2017, due to gaps in CENTCOM data on strike date and location. Data for 2020 is through December 1, 2020.

U.S. drone strikes were accurate in terms of targeting. "The number of innocent people being killed is relatively low," Mehmood said, and "most of the targets are hard-core militants." It was the first such public acknowledgment by a senior Pakistani military officer. ${ }^{75}$

Despite improvements in precision, U.S. drone strikes in Pakistan's tribal regions are a continued point of tension contributing to the fracture of U.S.-Pakistan relations. On June 15, 2017, after a drone strike killed Abubakar Haqqani, a commander of the Haqqani network, Pakistan Army Chief General Qamar Javed Bajwa called U.S. strikes "counterproductive" and "against [the] spirit of . . ongoing cooperation and intelligence sharing being diligently undertaken by Pakistan."76

The widespread perception in Pakistan that drones kill too many civilians has persisted. According to a 2014 Pew poll, two-thirds of Pakistanis believe this to be the case. ${ }^{77}$ A Pew poll conducted two years earlier found that just $17 \%$ of Pakistanis supported the U.S. drone campaign to combat militants in their country. ${ }^{78}$

The drone attacks in Pakistan have undoubtedly hindered some operations of al-Qaida and the Taliban and have killed a significant number of their top commanders and their lower-level fighters. But they may also be fueling terrorism. Faisal Shahzad, an American citizen of Pakistani descent trained by the Pakistani Taliban, tried to detonate a car bomb in Times Square on May 1, 2010. The plot failed, but Shahzad subsequently claimed that the drone program had stoked his anger against the United States. ${ }^{79}$

Since 2012, Pakistani officials have rarely based their criticism of U.S. drone strikes on the incidence of civilian casualties but instead have pointed, quite reasonably, to another objection: the violation of Pakistan's national sovereignty. In April 2012, the Pakistani Parliament voted to end any authorization for the program, a vote the U.S. government has so far ignored. ${ }^{80}$ This may be because, despite their public protests, some senior Pakistani officials privately supported the drone strikes.

Confirmation of official Pakistani support for the strikes came in April 2013, when former Pakistani President Pervez Musharraf acknowledged to the media that his government had secretly signed off on some U.S. drone strikes under the Bush administration. This was the first public admission by a senior Pakistani official of such a deal. Musharraf claimed that Pakistan's government allowed strikes "only on a few occasions, when a target was absolutely isolated and no chance of collateral damage." ${ }^{81}$ 
Meanwhile, in the United States, the drone program has enjoyed significant support. In a 2015 Pew poll, 58\% of Americans said they approved of lethal drone attacks in countries such as Pakistan, Yemen, and Somalia. ${ }^{82}$ This is not surprising because the human, financial, and political costs of the drone program for Americans are very low. Drone pilots and their support staff are not on the field of battle, and a drone costs a tiny fraction of the price of a fighter jet or a bomber. ${ }^{83}$

\section{The CIA drone program comes out of the shadows}

The U.S. government has somewhat pulled back the curtain on the drone program, which was shrouded in secrecy for more than a decade. The United States has acknowledged the program and has increased transparency regarding the rules that govern counterterrorism operations. President Obama made his first public comments about the covert drone program on January 30, 2012, when he told participants of a Google+ Hangout that the United States conducts only "very precise, precision strikes against al-Qaida and their affiliates, and we're very careful in terms of how it's been applied." ${ }^{84}$

Obama explained the rationale for the drone program in a 2013 speech at National Defense University, saying: "In some of these places — such as parts of Somalia and Yemen - the state has only the most tenuous reach into the territory. In other cases, the state lacks the capacity or will to take action," implicitly referring to Pakistan's unwillingness or inability to capture or kill militants in FATA. Obama also pointed to the degradation of al-Qaida core's capabilities since $9 / 11$ as evidence of the program's efficacy.

During the same speech, Obama announced the codification of his Presidential Policy Guidance, which established a framework and standards for the targeted killing of combatants. ${ }^{85}$ The American Civil Liberties Union petitioned for the document's release in 2013, but was denied on the basis of "presidential communications" privilege. ${ }^{86}$ After a judicial review raised questions regarding the privilege, the Obama administration released a redacted version of the document in August 2016.

Obama's Presidential Policy Guidance states, "Lethal action should be taken in an effort to prevent terrorist attacks against U.S. persons only when capture of an individual is not feasible and no other reasonable alternatives exist to effectively address the threat." The 18-page document also states that lethal action can be taken only against lawful targets who pose a "continuing, imminent threat," a determination that is made by the "nominating department's or agency's counsel" and is subject to legal review. There must also be a "near certainty" that the action will not kill civilians, termed "non-combatants" in the Presidential Policy Guidance.

The Presidential Policy Guidance release followed a separate drone program disclosure just one month prior. In July 2016, the White House released Obama's executive order on "United States Policy on Preand Post-Strike Measures to Address Civilian Casualties in U.S. Operations Involving the Use of Force," which outlined best practices to avoid civilian casualties. ${ }^{87}$ The U.S. government "routinely imposes certain heightened policy standards that are more protective" than required by the law of armed conflict, according to the document. ${ }^{88}$

In accordance with these standards, the order says the agencies involved in lethal activities must accept responsibility for civilian casualties and "offer condolences, including ex gratia payments" to injured civilians or the families of those killed. ${ }^{89}$ Obama's directive also required an unclassified summary of strike information, including civilian casualties, no later than May 1,2017, and by May 1 of each subsequent year. ${ }^{90}$

A supplemental fact sheet accompanying the executive order included a release of aggregate data on lethal strikes undertaken against terrorist targets by the Obama administration..$^{91}$ The Office of the Director of National Intelligence estimated the civilian death toll from the covert drone program to be between 64 and 116 from January 20, 2009, to December 31, 2015, which was below the estimates of independent organizations such as New America. ${ }^{92}$ Across Pakistan and Yemen, drone strikes and other counterterrorism 
operations killed an estimated 218 to 263 civilians during this period, according to New America data. New America recorded no civilian casualties in Somalia during this period.

In 2013, Obama signaled plans to transfer the drone program in Yemen to the Pentagon. This resulted in a years-long push by the White House to have the Department of Defense run the program in the interests of transparency and greater oversight. ${ }^{93}$ This move, however, garnered bipartisan pushback in Congress, including leaders on the House and Senate Intelligence Committees, who said the CIA had a more robust intelligence infrastructure for conducting precise strikes. ${ }^{94}$ In 2016, the U.S. military began reporting strikes in Yemen and Somalia in press releases, indicating that the program had, in fact, been transferred to the Pentagon. ${ }^{95}$

As of November 2020, much of the U.S. drone program has been transferred from the CIA to the Department of Defense, although there were efforts by the Trump administration to expand the CIA's authority over the program. ${ }^{96}$ The U.S. military has long operated armed drones throughout the wars in Afghanistan and Iraq and the conflict in Syria. ${ }^{97}$ The CIA has always overseen the U.S. drone program in Pakistan, and both the CIA and Joint Special Operations Command have conducted drone strikes in Yemen.

In 2017, the Air Force retired the MQ-1 Predator drone, which the United States had used to conduct its first drone strikes in the wake of $9 / 11 .{ }^{98}$ The Predator's replacement, the similarly designed but much larger MQ-9 Reaper, is outfitted with a two-ton payload, a significant increase from the maximum 200pound payload of missiles and bombs that the Predator could carry at a given time. It is the reconnaissance ability of drones that makes the Reaper's option of carrying two tons of missiles and bombs a more effective counterterrorism weapon than, for instance, an F-16 that carries a similar payload but cannot surveil potential targets for hours.

The U.S. drone program has influenced global drone production and drone use in combat. On September 7, 2015, Pakistan conducted a drone strike-using an indigenously built drone-in the Shawal Valley in North Waziristan, a tribal region bordering Afghanistan. ${ }^{99}$ Three "high-profile" terrorists were killed, according to a Pakistan Army spokesman. ${ }^{100}$ While the U.S. sells armed drones only to select allied nations, ${ }^{101}$ China is a growing drone exporter and has filled gaps in the market with its more liberal export policy. ${ }^{102}$

In December 2015, Iraqi armed forces released video footage of a Chinese Cai Hong-4 blasting an Islamic State position in Ramadi. ${ }^{103}$ A photo appeared on an online blog in January 2015 of a crashed Chinese-made drone in Nigeria. ${ }^{104}$ On February 3, 2016, Nigeria reported the military's first use of an armed drone, striking at the militant group Boko Haram. ${ }^{105}$ Nigeria used the Chinese Cai Hong-3 to conduct the strike. ${ }^{106}$

\section{Conclusion}

Armed drones raise a number of moral and political questions. In Pakistan, the CIA drone campaign is deeply unpopular because many Pakistanis ask themselves: What gives the United States the right to invade the sovereign airspace of our nation and sometimes kill our civilians, even in the service of the laudable goal of killing al-Qaida and Taliban militants?

That said, the ability of drones to linger over and assess a target for many hours, and then act against that target immediately, is a capability that can quite dramatically lower the civilian casualty rates typical of earlier eras of warfare. A drone can provide a heightened level of distinction between combatants and non-combatants because it can loiter at length over a target. In that sense, there is a case to be made that armed drones presage a more ethical form of warfare that kills fewer civilians.

It is not an accident that the rise of drone warfare has coincided with America's unconventional war against al-Qaida and its allies. In conventional wars, armies wearing uniforms attack each other. Yet with 
the type of drone warfare that the United States has conducted since 9/11 outside of conventional war zones in countries such as Pakistan and Yemen, drone strikes are not directed at individuals because of their status as a uniformed member of another military force but rather because of the individual's suspected connection to al-Qaida or an allied militant group.

In many ways, the use of armed drones is akin to the use of cyber warfare. Both tactics greatly reduce or eliminate the deaths that would result from a conventional armed conflict. Whoever launches a drone attack or a cyberattack pays no costs of the kind that would typically take place on a conventional battlefield. An adversary cannot shoot down a drone pilot or kill a computer technician launching a cyberattack thousands of miles from the intended target. For this reason, an argument can be made that drones and cyber capabilities can make conflict more likely, as the barriers to engage in either drone warfare or cyber conflict are relatively low.

Drones have also consolidated military and intelligence roles such as reconnaissance, data collection, targeting, communications, and killing into a single platform, making drones the counterterrorism weapon of choice for three very different U.S. presidents. The fact that Presidents Bush, Obama, and Trump all embraced armed drones as a key counterterrorism tool underlines that this tactic is now an embedded feature of U.S. national security policy.

\section{Notes}

1 Thanks to David Sterman and Albert Ford for their input on this chapter. Also, thanks to Joshua Geltzer, Luke Hartig, and Daniel Rothenberg for their feedback. Thanks to Ethan Walker and Brianna Kablack for their help with footnotes, data updates, and appendices.

2 Thomas Gibbons-Neff, "U.S. Airstrike Kills More Than 150 at Somalia Terrorist Camp, Military Says," Washington Post, March 7, 2016, www.washingtonpost.com/news/checkpoint/wp/2016/03/07/u-s-drone-strikekills-more-than-150-in-somalia/.

3 Ibid.; Helene Cooper, "U.S. Strikes in Somalia Kill 150 Shabaab Fighters," New York Times, March 7, 2016, www. nytimes.com/2016/03/08/world/africa/us-airstrikes-somalia.html.

4 Chris Woods, "The Story of America's Very First Drone Strike," The Atlantic, May 30, 2015, www.theatlantic. com/international/archive/2015/05/america-first-drone-strike-afghanistan/394463/; James Cavallaro, Stephan Sonnenberg, and Sarah Knuckey, Living Under Drones: Death, Injury, and Trauma to Civilians From US Drone Practices in Pakistan (Stanford: International Human Rights and Conflict Resolution Clinic, 2012), 11-12.

5 In this chapter, the term "counterterrorism operations" includes drone strikes and U.S. Special Operations Forces ground raids.

6 Barton Gellman and Ashkan Soltani, "NSA Surveillance Program Reaches 'Into the Past' to Retrieve, Replay Phone Calls," Washington Post, March 18, 2014, www.washingtonpost.com/world/national-security/nsa-surveillance-program-reaches-into-the-past-to-retrieve-replay-phone-calls/2014/03/18/226d2646-ade9-11e3-a49e76adc9210f19_story.html.

7 This passage draws from Daniel Rothenberg, "Drones and the Emergence of Data-Driven Warfare," in Drone Wars: Transforming Conflict, Law, and Policy, ed. Peter Bergen and Daniel Rothenberg (New York: Cambridge University Press, 2014), 441-462; Peter Bergen "Drones Will Fill the Sky," CNN, May 13, 2014, www.newamerica.org/ international-security/articles/drones-will-fill-the-sky/.

8 Spencer Ackerman and Noah Shachtman, "Almost 1 in 3 U.S. Warplanes Is a Robot," Wired, January 9, 2012, www.wired.com/2012/01/drone-report/.

9 Since 2011, Libya has been both a conventional war zone authorized by the United Nations and a nontraditional battlefield.

10 Authorization for Use of Military Force, Pub. L. No. 107-40 \1, 115 Stat. 225 (2001), www.congress.gov/107/ plaws/publ40/PLAW-107publ40.pdf.

11 Ibid.

12 Ibid.

13 Office of the Historian, Foreign Relations of the United States, 1945-1950, Emergence of the Intelligence Establishment: National Security Council Directive on Office of Special Projects (Washington, DC: U.S. Department of State, 1948).

14 Fred Kaplan, “The First Drone Strike," Slate, September 14, 2016, https://slate.com/news-and-politics/2016/09/ahistory-of-the-armed-drone.html. 
15 Peter Bergen, The Longest War: The Enduring Conflict Between America and Al-Qaeda (New York: Simon and Schuster, 2011), 45.

16 Ibid.

17 Woods, "The Story of America's Very First Drone Strike."

18 "Operation Enduring Freedom Fast Facts," CNN, October 5, 2016, www.cnn.com/2013/10/28/world/opera tion-enduring-freedom-fast-facts/index.html.

19 Peter Bergen, Manhunt: From 9/11 to Abbottabad - The Ten-Year Search for Osama Bin Laden (London: The Bodley Head, 2012), 39.

20 Ibid.

21 Mark Mazzetti, “A Secret Deal on Drones, Signed in Blood," New York Times, April 6, 2013, www.nytimes. com/2013/04/07/world/asia/origins-of-cias-not-so-secret-drone-war-in-pakistan.html.

22 Peter Bergen and Katherine Tiedemann, “The Drone War," The New Republic, June 3, 2009, https://newrepublic. com/article/61767/the-drone-war.

23 Ibid.

24 “America's Counterterrorism Wars-Drone Strikes: Pakistan," New America, 2017, www.newamerica.org/ in-depth/americas-counterterrorism-wars/pakistan/.

25 Bergen and Tiedemann, "The Drone War."

26 Peter Bergen and Jennifer Rowland, “Drone Wars,” The Washington Quarterly 36, no. 3 (2013): 7-26.

27 "America's Counterterrorism Wars-Drone Strikes: Pakistan."

28 Ibid.

29 Ibid.

30 Eric Schmitt, "U.S. to Step Up Drone Strikes in Yemen," New York Times, April 25, 2012, www.nytimes. com/2012/04/26/world/middleeast/us-to-step-up-drone-strikes-inside-yemen.html.

31 "America's Counterterrorism Wars-Drone Strikes: Pakistan."

32 These percentages are based on New America data.

33 Zahir Shah Sherazi, "US Drone Strikes in Orakzai Kill 16 Suspected Militants," Dawn, October 11, 2012, www. dawn.com/news/755894/us-drone-attack-kills-five-suspected-militants-in-orakzai-agency.

34 Helene Cooper and Eric Schmitt, "U.S. Officials Debate Speeding Afghan Pullout," New York Times, March 13, 2012, www.nytimes.com/2012/03/13/world/asia/us-officials-debate-speeding-up-afghan-pullout.html.

35 Salman Masood, “C.I.A. Leaves Base in Pakistan Used for Drone Strikes,” New York Times, December 11, 2011, www.nytimes.com/2011/12/12/world/asia/cia-leaves-pakistan-base-used-for-drone-strikes.html.

36 Adam Entous, Siobhan Gorman, and Julian E. Barnes, "U.S. Tightens Drone Rules," Wall Street Journal, November 4, 2011, www.wsj.com/articles/SB10001424052970204621904577013982672973836.

37 "Public Opinion about Drone Strikes in Pakistan," Gallup Pakistan, December 7, 2013, https://gallup.com.pk/ bb_old_site/pollsshow.php?id=2013-12-07.

38 The data in this figure is drawn from research conducted by the authors and New America.

39 Peter Bergen and David Sterman, "Will President Trump Restart the Drone War in Pakistan?" CNN, January 21, 2017, www.cnn.com/2017/01/21/opinions/trump-drone-war-in-pakistan-bergen-sterman/index.html.

40 Scott Shane, "Inside Al Qaeda's Plot to Blow Up an American Airliner," New York Times, February 22, 2017, www. nytimes.com/2017/02/22/us/politics/anwar-awlaki-underwear-bomber-abdulmutallab.html.

41 Peter Bergen, United States of Jihad: Investigating America's Homegrown Terrorists (New York: Crown Publishers, 2016), 203.

42 A small number of the 185 strikes conducted in Yemen under Obama were cruise missile strikes or ground operations by Special Operations Forces.

43 “America's Counterterrorism Wars—Drone Strikes: Yemen," New America, 2017, www.newamerica.org/in-depth/ americas-counterterrorism-wars/us-targeted-killing-program-yemen/.

44 Peter Bergen, “Obama's High-Stakes Drone War in Yemen," CNN, April 21, 2014, www.cnn.com/2014/04/21/ opinion/bergen-yemen-obama-drone-war/index.html.

45 Jo Becker and Scott Shane, "Secret 'Kill List' Proves a Test of Obama's Principles and Will," New York Times, May 29, 2012, www.nytimes.com/2012/05/29/world/obamas-leadership-in-war-on-al-qaeda.html.

46 Ibid.

47 Peter Bergen, "The American Who Inspires Terror From Paris to the U.S.," CNN, January 12, 2015, www.cnn. com/2015/01/11/opinion/bergen-american-terrorism-leader-paris-attack/index.html.

48 Ibid.

49 Office of the Assistant Attorney General, "Memorandum for the Attorney General Re: Applicability of Federal Criminal Laws and the Constitution to Contemplated Lethal Operations Against Shaykh Anwar al-Aulaqi" (official memorandum, Washington, DC: Department of Justice, 2010). 
50 Michael Isikoff, "Justice Department Memo Reveals Legal Case for Drone Strikes on Americans," NBC News, February 5, 2013.

51 Mark Mazzetti, Eric Schmitt and Robert F. Worth, "Two-Year Manhunt Led to Killing of Awlaki in Yemen," New York Times, September 30, 2011, www.nytimes.com/2011/10/01/world/middleeast/anwar-al-awlaki-is-killed-inyemen.html.

52 Peter Finn and Greg Miller, "Anwar al-Awlaki’s Family Speaks Out Against His, Son's Deaths," Washington Post, October 17, 2011, www.washingtonpost.com/world/national-security/anwar-al-awlakis-family-speaks-outagainst-his-sons-deaths/2011/10/17/gIQA8kFssL_story.html.

53 The data in this figure is drawn from research conducted by the authors and New America; data for 2020 is through December 1, 2020.

54 Saeed al-Batati and Kareem Fahim, "Affiliate of Al Qaeda Seizes Major Yemeni City, Driving Out the Military," New York Times, April 3, 2015, www.nytimes.com/2015/04/04/world/middleeast/al-qaeda-al-mukallayemen.html; "America's Counterterrorism Wars—Drone Strikes: Yemen."

55 Ibid.; "America's Counterterrorism Wars—Drone Strikes: Pakistan."

56 Bergen, "Drones Will Fill the Sky."

57 Charlie Savage and Eric Schmitt, "Trump Is Said to Be Working to Loosen Counterterrorism Rules," New York Times, March 12, 2017, www.nytimes.com/2017/03/12/us/politics/trump-loosen-counterterrorism-rules.html; Paul D. Shinkman, “'Areas of Active Hostilities': Trump's Troubling Increases to Obama's Wars,” U.S. News \& World Report, May 16, 2017, www.usnews.com/news/world/articles/2017-05-16/areas-of-active-hostilities-trumpstroubling-increases-to-obamas-wars.

58 Charlie Savage and Eric Schmitt, "Trump Eases Combat Rules in Somalia Intended to Protect Civilians," New York Times, March 30, 2017, www.nytimes.com/2017/03/30/world/africa/trump-is-said-to-ease-combat-rulesin-somalia-designed-to-protect-civilians.html.

59 "Transcript: Telephonic Press Briefing with AFRICOM, MNJTF, AMISOM Commanders on African Security," Global Sentinel, April 21, 2017, https://globalsentinelng.com/2017/04/21/transcript-telephonic-pressbriefing-africom-mnjtf-amisom-commanders-african-security/.

60 The data in this figure is drawn from research conducted by the authors and New America; data for 2020 is through December 1, 2020.

61 Peter Bergen, “A Gripping Glimpse into Bin Laden's Decline and Fall," CNN, March 12, 2015, www.cnn. com/2015/03/10/opinions/bergen-bin-laden-al-qaeda-decline-fall/index.html.

62 Usama bin Ladin, "Letter from UBL to 'Atiyatullah Al-Libi 2," SOCOM-2012-0000010, April 26, 2011, 8, https://ctc.usma.edu/wp-content/uploads/2013/10/Letter-from-UBL-to-Atiyatullah-Al-Libi-2-Translation.pdf; Usama Bin Ladin, "Letter from UBL to "Atiyatullah Al-Libi 3," SOCOM-2012-00000015, October 21, 2010, https://ctc.usma.edu/wp-content/uploads/2013/10/Letter-from-UBL-to-Atiyatullah-Al-Libi-3-Translation1.pdf.

63 David Rohde, "My Guards Absolutely Feared Drones: Reflection on Being Held Captive for Seven Months by the Taliban," in Drone Wars: Transforming Conflict, Law, and Policy, ed. Peter Bergen and Daniel Rothenberg (New York: Cambridge University Press, 2014), 9-11.

64 Declan Walsh and Eric Schmitt, "Drone Strike Killed No. 2 in Al Qaeda, U.S. Officials Say," New York Times, June 5, 2012. www.nytimes.com/2012/06/06/world/asia/qaeda-deputy-killed-in-drone-strike-in-pakistan. html.

65 Peter Bergen, “Al Qaeda's Bench of Leaders Dwindles," CNN, April 14, 2015, www.cnn.com/2015/04/14/opinions/al-qaeda-fading-peter-bergen/index.html.

66 Ibid.

67 Patrick Johnston and Anoop Sarbahi, "The Impact of US Drones Strikes on Terrorism in Pakistan," International Studies Quarterly 60, no. 2 (2016): 203-219.

68 Scott Shane, "C.I.A. Is Disputed on Civilian Toll in Drone Strikes," New York Times, August 11, 2011, www. nytimes.com/2011/08/12/world/asia/12drones.html.

69 "America's Counterterrorism Wars-Drone Strikes: Pakistan."

70 It has been reported that the Obama administration considered any military-age male in the strike target area a "militant." Our data, however, is not based on the official U.S. definition of a militant and does not rely on any official U.S. counting of the strikes. Rather, we record a militant only as someone identified in credible news reports as a militant or a "suspected militant." Credible news reports must come from certain respected media outlets. We judge a variety of sources to be credible in collecting information, including the Associated Press, Reuters, and Agence France-Presse; the New York Times, the Washington Post, the Los Angeles Times, and the Wall Street Journal; the British newspapers The Telegraph and The Guardian; the Pakistani news outlets The Express Tribune, Dawn, The Daily Times, Geo TV, and The News; and the BBC and CNN. The majority of these sources acquire information on CIA drone strikes in Pakistan from Pakistani intelligence, security, and local government officials, as well as local 
villagers. With such a range of sources, one can be reasonably sure that the data avoids the official U.S. government definition of a militant. If two or more media reports refer to those killed as militants, they are labeled as militants in our data. Similarly, if two or more media reports refer to those killed as civilians, they go under the civilian column. The murkiness of some reporting in the tribal regions of Pakistan and in Yemen led our researchers to designate another category for "unknown" casualties, which are assigned if different media reports on a single strike are so contradictory that researchers do not feel comfortable placing either label on those killed.

71 Becker and Shane, "Secret 'Kill List'."

72 The data in this figure is drawn from research conducted by the authors and New America. This graphic likely undercounts the number of deaths in Yemen in 2017 due to gaps in CENTCOM data on strike date and location. Data for 2020 is through December 1, 2020.

73 Bergen and Rowland, "Drone Wars."

74 Joby Warrick and Peter Finn, "Amid Outrage Over Civilian Deaths in Pakistan, CIA Turns to Smaller Missiles," Washington Post, April 26, 2010.

75 Peter Bergen and Jennifer Rowland, "Drones Decimating Taliban in Pakistan," CNN, July 3, 2012, www.cnn. com/2012/07/03/opinion/bergen-drones-taliban-pakistan/index.html.

76 “Bajwa Terms US Drone Strike Counterproductive," Dawn, June 15, 2017, www.dawn.com/news/1339621/ bajwa-terms-us-drone-strike-counterproductive.

77 “A Less Gloomy Mood in Pakistan,” Pew Research Center, August 27, 2014, www.pewresearch.org/ global/2014/08/27/a-less-gloomy-mood-in-pakistan/.

78 “Pakistani Public Opinion Ever More Critical of U.S.," Pew Research Center, June 27, 2012, www.pewresearch.org/ global/2012/06/27/pakistani-public-opinion-ever-more-critical-of-u-s/.

79 Lorraine Adams and Ayesha Nasir, "Inside the Mind of the Times Square Bomber," Guardian, September 18, 2010, www.theguardian.com/world/2010/sep/19/times-square-bomber.

80 Richard Leiby, "Pakistan Calls for End to U.S. Drone Attacks," Washington Post, April 12, 2012, www.washingtonpost.com/world/pakistan-calls-for-end-to-us-drone-attacks/2012/04/12/gIQAN1ZFDT_story.html.

81 Nic Robertson and Chris Botelho, "Ex-Pakistani President Musharraf Admits Secret Deal With U.S. on Drone Strikes," CNN, April 12, 2013, www.cnn.com/2013/04/11/world/asia/pakistan-musharraf-drones/index.html.

82 "Public Continues to Back U.S. Drone Attacks," Pew Research Center, May 28, 2015, www.pewresearch.org/ politics/2015/05/28/public-continues-to-back-u-s-drone-attacks/.

83 Bergen and Rowland, "Drone Wars."

84 Ibid.; Bergen and Rowland, "Drones Decimating Taliban."

85 “Obama's Speech on Drone Policy," New York Times, May 23, 2013, www.nytimes.com/2013/05/24/us/politics/ transcript-of-obamas-speech-on-drone-policy.html.

86 Karen DeYoung, "Newly Declassified Document Sheds Light on How President Approves Drone Strikes," Washington Post, August 6, 2016, www.washingtonpost.com/world/national-security/newly-declassified-documentsheds-light-on-how-president-approves-drone-strikes/2016/08/06/f424fe50-5be0-11e6-831d-0324760ca856_ story.html.

87 Office of the Press Secretary, Executive Order-United States Policy on Pre- and Post-Strike Measures to Address Civilian Casualties in the US Operations Involving Use of Force (Washington, DC: White House, 2016).

88 Ibid.

89 Ibid.

90 Ibid.

91 Ibid.

92 "Summary of Information Regarding U.S. Counterterrorism Strikes Outside Areas of Active Hostilities," Office of the Director of National Intelligence, July 1, 2016, www.dni.gov/index.php/newsroom/reports-publications/reportspublications-2016/item/1607-summary-of-information-regarding-u-s-counterterrorism-strikes-outside-areas-ofactive-hostilities.

93 Jack Goldsmith, "Questions About CIA v. DOD Drone Strikes," Lawfare (blog), May 13, 2014, www.lawfareblog. com/questions-about-cia-v-dod-drone-strikes.

94 Jim Acosta, "Obama to Make New Push to Shift Control of Drones from CIA to Pentagon," CNN, April 27, 2015, www.cnn.com/2015/04/27/politics/drones-cia-pentagon-white-house/index.html; Greg Miller, "Obama's New Drone Policy Leaves Room for CIA Role," Washington Post, May 25, 2013, www.washingtonpost.com/ world/national-security/obamas-new-drone-policy-has-cause-for-concern/2013/05/25/0daad8be-c480-11e2914f-a7aba60512a7_story.html.

95 "U.S. Central Command Announces Yemen Counterterrorism Strikes," U.S. Central Command, May 9, 2016, www.defense.gov/Explore/News/Article/Article/755391/us-central-command-announces-yemen-counter terrorism-strikes/; "U.S. Forces Conduct Defensive Fires in Somalia Against al-Shabaab Terrorists in May," U.S. 
Africa Command, June 17, 2016, www.africom.mil/pressrelease/28236/u-s-forces-conduct-defensive-fires-insomalia-against-al-shabaab-terrorists-in-may.

96 Eric Schmitt and Matthew Rosenberg, "C.I.A. Wants Authority to Conduct Drone Strikes in Afghanistan for the First Time," New York Times, September 15, 2017, www.nytimes.com/2017/09/15/us/politics/cia-drone-strikeauthority-afghanistan.html.

97 Dan Gettinger, Drone Operating in Syria and Iraq (Annandale-On-Hudson, NY: Center for the Study of the Drone, 2016).

98 Christian Clausen, "Air Force to Retire MQ-1 Predator Drone, Transition to MQ-9 Reaper," U.S. Department of Defense, February 27, 2017, www.defense.gov/Explore/News/Article/Article/1095612/air-force-to-retiremq-1-predator-drone-transition-to-mq-9-reaper/.

99 Mateen Haider, “Three Killed in Military's First Drone Strike in North Waziristan,” Dawn, September 7, 2015, www.dawn.com/news/1205455.

100 Ibid.

101 Missy Ryan, "Obama Administration to Allow Sales of Armed Drones to Allies," Washington Post, February 17, 2015, www.latimes.com/nation/la-na-drone-sales-20150217-story.html.

102 ValerieInsinna, “GeneralAtomics:ExportRestrictionsHelpChina GrowItsDrone Tech,” Defense News, August18,2017, www.defensenews.com/air/2017/08/18/general-atomics-export-restrictions-help-china-grow-its-drone-tech/.

103 Patrick Boehler and Gerry Doyle, "Use by Iraqi Military May Be a Boon for China-Made Drones," New York Times, December 17, 2015, www.nytimes.com/2015/12/18/business/international/china-drone-export-iraq.html.

104 Jeffrey Lin and P.W. Singer, "Did an Armed Chinese-Made Drone Just Crash in Nigeria?” Popular Science, January 28, 2015, www.popsci.com/did-armed-chinese-made-drone-just-crash-nigeria/.

105 Kelsey D. Atherton, "Watch Nigeria's First Confirmed Drone Strike-Against Boko Haram: Video Proof of a Long-Suspected Weapon,” Popular Science, February 3, 2016, www.popsci.com/watch-nigerias-first-confirmeddrone-strike/.

106 Ibid. 


\title{
34 \\ THE UNITED KINGDOM'S APPROACH TO COUNTERTERRORISM
}

\author{
Robin Simcox and Hannah Stuart
}

The United Kingdom suffered its first major Islamist terrorist attack on July 7, 2005. In the years that followed, it faced several more attacks, including five separate incidents in 2017. ${ }^{1}$ Since September 2001, acts of terrorism carried out in Great Britain ${ }^{2}$ have led to 97 deaths. ${ }^{3}$

The United Kingdom had hosted, and even provided refuge to, Islamist-inspired activists long before it began to be targeted by jihadi terrorists. These activists helped embed Islamist perspectives and attitudes within elements of Britain's Muslim communities that likely made jihadi recruiters' task easier in the decades to come.

This chapter offers a brief overview of the origins of Islamism in the United Kingdom. It then explains how the 9/11 attacks resulted in the United Kingdom fighting terrorism abroad to prevent attacks on British soil. Next, it discusses the impact of the London bombings in 2005, which caused the United Kingdom to focus its counterterrorism approach on homegrown terrorism. It then examines the impact of the Islamic State and its self-proclaimed caliphate on the United Kingdom. Finally, the chapter briefly examines the diversity of European responses in combating Islamist terrorism.

\section{Islamism in the United Kingdom}

The Islamist terrorism threat to the United Kingdom today comes predominantly from Salafi-jihadi groups, such as the Islamic State and al-Qaida. ${ }^{4}$ The broader spectrum of Islamism-understood as the organized effort to advocate for Sharia (Islamic law) as the basis for society and the state- has a distinct history in Britain dating back decades. ${ }^{5}$

Mainstream Islamism has its origins in two 20th-century movements, al-Ikhwan al-Muslimin (est. 1928, Egypt), known as the Muslim Brotherhood, and Jamaat-i-Islami (est. 1941, India) in South Asia. ${ }^{6}$ While Islamists in the West today have mostly abandoned the aim of a Sharia-governed state in their own country for now, they belong to a trans-ethnic network of like-minded individuals and groups that work through institutions and mosque networks to revive their understanding of Islam in all aspects of social and political life. ${ }^{7}$ In the United Kingdom, mainstream Islamists sometimes refer to themselves as the "Islamic Movement" and operate across multiple spheres, including education, welfare, community activism, media, and advocacy.

These organizations comprised mainly exiles and overseas students. Fifty years ago, many Muslim Brotherhood-inspired groups in the United Kingdom prioritized recruiting members who would support 
the cause in the Middle East. ${ }^{8}$ Other older Jamaati-i-Islami inspired groups were established to serve specific ethnic or linguistic Muslim communities living in the United Kingdom. ${ }^{9}$

From the 1980s and 1990s onwards, however, mainstream Islamists developed a more cohesive approach to engaging with Britain's diverse settled Muslim communities, resulting in the creation of several ostensibly national, umbrella Muslim bodies. Groups such as the Muslim Association of Britain and the Muslim Council of Britain sought to promote their Islamist views and to serve as interlocutors between the government, British Muslims, and recently the media. ${ }^{10}$

This new strategy was in part a response to challenges posed by militant Salafis to the authority of Britain's Brotherhood and Jamaati-inspired groups. These militant Salafis had returned to the United Kingdom having fought with the mujahidin in Afghanistan during the war against the Soviet Union and the factional fighting that followed. ${ }^{11}$ Several high-profile exiles and former mujahidin claimed asylum in the United Kingdom in the 1980s and 1990s and promoted Salafi-jihadi ideas among young British Muslims. ${ }^{12}$ Preaching in mosques across the country—but particularly focused on London-these clerics helped inject international jihadi causes into the bloodstream of British Islam.

Key to this was Bosnia, where Western inaction in response to the persecution of Muslims-which included, most emotively and profoundly, the Serb slaughter of Bosniak Muslims in Srebrenica in July 1995-energized an Islamist narrative that warned that when it came to Muslim suffering, nonMuslims were at best indifferent and worst complicit. ${ }^{13} \mathrm{~A}$ small number of Brits headed to Bosnia to fight in defense of Muslims, with pro-mujahidin online forums subsequently glorifying their "martyrdom." 14 Survivors of the conflict emerged as key Islamist recruiters for years to come, in part due to the legitimacy that fighting in Bosnia bestowed upon them in certain circles. ${ }^{15}$

In addition, Brotherhood and Jamaati Islamist groups were also being challenged by the emergence in the United Kingdom of revolutionary Islamist groups Hizb ut-Tahrir and al-Muhajiroun, which, dissatisfied with the gradualist approach of mainstream Islamist groups, advocated a more radical means to capture state power. ${ }^{16}$

A violent brand of Islamism was clearly developing in the United Kingdom. Yet the presence of these extremist discourses, such as justifying suicide bombing and the killing of civilians overseas, was tacitly tolerated by the British authorities in return for self-policing and an understanding that there would be no bombs on the streets of the United Kingdom. ${ }^{17}$

It would later become clear that such Islamist ideologues had paved the way-ideologically and operationally - for the al-Qaida networks operating in the United Kingdom in the 2000s. ${ }^{18}$ Yet it was not in the United Kingdom where Western policymakers first had to confront how devastating a lax approach toward this increasingly ambitious Salafi-jihadi movement could be. It was in the United States.

\section{The impact of the 9/11 attacks on the UK}

The British government's support for the United States following al-Qaida's terrorist attacks on September 11, 2001, was unflinching. Prime Minister Tony Blair proclaimed that the United Kingdom would "stand shoulder to shoulder" with the United States and that "we, like them, will not rest until this evil is driven from our world." ${ }^{19}$ They were not empty words. On October 7, 2001, Blair announced that British forces were fighting at the side of U.S. soldiers in Afghanistan, targeting al-Qaida and the Taliban. The Special Air Service were deployed on the ground while the Royal Navy targeted terrorist training camps and bases from the sea. ${ }^{20}$

Soon enough, British troops discovered that they were fighting against some of their own countrymen on the battlefield: British Muslims who had left to defend the Taliban and al-Qaida. ${ }^{21}$ Reports quickly emerged of British Muslims killed in the fighting. ${ }^{22}$ Others ended up detained at Guantanamo Bay (although most would later claim to be innocent of taking part in any fighting). ${ }^{23}$ 
Inevitably, the United Kingdom began to contemplate how best to avoid a domestic attack. It had faced a tiny number of Islamist terrorist plots prior to $9 / 11 .{ }^{24}$ The most significant was planned by Moinul Abedin, who had trained in the Afghanistan-Pakistan region in 1996 and was arrested by British police in November 2000 over a nascent plan to use explosives. He was sentenced to 20 years in jail for what the judge described as "a serious plot." 25 But the perception of the threat in the wake of 9/11 was similar to the United States: how to strengthen one's defenses at home to stave off attacks planned overseas.

That meant updating legislation. In December 2001, the government passed the Anti-Terrorism, Crime and Security Act 2001. This legislation included a focus on increased intelligence sharing, terror financing, aviation security, as well as strengthening security around nuclear sites. ${ }^{26}$

It also strengthened government powers on immigration and asylum. The United Kingdom said it faced a "public emergency" from certain "foreign nationals . . . who are a threat to the national security of the United Kingdom." 27 Yet deportation was not an option the United Kingdom could easily pursue: these men were from countries with poor human rights records. A 1996 European Court of Human Rights ruling had established a precedent where national security concerns were essentially irrelevant when weighed against human rights of the individual. ${ }^{28}$ Therefore, any attempt to deport these men would lead to a breach of Article 3 of the European Convention on Human Rights (prohibition of torture).

The government subsequently signaled the United Kingdom's intent to derogate from parts of Article 5 of the European Convention on Human Rights, pertaining to the right to liberty and security, to be able to detain, without trial, foreign national security threats that it could not deport. ${ }^{29}$ The United Kingdom quickly arrested nine such terrorism suspects and detained them at Belmarsh Prison in southeast London. This included Abu Qatada, a Palestinian theologian close to various jihadi groups (including al-Qaida) and whom a litany of home secretaries would spend the next decade trying to deport back to Jordan.

When it could, the government also prosecuted Islamist ideologues based in the United Kingdom. In February 2002, for example, the British government charged Abdullah el-Faisal with offenses that ultimately resulted in his conviction of soliciting to murder and inciting racial hatred based on sermons where he urged his audiences to wage jihad. A Jamaican convert to Islam, el-Faisal preached to study groups and universities throughout the United Kingdom. ${ }^{30}$

There also was Abu Hamza al-Masri, the imam at Finsbury Park Mosque in north London, who had gained significant notoriety in the British press due to his incendiary speeches. ${ }^{31}$ In August 2004, he was arrested on charges that led to his conviction of multiple counts of soliciting to murder and inciting racial hatred based on speeches made between 1997 and 2000.

This state clampdown on jihadi preachers was a necessary, albeit belated, response to the pernicious influence they had wielded over the previous decade. Yet it became increasingly clear that such measures were inadequate. The ideas pumped out by foreign clerics had long been heard by British Muslims. ${ }^{32}$ Now they were beginning to act on them.

\section{The impact of the 7/7 London bombings on the UK}

On July 7, 2005 (known as “7/7”), four suicide bombings on the London transport network killed 52 people. It had a profound effect on how the government and wider society came to understand the nature of the threat it faced. The four al-Qaida-trained bombers-led by special needs teaching assistant Mohammed Sidique Khan — had all been raised in the United Kingdom. Islamism was no longer primarily viewed as a foreign threat; instead, the terms "homegrown" and "radicalization" were commonly utilized by those seeking to explain how and why the attack had happened.

Speaking in a strong Yorkshire accent in a video released after the attack, Khan told his fellow Britons, "Your democratically elected governments continuously perpetuate atrocities against my people all over the world," before making the case that he is "directly responsible for protecting and avenging my Muslim 
brothers and sisters." While ostensibly an expression of anger at British foreign policy, Khan's language revealed that he saw himself as a "true inheritor of the prophet," defending Islam from the West. "We are at war," he said, "and I am a soldier." 33

Responding to public alarm, Blair announced that "the rules of the game have changed" as he set out a series of commitments to keep the country safe. ${ }^{34}$ Some of these measures were introduced quickly, such as powers to exclude foreign nationals on the grounds of extremism-related "unacceptable behaviors." ${ }^{35}$ The Terrorism Act 2006 made it an offense to encourage or glorify terrorism. This paved the way that year for the proscription of al-Ghurabaa and the Saved Sect, the two names under which the extremist group al-Muhajiroun operated following then leader Omar Bakri Muhammed's public disbanding of the group in 2004.

This marked the first proscription of an Islamist group that was based and operated in the United Kingdom. ${ }^{36}$ Other measures - such as the proscription of Hizb-ut-Tahrir (out of which al-Muhajiroun had previously emerged $)^{37}$ and a power to order closure of places of worship for fomenting extremism-were abandoned, having been found disproportionate or unworkable.

Arguably, however, the area where Blair most influenced events was in his desire to root out Islamist extremism within Britain's Muslim communities. Under his leadership, the United Kingdom shifted away from relying solely on the traditional policing or military approach to counterterrorism that had characterized the conflict in Northern Ireland toward a focus on interventions and stopping people from being attracted to extremism and terrorism in the first place. This initiative was known as Prevent. ${ }^{38}$

Prevent began in the form of "Preventing Extremism Together" working groups with Muslim faith and community leaders. Set up to provide practical recommendations on the themes of young people, education, women, civil society, mosques, community security, and extremism, they published an action plan containing numerous recommendations, including a national advisory board for mosques and imams, a roadshow of Muslim scholars to counter extremist ideas, and actions to tackle assumed drivers of radicalization, such as inequality and discrimination. ${ }^{39}$

Four distinct approaches emerged to address the challenge of radicalization: tackling "disadvantages" and "grievances" that can contribute to radicalization, deterring or disrupting those who promote violent extremism, "engaging in the battle of ideas" to debunk the ideologies behind violence, ${ }^{40}$ and supporting individuals who may be vulnerable to recruitment by violent extremists—a precursor to today's safeguarding focus. ${ }^{41}$

In many ways, Prevent's approaches mirrored discussions in academia and policy institutions on how best to understand and respond to homegrown radicalization. Early debates had focused on the extent to which ideology was a driving factor attracting people to terrorism, as opposed to grievances, in particular foreign policy, and other drivers such as socioeconomics and disenfranchisement.

In the two years before the $7 / 7$ attacks, Khan had been a trustee at a charity bookshop. He had used the venue to give lectures, criticizing Western foreign policy, and supporting suicide bombing in Palestine after he had been moved on from several local mosques for "inappropriate behavior." ${ }^{2}$ Policymakers rightly raised questions around the role of institutions - such as mosques, charities, and gyms - the reach and influence of charismatic preachers, and the internet as venues for mobilization to engage in violent extremism.

Above all, Prevent envisaged "winning hearts and minds" through community-centered and community-led projects to tackle violent extremism at a local level..$^{43}$ Police involvement, however, led to accusations in the media that the strategy justified spying on Muslim communities ${ }^{44}$ and in academia that it blurred the lines between policing and the security services, securitizing Muslim communities, and integration efforts. ${ }^{45}$ The Equality and Human Rights Commission warned of a "danger that Muslims in contemporary Britain may become the new suspect community." ${ }^{66}$ The government was also quickly mired in Prevent funding and engagement controversies, some of which continue to this day. ${ }^{47}$ 
Mainstream Islamists and their supporters in government and public bodies had argued for the inclusion of more radical voices, so long as they were willing to reject terrorism in the United Kingdom. ${ }^{48}$ Influential foreign scholars, such as Muslim Brotherhood spiritual leader Yusuf al-Qaradawi, they argued, were well placed to tackle violent interpretations of Islam. ${ }^{49}$ Al-Qaradawi's form of political Islam was regarded as a "safety valve" for disaffected young Muslims who may otherwise have turned to terrorism in the UK homeland. In practice, this approach meant that government funding went to groups accused of having links to the Brotherhood, as well as to individuals and groups espousing views at odds with the United Kingdom's Western democratic values. ${ }^{50}$

For some, the line between supposedly non-violent political Islam and violent Islamist terrorism was not so clear. Momentum began to form around the notion that those who eschew terrorism in the United Kingdom but still believe that, in certain contexts, the targeting of civilians or Western forces in Muslimmajority countries is legitimate, or who agitate for the return of the caliphate, were not the solution. Instead, they were part of the problem and rather than having their voices amplified should instead be excluded from government counterextremism efforts. ${ }^{51}$

With the United Kingdom being the target of several other al-Qaida-linked plots in the years after 7/7, and with the threat showing no sign of abating, it was these more hawkish voices that increasingly gained prominence. This outlook found a voice in new Prime Minister David Cameron. In his 2011 Munich Security Conference speech, he argued for a shift away from the laissez-faire "doctrine of state multiculturalism," which had allowed people from different religions and backgrounds to live separate, parallel lives, and away from "passive tolerance" of intolerance. In seeking to confront the ideological challenge of Islamist extremism, he was clear that government and wider society should be more confident in its liberal values. ${ }^{52}$

In 2015, he remarked that the government needed to be clear about the ideological nature of the threat to better understand the ways in which Islamist extremists exploited grievances and injustice and not to accept their characterization of an oppressed Muslim community subject to attacks from Jews or the West. ${ }^{53}$

This revision in attitudes toward Islamists, both violent and non-violent, can be tracked to the election of the coalition government in 2010 and the subsequent independent review of Prevent. The 2011 review re-cast Prevent, transforming what was previously a narrow focus on opposing violent extremism (on British shores) into a commitment to respond to the "ideological challenge of terrorism," which included ruling out working with or funding organizations that did not accept the fundamental values of "universal human rights, equality before the law, democracy and full participation in our society." 54

Through Prevent, the United Kingdom attempted to head off the homegrown threat. All the while, however, it was also facing legal issues dating back to the 2001 Act after the nine foreign national terror suspects housed at Belmarsh Prison had appealed the legality of their detention to the European Court of Human Rights. In December 2004, the court ruled against the British government. It declared that the 2001 Act was incompatible with Article 5 (right to liberty and security), as the United Kingdom had not made the case that it faced a "public emergency threatening the life of the nation" and derogation from Article 5 to detain these terror suspects was a disproportionate response. It went on to conclude that the Act was also incompatible with Article 14 (prohibition of discrimination), as it was discriminating against the terror suspects based on their nationality. ${ }^{55}$

Despite the court ruling, the government deemed these terror suspects too dangerous to set free. It therefore passed the Prevention of Terrorism Act in March 2005, which allowed the government to place a terror suspect under a Control Order. ${ }^{56}$ This was a measure allowing the state to impose a series of restrictions on individuals to prevent or limit their involvement in suspected terrorist activities. It included home curfew, electronic tagging, banning travel abroad, relocation powers, and prohibiting the use of certain electronic devices. ${ }^{57}$

Control Orders, too, would face legal challenges that led to some of these restrictions becoming less onerous (for example, the length of home curfew) ${ }^{58}$ The system remained in place, however, until it was 
replaced by a new government with Terrorism Prevention and Investigation Measures in 2011, which paid lip service to being less intrusive toward terror suspects but were, for all intents and purposes, simply Control Orders repackaged and rebranded. ${ }^{59}$ These measures remain in operation today and can be served against British citizens as well as foreign nationals.

All the while, the fundamental issue that led to both detention without trial and then Control Ordersthe inability to deport foreign terror suspects to countries with poor human rights records-was being chipped away at the margins. The government negotiated deportation with assurances agreements with Algeria, Ethiopia, Jordan, Lebanon, Libya, and Morocco between 2005 and 2011, containing safeguards that allowed deportations to occur that did not imperil the human rights of the deportee nor contravene international law. ${ }^{60}$

The most symbolic victory for this approach occurred in July 2013, when extremist cleric Abu Qatada was sent to Jordan to face trial after sufficient assurances were received that no evidence gained via torture could be used against him during criminal hearings. In September 2014, Qatada was acquitted of terrorism offenses in Amman. ${ }^{61}$

\section{The caliphate and beyond}

On June 30, 2014, the Islamic State of Iraq and Syria declared a caliphate spanning from Diyala in eastern Iraq to Aleppo in northern Syria. The group renamed itself the Islamic State, and it began beheading Western hostages - including two British citizens - in grisly propaganda videos disseminated around the world. The balaclava-clad executioner had a British accent and was later revealed to be Mohammed Emwazi, a Kuwaiti-born and British-raised terrorist, who had left the United Kingdom for Syria in 2013.

With al-Qaida's leadership perceived by some as having been decimated, Emwazi helped sharpen minds within the government about the scale of the security problem the United Kingdom still faced. For several years, British citizens had been leaving to fight the Bashar al-Assad regime in Syria and joining rebel factions with varying commitment to Islamist ideology. Britons traveling to jihadi conflict zones around the world was nothing new. Syria and the call of the caliphate was on a different scale. Over 900 people would ultimately leave the United Kingdom for Syria. ${ }^{62}$ Approximately $20 \%$ would be killed there, with some $40 \%$ returning to the United Kingdom. ${ }^{63}$

Now, a Briton was on screens around the world beheading civilians and warning British citizens that the Islamic State "will continue to wage jihad, break borders and one day invade your land where we will rule by the Sharia." ${ }^{64}$ Finally, the government chose to step up its response to the foreign fighter phenomenon.

Most strikingly, the government targeted its own citizens overseas via drone strikes. In August 2015, the Royal Air Force killed Reyaad Khan in the Islamic State's capital of Raqqa, Syria. ${ }^{65}$ The government acted after British intelligence assessed that Khan and a fellow Brit-Junaid Hussain, who was killed in a U.S. drone strike in August 2015-were using social media to plan attacks in the West "on an unprecedented scale." ${ }^{6}$ This included plans to kill a U.S. airman stationed in the United Kingdom and a plot to target Victory in Europe Day and Armed Forces Day celebrations. ${ }^{67}$

The United Kingdom also increasingly used its citizenship-stripping powers of dual nationals who had left the country to engage in terrorist activity. This power, available to the government long before the conflict in Syria, began to be deployed far more regularly. ${ }^{6}$ Some, including a government independent reviewer, were critical of the policy due to a lack of due process. ${ }^{69}$

Yet the Immigration Act of 2014 strengthened these powers further, enabling the home secretary to strip even naturalized Brits of their citizenship provided it did not result in them being made stateless and the individual in question had "conducted him or herself in a manner which is seriously prejudicial to the vital interests of the United Kingdom.."70

More powers became available to the government following the Counter-Terrorism and Security Act 2015, with the government using the Royal Prerogative to provide police with the power to remove the 
passports "of those who want to travel abroad to engage in terrorism." ${ }^{\text {"1 }}$ In the same act, Temporary Exclusion Orders made it illegal for a British citizen "suspected of involvement in terrorist-related activity abroad" to return to the United Kingdom from overseas without checking with British authorities beforehand. ${ }^{72}$

This led police to question foreign fighters and, theoretically, increase the prospect of prosecution. Bringing such individuals to court, however, was an area where the United Kingdom has struggled: only $10 \%$ of foreign fighter returnees from Syria and Iraq have been prosecuted. ${ }^{73}$ This was due to jurisdictional, legal, and practical issues regarding the collection of evidence from a war zone and its subsequent use in a civilian court. ${ }^{74}$ Some legislative effort has been made to close loopholes to allow more prosecutions in the future. The Serious Crime Act 2015 amended the Terrorism Act 2006 to ensure that extra-territorial jurisdiction now applied to those preparing to commit or assist another in an act of terrorism or those who provide or receive terrorist training.

The government's logic was that

extending the territorial jurisdiction in respect of these offenses may allow for prosecutions of people preparing or training more generally for terrorism who have, for example, traveled from the United Kingdom to fight in Syria, where various terrorist groups, including al-Qaida affiliated groups, are involved in the conflict. ${ }^{75}$

While this is correct, it was also correct in the 1990s and in 2006 when the Terrorism Act was passed. Foreign fighter travel had simply not been treated with the seriousness it deserved until years into the Syria conflict.

The government also passed the Counter-Terrorism and Border Security Act 2019, which extended the extra-territorial jurisdiction the government had over terrorism offenses. ${ }^{76}$ It created an offense of "entering, or remaining in, an area outside the United Kingdom that has been designated in regulations made by the Home Secretary." ${ }^{\prime 7}$ In practice, this meant just the act of travel to a jihadi conflict zone such as Syria without a reasonable excuse was now an offense punishable by up to 10 years in prison. It could not, however, be applied retrospectively to foreign fighters who left the United Kingdom prior to the law being passed and was therefore of limited utility with regard to Syria. ${ }^{78}$

While updating legislation, the government also stepped up its efforts to tackle the upstream threat. In October 2015, it published the first ever Counter-Extremism Strategy, a groundbreaking attempt to address the wider harms of extremism. The strategy set out commitments for departments and regulators across government in five areas: increasing understanding of extremism, countering extremist ideology, building partnerships with those within communities opposing extremism, disrupting extremists, and building more cohesive communities. ${ }^{79}$

The strategy also promised new targeted powers-such as banning orders and disruption orders- to disrupt extremists and "key radicalizers" who spread extremist views but had not broken the law. ${ }^{80}$ The context for this was the deliberately provocative public activities of Anjem Choudhury, the extremist cleric and leader of al-Muhajiroun, whose Islamist supporters had murdered British soldier Lee Rigby in South London in May 2013. ${ }^{81}$

In his foreword to the strategy, Cameron was clear about its rationale:

We know that terrorism is really a symptom; ideology is the root cause. But the stakes are now rising. The menace of [the Islamic State] and the sophisticated efforts of extremists to groom and radicalize young British people demands a response of a different magnitude. ${ }^{82}$

In response to this uptick in the attractiveness of the Islamic State and its self-declared caliphate, the Counter-Extremism Strategy laid out plans for a cultural counterinsurgency to defeat Islamist extremism and address its root causes. 
In 2015, in response to increasing numbers of British citizens and residents leaving the United Kingdom for Syria, the government moved to place Prevent on a statutory footing, making it a legal requirement for the police, prisons, local authorities, schools, and universities to put in place safeguards to prevent people from being drawn into terrorism. Home Office data on the five years since the duty came into force shows between 5,700 and 7,000 individuals were referred to the program annually due to concerns that they were at risk of radicalization, with a smaller number subsequently referred for specialist, multi-agency support known as Channel..$^{83}$

Such moves were an understandable response to the latest iteration of the Islamist terrorism threat. In 2017, however, the counterterrorism apparatus was tested once again after three Islamist terrorist attacks occurred between March and June, with a fourth attack carried out by a far-right terrorist - motivated by an ideology of hate toward Muslims - shortly thereafter. Together, these attacks killed 36 people. Later in 2017, an Iraqi teenager, motivated by the Islamic State's extremism and a hatred of Britain, ${ }^{84}$ partially exploded a bomb on a London underground train, injuring over 50 people. ${ }^{85}$

These attacks made it clear that the nature of the terrorism threat was becoming increasingly complex and changing rapidly. ${ }^{86}$ In the years following the $7 / 7$ attacks, the most serious terrorists typically engaged in long-term planning that often involved explosives or terrorist training overseas. Al-Qaida had retained its ability to deliver centrally directed attacks in the United Kingdom, with suicide a frequent feature. ${ }^{87}$

Over time, however, terrorism had diversified to include less sophisticated methods, often using vehicles or knives with a relatively short planning period but with a lethal effect. For counterterrorism policing, online radicalization was also an increasingly common component of terrorism cases. The number and tempo of credible threats were high and evolving, with rapid, low-tech attacks featuring alongside more traditional sophisticated bombings.

In response, the United Kingdom attempted to ensure its counterterrorism apparatus remained fit for purpose to deal with this different type of threat. Its counterterrorism strategy, CONTEST, is built around four pillars: Prevent, to stop people becoming terrorists or supporting terrorism; Pursue, to stop terrorist attacks; Protect, to strengthen our protection against a terrorist attack; and Prepare, to mitigate the impact of a terrorist attack. The British government updated CONTEST in June 2018 to reflect the shift in capabilities in response to the evolving terrorism threat and to take into account the recommendations from MI5, the British security service, and the Counter Terrorism Policing's Operational Improvement Review. To improve operational effectiveness, several key themes emerged. ${ }^{88}$

First, the review made recommendations to improve the ability of MI5 and the police to exploit big data to better detect activity of concern across the spectrum of risk, from initial leads, through priority investigations, to closed subjects of interest.

Second, the review urged multi-agency work across the intelligence community and between MI5 and Counter Terrorism Policing. The 2017 attacks in London and Manchester highlighted the challenges of identifying potential attackers and the pace at which plots can move to violence. The review won a commitment by MI5 to allow knowledge derived from intelligence to be shared more widely beyond intelligence circles, enabling, for example, neighborhood policing to better understand risk and put in place early interventions.

Third, the review called for consistent assessment and investigation of all terrorist threats, notably the evolving and growing risk posed by far right terrorism. As a result, in April 2020, MI5 and the Joint Terrorism Analysis Center replaced the police as the lead agency for detecting far right terrorism. ${ }^{89}$

The shift in the nature of the terrorism threat has also led to a greater emphasis on the ways in which different counterterrorism working strands interact. CONTEST 2018 introduced leveraging people who have previously engaged in terrorism as a new element to Prevent. The Desistance and Disengagement Program was designed to manage the risk from returning foreign fighters or terrorism prisoners on license. It was also intended to complement the work being done under Pursue to "disrupt terrorist activity, 
including through prosecutions." ${ }^{90}$ The widening of Prevent to include working with people who had already crossed the threshold into criminal activity was a significant policy shift away from the program's previous emphasis on the "non-criminal" space. ${ }^{91}$

In the United Kingdom, as elsewhere, there has been a greater recognition on the ability of terrorist groups to exploit permissive spaces online and a corresponding focus on preventing the dissemination of terrorist material online. A unit within the Metropolitan Police's Counter Terrorism Command works with the internet companies to remove online content that incites or glorifies terrorism, ${ }^{92}$ and proscription of far right terrorist groups and their aliases is now seen as a tool to take down material associated with these groups. ${ }^{93}$

The United Kingdom is pursuing online safety legislation that would place responsibilities on technology companies regarding the management and removal of terrorist content. In December 2020, the government published its latest proposals for the upcoming Online Safety Bill, which will introduce a new duty of care on companies to improve user safety overseen by the independent regulator Ofcom. One contested area remains the responsibilities placed on certain (typically high-reach) technology companies for handling so-called "legal but harmful" content, which may include extremist or hate material. ${ }^{94}$

\section{Diversity of European response}

Islamist terrorism is clearly not just a concern for the United Kingdom. Terrorists have conducted attacks throughout Europe over the decades. How that has manifested itself country by country has varied slightly. The response to this, too, has widely differed.

In France, for example, the terrorism threat has a distinctive (although certainly not exclusive) homegrown element. High-profile attacks from the last decade-for example, Mohamed Merah's March 2012 shooting spree, the al-Qaida operation on Charlie Hebdo magazine in January 2015, and Amedy Coulibaly's attacks on police forces and Jewish civilians days later-were carried out by French citizens.

French citizens also formed the bulk of the cell that carried out the Islamic State's coordinated attacks across Paris in November 2015. The cell's ringleader, Abdelhamid Abaaoud, was Belgian, highlighting the localized element of the threat in France. In this regard, there are similarities between France and the United Kingdom, where $72 \%$ of all Islamism-related offenses committed between 1998 and 2015 were committed by UK nationals or individuals holding British nationality. ${ }^{95}$

The Islamist terrorist threat in other countries has less of a homegrown component. Germany is an obvious example of how security problems can be linked to asylum policies. Germany disrupted 11 terrorist plots between 2000 and 2013, ${ }^{96}$ suffering no major Islamist terrorist attacks in this period. ${ }^{97}$ Instead, Germany was largely focused on dealing with flare-ups from white supremacists. For example, neo-Nazi murders of Turkish small business owners at the turn of the century demonstrated a clear and ongoing issue with far-right terrorism. ${ }^{98}$

Then, between 2015 and 2017, Germany accepted nearly 1.5 million asylum seekers, mainly from Muslim-majority countries wracked by war: Afghanistan, Iraq, and Syria. ${ }^{99}$ Germany has suffered from numerous Islamist terrorist attacks since, a significant number of which were carried out by recent arrivals claiming asylum. ${ }^{100}$

The European attitude toward Muslim asylum seekers is far from universal. For example, Sweden took a similarly welcoming approach to Germany, accepting 163,000 asylum seekers in 2015. As a proportion of the population, this was the equivalent of the United States accepting over 5 million in a single year. Yet some Eastern European countries-Poland and Hungary, for example - took a far more guarded approach, explicitly citing security concerns. ${ }^{101}$

European countries have also placed contrasting levels of importance on early intervention programs similar to Prevent. Italy, for example, is far less concerned about such initiatives or even building criminal 
cases for prosecution. Its aim is disrupting plotting at an early stage and taking a forward-leaning and expansive approach to deportation of foreign nationals who pose a suspected threat. ${ }^{102}$

Yet even those countries that have emphasized the importance of intervention programs take different approaches to conception and implementation. Where the United Kingdom has been willing to delve into ideology, for example, Sweden and Finland are far more cautious about involving themselves in such thorny matters, preferring to focus on addressing inequalities and grievances. ${ }^{103}$

All European countries, however, are to some extent reliant on diligent intelligence services and law enforcement to stop terrorist plotting. Post-9/11, such efforts were given greater emphasis in Europe than in the United States, whose superior war-fighting capacity gave it the option to take the fight to jihadi groups overseas in a manner that most European countries did not possess. This inevitably led to a more militarized approach in the United States and helped exacerbate fundamental philosophical differencesfor example, over the morality concerning law of war detentions - between Europe and the United States.

A collective experience that Europe and the United States did share after 9/11 was in learning how to break down more intelligence and policing firewalls domestically. This has involved not only restructuring bureaucracies but also persuading intelligence agencies protective of sensitive information to trust other parts of the government with that information. ${ }^{104}$ While far from perfect, countries such as Italy and the United Kingdom, which have historical experience facing such issues due to the operation of active domestic terrorist movements in the pre-9/11 era, have often fared better in this task than other European counterparts. ${ }^{105}$

The process has proven more complicated in France, where a July 2016 parliamentary investigation found an unwieldy bureaucracy with six intelligence agencies reporting to different government ministries (economic, national defense, the interior) and which collected significant information but failed to sufficiently connect dots. ${ }^{106}$

The improvements still required at the nation-state level help explain why talk of broader pan-European intelligence sharing initiatives - a "European CIA," in the words of ex-Belgian Prime Minister Charles Michel-are premature. ${ }^{107}$ Not only are there more pressing intelligence sharing issues that need to be resolved at the state level, but intelligence agencies will remain wary of divulging sensitive information to other countries, even their European Union allies.

After all, the consequences of over-sharing can be deadly. As the former head of Britain's foreign intelligence service MI6, John Sawers, spelled out, "no intelligence service risks compromising its sources. . . . Because whenever intelligence is revealed, others try to hunt down the source. Agents can get identified, arrested, tortured, and killed." ${ }^{108}$ It is clear that improving intelligence sharing is critical to preventing terrorist attacks. Yet the precise mechanics for doing so remain complex at both a local and state level.

\section{What comes next}

The fall of the self-declared caliphate has reduced the momentum the Islamic State possessed. This loss of territory, along with reverses on the battlefield, has dented the group's appeal to potential new recruits. The United States and its allies have killed key terrorist planners in Syria and Iraq who had been targeting Europe. The Islamic State is also no longer able to use its control of territory as a springboard from which to launch external attacks. ${ }^{109}$ Furthermore, the pace of foreign fighter plots seems to have slowed since 2016.

Despite these welcome developments, it is certain that the Islamist terrorist threat facing the United Kingdom and Europe will endure. After all, plotting continued in Europe after March 2019, which was when the last town in the Islamic State's caliphate was recaptured in Syria. In the 15 months that followed, there were, on average, two Islamist terrorism plots per month either successfully executed or thwarted in Europe. Most perpetrators acted alone and did not have direct organizational links to the Islamic State. ${ }^{110}$ 
Then there are those whose previous attempts to travel to conflict zones were thwarted and who are instead looking to lash out closer to home. Kujtim Fejzulai, the Austrian Macedonian who killed four and injured 23 in a firearms attack in Vienna in November 2020 is an example. He had unsuccessfully attempted to travel to both Syria and Afghanistan prior to carrying out his attack in Austria. ${ }^{111}$ There have been dozens of similar plots across Europe. ${ }^{112}$

Another security concern are jihadi prisoners who have been released from prison in various European countries. Several Islamist attacks and alleged plots in France, the United Kingdom, and Germany in recent years have involved individuals who had been released from detention having previously been convicted of at least one terrorism offense. Cherif Kouachi, one of the gunmen in the Charlie Hebdo attack, had previously been convicted of a terrorism-related offense in France after he was arrested preparing to leave for Iraq to take part in fighting there. ${ }^{113}$

Furthermore, while foreign fighter plotting has slowed, such individuals do not have to be actively planning atrocities to constitute a national security threat. The "credibility" they have gained by fighting overseas can be utilized to recruit others for future conflicts.

These disparate threats need to be addressed. There also should be a broader reconceptualization of the risks posed by Islamist extremism. Without more strategic thinking across the continent, Europe will be reduced to just having to deal with the most imminent terrorist plot in perpetuity. That is both an unwelcome and unsustainable prospect. Therefore, the entire ecosystem from which terrorists recruit needs addressing. Taking a more robust approach towards Islamism will lead to some uncomfortable conversations on theology, freedom of speech, and democratic values.

\section{Notes}

1 This includes four Islamist terrorist attacks and one attack from the far right.

2 Northern Ireland faces a profoundly different threat from terrorism and has been omitted from this analysis.

3 Islamist terrorists caused 91 of these deaths, 3 were caused by the far right, and 3 by a perpetrator whose ideology is currently unclear. See Vikram Dodd, "Khairi Saadallah Pleads Guilty to Three Murders," Guardian, November 11, 2020, www.theguardian.com/uk-news/2020/nov/11/reading-terror-attacker-khairi-saadallah-pleads-guilty-to.

4 Home Office, CONTEST: The United Kingdom's Strategy for Countering Terrorism (London: HM Government, 2018).

5 Kim Knott, Muslims and Islam in the UK: A Research Synthesis (Lancaster, UK: Centre for Research and Evidence on Security Threats, 2018), 47.

6 For more detail on Jamaat-i-Islami, see Matthew Wilkinson, The Genealogy of Terror (London: Routledge, 2019).

7 Damon L. Perry, Mainstream Islamism in Britain: Educating for the "Islamic Revival" (London: Commission for Countering Extremism, 2019), 1.

8 Home Office, Muslim Brotherhood Review: Main Findings (London: HM Government, 2015), para. 20.

9 Perry, Mainstream Islamism in Britain, 2.

10 Home Office, Muslim Brotherhood Review, paras. 23-24.

11 Ibid., para. 22.

12 For more detail on the emergence of Salafi-jihadi ideology in the United Kingdom, see Shiraz Maher, SalafiJihadism: The History of an Idea (London: Hurst, 2016).

13 Maajid Nawaz, "Bosnia Changed My Life," Emel no. 91 (2012).

14 "Abu Muslim Al-Turki," Caravan of Martyrs, accessed December 5, 2020, http://caravansofmartyrs.atspace.com/ html/Abu_Muslim_Al-Turki.htm.

15 "The Terrorist Diaspora: After the Fall of the Caliphate: Testimony Before the Committee on Homeland Security," 115th Cong. (2017) (statement of Robin Simcox, Margaret Thatcher Fellow, The Heritage Foundation).

16 For more detail on these dynamics within British Muslim communities in the United Kingdom during the 1990s, see Rafaello Pantucci, “We Love Death as You Love Life” Britains' Suburban Terrorists (London: Hurst, 2015).

17 Michael Clarke, “The Contract with Muslims Must Not Be Torn Up," Guardian, August 26, 2005, www.theguardian.com/politics/2005/aug/26/terrorism.religion.

18 Hannah Stuart, Islamist Terrorism: Analysis of Offences and Attacks in the UK (1998-2015) (London: Henry Jackson Society, 2017). 
19 Tony Blair, "Blair's Statement in Full," BBC, September 11, 2001, http://news.bbc.co.uk/1/hi/uk_politics/ 1538551.stm.

20 Ministry of Defense, “Operations in Afghanistan: Chronology of Events, September 2001-December 2002” (London: UK Ministry of Defense, no date).

21 Nick Hopkins, "British Muslims Who Fought with Taliban Face Prosecution,” Guardian, November 20, 2001, www.theguardian.com/uk/2001/nov/20/september11.world; James Kirkup, "British Muslims Fighting Alongside Taliban, Commanders Claim," Daily Telegraph, January 2, 2009, www.telegraph.co.uk/news/worldnews/asia/ afghanistan/4076591/British-Muslims-fighting-alongside-Taliban-commanders-claim.html.

22 "UK Muslims 'Killed' in Afghanistan,” BBC, October 29, 2001, http://news.bbc.co.uk/1/hi/uk/1625115.stm.

23 “The Guantanamo Docket: Citizens of Britain," New York Times, accessed December 6, 2020, www.nytimes.com/ interactive/projects/guantanamo/country/britain.

24 Stuart, Islamist Terrorism, 2-6.

25 Ibid., 4-5.

26 Anti-Terrorism, Crime and Security Bill, House of Commons, session 2001-02, https://publications.parliament. $\mathrm{uk} / \mathrm{pa} / \mathrm{cm} 200102 / \mathrm{cmbills} / 049 / \mathrm{en} / 02049 \mathrm{x}--$.htm.

27 House of Lords, Judgments-A (FC) and others (FC) (Appellants) v. Secretary of State for the Home Department (Respondent), UK Parliament, session 2004-05, December 16, 2004, para. 11, https://publications.parliament.uk/pa/ ld200405/ldjudgmt/jd041216/a\&oth-1.htm.

28 Chahal v. The United Kingdom, 22414/93 (Grand Chamber, 1996), www.bailii.org/eu/cases/ECHR/1996/54. html.

29 Anti-terrorism, Crime and Security Act 2001, UK Parliament, www.legislation.gov.uk/ukpga/2001/24/section/ 30/2001-12-14.

30 Stuart, Islamist Terrorism, 18-19.

31 Ibid., 86-88.

32 Douglas Murray, “Abu Hamza Embodies Britain’s Self-Destructive Madness,” Spectator, May 20, 2014, www.spectator.co.uk/article/abu-hamza-embodies-britain-s-self-destructive-madness.

33 “London Bomber: Text in Full," BBC, September 1, 2005, http://news.bbc.co.uk/1/hi/uk/4206800.stm.

34 Tony Blair, "Full Text: The Prime Minister's Statement on Anti-Terror Measures," Guardian, August 5, 2005, www.theguardian.com/politics/2005/aug/05/uksecurity.terrorism1; Patrick Wintour, "Blair Vows to Root Out Extremism," Guardian, August 6, 2005, www.theguardian.com/politics/2005/aug/06/terrorism.july7.

35 Michael Bates, "Exclusion Orders: Question for Home Office UIN HL4168," UK Parliament, January 22, 2015, https://questions-statements.parliament.uk/written-questions/detail/2015-01-14/HL4168.

36 Home Office, Proscribed Terrorist Organisations (London: HM Government, 2020), 7-8.

37 For more on Hizb-ut-Tahrir, see Houriya Ahmed and Hannah Stuart, Hizb ut Tahrir: Ideology and Strategy (London: Centre for Social Cohesion, 2009), 61, 109-111.

38 Home Office, CONTEST, 8.

39 Home Office, 'Preventing Extremism Together' Working Groups: August-October 2005 (London: HM Government, 2005), 1.

40 Home Office, Countering International Terrorism: The United Kingdom's Strategy (London: HM Government, 2006), 1-2; Home Office, Pursue Prevent Protect Prepare the United Kingdom's Strategy for Countering International Terrorism (London: HM Government, 2009), 14.

41 Home Office, The Prevent Strategy: A Guide for Local Partners in England (London: HM Government, 2008$), 5$.

42 Russell Jenkins, "Killers May Have Been Recruited at Youth Centre," The Times, July 16, 2005, www.thetimes. co.uk/article/killers-may-have-been-recruited-at-youth-centre-nzpkfrq9tph.

43 Department for Communities and Local Government, Preventing Violent Extremism Pathfinder Fund 2007/08: Case Studies (London: Department for Communities and Local Government, 2007), 4.

44 Vikram Dodd, “Government Anti-Terrorism Strategy 'Spies' on Innocent,” Guardian, October 16, 2009 , www. theguardian.com/uk/2009/oct/16/anti-terrorism-strategy-spies-innocents.

45 Arshad Isakjee and Chris Allen, “ “A Catastrophic Lack of Inquisitiveness': A Critical Study of the Impact and Narrative of the Project Champion Surveillance Project in Birmingham," Ethnicities 13, no. 6 (2013): 753.

46 Tufyal Choudhury and Helen Fenwick, The Impact of Counter-Terrorism Measures on Muslim Communities (Manchester: Equality and Human Rights Commission, 2011), iii.

47 The Labour government suspended dialogue with the Muslim Council of Britain in 2009 because of its support for the Istanbul Declaration, an Islamist proclamation which justified attacks on British forces enforcing an arms blockade on Gaza, and there has been no substantive dialogue since then. Ministers have rejected recent efforts by the Muslim Council of Britain to obtain dialogue.

48 Home Office, Radicalisation: The Counter-Narrative and Identifying the Tipping Point (London: HM Government, 2017). 


\section{The UK's approach to counterterrorism}

49 Mockbul Ali, "Shaykh Yusuf al Qaradawi," Memorandum to the Home Secretary, July 14, 2005, http://image.guardian. co.uk/sys-files/Observer/documents/2005/09/04/Document1.pdf.

50 Shiraz Maher and Martyn Frampton, Choosing Our Friends Wisely: Criteria for Engagement With Muslim Groups (London: Policy Exchange, 2009); Home Office, Prevent Strategy (London: HM Government, 2011).

51 Ibid.

52 David Cameron, "PM’s Speech at Munich Security Conference," Prime Minister's Office, February 5, 2011, www. gov.uk/government/speeches/pms-speech-at-munich-security-conference.

53 Ibid.; David Cameron, "Extremism," Prime Minister's Office, July 20, 2015, www.gov.uk/government/speeches/ extremism-pm-speech.

54 Home Office, Prevent Strategy.

55 House of Lords, Judgments $-A(F C)$ and others $(F C) v$. Secretary of State.

56 Prevention of Terrorism Act 2005, UK Parliament, www.legislation.gov.uk/ukpga/2005/2/pdfs/ukpga_2005 0002_en.pdf.

57 Robin Simcox, Control Orders: Strengthening National Security (London: Centre for Social Cohesion, 2010).

58 Home Office, Counter-Terrorism Policy and Human Rights (Fourteenth Report): Annual Renewal of Control Orders Legislation 2009 (London: HM Government, 2009).

59 Terrorism Prevention and Investigation Measures Act 2011, UK Parliament, www.legislation.gov.uk/ukpga/ 2011/23/contents/enacted.

60 David Anderson, Deportation With Assurance (London: HM Government, 2017).

61 "Abu Qatada Cleared of Terror Charges," BBC, September 24, 2014, www.bbc.co.uk/news/world-29340656.

62 Sajid Javid, “UK Nationals Returning From Syria: Volume 654," UK Parliament, February 18, 2019, https:// hansard.parliament.uk/commons/2019-02-18/debates/69E286BB-03A2-4467-AB65-B3059436CD53/ UKNationalsReturningFromSyria.

63 Home Office, CONTEST, 18.

64 Lizzie Dearden, “ISIS Video: Full Transcript of 'A Message to David Cameron',' Independent, January 5, 2016, www.independent.co.uk/news/uk/home-news/isis-video-full-transcript-message-david-cameron-siddharthadhar-isa-dare-a6797671.html.

65 Killed alongside Khan was Ruhil Amin, another British Islamic State recruit.

66 Intelligence and Security Committee of Parliament, UK Lethal Drone Strikes in Syria (London: HM Government, 2017).

67 "Father Fears Sons Are on 'Hit List' After Reyaad Khan Drone Strike," BBC, September 8, 2015, www.bbc.com/ news/uk-wales-34183320; "US Airmen Terror Attack: Junead Khan Found Guilty," BBC, April 1, 2016, www. bbc.com/news/uk-35944661.

68 Lizzie Dearden, "Shamima Begum: Number of People Stripped of UK Citizenship Soars by $600 \%$ in a Year," Independent, February 20, 2019, www.independent.co.uk/news/uk/home-news/shamima-begum-uk-citizenshipstripped-home-office-sajid-javid-a8788301.html.

69 Ibid.

70 Immigration Act 2014, UK Parliament, www.legislation.gov.uk/ukpga/2014/22/section/66/enacted.

71 Home Office, "Factsheet-The Counter-Terrorism and Security Bill" (London: HM Government, no date).

72 Home Office, "Factsheet-Part 1 Chapter 2-Temporary Exclusion Orders, Counter-Terrorism and Security Bill" (London: HM Government, no date).

73 Lizzie Dearden, "Only One in 10 Jihadis Returning from Syria Prosecuted, Figures," Independent, February 21, 2019, www.independent.co.uk/news/uk/home-news/shamima-begum-isis-return-uk-syria-jihadis-terror-threatprosecute-nationality-a8790991.html.

74 For an exploration of these issues as related to the wars in Afghanistan and Iraq, see Robin Simcox, The Presumption of Innocence: Difficulties in Bringing Suspected Terrorists to Trial (London: Henry Jackson Society, 2013).

75 Serious Crime Act 2015, UK Parliament, www.legislation.gov.uk/ukpga/2015/9/notes.

76 Home Office, "Counter-Terrorism and Border Security Act 2019 Terrorism Offences Fact Sheet" (London: HM Government, no date).

77 Home Office, "Counter-Terrorism and Border Security Act 2019 Designated Area Offence Fact Sheet" (London: HM Government, no date).

78 Ibid.

79 Home Office, Counter-Extremism Strategy (London: HM Government, 2015).

80 Ibid., 6.

81 Raffaello Pantucci, "How Lee Rigby's Murder Changed the Face of Terror," Guardian, April 15, 2018, www.theguardian.com/commentisfree/2018/apr/15/day-new-terror-unleashed-lee-rigby-murder-woolwich.

82 Home Office, Counter-Extremism Strategy, 5. 
83 Home Office, Individuals Referred To and Supported Through the Prevent Programme, April 2019 to March 2020 (London: HM Government, 2020).

84 Judiciary of England and Wales, The Queen v. Ahmed Hassan: Sentencing Remarks of the Hon. Mr Justice Haddon-Cave (London: Judiciary of England and Wales, 2018), para. 17.

85 Ian Cobain, "Parsons Green Tube Bomber Ahmed Hassan Jailed for Life," Guardian, March 23, 2018, www.theguardian.com/uk-news/2018/mar/23/parsons-green-tube-bomber-ahmed-hassan-jailed-for-life.

86 Kate Forrester, "Reading Attack: Threat From 'Lone Actors' Growing, Warns Priti Patel,' Politics Home, June 22, 2020, www.politicshome.com/news/article/threat-from-lone-actors-growing-warns-priti-patel-in-wake-of-read ing-stabbing-attacks.

87 Peter Clarke, Learning from Experience: Counter Terrorism in the UK Since 9/11 (London: Policy Exchange, 2007).

88 David Anderson, Implementation Stock Take: Unclassified Summary of Conclusions (London: HM Government, 2019), 2.

89 Home Office, "Fact Sheet: Right-Wing Terrorism," Home Office in the Media (blog), September 20, 2019, https:// homeofficemedia.blog.gov.uk/2019/09/20/fact-sheet-right-wing-terrorism/.

90 Home Office, CONTEST, 8, 29 and 40.

91 National Health Service, Prevent: Basic Prevent Awareness Level 1 and 2 (London: National Health Service), 3.

92 “Together We're Tackling Online Terrorism," Counter Terrorism Policing, December 19, 2018, www.counterterrorism.police.uk/together-were-tackling-online-terrorism/.

93 James Brokenshire, "Security Minister Speech to the Royal United Services Institute" (London: HM Government, 2020), www.gov.uk/government/speeches/security-minister-speech-to-the-royal-united-services-institute.

94 Home Office, Online Harms White Paper: Full Government Response to the Consultation (London: HM Government, 2020).

95 Stuart, Islamist Terrorism.

96 “11 Terror Plots Foiled in Germany Since 2000," The Local, March 29, 2016, www.thelocal.de/20160329/ german-security-service-saves-its-sheep-from-terrorism.

97 Islamist terrorism, however, was still a factor during this period. See Robin Simcox, "Merkel's Generous Refugee Policy Puts Germany at Risk," National Review, August 9, 2017, www.nationalreview.com/2017/08/ angela-merkel-refugee-policy-threatens-german-security-islamist-terrorism/.

98 Iveta Ondruskova, “The Victims of the Neo-Nazi NSU Murder Spree," Die Welle, June 10, 2018, www.dw.com/ en/the-victims-of-the-neo-nazi-nsu-murder-spree/g-44606301.

99 “German Interior Minister Revises 2015 Refugee Influx From 1.1 Million to 890,000," Deutsche Welle, September 30, 2016, www.dw.com/en/german-interior-minister-revises-2015-refugee-influx-from-11-million-to890000/a-35932746; Federal Ministry of the Interior, Asylum Seekers in 2017 (Berlin: Federal Ministry of the Interior, 2018).

100 Robin Simcox, The Asylum — Terror Nexus: How Europe Should Respond (Washington, DC: Heritage Foundation, 2018).

101 Matthew Kaminski, “All the Terrorists Are Migrants," Politico, November 23, 2015. www.politico.eu/article/ viktor-orban-interview-terrorists-migrants-eu-russia-putin-borders-schengen/; "Terrorism Linked to Migration: Polish President," Radio Poland, September 15, 2017, http://archiwum.thenews.pl/1/10/Artykul/325885, Terrorism-linked-to-migration-Polish-president.

102 Robin Simcox, "Is Italy Immune From Terrorism?" Foreign Policy, July 18, 2019, https://foreignpolicy.com/ 2019/07/18/is-italy-immune-from-terrorism/.

103 Robin Simcox, "Scandinavian Approach to Counterterrorism, Islamist Ideology Is Flawed," The Daily Signal, May 11, 2018, www.dailysignal.com/2018/05/11/scandinavian-approach-to-counterterrorism-islamist-ideologyis-fatally-flawed/.

104 Robin Simcox, "Europe, Stop Trying To Make 'Intelligence Sharing' Happen,” Foreign Policy, April 14, 2016, https://foreignpolicy.com/2016/04/14/europe-stop-trying-to-mak-brussels-paris-bombings/.

105 Simcox, "Is Italy Immune From Terrorism?".

106 Robin Simcox, "French Intelligence Reform: The Counterterrorism Commission Won't Prevent the Next Attack," Foreign Affairs, July 17, 2016, www.foreignaffairs.com/articles/france/2016-07-17/french-intelligence-reform.

107 Euronews, "Belgium's PM Michel Calls for a European CIA," Euronews, November 30, 2015, www.euronews. com/2015/11/30/belgium-s-pm-michel-calls-for-a-european-cia.

108 John Sawers, “Sir John Sawers's Speech," Guardian, October 28, 2010, www.theguardian.com/uk/2010/oct/28/ sir-john-sawers-speech-full-text.

109 Robin Simcox, The Post-Caliphate Terror Threat in Europe-And the Need for Continuing U.S. Assistance (Washington, DC: The Heritage Foundation, 2018).

110 Robin Simcox, Europe and the Fall of the Caliphate (London: Counter Extremism Group, 2020). 


\section{The UK's approach to counterterrorism}

111 Oliver Moody, "Vienna Terrorist Kujtim Fejzulai, a Football-Crazed Boy Who Became a Cold-Blooded Gunman," The Times, November 7, 2020, www.thetimes.co.uk/article/vienna-terrorist-kujtim-fejzulai-a-foot ball-crazed-boy-who-became-a-cold-blooded-gunman-pmpjbpn99.

112 Robin Simcox, "When Terrorists Stay Home: The Evolving Threat to Europe From Frustrated Travelers," CTC Sentinel 12, no. 6 (2019): 46-55.

113 Andrew Higgins and Maïa de la Baume, "Two Brothers Suspected in Killings Were Known to French Intelligence Services," New York Times, January 8, 2015, www.nytimes.com/2015/01/08/world/two-brothers-suspected-inkillings-were-known-to-french-intelligence-services.html. 


\title{
CONCLUSION
}

\author{
Hy Rothstein
}

This is a handbook about counterterrorism and irregular warfare. Its contents cover contemporary threats, selected regional security issues, and case studies to illuminate the challenges and potential solutions for confronting these types of threats. ${ }^{1}$ While there is an abundance of literature about conventional warfare and its great captains, there is far less about irregular warfare and the competencies required to lead irregular warfare or counterterrorism campaigns.

This handbook attempts to fill this gap and distill the essence of what works and what does not in irregular warfare. The pages of this concluding chapter draw on much of the material covered in the book, but also on my 50 years of service to the U.S. military both in uniform as a Special Forces officer and afterwards as a scholar, teacher, and author at the Naval Postgraduate School. ${ }^{2}$

This chapter summarizes some of the key findings from the handbook. It starts by examining how the nature of terrorism has remained constant while its character has changed. It then reviews key lessons learned from the irregular warfare campaigns discussed in this volume. It concludes by acknowledging key insights derived from domestic counterterrorism efforts post-9/11.

\section{The contemporary threat}

Among terrorist groups, Islamist extremists have posed the greatest threat to regional and international security over the past several decades. While few have been able to achieve more than limited goals, the ideology remains appealing to vulnerable populations. Discontent has increased as the governments of these countries have failed to provide a better life for portions of their populations. This has resulted in the rise of charismatic demagogues fueled by religious passion in cultures where religion is a central feature of daily life.

Carl von Clausewitz said that while the character of war changes, the nature of war does not. The nature of war is "violent, interactive, and fundamentally political." ${ }^{3}$ Its character is shaped by "technology, law, ethics, culture, methods of social, political, and military organization, and other factors that change across time and place." ${ }^{4}$ The chapters from this book seem to bear this out.

The goal of many terrorist organizations remains fundamentally political. For many of the Islamist terrorist groups discussed in this handbook, that means creating a state (or caliphate) governed by Sharia (Islamic law). Many groups trace their militant interpretations of Islam to Ibn Taymiyya, Sayyid Qutb, and other early Islamic reformers and activists, but the manner in which they seek to accomplish their goal has 
evolved. In other words, the nature of modern terrorism remains "violent, interactive, and fundamentally political," yet its character has changed as a result of many factors ranging from technology to society and culture.

Terrorist groups have become increasingly violent, and their use of suicide attacks has become more frequent, while tactics such as airline hijackings have receded. Their target selection has expanded as well. Initially, suicide attacks primarily targeted "hard" targets, such as government or military buildings. Examples include Hezbollah's bombing of the Marine Barracks in Beirut or al-Qaida's attacks on the U.S. Embassies in East Africa and the USS Cole. But over the past two decades, suicide attacks are increasingly being employed against "soft" targets, often killing many more Muslims than traditional "combatants."

Technology has also changed the character of war. Modern information technologies catalyze the pathway toward terrorism and insurgency. The dissemination of ideas, the ability to organize virtually and clandestinely, and the ease of access to communications through social media all reduce the risks associated with the growth of radical groups as they proceed on the pathway to action.

Another change is the origin of the attack. As it has become harder for terrorists to conduct attacks on the West from overseas, attacks from so-called "lone wolves" or domestic inspired terrorists have increased. The spectacular 9/11,7/7, and Madrid attacks have become more difficult to execute and are now much less common. Aggressive counterterrorism operations overseas, such as the relentless drone campaign in Pakistan's Federally Administered Tribal Areas, make it harder for terrorist groups to plan complex operations.

Likewise, better intelligence and "watch lists" have made it more difficult for individuals to travel overseas to conduct training and then return home to conduct attacks without being arrested upon departure or return. Thus, attacks conducted by domestic citizens using less sophisticated methods-wielding guns or knives, using vehicles, or building improvised explosive devices-have been on the rise.

It is not just the character of war that has evolved but the groups themselves. As Fishman noted, the Islamic State does not fit neatly into traditional analytical categories: "it [is] a pseudo-state, a terrorist group, and an insurgency simultaneously." The morphing of terrorist groups is not limited to Islamic groups, as Ortiz finds a similar observation when examining terrorism in Latin America with the evolution of the Revolutionary Armed Forces of Colombia (FARC) and criminal insurgency in Mexico.

Yet despite the growth of terrorist violence and proliferation of terrorist groups, this volume has shown that while groups may gain control of territory for limited or even extended periods of time, they are unable to maintain long-term control. These short-term successes demonstrate the seriousness of the threat and often spur international action.

The cases from this volume offer several insights. Responses to these threats often occur only after the problem metastasizes. As a result, the costs and difficulty for mitigating the threat are high, and the solutions are more temporary. Long-term engagement often results in more efficient and effective solutions. Decades-long investments in Colombia and the Philippines provided the United States strategic options. By contrast, episodic engagement, as demonstrated in Yemen, is not likely to yield great returns.

Additionally, assistance should not be conditioned on changing local culture; instead, local culture must be considered whether building security forces or building governance. Finally, the government must have the potential for capable security forces so that populations do not feel that their best option is to join or support a terrorist or insurgent organization.

The volume offers a cautionary tale on the ability to defeat radical ideologies that remains appealing to a small sector of the population. Despite "defeats" of groups like Jemaah Islamiyya or "near defeats" of groups like al-Qaida in Iraq, the defeat will not endure unless some of the fundamental conditions that make terrorism appealing to a small minority of the population change. 
Hy Rothstein

\section{Learning from operational case studies}

What can a few special operators achieve? Accordingly, this section addresses the following questions: 1) Can irregular warfare achieve favorable political outcomes? 2) When is an irregular warfare option the best military course of action? 3) What are the distinguishing attributes of effective irregular warfare leaders?

\section{Can irregular warfare achieve favorable political outcomes?}

The quick answer to this question is "no," but that is also true for conventional, naval, cyber, air, and any other new form of warfare that may emerge. The type of warfare selected is a tactical decision. While tactical excellence is desirable, it is not sufficient. Tactical superiority is usually wasted if it is not employed as part of a broader strategy designed to achieve political goals.

In the majority of the cases in this handbook, the United States and allied forces repeatedly demonstrated superior tactical performance. Unfortunately, these tactical measurements were often disconnected from the only measurement that counts: achieving a favorable political outcome.

The search for that special solution-whether technical, a new type of warfare, or the politically popular "whole of government" approach—all miss the ageless reality that wars are waged to secure political ends through the use of force. Strategy is the link between political purpose and military power. While the tactics of warfare bend to changes in geography, politics, economics, and technology, the distinctive nature of war and strategy remains constant.

It is beyond the scope of this book to address serious policy and strategy deficits, but it is proper to raise the issue for students of war and strategy. Today, even after an opponent appears defeated, they seem to regroup almost overnight. The fight never quite ends and often morphs into a new conflict. The United States has neither won nor lost many of its 21 st-century conflicts.

Some of the cases from this handbook (El Salvador, Colombia, and the Philippines) provide clear evidence that irregular warfare can deliver favorable political outcomes. While some might claim that success results when a military strategy is nested inside of a clear policy, this is not always the case. In fact, success in El Salvador, Colombia, and the Philippines was likely enhanced by the fact that they were countries of secondary importance. This allowed for bottoms-up solutions where Special Operations Forces (SOF) could work closely with local counterparts to produce durable policy outcomes. The likelihood of achieving these positive outcomes might have been diminished with a large U.S. military presence and high-level attention from Washington.

The case of "Plan Colombia and the 7th Special Forces Group" is remarkable for its scope, duration, and low cost but, most significantly, the results. This is a case where irregular warfare achieved political outcomes that were disproportionally high compared to the overall U.S. investment, by some estimates $\$ 10$ billion compared to the Afghan war, which exceeded $\$ 1$ trillion. ${ }^{7}$ Plan Colombia is widely viewed as a counterinsurgency success, even if it was less successful from a counterdrug perspective.

For more than three decades, U.S. Southern Command deployed 7th Group soldiers to train and equip Colombian military and police forces and their staffs and help establish their support structures. This protracted effort was so successful that the students became the masters, as demonstrated in 2008 during Operation Jacque when the Colombian military unilaterally rescued hostages held by the FARC for years in remote jungle locations. The Colombians ultimately took the fight to the FARC and created the conditions that resulted in a peace accord, the desired political outcome. But this would not have been possible without the efforts of the soldiers from the 7th Special Forces Group that started more than a decade earlier.

There are three cases in this book-killing Pablo Escobar, Operation Serval, and America's drone wars-that minimally involved U.S. SOF and would stretch the concept of irregular warfare to the point of making the definition meaningless. But two of these are worth a brief discussion. Plus, there is one 
case- "Dismantling al-Qaida in Iraq" - that has achieved a lopsided amount of notoriety compared to the actual outcome achieved that will also be discussed.

In Mali, the French operation required outside assistance: strategic airlift; intelligence, surveillance, and reconnaissance aircraft; refueling aircraft; and intelligence support. It was a masterful operation, but some would argue that it was largely a conventional operation on the ground even if fought against an unconventional opponent. Even French SOF resembled those of an elite strike force more than what one would see in a classic irregular warfare scenario-in other words, they were used primarily for direct action rather than an advisory role. Nevertheless, Operation Serval was a success, and by keeping its political aims limited, France was able to achieve its political objectives despite a relatively low number of troops employed, especially when compared to Afghanistan or Iraq.

Drones have become an important tool in the military arsenal. Modern technology and vastly improved intelligence have made drone warfare a preferred method of engaging suspected terrorists in hard-to-reach places. Drones lower the risk to American forces while wreaking havoc, physically and psychologically, on the enemy. In fact, drones may be too much of a good development and arguably lead to an overreliance on them. Three U.S. presidents have made extensive use of drones inside and outside of designated war zones without Congressional consent. But drones, like their air warfare cousin, cannot, by themselves, be decisive. Despite hundreds of drone strikes in Yemen, the U.S. is no closer to achieving its policy objectives. Drones cannot compensate for a flawed or insufficient strategy.

General McChrystal's special operations task force nearly decimated al-Qaida in Iraq, and it is well acknowledged as a tactical success. But the big question is whether it contributed to positive political outcomes, the ultimate measure of success. In the short term, it did. The task force largely defeated al-Qaida in Iraq and bought time for the fledgling Iraqi government to build its own security capability.

In the long term, however, the task force could not maintain its gains, and positive political outcomes were elusive. When the Talabani-led government in Iraq effectively disenfranchised the Sunni populace, it left the Islamic State as the only viable option for many Sunnis. This case is a reminder that success in irregular warfare requires a willing, somewhat capable, and fairly legitimate partner. This was the case in Colombia, El Salvador, Syria, and the Philippines; lacking in Yemen; and episodic in Iraq.

Collectively, the cases also demonstrate that when SOF imperatives are followed, operations are more likely to be effective. These imperatives include understanding the operational environment; recognizing political implications; facilitating interorganizational cooperation; engaging the threat discriminately; anticipating long-term effects; ensuring legitimacy, credibility, and trust; anticipating psychological effects and the impact of information; operating with and through others; developing multiple options; ensuring long-term engagement; providing sufficient intelligence; and balancing security and synchronization. ${ }^{8}$

"Playbooks" for the operational employment of SOF, such as the Army Special Operations manual, already exist. But the tactical employment must be part of a coherent political strategy. If not, then SOF should be not employed. One final note of caution worth noting: SOF should not be the answer for anything that defies a conventional response. As one of the basic SOF operational mission criteria correctly notes, "the mission must be an appropriate special operations force mission or task." ${ }^{9}$ Despite some notable success over recent decades, SOF should not be viewed as the "easy button" for policy officials.

\section{When is an irregular warfare option the best military course of action?}

A common characteristic of irregular warfare is that it is as much about politics—external and internalas it is about war. Accordingly, irregular warfare can satisfy a controversial policy demand by offering expanded options for decision-makers. In the Salvadoran, Philippine, Colombian, Somali, Yemeni, and Mali cases, politics precluded the employment of U.S. conventional forces. A large American footprint would have delegitimized the governments the United States was trying to support and would have provided a source of propaganda for the enemy to exploit. 
Internal politics also play a role. Even though irregular conflicts proliferate the global landscape, they have rarely dominated the collective consciousness of U.S. military leaders. As a result, leaders of irregular warfare generally have had to swim against the currents of conventional thinking to develop the appropriate solutions to the problems that they face. Fortunately, SOF offer expanded options to meet the policy needs for political and military leaders when conventional options are either not possible or inappropriate.

The U.S. war in Afghanistan presents additional insights into when irregular warfare is the best military course of action. The reflexive military thinking about how to strike back against those responsible for the 9/11 attacks was to move conventional forces, including air power and logistics, within striking distance of Afghanistan. The buildup would have taken months. Political requirements drove the need for a quicker response. The American public demanded swift action against those responsible for the attacks.

Luckily, the Central Intelligence Agency (CIA) provided the non-standard thinking that led to the rapid employment of SOF and CIA teams into Afghanistan. The CIA knew that their proposal required the employment of SOF, while the initial plan proffered by U.S. military leaders marginalized at best, and rejected at worst, a concept that exploited SOF's capabilities. The swift collapse of the Taliban and the scattering of al-Qaida that resulted from the CIA-initiated irregular campaign was extraordinary. ${ }^{10}$

The chapter on defeating the Islamic State in Syria is also instructive primarily based on the context of limited options resulting from political constraints. By 2018, Americans were tired of costly, never-ending wars involving large deployments of forces. At the same time, the atrocities committed by the Islamic State required a response. The president had to respond short of deploying conventional combat units and their massive support structure. SOF became the option that was politically feasible, was relatively efficient, and signaled U.S. commitment and resolve to our allies. The option also satisfied the public's demand for action.

Again, an irregular approach emerged when there was no reasonable conventional alternative and when policy demanded that action be taken quickly. Unfortunately, in the case of Afghanistan, initial success was followed by the arrival of conventional forces and the conventionalization of what should have remained an irregular warfare campaign.

Bolduc's analysis of irregular security forces showed that SOF continued to work with local Afghan leaders to develop capable village security forces. SOF presence in the rural areas gave them unprecedented access to the population. Living and working at this level created trusted relationships with Afghans, resulting in improved situational awareness.

Regrettably, and in sharp contrast to the initial success against the Taliban and al-Qaida, SOF's utility was often marginalized by strategies that were more in line with how conventional forces preferred to fight. Too often, a significant portion of SOF was diverted to pursuing enemy leaders rather than building local capacity. ${ }^{11}$ As a result, the Taliban was able to reclaim territory, and the spectacular initial success became a stalemate with little possibility of a military victory.

\section{What are the distinguishing attributes of irregular warfare leaders?}

The literature on military leadership is extensive, and thus trying to add value to this already rich collection is difficult. To be sure, the leadership attributes necessary for conventional military success generally apply for irregular warfare as well. Integrity and character are mandatory, as are ambition, drive, tenacity, self-confidence, psychological openness, realism, physical fitness, and an insatiable appetite for learning. But what do the irregular warfare cases reveal about the people who succeed in this arena?

The circumstances surrounding irregular warfare are almost always very different from the circumstances surrounding conventional operations. For example, SOF generally operate beyond the range of traditional logistical and fire support. SOF always have a force ratio disadvantage. But numbers are less important than how forces are employed.

Distances from higher headquarters and quickly emerging political and military predicaments may require on-the-spot decisions without the luxury of consultation with military and civilian superiors. Plus, 
these decisions may generate long-term effects. Last, while war can be planned, it cannot be scripted. This is especially relevant for special operations. Therefore, while general leadership principles apply to SOF leaders, these unique circumstances generate a few distinctive leadership attributes necessary for irregular warfare. Leaders of successful irregular warfare operations must be ready to seize opportunities, be prepared to break long-held paradigms, understand the big picture, and experiment and learn from mistakes.

\section{Be ready to seize opportunities}

Good SOF leaders are able to seize opportunities. In many of the cases in this volume, leaders had to fight both the enemy and their own military that either wanted to confront irregular threats in standard conventional ways or found irregular threats insufficiently imposing for a response. Irregular warfare is rarely the choice of the U.S. military and becomes possible only when circumstances preclude the use of overwhelming force and when a special operations leader is ready to seize the initiative. The horse soldiers, McChrystal building his Task Force, and Captain Charlie Cleveland creating the Garras de Leopardo course in Colombia's Andean Ridge are but a few of the examples of SOF leaders seizing the opportunity.

\section{Be prepared to break long-held paradigms}

Above all, irregular warfare is a thinking man's game, and breaking long-held paradigms is often necessary. Nothing illustrates this better than the El Salvador case. The post-Vietnam phobia led the U.S. Congress to reject another costly military counterinsurgency adventure in El Salvador, and the manpower limitation further restrained American assistance. Yet innovative SOF leaders were able to leverage the mobile training team and Extended Training Services Support constructs to deploy advisors to train the Salvadorans. The latter was designed to provide engineering and technical specialists, but it was leveraged instead to provide combat advisors.

There was no deployment of forces from the United States in the commonly understood sense. To be fair, the plan was mostly ad hoc and evolved over time, but it broke new ground and in many ways illustrates the best attributes of irregular warfare leadership in support of the national interest. It is remarkable to note that breaking these paradigms was possible because the conventional military viewed El Salvador, irregular warfare, and the people who specialized in it as irrelevant. In other words, low interest on the part of conventional leaders provided irregular warfare leaders greater room to maneuver.

Assignment for duty in El Salvador also shattered Army assignment models. SOF leaders figured out how to bypass the normal assignment model to get only the most qualified advisors. As a result, repetitive tours became common, creating continuity and trust between Special Forces advisors and Salvadoran officials. The result was that senior Salvadoran officials often grew to trust relatively junior Special Forces officers and sergeants over senior U.S. Embassy government officials who had comparatively limited contact with host country officials or experience outside the capital.

Getting the right people to El Salvador would also not have been possible if service there was viewed as a mainstream military activity and therefore career enhancing. Specifically, military personnel would have felt compelled to volunteer for service in a combat environment to be competitive for promotion and command opportunities. The Army would have cycled people into El Salvador based on "fairness" rather than qualifications.

\section{Understand the big picture}

For SOF to succeed in irregular warfare, the enemy must be out-thought before they can be out-fought. SOF must understand more of the variables that affect the battlespace. Irregular warfare missions are generated at the highest civil-military levels, ideally guided by political-military assessments that are modified as 
necessary once deployed. SOF elements obtain a greater degree of "ground truth" to support subsequent military planning. From time to time, the higher-level assessments and plans are inconsistent with the realities on the ground. In theory, such inconsistencies should result in modifying the plan, but theory and reality often have their own gap, requiring SOF leaders to act.

The case of the Afghan Local Police comes closest to demonstrating the importance of understanding the big picture. Unfortunately, getting to this "understanding" was not easy and likely came too late. Coalition leaders remained committed to building a strong central security apparatus, despite years of evidence demonstrating the centralized approach was incapable of providing security in many rural areas. Coalition leaders failed to recognize the centuries-old nature of Afghan governance, social structure, and sense of justice.

The security design not only left the countryside and villages vulnerable to the Taliban but was so out of step with how Afghanistan has been historically governed that it produced more insurgents. The repetitive deployments of SOF personnel compared to their conventional counterparts allowed them to more clearly identify the need for local police. Changing priorities and inconsistent execution, however, ultimately left the countryside vulnerable, resulting in the Taliban expanding their control in rural areas, where the majority of Afghans live.

\section{Experiment and learn from mistakes}

While general principles for planning and conducting irregular warfare exist, the political geography can differ dramatically from country to country and even within a country. When countries go to war, or simply choose to use military force in unorthodox ways, leaders often know far less about the dynamics in the conflict zone than is ultimately necessary to prevail. As knowledge is gained, plans and even policies may require modifications. Deep knowledge of the political geography within a target area is a prerequisite for creating an initial plan and for the inevitable subsequent experimentation necessary for success. Learning from mistakes involves making a few and, more importantly, taking corrective actions.

The Salvadoran and horse soldiers cases demonstrate this attribute in action. Although the former case played out over more than a decade and the latter over several weeks, the officers and noncommissioned officers involved with each were constantly taking action, assessing the results of those actions, and making both minor and bold adjustments as required. Likewise, McChrystal's task force and the New York City Police Department's (NYPD) Counterterrorism Bureau were exemplars of constant experimentation.

\section{Other traits}

There are a few important leadership traits that are both indirectly derived from the cases and from my almost 50 years of association with special operators. Common sense and a pragmatic approach that enables one to learn from successes and failures is essential. Decisiveness, energy, persistence, patience, and persuasion must overpower any dictatorial tendencies.

Finally, a sincere empathy for the local population and an unwavering devotion to justice, locally defined, are essential. The wholesale imposition of American values on an indigenous population is professional malpractice in irregular warfare. That said, we do not check our own values at the border when we operate inside another country and culture. The most successful irregular warfare practitioners I have known exhibited most of these characteristics and, as a result, were able to succeed while their peers failed.

\section{Domestic counterterrorism}

The 9/11 attacks made it abundantly clear that Americans were vulnerable to foreign threats, but the link between foreign and domestic threats was not immediately apparent. Previous lax attitudes toward foreign political Islamist groups and homegrown terrorists had to change. The United Kingdom had its awakening 
after $7 / 7$. While both nations initially focused on attacking the threat overseas, the United States did a better job at leveraging its law enforcement capabilities to prevent future terrorist attacks on domestic soil.

Additionally, both learned that in addition to preventing future attacks, they needed to limit people from being drawn to terrorism. Like previous cases studies, those in Part III of this handbook find that organizations - such as the Joint Terrorism Task Force (JTTF), Theater Special Operations Commands, and the NYPD's Counterterrorism Division and Intelligence Division—and leadership matter.

\section{The FBI, JTTF, NYPD, and combating terrorism}

The cases throughout this volume, but the case on the JTTF in particular, demonstrate the importance of an interagency approach to counterterrorism. The JTTF's seamless blending of apparently disparate resources, talent, and connections - all focused on a common purpose-represents the gold standard in uniting multiple agencies for large terrorism investigations.

The benefits of having the right leadership in place are clearly illustrated in the chapters about New York City's response to the 9/11 attacks. Mayor Michael Bloomberg's selection of Raymond Kelly as police commissioner, and Kelly's emphasis on counterterrorism, allowed New York to build an array of unique capabilities and partnerships to prevent future attacks.

While some of these efforts were controversial, they proved groundbreaking for a police department and were effective in preventing dozens of potential attacks against the city. Additionally, by establishing its own counterterrorism capability, the NYPD did not have to rely on the Federal Bureau of Investigation (FBI) to protect the city from terrorist attacks. Other jurisdictions, lacking this luxury, remain reliant on the FBI. While it is impossible to protect against every attack, the perpetrators of the attacks in Orlando, Fort Hood, and Boston had all been on the FBI's radar, and thus the attacks were potentially preventable. But when the FBI closed preliminary investigations, they eliminated any chance to prevent the attacks. New York refused to depend on external organizations for its security.

Kelly's appointment of CIA veteran David Cohen to head his Intelligence Division, and retired General Frank Libutti and subsequently Ambassador Michael A. Sheehan to head his Counterterrorism Division, provided the department with leaders who were prepared to seize opportunities, break long-held paradigms, understood the big picture, and were not afraid to experiment and make mistakes. These are the same leadership traits required to lead successful irregular warfare campaigns.

\section{Terrorism in the information environment}

Terrorists not only operate on terra firma, but operations take place within the information domain. Terrorists easily exploit modern media and digital communications to disseminate propaganda instantly around the globe, drive recruitment, and increase public support. Virtual jihadi entrepreneurs seek to introduce Western recruits into wider extremist milieus, as well as offer suggestions on conducting attacks.

Terrorist groups enjoy advantages in information domain operations due to the inherently dispersed and distributed nature of the environment and the easy access to populations in free societies. As a result, they have been more effective than the governments and organizations tasked with countering them. Extremist groups' digital operations are continuously evolving in parallel with the rapid transformation of communications technologies. Sadly, many governments, including the United States, have not been able to successfully counter this threat due to bureaucratic inefficiencies and the need for policy reform.

\section{International responses}

The United Kingdom's approach to counterterrorism demonstrates that a parliamentary government faces many of the same challenges of a federal government and is not inherently better at forming effective 
counterterrorism policy. The United Kingdom also faced the challenge of trying to extradite suspected terrorists while being a member of the European Union. Brexit may alleviate some of these challenges arising from European Union law, but only time will tell.

While many European states have taken more of a law enforcement and criminal approach to terrorism as opposed to a more militaristic approach, it has not prevented them from being the subject of attack, as demonstrated by numerous attacks in France and elsewhere on the continent. What remains consistent is that an interagency approach, combined with international cooperation and information sharing, remains a best practice for counterterrorism.

\section{Conclusion}

In a monograph about irregular enemies and strategy, contemporary scholar of war and strategy Colin Gray identified an unstable relationship among irregular threats, strategy, and the American way of war. Specifically, the American way of war evolved to defeat conventional threats. The American military reflects a society and culture that is deeply rooted in history. As a result, the American way of war is not optimal for the challenges posed by irregular threats. Furthermore, in the post-Cold War era, the American military has demonstrated exceptional competence in winning battles with the enemy but much less competence in winning wars and achieving political aims. To conclude, American military culture is not friendly to the ways and means necessary for irregular warfare. ${ }^{12}$

This unstable relationship is demonstrated in the cases throughout this volume. Only after it becomes clear that waging war the "American way" is not possible does an irregular warfare option become viable. Alternatively, an irregular approach may also emerge when traditional military leaders are disinterested in the irregular threat. The clear understanding that different kinds of threats may require different forms of warfare does little to disturb the American military culture that also tends to infect the special operations community. Winston Churchill is purported to have said: "Americans can always be trusted to do the right thing, once all other possibilities have been exhausted." ${ }^{13}$ Although it is not clear that Churchill ever spoke these words, the sentiment accurately reflects when the U.S. military will advance an irregular approach over a conventional one.

There is a substantial literature about irregular warfare and counterterrorism, and that literature is growing. Unfortunately, some of this work is of questionable quality, and most focuses on tactical issues. This is unfortunate because bad strategy can be costly, and a lack of strategy is almost always catastrophic. The point is simple: the future great captains of irregular warfare must be strategic thinkers first and irregular warfare or counterterrorism specialists second. Competent irregular warfare specialists can easily perfect "doing things right," but wars are won by "doing the right things."

How do you develop strategic thinkers? First, and contrary to contemporary thinking, proper civilian-military relations necessitate senior military leaders having a role in policy formulation. This dialog between civilian and military leaders ensures that policy is calibrated so it is in line with what military power can deliver. After all, policy is nothing by itself. It is the duty of senior military officers to enter the policy world, but this dialog does not change who has the final word. Good policy and supporting strategy require this dialog continue throughout the course of the war, since circumstances always change and thus so should policies and strategies.

Second, senior military officers and diplomats will need to know more to have a greater voice in policy formulation. The scope of this chapter does not permit offering a detailed agenda for identifying and developing competent political-military senior officers, but one truth is clear-trying to create these people after the war starts is too costly.

One final and non-trivial thought based on the cases and my own personal experiences: there is something about the American way of war that limits success against irregular threats. It seems that the greater the involvement of conventional forces in irregular warfare, the greater the likelihood that the operation 


\section{Conclusion}

will become large and unwieldy, thereby increasing the probability of mission failure. Strategic thinking for irregular warfare paradoxically benefits from diminished conventional involvement. The strategic potential of our nation's SOF lies in their ability to operate independent of conventional forces and in taking the lead in doing so.

\section{Notes}

1 Most of the cases are clear examples of irregular warfare, while others only display selected irregular warfare characteristics.

2 I would also be remiss if I failed to identify some of the people who have influenced my thinking about policy, war, strategy, and irregular warfare. The late Colin Gray was arguably the best contemporary scholar of war and strategy. His ideas are revealed in most of my own writing and permeate this chapter. Gray's work complements the writings of Carl von Clausewitz, Sun Tzu, B.H. Liddell Hart, Herman Kahn, Bernard Brodie, Albert Wohlstetter, Donald Kagan, Edward Luttwak, Martin van Creveld, Michael Handel, and Robert Asprey. This is obviously only a partial list of influential thinkers, but it is a good starting point for a young soldier-scholar.

3 Christopher Mewett, "Understanding War's Enduring Nature Alongside Its Changing Character," War on the Rocks, January 21, 2014, https://warontherocks.com/2014/01/understanding-wars-enduring-nature-along side-its-changing-character/.

4 Ibid.

5 Scott Helfstein et al., Deadly Vanguards: A Study of al-Qa'ida's Violence Against Muslims (West Point: Combating Terrorism Center, 2009), 10.

6 See Brian Fishman, "A History of the Islamic State: From Abu Musab al-Zarqawi to Abu Bakr al-Baghdadi," in this handbook.

7 Rafael Romo, "Plan Colombia Revisited: Mixed Results for U.S. Anti-Drug Initiative," CNN, January 17, 2011, www.cnn.com/2011/WORLD/americas/01/17/colombia.us.drugs/index.html; Niall McCarthy, "The Financial Cost of U.S. Involvement in Afghanistan," Forbes, August 17, 2017, www.forbes.com/sites/niallm ccarthy/2017/08/24/the-financial-cost-of-u-s-involvement-in-afghanistaninfographic/\#1985c3021ee3.

8 Department of the Army, Army Special Operations, ADP 3-05 (Washington, DC: Department of the Army, 2019), $1-17$ to $1-19$.

9 Ibid., $1-5$.

10 Bob Woodward, Bush at War (New York: Simon \& Schuster, 2003); Hy S. Rothstein, Afghanistan and the Troubled Future of Unconventional Warfare (Annapolis: Naval Institute Press, 2006).

11 This change of mission focus was the preference of both SOF and conventional leaders.

12 Colin Gray, Irregular Enemies and the Essence of Strategy: Can the American Way of War Adapt (Carlisle: Strategic Studies Institute, 2006).

13 “Americans Will Always Do the Right Thing. . .," The Churchill Project, November 22, 2016, https://winston churchill.hillsdale.edu/americans-will-always-right-thing/. 


\section{INDEX}

Abduh, Muhammad 29-30, 34

Abdulkader, Munir 414-415, 418

Abdulmutallab, Umar Farouk 48, 307, 463

Abizaid, John 270, 447-451

Abu Nidal Organization 14

Abu Sayyaf Group 1, 3-4, 119-123, 129-130, 281-285, 288-290

Abu Zubaydah 355, 358-359

Achille Lauro 14

advanced operations base: in Afghanistan 242; in Colombia 200; in the Philippines 284; in Syria 325-329, 332-333, 336-341, 344

Afghan Highway Patrolmen 240-242, 251

Afghan Local Police 5, 239-240, 245-251, 259-261, 498

Afghan National Auxiliary Police 138, 240, 243-244, 251

Afghan Public Protection Program 240, 244, 251

Afghan Services Bureau 22, 36, 352

Afghan Task Force 5, 212, 217-220

African Union Mission in Somalia 108-114

Air Bridge Denial program 193, 199

al-Adl, Sayf 57-58

al-Ahmar, Ali Muhsin 85-86, 90, 308

al-Assad, Bashar 58, 74, 90-91; civil war 18, 62, 64, 66, 152, 154, 323, 482; Iranian support 153, 155-156, 324 ; terrorist threat 443

al-Assad, Hafez 74

al-Awlaqi, Anwar 47-49, 414, 464-465; death 87, 309, 395; engagement with Abdulmutallab 463-465; engagement with Nidal Hassan 48, 391-393, 404; inspiring the Orlando attackers 401-402, 405; influencing the Tsarnaev brothers 395; internet disciple Jose Pimentel 381

al-Baghdadi, Abu Bakr: allegiance with the Abu Sayyaf Group 122; allegiance with Boko Haram 100; death 39, 67; early years 58; Islamic State expansion into Yemen 88; leading the Islamic State 3, 61-62, 65;
Omar Mateen pledge 401; relationship with Jamaah Ansharut Tauhid 125; Tashfeen Malik pledge 397, 399

al-Baghdadi, Abu Omar 59-61, 63, 277

al-Banna, Hassan 11-12, 22-23, 30-31, 33-35

al-Dawa 16-17

Algeria: affiliation with Ansaru 99; Afghan-Soviet War fighters 23, 43; AQIM and GSPC 4, 42, 51, 97-98, 101, 268, 300; Armed Islamic Group 11, 19, 21, 23-24, 95-98; deportation agreement 482; foreign fighters in Iraq 46; hijacking destination 13, 18; Lakhdar Brahimi 448; National Liberation Front 77; relations with Mali 293-296, 299-300, 302; revolution 18-19, 295

al-Hazmi, Nawaf 356

al-Jolani, Abu Muhammad 62-63

al-Maqdisi, Abu Muhammad 35, 38, 55

al-Masri, Abu Ayyub 56, 59-61, 64, 275, 277

al-Mihdhar, Khalid 356

al-Nasser, Gamal Abd 12, 30-31, 33-34, 76, 84

ALP see Afghan Local Police

al-Qaida in the Arabian Peninsula: drone strikes 461, 463-465; growth 4, 38, 42, 48-50; terrorist threat 1 , 3; U.S. counterterrorism policy 6, 307-318; Yemen policy $83,85-89,92$

al-Qaida in the Indian Subcontinent 50

al-Qaida in Iraq: emergence of group 55, 57-58;

formation of Islamic State 59-60, 62; information operations 425; tension with al-Qaida 58-59; terrorist threat $1,38,42,46-47$; U.S. operations against group 267-269, 274-275, 277

al-Qaida in the Islamic Maghreb: baya to al-Qaida 42; birth of AQIM 4, 97-98, 101; death of Abdelmalek Droukdel 42, 50; Operation Serval 293-297, 300-301, 303

al-Quso, Fahd 356-357

al-Rahman, Abd 275-276 
al-Raymi, Qasim 49, 86, 427

al-Shabaab: Ahmed Warsame 360; al-Qaida affiliate 1, 3-4, 38, 42, 50, 105, 108; attacks 50, 427; drone strikes 460-461, 463; FBI investigations 380, 387, 399; future 114; rise and fall 108-111; tactics 111-113; threats 424; virtual entrepreneurs 418 al-Sudani, Abu Sa'ad 416-417, 419

al-Wuhayshi, Nasir 86, 311, 315

al-Zarqawi, Abu Musab: attacks 66; influence on Islamic State 59-65; information operations 51, 425; leading AQI 3, 38-39, 46-47, 55-59, 271; U.S. operations 6, 267, 273, 275-277

al-Zawahiri, Ayman: al-Qaida leader 41, 49, 467; establishing al-Qaida 37, 42; fatwa 43; ideology 37; information operations 51, 425; investigations 357; living in Yemen 86; pre-al-Qaida years 20-22, 24, 34, 36, 352; relations with al-Qaida affiliates 47, 50, 58, 63, 97, 311; relations with Islamic State 38

AMAL see Lebanese Resistance Regiments AMISOM see African Union Mission in Somalia Amnizat 66, 112, 114

Ansar Dine 293-296

AOB see advanced operations base

AQAP see al-Qaida in the Arabian Peninsula AQI see al-Qaida in Iraq

AQIM see al-Qaida in the Islamic Maghreb

AQIS see al-Qaida in the Indian Subcontinent

Arab League 76-77

Arab Spring 43, 49, 61, 465; in Egypt 62; impact on Iran 152-153; in Yemen 85, 87, 90, 308

Arafat, Yasser 13-15, 77, 79

Armed Islamic Group 11, 19, 23, 96-98

ASG see Abu Sayyaf Group

Azawad 6, 293-294, 296

Aziz, Ameer 416

Azzam, Abdullah 22-23, 30, 33, 36, 43

Bangladesh 23, 37, 50, 425

Bangsamoro Islamic Freedom Fighters 4, 119-123, 130, 281

Bin Ladin, Usama: 9/11 attacks 357, 365; Afghan Task Force 218; arrest warrant 21; association with JI 124; contribution to Afghan-Soviet War 22-23, 42, 352; death 20, 39, 42, 63, 142, 235, 280, 443; drone warfare 461-464, 467; fatwa 43-45; formation of al-Qaida 30, 33-37; ideology 85-86, 96; influence on Nidal Hasan 391; influence operations 425; prioritizing the "far enemy" $21,55,97$; public opinion 51; relations with al-Zarqawi 46, 56-57; U.S. counterterrorism operations $45,49,137,223$, 225-226, 353-356, 365

Black September 13-14, 77

Blair, Tony 478, 480

"blind sheikh" see Rahman, Omar Abdel

Bloomberg, Michael 364, 377, 499

Boko Haram 1, 3-4, 95, 98-101, 296, 471

Bosnia 23, 43, 151, 225, 478
Boston Marathon Bombings 7, 87, 385-386, 390; genesis of plot 394-395; influence on Orlando attack 401; missed warning signs 395-397, 404, 499

Bush, George H.W.: Colombia policy 204-205; El Salvador policy 179; Iran-Contra 216

Bush, George W.: Afghanistan policy 223; Department of State policy 429; drone policy 461-465, 464, 468-469, 472; Iraq policy 61

Cameron, David 414, 481, 483

Carter, Jimmy 148, 177-178, 217

Casey, William "Bill" 212-216, 220

CAT see civil affairs, civil affairs team

CENTCOM see U.S. Central Command

Central Intelligence Agency: Afghan Task Force 22, 217-218, 225; collaboration with NYPD 369, 386; conflict with FBI 355-356, 358-360; coordination with Department of Defense 440; David Cohen 7, 365-366, 373, 377, 499; drone program 461-463, 466-468, 470-471; invasion of Afghanistan 1, 5, 45, 223, 227, 229, 231, 233, 496; Iran-Contra 213-217; Iran policy 149; Jack Devine 5; lessons learned 219-220; Mike Spann 234; murder of Robert Ames and William Buckley 17; plot to attack CIA headquarters 20; support to Afghanistan 243, 259; support to El Salvador 182; support to Iraq 47; support to JIATF 270-271; warning from Moscow 394, 396; William Casey 212

CFC-A see Combined Forces Command-Afghanistan

CFSOCC-A see Combined Forces Special Operations Component Command-Afghanistan

CIA see Central Intelligence Agency

civil affairs 6, 190, 437, 439-440; in Afghanistan 262; civil affairs team, in Syria 323, 328, 332-333, 340-346; in Colombia 200; in El Salvador 185; in the Philippines 286-287; in Syria 332, 340-344

CJSOTF-A see Combined Joint Special Operations Task Force-Afghanistan

CJTF-180 see Combined Joint Task Force-180

Clarke, Richard 365, 461-462

Clarridge, Duane "Dewey" 213-214, 216

Cleveland, Charles 7, 191-192, 200, 297

Colombia: National Liberation Army 163, 169; Operation Titan 168; Operation Willing Spirit 441-444; Pablo Escobar 5, 203-210; Plan Colombia 5, 198-201, 260, 494-495; strategic context 159-161; terrorist threat 4, 162-163, 165-166, 493; United Self-Defense Forces 159, 165-167, 194; U.S. operations in the Andean Ridge 190-198, 201, 497, 493

Combined Forces Command-Afghanistan 450-452

Combined Forces Special Operations Component Command-Afghanistan 245-247, 249-251

Combined Joint Special Operations Task ForceAfghanistan 245-250

Combined Joint Task Force-180 449-450, 453, 455

CONTEST 484-485 
counterinsurgency $1-2,224,437,440,483$, 497; in Afghanistan 5, 7, 140, 239-241, 243, 248, 251, 254-256, 448-456; in Colombia 194, 494; in El Salvador 5, 175-187, 497; in Iraq 59; in Latin America 191; in the Philippines 286-290; in Somalia 108

Crocker, Ryan 255

CTB see New York City Police Department, Counterterrorism Bureau

CTD see New York City Police Department, Counterterrorism Division

Daniels, Aaron 417

DEA see Drug Enforcement Administration

Democratic Front for the Liberation of Palestine 13

Dostum, Abdul Rashid 137, 227-234, 262

Downing, Wayne 190

Droukdel, Abdelmalek 50, 97-98, 294, 296

Drug Enforcement Administration 167, 190-192, 194, 208, 440

East Indonesian Mujahidin 125-126

Egypt: Afghan Task Force 217-218; airplane bombing 66; Arab Spring 61-62; contemporary history 76-77; contribution to extremist groups 28, 31-36, 38, 56; destination for fleeing Shaw 149; Egyptian al-Qaida leader 465; failed union with Syria 74; formation of the Muslim Brotherhood 11-12, 23, 29-31, 43, 477; Palestinian refugee camps 13; part of CENTCOM 223, 436; PIJ 14; splintering of EIJ 19-23; support to Afghan-Soviet War 23; Yemen policy 84-86

Egyptian Islamic Group 19-20, 23, 34

Egyptian Islamic Jihad 11, 19-20, 23, 34

EIJ see Egyptian Islamic Jihad

El Salvador: Armed Forces 175-186; insurgency 161, 164; terrorist threat 4; U.S. operations 5, 159 , 175-186, 191, 214, 216, 224, 284, 444, 494-497

EOD see explosive ordnance disposal

ESAF see El Salvador, Armed Forces

Escobar, Pablo 5, 166, 203-210, 494

Ethiopia 105, 106, 107-110, 114, 482

ETSS see Extended Training Services Support

Europol 419

EXEVAL see external evaluation

explosive ordnance disposal 328, 331, 333, 341

Extended Training Services Support 177, 180, 182-184, 497

external evaluation 325

F3EA see find, fix, finish, exploit, and analyze Farabundo Martí National Liberation Front 159, 164-165, 169, 179-181, 183-184, 186, 216

Faraj, Muhammad Abd al-Salam 20, 34-36

"far enemy" 11, 21, 35, 37, 43, 64, 97, 124

FARC see Revolutionary Armed Forces of Colombia

Farook, Syed Rizwan 397-401, 404

FATA see Federally Administered Tribal Areas
Fatwa 29, 33, 36, 43, 45, 353

FBI see Federal Bureau of Investigation

Federal Bureau of Investigation 6, 464; Attorney General's Guidelines for Domestic FBI Operations 382; the blind sheikh cell 351-353; contribution to the JIATF 271, 276; counterterrorism hotline 385; interrogating Abu Zubaydah 357-359; investigations related to highcasualty attacks 390-405; investigations related to the Islamic State 414, 416-418; JTTF 7, 353-355, 364-366; Most Wanted Terrorists list 357; NYPD contingent of the JTTF 373-374, 379; relationship with NYPD 386, 499; support to the Philippines 285; Zazi investigation 49, 359-360, 381

Federal Government of Somalia 109-110, 112-114

Federally Administered Tribal Areas 142, 454, 462-464, 467, 470, 493

Federal Security Service 394-396

FGS see Federal Government of Somalia

find, fix, finish, exploit, and analyze 267-269, 273-274, 276-277

FMLN see Farabundo Martí National Liberation Front

Fort Hood Shooting 7, 48, 390-393, 398, 404, 499

Fridovich, David 283-284

FSB see Federal Security Service

Gaddafi, Muammar 21, 294, 381

Gaza 14-15, 38, 76-79

GCC see Geographic Combatant Command

Geographic Combatant Command 223, 436, 438-440

Germany 73, 138, 225, 256, 485, 487; Muslim

Brotherhood 31; synagogue attack 425

Ghali, Iyad Ag 293, 295-296

GIA see Armed Islamic Group

Global Engagement Center 429

Goldwater-Nichols Act 439

Grenada 214, 438, 447

GSPC see Salafist Group for Preaching and Combat

Guantanamo Bay 57, 311, 354, 359, 465, 478

Gulf War 76, 225, 355

Hadi, Abdu Rabbu Mansour 85, 87, 90-92, 308-318

hadith 28, 30, 32

Hamas: attacks on Western targets 18; conflict with Israel 78; focus of NYPD cyber unit 382; formation and rise 11-12, 14-15, 30, 71, 79; link to "cigarette case" 385 ; social services 18 ; suicide bombing 15-16, 23

Haqqani network 50, 140, 142-143, 463, 467, 469

Hasan, Nidal Malik 48, 390-393, 395, 398-399, 403-404

Hezbollah: comparison to Hamas 79; evolution 78-79; information operations 427; Iran-Contra 215; Iranian support 148, 150, 153; NYPD concern 382; Omar Mateen 402; operations in South America 159, 168-169; relationship with PIJ 14; support to Houthis 90; tactics 15-19, 24, 493; U.S. operations in Lebanon 443-444 
hijacking 13, 20, 23, 129, 374, 493; Achille Lauro 14; al-Qaida 45, 356-357; GIA 19, 96; Hezbollah 17-18; PLO 77; Tsarnaev brothers 394

Hoffman, Bruce 13, 424

Hostey, Raphael 414, 416, 419

Houthi: insurgency 3-4, 50, 83, 85, 88-92, 307, 312-318, 465; Iran backing 154; U.S. policy 6

Hussain, Junaid 414-419

Hussein, Saddam: invasion of Kuwait and the Gulf War 15, 22, 76, 225, 355; Iran-Iraq War 149-150; Iraq War 56, 80, 267-268, 358; rise to power 75

Ibn Taymiyya 3, 27-29, 31-32, 34-36, 38-39, 492 ICU see Islamic Courts Union IDF see Israel, Defense Forces information operations 1, 249, 288, 290, 328, 454 Inspire 87, 308-309, 380, 394-395, 398, 465

intelligence, surveillance, and reconnaissance 268-269, 272-276, 300, 328, 330, 334-339, 495

International Military Education and Training 284, 287, 291

International Security Assistance Force 137-138, 140-141, 243-247, 249, 255, 259, 448, 451, 454

Inter-Services Intelligence 22, 135, 217

Intifada 15,79

Iran 72; al-Qaida refuge 45, 49, 56-57; Desert One 437; foreign policy 4, 150-156, 444; hostage crisis 16; influence in Afghanistan 141; influence in Iraq 46, 56, 61; influence in Syria 62, 64-65, 67, 323-324, 326-327, 343; Iran-Contra 5, 212, 215-216, 219; Iran-Iraq War 76, 149-150; markets for Afghanistan 258; operations in South America 168-169; opium production 139; refuge during Afghan-Soviet War 135; revolution $16,78,148-149,437$; support to Hezbollah 17-18, 78, 443; support to Houthis 85, 89-92, 312-313, 315-316, 318; support to Northern Alliance 235-236; training PIJ 14

Iran-Contra 5, 212, 214-217, 219

Iranian Revolution 78, 149-150, 437

Iraq 1, 3-7, 72; 5th Special Forces Group operations 224-225; al-Dawa attack 17; AQIM learning from the insurgency 97; comparison with Southeast Asia terrorist groups 129-130; drone strikes 49, 461, 471; growth of AQI 46-47, 54-59, 425, 493; growth of the Islamic State $54-55,59-68,313$; history as part of the Levant 71-76; impact on Afghanistan War 138, 140-141, 241, 244, 249, 449-450, 455; inclusion in National Security Strategy 429; interagency operations 259; Iraq War 42, 45, 80, 86, 203, 358, 391, 464; Kuwait invasion and Gulf War 22, 36, 76; Omar Mateen justification for attack 401; relations with Iran 149-155; supporting operations in Syria 332, 335-336, 343; support to Abu Nidal Organization 14; Task Force 714 operations 267-277; see also Islamic State, in Iraq

IR GC see Islamic Revolutionary Guards Corps

ISAF see International Security Assistance Force
ISI see Islamic State, of Iraq

ISIS see Islamic State, in Iraq and al-Sham

Islamic Courts Union 4, 108-110

Islamic Revolutionary Guards Corps 14, 16-17, 149-150, 152-155, 169, 444

Islamic Salvation Front 18-19, 96-97

Islamic State: attacks and plots 11, 57, 405, 485;

Boko Haram 100; comparison with AQIM 297; competition with al-Qaida 49-51, 58-59; conflict with al-Shabaab 113; conflict with Iran 153; conflict with Lebanon 444; drone warfare 461, 471; evolution 2-3, 38-39, 54-68, 493; goals 24, 27; the Greater Sahara 98; ideology 28-29; influence on Omar Mateen 401-402; influence on Tashfeen Malik 397-399; information operations 47, 101, 424-426, 429, 431; in Iraq 155, 277, 495; in Iraq and al-Sham 62-65; in Iraq and Syria 313; Khorasan 142-143; MILF criticism 120; social media recruitment 7, 413-419; in Southeast Asia 121-122, 126, 129-130; terrorist threat 1-2, 4, 486; threat to UK 8, 477, 482-484; in Trinidad and Tobago 169; U.S. operations 6, 323-345, 444, 496; in West Africa Province 101; in Yemen 4, 83, 88-89, 92, 314-315

ISR see intelligence, surveillance, and reconnaissance Israel 72; Arab-Israeli conflicts 3, 17, 76-77, 80, 84; bombing of embassy in Buenos Aires 18, 168; Defense Forces 18, 78; emergence of Palestinian terrorist groups 13-16; Iranian foreign policy 149, 150, 153, 155; McChrystal visit 273; Mossad 49; occupation of Lebanon 24, 443; regional demographics 71-73; state formation 30, 73-76; target of Hamas 79; target of Hezbollah 16-18, 78-79, 168, 427, 443; target of Islamists 22, 35, 43, $45,90,92,308,368$; target of PLO 77-78

Jalloh, Mohamed Bailor 416-417

Jamaah Ansharut Tauhid 123-125

Jamaat al-Tawhid wal-Jihad 46, 57

JAT see Jamaah Ansharut Tauhid

Jemaah Islamiyya 1, 3-4, 120, 123-126, 129, 281, 283, 493

JI see Jemaah Islamiyya

JIATF see Joint Interagency Task Force

Joint Interagency Task Force 269-271, 274-276

Joint Planning and Assistance Team 190, 193, 196, 200,444

Joint Special Operations Agency 438-439, 444

Joint Special Operations Command 436, 438, 471

Joint Special Operations Task Force-North 226-228

Joint Special Operations Task Force-Philippines 280, 284-288, 290-291

Joint Terrorism Task Force: 9/11 investigation 356-357; Benghazi investigation 360; blind sheikh cell investigation 351-353; Boston Marathon Bombings investigation 396-397, 404; East Africa embassy bombings investigation 365; enhanced interrogations 357-359, 361; Faisal Shahzad investigation 360; interagency approach 499; Kampala investigation 
360; Nidal Hasan investigation 392-393, 404; NYPD contribution 364, 366-367, 373-374, 379; pre9/11 terrorism investigations 353-356; Somali pirate investigation 360; USS Cole investigation 365; Zazi investigation 359-360

Jordan 72; Abu Musab al-Zarqawi 55-56, 58; AfghanSoviet War fighters 22, 43; bombing of embassy 46; deportation agreement 479, 482; Egypt foreign policy 84; foiled Millennium Eve plot 355; hijacking destination 13; Muslim Brotherhood 30, 33; state formation and conflict 71-72, 74-77

JPAT see Joint Planning and Assistance Team

JSOTF-N see Joint Special Operations Task Force-North JSOTF-P see Joint Special Operations Task Force-

Philippines

JTTF see Joint Terrorism Task Force

K2 see Karshi Khanabad airbase

Karshi Khanabad airbase 226-228

Karzai, Hamid: critical of PRTs 256-257; election 456; policy 139-140, 143, 261, 447, 454; support to irregular forces 241-243, 246

Kelly, Raymond 364-367, 369, 371-374, 377-378, 380-381, 384, 387, 499

Kennedy, John F. 214, 396, 437, 440

Kennedy, Robert F. 13

Kenya 106; al-Shabaab operations 109-114; embassy bombings 45, 136, 353, 365; regional history 105-109; terrorist attacks 50, 424

Khalilzad, Zalmay 452, 454, 457

Khan, Mohammad Sidique 46, 479-480

Khan, Reyaad 414-416, 419

Khan, Samir 309, 380, 465

Khomeini, Ayatollah Ruhollah 4, 16, 148-151

Kuffar 29, 417

Kuwait 15, 20, 22, 36, 150, 225

Lebanese Resistance Regiments 16-18

Lebanon 72; deportation agreement 482; Hezbollah 15-19, 78, 150, 168, 215, 438; history and conflict 71-74, 76-78, 80; Iran-Contra 216; Iran policy 154; the rise of Islamist terrorist groups 13-15, 24; SOCCENT operations 443-444; withdraw of U.S. forces 19

Legion, The 414-417, 419

Libutti, Frank 366-367, 377, 499

Libya: Afghan-Soviet War 22; Arab Spring 61; Benghazi 311, 360; civil war 294; comparison with Southeast Asia terrorist groups 129; deportation agreement 482; foreign fighters to Iraq 46, 268; Islamic State 66-67, 416-417; support to Abu Nidal Organization 14; support to MNLF 119; terrorism against the West 21; U.S. strike operations 317, 461, 467, 468, 469

Libyan Islamic Fighting Group 21

Local Defense Initiative 245-247

London bombings 8, 42, 46, 49, 371-372, 384, 462, 477, 479

Los Zetas 4, 159, 162, 167-169
Madrid bombings 42, 46, 368, 383, 493

Mali 3-4, 6, 50-51, 98, 293-303, 495

Malik, Tashfeen 397-400, 402

Mateen, Omar 401-405

McChrystal, Stanley 5, 140, 245-247, 267-276, 495, 497-498

McRaven, Bill 271

Milestones 12, 31-32, 43

MILF see Moro Islamic Liberation Front

MILGP see Military Group

Military Group 4-5, 179-184, 186, 193-195, 199-200

Miller, Scott 245-246, 248-250, 269

mission support site 327-330, 333-338

MIT see Mujahidin Indonesia Timor

MNLA see National Movement for the Liberation of

Azawad

mobile training team 177-180, 182-183, 185, 281, 441, 497

Mogadishu 108-112, 114, 225, 427, 460

Mohammed, Khalid Sheikh 20, 358-359, 364

Moro Islamic Liberation Front 119-124, 129, 281, 284-285, 289

Mosul 54, 60-61, 64-67, 74, 268, 277

Movement for Oneness and Jihad in West Africa 98, 294, 297, 299

MSS see mission support site

MTT see mobile training team

Mujahidin: in Afghanistan 22, 43, 108-109, 120, 135-136, 212, 217-220, 254, 478; waging global holy war 21, 36, 41, 48; in Yemen 88

Mujahidin Indonesia Timor 123

MUJAO see Movement for Oneness and Jihad in West Africa

Muslim Brotherhood: evolution 11-12, 19-20, 29-30, 33-34, 79; objectives 23; influence on Islamist groups 3, 24, 47, 56, 79, 477, 481; in the Palestinian territories 14; Sayyid Qutb 43, 47

Muslim World League 32-34

Nasrallah, Hassan 150, 427

National Media Exploitation Center 273-274

National Movement for the Liberation of Azawad 6, 293-295, 301

National Security Council 5, 215-217, 439, 461

NATO see North Atlantic Treaty Organization

"near enemy" 11, 35, 37, 43, 64, 97

Neglected Duty, The 20, 34-35

New People's Army 4, 119, 122-123, 130, 281, 284

New York City Police Department 3, 7, 351-352, 377-388, 498-499; Counterterrorism Bureau 7, 364, 366-367, 374, 377, 384, 498; Counterterrorism Division 7, 364, 366-372, 374

Nigeria: Boko Haram 1, 4, 95, 98-101; drone strike 471; Mohamed Bailor Jalloh 416; target of counterterrorism messaging 429; Umar Farouk Abdulmutallab 48, 87, 463-464

North, Oliver 215-216 
North Atlantic Treaty Organization: invoking Article 5 1; support to Afghanistan 138-139, 248, 256, 259-260, 262-263, 448, 463, 468

Northern Alliance 5-6, 136-137, 141, 151, 223-224, 228-236, 462

NSC see National Security Council

Nusra Front 38, 42, 62-64

NYPD see New York City Police Department

Obama, Barack: Afghanistan policy 2, 140, 251; drone warfare policy 49, 462-466, 464, 468, 470-472; inauguration 392 ; interrogation and detention policy 359; Iraq policy 61, 66; Madison Valleywood Project 419; Nigeria policy 100; strategic messaging policy 429; Yemen policy 6, 307, 311-315, 318

ODA see Operational Detachment Alpha

ODC see Operational Detachment Charlie

Office of Strategic Services 212-213, 224, 437

Omar, Mullah Muhammad 51, 56, 136-137, 227, 357, 460, 462

O’Neil, John 365-370, 372

OPATT see Operations and Planning Assistance Training Team

Operational Detachment Alpha 196, 200, 223, 323, 343-345; ODA 555 227-228, 232; ODA 595 227-234; ODA 773 192; ODA 774 191-192; ODA 784 192; ODA 5131 327-328, 333-337; ODA 5132 327-328, 336-339; ODA 5133 327-333, 329, 336; ODA 5136 325, 327-328

Operational Detachment Charlie 228-236

Operation Eagle Claw 437

Operation Jaque 442

Operation Jazeera Storm 334-336

Operation Nexus 385-387

Operation Olive Branch 323, 326

Operations and Planning Assistance Training Team 5, 175-187

Operation Sentry 384-385

Operation Serval 6, 293-303, 494-495

Operation Urgent Fury 438

Operation Willing Spirit 440-443

Oplan Bojinka 20, 121

Orlando nightclub attack 7, 87, 390, 401-404, 499

Oslo Accords 15, 79

Ottoman Empire 21, 30, 38, 73-74, 83-84

PACOM see U.S. Pacific Command

Pakistan: Abdel Rahman preaching 20; al-Qaida sanctuary 21, 23, 36, 42, 45, 50, 58, 60, 268, 271, 357, 448; al-Qaida training camps 46, 48-49, 352, 355, 387, 479; Azzam assassination 22; Bin Ladin raid 280, 443; drone warfare 42, 49, 460-472, 464, 469, 493; information operations 426-427; intolerancew toward Arab jihadi fighters 86; Iranian influence 151; Johnny Walker Lindh transit 234; Khalid Sheikh Mohammed arrest 21; as part of CENTCOM 223; policy with U.S. 137-138, 141-142, 357-359, 448,
450, 454, 456; support to mujahidin 22, 43, 135-136, 217-218; Taliban sanctuary 139-140, 142-143, 226, 235, 244, 448; Tashfeen Malik 398, 400; Yousef arrest 121, 364-365

Palestine Liberation Organization 3, 11, 13-16, 77-79

Palestinian Islamic Jihad 11-12, 14-16, 23

Palestinian Territories 3, 11-24, 30, 56, 71-79, 72, 153, 480

Peru 4, 159-162, 164-165, 190, 192-194, 197

Petraeus, David 247, 249, 268, 451

PFLP see Popular Front for the Liberation of Palestine Philippines 118, 282; airplane bombing 20; history 117-119; Islamic State 66-67; MNLF 119-120; terrorism 1, 4, 23, 119-124, 129-130; U.S.

operations 6, 280-291, 444, 493-495

PIJ see Palestinian Islamic Jihad

Plan Colombia 5, 190-201, 441, 494

PLO see Palestine Liberation Organization

Popular Front for the Liberation of Palestine 13, 21

Prevent 480-481, 484-485

PRF see pro-regime forces

pro-regime forces 323, 325-328, 338-339

Provincial Reconstruction Team 242, 255-257, 256, 259-260, 262-263, 448, 453-454, 456

PRT see Provincial Reconstruction Team

psychological operations: in El Salvador 181-185; as an irregular warfare activity 1 ; in the Philippines 286, 288, 328; as a Special Operations Force 190, 437, 439; in Syria 332-333, 340-341, 344

Qatar 62, 143, 467

Quds Force 150-151, 154, 169, 444

Qutb, Sayyid 12, 20, 23, 29, 31-36, 43, 47, 492

Rahim, Abdullah 415

Rahman, Omar Abdel 20, 35-36, 352-353, 385

Rapoport, David 41

Reagan, Ronald: Afghanistan policy 5, 212, 217, 219-220, 225; air strikes against Libya 21; Colombia policy 191, 203; defense reform 250, 439; El Salvador Policy 177-178; Grenada 438; Iran-Contra 5, 212-217, 219-220; Lebanon policy 17

Revolutionary Armed Forces of Colombia: a new model of insurgency 4, 165-166, 493; Operation Jacque 494; Operation Willing Spirit 441-442; organization and tactics 160-163, 169, 194-195, 197-198, 260; Plan Colombia 190, 198-200, 260

Rumsfeld, Donald 227, 356, 448, 452

Russia: Afghan Task Force 212-213, 216-218, 220; airline bombing 66; Bonn Conference 137; Boston Marathon bombers 394-396, 404; cargo jets 235; counterterrorism 55, 64; Iran policy 154-155; mafia 168; part of EUCOM 436; support to Syria 6, 66-67, 323-327, 343; threat to U.S. 429

Sadat, Anwar 14, 20, 35-36

Salafism 24, 27-29, 32-36, 38-39, 56, 60, 90, 92, 293-295, 313, 477-478 
Salafist Group for Preaching and Combat 19, 95, 97-98, 100-101

Saleh, Ali Abdullah 83-86, 90, 307-310, 312-313, 318, 355,465

San Bernardino attack 7, 390, 397-401, 404-405

Saudi Arabia: Afghan-Soviet War fighters 22, 43; al-Qaida attack in Riyadh 46, 353; AQAP and Yemen policy 268, 307-308, 312-313, 318; Arab Cold War 32-34; Ayman al-Zawahiri 21; condemnation of Bin Ladin 36-37; foreign fighters to Iraq 46; Gulf War 22, 224; Iran policy 151, 155; Islamic State 38; Khobar Towers bombing 18; Muslim Brotherhood 30; Omar Mateen 402-403; state formation 75; support to

Nusra Front 62; Tashfeen Malik 398; Wahhabism 28;

Yemen policy 84-87, 90-91

SDF see Syrian Democratic Forces

Sea, Air, and Land Forces 195, 250, 315, 335, 441-442, 463, 467

SEAL see Sea, Air, and Land Forces

Sharia 12, 27, 29-30, 32, 35-36, 477, 482, 492: in

Afghanistan 136, 138-139; al-Qaida 41, 46; in Indonesia 124; in Iran 16; in Mali 6, 293-294; in the Philippines 120; in Somalia 108-110; in Syria 324; in Thailand 127; in Yemen 87-88

Sheehan, Michael 6-7, 196; as ambassador for counterterrorism 281, 295-296, 365, 461; in El Salvador 180; at the NYPD 365, 367, 369, 372-373, 384, 499

Shekau, Abubakar 99-101

Shining Path 4, 159-162, 164-166, 169, 192

Six-Day War 13, 76, 84

SOCCENT see U.S. Special Operations Command, Central

SOCOM see U.S. Special Operations Command

SOCPAC see U.S. Special Operations Command, Pacific

SOCSOUTH see U.S. Special Operations Command, South

SOF see Special Operations Forces

soft targets 23, 108-109, 111, 114, 125, 493

Somalia 106; al-Shabaab 4, 42, 49-51, 109-114, 268, 418; Arab Spring 43, 49; drone warfare 460-461, 463, 466, 467, 468, 469, 470-471; FBI investigations 354; history 105-109; information operations 203, 429; NYPD investigation 380; U.S. operations 50,225

SOUTHCOM see U.S. Southern Command

Special Forces: building Afghan Local Police 241-251;

FARC 165; French operations in Mali 297-300; horse soldiers 223-236, 230; Jim Lindsay 439; Mexican Special Forces 167; Operation Willing Spirit 441-443; Plan Colombia 5, 198-200, 494; reservist in NYPD 372; Russian Spetsnaz 217; Special Action Forces 437; UAE 88; U.S. operations in the Andean Ridge 190-198, 494, 201; U.S. operations in El Salvador 176, 178, 180-181, 184-186, 497; U.S. operations in the Philippines 280-284, 286, 289-290; U.S. operations in Syria 323, 325, 331-332, 336
Special Operations Forces: building Afghan Local Police 239, 241-251; chain of command 448; collaboration with JTTF 360; core competencies 280; counterterrorism operations 454; defeating the Taliban 1, 45, 137-138, 218, 223, 226-227; expanding role 2, 445; French 303; killing Bin Ladin 142; lessons on employment 494-498, 501; operations in Lebanon 443-444; operations in the Philippines 281, 284, 286, 288-291, 444; operations in Syria 6, 326-328, 331, 340-341, 343; operations in Yemen 308, 310, 315, 464; stabilization operations in Afghanistan 259-260, 263; supporting Centra Spike 207; Task Force 714 267; TSOCs 7, 436, 438-441; U.S. operations in Iraq 47, 56, 59; U.S. operations in Somalia 108; U.S. operations in Syria 66-67; Wayne Downing 190

Sudan 20-21, 23, 43, 45, 105, 106, 107, 137

Suicide attacks: by al-Dawa 17; by al-Qaida 21, 46, 87, 234, 462, 468, 484; by al-Shabaab 110, 112-114; American bomber in Syria 402; by AQAP 48, 87; by AQI 46, 57-58, 274, 277; by AQIM 97; by Boko Haram 99; East Africa embassy bombings 136; effectiveness 16-17, 124, 140, 271, 425, 493; by Hamas 15, 23; by Hezbollah 11, 16-18, 24, 78-79, 168; by Islamic State 60, 64, 66-67; London bombings 46, 371, 479; by MUJAO 299; MV Limburg 86; Nidal Hasan 391; Omar Mateen claim 401; by PIJ 14, 23; selection of attackers 142; by the Taliban 234, 242, 263; using planes 20; USS Cole 86; Zazi plot 49, 359,381

Sullivan, Justin 415-416

Sykes-Picot Agreement 73, 75

Syria 72: al-Qaida operations 41-43, 46, 54; American bombing 402; Arab Spring 49; civil war 54, 62, 382; destination of hijacked airplane 13; drone warfare 461, 471; emergence of ISIS 62-63; emergence of the Islamic State 63-67, 89; emergence of terrorist violence in the Levant 75-80; fighters in Afghan camps 56; fighters in Iraq 56; foreign fighters from Trinidad and Tobago 169; goal of a caliphate 58; growth of Islamic State in Iraq 61-62; impact of Iranian Revolution 16; impact of Yemen civil war 89-91; Iranian influence 151-155; Islamic State rise to power 3; murder of U.S. hostages 313; Muslim Brotherhood 12, 30; as part of the Levant 71-73; relationship with Hezbollah 18; social media recruitment 414-418; Southeast Asia fighters in Syria 126; state formation 73-75; support for Abu Nidal Organization 14; support to Afghan-Soviet War 23; UK policy 482-487; U.S. operations 4, 6, 51, 323-346, 443-444, 495-496

Syrian Democratic Forces 6, 323-346

tactical analysis team 190, 192-193, 441

Tajik 135, 140-141, 151-152, 229, 234, 255, 263

takfir 12, 27-29, 32, 35, 96 
Takfir wal-Hijra 19

Taliban: defeat after 9/11 1, 5, 45, 56, 137-138, 218, 223-229, 232-236, 239, 267, 496; drone warfare 460-463, 467-469, 471; information operations 426; Iranian influence 151; relationship with al-Qaida 55, 354, 357; resurgence 139-143, 240-245, 248-249, 251, 255, 260-263, 448, 452, 454-457, 496, 498; rise to power 4, 135-137; terrorist threat 3, 50-51; UK support to U.S. 478

Tanzania 24, 45, 108, 136, 353, 359, 365

Task Force 31 241, 243

Task Force Dagger 223, 226, 228, 231, 233-236

TAT see tactical analysis team

Tawhid 50

Thailand 4, 20, 117, 118, 124, 127-130

Theater Special Operations Command 7, 436-445, 499

Trump, Donald: Afghanistan policy 143; drone warfare policy 463, 464, 466, 468, 471-472; Iran policy 154-155; strategic messaging policy 429; Yemen policy 315,318

Tsarnaev, Dzhokhar 386, 394-395, 398

Tsarnaev, Tamerlan 386, 394-399, 401, 403-405

TSOC see Theater Special Operations Command

UNAMA see United Nations, Mission in Afghanistan Union of Soviet Socialist Republics 77, 213

United Arab Emirates 62, 85-86, 88-89, 91, 248

United Kingdom: al-Qaida plots 424; counterterrorism policy 6, 8, 47, 100, 382, 477-487, 498-500; friendly fire casualties 234; investigations 354; Muslim Brotherhood refuge 31 ; ricin plot 368 ; state formation in the Levant 73-75; support to ALP program 260; Westminster attack 87; Yemen policy 87; Zazi plot 49

United Nations: Afghanistan reconstruction 138; AQIM attack 97, 101; basing in Somalia 112; Boko Haram bombing 99; Charter 205; estimation of al-Shabaab strength 109; Indonesia mediation 123; Iraq headquarters bombing 46, 56; journalism handbook 431; leaving Yemen 91; Mazar-i-Sharif compound attack 262; Mission in Afghanistan 426, 448, 450-451, 454-456; murder of Colonel Higgins 18; National Dialogue Conference 90; negotiated cease fire 18, 76; peacekeeping operations in Somalia and Haiti 225; PLO granted special observer status 14; policy in Mali 293-297, 302-303; program to monitor 1988 withdraw from Afghanistan 218; resolution to partition Palestine 13, 76; ruling on Iranian support to Yemen 91; Security Council Resolution 1701 443; Taliban sanctions 137; terrorist target 353; trust fund request 100; Truth Commission 186; U.S. Ambassador 213; withdraw from Somalia 108; Yemen policy 313, 316

United States Congress: Afghan policy 217-218; antiterrorism legislation 370; Arms Control Export Act 175-178, 184; Authorization for Use of Military
Force 1, 461; Colombia policy 191, 199; Comey testimony 405; drone policy 463, 468, 471, 495; El Salvador policy 176-179, 181, 186, 497; GoldwaterNichols Act 439; Iran-Contra 213-216; Leahy Law 196; Lebanon policy 444; lessons on covert action 219-220; Nigeria policy 100; oversight of abuses 315; SOF legislation 437; support to indigenous forces 231, 247, 249-250; War Powers Resolution 175-178, 184

U.S. Agency for International Development 56, 440; in Afghanistan 247, 256-258; in Colombia 200; in El Salvador 182-183; in the Philippines 286-287; in Syria 341, 440

USAID see U.S. Agency for International Development U.S. Central Command 223-226, 231, 270, 444, 467

U.S. Pacific Command 281-282, 284, 288-289

USS Cole 45, 86, 355, 365, 462, 493

U.S. Southern Command 7, 436; in Colombia 190-193, 195, 198, 441-442, 494; in El Salvador 176, 179-183

U.S. Special Operations Command 59, 245, 249-250, 267, 273, 439-440; Central 226, 436, 443-444; Pacific 281, 283-285; South 193, 195-196, 200, 440-444

USSR see Union of Soviet Socialist Republics

USS The Sullivans 86, 355, 365

Uzbekistan 23, 223, 225-227, 234, 258

village stability operations 5, 239-240, 245-251, 259

VSO see village stability operations

Wahhabism 27-29, 32-34, 38, 90, 143, 295

Warsame, Ahmed 360

weapons of mass destruction 267, 358, 368-370

West Bank 14-15, 75-79

WMD see weapons of mass destruction

World Islamic Front for Jihad against the Jews and Crusaders, The 21, 24, 37

World Trade Center: 1993 bombing 20-21, 36, 121, $351-353,364-365,368,370,372$, 374; 9/11 attack $37,45,223,357,364,461$

Yemen: 1992 plot 23; AQAP 46-48, 85-88; Arab Spring 153; contrasting radical ideology with Thailand 129; corruption 107; drone warfare 49-50, 460-466, 466, 468-472, 469, 495; FBI investigations 353, 355-358, 391, 394, 398; history 83-85; Houthi insurgency 89-92; Iran relations 154; Islamic State 88-89; plots and attacks 45, 365; Saudi intervention 155; terrorism 42-43, 268, 394; transit to Afghanistan 234; U.S. counterterrorism policy 307-318, 493, 495

Yousef, Ramzi 10, 121, 352-353, 364

Yusuf, Mohammed 98-99, 101

Zazi, Najibullah 42, 48-49, 359-360 


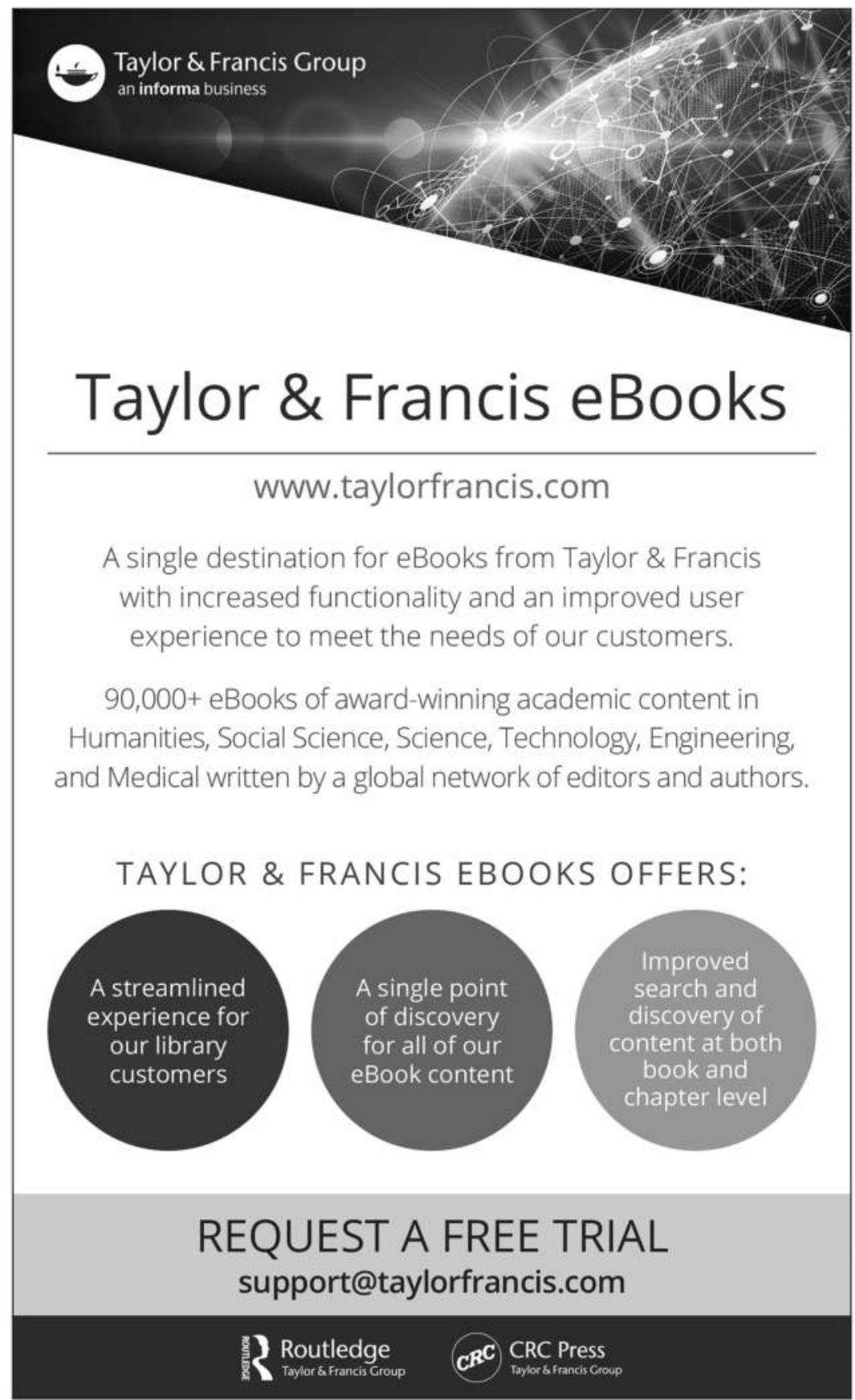

